(1)

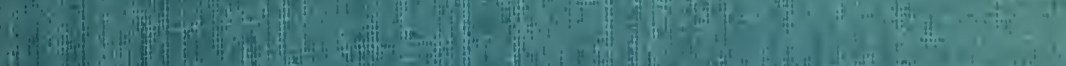

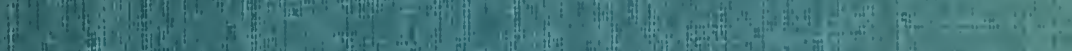

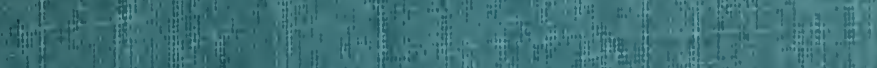

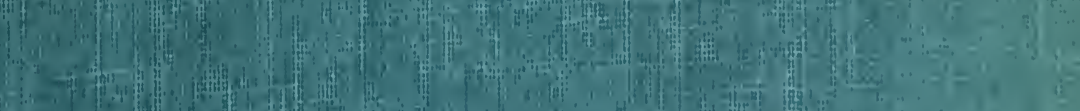

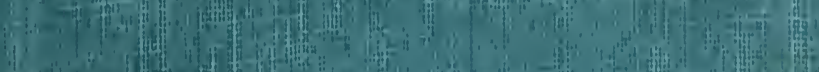
14 (1)

16 (16) 4. 4 (4)

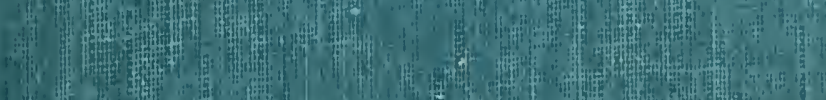

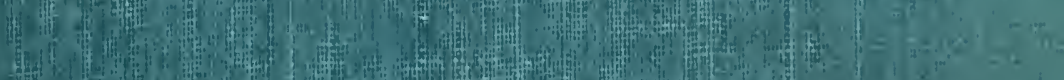

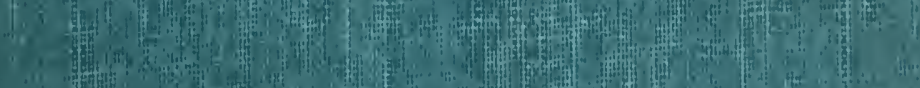

1.

4. 14. If

40 .

(1)

(19)

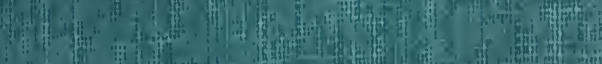

in

140 (1)

1.

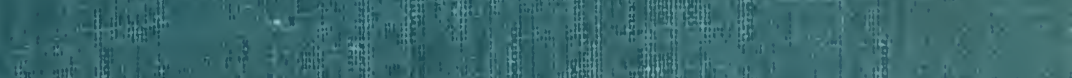
1.

(f)

a. 1 .

(19)

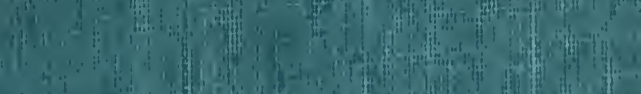

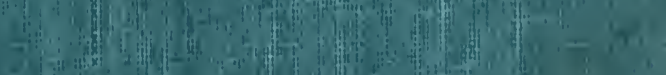

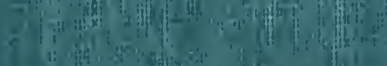

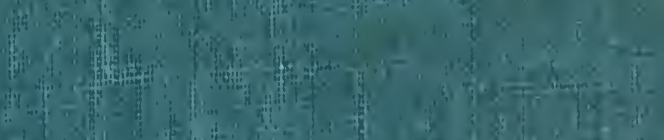

is 14 a

3 , the

$y=\hat{x}$

-16.

1. $\mid \begin{aligned} & 0 \\ & 4\end{aligned}$ 


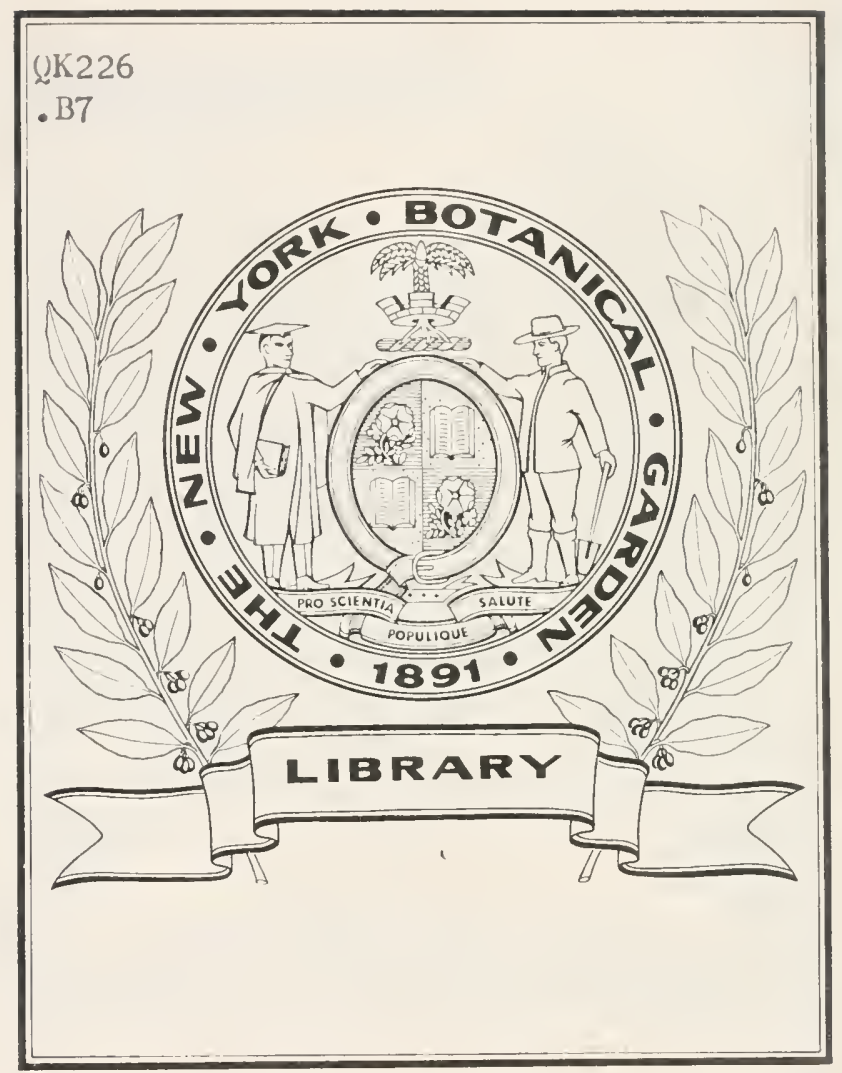








\title{
THE BAHAMA FLORA
}

B Y

NATHANIEL LORD BRITTON, Ph.D., Sc.D., LL.D. DIRECTOR-IN-CHIEF OF THE NEW YORK BOTANICAL GARDEN, PROFESSOR IX COLUMBIA UNIVERSITY

AND

CHARLES FREDERICK MILLSPAUGH, M.D. CIFATOR OF BOTAAY, FIFID A TEECM OF NATURAL HISTORY

\author{
LIB:P. \\ NEW iU \\ BOTANICA. \\ OARDEN
}

\author{
NEW YORK \\ PUBLISHED BY THE AUTHORS \\ JUNE 26,1920
}


Copyright, 1920

By Nathaniel Lord Britton LANCASTER, PA. 


$$
\underline{E}^{-}
$$





\section{INTRODUCTION.}

The numerous Bahama Islands form an archipelago situated east of Florida and north of Cuba and Hispaniola, comprising 29 islands, 661 cays and 2387 roeks with a total land area of about 4424 square miles; the nearest island to the Florida coast is Gun Cay, distant about 40 miles nearly east from Cape Florida; the island nearest Cuba is the little Cay Sal, about 35 miles north, across the Nicholas Channel, while the nearest to Hispaniola is Great Inagua, lying about 60 miles north of Cape St. Nicholas.

The axis of the arehipelago is in a general way northwest and southeast, with a total length of over 600 miles; the greatest width, disregarding the islands of the ontlying Cay Sal Bank, from Gun Cay to Man-of-War Cay, Abaco, is about 150 miles.

The most northern cays of the Little Bahama Bank north of the Great Bahama Island are in north latitude about $27^{\circ} 30^{\prime}$; the southern side of Great Inagua is in north latitude about $20^{\circ} 55^{\prime}$. Gun Cay is in west longitude about $79^{\circ} 20^{\prime}$; cays of the Turk's Islands are in west longitude about $71^{\circ} 10^{\prime}$.

The many islands and cays stand on banks, in shallow water, with oceanic depths among and between them. The region has, doubtless, been subjected to alternate periods of uplift and depression in past geologic time, but the vertical movements have probably been relatively small; during times of uplift, some of the present islands may have been connected, but there is no evidence that there ever was land conneetion with either Florida, Cuba or Hispaniola.

Most of the islands are low, but hilly and rocky, the ranges of hills usually running lengthwise of the island; on New Providence, the hills rise to about 100 feet elevation; on Cat Island, aneroid barometer readings indicated altitudes up to 205 feet (published records of greater elevations on Cat Island were not substantiated by our observations); on Watling's Island, hills rise to about 140 feet. Most of Andros, the Great Bahama and Abaco are low and nearly level. At points where the hills come to the sea there are bold rocky headlands, such as Columbus Bluff, at the southern end 
of Cat Island. On the western side of Andros and on the southern side of New Providenee are large areas known as "swash," subject to overflow by the sea in storms. Beaches of white limestone sand are occasional, and the interior of parts of some of the islands is quite sandy (white-lands), notably Eleuthera, Little San Salvador and some of the Berry Islands. Large salt-water lakes at sea level, but without connection with the ocean, unless underground, are striking features on New Providence (Lake Cunningham) and on Watling's Island. Mangrove swamps are local along the coastal lines. There are no fresh-water streams, but fresh-water marshes exist on some of the larger islands.

The rocks of the Bahama Islands are wholly aeolian limestone; their surface is often greatly eroded into sharp "dog-tooth" projections, and there are many "sink-holes," these sometimes 10 feet deep or deeper. Sinall caves are occasional. Where composed mainly of sand, the soil is often of considerable depth, but it is usually thin and meagre, often colored red or reddish (red-lands) by iron oxide leached from the limestone.

There are extensive forests of the Caribbean Pine (Pinus caribaea), much reduced in recent years by lumbering, on the Great Bahama, Abaco, Andros and New Providence, and this tree occurs again on the Caicos Islands, but does not exist on any other islands of the Archipelago. On the larger islands, notably Andros, New Providence and Great Bahama, and on some of the smaller ones, hardwood forests (coppices) occur, sometimes wholly enclosed by pinelands, like the similar "hammocks" of southern Florida. These coppices are made up of a considerable variety of tall tree species. On'most of the smaller islands, however, and in parts of the larger ones, the woody vegetation is wholly of shrubs and low trees, often of great density of growth, forming the "serub-lands." Portions of these areas may have had larger trees upon them in the past, cut out for lumber and firewood, but over great areas there is no evidence of large trees ever having existed. Locally some of these areas are known as "low coppices."

The relationships of the native Bahamian flora are, as would be expected, with those of Florida, Cuba and Hispaniola, and it may be assumed that the species which are in common have been transported from one or another of the land masses by natural agencies of winds, migratory birds or oceanic currents. 
The flora as here recorded is composed of species as follows:

\begin{tabular}{|c|c|c|}
\hline Spermatophyta & $\begin{array}{l}\text { Bahama Flora } \\
.995\end{array}$ & $\begin{array}{c}\text { Endemic } \\
133\end{array}$ \\
\hline Pteridophyta ......... & 33 & 0 \\
\hline 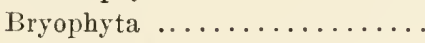 & 69 & 1 \\
\hline \multicolumn{3}{|l|}{ Thallophyta: } \\
\hline Fungi ... & 150 & 18 \\
\hline Lichens ......... & 197 & 19 \\
\hline Algae (incl. Diatomeae) . & 519 & 14 \\
\hline \multirow[t]{2}{*}{ Myxomycetes .............. } & 11 & 0 \\
\hline & $\overline{1982}$ & $\overline{185}$ \\
\hline
\end{tabular}

The Fungi, cxeept the Basidiomyeetes, are as yet very incompletely known, many more lichens probably exist in the Bahamas, and the fresh-water and aerial algae have been little collected or studied. Practically nothing is known about the Baeteria.

In addition to the numerous collections made by the anthors, or under their supervision, the herbaria of the New York Botanical Garden and the Field Museum of Natural History contain the personal herbarium of Mr. Lewis J. K. Brace and the prime set of the eollections of Mrs. Northrop, Dr. W. C. Coker, Mr. Wm. Cooper, Mr. A. H. Curtiss, Mr. Alex. E. Wight, Dr. J. T. Rothrock and Prof. F. S. Earle. In addition the Missouri Botanical Garden kindly loaned to the authors the complete original collection of Prof. A. S. Hitcheock. These collections enabled them to substantiate the species published in Dolley's "Provisional List of the Bahamas, etc."; Mrs. Northrop's "Flora of New Providence and Andros," and Coker's "Vegetation of the Bahama Islands." The authors have also, at various intervals, been able to consult the collections of Catesby, Eggers, Hjalmarson, Daniell, Herrick, Allen, Barbour and Bryant, and others deposited in European and American herbaria. This has rendered possible the critical notes and observations reeorded in the text concerning a large number of speeies heretofore erroneonsly accredited to the Bahamas.

In addition to the exsiceatae mentioned above a complete series of living orchids, eacti and bromeliads, together with many other plants of special interest were brought into the Garden conservatories and there observed through several flowering seasons.

The authors have not included cultivated species exeept sueh as have shown a strong tendeney to become spontaneous. 
Grateful acknowledgment for assistanee in the preparation of this volume is tendered to Dr. John K. Small, for eritical eomparative work as regards plants of Florida and for proof-reading; to Mr. Percy Wilson for bibliographical work, proof-reading and indexing; to Mr. W. R. Maxon for information relative to the Ferns; to Mrs. N. L. Britton for her contribution of the treatment of the Musci; to Professor Alexander W. Evans for his contribution of the Hepaticae; to Professor Lincoln W. Riddle for the chapter on Lichens; to Dr. Marshall A. Howe and Mr. Frank S. Collins for the chapters on Algae; to Mr. Charles S. Boyer for the list of Diatoms; to Dr. Fred J. Seaver and Dr. William A. Murrill for their work on the Fungi; and to Mr. L. J. K. Brace for many notes and for lists of common names of plants. Much information regarding species was also obtained from the Royal Gardens, Kew, England, and from the British Museum of Natural History, and is highly appreciated. 


\section{THE BAHAMA FLORA}

All plants may be grouped in four main eategories, known as Phyia or Subkingdoms, as follows:

Phylum 1. Spermatophyta, those which bear seeds, a seed being different from all other vegetable struetures by containing an embryonic plantlet. All spermatophytes bear flowers of one kind or another, and this phylum is also called Anthophyta, or flowering plants and, to distinguish it from the three other phyla collectively, Phanerogamia. Phyla 2, 3 and 4 taken together are called Cryptogamia; all these are seedless.

Phylum 2. Pteridophyta, comprises ferns and fern allies; all are flowerless and have two separate and distinct alternating generations, the one represented by the fully developed plant having root, stem and leaves, with vascular tissue and bearing spores, a spore being a single vegetable cell capable of growing into a new plant; the other, called the prothallium stage, is small, inconspicuous, grows from the spores, has no vascular tissue, is not differentiated into root, stem and leaves, and bears the sexual organs; from the female organ of the prothallium (archegonium) the fully developed spore-bearing plant again arises; the male organ, borne either on the same prothallium or on a different one, is called an antheridium.

Phylum 3. Bryophyta, consists of mosses and their allies; all are small flowerless plants with alternating sexual and nonsexual (spore-bearing) generations, but the spore-bearing generation never becomes separated and independent; the sexual generation is commonly the more conspienous and is, in most cases, differentiated into stem and leaves, while the spore-bearing generation is never thus differentiated; their spores are borne in conceptacles termed capsules, and from the spores the plant again develops. Bryophytes consist almost wholly of cellular or nonvascular tissue.

Phylum 4. Thallophyta, includes the algae, fungi and lichens; 
all are flowerless and their methods of reproducing and propagation are varied. They contain no rascular tissue (except a few large algae) and the plant body is not differentiated into stem and leaves. Many of them are of microscopic size.

\section{Phylum 1. SPERMATÓPHYTA.}

\section{Seed-bearing Plants.}

Plants producing seeds which contain an embryo formed of one or more rudimentary leaves (cotyledons), a stem (hypocotyl, radicle), and a terminal bud (plumule), or these parts sometimes undifferentiated before germination. Microspores (pollen-grains) are borne in microsporanges (anther-sacs) on the apex or side of a modified leaf (filament). The macrosporanges (ovules) are borne on the face of a flat or inrolled much modified leaf (carpel) and contain one macrospore (embryo-sac); this develops the minute female prothallium, an archegone of which is fertilized by means of a tube (pollen-tube), a portion of the male prothallium sprouting from the pollen-grain.

There are two classes which differ from each other as follows:

Ovules and seeds contained in a closed cavity (orary); stigmas 1 or more.

Class 1. AxgIOSPERMAE.

Orules and seeds borne on the face of a scale; stigmas none.

Class 2. GrMyospermae.

\section{Class 1. ANGIOSPÉRMAE.}

Ovules (macrosporanges) enclosed in a cavity (the ovary) formed by the infolding and uniting of the margins of a modified rudimentary leaf (carpel), or of several such leaves joined together, in which the seeds are ripened. The pollen-grains (microspores) on alighting upon the summit of the carpel (stigma) germinate, sending out a pollen-tube which penetrates its tissues and reaching an ovule enters the orifice of the latter (micropyle), and its tip coming in contact with a germ-cell in the embryo-sac, fertilization is effected. In a few cases the pollen-tube enters the ovule at the chalaza, not at the micropyle.

There are two sub-classes, distinguished as follows: 


\section{Sub-class 1. MONOCOTYLÉDONES.}

Embryo with a single cotyledon and the first leaves of the germinating plantlet alternate. Stem composed of a ground-mass of soft tissue (parenchyma) in which bundles of wood-cells are irregularly imbedded: no distinction into wood, pith and bark. Leaves usually parallel-veined, mostly alternate and entire, commonly sheathing the stem at the base and often with no distinction of blade and petiole. Flowers mostly 3-merons or 6-merous.

$\dagger$ CARPELS 1 Or More, DISTIXCT (united, at least partially, in Vallisneriaceae and others of the Naiadales, which are aquatic herbs, in Hydrocharitales and in some palms and Pandanales); parts of the usually imperfect flowers mostly unequal in number.

Inflorescence various, not a true spadix.

Leaves neither compound nor flabellate.

Flowers not in the axils of dry chaffy scales.

Endosperm mealy or fleshy : perianth of bristles or chaffy scales, or wanting; flowers monoecious, spicate or capitate.

Endosperm none, or very little. Order 1. PAxDaxales. Perianth rudimentary, of 4 small sepals in Potamogeton, or none. Order 2. Naradales. Perianth present. Carpels distinct. Carpels united.

Flowers in the axils of dry chaffy scales, arranged in spikes or spikelets.

Leaves pinnately or palmately compound, or flabellate; trees or shrubs.

Inflorescence a fleshy spadix, with or without a

Order 2. NaIAdales.

Order 3. Alismales.

Order 4. Hrdrocharitales.

Order 5. PoAles.

Order 6. ARECALES. spathe; or plants minute, floating free, the flowers few or solitary on the margin or back of the thallus.

t† CARPELS UXITED IXTO A COMPOCXD OVARY; palts of the usually complete flowers mostly in 3 's or 6's.

Seeds with endosperm.

Endosperm mealy; ovary mostly superior,

Endosperm fleshy or horny.

Seeds without endosperm, very numerous and minute; ovary inferior; flower's very irregular.

Order S. XYridiles. Order 9. Liliales.

\section{Order 1. PANDANĀLES.}

Our species aquatic or marsh plants, with narrow elongated leaves and very small, imperfect and incomplete flowers in spikes or heads. Periantl of bristles, or of chaffy scales. Orary 1, 1-2-celled. Endosperm mealy or fleshy.

The order takes its name from the tropical genus Pandanus, the socalled Screw-Pine.

\section{Family 1. TYPHÀCEAE J. St. Hil.}

\section{Cat-TaIL Famil.}

Marsh or aquatic plants with ereeping rootstocks, fibrous roots and glabrous erect, terete stems. Leares linear, flat, ensiform, striate, sheathing at the base. Flowers monoecions, densely crowded in terminal spikes, which are subtended by spathaceous, usually fugacious bracts, and divided at intervals by smaller bracts, which are caducous, the staminate spikes uppermost. Perianth of bristles. Stamens 2-7, the filaments connate. 
Ovary 1, stipitate, 1-2-celled. Ovules anatropous. Styles as many as the cells of the ovary. Mingled among the stanens and pistils are bristly hairs, and among the pistillate flowers many sterile flowers with elarate tips. Fruit nut-like. Endosperm copious. The family comprises only the following genus :

\section{TỲPHA L. Sp. Pl. 971. 1753.}

Characters of the family. [Name ancient.] About 10 species, widely distributed in temperate and tropical regions. Type species: Typha latifolia L.

1. Typha angustifòlia L. Sp. Pl. 971. 1753.

Typha domingensis Pers. Syn. Pl. 2: 532. 1807.

Typha angustifolia domingensis Griseb. Fl. Br. W. I. 512. 1864.

Stems slender, 1.5-3.5 m. high. Leaves narrowly linear, 3-20 mm, wide, erect, often as long as the sten; spikes light brown, the staminate and pistillate portions usually separated, the two together sometimes $0.5 \mathrm{~m}$. long, the pistillate, when mature, 6-16 mm. in diameter, and provided with bractlets; stigmas linear or linear-oblong; pollen-grains simple; fruit not furrowed, not bursting in water; outer coat of the seed not separable.

In fresh water or slightly brackish marshes, Great Bahama, Abaco, New Providence, Andros, Eleuthera, Watling's Island:-Bermuda; Jamaica; Cuba to Tortola and Trinidad; southern United States to Iatagonia; Europe; Asia. Referred by Dolley to Typha latifolia L. Cat-TaIL. SLAg.

\section{Order 2. NAIADÀLES.}

Aquatic or marsh herbs, the leaves various. Flowers perfect, monoecious or dioecious. Perianth rudimentary, or wanting. Parts of the flower mostly unequal in number. Carpels 1 or more, distinet and separate or united; endosperm none, or very little.

\section{Family 1. ZANNICHELLIÀCEAE Dumort.}

\section{Pondweed Fadilly.}

Peremnial plants, the foliage mostly submerged. Leaves very narrow or broad. Flowers monoecious or perfect, small, and inconspicuous. Perianth present or none. Stamens 1-4, with extrorse anthers. Carpels 1-seeded. Fruit drupe-like. Endosperm none. Four genera and sixty or more species, mostly inhabiting fresh water.

Perianth of 4 segments. Perianth wanting.
1. Potamogeton. 2. Ruppia.

\section{POTAMOGETON L. Sp. Pl. 126. 1753.}

Leares alternate or the uppermost opposite, often of 2 kinds, submerged and floating, the submerged mostly linear, the floating coriaceons, lanceolate, ovate or oval. Spathes stipular, often ligulate, free or connate with the base of the leaf or petiole, enclosing the young buds and usually soon perishing after expanding. Peduncles axillary, usually emersed. Flowers small, spicate, green or red. Perianth-segments 4, short-clatred, concave, valvate. Stamens 4, 
inserted on the elaws of the perianth-segments. Anthers sessile. Oraries 4, sessile, distinct, 1-celled, 1-oruled, attenuated into a short style, or with a sessile stigma. Fruit of 4 drupelets, the pericarp usually thin and hard or spongy. Seeds erustaceous, campylotropons, with an uneinate embryo thickened at the radicular end. [Greek, in allusion to the aquatic habitat.] About 65 species, mostly natives of temperate regions. Type species: Potamogeton natans L.

\section{Potamogeton heterophýllus Schreb. Spic. Fl. Lips. 21. 1771.}

Stems slender, compressed, much branched, sometimes $4 \mathrm{~m}$. long. Floating leaves pointed at the apex, mostly' rounded or subeordate at the base, 1.5$10 \mathrm{~cm}$. long, 8-30 mm. wide, 10-18-nerved, on petioles 2-10 cm. long; submerged leaves pellucid, sessile, linear-lanceolate, acuminate, cuspidate, rather stiff, $2-15$ cm. long, 2-16 $\mathrm{mm}$. wide, 3-9-nerved, the uppermost often petioled; peduncles often thickened upward, sometimes elustered; stipules spreading, obtuse, 1.5-2.5 cm. long; spikes 1.8-4 cm. long; fruit roundish or obliquely oboroid, 2-3 nm. long, 1-2 mm, thick, indistinctly 3-keeled; style short, obtuse, apical; apex of the embryo nearly touching the base, pointing slightly inside of it.

In fresh water pools and ditches, Great Bahama, Andros, Nes Providence, Great Exuma:-North America and Europe. PoxdweEd.

\section{RÚPPIA L. Sp. Pl. 127. 1753.}

Slender, widely branched aquatics with capillary stems, slender alternate 1-nerved leaves tapering to an aeuminate apex, and with membranous sheaths. Flowers on a capillary spadix-like peduncle, naked, consisting of 2 sessile anthers, each with 2 large separate saes attached by their backs to the peduncle, having between them sereral pistillate flowers in 2 sets on opposite sides of the rachis, the whole cluster at first enclosed in the sheathing base of the leaf. Stigmas sessile, peltate. Fruit a sinall obliquely-pointed drupe, several in each cluster and pedicelled; embryo oral, the cotyledonary end inflexed, and both that and the hypocotyl immersed. [Name in honor of Heinrich Bernhard Rupp, a German botanist.] In the derelopment of the plants the staminate flowers drop off and the peduncle elongates, bearing the pistillate flowers in 2 clusters at the end, but after fertilization it coils up and the fruit is drawn below the surface of the water. Three or four species, widely distributed, the following typical.

\section{\ 1. Ruppia marítima L. Sp. Pl. 127. 1753.}

Stems usually whitish, often $1 \mathrm{~m}$. long, the internodes irregular, naked. Leaves $2-8 \mathrm{~cm}$. long, $1.5 \mathrm{~mm}$. or less wide; sheaths with a short free tip; peduncles in fruit sometimes $0.3 \mathrm{~m}$. long; pedicels $t-6$ in a eluster, $1-3.5 \mathrm{~cm}$. long; drupes with a dark hard shell, oroid, about $2 \mathrm{~mm}$. long, of ten oblique or gibbous at the base, pointed with the long style, but varying much in shape; forms with very short peduncles and pedicels, and with broad, strongly marked sheaths occur.

In shallow salt and brackish water throughout the archipelago:-Coast of Eastern North America; Bermuda; Cuba to Trinidad; temperate and tropical regions of the Old World. Ditcu-grass. 


\section{Family 2. CYMODOCEACEAE Kerner.}

Manatee-grass Family.

Submerged marine perennial herbs, with long rootstocks. Leares linear, sheathing. Flowers monoecious or dioecious, solitary or cymose. Staminate flowers of 2 long-pedicelled anthers, the anthers 2-celled, longitudinally dehiscent. Pistillate flowers of 1 or 2 carpels, the 1 or 2 stigmas filiform. Fruit mut-like, 1-seeded. Two known genera, the following.

Stigmas 2:; leares mostly terete.

Stigma 1 ; leares flat.

1. Cymodocea.

2. Halodulc.

1. CYMOdòcéA Konig; Konig \& Sims, Ann. Bot. 2: 96.1805.

Leaves terete in our species, acute. Flowers dioecious. Pistillate flowers of 2 earpels; stigmas 2. Seed pendulous. [Named for Cymodoce, one of the Nereids.] Type species: Cymodocea acquorea Konig.

1. Cymodocea manatòrum Aschers. Sitzb. Ges. Naturf. Freunde, 1868: 19. 1868.

Rootstock branched, rooting at the nodes. Leares 0.4-3.2 dm. long, terete or nearly so, about $2 \mathrm{~mm}$. thick, their bases enclosed by membranous stipular sheaths 1-5 em. long.

Shallow salt water, Great Bahama, Abaco, Mariguana:-Bermuda; Florida; West Indies. MaNatee-grass.

\section{HALOdÙLE EndI. Gen. 1368. 1811.}

Marine perennials with jointed rootstocks and linear, flat sheathing leares, the small flowers dioecious. Perianth wanting. Staminate flower of 2 anthers unequally attached to a pedicel. Pistillate flower a solitary naked carpel; style short; stigma one, slender. Fruit globular, small. [Greek, referring to the saline habitat.] A few species of tropical and subtropical waters. Type species: Diplanthera tridentata Steinh.

1. Halodule Wrìghtii Aschers. Sitzb. Ges. Naturf. Freunde, 1868: 19. 1868.

Diplanthera. Trightii Aschers. in E. \& P. Nat. Pfl. Nachtr. 37. 1897.

Rootstock slender, nearly white, $3 \mathrm{dm}$. long or longer, copiously rooting at the nodes. Leares narrowly linear, $1 \mathrm{~mm}$. wide or less, acute, sheathing at the base, the scarious sheath 1-3 $\mathrm{cm}$. long; anthers about $6 \mathrm{~mm}$. long; fruit nearly black.

Shallow salt water, Rose Island, Eleuthera, Mariguana:-Florida ; Cuba ; Porto Rico; St. Thomas; St. Croix; Jamaica; Martinique; Panama.

\section{Order 3. ALISMÀLES.}

Aquatic or uliginous herbs, mostly acaulescent and with rootstocks. Leaves alternate, mostly basal, broad or narrow. Flowers perfect, monoecious or dioecious, clustered. Calyx of 3 sepals. Corolla of 3 thin petals, or sometimes wanting. Stamens several or many; filaments slender or short; anthers with inconspicuous connectives. Pistils few to many, distinct; orary superior; style stont or slender; stigma small. Fruit a head of achenes in the following family. 


\section{Family 1. ALISMÀCEAE DC.}

\section{Water-Plantain Familit.}

Aquatic or marsh herbs, mostly glabrous, with fibrous roots, scapose stems and basal long-petioled sheathing leaves. Inflorescence racemose or paniculate. Flowers pedicelled, the pedicels rerticillate and subtended by bracts. Receptacle flat or convex. Sepals 3, persistent. Petals 3, larger, deciduous, imbricated in the bud. Stamens 6 or more; anthers 2-celled, extrorse or deliscing by lateral slits. Oraries 1-celled, nsually with a single ovule in each cell. Carpels becoming achenes in fruit in our species. Seeds uncinate-curved. Embryo horseshoe-shaped. Endosperm none. Latextubes are found in all the species, according to Micheli. About 13 genera and 70 species, of wide distribution in fresh water swamps and streams.

Flowers perfect.

Flowers monoecious or dioecious.
1. Echinodorus. 2. Sagittaria.

\section{ECHINóDoRUs Richard; Engelm. in A. Gray, Man. 460. 1848.}

Perennial or annual herbs with long-petioled elliptic, orate or lanceolate, often cordate or sagittate leares, 3-9-ribbed and mostly punctate with dots or lines. Scapes often longer than the leaves; inflorescence racemose or paniculate, the flowers verticillate, each verticil with 3 outer bracts and numerous inner bracteoles. Flowers perfect; sepals 3, distinct, persistent; petals white, deciduous; receptacle large, convex or globose; stamens $12-30$; ovaries numerous; style obliquely apical, persistent; stigma simple. Fruit achenes, more or less compressed, coriaceous, ribbed and beaked, forming spinose heads. [Greek, in allusion to the spinose heads of fruit.] About 14 species, mostly natives of America. Type species: Echinodorus rostratus Engelm.

\section{Echinodorus cordifòlius (L.) Griseb. Kar. 109. $185 \overline{7}$.}

Alisma cordifolia L. Sp. Pl. 343. 1753.

Echinodorus rostratus Engelm. in A. Gray, Man. 460. 1848.

Leaves variable in form, often broady ovate, obtuse, cordate at the base, 15-20 $\mathrm{em}$. long and wide, but in smaller plants sometimes nearly lanceolate, acute at each end and but 2-5 cm. long; petioles angular, striate; seapes 1 or more, erect, 12-40 cm. tall; flowers 3-6 in the verticils; pedicels erect after flowering; sepals shorter than the heads; petals $4-6 \mathrm{~mm}$. long; stamens often 12 ; styles longer than the ovary; fruiting heads bur-like, 4-6 mm. in diameter; achenes about $3 \mathrm{~mm}$. long, narrowly obovate or falcate, 6-8-ribbed; beak apical, oblique, about one-half the length of the achene.

In sink-holes and flesh watel swamps. Andros. Cat Island, Watling's Island, Crooked Island, Acklin's Island, Fortune Islind. Great Exuma, Grand Turk:-Southeastern United States; Jamaica; Cuba to St. Thomas and Barbadoes. Bcr-head.

\section{SAGITTÀRIA L. Sp. Pl. 993. 1753.}

Perennials, mostly with tuber-bearing cr nodose rootstocks, basal longpetioled nerved leaves, the nerves connected by numerous reinlets, and ereet, decumbent or floating seapes, or the leaves reduced to bladeless phyllodes. Flowers monoecious or dioecious, borne near the summits of the scapes in rerticils of 3 's, perlicelled, the staminate usually uppermost. Verticils 3 -bracted. Sepals 
persistent, those of the pistillate flowers reflexed or spreading in our species. Petals 3, white, deciduous. Stamens inserted on the convex receptacle; staminate flowers sometimes with imperfect ovaries. Pistillate flowers with numerous distinct oraries, sometimes with imperfect stamens; orule solitary; stigmas small, persistent. Achenes numerous, densely aggregated in globose or subglobose hearls, compressed. Seed erect, curved. [Latin, referring to the arrow-shaped leares of some species.] About 40 species, natives of temperate and tropical regions. Type species: Sagittaria sagittifolia L.

\section{Sagittaria lancifòlia L. Pl. Jam. Pug. 27. 1759.}

Monoecious, glabrous; scape rigid, erect, stout or rather slender, striate, branched or simple, longer than the leares. Leaves lasceolate or oblonglanceolate, acute or acuminate at both ends, firm, entire, the blades 5-9-nerved, $0.2-0.4 \mathrm{~m}$. long, gradually narrowed into the long petioles, apparently pinnately reined; flowers numerous, $1-2.5 \mathrm{~cm}$. broad; bracts ovate or ovate-lanceolate, usually not united at the base, glabrous or nearly so, equalling or shorter than the fruiting pedicels; stamens numerous; filaments cobwebby-pubescent, equalling or longer than the anthers; achene narrowly oborate-cuneate, 2-3 mm. long, winged on both margins, its sides smooth, its beak tapering, oblique.

In fresh water or slightly brackish swamps and savannas, New Providence. Andros, Great Bahama :- Southern Enited States to Argentina; Jamaica; Cuba to Barbadoes. Laxce-leated SagitTaria.

\section{Order 4. HYDROCHARITÀLES.}

Floating or more or less emersed herbs, perennial by rootstocks or stolons. Flowers monoecious or dioecions, arising from spathes. Perianth of 2 dissimilar series of parts or the corolla wanting. Stamens 3-12. Carpels 3-15, nnited. Ovary inferior, with several parietal placentae or several-celled. Endosperm none.

Ovary 1-celled, with 2-5 parietal placentae; stigmas 3-5. Fam. 1. Elodeaceae. ovary 6-9-celled; stigmas 6-9.

Fam. 2. Hrdrocharitaceae.

\section{Family 1. ELODEÀCEAE Dumort.}

\section{TAPE-GRass FAMILY.}

Stoloniferous or rhizomatous aquaties, fresh-water or marine, submerged or the leaves sometimes floating. Leaves rarious, opposite, verticillate or fascicled. Flowers small. regular or nearly so, monoecions, dioecious or polygamons, enclosed in a spathe composed of 1-3 bracts. Calyx of the pistillate flowers with a tube and 3 lobes or sepals, that of staminate flowers often small or obsolete. Petals 3 or wanting. Stamens 3-12; filaments short or the anthers sessile. Pistil 1; orary 1-celled with 2-5 parietal placentae; orules usually numerous. Fruit small, indehiscent. Seeds without endosperm.

1. HALOPHILA Thouars; Gaud. in Freyc. Voy. 429. 1829.

Submerged or floating marine herbs, with slender rootstocks, branched stems and opposite or whorled, petioled leaves, the dioecious flowers solitary in spathes. Staminate flower peduncled, with 3 sepals, and 3 stamens with nearly 
sessile, extrorse anthers. Pistillate flower sessile, with 3 rery small sepals, a 1-celled, beaked ovary and a 3-parted style. Fruit enclosed in the spathe. Seeds numerous, the embryo with spirally bent cotyledons. [Greek, salt-loving.] About 7 species of tropical distribution. Type species: Caulinia ovalis $\mathrm{R}$. Br.

1. Halophila Engelmànni Aschers. in Neumayer, Anleit. Wiss. Beob. 368. 1875.

Rootstocks buried in sand or mud in water up to $4 \mathrm{~m}$. deep or deeper, branched, the slender stems $3-6 \mathrm{dm}$. long. Leaves linear-oblong to oblanceolate, mostly whorled at the ends of the branches, short-petioled, $1-3 \mathrm{~cm}$. long, 3-6 $\mathrm{mm}$. wide, obtuse or acutish at the apex, narrowed at the base, 3-nerved, finely and sharply serrulate; pistillate flowers axillary, enclosed by 2 lanceolate bracts, the hypanthium flask-shaped, about $\mathrm{s} \mathrm{mm}$. long, the sepals minute, the 3 stigmas filiform, about $3 \mathrm{~cm}$. long; staminate flowers unknown.

In salt water, often washed ashore, Abaco, North Bimini, Rose Island, Great Exuma :-Florida; Cuba. HaLOpHiLA.

\section{Family 2. HYDROCHARITÀCEAE Aschers.}

Frog's-Bit FAMILT.

Submerged or floating aquatic herbs, the leaves various. Flowers regu-lar, mostly dioecious, appearing from an involuere or spathe of 1-3 bracts or leaves. Perianth 3-6-parted, the segments either all petaloid or the 3 outer ones small and herbaceous, the tube adherent to the ovary at its base in the pistillate flowers. Stamens 3-12, distinet or monadelphous. Anthers 2-celled. Ovary 6-9-celled. Styles 6-9, with eutire or 2-cleft stigmas. Ovules anatropous or orthotropous. Fruit ripening under water, indehiscent. Seeds numerous, without endosperm. About 14 genera and 40 species of wide distribution in warm and temperate regions.

\section{THALÀssiA Banks; Konig \& Sims, Ann. Bot. 2: 96. 1805.}

Marine herbs, with elongated rootstocks. Leaves several at a joint, sheathing at the base, linear, elongated, the scape arising from the cluster of leares. Flowers dioecious, solitary in narrow spathes of two bracts, these united into a tube at the base. Staminate flowers long-pedicelled; perianth of 3 petaloid sepals; stamens 6; filaments rery short; anthers opening laterally. Pistillate flower nearly sessile in the spathe, eadneous; orary 6-9-celled, beaked. Fruit stalked, rugose or nearly echinate, opening by many valves. Seeds numerous. [Greek, referring to its growth in the ocean.] Two known species, the following typical.

1. Thalassia testùdinum Konig; Konig \& Sims, Ann. Bot. 2: 96. 1905.

Submersed, glabrous. Rootstocks ereeping, elongated; stems short, arising from the nodes of the rootstock; leaves 2-5, sheathing the stem; blades linear. strap-like, 0.5-3 dm. long, obtuse, withering-persistent; scapes solitary, central; fruit globose or oval, echinate-pubeseent, pointed.

In shallow salt water, Andros and New I'rovidence to Watling's Island and Inagua :-Bermuda; Florida; throughout the West Indies. TurtuE-Giss. Cittesby, 2: $p l, s 8$. 


\section{Order 5. POÀLES.}

Grasses and sedges. Monocotyledonous plants, mostly herbaceous, with leafy or leafless, usually simple, stems (culms), the leaves usually narrow and elongated, entire or minutely serrulate. Flowers mostly perfect, small, incomplete, in the axils of dry, chaffy scales (glumes) arranged in spikes or spikelets.

Fruit a carsopsis (grain) : culm mostly hollow. Fruit an achene; culm solid.

Fam. 1. POACEAE.

Fam. 2. CYPERACEAE.

Family 1. POÀCEAE R. Br.

Grass FAMIILY.

Annual or perennial herbs, of rarious habit, rarely shrubs or trees. Culms (stems) generally hollow, but occasionally solid, the nodes closed. Leares sheathing, the sheaths usually split to the base on the side opposite the blade; a scarious or cartilaginous ring, naked or hairy, rarely wanting, called the ligule, is borne at the orifice of the sheath. Inflorescence spicate, racemose or paniculate, consisting of spikelets composed of two to many 2-ranked imbricated bracts, called scales (glumes), the two lowest in the complete spikelet always empty, one or both of these sometimes wanting. One or more of the upper scales, except sometimes the terminal ones, contains in the axil a flower, which is usually enclosed by a bract-like awnless organ called the palet, placed opposite the scale and with its back toward the axis (rachilla) of the spikelet, generally 2keeled; sometimes the palet is present without the flower, and vice versa. Flowers perfect or staminate, sometimes monoecions or dioecious, sub. tended by 1-3 minute hyaline scales called the lodicules. Stamens 1-6, usually 3. Anthers 2-celled, rersatile. Ovary 1-celled, 1-ovuled. Styles 1-3, commonly 2 and lateral. Stigmas hairy or plumose. Fruit a seedlike grain (caryopsis). Endosperm starchy. About 3500 species widely distributed throughout the world, growing in water and on all kinds of soil. Those yielding food-grains are called cereals. The species are more numerous in tropical countries, while the number of individuals is much greater in temperate regions, often forming extended areas of turf.

A. Spikelets articulated below the empty scales or below a subtending involucre, or attached to and deciduous with the internodes of a readily disarticulating rachis, 1-flowered, or if 2-flowered the lower flower imperfect.

1. Fruiting scale and palet hyaline, thin, more delicate than the empty scales.

* Spikelets unisexual, the pistillate borne in the lower, the staminate in the upper, part of the same spike.

** Spikelets in pairs, one sessile and perfect, the other pedicellate and sometimes perfect, more commonly staminate or empty, or sometimes reduced to a single scale, or wanting.

Axis of the racemes continuous.

$A x i s$ of the racemes articulated.

Raceme single: pedicels and internodes of the rachis club-shaped.

Racemes in pairs or more; pedicels and rachis. internodes filiform.

2. Fruiting scale and palet never hyaline and thin, as firm as the emptr scales, or firmer.

1. Spikelets prickly.

2. Spikelets not prickly, but sometimes enclosed in a 1. Tripsacum. spiny involucre.

\section{Imperata.}

3. Schizachyrium.

4. Andropogon.

5. Nazia. 
* Spikelets in clusters of 3 or 4 , the empty scales forming a false iuvolucre.

* * Spikelets othel.wise arlanged.

f Spikelets not sunken in the rachis.

† Spikelets without a subtending involucre of bristles or valves.

$\$$ Scales awnless.

Fluiting seale chartaceous, the mar. gins hraline and flat.

Racemes in $\pi^{*}$ lols, or apploximate at the summit of the stem; outer scales of the spikelet with short hail's or glabrous.

Racemes on an elongated axis ; outer scales of the spikelet clothed with long hairs exceeding the spikelet.

Fruiting scale indurated, rigid, the margins inlolled and not hyaline. Opening in the fruiting scale turned toward the rachis.

Opening in the fruiting scale turned away from the rachis.

Spikelets plano-convex, arranged ill secund racemes, of 3 scales. Spikelets mnequally bi-convex, in panicles, or rarely in secund racemes, of 4 scales.

Culms herbaceous.

Culms woody.

$\S \S$ Scales, or some of them, awned or awnpointed.

Third scale awned $0 l^{\circ}$ awn-pointed, the second and fil'st scales awnless or with awns successively shorter.

Third scales awnless or awn-pointed, the second and first scales with awns successively longer.

$\frac{1}{4}$ spikelets with an involucre.

Inrolucre of bristles.

Bristles persistent; spikelets deciduous.

Bristles deciduous with the spikelets. Inrolucre of 2 spine-bearing ralves.

$\pitchfork+$ Spikelets sunken in one side of a flat thick rachis.

B. Spikelets articulated above the empty persistent scales, 1-many-flowered.

1. Stems herbaceous, hence annual: leaves scattered.

* Spikelets of 3 scales, 1 -flowered.

Flowering scale awned, closely embracing the grain. Amins 3

Awn 1.

Flowering scales awnless, the grain dropping from it when mature.

* Spikelets of 1 or more scales, usually with 2 or more flowers.

+ Spikelets in 2 rows, folming 1-sided spikes or l'acemes.

Spikelets wholly deciduous.

Spikelets not wholly decidnous.

1 pelfect flower in each spikelet.

To empty scales abore the flowers.

1-several empty scales above the flower.

Spikes in whorls or closely approxi. mate.

Second empty scale acute; awn of the flowering scales usually long.

Second emptr scale truncate or 2. toothed: flowering scales awnless ol* awn-pointed.

Spikes remote.

2-sereral perfect flowers in each splkelet.

Spikelets densely cromded; spikes digltate.

Snikes with terminal spikelets.

Spites witl the rachis extending berond the spikelets in a naked point.
6. Anthephora.

\section{Syntherisma.}

\section{Valota.}

9. Axonopus.

10. Paspalum.

11. Panicum.

12. Lasiacis.

13. Echinochlod

14: Oplismenus.

15. Chaetochloa.

16. Ccuchrousis.

17. Cenchrus.

18. Stcnotaphrum.

19. Aristida.

20. Huhlenicrgia.

21. Sporobolus.

22. Spartina.

23. Cupriolu.

24. Chloris

25. Eustachys.

26. Boutclour.

27. Eleusine.

28. Dactyloctenium. 
Spikelets alternate: spikes remote.

29. Leptochloa.

tf $S_{p}$ lkelets in open or spike-like panicles or lacemes,

Raclilla with hairs longel than the flowerlng scales and enveloping them; tall reed-like graisses.

Rachillil and flowering scales glabrous.

r'lowering scales 3-nerved; first "2 scales of the spikelets empty.

Inflorescence of long branches, along which the appressed spikelets are arranged on sliort pedicels: lateral nerres of the flowering scales pubescent.

Infforescence an open or contracted panicle, rarely racemose; lateral nerves of the flowering scale glabrous.

Flowering scales 5 -many-nerved ; first 2-6 scales of the spikelets empty.

I'lants not dioecious: spikelets flat, 2-edged.

rlants dioecious; spikelets complessed.

2. Stems woody, perennial; leaves on short branches which form dense whorls at the nodes.

30. Phragmitcs.

\section{Diplachne.}

32. Eragrostis.

33. Triola.

34. Distichtis.

35. Arthrostylidium.

1. TRÍPSACUM L. Syst. Nat. ed. 10, 1261. 1759.

Tall perenuial grasses with thick rootstocks, rather broad, flat leaves and monoecions flowers. Spikelets 1-2-flowered, in terminal or axillary, solitary or clustered, elongated spikes. Staminate spikelets in 2 's at each node of the upper part of the axis, 2-flowered, consisting of four scales, the two onter coriaceous, the tro inner thinner, the palet hyaline; stamens 3. Pistillate spikelets in excarations at the lower joints of the spike, 1-flowered; stigmas exserted; style slender. Grain partly enclosed in the excavations of the spikes, corered in front by the horny exterior lower scale. [Name from the Greek, in allusion to the polished outer scales.] About 7 species, natives of America, the following typical.

\section{Tripsacum dactyloides L. Syst. Nat. ed. 10, 1261. 1759.}

Rootstock 1.25-2.5 cm. thick; culms stout, erect, 1-2 m. tall. Leares smooth and glabrous, $3 \mathrm{dm}$. or more long, $1.25-3.75 \mathrm{~cm}$. wide; spikes terminal, and in the upper axils, solitary or 2-3 together, 1-1.25 dm. long; outer scales of the staminate spikelets linear and obtuse, $8 \mathrm{~mm}$. long, about $2 \mathrm{~mm}$. wide, faintly many-nerved; exterior scale of the pistillate spikelets borny, shining.

Scrub-lands. Inagua :-Thode Island to Nebraska, Florida and Texas : Hispaniola ; Trinidad: Ifexico; South Amerien. GaMA-GRAss.

2. IMPERÀTA Cirillo, Pl. Rar. Neap. 2: 26.1792.

Perennial grasses with elongated leares, the spikelets in dense terminal spike-like, silvery-hairy panicles. Spikelets 1-flowered, rarely 2-flowered, unequally pedicellate in pairs; scales 4 , thin, hyaline, arnless, the 2 outer ones empty, pilose, the third glabrous, usually empty, the fourth glabrous, subtending a perfect flower and its 2 -nerved palet. Stamens 1 or 2. Styles distinct, stigmas plumose. [Commemorates Ferrante Imperate, Italian naturalist of the sixteenth century.] About 5 species of tropical distribution. Type species: Lagurus cylindricus L.

1. Imperata brasiliénsis Trin. Mem. Acad. St. Petersb. VI. 2: 331.1832.

Culms $8 \mathrm{dm}$. high, or less; sheaths glabrous; leaf-blades erect, 1-4 dm. long, less than $1 \mathrm{~cm}$. Wide, the upper surface densely hirsute near the base, the 
apex long-acuminate, the base narrowed; panicle 1-2 dm. long, 2-3 cm. thick, obtuse, its branches erect or nearly so; spikelets $3-4.5 \mathrm{~mm}$. long, the subtending hairs about twice as long, nearly white.

Borders of savannas, Andros, New lrovidence and Eleuthera:-Florida; Cuba; continental tropical America, Silver-plude Grass.

\section{SCHIZACHỲriUM Nees, Agrost. Bras. 331. 1829.}

Annual or perennial grasses, the spikelets in spike-like racemes, terminating the culm or its branches. Rachis articulated, the internodes cup-shaped or appendaged, the basal callus barbed. Spikelets in pairs at each node of the rachis, one sessile, the other stalked, the sessile one dorsally compressed, 1-flowered, the flower perfect; first scale 2-keeled with infolded margins, the second awnless or bristle-tipped, the third 2-nerved or nerveless, the fourth usually 2-cleft, usually bearing a bent awn. Stalked spikelet usually flowerless. Stamens mostly 3. Styles distinct; stigmas plumose. [Greek, cleft-chaff.] Some 40 species, or more, of tropical and subtropical America. Type species: Andropogon brevifolius $\mathrm{S} w$.

Leaf-blades flat, or sometimes conduplicate when dry, never terete; racemes glabrous or nearly so.

Leaf-blades terete; racemes long-hairy.

1. S. semiberbe.

2. s. gracile.

1. Schizachyrium semibèrbe Nees, Agros. Bras. 336. 1829.

Andropogon semiberbis Kunth, Enum. 1: 489. 1833.

Perennial ; culms glabrous, branched, erect, $6-12 \mathrm{dm}$. high ; leaves glabrous; sheaths compressed, keeled; blades $1-3 \mathrm{dm}$. long, $2-5 \mathrm{~mm}$. wide; racemes narrow, 5-5 cm. long, the internodes of the rachis as long as the sessile spikelets or shorter, glabrous or nearly so; sessile spikelets $\overline{5}-\bar{i} \mathrm{~mm}$. long, the first scale glabrous or with a few short hairs, its infolded margins touching, the third anit fourth scales ciliate, the fourth 2-cleft nearly to the base, its awn $12-15 \mathrm{~mm}$. long; stalked spikelet of one hispidulous scale about $3 \mathrm{~mm}$. long, $\pi i t h$ an a $\pi \mathrm{n}$ about as long.

Pine-lands, New Providence:-Florida: Cuba: Hispaniola: I'orto Rico; Trinidad: South America. Recolded by Cokel as Andropogon tener Kunth. STIFl BEARD-GLASS.

2. Schizachyrium grácile (Spreng.) Nash, in Small, Fl. SE. U. S. 60. 1903. Andropogon gracilis Spreng. Syst. 1:284. 1825.

Perennial, tufted, glabrous, except the inflorescence; culms slender, branched, 2-6 dm. high. Sheaths striate; leaf-blades $2 \mathrm{dm}$. long or less, terete, less than $1 \mathrm{~mm}$. in diameter; racemes long-stalked, $3-5 \mathrm{~cm}$. long, the rachis clothed with long silky hairs; sessile spikelet 5-6 mm. long, the first seale chartaccous with hispidulous kecls, the second scale acute, the fourth 2-cleft, bearing an awn 13-20 mm. long; stalked spikelet of one short-awned seale 1-2.5 mm. long.

Pine-lands and scrub-lands, Abaco, Great Bahama, Andros, New I'rovidence, Elenthera, Cat Island, Nosth Caicos:-Florida; Jamaica; IIspaniola; Porto Rico; Cuba ; Guadaloupe. SLASADER BEARD-Grass.

\section{ANDROPÒGON L. Sp. Pl. 1045. 1753.}

Perennial grasses with usually long narrow leares, and terminal and axillary racemes. Spikelets in pairs at each norle of the jointed hairy rachis, one sessile, and perfect, the other with a pedicel and either staminate, empty or 
reduced to a seale, or none. Perfect spikelet consisting of 4 scales, the outer 2 coriaceous, the sceond keeled and acute, the two inner hyaline, the fourth more or less awned and subtending a palet and perfect flower. Stamens 1-3. Grain free. [Greek, in allusion to the bearded rachis.] About 150 species, widely distributed in tropical and temperate regions. Type species: Andropogon hirtum L.

Branches of the inflorescence crowded at the summit of the stem in 1 or more dense corrmbiform clusters.

Branches of the inflorescence scattered along the stem in a long narrow panicle.

1. A. glomeratis.

2. A. virginicus.

1. Andropogon glomeràtus (Walt.) B. S. P. Prel. Cat. T. I. 67. 1888.

Cinna glomerata Walt. Fl. Car. 59. $178 \mathrm{~s}$.

Andropogon tenuispatheus Nash, N. A. FI. 17: 113. 1912.

CuIns $1.5 \mathrm{dm}$. high or less, much branched, the ultimate flotrering branches forming oblong corymbiform clusters, the nodes of the secondary branches densely barbed. Sheaths keeled; leaf-blades $4 \mathrm{dm}$. Iong or less, $3-7 \mathrm{~mm}$. wide; spathes $2.5-3 \mathrm{~cm}$. long, glabrous; racemes in pairs, 1-2 cm. long; sessile spikelet 3-4 $\mathrm{mm}$. long, the a $\pi_{\mathrm{n}} 10-15 \mathrm{~mm}$. long; pedicellate spikelet a rudimentary scale, or wanting.

Pine-lands, scrub-lands, and sarannas, Abaco. Andros, New Proridence, Eleuthera, Acklin's Island, Fortune Island. Crooked Island, IIariguana, Inagua :-southeastern United States: MIexico: West Indies: tropical continental America. Referred by Dolley to Anatherum macrurum, following Grisebach. BcsHr BEARDGRASS. BED-GRASS.

\section{Andropogon virgínicus L. Sp. Pl. 1046. 1753.}

Culms tufted, 5-10 dm. tall, many times longer than the basal leaves; sheaths, at least the lower ones, more or less tuberculate-hirsute on the margins; leares $4 \mathrm{dm}$. long or less, more or less hirsute on the upper surface near the base; spathes $3-5 \mathrm{~cm}$. long, racemes generally in pairs, $2-3 \mathrm{~cm}$. long; sessile spikelet $3-4 \mathrm{~mm}$. long, the awn $10-15 \mathrm{~mm}$. long; pedicellate spikelet wanting or rarely present as a minute scale.

Pine-lands and white-lands, Abaco. Elbow Car. Great Bahamas, Great Sturrup Car. New Proridence, and Watling's Island:- Bermuda; Massachusetts to Missourl and southwald to Mexico; Cuba; Hispaniola; Jamaica. Virgixia Beard-grass.

5. NÀZIA Adans. Fam. PI. 2: 31, 581. 1763.

Annual grasses, diffusely branched, with flat leavez and 1-florrered deciduous spikelets, either solitary or in clusters of $3-5$ in a terminal spike. Scales of spikelet 2 or 3 , the outermost small or wanting, the second rigid and covered with hooked prickles, the third membranous, subtending a palet and perfect flower. [Name unexplained.] Two species, of tropical and temperate regions. Type species: Cenchrus racemosus $\mathrm{L}$.

1. Nazia alièna (Spreng.) Scribn. Bull. U. S. Dep. Agr. Agrost. 17: 28. 1899.

Lappago aliena Spreng. Neue Entdeck. 3: 15. 1822.

Tufted, 1-3 dm. high, the culms often rooting at the lower nodes, slender, glabrous. Sheaths glabrous; leaf-blades $2-8 \mathrm{~cm}$. long, $4 \mathrm{~mm}$. wide or less, their margins ciliate. Inflorescence 4-10 cm. long; spikelets $2-3 \mathrm{~mm}$. long; the second scale bearing prickles $0.5 \mathrm{~mm}$. long or less, the prickles with swollen opaque bases.

Sandr fields, Grand Turk Island and Ambergris Cay :-southwestern United States to the Argentine; Cuba to St. Thomas and Antigua. Pricklergrass. 
6. ANTHÈPHORA Sehreb. Beschr. Gras. 2: 105. pl. 44. 1810.

Tufted grasses, the culms often branched, erect or prostrate, the leares mostly flat, the 1-flowered spikelets in deciduous clusters of 3 or 4 , forming elongated terminal, slender spikes. Empty scales of the spikelets rigid, the first one indurated, large, involucre-like, the others acute or short-awned; upper and inner seales thin, the innermost enclosing a thin palet and a perfect flower, the stamens 3, the styles united at the base, the stigmas plumose. [Greek, flower-bearing.] Fire known species, of tropical distribution, the following typical.

1. Anthephora hermaphrodita (L.) Kuntze, Rev. Gen. Pl. 759. 1891.

Tripsacum hermaphroditum L. Syst. ed. 10, 1261. 1759.

Annual; culms 3-10 dm. long, rooting and branching at the lower nodes. Leaves flat, $7-20 \mathrm{~cm}$. long, 4-10 $\mathrm{mm}$. wide, glabrous or hirsute, acuminate; spikes 2-12 cm. long, continuous and dense, or interrupted below, about $4 \mathrm{~mm}$. thick, the slender rachis flexuous; elusters of spikelets about $7 \mathrm{~mm}$. long; lower scales ovate to elliptic, acute to acuminate, glabrous or hispidulous.

South Caicos:- West Indies and continental tropical America, commonly in waste and cultirated grounds. AxthepHors.

\section{SYNTHERÍSMA Walt. Fl. Car. 76. 17 Ss.}

Annual grasses, with flat leaves and spikelets borne in pairs or sometimes in 3 's, in secund spikes which are digitate or approximate at the summit of the culm. Spikes often purplish. Scales of the spikelet 4, sometimes 3 by the suppression of the lowest one; the fourth or innermost seale chartaceous, subtending a palet of similar texture and a perfect flower. Stamens 3. Stigmas plumose. [Greek, erop-making, in allusion to its abundance.] Species about 20, widely distributed in temperate and tropical regions. Type species: Syntherisma praecox Wait.

Rachis of the racemes with the angles naked, not winged; first scale of the spikelet usually wanting.

Rachis of the racemes with the lateral angles broadly winged, thus making it appear flat; first scale of the spikelet usually present.

Spikelets about $2.5 \mathrm{~mm}$. long, one fifth as wide as long. acuminate.

Spikelets 3-3.5 mm. long, one fourth as wide as long or more. acute.

1. S. filiformis.

\section{S. digitata.}

3. S. sanguinalis.

1. Syntherisma filifòrmis (L.) Nash, Bull. Torrey Club 22: 420. 1895.

Panicum filiforme L. Sp. Pl. 57. 1753.

Milium paniceum Sw. Prod. 24. 1788.

Syntherisma paniceum Nash, N. A. Fl. 17: 152. 1912.

Culms 1.5-7 dm. tall. Sheaths at least the lower ones hirsute; leares $3-20$ $\mathrm{cm}$. long, $1-4 \mathrm{~mm}$. wile; racemes $2-5,2-10 \mathrm{~cm}$. long, erect or ascending; spike. lets about $1.8 \mathrm{~mm}$. long, $0.75 \mathrm{~mm}$. wide, elliptic, acute, in pairs, the first scale manting, the second 3 -nerred, the third 7 -nervel, the fourth scale deep chestnutbrown at maturity.

White-lands, sea-beaches, and roadsides, Andros, New Providence, and Cat Island :- New Hampshire to Michigan, Florida and Mexlco; Cuba; Hispanlola; Jamaica; Porto Rico. Slexider Friger-griss. 
2. Syntherisma digitàta (Sw.) Hitchc. Contr. U. S. Nat. Herb. 12: 142. 1908.

Mitium digitatum Sw. Prohl. 24. 1788.

Digitaria horizontalis Wille. Enum. 92. 1809.

Panicum horizontalc Meyer, Prim. FI. Esseq. 54. 1818.

Syntherisma setosa Nash, Bull. Torrey Club 25: 300. 1898.

Culms 4-10 $\mathrm{im}$. long, branched, tufted, at length decumbent below and rooting at the lower nodes. Leaves more or less densely hirsute, $2-12 \mathrm{~cm}$. long, $2-7 \mathrm{~mm}$. wille; racemes several, $3-14 \mathrm{~cm}$. long, whorled or alternate or approximate in pairs, wilely spreading; rachis very narrow; spikelets in pairs, about $2.5 \mathrm{~mm}$. long, lanceolate, acuminate; first scale minute, glabrous; second scale 3-nerved, appressed-pubescent; third scale 7 -nerved, also appressedpubescent; fruiting scale nearly $2 \mathrm{~mm}$. Iong, shorter than the third, elliptic, greenish when mature.

Sandy places and cultirated ground, Berry Islands, Andros, New Providence, Great Exuma, Eleuthera, Watling's Island, Long Islaud:- Florida: throughout tropical America. Socthern CRAB-gRASS.

\section{Syntherisma sanguinàlis (L.) Dulac, Fl. Haut. Pyr. 77. 1867.}

Panicum sanguinale L. Sp. P1. 57. 1753.

Digitaria sanguinalis Scop. Fl. Carn. ed. 2, 1: 52. 1772.

Digitaria marginata Link, Enum. Hort. Berol. 1: 102. 1821.

Digitaria fimbriata Link, Hort. Berol. 1: 226. 1827.

Panicum fimbriatum Kunth, Rer. 33. 1829.

Syntherisma marginatum Nash, N. A. Fl. 17: 154. 1912.

Culms $8 \mathrm{dm}$. long or less, finally branched, prostrate at the base and rooting at the lower nodes. Lower leaf-sheaths densely papillose-hirsute; blades 2-8 cm. long, 5-10 $\mathrm{mm}$. Wille, erect or ascending, glabrous or more or less pubescent; racemes $2-9,2-12 \mathrm{~cm}$. long, erect or ascending, alternate, in pairs or whorls; spikelets $3-3.5 \mathrm{~mm}$. long, about $0.8 \mathrm{~mm}$. wide, lanceolate, very acute, in pairs; first seale small, glabrous, the second and third appressed-pubescent with long hairs, the second one 3-nerved, the third slightly exceeding the flowering scale, 7 -nerver, the pubescence usually becoming widely spreading, the fourth one lanceolate, rery acute, yellowish white at maturity.

Sandy places, roadsides and waste places, Great Bahama, Abaco. New Proridence, Eleuther, Long Island, Elbow Cay, Fortune Island, Acklin's Island, Inagua :temperate and tropical America. Native of the old World. Referred by Hitchcock to Panicum Linkianum Kth. Larger Crab-grass.

\section{S. VALòta Ađans. Fam. Pl. 2: 495. 1763.}

Tall perennial grasses, with flat leaves and large terminal pubescent panicles. Spikelets lanceolate, acute or acuminate; scales 4, the 3 outer ones membranous, empty, the first minute or rudimentary, the second silky-pilose and ciliate, the fourth one shorter, glabrous, shining, chartaceous. [Perhaps in honor of P. Vallot.] Sereral species, of narm temperate and tropical America, the following typical.

1. Valota insulàris (L.) Chase, Proc. Biol. Soc. Wash. 19: 18s. 1906.

Andropogon insulare L. Syst. Nat. er. 10, 1304. 1759.

Panicum leucophaeum H.B.K. Nov. Gen. \& Sp. 1: 97. 1815.

Panicum insulare Meyer, Prim. Fl. Esseq. 60. 1818.

Trichachne insularis Nees, Agrost. Bras. S6. 1829.

Culms erect, slender, $1-1.6 \mathrm{~m}$. high, clustered. Leares $3 \mathrm{dm}$. long or less, 1-2 cm. wide, acuminate, glabrous or their sheaths pubescent; panicle narrow, often $3 \mathrm{dm}$. long, little, if any more than $3 \mathrm{~cm}$. thick; spikelets $4-6 \mathrm{~mm}$. long, 
acuminate; second and third scale 3-nerved, long-hairy; fruiting scale chestnutbrown.

Sandy soil and cultivated ground, Abaco, Andros. New Providence, Eleuthera, Great Exuma, Cat Island, Long Cay, Acklin's Island, Inagua, and Anguilla Isles :Florida; Bermuda: West Indies and continental tropical America. Referred by Dolley to Tricholacna leucophaca. SILKY-GRAss.

\section{AXONÒPUS Beauv. Agrost. 12. 1812.}

Pereunial grasses, with the culns usually rooting at the lower nodes, with flat leares and 1-flowered spikelets, borne singly in 2 rows in one-sided spikes which (in our species) are disposed in a single pair at the summit of the culm, or sometimes with an additional one a short distance below. Spikelets oblong to lanceolate, convex on the outer surface, flat on the inner. Scales 3 , the outer 2 membranous, the inner one firm and with its opening turned toward the rachis, substending a perfect flower. Stamens 3. Styles separate. Stigmas plumose. Grain free. [Greek, foot-axis.] About 12 species, of warm temperate and tropical regions, the following typical.

\section{Axonopus compréssus (Sw.) Beanr. Agrost. 12, 154. 1812.}

Mitium compressum Sw. Prodr. 24. 1788.

Paspalum tristachyon Lam. Tab. Eneycl. 1: 176. 1791.

Anastrophus compressus Schlecht.; Nash, in Small, Fl. SE. U. S. 79.1903.

Stolons numerous, leafy, sometimes $6 \mathrm{dm}$. long. Culms $1.5-6 \mathrm{dm}$. tall, slender, compressed, glabrous; sheaths loose; leaves glabrous, sometimes sparsely ciliate, obtuse, those of the culm $5-10 \mathrm{~cm}$. long, 4-6 mm. wide, those of the stolons about $2.5 \mathrm{~cm}$. long, 2-4 mm. Tide; spikes 2-5, 2.5-5 $\mathrm{cm}$. long, approximate at the summit of the long and slender stalk; spikelets not crowded nor secund, about $2 \mathrm{~mm}$. long, acute.

Grassy places, New Providence:- Virginia to Florida and Texas: the Test Indies and continental tropical America. FLat Jorit-grass.

\section{PÁSPALUM L. Syst. Nat. ed. 10, 85.5. 1759.}

Perennial grasses, various in habit, with generally flat leaves and 1 -flowered spikelets, borne singly or in pairs in 2 rows on 1-sided spikes, which are single, in pairs or panicled. Spikelets oblong to orbicular, flat on the outer surface, convex on the inner. Scales 3, the outer ones membranous, the inner one indurated and subtending a palet and perfect flower. Stamens 3. Styles separate. Stigmas plumose. Grain ovoid or oblong, free. [An ancient Greek name for some grass, used by Hippocrates.] About 160 species, of wide distribution in tropical and temperate regions, most abundant in America. Type species: Panicum dissectum. L.

Racemes single, or, if more than 1 , distant, never in pairs.

spikelets wingless.

Spikelets $1.5 \mathrm{~mm}$. long or less; racemes usually short, rarely exceeding $4 \mathrm{~cm}$. long.

Spikelets singly disposed.

Spikelets normally in pairs.

1. P. I'oirctii.

Spikelets appressed-pubescent or glabrous.

Primary pedicel much shorter than its spikelet.

Primary pedicel nearly as long as its spikelet. Spikelets glandular-pubescent. Spikelets exceeding $1.5 \mathrm{~mm}$. long; lacemes long, rarely
under $6 \mathrm{~cm}$.

2. I. caspitosum.

3. P. portoriernse.

4. T. Simpsoni. 
Racemes 6 or fewer: blades usually $4-8 \mathrm{~mm}$. wlde or less; stems slender.

Racemes numerous, usually 10 or more: blades up to $1 \mathrm{~cm}$. Wlde or more; stems stout.

Rachis of the spikelet glabrous; sheaths not nodulose.

Rachis sparingly pilose; lower sheaths nodulose.

Spikelets with a fimbriate wing.

Racemes in pairs at the summit of the stem; spikelets singly disposed.

Racemes long and slender; spikelets less than $2 \mathrm{~mm}$. long. nearly orbicular.

Racemes short and stout: spikelets orer $2 \mathrm{~mm}$. long, ovate. Spikelets pubescent, ovate, $2.5-3 \mathrm{~mm}$. long.

Spikelets glabrous, ovate-lanceolate, 3-4 mm. long.

5. P. glabrum.

6. $P$. secans.

7. P. millegrana.

8. P. fimbriatum.

9. P. conjugatum.

10. P. ristirhum.

11. P. veryinatum.

\section{Paspalum Poirètii R. \& S. Syst. 2: 878. 1817.}

Perennial; culins densely tufted, $5 \mathrm{dm}$. high or less, slender, glabrous, simple, or sometimes branched at the base. Leaves 5-10 $\mathrm{cm}$. long, 3-6 mm. wide, glabrous or sparingly hirsute, or ciliate; racemes $1-3$, erect or ascending, 2-4 cm. long, the rachis about $0.5 \mathrm{~mm}$. nide; spikelets $1.5 \mathrm{~mm}$. long, $0.9 \mathrm{~mm}$. wide, elliptic, appressed-pubescent, singly disposed, the scales 3 -nerved, the fruiting one oval. PALCM.

Savanna, Andros:-Cuba; Hispaniola; Porto Rico; Jamaica. Polret's Pas-

\section{Paspalum caespitòsum Fluege, Gram. Monog. 161. 1810.}

Paspalum Blodgettii Chapm. Fl. S. U. S. 5il. 1860.

Tufted; culms slender, 3-6 dm. high. Leaves glabrous, narrowly linear, flat, 5-20 $\mathrm{cm}$. long, $3-7 \mathrm{~mm}$. wide, erect or nearly so, with glabrous sheaths; racemes $2-6$, erect, $1-5 \mathrm{~cm}$. long, the rachis rery narrow; spikelets in pairs, a little less than $2 \mathrm{~mm}$. long and nearly $1 \mathrm{~mm}$. wide, elliptic, the first scale manting, the second and third sparingly papillose-pubescent with appressed hairs, 3-nerved, the fruiting scale yellowish white.

Pine-lands, scrub-lands, and clearings, Abaco. Great Bahama, Berry Islands. South Bimini, Andros, New Providence, Eleuthera, Cat Island, Great Exuma, Inagua, and the Anguilla Isles:-Florida; Cuba to Porto Rico; Jamaica. Slender PasPALCJP.

3. Paspalum portoricénse Nash, Bull. Torr. Club 30:37т. 1903.

Culms tufted, glabrous, very slender, spreading, $6 \mathrm{dm}$. long or less, simple or rarely branched. Leares flat, 5-12 $\mathrm{cm}$. long, 3-5 mm. wide, with a few long hairs at the base; racemes $1-3$, very slender, $2-6 \mathrm{~cm}$. long, ascending; spikelets geminate, oblong-elliptic, acute, about $1.8 \mathrm{~mm}$. long, $0.8 \mathrm{~mm}$. wide, glabrous, about as long as the primary pedicel, the first and second scales 3-nerved.

Crooked Island (according to Ifitchcock); Porto Rico.

4. Paspalum Simpsoni Nash, Bull. Torr. Club 24: 39. 1897.

Paspalum gracillimum Nash, in Small, Fl. SE. U. S. 73. 1903.

Tufted, similar to $P$. caespitosum; culms slender, 4-8 dm. high. Basal sheaths hirsute, the upper glabrous; leares flat, linear-lanceolate, 4-10 cm. long, $3-10 \mathrm{~mm}$. Wide, glabrous on both sides, the margins ciliate; racemes $3-\overline{5}$, spreading, 2-7 cm. long, the rachis narrow; spikelets in pairs, obovoid, about $1.5 \mathrm{~mm}$. long, and $0.8 \mathrm{~mm}$. thick, the first scale ranting, the second and third 3-nerved, densely pubescent with short glandular hairs.

Scrub-lands, white-lands, and clearings, Great Bahama, Abaco, Berry Islands, Andros, New Providence, Cave Cay, Watling's Island, Little San Salvador, Acklin's Island, Fortune Island, Mariguana, and Inagua:-Florida; Cuba; Jamaica; Porto Rico.' Simpson's PASPALUM. 
5. Paspalum glàbrum Poir. in Lam. Enç̣cl. 5: 30. 1804.

Paspalum Helleri Nash, Bull. Torr. Club 30: 376. 1903.

Culms tufted, slender, glabrous, erect or ascending, simple, 3-10 dm. high. Leaves 5-20 cm. long, 3-8 mm. wide, roughish-margined, with a few hairs at the base of the blade; racemes $2-6$, narrow, $10 \mathrm{~cm}$. long or less, erect or spreading; spikelets many, oral, glabrous or pubescent, $1.7-2 \mathrm{~mm}$. long, obtuse.

Moist grounds, Abaco and Great Sturrup Cay to Andros, North Caicos, Grand Turk and Inagua:-Cuba to Tortola and Barbadoes; Jamaica. Referred by Hitchcock to $P$. nanum C. Wright.

6. Paspalum sécans Hitch. \& Chase, Contr. U. S. Nat. Herb. 18: 319. 1917.

Perennial, forming clumps; culms simple, erect glabrous, 1-2 m. tall. Leafsheaths with a row of white hairs at the mouth, the blades much elongater, sometimes $1 \mathrm{~m}$. long, 5-10 mm. wide, flat, but in drying more or less inrolute, their margins serrulate; racemes 5-20, slender, spreading, 5-15 cm. long; rachis glabrous; spikelets glabrous, about $2.5 \mathrm{~mm}$. long, $1.5 \mathrm{~mm}$. wide.

Moist soil, New Frovidence, Acklin's Island, and Inagua:-Cuba ; Porto Rico ; Barbadoes: Jamaica; St. Croix; Antigua. Referred by Nash to P. Schreberianum, TAly PASPALCM.

7. Paspalum millegràna Schrad. in Schultes, Nant. 2: 175. 1824.

Paspalum Underwoodii Nash, Bull. Torrey Club 30: 375. 1903.

Culms stout, 1-1.5 m. high, often elustered, smooth. Lower sheaths nodulose, overlapping; leaves elongated, roughish, 5-10 mm. wide, commonly pubescent above; racemes many, close toegther, ascending or nearly erect, 4-10 $\mathrm{cm}$. long; spikelets glabrous, suborbicular or oborate-orbicular, about $2 \mathrm{~mm}$. long, usually purplish; rachis sparingly pilose.

New Providence (according to Hitchcock and Chase) :-Jamaica: Cuba : Porto Rico; Tobago; Trinidad to southern Brazil. UNDERTtood's Paspales.

8. Paspalum fimbriàtum H.B.K. Nor. Gen. \& Sp. 1: 93.1815.

Annual; culms tufted, glabrous, often branched below, 3-8 dm. high, the sheaths hirsute or glabrous. Leares $1-2.5 \mathrm{dm}$. long, $1.5 \mathrm{~cm}$. wide or less, eiliate; racemes $2-6$, erect or ascending, $2.5-7 \mathrm{~cm}$. long; spikelets mostly in pairs, suborbicular, $2.5-3.5 \mathrm{~mm}$. long, the scales papillose, 3-nerved, the lower one with a broad cleft wing, with ciliate segments, the next with a similar partial wing, the fruiting scale 7 -ridged.

Wraste and cultivated grounds, Andros, New Providence, Eleuthera, Cat Island: - Cuba, IIspaniola and Porto Rico to Trinidad; Jamaica; South America. Frisged PASPALUa.

\section{Paspalum conjugàtum Berg. Acta Helv. 7: 129. 1762.}

Smooth and glabrous. Culms compressed, 2-9 dm. tall, finally decumbent at the base and rooting at the lower nodes; leares $4-16 \mathrm{~cm}$. long, $4-12 \mathrm{~mm}$. wide; racemes in pairs, slender, often curved, spreading or ascending, 5-12 $\mathrm{cm}$. Iong, the rachis straight, or flexuous toward the apex, $0.6-0.8 \mathrm{~mm}$. broad; spikelets crowded, much compressed dorsally, singly disposed, $1.5 \mathrm{~mm}$. long, 1-1.2 mm. broad, apiculate, the 2 outer scales 2-nerved, the nerves marginal, the first seale ciliate on the margins with very long lax hairs, the third scale smooth, white.

Grassy places along roads, apparently introduced, New Providence:-Bermuda : Southern Inited States: Cuba to St. Thomas and Barbadoes: Jamalca; continental tropical America; Old World tropics. Two-splked Paspalua. 
10. Paspalum dístichum L. Pugil. Pl. Jam. 5. 1759.

Culms 1-6 dm. tall, from a long stout rootstock; sheaths compressed, keeled, usually crowded and overlapping, especially at the base and on the innovations, glabrous, or more or less hairy on the margins; leaves commonly less than 1 dm. long, 3-6 mm. wide, nsually glabrous; racemes terninal, in pairs, ascending, 2-5 cm. long; spikelets singly disposed, ovate, $2.5-3 \mathrm{~mm}$. long, acute, the 2 oufer scales firm, 5-nerved, rarely 7 -nerved, the first scale glabrous, the second appressed-pubescent, the third apiculate, pubescent at the apex.

Fresh water marsl. New Providence:-Permuda: Virginia to Florida, Texas and California, and north on the coast to Oregon: the West Indies and tropical America. Ilitcheock's plant from Fortune Island, referred to this species, proves to be $t:$ vaginatum SW. JolNT-GRASS.

\section{Paspalum vaginàtum Sw. Prodr. 21. 17 S8.}

Culns 2-6 dm. tall, from a long stout rootstock; sheaths compressed, keeled, nsually crowded and overlapping, at least at the base and on the innorations, glabrous; leaves folded, or involute when dry, $1.5 \mathrm{dm}$. long or less, 2-4 $\mathrm{mm}$. wide, glabrous, or sparingly hairy; racemes terminal, usually in pairs, rarely more or but a single one, erect or ascending, 3-7 cm. long; spikelets singly disposed, ovate-lanceolate, acnte, $3-4 \mathrm{~mm}$. long, the 2 outer seales glabrous, thin, the first scale 4-nerved, the lateral nerves approximate at the margin, the milnerve suppressed, the second scale 5-nerved, the lateral nerves rather near together, the third scale glabrous at the apex or with 2 or 3 hairs.

Borders of marshes, New Providence, Watling's Island, Fortune Island, and Inagua :-Bermuda; southern United States; West Indies; tropical continental America. SHEATHED PASPALuM.

Paspalum sp. Hitchcock and Chase (Contr. U. S. Nat. Herb. 18: 316) record a plant of this genus from Inagua, not certainly referable to any known species.

\section{PANICUM L. Sp. Pl. 55. 1753.}

Annuals or perennials, various in habit, with open or contracted panicles. Spikelets 1-2-flowered, when 2-flowered the lower one staminate only. Scales 4 , the 3 lower membranous, empty, or the third with a staminate flower, varying in the same species; the inner or fourth scale chartaceous, shining, enclosing a palet of similar texture and a perfect flower. Awns none. Stamens 3. Styles distinct. Stigmas plumose. Grain free, enclosed in the hardened fruiting scale and palet. [Old Latin name for some grass, probably the cultivated sorghum, referring to its panicle, taken from Pliny.] About 500 species, in temperate and tropjeal regions. Type species: Panicum miliaceum $\mathrm{L}$.

A. Palet little or not at all enlarged when mature.

1. Inflorescence consisting of spike-like often 1-sided branches or racemes.

Spiliplets singly disposed, in 2 distinct rows, on very short equal pedicels; first scale truncate.

Spikelets otherwise arranged, on mequal pedicels; 1. 1 . geminatum. first scale acute or obtuse, never truncate.

Fourth scale of the spikelet transversely rugose. Panicle branches terminating with a spikelet, no prolongation.

Pedicels shorter than the spikelets.

Stems all fertile, the nodes naked, or occasionally sparsely pubescent.

Outer scales of the spikelet with no cross-veinlets; stems often rooting at the lower nodes.

2. P. adspersum

Onter scales of the spikelet with manifest cross-reinlets : stems rarely rooting at the lower nodes.

3. P. fasciculatum. 
Fertile stems tall and stout, the sterile long and creeping, the nodes densely barbed.

Some of the pedicels equaling or longer than the spikelets.

Panicle branches extending beyond the spikelet in a sterile rudiment.

Spikelets less than $2 \mathrm{~mm}$. long.

Spikelets $2 \mathrm{~mm}$. long or more.

Fourth scale of the spikelet smooth.

2. Inflorescence usually a diffuse, rarely narrow panicle, its branches not spike-like.

Fourth scale of the spikelet transversely rugose.

Fourth scale smooth.

Annuals, or if perennials, not with tufts of leares at the base of the stem.

Spikelets lanceolate to ovate, acute to acuminate, glabrous: leaf-blades elongated, linear.

Plants tufted, no long creeping rootstocks; spikelets $3 \mathrm{~mm}$. long or less.

Panicle narrow, dense, its branches appressed.

Stems slender, $6 \mathrm{dm}$. tall or less : hasal sheaths round.

Stems stout, usually $1 \mathrm{~m}$. tall or more: basal sheaths compressed, keeled, equitant.

Panicle broad at maturity, loose and open, its branches sprearing or ascending.

First scale one half as long as the spikelet or more, broadiy orate, acute.

Sheaths glabrous: stems slender. 11. P. diffusum.

Sheaths densely papillose-hispid; stems stont.

First scale rarely exceeding one fourth the length of the spikelet, orbicular, truncate or rounded at the apex.

Plants with long stout rootstocks: leaf

blades rery thick and firm; spikelets 4-5 $\mathrm{mm}$, long: seacoast grass.

Spikelets elliptic. pubescent; leaf-blades broad ovate-lanceolate.

Perennials. with basal tufts of leaves.

Spikelets $1.5 \mathrm{~mm}$. long. glabrous.

Spikelets $2 \mathrm{~mm}$. long, pubescent.

Primary leaf-blades $5 \mathrm{~mm}$. wide or less, strongly striate; spikelets broadly oboyoid.

Primary leaf-blades up to $12 \mathrm{~mm}$. wide; spikelets ellintic.

B. Palet much enlarged when mature

4. I'. barbinode.

5. P. пахітит.

6. P. distantiflorum.

7. P. Chapmani.

S. P. laxum.

5. I'. maximum.

10. P. condensum.

12. P. Ghicsureghtii.

13. P. dichotomiflorum.

14. P. amarulum.

15. P. trichoides.

16. P. cocrulesecns.

17. P. neuranthum.

1.8. P. nitidum.

19. P. exiquiflorum.

1. Panicum geminàtum Forsk. Fl. Aegypt.-Arab. 18. 1775.

Aquatic. Culms 6-12 din. long, usually elothed with sheaths below; leaves glabrous, $2.5 \mathrm{dm}$. long or less, $6-10 \mathrm{~mm}$. nide; racemes 10-20, one-sited, the rachis broadly winged, appressed, 2-4 cm. long; spikelets about $2.5 \mathrm{~mm}$. long, ovate, acute, glabrous, singly disposed in 2 rows, the first scale broader than long and clasping the spikelet at its base, truncate at the apex, the fourth scale transversely wrinkled.

Wet or moist places, Great Bahama, Ahaco, Berry Islands, New Providence, Eleuthera, Cat Island, Great Exuma, I,ong Island, Fortune Island, Crooked Island, and Inagua :- Bermuda; southern Florida and Texas; in tropical regions generally. Erroneously referred, by authors, to P'. paspaloides P'ers. Watrik-grass.

2. Panicum adspérsum Trin. Gram. Pan. 146. 1826.

Culms ascending or spreading, rooting at the lower notes, brancherl, compressed, glabrous, 3-10 dm. long. Sheaths ciliate above; leaf-blades 5-20 $\mathrm{cm}$. 
long, 8-20 mnı. wide, glabrous, or sometimes ciliate at the base, abruptly acuminate, rough-margined; panicles $6-15 \mathrm{~cm}$. long, composed of many spikelike racemes; spikelets short-stalked, 3-4 $\mathrm{mm}$. long, 1.5-1.5 mm. wide, fusiform; first scale acute, glabrous, 5-nerved, about one-third as long as the whole spikelet; second and third scales 5-7-nerved, hispid at least above, rarely glabrous.

New Providence and Anguilla Isles:-Florida; Cuba to Porto Rico, Tortola and Martinique; Jamaica. Loose Paxic-grass.

3. Panicum fasciculàtum Sw. Prodr. 22. 1795.

Panicum fuscum Sw. Prodr. 23. 1788.

Panicum flavescens Sw. Prodr. 23. 1788.

Panicum paniculatum Nash, Bull. Torr. Club 30: 381. 1903.

Perennial; culns glabrous or somerhat pubescent abore, slender or rather stout, erect, spreading or ascending, $0.3-1 \mathrm{~m}$. long. Leaves flat, $3 \mathrm{dm}$. long or less, $0.6-2 \mathrm{~cm}$. wide, glabrous or more or less pubescent, the sheaths sometimes pilose or hispid; panicles $\overline{0}-15 \mathrm{~cm}$. long, the branches raceme-like, ascending; spikelets conmonly approximate, short-stalked, brown, 2-2.5 min. long, glabrous, the outer scales reticulate-reined, the fourth scale rugose.

Waste places, Grand Turk Island:-southern Florida and Texas; the West Indies and tropical continental America. DIOWN PANIC-GRASS.

4. Panicum barbinòde Trin. Mém. Acad. St. Petersb. VI. Sci, Nat. 1: 256. 1834.

Sterile culms 1-2 m. long, rooting at the nodes, the fertile ones erect, 6-10 dm. tall or more, the nodes densely barbed; leaf-sheaths often overlapping, papillose-hirsute; blades 1-3 dm. long, glabrous or pubescent, $6-16 \mathrm{~mm}$. wide; panicle 1.5-2 dm. long, its branches spreading or ascending; spikelets about $3 \mathrm{~mm}$. long, glabrous.

New Froridence and Acklin's Island:-Bermuda; Florida to Texas; the West Indies and tropical America and Old World tropics. Has been confused with $P$. molle Sw. PARA Grass.

\section{Panicum máximum Jacq. Ic. Pl. Rar. 1: 2, pl. 13. 1791-6.}

Culm 1-2 m. tall or more, leafy; leaf-sheaths overlapping, glabrous, or tuberculate-pubescent; blades elongated, $1-4 \mathrm{~cm}$. wide, glabrous; panicle 3-6 $\mathrm{dm}$. long, its branches erect or nearly so, very long; spikelets glabrous, $3-4 \mathrm{~mm}$. long, the fourth scale transversely rugose.

In swales and along swamps, New Providence, Eleuthera. Fortune Island, Turks Islands, and Inagua :- Bermuda: Georgia and Florida to Texas; the West Indies and continental America. Referred by Coker to $P$. elephantipes Nees. Guinea GrAss.

\section{Panicum distantifiòrum A. Rich. in Sagra, Hist. Cuba 11: 304.1850.}

Culms glabrous, tufted, slender, wiry, branched, 6-8 dm. high. Sheaths compressed; leaf-blades 1-3 dm. long, only 1 or $2 \mathrm{~mm}$. wide, involute in drying; panicles narrow, $2-7 \mathrm{~cm}$. long, their branches nearly erect; spikelets elliptic, glabrous, acute, about $1.5 \mathrm{~mm}$, long; first scale about one-half as long as the whole spikelet, 5 -nerved, acute; second scale obtuse, about two-thirds as long as the fruit.

Srrub-lands, Long Island and Inagua :-Cuba; Hispaniola; Curaģao. Narrow PANIC-GRASS.

\section{Panicum Chàpmani Vasey, Bull. Torrey Club 11: 61. 1854.}

Culms glabrous or nearly so, tufted, slender, 3-10 $\mathrm{dm}$. high, simple, or sometimes branched below. Leaves $2-4 \mathrm{dm}$. long, 4-6 mm. wide, acuminate, the sheaths sparingly ciliate; panicles $3 \mathrm{dm}$. long or less, composed of sessile 1-sided spike-like racemes of $3-12$ spikelets, the flexuous rachis terminated by $a$ 
short bristle; spikelets nearly sessile, about $2 \mathrm{~mm}$. long, in 2 rows, oboroid, glabrous, the first scale obtuse, about one-half as long as the whole spikelet, the second scale $i$-nerved, the fourth scale transversely wrinkled.

Scrub-lands and along marshes, New Iroridence, Rose Island, Great Exuma :southern Florida. Cilapaiax's Paxic-GRass.

8. Panicum láxum Sw. Prodr. 23. 178s.

Panicum agrostidiforme Lam. Tabl. Encrel. 1: 172. 1791.

Panicum tenuiculmum Meyer, Prim. Fl. Esseq. 5S. 1818.

Culms simple or little branched, often decumbent and rooting at the lower nodes, 4-12 dm. high. Sheaths hirsute above, otherwise glabrons; leaves 1-2.5 dm. long, 4-15 mm. wide, glabrous, or sparingly pubescent on the upper side; panicles $0.5-3 \mathrm{dm}$. long, with many, slender spike-like branches, the lower branches spreading, the ultimate branchlets mostly secund; spikelets 1-1.5 $\mathrm{mm}$. long, about $0.7 \mathrm{~mm}$. wide, short-stalked; first scale 1-3-nerved, about onethird the length of the whole spikelet, the second somewhat shorter than the third.

Turks Islands:--nearly throughout tropical America. RED-Top Paxic-grass.

9. Panicum ténerum Beyr.; Trin. Mem. Acad. St. Petersb. VI 1: 341. 1834.

Culms slender, stiff, tufted, glabrous, 4-9 dm. high. Sheaths glabrous, or the lower softly pubescent; leaf blades $4-15 \mathrm{~cm}$. long, $2-4 \mathrm{~mm}$. wide, or the upper much smaller, erect, somewhat involute in drying, somewhat pubescent, at least torrard the base; panicles solitary and terminal, $3-8 \mathrm{~cm}$. long, or also a few smaller ones lateral; spikelets $2-2.8 \mathrm{~mm}$. long, about $1 \mathrm{~mm}$. wide, shortstalked, rather crowded; first scale about one-half the length of the whole spikelet, 1-nerved, the second and third $5-\bar{i}$-nerved.

Open places in pine and scrub-lands, Andros and New Proridence:-Georgia and Florida to Texas; Cuba ; Porto Iico. SLENDER PaNiC-Grass.

10. Panicum condènsum Nash, in Small, Fl. SE. U. S. 93. 1903.

Culms tufted, branched, $0.6-1 \mathrm{~m}$. tall, the basal sheaths compressed and keeled. Leaves $2-4 \mathrm{dm}$. long, 6-8 $\mathrm{mm}$. wide, erect or nearly so; panicles large, dense, oblong, 1-2.5 dm. long, their branches erect; spikelets numerous, about $2.3 \mathrm{~mm}$. long, acute, glabrous; first scale acuminate, about one-half the length of the whole spikelet; second and third scales acuminate.

Fresh water swamps and wet places, Andros, New Providence, Acklin's Island and Cat Island:- New Jersey to Florida and Texas; Cuba; Porto Rico; Guadaloupe; Jamaica; Mexico. DENSE PAXic-Grass.

\section{Panicum diffùsum Sw. Prodr. 23. 1788.}

Perennial; culnıs tufted, spreading or ascending, simple or little branched, glabrous with pubescent nodes, $2-5 \mathrm{dm}$. high. Sheaths striate, glabrous or pubescent; leaf-blades $2 \mathrm{dm}$. long or less, 1-3 mm. wide, sparingly pubescent; panicles 5-10 $\mathrm{cm}$. long, open, the branches filiform; spikelets few, near the ends of the panicle-branches, short-stalked, about $2 \mathrm{~mm}$. long and $1 \mathrm{~mm}$. wide; first scale acute, about one-half as long as the spikelet; second and third scales 7-9-nerved.

Coppice, New Providence:-Jamaica; Cuba to St. Thomas, Tortola and Martinique, Diffuse PaNiC-GRass.

\section{Panicum Ghiesbreghtii Fourn. Mex, Pl. 2: 29. 1856.}

Panicum hirtivaginum Hitche. Contr. U. S. Nat. Herb. 12: 223. 1909.

Perennial; culms erect, tufted, rather stout, 6-8 $\mathrm{dm}$. high, the nodes hirsute. Sheaths hirsute; leaf-blades flat, up to $6 \mathrm{dm}$. long and $12 \mathrm{~mm}$. Wide, hirsute or glabrate; panicle $2-3 \mathrm{dm}$. long, its branches ascending; spikelet3 numerous, short-stalked, about $3 \mathrm{~mm}$. long and $1 \mathrm{~mm}$. wide; first scale acute, 
onc-half to two-thirds as long as the whole spikelet; second and third scales i-9-nerved.

A weed, Crooked Island:-Cuba; Porto Rico; Cruadelonpe; Antigua ; continental tropical Amerlea.

13. Panicum dichotomiflòrum Michx Fl. Bor. Am. 1: 48. 1803.

Panicum bartowense Seribn. \& Merr. Cire U. S. Dept. Agrie. Agrost. 35: 3. 1901.

Culms at first erect, 3-6 dm. tall, simple, later decumbent and geniculate, 1-1.5 m. long, branched at all the upper norles. Sheaths loose, glabrous, or papillose-hispir, somewhat flattened; leares $1.5-6 \mathrm{dm}$. long, 4-20 mm. wide; longacuminate, scabrous on the margins and oceasionaly on the nerves; panicles pyramilal, 1-4 dm. long; spikelets $2-3 \mathrm{~mm}$. long, crowded, lanceolate, acute, glabrous, sometimes purplish; first seale about one-fourth as long as the spikelet; second and third scales about equal, acute, 5-7-nerved; fourth scale elliptic, shining.

Swamps and water holes, Great Bahama. North Bimini, Andros, New Providence, Cat Cay, Watling's Island, Crooked Island, and Great Exuma :- I Iaine to Nebraska, Florida and Texas: Bermuda: Cuba. Recorded by Coker as $P$. clephantipes Nees; has been confused with $P$. proliferum Lam. SPREadixg WitchGRASS.

14. Panicum amàrulum Hitchc. \& Chase. Contr. U. S. Nat. Herb. 15: 96.1910.

Culms rather stout, tufted, glabrous, glancous, 4-15 $\mathrm{rm}$. high, the sheaths orerlapping. Leares $1.5-3 \mathrm{dm}$. long, 6-12 mm. wide, leathery, the margins involute; panicle narrow, sometimes $7 \mathrm{dm}$. long, its branches erect; spikelets about $5 \mathrm{~mm}$. long; first scale about one-half as long as the whole spikelet, the third somewhat longer than the second.

Sea-beaches and sand dunes, Great Bahama and New Providence:-Virginia to Florida and Mississippi ; Cuba: Jamaica. SEA-BEAch Grass.

15. Panicum trichoìdes Sw. Prodr. 24. 1788.

Panicum brevifolium of authors. Not L. 1753.

Panicum capillaceum Lam. Tabl. Enescl. 1: 173. 1791.

Culms slender, ascending or erect, $6 \mathrm{dm}$. high or less, pubescent. Sheaths pubescent and ciliate; leaf-blades membranous, $2-7 \mathrm{~cm}$. long, $1-2 \mathrm{~cm}$. wide, orate-lanceolate, acuminate at the apex, cordate-clasping at the base, glabrous or sparingly pubescent; panicles $2 \mathrm{dm}$. long or less, their branches filiform, spreading and ascending; spikelets nearly ellipsoid, about $1.2 \mathrm{~mm}$. long, sparingly hirsute; first scale acute, 1-nerved, about one-half as long as the whole spikelet; second and third scales 3-nerved.

Turks Islands:--Jamaica: Cuba to Tortola and Trinidad; tropical continental America. HAIR-LIKE P'ANIC-GRASS.

16. Panicum coeruléscens Hack.; Hitche. Contr. Nat. Herb. 12: 219. 1909.

Culms slender, tufted, glabrous, at first erect and simple, later reclining and with short, fascicled branches at the nodes, $8 \mathrm{dm}$. long or less. Sheaths glabrons, or the lower sometimes pubescent; leaves of the vernal stage $5-8 \mathrm{~cm}$. long, $3-7 \mathrm{~mm}$. wide, glabrous or very nearly so; panicles of the vernal stage $3-7 \mathrm{~cm}$. long, those of the autumnal stage usually rednced to a few spikelets; spikelets about $1.5 \mathrm{~mm}$. long, obovoid, glabrous; first scale about one-third the length of the whole spikelet.

Moist places and in swamps, Great Bahama, Andros, New Providence. Cat Island (?) Crooked Island:-New Jersey to Florida and Texas; Cuba. Referred by Dolley to $P$. dichotomum L. BLeish PaxiC-grass.

17. Panicum neurànthum Griseb. Cat. Pl. Cuba 232. 1866.

Culms tufted, slender, at length much branched, 3-7.5 dm. tall. Sheaths glabrous, or the lower pubescent; leares smooth and glabrous, the primary 
erect, acuminate, 2.5-10 $\mathrm{cm}$. long, 2-5 mm. wille, those on the branches shorter, erect or ascending, usually involute when dry, concealing the small secondary panicles; primary panicle $2.5-10 \mathrm{~cm}$. long, its branches at first erect, at length spreading; spikelets numerous, about $2 \mathrm{~mm}$. long, densely pubescent with short, spreading hairs, the second and third scales $\mathbf{i}$-nerved.

siwamps and savannas, Andros and New Providence:-Florida; Cuba. NERED PANIC-GRASS.

\section{Panicum nítidum Lam. Tabl. Eneycl. 1: 172. 1791.}

Culms slender, tufted, 3-10 im. long, erect or reclining, often becoming much-branched, the nodes bearded. Sheaths glabrons, ciliate, or the lower pubescent; leaves of the rernal stage $5-12 \mathrm{~cm}$. long, 3-10 mm. wide, the basal ones tufted, those of the autumnal stage much smaller, $1-3 \mathrm{~cm}$. long, 1-3 $\mathrm{mm}$. wide; panicles of the vernal stage $5-8 \mathrm{~cm}$. long, often nearly as wide, those of the autumnal stage smaller, sometimes reduced to a few spikelets; spikelets $2 \mathrm{~mm}$. long, $1 \mathrm{~mm}$. wide, pubescent, the first seale about one-third as long as the whole spikelet.

I'ine and palmetto lands, Great Bahama:- Virginia to Missouri, Florida and Texas; Cuba. SHINiNg PANic-grass.

19. Panicum exiguifiòrum Griseb. Cat. Pl. Cub. 234. 1866.

Panicum tricolor Hack. Oest. Bot. Zeitsch. 51: 370. 1901.

Perennial; culms.tufted, glabrous, slender, simple or somewhat branched, erect or ascending, $1-5 \mathrm{dm}$. high. Leaves $1-6 \mathrm{~cm}$. long, $0.5-1.5 \mathrm{~mm}$. wide, flat, glabrous or their sheaths ciliate; panicles $2-10 \mathrm{~cm}$. loug, their few slender branches spreading or finally reflexed, bearing several, short-stalked spikelets about $1.5 \mathrm{~mm}$. long; first scale 3-nerved, about one-third as long as the spikelet; second seale nearly as long as the first; palet large, subcoriaceous, forcing the spikelet open at maturity.

Moist grounds, Acklin's Island, Fortune Island and Inagua :-Cuba.

An imperfect specimen of a Panicum, perhaps representing $P$. lucidum Ashe, was collected on Cat Island (Britton of Millspaugh 5776).

12. LASIÀCIS (Griseb.) Hitche. Contr. U. S. Nat. Herb. 15: 16. 1910.

Perennial, wooly, often elongated and vine-like grasses, with flat leares, the inflorescence of terminal panicles of large subglobose somenhat oblique 1-flowered spikelets. Scales 4, somewhat coriaceous or chartaceous, not awned, bearing an apical tuft of short hairs. Grain enclosed in the hard fruiting scale and palet. [Greek, hairy-tip.] Ten species or more, of tropical and subtropical America. Type species: Panicum divaricatum L.

1. Lasiacis divaricàta (L.) Hitehe. Contr. U. S. Nat. Herb. 15: 16. 1910.

Panicum divaricatum L. Syst. Nat. ed. 10, 871. 1759.

CuIm glabrous, smooth, much branched, erect or arching, 2-3 m. long, the branches sometimes pendent. Sheaths ciliate; leaves glabrous, acuminate, those of the main enlm 8-12 $\mathrm{cm}$. long, 1-2 cm. wide, those of the branches smaller; panicle 5-10 cm. long, its slender branches spreading; spikelets swollen, 4, $5 \mathrm{~mm}$. long, the scales tipped with woolly hairs, the broad lower scale clasping.

Coppices and scrub-lands. Great Bahama, Abaco. Andros. New I'rovidence, Rose Island, Eleuthera. Cat Island. I,ittle San Salvador, Watling's Island, Rum Cay, Conception Island, Crooked Island, Acklin's Island, Fortune Island, North Caicos, Little Inagua. Inagua, and Anguilla Isles - southern Florida; West Indies and continental tropical America. CAxE-GRASS. WiLD CANE. 
13. ECHINóCHLOA Beauv. Agrost. 53. pl. 11, f. 2. 1812.

Usually tall grasses, commonly annuals, with broad leaves and a terminal inflorescence consisting of one-sided racenes racemosely or paniculately arranged. Spikelets 1-flowered, singly disposed, or in smaller racemes or clusters on the ultimate dirisions of the inflorescence. Scales 4 , the outer $3 \mathrm{mem}$ branous, hispid on the nerves, the third and usually also the second scale awned, or sometimes merely amn-pointed, the amn often rery long; fourth seale indurated, shining, frequently pointed, enclosing a palet of similar texture and a perfect flower. Stamens 3. Styles distinct. Stigmas plumose. Grain free. [Greek, in reference to the stout hispid hairs of the spikelets.] Species about 12, mostly in warm and tropical countries. Type species: Panicum Crus-galli L.

Outer scales of the spikelet not awned: spikelets $2.5-3 \mathrm{~mm}$. long. 1. E. colonum.

nter scales of the spikelet, at least one of them, awned; spikelets

$3.5-4 \mathrm{~mm}$. long, exclusive of the awns.

2. E. Crus-gulli.

1. Echinochloa colònum (L.) Link, Hort. Berol. 2: 209. 1833.

Panrcum colonum L. Syst. Nat. ed. 10, 870. 1759.

CuIms tufted, smooth and glabrous, $1.5-7.5 \mathrm{dm}$. tall, often decumbent and rooting at the lower nodes. Sheaths compressed, usually crowded; leaves flat, 2.5-17 cm. long, 2-8 $\mathrm{mm}$. wide; inflorescence composed of 3-18, 1-sided, more or less spreading dense racemes $6-50 \mathrm{~mm}$. long, disposed along a 3 -angled rachis and generally somewhat exceeding the length of the internodes; spikelets single, in pairs, or in 3 's in 2 rows on one side of the hispidulous, triangular rachis, obovate, pointed, the first scale about one-half as long as the spikelet, 3 -nerred, the second and third scales a little more than $2 \mathrm{~mm}$. long, awnless, 5 -nerred, hispid on the nerres, the fourth scale cuspidate.

Waste places, Turks Islands :-Virginia to Florida and Texas; tropical regions. JUXGLE RICE.

\section{Echinochloa Crús-galli (L.) Beaur. Agrost. 53, 161. 1812.}

Panicum Crus-galli L. Sp. Pl. 56. 1753.

Culms 6-12 dm. tall, often branching at base. Sheaths smooth and glabrous; leares 1.5-6 dm. long, 6-25 mm. wide, glabrous, smooth or seabrous; panicle composed of 5-15 sessile, erect or ascending branches, or the lower branches spreading or reflexed; spikelets ovate, green or purple, densely crowded in 2-4 rows on one side of the rachis; second and third scales about 3 $\mathrm{mm}$. long, scabrous or hispid, the third scale more or less amned, empty, the fourth ovate, abruptly pointed. Widely distributed as a weed in all cultivated regions. Naturalized from Europe.

Waste places, Turks Islands:- widely distributed in temperate and subtropical regions. Native of the Old World. BARNYARD-Grass.

\section{OPLÍSMENUS Beauv. Fl. Orar. 2: 14, pl. 68. 1807.}

Perennial grasses, often decumbent and branched at the base, with broad flat leaf-blades and inflorescence composed of spikes, bearing on the lower side scattered elusters of a few spikelets. Spikelets 1-flomered. Seales 4 , the 3 outer membranous, the first and second empty, awned, the first equalling or somemhat shorter than the spikelet, the third scale usually awned, empty, or enclosing a small palet, the fourth one shorter than the others, obtuse, amnless, chartaceous, finally indurated, enclosing a shorter palet of similar texture and a perfect flower. Stamens 3. Styles distinct to the base. Stigmas plu- 
mose. [Greek, armed, presumably referring to the arns.] Abont 4 species, natives of warm regions. Type species: Oplismenus africanus Beauv.

\section{Oplismenus hirtéllus (L.) R. \& S. Syrst. 2: 491.1817.}

Panicum hirtellum L. Syst. Xat. ed. 10, s70. 1759.

Oplismenus setarius R. \& S. Syst. 2: 481.1817.

Culms prostrate or nearly so, rooting at the nodes, very slender, $6 \mathrm{dm}$. long or less. Leaves ovate to ovate-lanceolate, acuminate, 1-6 cm. long, $1 \mathrm{~cm}$. wide or less, their sheaths often pubescent; panicle $8 \mathrm{~cm}$. long or less, its filiform short branches erect or spreading; spikelets $3 \mathrm{~mm}$. long, the awns up to $8 \mathrm{~mm}$. long.

Cultirated ground, New Providence:-Bermuda; Sonth Carolina to Florida and Texas; the West Indies and tropical continental America. Wood-Grass.

15. ChaftochloA Scribn. Bull. U. S. Dep. Agr. Agrost. 4: 38.1897

Mostly annual grasses with erect culms and flat leares, the inflorescence in spike-like clusters. Spikelets 1 -flowered, or rarely with a second staminate flower, the basal bristles single or in clusters below the articulation of the rachilla, and therefore persistent. Seales of the spikelet 4, the three outer membranous, the third often subtending a palet and rarely a staminate flower; the inner or fourth seale chartaceous, subtending a palet of similar texture and a perfect flower. Stamens 3. Styles distinct, elongated. Stigmas plumose. Grain free, enclosed in the scales. [Greek, in reference to the bristles of the inflorescence.] Species about 35, in temperate and tropical regions. Type species: Setaria longiseta Beaur.

Inflorescence with the spikelets racemosely arranged; bristles $5-16$ at the base of each spikelet, in roluclate.

Inflorescence with the spikelets in clusters or on manifest branches; bristles $1-3$ at the base of each spikelet, not involucrate.

Spikelets $2 \mathrm{~mm}$. long; leaves pubescent.

Spikelets $3 \mathrm{~mm}$. long; leaves glabrous.

1. Chaetochloa geniculàta (Lam.) Millsp. \& Chase, Field. Mus. Bot. 3: 3i. 1903.

Panicum geniculatum Lam. Encycl. 4: 727. 1798.

Panicum imberbe Poir. Eneycl. Suppl. 4: 272. 1816.

Chaetochloa imberbis Scribn. Bull. U. S. Dep. Agr. Agrost. 4: 39. 1897.

Perennial; culms 6-12 dm. long, ascending. Sheaths snooth and glabrous, compressed and keeled; leares 1-3.5 $\mathrm{dm}$. long, 2-6 mm. wide, pale green or glaucous, smooth or nearly so; spike-like panicle long-exserted, rather slender, 2.5-7 cm. long, about $1.5 \mathrm{~cm}$. thick; spikelets usually single, about $2.5 \mathrm{~mm}$. long and $1.25 \mathrm{~mm}$. wide, the first scale orate, 3-nerved, about one-half as long as the spikelet, the second scale acute, 3-nerved, the third scale 5-nerved; bristles in two nearly equal clusters of 5 each, very slender, 6-10 $\mathrm{mm}$. long.

Waste places, sink-holes, and in the scrub. Abaco, Great Bahama, Rerry Islands, Andros, New Providence, Exuma Chain, Acklin's Island, Fortune Island, Caicos Islands, Grand Turk, Inagua, and Anguilla Isles:-Permuda; Massachusetts to Kansas, Florida and Texas: West Indles: troplcal continental America, Referred by Ilitchcock and by Coker to Sctaria glauca Beauv.; and by Mrs. Northrop to chactochloa glauca. Fox-TAil Grass. 
2. Chaetcchloa setòsa (Sw.) Seribn. Bull. U. S. Dep. Agr. Agrost. 4: 39. 1597 .

Panicum sctosum Sw. Prodr. 22. 1785.

Seturia setosa Beauv. Agrost. 51, 178. 1812.

Panicum paractaenoides Trin. Mem. Acarl. St. Petersb. VI. 3²: 219. 1834.

Perennial, tufted; culms wiry, slender, 3-9 dm. high, somewhat flattened. Leaves $2 \mathrm{dm}$. long or less, pubescent or scabrous, 5-15 mm. wide; inflorescence more or less branched, the branches erect, or ascending, the lower sometimes $3 \mathrm{~cm}$. long; bristles 1-3 at the base of all the spikelets or of some of them, 6-12 mm. long; spikelets oroid, about $2 \mathrm{~mm}$. long.

Sandy or rocky soil, Berry Islands, Water Cay, Acklin's Island, Elenthera. Crooked Island, Inagua, Little Inagua and Anguilla Isles:-Western Texas and New Mexico: tropical America. Referred by IIitchcock to Setaria caudata (Lam.) R. \& S., and by coker to setaria mucrostachya H.P.K. BRISTLY Fox-TAIL Grass.

3. Chaetochloa macrospérma Scribu. \& Merr. Bull. U. S. Dep. Agr. Agrost. $21: 33.1900$.

Pereunial; culms rather stont, glabrous, up to $1.2 \mathrm{~m}$. high. Leaf-sheaths compressed, the margins ciliate, the blades 1-3 dm. long, 1-2 em. wide, glabrous; spike-like panicle $2.5 \mathrm{dm}$. long or less, 2-4 cm. thick; bristles $1.5-3 \mathrm{~cm}$. long; spikelets acute, $3 \mathrm{~mm}$. long, the narrowly ovoid flowering seale transversely wrinkled, acute.

Coastal thicket, Frozen Cas, Berry Islands:- southern Florida and Texas. LARge FOX-TAIL Grass.

[Setaria filiformis of Coker is a misprint for Scleria filiformis.]

\section{CENCHRòpSIS Nash, in Small, Fl. SE. U. S. 109. 1903.}

Perrenial grasses, with long rootstocks and flat leaves, the spikelets in terminal spikes, each spikelet subtended by an involuere of 1 or 2 outer rows of barbed, thick-based bristles, and 1 or 2 inner rows of barbed spines longer than the bristles, the involvere jointed to the rachis and deciduous. Spikelets of 4 scales, the first and second ones empty, the third enclosing a palet onehalf its length or less, the fourth enfolding a similar palet and a perfect flower. Stamens 3. [Greek, resembling Cenehrus.] A fer species, of tropical America. Type species: Cenchrus myosuroides H.B.K.

1. Cenchropsis myosuroides (H.B.K.) Nash, in Small, Fl. SE. U. S. 109. 1903.

Cenchrus myosuroides H.B.K. Nor. Gen. 1: 115. 1815.

Culms erect, slender, $0.6-1.5 \mathrm{~m}$. tall, simple or branched above, glabrous. Leaves 1-3 $\mathrm{dm}$. long, 3-5 mm. wide, glabrous; spikes 5-20 em. long; involueres numerous, the barbed spines about $5 \mathrm{~mm}$. long, and about as long as the spikelet.

In sandy places, Grand Turk, Inagua, and Anguilla Isles:- southern Florida: Mexico; Cuba; Hispaniola; Porto Rico; tropical South America. SPIKED Fox-TAIL GRASS.

\section{CÉNCHRUS L. Sp. Pl. 1049. 1753.}

Annual or perennial grasses, with usually flat leares. Inflorescence spikelike. Spikelets subtended by a spiny involucre which is decidnous with them at maturity. Scales 4; the first hyaline; the second and third membranous, the latter sometimes having a palet and staminate flower in its axil; the fourth chartaceous, subtending a palet of similar structure which encloses a perfect 
flower. Stamens 3. Styles united below. Stigmas pumose. Grain free, enclosed in the scales. [Ancient Greek name for some grass, probably Millet.] About 12 species, in tropical and temperate regions. Type species: Cenchrus cchinatus L.

Involucre 2-spikeleted, armed at the hase with commonly shorter often reflexed spines, usually glabrous, or merely puberulent at the base.

Involucre, over all, S-12 $\mathrm{mm}$, in diameter.

Body of the involucre 5-6 mm thick finely pubescent. Body of the intolncle $8-10 \mathrm{~mm}$. thick, densely woolly. Involucre, over all, $5 \mathrm{~mm}$, in diameter or less.

Involucre more than 2-spikeleted, armed at the base with barbed bristles.

Spines on the usually 3-spikeleted involucle basal and slender, rarely any aliove, erect; bristles rery slender.

Spines on the msually 4 -6-spikeleted involucre not basal but occurring on rarious parts, spreading or often reflexed; bristles stouter and almost spine-like.

1. ('. arolinimus.

2. (r. tribuloides.

3. C. microcephulus.

5. C. cchinatus.

1. Cenchrus caroliniànus Walt. Fl. Car. 79. 1788.

Culms erect or decumbent from an annual root, 2-9 dm. long. Sheaths usually loose, compressed, smooth; leaves $6-12.5 \mathrm{~cm}$. long; spikes $2.5-6.25$ cm. long, sometimes partially included in the upper sheath; involucres crowded on the scabrous rachis, 2 -spikeleted, globose, pubeccent except at the base, the spines stout; spikelets about $6 \mathrm{~mm}$. long.

Sand dunes, cultirated grounds, and waste places from South Bimini and Andros to Mariguana. Turks Islands, Inagua, Anguilla Isles and Salt Cay Bank:Iaine to Nebraska, Arizona, Texas and Florida: West Indies and tropical continental America. Referred by Hitchcock, Coker, Dolley, Mrs. Northrop, and Herrick to C. tribuloides I. SIILL I?ER-GRISS. DEVIL-GRASS.

\section{Cenchrus tribuloìdes L. Sp. Pl. 1050. 1753.}

Culms at first erect, later prostrate and forming mats, 4-6 dm. long, branching; leaf-sheaths compressed; blades 6-12 cm. long, 4-8 mm. wille, smooth or rough, usually flat; spikes $2-6 \mathrm{~cm}$. long; involucres $6-20,1.5-2 \mathrm{~cm}$. broad, enclosing 2 spikelets, pubescent, the spines $3-4 \mathrm{~mm}$. long; spikelets $6-7$ long, usually not exserted beyond the involuere.

Sandr sea-beaches, New I'rovidence (according to Ilitchcock):-New York to Florida and Mississippi ; Brazil. LARGE Bur-grass.

3. Cenchrus microcéphalus Nash; Hitche. \& Chase, Contr. U. S. Nat. Herb. 18: 356.1917 .

Culms at length prostrate and branching, up to $1 \mathrm{~m}$. long, smooth and glabrous; leaf-sheaths glabrous, or often ciliate on the margins; blades up to $1 \mathrm{rm}$. long, or those on the innorations longer, $2-3 \mathrm{~mm}$. wide, rough, commonly pubescent on the upper surface, ascending; spike $3-4 \mathrm{~cm}$. long, exserted; in. volucres 8-12,5-6 mm. long, $5 \mathrm{~mm}$. in diameter or less, the larger spines broad and flat, long-ciliate, the basal spines much shorter, not ciliate; spikelets 2, much exserted beyond the borly of the involucre.

Moist soil, Little Harbor Cay and Frozen Cay, Rerry Islands. Endemic. BdIIAIA BUR-GRASS.

\section{Cenchrus víridis Spreng. Syst. 1:301. 1825.}

C. echinatus viridis Griseb. Fl. Br. W. I. 556. 1864.

Culms erect or ascenting, usually $6-8 \mathrm{Am}$, high, branched or simple, the leaf-blates flat, $4 \mathrm{dm}$. long or less. Spike usually dense and cylindric, 8-12 $\mathrm{cm}$. long and often much exserted; involueres nsually 3 -spikeleted, armed helow with slender spines, the body about $4 \mathrm{~mm}$. in diameter, the barbed bristles slender.

Cultivated land, Andlos. New l'rovidence, Elouthera, Long Island and Mariguana :-Florida: West Indies and tropical continental Imerica. Grex. Bur-Griss. 


\section{Cenchrus echinàtus L. Sp. Pl. 1050. 1753.}

Culms finally prostrate and rooting at the nodes, branched; leaf-sheaths loose; blades 1-4 dm. long, 5-16 mm. wirle, smooth or rough, flat: spikes 3-12 cm. long, finally more or less exserted; involucres 20-50, containing 4-6 spikelets, green to purplish, villous at the base, the spines $34 \mathrm{~mm}$. long, the bristles at the base numerous, slender, distinctly barbed for their whole length; spikelets $6-i \mathrm{~mm}$. long.

Sandy soil. waste places and roadsides, Frozen Cay. New Providence, Eleuthera, Watling's Island, Fortune Island. Grand Turk and Inagua :-Bermuda : North Carolina to Florida and Texas; West Indies; tropical continental America. SOUTHERN BUR-GRASS

[Cenchrus hirsutus. Dolley's reference to this name is an error for Corchorus hirsutus into which he was led by Herrick's misprint of Cenchorus hirsutus for the same species.]

\section{STENOTÀPHRUM Trin. Fund. Agrost. 175. 1820.}

Perennial creeping branched grass, with rather stout flattened culms and shart linear leaves. Spikelets spicate or panicled, acute, mostly 2-flowered, imbedded in depressions on one side of the flattened rachis. Scales 4 ; first scale small or minute, second about as long as the spikelet, third similar to the second, subtending a staminate flower, fourth rigid, enclosing a perfect flower. Stigmas plumose. [Greek, a narrow depression.] A few species of tropical and subtropical distribution, the following typical.

1. Stenotaphrum secundàtum (Walt.) Kuntze, Rev. Gen. 794. 1891.

Ischaemum secundatum Walt. Fl. Car. 249. 1788.

Stenotaphrum americanum Schrank, Pl. Rar. Monac. pl. 98. 1819.

Tidely creeping, sometimes $5 \mathrm{~m}$. long, glabrous, rooting at the lower nodes. Leaf-sheaths keeled, flattened, the blade linear, 3-15 $\mathrm{cm}$. long, 4-10 mm. wide, blunt and rounded at the apex; spikelets about $6 \mathrm{~mm}$. long in spikes $4-13 \mathrm{~cm}$. long.

Waste places and roadsides, North Bimini, Great Bahama, Abaco, Andros, New Providence, and Fortune Island:- -Bermuda: South Carolina to Florida and Texas; West Indies and tropical continental America. Ruxisng Crab-grass.

\section{ARÍSTIDA L. Sp. Pl. S2. 1753.}

Grasses varying greatly in habit and inflorescence. Leaves narrow, often involute-setaceous. Spikelets narrow, 1-flowered. Scales 3, narrow, the two outer carinate; the third rigid and convolute, bearing three amns occasionally united at the base, the lateral aाns rarely wanting or reduced to rudiments. Palet 2-nerved. Stamens 3. Styles distinct. Stigmas plumose. Grain free, tightly enclosed in the scale. [Latin, from arista, an awn.] About 100 species, in the warmer regions of both hemispheres. Type species: Aristida adscensionis $\mathrm{L}$.

Awns about equal in length.

First scale shorter than the second. Annual: blades thin, flat or inrolute.

Perennial: blades thick, folded or involute.

First scale about as long as the second; perennial. Lateral awns minute.

1. A. adscensionis.

2. A. cognata.

3. A. gyrans.

4. A. scabra. 
1. Aristida adscensiònis L. Sp. P1. S2. 1753.

Aristida stricta Griseb. Fl. Brit. W. I. 534. 1564. Nat Michx. 1803.

Annual, tufted, glabrous; culms slender, erect, or ascending, $3-7 \mathrm{dm}$. long, branching from the lower nodes. Leaf-blades thin, flat or involute; panicles narrow, $1.5 \mathrm{dm}$. long or less, with short appressed branches or the lower branches spreading; awns about equal in length, 12-20 mm. long.

In sandy places and in the scrub, Great Exuma. Long Island, Fortune Island, Crooked Island, Grand Turk, Caicos Islands, and Inagua :- West Indies ; Ascension Island; continental tropical America. Axxul Triple-AWNed Grass.

2. Aristida cognàta Trin. \& Rupr. Mem. Acad. St. Petersb. VI. Sei. Nat. $5^{1}$ : 127. 1842.

Perennial; culms slender, tufted, spreading, 3-6 dm. tall. Leares involute-filiform, the upper shorter; panicle spike-like, strict, or the top sometimes nodding, its short branches ascending; awns 1-2 cm. long, horizontal when old, nearly equal in length.

Roadside, Long Cay :-Jamaica ; Porto Rico; St. Thomas ; St. Croix. I'Erexyid, TRIPLE-AWNED GRASS.

3. Aristida gýrans Chapm. Bot. Gaz. 3: 18. 1878.

Perennial; culms tufted, wiry, erect, $3-7.5 \mathrm{dm}$. tall, usually simple, or little branched. Leaves $3-5 \mathrm{~cm}$. long, about $1 \mathrm{~mm}$. wide, flat, or becoming involute in drying; spike-like panicles $0.5-1.5 \mathrm{dm}$. long, strict, or sometimes nodding, the few short branches appressed; outer scales of spikelet awn-pointed, the third scale from two-thirds to three-quarters as long as the first, mildle amn 1-1.5 $\mathrm{cm}$. long, horizontal, the lateral amns somewhat shorter, erect or divergent.

White-lands and palmetto-lands, New Providence:-Florida; Cuba: Hispaniola. Recorded by Small in Iliami Flora as 4. purpurascens Poir., which it resembles. Florida TRIPLE-A WNED GRASS.

\section{Aristida scàbra (H.B.K.) Kunth, Rev. Gram. 1: 62. 1829.}

Streptachne scabra H.B.K. Nor. Gen. 1: 124. 1815.

Streptachne cubensis A. Rich. in Sagra, Hist. Cub. 11: 311.1850.

Perennial; culms $1 \mathrm{~m}$. high or less, erect, simple. Leaves involute, at least when dry, 2-3 dm. long, about $1 \mathrm{~mm}$. thick; panicle 2-3 dm. long, its branches ascending, the longer ones up to $14 \mathrm{~cm}$. long; spikelets short-stalked; terminal awn about $2 \mathrm{~cm}$. long, the lateral ones minute.

Pine and scrub-lands, Great Sturrup Cay, Andros, New Providence, Eleuther:i. Cat Island, Cave Cay, Rum Cay, Watling's Island, Acklin's Island, Crooked Island, Fortune Island, Mariguana and Inagua:-Cuba; IIexico, Referred by Dollex to Stipa sp. Ortachne floridana (Chapm.) Nash may not be distinct from this. TALL TRIPLE-AWNED GRASS.

\section{MUHLENBÉRGIA Schreb.; Gmel. Syst. Nat. 2; 1i1. 1i91.}

Mostly perennial grasses, with flat or convolute leaves and paniculate inflorescence. Rootstocks often scaly. Spikelets 1-flowered, rery rarely 2-flowered. Scales 3, rery rarely 4 ; the outer ones empty, membranous or hraline, acute and sometimes arned; third scale 3-5-nerved, subtending a palet and perfect flower, obtuse, acute, or rery often produced into a capillary awn; palet 2-keeled. Stamens often 3. Styles distinct. Stigmas plumose. Callus minute. Grain narrow, free, tightly enclosed in the scale. [In honor of Henry Muhlenberg, 1756-1817, North American botanist.] About 60 species, chiefly natives of America, a few Asiatic. Type species: Muhlenbergia Schreberi Gmel. 
1. Muhlenbergia capillàris (Lam.) Trin. Gram. Unifl. 191. 18ュ4.

Stipa capillaris Lam. Tabl. Encycl. 1: 15S. 1791.

Culms $4.5-12 \mathrm{dm}$. tall, erect, simple, smooth or nearly so. Sheaths smooth, the lomer short and orerlapping, the upper ones much longer; leaves $1.5-3 \mathrm{dm}$. long, 2-4 mm. wiile, scabrous; panicle $1.75-3 \mathrm{dm}$. in length or more, diffuse, the eapillary branches 1-2 dm. long, at length widely spreading; spikelets on long hair-like pedicels which are clavate-thickened at the apex; outer scales uneqnal, acute or short-amned, slightly scabrous; third scale, exclusive of the awn, $4 \mathrm{~mm}$. loug, abaut twice as long as the first one, the awn 6-18 mm. long.

Palmetto-lands, Andros and New I'rovidence:-Massachusetts to Missouri, Florida and Texas; Cuba; Porto Rico. Loxg-AWxed HAIR-Grass. PLRPLE-GRAsi.

\section{SPoRóbolus R. Br. Prodr. 169. 1810.}

Perennial or rarely annual grasses, with flat or convolute leaves and open or contracted panicles. Spikelets generally small, 1-flowered, occasionally 2-3flowered. Scales in the 1 -flowered spikelets 3 , membranous; the 2 outer empty, the first somewhat shorter; the third scale equalling or longer than the empty ones; palet 2-nerved. Stamens 2-3. Styles rery short, distinct. Stigmas plumose. Grain free, aud often early deciduons. [Greek, referring to the deciduous grain.] About 100 species, in tropical and temperate regions, rery numerous in America. Type species: Agrostis indica L.

Plants with no rootstocks: culms tufted.

Second scale one half as long as the spikelet or less.

Panicle usually long and narrow, its branches spikelet-bearing to the base; spikelets numerous.

Second scale orbicular, rounded and erose-denticulate at the apex, one fourth to one third as long as the spikelet; spikelets loosely arranged on long slender branches.

Second scale ovate or oblong, acute or obtuse, about one half as long as the spikelet; spikelets densely arranged on the short and appressed branches.

Panicle loose and ojen, its branches naked at the base, spreading; spikelets few.

Second scale as long as the spikelet or nearly so.

Spikelets about $1.5 \mathrm{~mm}$. long: first scale about one fourth as long as the second; panicle branches rarely over $1.5 \mathrm{~cm}$. long.

Spikelets about $2 \mathrm{~mm}$. long; first scale about one half as long as the second; panicle branches longer.

Plants with long stout rootstocks; grass of sea beaches or saline situations.

1. S. indicus.

2. S. Berteroanus.

3. S. atrovirens.

4. S. argutus.

5. S. domingensis.

6. S. virginicus.

* 1. Sporobolus índicus (L.) R. Br. Prodr. 170. 1810.

Agrostis indica L. Sp. P1. 63. 1753.

Agrostis tenacissima L. f. Suppl. 107. 17S1.

Sporobolus Jacquemontii Kunth, Rev. Gram. 2: 427, pl. 12\%. 1831.

Glabrous. Culms 3-12 dm. tall, erect, tufted; leares $2-6 \mathrm{~mm}$. wide, attenuate into a long slender tip, the lower 2-3 dm. long, the uper shorter; panicle 1-4 dm. in length, usually elongated, narrow, spike-like; spikelets 1.5-2 mm. long, the outer scales unequal, the second about one-third as long as the third, obtnse, smooth and g]abrous, the lower one shorter, and often erosetruncate.

Waste and cultivated grounds. New Providence and Eleuthera:- West Indies; continental tronical America. Referred by Dolley to S. tenacissimus Beaur. WEST INDIAN RUSH-GRASS. 
2. Sporobolus Berteroànus (Trin.) Hitche. \& Chase, Contr. U. S. Nat. Herb. 18: 370.1917 .

Tilfa Berteroana Trin. Mem. Acar. St. Petersb. VI. Sci. Nat. $4^{1}$ : 100. 1840.

Sporobolus angustus Buckley, Proc. Phila. Acad. 1862: 88. 1563.

Slender, wiry, $1 \mathrm{~m}$. tall or less. Leaves smooth, nearly erect, 1-3 $\mathrm{mm}$. wide, long-attenuate, the lower ones 1.5-2.5 dm. long, the upper shorter; panicle narrow, often $3 \mathrm{dm}$. long; spikelets about $3 \mathrm{~mm}$. long, crowded on the short appressed branches of the panicle; second scale ovate-oblong, about one half as long as the spikelet.

Sandy places, Andros, New Providence and Turks Islands:-Bermuda; Virginia and Tennessee to Florida and Texas; West Indies. BuLL-grass.

3. Sporobolus atrovirens (H.B.K.) Kunth, Rev. Gram. 1:68. 1829.

Tilfa atrovirens II.B.K. Nor. Gen. 1: 1381815.

Sporobolus bahamensis Hack, Oest. Bot. Zeitsch, 52: 56.1902.

Perennial, the roots of long filiform filures. Culms very slender, tufted, erect, glabrous, $3 \mathrm{dm}$. high or less. Leares glabrous, mostly elustered at the base, narrotly linear, 2-\$ cm. long; panicle loose, open, much-branched, 6-15 cm. long, its filiform branches spreading, scattered, 2-4 cm. long; the brauchlets bearing a few spikelets about $1.5 \mathrm{~mm}$. long.

Acklin's Island:- Mexico. FlLıform Resh-grass.

\section{Sporobolus argùtus (Nees) Kunth, Enum. 1: 215. 1833.}

Tilfa arguta Nees, Agrost. Bras. 395. 1829.

Perennial; culms $3 \mathrm{dm}$. tall or less, erect, or somewhat decumbent at the base. Sheaths shorter than the internorles, their margins sometimes hirsute at the top; leaves 2.5-5 cm. long, 2-4 $11 m$. wide at the base, acuminate, smooth and glabrous beneath, scabrous, anil often sparingly hairy at the base above; panicle $3.75-7.5 \mathrm{~cm}$. in length, the branches $1.25-2.5 \mathrm{~cm}$. long, rerticillate, at first appressed, finally widely spreading; spikelets $1.5 \mathrm{~mm}$. long; outer scales smooth and glabrous, the first rounded or obtuse, one-quarter the length of the acute second one; third scale about equalling the second, acute.

Sandy soil and in the scrub. Eleuthera. Long Island, Fortune Island, Mariguana, Frand Turk, and Inagua :-Kansas and Colorado to Louisiana and Texas; Jamaica ; Cuba to St. Croix; Antigua; 'Trinidad; tropical continental America. PorxTED DlROPSEED-GRASS.

5. Sporobolus domingénsis (Trin.) Kunth, Enum. 1: 214. 1833.

Vilfa domingensis Trin.; Spreng. Neue Entdeck, 2: 59. 1821.

Perennial, similar to $S$. argutus, but usually larger, the culms up to $4 \mathrm{dm}$. long, the panicle densely many-flowered, narrow, $9 \mathrm{~cm}$. long or less, its branches 2-4 cm. long. Spikelets $2 \mathrm{~mm}$. long; first scale about one-half as long as the second.

Sandy places, scrub, and roadsides, Abaco, New Providence, Elenthera, Little San Salvador, South, Cat Bar, Watling's Island, Long Island, Acklin's Island, Fortune Island, Ambergris Cay, Caicos Islands. Grand Turk. Little Inagua, Inagua, and Anguilla Isles:- southern Florida and Texas; Cuba: Hispaniola; Porto Rico; Jamaica. DOMINGAN DROPSEED-GRASS.

\section{Sporobolus virgínicus (L.) Kunth, Rev. Gram. 1:67. 1529.}

Agrostis virginica I. Sp. Pl. 63. 1753.

Culms 1.5-6 dm. tall, erect or decumbent, from a stout rreeping rootstock. Sheaths numerous, short, orerlapping and erowded at the lower part of the culm, smooth, glabrous or sometimes pilose on the margins ani at the throat; leaves 2.5-20 cm. long, $4 \mathrm{~mm}$. wide or less at the base, distichous, acuminate into a long point, involute on the margins and at the apex, smooth beneath, 
scabrous above or sometimes sparingly hairy; panicle $2.5-7.5 \mathrm{~cm}$. long, 4-10 $\mathrm{mm}$. thick, dense and spike-like, usually exserted; spikelets $2-2.5 \mathrm{~mm}$. long, the outer scales about equal, acute, smooth and glabrous; third scale smooth and glabrous, acute, slightly shorter than the second and about equalling the obtuse palet.

Moist sltuations, especially in brackish swamps, Great Bahama, Gun Cay. Andros, New Providence, Eleuthera, Rum Cay, Long Island, Fortune Island, Crooked Island, Grand Turk, Little Inagua, Inagua, Water Cay, and Anguilla Isles :-Bermuda; Virginia to Florida and Texas; West Indies and tropical continental America. SEA-SHORE RUSH-GRASS.

22. SPARTINA Schreb.; Gmel. Syst. 123. 1791.

Perennial glabrous grasses, with long horizontal rootstocks, flat or inrolute leaves, and an infloreseence of one-sided spreading or erect alternate spikes. Spikelets 1-flowered, narrow, deciduous, borne in two rows on the rachis, articulated with the very short pedicels below the scales. Scales 3 ; the two outer empty, keeled, rery unequal; the third subtending a perfect flower, keeled, equalling or shorter than the second; palet often longer than its scale, 2-nerred. Stamens 3. Styles filiform, elongated. Stigmas filiform, papillose or shortly plumose. Grain free. [Greek, referring to the cord-like leaves of some species.] About 7 species, widely distributed in saline soil, a few in fresh-water marshes. Type species: Spartina Schreberi Gmel.

1. Spartina pàtens (Ait.) Muhl. Gram. 55. 1817.

Dactylis patens Ait. Hort. Kew. 1: 104. 1789.

Spartina juncea Willd. Enum. 81. 1809.

Culms 3-9 dm. tall, erect, or decumbent at base, smooth. Leares $1 . \bar{i}-3$ $\mathrm{dm}$. long, 2-4 mm. broad, involute, attenuate into a long tip, smooth and glabrous beneath; spikes $2-10,2.5-5 \mathrm{~cm}$. long, usually ascending, more or less peduncled, the rachis slightly scabrous; spikelets $6-8 \mathrm{~mm}$. long; outer scales acute, scabrous-hispid on the keel, the first usually' rather less than one-half as long as the second; third scale somewhat seabrous on the upper part of the keel, emarginate or 2-toothed at the apex, longer than the first and exceeded by the palet.

Sea-beaches, Eleuthera; Fortune Island:-eastern United States; Bermuda; Jamaica; Porto Rico; Guadaloupe; Martinique. SALT Grass.

\section{CAPRİolA Adans. Fam. Pl. 2: 31. 1763.}

[CrNodon Rich.; Pers. Syn. 1: 85. 1805.]

Perennial grasses with short flat leares and spicate inflorescence, the spikes digitate. Spikelets 1-flomered, secund. Scales 3 ; the 2 lower empty, keeled; flowering scale broader, membranous, compressed; palet a little shorter than the seale, hyaline, 2-keeled. Stamens 3. Styles distinct. Stigmas short, plumose. Grain free. [Name mediæral Latin for the wild goat, that feeds on this grass in waste rocky places.] Four known species, of which three are Australian, the following typical one widely distributed.

* 1. Capriola Dáctylon (L.) Kuntze, Rer. Gen. 764. 1891.

Panicum Dactylon L. Sp. Pl. 58. 1753.

Cynodon Dactylon Pers. Syn. 1:85. 1805.

Culms $1-3 \mathrm{dm}$. tall, erect, from long ereeping and branching stolons, smooth and glabrous. Sheaths glabrous or somewhat hairy, crowded at the 
bases of the culms and aloug the stolons; leaves $2.5-5 \mathrm{~cm}$. long, $2-4 \mathrm{~mm}$. wide, flat, scabrous above; spikes 4 or 5 , digitate, $1-5 \mathrm{~cm}$. long, the rachis flat; spikelets $2 \mathrm{~mm}$. long; outer scales hispid on the keel, narrow, the first shorter than the second.

Waste and cultivated lands, New Proridence, Eleuthera and Inagua:-Bermuda : southern New York to Kansas, Florida and Texas; warm and tropical regions of both the Old World and the New. Bernilda-grass.

\section{CHLÒrIs Sw. Prod. 25. 1788.}

Mostly perennial grasses with flat leaves and spicate inflorescence, the spikes few or numerous, verticillate or approximate. Spikelets 1-flowered, arranged in two rows on one side of the rachis. Scales 4 ; the 2 lower empty, unequal, keeled, acute; third and fourth usually awned, the former subtending a perfect flower; palet folded and 2-keeled. Stamens 3. Styles distinct. Stigmas plumose. Grain free, enclosed in the scale. [Greek, greenish-yellow, referring to the color of the herbage.] About fifty species, mostly natives of warm and tropical regions. Type species: Agrostis cruciata L.

Hairs on the margins or nerres of the third scale short, not manifest, appressed to and not extending berond the apex.

Fourth scale of the spikelet at least one third as long as the second scale and bearing a long awn $4 \mathrm{~mm}$. long or more; spikes $4-6$, widely spreading at maturity.

Fourth scale of the spikelet rudimentary, bearing an awn less than $4 \mathrm{~mm}$. long; spikes usually numerous, erect or ascending at maturity.

1. C. Śagrueaña.

on the margins or nerres of the third scale long, manifest, widely spreading or extending much beyoud the apex.

Third and fourth scales only awned, the former densely long-hairy on the midnerre, its awn less than twice the length of the scale.

Marginal hairs less than one half the length of the body of the scale, barely extending beyond its apex; spikes $3-5$.

Marginal hairs equaling in length the body of the scale and extending much beyond its apex; spikes usually 6 or more.

Third, fourth and fifth scales awned. the first glabrous on the midnerve, its awn about three times the length of the scale.

2. C. radiata.

3. C. ciliata.

4. C. polydactyla.

5. C. paraguiensis

1. Chloris Sagraeàna A. Rich. in Sagra, Hist. Cub. 11: 215. 1850.

Chloris eleusinoides Griseb. Fl. Brit. W. I. 539. 1864.

Perennial; culms ascending, $6 \mathrm{dm}$. long or less, usually branched below. Leaf-sheaths keeled, the blades narrow, involute; spikes $4-6$, slender, 4-8 $\mathrm{cm}$. long, horizontally spreading when old, not pectinate; spikelets imbricated, the fourth scale bearing a filiform awn 4-12 $\mathrm{mm}$. long.

Waste grounds and roadsides, New Providence, Fortune Island and Inagua :Cuba: Hispaniola : St. Croix: Antigua: Guadeloupe; Jamaica. Referred by Hitchcock to Chloris cruciata. Sw. SAGRA's Chloris.

2. Chloris radiàta (L.) Sw. Prodr. 26. 1788.

Agrostis radiata L. Pl. Jam. Pugil. 7. 1759.

Annual; culms decumbent, ascending or erect, 2-4 dm. long, usually branched, smooth and slender. Leaf-sheaths compressed, the blades flat, blunt or short-pointed, $2-15 \mathrm{~cm}$. long; spikes several or many, radiating, slender, 4-8 cm. long, not pectinate; spikelets densely imbricated, the fourth scale rudimentary, bearing a filiform awn about $3 \mathrm{~mm}$. long.

Waste places and roadsides, New Providence:- West Indles and troplcal continental America. Radith CHLoris. 
3. Chloris ciliàta Sw, Prodr. 25. 1788.

Annual; culms decumbent, aseending or nearly erect, rather stiff, $s \mathrm{dm}$. long or less, snooth, mostly simple. Leaf-sheaths somewhat compressed, the blades flat, long-acuminate, $7-20 \mathrm{~cm}$. long; spikes few, stout, radiate, pectinate, 4-7 cm. long, conmonly curved; spikelets pale, approximate, the third and fourth seales short-awned.

Waste places and roadsides, New Proridence:- Cuba to St. Thomas, St. Croix, Martinique and Grenada; Jamaica; South America. Frixgen CHLoris.

4. Chloris polydáctyla (L.) Sw. Prodr. 26. 1785.

Andropogon barbatum L. PI. Jam. Pugil. 30. 1759. Not Chloris barbata Sw. 1797.

Andropogon polydactylon L. Sp. PI. ed. 2, 1483. 1763.

Chloris barbata Nash, Bull. Torrey Club 25: 443. 1898.

Perennial; culms 7-12 dm. high. Leares smooth, up to $6 \mathrm{dm}$. Iong, 5-10 mm. rile, long-attenuate. Spikes 6-25, spreading, 5-15 cm. long; spikelets, exclusive of the awns, about $3 \mathrm{~mm}$. Iong; scales 6 , the 2 empty ones acuminate; third seale pilose on the nerres, bearing an awn $3-4 \mathrm{~mm}$. long; fourth scale bearing an awu 2.5-3 $\mathrm{mm}$. long; fifth and sixth seales awnless.

Cultivated ground, New Providence, IIog Island. Elenthera, Cat Island, Rum Caf, Long Island:-Florida; Jamaica; Antigua; South America. MIANY-SPIKED CHLORIS.

5. Chloris paraguaiénsis Steud. Syn. PI. Gram. 204. 1854.

Chloris barbata Sw. Fl. Ind. Oce. 1: 200. 1797. Not Andropogon barbatum L. 1759.

Annual; culms decumbent, ascending or erect, 3-6 dm. long, slender, smooth. Leaf-sheaths compressed, the blades flat or folderl, long-acuminate, 4-12 cm. long. Spikes few or numerous, radiate, pectinate, 4-8 cm. Iong; spikelets usually purple, the third, fourth and fifth seales filiform-anned.

Waste places, New Providence, Grand Turk, and Inagua:-tropical and warm temperata regions. Paraguar Chloris.

25. eUStÁCHys Desv. Nouv. Bull. Soc. Philon. 2: 18s. 1810.

Perennial grasses, with flat or folded, usually obtuse leaf-blades, and spicate inflorescence, the spikes single, in pairs or 3-many and digitate. Spikelets usually 1-flowered, rarely 2-flowered, sessile, crowded in 2 rows. Scales 4, rarely 5 , the 2 lower empty, persistent, unequal, keeled, the first generally acute, the second oblong, truncate or 2-Iobed at the apex, short-awned, the others awnless, mucronate, or short-awned, firmer than the empty scales, the third seale enclosing a perfect flower and a palet, the fourth scale empty, or rarely enclosing a staminate flower. [Greek, beautiful spikes.] About 6 species, natives of tropical America, the following typical.

1. Eustachys petraèa (Sw.) Desv. Nouv. Bull. Soc. Philom. 2: 189.1810.

Chloris petraea $\mathrm{S} \pi$. Prodr. 25. 1788.

Chloris Swartziana Doell. in Mart. Fl. Bras. $2^{3}: 68.1878$.

Culms 3-11 dm. tall; leaves $3 \mathrm{dm}$. long or less, $10 \mathrm{~mm}$. wide or less, smooth; spikes 3-11, usually 4-6, erect, 4-11 $\mathrm{cm}$. long; spikelets about $2 \mathrm{~mm}$. long; scales 4 , the second, exclusive of the awn, $1.5-1.75 \mathrm{~mm}$. long, 2-toothed at the apex, the teeth triangular, acute or obtusish, the awn about $0.5 \mathrm{~mm}$. long; third scale about $2 \mathrm{~mm}$. long, in side view elliptic and about $1 \mathrm{~mm}$. wide, the 
awn short or wanting; fourth seale, in side view, oborate-elliptie, rounded at the apex, awnless.

Waste and cultivated lands, Great Bahama, Abaco, North Bimini, Andros, New Providence, $\mathrm{Hog}$ Island, Eleuthera, Cat Island, Watling's Island, Acklin's Island, Crooked Island, Long Cay, Mariguana, Grand Caicos, Little Ambergris Cay, Grand 'Turk, Inagua, Salt Key, and Anguilla Isles:-Bermuda; North Carolina to Florida and Texas; Cuba: Hispaniola: Forto Rico; Jamaica; tropical continental America. West INDiAN GRASS. FiNger-griss.

\section{BouteloùA Lag. Varied. Cienc. $2^{4}$ : 134. 1805.}

Annual or peremuial grasses with flat or convolute leaves and numerous spikelets in few one-siled spikes. Spikelets 1-2-flowered, arranged in two rows on one side of a flat rachis, the rachilla extended beyond the base of the flowers, bearing 1-3 awns and 1-3 rudimentary seales. Two lower seales empty, acute, keeled; flowering scale broader, 3-toothed, the teeth awn-pointed or arned; palet hyaline, entire or 2-toothed. Stamens 3. Styles distinct. Stigmas pilmose. Grain oblong, free. [In honor of Clandius Boutelou, a Spanish botanist.] About 30 speeies, partieularly numerous in Mexico and in the southwestern United States. Type species: Bouteloua racemosa Lag.

1. Bouteloua americàna (L.) Seribn. Proc. Phila. Aead. 1891: 306.1892.

Aristida americana L. Syst. Nat. ed. 10, s79. 1759.

Boutelona litigiosa Lag. Gen. \& Sp. Nor. 5. 1816.

Pereunial, tufterl. Culms wiry, compressed, decumbent or aseeniling, $7 \mathrm{dm}$. long or less, often much branched, glabrous. Leaves involute-margined, hairy near the base, 6-10 $\mathrm{cm}$. long, $2 \mathrm{~mm}$. wide or less; raceme open, composed of several spike-like branches $2-3 \mathrm{em}$. long; spikelets abont 7 on each spike, appressed; seeond flower rudimentary, with 3 awns of about equal length.

Inagua :-Cuba to Tortola and Barbados; Jamaica; northern South America to Panama. Mesquite-ghiss.

\section{ELEUSINE Gaertn. Fruct. \& Sem. 1: 7. 1788.}

Tufted annual or peremial grasses, with flat leares and spicate inflorescence, the spikes digitate or elose together at the summit of the culm. Spikelets several-flowered, sessile, elosely imbricated in two rows on one side of the rachis, which is not extencled beyond them; flowers perfeet or the upper staminate. Scales compressed, keeled; the 2 lower empty; the others subtending flowers, or the upper empty. Stamens 3. Styles distinet. Stigmas plumose. Grain loosely enclosed in the scale and palet. [From the Greek name of the town where Ceres was worshipped.] Species 6, natives of the Oll Torld. Type species: Cynosurus coracuna L.

\section{Eleusine índica (L.) Gaertn. Frnet. \& Sem. 1: 8. 1788.}

Cynosurus indicus L. Sp. Pl. 72. 1753.

Andropogon repcns Schoepf, Reise 2: 493. 17ss.

Culms 1.5-6 dm. tall, tufted, ereet, or decumbent at the base. Sheaths loose, overlapping and often short and crowded at the base of the culm, glabrous or sometimes sparingly villous; leaves $7.5-30 \mathrm{~cm}$. long, 2-6 $\mathrm{mm}$. vide, smooth or seabrous; spikes 2-10, 2.5-7.5 cm. long, whorled or approximate at the summit of the eulm or one or two sometimes distant; spikelets 3-6-flowered, 3-4 mm. long; seales aeute, minutely scabrous on the keel, the first 1-nervel, the second 3-7-nerved, the others 3-5-nerved.

Waste places, Abaco, New Irovidence, Eleuthera, Fortune Island, Grand Turk, Rum Cay, and Inagua :- Fermula; common as a weed in all warm temperate and tropical regions. WIRE-Griss. 
2S. DACTYLoctènium Willd. Enum. Hort. Berol. 1029. 1809.

An annual grass, with flat leares and spicate inflorescence, the spikes in pairs or digitate. Spikelets sereral-flowered, sessile, closely imbricated in two rows on one side of the rachis, which is extended beyond them into a sharp point. Scales compressed, keeled, the 2 lower and the uppermost ones empty, the others subtending flomers. Stamens 3. Styles distinct, short. Stigmas plumose. Grain free, rugose, loosely enclosed in the scale. [Greek, referring to the digitately spreading spikes.] A monotypie genus of the warmer parts of the Old World.

* 1. Dactyloctenium aegýptium (L.) Willd. Enum. Hort. Berol. 1029. 1809.

Cynosurus aegyptius L. Sp. P1. 72. 1753.

Culms 1.5-6 dm. long, usually decumbent and extensively ereeping at the base. Sheaths loose, overlapping and often erorded, smooth and glabrous; leares $1.5 \mathrm{dm}$. in length or less, $2-6 \mathrm{~mm}$. Wide, smooth or rough, sometimes pubescent, ciliate tomard the base; spikes in pairs, or 3-5 and digitate, 1.25-5 cm. long; spikelets 3-5-flomered; scales compressed, scabrous on the keel, the second awned, the flomering ones broader and pointed.

Waste places. New Proridence, Eleuthera, Great Bahama, Fortune Island, Caicos Islands, and Inagua:- New York to California, Florida and Texas; common as a weed in the West Indies, in tropical America, and in the tropies of the old World. EgYPTIA: Grass.

\section{LEPTÓCHLOA Beauv. Agrost. $71, p l .15, f .1 .1512$.}

Usually tall annual or perennial grasses, with flat leaves and numerous spikes forming a simple panicle. Spikelets usually several-flomered, flattened, alternating in two rows on oue side of the rachis. Scales 4 to many; the 2 lower empty, keeled, shorter than the spikelet; the flowering scales keeled, 3-nerred. Palet 2-nerred. Stamens 3. Styles distinct. Stigmas plumose. Grain free, enclosed in the seale and palet. [Greek, in allnsion to the slender spikes.] About 12 species, natires of the marmer regions of both hemispheres. Type species: Cynosurus virgatus $\mathrm{L}$.

Spikelets with 7 or 8 scales, the flowering scales amnless, or sometimes the first and rarely the second short-awned; leaves glabrous.

Spikelets with 5 or 6 scales, the flowering scales all awned,

the awn of the first scale more than one-half as long as the body; leares sparingly pilose.

1. L. virgata.

2. L. domingensis.

\section{Leptochloa virgàta (L.) Beaur. Agrost. 71, 166. 1512.}

Cynosurus virgatus L. Syst. Nat. ed. 10, 876. 1759.

Perennial; culms rather slender, smooth, erect or decumbent, somewhat tufted, 2-10 $\mathrm{dm}$. high, little branched or simple. Leares glabrous, the blades 6-18 cm. long, 4-15 mm. wide; spikes slender, weak, 3-12 cm. long, racemose near the top of the eulm; spikelets about $4 \mathrm{~mm}$. long; flowering scales awnless or very short-amned.

New Providence:-West Indies and tropical continental America. Virgate LEPTOCHLOA. 
2. Leptochloa domingénsis (Jacq.) Trin. Fund. Agrost. 133. 1820.

Cynosurus domingensis Jacq. Mise. Austr. 2: 363. 1781.

Leptochloa virgata gracilis Griseb. Fl. Brit. W. I. 538. 1864.

Perennial, similar to the preceding species, but the leaf-sheaths often more or less hispid and the blades somewhat villous on the upper surface; flowering scales tipped by filiform awns 1-3 $\mathrm{mm}$. long.

Cultivated grounds and scrub lands, New Providence, Eleuthera, and Great Exuma:-Florida; Mexico; and the West Indies. Slexder LeptochloA.

\section{PHRAGMìtes Trin. Fund. Agrost. 134. 1820.}

Tall perennial reed-like grasses, with broad flat leaves and ample panicles. Spikelets 3-several-flowered, the first flower often staminate, the others perfect; rachilla articulated between the flowering scales, long-pilose. Two lower scales empty, unequal, membranous, lanceolate, acute, shorter than the spikelet; the third scale empty or subtending a staminate flower; flowering scales glabrous, narrow, long-acuminate, much exceeding the short palets. Stamens 3. Styles distinct, short. Stigmas plumose. Grain free, loosely enclosed in the scale and palet. [Greek, referring to its hedge-like growth along ditches.] Three known species, the following typical one widely distributed, one in Asia, the third in South America.

I. Phragmites Phragmites (L.) Karst. Deutsch. F1. 379. 1881.

Arundo Phragmites L. Sp. Pl. S1. 1753.

Phragmites communis Trin. Fund. Agrost. 134. 1820.

Culms 1.5-5 m. tall, erect, stout, from long horizontal rootstocks, smooth and glabrous. Sheaths overlapping, loose; blades $1.5-3 \mathrm{dm}$. long or more, $8-50$ $\mathrm{mm}$. wide, flat, smooth, glabrous; panicle $1.5-3 \mathrm{dm}$. long or more, ample; spikelets crowded on the ascending branches; first scale 1-nerved, half to two-thirds as long as the 3-nerved second one; flowering scales 1-1.2 cm. long, 3-nerved, long-acuminate, equalling the hairs of the rachilla.

Marshes, Andros, New Providence, and Watling's Island:- Widely distributed in tropical and temperate regions. REED-GRASS.

\section{DIPLÁCHNe Beaur. Agrost. 80, pl. 16, f. 9. 1812.}

Tufted grasses, with narrow flat leaves and Jong slender spikes arranged in an open panicle, or rarely only one terminal spike. Spikelets several-flowered, narrow, sessile or shortly pedicelled, erect. Two lower scales empty, membranous, keeled, acute, unequal; flowering scales 1-3-nerred, 2-toothed and mucronate or short-awned between the teeth. Palet hyaline, 2-nerved. Stamens 3. Styles distinct. Stigmas plumose. Grain free, loosely enclosed in the scale and palet. [Greek, referring to the 2-toothed flowering scales.] About 15 species, natives of the warmer regions of both hemispheres, the following typical.

1. Diplachne fasciculàris (Lam.) Beauv. Agrost. 160. 1812.

Festuca fascicularis Lam. Tabl. Encycl. 1: 189.1791.

Leptochloa fascicularis A. Gray, Man. 588. 1848.

Culms tufted, finally branching, 3-8 dm. tall. Leaves erect, 1-2 dm. long, $3 \mathrm{~mm}$. or less wide, involute when dry, rough; racemes 8 or more, erect or 
ascending, the larger ones 4-8 cm. long; spikelets 4-8 mm. long; scales 10-12, the flowering scales, exclusive of the awn, 3-t nm. long, the midnerve extending into an awn $1 \mathrm{~mm}$. long or less.

Sramps, Andros, New Frovidence, Great Exuma, Cat Island, Long Cay, and Inagua :- Florida to Texas, and northward in the Mississippi ralley to llinois; Cuba : St. Croix; Jamaica; Nexico. SpIKe-Grass.

\section{ERAGRóstis Host, Ic. Gram. Austr. 4: 14, pl. 24. 1809.}

Annual or perennial grasses, rarely dioecious, from a few inches to several feet in height, the spikelets in contracter or open panicles. Spikelets 2-inanyflowered, more or less flattened. Two lower scales empty, unequal, shorter than the flowering ones, keeled, 1-nervel, or the second 3-nerved; flowering scales membranous, keeled, 3-nerved; palets shorter than the scales, prominently 2-nerved or 2-keeled, usually persisting on the rachilla after the fruiting scale has fallen. Stamens 2 or 3 . Styles distinct, short. Stigmas plumose. Grain free, loosely enclosed in the scale and palet. [Greek, etymology doubtful, perhaps signifying a low grass, or Love-grass, an occasional English name.] A genus of about 100 species, widely distributed throughout all warm and temperate countries. Type species: Briza Eragrostis L.

Palets glabrous on the keels. or merely hispidulous.

Annual: roots filrous; spikelets not over $1.5 \mathrm{~mm}$. wide.

Perennials.

P'edicels several times longer than the spikelets.

Pedicels sliorter than the spikelets.

Stems low, $3 \mathrm{dm}$. tall or less; inflorescence racemose or nearly so.

Stema tall, usually over $1 \mathrm{~m}$; inflorescence profusely paniculate.

Palets with keels conspicuousiy ciliate: annuals.

Panicle contracted, spike-like. the branches short and appressed; palets with very long hairs; spikelets $3-4 \mathrm{~mm}$. long.

Panicle open, its branches spreading; palets with shorter hairs: spikelets about $2 \mathrm{~mm}$. long.

1. E. tephrosanthos.

2. E. Elliottii.

3. E. Uahancusis.

4. L. prolifera.

5. E. ciliaris.

6. L. amabilis.

\section{Eragrostis tephrosánthos Schult. Mant. 2: 316. 1824.}

Annual ; culms tufted, slender, erect or ascending, 1-3 dm. high, glabrous. Leaves 4-8 cm. long, $1.5-3 \mathrm{~mm}$. Wide, glabrous or nearly so, the sheath ciliate at the top; panicle open, 4-8 cm. long, its filiform branches spreading or ascending; spikelets filiform-peduncled, ovate to ovate-lanceolate, $4-7 \mathrm{~mm}$. long, about $2 \mathrm{~mm}$. wide; scales and palets glabrous.

Waste places and cultivated grounds, New Yrovidence:-Cuba to St. Thomas and Trinidad: Jamaica; continental tropical America. ANNUAL LOVE-Grass.

2. Eragrostis Elliòttii S. Wats. Proc. Am. Acad. 25: 140. 1890.

Poa nitida Ell. Bot. S. C. \& Ga. 1: 162. 1817. Not Lam. 1791.

Eragrostis macropoda Pilger, in Urb. Symb. Ant. 4: 106. 1903.

Peremial; culms tufted, glabrous, rather slender, erect, 4-10 dm. high. Sheaths glabrous; leaf-blades $1-4 \mathrm{dm}$. long, $3-5 \mathrm{~mm}$. wide, scabrous above, smooth beneath; panicle $2-5 \mathrm{dm}$. long, open, its nearly filiform branches spreading or ascending; pedicels filiform, much longer than the spikelets; spikelets 6-13-flowered, $5-10 \mathrm{~mm}$. long, the flowering seales about $2 \mathrm{~mm}$. long.

Ioist places in pine and palmetto-lauds and open scrub-lands, Great Pahama, Abaco, Andros, New Providence, Eleuthera, Little San Salvador:- South Carolina to Florida and Louisiana: Cuba; Porto Rico; St. Thomas; Jamaica. Referred by Dolley to $E$. pectinacea Gray. EllotT's Loite-grass. 
3. Eragrostis bahaménsis Hitche. Rep. Mo. Bot. Gard. 4: 149. 1893.

Perennial, somewhat glaucous; culms slender, wiry, glabrous, 1-3 dm. high. Leaves setaceous, $8 \mathrm{~cm}$. long or less; spikelets sessile, distant, loosely spicate, oblong, many-flowered, 6-10 $\mathrm{mm}$. long, about $2 \mathrm{~mm}$. wide; flowering seales 3-nerved, glaucous, compressed.

Wet or moist rocky places, Rum Cay, Acklin's Island, Ambergris Cay, Little Inagua, Inagua and Grand Turk. Endemic. BaHama Love-Grass.

4. Eragrostis prolífera (Sw.) Steud. Syn. Pl. Gram. 278. 1855.

Poa prolifera Sw. Prodr. 27. 1788.

Poa domingensis Pers. Syn. 1: 88. 1805.

Eragrostis gigantea Trin. Mem. Acad. St. Petersb. VI. 1: 403. 1831.

Perennial, tall; culms slender, up to $2 \mathrm{~m}$. high, often forming large clumps. Leaves elongated, 1.5-6 mm. wide; panicle large, sometimes 6-7 dm. long, broad or narrow, the axils of its branches usually without hairs; spikelets several on the branchlets of the panicle, pale green, short-stalked, linear, about $10 \mathrm{~mm}$. long; palets glabrous.

In sand, Whale Cay:-Cuba; Hispaniola; Guadeloupe; Martinique; Jamaica; Cayman Islands. TALL Love-GRAss.

5. Eragrostis ciliàris (L.) Link, Hort. Berol. 1: 192. 1827.

Poa ciliaris L. Syst. Nat. ed. 10, 875. 1759.

Annual; culms densely tufted, slender, erect or ascending, $3 \mathrm{dm}$. high or less; leaf-sheaths with a tuft of hairs at the top and usually eiliate, the blades flat, 2-7 cm. long, 2-5 mm. wide; panicle narrow, dense, 2-10 cm. long, its branches appressed; spikelets 3-4 mm. long, 6-16-flowered; palet-nerves longciliate.

Waste places and roadsides, Great Bahama, Abaco, Little Harbor Cay, New Providence, Eleuthera, Cat Island, Acklin's Island, Long Cay, Sand Cay, Grand Turk, Inagua, and Anguilla Isles:-Georgia and Florida to Mississippi; West Indies and tropical America.

6. Eragrostis amábilis (L.) W. \& A.; H. \& A. Bot. Beechey Voy. 251. 1811.

Poa amabilis L. Sp. Pl. 68. 1753.

Poa plumosa Retz. Obs. 4:20. 1786.

Eragrostis plumosa Link, Hort. Berol. 1: 192. 1827.

Annual; culms slender, densely tufted, erect or ascending, 1-4 dm. high. Sheaths commonly with a tuft of hairs at the top, their margins usually cilate; leaf-blades $2-10 \mathrm{~cm}$. long, $4 \mathrm{~mm}$. wide or less; panicle-branches spreading or ascending; spikelets about $2 \mathrm{~mm}$. long, 4-8-flowered, the palets ciliate with very short hairs.

Waste places and cultivated grounds, New Providence and Inagua :-Georgia and Florida: West Indies: tropical continental America : old World Tropics. Recorded by Hitchcock as W. major Retz, but written up by him on the label of his Inagua specimen as $E$. minor. I'LUMED LorE-GRASS.

\section{UNIOLA L. Sp. Pl. 71. 1753.}

Erect and often tall grasses with flat or convolute leaves and paniculate inflorescence. Spikelets 3-many-flowered, flat, 2-edged, the flowers perfect, or the upper staminate. Scales flattened, keeled, sometimes winged, rigid, usually acute; the lower 3-6 empty, unequal; the flowering scales many-nerved, the uppermost scales often smaller and empty; palets rigid, 2-keeled. Stamens 1-3. Styles distinct. Stigmas plumose. Grain compressed, free, loosely enclosed 
in the seale and palet. [Name diminutive of unus, one, of no obvious application.] About 8 species, natives of America. Type species: Uniola paniculata 1.

Spikelets $12 \mathrm{~mm}$. long or more; inflorescence an open loose panicle.1. U. paniculata. Spikelets 3-4 mm. loug; inflorescence of numerous short secund racemes.

2. U. virgatu.

\section{Uniola paniculàta L. Sp. Pl. 71. 1753.}

Culms 1-2.5 m. tall. Leaves $3 \mathrm{dm}$. long or more, about $6 \mathrm{~mm}$. wide, involute when dry, attenuate into a long slender tip; panicle open, loose, $2.25-3$ dm. in length or more, the branches erect or ascending, strict, rigid, the lower 6-12.5 cm. long; spikelets many-flowered, short-pedicelled, ovate to oval when mature, $1.25-2.5 \mathrm{~cm}$. long; flowering seales $8-10 \mathrm{~mm}$. long and seabrous on the keels.

Sand dunes and beaches, Abaco, New Providence, Eleuthera, Cat Island, Great Ragged Island, Atwood Cay, Crooked Island, Fortune Island, Mariguana, Turk's Islands, Inagua. and Salt Key :-Virginia to Florida and Texas; Cuba. Ses OATs. Catesby 1: $p l$. 32 .

2. Uniola virgàta (Poir.) Griseb. Fl. Brit. W. I. 531. 1864.

Poa virgata Poir. in Lam. Eneycl. 5: 78. 1804.

Uniola racemiflora Trin. Bull. Acad. St. Petersb. 1: 68. 1836.

Culms tufter, 1-2 m. tall, rigid. Leaves $3-5 \mathrm{dm}$. long, rigid, involute, usually curved, $2-3 \mathrm{~mm}$. wide; panicle narrow, virgate, $2-5 \mathrm{dm}$. long, about $2 \mathrm{~cm}$. thick, its many short branches erect, appressed, the spikelets racemosespicate, secund, 3-4 mm. long, oval, few-flowered; flowering scales about 2 mm. long.

Sandy sea-beaches, Abaco, Andros, New I'rovidence, Eleuthera, Cat Island:Cuba; Hispaniola ; Porto Rico; Vieques; St. Thomas; St. Jan; Saba. SPIKE-Grass.

\section{DISTICHLIS Raf. Journ. de Phys. 89: 104. 1819.}

Dioecious grasses, with rigid eulms ereeping or decumbent at the base, flat or convolute leaves and spike-like panieulate inflorescence. Spikelets flattened, more numerous on the staminate plants than on the pistillate, 6-16-flowered; rachilla continuous in the staminate spikelets, artieulated in the pistillate. Two lower scales empty, narrow, keeled, acute, shorter than the flowering ones; flowering scales broader, many-nerved, acute, rigid; palets 2-keeled. Stamens 3. Styles thickened at the base, rather long, distinct. Stigmas longplumose. Grain free, enclosed in the seale and palet. [Greek, signifying tworanked, probably in reference to the spikelets.] Four known species, natives of America, inhabiting the seacoast or alkaline soil; one of them is also found in Australia. Type species: Uniola spicata L.

1. Distichlis spicàta (L.) Greene, Bull. Cal. Acad. 2: 415.1887.

Uniola spicata L. Sp. Pl. 71. 1753.

Culms $7.5-60 \mathrm{~cm}$. tall, erect from a horizontal rootstock, or often decumbent at the base. Sheaths overlapping and often crowded; leaves 1.25-15 $\mathrm{cm}$. long, 2-4 mm. wide, flat or involute; panicle dense and spike-like, $1.8-6 \mathrm{~cm}$. in length, the branches $2.5 \mathrm{~cm}$. long or less, erect; spikelets 6-16-flowered, 8-18 mm. long, pale green; empty scales acute, the first 1-3-nerved, two-thirds as long as the 3-5-nerved second one; flowering scales $3-5 \mathrm{~mm}$. long, acute or acuminate.

Brackish soil. Andros, New Providence, Eleuthera, Watling's Island, Inagua :Nova Scotia to Washington. California, Texas, and Florida: IIexico; Cuba; South Amerjca. Erroneously called Bulrush. IARSh Spike-grass. RabBit-grass. 
35. ARthrostylidium Rupr. in Mem. Acad. St. Petersb. VI. 5²: 117. 1839.

Woody, mostly rine-like grasses, the leares usually borne on short branches whorled at the nodes, the leaf-blades linear or lanceolate, jointed with the sheaths. Spikelets racemose, usually appearing only after long intervals, sometimes only after many years. Spikelets linear, few-several-flowered, stalke, or nearly sessile, more or less secund, articulated above the lower 3 or 4 empty scales; lowest scale small, the others similar to earh other, acute or acuminate, many-nerved, not awned; palets narrow, 2-carinate, scarcely shorter than the seales. Flowers perfect. Stamens 3. Orary glabrous; styles 2. Grain oblong. [Greek, referring to the jointed spikelets.] About 20 species, natives of tropical America. Type species: Arthrostylidium Haenliei Rupr.

1. Arthrostylidium capillifòlium Griseb. Mem. Am. Acad. II. 8: 531. 1862.

Glabrous; stem slender, wiry, woody, climbing over shrubs and small trees, sometimes $5 \mathrm{~m}$. long, often forming large colonies. Branches numerous, fascicled at the norles, short; leaves capillary, flexible, $5-15 \mathrm{~cm}$. long; spikelets few, at the emis of the branches, lanceolate, $8-12 \mathrm{~mm}$. long, $2-3 \mathrm{~mm}$. wide, several-flowerell.

In low dense coppices aud pinelands, Andros, New Providence, Cat Island, Great Exuma:-Cuba; Porto Rico. Oly Max's BEard.

\section{Family 2. CYPERÀCEAE J. St. Hil.}

Sedge Family.

Grass-like or rush-like herbs. Stems (culms) slender, solid (rarely hollow), triangular, quadraugular, terete or flattened. Roots fibrous (many species perennial by long rootstocks). Leaves narrow, with closed sheaths. Flowers perfect or imperfect, arranged in spikelets, one (rarely 2) in the axil of each scale (glume, bract), the spikelets solitary or clustered, 1many-flowered. Scales 2-ranked or spirally imbricated, persistent or deciduous. Perianth hypogynous, composed of bristles, or interior scales, rarely calyx-like, or entirely wanting. Stamens $1-3$, rarely more. Filaments slender or filiform. Anthers 2-celled. Ovary 1-celled. Ovule 1, anatropous, erect. Style 2-3-cleft or rarely simple or minutely 2-toothed. Fruit a lenticular, plano-convex, or trigonous achene. Endosperm mealy. Embryo minute. About 65 genera and 3000 speices, of very wide geographic distribution.

Fertile flowers perfect.

Basal empty scales of the spikelet none, or not more than two.

Scales of the spikelets distichous; bristles none.

Scales of the spikelets spirally imbricated (apparently distichous in Abildgaardia).

Base of the strle persistent as a tubercle on the achene.

Spikelet 1; perianth-bristles usually present; culms leafless.

Spikelets usually several or numerous: bristles none; culms leafy below.

Style wholly deciduous; no tubercle on the achene.

Base of the style swollen; bristles none. Spikelets nearly terete, not flattened. Spikelets distinctly flattened.

Base of the style not swollen; bristles usually present.

Basal empty scales of the spikelets 3 or more.

Style 2-cleft, its base persistent as a tubercle on the achene.

Bristles none: culm monocephalous.

Bristles usually present; culm ustilly polycephalous.

1. Cypcrus.

2. Eleocharis.

3. Stenophyllus.

4. Fimbristylis.

5. Abildgatidir.

6. scirpus.

7. Dichromena.

8. Rynchospora. 
Style 3 -cleft, its base fused with the top of the achene; tubercle none.

Bristles none.

Bristles present.

Flowers all impelfect: achene bony or crustaceous.

9. Mariseus.

10. Schocnus.

11. Scleria.

\section{CYPÈRUS L. Sp. Pl. 44. 1753.}

Annual or perennial sedges. Culms in our speeies simple, triangular, leafy near the base, and with 1 or more leares at the summit forming an involucre to the simple or compound, umbellate or capitate inflorescence. Rays of the umbel sheather at the base, usually rery unequal, one or more of the heads or spikes commonly sessile. Spikelets flat or subterete, the scales falling away from the rachis as they mature (nos. 1- 7 ), or persistent and the. spikelets falling away from the axis of the head or spike with the scales attacherl (nos. 8-14). Seales concave, conduplicate or keeled, 2-ranked, all flotrer-bearing or the lower ones empty. Flowers perfect. Perianth none. Stamens 1-3. Style 2-3-cleft, deciduous from the summit of the achene. [Ancient Greek name for these sedges.] About 600 species, of wide distribution in tropical and temperate regions. Type species: Cyperus esculentus $\mathrm{L}$.

Strle-branches 2: achene lenticular.

1. C. paniculatus.

Style-branches 3 ; achene trigonous.

Spikelets not breaking up into one-fruited joints.

Scales deciduous from the persistent rachis of the spikelets.

Rachis-wings none, or very narrow.

Annuals.

Scales tipped with recurved awns.

Sicales acuminate, not awned.

Perennials.

Leares flat; plants not viscid.

Spikelets yellow, oblong-lanceolate.

spikelets green-brown, ovate. Leares involute; plant riscid.

Rachis-wings manifest; perennial.

Spikelets falling away above the two persistent lower scales.

Leares and culms filiform, reclining.

Leaves flat; culms stout or slender, erect. Spikelets with $1-4$ achenes.

Spikelets in a single capitate cluster. T'mbel compound: spikes cylindric.

Spikelets with $5-20$ achenes.

Scales acute or cuspidate, not awned.

Scales awned.

Spikelets breaking up into one-fruited joints.

[mbel compound: annual with flat leares.

Spikelets in a single cluster or two: perennial with

filiform leares.

2. C. cuspidatus.

3. C. compressus.

4. C. ochraceus.

5. C. pseudovegetus.

i. $C$. elegans.

i. C. rotundus.

S. C. foridanus.

¿. C. fuligineus.

10. C. ligularis.

11. C. brunneus.

12. C. confertus.

13. C. ferax.

14. C. filiformis.

1. Cyperus paniculàtus Rottb. Deser. \& Icon. 40. 1773.

Cyperus Gatesii Torr. Ann. Lyc. N. Y. 3: 255. 1836.

Annual, bright green. Leaves 1-4 mm. wide; cnlms slender, tufted, 1-4. $\mathrm{dm}$. tall, often surpassing the leaves; bracts of the involncre $3-\overline{5}$, surpassing the umbel, the longer ones up to $2 \mathrm{dm}$. long; umbel with 3-8 rays, or rarely nearly capitate: spikelets few, linear or linear-lanceolate, $6-15 \mathrm{~mm}$. long, acute; scales light chestnut-brown, oblong-lanceolate, acute, shining, striate, deciduous at maturity; style 2-cleft; achene lenticular, oblong, grayish, abruptly apiculate, fully half as long as the scale.

Moist ground, New Providence:-southeastern Lnited States: West Indies : tropical continental America. Referred by Clarke to Pycracus ferrugineus; recorded by Dolley as C. polystachyus Rottb. PANicled CrPercs. 
2. Cyperus cuspidàtus H.B.K. Nov. Gen. 1: 204. 1816.

Annual, glabrous; culms tufted, 2-14 cm. tall, as long as the leaves, or longer. Leares 1-2 mm. wide, those of the umbel usually 3 or 4 , sometimes 1 dm. long; umbel 2-5-rayed, rarely capitate; rays $0.5-5 \mathrm{~cm}$. long; spikelets linear, 5-12 mm. long, about $1.5 \mathrm{~mm}$. wide, digitate, many-flowered; seales chestnut-brown, nearly $2 \mathrm{~mm}$. loug, strongly 3-5-nerved, keeled, the recurvedspreading awn-like tip nearly as long as the body; stamens $1-3$; achene broadly obovoid, $0.5 \mathrm{~mm}$. long, trigonous, brown, apiculate; style very short.

Wet soil, New F'lovidence, Cat Island, Fortune Island, Acklin's Island, South Caicos, Inagua :-southern United States; Cuba: Anegada; Fincitin; Siouth Amelica. Recorded by Iitchcock as C. aristutus Rottb. CusPidate CrPEnus.

3. Cyperus compréssus L. Sp. Pl. 46. 1753.

Annual; culms slender, erect or reclining, smooth, $7-25 \mathrm{~cm}$. long. Leares light green, about $2 \mathrm{~mm}$. wide, those of the involuere $2-3$, the longer exceeding the spikelets; umbel capitate or with $2-3$ short rays; spikelets narrowly lanceolate, acute, S-20 mm. long, 3-4 mm. wide, very flat, many-flowered; scales light green with a yellow band on each side, ovate, acnminate, firm, keeled, several-nerved, falling away from the narrowly-minged rachis at maturity; stamens 3 ; style 3 -cleft; achene sharply 3 -angled, obovoid, obtuse, dull, brown, about one-third as long as the scale.

Waste gromuds, New Providence:- Lnited States; Cuba to Virgin Gorda and Trinjdad; Jamaica; tropical continental America and old World tropics. Flat CYPFiRUS.

\section{Cyperus cchràceus Tahl, Enum. 2:325. 1806.}

Perenuial; culms rather stout, $2-\tau \mathrm{dm}$. tall. Leares $6 \mathrm{~mm}$. wide or less, the basal ones mostly shorter than the culm, those of the involucre several, sprealing, 2 or more of them much longer than the compound or simple umbel; umkel-rays $15 \mathrm{~cm}$. long or less; spikelets numerous, capitate, flattish, blunt, many-flowered, $5-12 \mathrm{~mm}$. long, about $2 \mathrm{~mm}$. wille; scales yellow, orate to ovatelanceolate, obtusish: stamen 1; achene oroid, 3-angled, narrowed at both ends.

Swamps, New Providence:- - southern rnited States: Cuba to Guadaloupe; Jamaica; tropical continental America. Erroneously referred by Clarke to $C$. Lu心ulae Rottb., citing Brace no. 498 ; referred also hele by Dolley. YELlow Crpents.

\section{Cyperus pseudovégetus Steud. Syn. Pl. Cyp. 24. 1855.}

Perennial by thickened tuber-like joints of the rootstocks; culm lather stout, $0.3-1.3 \mathrm{~m}$. high, often equalled by the leaves. Leaves $3-4 \mathrm{~mm}$. wide, smooth, nodulose, the midrein prominent; leaves of the involucre $1-6$, spreading; umbel several-rayed, compound; spikelets ovate, flat, many-flowered, light green, densely capitate, 1-6 mm. long; scales keeled, conduplicate, 1-nerved, curved, acute, longer than the linear 3-angled slightly stalked achene; stamen 1 ; stỵle 3 -cleft.

Swamps, New Providence at Southwest Bay:-southeastern Lnited States. Marsit Crperts.

6. Cyperus élegans I. Sp. Pl. 45. 1753.

Cyperus viscosus Sw. Prodr. 20. 1788.

Perennial by short rootstocks; culms riseid-pubescent, $S \mathrm{dm}$. tall or less. Leares convolute in drying, the basal ones about as long as the culm, those of the involuere about 3 , the longer ones much surpassing the inflorescence; umbel usually compound, the rays up to $15 \mathrm{~cm}$. long; spikelets 2-12 in the clusters, digitate, oblong-lanceolate, 6-15 $\mathrm{mm}$. long, 3-5 $\mathrm{mm}$. wide, compressed; scales green-brown, ovate, strongly mucronate, about $3 \mathrm{~mm}$. long; stamens and stylebranches 3 ; achene obovoil, 3-angled, nearly black, about half as long as the scale.

Marshes and sink-holes, Great Bahama, New Providence, Eleuthera, Cat Island, IVatling's Island, Acklin's Isand, Great Exuma, Ingau:-Florida: Cuba to St. Jan and 'Trinidad; Jamaica; Iucatan; South America. Viscin Crpenus. 
7. Cyperus rotúndus I. Sp. Pl. 45. 1753.

Perenuial by sealy tuber-bearing rootstocks; culm rather stout, $0.1-0.5 \mathrm{~m}$. high, usually longer than the leares. Leares $3-6 \mathrm{~mm}$. wide, those of the involncre $3-5$; umbel 3-8-rayed, the longer rays $5-11 \mathrm{~cm}$. long; spikelets linear, clusterel, few in each cluster, acute, $8-20 \mathrm{~mm}$. long, 2-3 mm. wide; seales dark purple-brown or with green margins and centre, orate, acute, appressed when mature, about 3 -nerved on the kee]; stamens 3 ; style 3 -cleft, its branches exserted; achene 3-angled, about one-half as long as the scale.

Wiste and cultivated grounds, New Providence:- Tnited States: Bermuda: West Indies: tropical continental imerica: warm-temperate and tropical parts of the Old World. Nut-GRass.

8. Cyperus floridànus Britton; Small, Fl. S. E. U. S. 170. 1903.

Perennial by tuber-like bases of the culms. Culms filiform, wiry, densely clustered, erect or reclining, 0.5-2.5 $\mathrm{dm}$. long; leaves filiform, or the lowest reduced to scales, some of them usually as long as the eulm or longer, about $0.5 \mathrm{~mm}$. wide, those of the involuere 2 or 3 , similar to the lower ones, the longer much exceeding the head of spikelets, sometimes $10 \mathrm{~cm}$. long; hearl composed of few to several spikelets; spikelets digitate, flattened, linearsubulate, $6-15 \mathrm{~mm}$. long, $1 \mathrm{~mm}$. wide, several-flowered, acuminate; scales oblong, 2 $\mathrm{mm}$. Jong, chestnut-brown, blunt, strongly several-nerved, firm in texture; stamens 3 ; achene linear-oblong, about $1.5 \mathrm{~mm}$. long and $0.5 \mathrm{~mm}$. thick, dull, dark brown. Plant with the habit of $C$. filiformis.

Moist sandy soil, Abaco, Berry Islands, Andros. New Providence:-Florida; Cuba: Santo Domingo. FloridA CrPeres.

9. Cyperus fuligíneus Chapm. FI. S. States 511. 1860.

Mariscus fuligineus Clarke, Kew Bull. Add. Ser. 8: 16. 1908.

Perennial; eulms very slender, smooth, tufted, 1-4 $\mathrm{dm}$. high, rather rigid. Leaves recolute-margined, shorter than the culm, those of the involucre usually 2, unequal; spikelets linear, 6-10 mm. long, 1-1.5 mm. wide, densely crowded in a single terminal head; seales ovate to oral, about $2 \mathrm{~mm}$. long, dark brown, striate, mucronulate; style 3 -cleft; achenes oblong-oboroid, trigonons, about $1.5 \mathrm{~mm}$. Jong, dull, brown.

Sandy and rocky soil, Berry Islands, New Providence and Eleuthera to Ambergris Cay. Grand Turk, Inagua and the Anguilla Isles :-Florida : Cuban Cays; Anegada: Bcnaire: Curacao. Recorded by Coker and presumably by Dolley as $C$. Tahlii Steud.: by Hitchcock as C. brunneus Sw.

10. Cyperus ligulàris L. Amoen. Acad. 5: 391. 1759.

Perennial; roots fibrous, thick; rootstock short or none; culms stout, 1.2 $\mathrm{m}$. high or ]ess. Leaves $8-20 \mathrm{~mm}$. wide, pale green, rough-margined, the basal ones often overtopping the culm, those of the involuere sometimes $7 \mathrm{dm}$. long; umbel 4-12-rayed, large, compound; spikes oblong or subglobose, 8-10 mm. thick, very dense; spikelets gray to brown, 4-6 $\mathrm{mm}$. long, about $1.5 \mathrm{~mm}$. wille, bearing 2-4 achenes; frniting seales oral or orate, striate, blunt, $2.5-3$ mm. long; achene narrowly obovoid to ellipsoid, dark brown, dull, 3-angled, about $1.5 \mathrm{~mm}$. long, half as long as the seale.

Swamps. Great Bahama to Andros, New Providence. Fortune Island, North Caicos and Inagua :- Southern Inited States: West Indies and tropical continental America; tropical Africa. LARge C'TPERCS. Sitw-Gluss.

11. Cyperus brúnneus Sw. Fl. Ind. Oce. 1: 116. 1797.

Mariscus brizaeus Clarke in Urban, Symb. Ant. 2: 52. 1900.

Perennial by stout rootstocks; culms stout, $i \mathrm{dm}$. high or less. Leares 4-10 mm. wide, pale green, the basal often overtopping the culm, those of the involucre $3-5$, the longer much surpassing the inflorescence; umbel few-rayed, 
or glomerate, simple or little compound, the rays up to $3 \mathrm{~cm}$. long; spikelets short-spicate, 1-2 $\mathrm{cm}$. long, about $3 \mathrm{~mm}$. wide, with 5-10 achenes; scales brown, ovate, apiculate, strongly striate-nerved; achene obovoid, 3-angled.

Sand dunes and white-lands, throughout the alchipelago from Abaco and firent Bahama to the Caicos Islands, Little Inagua and Cay Sal:-Bermuda; Florida; West Indies; Mexico. Consists of several races differing in stalked or sessile spikes, width of leares, the scales orate to elliptic-oblong. Recorded by Herrick as C. Vahiii Steud. SAND or CoAst Crpenus.

\section{Cyperus confèrtus Sw. Prodr. 20. 1788.}

Perennial by short rootstocks; culms rather slender, 1-4 dm. high, elustered. Leares $3-5 \mathrm{~mm}$. wide, the basal ones as long as the culms or shorter, those of the involuere $2 \mathrm{dm}$. long or less, the longer much surpassing the inflorescence; umbel simple, 1-7-rayed; hearls subglobose, about $1 \mathrm{~cm}$. thick; spikelets greenish-yellow, $5-7 \mathrm{~mm}$. long, about $2 \mathrm{~mm}$. wide, flat, bearing $5-9$ achenes; fertile scales ovate, keeled, strongly striate, tipped with short, somewhat curved awns; stamens 3 or sometimes 2; achene oblong-oboroid, 3-angled, 1-1.5 mm. long, about half as long as the scale.

Inagua :-Ifispaniola to St. Thomas and to Martinique; Jamaica. Curaço; northern South Anerica; Galapagos. CAPitate Cyperus.

13. Cyperus fèrax L. C. Rich. Act. Soc. Hist. Nat. Paris 1: 106. 1792.

Annual; smooth; eulms rather stout, 3-8 dm. tall, usually tufted. Leaves 5-10 mm. wide, the lower ones as long as the culm or shorter, those of the iuvoluere 3 or more, the longer equalling or exceeding the umbel; umbel simple or compound, several-rayed; spikelets linear, subterete, 10-20-flowered, 1.5-2.5 $\mathrm{cm}$. long, $1.5-2.5 \mathrm{~mm}$. thick, the ovate-oblong, appressed, yellow-green, 7-9-nerved scales scarcely imbricated; stamens 3 ; style 3 -cleft; achene trigonous, narrowly oboroid, obtuse.

Swamps, Abacn, Cat Cay, New Providence, Exuma Chain, Eleuthera:-United States: West Indies; Central and South America. CoArse Crperes.

\section{Cyperus filifòrmis Sw. Prodr. 20. 1788.}

Mariscus filiformis H.B.K. Nov. Gen. 1: 213. 1816.

Perennial; glalyrous; culms very slender or filiform, tufted, 'rather weak, 2-7 dm. long. Leaves usually much shorter than the culm, about $2 \mathrm{~mm}$. wide, those of the involuere 1 or 2 , mostly longer than the 1 or 2 loose spikes; spikelets 3-10, nearly digitate, $1-2.5 \mathrm{~cm}$. long, about $1 \mathrm{~mm}$. thick, terete, erect or ascending, several-flowered; scales yellowish with a green keel, acutish, shining, faintly striate, ovate, inrolled, not overlapping; achene shorter than the scale, trigonous, ellipsoid, blackish, pointed at both ends.

Grassy places, New Providence:-Cuba to St. Thomas and St. Croix: Jamaica. The Crooked Island reference of IIitcheock proves to be an error, his plant being Schoenus nigricans L. SLEvDER CYPERUS.

Schoepf records fiyllinga monocephala Rotib. as observed by him on New Providence in 1784 , but no species of that genus has been collected in the Bahamas by subsequent botanists.

\section{ELEÓcHARIS R. Br. Prodr. 1: 224. 1810.}

Anmual or perennial serges. Culms simple, triangular, quadrangular, terete, flattened or grooverl, the leaves reduced to sheaths or the lowest rery rarely blade-bearing. Spikelets solitary, terminal, erect, several-many-flowered, not subtended by an involucre. Scales concare, spirally imbricated all around. Perianth of 1-12 bristles, usually retrorsely barbed, or wanting in some species. 
Stamens 2-3. Style 2-eleft and achene lenticular or biconvex, or 3-cleft and achene 3 -angled, but sometimes with very obtuse angles and appearing turgid. Base of the style persistent on the summit of the achene, forming a terminal tubercle. [Greek, referring to the growth of most of the species in marshy ground.] About 140 species, widely distributed. Type speeies: Scirpus palustris $\mathrm{L}$.

Spikelets little, if at all, thicker than the culms; scales rigid; tall sedges.

Achenes transverselr ridged: culms nodose-septate. 1 . $\boldsymbol{E}$. interstincta.

Achenes copiously pitted: culms continuous. 2 . cellulosa.

Spikelet thicker than the culm; scales membranous; low sedges. Tppel sheatl hyaline, scarious.

Lpper sheath truncate, oblique or 1-toothed.

Perianth-bristles nearly white; achene $0.5 \mathrm{~mm}$. long; culms nearly filiform.

Perianth-bristles brown; achene $1 \mathrm{~mm}$. long; culms slen-

3. E. flaccida. der.

4. E. atropurpurea.

5. E. capitata.

1. Eleocharis interstíncta (Tahl) R. \& S. Syst. 2: 149.1817.

Scirpus interstinctus Tahl, Enum. 2: 251. 1806.

Perennial by stout rootstocks; culms stout, terete, 4-10 dm. tall, nodose, hollow. Sheaths oblique, the lower sometimes bearing short blades; spikelet crlindric, terete, 2-4 cm. long, 4-5 mm. thick; scales coriaceons, obtuse, faintly many-nerved, scarious-margined; bristles ahout 6 , retrorsely barbed, as long as the achene or shorter; strle 3 -cleft rarely 2-cleft; achene obovold, shining, brown, minutely many-striate and transversely ridged; tubercle conic, acute.

Marshes, Great Bahama, New Providence, Acklin's Island:-eastern Tnited States: Bermuda; Cuba to St. Thomas and Trinidad; Jamaica; tropical continental America. KNOTTED SP1KE-RUSH.

2. Eleocharis cellulòsa Torr. Ann. Lye. N. Y. 3: 298. 1836.

Perennial by long rootstocks; culms obscurely 3-angled below, terete above, $7 \mathrm{dm}$. tall or less, not nodose. Sheaths membranous, oblique; spikelet $1.5-3$ em. long, $2.5-4 \mathrm{~mm}$. thick, cylindric, somewhat thicker than the culm; seales coriaceous, obtuse, membranous-inargined, many-striate; bristles 6 or 7 , nearly or quite smooth, about as long as the achene; style 3-cleft; achene broadly obovoid, trigonons, striate, copiously pitted; tubercle deltoid, about one-half as wide as the achene.

Marshes, Abaco, Great Bahama, Andros, New Providence, Rose Island, Eleuthera, Crooked Island, Fortune Island, Great Exuma, Inagua:-southern Tnited States; Bermuda; Cuba; Porto Rico; Jamaica; Yucatan. Rouxd-STEMMEd SPIKERUSH.

* 3. Eleocharis fláccida (Rehb.) Urban, Symb. Ant. 2: 165. 1900.

Scirpus flaccidus Rehb.; Spreng. Tent. Suppl. 3. 1828.

Eleocharis ochreata Nees, Linnaea 9: 294. 1834.

Scirpus ochreatus Griseb. Fl. Br. W. I. 570. 1864.

Heleocharis bahamensis Boeckl. Crp. Nov. 2: 11 in part. 1590.

Perennial by slender rootstocks; culms slender or filiform, 3-angled, 0.5-3 $\mathrm{m}$. long. Upper sheath white, hyaline, membranous; spikelet oblong or oroid, 3-6 $\mathrm{mm}$. Iong, 2-2.5 $\mathrm{mm}$. thick, much thicker than the culm; scales elliptic to oblong-lanceolate, obtuse or the upper acute, thin, pale green with a faint midrein; style '2-cleft; achene lenticular, oborate, smooth, $0.5 \mathrm{~mm}$. long, 2-4 times as long as the conic, acute tubercle; bristles 6 or 7 , retrorsely barbed, as long as the achene, or shorter, or none.

Tet grounds, New Providence, Eleuthera:-Southeastern Inited States: Cuba ro St. Thomas and Trinidad; Jamaica; tropical continental America; Philippine Islands. PALE SPIKE-TESH. 
4. Eleocharis atropurpùrea (Retz.) Kunth, Enum. 2: 151. 1837.

Scirpus atropurpureus Retz. Obs. 5: 14. 1789.

Heleocharis Sintenisii Boeckl. Cyp. Nov. 1: 16. 1888.

Heleocharis bahamensis Boeckl. Cyp. Nov. 2: 11. 1890.

Annual; roots fibrous; culms tufted, very slender, 2-9 cm. high. Upper sheath 1-toothed; spikelet ovoid, many-flowered, subacnte, 3-4 mm. long, $2 \mathrm{~mm}$. in diameter or less; scales minute, orate-oblong, persistent, purple-brown with green midvein and rery narrow scarious margins; stamens 2 or 3 ; style 2-3cleft; bristles 2-4, fragile, white, minutely downwardly hispid, about as long as the achene; achene jet black, shining, $0.5 \mathrm{~mm}$. long, smooth, lenticular; tubercle conic, mintute, depressed but rather acute, constricted at the base.

Hog Island, New Providence, Andros, Acklin's Island :-Florida; Cuba ; Porto Rico; Central and westerll Lnited States to Central America; Europe; Asia. Referred by Clarke to $E$. camptotrich Schueinitzii Clarke, citing Northlop'524 b, from Conch Sound, Andros, but that has trigonous achenes, proliferous spikelets and is the same as $E$. prolifera Torr., its older name. Our specimen of this number has lenticular achenes; it is possible that two species were distributed under the same number. Mis. Northlop's no. 745 , indicated on her label as the same as $524 \mathrm{~b}$, was determined by $\mathbf{3 1}$. C'larke as $E$. atropurpureu. I'URPLE SPIKE-liush.

5. Eleocharis capitàta (L.) R. Br. Prodr. 225. 1810.

Scirpus capitatus L. Sp. Pl. 4S. 1753.

Annual; roots fibrous; culms densely tufted, nearly terete, almost filiform, 5-25 cm. tall. Upper sheath 1-toothed; spikelet ovoid, obtuse, much thicker than the eulm, 3-5 mm. long, 2-3 $\mathrm{mm}$. thick, many-flowered; seales broadly ovate, obtuse, firm, pale or dark brown with a greenish midvein, narrowly searious-margined, persistent; stamens mostly 2; style 2-cleft; bristles $5-8$, slender, downwardly hispid, as long as the achene; achene oborate, jet black, smooth, shining, nearly $1 \mathrm{~mm}$. long; tubercle depressed, apiculate, constricted at the base, very much shorter than the achene.

Moist and wet grounds, Great Bahama, and Andros to Crooked Island, North Caicos and Inagua :- Tnited States: Bermuda; West Indies; tropical continental America; Old World tropies. Capitate Spike-Rush.

\section{STENOPHÝlLUS Raf. Neog. 4. 1825.}

Mostly annual sedges, with slender erect culms, leafy below, the leares narrowly linear or filiform, with ciliate or pubescent sheaths. Spikelets umbellate, capitate or solitary, usually subtender by a 1-several-leaved involucre, their scales spirally imbricated all around, mostly decidnous. Flowers perfect. Perianth none. Stamens 2 or 3. Style 2-3-cleft, glabrous, its base much swollen and persistent as a tubercle on the achene as in Eleocharis. Achene 3angled, turgid or lenticular. [Greek, referring to the narrow leaves.] A genus of some 90 species, natives of temperate and warm regions. Type species: Scirpus stenophyllus Ell.

\section{Stenophyllus Wilsoni Britton, Torreya 13: 215. 1913.}

Perennial by short stout rootstocks; culms clusterer, somewhat flattened, smooth, stiff, but rather slender, erect, 2-3 dm. tall. Basal sheaths 3 or 4, bladeless, acute, many-nerved, floccose-pubescent, the upper with a scarious margin; spikelets 2-5 together, in a terminal capitate cluster subtended by a subulate bract $0.5-2 \mathrm{~cm}$. long, or sometimes by 2 bracts, linear-oblong, much compressed, 1-2 $\mathrm{cm}$. long, $4 \mathrm{~mm}$. wide; scales narrowly oblong to oblonglanceolate, loosely pulescent, eiliate, light brown, membranous, obtusish, 5 $\mathrm{mm}$. long, $1.5 \mathrm{~mm}$. wirle, the midvein prominent; stanens 3 ; style 3 -eleft, the 
pubescent branches about as long as the glabrous lower part; achene obovoid: dull black, bluntly trigouous, nearly 1 mm. long, capped by a minute de: pressed tubercle.

Castle Island and Little Inagua. Endemic. Wrisox's Stexophrilus.

4. FIMBRISTYLIS Tahl, Enum. 2: 285. 1806.

Aunual or perennial sedges. CuIms leafy below. Spikelets umbellate or capitate, terete, several to many-flowered, subtended by a 1-many-leaver inrolucre, their scales spirally imbricated all around, mostly deciduons, all fertile. Perianth none. Stamens 1-3. Style 2-3-cleft, pubecent or glabrous, its bace much enlarged, falling away from the summit of the achene at maturity. Achene lenticular, biconvex, or 3-angled, reticulated, cancellate, or longitudiually ribbed or striate in our species. [Greek, in allusion to the fringed style of some species.] A large genus, the species widely distributed in temperate and tropical regions. Type species: Fimbristylis acuminata VahI.

Strle branches 2; achene lenticular.

Achene longitudinally ribbed.

Achene cancellate, reticulate or granular, not ribbed. Scales pilose-puberulent; leaves short. Scales glabious.

Leares elongated: inflorescence loose. Leares involute or plano-convex. Leaves flat.

Leares short: inflorescence compact.

Style branches 3 ; achene trigonous.

1. F. diphylla.

2. F. forruginca.

3. $F$. castanca.

4. $F_{\text {. inaguensis. }}$

5. $F$. sprithacea.

6. F. hirta.

1. Fimbristylis diphýlla (Retz.) Tahl, Enum. 2: 289. 1806.

Scirpus diphyllus Retz. Obs. 5: 15. 1789.

Perennial by short rootstocks, glabrous or pubescent; culms tufted, 1-6 dm. high, slender. Leaves $1-3 \mathrm{~mm}$. wide, shorter than the culm; involucrebracts 3 or 4 , shorter than or surpassing the simple or compound umbel; spikelets oblong or ovoid, 5-10 $\mathrm{mm}$. long, 2.5-4 mm. thick; seales ovate, acute, glabrous; style 2-eleft; achenes scarcely $1 \mathrm{~mm}$. long, oboroid, biconrex, white or yellowish, longitudinally ribbed, reticulated, the ribs smooth.

IIoist soil, New Providence and Fortune Island:-southern Inited States; West Indies; tropical continental America; Old World tropies. SuExder FranbriSTYLIS.

\section{Fimbristylis ferruginea (L.) Tahl, Enum. 2: 291. 1806.}

Scirpus ferrugineus L. Sp. Pl. 50. 1753.

Culms tufted, erect, 2-8 dm. tall, rather slender. Leares much shorter than the culm, often very short; involucre-bracts $2-4$, rarely exceeding the simple or slightly compound umbel; spikelets few or several, oroid-oblong, 8-20 mm. long, 3-4 mm. thick; seales orate, acutish or mucronulate, brown, pilose-puberulent towarl the apex; style 2-cleft; achene oboroid, biconvex, smooth, brownish, half as long as the scale.

Moist saline soil. Berry Islands, Cat Cav. Andros, New Providence and Elenthera to IIariguani and Inagua:-West Indies; continental tropical America. Salt Marsh Finbistilis.

3. Fimbristylis castànea (Michx.) Tahl, Enum. 2: 292. 1806.

Scirpus castaneus Michx. FI. Bor. Am. 1: 31. 1803.

Perennial; glabrous; culms stiff, slender, wiry, trigonous, 3-10 dm. high. Leares rigid, involute, usually somewhat shorter than the culm, about $2 \mathrm{~mm}$. wide when unrolled, their sheaths often brown, those of the involuere $3-6$, the 
longer sometimes exceeding the simple or compound umbel; umbel-rays several, nearly erect; spikelets oroid or ovoid-cylindric, acute, 5-12 mm. long, the central ones sessile, the others stalked; scales obtuse, coriaceous, glabrous, brown with a green midrein; stamens 2 ; style 2-cleft; achene lenticular, oborate, brown, reticulate.

Noist saline soil, Andros, New Providence, Rose Island, Eleuthera, Cat Island, Ijttle San Salvador, Watling's Island: Anguilla Isles :-Bermuda: eastern Tnited States: Cuba. Recorded by IItchcock, by Dolles and by Mrs. Northrop as Fimbristylis spadicea (L.) Vahl. Marsh Fimbristylis.

\section{Fimbristylis inaguénsis Britton, Torreya 13: 216. 1913.}

Perennial by short stout rootstocks; culms rather stout, stiff, smooth, compressed, 3-5 dm. tall. Basal leares one-third to two-thirds as long as the eulm, flat, rather stiff, smooth, 1-2.5 mm. wide, obtuse; leaves of the involucre $2-4$, the longer one usually a little exceeding the inflorescence; umbel compound, $5-7 \mathrm{~cm}$. broad, the rays $2-4 \mathrm{~cm}$. long, ascending, the raylets slender, 0.5-2 cm. long; spikelets narrowly oblong, 8-12 $\mathrm{mm}$. long, about $2.5 \mathrm{~mm}$. thick, acute, many-flowerer, solitary at the ends of the rays and raylets; scales brown, glabrous, dull, orate, carinate, mucronate or the lower short-awned; achene elliptic or aborate-elliptic, flat, blunt, finely reticulated, nearly $1.5 \mathrm{~mm}$. long; style-branches 2.

White-lands and rocky soil, Cat Island. Little San Salvador. Watling ${ }^{\circ}$ Island, Fortune Island, Crooked Island, Fxuma Chain, Little Ambergris Car, Inagua:Cuban Cass: Anegada. West INDiax Fimbristilis.

5. Fimbristylis spathácea Roth, Nov. Sp. 24.1821.

Scirpus glomeratus Retz. Obs. 4: 11. 1786.

Fimbristylis glomerata Urban, Symb. Ant. 2: 166. 1900. Not Nees. 1834.

Culms tufted, stiff, erect, rather slender, 1-t dm. high. Basal leares flat, stiff, much shorter than the culm, 1.5-3 mm. wide, spreading or ascending, the apex bluntish and mucronate; involucral leaves mostly shorter than the compound small dense umbel; spikelets ellipsoid to short-cylindric, 3-6 mm. long, about $2 \mathrm{~mm}$. thick; scales orate, brownish, glabrous, emarginate, scarious-margined; style 2-cleft: achene about one-half as long as the scale, biconvex, obovate, brown, granular or subtuberculate.

Coppices, waste and cultivated grounds, Great Bahama, Andros, Rum Cay, Fortune Island. Cay Sal:- West Indies and tropical continental America; OId World tropics.

Justice Joseph E. Adderley, at Eight Mile Rocks, Great Rahama, informed us at the time of our risit there in Februars, 1905, that soon after the hurricane of Augnst 13, 1899, this sedge appeared in clearings, and had soon spread as a troublesome weed through cultivated lands. killing out pasture grasses in places; it had therefore come to be called there "Inrricane Grass."

6. Fimbristylis hirta (Thunb.) R. \& S. Syst. 2: 99. 1817.

Cyperus hirtus Thunb. Phyt. Blaett. 1:6. 1803.

Scirpus exilis Poir. Encyel. Suppl. 5: 105. 1817.

Fimbristylis exilis R. \& S. Syst. 2: 98. 1817.

Annual; culms 1-4 dn. long, slender, pilose at least above. Leares nearly filiform, pubescent, half as long as the culm or less, 0.2-0.5 mm. wide; involueral bracts 3-5, longer or shorter than the umbel; spikelets 3-14, on filiform pilose umbel-rays, ovoid, 6-12 mm. long; scales few, orate, mucronate, chestnut-brown, pilose-puberulent, the midrein green; style glabrous, its 3 branches linear; achene pyriform, pale brown, $1 \mathrm{~mm}$. long, irregularly rugose, sometimes tuberculate.

Bahamas, collected by Dale, according to Clarke:-Cuba; northern South America ; Africa. HaIRT FinBristilis. 


\section{ABILdGAàrdia Yahl, Enum. 2: 296, 1806.}

Low, perennial or annual sedges, with slender culms, narrow or setaceous basal leares, the involuere usually of 1 small bract, the flattened spikelets solitary or few together, several-many-flowered. Scaly imbricated in 2 rows, kecled, deciduous. Bristles none. Stamens 1-3. Style pubescent, deciduous, its base swollen. Stigmas 3. Achene trigonous. [Commemorates P. S. Abildgaard, Danish botanist.] About 15 species of tropical and subtropical dis. tribution, the following typical.

\section{Abildgaardia monostàchya (L.) Vahl, Enum. 2: 296.1806.}

Cyperus monostachyos L. Mant. 180. 1771.

Fimbristylis monostachya Hassk. P1. Jar. Rar. 61. 1818.

Perennial, glabrous; culms tufted, very slender, smooth, thickened at the base, 1-t dm. high. Leares setaceous, $0.5 \mathrm{~mm}$. wide, about half as long as the culm; involueral bract short, rarely as long as the spikelet; spikelet orate or ovate-lanceolate, flat, $1-1.5 \mathrm{~cm}$. long, about $5 \mathrm{~mm}$. wide; scales ovate, keeled, mucronate, pale greenish-brown with white margins; style villous, with 3 short branches; achene oboroid, 2-2.5 mm. long, 3-angled, yellowish, tubereulate.

Grassy places and scrub-lands, Great Bahama, Andros, New Providence, Cat Island, Fortune Island, Inagua :-Florida; Cuba to Porto Rico; St. Jan to Tobago; Anegada; continental tropical Amelica and old World tropics. Flat-spiKed Iush.

\section{SCÍrPUS L. Sp. Pl. 47. 1753.}

Annual or perennial-very small or very large sedges, with leafy culms or the leaves reduced to basal sheaths. Spikelets terete or somewhat flattened, solitary, capitate, spicate or umbellate, subtended by a 1-several-leaved involucre or the involucre wanting in some species. Scales spirally imbricated all around, usually all fertile, the 1-3 lower sometimes empty. Flowers perfect. Perianth of 1-6, slender or rigid, short or elongated, barbed, pubescent or smooth bristles, or none in some species. Stamens 2-3. Style 2-3-cleft, not swollen at the base, wholly deciduous from the achene, or its base persistent as a subulate tip. Achene triangular, lenticular or plano-convex. [Latin name of the Bulrush, said to be from sirs, the Celtic word for rushes.] About 200 species of very wide geographic distribution. Type species: Scirpus lacustris $\mathrm{L}$.

Bracts of the involucre several: scales long-amned: culm trigonous. 1. S. robustus. Bract of the involucre only 1 ; scales short-tipped; culm terete. 2. S. validus.

\section{Scirpus robústus Pursh, Fl. Am. Sept. 56. 1814.}

Perennial by rootstocks; culm stout, stiff, 3 -angled with flat sides, smooth, $0.5-1.4 \mathrm{~m}$. tall. Leaves dark green, smooth, $5-10 \mathrm{~mm}$. wide; involueral leaves 2-4, elongated, similar to the lower ones; spikelets ovoid-oblong, stout, $1.5-2.5$ cm. long, 8-10 mm. in diameter, 6-20 together in a dense terminal cluster; scales ovate, brown, puberulent, thin, the midrein excurrent into an, at length, reflexed awn 3-5 mm. long; bristles 1-6, fragile, shorter than the achene, or none; style 3-cleft; achene compressed, flat on the face, convex or with a low ridge on the back, obovate-orbicular, dark brown, shining, $3 \mathrm{~mm}$. long.

Marshes, Little Inagua :-Atlantic and Gulf coasts of the United States. SaLr MaRsh BtLRUSH. 
2. Scirpus válidus Vahl, Enum. 2: 268. 1806.

Perennial by stout rootstocks; culms stout, smooth, terete, erect, 1-3 m. tall, sheathed at the base. Involucre-bract 1, erect, shorter than the umbel, appearing as if continuing the culm; umbel compound, its primary rays slender, 1-6 cm. long; spikelets several or many, oblong-conic, 1 to 5 together, 5-12 mm. long, 3-4 mm. thick; scales ovate, short-tipped; bristles 4-6, dowumardly barbed, as long as the achene or longer; stamens 3 ; style 2-cleft; achene obovate, plano-convex, nucronate.

Ponds, Fortune Island:-Continental North America; Bermuda; Cuba; Haitl ; Porto Rico; Jamaica. AMERICAX Great Bulrusir.

\section{DICHRómENA Michx. F'. Bor. Am. 1:37. 1503.}

Leafy-stemmed sedges, perennial by rootstocks, the spikelets crowded in a terminal head involucrate by the upper leaves, which are often white at the base. Spikelets compressed, sereral-many-flowered. Scales spirally imbricaterl all around, several of them with imperfect flowers, or empty. Perianth none. Stamens 3. Style 2-cleft, its branches subulate. Achene lenticular, transversely rugose, crowned with the broad persistent base of the style (tubercle). [Greek, alluding to the two-colored involueral leaves.] Abont 8 species, natives of America. Type species: Dichromena leucocephala Michx.

Spikelets capitate: involucral bracts reflexed.

Spikelets subspicate; bracts erect or the lower one spreading

1. D. colorata.

2. D. inuguensis.

1. Dichromena coloràta (L.) Hitchc. Rep. Mo. Bot. Gard. 4: 141. 1893.

Schoenus coloratus L. Sp. Pl. 43. 1753.

Dichromena leucocephala Michx. Fl. Bor. Am. 1: 37. 1803.

Glabrous; culm slender, erect, rather sharply triangular, $0.3-0.6 \mathrm{~m}$. tall. Leaves distant, narrowly linear, about $2 \mathrm{~mm}$. wide, much shorter than the culm, those of the involnere 4-6, reflexed when mature, yellowish white at the base; head globose, 1-2 cm. in diameter; spikelets narromly oblong, acute; scales membranous, lanceolate, nearly white, 1-nerved, subacute at the apex; achene obovate, brown, nearly truncate at the summit, compressed, covered by the tubercle which is not decurrent on its edges.

Scrub-lands and borders of marshes, Abaco. Great Rahama, Andros and Vew Providence to Caicos Islands and Inagua:- southeastern Inited States; Bermuda ; Cuba to Yorto Rico and Martinique; Texas to Yucatan. NARrow-Leaved DrchroMEXA. WIITE-HEADED RUSH.

\section{Dichromena inaguénsis Britton, spec. nov.}

Densely tufted; culm very slender, erect, abont $3 \mathrm{dm}$. tall. Leaves 1-1.5 $\mathrm{mm}$. wide, two-thirds as long as the culm; involucral bracts $3-5$, glabrous, erect, green or whitened only at the base, or the lower one spreading and sometimes $14 \mathrm{~cm}$. long; bractlets eiliolate; spikelets few, subspicate, nearly erect, about $7 \mathrm{~mm}$. long; scales white, obtusish; achene yellowish brown, a little more than $1 \mathrm{~mm}$. long, copiously transversely rugose, capped by a low flatconic tubercle of about one-fonrth its length.

Scrub-lands between Northwest Point and Southwest Foint, Little Inagua (Nush and Taylor 125\%). Endemic. INAGUA DICHROMENA.

\section{RYNCHÓSPORA Vahl, Enum. 2: 229. 1806.}

Leafy sedges, mostly perennial by rootstocks, with erect 3 -angled or terete culms, narrow flat or involute leaves, and ovoid oblong or fusiform, variously 
clustered spikelets. Scales thin, 1-nerved, imbricated all around, usually mucronate by the excurrent milvein, the lower empty. Lpper flowers inperfect, the lower perfect. Perianth of 1-20 (mostly 6) upwardly or downwardly barbed or seabrous bristles, wanting in some species (no. 2). Stamens commonly 3. Style 2-cleft, 2-toothed or rarely entire. Achene lenticular or swollen, not 3-angled, smooth or transversely wrinkled, eapped by the persistent base of the strle (tubercle), or in some species by the whole style. [Greek, referring to the beak-like tubercle.] About 200 species, of wide geographie distribution, most abundant in warm regions. Type species: Rynchospora aurea Tahl.

Style long, stout. its branches much shorter than the undivided part; spikelets densely capitate.

Ileads several or numerous, panicled: achene $1 \mathrm{~mm}$. long.

Heads only 1-6; achene $2.5 \mathrm{~mm}$. long.

Style short, its branches mostly as long as the undivided part: spikelets loosely clustered, not capitate.

Perianth-bristles none. Achene transversely wrinkled.

Achene reticulated.

Perianth-bristles present, upwardls barbed; achene transversely wrinkled.

Achene not stipitate: spikelets ahout $2 \mathrm{~mm}$. long.

l'erianth-bristles much shorter than the achene or obsolete.

Perianth-bristles as long as the achene or longer. Leaves 2-1 mm. wide.

Leares less than $1 \mathrm{~mm}$, wide

Achene stipitate; spikelets $\overline{5}-\bar{t} \mathrm{~mm}$. long.

1. li. cypcroidcs.

-.R. Trieyi.

3. R. tenuis.

4. R. divergens.

6. R. microcarpa.

T. I. bahamensis.

S. R. marisculus.

1. Rynchospora cyperoìdes ( $\mathrm{S}$.) Mart. Denksehr. Akad. Wiss, Muench.6: 149. 1816-17.

Schoenus cyperoides Sw. Prodr. 19. 1788.

Culms $8 \mathrm{dm}$. high or less, clustered, rather stout, trigonous, leaf-bearing up to or beyond the middle. Leaves $3-5 \mathrm{~mm}$. wide, the upper ones sometimes overtopping the euln; heads subglobose, dense, usually several or numerous, corymbose-paniculate, $8-12 \mathrm{~mm}$. in diameter; bracts similar to the leares, but shorter; spikelets numerous, their scales 7 , the 4 lower ones empty, 1 of the others subtending an achene; bristles 6, upwardly hispid, longer than the achene; style long, 2-cleft at the apex; achene oboroid, about $1 \mathrm{~mm}$. long, faintly transversely undulate; tuberele subulate, ciliate, about as long as the achene.

Swampy grounds. Great Bahama, New Providence, Eleuthera, Cat Island, Great Exuma, Acklin's IslanrI. Crooked Island, Inagua:- West Indies; tropical continental America. Capitate Binked-Resh.

2. Rynchospora Tràcyi Britton, Trans. N. Y. Acad. Sci. 11: 84. 1892.

Ceratoschoenus capitatus Chapm. Fl. S. U. S. 529. 1860. Not Rynchospora capitata R. \& S. $181 \%$.

Perennial; culms tufted, slender, glabrous, nearly terete, erect, 5-12 dm. high. Leares elongated, channelled, 4-8 $\mathrm{mm}$. wide; spikelets lanceolate, 5-7 $\mathrm{mm}$. long, densely elustered in 1-6 globose heads which are 1-2 $\mathrm{cm}$. in diameter; scales yellowish-brown, orate, acute; bristles 6 , longer than the achene, uprardly barbed; achene flat, oborate, about $2.5 \mathrm{~mm}$. long. eiliate, finely wrinkled; style 2-cleft at the apex; tubercle subulate, setose, at least as long as the achene.

Wet soil, Great Bahama at West End; Andros, in saranna near Staniard Creek :Florida; Cuba. Tracr's BEAKED-Resh. 
3. Rynchospora ténuis Link, Jahrb. 13: 66 . 1820

Rootstocks short, slender; culms very slender, tulted, 1.5-4 dm. long, glabrous and smooth, erect or reclining. Leaves $0.5-2 \mathrm{~mm}$. wide, as long as the culm or shorter; corymbs of spikelets 1-3, filiform-stalked; spikelets usually rather loosely clustered, about $4 \mathrm{~mm}$. long, narrowly lanceolate, acute, pale, bearing a single achene; scales acute, the lower orate, the upper lanceolate; bristles none; style deeply 2-cleft; achene obovate or nearly orbicular, sessile, transversely rugose, about $1 \mathrm{~mm}$. broad; tubercle acute, onefourth to one-half as long as the achene and decurrent on its margins.

Moist ground, Andros. New Proridence:-Cuba: Dominica to Grenada; tropical continental America. SLEXDEI: BEAKED-RUSH.

4. Rynchospora divèrgens Chapm.; II. A. Curtis, Am. Journ. Sci. II. 7: 409. 1549.

Perennial; culms nearly filiform, densely tufted, 1-4 dm. bigh. Leares similar to the culms, usually somewhat shorter; spikelets loosely corymbose, ellipsoid, acute, about $3 \mathrm{~mm}$. long; scales orate to elliptic; bristles none; stṛle 2-cleft, the branches about as long as the undivided part; achene orbicularoborate, 0.5-0.S mm. long, pale, reticulated, contracted at the base, the short tubercle depressed.

Moist soil, Great Bahama, Andros, New Proridence:-southeastern United States ; Cuba. Low BeskED-RLSH.

\section{Rynchospora perpléxa Britton; Small, Fl. SE. U. S. 197. 1903.}

Perennial by rootstocks; culms slender, usually elnstered, 3-12 dm. high. Leaves flat, grass-like, elongated, smooth, $1.5-3 \mathrm{~mm}$. wide; corymbs usually sereral, rather loose, slender stalkerl; spikelets numerons, oroid, about $2 \mathrm{~nm}$. long; scales bromn, obtuse or acutihh; bristles 6, upwardly barked, shorter than the achene; style 2-cleft at the summit; achene biconrex, transversely wrinkled, about $1 \mathrm{~mm}$. long, the depressed tubercle broader than high.

Tet grounds, Great Pahama. Abaco, Andros, New Irovidence, Eleuthera, Cat Island:- southeastern Cnited States. SHort-BRistLed BEAKED-RTSil.

6. Rynchospora microcàrpa Baldw.; A. Gray, Ann. Lyc. X. I. 3: 202. 1536.

Perennial by rootstocks; culms rather slender, elustered, $11 \mathrm{dm}$. high or less. Leares flat or slightly channeler, $1-5 \mathrm{~mm}$. wide; corymbs $3-6$, slenderstalked, with few or many oroid spikelets about $2.5 \mathrm{~nm}$. long; scales brown; bristles 5 or 6, upwardly barbed, about as long as the achene or a little longer; style 2-cleft at the summit; achene lenticular, transversely wrinkled, scarcely $1 \mathrm{~mm}$. long, the depressed tubercle blunt.

Wet grounds, Andros, New Providence, Crooked Island:-southeastern Cnited states. SMALL-Frtited BEaKED-RUSH.

\section{Rynchospora bahaménsis Britton, Torreya 13: 217. 1913.}

Densely tufted; rootstocks short. Culms nearly filiform, roughish, spreading or reclining, $2-3.5 \mathrm{dm}$. loug; leaves setaceous-flattened, less than $1 \mathrm{~mm}$. wide, roughish-marginer, the basal ones about one-fourth as long as the culm, the upper $3-5 \mathrm{~cm}$. long; spikelets oblong, 1.5-2 $\mathrm{mm}$. long in 2-1 distant slender-peduncled clusters, each with a single achene; scales dark brown, ovate-oblong, mucronulate; achene elliptic-oborate, faintly transversely wrinkled, $1.5 \mathrm{~mm}$. long; tubercle flattened, conic, one-third to one-half as long as the achene; bristles upwardly barbed, as long as the achene.

Coppices and borders of swamps, New Providence, Andros:-Cuba; Porto 
8. Rynchospora marísculus Lindl. \& Nees; Mart. Fl. Bras. 21 : 142.1842.

Rynchospora jubata Liebm. Vidensk. Selsk. Skr. V. 2: 254. 1851.

Perennial by rootstocks, glabrous. Culm rather slender, $0.5-1 \mathrm{~m}$. long. Leares $2-5 \mathrm{dm}$. long, $7 \mathrm{~mm}$. wide or less; corymbs usually screral, distant, or the upper ones approximate, dense, the lower slender-stalked, nording; spikelets numerous, clustered, narrowly ellipsoid, acute, $5-7 \mathrm{~mm}$. long; scales brown, lanceolate or ovate-lanceolate, acute, from 1 to 3 of them subtending achenes; bristles 6 or 7 , longer than the achene, scabrous above, pilose at the base; style 2-cleft at the apex; achene short-stipitate, obovate, transrersely undulate, 1.5-2 mm. long; tubercle flat-conic, acute, about one-half as long as the achene.

Ioist grounds, New Providence:-Cuba; Haiti; Jamaica; tropical continental America. Loxa BEAKED-RUSH.

9. MARÍscus (Hall.) Zinn, Cat. Hort. Goett. 79. 1757.

Perennial leafy serlges, similar to large Rynchosporas, the spikelets oblong or fusiform, few-flowered, variously clustered. Seales imbricated all around, the lower empty, the middle ones mostly subtending imperfect flowers, the upper usually fertile. Perianth none. Stamens 2 or sometimes 3. Style 2-3. cleft, deciduous from the summit of the achene, its branches sometimes 2-3parted. Achene oroid to globose, smooth or longitudinally striate. Tubercle none. [Greek, referring to the branched inflorescence of some species.] About 40 species, natires of tropical and temperate regions. Type species: Schoenus Mariscus L.

1. Mariscus jamaicénsis (Crantz) Britton in Britton \& Brown, Ill. Fl. ed. ?, $1: 348.1913$.

Cladium jamaicense Crantz, Inst. 1: 362. 1766.

Cladium occidentale Schrad. Fl. Germ. 1: 76. 1806.

Culm stout, $1.5-3 \mathrm{~m}$. high, obtusely 3 -angled. Leaves very long, glabrous, 6-20 $\mathrm{mm}$. Wide, the margins spinulose-serrulate; umbels several or numerous, decompound, forming a large panicle; spikelets mostly 2-5 together at the ends of the raylets, narrowly ovoid, acute, $4-5 \mathrm{~mm}$. long; uppermost scale subtending a perfect flower; stamens 2; achene ovoid, abruptly sharp-pointed, wrinkled, narrowed to the base, $2 \mathrm{~mm}$. long.

Marshes, Abaco. South Bimini, Andros and New Providence to Crooked Island and Inagua :- southern United States; Bermuda; Jamaica; Cuba to Porto Rico; Guadaloupe to Grenada; Mexico. Erroneously recorded by C. B. Clarke as Lagenocarpus guiancnsis . Nees, and by Hitchecck as Cladium mariscus (L.) R. Br. SAW GRASS.

\section{SCHOÈNUS L. Sp. Pl. 42. 1753.}

Perennial sedges, with stiff, tufted culms, basal, narrow or semiterete leares, the 1-few-flowered spikelets clustered, capitate or paniculate, the clusters subtended by 1 bract or few. Scales imbricated in 2 series, the lower ones empty the upper subtending flowers. Perianth of $3-6$, scabrous or plumose bristles. Stamens 3. Style slender, scarcely enlarged at the base, 3cleft, deciduous. Achene trigonous; tubercle none. [Greek, a rush.] Sixty species or more, mostly natives of the old World, the following typical. 


\section{Schoenus nígricans L. Sp. Pl. 43. 1753.}

Glabrous; culms $2-7$ dm. tall, mostly longer than the leaves. Leaves similar to the eulm, stiff, sharp-pointed, semiterete, 0.5-1.5 mm. thick, their bases dark brown or nearly black, shining; involuere of 2 bracts, one of them elongated, sometimes $8 \mathrm{~cm}$. long; spikelets about $1 \mathrm{~cm}$. long in a dense, terminal, capitate cluster, 5-8-flowered, compressed, their seales dark ehestnutbrown, or nearly black, lanceolate, carinate, acuminate, somewhat shining; perianth-bristles 6, plumose; achene ellipsoid, white, shining, about $2 \mathrm{~mm}$. loug; shorter than the bristles.

Swamps, Andros, New Providence, Eleuthera, Crooked Island, Caícos:-Florida ; Cuba ; southern California; Europe. Black-Iieaded SEdGe.

\section{SCL亡̀RIA Berg. Tet. Acad. Handl. 26: 142. 1765.}

Leafy sedges, mostly perennial, the spikelets small, clustered in terminal, or terminal and axillary fascicles, or sometimes interruptedly spicate. Flotiers monoecious. Fertile spikelets 1-flowered. Staminate spikelets nuany-flowered. Scales imbricated, the 1-3 lower and sometimes also the upper ones of the fertile spikelets empty. Perianth none. Style 3-cleft, slender or sometimes swolleu at the base, deciduous. Ovary supported on a disk (hypogynium), or this wanting. Stamens 1-3. Achene globose or ovoid, obtuse, crustaceous or bony, white in our species. [Greek, in allusion to the hard fruit.] About 200 species, natives of tropical and temperate regions. Type species: Scleria Flagellum-nigrorum Berg.

Annual: achene with sharp transverse ridges. Perenuial; acheno smooth.
1. S. vertieillata.

2. s. lithosperma.

1. Scleria verticillàta Willd. Sp. Pl. 4:317. 1805.

Roots fibrous; culms very slender or filiform, 3-angled, smooth or nearly so, erect, $1-\bar{\jmath} \mathrm{dm}$. tall. Leaves very narrowly linear, $0 . \tilde{-}-1 \mathrm{~mm}$. wide, erect, shorter than the culm; spikelets in several separated elusters; bracts bristlelike; scales glabrous; achene globose, $1 \mathrm{~mm}$. in diameter, crustaceous, marked by sharp distinct trancerse ridges, or somewhat reticulated; hypogynium none.

Borders of marshes, New I'rovidence:-eastern Lnited States; Cuba. Low NuT-RUSi.

2. Scleria lithospérma (L.) Sw. Prodr. 18. 1788.

Scirpus lithospermus L. Sp. P1. 51. 1753.

Scleria filiformis Sw. Prodr. 19. 1788.

Perennial by rather short rootstocks, the culms often clustered, slender, weak, glabrous, 2-6 dm. long. Leaves $0 . \bar{j}-3 \mathrm{~mm}$. wide, the upper elongated, the lowest reduced to pubescent or puberulent sheaths; panicles 1-3, distant, glabrous, small, stalker or the upper sessile; bracts filiform, glabrous; achene obovoid-ellipsoid, white, smooth, shining, about $2 \mathrm{~mm}$. long, its base trigonous; hypogynium none.

Coppices and scrub-lands, Abaco, Great Iahama, Rerry Islands and Andros to Mariguana and Inagua:-Florida; West Indies; continental tropical America; Old World tropics. SLEXDER NUT-RUSH. 


\section{Order 6. ARECALES.}

Mostly trees with unbranched, ereet trunks and a terminal bud, the large leaves pinmately or palmately divided, forming a terminal crown, the small, perfect or imperfect flowers usually panicled, sessile or pedicelled, the panicle subtended by a spathe and usually bracted. Sepals and petals each 3. distinct or connate. Stamens commonly 6, sometimes 9-12; filaments distinct or connate below; anthers introrse; pistillate flowers sometimes with staminodia. Orary varions, 1-celled, 3-eelled or of 3 distinet carpels; style usually short or wanting; orules 1 in each carpel, anatropous. Fruit drupaceons, 1-seeded. Seed with horny or cartilaginons endosperm, the small embryo near the surface.

\section{Family 1. ARECACEAE Rehb.}

Palid Fajilly.

Characters of the order. Abont 150 genera and 1200 species, mostly tropical.

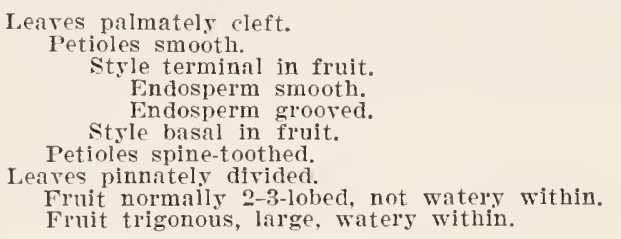

Fruit trigonous, large, watery within.
1. Thrinax.
2. Corcothrinax.
5. Sabal.
4. Paurotis.
5. Pseudophoenix.
6. Cocos.

\section{THRINAX Sw. Prodr. 57. 1788.}

Unarmed, mostly tall and slender palms with nearly orbicular, palmately cleft, long-petioled leaves, the narrow segments mostly 2 -cleft at the apex, the petioles flat, the inflorescence sheathed, paniculately brauched, the small, perfect flomers white. Calyx and corolla more or less united into a lobed or truncate cup. Stamens mostly 6 , the filaments conuate at the base. Orary 1-celled; style terminal, slender; stigma flat or concave. Drupes small, globose. Seed erect; endosperm horny, not grooved; embryo lateral. [Greek, fan.] About 12 species of Floriła, the West Indies and Central America. Type species: Thrinax parviflora $\mathrm{Sw}$.

Fruit essentially sessile.

Fruiting pedicels about as long as the fruit.
1. T. microcarpa.

2. T. pariflori.

1. Thrinax microcárpa Sargent, Gard. \& For. 9: 162. 1896.

Thrinax keyensis Sargent, Bot. Gaz. 27: 86. 1899.

Thrinax bahamensis O. F. Cook, Mem. Torr. Club 12: 20. 1902.

A tree, up to $12 \mathrm{~m}$. high, with a trunk 2-2.5 $\mathrm{dm}$. in diameter, usually much smaller. Leaves $1.5 \mathrm{~m}$. in diameter or less, deeply eleft into many narrow segments, green and shining above, bluish or silvery-white beneath, the ligule blunt or acute, $1.5-2.5 \mathrm{~cm}$. wide; inflorescence $2 \mathrm{~m}$. long or less, as long as the leares or shorter; pedicels very short, disk-like; perianth abont $3 \mathrm{~mm}$. long; 
filaments nearly triangular; drupes $4-6 \mathrm{~mm}$. in diameter, white, very nearly sessile.

Sandy and rocky soil, throughout the archipelago from Great Bahnma and Abaco to Mariguana, Caicos Islands and Inagua :-Florida; Cuba. SMALL-FrutTED THATCH-YALI. BUFFALO-TOP,

2. Thrinax parvifiòra Sw. Prodr. 57. 1788.

Thrinax floridana Sargent, Bot. Gaz. 27: S4. 1599.

A tree up to $9 \mathrm{~m}$. high or more, with a trunk about $1.5 \mathrm{~cm}$. in diameter. Leares up to $1.5 \mathrm{~m}$. in diameter, deeply cleft into numerous narrow segments, green and shining above, silvery-white beneath, at least when young, the acute ligule 1-2 cm. long; inflorescence up to $1 \mathrm{~m}$. long; perticels slender, about $3 \mathrm{~mm}$. long; drupes $6-9 \mathrm{~mm}$. in diameter, white, distinctly stalked. PALAY.

Sandy soil, North Cat Cay:-Florida ; Cuba ; Jamaica. LarGE-Fruited Tiatcit-

\section{COCCOTHRÌNAX Sargent, Bot. Gaz. 27: 87. 1899.}

Unarmed, tall or low palms, with nearly orbicular, palmately cleft, petioled leares, the petioles flat, the segments usually 2-cleft at the apex, the sheathed inflorescence paniculately branched, the small perfect pedicelled flowers white. Calyx and corolla united into a 6-lobed perianth. Stamens 9-12; filaments sukulate. Orary 1-celled; style terminal; stigma funnelform. Drupes small, globose. Seed erect; endosperm grooved; embryo lateral. [Greek, berryThrinax.] About 10 species, of Florida and the Test Indies. Type species: Coccothrinax jucunda Sargent.

1. Coccothrinax argéntea (Lodd.) Sargent, Silva N. A. 14: 85. 1902.

Thrinax argentea Lodd.; R. \& S. Syst. 7: 1300. 1830.

Coccothrinax jucunda Sargent, Bot. Gaz. 27: 89. 1899.

Trunk sometimes $10 \mathrm{~m}$. high, usually not more than $6 \mathrm{~m}$., sometimes very short, 1.5-2 dm. in diameter. Leares nearly orbicular, 7 im. broad or less, cleft to beyond the middle into narrowly lanceolate, acuminate segments, bright green and shining above, silvery-white beneath, at least when young, the slender petioles about as long as the blades, their bases expanded into persistent fibrous sheaths; panicles short-stalked, mostly shorter than the petioles; pedicels 1-3 mm. long, thickened in fruit; flowers abont $3 \mathrm{~mm}$. broad; stamens usually 9 ; fruit globose, black, $\mathrm{S}-12 \mathrm{~mm}$. in diameter.

Throughout the archipelago from Abaco, Rerry Islands and Andros to the Caicos, Inagua and Anguilla Isles and Cay Sal (not observed on Great Ballama) :Florida: Cuba: Hispaniola : Porto Rico: St. Thomas: St. Jan : St. Croix: Iamaica. liecorded by Dolley and by Hitcheock is Thrinax parviflora Sw. SILren THATcir. SILVER-TOP. BAY-TOP.

3. SABÁL Adans; Guersent, Bull. Soc. Philom. 3: 206. 1503.

Unarmed palms, the stems erect, creeping or subterranean, the leares palmately cleft, with a long petiole ani a short rachis, the narrow segments bearing marginal fibres, 1 -cleft or 2-cleft, the petiole concare abore. Panicles spreading or drooping. Flowers perfect, white or greenish. Calyx-lohes 3, unequal. Petals 3, imbricated. Stamens 6; filaments subulate or lanceolate, united at the base. Ovary 3-celled; style 3-angled; stigma truneate. Drupes solitary, with a thin epicarp and a fleshy pericarp. Seed depressed-globose, 
hard, the endosperm bony. [Name not explained.] About 18 species, of the southern Inited States, Bermuda, West Indies, Mexico, and northern South America. Trpe species: Sabal Adansoni Guersent (S. glabra (Mill.) Sargent).

1. Sabal Palmétto (Walt.) Lodd.; R. \& S. Syst. 7: 1487. 1830.

Corypha Palmetto Walt. Fl. Car. 119. 1788.

Sabal umbraculifera Mart. Hist. Nat. Palm. 3: 245. 1839.

Inodes Palmetto O. F. Cook, Bull, Torr. Club 28: 532. 1901.

Sabal Palmetto bahamensis Bece. Palm. Amer. 38. 1907.

Trunk 10-20 m. high, 3-T $\mathrm{dm}$. in diameter, often clotherl, when young, with persistent leaf-bases. Leares $1-2.5 \mathrm{~m}$. broad, their many linear-lanceolate segments 2-cleft and somewhat drooping at the apex, the stout petioles concare above, often as long as the blarles; panicles as long as the leaves or shorter; flower's white, sessile; calyx cup-shaped, 3-lobed, its lobes obtuse, about $1 \mathrm{~mm}$. long; petals oblong-lanceolate 5-6 $\mathrm{mm}$. long; stamens about as long as the petals; drupes globose, black, 6-12 mm. in diameter, the pulp thin.

Borders of marshes, and in rocky soil, throughout the archipelago from Great Bahama to Watlings, Caicos Islands, Inagua, Anguilla Isles and Cay Sal:- North Carolina to Florida: ?Cuba. loxd-top. Poxd Tuatch. Hat Palmetio.

4. PAURòtis O. F. Cook, Mem. Torr. Club 12: 21. 1902.

[ACOelorraphe Wendl. Bot. Zeit. 37: 147. Hyponym. 1879.]

A slender, clustered palm, the trunks united underground, forming colonies, the leares palmately cleft with spiny-toothed petioles, the large panicles of greenish-white flowers erect or ascending, the petiole-bases long-persistent. Flowers very small and numerous, sessile and glomerate. Sepals 3, nearly orbicular; petals 3 , valyate. Stamens 6 ; filaments short, their bases dilated and nniter into a short cup; authers orate. Orary 3-carpellary. Fruit small, globose. Seed globose, separable from the pericarp, the raphe not intruded into the endosperm. [Greek, referring to the few spathes of the inflorescence.] A monotypic geuus. Type species: Paurotis androsana O. F. Cook.

1. Paurotis Wrìghtii (Griseb. \& Wendl.) Britton, N. A. Trees 141. 1908.

Copernicia Wrightii Griseb. \& Wendl.; Griseb. Cat. Pl. Cub. 220. 1866.

Serenoa arborescens Sargent, Bot. Gaz. 27: 90. 1899.

Paurotis androsana O. F. Cook, Nem. Torr. Club 12: 22. 1902.

Gregarious; trunks 5-8 m. high or exceptionally 10-15 m., 1-1.5 dm. thick. Leares $6-10 \mathrm{dm}$. in diameter, deeply cleft into linear-lanceolate, acuminate segments 1-2 cm. broar, light green above, pale green or whitish beneath, 2-cleft above the middle, the slender, compressed petiole about as long as the blare, its margins armed with many rigid, triangular, spine-like teeth $4-7 \mathrm{~mm}$. long; panicles longer than the leaves; flowers about $1.5 \mathrm{~mm}$. broad; fruit $6-8 \mathrm{~mm}$. in djameter.

Iiorders of swales and sandy ridges, Andros:-Florida; Cuba. Sam Palmetro. SPANISH-TOP.

5. PSEUdOPHok̀nIX Wendl. Bot. Gaz. 11: 31t. 1886.

Unarmed palms, with a cylindric or somewhat spindle-shaped trunk enlarged at the base, and large, pinnate leaves of many, narrow segments, the rachis concave above, the petiole short. Inflorescence drooping, usually much 
shorter than the leaves. Flowers pedicellate, monoecious, the pistillate with a short, 3-lobed calyx, 3 valvate petals and 6 stamens or staminodia, the staminate similar, a little larger. [Greek, false late.] Only one species, native of Florida, the Bahamas, Cuba and Hispaniola. Type species: Pseudophoenix Sargentii Wendl.

1. Pseudophoenix vinífera (Mart.) Beec. Pomona College Journ. Econ. Bot. 2: 268.1912.

Euterpe vinifera Mart. Hist. Nat. Palm. 3: LXXXV. 1545.

Pseudophoenix Sargentii Wendl. Bot. Gaz. 11: 314. 1886.

Cyelospathe Northropi O. F. Cook, Mem. Torr. Club 12: 25. 1902.

A tree up to $\mathrm{S} \mathrm{m}$. high, usually lower, the trunk 2-3 dm. in diameter. Leaves spreading, 1-2 $\mathrm{m}$. long; petiole concave, thin-margined, 1-2 dm. long; segments linear-lanceolate, acuminate, those at the middle of the leaf $4-5 \mathrm{dm}$. long, those toward the base and apex shorter; panicle about half as long as the leaves, its branches rather widely spreading, flattened and angled; petals ovate or ovate-oblong, 5-6 mm. long, obtuse, yellowish-green; staninodia less thian half as long as the petals; fruiting pedicels 4-6 mm. long; drupe orangered, fleshy, normally 2-3-lobed, 1-2 cm. broad, the calyx persistent at its base.

Sandy and rocks soil, Frozen Caf, Berry Islands: South Bimini; Andros; New Providence; Ship Channel Cay to Great Exuma; Little San Salrador; Mariguana; Inagu:1 :- Long Key and Elliott's Key, Florida; Cuban Cays ; Santo Domingo. Re-

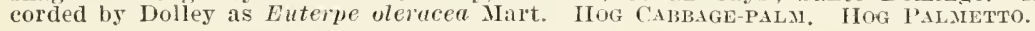

\section{6. còcos L. Sp. Pl. 11ss. 1753.}

Unarmed palns, with pinnate leaves, their uumerous segments narrow, their petioles concave above, the monoecions, bracted flowers mostly densely clustered among the petioles, the staminate uppermost in the clusters, smaller than the pistillate. Staminate flowers with 3 small valvate sepals, 3 oblong valvate petals, and 6 stamens with subulate filaments, the anthers linear. Pistillate flowers ovoid, the 3 thick sepals imbricated, the 3 coriaceous petals valvate, the ovary 3 -celled, with 2 of the cells usually empty, the ovule ascending. Fruit 1-seeded, often large, the pericarp fibrous, the bony endocarp 3 porose near the base. Seed with a hollow or solid endosperm, the embryo opposite one of the pores of the endocarp. [The coco-nut.] Perhaps 30 species, of tropical America ani subtropical South America, the following typical one widely distributed also in the Old World tropies, its original home unknown.

\section{* 1. Cocos nucífera L. Sp. Pl. 1188. 1753.}

Trunk up to $30 \mathrm{~m}$. high, usually $10-20 \mathrm{~m}$. Leaves $3-6 \mathrm{~m}$. long, somewhat drooping, short-petioled, the numerous linear-lanceolate, acuminate seg. ments shining above, $5-7 \mathrm{dm}$. long, about $5 \mathrm{~cm}$. wide; staminate flowers $10-12$ $\mathrm{mm}$. long; pistillate flowers about $2.5 \mathrm{~cm}$. Iong; fruit ovoid or ellipsoid, bluntly 3-angled, $2-3 \mathrm{dm}$. long, the fibrous husk 2-4 $\mathrm{cm}$. thiek, the bony endocarp $3-5 \mathrm{~mm}$. thick, the hollow endosperm about $1 \mathrm{~cm}$. thick, filled with a clear saccharine liquid, which ultimately disappears.

Locally spontaneous after cultivation, nearly throughout the archipelago:-all tropical insular and coastal regions. Coco-xut.

Roystonea regia (H.B.K.) O. F. Cook, Royal PALM, recorded from the Bahamas, is known to us in the archipelago only as a planted tree. 


\section{Order 7. ARÀLES.}

Monocotyledonous herbs, mostly fleshy. Inflorescence in the Araceae (which are not now known to be represented by any wild plants in the Bahama flora although Schoepf records observing Arum sagittifolium and Orontium aquaticum on New Providence in 17S4) a fleshy spadix, subtended by a spathe, or naked. The Lemnaceae are minute floating thalloid plants, with flowers on the margin or back of the thallus.

\section{Family 1. LEMNÀCEAE Dnmort.}

\section{Duckweed Fajhly.}

Minute perennial floating aquatic plants, without leaves or with only very rudimentary ones. The plant-body consists of a disk-shaped, elongated or irregular thallus, which is loosely cellular, densely chlorophyllous and sometimes bears one or more roots. The regetative growth is by lateral branching, the branches being but slightly connected by slender stalks and soon separating. The inflorescence consists of one or more naked monoecious flowers borne on a slight lateral prominence on the edge or upper surface of the plant. Each flower commonly consists of but a single stamen or a single flask-shaped pistil. The anther is provided with two to four pollen-sacs, containing spherical minutely barbellate grains. The pistil is narowed to the funnel-shaped sear-like stigmatic apex, and produces 1-6 erect or inverted ovules. The fruit is a 1-6 seeded ntricle. The family comprises the smallest of the flowering plants and contains 4 genera and about 30 species of wide distribution.

\section{LÉMNA L. Sp. Pl. 970. 1753.}

Thallus disk-shaped, usually provider with a central nerve and with or without two or four lateral nerves. Each thallus produces a single root, which is devoid of vasenlar tissue and is commonly provided with a thin blunt or pointed rootcap. The orary contains from one to six orules. Fruit ovoid, more or less ribbeil. Endosperm in one or three layers. [Greek, in allusion to the growth of these small plants in swamps.] About 10 species, in temperate and tropical regions. Type species: Lemna trisulca $\mathrm{L}$.

\section{Lemna mìnor L. Sp. Pl. 970. 1753.}

Thallus obovate or subcircular, $1.5-5 \mathrm{~mm}$. long, thickish, rarely reddish or purplish tinged, short-stalked when young, provided throughout with stomata, nearly symmetrical, obscurely 3 -nerved, very rarely 4-5-nerved. Rootcap obtuse or subtruncate; fruit symmetrical, subturbinate; seed with a prominent protruding hilum, deeply and unequally 12-15-ribbed; ovule 1.

Water-holes and sink-holes, near The Bight, Cat Island:-North temperate and subtropical zones, but not known to us elsewhere in the West Indies. Duck-WeED. 


\section{Order 8. XYRIDÀLES.}

Monocotyledonous herbs, mostly with narrow leaves. Flowers usually complete, their parts mostly in 3's or 6's. Corolla regular or nearly so (except in Commelina). Ovary compound, superior. Endosperm of the seed mealy.

Epiphytic plants with scurfy leaves.

Terrestrial plants, their leaves not scurfy.

Fam. 1. BromeliaceaE.

Fam. 2. CoMmelixaceae.

\section{Family 1. BROMELIACEAE J. St. Hil.}

Pine-Apple Family.

Epiphytic herbs (some tropical species terrestrial), mostly scurfy, with elongated, entire or spinulose-serrate leaves. Flowers spiked, panicled, or solitary, regular and perfect, usually conspicnously bracted. Perianth of 3 thin distinct or somewhat united sepals, and 3 clawed distinct or united petals. Stamens 6, usually inserted on the base of the corolla. Ovary inferior or superior, 3-celled; ovules numerous in each cavity, anatropons; style short or elongated; stigmas 3 . Capsule 3 -valved in our species. Seeds numerous, the testa membranous. Embryo small, situated at the base of the copions endosperm. About 45 genera and 900 species, all natives of tropical and subtropical America.

Style filifol'm.

Stems thread-like, pendent: flowers solitary, maly 2.

Stems not thread-like, rigid; flowers spicate. Style short or none.

1. Dendropogon.

2. Tillandsia.

3. Catopsis.

\section{DENDROPÒGON Raf. Neog. 3. 1825.}

Pendulous, much-branched plants, with thread-like stems and branches, very narrow, entire leaves and yellow or greenish flowers. Sepals distinct or very nearly so. Petals distinet. Stamens long, the 3 inner oues borne on the bases of the petals; filaments filiform; anthers linear. Ovary superior; style columnar; stigmas short. Capsule septieidally 3-ralred. Seeds erect, narrow, supported on a long funiculus which splits into fine threads. [Greek, tree-beard.] About 3 species, the following typical.

1. Dendropogon usneoìdes (L.) Raf. Fl. Tell 4: 25. 1838.

Renealmia usneoides L. Sp. Pl. 287. 1753.

Tillandsia usneoides L. Sp. Pl. ed. 2, 411. 1762.

Stems flexuous, hanging clustered in festoons from the branches of trees, 1-8 $\mathrm{m}$. long, gray and, like the filiform leaves, densely silvery-scurfy all over. Leaves seattered, $2-8 \mathrm{~cm}$. long, searcely $1 \mathrm{~mm}$. thick, their bases somewhat dilated; flowers sessile and solitary or rarely 2 together in the axils of the leaves; sepals about $6 \mathrm{~mm}$. long, pale green; petals yellow; stamens about as long as the calyx; capsule linear,..2-3 cm. long, at length splitting into 3 linear valves.

Hanging from shrubs and trees, New Providence, Cat Island. Inagua :- Tirginia to Florida and Texas: West Indies and continental America south to Paraguay. SPAXISII Moss. OLD MaN's BeARD. 
2. TILLÁNDSIA L. Sp. Pl. 286. 1753.

Epiphytic plants with uarrow entire leaves and white, yellow or purple flowers. Sepals distinct and separate or very nearly so. Petals distinct. Stamens hypogynous or the three inner omes inserted on the bases of the petals; filaments filiform; anthers linear or linear-oblong. Ovary superior; style subulate; stigmas short. Capsule septicidally 3-valved. Seeds erect, narrow, supported on a long funiculus which splits up into fine threads. [Dedicated to Elias Tillands, Swedish (?) botanist of the seventeenth century.] About 350 species, natives of warm and tropical America. Type species: Tillandsia utriculata L.

Floweling stems scape-like; leaves setaceous-filiform.

Floweriug stems leafy, their leaves smaller than the basal ones.

Lasal leares about as long as the flowering stems, or longer.

Leaf-bases strongly convex.

Leaf-bases flat or nearly so.

Leaves soft in texture; bracts ribbed.

Leaves firm and stiff: bracts not ribbed.

Basal leaves shorter thau the floweriug stems.

Bracts and flowers erect or appressed.

Stem-leaves with long tips.

stem-leaves reduced to clasping scales.

Bracts and flowers spreading.
1. T. recurvata.

2. T. Balbisiana.

3. T. Talenzueluna.

4. T. fasciculata.

5. T. circinata.

6. T. utriculata.

†. $T$, aloifolit.

* 1. Tillandsia recurvàta L. Sp. Pl. ed. 2, 410. 1762.

Stems clustered on the branches of trees or shrubs, sometimes on other objects, even on telegraph wires, often forming large masses, the leaf-bearing part 3-8 cm. long, terminated by a scape-like, 1-5-flowered (mostly 2-flowered), very slender peduncle 5-12 cm. long. Leaves filiform-setaceous, about as long as the peduncle or shorter, densely covered with soft, spreading scales, their bases a little dilated; bracts lanceolate, 1-1.5 cm. long; sepals lanceolate, acute, shorter than the bracts; petals blue, narrow, about as long as the bracts; capsule linear, prismatic, $2-2.5 \mathrm{~cm}$. long.

On trees and shrubs, Andros, Eleuthera, Cat Island, Watling's Island, Great Exuma, Acklin's Island, Inagua:-Florida; West Indies and continental tropical America. THREAD-LeAVEd WiLd PINe.

\section{Tillandsia Balbisiàna Schultes; R. \& S. Syst. 7: 1212. 1830.}

Plants usually solitary on trees or shrubs, sometimes clustered. Leaves densely appressed-scurfy, linear-attenuate from much dilated bases which form a swollen cluster 2-6 dm. long, the lower ones often as long as the rather slender flowering stems, sometimes longer; inflorescence narrow; spikes 3-8, compressed, 5-10 cm. long, the flotrers rather close together; bracts oblonglanceolate, acute, $1.5-2 \mathrm{~cm}$. long; sepals narrowly lanceolate, acute, about as long as the bracts; petals blue, 4-5 $\mathrm{cm}$. long; capsule subeylindric, about twice as long as the bracts.

On shrubs and low trees. in coppices and scrub-lands, Great Bahama, Abaco, Andros, New Providence, Crooked Island, Inagua, Caicos:-Florida; Cuba; Hispaniola : Jamaica : Central America. BAlbis' WILD Pixe. CutTlefish.

Referred to $T$. polystachya L., in Bull. N. I. Bot. Gard. 3: 441, as determined by Prof. Wittmack, but that species is not definitely known to us from the archipelago, although also recorded by Schoepf as observed by him in 1784 .

3. Tillandsia Valenzuelàna A. Rich. in Sagra, Hist. Cub. 11: 267. 1850.

Plants usually clustered on trees or shrubs, densely appressed-scurfy. Leaves narrowly lanceolate, gradually attenuate from near the base, soft in 
texture, $4 \mathrm{dm}$. long or less, the lower often as long as the flowering stems, their bases 2-4 em. wide, the upper similar, much smaller; spikes few or several, rather loosely flowered, $i-12 \mathrm{~cm}$. long; bracts pink, numerous, 1.5-2 cm. long, oblong-lanceolate, acute; sepals lanceolate, rather shorter than the bracts; petals blte, $2-3 \mathrm{~cm}$. loug; capsules linear-prismatic, about twice as long as the bracts.

On trees in coppices, Marsh Harbor, Abaco:-Florida; Cuba, Jamaica; Iexico to Colombia. Valexzela's Wild PiNe.

\section{Tillandsia fasciculàta Sw. Prodr. 56. 1788.}

Plants usually clustered on trees, the flowering stems stout, $2-6 \mathrm{dm}$. long. Leaves densely appressed-scurfy, lanceolate-attenuate, their bases $5 \mathrm{~cm}$. wide or less, the lower ones often as long as the flowering stems, the upper smaller; spikes subdigitate, compressed, 5-15 cm. long, 1-3 cm. wide, acute, manyflowered; bracts oblong, acute, appressed, rigid, 2-3 cml. long, red or reddish; sepals lanceolate, about as long as the bracts; petals blne, nearly twice as long as the sepals; capsules as lorig as the bracts or somewhat longer.

On trees and shrubs, Great Bahama, Abaco, Andros, New Providence, Eleuthera, Cat Island, Crooked Island, Fortune Island. Inagua:-Florida: West Indies and continental tropical America. Clustered Wild Pine. Dog-drikK-Water. C'atesby, $2: p l .89$.

\section{Tillandsia circinàta Schl. Linnaea 18: 430. 1844.}

Tillandsia bulbosa Chapm. Fl. S. States 471. 1860. Not Hook. 1527.

Plants usually clnstered on trees or shrubs, 1-3 dm. high, densely silvery scaly. Lowest leaves ovate, acute, $1.5-3 \mathrm{~cm}$. long, the next with broadly expanded bases $2-4 \mathrm{~cm}$. wide, abruptly narrowed above into linear-attenuate, usually recurved tips $2-8 \mathrm{~cm}$. long; the upper ones similar, smaller; spikes $1-3$, compressed, 1-2 dm. long, rather dense; bracts oblong to lanceolate, little spreading, 2-3 cm. long; sepals narrowly lanceolate, about $2 \mathrm{~cm}$. long; petals blue, $2.5-3 \mathrm{~cm}$. long; capsules $2-3$ times as long as the bracts.

On trees and shrubs, Great Bahama, New Providence, Andros, Cat Island, Watling's, Fortune, Inagua, Mariguana, Caicos:-Florida; Cuba; Hispaniola ; Iexico. Erroneously called Wild onion. SHLYerY WiLd I'sie.

\section{Tillandsia utriculàta L. Sp. PI. 286. 1753.}

Plants solitary or clustered on trees or shrubs, large, sometimes $4 \mathrm{~m}$. high. Basal leaves numerous, densely appressed-scaly, 3-7 dm. long, lanceolate-attenuate with bases gradually expanded and $5-10 \mathrm{~cm}$. wide, the lower ones of the flowering stem similar, but smaller, the upper reduced to acute sheathing seales 2-4 cm. long; inflorescence usually much branched, the branches long, ascending or nearly erect; spikes few-flowered; bracts oblong, appressed, $1.5-3 \mathrm{~cm}$. long; sepals oblong, $2-2.5 \mathrm{~cm}$. long; petals white or nearly white, shorter than the stamens; capsules subcylindric, 4-5 cm. long.

On trees and shrubs, Great Bahama, Berry Islands, Andros. New Providence, Exuma Chain, Cat Island, Crooked Island, Acklin's Island, Little Inagua, Inagua :Florida: Cuba to Anegada and Trinidad; Jamaica; continental tropical America. SWOLLEX WILD PINE.

\section{Tillandsia aloifòlia Hook. Exot. Fl. pl. 205. 1826.}

\section{Tillandsia flexuosa Lindl. Bot. Reg. pl. 749. 1823. Not Sw. 178s.}

Plants usually solitary en trees or shrubs, 3-10 dm. long, the flowering stem much longer than the densely appressed-seurfy leaves. Lowest leaves ovate, acute, $8 \mathrm{~cm}$. long or less, the next lanceolate, attennate-acuminate, 10-20 $\mathrm{cm}$. long, 3-5 cm. wide near the base, those of the stem sheathing, acute, $2-5$ 
em. long; inflorescence paniculate; bracts linear-lanceolate, concare, spreading, 2-3 cm. long; sepals oblong, $2-2.5 \mathrm{~cm}$. long; petals white to purple, about i2 em. long; stamens longer than the petals; capsules cylindric, pointed, about twice as long as the bracts.

On trees and rocks, Great Bahama, Abaco, Andros, New Providence, Eleuthera, Great Exuma, Crooked Island, Acklin's Island, Fortune Island, Inagua, Mariguana and Caicos Islands:-Florida; Cuba: Hispaniola; Porto Rico; Grenada; Curacao: Trinidad; Jamaica; continental tropical America. FLExuous WiLD Pise.

As to the Tillandsia canescens Sw., doubtfully recorded from Abaco by Eaton and Setchell, collected by Herrick, the determination was based on a very young plant without flowers or fruit; an examination of the specimen shows that it call not be certainly named, but it may be $T$. fasciculata $\mathrm{S}_{\mathrm{w}}$.

\section{CATÓPsis Griseb. Fl. Br. W. I. 599. 1864.}

Epiphytic herbs, the basal leaves tufted, lepidote, entire, the flowering stem scapose, usually longer than the leaves, the inflorescence spicate or paniculate, the white or yellow flowers sessile. Flowers perfect or sometimes dioecious. Sepals distinct or nearly so. Petals distinct. Stamens shorter than the petals, those of pistillate flowers very short, with sterile anthers, those of staminate or perfect flowers with slender filaments and ovate or elliptic anthers. Ovary of pistillate or perfect flowers ovoid or ellipsoid; style shorter than the ovary or none. Capsule septicidally dehiscent above the middle. Seeds thick, comose. [Greek, a view, the significance not evident.] About 16 species, of tropical and subtropical America. Type species: Catopsis nutans (Sw.) Griseb.

1. Catopsis Berteroniàna (Schultes) Mez. in DC. Mon. Pham. 9: 621. 1896. Tillandsia Berteroniana Schultes; R. \& S. Syst. 7: 1221. 1830.

Plants solitary or clustered on trees or shrubs. Basal leaves numerous, tufted, lanceolate or oblong-lanceolate, thin, 1-4 dm. long, acute or acuminate, pale green and whitish-pruinose; flowering stem rather slender, 3-9 dm. high, elothed with small, appressed narrowly lanceolate leares; inflorescence paniculate; flowers close together or the lower distant; bracts subcoriaceous, ovate to огal, obtuse, $6-8 \mathrm{~mm}$. long; sepals oval, a little longer than the bracts; petals white, oblong, about as long as the sepals; capsule ovoid, 6-10 mn. long.

On trees and shrubs in coppices, Abaco, Andros, New Providence:-Florida : Cuba; Jamaica; northern South America. Recorded by Eaton and Setchell and by Dolley as $C$. nutans Griseb., by Hitcheock as $C$. vitellina (L, K. \& O.) Baker. Mealy Wild Pine. Catesby, $2: p l$. $\%$.

Bromelia Pinguin L. is recorded as a Bahamian plant by Dolley, but we have not found it wild on any island visited. It is widely distributed in the southern West Indies, and has been planted in the Bahamas.

Guzmania lingulata (L.) Mez. [Tillandsia lingulata L.] recorded by Schoepf as seen by him in New Providence in 1784, is not known to inhabit the Bahamas at the present time.

\section{Family 2. COMMELINÀCEAE Rehb.}

SPIDERTORT FAMILF.

Perennial or annual leafy herbs with regular or irregular perfect and often showy flowers in cymes, commonly subtended by spathe-like or leafy bracts. Perianth of 2 series; a calyx of mostly 3 persistent sepals and a 
corolla of mostly 3 membranous and deciduous or fugacious petals. Stamens mostly 6, hypogynous, rarely fewer, all similar and perfect or 2 or 3 of them different from the others and sterile; filaments filiform or somewhat flattened; anthers 2-celled, mostly longitudinally dehiscent. Ovary superior, sessile or very nearly so, 2-3-celled; ovules 1 or sereral in each cell, anatropous or half anatropous; style simple; stigmas terminal, entire or obscurely 2-3-lobed. Seeds solitary or several in each cell of the capsule. Capsule 2-3-celled, loculicidally 2-3-valved. Embryo small. Endosperm copions. About 25 genera and 350 species, mostly natives of tropical regions, a few in the temperate zones.

Fertile stamens $1-3$.

Fertile stamens 5 or 6 .
1 Commetina.

2. Rhoeo.

\section{COMMELINA L. Sp. Pl. 40. 1753.}

Somewhat succulent, branching herbs, with short-petioled or sessile leaves, and irregular mostly blue flowers in sessile cymes subtended by spathe-like bracts. Sepals unequal, the larger ones sometimes slightly united. Petals unequal, 2 of them larger than the third. Perfect stamens 3, rarely 2, one of them incurved and its anther commonly larger. Sterile stamens usually 3, smaller, their anthers rarious. Filaments all glabrous. Capsule 3-celled. Seeds 1 or 2 in each cavity, the testa roughened, smooth or reticulated. [Dedieated to Kaspar Commelin, 166i-1731, Dutch botanist.] Abont 95 species of wide distribution in warm and temperate regions. Type species: Commelina communis L.

Spathes not united at the base. Spathes united at the base.

1. C. longicaulis. 2. C. clegans.

\section{Commelina longicaùlis Jacq. Coll. 3: 234. 1789 .}

Glabrous or very nearly so; stems procumbent or creeping, $3-8 \mathrm{dm}$. long. Leares lanceolate or orate-lanceolate, $2.5-7.5 \mathrm{~cm}$. long, acute or acuminate at the apex, their sheaths sometimes ciliate; spathe acuminate, 1-2.5 cm. long, peduncled, the 2 bracts not united by their margins; flowers few in each spathe, 6-12 mm. broad; ventral cavities of the orary 2-oruled, the dorsal 1 ovuled; capsule commonly 5 -seeded (2 seeds in each of the rentral cells, 1 in the dorsal); seeds oblong, reticulated, about $2 \mathrm{~mm}$. long.

Moist waste places, New Providence:-all tropical and warm temperate regions. Referred by previous authors to $C$. nudifiora I. Creepixg DAY-Flower.

\section{Commelina élegans H.B.K. Nov. Gen. 1: 259. 1816.}

Stems branching at the base, the branches decumbent, rooting at the nodes, with puberulent internodes; leaves lanceolate to elliptic or oblonglanceolate, 4-10 cm. long, acute or acuminate at the apex, often rouniled at the base, the sheaths $1-1.5 \mathrm{~cm}$. long, naked or sparingly ciliate on the margin; spathes short-peduncled, glabrous or puberulent, $1.5-2 \mathrm{~cm}$. long, acute; petals blue or white; capsules oboroid, $4 \mathrm{~mm}$. long, reticulated especially on the dorsal lobe; seeds 3 , smooth.

Moist shaded situations, New Providence:-Permuda; Florida; West Indies and continental tropical America. $P C$. commulis of Schocpf. IARGER D.AY-Frownr. 


\section{RHOÈo Hance; Walp. Ann. 3: 659. 1852-3.}

A somewhat fleshy, short-stemmed, low herb, glabrous throughout or the mouth of the leaf-sheaths pilose, the leaves much longer than the large-bracted inflorescence, the axillary peduncles simple or forked, the umbelled flowers almost concealed within the bracts. Sepals 3, petal-like, orate-lanceolate, distinct. Petals 3, ovate. Stamens 6, nearly equal; filaments pilose; anthers oblong. Orary 3-celled, sessile; orules solitary in each carity. Fruit a 3-valved capsule. Seeds rugose. [Name unexplained.] A monotypic genus.

1. Rhoeo discolor (L'Her.) Hance; Walp. Ann. 3: 660. 1852-3.

Tradescantia discolor L'Her. Sert. Angl. 5. 1788.

Stems stout, 2-15 $\mathrm{cm}$. high, about $1.5 \mathrm{~cm}$. thick, often clustered and sometimes forming large colonies. Leares few, nearly erect, oblong-lanceolate, 2-4 dm. long, 3-6 $\mathrm{cm}$. wide, acuminate, dark green abore, purple beneath, rather fleshy; peduncles $2-4 \mathrm{~cm}$. long; bracts compressed-conduplicate, broader than high, $1.5-3 \mathrm{~cm}$. high, acute; umbel many-flowered; pedicels about $1 \mathrm{~cm}$. long; petals white, $5-8 \mathrm{~mm}$. long; capsule oroid, obtuse, 3 -angled, about $4 \mathrm{~mm}$. long; seeds about $3 \mathrm{~mm}$. long.

Shaded walls and other rocky places, Andros, New Providence:-Cuba to St. Thomas and Barbadoes; Jamaica; Mexico. OrSter PLAxt. Bost LiLT.

Schoepf records Tradescantia virginica L. as seen by him in New Proridence in 1784 , but this tnited States species is not now known to grow in the Bahamas.

\section{Order 9. LILIÀLES.}

Monocotyledonous plants, mostly with well-developed perianth, the flowers usually regular and complete, and their parts in $3{ }^{\circ} \mathrm{s}$ or 6 's. Orary superior or inferior, compound. Endosperm of the seed fleshy or horny.

Ovary superior (partly inferior in Aletris).

Herbaceous plants or vines.

Fruit a capsule.

Fruit a fleshy berry; dioecious vines.

Large tall woody plants. Orarr inferior.

Stamens 6 in our species.

Erect perennial herbs; flowers perfect.

Twining vines; flowers dioecious.

Stamens 3, opposite the outer corolla-segments.

Fam. 1. Liliaceae.

Fam. 2. SAILACACEAE.

Fam. 3. DracaexiceaE.

Fam. 4. AirarilidiceaE. Fam. 5. Dios CoreaceaE.

Fam. 6. IRIDACEAE.

\section{Family 1. LILIÁCEAE Adans.}

\section{LiLy Fayils.}

Scapose or leafy-stemmed herbs from bulbs or corms, or rarely with rootstocks or a woody candex ( $($ ucca), the leaves various. Flowers solitary or clustered, regular, mostly perfect. Perianth parted into 6 distinct or nearly distinct segments, or these more or less united into a tube inferior or partly superior (Aletris). Stamens 6, hypogynous or borne on the perianth or at the bases of its segments; anthers 2-celled, mostly introrse, sometimes extrorse. Ovary 3-celled; ovules few or numerous in each cavity, anatropous or amphitropous; stỵles united; stigma 3-lobed or capitate. Fruit a usually loculicidal capsule, or in Iucca sometimes fleshy 
and indehiscent. Seeds various, winged or wingless. Embryo in copious endosperm. About 125 genera and 1300 species, widely distributed.

Carities of the fruit each 1 -seeded.

Carities of the fruit mans-seeded.

Fruit with a thin rupturing periearp.

Fruit a loculicidal capsule.
1. Aloe.

2. Cordyline. 3. Aletris.

\section{ALÒE L. Sp. Pl. 319.1753.}

Succulent plants with a short or elongated caudex, the thick tufted leaves with spiny-toothed margins, the racemose flowers nodding. Perianth subcylindric, the segments connivent or coherent, their tips somewhat spreading. Stamens 6, with slender filaments and oblong anthers. Ovary sessile, 3-angled and 3-celled; style filiform, tipperl by the small stigma; orules many in each cavity of the orarr. Capsule leathery, loculicidally dehiscent. Seeds numerous, black. [Name ancient.] Over 75 species, mostly African. Trpe species: Aloe perfoliata $\mathrm{L}$.

\section{Aloe vèra L. Sp. Pl. 320. 1753.}

Aloe vulgàris Lam. Encycl. 1: 86. 1783.

Aloe perfoliata vera L. Sp. Pl. 320. 1753.

Aloe barbadensis Mill. Gard. Dict. ed. S, no. 2. 1768.

Acaulescent, or nearly so, stoloniferous. Leares 3-6 dm. long, narrowly. lanceolate, long-acuminate, turgid, rery watery within, pale glancons-green, the marginal spinr teeth $1 \mathrm{~cm}$. apart or less; scape stont, 6-12 $\mathrm{lm}$. high, bearing distant. broad, acute scales; raceme dense, 1-3 $\mathrm{dm}$. long: bracts lanceolate, acute, longer than the short pedicels; flowers yellow, about $2.5 \mathrm{~cm}$. long; stamens about as long as the perianth, the style longer.

Coastal rocks. sand plains and dunes, snontaneons after cultiration. Great Exuma. Cat Island. Nolth. East and South Caicos and Salt Cay. Native of the Mediterranean Region, eseaped in Permuda, the West Indies and Central America. ALOES.

2. CORDYLINE Adans. Fam. P1. 2: 54. 543. 1763.

[SANsevieria Thunb. Prorir. Fl. Cap. 65. 1794.]

Fleshy perennial herbs, the leares tufted, basal, flat or terete, elongated, containing a strong fibre, the rather large flowers in a raceme at the end of a simple scape. Perianth-tube slender, its lobes narrow, spreading. Stamens 6, borne near the top of the perianth-tube, the filaments filiform, the anthers oblong or linear. Orary 3-celled; ovules 1 in each carity, erect. Fruit with a thin pericarp. Seens 1-3, subglobose, fleshy. [Greek, a club.] About 25 species, natives of Asia and Africa. Type species: Aloe hyacinthoides L.

1. Cordyline guineénsis (L.) Britton, Mem. Brooklyn Bot. Gard. 1: 35. 1918.

Aletris hyacinthoides guianensis L. Sp. Pl. er. 2, 456.1762.

Aletris guineensis . Tacq. Hort. Vind. 1: 36. 1770.

Sansevieria guineensis Will. Sp. Pl. 2: 159. 1799.

Leares linear, $1 \mathrm{~m}$. long or less, nearly flat, $5-8 \mathrm{~cm}$. wide, dark green and mottled, narrowed at both ends. Scape ahout as long as the leaves: raceme many-flowered; pedicels $5-8 \mathrm{~mm}$. long; perianth nearly white, its lobes about 
$1.5 \mathrm{~cm}$. long, linear or linear-spatulate, recurved, somewhat shorter than the tube.

Waste grounds, spontaneous after cultiration, New Proridence:-Florida: Porto Rico: Cuba ; st. Thomas; St. Croix; Jamaica. Native of tropical Africa. AFlicas BOWSTR1XG-IIENH.

\section{3. ÁLETRIS L. Sp. Pl. 319. 1753.}

Scapose perennial bitter fibrous-rooted herbs, with basal lanceolate leares, and small, white or yellow, bracted perfect flowers in a terminal spike-like raceme. Perianth oblong or campauulate, roughened without, 6-lobed, its lower part adnate to the ovary. Stamens 6 , inserted on the perianth at the bases of the lobes, included; anthers introrse. Orary 3-celled; orules numerous, anatropons; style 3-eleft above; stigmas minutely 2-lobed. Capsule oroid, enclosed by the persistent perianth, 3-celled, many-seeded, loculicidal. Seeds oblong, ribbed. Embryo small. Endosperm fleshy. [Greek, signifying to grind corn, apparently in allusion to the rough, mealy flowers.] About 8 species, natives of eastern N. Am. and Asia. Type species: Aletris farinosa L.

1. Aletris bracteàta Northrop, Mem. Torr. Clıb 12: 27. 1902.

Basal leaves tufted, grayish green, spreading, narrowly lanceolate, $10 \mathrm{~cm}$. long or less, $6-10 \mathrm{~mm}$. wide, acuminate at the apex, narrowed at the base, those of the scape few, distant and very small. Scape about $6 \mathrm{dm}$. high, erect; raceme erect, many-flowered; pedicels about $1 \mathrm{~mm}$. long; bracts subulate, 4-6 $\mathrm{mm}$. long; perianth white, 6-8 $\mathrm{mm}$. long, tubular-oblong, about $3 \mathrm{~mm}$. thick, its oblong-lanceolate lobes about one-fourth as long as the tube; anthers longer than the filaments; fruit oral, about $\overline{\mathrm{mm}}$. long.

Wet grounds in savannas and pine-barrens, Abaco and Andros:-Florida. SOUTHERX COLIC-ROOT.

\section{Family 2. SMILÀCACEAE Vent.}

\section{Saituax Fajilly.}

Mostly vines with woody or herbaceous, often prickly stems. Leaves alternate. netted-reined, sereral-nerved, petioled. Petiole sheathing, bearing a pair of slender tendril-like appendages, persistent, the blade falling away. Flowers small, mostly green, dinecious, in axillary umbels. Perianth-segments 6. Stamens mostly 6, distinct: filaments ligulate; anthers basifixed, 2-celled, introrse. Orary 3-celled, the carities opposite the inner perianth-segments; ovules 1 or 2 in each cavity, orthotropous; style very short or none; stigmas 1-3. Fruit a globose berry containing 1-6 brownish seeds. Endosperm horny. copious; embryo small, oblong. remote from the hilum. Genera 3, only the following in North America; species about 230, in warm and temperate regions.

\section{SMILAX L. Sp. Pl. 1028. 1753.}

Rootstocks usually large and tuberous, stems usually twining, and climbing by means of the coiling appendages of the petiole. Lower leaves reduced to scales. Flowers regular. Perianth-segments distinct, deciduous. Pedicels borne on a globose or conic receptacle, inserted in small pits, generally among 
minute bractlets. Filaments inserted on the bases of the perianth-segments. Staminate flowers without au ovary. Pistillate flowers usually smaller than the staminate, usually with 1-6 abortive stamens. Berry black, red or purple (rarely white), with 3 strengthening bands of tissue running through the outer part of the pulp, connected at the base and apex. Embryo lying under a tubercle at the upper end of the seed. [Ancient Greek name, perhaps not originally applied to these plants.] About 225 species of wide distribution, most abundant in tropical America and Asia. Type species: Smilax aspera L.

Leares normally armed with prickels: leaves coriaceous. Leaves unarmed.

Leares chartaceous, ovate, mostly 2-lobed near the base.

Leaves coriaceous, elliptic or oblong-Ianceolate.

1. S. havanensis.

2. St. auviculata.

3. S. laurifolia.

\section{Smilax havanénsis Jacq. Enum. 33. 1760.}

Smilax havanensis dentata O. E. Schulz, in Urban, Symb. Ant. 5: 40, as to Bahama plant, 1904.

Smilax havanensis ovata laevis O. E. Sehulz, loc. eit. 41. 1904.

Smilax oblongata O. E. Schulz, loc. eit. 42, as to Bahama plant. 1904.

Smilax oblongata viscifolia O. E. Schulz, loc. cit. 43 , at least as to Bahama plant. 1904.

Smilax populnea O..E. Schulz, loc. cit. 43, as to Bahama plant. 1904.

Woody, climbing or trailing, armed with short hooked prickles or nearly unarmed, 1-4 m. long, the branches angled, often zigzag. Leaves coriaceous, oblong to ovate or suborbicular', spinulose-dentate or entire, 2-12 cm. long, reticulate-reined, 3-7-nerved, obtuse, mucronate or emarginate at the apex, rounded, narrowed or subcordate at the base, the petioles $10-18 \mathrm{~mm}$. long, the stipular sheaths about half as long as the petioles; peduncles about as long as the petioles, 4-30-flowerel; pedicels about $4 \mathrm{~mm}$. long; flowers $2-3 \mathrm{~mm}$. broad, the staminate somerhat larger than the pistillate; sepals and petals oblong; berries black, subglobose or oroid, 4-6 $\mathrm{mm}$. in diameter.

Rocky and sandy soil, throughout the archipelago from Abaco and Great Bahama south to the Caicos and Inagua:-Florida: Cuba; Hispaniola. Our field observations, and specimens, show that the synonyms cited above are of no ralue in differentiating the large number of races which constitute this species; there being a wide range in leaf-form and renation and in the relative number of prickles: also in the relative leafiness of the upper parts of the plants; individual specinens may be unarmed. Hitchcock referred a part of his specimens of this species to $S$.

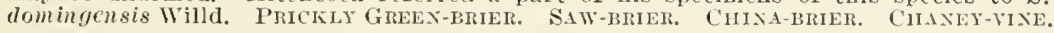

\section{Smilax auriculàta Walt. Fl. Car. 245. 1788.}

\section{Smilax Beyrichii Kunth, Enum, Pl. 5: 207. 1850.}

A glabrous vine, often $5 \mathrm{~m}$. long or longer, trailing or climbing, the branches angular, zigzag, bearing a few prickles or unarmed. Leaves oblong to ovate, chartaceous, $2-10 \mathrm{~cm}$. long, abruptly short-pointed, narrow or obtuse at the base, often dilated or auricled below, shining, coarsely reticulate-veined, the stont petioles 6-10 mm. long; peduncle 3-12 $\mathrm{mm}$. long; pedicels several or many, slender, 4-10 $\mathrm{mm}$. long; flowers yellowish-green, fragrant; sepals and petals of staminate flowers nearly linear, $4-5 \mathrm{~mm}$. long, those of pistillate flowers oblong, about $2.5 \mathrm{~mm}$. long; berries black, globose, about $5 \mathrm{~mm}$. in diameter.

Coppices, scrub-lands, sarannas and pine-barrens. Abaco, Great Baliama, Andros, South Cat Cay, New I'rovidence and Elenthera:-Georgia to Florida and Loulslana. A tricled Grestrier. CHINA-BRIER. 


\section{Smilax laurifòlia L. Sp. Pl. 1030. 1753.}

Rootstocks bearing tubers sometimes $1.5 \mathrm{~lm}$. thick; stem high-climbing, terete, armed with strong straight prickles, the branches anglerl, mostly unarmed. Petioles stout, 6-16 mm. long; leaves leathery, evergreen, elliptic or oblong-lanceolate, acute or abruptly cuspiclate at the apex, narrowed at the base, entire, 3-nerved, or sometimes with an additional pair of nerves near the margins, $5-11 \mathrm{~cm}$. long; peluncles stout, angler, $4-20 \mathrm{~mm}$. long; umbels $6-30$ flowered; pedicels 4-6 mm. long; staminate flowers 4-6 mm. long; anthers lisually about one-third shorter than the filaments; stigma 1, sometimes 2; berries black, ovoid, 4-6 $\mathrm{mm}$. thick.

Border of swamp, Delaport, New Providence: coppices at Staniard Creek, Andros :- Southeastern Y"nited States; Cuba. LAcrel-Leared Greerbrier. Catesby 1: $p l .15$.

Smilax Walteri Pursh, attributed to the Bahamas by O. E. Schulz, from a specimen supposed to hare been collected by Maerter, preserted in the IIunich herbarium, has not been found on any of the islands in the course of our explorations; we presume the specimen was collected in the United States.

\section{Family 3. DRACAENÀCEAE Link.}

\section{Dracaexa Fajilli.}

Perennial, often large, woody plants, mostly with erect and leafy stems, the leares alternate, the flowers in terminal panicles or racemes. Sepals and petals each 3, nearly alike. Stamens 6: filaments distinct; anthers 2-celled. Ovary superior. 1-3-celled; orules 2 to numerous in each cavity; styles united. Fruit capsular or baccate, dry or fleshy, loculicidally dehiscent or rarely indehiscent. About 10 genera and 100 species, natives of warm and tropical regions.

\section{YÜCCA L. Sp. Pl. 319. 1753.}

Large plants, with a short sometimes subterranean candex, or tall woody and leafy stem, or bracted scape, the leares linear or lancealate, usually rigid and sharp-pointed, bearing long marginal thread-like fibres in our species. Flowers large, nodding in a terminal raceme or panicle. Perianth campanulate, or nearly globular, white in our species, of 6 orate, or orate-lanceolate connirent segments. Stamens hypogrnous, shorter than the perianth; filaments thickened above; anthers small, rersatile. Orary sessile, 3-celled, or imperfectly 6-celled; orules numerous; style columnar, short, with 3 stigmatic lobes. Fruit a capsule, or fleshy, or spongy and indehiscent. Seeds numerons, flattened, horizontal. [The Haitien name.] About 30 species, natives of North and Central America. Type species: Yucca aloifolia L.

\section{Yucca aloifòlia L. Sp. Pl, 319. 1753.}

Caudex stout, up to $3.3 \mathrm{~m}$. high, often branched; plant usually growing in colonies, forming large masses. Leares $1 \mathrm{~m}$. long or less, stiff, sharp-pointer, the upper spreading, the older lower ones deflexed, the base expanded; panicle ample, often $6 \mathrm{dm}$. long, showy; perianth white or purplish-tinged, about $5 \mathrm{~cm}$. long, its segments oblong; capsule pulps, indehiscent, oblong, 6-8 cm. long; seeds thin.

Sand dunes, New Providence:-Bermuda ; Florida to Louisiana ; Cuba ; Jamaica ; Mexico. Spaxish Baronet. 


\title{
Family 4. AMARYLLIDÀCEAE Lindl.
}

\author{
AMARYLLIS Family.
}

Perennial herbs (some tropical species woody or even arboreous), with bulbs or rootstocks, scapose or sometimes leafy stems and usually narrow and entire leaves. Flowers perfect, regular or nearly so. Perianth 6parted or 6-lobed, the segments or lobes distinct, or united below into a tube which is adnate to the surface of the ovary (adnate only to the lower part of the ovary in Lophiola). Stamens 6 in our genera, inserted on the bases of the perianth-segments or in the throat of the perianth opposite the lobes. Anthers rersatile or basifixed, 2-celled, the saes usually longitudinally dehiseent. Ovary wholly or partly inferior, usually 3-celled. Style filiform, entire, lobed, or cleft into 3 stigmas at the summit. Orules usually numerous, rarely only 1 or 2 in each cavity of the ovary, anatropous. Fruit capsular, rarely fleshy. Seeds mostly black, the embryo small, enclosed in fleshy endosperm. About 70 genera and $\$ 00$ species. principally natives of tropical and warm regions, some in the temperate zones.

Plants with rootstocks or corms.

Inflorescence umbellate; capsule circumscissile: low herbs.

Inflorescence paniculate; capsule 3 -valved; large plants with flowers on tall scapes.

Perianth funnelform.

Perianth rotate-campanulate.

Bulbous plants.

Filaments distinct.

Filaments united below into a cup.

\section{Hypoxis.}

2. Agave.

3. Furcraca.

4. Atamoseo.

5. Hymenocallis.

1. HYPóxIS L. Syst. ed. 10, 9\$6. 1759.

Low, mostly villous herbs, with a corm or short rootstock, grass-like leaves and slender few-flowered scapes, the flowers rather small. Perianth 6-parted, its segments equal or nearly so, separate to the summit of the ovary, witheringpersistent. Stamens inserted on the bases of the perianth-segments; filaments short; anthers erect, sagittate or entire. Orary 3-celled; style short; stigmas 3 , erect; orules numerous, in 2 rows in each carity. Capsule thin-walled, not dehiscent by ralres. Seeds globular, black, laterally short-beaked by their stalks. [Greek, originally given to some plant with sour leares.] About 50 species, widely distributed. Type species: Hypoxis decumbens L.

\section{Hypoxis juncea J. E. Smith, Spic. 15. 1792.}

Leaves linear-filiform, curved, $3 \mathrm{dm}$. long or less, 1-2 mm. wiıle, glabrous abore, sheathing at the base. Scapes 2 or 3 together or solitary, filiform, mostly shorter than the leares, 1-flowered or 2-flowered at the summit, weak, reclining or prostrate when old; bracts linear-subulate; perianth about $2 \mathrm{~cm}$. broad, its acute segments oblong-lanceolate, pubescent outside, yellow within; capsule 4-6 mm. long; seeds about $0.5 \mathrm{~mm}$. in diameter.

Grassy places and in pine-barrens, Andros, New Proridence and Eleuthera:Georgia to Florida, west to Texas; Cuba. Soutuern Yellow-Erbd Griss.

2. AGÀVE L. Sp. Pl. 323. 1753.

Fleshy herbs, some species very tall, with a short crown-like or erect caudex and a tall bracted seape, the leares large, thick, sometimes spiny-toothed, 
basal, or clustercil at the top of the caudex, the large bracted flowers in terminal spikes or compound clusters. Perianth tubular or funmelform, withering-persistent, with 6 equal or nearly equal lobes. Stamens inserter on the perianth at the bases of the lobes, exserted. Orary 3-celled; style sleniler, exserted, 3-lobed; ovules numerous, in 2 rows in each eavity of the ovary. Capsule 3-lobed, thick-walled, many-seedel. Seeds compressed, somewhat cuneate, black. [Greek, signifying noble.] Perhaps 150 species. All these plants, except the Sisal, are called "Bamboo"' in the Bahamas. We have copied here the original descriptions of the Bahama species by Professor Trelease, who had all our specimens for his investigation, and we have nothing to add to them.

Plants not suckering; leaves broad, fleshy, curved.

Leares broad and stout, about 3 times as long as wide.

Leares elongated-lanceolate, much longer than wide.

Prickles of the leaf-margins $10-25 \mathrm{~mm}$, apart, $2-5$ $\mathrm{mm}$. long.

Capsules broadly oblong.

Leaves dull, gray: spine rather short

Leaves somewhat glossy, greenish; spine elongated.

Capsules nalrowly oblong.

Prickles $5-10 \mathrm{~mm}$. apart, about $1 \mathrm{~mm}$. long.

Spine stout: prickles often with lenticliar bases.

Spine slender ; prickles not lenticular.

Plants freely suckering; leares narrow, hard, straight.

Leaves erect: flower's $3.5-5 \mathrm{~cm}$. long, yellow.

Leares gradually tapering. deeply concave; prickles deltoid.

Leaves abruptly acute, nearly flat; prickles slender.

Leares ascending; flowers $4.5-6.5 \mathrm{~cm}$. long, yellow-green.

\section{A. Braccana.} 5

2. A. bahamana.

3. A. Millspaughii.

4. A. cacosela.

5. A. acklinicola.

6. A. indagatorum.

7. A. Nashii.

8. A. inaguensis.

9. 1. sisalana.

1. Agave Braceàna Trelease, Mem. Nat. Acad. Sci. 11: 40. 1913

Acáulescent, not cespitose. Leaves gray, broadly oblanceolate. nearly flat, 19 by $65 \mathrm{~cm}$. (or larger?); spine from brownish becoming gray, smooth, dull, straight or gently curved, conical, flat or round-groored to about the middle or becoming involute, 3 by $10-15 \mathrm{~mm}$., slightly decurrent; prickles usually $5-10 \mathrm{~mm}$. apart, $2-3 \mathrm{~mm}$. long, straight or the lower gently recurred, triangular, scarcely lenticular at base, the intervening margin straight, or concave when they are raised on low green bases; inflorescence about $7 \mathrm{~m}$. high, paniculate; pedicels about $10 \mathrm{~mm}$. long; flowers golden-yellow, 40-45 mm. long; ovary $20 \mathrm{~mm}$. long, nearly half as long again as the perianth, oblongfusiform; tube conical, about $7 \mathrm{~mm}$. deep; segments $3-4$ by $15-17 \mathrm{~mm}$., threefourths as long as the ovary; filaments inserted nearly in the throat, $35 \mathrm{~mm}$. long, about twice as long as the segments; capsules broadly oblong, 20 by 35 mm., shortly stipitate and beaked; seeds 6 by $8 \mathrm{~mm}$.; bulbils unknown.

Rocky and sandy soil, Abaco; Great Bahama; Andros (?). Endemic. Brace's CENTURY-PLANT.

\section{Agave bahamàna Trelease, Mem. Nat. Acad. Sci. 11: 40. 1913.}

Acaulescent, not cespitose. Leares dull grayish, rather narrorly lanceolate, concave, occasionally somewhat plicate, 15 by $200-300 \mathrm{~cm}$.; spine from brownish becoming gray, smooth, dull, slightly recurved, stoutly conical, usually becoming involutely groored below the middle, $4-5$ by $10-15 \mathrm{~mm}$., decurrent; prickles usually $5-10 \mathrm{~mm}$. apart, $3-5 \mathrm{~mm}$. long, reduced above and below, straight or the longer ones appressed-recurved, triangular, scarcely lenticular at base, sometimes on small green prominences, the intervening margin nearly straight; inflorescence about $10 \mathrm{~m}$. high, the upper third or so 
ovoid-paniculate with slightly ascending branches; bracts deltoid, not imbricated; pedicels about $10 \mathrm{~mm}$. long; flowers golden, 50-60 mm. long; ovary 30-35 mm. long, half as long again as the perianth, oblong-fusiform; tube conical, about $7 \mathrm{~mm}$. deep; segments 4 by $15 \mathrm{~mm}$, about half as $\mathrm{long}$ as the ovary, filaments inserted nearly in the throat, $30-35 \mathrm{~mm}$. long, more than twice as long as the segments; capsules oblong, 25 by $50 \mathrm{~mm}$., shortly stipitate and beaked; seeds 6 by $8 \mathrm{~mm}$.

Rocky plains and ridges, Berry Islands, Andros, Eleuthera, Cat Island, Cave Cay and Great Exuma. Endemic. Erroneously referred by Dolley and by Urban to Aguve americame $\dot{\mathrm{L}}_{2}$; by IIteheock to Agare sobolifera Salm-Dyck.; and by Urs. Northrop and Coker to Agave rigida Mill. BahaMA Centrir-plant.

The four following species deseribed by Professor Trelease, may be but races of $A$. bahamana.

\section{Agave Millspaùghii Trelease, Mem. Nat. Acad. Sci. 11: 41. 1913.}

Acaulescent, not cespitose. Leaves somewhat glossy, green, narrowly oblanceolate, concave, 15 by $125 \mathrm{~cm}$. or more; spine rer-brown, smooth, rather dull, straight, conical, triquetrous or V-grooved below the middle, 3-4 by $15-20$ $\mathrm{mm}$, decurrent for its length or more; prickles usually $15-25 \mathrm{~mm}$. apart, 3-5 mm. long, straight and spreading or oceasionally reflexed sometimes with upcurved tips, narrowly triangular, searcely lenticular at base, the intervening margin nearly straight; inflorescence large, panieulate; bracts broadly triangular; pedicels about $10 \mathrm{~mm}$. Iong; flowers (yellow?) $50 \mathrm{~mm}$. long; ovary $25 \mathrm{~mm}$. long, little longer than the perianth, fusiform; tube conical, about 7 $\mathrm{mm}$. leep; segments 4 by $15-20 \mathrm{~mm}$., three-fourths as long as the ovary; filaments inserted nearly in the throat, scarcely $30 \mathrm{~mm}$. long, about one-half longer than the segments; eapsules short-oblong, 20 by $35 \mathrm{~mm}$, shortly stipitate and beaked; seeds 5 by $7 \mathrm{~mm}$.

Low coppices and serub-lands, Great Exuma. Endemic. Mildspaugu's CevTURY-PLANT.

\section{Agave cacozèla Trelease, Mem. Nat. Acad. Sei. 11: 41. 1913.}

Acaulescent, not cespitose. Leaves yellowish green, somewhat overeast with gray, typically roughish, lanceolate, leeply concave, 20 by $150-200 \mathrm{~cm}$.; spine from brownish becoming gray, smooth; dull, straight or the tip slightly refracted, triquetrously conical, openly grooved below the midale, $3-5$ by $15-20$ mm., decurrent; prickles usually 10-15 $\mathrm{mm}$. apart, $2-5 \mathrm{~mm}$. long in the middle, nearly straight or the larger ones appressed-recurved, narrowly triangular, rarely lenticular at base, the intervening margin straight or somewhat coneave; inflorescence 6-7 $\mathrm{m}$. high, the upper third densely oroid-paniculate with horizontal or slightly ascending branches; bracts broadly triangular, not imbricated; pedicels about $10 \mathrm{~mm}$. long; flowers golden, 50-60 mm. long; ovary 35-40 $\mathrm{mm}$. long, about half as long again as the perianth, oblong-fusiform; tube rather open, about $7 \mathrm{~mm}$. deep; segments $4-5$ by $20 \mathrm{~mm}$, about half as long as the ovary; filaments inserted nearly in the throat, $40-45 \mathrm{~mm}$. long, rather more than twice as long as the segments; capsules narrowly oblong, 15 by $35-45 \mathrm{~mm}$., shortly conical-stipitate, beaked; seeds 4 by $6-7 \mathrm{~mm}$. Said to be bulbiferous sometimes.

liocky margins of salt marshes, New Providence. Endemic. NEw Provonxcp CENTURY-PLANT.

5. Agave acklinícola Trelease, Mem. Nat. Acal. Sei. 11: 41. 1913.

Aspect of $A$. bahamana. Spine from red-brown becoming gray, smooth, glossy, somewhat flexuously recurved, conical, involntely grooved to or beyond the middle, 4-6 by 20-25 $\mathrm{mm}$., decurrent; prickles 5-10 $\mathrm{mm}$. apart, $1-1.5 \mathrm{~mm}$. 
long, straight or gently curved, rather acuminately deltoid often from oblique green prominences, or with lenticular bases, the intervening margin nearly straight; inforescence, flowers, fruit, and bulbils unknown.

Acklin's Island. Endemic. ACKLIx's ISLAND CExturY-Plaxt.

6. Agave indagatòrum Trelease, Mem. Nat. Acar. Sci. 11: 42. 1913.

Acaulescent, not cespitose. Leaves somerhat gravish and at first rery glaucous beneath, lanceolate, somewhat concare, gradually acute, 20-25 by 150-250 cm.; spine chestnut, smooth, rather glossy, nearly straight, conical, involutely grooved to the middle, 3 by $12 \mathrm{~mm}$., decurrent for about its own length; prickles 5-12 mm. apart, about $1 \mathrm{~mm}$. long, straight or slightly recurred, narrowly triangular, not lenticular at base, the somewhat membranous at first slightly pink intervening margin straight; infloreseence $9 \mathrm{~m}$. high, paniculate; pedicels $15-20 \mathrm{~mm}$. long; flowers unknown; capsules narrowly oblong, 20 by $55-60 \mathrm{~mm}$., thick-stipitate, acuminately pointed; seeds 5 by $7-8$ $\mathrm{mm}$. Said by Dr. Britton to be bulbiferous.

Rocky soil, Watling's Island. Endemic. Wathing's Islaxd Cextery-plaxt.

\section{Agave Náshii Trelease, Mem. Nat. Acad. Sci. 11: 45. 1913.}

Acaulescent, cespitose. Leares gray-green, sometimes purple-tinged, graygreen, somewhat glaucous and transversely banded, attenuate-oblong, coneare, 4-5 by 30-50 cm.; spine purplish brown, smooth, somewhat polished and recurved or upcurved toward the end, conical tapered, narrowly slit-groored to beyond the middle, 3 by $15 \mathrm{~mm}$., decurrent; prickles usually $3-5 \mathrm{~mm}$. apart, scarcely $2 \mathrm{~mm}$. long, straight or somewhat curred, acuminately triangular, sometimes nearly or quite confluent, the intervening margin nearly straight; inflorescence $3.5-4 \mathrm{~m}$. high, the upper third or more very loosely paniculate with slender outeurved branches; pedicels $5-10 \mathrm{~mm}$. long; flowers light yellow, $35 \mathrm{~mm}$. long; ovary $20 \mathrm{~mm}$. long, exceeding the perianth, subfusiform or oboroil in development; tube openly conical, $3 \mathrm{~mm}$. deep; segments 3 by 10 $\mathrm{mm}$., half as long as the ovary; filaments inserted nearly in the throat, $25 \mathrm{~mm}$. long, more than twice as long as the segments; capsules oblong or oblongpyriform, 20 by $35 \mathrm{~mm}$., or less, slightly stipitate and beaked; seeds 4 by 4-5 $\mathrm{mm}$.

\section{Sandy soil, Inagua. Endemic. Nash's Cextery-Plaxt.}

\section{Agave inaguénsis Trelease, Mem. Nat. Acad. Sci. 11: 47. 1913.}

Habit of $A$. Nashii. Leares typically white-glancous, oblong or oblanceolate, more quickly acute, flatter, sometimes plicate, $6-9$ by $40-60 \mathrm{~cm}$.; spine often shorter and stouter; prickles closer, 2-3 mm. apart, more recurred and less uniform, rery narrowly triangular, almost continuously joined by a narrow blackish border; inflorescence and fruit unknown; pedicels $5-10 \mathrm{~mm}$. long; flowers yellow, $50 \mathrm{~mm}$. long; orary $25-30 \mathrm{~mm}$. long. exceeding the perianth, subfusiform; tube open, $5 \mathrm{~mm}$. deep; segments 5 by $15-17 \mathrm{~mm}$., half as long as the orary; filaments inserted nearly in the throat, $35 \mathrm{~mm}$. long, fully twice as long as the segments.

Little Inagua; South Caicos. Endemic. Ixagda Cextcry-Plaxt.

9. Agave sisalàna (Engelm.) Perrine, House Rep. Document 564: 8. 1838.

Agave rigida sisalana Engelm. Trans. Acad. St. Louis, 3: 316. 1876.

Agave sisalana armata Trelease, Mem. Nat. Acad. Sci. 11: 49. 1913.

Subacaulescent. Leares finally green and somemhat glossy, at first lightly glaucous and transversely bancled on the back, linear-lanceolate, nearly flat, about 10 by $150 \mathrm{~cm}$; spine dark bromn, somewhat pitted and glossy, tumidly 
conical or triquetrous, slightly recurved, shallowly round-grooved near the base, 4-5 by $20-25 \mathrm{~mm}$., not decurrent; prickles exceptionally numerous and $2-4 \mathrm{~mm}$. loug, but typically.minute or almost entirely suppressed; inflorescence about $6 \mathrm{~m}$. high, the upper half loosely oblong-paniculate; pedicels $5-10 \mathrm{~mm}$. long; flowers yellowish green, $45-60 \mathrm{~mm}$. long; ovary $20-25 \mathrm{~mm}$. long, shorter than the perianth, soon broadly fusiform; tube urceolate, $15-20 \mathrm{~mm}$. deep; segments $6-8$ by $15-20 \mathrm{~mm}$., a little shorter than the ovary; filaments inserted about the upper third of the tube, $40-70$ or even $80 \mathrm{~mm}$. long, twice or thrice as long as the segments; capsules, when produced, which is rare, oblong, 20-25 by $60 \mathrm{~mm}$., stipitate and beaked; seeds $i$ by $10 \mathrm{~mm}$. Freely bulbiferous.

Rocky plains, spontaneous after cultivation, Andros, New I'rovidence, Cat Island. Native of Iucatan. Cultivated throughout the archipelago.

In fields of the cultivated plant many individuals were found with spineless leaf margins, others with very spiny margins, and still others both spiny and spineless margins on the same plant. Sisal.

\section{FURCRAEA Vent. Bull. Soc. Philom. 1: 65. 1793.}

Large succulent plants with tufted basal leares and tall scapes, the inflorescence terminal, paniculate. Perianth of 6 spreading segments, slightly united at the base. Stamens borne on the bases of the segments; filaments thickened below the middle; anthers linear-oblong. Ovary 3-celled, with many orules in 2 rows in each carity; style rather stout, 3-angled and thickened below, tipped by a small stigma. Capsule oblong, 3-sided, 3-ralved. Seeds numerous, flat. [Dedicated to Antoine Francois de Foureray.] About '20 species, natives of tropical America. Type species: Fureraea cubensis Vent.

\section{Furcraea macrophýlla Baker in Hook. Ie. pl. 2501. 1899.}

Leaves many, the larger about $2.3 \mathrm{~m}$. long by $18 \mathrm{~cm}$. wide, nearly equally bright green on both sides, shallowly channeled above, rather firm, gradually narrowed to $5 \mathrm{~cm}$. or $7 \mathrm{~cm}$. wide above the expanded base, the lower prickles 2-3 $\mathrm{mm}$. long, the upper strongly hooked forward, $2-7 \mathrm{~cm}$. apart, borne on triangular, distant teeth 4-6 mm. high; scape up to $10 \mathrm{~m}$. tall, about $1.5 \mathrm{dm}$. thick toward the base, its lanceolate bracts broad-based, the lower $3-6 \mathrm{dm}$. long, ascending, the upper, shorter, widely spreading; panicle branches curved and tortuous when young; flowers white, fading yellowish green; ovoid bulbils $2-4 \mathrm{~cm}$. long are freely developed on the panicle in place of flowers.

Poadsides and waste grounds, New Providence, Cat Island, Acklin's Island, North and Sonth caicos:- liermuda inaturalized), Cuba, Jamaica. Originally de. scribed from garden specimens, of New Providence, grown at Iiew. Mr. Percy Wilson says that the North Caicos plants grow in a forest far from habitations and have all the appearances of being native. Referred by Irs. Northrop to $F$. cubensis and, doubtfully by Drummond to $F$. undulata Jacobi. Drummond (Rep. Mo. Bot. Gard. 18: 43 ) doubtfully records $F$. ('ubensis (Jacq.) Vent. from East Caicos. Wild Sistal.

\section{Atamósco Adans. Fam. Pl. 2: 5i, 522. 1763.}

Acaulescent herbs, with coated bulbs and glabrous foliage. Leaves sasal, narrowly linear, flat or channeled. Scape 1-flowered. Perianth white, red, pink, purple or yellow, its tube funnelform, its 6 lobes equal. Stamens 6 , equal or nearly so; filaments adnate to the throat of the perianth-tube; anthers versatile. Ovary 3-eelled; style filiform, 3-lobed at top, or stigma nearly capitate. Orules numerous, in two rows in each carity. Capsule 3-celled, subglobose or depressed, more or less 3-lobed, loculicidally 3-valved. Seeds black or nearly 
so, usually flattened. [Aboriginal name.] Abcut 35 species, natives of America. Type species: Amaryllis Atamasco L.

Flower rose-pink, $2-3 \mathrm{~cm}$. wlde.

Flower bright red, $7-8 \mathrm{~cm}$. wide.

1. A. rosea.

2. A. cardinalis.

1. Atamosco ròsea (Lindl.) Greene, Pittonia 3: 18s. 1897.

Zephyranthes rosea Lindl. Bot. Reg. 10: pl. 821. 1824.

Bulbs subglobose, usually less than $2 \mathrm{~cm}$. in diameter, short-necked. Scape rather sleuder, 2 $\mathrm{dm}$. high or less, as long as the leaves or longer; leaves $3-4 \mathrm{~mm}$. wide; spathe about half as long as the peduncle, 2 -cleft at the top; perianth 2-3 cm. long, rose-pink, with a short tube and obovate bluntish segments; style 3 -cleft; capsule about $8 \mathrm{~mm}$. thick.

Roadsides, spontaneous after cultivation. New Providence and on Grand Turk where it was observed carpeting a pasture of over five acres in extent. Native of

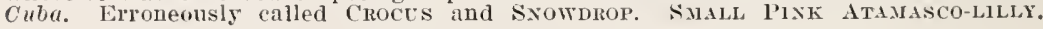

\section{Atamosco cardinàlis (C. H. Wright) Britton.}

Zephyranthes cardinalis C. H. Wright, Bot. Mag. pl. 8553. 1914.

Bulbs up to $6 \mathrm{~cm}$. in diameter. Scape rather stout, 10-12 $\mathrm{cm}$. high, pink at the base, green above, about as long as the leaves; leaves $6-8 \mathrm{~mm}$. wide; spathe somemhat longer than the pecluncle, acute, pink, 2-3 cm. long; perianth bright red, its funnelform tube $2-3 \mathrm{~cm}$. long, its oblong-oblanceolate segments $4-5 \mathrm{~cm}$. long.

Grown in Bahama gardens: perhaps native somewhere in the archipelago. Red ATAMASCO-LILY.

\section{HYMENOCÁLLIS Salisb. Trans. Hort. Soc. 1: 338. 1812.}

Mostly tall bulbous herbs with usually lanceolate or linear-oblong leaves, and large white capitate or umbellerl flowers on solid scapes, each flower subtended by 2 membranous bracts. Perianth of 6 spreading or recurved, narrow equal elongated lobes, united below into a long cylindric tube. Stamens inserted in the top of the perianth-tube, the lower parts of the long filaments connected by a membranous crown; anthers linear, versatile. Ovary 3-celled; ovules only 1 or 2 in each cavity; style filiform, long-exserted; stigma small, entire or nearly so. Capsule rather fleshy. Seeds usually only 1 or 2, large, green, fleshy. [Greek, beautiful membrane, referring to the crown.] About 30 species, all American. Type species: Hymenocallis littoralis Salisb.

Perianth-segments as long as the tube or longel.

Perianth-segments shorter than the tube.
1. H. declinata.

2. H. caymanensis.

\section{Hymenocallis declinàta (Jacq.) M. J. Roem. Fam. Nat. 4: 171. 1847.}

Pancratium declinatum Jacq. Select. Am. 99. 1763.

Hymenocallis arenicola Northrop, Mem. Torr. Club. 12: 28. 1902.

Bulb subglobose, often $8 \mathrm{~cm}$. in diameter. Leares fleshy, sessile, nearly linear or linear-oblong, $6 \mathrm{dm}$. long or less, 4-6 $\mathrm{cm}$. wille, rounded or acute at the apex, gradually narrowed to the broadenerl base, many-nerved, dark green; scape stout, as long as the leaves or shorter; flowers 5-13, sessile, fragrant; bracts ovate to lanceolate, acute or acuminate, 3-6 $\mathrm{cm}$. long; ovary oblong, 1-1.5 cm. long; perianth-tube slender, $5-10 \mathrm{~cm}$. long; perianth-segments 
linear, S-12 cm. long, longer than the tube; crown $3-4 \mathrm{~cm}$. long, about one-third as long as the stamens; style about as long as the perianth.

Sandy coastal ridges and dunes, Great Bahama to Andros. New Providence, Eleuthera, Cat Island and Great Exuma :- IIispaniola to st. Jan, St. Kitts and Montserrat. SPIDER-LILY, DAY-LILY.

2. Hymenocallis caymanénsis Herb. Amaryl. 214. 1837.

Bulb subglobose. Leaves fleshy, sessile, 3-8 $\mathrm{dm}$. long, 3-8 cm. wide, linear or linear-oblong, acute or obtuse at the apex, somewhat narrowed toward the base, green, many-nervel; seape rather stout, about as long as the leaves; flowers 6-12, sessile; bracts lanceolate to ovate-lanceolate, acuminate, $7 \mathrm{~cm}$. long or less; ovary oblong, 1-2 cm. long; perianth-tube 12-16 cm. long; perianth-segments linear, $8-10 \mathrm{~cm}$. long, shorter than the tube; crown about $3 \mathrm{~cm}$. long; style very slender, about as long as the perianth.

In sand, Anguilla Isles and Water Cay:-Florida: Cuba; IIaiti; Casman Islands. Caxiar ISLANDS SPIDER-LiLY. CHRSOLITE LilY.

Hymenocallis caribaèa (L.) Herb. of the Lesser Antilles, is recorded from the Bahamas by Urban (Symb. Ant. 4: 151) and also doubtfully by Schoepf, but has not been found by us in the archipelago. It has been confused with H. declinúta.

Hymenocallis crassifolia Herb., of Florida, is recorded by Baker (Amaryl. 126) as from the Bahamas, but has not been found by us in the archipelago. Perhaps the specimen studied by him was of $H$. declinata.

\section{Family 5. DIOSCOREÀCEAE Lindl.}

\section{YAMI FAMILY.}

Herbaceons or slightly woody twining vines with fleshy or woody rootstocks, slender stems, petioled, mostly cordate, several-nerved and reticulateveined leaves, and small inconspienons dinecious or monoecious (in some exotic genera perfect) regular flowers in spikes, racemes or panicles. Perianth 6-parted, that of the pistillate flowers persistent. Staminate flowers with 6 or 3 stamens, sometimes with a mudimentary ovary. Pistillate flowers with an inferior 3 -celled ovary, 3 styles and 3 terminal stigmas. sometimes also with 3 or 6 staminodia; orules 2 (rarely 1 ) in each cavity of the ovary, pendulous, anatropous or amphitropons. Fruit a 3-ralved, 3-angled capsule or samaroid. Endosperm of the seed fleshy or cartilaginous, enclosing the surall embryo. About 9 genera and 175 species, mostly natives of America, a few in the Old World.

Fruit a 3-celled, 3-winged or 3-angled capsule.

Fruit a 1 -seeded samara.

1. Dinscorea.

2. Rajania.

1. DIOSCORÈA L. Sp. PI. 1032. 1753.

Characters of the fanily as defined above, the fruit a 3-angled capsule. [Name in honor of the Greek naturalist Dioscorides.] Abont 160 species, most numerous in tropical regions, a few in the temperate zones. Type species: Dioscorea sativa L.

1. Dioscorea alàta L. Sp. Pl. 1033. 1753.

Glabrous, dioecious, high-climbing from a large tuber, the stem 4 -wingen or 4-angled. Leaves opposite, the blades broadly orate, $i-15 \mathrm{~cm}$. long, palmately 
nerved, acuminate at the apex, cordate at the base; petioles slender, as long as the blates or somewhat shorter; staminate flowers in whorled, often panicled spikes, the rachis flexwous, the perianth about $2 \mathrm{~mm}$. broad, the stamens mostly 6 ; pistillate flowers distant in simple spikes; capsule elliptic, 3-winged, 1.5-2 cm. long.

Spontaneous after cultiration, Andros, Eleuthera:-Jamaica; Porto Rico: Tortola to Trinidad. Generally enitivated in tropical and subtroplcal countries. r'robably native of southeastern Asia.-YAs.

\section{RAJÀNIA L. Sp. Pl. 1032. 1753.}

Twining vines, with alternate, petioled leares and small, greenish, dioecious, racemose flowers, the staminate ones commonly clustered in the racemes, the pistillate solitary. Staminate flowers with a 6-eleft perianth and 6 stamens with short filaments, the pistil rudimentary or none. Pistillate flowers with 6 distinct perianth-segments, the styles 2-cleft; staminodia minute or wanting. Fruit samaroid, 1-seeded, indehiscent, the wing terminal, thin. [Commemorates John Ray, 1628-1705, famous English botanist.] Ten species or more, natives of the West Indies. Type species: Rajania hastata L.

\section{Rajania microphýlla Knuth, Enum. 5: 451. 1850.}

Slender, glabrous, often much-branched, 1-2 m. long or longer. Leaves lanceolate to ovate in outline, $2-8 \mathrm{~cm}$. long, acute or acuminate and mucronate at the apex, hastate or cordate at the base, the auricles rounded, the petiole much shorter than the blade; staminate racemes about as long as the leaves; pistillate racemes as long as the leaves or shorter; samaras oblong, obtuse, thin, shining, 8-12 mm. long.

Rocky plains, pine-lands and interior ridges, Abaco, Great Bahama, Andros, New Providence, Cat Island and Grent Exuma:-Cuba. SMALl RaJAxi. Wild YaM. Referred to $R$. hastata L., by Mrs. Northrop, a species now understood to be restricted to Hispaniola.

\section{Family 6. IRIDÀCEAE Lindl.}

\section{IrIS FAMILY.}

Peremial herbs with narrow equitant 2-ranked leaves and perfect, mostly clustered flowers subtended by bracts. Perianth of 6 segments or 6 -lobed, its tube adnate to the ovary, the segments or lobes in two series, convolute in the bud, withering-persistent. Stamens 3, inserted on the perianth opposite its outer series of segments or lobes; filaments filiform, distinct or united; anthers 2-celled, extrorse. Ovary inferior, mostly 3celled; ovules mọstly numerous in each cell, anatropous; style 3 -cleft, its branches sometimes divided. Capsule 3-celled, loculicidally dehiscent, 3angled or 3-lobed (sometimes 6-lobed), many-seeded. Endosperm fleshy or horny; embryo straight, small. About 57 genera and 1000 species, of wide distribution.

\section{SISYRÍNCHIUM L. Sp. Pl. 954. 1753.}

Perennial mostly tufted slender herbs with fibrous roots from contracted roctstocks, simple or branched 2-minged or 2-edged stems, and linear grass-like leaves. Flowers from terminal spathes consisting of mostly one pair of opposite conduplicate herbaceous bracts enclosing membranous seales; perianth 
blue, riolet or white with a sellow eye, rarely all yellow, the 6 oblong or oborate segments spreading and aristulate; filaments monadelphous; anthers linear or oblong, the sacs distinct at base; style threadform, the branches filiform or obsolete; ovary 3-celled; capsule globose, oval or oboroid, usually trigonous, loculicidally 3 -ralved; seeds globose to obovoid, often angled, pitted or smooth. Flowers fugacious, opening successively in sunlight, each usually lasting but a day. Probably not fewer than 125 species, nearly all American. Type species: Sisyrinchium Bermudiana L.

1. Sisyrinchium miamiếnse Bicknell, Bull. Torr. Club 26: 226. 1899.

Glabrous; stems erect, 2-3 dm. high, somewhat longer than the leares. Leares 1-2 mm. wide, striate-nerred, acute, serrulate; peduneles 2-4, slender, $3-7 \mathrm{~cm}$. long; spathes $12-15 \mathrm{~mm}$. long, the bracts keeled, the outer one slightly longer than the inner; flotrers blue, about $1 \mathrm{~cm}$. wide; fruiting pedicels exserted, 10-15 mm. long; capsules oboroid, 3-5 mm. long, mucronulate.

Margins of swamps, Great Bahama near West End:-Florida. Mrani BleEEYED GRASS,

\section{Order 10. ORCHIDALES.}

Monocotyledonous herbs, many tropical species epiphytes. Flowers mostly very irregular, complete and perfect, their parts in 3 's or 6's. Orary inferior, componnd. Seeds rery numerous and minute, withont endosperm.

\section{Family 1. ORCHIDÀCEAE Lindl.}

\section{ORCHID FAMILF.}

Perennial herbs, with corms, bulbs or tuberous roots, sheathing entire leares, sometimes rednced to seales, the flowers perfect, irregular. bracted. solitary, spiked or racemed. Perianth superior, of 6 segments, the 3 onter (sepals) similar or nearly so, 2 of the inner ones (petals) lateral, alike; the third inner one (lip) dissimilar, often markedly so, msually larger, often spurred, sometimes inferior by torsion of the orary or pedicel. Stamens varionsly mited with the style into an nnsymmetrical column: anther 1 or in Cypripedium 2, 2-celled; pollen in 2-S pear-shaped. usually stalked masses (pollinia), mited by elastic threads, the masses waxy or powdery, attached at the base to a riseid disk (gland). Style often terminating in a beak (rostellum) at the base of the anther or between its saes. Stigma a viscid surface, facing the lip beneath the rostellum, or in a cavity between the anther-saes (elinandrium). Orary inferior, nsually long and twisted. 3-angled, 1-celled; ornles numerous, anatropous, on 3 parietal placentae. Capsule 3-ralved. Seeds very numerous, minute, mostly spindle shaped, the loose coat hyaline, retienlated; endosperm none; embryo flesliy. About 410 genera and 5000 species, of wide distribution, most abundant in the tropies, many of those of warm regions epiphytes.

Flowering stem or peduncle terminal.

Leaves convolute.

Anther blunt, generally rounded, usually much exceeding the rostellum and appressed to or incumbent upon it.

Lip not enclosing the column; flowers erect or ascending: low erect herbs.

Lip enclosing the column; flowers nodding; succulent rines.

1. Carteria.

2. Tanilla. 
Anther, at least the body, ahout as long as the rostel. lum and not ipplessed to it, when beaked, the beak sometimes exceeding the rostellum. rollinia not in distinct masses.

Lip turned ontward.

lateral sepals united at the base into a long spur.

lateral sepals free.

Flowers in a 1-sided spike which is sometimes spirally twisted, the perianth spreading or nodding; lip not saccate.

Flowers in a many-sided spike, the perianth ascending or erect; lip saccate at the base.

Lip turned upward.

Sepals united at the base; lip arnate to the sepal-tube, the base free from the short column.

Sepals free: lip free from the sepals, the base adnate to the elongate column.

Pollinia in several distinct masses.

Leares duplicate.

Leaf-blades not plaited.

Leaves not articulated near the base: pollinia unappendaged.

Leaves articulated near the base; pollinia with taillike appendages.

Column with a distinct foot; lip and lateral sepals about equal in size.

Colmmn without a foot; lip much larger than the lateral sepals.

Ovary not produced into a hollow neck. Pollinia 4.

Plants without psendobulbs.

Flowers axillary to bracts borne along a rachis.

Flower's in a terminal raceme or panicle or solitary.

Plants with pseudobulbs.

Lip 3-lobed, longitudinally crested or appendaged: sepals and petals not attenuate.

Lip deeply 3 -lobed, the middle lobe broad: pseudobulbs terete: scape without a long basal sheath.

Lip obscurely 3-lobed, the middle lobe minute: psendobulbs flattened; scape with a long basal sheath.

Lip entire, or undulate, neither crested nor appendaged.

Lip concave, shell-like.

Pollinia 8.

Lip nearly linear.

Ovary produced into a hollow neck.

Leaf-blades plaited.

Flowering stem or peduncle lateral.

Leaves convolute: column elongate.

Column without a foot: lip attached to the base of the column: lateral sepals free.

Column with a distinct foot: lip attached to the apex of the foot; lateral sepals adnate to the column-foot. Leaves duplicate; column rery short.

3. Pelexia.

4. Ibidium.

5. Stcnorrhynchus.

6. Prescottia.

7. Ponthiera.

8. Physurus.

9. Ialaxis.

10. Polystachya.

11. Spathiger.

12. Auli:a.

13. Encyelia.

14. Epicladium.

15. Anacheilium.

16. Nidema.

17. Tetramicra.

18. Lacliopsis.

19. Limodorum.

\section{Blctia.}

21. Gorenia. 2. Oncidium.

1. CARTĖRIA Small, Torreya 10: 187. 1910.

Caulescent terrestrial orchids with clustered, fleshy tubers and erect simple stems. Leaves various, the basal ones firm, narrow, with plicate blades, the cauline ones mere sheathing scales. Flowers several, erect, axillary to sealelike bracts. Perianth colored. Sepals nearly equal, narrow, longer than the petals. Petals decidedly narrower than the sepals. Lip short, sessile, slightly 
3-lobed at the apex, with the mildle lobe much longer than the lateral ones, the body with 5 longitudinal erests. Capsules erect. [Commemorates Joci Jackson Carter, 1843-1912, a diligent American botanical collector.] A monotypic genus.

1. Carteria corallícola Small, Torreya 10: 188. 1910.

Stems 2-3.5 dm. tall, rather slender, fleshy. Basal leaves $2-i \mathrm{~cm}$. long: blades nearly linear, narrowed at both ends, often curved; spike of flowers rather inconspicuous, erect; lateral sepals linear-lanceolate to broadly linear, $6.5-7.5 \mathrm{~mm}$. long, green or greenish-yellow; petals linear or nearly so, yellowish-green or greenish-white; lip oval to orbicular-oval, 6-7 $\mathrm{mm}$. long, the body yellowish, with the crests extending to the base of the midale lobe, the lobes magenta, or magenta-pink at the tips; anther magenta; mature fruit not seen. Orcuid,

Scrub-łands, New Providence along Farringdon Road:-Florida. Carter's

2. VANÍLLA Juss. Gen. 66. 1789.

Fleshy, climbing orchids, the leaves broad or reduced to mere scales, the stems giving off aerial roots, the mostly large flowers in axillary spikes or racemes. Sepals nearly alike, distinct, spreading. Petals resembling the sepals. Lip clawed, the claw adnate to and embracing the long columm. Stigma borne under the rostellum. Anther convex, its sacs separate; pollinia powiery. Capsule elongated, fleshy, indehiscent or tardily partly dehiscent. [From the Spanish name for the fruit.] About 20 species, of tropical and subtropical regions. Type species: Epidendrum Tanilla L.

Plants leaf-bearing: lip not Iobed.

Leares lanceolate, $4 \mathrm{~cm}$. Iong or less.

Leaves ínear-oblong, $7-12 \mathrm{~cm}$. long. $1 . \overline{1}-25 \mathrm{~cm}$. wide.

Plant leafless, except on youngest shoots; lip 3 -lobed.

1. T. Egyersii.

2. I. phacantha.

3. T. articulata.

1. Vanilla Eggèrsii Rolfe, Jour. Linn. Soc. 32: 472. 1896.

Fleshy, elongated, deseribed as sometimes $30 \mathrm{~m}$. in length and often $10 \mathrm{~m}$. long or longer, the stems terete, 1 -grooved, $1-1.5 \mathrm{~cm}$. thick, the aerial roots $5-8$ em. long, tendril-like. Leaves sessile, oblong-lanceolate, acute or acuminate, 2-8 em. long, 8-15 mm. wide; perluncle stout, geniculate, $5-10 \mathrm{~cm}$. long, bearing an ovate or oblong, acute bract at each node; spike several-flowered, 6-14 cm. long, its bracts triangular-ovate, about $5 \mathrm{~mm}$. long; ovary eylindrie, about as long as the sepals; sepals and petals oblong-lanceolate, obtuse or acutish, 4-6 cm. long; lip abont as long as the sepals, rounded, crenate or unlulate, not lobed; colnmn 2-2.5 cm. long; capsule fleshy, indehiscent, eylindric or subclavate, $7-12 \mathrm{~cm}$. long, 8-10 $\mathrm{mm}$. thick.

Coastal thickets and coppices, Andros :-Florida: lispaniola to Virgin Gorda, Eggers' Vaxilus. Faweett and Rendle (1\%. Jam. 2: 17) aceredit Tamilla rlariculata Sw. to the Bahamas, Porto Rico and St. Thomas, presumably including V. Eygersii as a synonym of that species. This view may be correct, but we do not have specimens to corroborate it. The petals of $T$. clariculata are described as obtuse, whlle those of V. Eggersii are acute.

\section{Vanilla phaeántha Rchb.f. Flora 48: 274. 1565.}

Fleshy, often $6 \mathrm{~m}$. long or longer. Leaves oblong or linear-oblong, nearly sessile, $6-18 \mathrm{~cm}$. long, $1.5-5$ cul. wide, acute or obtuse; perluncle stout, $2-8 \mathrm{~cm}$. long, geniculate, leafy-bracted; spike few-several-flowered, its bracts orate, obtuse, 6-12 mm. long; ovary cylindric, $5-6 \mathrm{~cm}$. long; sepals and petals nar- 
rowly oblong or linear-oblanceolate, acutish, 6-8 cm. long, 1-2 cm. broad; lip luroadly ovate, convolute, retuse, erenulate, crested, about $8 \mathrm{~cm}$. long; capsule narrowly eylintrie, $7-8 \mathrm{~cm}$. Jong, about $1 \mathrm{~cm}$. thick.

Copplees, Ahaco and Great Bahama:-Florida; Cuba ; Jamalea; St. I'incent ; Trinidad. Our Isahama specimens are barren; they were determined by Mr. $R$. A. Rolfe, of Kew. Obloxg-leaved Vaxilla.

\section{Vanilla articulàta Northrop, Mem. Torr. Club 12: 31. 1902.}

High-climbing, sometimes $10 \mathrm{~m}$. long or longer, branched, subterete, the stems $2 \mathrm{~cm}$. in diameter or less, only the youngest shoots leaf-bearing, their leares linear-lanceolate, $2 \mathrm{~cm}$. long or less. Peduncle geniculate, $3-7 \mathrm{~cm}$. long, bearing triangular-orate bracts $5-7 \mathrm{~mm}$. long; spike few-several-flowered; ovary narrowly cylindric, about $3 \mathrm{~cm}$. long; sepals and petals white or slightly pink, oblanceolate, acutish or obtuse, 3-4 cm. long, about $1 \mathrm{~cm}$. wide; lip broadly oborate, conrolute, 3 -lobed, about $3 \mathrm{~cm}$. wide, the middle lobe somewhat crested; capsule subcylindric, $5-\pi \mathrm{cm}$. long.

Thickets and low coppices, Andros, New Providence, Eleuthera, Great Exuma, Great Guana, Watling's and Crooked Islands:-Florida and Cuba. Lixk-VINE. WORMIINE.

\section{Peléxia Poit.; L. C. Rich. Mem. Mus. Paris 4: 59. 1818.}

Terrestrial orchids, with thick, clustered roots, petioled basal leaves, the flowers spicate at the summit of a sheathed scape. Sepals narrow, the median one adnate to the petals, the lateral ones united below and prolonged into a spur. Lip concave, elongated, embracing the short column. Column without a foot. Rostellum subulate. Anther narrowly oblong; pollinia powdery. Capsule ellipsoid. [Greek, from the fancied resemblance of the lip to a hatchet.] About 20 species, of tropical and subtropical America. Type species: Neottia adnata Willd.

Perianth $6 \mathrm{~mm}$. long: spur short, adnate.

I'erianth $2.5-3 \mathrm{~cm}$. long: spur subulate, free.

1. P. adnata.

2. $P$. setacea.

1. Pelexia adnàta (Sw.) Spreng. Syst. 3: 704. 1826.

Neottia adnata Sw. Fl. Ind. Oce. 3: 1409. 1806.

Pelexia spiranthoides Lindl. Bot. Reg. 12: pl. 985. 1826.

Scape pubescent above, 2.5-4 dm. high. Basal leaves 2-5, glabrous, the blades elliptic or orate-elliptic, 5-12 $\mathrm{cm}$. long, 3-nerved, acute at the apex, rounded at the base, the slender, nearly erect petioles $i-14 \mathrm{~cm}$. long, reddish; sheaths of the scape acuminate, $2-5 \mathrm{~cm}$. long; spike pubescent, many-flowered, 6-12 cm. long; bracts narrowly lanceolate, about as long as the whitish flowers; sepals about $6 \mathrm{~mm}$. long, the median one elliptic, obtuse, coneave, the lateral ones linear, acute; petals linear, nearly as long as the sepals; lip tubular below, 5-6 mm. long; capsule about $1.5 \mathrm{~cm}$. long, 6-ribbed.

In shadr coppice, Andros at Conch Sound:-Cuba to Guadeloupe: Jamaica; Venezuela. Determination based on fruiting specimen only; recorded by Mrs. Northrop as Cranichis sp. Short-SPURRed Pelexia.

\section{Pelexia setàcea Lindl. Gen. \& Sp. Orch. 482. 1840.}

Scape 3-6 dm. high, puberulent above, bearing several acuminate sheaths 2-4 cm. long. Basal leaves 1-3, the blades elliptic or oral, 8-15 cm. long, acute at the apex, obtuse or rounded at the base, sereral-nerved, the slender petioles 10-18 cm. long; spike few-several-flowered, pubescent, $15 \mathrm{~cm}$. long or less; bracts orate-lanceolate, $2-2.5 \mathrm{~cm}$. long, long-acuminate into a filiform tip; ovary fusiform, about $2 \mathrm{~cm}$. long; perianth purplish-green or greenish-white; 
sepals narrowly lanceolate, 2.5-3 cm. long, the spur 8-10 mm. long; petals narrowly lanceolate, about $2 \mathrm{~cm}$. long; lip white; capsule about $2 \mathrm{~cm}$. long, 6-ribbed.

Shady coppices, Great Bahama, Andros and New Providence:-Florida; Cuba to Guadeloupe and Trinidad; Colombia to Brazil. Losg-Spurede Pelexia.

\section{IBIDIUM Salisb. Trans. Hort. Soc. Lond. 1: 291. 1812.}

Erect terrestrial orehids, with fleshy-fibrous or tuberous roots and slender stems or seapes, leaf-bearing below or at the base. Flowers small, spurless, spiked, 1-3-rowed, the spikes more or less twisted. Sepals free, or more or less coherent, or sometimes united with petals into a galea. Lip concave, erect, embracing the column and often adherent to it, spreading and crisped, or rarely lobed or toothed at the apex, bearing minute callosities at the base. Column arched below, obliquely attached to the top of the orary. Anther without a lid, borne on the back of the column, erect. Stigma ovate, prolonged into an acuminate beak, at length bifid. Pollinia 2, 1 in each sac, powdery. Capsule ovoid or oblong, erect. About 80 species, natives of temperate and tropical regions. Type species: Ophrys spiralis J. E. Smith.

Flowers white; basal leaves linear.

Flowers green; basal leaves oblong-lanceolate to elliptic.

1. I. tortile.

2. I. lucayanum.

\section{Ibidium tortile (Sw.) House, Muhlenbergia 1: 129. 1906.}

Neottia tortilis Sw. Vet. Akad. Handl. 1800: 226. 1800.

Spirunthes tortilis L. C. Rich. Mem. Mus. Par. 4: 59. 1818.

Stem slender, erect, 3-6 dm. high, glabrous below, pubescent above, bearing 2-4 bladeless acute sheaths above, and sometimes a narrowly linear leaf 2-7 $\mathrm{cm}$. long, below the middle. Basal leaves 2 or 3 , present at flowering time, linear, 8-30 cm. long, 1.5-2.5 mm. wide; spike erect, 6-13 cm. long, pubescent, the approximate flowers in a single spiral; flowers white; bracts orate or oratelanceolate, pubescent, acute or acuminate, $6-7 \mathrm{~mm}$. long, about as long as the ovary; sepals 5-6 mm. long, the median one elliptic, obtuse, the lateral ones oblong, oblique; petals oblong, about as long as the sepals; lip 4-6 $\mathrm{mm}$. long, ovate-elliptic, emarginate, the callosities short; capsule about 5 mn. long.

Savannas and borders of marshes. Great Bahama, Andros and New Providence :-Florida; Louisiana: West Indies. Recorded by IIrs. Northrop as Gyrostachys peruviana Kuntze. SoUTHERx LADies-TRESSES.

\section{Ibidium lucayànum Britton, Bull. N. Y. Bot. Gard. 5: 312. 1907.}

\section{Spiranthes lucayana Cogn. in Urban, Symb. Ant. 6: 338. 1909.}

Root of cylindric, fleshy tubers 2-5 cm. long, 8-10 mm. thick. Basal leaves present at flowering time, oblong-lanceolate, oblanceolate to elliptic, thin but somewhat fleshy, spreading, 5-nerved, reticulate-reined, at least when dry, 5-17 cm. long, 1-3 cm. wide, acute at the apex, narrowed at the base into a rather slender petiole, which is one half to two thirds the length of the blade; scape slender, including the spike 2-4 dm. high, its several leaves linear or linear-lanceolate, acute or acuminate, appressed, 1-3 cm. long; spike $5-25 \mathrm{~cm}$. long, about $1 \mathrm{~cm}$. thick, usually many-flowered; bracts lanceolate, acuminate, erect, as long as the ovary or longer; flowers green, spreading; sepals linearlanceolate, acutish, $3-4.5 \mathrm{~mm}$. long; petals linear a little shorter than the sepals; lip orate-oblong, obtusish, concave, $3-5 \mathrm{~mm}$. long, about one third as 
wide as long, with two minute callosities at the base; capsule oblong, blunt, about 5 111m. long.

coppices and white-lands, Lignum Vitale Cay, Andros, Eleuthera, Cat Island, Jong lsland. Watling's, (xreat Exuma, Crooked lsling and Xorth faicos:-Florida: Anegada: I'olto Rico. Erroneously recorded by Cogniaux as spiranthes clutu. GiRERA LADIESTRESSES.

\section{StenorrhÝnchus L. C. Rich. Mem. Mus. Paris 4: 59. 1818.}

Erect, terrestrial orchils, with lanceolate to elliptic basal leaves often wanting at flowering time, the sheathed scape terminated by a spike of rather large, often showy, mostly red or yellow flowers. Sepals nearly equal, the median one adnate to the petals, the lateral ones united below and produced into a sac or spur. Petals mostly shorter than the sepals. Lip entire or nearly so, concave, without callosities. Column with a foot; stigma under the beaker rostellum. Anther oblong or laneeolate; pollinia powdery. [Greek, narrow beak.] About 25 species, of tropical and subtropical America. Type species: Neottia speciosa Willd.

1. Stenorrhynchus lanceolàtus (Aubl.) Griseb. Fl. Br. W. I. 642. 1864.

Limodorum lanceolatum Aubl. Pl. Guian. 2: 821. 1775.

Satyrium orchioides Sw. Prodr. 118. 1788.

Stenorrhynchus orchioides L. C. Rich. Mem. Mus. Paris 4: 59. 1818.

Leaves 1-3, oblong to oblong-lanceolate, bright green, glabrous, 1-3 dm. long, 2-5 cm. wide, acute at the apex, narrowed at the base into margined petioles, wanting at flowering time. Scape rather stout, 3-6 $\mathrm{dm}$. high, erect, scurfy or somewhat glandular-pubescent, bearing several, acuminate, sheathing seales 2-4 cm. long; spike several-many-flowered, 1-2.5 cm. long; bracts lanceolate, acuminate, shorter than the flowers; flowers red or yellow, $2-3 \mathrm{~cm}$. long; ovary oblong, oblique at the apex: sepals glandular, lanceolate, acute, 5-7-nerved; petals oblong-lanceolate, acute, 5- 7 -nerved; lip lanceolate, acute or acuminate, saccate at about the middle; capsule about $1 \mathrm{~cm}$. long.

Pine-lands and scrub-lands, Great Pahama, Andros and New Providence:Florida; Cuba to Porto Rico and Trinidad; Mexico to Colombia and Paraguay. LEAFLESS IBEAKEDORCHID.

6. PRESCótTIA Lindl. in Hook. Exot. Fl. pl. 115.1825.

Terrestrial orchids, with clustered roots, erect, scape-like stems, broad, tufted, basal leaves convolute in the bud, and small flowers in a terminal spike. Sepals broad, connate at the base. Petals uarrow, thin, mostly shorter than the sepals. Lip broad, concare, 2-auricled at the base of the blade, erect. Column short; rostellum retuse, as long as the anther or longer. Pollinia powdery. Capsule small, oblong or ovoid. [Commemorates John D. Prescott, English botanist, died 1837.] About 30 species, of tropical and subtropical America. Type species: Prescottia plantaginifolia Lindl.

1. Prescottia oligántha (Sw.) Lindl. Gen. \& Sp. Orch. 454. 1840.

Cranichis aligantha Sw. Prodr. 120. 1785.

Slender, glabrous, 2-4 dm. high. Basa! leaves few, ovate to elliptic, 2-7.5 $\mathrm{cm}$. long, acute or obtuse at the apex, obtuse or narrowed at the base, 
about 13-nerved, the petioles 1.5-3 mm. long; scape with several, narrow, acute, bladeless sheaths $1-3 \mathrm{~cm}$. long; spike slender, iensely flowered, $2-7 \mathrm{~cm}$. long; bracts ovate-lanceolate, acuminate, $2-3 \mathrm{~mm}$. long; ovary obovoid-oblong; sepals 1-nerved, pinkish, rounded, about $1 \mathrm{~mm}$. long; petals uarromly obovate or oblong, obtuse, a little shorter than the sepals, white or pink; lip 3-nerved, 1-1.5 $\mathrm{mm}$. long, the blate roundish, minutely auricled; capsule about $4 \mathrm{~mm}$. $\operatorname{long}$.

Coppices and shaded stone walls. Andros and New Providence:-Florida; Cuba to Tortola and Guadeloupe: Jamaica. SMAll PREscotTi.

7. PONTHiEva R. Br. in Ait. Hort. Ker. erl. 2, 5: 199. 1813.

Terrestrial orchids with fibrous roots, tufted basal leaves, and small, loosely racemose flowers on sheathed, erect scapes. Sepals spreading, the lateral ones slightly inequilateral. Petals clawed, spreading, nearly triangular, adnate to the short column, unsymmetrical. Lip adnate to the column, clawed, concare, ascending, spurless. Anther shorter than the rostellum; pollinia 4, in pairs, powdery, pendulous. Capsule ellipsoid. [Commemorates de Ponthieu, who sent American plants to Sir Joseph Banks.] About 20 species, of tropical anil walm temperate America. Type species: Neottia glandulosa Sims.

1. Ponthieva Bríttonae Ames, Torreya, 10: 90. 1910.

Roots clustered, slender, villous. Basal leares about 4, oblong-lanceolate to oblanceolate, $10 \mathrm{~cm}$. long or less, acute at the apex, uarrored into petioles 1-2.5 cm. long; scape slender, 2-4 dm. high, bearing sereral oblong, acute sheaths, pubescent above; raceme 1-2 dm. long, pubescent, several-manyflowered; bracts oblong, acute or acuminate, about $5 \mathrm{~mm}$. long; pedicels ascending, $\mathrm{S}-10 \mathrm{~mm}$. long; sepals about $4 \mathrm{~mm}$. long; petals lanceolate, obtuse, a little longer than the sepals; lip 3 -lobed, subsaceate, $4.5 \mathrm{~mm}$. long, the lateral lobes rounded, the median lobe oblong.

Pine-land near Fresh Creek, Andros, Maidenhead Coppice, New Providence:Florida. II RS. BittTox's I'ONTHIEv.

8. Physurus L. C. Rích. Mem. Mus. Paris 4: 55. 1818.

[Erythrodes Blume, Bijdr. Fl. Ned. Ind. 410. 1S25.]

Leafy-stemmer, terrestrial orchids, with thick, clustered roots, the leares broad, petioled, parallel-nerved and reticulate-reined, convolute in the bud, the small flowers in a terminal spike. Sepals distinet, nearly equal, the small petals cohering with the median one. Lip erect, 3 -lobed, embracing the short column, produced below into a blunt pouch-like spur. Anther about as long as the rostellum. Pollinia granular, pendent. Capsule ellipsoid to oboug. [Greek, referring to the pouch-like spur.] About 60 species, natives of tropical and subtropical regions. Type species: Orchis plantaginea Willd.

1. Physurus querceticola Lindl. Gen. \& Sp. Orch. 505. $18+0$.

Physurus Sagraeanus A. Rich. in Sagra, Hist. Cub. 11: 253. 1550.

Stem slender, erect, glabrous, 3 lnı. high or less. Leares several, distant, orate to lanceolate, $2-6 \mathrm{~cm}$. long, acute, acuminate, or the lower ones obtuse at the apex, rounded or subtruncate at the base, the petioles $5-20 \mathrm{~mm}$. long, their 
bases much dilated, sheathing the stem, the upper sheaths bladeless; spike 2-7 cm. long; bracts lanceolate, or ovate-lanceolate, acute, a little shorter than the ovary; sepals about $4 \mathrm{~mm}$. long, linear or linear-lanceolate; lip with a dilated claw and a nearly orbicular blade terminated by a drooping or recurred triangular tip, the pouch-like spur shorter than the ovary.

Lnder bushes in pine-lands and in savannas. Great Bahama and Andros:Florida to I،oulslana; Cuba; Guadeloupe. Low PHYsunds.

\section{MALÁXIS Sw. Prodr. 119. 1788.}

Low orchids with a solid bulb, 1-leaved or 2-leaved. Flowers small, white or green, in a terminal raceme. Sepals spreading, separate, the lateral ones equal at the base. Petals filiform or linear, spreading. Lip cordate or eared at the base, embracing the column. Anther erect between the auricles, 2 -celled; pollinia 4, smooth and waxy, 2 in each sac, the pairs cohering at the summit, without eaudicles or glands. Capsule oval, sometimes nearly globose, beakless. [Greek, in allusion to the soft tissues.] About 140 species, widely distributed, the following typical.

1. Malaxis spicàta Sw. Prodr. 119. 1788.

Microstylis spicata Lindl. Gen. \& Sp. Orch. 19. 1830.

Glabrous, 1-3 dm. high, 2-leaved near the base, and with 1 or 2 sheaths below the leares. Leaves ovate or elliptic-orate, $5-10 \mathrm{~cm}$. long, acute, the lower one the larger, the sheathing petioles $1-5 \mathrm{~cm}$. long; raceme narrow, $8 \mathrm{~cm}$. long or less, many-flowered; bracts ovate or ovate-lanceolate, acute, $2-4 \mathrm{~mm}$. long; pedicels $5-9 \mathrm{~mm}$. long; middle sepal about $3 \mathrm{~mm}$. long, ovate-lanceolate, acute or bluntish, the lateral ones about as long, obtuse; petals linear, $2 \mathrm{~mm}$. long; lip about $4 \mathrm{~mm}$. long, its terminal lobe linear-oblong; capsule about 8 mm. long.

Coppice, Crooked Island:-Florida; Cuba to Porto Rico and Martinique: Jamaica. We are indebted to $\mathrm{Mrr}$. Oakes Ames for the determination of the Crooked Island specimen. Slevier MaLAXis.

10. POLYSTÀCHYA Hook. Exot. Fl. pl. 103. 1825.

Epiphytic, leafy-stemmed orchids, the stems usually clustered, sheathed at the base, the roots thick-fibrous, the many-nerved leaves conduplicate in the bud, the upper reduced to loug, narrow seales, the small flowers in terminal, panicles or spike-like racemes. Median sepal narrower than the lateral ones. Petals narrower than the lateral sepals. Lip jointed with the base of the column, spurless, sessile, bent below, 3-lobed, the lateral lobes small. Column short, with a distinct foot. Anther terminal, lid-like, convex, usually 1-celled; pollinia 4, waxy, broadly ovate or nearly hemispherie, not appendaged. [Greek, many spikes.] About 170 species, mostly of tropical regions. Type species: Cranichis luteola $\mathrm{Sw}$. 
1. Polystachya minùta (Aubl.) Britton; Snall, Fl. SE: U. S. 328, 1329. 1903.

Epidendrum minutum Aubl. PI. Guian. 2: 824. 1775.

Dendrobium polystachyum Sw. Act. Holm. 21: 247. 1800.

Cranichis luteola Sw. Fl. Ind. Oce. 3: 1433. 1806.

Polystachya luteola Hook. Exot. F'l. pl. 103. 1825.

Stems rather slender, 2-6 dm. long. Sheaths many-striate, $2-4 \mathrm{~cm}$. long; leaves oblong or linear-oblong, 6-30 $\mathrm{cm}$. long, 1-3 $\mathrm{cm}$. wide, acute or obtuse, shorter than the stem; panicle $3 \mathrm{dm}$. long or less, sometimes reduced to a single raceme; racemes rather densely several-many-flowered; bracts acute, about $2 \mathrm{~mm}$. long; flowers greenish-yeliow; buds obliquely 3 -angled; median sepal ovate, $3-4 \mathrm{~mm}$. long, the lateral ones oblique, a little longer; petals narromly spatulate, shorter than the sepals; lip about $4 \mathrm{~mm}$. long, glandular-hairy within, the median lobe emarginate, the lateral lobes incurved; capsule 10-12 mm. long.

On trees in coppices, Abaco, Andros and New Providence:-Florida; Cuba to Tirgin Gorda, south to Trinidad and South America. Large Polystachya. Catesby, $2: p l .55$.

2. Polystachya foliòsa (Hook.) Rehb. f.; Walp. Ann. Bot. 6: 640. 1863.

Stelis foliosa Hook. Ann. Nat. Hist. 2: 330. 1839.

Stems slender, $2 \mathrm{dm}$. long or less. Sheaths striate, 1-3 cm. long; leaves usually 2, linear or linear-lanceolate, $\bar{\jmath}-16 \mathrm{~cm}$. long, 3-8 $\mathrm{mm}$. wide, obtuse or minutely 2-3-toothed at the apex, shorter than or equalling the stem; racemes 1-5, narrow, rather densely several-many-flowered; flowers yellow or yellowish; bracts acute or acuminate, 1-2 $\mathrm{mm}$. long; median sepal ovate, about $1.5 \mathrm{~mm}$. long; lateral sepals broadly ovate, about $2 \mathrm{~mm}$. long; petals spatulate, rounded, 1.5-2 mm. long; lip nearly $2 \mathrm{~mm}$. long, obovate, its lateral lobes incurved, not much smaller than the median one.

On tree-trunks, Andros :-Grenada; Trinidad; northern South America. SuraL. POLYSTACHYA.

\section{SPÀTHIGER Small, Fl. Miami 55. 1913.}

Epiphytic, usually branched, ereeping or pendent orchids, with slender leafy stems, narrow sessile leaves and small flowers in the axils of spathe-like bracts, forming terminal spikes; pseudobulbs none. Leaves duplicate in the bud, the blades not plaited, jointed at the base. Lateral sepals broader than the median one. Petals scarcely broader than the sepals. Lip reniform or nearly orbicular, concave. Column adnate to the lip. Pollinia 4, appendaged. [Greek, spathe-bearing.] About 10 species of tropical and subtropical America, the following typical.

1. Spathiger rígidus (Jacq.) Small, Fl. Miami 55. 1913.

Epidendrum rigidum Jaeq. Enum. 29. 1760.

Often much branched, $5 \mathrm{dm}$. long or less. Leaves oblong or linear-oblong, subcoriaceous, 3-8 $\mathrm{cm}$. long; flowers greenish-white; lateral sepals ovate, about $6 \mathrm{~mm}$. long; petals narrowly spatulate or oblong; blade of the lip about 3 $\mathrm{mm}$. long, suborbicular, with callosities near the base; capsule about $1.5 \mathrm{~cm}$. long.

On trees, New Providence:-Florida; Jamaica; Hispaniola; Guadeloupe to Trinidad; continental tropical America. 
12. AULİA Salisb. Trans. Iort. Soc. 1: 294. 1812.

Epiphytic or terrestrial orchids, with erect or ascending, leafy, often clustered stems, subcoriaceous sessile leares with sheathing bases, and rather large pedicelled flowers in terminal racemes or panicles, or solitary; pseudobulbs none. Sepals often elongated. Petals linear to spatulate. Lip rarious. Column alnate to the base of the lip. Pollinia 4, appendaged. [Greek, perching.] Eighty species or more, of tropical and subtropical America. Type species: Epidcndrum ciliare L.

\section{Auliza noctùrna (Jacq.) Small, Fl. Miami 56. 1913.}

Epidendrum nocturnum Jacq. Enum. 29. 1760.

Epiphytic or saxicolous; stems stiff, clustered, rather slender, usually erect, 3-11 dm. high. Leaves oblong to elliptic, oblong-lanceolate or linearoblong, $7-16 \mathrm{~cm}$. long, acute at the apex, partly clasping at the base, the sheaths cylindric, the lower ones bladeless; flowers solitary or two together, peduncled, the perduncle $2-10 \mathrm{~cm}$. long; bracts orate or lanceolate, $3-6 \mathrm{~mm}$. long; lateral sepals green, linear-attenuate, $3-6 \mathrm{~cm}$. long, 2-4 mm. wide; petals rellow, similar to the sepals, but a little narrower; lip white, 3-cleft, the 2 lateral lobes orate or ovate-oblong, $10-15 \mathrm{~mm}$. long, the middle lobe setaceous, 3-5 cm. long; capsule oblong, narrowed at both ends, $2.5-4 \mathrm{~cm}$. long.

On trees in coppices, Abaco, Andros and Nem Providence:-Florida; Cuba ; IIispaniola: Polto Rico; Tamaica; Trinidad; tropical South America. SLExDER AULIZA. Catesby, 2: $p l$. 68 .

\section{ENCY்CLIA Hook. Bot. Mag. pl. 2831. 1828.}

Epiphytic or rarely terrestrial orchids, with mostly terete, short or elongited pseudobulbs, flat, mostly stiff, elongated narrow leaves duplicate in the bud, and rather large, racemose or panicled bracted flowers on a long terminal seape. Lateral sepals broar or narrom, about as wide as the similar median one; petals spatulate to linear. Lip longitudinaly erested or appendaged, 3 -lobed, the middle lobe much wider than the lateral ones, often emarginate. Column usually adnate to the lip at its base and sometimes enclosed by it. Capsules ribbed. [Greek, wrapped around.] Perhaps 75 species, of tropical ani subtropical America. Trpe species: Encyclia viridiflora Hook. These orchids are locally called WILD IXdian.

Middle lobe of the lip acute or tipped.

1. E. fucata.

II idle lobe of the lip rounded or retuse.

Flowers panicled; middle lobe of the lip rounded, retuse or apiculate.

Column short, $6 \mathrm{~mm}$. long or less.

Sepals obtuse: lip sessile or nearly so.

Sepals acute: lip clawed.

Column long. $\tau-10 \mathrm{~mm}$. long.

Pseudobulbs ovoid, $4-T \mathrm{~cm}$. long.

Pseudobulbs oroid-oblong, up to $10 \mathrm{~cm}$. long.

Sepals and petals purplish or greenish; lenres $1.5-2.5 \mathrm{~cm}$. Wide.

Sepals and petals sellow; leaves $1 \mathrm{~cm}$. wide or less.

Flowers racemose or inflorescence with a few branches.

Leaves broadly linear; middle lobe of the lip cordate.

Leares norrowly linear; middle lobe of the lip orate, rounded.

2. E. bahamensis.

3. E. v"ufa.

4. E. tampensi.s.

5. E. diurna.

6. E. inaguensis.

Ђ. E. plicata.

S. E. acicularis. 


\section{Encyclia fucàta (Lindl.) Britton \& Millspaugh.}

Epidendrum fucatum Lindl. Bot. Reg. 24: Mise. 15. 1838.

Pseudobulbs slender, ovoid to oblong, 2-5 $\mathrm{cm}$. long. Leares 1 or 2, linear, 1-3 dm. long, 1-2.5 cm. wide; scape slenter, usually branched, $3-7 \mathrm{dm}$. long; pedicels slender or filiform, 1-2 cm. long; sepals yellow or brownish yellom, oblong or oblong-oblanceolate, obtuse, 1.5-2 cm. long; petals oblanceolate, similar to the sepals but a little shorter; lip yellow, 3-lobed, the lateral lobes oblong, obtuse, about $1 \mathrm{~cm}$. long, the middle lobe suborbicular, tipped; column wingless; capsule oblong, $1.5-2.5 \mathrm{~cm}$. long.

On trees in coppices and scrub-lands, Abaco, Great Bahama, and Andros:-

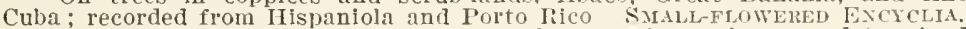

A fruiting specimen from Abaco, plohably of this species, was determined bs $R$. A. Rolfe as $E$. primulinum Batem, of Mexico, and recolded under that name in Piull. S. Y. Bot. Gard. $4: 116$

\section{Encyclia bahaménsis (Griseb.) Britton \& Millspaugh.}

Epidendrum bahamense Griseb. Fl. Br. W. I. 614. 1864.

Pseułobulbs oroid-oblong, $10 \mathrm{~cm}$. long or less. Leaves 1-3, coriaceous, linear, blunt or acutish, $1.5-5 \mathrm{dm}$. Iong; $1-3.5 \mathrm{~cm}$. wide; scape usually muchbranched, paniculately many-flowered, 5-9 dm. long; peảicels slender, $1-2 \mathrm{~cm}$. long; sepals oblong, 7 -nerved, obtuse or obtusish, 15-19 mm. long; petals obtuse, oblong or spatulate-oblong, narrowed toward the base, about as long as the sepals; lip sessile or nearly so, deeply 3-lobed, 16-19 $\mathrm{mm}$. long, its lateral lobes triangular-ovate, much shorter than the orbicular-obovate, rounded or retuse, nearly sessile, middle one; column narrowly winged to the base; capsule oblong, $1.5-3 \mathrm{~cm}$. long.

On trees, Great Bahama, Abaco. Andros, Eleuthera, Ship Channel Cay, Crooked Island, Little Inagua and Inagua. An Andros specimen was referred to Epidcndrum odoratissimum Lindl., by Mr's. Nortbrop. BaHAMA Excyclis.

3 Encyclia rùfa (Lindl.) Britton \& Millspaugh.

Epidendrum rufum Lindl. Bot. Reg. 31: Mise. 33. 1845.

Pseudobulbs "pyriform." Leares 2 or 3, ligulate, obtuse, 15-18 cm. long, about $15 \mathrm{~mm}$. wide; scape little branched, paniculately many-flowered, 2-3.5 $\mathrm{dm}$. long; pedicels slender, about $1 \mathrm{~cm}$. long; flowers yellowish-brown; sepals oblong or oblong-spatulate, acute, 19-25 mm. lang; petals oblong-cuneate, about as long as the sepals; lip short-claried, about $2 \mathrm{~cm}$. long, deeply 3 -lobed, the lateral lobes short "acute," much shorter than the obovate, rounded middle one; column narrowly winged to the base.

Bahamas, collected by Skinner (according to Cogniaux) and also attributed to the Bahamas by Grisebach:- Hispaniola. Not known to us from the arehipelago. Cogniaux's reference to this species as recorded br Britton from Abaco (Lrban, Symb. Ant. 6:494) is an error. The trpe specimen is said by Lindley to bave been sent from Rio Janeiro. Brazil. Our specimen from Hispaniola was collected at Baseux, Haiti, by George V. Nash (To. Som and determined as Epidendrum rufum Lindl., by R. A. Rolfe at Kew. lufoes Excyclis.

\section{Encyclia tampénsis (Lindl.) Small, Fl. Miami 56. 1913.}

Epidendrum tampense Lindl. Bot. Reg. 1847: under pl. 35.1847.

Pseudobulbs narrowly oroid, terete, $4-7 \mathrm{~cm}$. long. Leaves $1-3$, linear or linear-lanceolate, $0.5-2.5 \mathrm{dm}$. long, 8-18 mm. wide, acutish or obtuse, rather rigid; seape slender, branched, often $513 \mathrm{~m}$. long or longer; pedicels rather slender, 7-12 mm. long; lateral sepals yellowish-brown, narrowly oblanceolate, acutish, about $2 \mathrm{~cm}$. long: petals similar to the sepals but somewhat narrower; lip nearly sessile, deeply 3-lobed, white lined with purple, a little shorter than the petals, the middle lobe reniform-orbicnlar, short-clatred, rounded or apiculate, the lateral lobes oblong, obtuse; column about $8 \mathrm{~mm}$. long, 2-auricled at the top and narrowly winged.

On trees and shrubs, Abaco. New Providence:-Florida: Cuba. Recorded by Coker as Epidendrum fucatum Lindl, TAMPA Excrelia. 


\section{Encyclia diùrna (Jacq.) Britton \& Millspaugh.}

Limodorum diurmum Jaeq. Ie. Rar. 3: pl. 603. 1786-93.

Epidendrum gracile Lindl. Bot. Reg. 21: pl. 1765. 1835.

Epidendrum altissimum Batem.; Lind1. Bot. Reg. 24: Mise. 35. 1838.

Epidendrum virens Lindl. in Paxton, Fl. Gard. 1: 152. 1850-51.

Epidendrum diurnum Cogn, in Urban, Symb. Ant. 6: 497. 1910.

Plants usually clustered, sometimes forming large colonies. Pseudobulbs elongated, ovoid-oblong, $10 \mathrm{~cm}$. long or less. Leaves 2 or 3, linear, rigid, acute or obtuse, $2-5 \mathrm{dm}$. long, $1.5-2.5 \mathrm{~cm}$. wide; scape more or less branched, 5-10 dm. high; pedicels 1-1.5 cm. long; lateral sepals greenish or purplish, narrowly oblong, acute or obtusish, about $2 \mathrm{~cm}$. long; petals similar to the sepals, obtuse, narrowed below; lip a little shorter than the sepals, white lined with purple, deeply 3-lobed, the middle lobe suborbicular or rbomboid-orbicular, rounded or retuse and apieulate, the lateral lobes oblong, obtuse; column clariform, about $1 \mathrm{~cm}$. long; capsule oval, $1.5-3 \mathrm{~cm}$. long.

On the ground, in rocky soil, or sometimes on trees, throughout the archipelago, from Abaco and Great Bahama to Andros, Mariguana, Acklin's and Caicos Islands:Cnba: Mexico to Venezuela. Consists of many races. differing in size of the plant, of the leaves and of the flowers, and in color of the perianth. TaLL Excrchit.

\section{Encyclia inaguénsis Nash, sp. nor.}

Stems slender, up to $1 \mathrm{~m}$. tall, usually from a ereeping rootstock, the pseudobulbs up to $1 \mathrm{dm}$. long and $1.5 \mathrm{~cm}$. in diameter at the base, gradually narrowed from the base to the apex. Leaves linear, up to $5 \mathrm{dm}$. long and $1 \mathrm{~cm}$. wide, acute; inflorescence up to $6 \mathrm{dm}$. long, paniculate, the branches ascending, the lower ones longer and bearing 2-5 flowers. Flowers $2.5-3 \mathrm{~cm}$. in diameter, fragrant; sepals and petals yellow, irregularly striped with purple, the sepals oblong-elliptic, acute, the petals oblanceolate-spathulate, acute; lip about as long as the sepals, white, the lateral lobes and margin of the middle lobe yelow, all flushed and striped with purple; lateral lobes ascending, oblong, acutish, S-10 mm. long, the middle lobe almost orbicular, undulate on the margin, retuse, 8-9 mm. in diameter, almost sessile; column white, striped with purple, about $1 \mathrm{~cm}$. long.

On shrubs and trees. Type collected between Northwest Point and Sonthwest Point, Little Inagua, Oct. 21, 1.044 (Nash and Taylor, 1251). A barren specimen from East Caicos (Millspangh 9111) may be of this species. INAgua Excrclia.

\section{Encyclia plicàta (Lindl.) Britton \& Millspangh.}

Epidendrum plicatum Lindl. Bot. Reg. 33: under pl. 10. 1847.

Pseudobulbs ovoid, terete, $8 \mathrm{~cm}$. long or less. Leaves 2 or sometimes 3 , coriaceous, stiff, $1.5-2.5 \mathrm{dm}$. long, $1.5-2.5 \mathrm{~cm}$. wide; seape usually much longer than the leaves, simple or more or less branched; pedicels slender, $1-1.5 \mathrm{~cm}$. long; lateral sepals oblong to oblong-oblanceolate, purplish or greenish, 2.5-3 $\mathrm{cm}$. long; petals similar to the lateral sepals; lip about as long as the petals, yellowish or whitish striped with purple, deeply 3-lobed, the middle lobe suborbicular, cordate, emarginate and sometimes cuspidate, the lateral lobes oblonglanceolate, obtuse; column about $15 \mathrm{~mm}$. long; fruit oval, $2-3 \mathrm{~cm}$. long.

On shrubs and trees in thickets. Abaco, Andros, New Providence, Fortune Island, Cat Island, Crooked Island and Inagua:-Cuba. Recorded by Hitchcock as E. virens Lindl., and by Mrs. Northrop as $E$. phocniceum Lindl. Plicate Excrclia. Catesby, $2: p l$. 88 .

\section{Encyclia aciculàris (Batem.) Britton \& Millspaugh.}

Epidendrum aciculare Batem.; Lindl. Bot. Reg. 27: Mise. 46.1841.

Pseudobulbs ovoid, clustered, 2-3 cm. long; leaves 1 or 2, narrowly linear, 2-7 cm. long, about $5 \mathrm{~mm}$. wide. Scape usually simple, few-several-flowered, longer than the leaves; pedicels very slender, about $1 \mathrm{~cm}$. long; lateral sepals 
narrowly spatulate or oblanceolate, purple, acute, 2-3 cm. long, 2-4 mm. wide; petals similar to the sepals; lip white, lined with rose, a little shorter than the sepals, deeply 3-lobed, the middle lobe ovate, rounded, the lateral lobes oblong, obtuse; column about $1 \mathrm{~cm}$. long, 2-auricled at the summit.

Bahamas, collected by Skinner, according to Lindley :-Mexico. A plant found on Conocurpus in an open coastal coppice, at Great Bahama at Golden Grove (Britton and Millspangh 2725), was doubtfully referred to this species by Mr. R. A. Rolfe at Kew. It subsequently ploduced a few flowers at the New York Botanical Garden which do not wholly agree witb those of Mexican specimens. NArliow-LEAYED ExCYCLIA.

Epidendrum papilionàceum Tahl, is doubtfully recorded as Bahamian by Urban and by Cogniaux, the determination based on barren specimens collected by Eggers in New Providence.

\section{EPICLÀdIUM Small, Fl. Miami 56. 1913.}

An epiphytic orchid, with nearly orbicular flattened pseudobulbs, narrow, erect, flat leares, duplicate in the bud, the flowering scape subtended by an elongated spathe-like sheath. Flowers racemose or solitary, minntely bracted, showy, mottled. Lateral sepals about as wide as the median one; petals similar to the lateral sepals; lip subrhombic, shorter than the sepals; column without a foot, partly adnate to the lip. Capsules nodding, winged. [Greek, upon a branch.] A monotypic genus.

1. Epicladium Boothiànum (Lindl.) Small, Fl. Miami 56. 1913.

Epidendrum Boothianum Lindl. Bot. Reg. 24: Misc. 5. 1838.

Epidendrum erythronioides Small, Fl. SE. U. S. 328. 1903.

Pscndobulbs clustered or solitary on branches, about $2.5 \mathrm{~cm}$. long, less than $1 \mathrm{~cm}$. thick, subtended by ovate, subscarious scales 1-2 $\mathrm{cm}$. long. Leaves oblong-oblanceolate, obtuse or acutish, 6-12 cm. long; flowering stem simple, mostly longer than the leaves, 2-3 times as long as the sheath; flowers 1-several; pedicels $3-5 \mathrm{~mm}$. long; lateral sepals oblong to elliptic-oblanceolate, acute, yellow, mottled with brown, about $13 \mathrm{~mm}$. long; petals spatulate, yellow, brown-mottled, about as long as the sepals; lip yellowish, about $7 \mathrm{~mm}$. long; capsule 2-3 cm. long, oblong, 3-winged.

On trees, Andros:-Florida; Cuba. Epiclabium. Catesby, $2: p l . \%$

\section{ANACHEILIUMI Hoffmg. Linnaea 16: Litt. '229. 1842.}

Epiphytic orchids, with elongated, somewhat flattened psudobulbs, long flat leaves duplicate in the bud, and nodding racemose bracted flowers on a simple terminal scape. Sepals all nearly alıke, elongated, narrow, acuminate. Petals similar to the sepals, but somewhat shorter; lip concave, entire, much shorter than the sepals. Column partly adnate to the lip, footless. Capsules winged, drooping. [Greek, upturned lip.] The genus is probably monotypie.

1. Anacheilium cochleàtum (L.) Hoffmg. Linnaea, 16: Litt. 229. 1812.

Epidendrum cochleatum L. Sp. Pl. ed. 2, 1351. 1763.

Pseudobulbs lanceolate to ovate, compressed, $8-12 \mathrm{~cm}$. long, clustered. Leaves 2 or 3 , linear or linear-oblong, acute, 1-4 dm. long; scape simple, 1.5-6 $\mathrm{dm}$. long, bearing several Iirear-lanceolate scarious scales 1-3 $\mathrm{cm}$. long and subtended by a larger, scarious, spathe-like scale 5-8 cm. long; flowers fewseveral, racemose; bracts small; lateral sepals linear-lanceolate, greenish yellow, 
2-3 cm. long, similar to the petals; lip purple or variegated, about $2 \mathrm{~cm}$. long, abruptly acute, entire; capsule 2-3 cm. long.

On trees in roppices, Abaco. Andros and New Providence:-Florlda; Cuba ; Hispaniola; Porto Rico; Jamaica: Mexico to Colombia and Fenezuela. Ilecorded from St. Croix. Catesby, 2: pl. 88 . SHeLl Orcinid.

\section{NIDĖMA Britton \& Millspaugh, gen. nov.}

Epiphytic orchids, with flattened l-leaved pseudobulbs subtended by narrow scales, the leaves narrowly linear, the slender scapes bearing several, rather small, racemose flowers, or but one. Lateral sepals lanceolate or linear-lanceolate, 3-5-nerved, acute or acuminate; petals linear to lanceolate, somewhat shorter than the sepals; lip linear or ligulate, somewhat fleshy, entire or undulate; column free from the lip or but slightly adnate at the base, footless. Capsule oblong. [Anagram of Dinema, a related genus.] Two species or more, natives of the West Indies, the following typical.

\section{Nidema Ottònis (Rchb. f.) Britton \& Millspaugh.}

\section{Epidendrum Ottonis Rehb. f.; Griseb. Fl. Br. W. I. 613. 1864.}

Pseudobulbs narrowly oblong, clustered, compressed, 2-3.5 cm. long, 1leaved. Leaf thin in texture, linear, 6-13 $\mathrm{cm}$. long, 5-S mm. wide, obtuse or acutish; scape very slender, little, if any, longer than the leaf, bearing several linear scales and 3-6 bracted whitish flowers; ovary shorter than the linear bract; sepals lanceolate, acuminate, about $8 \mathrm{~mm}$. long; petals linear, acute, about $6 \mathrm{~mm}$. long; lip linear, acute, undivided, about $5 \mathrm{~mm}$. long; column free, claviform, $4 \mathrm{~mm}$. long, 5 -toothed; capsule oblong, about $1 \mathrm{~cm}$. long.

On tree, Blue Hills, New Providence. collected by Eggers (according to Cogniaux). not found by us in the Bahamas:--Jamaica; Cuba; Hispaniola; Porto Rico; Trinidad; Venezuela.

17. TETRAMìCRA Lindl. Gen. \& Sp. Orch. 119. 1831.

Mostly terrestrial orchids, without pseudobulbs, the roots thick fibers, the few subterete fleshy leaves basal, the pink to purple flowers in a simple raceme at the end of a slender sheathed scape. Bracts very small. Sepals about equal, distinct, spreading. Petals similar to the sepals. Lip 3-lobed, spreading, the lobes entire or nearly so. Column 2-winged. Anther convex, imperfectly 4-celled; pollinia 4, wasy, appendaged. Capsule oblong, beakless. [Greek, small four.] Abont 8 species, of tropical America. Type species: Cymbidium rigidum Willd.

\section{Tetramicra Urbaniàna Cogn. in Urban, Symb. Ant. 6: 551. 1910.}

Roots few, thick, canescent. Leares 2 , lanceolate or oblong-ovate, $3 \mathrm{~cm}$. long or less, acute or acumirate, fleshy; scape very slender, $2-4.5 \mathrm{dm}$. high, its small membranous sheaths appressed; raceme 2-5-flowered, the flowers distant; bracts ovate, membranous, acute, $1-3 \mathrm{~mm}$. long; pedicels $2-3 \mathrm{~mm}$. long; ovary slender, 5-7 $\mathrm{mm}$. long; sepals ovate or oblong, 5-nerved, about $4 \mathrm{~mm}$. long; petals linear, about as long as the sepals; lip 4-6 mm. long, deeply 3 lobed, the lobes rounded; column narrowly 2 -winged, $3 \mathrm{~mm}$. long.

On the ground, New Providence near Nassau:-Endemic. Bahama Terramicra. 


\section{LAELIóPSIS Lindl. in Paxton, Fl. Gard. 3: 155.1853.}

Epiphytic orchids, with small oblong, 1-leaved or 2-leaved pseudobulbs, the leaves linear or oblong, coriaceous, the few or several large, rose or purple flowers in a terminal, long-peduncled raceme. Sepals equal, distinct, erect or somewhat spreading. Petals similar to the sepals, but a little broader. Lip broad, spreading, sometimes slightly 3-lobed, sessile at the base of the column. Anther terminal, 2-eelled; pollinia 8. Capsule oblong to obovoid. [Greek, similar to Laelia.] Three or four species, inhabiting Cuba, Jamaica, Hispaniola and the Bahamas, the following typical.

1. Laeliopsis domingénsis Lindl. in Paxton, Fl. Gard. 3: 155, pl. 105. 1853.

Cattleya domingensis Lindl. Gen. \& Sp. Orch. 118. 1831.

Broughtonia lilacina Henfr. in Moore \& Ayres, Gard. Mag. Bot. 3: 201. 1851.

Broughtonia domingensis Rolfe, Gard. Chron. III. 5: 491.1889.

Cattleyopsis Northropiorum Cogn. in Urban, Symb. Ant. 6: 545. 1910.

Psendobulbs narrow, $3-7 \mathrm{~cm}$. long, 5-9 mm. in diameter. Leaves linearoblong, 7-14 cm. long, $2 \mathrm{~cm}$. wide or less, obtuse, the margin more or less crose-denticulate, the midvein prominent; peduncle slender, terete, erect, 4- 7 dm. long, with several distant scarions appressed sheaths; flowers 4-15; pedicels slender, $1.5-2 \mathrm{~cm}$. long; bracts ovate, acute, about $2 \mathrm{~mm}$. long; sepals lanceolate, acute, $5-7$-nerved, $2.5-3 \mathrm{~cm}$. long, $5-7 \mathrm{~mm}$. wide; petals $7-10 \mathrm{~mm}$. wide; lip broadly obovate, $3-4 \mathrm{~cm}$. long, emarginate, undulate; eapsule 2-3 cm. long.

On trees and shrubs in coastal coppices and pine-lands, Abaco and Great Bahama, Andros, South Bimini and Eleuthera:-Cuba; Hispaniola; Jamaica.

\section{LIMODORUM L. Sp. Pl. 950. 1753.}

Scapose terrestrial orchids, with round solid bulbs which arise from the bulb of the previous year, a leaf appearing the first season, succeded in the following year by the scape. Flowers several in a loose terminal spike or raceme. Sepals and petals nearly alike, separate, spreading. Column elongated, 2-winged above. Anther terminal, opercnlate, sessile; pollinia solitary, 1 in each sac, loosely granular. Lip spreading, raised on a narrow stalk, dilated at the apex, bearded on the upper side with long club-shaped hairs. [Greek, a meadow-gift.] Five speeies of the eastern United States, the Bahamas and Cuba. Type species: Limodorum tuberosum L.

1. Limodorum Símpsoni Small, Fl. SE. U. S. 322. 1903.

Calopogon pulchellus Simpsoni Ames, Contr. Ames Bot. Lab. 1: 18. Hyponym. 1904.

Scape slender, erect, $3-\tau \mathrm{dm}$. tall, bearing 1 or 2 short basal scales and usually but 1, linear, acute leaf $1-3 \mathrm{dm}$. long, borne near the base. Spike loosely few-flowered; bracts lanceolate, acute, usually much shorter than the ovary; flowers purple, rarely white; lateral sepals suborbicular, acute, about $18 \mathrm{~mm}$. long; petals ovate-oblong, a little longer than the sepals; middle lobe of the lip 8-10 mm. wide, emarginate; capsule $1.5-2 \mathrm{~cm}$. long.

Savannas and pine-lands, Andros:-Florida; Cuba. Determined by Mrs. Northrop as $L$. tubcrosum $\mathrm{L}_{\text {. }}$, and refered to that species by Cogniaux. Souturrs GRASS-PINK. 
20. BLÈtIA R. \& P. Syst. 229. 1798.

Terrestrial orchids, with globose or ovoid corms, narrow, elongated linear or lanceolate leaves, the slender sheathed seape arising from the side of the corm, the large purple or pink flowers in simple or branched racemes. Sepals nearly alike, orate to oblong. Petals similar to the sepals. Lip broad, 5-7crested, 3-lobed. Column elongated. Anther 2-celled; pollinia obovate, waxy. Capsules oblong, erect. [Commemorates L. Blet, a Spanish apothecary.] About 45 species, mostly of tropical America. Type species: Bletia catenulata R. \& P.

1. Bletia purpùrea (Lam.) DC. Mem. Soe. Phys. Hist. Nat. Geneve 9: 100. 1841.

Limodorum purpureum Lam. Encycl. 3: 515. 1789.

Limodorum altum Jacq. Je. Rar. 3: 17, pl. 602. 1786-93. Not. L. 1767. Bletia verecunda R. Br. in Ait. Hort. Kew ed. 2, 5: 206. 1813.

Corm subglobose, 2-3 cm in diameter; scape slender, 3-11 $\mathrm{dm}$. high. Leaves $1.5-5 \mathrm{dm}$. long, 1-2 $\mathrm{cm}$. wide at about the middle, tapering to both ends, narrowed below into a sheath; sheaths of the scape 1-1.5 $\mathrm{cm}$. long, ovate, appressed; bracts ovate, $4-5 \mathrm{~mm}$. long, acute or acuminate; sepals $11-18 \mathrm{~mm}$. long, acute, the median one ovate-lanceolate, the lateral ones ovate to oblong; petals oval, a little shorter than the sepals; lip 7-crested, nearly as long as the petals, its middle lobe notched, crenate crisped; capsule cylindric, $2.5-4 \mathrm{~cm}$. long.

Pine-lands and scrub-lands, Abaco, Great Bahama, Andros, New Providence, Eleuthera :-Florida: Cuba: Hispaniola; Jamaica. Recorded by Hitchcock as Blctia alta (L.) Hitchc. PURPle Bletia.

21. GOVÈNIA Lindl. in Lodd. Bot. Cab. pl. 1709. 1831.

Terrestrial orchids with rootstocks, the leaves few, plaited, the stem erect, the rather small flowers in a simple, terminal, spike-like raceme. Sepals connivent, nearly equal, the median one erect, incurved. Petals similar to the sepals. Lip concare, simple. Column winged, incurved, its foot short. Anther incumbent, convex, 1-celled; pollinia 4, raxy, not appendaged. Capsule oblong. [Commemorates James Robert Gowen, an English botanist, who died in 1862.] About 17 species, natives of tropical America. Type species: Govenia superba Lindl.

1. Govenia utriculàta (Sw.) Lindl. Bot. Reg. 25: Misc. 47. 1839.

Cymbidium utriculatum Sw. Nov. Act. Ups. 6: 75. 1799.

Plant 3-7 dm. high, the stem rather stout, bearing large basal inflated bladeless sheaths and 1 or 2 broad leaves. Basal sheaths usually 2 , mem. branous, 4-20 cm. long; leaves usually 2, elliptic, 1-2.7 dm. long, 5-9 cm. wide, acute or acuminate at the apex, narrowed at the base, finely many-nerved; cauline sheaths 1 or 2 , obtuse, about $5 \mathrm{~cm}$. long; raceme few-several-flowered, $1.5 \mathrm{dm}$. long or less; pedicels $3-5 \mathrm{~mm}$. long; bracts narrowly lanceolate, 1-2 $\mathrm{cm}$. long; flowers whitish; sepals about $1.5 \mathrm{~cm}$. long, the lateral lanceolate, the median oblong; petals about as long as the sepals; lip ovate, acute, about $9 \mathrm{~mm}$. long; capsules deflexed, $2.5-3 \mathrm{~cm}$. long.

Coppices and pine-barrens, Abaco, Andros:-Cuba; Hispaniola; Porto Rico; Jamaica; Mexico to South America. Swollen Govexia. 
22. ONCÍdIUM Sw. Tet. Akad. Stock. Handl. 21: 239. 1800.

Mostly epiphytic orchids, with or without pseudobulbs, the leaves flat or 3-edged, elongated or short, the stems short, the peduncles or scapes lateral, the flowers in loose racemes or panicles. Sepals nearly equal, spreading or reflexed, the lateral ones connate in some species. Petals similar to the median sepal. Lip clawed or sessile, 3-lobed, erested or tubercled, the middle lobe broad, notehed or 2-cleft. Column short, winged, without a foot. Anther inclined, convex or semiglobose, 1-celled or imperfectly 2-celled; pollinia 2, waxy, not appendaged. Capsule ovoid to fusiform, beaked. [Greek, referring to the tubercled lip.] More than 400 species, natives of tropical and subtropical America. Type species: Oncidium carthaginense (Jacq.) Sw.

Terrestrial; leaves $3-5 \mathrm{dm}$. long; scape $1 \mathrm{~m}$. or more high.

1. O. sphacelatum. Epiphytic; leaves $1-1.5 \mathrm{dm}$. long; scape $3-5 \mathrm{dm}$. long. Leaves elongated-linear.

Leaves oblong-falcate.

2. O. bahamense. 3. O. lucayanum.

1. Oncidium sphacelàtum Lindl. Sert. Orch. under $p l .48 .1841$.

Pseudobulbs nearly cylindric, 8-12 $\mathrm{cm}$. long, 1.5-2 cm. thick. Leaves linear, elongated, 3-10 dm. long, 1-2 cm. wide, flat, finely many-nerved; seape slender, $2 \mathrm{~m}$. long or less, the flowers loosely panicled; bracts linear-lanceolate, s-15 mm. long; pedicels slender, 1-2.5 cm. long; sepals lanceolate, about $16 \mathrm{~mm}$. long, brownish, barred with yellow; petals similar to the sepals, but somemhat broader and shorter; lip bright yellow, about as long as the petals, its middle lobe 11-14 mm. wide; capsule oblong, about $2 \mathrm{~cm}$. long.

On the ground in pine-lands and coppices, Abaco, Great Babama, Andros, New Providence, Watling's Island, Crooked Island:-Florida; Cuba; Central America.

2. Oncidium bahaménse Nash, sp. nov.

A stoloniferous plant, creeping along branches and tree trunks, with equitant leaves which are long, eurved and narrow, and a raceme of yellow flowers much exserted beyond the leaves. Leaves up to 8 , crowded at the base, the lower 1 or 2 short, triangular and scale-like, the larger ones up to $2 \mathrm{dm}$. long, 2-3 mm. wide, laterally compressed, acutely angled on the back, channeled on the upper side, smooth and glabrous, linear, acute; scape up to $4.5 \mathrm{dm}$. long, smooth and glabrous, with scattered ovate scarious acute seales $5-7 \mathrm{~mm}$. long; raceme 5-7 cm. long, of 10-15 spreading flowers on slender pedicels up to $1 \mathrm{~cm}$. long, the bracts ovate, acuminate, about $3 \mathrm{~mm}$. long; dorsal sepal obovate-spatulate, concave, much narrowed at the base, emarginate and apiculate at the apex, 1-nerved, 5-6 $\mathrm{mm}$. long, about $3 \mathrm{~mm}$. wide at the broadest part when spread out; lateral sepals united to the apex into an obovate-cuneate concave body about $6 \mathrm{~mm}$. long and $4 \mathrm{~mm}$. wide when spread out, rounded-truncate at the apex, 2-nerved, running out into short apiculations: petals obovate, 5 -nerved, undulate on the margins, apiculate at the apex, $7 \mathrm{~mm}$. long and $5 \mathrm{~mm}$. wide; lip sessile with a broad rounded base, $9-10 \mathrm{~mm}$. long and 10-12 mm. wide, puberulent on the upper surface, of equal width at base and apex, 3-lobed, the lateral lobes spreading and somewhat reflexed, broad, rounded at the apex, irregularly crenulate on the margins, the middle lobe much broader than long, reniform, irregularly lobulate on the margins, strongly emarginate at the apex, apiculate, the crest with two processes, one of them with long lohes, the other smaller and with 3 lobes; column stout, about $2.5 \mathrm{~mm}$. long, the wings puberulent, ovate, rounded at the base, obtuse at the apex, and extending considerably beyond the summit of the column, 3.5 $\mathrm{mm}$. long and about $2 \mathrm{~mm}$. wide.

Trpe collected by L. J. K. Brace, at Eight Mile Rocks, Great Bahama, April 16Iay 8,1905 , no. 8689 , in the herbarium of the New York Botanleal Garden. A 
specimen in the herbarium of Columbia Iniversity, collected by John I. and Allce I2. Northrop, on Andros Island, in May, 1890, no. 5\%, doubtfully determined by Mrs. Northrop as $O$. sylvestre Lindl., is also this species; it was also referred to $O$. sylerstre by Cogniaux. The plant recorded by Eaton and Setchell, and also by Dolley, from Abaco, collected by Herrick, is apparently this species.

This orchid is related to oncidium syleestre lindl., but the longer leaves, smaller flowers, and the differences in the lip at once distinguish it. In U. sylvstre the leares are not orer $4 \mathrm{~cm}$. long, the flowers are fully twice the size, and the lip has the lateral lobes very small; in 0 . bahamense the lip is as broad across the lateral lobes as it is at the apex.

\section{Oncidium lucayànum Nash, sp. nov.}

Plant with short compressed leaves and a few-flowered raceme. Leaves 4-6, crowded at the base, curvel, spreading, acute, compressed, acutely angled on the back, channeled on the upper surface, wrinkled on the upper margins, smooth and glabrous, $1-1.5 \mathrm{~cm}$. long and about $3 \mathrm{~mm}$. wide; scape smooth and glabrous, with a few scattered ovate acute appressed scarious scales $3-4 \mathrm{~mm}$. long; flowers on pedicels $5-\bar{t} \mathrm{~mm}$. long; dorsal sepal oblanceolate-cuneate, aeutish at the apex, narrowed toward the base, $7 \mathrm{~mm}$. long and 2-2.5 $\mathrm{mm}$. wide, the margins repand; lateral sepals united into a concave 2-nerved oblanceolate-cuneate body which is 2 -toothed at the apex, the teeth rounded and about $0.75 \mathrm{~mm}$. long, about $8 \mathrm{~mm}$. long and $2.5-3 \mathrm{~mm}$. wide; petals lyrate-ovate, acute at the apex, abruptly narrowed below the middle into a claw about $2 \mathrm{~mm}$. long and $1.5 \mathrm{~mm}$. wide, $8 \mathrm{~mm}$. long and $3-3.5 \mathrm{~mm}$. wide, undulate on the margin; lip adnate to the column up to its wings by a bi-lamellate process, $8 \mathrm{~mm}$. long and $7 \mathrm{~mm}$. wide, sessile by a rounded or truncate base, 3-lobed, the lateral lobes $1.5-2 \mathrm{~mm}$. long and $1.5 \mathrm{~mm}$. wide, somewhat reflexed, rounded or a little acute at the base, merging into a hemispherical somewhat toothed isthmus which joins them to the middle lobe, the middle lobe flabellate, on a triangular claw, round-truncate and apiculate at the apex, irregularly lobulate on the margins, the crest of 3 lobes, the lateral divaricate, separated by a rounded protuberance, the middle lobe the largest and again 3 -lobed; column $3-3.5 \mathrm{~mm}$. long, the wings semiovate, rounder at the base, acute at the apex, irregularly lobed and extending somewhat beyond the summit of the column.

Type, in the herbarium of Columbia University, collected by John I. and Alice R. Northrop, at Fresh Creek, Andros Island, June 10, 1890, no. 6:\%. Resembles $O$. variegatum considerably. but the sepals are nearly as long as the lip, and the middle lobe of the lip flabellate while in 0 . variegatum the sepals do not exceed one half the length of the lip which has the middle lobe reniform and sessile. Refer'ed by Cogniaux to O. Leiboldi Rehb. f.

Oncidium variegatum $\mathrm{Sw}$. is recorded by Cogniaux as collected on Andros (Northrop 587) but our specimens of this number appear to be 0 . lucayanum. We have fruiting specimens of apparently the same plant from Abaco and Great Bahama.

A small Oncidium, collected on Cat Island, died before flowering.

\section{Sub-class 2. DICOTYLEDONES.}

Embryo of the seed with two cotyledons (in a few genera one only), the first leaves of the germinating plantlet opposite. Stem exogenous, of pith, wood and bark (endogenous in structure in Nymphaeaceae), the wood in one or more layers surrounding the pith, traversed by medullary rays and covered by the bark. Leaves usually pinnately or palmately veined, the veinlets forming a network. Parts of the flower rarely in 3's or 6's.

Dicotyledonous plants are first definitely known in Cretaceous time. They constitute between two-thirds and three-fourths of the living angiospermous flora. 


\section{Series I. Choripétalae.}

Petals separate and distinct from each other, or wanting.

The series is also known as Archichlamideae, and comprises most of the families formerly grouped under Apetalae (without petals) and Polypetalae (with separate petals). Exceptions to the typical feature of separate petals are found in the Fabaceae, in which the two lower petals are more or less united; in the Fumariaceae, where the two inner petals or all four of them are sometimes coherent; in some Crassulaceae; the Polygalaceae, in which the three petals are united with each other, and with the stamens; Oxalidaceae and Ilicaceae, whose five petals are sometimes joined at the base.

Petals none (except in family Poltulacaceae and in most Cillyophrllaceae, which are herbs with the leaves nearly always opposite, the seeds with endosperm).

Calyx none (except in some of the SAxtaldLEs, and sometimes in Casuarinaceae). Loosely jointed trees, the leares reduced to Ferticillate scales.

Plants not loosely jointed; leares normal.

Herbs with small perfect flowers in spikes.

Trees or shiubs; staminate flowers, and some. times also the pistillate, in aments.

Leaves simple.

Leaves odd-pinnate or trifoliolate; fruit a nut enclosed in a husk. or diupe-like.
Order 1. Castarisales.
Order 2. PIPERALES.
Order 3. Mrifiles.
Order 4. Juglaxidats.
Order 5. URTicales.
Order 6. SAx゙TALALES.
Order 7 . Aristolochiales.
Order S. Polygoxales.
Order 9. CHExopodiates.

Calsx present.

Flowers monoecious, dioecious or polygamous, orary superior, 1-celled.

Flowers dioecious or perfect: orary inferior, at least in part.

Ovary 1-celled.

Orary several-celled (usualls 6-celled); flowers perfect.

Flowers mostly perfect : orary superior.

Embryo straight or nearly so: fruit an achene.

Embryo coiled, curred or annular; fruit not an achene.

Petals present (wanting in Ceratoph ${ }^{\prime}$ llaceae. aquatic herbs with whorled dissected leares; in many lanunculaceae; in Lauraceae, alternate-leared aromatic trees and shrubs: in Zanthoxylum, pinnate-leared trees of the liutaceae: in many Euphorbiaceae: in some species of Luduigia in Onagraceae; in Proscrpinaca of the Haloragidaceae).

A. Oxary supcrior, free from the calyx (partly or wholly inferior in Loasaceae).

Carpels solitary, or sereral and distinct (united in some Nymphaeaceae); sta. mens mostly hypogynous and more numerous than the sepals; sepals mostly distinct.

Carpels 2 or more, united into a compound orary; stamens hrpogrnous; sepals mostly distinct.

Carpels solitars, or several and distinct, or sometimes united; stamens mostly perigynous or epigrnous; sepals mainly united or confluent with the concare receptacle (hrpanthium).

Carpels united into a compound orars; sepals mostly distinct.

Stamens few, rarely more than twice as many as the petals.

Stamens as many as the sepals or fewer and opposite them, or more numerous.

Orules pendulous, the raphe toward the axis of the ovary.

Orules pendulous, the raphe away from the axis of the ovary, or erect, or ascending.

Stamens as many as the sepals and alternate with them, opposite the petals when these are present; ovules erect.

Stamens usually very numerous (except in Order 10. Rarales.

Order 11. PAPArerales.

Order 12. RosAles.

Order 13. Gerixiales.

Order 14. SAPINDiles.

Order 15. Rulamales. Violaceae and Passifloraceae); disc in. conspicuous, or none. 
Sepals ralrate; placentae united in the axis. Sepals or calyx-segments imbricated or convolute: placentae mainly parietal, sometimes united in the axis.

Sepals separate.

Sepals united.

Order 16. Malvales.

Order 17. IIYPERICALES.

Order 18. I'ASSIFLORALES.

B. Orary inferior, adnate to the calyx, wholly or in part (except in Lythraceae where it is usually merely enclosed by it).

Herbs with barbed or stinging hairs.

Order 19. LoAsALES.

Plants without barbed or stinging hairs.

Fleshy sping plants, with jointed stems, the

leares mostly rery small or none; calyx-seg-

ments and petals several or numerous.

Herbs, shrubs or trees, not fleshy ol" spiny ; calyx-segments rarely more than 5 .

Orules several or numerous in each cavity of the ovary (except in Haloragidaceae, aquatic herbs).

Orule 1 in each cavity of the ovary.

Order 20. Opuntiales.

Order 21. Myrtales.

Order 22. AMIIILES.

\section{Order 1. CASUARINÀLES.}

Trees $01^{*}$ shrubs, with rery slender, jointed, angled branches and twigs, the leares reduced to minute verticillate scales at the nodes, the scales sometimes connate, the small imperfect bracted flowers in terminal spikes or cone-like heads. Staminate flowers with 1 or 2 sepals and 1 stamen with a large anther. Pistillate flowers without a perianth; ovary small, 1-celled; style short, with 2 slender branches; orules 1 or 2 , ascending. Fruit a cone-like mass of accrescent bracts, subtending winged achenes. Seed with a membranous testa and no endosperm, the embryo straight.

\section{Family 1. CASUARINĀCEAE Lindl.}

\section{BeEF-WOOD FAMILY.}

Only one genus, with about 25 species, most abundant in Australasia.

1. CASUARINA Forst. Char. Gen. Pl. 104. 1776.

Characters of the order. [From the zoological same of the Cassorary.] The following species is typical.

\section{Casuarina equisetifòlia Forst. Char. Gen. Pl. 104. 1776.}

A tree, reaching in the American tropies a maximum height of about $20 \mathrm{~m}$. with a trunk up to $1 \mathrm{~m}$. in diameter, much larger in Australia, with long and slender branches, the upper ones erect or nearly so, the dark brown bark furrowed. Twigs angular, very slender, drooping; leaves 6-8 in each whorl, only 1-3 mm. long, acute, appressed, ciliate, decurrent on the twigs; staminate flowers in slender terminal cylindric spikes 1-4 $\mathrm{cm}$. long, the bracts imbricated, the anthers exserted; pistillate flowers in lateral dense subglobose heads which become about $2 \mathrm{~cm}$. in diameter in fruit.

Sandr sea shores, spontaneous after cultiration, Abaco, Andros, New Proridence, Eleuthera. Crooked Island, the Caicos, Grand Turk, and Inagua :-A native of Australia more or less naturalized in Florida, the Viest Indies and Yucatan. Erroneousiy called Spaxish CedAR. BeEF-TOOD. 


\title{
Order 2. PIPERÀLES.
}

I)icotyledonons plants, with neither petals nor sepals, the spicate flowers bracteolate.

\section{Family 1. PIPERÀCEAE H.B.K.}

\author{
Pepper Fajilly.
}

Herbs, shrubs or rarely small trees, with alternate, opposite or verticil. late leaves, almost alwars entire-margined, the mostly minute bracteolate flowers in spikes or rarely in racemes. Perianth none. Stamens mostly 2-6, hypogynous; anthers erect. terminal, their sacs distinct or confluent, longitudinally dehiscent. Ovary sessile or rarely stipitate, 1-celled, 1oruled; style 1; ovule erect, orthotropous. Frnit baccate, indehiscent. Seed solitary, the testa membranons, the endosperm copious, the embryo minute. About 6 genera with orer 1000 species, mostly of tropical distribution.

1. PEPERÒMIA R. \& P. Prodr. 8. 1794.

Herbs, mostly succulent, with alternate, opposite or verticillate leaves, the fiowers in slender, solitary or clustered spikes, subtended by circular or elliptic bracts. Stamens 2; filaments short. Ovary mostly sessile, sometimes stalked, sometimes beaked; stigma terminal or lateral. Berry very small, globose, oblong or ellipsoid, viscid. [Greek, pepper.] Six hundred species or more, mostly of tropical America. Type species: Peperomia secunda R. \& P.

\section{Peperomia spathulifòlia Small, sp. nor.}

Plants mainly terrestrial, strongly aromatic. Stems and branches decumbent, partly creeping; leaf-blades cuneate to spatulate, 6-11 $\mathrm{cm}$. long, rounded, truncate or notched at the apex, glabrous, bright-green, obseurely reined, except sometimes in drying, acuminate at the base or attenuate into long or rather loug petioles; inflorescence with a slender often elongate stalk, with one to five slender recurved-nodding branches ; spikes mostly 1-2 dm. long, yellowish, the rachis less than $2.5 \mathrm{~mm}$. thick, slender-tipped; bracts orbicular, about $0.3 \mathrm{~mm}$. in diameter; anthers about $0.25 \mathrm{~mm}$. in diameter; berries not densely crowded, broadly ellipsoid or ovoid, nearly $1 \mathrm{~mm}$. long, rounded at the base, the beak much shorter than the body, strongly curved or hooked.

Deep woods, Abaco, in coppice at Eight Mile Bay:-Florida; Haiti. SpatuLATE-LEALED WiLd PEPPER.

\section{Order 3. MYRICÀLES.}

Shrubs or trees, with simple leares and small monoecious or dioecious flowers in aments. Perianth none. Orary 1-celled; style short; stigmas 2. Ovule erect, orthotropous. Endosperm none. Only one family.

\section{Famil̦ 1. MYRICÀCEAE Dumort.}

\section{BAYBERRT FAMILY.}

Leaves alternate, mostly coriacenus and aromatic. Flowers soiitary in the axils of the bracts. Staminate flower with 2-16 (usually 4-S) stamens 
inserted on the receptacle; filaments short; anthers orate, 2-celled, the sacs longitudinally dehiscent. Orary subtended by $2-8$ bractlets; stigmas linear. Fruit a small drupe or mut, the exocarp often waxy. Seed ereet. Cotyledons plano-convex. Radicle short. Two genera and about 36 species.

\section{MYRİCA L. Sp. Pl. 1024. 1753.}

Leaves entire, dentate or lobed, mostly resinous-dotted. Staminate aments cklong or narrowly cylindric, expanding before or with the leaves. Stamens 4-S. Pistillate aments ovoid or subglobose; orary subtended by 2-4, mostly short, bractlets. Drupe globose or oroid, its exocarp waxy. [Ancient Greek name of the Tamarisk.] About 35 species, widely distributed. Type species: Myrica Gale L.

\section{Myrica cerífera L. Sp. Pl. 1024. 1753.}

Cerothamnus ceriferus Small, Fl. Miami 61. 1912.

A slender dioecious shrub, or a tree, sometimes $12 \mathrm{~m}$. high, with a trunk $5 \mathrm{dm}$. in diameter, the bark gray, nearly sincoth. Leaves narrow, oblong or oblanceolate, mostly acute, entire or sparingly dentate, narrowed at the base, fragrant, short-petioled, dark green above, paler and sometimes pubescent beneath, golden-resinous, 2-8 cm. long, unfolding with or before the aments; staminate aments cylindric; pistillate aments short, oblong; ripe drupes globose, bluish white, waxy, tipped with the base of the style, long-persistent.

Sandy thickets, coppices and pine-lands, Abaco, Andros. Great Bahama. New Proridence, Eleuthera, Cat Island, and Acklin's Island:-New Jersey southward along the coast to the rolorida Keys and to Texas: Bermuda: cuba; Ifispaniola;

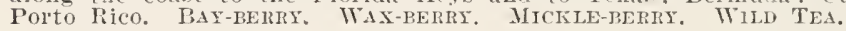

\section{Ordè 4. JUGLANDÀLES.}

Trees with alternate pinnately compound or trifoliolate leares, and monnecious or dioecious bracteolate flowers, the staminate in long drooping aments, the pistillate solitary or sereral together. Staminate flowers consisting of 3-numerous stamens with or without an irregularly lobed perianth adnate to the bractlet, very rarely with a rudimentary ovary. Anthers erect. 2-celled, the sacs longitudinally dehiscent; filaments short. Pistillate flowers with a 3-5-lobed calyx or with both ealyx and petals, and a 1-celled or 2-4-celled ovary. Ovules solitary or 2, erect, orthotropous; styles 1 or 2. Fruit a drupe with indehiscent or dehiscent. fibrous, fleshy or woody exocarp, enclosing the bony endocarp or nut which is 2-4-celled. Seed large: 2-4-lobed. Endosperm none. Cotyledons corrugated, Two families, that of the Walnuts (Juglandaceae) and the following.

\section{Family 1. PICRODENDRÀCEAE Small.}

Rongh-barked trees, or shrubs. with bitter wood, alternate, slenderpetioled. 3-foliolate leares, and dioecions flowers, the pistillate ones solitary, axillary, pednneled, the staminate in long drooping aments. Staminate flowers each subtended by 3 hracts, the middle bract the larger; perianth none: stamens many, clustered: filaments glabrous, shorter than the anthers 
or as long: anther's oval, sparingly pubescent. Calyx of the pistillate flowers small, 4-parted, the lobes or sepals narrow, decidnous; petals none; orary sessile, 2-celled; ovules 2 in each cavity; style columnar; stigmas subulate, longer than the style. Drupe globose or oval, stalked. Seed solitary. Only the following gemus.

1. PICROdÉNDRON Planch. in Hook. Lond. Jour. Bot. 5: 579. 1846.

Characters of the family. [Greek, bitter tree.] Three species, natives of the Bahamas, Janaica, Cuba and Hispaniola. Type species: Juglans baccata L. (Picrodendron arboreum Macfad.).

1. Picrodendron macrocárpum (A. Rich.) Britton, Bull. N. Y. Bot. Gard. 4: 139. 1906.

Schmidelia macrocarpa A. Rich. in Sagra, Hist. Cub. 10: 116. pl. 30. 1845.

Picrodendron backatum bahamense Krug \& Urban, Bot. Jahrb. 15: 308. 1893.

A tree, up to $20 \mathrm{~m}$. high, or sometimes a shrub. Petioles minutely pubescent, 2-5 cm. long; leaflets $1.5-9 \mathrm{~cm}$. long, oblong, oval or obovate, usually rounded or emarginate at the apex, narrowed or cuneate at the base, finely pubescent, or becoming glabrate, finely reticulate-veined; calyx yellowish, the narrowly linear-lanceolate lobes $2.5-3.5 \mathrm{~mm}$. long; drupe oval or ovoid, $2-2.5$ cm. long, longer than its stalk.

Rocky coppices, Abaco, Andros, New Providence, Eleuthera, Cat Island, Great Guana Car, and Long Island:-Cuba. Referred by Dolles to Picrodendron juglans Griseb. Erroneously called Olive. BLACK 1 OOOD. Catesby, $2: 1, l$. 32.

\section{Order 5. URTICÀLES.}

Trees, shrubs or herbs, the flowers with a calyx but withont corolla, surall, not borne in aments, monoecious, dioecious or polygamous; ovary 1-celled, superior.

Fruit not an achene: trees, shrubs or herbs:'orule pendulous.

Trees with alternate leares, the sap not milky.

Trees with alternate leaves and milky sap.

Fruit an achene; herbs with small clustred greenish flowers:

orule erect or ascending.

Fam. 1. I'LMACEAE.

Fam. 2. MORACEAE.

Fam. 3. Urticacene.

\section{Family 1. ULMÀCEAE Mirbel.}

\section{Elit Family.}

Trees or shrubs, with alternate simple serrate petioled pinnately-reined stipulate leaves, the stipules usually fugacious. Flowers small, monoecious, dioecious, perfect or polygamons, clustered, or the pistillate solitary. Perianth 3-9-parted or of 3-9 distinct sepals. Petals none. Stamens in our species as many as the perianth-lobes or sepals and opposite them; filaments straight: anthers ovate or oval, longitudinally dehiscent. Ovary 1-celled (rarely 2-celled). mostly superior; ovule solitary, pendulnus, apatropous or amphitropous; styles or stigmas 2. Funit a samara, drupe or nut. Endosperm of the seed little or none. Embryo straight or enrved; cotyledous mostly flat. About 13 genera and 140 species, widely distributed in temperate and tropical regions. 
1. TRÈmA Lour. Flor. Coch. 562.1790.

Tall shrubs or trees, unarmed, usually pubescent. Leares alternate, toothed, 3-nerved at the base, equilateral or only slightly inequilateral, shortpetioled, the stipules lateral. Flowers small, mostly monoecious or polygamous, greenish or whitish, the perfect mostly fertile, in axillary cymes. Sepals of pistillate flowers induplicate-valvate, those of the perfect flowers slightly imbricated. Stamens 4 or 5. Orary sessile. Stigmas 2, entire. Ovule pendulous. Drupe ovoid to globose. [Name unexplained.] Some 30 tropical species. Type species: Trema cannabina Lour.

\section{Trema Lamarckiàna (R. \& S.) Blume, Mus. Bot. Lugd. 2: 58. 1853.}

Celtis Lamarckiana R. \& S. Syst. 6: 311. 1820.

Sponia Lamarckiana Decn. Nouv. Ann. Mus. Paris 3: 498. 1834.

Trema Lima Hiteh. Rep. Mo. Bot. Gard. 4: 129. 1893.

A tree, up to $8 \mathrm{~m}$. high, the trunk sometimes $3 \mathrm{dm}$. in diameter, or more often a shrub $1.5-3.5 \mathrm{~m}$. high, the trigs slender, rough-pubescent. Leares orate to lanceolate, short-petioled, $5 \mathrm{~cm}$. long or less, very rough on the upper side, 3-nerved at the base, reticulate-veined and finely tomentose keneath; flowers only about $2 \mathrm{~mm}$. wide, the staminate clusters sessile, the pistillate shortstalked; fruit ovoid, about $3 \mathrm{~mm}$. long, smooth.

Scrub-lands and coppices, Great Bahama. Andros. Mangrove Car. St. George's Car. New Providence, Rose Island, Hog Island, Eleuthera, Great Guana Cay, Watling's, Crooked Island and Mariguana:-Florida: Bermuda: Cuba to Porto Rico; IIontserrat to St. Vincent. LaMarCK's Treara. PAIX-IX-Back.

\section{Family 2. MORÀCEAE Lindl.}

\section{Mulberrt Fayilit.}

Trees, shrubs or herbs, mostly with milky sap, petioled stipulate leaves, and small monoecious or dioecious axillary clustered flowers, or the pistillate flowers solitary in some exotic genera. Calyx mostly 4-5-parted. Petals none. In Ficus the minute flowers are wholly inclosed in receptacles. Staminate flowers panicled, spicate or capitate, the stamens as many as the calyx-segments. Pistillate flowers capitate, spicate or cymose. Ovary superior, 1-celled in our genus. Ovule solitary, pendulous, anatropons. Styles 1 or 2. About 55 genera and 925 species, natives of temperate and tropical regions.

\section{FİUS [Tourn.] L. Sp. Pl. 1059. 1753.}

Woody plants, mostly 'arge trees, with milky sap, weak wood, and alternate leaves with interpetiolar stipules. Flowers minute, wholly enclosed in receptacles, the staminate with 1,2 or 3 stamens with short, stout filaments, the pistillate with a sessile 1-celled ovary, the style lateral, the ovule anatropous. Achenes enclosed in the receptacle. [Latin fig.] Some 600 species, of tropical and warm regions. Type species: Ficus Carica L.

\footnotetext{
Receptacles normally sessile. Receptacles peduncled.

Leaves $6 \mathrm{~cm}$. long or less, short-petioled.

Leaves $3-10 \mathrm{~cm}$. Iong, long-petioled.

\section{F. aurea.}

‥ F. jacquinifolia. 3. F. brevifolia.
} 
1. Ficus aùrea Nutt. Sylva 2: 4. 1846.

Ficus sapotaefolia Kunth \& Bouché, Ind. Sem. Hort. Berol. 1846: 17. 1846.

Ficus dimidiata Griseb. Fl. Br. W. I. 151. 1859.

A tree, attaining a maximum height of about $20 \mathrm{~m}$. with a trunk diameter up to $1.2 \mathrm{~m}$., the stout branches spreading, sending down aerial roots which sometimes reach the ground and form secoudary trunks, the thick, nearly smooth bark gray, the stout twigs yellow, glabrous. Leaves oblong or elliptic, firm in texture, $5-10 \mathrm{~cm}$. long, acute or short-acuminate at the apex, narrowel or obtuse at the base, glabrous, the petioles 1-6 $\mathrm{cm}$. long; figs oboroid, sessile (rarely short-stalked), yellow or red, $6-15 \mathrm{~mm}$. in diameter.

Sandy and rocky soil. Abaco, Great Bahama, Berry Islands, Cat Cay, Andros, New Frovidence, Eleuthera, Cat Island and Great Exuma :-Florida; Cuba; Hispaniola; Jamaica. Goldex WiLd Fig. Erroneously called Birisy.

2. Ficus jacquinifòlia A. Rich. in Sagra, Hist. Cub. 11: 221. 1850.

A tree up to $15 \mathrm{~m}$. high with a trunk $1 \mathrm{~m}$. in diameter, usually much smaller and sometimes shrubby, the smooth bark pale gray or nearly white, the branches often emitting many aerial roots, the twigs slender, glabrous. Leares obovate to oblong, coriaceous, $2-6 \mathrm{~cm}$. long, acute or rounded at the apex, narrowed or obtuse at the base, glabrous, finely many-veined, the petioles $2-5 \mathrm{~mm}$. long; figs globose, in pairs or solitary, $3-5 \mathrm{~mm}$. in diameter, on peduncles $2-4$ mnl long, the ostiolum prominent. The leaves of shoots are sometimes considerably larger than those of older branches.

Coppice and pine-lands, Abaco, Great Bahama, Andros, Mangroce Cay, New Providence and rat Island:-Cuba, Referred to F. pertusa L. f., by Hitchecek, Dolley and Mrs. Northrop. SuALL-LEAved WiLD Fig.

\section{Ficus brevifòlia Nutt. Sylva 2: 3. 1846.}

Ficus populnea bahamensis Tarb. in Urban, Symb. Ant. 3: 473. 1903.

A tree, reaching a maximum height of about $15 \mathrm{~m}$. with a trunk up to 5 dm. thick, the branches spreading, the smooth bark brownish, the twigs slender, glabrous, or sparingly pubescent when young. Leaves rather thin, glabrous, ovate or oval, 3-10 $\mathrm{cm}$. long, acute or obtuse at the apex, rouniled or cordate at the base, the slender petioles $1.5-4 \mathrm{~cm}$. long; figs globose or globose-obovoid, 7-12 $\mathrm{mm}$. in diameter, on peduncles $4-20 \mathrm{~mm}$. long, red when mature, the ostiolum not prominent.

Rocky and sandr soil, throughont the archipelago from Abaco and Great Bahama to Andros, Caicos Islands and Inagua:- Morida: Cuba: Santo Domingo. Closely related to $F$. laevigata Vahl, of Porto Rico and the Lesser Antilles, to which species it was referred by IItcheock; recorded by Mrs. Northrop as $F$. pedunculata Willd. ShorT-LEATED WiLd Fig. Cateshy 2: App.pl. 18.

\section{Family 3. URTICÀCEAE Rchb.}

\section{Nettle Famils.}

Herbs (some tropical species shrubs or trees). with watery sap. mostly stipulate simple leaves, and small greenish dioecious, monnecious or polygamous flowers, variously clustered. Calyx 2-5-eleft, or of distinet sepals. Petals none. Stamens in the staminate flowers as many as the lobes or segments of the calyx (sepals) and opposite them, the filaments inflexed and anthers reversed in the bud. straightening at anthesis. Ovary superior, 1-celled; style simple; orule solitary, erect or ascending, orthotropous, or 
in some genera partly amplitropons. Fruit an achene. Endosperm oily, usually not copious: embryo straight. About 40 genera and 550 species of wide geographic distribution.

Ierbs with stinglng hairs.

lierbs without stinging hails.

Stigma peniceliate.

Stigma not penicellate.

1. Fleurya.

2. Pilca.

3. Roussclia.

1. FLEURỲA Gaud. Bot. Voy. Freyc. 497. 1830.

Annual herbs, with stinging hairs similar to those of nettles, alternate petioled dentate leaves, and minute clustered monoecious or dioecious flowers. Staminate flowers with a 4-5-parted perianth, 4 or 5 stamens and a rudimentary ovary. Pistillate flowers with 4 imbricated perianth-segments, a somewhat oblique ovary, the stigma papillose; ovule erect. Fruit an oblique achene. [Commemorates J. F. Fleury, French botanist.] About 8 species, of tropical regions. Type species: Fleurya paniculata Gaud.

\section{Fleurya aéstuans (L.) Gaud.; Griseb. Fl. Br. W. I. 154. 1859.}

\section{Urtica aestuans L. Sp. PI. ed. 2, 1397. 1763.}

Erect or ascending, simple or little-branched, 3-9 dm. high, the stinging hairs copions or few. Leares thin, ovate or ovate-orbicular, 2-12 cm. broad, coarsely and sharply dentate, acute or acuminate at the apex, rounded or subcordate at the base, the petioles 1-10 $\mathrm{cm}$. long; panicles androgynous, shorter than or equalling the leaves, slender-peduncled; achene ovate, compressed, about $2.5 \mathrm{~mm}$. long.

A weed in waste places. New Providence at Nassau and Grant's Town :Haiti to Tortola and Trinidad; Jamaica; continental tropical America. WEST INDiAN NETTLE. COW-ITCH.

\section{PİLEA Lindl. Coll. pl. 4. 1821.}

Herbs, with opposite petioled mostly 3-nerved leaves, connate stipules, and small monoecious or dioecious flowers in axillary clusters. Staminate flowers mostly 4-parted (sometines 2- or 3-parted) and with a rudimentary ovary. Pistillate flowers 3-parted, the segments in most species unequal, each subtending a staminodium in the form of a concave scale; ovary straight; stigma sessile, penicillate. Achene compressed. Seed-coat thin. Endosperm scanty or none. [Name unexplained.] About 160 species, chiefly in the tropics, most abundant in tropical America. Type species: Pilea muscosa Lindl.

Leaves firm, thick or succulent; stems erect.

1. P. microphylla. Leaves very thin and flaccid, slender-petioled; stems prostrate. 2. $P$. tencrrima.

1. Pilea microphýlla (L.) Liebm. Vid. Selsk. Skr. V. 2: 296. 1851.

Parietaria microphylla L. Syst. ed. 10, 1308. 1759.

Pilea muscosa Lindl. Coll. pl. 4. 1821.

Annual or biennial, slender, glabrous. Stems erect or ascending, or sometimes ereeping at the base, 5-30 cm. long, fleshy, simple or mostly branched; leaves elliptic or oblanceolate, 4-10 $\mathrm{mm}$. long, acute or acutish at the apex, entire, acuminate at the base, transversely wrinkled; petioles filiform, shorter than the blades; flower-clusters very small, shorter than the petioles; sepals ovate, very thin, acutish; achenes oblong, lenticular.

On walls and in waste rocky places, New Providence, Eleuthera, Great Exuma:-Bermuda; Florida; Test Indies: continental tropical America. LACEPLAXT. 


\section{Pilea tenérrima Miquel, Linnaea 26: 219. 1854.}

Stems very slender or nearly filiform, usually tufted, prostrate or nearly so, somewhat fleshy, 3-10 $\mathrm{cm}$. long, more or less branched. Leaves suborbicular or eborate, usually thin and flaceid, the blades 3-6 $\mathrm{mm}$. long, rounded or obtuse at the apex, obliquely narrowed or obtuse at the base, the raphides linear, $0.3-0.5 \mathrm{~mm}$. long, irregularly transverse, the slender petioles $2-5 \mathrm{~mm}$. long; flowers and achenes similar to those of the preceding species of which it may be a slender, small-leaved race.

Crevices of rocks, Andros, Eleuthera, Rum Cay, Long Island, Acklin's and South Caicos:-Florida; Cuba; St. Jan; Anegada: Curaça; Jamaica. This plant has been confused with $P$. herniarioides (Sw.) Lindl., of wet mountain rocks in Cuba and Jamaica. SAILL IACE-PLANT.

\section{Roussèlia Gaud. Bot. Voy. Freyc. 503. 1830.}

A low, diffuse, perenuial herb, without stinging hairs, the leaves alternate, entire, the small axillary flowers monoecious. Staminate flowers in small racemes, the calyx 4-parted, the stamens 4, the ovary rudimentary. Pistillate flowers geminate, 2-bracted, sessile, the bracts foliaceous; ealyx ovoid, dentate; ovary straight; style filiform, curved, plumose on one side. Achene flat, ovate, acute, surrounded by the bracts. Seed with a membranous testa and scanty endosperm. [Commemorates H. F. A. de Roussel, professor at Caen.] A monotypic genus.

\section{Rousselia hùmilis (Sw.) Urban, Symb. Ant. 4: 205.1905.}

Urtica humilis Sw. Vet. Akad. Stockh. Handl. 6: 34. 1785.

Urtica lappulacea Sw. loc. cit. 8: 69. 1787.

Rousselia lappulacea Gaud. Bot. Voy. Freyc. 503. 1830.

Pubescent; stems slender, branched, prostrate or ascending, 1-4 dm. long. Leaves ovate, membranous, 3 -nerved, $0.5-3 \mathrm{~cm}$. long, acute or obtuse at the apex, rounded at the base; stipules minute; bracts of the pistillate flowers ovate, $3-4 \mathrm{~mm}$. long, entire; achene shining, about $2 \mathrm{~mm}$. long. SELIA.

On rocks, New Providence at Nassau:-Cuba to St. Thomas; Jamaica. Rous-

\section{Order 6. SANTÀLALES.}

Trees, or shrubs, and a few species herbaceous, many of them parasitic on the roots or branches of other plants, with simple, mostly entire leaves, and inconspicuous clustered perfect or imperfect flowers, the corolla present or wanting. Ovary partly or wholly inferior, compound. Stanens as many or twice as many as the sepals or petals. Fruit various. Seeds mostly with fleshy endosperm. A large order, mostly tropical. 


\title{
Family 1. LORANTHÀCEAE D. Don.
}

\author{
Mistletoe Familx.
}

Parasitic green shrubs or herbs, containing chlorophyll, growing on woody plants and absorbing food from their sap through specialized loots called haustoria (a few tropical species terrestrial). Leaves in the following genera opposite, in Razoumofskya reduced to opposite scales. Flowers regular, terminal or axillary, dioecions or monoecions, and perianth simple, or in some genera perfect, and with perianth of both ealyx and corolla. Calyx-tube adnate to the ovary. Stamens 2-6. Ovary solitary, erect; style simple or none; stigma terminal, undivided, obtuse. Fmit a berry. Seed solitary, its testa indistinguishable from the endosperm, which is usually copions and fleshy; embryo terete or angled. About 21 genera and 500 species, widely distributed; most abundant in tropical regions.

Pelianth of two series of parts: flowers mostly perfect. lerianth of one series of parts; flowers imperfect.

1. Dendropemon.

2. Phoradendron.

\section{DENDROPEMON Blume, in Schultes, Syst. 7: 1729. 1830.}

Parasitic shrubs, with opposite, coriaceous or somewhat fleshy, mostly flat leares, and small, axillary, bracteolate flowers in simple axillary spikes or racemes, the bractlets connate, cupulate. Calyx-limb truncate or 4-6 toothed, Petals usually 5 or 6 , small. Stamens short, borne at the base of the petals; anthers dorsifixed. Style short; stigma terminal. Fruit a small, fleshy berry. [Greek, injurious to trees.] About 15 species, natives of the West Indies. Type species: Loranthus parvifolius $\mathrm{Sw}$.

Plants glabrous, not scaly.

Leaves long-petioled; berry oblong to obovold.

Leaves subsessile; berry subglobose. Inflorescence scaly.

Leares mostly acute; twigs angular ; inflorescence densely scaly.

Leaves rounded, emarginate or cuspidulate; twigs terete; inflorescence lightly scaly.

1. D. purpureus.

2. U. brevipes.

3. D. bahamensis.

4. D. emarginatus.

1. Dendropemon purpùreus (L.) Krug \& Urban, Bot. Jahrb. 24: 26. 1897.

Tiscum. purpureum L. Sp. Pl. 1023. 1753.

Loranthus uniflorus A. Rich. Ess. Fl. Cub. 648. 1845. Not. Jaeq. 1760.

Smooth, not at all sealy; branches 2-4 dm. long, a little flattened when roung, soon terete. Leares oborate or oblanceolate, 3-6 cm. long, obtuse, subtruncate or acute at the apex and usually mucronulate, rarely retuse, narrowed at the base, the petioles 3-12 mm. long; racemes glabrous, several-manyflowered, as long as the leaves or shorter, the peduncles somewhat flattened; pedicels $1-3 \mathrm{~mm}$. long; bractlets connate to about the middle; flowers reddish; berry obovoid-cylindric, blue-black, or red, or black with a red base, 5-8 $\mathrm{mm}$. long.

On trees, Andros, New Providence, Caicos:-Cuba; Hispaniola; Porto Ríco. Catesby $2: p l .95$. SMOOTH MistLetoe.

2. Dendropemon brévipes Britton, sp. nor.

Smooth throughout, not at all scaly; young branches slightly flattened, the older terete, $3 \mathrm{dm}$. long or less. Leares oral to elliptic-oborate, dull green, 
2.5-4 cm. long, 1-2 $\mathrm{cm}$. wide, rounder or minutely apiculate at the apex, narrowed at the base, the midrein prominent on the under side, the lateral venation obscure, the petioles about $0.5 \mathrm{~mm}$. long; inflorescence peduncled, fewflowered, short-racemose; peduncles about one-half as long as the leaves; pedicels 3 or $4 \mathrm{~nm}$. long; bractlets connate to about the middle; calyx truncate; fruit subglobose, bluish purple, $\mathrm{s}-9 \mathrm{~mm}$. in diameter.

On Suiftria Mahagoni, Long Island near Clarence Town on Galloway Road Britton \& Millspaugh 63\%.) SHORT-STALKED MISTLETOE

3. Dendropemon bahaménsis Britton, sp. nov.

Similar to $D$. emarginatus, but the twigs strongly angled, not scaly. Leares ovate-elliptic to elliptic-oborate, $5 \mathrm{~cm}$. long or less, $1.5-3 \mathrm{~cm}$. wide, acute, acutish or rounded at the apex, narrowed at the base; petioles stont, about $2 \mathrm{~mm}$. long; rachis of the inflorescence densely white-scaly, $3 \mathrm{~cm}$. long or less; calyx densely white-scaly, broally triangular, $3 \mathrm{~mm}$. long in fruit, its teeth broadly triangular, horny, glabrous: ripe fruit eylindric with a conic apex, red-brown, $9 \mathrm{~mm}$. long, $5 \mathrm{~mm}$. thick.

On Lysiloma Sabicu, Nassan. New Providence (Britton and Brace 269. type: Brace $3.2 \%$ ): on the same host, Hasnes Road, Great Exuma (Britton \& Millspangh $29 \% 5$; on Conocarpus rrecta. Georgetown. Freat Exuma (Britton of Millspaugh 2906). Presumably recorded by Dolley as Lorrithus parriflorus Sw. BAIAMA MistLetoe.

4. Dendropemon emarginàtus (Sw.) Steud. Nomencl. ed. 2, 491. 1841.

Loranthus emarginatus Sw. Prodr. 58. 1788.

Dendropemon emarginatus lepidotus Krug \& Urban, Bot. Jahirb. 24: 25. 1897 .

Stems rather stout, terete, 3-t $\mathrm{dm}$. long, the twigs terete or very nearly so, usually scaly. Leaves obovate or elliptic obovate, $2-7 \mathrm{~cm}$. long, rounded or emarginate at the apex, narrowed or cuneate at the base, the petioles 2-6 $\mathrm{mm}$. long; inflorescence scaly, several-flowered, 2-5 cm. long, the peduncles terete or slightly angnlar, the perlicels $1 \mathrm{~mm}$. long or less; bracts connate; calyx more or less scaly, its teeth short; berry evlindric, $6-8 \mathrm{~mm}$. long, black, or red with a black base. On Ficut

On Ficus and Elaphrium Simaruba, Andros:-Cuba; Hispaniola. Scalx

\section{PHORADÉNDRON Nutt. Journ. Acad. Phila. II. 1: 1S5. 1848.}

Shrubs, parasitic on trees, mostly brittle at the nodes, with opposite coriaceous flat leares, sometimes reduced to scales (cataphyls), terete or angled trigs, and monoecious or äioecious axillary spicate bracted small flowers, solitary or several in the axil of each bract. Staminate flowers with a 3-iobed (rarely 2-4-lobed) calyx, bearing a sessile transversely 2-celled anther at the base of each lobe. Pistillate flowers with a similar calyx adnate to the ovoid inferior ovary; style short; stigma obtuse or capitate. Fruit a sessile fleshy berry. Endosperm copious. [Greek, tree-thief, from its parasitic habit.] (wer 200 species, all American. Type species: Phoradendron californicum Nutt.

Branches distinctly tetragonal; leares scarcely petioled or shortpetioled

Leares oblanceolate to spatulate or oblong-spatulate; petioles $3-8 \mathrm{~mm}$. long.

Leaves oborate to obovate-elliptic, $\bar{j} \mathrm{~cm}$. long or less, petioles 1-2 $\mathrm{mm}$. long.

Branches terete or nearly so: leaves distinctly petloled.

Leares ovate, lanceolate or elliptic, blunt at the apex; berty white.

Leaves obovate, rounded or retuse at the apex; berry red.

1. P. rubrum.

2. I'. trinerrium.

3. I'. racrmosum.

4. P. Northropiac. 
1. Phoradendron rùbrum (L.) Griseb. Fl. Br. W. I. 314. 1860.

Tiscum rubrum L. Sp. Pl. 1023. 1753.

Phoradendron spathulifolium Krug \& Urban, Bot. Jahrb. 24: 41. 1897.

Branches slender, $5 \mathrm{dm}$. long or less, pseudodichotomous, bearing 2-4 blunt cataphyls near the base, the internodes short, 4-angled, upwardly somewhat enlarged. Leaves oblanceolate to oblong-spatulate, $2-7 \mathrm{~cm}$. long, obtuse at the apex, narrowed or cuneate at the base, scarcely petioled; spikes usually several together, $2 \mathrm{~cm}$. long or less, 2-3-jointed, the joints about 12 -flowered; berry subglobose, about $4 \mathrm{~mm}$. in diameter, smooth, red or sometimes yellow.

On trees, especially mahogany, Abaco. New Providence, Cat Island, Long Island, Fortune Island, Acklin's Island, Crooked Island, Mariguana, Inagua :-Cuba. Catesby, 2: $p 1$. 81. Recorded as Phoradendron tetrastichum Griseb. by IItchcock. NARROW-LEATED MISTLETOE.

\section{Phoradendron trinérvium (Lam.) Griseb. Fl. Br. W. I. 314. 1860.}

Tiscum trinervium Lam. Eneyc. 3: 57. 1789.

Branches slender, 3-5 cm. long, pseudodichotomons, bearing 1 or 2 pairs of cataphyls near the base, the internodes $3-5 \mathrm{~cm}$. long, 4-angled. Leaves obovate or elliptic-obovate, $2-5 \mathrm{~cm}$. long, rounded at the apex, narrowed or subcuneate at the base, scarcely petioled; spikes usually clustered, 1-2 cm. long, 2-3-jointed, the joints usually 6-flowered or 8-flowered; berry oblong when young, subglobose, smooth, orange and $3-4 \mathrm{~mm}$. in diameter when mature.

On various trees, Watling's Island, Great Ragged Island, Acklin's Island:Porto Rico and St. Thomas to Trinidad; Jamaica. Closely related to the preceding species. AxGled Mistítetoe.

\section{Phoradendron racemòsum (Aubl.) Krug \& Urban, Bot. Jahrb. 24: 46.} 1897.

Tiscum racemosum Aubl. Pl. Guian. 2: 895. 1775.

Brauches elongated, rather stout, 3-6 dm. long, most of the joints bearing 1-3 pairs of cataphyls, the internodes terete or nearly so, somewhat enlarged above, $7-15 \mathrm{~cm}$. long. Leaves various, lanceolate or elliptic or orbicular, 5-16 $\mathrm{cm}$. long, pinnately veined, rounded or obtuse at the apex, abruptly narrowed into winged petioles 1-2 cm. long; spikes often elustered, $3-7 \mathrm{~cm}$. long, 3-5jointed, the long joints several-many-flowered; berry ellipsoid, white, about $4 \mathrm{~mm}$. long.

On Ocotea, Andros at Deep rreek:-Cuba: Hisnaniola: Porto Rico: northern South America. Erroneously called Siakeroot. Broad-Leived Mistletoe. Big MAN.

4. Phoradendron Northròpiae Urban; Northrop, Nem. Torr. Club 12: 33, pl. 4. 1902.

Dichotomously or trichotomously branched, 2-4 dm. long, the subterete branches glabrous, $3-5 \mathrm{~mm}$. thick, usually with cataphyls in all joints, the internores 4-10 cm. long. Leaves obovate, thick, $3-7 \mathrm{~cm}$. long, $2.5-4 \mathrm{~cm}$. wide, rounded, subtruncate or emarginate at the apex, narrowed at the base, very indistincty few-veined, the petioles $3-7 \mathrm{~mm}$. long; spikes several or numerous at the nodes, $2.5 \mathrm{~cm}$. long or less, short-peduncled, 4-6-jointed; joints 8-18flowered, subfusiform, rather thick; berry subglobose, red.

On Mimusops, Andros, at Conch Sound and Llsbon Creek:-Endemlc. Mrs. NorthroP's Mistletoe. 


\section{Family 2. OLACÀCEAE Lindl.}

\section{OLAX FamiLY.}

Shrubs, trees or woody vines, mostly with alternate and entire, pinnately reined, estipulate leares, and regular perfect or polygamous flowers in axillary clusters. Calyx +6 -toothed or $4-6$-parted. Corolla 4-6-lobed or of $4-6$ distinct petals. Disk various. Stamens $4-12$; filaments distinct or rarely monadelphous; anthers 2-celled. Orary 1-3-celled, inferior, halfsuperior, or partly immersed in the disk; ornles few, anatropous; style short, usually simple; stigma entire or 2-5-Iobed. Fruit drupaceous, 1celled. Testa of the seed membranous; endosperm fleshy, or rarely wanting. About 25 genera and 140 species, mostly tropical.

Petals united to above the middle. Petals nearly separate.

1. Schoepfia. 2. Timenia.

1. SCHOÈPfIA Schreb.; Gmel. Syst. 376. 1791.

Glabrous trees or shrubs, with coriaceous entire leaves and small perfect flowers in axillary cymes. Calyx very small, 4-toothed. Petals united to above the middle, forming a tubular or urceolate, 4-6-lobed corolla, the lobes valvate, recurved. Stamens as many as the corolla-lobes and opposite them; filaments filiform or short; anthers didymons. Ovary sessile, 3-celled, partly immersed in the Jisk; style slender or short; stigma capitate or 3-lobed; ovules usually 1 in each cavity. Fruit a small drupe nearly enclosed by the acerescent disk. [Commemorates J. D. Schoepf, 1752-1800, German botanist.] About 15 species, of tropical and subtropical America and Asia. Type species: Schoepfia Schreberi Gmel.

Leaves obovate, obtuse.

Leaves ovate, elliptic or lanceolate, acute.
1. S. obovata.

2. S. chrysophylloides.

1. Schoepfia obovàta C. Wright; Sauv. Anales Acad. Habana 5: 2s9. 1868.

A glabrous shrub 1-3 m. high, or sometimes a tree up to $10 \mathrm{~m}$. high, the twigs slender, gray, the bark rough in narrow plates. Leaves obovate, oblong or elliptic, coriaceous, 2-4 cm. long, rounded or obtuse at the apex, narrowed or cuneate at the base, few-veined, the petioles 1-3 $\mathrm{mm}$. long; peduncles solitary or few together in the axils, 2-8 $\mathrm{mm}$. long, 1-3-flowered; flowers sessile; corolla ovoid-cylindric, 4-5 mm. long, red to greenish yellow, the lobes ovate or triangular-ovate; fruit globose-obovoid to ellipsoid, $5-8 \mathrm{~mm}$. long; fruit yellow or red when mature.

Thickets and coppices, Abaco, Great Bahama. New Frovidence. Mariguana and Acklin's :-Cuba; Irispaniola; Porto Rico: Anegada. Referred to by Mrs. Northrop as Elaeodendron xylocarpum. WHITE BEEFWoOD.

2. Schoepfia chrysophylloìdes (A. Rich.) Planch. Ann. Sci. Nat. IV. 2: 261. 1854.

Diplocalyx chrysophylloides A. Rich. in Sagra, Hist. Cub. 11: 81. 1850.

A shrub or small tree sometimes up to $8 \mathrm{~m}$. high, with crooked branches and slender glabrous twigs. Leaves subcoriaceous, ovate to lanceolate, $2-6 \mathrm{~cm}$. long, acute or obtusish at the apex, narrowed at the base, glabrous, the margined petioles 4-8 $\mathrm{mm}$. long; flowers solitary or 2 or 3 together in the axils, reddish; calyx about $2 \mathrm{~mm}$. long; corolla narrowly campanulate, about 
$4 \mathrm{~nm}$. long, its lobes reflexed; stamens 4, borne at the base of the corollalobes, the anthers sessile; drupe oroid or oral, scarlet, 10-12 $\mathrm{mm}$. long, nearly enclosed by the accrescent calyx.

Coppices, scrub-lands and pine-lands, Abaco, Great liahama, Andros and Eleuthera:-Florida; cuba ; Jamaica. W'nute Wood.

\section{XIMÈNIA L. Sp. Pl. 1193. 1753.}

Spinescent shrubs or trees, with entire, often fascicled leares and small white or yellow, perfect axillary, solitary or ejmose flowers. Calyx very small, 4-5-toothed. Petals 4 or 5, mited only at the base, coriaceous, valvate, pubescent on the inner side. Stamens 5-10, the filaments filiform, the anthers linear. Orary 3-celled; style simple; stigma subcapitate; orules 3 or 4 in each cavity. Drupe with a fleshy exocarp and a woody or crustaceous stone. Embryo of the seed rery small. [Commemorates Francesco Ximenes, a Spanish naturalist.] About 5 species, of tropical distribution, the following typical.

1. Ximenia americàna L. Sp. Pl. 1193: 1753.

Timenia inermis L. Sp. Pl. ed. 2, 497. 1762.

A thorny shrub or small tree, rarely $6 \mathrm{~m}$. high, with reddish smooth astringent bark, the slender branches spreading. Leaves oblong to orbicular, subcoriaceous, $3-7 \mathrm{~cm}$. long, obtuse or emarginate at the apex, narrowed or rounded at the base, sparingly pubescent when young, mostly glabrous when old, the slender petioles $5-10 \mathrm{~mm}$. long; clusters 2-4-flowered, much shorter than the leaves; calyx about $1 \mathrm{~mm}$. long; corolla-lobes linear, reflexed, $1 \mathrm{~cm}$. long; drupe yellow or red, 12-17 $\mathrm{mm}$. in diameter.

Coastal white-lands and coppices, New. Trovidence, Conception IsIanr. Long Island, Fortune Island, Crooked Island, Caicos and Cay Sal :-Florida: Cuba to Porto Rico and Martinique; Jamaica; Nexico and South America; Old World tropics. When growing on sand dunes this shrub is much depressed and has nearly orbicular. fleshy leaves: when growing in coppices or sclub-lands it is tall, with eIongated oblong to oblanceolate leaves. Tallow Woon. Spaxisir Plum.

\section{Order 7. ARISTOLOCHIÀLES.}

Herbs or vines, mostly with cordate or leniform leaves and perfect flowers. Calyx inferior, its tube wholly or partly adnate to the ovary. Corolla none. Orary sereral- (mostly 6-) celled. Only the following family.

\section{Family 1. ARISTOLOCHIÀCEAE Blume.}

\section{Birthwort FAMILT.}

Acaulescent plants. or with erect or twining stems. Leaves alternate, often basal, estipulate. Flowers regular or irregular, sometimes clustered. Calyx-limh 3-6-lobed or irregular. Stamens 6-many, adnate to the pistil; anthers 2-celled, their sacs longitudinally dehiscent. Orules numerous in each cavity, anatropous, horizontal or pendulous. Fruit a many-seeded 6-celled capsule. Seeds angled or compressed, with a crustaceous testa and usually with a fleshy or dilated raphe; endosperm fleshy. copious; embryo minute. Six genera and about 200 species of wide distribution in tropical and temperate regions. 
1. ARISTOLÒCHIA L. Sp. Pl. 960. 1753.

Perennial herbs or twining vines. Leaves alternate, mostly petioled, or entire, 3-i-lobed cordate or auriculate palmately nerved. Flowers irregular. Caly $x$ adnate to the ovary, at least to its base, the tube usually inflated around the style and contracted at the throat, the limb spreading or reflexed, entire, 3-6-lobed or appendaged. Stamens mostly 6 ; anthers adnate to the short style or stigma, 2-celled, the sacs longitudinally dehiscent. Ovary mostly 6-celled with 6 parietal placentae. Style 3-6-lobed. Capsule naked, septicidally 6valved. Seeds very numerous, horizontal, compressed. [Named for its sup[osed medicinal properties.] About 180 species, widely distributed in tropical and temperate regions. Type species: Aristolochia rotunda L.

Leaves cordate: fruits short-peduncled; peduncles leafy-bracted.

Leares sagittate to hastate; fruits sleuder-peduncled;

peduncles not bracted.

1. A. pentandra.

2. A. passiflorucfoliu.

\section{Aristolochia pentándra Jacq. Enum. 30. 1760.}

Stems loosely pubescent or glabrate, trailing or low-climbing, branched, 3 m. long or less. Leaves rather fleshy, glabrous or nearly so, broadly ovate, 4-10 $\mathrm{cm}$. long, entire or 3-Iobed, acute or acuminate at the apex, cordate at the base, the slender petioles $1-4 \mathrm{~cm}$. long; peduncles solitary in the axils, shorter than the petioles, leafy-bracted at about the middle, the bract ovate, cordate, sessile, 1-3 cm. long; orary and calyx pubescent; calyx $2-3 \mathrm{~cm}$. long, expanded to one side, the limb acuminate, veined; stamens 5 ; capsule globose, $1.5-2 \mathrm{~cm}$. in diameter, usually longer than the peduncle.

Varitime sand plains, Abaco, Great Bahama, New Providence, Andros, Eleuthera, Watling's and Long Island:-Florida: Cuba. CoAstal Aristolocilla. PITCIIER-PLANT

2. Aristolochia passifloraefòlia A. Rich. in Sagra, Hist. Cub. 11: 195. 1850.

A glabrous vine, sometimes becoming $3 \mathrm{~m}$. long, usually not more than 1 m., usually climbing, the stem slender. Leaves sagittate or auriculate to hastate, rarious, $3-6 \mathrm{~cm}$. long, acute, obtuse or acuminate at the apex, the basal auricles rounded, the petiole shorter than the blade; peduncles solitary in the axils, as long as the leaves or shorter, not bracted; calyx $3-4 \mathrm{~cm}$. long, bromnpurple or greenish yellow, its base obliquely inflated, its tube slender, curved, its limb suborbicular, bearing slender processes $6-10 \mathrm{~mm}$. long; capsule oblong or oblong-globose, 1-2 cm. long.

Pine-lands and sclub-lands, Andros, New Providence and Great Exuma :-Cuba. Slexder Aristolocilia.

\section{Order 8. POLYGONÀLES.}

Herbs, twining vines, shrubs or trees, with alternate, or sometimes opposite or whorled, simple mostly entire leaves, jointed stems, and usually sheathing united stipules (oereae). Flowers small, regular, perfect, dioecious, monnecions or polygamous. Petals none. Calyx inferior, 2-6-eleft or 2-6-parted, the segments or sepals more or less imbricated, sometimes petaloid, sometimes developing wings in fruit. Stamens 2-9, inserted near the base of the calyx: filaments filiform or subulate, often dilated at the base, distinet or united into a ring: anthers 2-celled, the saes lnugitudinally dehiscent. Orary superior, 1-celled; ornle solitary, orthotropons, erect or 
pendulous; style 2-3-eleft or 2-3-parted, sometimes very short; stigmas capitate $01^{\circ}$ tufted, rarely 2-cleft; fruit a lenticular 3 -angled or rarely 4 angled achene, usually invested by the persistent ealyx; endosperm mealy; cotyledons acembent or incumbent; embryo straight or nearly so. Only the following family.

\section{Family 1. POLYGONÀCEAE Lindl.}

\section{BuckWheat Fasilt.}

About 40 genera and 800 species, of wide geograplic distribution.

Herbaceous plants.

Erect or ascending herbs. Ocreae crlindric, truncate. Ocreas oblique.

rines: racemes terminating in tendrils. Trees and shrubs.

1. Persicaria.

2. Fogopyrum.

3. Antigonon.

4. Coccolobis.

1. PERSICÀRIA [Tourn.] Mill. Gard. Dict. Abr. ed. 4. 1754.

Herbs, with alternate entire leaves, cylindric ocreae, and flowers in slender spike-like racemes, the ocreolae funnelform, the short pedicels jointed at the base of the calyx. Sepals mostly 5, neither winged nor keeled. Stamens 4-8, included or exserted, the filaments erect or nearly so. Styles 2 or sometimes 3 , usually partly united; stigmas capitate. Achene lenticular, or sometimes í-angled, usually black. Endosperm horny; cotyledons accumbent. [From Tersica, the leares resembling those of the peach.] About 125 species, widely distributed. Type species: Polygonum Persicaria L.

Ocreae ciliate.

Flower clusters contiguous.

Flower clusters separated.

Ocreae eciliate.

1. I. hydropiperoides.

2. I. punctata.

3. P. portoricensis.

1. Persicaria hydropiperoìdes '(Michx.) Snall, Fl. SE. U. S. 378. 1903.

Polygonum hydropiperoides Michx. Fl. Bor. An. 1: 239. 1803.

Perennial, strigillose; stem erect, decumbent or prostrate, slender, 3-9 $\mathrm{dm}$. long. Leaves narrowly lanceolate or oblcng-lanceolate, varying to linearlanceolate, 5-15 $\mathrm{cm}$. long, short-petioled, acute at apex, ciliate, pubescent with appressed hairs on the midrib beneath; ocreae cylindric, loose, strigose, fringed with long bristles; racemes panicled, terminal, erect, narrow, more or less interrupted, $3-7.5 \mathrm{~cm}$. long; calyx pink or greenish; stamens 8; style 3-parted to below the middle; achene 3-angled, ovoid or oblong, $2-2.5 \mathrm{~mm}$. long, smooth, shining.

Water-holes, Great Bahama at West End:-Continental North America south to Florida and California. MiLd TITER PEPPER.

2. Persicaria punctàta (E1l.) Small, Fl. SE. U. S. 379. 1903.

Polygonum punctatum Ell. Bot. S. C. \& Ga. 1: 455. 1817.

Polygonum acre H.B.K. Nov. Gen. 2: 179. 1817. Not Lam. 1778.

Annual or perennial, glabrous or very nearly so; stem erect or ascending, rarely prostrate, simple or branched, 3-12 dn. long. Leaves lanceolate or oblong-lanceolate, $3-20 \mathrm{~cm}$. long, acuminate at both ends, petioled, ciliate, conspicuously punctate, acrid, the midrib often with a few scattered hairs; ocreae 
erlindric, fringed with long bristles falling away at maturity, racemes narrow, erect or slightly drooping, loosely-flowered, 2-8 cm. long; calyx greenish; stamens 8 ; style 2-3-parted to the base; achene oblong, thick, lenticular or 3angled, $2.5 \mathrm{~mm}$. long, smooth, shining.

Swampr ground, Andros, along road to Morgan's Bluff:-Bermuda: temperate and tropical continental America; Cuba to Trinidad; Jamaica. WATER SMARTWEED.

\section{Persicaria portoricénsis (Bert.) Small, Fl. SE. U. S. 377. 1903.}

Polygonum portoricense Bert.; Small, Mem. Bot. Col. Coll. 1: 46. 1895. Polygonum glabrum C. \& S. Linnaea 3: 46. 1828. Not Willd. 1799.

Perennial, more or less scurfy; stem erect, decumbent or floating, 1-1.5 $\mathrm{m}$. long or longer, branched, enlarged at the nodes. Leares lanceolate or linearlanceolate, 4-30 $\mathrm{cm}$. long, acuminate at both ends, obscurely punctate, shortpetioled, the nerves prominent beneath; ocreae cylindric, sometimes bristly when young, naked when mature, sometimes hispid; racemes narrow, panicu. late, often in pairs, $2.5-13 . \mathrm{cm}$. long, dense, erect; calyx white or whitish, 5 parted to near the base; stamens $6-8$, included; style 2-3-cleft, somerhat exserted; achene lenticular and strongly biconvex or 3 -angled, $2-3 \mathrm{~mm}$. long, broadly oblong, orbicular or even broader than high, black, smooth and shining, or minutely granular.

Fresh water swamps and water-holes, Great Bahama, Andros, New Providence, Great Exuma and Cat Island:-southern Inited States to Mexico and northern South America; Cuba to Martinique; Jamaica. Dexse-flowered Persicaria.

2. FAGOPỲRUM Gaertn. Fr. \& Sem. 2: 182. 1791.

Annual or perennial, rather fleshy, usually glabrous leafy herbs, with erect striate or grooved stems. Leaves alternate, petioled, hastate or deltoid, with cblique, eylindric or funnelform ocreae. Flowers small, white or green, in terminal or axillars, usually paniculate racemes, perfect, borne solitary or several together from each ocreola, slender-pedicelled. Calyx about equally 5parted, persistent and unchanged in fruit, the segments petaloid, shorter than the achene. Stamens S; filaments filiform, glabrous. Ovary 1-celled, 1oruled; style 3-parted; stigmas capitate. Achene 3-angled. Embryo central, dividing the mealy endosperm into two parts; cotyledons broad. [Greek, beech-wheat, from the similarity of the grain.] About 6 species, native of Europe and Asia. Type species: Fagopyrum tataricum Gaertn.

1. Fagopyrum Fagopỳrum (L.) Karst. Deutseh. Fl. 522. 18s0-\$3.

Polygonum Fagopyrum L. Sp. PI. 364. 1753.

Fagopyrum esculentum Moench, Meth. 290. 1794.

Annual, glabrous except at the nodes, stem 3-9 dm. high. Leares hastate, $2.5-7.5 \mathrm{~cm}$. long, abruptly narrowed above the middle, acuminate, the nerves on the lower surface slightly seurfy; oereae brittle and fugacious; racemes mostly panieled, sometimes corymbose, many-flowered, erect or inclined to droop; pedicels as long as the calyx; calyx-segments white or whitish; stamens included; style-branches deflexed in fruit; achene acute, $5 \mathrm{~mm}$. long, about twice as long as the calyx, its faces pinnately-striate when mature, the angles acute, not erested.

Waste grounds, New Irovidence:-native of eastern Europe or westelu Asia. Widely distributed through cultivation. BUCKWIIEAT. 
3. ANTígonoN Endl.; H. \& A. Bot. Beech. Voy. 308. 1838.

Tines with alternate petioled corlate entire leares, the petiole-bases clasping, and small flowers in racemes opposite the leaves or clustered at the summit, the racemes terminating in tendrils. Sepals 5, unequal, the 3 outer ones cordate, orate, the 2 inner ones oblong. Stamens 8 , equal, the filaments subulate, connate at the base. Ovary 3 -angled; orule erect; styles 3 , recurved. Achene enclosed in the accrescent calyx. [Greek, opposite the nodes.] Three or four species native of Mexico and Guatemala, the following typical.

\section{Antigonon léptopus H. \& A. Bot. Beech. Voy. 308. 1838.}

Herbaceous, climbing, branched, often $5 \mathrm{~m}$. long or longer, finely pubescent at least above. Leaves thin, broadly ovate, $3-9 \mathrm{~cm}$. long, puberulent, acuminate at the apex, rather deeply cordate at the base, the petioles $1-5 \mathrm{~cm}$. long; racemes several or many, loosely several-flowered, the floriferous part $3-8 \mathrm{~cm}$. long, the tendril as long or shorter: pedicels slender, $10 \mathrm{~mm}$. long or less; flowering calyx pink or sometimes white, about $5 \mathrm{~mm}$. long; fruiting calyx $1-1.5 \mathrm{~cm}$. long, the sepals strongly reined.

Roadways and waste ground, spontaneous after cultivation. New Providence near Nassau:-Cuba to Martinique, and in Jamaica. Native of Mexico. Corallix.

4. Coccolòbis P. Br. Cit. \& Nat. Hist. Jam. 209.1756.

Shrubs or trees, with alternate entire leares, the ocreae cylindric or funrelform, often very small, the small, usually green flowers racemose or spicate, subtended by minute bracts and ocreolae. Calyx-tube acerescent, enclosing the achene, its lobes 5. Stanens 8, the filaments slender. Ovary 3-angled; orule erect; styles 3 . Fruit oroid or globose, the acerescent calyx-tube becoming 1)eshy and more or less adherent to the achene. Seed-coat thin; endosperm mealy. [Greek, referring to the adherent ealyx.] Orer 125 species of tropical and subtropical distribution, all American. Type species: Polygonum Uvifera L.

Flowering pedicels $1 \mathrm{~mm}$. long or longer.

Leaves very large, suborbicular, or broader than long, $7-20 \mathrm{~cm}$. wide.

Leares (except those of shoots) $6 \mathrm{~cm}$. Wide or less, orate to 1. C. Uvifera. elliptic, obovate or orbicular.

Leaves not reticulate-reined above.

Leaves coriaceous: racemes erect or spreading; fruit i-10 mm. long.

Leaves chartaceous: racemes long, drooping; fruit about $4 \mathrm{~mm}$. long.

Leaves prominentis reticulate-reined on both sides when old.

Flowering pedicels less than $1 \mathrm{~mm}$. long.

Inflorescence longer than the leaves, which are finely reticulate-reined above.

Inflorescence shorter than the leaves. Which are vers indis. tinctls reined above.

2. C. laurifolia.

3. C. bahamensis.

4. C. Northropiae.

5. C. diversifolia.

6. C. Krugii.

1. Coccolobis Uvifera (L.) Jacq. Enum. 19. 1760.

Polygnnum Tvifera L. Sp. Pl. 365. 1753.

Coccolobis leoganensis Jaeq. Enum. 19. 1760.

A tree, exceptionally up to $15 \mathrm{~m}$. high with a trunk $1 \mathrm{~m}$. in diameter, nsually not over $6 \mathrm{~m}$. high, the branches spreading, the smooth bark brown, the twigs stont, finely pubescent when young, soon glabrous. Leares orbicular or broader than long, coriaceous, $7-20^{\circ} \mathrm{cm}$. broad, cordate at the base, rery short- 
petioled, their sheaths $1 \mathrm{~cm}$. long or less; flowers numerous, white, in dense narrow glabrous racenes $7-12 \mathrm{~cm}$. long; pedicels $3-4 \mathrm{~mm}$. long; calyx white, about $6 \mathrm{~mm}$. broad, its lobes orate, rounded; fruits forming drooping clusters somewhat resembling bunches of grapes, globose, purple, 1-2 $\mathrm{cm}$. in diameter, the pulp thin, astringent.

Coastal thickets, throughout the archipelago from Abaco and Great Bahama to Grand Turk, Inagua, Anguilla Isles and Watel Cay :-Bermuda; Florida: West Indies; coasts of tropical continental America. SEA Gripe. Catesby, $2: j l .96$.

\section{Coccolobis laurifòlia Jaeq. Hort. Schoen. 3: 9. 1797.}

A tree, up to $20 \mathrm{~m}$. high, with a trunk sometimes $7 \mathrm{~m}$. thick, usually much smaller, and often shrubby, the thin gray bark brown mottled, the twigs and leares glabrous. Leaves ovate, elliptic or oborate, coriaceous, obtuse or acute at the apex, rounded at the base, 4-12 cm. long, or those of young shoots larger, the petioles 5-20 mm. long, the sheaths short; racemes slender, $5-10$ cm. long; pedicels 5-S mm. long; calyx greenish about $5 \mathrm{~mm}$. broad, its lobes suborbicular; fruits subglobose, red, acid, $8-10 \mathrm{~mm}$. in diameter.

Scrub-lands and coppices, throughout the archipelago from Abace and Great Bahama to Caicos and Inagua :-Florida; Cuba to St. Croix; Jamaica. Very various in size and shape of leaves, the species evidently composed of numerous races, one of which was lecorded in Mrs. Northrop's Flora as the Cuban C. Wrightii Lindau, a different species: and another as $C$. tenuifolia $\mathrm{L}$., as also recorded by Dolley and by him also as $C$. punctate L. I'lgeos-ples. Catesby, $2: p l .9$;.

\section{Coccolobis bahaménsis Britton, Bull. X. Y. Bot. Garả. 4: 116. 1905.}

A glabrous shrub, $4 \mathrm{~m}$. high or less. Leaves thin-coriaceous, elliptic to ovate or oborate-elliptic, obtuse to acutish at the apex, obtuse, somewhat narromed, or subcordate at the inequilateral base, $4-7 \mathrm{~cm}$. long, $5 \mathrm{~cm}$. wide or less, the primary reins 6-8 on each side, minutely but strongly reticulate-nerved on both surfaces, dull, the upper surface bright green, the lower surface paler; petioles $3-5 \mathrm{~mm}$. long; racemes very slender, numerous, recurved-drooping, finely puberulent when very young, in fruit glabrous; pedicels $1 \mathrm{~mm}$. long in fruit, much longer than the ocreolae; flowers bright white, $3-1 \mathrm{~mm}$. broad; sepals oval, obtuse, about as long as the stamens; fruit ovoid, narrowed at the base, bluntish at the apex, $6 \mathrm{~mm}$. long, 3-4 mm. thick, faintly several-ribbed, not coronate.

Ooppices, pine-lands and scrub-lands, Andros, New Providence, Great Exuma. Eleuthera, Acklin's Island, Watling's Island, Inagua. Endemic. Reported by Lindau and by Jirs. Northrop as $C$. obtusifolia Jacq. BAHAMA PIgEoN-PLUM.

\section{Coccolobis Northròpiae Britton, sp. nór.}

A shrub, or a tree up to $4 \mathrm{~m}$. high, the bark rough, the trigs and leaves glabrous. Leaves orbieular to obovate or obovate-orbicular, 3-5 cm. long, chartaceous or subcoriaceous, obtuse, rounded or acutish at the apex, narrowed or obtuse at the base, retiulate-reined on both sides when old, the petioles $3-6$ $\mathrm{mm}$. long, the ocreae short; racemes mostly as long as the leares or longer, the rachis puberulent or glabrous; pedicels $2-3.5 \mathrm{~mm}$. long, solitary or 2 or 3 together; perianth about $3 \mathrm{~mm}$. long; ocreolae obliquely truncate, abont $1 \mathrm{~mm}$. long; fruit ovoid, about $5 \mathrm{~mm}$. long, short-coronate, the exocarp fleshy.

Coppices and white-lands, Andros, New rrovidence, Elenthera and Gleat Exuma. Type collected near Xassau, New I'rovidence, hy A. H. Curtiss in 1903. Referred by Mrs. Northrop to $C$. retusa Griseb. Non'rinop's Prgen-pluar.

\section{Coccclobis diversifòlia Jacq. Enum. 19. 1760.}

A tree up to 10-12 $\mathrm{m}$. high, the bark gray, the many trigs short, glabrous or nearly so. Leaves ovate to elliptic or elliptic-obovate, coriaceous, glabrous, 4-10 cm!. long, rounderl or obtuse at the apex, obtuse, snbcordate, or some of them narrowed at the base, reticulate-reined on both sides, the rather stout 
petioles $\mathrm{S}-1 \overline{\mathrm{mm}} \mathrm{m}$. long; ocreae appressed, as long as the petioles or shorter; inflorescence spicate, slender, longer than the leares; flowers green, very nearly sessile, 2-2.5 $\mathrm{mm}$. long; fruit oroid, pointed, 6-10 $\mathrm{mm}$. long, coronate, the peri. carp slightly fleshy.

Sicrub-lands, pine-lands and coppices, throughout the archipelago from Abaco and Great lBahama to Caicos Islands and Inagua :- Hispaniola to Porto Iico, Virgln Gorda and Barbadoes; Jamaica, Aruba; Curaço; Bonaire. Leaves and filuit smaller than in specimens from the Windward Islands. TIE-TONGLE.

\section{Coccolobis Krùgii Lindau, Bot. Jahrb. 13: 145. 1890.}

A glabrous shrub or small tree, sometimes about $8 \mathrm{~m}$. high, the slender twigs short and numerous, the bark smooth, gray. Leares broadly ovate or nearly orbicular, light green, subcoriaceous, rounded or obtuse at the apex, cordate or subcordate at the base, $6 \mathrm{~cm}$. long or less, inconspicuously reined above, densely finely reticulate-veined beneath, the rather stout petioles 4-8 $\mathrm{mm}$. long, the ocreae appressed, short; spikes very slender, glabrous, mostly as long as the leares or shorter, loosely flowered; pedicels less than $0.5 \mathrm{~mm}$. long; perianth green, about $1.5 \mathrm{~mm}$. lone; stamens white; fruit ovoid or oroidglobose, 4-6 mm. long, sligntly ribbed, black, capped by the perianth-segments. the periarp somewhat fleshy.

Scrub-lands and coppices, New Providence, Cat Island. Watling's Island, Crooked Island, Acklin's Island, Fortune Island, Caicos Islands, Inagua :-Porto Rico; Jamaica; Anegada; St. Martin; Barbuda. Crab-Wood. Bow-PIGEox.

\section{Order 9. CHENOPODIÀLES.}

Herbs. mostly with perfect flowers. Calyx present. Corolla, if present, polypetalous. Ovary superior. Embryo coiled, curved or annular. Fruit not an achene, rarely achene-like.

Fruit not capsular, a utricle, berrs, antbocarp or achene-like; corolla none.

Fruit a ntricle.

Flowers bractless, or if bracted, the bracts not scarious.

Flowers with scarious bracts.

Fruit not a utricle.

Fruit an anthocarp.

Fruit not an anthocarp.

Fruit aggregate.

Fruit not aggregate.

Fruit a capsule, dehiscent by valres or teeth.

Capsule 2-sereral-celled; corolla none.

Capsule 1-celled: petals mostly present.

Sepals 5 or 4 .

Sepals only 2

Fam. 1. CheNopodiaceaE.

Fam. 2. AMARANTHACEAE.

Fam. 3. Nictagixaceae.

Fam. 4. Batidaceat.

Fam. 5. Phytolaccaceae.

Fam. 6. Aizodceae.

Fam. †. Alsinaceat.

Fam. 8. Portulacaceae.

\section{Family 1. CHENOPODIĀCEAE Dumort.}

\section{Goosefoot Family.}

Annual or perennial herbs, rarely shrubs, with angled striate or terete stems. Leares alternate or sometimes opposite. estipulate, simple, entire, toothed or lobed. mostly petioled (in Salicomia reduced to mere scales). Flowers small, green or greenish, regular or slightly irregular, variously clustered, occasionally solitary in the axils. Petals none. Calyx persistent, 2-5-lobed, 2-5-parted or rarely reduced to a single sepal, wanting in the pistillate flowers of some genera. Stamens as many as the lobes or divisions of the calyx, or fewer, and opposite them; flaments slender: anthers 2-celled, longitudinally dehiscent. Disk usually none. 
Ovary 1-celled; ovule solitary, amphitropous; styles 1-3; stigmas capitate, or 2-3-lobed or divided. Fruit a utricle, with a thin or coriaceous pericarp. Seed rertical or horizontal; endosperm mealy, fleshy or wanting. About 75 genera and 550 species, of wide geographic distribution.

Embryo annular or horseshoe-shaped: leares normal, at least the lower broad. Calyx present: fruit not enclosed by bractlets.

Calyx present in staminate flowers only; fruit enclosed by bractlets.

Embryo spiraliy coiled.

Leaves thick and fleshr, nearly terete.

Leaves reduced to rudimentary scales or ridges.

1. Chenopudium.

2. Atriplex.

3. Dondia.

4. Salicornia.

\section{CHENOPÒdium L. Sp. Pl. 218. 1753.}

Annual or perennial herbs, with alternate petioled leaves. Flowers small, green, perfect, sessile, bractless, clustered. Calyx 2-5-parted or 2-5-lobed, embracing or enclosing the utricle, its segments or lobes often keeled or ridged. Stamens 1-5; filaments filiform or slender. Styles 2 or 3 ; seed horizontal or rertical, sometimes in both positions in different flowers of the same species; endosperm mealy; embryo completely or incompletely annular. [Greek, goosefoot, from the shape of the leares.] About 60 species, mostly weeds, of wide geographic distribution. Type species: Chenopodium rubrum L.

Embryo a complete ring; plant not aromatic.

1. C. murale.

Embryo horse-shoe-shaped; plant aromatic.

2. C. ambrosioides.

1. Chenopodium muràle L. Sp. Pl. 219. 1753

Annual, somewhat scurfy above; stem $3-8 \mathrm{dm}$. high, leafy to the summit. Leares rhombic-ovate, thiu, bright green, acute or acuminate, sharply and coarsely sinuate-dentate, cuneate or subtruncate at the base, slender-petioled, 5-10 cm. long; flowers in loose axillary panicles often not louger than the petioles; calyx-segments not entirely enclosing the utricle; seed sharp-edged, horizontal, firmly attached to the periearp.

A weed of streets and waste grounds, on the inhabited islands of the archipelago, Great Bahama to Watling.s. Acklin's, and Long Islands. East Caicos and Grand Turk:- Tidely distributed as a weed in temperate and tropical regions. SOWBANE. GREENS.

\section{Chenopodium ambrosioides L. Sp. Pl. 219. 1753.}

Chenopodium spathulatum Sieb.; Moq. in DC. Prodr. 13²: 73. 1849.

Annual, glabrous or slightly glandular-pubescent, strong-scented; stem leafy. 6-10 dm. high, angular and grooved. Leares oblong or oblong-laneolate, narrowed to a short petiole, repand-dentate, undulate or the upper entire, 2-9 $\mathrm{cm}$. long, the upper numerous and much smaller; flowers in small dense axillary spikes; calyx usualy 3-parted, completely enclosing the fruit; pericarp readily separable from the horizontal or rertical, shining seed.

A weed, in waste grounds of the larger towns, New Providence, Elenthera and Cat Island:- Widely distributed as a weed in temperate and tropical regions. Tormseed, Jertsatem Parsley.

\section{ATRIPLEX L. Sp. Pl. 1052. 1753.}

Herbs or low shrubs, often seurfy-canescent or silvery. Leares alternate, or some of them opposite. Flowers dioccious or monoecious, small, green, in paricled spikes or capitate-clustered in the axils. Staminate flowers bractless, consisting of a 3-5-parted calyx and an equal number of stamens; filaments 
separate or united by their bases; a rudimentary orary sometimes present. Pistillate flowers subtended by 2 bractlets which enlarge in fruit and are more or less united, sometimes quite to their summits; perianth none; stigmas 2. Itricle completely or partially enclosed by the fruiting bractlets. Seed vertical or rarely horizontal; embryo annular; endosperm mealy. [From a Greek name of orache.] About 150 species, of wide geographic disribution. Type species: Artiplex hortensis $\mathrm{L}$.

Leares, at least some of them, toothed.

Sldes of the bracts tubercled or crested.

Sides of the bracts unappendaged.

Leaves entire.

1. A. pentandra.

2. A. domingensis.

3. A. arenaria.

\section{Atriplex pentándra (Jacq.) Standley, N. A. Fl. 21: 54. 1916.}

Axyris pentandra Jacq. Sel. Stirp. Am. 244. 1763.

Atriplex cristata H. \& B.; Willd. Sp. Pl. 4: 959. 1806.

Annual or perennial, branched, the branches procumbent or ascending, 3-8 dm. long, scurfy when young, becoming glabrate. Leares alternate, sessile or short-petioled, oblong to rhombic or obovate, 1-3 cm. long, obtuse or acute at the apex, mucronate, cuneate at the base, repand-dentate, undulate or the upper entire, white-scurfy beneath, green above; flowers monoecious, the staminate in dense short terminal spikes, the pistillate clustered in the axils; fruiting bracts cuneate-orbicular, about $3 \mathrm{~mm}$. long, united only at the base, sharply dentate, the sides bearing 2 dentate crests or irregularly tubercled; seed brown.

Coastal rocks and sands, thronghout the archipelago from Great Bahama south to Andros, Mariguana, Atwood Cay, and Grand Turk:-Florida; Cuba to St. Jan; Jamaica; Curaço; Venezuela and Colombia to Peru. Crested Atriplex.

\section{Atriplex domingénsis Standley, N. A. Fl. 21: 55. 1916.}

Annual, woody, much branched, the branches decumbent, spreading, scaly, $2 \mathrm{dm}$. long or longer. Leaves alternate, nearly sessile, deltoid or deltoidoblong, small, 4-6 $\mathrm{mm}$. long, 1-2 $\mathrm{mm}$. Tide, denticulate or entire, acute at the apex, crisped, thick, white-scaly on both sides; flotrers monoecious, the staminate in terminal spikes, the pistillate $2-4$ together in axillary clusters; bracts cuneate, $2 \mathrm{~mm}$. long, coarsely 5-toothed above, their sides unappendaged; seed dark brown.

White-lands, Eastern Cay, Turk's Islands:-Hispaniola. Domixadx ATtipLEx.

\section{Atriplex arenària Nutt. Gen. 1: 198. 1818.}

Atriplex cristata arenaria Kuntze, Rev. Gen. Pl. 546. 1591.

Annual, pale, stem densely silvery-scurfy, bushy-branched, 1-4.5 dm. high, the branches ascending or decumbent, angular. Leaves oblong to obovate, entire, short-petioled or sessile, 1-4 cm. long, whitish-scurfy beneath, the lateral veins few and obscure; staminate flowers in terminal or axillary spikes; pistillate flowers in axillary clusters much shorter than the leaves; fruiting bracts

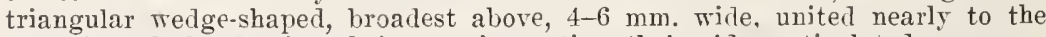
several-toothed summits, their margins entire, their sides reticulated, or sometimes crested or tubercled.

Coastal sands, Eleuthera, Anguilla Isles and Nater Cay:-Nova Scotia to Texas; Bermuda; Cayo Sabinal, Cuba. Sea-Beach Atrirlex.

3. DÓNDIA Adans. Fam. Pl. 2: 261. 1763.

Fleshy herbs or low shrubs, with alternate narrowly linear, thick or nearly terete, entire sessile leares, and perfect or polygamous bracteolate flowers, 
solitary or clustered in the upper axils. Calyx 5-parted or 5-cleft, the segments in fruit enclosing the utricle. Stamens 5. Styles usually 2, short. Pericarp separating from the seed. Embryo coiled into a flat spiral. Endosperm wanting or very little. [In honor of Jacopodi Dondi, Italian naturalist of the fourteenth century.] Abont 50 species, of wide geographic distribution. Type species: Chenopodium altissimum L.

Leares 2-5 cm. long, elongated-linear; calyx-lobes strongly keeled. 1. D. lincaris. Leaves $1-1,5 \mathrm{~cm}$. long, narrowly oblong; calyx-lobes intlexed, not keeled.

Leaves 2-5 mm. long, oblong; calrx-lobes inflexed, rounded.

2. D. fruticosa 3. D. insularis.

1. Dondia lineàris (Ell.) Heller, Cat. N. A. Pl. 3. 1898.

Salsoia linearis Ell., Bot. S. C. \& Ga. 1: 332. 1821.

Dondia carinata Nillsp. Field. Mus. Bot. 2: 297. 1909.

Usually annual, sometimes perennial; stem erect, strict, 3-10 dm. tall, pale green or nearly white, the branches slender, very leafy, erect-asending or sometimes recurved. Leares of the stem linear-subulate, $2-5 \mathrm{~cm}$. long, those of the branches much shorter, somewhat 3-angled, lanceolate-subulate, widest just above the base, the upper surface flat; calyx-lobes glaucous, acutely keeled or almost winged; seed orbicular, horizontal, black, shining, 1-1.5 mm. broad.

Salina borders and maritime rocks, South Bimini, New Proridence, Andros, Elenthra, Riding Rocks, Inagna, islands of the Cas Sal Bank:-Coast of eastel'n North America; Cuba. Referred by Mrs. Northrop to D. fruticosa (Forsk.) Northrop. TALL SEA-Blite.

2. Dondia fruticòsa (L.) Northrop, Mem. Torr. Club. 12: 35. 1902.

Chenopodium fruticosum L. Sp. Pl. 221. 1753.

Suacda intermedia S. Wats. Proc. Am. Acad. 14: 296.1879.

Dondia intermedia Heller, Cat. N. A. Pl. 3. 1898.

Dondia Wilsonii Millsp. Field Mus. Bot. 2: 297. 1909.

Perennial, woody, glabrous or nearly so, somewhat glaucous, much branched, $\mathrm{S} \mathrm{dm}$. high or less, the branches leafy, ascending. Leares subterete, $1-1.5 \mathrm{~cm}$. long, the upper little shorter than the lower; calyx-lobes rounded on the back, inflexed; seed red-brown or black, $1 \mathrm{~mm}$. broad.

Margins of salt pans. South Caicos Island:- Western Tnited States: Cuba ; Virgin Gorda; alkaline regions of Europe, Asia and Africa. BUSHY SEA-liLite.

The plant is much out of its general range on South Caicos; our specimen was referred to $D$. fruticosa by Standley (N. A. FI. 21: 91).

3. Dondia insulàris Britton, Bull. N. Y. Bot. Gard. 4: 138. 1906.

Perennial, shrubby, much branched, $3 \mathrm{dm}$. high or less, glabrous, glancous, the branches divaricately ascending. Leaves approximate, oblong, thick and Aeshy, 2-5 mm. long, 1.5-2 $\mathrm{mm}$. thick, obtuse, narromed to a subsessile base; flowers axillary to the upper leaves, about $2.5 \mathrm{~mm}$. broad; calyx-lobes orate, obtuse, rounded on the back; filaments shorter than the calyx; seed rertical, black, shining, $1 \mathrm{~mm}$. long.

In salinas, Grand Turk Island and Ambergis Cay:-Cuba: Santa Lucia, ISLAXI SEA-BLITE.

\section{SALICÓRNIA L. Sp. Pl. 3. 1753.}

Fleshy glabrous herbs with opposite terete branches, the leaves reduced to mere opposite scales, the flowers sunken $3-7$ together in the axils of the upper ones forming narrow terminal spikes, perfect or the lateral ones staminate. Calyx obpyramidal or rhomboid, fleshy, 3-t-toothed or truncate, becoming 
spongy in fruit, deciduous. Stamens 2, or sometimes solitary, exserted; filaments eylindric, short; anthers oblong, large. Ovary oroid; styles or stigmas 2. Itricles enclosed by the spongy fruiting ealyx, the pericarp membranous. Seed ereet, compressed; embryo conduplicate: endosperm none. [Name Greek, salt-horn; from the saline habitat, and horn-like branches.] About 10 species, natives of saline soil, widely distributed in both the Old World and the New. Trpe species: Salicornia europaea L.

Perennial: prostrate with erect branches. Annual ; ereet.

1. S. percunis. 2. S. Bigelovii.

* 1. Salicornia perénnis Mill. Gard. Dict. ed. 8, no. 2. 1768.

Salicornia ambigua Michx. Fl. Bor. Am. 1: 2. 1803.

Perennial by a woody rootstock; stem trailing or decumbent $1.5-6 \mathrm{dm}$. long, rooting, the branches ascending or erect, slender, nearly or quite simple, rather long-jointed. Scales broadly orate or wider than high, appressed or slightly dirergent; fruiting spikes 1-4 cm. long, their joints not longer than thick; flowers all about equally high and about equalling the joints; seeds covered with slender hairs.

Salinas, usually on the edge of mangrove colonies, throughout the archipelago from Abaco and Gleat Babama to Andros, the Caicos and Turks Islands and Inagua :- North American coasts, Massachusetts to Florida and west to Texas; Bermuda: Cuba: St. Croix: Jamaica. An Inagua specimen was referred by Standley (X. A. Fl. 21: 83) to the Euronean S. fruticosa L. which this species much resembles. Woody Glasswort. Willd Coral. Guixea-bead.

2. Salicornia Bigelòvii Torr. Bot. Mex. Bound. Surv. 184. 1859.

Salicornia mucronata Bigelor, F1. Bost. ed. 2, 2: 1824. Not Lag. 1817.

Annual, stout, erect or nearly so, $5-50 \mathrm{~cm}$. tall, more or less branched, the branches stout. Scales crate or triangular-ovate, sharply mueronate, 2-3 $\mathrm{mm}$. long, at length spreading; fruiting spikes 1-12 $\mathrm{cm}$. long, their joints not longer than thick; middle flower slightly higher than the lateral ones, reaching very nearly to the end of the joint; seed covered with short hairs.

In saline marshes, Abaco, Andros and Grand Turk:--Nova Scotia to Florida and Texas: California; Cuba; Polto Rico; Yucatan. Bigelow's GLasswort.

\section{Family 2. AMARANTHÀcEAE J. St. Hil.}

\section{Amaranth Family.}

Herbs, or a few genera low shrubs, with simple, mostly entire, thin leares. Flowers small, green or white. bractenlate. varionsly clustered, usually in terminal spikes or axillary heads. Petals none. Calyx herbaceons or membranons, 2-5-parted, the segments distinct, or mited at the base, equal. or the immer ones smaller. Stamens 1-5, mostly opposite the ealyx-segments, hypogrnous; filaments distinct, united at the base. or into a tube. Ovary 1-celled; ovule solitary in the majority of genera, amphitropons, several in some tropical genera; stigmas 1-3. Fruit a utricle, circumscissile, bursting irregularly, or indehiscent, 1-seeded or several-seeded. Seeed mostly smooth; embryo annular; endosperm mealy, usually copious. About 40 genera and 475 species, widely distributed, most abundant in warm regions. 
Anthers 4-celled.

Leaves alternate.

Fruit several-seeded.

Fruit 1-seeded.

Leaves opposite.

Anthers 2-celled.

Stigma capitate.

Stigmat-lobes subulate or fililurm.

Flowers in dense heads.

Stamens 2; perianth sessile.

Stamens 5 ; perjanth stalked.

Flowers in panicled spikes.
1. Celosia.
‥ Amaranthus.
3. Centrostachys.
4. Achyranthes.
5. Lithophila.
i. Philoxerus.
7. Iresine.

1. CELÒSIA L. Sp. Pl. 205. 1753.

Herbs or shrubs, with alternate leares and small perfect bracted flomers, in spikes or fascicles. Perianth 5-parted, the segments scarious, striate. Stamens 5; filaments filiform or subulate, connate at the base; anthers 4celled. Ovary 2-many-oruled; style present or wanting; stigmas 2 or 3. Utricle circumscissile or irregularly rupturing. Seeds 2 to many, lenticular, shining; embryo annular, endosperm starchy. [Greek, burned, from the dry parched flowers of some species.] Abont 40 species, of tropical and subtropical distribution. Trpe species: Celosia argentea L.

1. Celosia nítida V'ahl, Symb. 2: 44. 1791.

Perennial; glabrous. Stem slender, erect or vine-like, $3-15 \mathrm{dm}$. long; petioles slender, $5-20 \mathrm{~mm}$. long; leaves ovate to rhombic-lanceolate, $2-7 \mathrm{~cm}$. long, obtuse, acute or acuminate at the apex, truncate or obtuse and often oblique at the base; inflorescence of panicled spikes, 1-5 $\mathrm{cm}$. long; bracts nearly half as long as the sepals, ovate to lanceolate, keeled, acuminate; sepals elliptic-lanceolate, about $5 \mathrm{~mm}$. long, acuminate, dark brown, strongly parallelveined; style short; utricle globose-ovoid, shorter than the calyx; seeds black, smooth.

Moist soil and thickets, Acklin's Island, Anguilla Isles:-Florida; West Indies; Texas; Mexico; northern South America. Simexder Celosia.

\section{AMARÁNTHUS L. Sp. Pl. 959. 1753.}

Annual branched erect or diffusely spreading glabrous or pubescent herbs, with petioled pinnately veined leares and small monoecions polygamous or diocious, green or purplish, mostly 3 -bracteolate flowers in dense terminal spikes or axillary clusters. Calyx of 1-5 distinct sepals. Stamens 1-5; anthers longitudinally dehiscent. Styles or stigmas 2 or 3 . Fruit an ovoid or oblong utricle, 1-seeded, 2-3-beaked by the styles. Embryo annular. [Greek, unfading flower, from the dry, unwithering bracts.] About 60 species of wide geographic distribution. Type species: Amaranthus caudatus L.

Flowers all axillary: sepals of plstillate flowers spatulate.

Peduncles short and thick: ntricle indehiscent.

Peduncles none; utricle circumscissile.

1. A. crossipes.

2. A. polyyonoides.

Staminate flowers mostly in terninal spikes; sepals of pistillate flowers oblong or obovate.

Etricle inçehiscent.

Ttricle smooth.

itricle wrinkled.

Ltricle circumscissile or bursting lregularly.

Leaf axils with a pair of spincs.

I'lants not spiny.

Plants glabrous or nearly so.

Plants pubescent or villous.

3. A. riridis.

4. A. gracilis.

5. A. spinosus.

6. A. dutrius.

7. A. hybridus. 
1. Amaranthus crássipes Schlecht. Linnaea 6: 757. 1831.

Sclcropus amaranthoides Schrad. Ind. Sem. Hort. Goetting. 153 .

Glabrous; stems prostrate or somewhat ascending, rather fleshy, 2-6 dm. long. Petioles slender, $0.5-4 \mathrm{~cm}$. long; leaves orate to oblong or obovate, $0.5-$ $3.5 \mathrm{~cm}$. long, prominently whitish-veined, rounded and emarginate at the apex, narrowed at the base; flowers monoecious, in dense short-peduncled axillary clusters, the peduncles thickened; bracts rery small, ovate, acutish; sepals of the pistillate flowers 4 or 5 , spatulate, scarious, about $1.5 \mathrm{~mm}$. long, obtuse or emarginate; style-branches 2 ; utricle obovoid, compressed, coriaceous, finely tubereulate, indehiscent; seed dark brown or black, smooth, about $1 \mathrm{~mm}$. broad.

W:aste places, New Providence. Watling's and South Caicos:-Florida; West Indies; northern South America. THICK-STALKED AMARANTH.

\section{Amaranthus polygonoìdes L. Pl. Jam. Pug. 27. 1759.}

Amblogyna polygonoides Raf. Fl. Tell. 3: 42. 1836.

Stems slender, prostrate or ascending, much branched, 1-5 dm. long, villous abore. Petioles $2-7 \mathrm{~mm}$. loug; leares $0 . \overline{0}-2 \mathrm{~cm}$. long, rhombic-ovate to obovate, obtuse and usually emarginate at the apex, narrowed or cuneate at the base, glabrous, or sparingly pubescent beneath; flowers monoecious, in sessile dense axillary small clusters; bracts lanceolate, acuminate, much shorter than the sepals; sepals of the pistillate flowers spatulate, obtuse or apiculate, white, scarious, 3-nerved, connate at the base, those of the staminate flowers oblong, acute; stamens and style-branches 2 or 3 ; utricle circumscissile; seed dark brown or black, shining, less than $1 \mathrm{~mm}$. broad.

Sandy waste places, usually roadsides and paths, Eleuthera and Inagua:Florida: Texas; Cuba; Hispaniola ; St. Thomas to Hartinique; Curacao; Jamaica ; Mexico to northern South America. KxotweEd AMARANTu.

3. Amaranthus víridis L. Sp. Pl. ed. 2, 1405. 1763.

A maranthus emarginatus Salzm.; Uline \& Bray, Bot. Gaz. 19: 319. 1894.

Stems slender, prostrate or ascending, glabrous, usually branched, 1-6 dm. long. Leares slender-petioled, rhombic-orate, 1-4 cm. long, glabrous, deeply emarginate at the apex, rounded or narrowed at the base; flowers monoecious, in small axillary clusters and usually also in a short terminal spike; bracts orate to lanceolate, acute, as long as the sepals or shorter; sepals 3 , those of the pistillate flowers oblong or oblong-oblanceolate, obtuse or shorter than the utricle, those of the staminate flowers oblong, acute; stamens and stylebranches 3 ; utricle smooth, indehiscent; seed reddish-brown, shining, nearly 1 mm. broart.

In cultivated ground, New Proridence at Nassau:-southern Tnited States : Cuha: Porto Rico: Jamaica: Guadeloupe; tropical South America and old World tropics. Notcir-leaved AMARANTH.

\section{Amaranthus grácilis Desf. Tabl. Bot. 43. 1804.}

Glabrous; stem erect, usually branched, 2-9 dm. high. Leaves slenderpetioled, $8 \mathrm{~cm}$. long or less, ovate or rhombic-ovate, mostly obtuse and emarginate at the apex, narrowed or rounded at the base; flowers monoecious, in slender, axillary and terminal, sometimes panicled spikes 4-12 $\mathrm{cm}$. long, and also often in small dense axillary elusters; bracts orate to lanceolate, acute, searious, much shorter than the 3 sepals; serals cuspidate, 1-1.5 mm. long; stamens and style-branches 3; utricle wrinkled, indehiscent, as long as the sepals or longer; seed dull, dark brown, $1 \mathrm{~mm}$. broad.

Waste grounds near dwellings. Great Bahama. Andros. New Proridence. Eleuthera, Long Island and Watling's:-southeastern Tnited States; West Indies and tropical and subtropical America; OId World tropies. SLExder Araraxth. 
5. Amaranthus spinòsus L. Sp. Pl. 991. 1753.

Stem stout, ridged, erect or ascending, glabrous below, somewhat pubescent above, usually much brancher, sometimes red, 3-12 dnı. high. Leares orate, slender-petioled, rhomlic-orate or the upper lanceolate, acute at both ends, 2-8 cm. long, with a pair of rigid stipular spines at each node, the mirlrein excurrent; flowers monoecious, the pistillate in numerous capitate axillary clusters, the staminate in deuse terminal spreading or drooping spikes 2-18 $\mathrm{cm}$. long; bracts lanceolate-subulate, about as long as or longer than the 5 scarious oblong mueronate-tipped 1-nerved sepals, and the thin imperfectly eircumscissile utricle; stamens 5; style-branches 3 ; seed black, shining, nearly $1 \mathrm{~mm}$. broad.

Waste grounds, Great IIarbor Cax, and New Providence:- Tnited States: West Indies; all tropical and warm temperate regions. SpINx AMarintil. CaLalue.

6. Amaranthus dùbius Mart. Hort. Erlang. 197. 1814.

Amaranthus tristis Willd. Hist. Amar. 21. 1790. Not. L. 1753.

Glabrous, or somewhat pubescent abore: stem erect, often much branched. $1 \mathrm{~m}$. high or less. Leares long-petioled, the slender petiole $2-9 \mathrm{~cm}$. long, the blade orate, $2-12 \mathrm{~cm}$. long, acute or obtuse and usually emarginate at the apex, rounded or acute at the base; flowers monoecious, in slender, often drooping and numerous dense, terminal and axillary spikes, 5-25 cm. long, and sometimes in small, dense axillary clusters; bracts ovate or elliptic, acute, shorter than or about as long as the sepals; sepals of the pistillate flowers $1.5-2 \mathrm{~mm}$. long, mucronate, often emarginate, 1-nerved; stamens 5 ; style-branches 3 ; utricle a little longer than the sepals, rugulose, dehiseent at the middle; seed dark brown or black, circular, sharp-edged, $1 \mathrm{~mm}$. in diameter.

Waste places near dwellings, Abaco. New Proridence, Great Guana Cay, Cat Island, Little San Salvador. Fortune Island and Frand Turk:- West Indies: Central and Sollth America; tropical Africa; adrentive in Europe, Soctriers PIGWEed.

\section{Amaranthus hýbridus L. Sp. Pl. 990. 1753.}

Stem usually slender, erect, $0.3-2.5 \mathrm{~m}$. tall, often much-branched, villous above. Leares long-petioled, $1.5 \mathrm{dm}$. long or less, orate to lanceolate, usually acute; spikes linear-cylindric, $2-12 \mathrm{~cm}$. long, axillary and forming dense terminal panicles, ascending, or somemhat śpreading; bracts lanceolate to ovate, about twice as long as the 5 oblong acute or cuspidate sepals; stamens 5; style-branches 3 ; utricle scarcely wrinkled, cireumscissile; secd dark brown or black, shining, $1 \mathrm{~mm}$. in diameter.

Taste places, Fortune Island. Anguilla Isles:- United States; Rermuda; Cuba; Mexico. A. paniculatus as to Bahamian references. SLExder PIG WEed.

3. Centrostáchys Tall, in Roxb. Fl. Ind. 2: 497. 1824.

Herbs, some species somewhat woody, with opposite membranous broad leaves, and small green flowers sessile in slender elongated terminal spikes, the calyx deflexed after anthesis. Sepals 4 or 5 , cartilaginous, narrow, acuminate or aristate. Stamens 4 or 5 ; filaments subulate; anthers 4 -celled. Ovary 1-celled; ovule 1; style filiform; stigma capitate. Utricle thin-walled, indehiscent. [Greek, prickly-spike.] About 12 species, of warm and tropical regions. Type species: Controstachys aquatica Wall. 
1. Centrostachys indica (L.) Standley, Jouru. Wash. Acad. Sci. 5: 75.1915.

Achyranthes aspera indica L. Sp. Pl. 204. 1753.

Achyranthes indica Mill. Gard. Dict. ed. S, no. 2. 1768.

Achyranthes obtusifolia Lam. Encycl. 1: 545. 1785.

Achyranthes aspera obtusifolia Griseb. F1. Br. W. I. 62. 1859.

Herbaceous, erect or ascending, simple or branched, 6-12 dm. high, rather densely pubescent above. Leares suborbicular or obovate-orbicular, pubescent, 2-5 cm. long, abruptly short-tipped at the apex, narrowed or cuneate at the base, pinnately reined, the slender petioles 1-3 $\mathrm{cm}$. long; spikes rery slender, $2-6 \mathrm{dm}$, long, densely flowered above, the lower flowers scattered; flowers about $4 \mathrm{~mm}$. long; bracts subulate, horny, glabrous, a little shorter than the ealyx, deflexed; sepals acuminate.

A weed in waste places and cultirated soils, throughout the archipelago from Abaco south to Acklin's Island :- a weed in tropical and subtropical regions. Blust-Leaten Cextrostachys.

4. ACHYRÁNTHES L. Sp. Pl. 204. 1753.

Decumbent or prostrate herbs. Leaves opposite, entire or nearly so. Flowers perfect, in sessile or peduncled, head-like, usually white or silvery spikes. Sepals 5, unequal. Stamens 5, the filaments partially united into a cup-like tube; staminodia surpassing the filaments and 2-celled anthers, or shorter. Orary 1-celled; stigma capitate. Ovule solitary. Utricle flattened, indehiscent. Seeds lenticular, smooth. [Greek, straw-flower.] Forty species or more, mostly of tropical distribution. Type species: Achyranthes repens L.

Plants succulent: leaves sessile.

Plants not succulent.

Sepals merely acute.

Sepals spinulose-tipped.
1. A. maritima.

2. A. polygonoides. 3. A. repens.

1. Achyranthes marítima (St. Hil.) Standley, Journ. Wash. Acad. Sci. 5: 74. 1915.

Alternanthera maritima St. Hil. Voy. Bras. 2: 437. 1833.

Plants glabrous, fleshy. Stems or the branches prostrate, 2-8 dm. long, angled, branched; leares leatherr, cuneate to oblong or elliptic, $1.5-6 \mathrm{~cm}$. long, obtuse, commonly mueronate, entire, sessile or somewhat petioler; spikes dull straw-colored, 6-12 mm. long, sessile, leaving a conspicuous scar when detached; bracts ovate, keeled; calyx $\frac{1}{3}$ longer than the bracts; sepals rigid, ovate, acute and slightly awn-tipped, usually 5-nerved, glabrous; staminodia longer than the filaments, cleft or lacerate at the tip.

Iaritime sands at the wave line, Great Bahama, Frozen Cay, South Biminl. Little Mangrove Cay, New Providence and Cat Island:-Permuda: Florida: Cuba: Guiana to Brazil: West mast of Africa. Referred to by Dolles and by Herrick as Gomphrena sp. BEACH ACHYRANTHES.

2. Achyranthes polygonoìdes (L.) Lam. Encyel. 1: 547. 1785.

Gomphrena polygonoides L. Sp. P1. 225. 1753.

Alternanthera paronychioides St. Hil. Voy. Bras. 2: 439. 1833.

Glabrous or sparingly pilose, branched, the branches procumbent or ereeping. 1-4 dm. long. Leaves spatulate to elliptic, $2 \mathrm{~cm}$. long or less, obscurely reined, acute or obtuse at the apex, narrowed at the base, the petioles $5-10 \mathrm{~mm}$. long; flowers in dense sessile globose axillary heads $8-12 \mathrm{~mm}$. in diameter; sepals bright white, shining, lanceolate, acute, slightly unequal, about $3 \mathrm{~mm}$. 
long, somerthat longer than the lanceolate bracts; staminodia about as long as the filaments, toothed to the apex; utricle obcordate, included.

Sandy waste places, Great Bahama, New Proridence, Grand Turk and Inagua :southeastern Lnited States; Cuba to St. Thomas and to Barbadoes; Jamaica; continental tropical America. Kxotweed Achrinthes.

\section{Achyranthes rèpens L. Sp. Pl. 205. 1753.}

Alternanthera Achyrantha R. Br. Prodr. 417. 1810.

Alternanthera repens Kuntze, Rev. Gen. Pl. 2: 540. 1891.

Loosely pilose, branched, the branches prostrate, $5 \mathrm{dm}$. long or less. Leares spatulate, or obovate to oral or suborbicular, $2 \mathrm{~cm}$. long or less, pinnately veined, obtuse or abruptly tippel, narrowed at the base into short petioles; flowers in dense sessile globose or oblorg heads $6-12 \mathrm{~mm}$. long; sepals dull whitish, unequal, about $2 \mathrm{~mm}$. long, longer than the bracts, the outer aristate, villous; staminodia somewhat shorter than the filaments, entire, or fewtoothed below; utricle ovoid, included.

Tiaste places and cultirated lauds, Abaco, St. George's Cay. New Iroridence. Eleuthera and Long Island:- South Carolina to Florida, Texas and California: Cuba to St. Thomas and to South America: Mexico to Panama, Peru and Argentina; Canary Islands; Iadeira; Spain. Creepisg ACHYrasthes. Washerwodax.

\section{LITHÓFHILA Sw. Prodr. 14. 1788.}

Perennial, more or less villous herbs, the leaves mostly in basal tufts, the small perfect bracteolate flowers in spikes or heads. Calyx flattened, 5parted, sessile. Stamens 2; filaments connate below; anthers 2-celled; staminodia 3. Ovary ovoid; style short; stigmas 2, slender; orule 1, pendulous. Utricle ovoid, compressed. Seed lenticular, smooth. [Greek, rock-loving.] About 4 species, of the West Indies and Galapagos, the folloming typical.

\section{Lithophila muscoides Sr. Prodr. 14. 1788.}

Achyranthes linearifolia Sw. Tet. Acad. Handl. 1825: 48. 1825.

Root woody, often deep; stems few or several, prostrate or ascending, villous, branched, 01.-2 dm. long. Basal leaves several or many, tufted, filiform to oblong-spatulate, $1.5-5 \mathrm{~cm}$. long, $0.3-5 \mathrm{~mm}$. wide, obtuse, villous near the base; cauline leaves fer, similar but smaller, glabrous; spikes $3-15 \mathrm{~mm}$. long, about $5 \mathrm{~mm}$. thick, solitary or clustered, terminal or axillary, sessile or nearly so; bracts white, membranous, ovate, acute or acuminate, about one-half as long as the sepals; bractlets similar, nearly as long as the sepals; sepals oblong, 1-2.5 $\mathrm{mm}$. long, the onter obtuse, villous at the base, the inner acute; seed nearly orbicular, brown, shining, $0.5 \mathrm{~mm}$. in diameter.

In trodden sands of roadside paths, and in rocky and sandy soll, throughout tho al chipelago from Great Bahama to Grand Turk and Ambergris Car:-Cuba to St. Croix, Anegada and Martinique; Bonaire; Curaço. Moss-Like Litiophil..

\section{PHILóxeruS R. Br. Prodr. 416. 1810.}

Herbs, mostly fleshy, with opposite entire leares, the perfect bracteolate flowers in dense heads or short spikes. Calyx compressed, thickened at the base, 5-parted, the segments obtuse. Stamens 5; filaments subulate, connate below; anthers oblong, 2-celled. Ovary ovoid, compressed; style short; stig. mas 2, subulate; orule suspented on a long funicle. Utricle compressed, 
nтoid, indehiscent. Seed lenticular; embryo annular; endosperm starehy. [Greek, dirr-loving, some species inhabiting dry situations.] About 10 species of coastal distribution in tropical and subtropical America, Africa and Australasia. Trpe species: Philoxerus conicus R. Br.

1. Philoxerus vermiculàris (L.) Nutt. Gen. 2: 78. 1818.

Gomphrena vermicularis L. Sp. Pl. 224. 1753.

Lithophila vormiculata Uline, Field Mus. Bot. 2: 39. 1900.

Fleshy, the stems prostrate, branched, $1-8 \mathrm{dm}$. long, the branches prostrate or ascending, sometimes $1.5 \mathrm{dm}$. high. Leaves thick, or subterete, linear, linear-oblong or clarate, $1-5 \mathrm{~cm}$. long, acutish or blunt at the apex, narrowed to the sessile base; heads subglobose to cylindrie, densely many-flowered, bright white, 1-2.5 $\mathrm{cm}$. long, 6-10 $\mathrm{mm}$. thick; sepals about $3 \mathrm{~nm}$. long, obtuse, a little longer than the bracts.

Margins of salt water ponds and on maritime rocks. Abaco and Great $\mathrm{Ba}$ hama to Watling's Island and the Anguilla Isles:-Florida; West Indies; northern South Amcrica. SAMPIRF. SALT-WEED.

7. IRESINNE P. Br. Hist. Jam, 35S. 1756.

Tall herbs, with opposite broad petioled leaves and small 3-bracted white flomers, in large terminal panicles or panicled spikes. Calyx 5-parted, the pistillate usually woolly. Stamens 5, rarely ferter; filaments united by their bases, filiform; anthers 2-celled. Utricle very small, subglobose, indehiscent. [Greek, in allusion to the woolly pubescence.] About 40 species, natives of "arm and temperate regions. Type species: Celosia paniculata L.

Leaves large, broadly ovate-lanceolate, acute.

Leaves lanceolate to ovate-Janceolate, petiolate, obtuse.

Leaves linear, sessile or rery nearly so.
1. 1. Celosia.

2. I. flavescens.

3. I. inaguensis.

1. Iresine Celòsia L. Syst. cd. 10, 1291. 1759.

Celosia paniculata L. Sp. Pl. 206. 1753.

Iresine celosioides L. Sp. Pl, ed. 2, 1456. 1763.

Iresine paniculata Kuntze, Rev. Gen. Pl. 2: 542. 1891. Not Poir. 1813.

Annual or perennial; stem erect, ascending or clambering, 0.6-3 m. long, glabrous or nearly so. Leaves ovate, ovate-lanceolate or the upper lanceolate, 0.5-1.5 dm. long, acute or acuminate, the slender petioles 1-6 cm. Iong; flowers rery numerous, $2 \mathrm{~mm}$. broad or less, calyx and bracts silvery; sepals $1-1.5 \mathrm{~mm}$. long; pistillate flowers white-villous at the base, about twice as long as the bracts; utricle shorter than the sepals; seed red, shining, $0.5 \mathrm{~mm}$ in diameter. Coastal sands and on waste and cultivated lands, Abaco and Great Bahama:-
southeastern United States: Tamaica; Cuba to Porto Rico; Antiqua to Trinidad; Mexico to Brazil and Argentina. New-BURN WeEd.

2. Iresine flavèscens H. \& B.; Willd. Sp. PI. 4: 766. 1806.

Alternanthera flavescens Moq. in DC. Prodr, 132: 350. 1849.

Iresine keyensis Millsp. Field Mus. Bot. 2: 148, 1906.

Perennial by a woody root; stems erect, rather stout, $1 \mathrm{~m}$. high or less, glabrous, simple or much branched, the nodes often swollen. Leaves linearoblong to lanceolate or ovate-lanceolate, 2-10 cm. long, 0.4-2.5 cm. wide, mostly obtuse or rounded at the apex, narrowed at the base, glabrous, the petioles $1 \mathrm{~cm}$. lorg or less; panicles narrow, dense, 1-3 dm. long, glabrous; spike.s $0.3-4$ 
cm. long; bracts ovate-orbicular, about one-half as long as the sepals; sepals about $1 \mathrm{~mm}$. long, those of pistillate flowers copiously woolly at the base; utricle shorter than the sepals; seed red-brown, shining, $0.5 \mathrm{~mm}$. long.

Maritime rocks and pine-lands, throughout the archipelago from Abaco. Great Bahama and Great Sturrul, southward to Andros, Great Ragged Car, Acklin's lsland and Watling's Island:-Florida: Cuba; Colombia. Referred by ilis. Nortll-

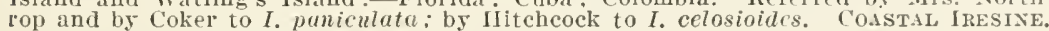

\section{Iresine inaguénsis Millsp. Field Mus. Bot. 2: 149. 1906.}

Perennial by a moody root; stems sereral, erect, rather stout, 3-9 dm. high, glabrous, little branched, the branches erect. Leares many, linear, $6 \mathrm{~cm}$. long or less, 1-2.5 mm. wide, obtuse, glabrous, nearly sessile, sometimes with fascicles of smaller ones in their axils; panicles narrow, $7-14 \mathrm{~cm}$. long, dense, glabrous; spikes densely tlowered, $3-12 \mathrm{~mm}$. long; bracts orate-orbicular, about one-third as long as the sepals; sepals oblong, about $1 \mathrm{~mm}$. long, obtuse, those of the pistillate flowers bearing long hairs at the base; utricle a little shorter than the sepals; seed red, shining, $0.5 \mathrm{~mm}$. long.

Sandy and rocky soil, Castle Island, Atwood Cay, Sheep Cay and Inagua:Endemic. BaHaja IRESixe.

\section{Family 3. NYCTAGINÀCEAE Lindl.}

\section{Fotr-oCLOCK FAMILT.}

Herbs, some tropical genera trees or shrubs, with simple entire leaves, and regular flowers in clusters, in many of the genera subtended by involucres. Petals none. Calyx inferior, usually corolla-like, its limb 4-5lohed or 4-5-toothed. Stamens hypogynons; filaments filiform; anthers 2-celled, dehiscent by lateral slits. Ovary enclosed by the tube of the perianth, 1-celled, 1-ovuled; ovule campylotropous; stigma capitate. Fruit a ribbed, grooved or winged anthocarp. About 25 genera and 350 species, of wide geographic distribution, most abundant in America.

Herbs: flowers perfect.

Perianth large, tubular-funnelform.

Perianth smali, campanulate or funnelform.

Fruit 5 -angled or $\overline{5}$-ribbed.

Fruit 10-ribbed.

Trees, shlubs or woody rines; flower's dioecious. Fruit drupe-like. fleshy.

Fruit dry, with 5 rows of glands.

1. Mirabilis.

2. Bocrhaarca.

3. Contmicarpus.

4. Torrubia.

5. Pisonia.

\section{MIRÁBILIS L. Sp. Pl. 177. 1753.}

Perennial herbs, with large tuberous-thickened roots and forking stems. Leares opposite, somewhat fleshy, petioled, or the upper sessile. Flower solitary or many flowers together in a 5 -lobed calyx-like involuere. Calyx colored, its tube elongated, constricted above the ovary, its limb expanding, deciduous. Stamens 5 or 6, unequal; filaments filiform, slender, incurred, united into a fleshy eup at the base. Style filiform. Fruit ribbed. Seed filling the pericarp, to which the testa adheres; endosperm mealy. [Latin, beautiful.] Twenty or more American species, the following typical.

1. Mirabilis Jalàpa L. Sp. Pl. 177. 1753.

Foliage decp green, glabrous or slightly pubescent. Stem erect, $3-\bar{i} \mathrm{dm}$. tall, much branched; leaves orate, acuminate, sometimes sparingly ciliate, 
entire, truncate or cordate at the base, the petioles about one half as long as the blades; involueres campanulate, $7-8 \mathrm{~mm}$. high, pubeseent, 1-flowerer, their lobes ovate-lanceolate, twice as long as the tube, acute, bristle-tipped; calyx trumpet-shaped, 3-5 cm. long, deep rel to purple or white, often more or less blotched, the edge notched; stamens exserted; fruit ovoid, black, 8-10 mm. long, wrinkled-tuberculate, 5-ribbed.

Waste grounds, spontaneous after cultiration, New Irovidence, Eleuthera and Fortune Island:- Rermuda; Florida; the West Indies; continental tropical America north through Mexico. Four-o'clock.

\section{BOERHAÀVEA L. Sp. Pl, 3. 1753.}

Slender herbs with forking stems and branches, opposite leaves, and small minutely bracted flowers on jointed pedicels. Calyx campanulate to funnelform, its limb 5-lobed. Stamens 1-5, exserted, the slender filaments united at the base. Ovary oblique; style filiform; stigma peltate. Fruit oboroid or elavate, 5-angled or 5-ribbed. [In honor of Hermann Boerhaave, 1668-1738, a celebrated Dutch scientist.] About 50 species, natives of warm and tropical regions. Type species: Boerhaavea diffusa L.

Fruit with riscid glands. Fruit not glandular.

1. B. coceinea. 2. B. erecta.

\section{Boerhaavea coccínea Mill. Gard. Dict. No. 8. 1768.}

Boerhaavea paniculata Rich. Act. Soc. Hist. Nat. Paris 1: 105. 1792.

Boerhaavia hirsuta Willd. Sp. Pl. 1: 20. 1797.

Perennial by somewhat fleshy roots; stems 2-10 dm. long, slender, branched, procumbent or ascending, usually pubescent, at least below, the branches glabrous or puberulent. Leaves rhombic-ovate to oblong or nearly orbicular, 2-6.5 $\mathrm{cm}$. long, rounded, obtuse or rarely acute at the apex, rounded or subcordate at the base, slender-petioled, entire or undulate; panicle slender, often $3 \mathrm{dm}$. long, its branches nearly filiform, glabrous or puberulent; flowers reddish, $2 \mathrm{~mm}$. broad, nearly sessile in small glomerules of 2 -several; fruit obovoid, 2.5-4 mni. long, 5-grooved, glandular.

Roadsides and waste places, North Bimini, Andros, New Providence, Great Guana Cay, Eleuthera, Cat Jsland, Fortune Island and Inagua :-Florida: West Indies: Mexico through Central America to northern South America; tropical Africa. VISCID Hog-TEED.

\section{Boerhaavea erécta L. Sp. Pl. 3. 1753.}

Stem erect or ascending, branched; leaves ovate to deltoid-ovate, sometimes inequilateral, $2-8 \mathrm{~cm}$. long, apiculate, repand or undulate, acute to cordate at the base, minutely black-dotted on the lower whitish surface, the petioles usually about one half as long as the blades or longer; peduncles filiform; flowers $2-6$ in a cluster; calyx white to purple, its tube glabrous, the limb campanulate, 1-1.5 mm. long, sparingly pubescent; stamens exserted; fruit obpyramidal, $3.5-4 \mathrm{~mm}$. long, 5-angled, the groores transversely wrinkled, the top flat.

Waste grounds, New Providence:-southern Tnited States; Bermuda: New Mexico and California to Peru and Brazil; the West Indies. Ssooth Hog-WEed.

3. COMMMCÁRPUS Standley, Contr. Nat. Herb. 12: 373. 1909.

Perennial herbs, with long forking stems, opposite entire petioled mostly cordate leares, and small perfect umbellate flowers. Calyx short-funnelform, 
the limb rather widely expaniled. Stamens 5, exserted, the filaments slender. Ovary oblique; style slender. Fruit clavate, 10-ribbed, mucilaginous-glandular, the glands rather large. [Greek, viscid fruit.] About 5 species, natives of tropical and subtropical America, the following typical.

1. Commicarpus scándens (L.) Standley, Contr. Nat. Herb. 12: 373.1909.

Boerhaavea scandens L. Sp. Pl. 3. 1753.

Glabrous; stems slender, pale, elongated and often vine-like, much branched, sometimes $2 \mathrm{~m}$. long. Leaves ovate, rather thin, somewhat fleshy, 1-4 cm. long, acute, acuminate or obtuse at the apex, cordate or truncate at the base, the petioles $2.5 \mathrm{~cm}$. long or less; peduncles sleuder, mostly longer than the leaves; umbels several-flowered; pericels filiform, 5-12 mn. long; calyx greenish, about 6 mru. broad, its tube and teeth short; fruit narrowly clavate, 7-10 $\mathrm{mm}$. long, glandular toward the blunt apex, its ribs low and obscure.

Scrub-lands. thickets and coppices, New Providence, Eleuthera. Care Cay. Acklin's Island. Grand Turk. Ambergris Cay and Anguilla Isles :- Florida: Texas and Arizona to Guatemala. Colombia and Yeru: Jamaica; Cuba to Virgin Gorda and St. Barts: Bonaire; Aruba; Curaçao. Comicarpes.

\section{TORRÙBIA Vell. Fl. Flum. 139. 1825.}

Shrubs or trees, with opposite often somerrhat fleshy leaves, and small greenish dioecious panicled flowers. Calyx-limb 5-toothed. Stamens about, 10, exserted, the filaments filiform. Ovary sessile; style slender or short. Anthocarp fleshy, drupe-like, obovoid to ellipsoid or subglobose, without glands in rows, enclosing the utricle. [Commemorates José Torrubia, a Spanish raturalist.] Fifteen species or more, of tropical and subtropical America. Type species: Torrubia opposita Vell.

Petioles stout: leares $6-9 \mathrm{~cm}$. long. coriaceous, reticulate-reined beneath. Leares broadly elliptic, mostly subcordate at the base.

Leares oborate, cuneate or narrowed at the base.

Petioles slender: leares $\$-6 \mathrm{~cm}$. long. fleshy-chartaceous, very indistinctly veined.

Fruit globose-oboroid to ellipsoid, little longer than thick; anthocarp $4-6 \mathrm{~mm}$. long.

Fruit oblong-oboroid. twice as long as thick; anthocarp i-s min. long.

2. T. Cokeri.

1. Torrubia obtusàta (Jacq.) Britton, Bull. Torr. Club 31: 612. 1904.

Pisonia obtusata Jacq. Hort. Schoen. 3: 35. 1798.

Pisonia calophylla Heimerl, Bot. Jahrb. 21: 625. 1896.

A shrub, or a small tree up to $13 \mathrm{~m}$. high, the twigs rather slender, subterete, pale gray, the bark of the trunk white. Leaves ovate or elliptic, coriaceous, 6-9 cm. long, about twice as long as wide, rounded at the apex, rounder, subcordate or some of them narrowed at the base, often involute-margined, the stout petioles $3-7 \mathrm{~mm}$. long; panicles usually many-flowered, as long as the leaves or shorter; flowers sessile, puberulent or glabrate; fruit oblong, bright red, shining, S-10 $\mathrm{mm}$. long.

I.ow conpices and scruh-lands, Abaco, freat Rahama. New Frovidence, Eleuthera. Cat Island. Freat Exuma. Acklin's, Crooked and Fortune Islands :-Cuba: Santo Domingo. BrodD-LEATED Birolir.

2. Torrubia Còkeri Britton, Bull. Torr. Club 31: 613. 1904.

Glabrous, the twigs gray. Leares firm, oborate, $8 \mathrm{~cm}$. Iong or less, $3-4$ cm. wide, rounded at the apex, narrowed or somewhat cuneate at the base; 
petioles stont, about $1 \mathrm{~cm}$. long; flowers sessile, the perianth and paniclebranches minutely tomentulose; staminate perianth about $3 \mathrm{~mm}$. long, bluntly 5 -toothel, about one-half as long as the stamens.

liock coppices and scrub-linds, Andros?, Elenthera and Inagua :-Cuba. COKER'S BLolly.

\section{Torrubia longifòlia (Heimerl) Britton, Bull. Torr. Club 31: 614. 1904.}

Pisonia discolor longifolia Hiemerl, Bot. Jahrb. 21: 627. 1896.

A tree, attaining a maximum height of about $16 \mathrm{~m}$. with a trunk up to 5 dm. in diameter, usually much smaller and often shrubby, the bark sealy, the twigs glabrous, slender. Leares oblanceolate to obovate or spatulate, firm in texture, 2-6 cm. long, glabrous, rounded or emarginate at the apex, narrowed or cuneate at the base, obscurely reined, the slender petioles $5-15 \mathrm{~mm}$. long; calyx 3-4 mm. long; fruit juicy, obovoid or globose-obovoid, bright red, little longer than thick; anthocarp 4-6 mn. long.

Rocky coppices and scrub-lands, Great Bahama, Andros, North Pimini. New Providence, Rose Island, Eleuthera, Watling's, Acklin's, Inagua and Anguilla Isles :Florida; Cuba; Jamaica. NARROW-LEATED Blolly. BEEF-WOOD.

4. Torrubia Bràcei Britton, Bull. Torr. Club 31: 614. 1904.

A slexder tree, $5 \mathrm{~m}$. high or less, the bark gray. Leaves thin, green on both sides; petioles very slender, $6-8 \mathrm{~mm}$. long; blades narrowly obovate, $5 \mathrm{~cm}$. long or less, rounded at the apex, cuneate-narrowed at the base; fruiting pedicels about $0.5 \mathrm{~mm}$. long; fruit very jnicy, oblong-obovoid, twice as long as thick, claret-red, truncate at the top; anthocarp 7-8 $\mathrm{mm}$. long, $2 \mathrm{~mm}$. thick.

Coppices and scrub-Iands, New Providence and Inagua. Endemic. Specimens from Cat Island, Conception, Acklin's and Fortune Islands, showing foliage only, are doubtfully referred to this species. Brace's BLoLlY.

\section{PISÒNIA L. Sp. Pl. 1026. 1753.}

Woody rines, shrubs or trees, with broad entire opposite leaves, and small, mostly dioecious, bracteolate, cymose or panicled flowers. Calyx-limb 5-toothed or 5-lobed. Stamens 6-10; filaments filiform, connate below into a tube or ring; anthers exserted. Orary sessile; style slender; stigma capitellate. Anthocarp coriaceous, linear or clavate, bearing stalked or sessile glands in rows, enclosing the elongated utricle. [Commemorates William Piso, a physician of Leyden, who travelled in Brazil, and died in 1648.] Twenty species or more, of tropical and subtropical distribution. Type species: Pisonia aculeata $\mathrm{L}$.

Climbing vine with hooked prickles: anthocarp with rows of stalked glands along its whole length.

Shrub or small unarmed tree; anthocarp with rows of stalked glands near its summit.

1. P. aculeata.

2. $P$. rotundata.

\section{Pisonia aculeàta L. Sp. Pl. 1026. 1753.}

A climbing woody vine sometimes $10 \mathrm{~m}$. long, armed with hooked opposite prickles. Leares orate to elliptic, rather thin, 2.5-10 $\mathrm{cm}$. long, glabrous, acute, obtuse or short-acuminate at the apex, cuneate or narrowed at the base, the petioles 1-4 cm. long; cymes many-florrered, pubescent; fruit clavate, slender-pedicelled, $8-10 \mathrm{~mm}$. long, 10-ridged, with 5 rows of glands from base to apex.

Coppices and scrub-lands, New Providence:-Florida; West Indies and continental tropical America; Philippine Islands. Cock-spur. Hold-Back. Pull-BAck. 
2. Pisonia rotundàta Griseb. Cat. Pl. Cub. 2S3. 1566.

Pisonia subcordata rotundata Heimerl, Bot. Jahrb. 21: 630. 1896.

Au unarmed shrub, or small tree, up to $5 \mathrm{~m}$. high, in Cuba becoming larger, the twigs and leaves glabrous or finely pubescent. Leares oral, oblong or obovate, firm in texture, $2 . \overline{5}-\overline{\mathrm{cm}}$. long, rounded or retuse at the apex, obtuse or broadly cuneate at the base, minutely reticulate-reined beneath, the petioles 3-10 mm. long; cymes many-flowered, rather densely pubesceut or glabrate; fruit clarate, $6-7 \mathrm{~mm}$. long, with 5 rows of short-stalked glands abore the middle.

Coppices, pine-lands and scrub-lands, Andros, New Providence, Eleuthera :Florida; Cuba. RotND-LedTed PISONIA.

\section{Family 4. BATIDÀCEAE Dammer.}

\section{Saltwort Famili.}

Low fleshy much-branched shrubs, with opposite semiterete, linear or club-shaped. entire sessile estipulate leaves, and small dioecions greenish flowers in axillary spikes. Staminate spikes with many persistent imbricated scales, each subtending a flower; calyx 2-lobed; stamens 4 or 5, with stout filaments alternating with staminodia; anthers introrse. Pistillate spikes 4-12-flowered, the scales decidnous: calyx and corolla wanting; ovary sessile, 4-celled; ovule 1 in each cavity, erect, anatropons: stigma sessile, somewhat 2-lobed: fruit agoregate, about 4-seeded. Seeds clubshaped, the testa membranous: endosperm none; cotyledons large. Only the following genus.

1. BÀTIS L. Syst. ed. 10, 1289. 1759.

Characters of the family. [Greek, from the fancied resemblance of the fruit to a blackberry.] A monotypic genus.

1. Batis marítima L. Syst. ed. 10, 1289. 1759.

A glabrous shrub $1 \mathrm{~m}$. high or less, the rather stout stems spreading, frostrate or ascending, the branches nearly erect, angular. Leaves acutish, ]-2.5 $\mathrm{cm}$. long; spikes oroid or oblong, $5-10 \mathrm{~mm}$. long, the staminate sessile, the pistillate short-peduncled; bracts nearly orbicular or reniform, longer than the calyx; stamens exserted, longer than the triangular staminodia; fruit 1-2 cm. long, drooping.

Mangrove mud and saline marshes, Great Bahama, North Bimini, Andros, Watling.s, Grand Turk, Inagua and Anguilla Isles:-Georgia to Florida: southern California: West Indies; continental tropical America. SAltwort. TLRTLE-TIEED.

\section{Family 5. PHYTOLACCÁCEAE Lindl.}

\section{PokeweEd Fanrer.}

Tlerbs, some tropical species shrubs, vines or trees, with alteruate entire mostly estipulate leares, and perfect regular polygamous or monoecions flowers. Calyx 4-5-parted $n r^{\circ}$ of $40 \% 5$ sepals, its segments a sepals imbricated in the bud. Petals wanting. Stamens as many as the calyxsegments or sepals and alternate with them. or more numerons. lypogyuous; filaments distinct, or mited at the base; anthers 2-celled, the saes 
longitudinally dehiseent, often nearly separated. Orary superior. severalcelled in most of the genera: nvules solitary in the cavities, amphitropous. Styles as many as the carpels, short. or none; stigmas linear or filiform. Fruit a berry or an achene. Endosperm of the seed mealy or fleshy. About 22 genera and 110 species, mostly in the tropies.

I'istll a single carpel.

Fruit a globular berry.

Stamens 4; style elongated.

Stamens 8-16: style none.

Fruit drs, achene-like, with bristles.

I'istil several-many-carpeled with as many styles as carpels.

1. Rivina.
2. Trichostigma.
3. Prticeria.
4. Phytolacca.

1. RIVÌNA L. Sp. Pl. 121. 1753.

Herbs, sometimes woody belor, the stems branched, erect, the leares thin in texture, the small perfect flowers in axillary or terminal, slender racemes. Scpals 4, not enlarging in fruit. Stamens 4, the filaments filiform, the anthers erect. Ovary 1-celled, subglobose; style curved; stigma capitate or 2-lobed. Fruit a small subglobose berry. Seed erect, lenticular, its testa crustaceous, the embryo curved, the endosperm mealy. [Commemorates August Rivinus, 1652-1725, professor in Leipzig.] A few species of tropical regions, the following typical.

\section{Rivina hùmilis L. Sp. Pl. 121. 1753.}

Rivina laevis L. Mant. 1: 41. 1767.

Glabrous or finely pubescent, branched, $3-S \mathrm{dm}$. high. Leaves ovate to oblong or lanceolate, $3-12 \mathrm{~cm}$. long, membranous, flaccid, undulate or entire, acute or acuminate at the apex, narrowed or subtruncate at the base, the slender petioles 1-5 cm. long; racemes $10 \mathrm{~cm}$. long or less, loosely several-manyflomered; pedicels 4-6 $\mathrm{mm}$. long; bracts deciciuous; calyx about $6 \mathrm{~mm}$. wide, the sepals oblong-cuneate, obtuse, pink or nearly white; stamens somewhat shorter than the sepals; berries subglobose, red, about $3 \mathrm{~mm}$. in diameter.

Coastal rocks and waste grounds, from Abaco throughout the archipelago to Parrot Cay (Caicos). Inagua. Anguilla Isles, and Water Cay:-Florida; West Indies; continental tropical America. WiLd Tomato.

2. TRICHOSTígMA A. Rich. in Sagra, Hist. Cuba 10: 306.1845.

[Tillamilia R. \& P.; Hook. f. in Benth. \& Hook. Gen. Pl. 3: 81.1880.$]$

Woody vines, or shrubs, with alternate petioled broad leaves, the small perfect flowers in slender bracted racemes. Sepals 4, concare, spreading or reflexer. Stamens 8-16; filaments filiform; anthers linear, versatile, 2-cleft. Ovary subglobose, 1-celled; orule sessile; style none; stigma penicillate. Fruit coriaceous, baccate, subglobose, the pericarp adherent to the erect seed. [Greek, referring to the penicillate stigma.] About 4 species, of tropical America, the following typical.

1. Trichostigma octándrum (L.) H. Walter, Pflanzenr. 39: 109. 1909.

Rivina octandra L. Cent. Pl. 2: 9. 1756.

Tillamilla octandra Hook. f. in Benth. \& Hook. Gen. Pl. 3: 81. 1880. Trichostigma rivinoides A. Rich. in Sagra, Hist. Cuba 10: 306. 1845.

A woody vine, often $10 \mathrm{~m}$. long or longer, usually climbing on trees, the stem up to $1.5 \mathrm{dm}$. in diameter at the base, the branches long and slender, 
glabrous. Leares elliptic, oblong, or elliptic-lanceolate, membranous, $5-15 \mathrm{~cm}$. long, acuminate or acute at the apex, narrowed at the base, glabrous, entire, the slender petioles 1-5 $\mathrm{cm}$. long; racemes usually numerous, loosely manyflowered, as long as the leaves or longer; pedicels 2-10 $\mathrm{mm}$. long; flowers white, about $S \mathrm{~mm}$. broad, the orate obtuse sepals at length reflexed; berry black, about $6 \mathrm{~mm}$. in diameter.

Waste grounds spontaneous after cultiration, Cat Island, at the Pight:-Florida; West Indies; continental tropical America north to Mexico. Tricrostigua.

\section{PETIVÈrIA L. Sp. Pl. 342. 1753.}

An erect slender perennial herb with the odor of garlic, the leaves broad, membranous, alternate, entire, the small perfect flowers in slender bracted spikes. Calyx 4-parted, conic at the base, the segments lanceolate, spreading in flower, erect in fruit. Stamens 4-8; filaments subulate; anthers linear, 2 cleft at apex and base. Orary oblong, flattened, truncate, tomentose, 2-celled, with 1-6 deflexed bristles near the apex; style very short or none; stigma penicillate. Fruit elongated, cuneate, flattened, striate, keeled on both sides, 2-lobed at the top and bearing 1-6 hooked bristles. Seed linear. [In honor of Jacob Petirer, English naturalist and apothecary, who died in 1718.] A monotypic genus.

\section{Petiveria alliàcea L. Sp. Pl. 342. 1753.}

Stem puberulent, at least above, or glabrate, erect, branched, 2-10 $\mathrm{dm}$. high, the branches slender, long, nearly erect or ascending. Leaves elliptic, oblong or oborate, sparingly pubescent or glabrous, 3-12 cm. long, acute or acuminate at the apex, narrowed at the base, short-petioled; spikes very slender, 1-4 dm. long, puberulent; flowers greenish, short-pedicelled; sepals narrowly linear, about $4 \mathrm{~mm}$. long: achene linear-cuneate, about $6 \mathrm{~nm}$, long, appressed to the axis of the spike, the terminal, reflexed bristles about $2 \mathrm{~mm}$. long.

Waste and cultivated grounds, New Providence at Nassau:-Florida: Test Indies; continental tropical America north to Mexico. GARLIC-WEed. ObeAir-besh.

\section{PHYTOLÁCCA L. Sp. Pl. 441. 1753.}

Tall perennial herbs, with petioled estipulate leaves, and small floners in terminal racemes, which by the further growth of the stem become opposite the leaves. Pedicels bracted at the base and often 1-3-bracted above. Calyx of 4 or 5 persistent rounded sepals. Stamens 5-15, inserted at the base of the calyx. Ovary composed of 5-15 distinct or somewhat united carpels. Fruit a depressed-globose 5-15-celled fleshy berry. Secds 1 in each cavity, erect, compressed; embryo annular in the mealy endosperm. [Name Greek and French, refering to the crimson juice of the berries.] About 24 species, mostly tropical. Type species: Phytolacca americana L.

\section{Phytolacca icosándra L. Syst. eđ. 10, 1010. 1759.}

Phytolacca octandra L. Sp. Pl. ed. 2, 631. 1762.

Erect, glabrous, or puberulent abore, branched, somewhat suceulent, 1-3 $\mathrm{m}$. high. Leaves elliptic to orate-lanceolate, membranous. $S-20 \mathrm{~cm}$. long, acute or acuminate at the apex, narrowed at the base, the rather stout petioles 1-5 
cm. long; racemes erect, densely many-floweren, 1-3 dm. long; pedicels 1.5-1 mm. long; flowers greenish white or yellowish, $6-\$ \mathrm{~mm}$. broad; sepals rounded; stamens S-20; carpels S-20; berry black, depressed-globose, about $8 \mathrm{~mm}$. in diameter.

Waste and cultirated ground, and in coppices, Great Bahama, Andros, New Providence, Eleuthera, Great Exuma:-Cuba:-Jamaica; Hispaniola; continental

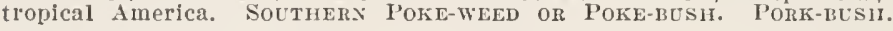

\section{Family 6. AIZOÀCEAE A. Br.}

\section{Carpet-iveed Family.}

Herbs, rarely somewhat woody, mostly prostrate and branehing, with (in our species) opposite, more or less fleshy leaves, and perfect small regular flowers. Stipules none or scarious, or the petiole-bases dilated. Calyx 4-5-cleft or 4-parted. Petals small or none in most species. Stamens perigynous. Orary usually free from the calyx, 3-5-celled, and ovules numerous in each cell in our genus. Fruit a capsule with loculicidal or circumscissile deliseence. Seeds amphitropous; endosperm scanty or copions; embryo slender, curved. About 22 genera and 500 species, mostly of $\pi$ arm regions, a few in the temperate zones.

\section{SESÙVIUM L. Syst. ed. 10, 1058. 1759.}

Fleshy decumbent or prostrate herbs, with opposite leares and axillary pink or purplish flowers. Stipules none, but the petioles often dilated and connate at the base. Calyx-tube top-shaped, 5-lobed, the lobes oblong, obtuse. Petals none. Stamens 5-60, inserted on the calyx-tube. Filaments filiform, sometimes united at the base. Orary 3-5-celled. Styles 3-5, papillose along the inner side. Capsule membranous, oblong, 3-5-celled, circumscissile. Seeds round-reniform, smooth; embryo annular. About 4 species, natives of seacoasts and saline regions. Type species: Sesuvium portulacastrum L.

Stamens 5.

1. S. maritimum.

Stamens numerous.

2. S. portulacastrum.

\section{Sesuvium marítimum (Walt.) B.S.P. Prem. Cat. N. Y. 20. 1888.}

Pharnaceum maritimum Walt. Fl. Car. 117. 1788.

Sesuvium pentandrum Ell. Bot. S. C. \& Ga. 1: 556. 1821.

Annual, glabrous; branches $0.5-3 \mathrm{dm}$. long. Leares obovate or spatulate, entire, rounded or slightly emarginate at the apex, narrowed into a petiole or the upper sessile, $8-25 \mathrm{~mm}$. long; flowers sessile or nearly so, about $2 \mathrm{~mm}$. broar, mostly solitary; stamens 5 , alternate with the calyx-lobes; capsule ovoid, about $4 \mathrm{~mm}$. high, scarcely lcnger than the calyx.

Salinas and edges of mangrove swamps, Andros, Ship Channel Cay, Cat Island, Long Island, Little San Salvador and Watling's:-Atlantic coast from Long Island to Florida; Cuba; Porto Rico. Slexder Sea Pursiaxe.

2. Sesuvium portulacástrum L. Syst. ed. 10, 1058. 1759.

Perennial, fleshy, glabrous. Stems usually diffusely branched, the branches prostrate, often creeping. forming large patches; leaves oblanceolate to oblong, $1.5-4 \mathrm{~cm}$. long, acute or acntish, the bases clasping; flowers short-pedicelled, solitary in the axils; calyx-lobes lanceolate, $7-10 \mathrm{~mm}$. long, hooded, purple 
within, the back prolonged into an appendage; stamens numerous; capsule conic, $8-10 \mathrm{~mm}$. long.

Sea beaches and saline "borders, throughout the archipelago to Tnrks Island and Cay sal:- Bermuda: North Carolina to Florida; the liest Indies: Mexico to Colombia and Venezuela: Old World tropics. Plants from saline borders have smaller leaves and seeds than those from sea beaches and coastal rocks. SEd P'URSLAE.

\section{Family †. ALSINÀCEAE ITahl.}

\section{Chichined Fanili:}

Annual or peremnial herbs with opposite entire leaves, estipulate or stipulate, and mostly small perfect flowers, solitary or in eymes or umbels. Calyx of 4 or 5 sepals, imbricated, at least in the bud, separate to the base, or nearly so. Petals as many as the sepals, not clawed, rarely wanting. Stamens twice as many as the sepals, or fewer, inserted at the base of the sessile ovary, or on a small disk: filaments distinct, or colnering below; anthers introrse, longitudinally dehiscent. Orary usually 1-celled; styles 2-5. distinct; ovtules several or numerous, amphitropous or campylotropous, borne on a central column. Fruit a capsule, dehiscent by valves or by apical teeth. Embryo mostly curved and with incumbent cotyledons. About 32 genera and 500 species, of wide distribution, most abundant in temperate regions.

1. DRYMÀRIA Willd; R. \& S. Syst. 5: 406. 1819.

Low branching herbs, with flat small leares, small, often fugacious stipnles, and small mostly white flowers in cymes or solitary. Sepals 5, distinct. Petals 5, eleft. Stamens 5 or fewer. Orary 1-celled, many-ovuled; style mostly 3-cleft. Fruit a 5-valced capsule. Seeds globose-reniform, the embryo peripheral. [Greek, pertaining to the forest.] About 20 species, of tropical and subtropical America, one also in the old World tropies. Type species: Lrymaria arenarioides $\mathrm{H}$. \& B.

1. Drymaria cordàta (L.) Willd.; R. \& S. Syst. 5: 406.1819.

IIolosteum cordatum L. Sp. Pl. 88. 1753.

Annual, glabrous or puberulent above; stems very slender, diffuse, 1-1 $\mathrm{Im}$. long. Leaves orbicular or broader than long, 6-20 min. wirle, membranous, palmately reined, obtuse or euspidulate at the apex, subeordate at the base, short-petioled; peduncles filiform, usually much longer than the leares, often forked; cymes few-sereral-flowered; pedicels as long as the bractlets or shorter; sepals 1.5-3 mm. long, oblong-lanceolate, acute; petals 2-cleft; stamens 2 or 3 ; eapsule about as long as the sepals.

Waste grounds, New Providence:-Florida: West Indies and continental tropical Americil. Drrimaria.

\section{Family S. PORTULACÀCEAE Rehb.}

\section{Putriane Fanile.}

Herbs, rarely somewhat woody. with regular perfect but unsymmetrical flowers. Sepals commonly 2 (rarely 5). Petals 4 to 6 , rarely more, 
hypogynous, imbricated. Stamens hypogynous, equal in number to the petals or fewer, rarely more; filaments filiform; anther's 2-celled, longitudinally dehiscent. Ovary 1-celled; style 2-3-eleft or 2-3-divided, the divisions stigmatic on the inner side: orules $2-\infty$, amphitropous. Capsule

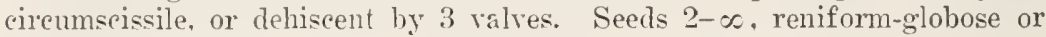
compressed: embryo curred. About 20 genera and 150 species, mostly natives of America.

1. PORTULȦCA L. Sp. Pl. 445. 1753.

Diffuse or ascending, glabrous or pubescent suceulent herbs, with terminal flowers. Sepals 2, united at the base and partly adnate to the orary. Petals 4-6 (mainly 5), inserted on the calyx, fugacious. Stamens $7-\infty$, also on the calyx. Ovary many-oruled; style deeply 3-9-cleft or parted. Capsule membranous, dehiscent by a lid, many-seeded. [Latin, in allusion to the purging qualites of some species.] A genus of about 20 species, all but 2 or 3 natives of America. Type species: Portulaca oleracea L.

Leares flat; flowers rellow.

Leaves subterete.

Flowers yellow; seeds brown.

Flowers purple; seeds black.
1. P. olcracea.

2. P. phacosperma.

3. P. gagatosperma.

\section{Portulaca oleràcea L. Sp. Pl. 445. 1753.}

Annual, usually prostrate, branching from a deep root; branches $1-7.5 \mathrm{dm}$. long. Leaves alternate and clustered at the ends of the branches, obovate or cuneate, 6-20 mim. long, rounded at the apex, very fleshy; flower-buds flat; flotrers solitary, sessile, 4-10 mm. broad, yellow, opening in bright sunshine; sepals broad, keeled, acutish; style 4-6-parted; capsule 6-10 mm. long; seeds finely rugose.

Cultirated soil, waste places and maritime rocks, throughout the archipelago:all temperate and tropical regions. Includes several races differing in slze of leares and flowers, and of a prostrate or ascending habit. PURSLAx.

\section{Portulaca phaeospérma Urban, Symb. Ant. 4: 233. 1905.}

Fleshy, branched, $1.5 \mathrm{dm}$. high or less, with tufts of bromnish hairs at the nodes. Leares linear-oblong, subterete, acute or obtuse, 5-10 $\mathrm{mm}$. long, about $2 \mathrm{~mm}$. thiek, alternate and clustered at the ends of the branches; flowers yellow, 6-10 $\mathrm{mm}$. broad; petals oblong to obovate, obtuse; eapsule about $3 \mathrm{~mm}$. in diameter, circumscissile at about the middle; seeds bromn.

Drr or rocks soil, throughout the archipelago from Great Bahama and Andros to Mariguana, Turk's Islands and Inagua :-Florida; Cuba to St. Croix and Virgin Gorda; Jamaica. Referred by Jrs. Forthrop and by Coker to $P$. halimoides L.; by Hitchcock and by Coker to $P$. pilosa L. BrowN-SeEded Portulaca.

\section{Portulaca gagatospérma Millsp. Field. Mus. Bot. 2: 299. 1909.}

Fleshy, diffusely branched, 5-10 $\mathrm{cm}$. high, with tufts of whitish hairs at the nodes. Leares alternate, subterete, acute, 6-12 $\mathrm{mm}$. long, about $2 \mathrm{~mm}$. thick, short-petioled; flowers sessile at the ends of the branches; sepals broadly orate, apiculate; petals purple, emarginate; eapsule about $4 \mathrm{~mm}$. in diameter, circumscissile below the middle; seeds jet black, $0.6 \mathrm{~mm}$. in diameter.

In moist soils and mud of lake borders, Great Bahama, New Proridence, Grand Turk, Salt Cay (Turk's Islands) and Inagua, attaining its highest development in our region on the dry rocks of East and Ambergris Cars of the Turk's Island group:- Endemic. Referred by Hitchcock to $P$. pilosa L., which it resembles. BAHaMa PoRTulaca. 


\section{Order 10. RANÀLES.}

Herbs, shrubs or trees. Calyx present, usually of separate sepals. Corolla usually present and of separate petals. Ovary or ovaries superior, free from the calyx: carpels 1 to many, usually separate. Stamens mostly hypogynous and more numerous than the sepals.

Aquatic herbs, the leares peltate or with a basal sinus. Fam. 1. NyaphaEaceaE. Terrestrial plants.

Stamens many; sepals distinet.

Flowers perfect (in the Bahama species).

Carpels distinct; sepals 4 or 5 ; petals, when present about as many (none in Clematis). Fam. 2. Raxuxctudceae.

Carpels more or less coherent; sepals 3 ; petals 6 ; trees or shrubs.

Flowers dioecious, small; elimbing rines.

Stamens 9 or 12 in 3 or $^{\circ} 4$ series of 3 each; sepals more or less united.

Shrubs or trees with broad leaves; fruit borne on the calyx-tube.

Leafless rines; fruit enclosed by the acclescent calyx-tube.

Fam. 3. Axyoxaceae.
Fam. 4. Mexislermacede.

Fam. 5. Latraceae.

Fam. 6. Cassytiaceae.

\section{Family 1. NYMPHAEÁCEAE DC.}

\section{Thater Lily Family.}

Aquatic perennial herbs, with horizontal rootstocks, floating, immersed or rarely emersed leares, and solitary axillary flowers. Sepals 3-5. Petals 5- $\infty$. Stamens 5- $\propto$; anthers erect, the connective continuous with the filament. Carpels $3-\infty$, distinct, united, or immersed in the receptacle. Stigmas distinct, or tinited into a radiate or annular disk; orules 1-x, orthotropous. Fruit indehiscent. Seeds enclosed in pulpy arils, or rarely naked; cotyledons fleshy; hypocotyl very short. Five genera and about 55 species, widely distributed in fresh water.

1. CAstÀliA Salisb. Par. Lond. 1: pl. 14. 1805.

Herbs with horizontal perennial rootstocks, floating leaves and showy flowers. Sepals 4. Petals in sereral rows, or but few, inserted on the orary, gradually passing into stamens; stamens $\infty$, the exterior with large petaloid filaments and short anthers, the interior with linear filaments and elongated anthers. Carpels $s$, united into a compound pistil with radiating linear projecting stigmas. Fruit globose, corered with the bases of the petals, ripening under water. [A spring of Parnassus.] About 40 species, of wide geographic distribution. Type species: Castalia magnifica Salisb.

1. Castalia pulchélla (DC.) Britton, Bull. N. Y. Bot. Gard. 4: 13S. 1906.

Nymphaea pulchella DC. Syst. 2: 51. 1821.

Nymphaea ampla pulchella Casp. in Mart. Fl. Bras. 42: 159. 1878.

Rootstock 2-4 cm. thick. Petioles $5-10 \mathrm{~mm}$. thick, various in length, depending upon the depth of water; leaf-blades suborbicular, rather thin, 1-3 dm. broad, glabrous, undulate or repand, green on both sides, very coarsely reticulate-reined beneath, the basal sinus rather narrow, the lobes acute; peduncles about as long and as thick as the petioles; sepals 4, lanceolate, 
acutish, $6 \mathrm{~mm}$. long or less; petals $4-8$, white, acute; stamens 50 or fewer; fruit $2-3 \mathrm{~cm}$. in diameter.

Fresh water swamps and water-holes, Vew Providence, Cat Island, Great Fxuma, Acklin's Island and Inagua :-Cuba to Haiti and St. Croix; South America. Referred to by Coker as C. ampla (DC.) Greene. Winte Water-LiLy.

\section{Family 2. RANUNCULÀCEAE Juss.}

\section{Crowfoot FAaIILY.}

Herbs, or rarely climbing shrubs, with acrid sap. Leaves alternate (except in Clematis and Atragene). Stipules usually none, but the base of the petiole often sheathing. Pubescence, when present, composed of simple hairs. Sepals 3-15, generally caducous, often petal-like, imbricate, except in Clematis and Atragene. Petals about the same number (occasionally more), or wanting. Stamens $\infty$, hypogynous, their anthers innate. Carpels os or rarely solitary. 1-celled, 1-many-ovuled. Ovules anatropous. Fruit achenes, follicles or berries. Seeds with endosperm. About 35 genera and 1100 species, distributed throughout the world, not abundant in the tropies.

\section{CLÉmAtis L. Sp. Pl. 543. 1753.}

Climbing vines or perennial herbs, more or less woody. Leaves opposite, slender-petioled, pinnately compound, lobed, or in some species entire. Sepals 4 or 5 , valvate in the bud, petaloid. Petals none. Stamens $\infty$. Pistils $\infty$. Achenes 1-seeded. Style long, persistent, plumose, silky or naked. [Greek name for some climbing plant.] About 25 species of very wide geographic distribution, most abundant in temperate regions. Type species: Clematis Titalba L.

1. Clematis bahàmica (Kuntze) Britton, Bull. N. Y. Bot. Gard. 4: 117. 1905.

Clematis dioica bahamica Kuntze, Verh. Bot. Ver. Prov. Brand. 26: 102. 1895.

Vine slender, trailing or high-climbing, the young plants sparingly and loosely pubescent. Leares trifoliolate or the uppermost simple; leaflets slenderstalkei, $4 \mathrm{~cm}$. long or less, varions in form eren on the same vine, ovate to oval or nearly orbicular, acute or obtuse and mucronulate at the apex, quite glabrous when mature, entire, or often 3-lobed, firm in texture and strongly reined on the under side; achenes plump, only $3 \mathrm{~mm}$. long, the filiform plumose style $3-5 \mathrm{~cm}$. long; flowers few, in small leafy-bracted panicles; pedicels loosely pubescent; sepals oblong-lanceolate, about $5 \mathrm{~mm}$. long, loosely pubescent, in a Mariguana specimen coherent and falling away as a cap.

Rocky thickets, pine-lands and sink-holes, Abaco, Great Bahama, Andros, Fleuthera, Cat Island, Great Exuma, and Mariguana. Endemic. Referied by Mrs. Northrop to $C$. dioica; by Hitcheock to $C$. flammulastrum, and by Dolley to $C$. Vitalba. BaHAMA VIRGIN'S-BOTER. 


\section{Family 3. ANNONẢCEAE DC.}

\section{Custard-apple Fajilly.}

Trees or shrubs, generally aromatic, with alternate entire leaves. Stipules none. Sepals 3 (rarely 2), ralvate or rarely imbricate. Petals about 6, arranged in 2 series. Stamens $\infty$; anthers adnate, extrorse. Carpels $\infty$, separate or coherent, mainly fleshy in fruit. Seeds large, anatropous: embryo minute: endosperm copious, wrinkled. About 46 penera and 550 species, mostly in the tropies, a few in the temperate zones.

\section{ANNÒNA L. Sp. Pl. 536. 1753.}

Mostly trees, with coriaceous or chartaceous leaves, and perfect, usually so!itary and axillary, nodding, peduncled flowers. Sepals 3, valvate, deciduous. Petals usually 6 , valvate, the 3 outer larger than the 3 inner. Receptacle hemispheric. Anther-sacs contiguous. Pistils borne at the top of the receptacle; oraries 1-ovuled; stigma sessile or nearly so. Fruit compound, aggregate, many-seeded; seeds arillate. [Name said to be derived from Malayan.] I'ifty species or more, of tropical and subtropical distribution. Type species: Annora muricata L.

Outer mptals broad, orate, the inner as Iong, or somewhat shorter; fruit smooth.

outer petals linear-oblong, the inner minute.

Fruit tubercled.

Fruit reticulated or areolate.

1. A. glabra

2. A. squamosit. 3. A. reticulatu.

\section{Annona glàbra L. Sp. Pl. 537. 1753.}

Annona palustris L. Sp. Pl. ed. 2, 757. 1762.

Anona laurifolia Dunal, Monogr. Anon. 65. 1817.

A tree, up to $12 \mathrm{~m}$. high, with a trunk 4 or $5 \mathrm{dm}$. in diameter, usually smaller, sometimes shrubby, the fissured bark reddish brown, the twigs glabrous. Leaves ovate to oblong, subcoriaceous, $8-18 \mathrm{~cm}$. long, acute or short-acuminate at the apex, usually rounded at the base, the petioles 1-4 cm. long: flowers solitary in the axils, nodring, short-peduncled, yellowish green, $2-3.5 \mathrm{~cm}$. long; sepals broader than long, slightly united; petals thick, concare, the onter a little larger than the inner; fruit ovoin, 6-13 $\mathrm{em}$. long, smooth, rounded at apex, impressed at base, yellowish brown; seeds $1-2 \mathrm{~cm}$. long.

londs and water-holes. Great lialuama, Andros, New Providoner, Cat Tsland, Watling's Island. Crooked Island:-Florida; West Indies; northern South America. Catesby, 2: $p l .6 \%, 6 \%$. POND-APPLE.

\section{Annona squamòsa L. Sp. Pl. 537. 1753.}

A tree, up to about $12 \mathrm{~m}$. high, the young twigs densely pubescent. Leares elliptic, lanceolate to oblong, chartaceous, 6-12 cm. long, pubescent, at least when young, sometimes glabrous when old, acnte at the apex, narrowed at the base, the petioles 5-12 $\mathrm{mm}$. long; perinneles about as long as the petioles; flowers greenish, about $2 \mathrm{~cm}$. Iong; sepals triangular, acute, pubescent, $1.5 \mathrm{~mm}$. long; outer petals linear-ohlong, puberulent; fruit globose, $5-9 \mathrm{~cm}$. in diameter, strongly tubercled, greenish, the tubercles rounder, the pulp white; sceds oblong, brown, shining.

Scrub-lands. New Providence, probably introduced:-Cuba to Virgin forda and St. Vincent; Jamaica; widely cultivated in troplcal regions. SugAR-AprLE. 
3. Annona reticulàta L. Sp. Pl. 537. 1753.

A small tree, sometimes $8 \mathrm{~m}$. kigh, usually smaller, the young twigs puberulent. Leares oblong, oblong-lanceolate, or narromly lanceolate, chartaceous, 8-15 cm. long, 2-4 cm. wide, puberulent when young, glabrous when old, acuminate at the apex, narrowed at the base, the rather stout petioles $2 \mathrm{~cm}$. long or less; peduncles longer than the petioles; flowers greenish, about $2 \mathrm{~cm}$. long; sepals triangular-orate, $2-3 \mathrm{~mm}$. long; outer petals narrowly oblong, puberulent; fruit globose, $8-12 \mathrm{~cm}$. in diameter, yellomish bromn, glabrous, coarsely reticulated, the pulp yellowish, the oblong, brown seeds shining.

Sink-holes, Great Bahama at Eight Mile Rocks:- West Indies. Widely cultlvated. Custard Apple. Catesby, 2: pl. 86.

\section{Familỹ 4. MENISPERMÀCEAE DC.}

\section{Mooxseed FaMiLY.}

Vines, shrubs or trees, with alternate leares, no stipules, and small dioecious panicled racemose or eymose flowers. Sepals 4-12. or fewer. Petals 6, imbricated in 2 rows, sometimes fewer, or none. Stamens about the same number as the petals or fetrer. Carpels $3-\infty$ (generally 6), 1ovuled, separate; styles commonly recurved. Fruit drupaceous. Embryo long. eurred. About 55 genera and 150 species, mainly of tropical distribution, a few extending into the temperate zones.

\section{CISSÁMPELOS L. Sp. PI. 1031. 1753.}

Slender vines, often high-climbing, the leaves broad, mostly entire and cordate, palmately reined, the staminate flowers cymose-paniculate, the pistillate clusters racemose, bracted. Staminate fiowers with 4 sepals, the petals united below into a cup, the 2-4 anthers sessile on the peltate top of the stamen-column. Pistillate flowers with a rudimentary seale-like perianth of 1 sepal and 1 petal and a single carpel with a 3-cleft or 3-toothed style. Drupe subglobose, convex; stone compressed, tubercled on the back, concave on both sides. [Greek, ivy-grape.] Perhaps 25 species, of tropical America and tropical and southern Africa. Type species: Cissampelos Pareira L.

\section{Cissampelos tomentòsa DC. Syst. 1: 535.1818.}

Climbing, often $5 \mathrm{~m}$. long or longer, the young branches, petioles, inflorescence and under leaf-surfaces densely tomentose. Leaves suborbicular, 2-10 $\mathrm{cm}$. broad, cordate or truncate at the base, not peltate, the petioles 1-7 $\mathrm{cm}$. long; racemes of pistillate flowers $5-8 \mathrm{~cm}$. long, the bracts orbicular, cordate or subcordate, $5-15 \mathrm{~mm}$. broad, the pedicels several at each bract, densely tomentose, about $2 \mathrm{~mm}$. long, the sepals about $1 \mathrm{~mm}$. long; panieles of staminate flowers $8 \mathrm{~cm}$. long or less, the flowers usually very numerous, about $1 \mathrm{~mm}$. broad, on filiform short pedicels.

Old fields and coppices, Andros, near Nicol's Town :-Cuba; Jamaica; Mexico and Central America, Veliety Cissasipelos. 
Family 5. LAURÀCEAE Lindl.

\section{Laurel Fanilr.}

Aromatic trees and shrubs, with alternate (very rarely opposite) mostly thick, punctate estipulate leaves. Flowers small, perfect, polygamous, dioecious, or sometimes monoecious, usually fragrant, yellow or greenish, in panicles, corymbs, racemes or umbels. Calyx 4-6-parted, the segments imbricated in 2 series in the bud. Corolla none. Stamens inserted in 3 or 4 series of 3 on the calyx, distinct, some of them commonly imperfect or reduced to staminodia; anthers opening by valves. Ovary superior, free from the calyx, 1-celled; orule solitary, anatropous, pendulous; stigma discoid or capitate. Fruit a 1-seeded drupe or berry. Endosperm none. Cotyledons plano-convex, accumbent. About 40 genera and 1000 species, widely distributed in tropical regions; a few in the temperate zones.

Staminodia of the fourth series small or none.

Staminodia of the fourth series large, sagittate.

1. OCOTEA

2. PERSEA.

1. OCOTĖA Aubl. Pl. Guian. 2: 780. 1775.

[NeCtandRA-Roland; Rottb. Deser. Pl. Surinam. 10. 1776.]

Evergreen trees, rarely shrubs, with alternate coriaceous leaves and small, perfect or polygamous flowers in axillary or terminal panicles. Perianthsegments 6 , nearly equal. Perfect stamens 9 , in 3 series; stamens of the first and second series eglandular, their anthers introrsely 4-celled; stamens of the third series with extrorsely 4-celled anthers; staminodia, representing a fourth series of stamens, are present in some species. Ovary wholly or partly enclosed by the perianth-tube; style short. Berry oblong to globose, partly enclosed by the enlarged perianth-tube. [Guiana name.] Probably 300 species, mostly natives of tropical Ameriea. Type species: Ocotea guianensis Aubl.

\section{Ocotea coriàcea (Sw.) Britton.}

Laurus coriacea $\mathrm{S} \pi$. Prodr. 65. 1788.

Laurus Catesbyana Michx. Fl. Bor. Am. 1: 244. 1803.

Nectandra coriacea Griseb. Fl. Br. W. I. 281. 1860.

Ocotea Catesbyana Sargent, Sylva 7: 11. 1595.

An evergreen tree, up to $12 \mathrm{~m}$. high, the trunk sometimes $3 \mathrm{dm}$. in diameter, the nearly smooth bark light gray, the twigs slender, glabrous, the wood brown. Leaves oblong or oblong-lanceolate, coriaceous, 6-15 em. long, acute or acuminate at the apex, narrowed at the base, dark green and shining above, dull beneath, glabrous or very nearly so, reticulate-reined, the petioles $5-15 \mathrm{~mm}$. long; panicles axillary, peduncled, puberulent, screral-many-flowered; pedicels 4-7 mm. long; calyx white, its 6 lobes oblong or ovate-oblong, obtuse, about $4 \mathrm{~mm}$. long; stamens shorter than the ealyx; drupe oval or subglobose, dark blue or nearly black, $10-18 \mathrm{~mm}$. long, the persistent red or yellow ealyx-base 3-4 mm. long.

Copplces and scrub-lands, Great Bahama, Andros, New Providence. Eleutlera. Cat Island, Watling's, Crooked Island and Sorth Caicos:- Florida: West Indies. Referred by Grisebach, Dolley, Mrs. Northrop and by Hitcheock to Ycetandra sau-

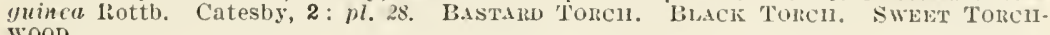
WOOD. 
2. PÉRSEA Gaertn. Fr. \& Sem. 3: 222. 1805.

Leares alternate, coriaceous, persistent, entire. Calyx 6-parted, persistent. Stamens 12, in 4 series of 3 , the inner series reduced to gland-like staminodia, the 3 other series anther-bearing, their anthers 4-celled, 4-valved, those of the third series extrorse and the others introrse in our species. Staminodia large, cordate, stalked. Fruit a berry. [Ancient name of some oriental tree.] About 50 species, natives of America. Type species: Persea gratissima Gaertn.

1. Persea pubéscens (Pursh) Sargent, Silva N. A. $7:$ T. 1895.

Tamala pubescens Small, Fl. SE. U. S. ed. 2, 822, 1375. 1913.

Laurus carolinensis pubescens Pursh, Fl. Am. Sept. 276. 1814.

A tree, with maximum height of about $14 \mathrm{~m}$. the trunk up to $3.5 \mathrm{dm}$. in diameter, the twigs densely short-pubescent, the thin bromn bark fissured. Leares lanceolate to oblong-lanceolate or oral, subcoriaceous, $0.5-2 \mathrm{dm}$. long, acute, obtuse or acuminate at the apex, narrowed at the base, glabrous, bright green and shining above, pale and pubescent beneath, the pubescent petioles $2 \mathrm{~cm}$. long or less; peduncles pubescent, shorter than the leares; pedicels rery short; inner sepals 5-6 mm. long, trice as long as the outer; filaments pubescent; drupe dark blue, glaucous, oral or subglobose, $8-15 \mathrm{~mm}$. in diameter. B.s.

Palmetto-lands, Great Bahama at Barnett's Point:-Virginia to Florida. RED

\section{Family' 6. CASSYTHÀCEAE Dumont.}

\section{Lore-Vixe FaMiLs.}

Tines, trailing, or parasitic by papillae on shrubs or on trees, the leaves none. or reduced to scales, the small regular and perfect flowers spicate, racemose, or capitate. Calyx 6-cleft, the lobes imbricated, in 2 series, the outer ones shorter than the inner. Corolla none. Perfect stamens 9, with 2-celled anthers; staminodes 3. Pistil 1; ovary 1-ovuled, becoming enclosed by the enlarging calyx-base; style simple; stigma small, mostly capitate. Fruit berry-like, fleshy. Only the following genus.

1. CASSṪTHA L. Sp. Pl. 35. 1753.

Characters of the family. About 15 known species, of tropical regions. [Srnonym of Cuscuta.] Type species: Cassytha filiformis L.

1. Cassytha americàna Nees. Syst. Laur. 644. 1836.

Cassytha filiformis Jacq. Sel. Amer. 115. 1763. Not L. 1753.

Slender, branched, often $5 \mathrm{~m}$. long or more, sometimes matted, yellow or yellowish green, the stems about $2 \mathrm{~mm}$. thick. Leares mere orate or lanceolate, acute scales 1-2 mm. long, few and distant; spikes peduncled, few-severalflowered, 1-2 cm. long; flowers white, about $2 \mathrm{~mm}$. broad, the inner sepals ovate, larger than the outer; fruit globose, white, $5-7 \mathrm{~mm}$. in diameter.

Coastal sand dunes and maritime rocks, throughout the archipelago from Abaco and Great Bahama south to Mariguana. Inagua and the Caicos and Anguilla Isles:Florida; West Indies; Mexico and continental tropical America. WoE-rrxe. 


\section{Order 11. PAPAVERÀLES.}

Mostly herbs, with clustered, regular and perfect flowers. Petals, with rery rare exceptions, present, separate. Sepals usually separate. Stamens hypogynons. Ovary superiol, free from the calyx, compound, composed of two united carpels, or more.

Sepals 2 (vers rarely 3 or 4 ): endosperm fleshr.

Fam. 1. PAPATERACEAE. Sepals or calyx-segments 4-8: endosperm none.

Capsule 2-celled by a longitudinal partition, usually 2-

valred. rarel $y$ indehiscent: sepals and petals 4.

Capsule 1-celled, of 2-6 carpels.

Style short or wanting: seeds wingless.

style elongated; seeds winged.

Fam. 2. BRASSICACEAE.

Fam. 3. Capparidaceae.

Fam. 4. Morisgaceae.

\section{Family 1. PAPAVERÀCEAE B. Juss.}

\section{Poppr Fajill.}

Herbs, witl milky or colored sap, and alternate leaves or the upper rarely opposite. Stipules none. Flowers perfect, regular. Sepals 2 (rarely 3 or 4 ), caducous. Petals $4-6$ or rarely more, imbricated, often wrinkled. deciduous. Stamens hypogynous, distinct: filaments filiform: anthers longitudinally dehiscent. Ovary 1, many-oruled. mainly 1-celled: style short; orules anatropous. Fruit a capsnle, generally dehiscent by a pore, or by ralves, rarely indehiscent. About 23 genera and 115 species, widely distributed, most abundant in the north temperate zone.

1. ARGEMÒNE L. Sp. Pl. 50S. 1753.

Glaucous herbs, with yellow sap, spiny-toothed leaves and large flowers. Sepals 2 or 3 . Petals 4-6. Stamens $\infty$. Placentae 1-6, many-oruled. Style very short. Stigma dilated, 3-6-radiate. Capsule prickly, oblong, dehiscent at the apex by valres. Seeds numerous, cancellate. [Greek, an eye disease, supposed to be relieved by the plant so called.] A genus of about 10 species, natives of the warmer parts of America. Type species: Argemone mexicana L.

\section{Argenone mexicàna L. Sp. Pl. 508. 1753.}

Stem 3-6 dm. high, spiny or sometimes nearly unarmed. Leaves sessile, clasping by a narrowed base, 1-2.5 dm. long, glaucous, runcinate-pinnatifid, spiny-toothed and more or less spiny on the reins; flowers orange or yellow, sessile or subsessile, $2-8 \mathrm{~cm}$. broal ; sepals acuminate, bristly-pointed; capsule $2.5 \mathrm{~cm}$. long or more; stigma sessile.

A weed of waste places near dwellings, throughout the archipelago from Great Pahama south to Grand Turk, Salt Car, Inagua:-Belmuda: southern Inited States: West Indies: continental tropical America; Old World tropies. 1)oxker THISTLE. MEXICAX POPPY.

\section{Family 2. BRASSICÀCEAE Lindl.}

\section{Mestarn Famili:}

Herbs, rarely somewhat woody, with watery acrid sap, alternats leares, and racemose or corrmbose flowers. Sepals 4, deciduous, or rarely persistent, the 2 outer narrow, the immer similar, or concare. or saceate 
at the base. Petals 4, hypogynous, cruciate, nearly equal, generally clawed. Stamens 6, rarely fewer, hypogynous, tetradynamous. Pistil 1. compound, consisting of 2 united carpels, the parietal placentae united by a dissepiment; style generally persistent. sometimes none; stigma discoid or usually more or less 2-lobed. Fruit a silique or silicle, generallv 2-celled, rarely 1-celled, in a few geenra indehiscent. Seeds attached to both sides of the septum; endosperm none: cotyledons incumbent, aceumbent or conduplicate. About 200 genera and is00 species, of wide geographic distribution.

Porl a silique or silicle, dehiscent into 2 valves.

Pod a flattened siltele.

Pod a short or long silique, not flattened.

1. Lepidium.

Flowers yellow; leaves lobed or toothed. Pod elongated, beaked.

por conic-beaked, its valves 1-3-nerred.

Pod stout-beaked, its ralves 3-5-nerved. Pod short, beakless.

Flowers white; leaves entire.

Fod indehiscent.

Pod suborbicular. didrmous.

Pod elongated, of 2 separating joints.
2. Brassica.
3. Sinapis.
4. Radicula.
5. Conringia.
f. Carara.
7. Cakile.

\section{LEPÍdiUM L. Sp. Pl. 643. 1753.}

Erect or rarely diffuse herbs, with pinnatifid lobed or entire leaves and racemose white or whitish flowers. Stamens often fewer than 6. Petals short, sometimes none. Silicles oblong to orbicular, flattened contrary to the partition, minged or wingless; ralres keeled, dehiscent. Seeds solitary in each cell, flattened; cotyledons incumbent or rarely aceumbent. [Greek, a little scale, from the flat scale-like pods.] About 65 species, widely distributed. Type srecies: Lepidium latifolium $\mathrm{L}$.

\section{Lepidium virgínicum L. Sp. Pl. 645. 1753.}

Annual, erect, glabrous. Basal leaves obovate or spatulate in outline, pinnatifid, generally with a large terminal lobe and numerous small lateral ones, all dentate, glabrous or slightly pubescent; stem-leaves lanceolate or oblong-linear, sessile, or the lower stalked; flowers 1-2 mm. broad, white; petals generally present, sometimes manting in the later flowers; pedicels slender, spreading, 4-6 $\mathrm{mm}$. long in fruit; pod flat, short-oval or orbicular, minutely winged above; cotyledons accumbent.

A weed of waste grounds and cultivated soils, throughout the archipelago from Abaco and Great Bahama to Andros, Turk's Islands. Ambergris Cay and Inagua :-Bermuda: native of continental North America: widely naturalized as a weed in the West Indies, Mexico and Central America. Wild Pepper-grass.

\section{BRÁSSICA L. Sp. Pl. 666.1753.}

Erect branching herbs, with pinnatifid basal leaves, and showy yellow. flotrers in elongated racemes. Siliques elongated, sessile, terete or 4-sided, tipped mith an indehiscent conic, usually 1-seeded beak. Valves convex, 1-3nerved. Seels in 1 row in cach cell, oblong, marginless; cotyledons conduplieate. [Latin name of the cabbage.] About 80 species, natives of Europe, Asia and northern Africa. Type species: Brassica oleracea L. 
1. Brassica integrifòlia (West) O. E. Sehulz, in Urban Symb. Ant. 3: 509. 1903.

Sinapis integrifolia West Bidr. St. Croix, 296. 1793.

Glabrous or sparingly pilose below, pale green, slightly glaucous, $8 \mathrm{dm}$. high or less. Basal and lowest cauline leaves broadly obovate, or ellipticobovate, coarsely dentate, obtuse, long-petioled, often 2-lobed near the base; upper leaves oblong to linear, few-toothed or entire, mostly acute, shortpetioled or sessile; racemes loosely sereral-many-flowered, erect; pedicels filiform, 6-12 mm. long; petals light yellow, 6-9 mm. long, broadly obovate, clated; pods erect-spreading, 3-4 cm. long, about $2 \mathrm{~mm}$. thick, the slender beak $4-7 \mathrm{~mm}$. long.

Cultivated soil. New Providence; Great Exuma at Georgetown :-Porto Rico to St. Jan and Trinidad; Tamaica: Yucatan; natice of Asia. Recolded by Dolley as Sinapis brassicata I. WILD MestaRD.

\section{SINÀPIS L. Sp. Pl. 668. 1753.}

Annual or biennial, usually erect, branching more or less hispid herbs, with pinnatifid or lobed leaves, and rather large, mostly yellow flowers in terninal racemes. Siliques linear, nearly terete, constricted between the seeds, sessile in the calyx, tipped with a flat sword-like beak which sometimes contains a seed near its base, its valves 3-5-nerved. Seeds oblong or subglobose, not winged nor margined. Cotyledons conduplicate. [Name Greek, said to ccme from the Celtic for turnip.] About 5 species, natives of southern Europe. Type species: Sinapis alba L.

1. Sinapis arvênsis L. Sp. Pl. 668. 1753.

Brassica Sinapistrum Boiss. Toy. Esp. 2: $39 . \quad$ 1839-45.

Erect, 3-6 dm. high, hispid with seattered stiff hairs, or glabrate. Leares oblong to elliptic, dentate, denticulate or subpinnatifid; flowers 1-1.6 cm. broad; pedicels stout; pods glabrous, spreading or ascending, sonewhat constricted between the seeds, 1-1.6 $\mathrm{cm}$. long, $2 \mathrm{~mm}$. wide, tipped with a flattened elongatedconic often 1 -seeded beak $10-12 \mathrm{~mm}$. long, the valres strongly nerved.

Taste grounds near Nassau. New Providence. Native of Europe: naturalized Ill continental North America and also in Bermuda and Jamaica. Cnimlock.

\section{RAdículA Hill, Brit. Herb. 264. 1756.}

Branching herbs, with simple or pinnate, lobed dissected or rarely entire leaves, and small yellow flowers. Sepals spreading. Stamens 1-6. Pods short, terete or nearly so. Stipe none. Talves nerveless or 1-nerved. Style short or slender. Stigma 2-lobed or nearly entire. Seeds turgicl, minute, in 2 rows in each cell or very rarely in 1 row. Cotyledons accumbent. [Name Latin, diminutive of radix, root.] About 50 species, of wide geographie distribution, most abundant in the north temperate zone. Type species: Sisymbrium amphibium L. 
1. Radicula brévipes (DC.) Britton, Torreya 6: 30. 1906.

Nasturtium palustre brevipes DC. Syst. 2: 192. 1821.

Nasturtium brevipes Griseb. Mem. Amer. Acad. II. 8: 154. 1860.

Annual, glabrous or sparingly pubescent below, branched from the base, the branches usually prostrate or nearly so, sleuder, $3 \mathrm{dm}$. long or less. Leaves pinnately divided into several or numerous, oblong, ovate or suborbicular dentate segments, or the upper segments coufluent; racemes several-manyflowererl, 6-12 cm. long; pedicels about $1 \mathrm{~mm}$. long; flowers about $1.5 \mathrm{~mm}$. long; petals minute or wanting; porls linear, 7-12 mm. long, about $1.5 \mathrm{~mm}$. wide.

Sink-holes, Andros, near Fresh Creek:-Cuba, Hispaniola, Porto Rico. The Andros specimens show foliage only and are referred to this species with hesitation. SHORT-STALKED YELLOW-CRESS.

\section{CONRÍNGIA [Heist.] Ailans. Fam. Pl. 2: 418. 1763.}

An erect glabrous annual herb, with elliptic or ovate entire leaves, sessile and cordate at the base, and middle-sized yellowish white flowers in terminal racemes. Sepals and petals narrow. Style 2-lobed or entire. Siliques elongated-linear, angled, the valres firm, 1-3-nerved. Seeds in 1 row in each cell, oblong, marginless; cotyledons incumbent. [In honor of Hermann Conring, 1606-1681, Professor at Helmstält.] About 7 species, natives of Europe and Asia, the following typical.

\section{Conringia orientàlis (L.) Dumort. F'. Belg. 123. 1827.}

Brassica orientalis L. Sp. Pl. 666. 1753.

Stem 3-9 dm. high. Leaves light green, obtuse, $5-13 \mathrm{~cm}$. long; racemes elongating in fruit; pedicels $\delta-16 \mathrm{~mm}$. long; petals about $1.2 \mathrm{~cm}$. long, nearly twice as long as the sepals; pods $7-13 \mathrm{~cm}$. long, about $2 \mathrm{~mm}$. wide, 4-angled, spreading.

Waste grounds, New Provdence, 1916. Tidely distributed as a weed in temperate North America; introduced from the old World. HaRE's-EAR.

6. CARÀRA Medic. Pflg. 1: 34. 1792.

[Coronopus Gaertn. Fr. \& Sem. 2: 293. 1791. Not Mill. 1754.]

Annual or biennial, diffuse herbs, with mostly pinnatifid leaves, and small whitish flowers. Silicles small, didymous, laterally compressed, sessile. Stamens often only 2 or 4 . Talves of the capsule oblong or subglobose, obtuse at each end, indehiscent, falling away from the septum at maturity. Seeds 1 in edch cell; cotyledons narrow, incumbent or conduplicate. [Greek, crow-foot, trom the shape of the leaves.] About 6 species, of wide distribution. Type opecies: Cochlearia Coronopus L.

1. Carara didyma (L.) Britton, in Britton \& Brown, Ill. Fl. ed. 2, 2: 167. 1913.

Lepidium didymum L. Mant. 92. 1767.

Coronopus didymus J. E. Smith, Fl. Brit. 2: 691. 1800.

Tufted, spreading on the ground, sparingly pubescent. Stems $0.5-4 \mathrm{dm}$. long; leares deeply 1-2-pinnatifid; flowers white, racemose; pedicels slender, 2-3 mm. long in fruit; pod about $2 \mathrm{~mm}$. broad and slightly more than $1 \mathrm{~mm}$. high; valves obtuse at each end and readily separating into 2 ovoid nutlets.

Streets and waste grounds, New Providence. Elenthera:-Bermuda; southern [nited States: Antigua: Martinique: South America; widely distributed in the Old World. Star-of-THE-EArTh. 
7. CAKILE [Tourn.] Mill. Gard. Dict. Abr. ed. 4. 175t.

Annual glabrous fleshy herbs, with purplish or white flowers. Siliques elongated, sessile, flattened or ridged, indehiscent, 2-jointed, the joints 1-celled and usually 1-seeded. Style none; cotyledons accumbent. [Old Arabic name.] A genus of about 3 species, natives of sea and lake shores of Europe and North America. Type species: Bunias Cakile L.

1. Cakile lanceolàta (Willd.) O. E. Schulz, in Urban, Symb. Ant. 3: 504.1903.

Raphanus lanceolatus Willd. Sp. Pl. 3: 562. 1801.

Cakile aequalis L'Her. DC. Syst. 2: 430. 1821.

Erect or ascending, often much branched, $8 \mathrm{dm}$. high or less. Basal and lower leaves broadly oblong, obtuse, $5-5 \mathrm{~cm}$. long, coarsely crenate-dentate; upper leares smaller, narrowly obovate to oblong, crenate-dentate or entire; flowers pale purplish, $6-10 \mathrm{~mm}$. broad; fruiting racemes often $3 \mathrm{dm}$. long; fruiting pedicels stout, ascending, 4-6 mm. long; pod $1.5-2.5 \mathrm{~cm}$. long, its upper joint $1 \frac{1}{2}-1$ times as long as the lower.

Maritime sands and white-lands, Abaco and Great Bahama southward throughout the arehipelago to Salt Car (Grand Turk). Inagua, the Anguilla Isles and Water Cay:-Bermuda; southern Lnited States; the liest Indies and northern South america. Southeri Sea-rocket. Galdexa. Porli Bush.

\section{Family 3. CAPPARIDÀCEAF Lindl.}

\section{Caper Fajily.}

Herbs or shrubs (rarely trees), with alternate or very rarely opposite leaves, and regular or irregular, mostly perfect flowers. Sepals 4-S. Petals 4 (rarely none). Receptacle elongated or short. Stamens $4 \infty$, not tetradyuamous. inserted on the receptacle; anthers oblong. Style generally short; orules $\infty$, on parietal placentae. Fruit a capsule, or indehiscent, or irregularly rupturing. Seeds varions; endosperm none; embryo generally coiled. Abont 35 genera and 450 species, mostly of warm regions.

IIerbs : fruit a longitudinally dehiscent capsule.

shrubs and trees; fruit indehiscent or irregularly rupturing.

1. Clrome.

2. Cappuris.

1. CLEÒME L. Sp. Pl. 671. 1753.

Herbs or low shrubs. Leares digitately 3-5-foliolate, or simple. Flowers mostly racemose. Calyx 4 -divided or of 4 sepals, often persistent. Petals 4 , cruciate, nearly equal, entire, more or less clawed. Receptacle short, slightly prolonged abore the petal-bases. Stamens 6 (rarely 4 ), inserted on the receptaclc. Ovary stalked, with a gland at its base. Capsule elongated, manyseeded. [Derivation uncertain.] About 75 species, mainly natives of tropical legions, especially American and African. Type species: Cleome gynandra L.

1. Cleome gynándra L. Sp. Pl. 671. 1753.

Cleome pentaphylla L. Sp. Pl. ex. 2, 935. 1763.

Pedicellaria pentaphylla Schrank: Roem. \& Ust. Mag. Bot. 8: 11. 1790. Gynandropsis pentaphylla DC. Prod. 1: 23S. 1824.

Annual, bright green, clammy-pubescent. Stem 5-10 dm. tall, branching; leaf-blades palmately 3-5-foliolate; petioles longer than the leaflets; leaflets 
2-6 cm. long, oval to obovate, acute or short-acuminate, serrulate; racemes 1-4 dm. long; bracts suborbicular, oval or broadly obovate; sepals lanceolate, 4-5 $\mathrm{mm}$. long, acuminate; petals white or pink, 5-10 $\mathrm{mm}$. long; blades suborbicular, longer than the claws; stamens 6 ; eapsules linear, 4-6 $\mathrm{cm}$. long, surpassing the glandular pedicel in length; seeds $1-5 \mathrm{~mm}$. broad, coarsely rugose and muricate.

Waste and cultivated lands, New Providence at Grant's Town:-Bermuda; southern Inited States; West Indies and tropical continental America. Native of the Old World tropics. SAall SPIDER-FLOWEn.

\section{CÁPPARIS L. Sp. Pl. 503. 1753.}

Trees or shrubs, with simple, mostly coriaceous leaves, sometimes stipulate on young or barren shoots, and large corymbose, mostly white flowers. Sepals 4, distinct or partly united, often with a gland at the base. Petals 4, distinct, imbricated. Stamens several or usually many, the filaments filiform, the anthers short. Ovary stalked, 1-4-celled; ovules few or many, usually on 2 parietal placentae; style none; stigma depressed. Fruit elongated-linear, or oblong, or short and subglobose, indehiscent, or irregularly rupturing. Seeds without endosperm; embryo convolute; cotyledons fleshy. [From the Greek name of the Caper-tree, Capparis spinosa L., of Europe.] About 150 species, natives of tropical and subtropical regions. Type species: Capparis spinosa L.

Leaves densely scaly beneath. Leares glabrous.
1. C. cynophallophora. 2. C. Alexuosa.

\section{Capparis cynophallóphora L. Sp. Pl. 504. 1753.}

Capparis jamaicensis Jacq. Enum. 23. 1760.

A shrub or a tree up to about $15 \mathrm{~m}$. high, with a trunk diameter reaching 2 or $3 \mathrm{dm}$., the bark brown, furrowed, the slender, angular twigs densely scaly. Leaves elliptic or oblong, coriaceous, 4-12 cm. long, 2-6 cm. wide, or those of shoots narrowly linear, sometimes $3 \mathrm{dm}$. long and only $5-10 \mathrm{~mm}$. wide, acute obtuse or emarginate at the apex, narrowed at the base, glabrous and shining above, densely silvery-scaly and with the lateral venation obsolete beneath, the scaly petioles $1-3 \mathrm{~cm}$. long; corymbs few-several-flowered; pedicels stout, scaly, 0.5-3 cm. long; flowers fragrant; flower-bud 4-angled; sepals distinct, valvate, 8-12 mm. long, densely scaly, reflexed, nearly as long as the white petals; stamens numerous, purplish, 2-3 times as long as the petals, the anthers yellow; fruit narromly linear, torulose, drooping, $8 \mathrm{~cm} .-4 \mathrm{dm}$. long, 6-8 mm. thick, irregularly rupturing, scarcely fleshy, often much longer than the gynophore.

Scrub-lands and thickets, Andros, Long Island, Cat Island, Watling's, Atwood Cay, Acklin's, Fortune, Crooked, Mariguana, Caicos and Inagua:-Florida; Cuba to Tortola and Barbadoes; Jamaica. BLACE WILLOW.

2. Capparis flexuòsa L. Sp. Pl. ed. 2, 722. 1762.

Capparis cynophallophora L. Syst. ed. 10, 1071. 1759.

A glabrous shrub, or a tree up to $8 \mathrm{~m}$. high, with a trunk $2 \mathrm{dm}$. in diameter, the bark bromn, the branches slender, sometimes vine-like. Leaves elliptic to oblong, lanceolate to linear, coriaceous, 4-9 $\mathrm{cm}$. long, obtuse, emarginate or sometimes acute at the apex, obtuse or narromed at the base, reticulate-reined on both sides, the rather stout petioles 2-6 $\mathrm{mm}$. broad, with a small sessile, oblong or subglobose gland in the axil; corymbs few-flowered; pedicels stout, $12 \mathrm{~mm}$. long or less; flowers fragrant; sepals suborbicular, $5-8 \mathrm{~mm}$. broad, slightly united at the base, the outer a little smaller than the inner; petals white to rose, obovate, $1.5-2 \mathrm{~cm}$. long; stamens numerous, about 3 times as long 
as the petals, the filaments white; fruit long-linear, 6-20 cm. long, 1-1.5 $\mathrm{cm}$. thick, more or less torulose, about twice as long as the slender gynophore, tardily opening longitudinally, its pulp scarlet.

Scrub-lands and thickets, Andros, Exuma Chain, Long and Acklin's Island:Florida; Cuba to Virgiu Gorda and Barbadoes; continental tropical America. CAPER-TIEE.

Crataeva Tapia L., reported by Dolley, we have been unable to find in the archipelago. It is native of Jamaica, Martinlque and of tropical continental America, and is unlikely to have been found in the Bahamas, unless planted.

\section{Family 4. MORINGÀCEAE Dumort.}

\section{HorSERADISH-TREE FAMILT.}

Trees with alternate, 2-3-pinnate, deciduous leaves, and perfect, slightly irregular flowers in large axillary panicles. Sepals 5, unequal, imbricated, reflexed or spreading, slightly united at the base. Petals 5, somewhat unequal, the lower one reflexed. Stamens 5, with slender fllaments and 1-celled anthers, alternating with as many staminodia. Orary 1-celled, with 3 parietal placentae, bearing numerous pendulous ovules; style slender; stigma minute. Capsule elongated, angled, beaked, 3-valved. Seeds 3winged or wingless; endosperm none; embryo straight, the cotyledons large. Only the following genus.

\section{MORINGA Adans. Fam. Pl. 2: 318. 1763.}

Characters of the family. [Malabar name.] Three known species, natives of Asia and Africa, the following typical.

1. Moringa Moringa (L.) Millsp. Field Mus. Bot. 1: 490. 1902.

Guilandina Moringa L. Sp. Pl. 381. 1753.

Moringa pterygosperma Gaertn. Fr. \& Sem. 2: 314. 1791.

A tree, up to $9 \mathrm{~m}$. high, the bark corky, rough, the puberulent twigs slender. Leaves 3-6 dm. long, their segments and leaflets opposite; leaflets numerous, thin, oblong to obovate, 1-2 cm. long, obtusé, entire; flowers numerous, fragrant; pedicels 5-10 mm. long; sepals linear to linear-oblong, 9-13 mm. long, reflexed; petals nearly white, a little larger than the sepals; capsule linear, 3 -angled, pendulous, $2-4.5 \mathrm{dm}$. long, $1-2 \mathrm{~cm}$. thick; seeds winged, $2.5-3 \mathrm{~cm}$. long.

Thickets, spontaneous after cultivation, New Providence, near Nassau; Grand Turk:-Florida: West Indies; Mexico to Panama. Native of the East Indies. IIORSERADISH-TREE.

\section{Order 12. ROSÀLES.}

Herbs, shrubs or trees, the flowers usually petaliferous and the petals distinct. Stamens mostly perigynous or epigynous. Sepals mainly united or confluent with the concare receptacle. Carpels one or more, distinct or sometimes united into a compound ovary.

Endosperm copious, fleshy" leaves withont stipules.

Endosperm little or none: leaves witl stipules.

Flowers regular.

Ovary 2-ovnled; frult a drupe: leaves simple.

Ovary several-oruled; frult a legume; leares compound.

Flowers irregular: fruit a legume or a loment.

toper petal enclosed by the lateral ones in the but. Lpper petal enclosing the lateral ones in the bud. Fam. 5. Fabicear.

Fam. 1. Crasstilacele.

Fam. 2. AMrgdalcese.

Fam. 3. Mros.ıce.se.

Fam. 4. CAESALPIXICEAE. 


\section{Family 1. CRASSULÀCEAE DC.}

\section{Orpine Fajille.}

Herbs, or somewhat shrubby rilants, mostly fleshy or sueeulent, with cymose or rarely solitary regular or symmetrical flowers. Stipules none. Calyx persistent, free from the ovary or ovaries, 4-toothed or 4-parted in our species. Petals or eorolla-lobes equal in number to the calys-lobes or calyx-segments, usually persistent, rarely wanting. Stamens of the same number or twice as many as the petals or corolla-lobes; anthers longitudinally dehiscent. Receptacle with a seale at the base of each carpel. Carpels equal in number to the sepals or ealyx-lobes, distinct, or united below; styles subulate or filiform; ovules numerous, arranged in 2 rows along the rentral suture. Follicles 1-celled, dehiscent along the rentral suture. Seeds minute; endosperm fleshy; embryo terete; cotyledons short. About 30 genera and 600 species, of wide geographic distribution.

Calyx inflated, 4-toothed. Calyx 4-parted.

1. Bryophyllum. 2. Kalanchoë.

\section{BRYOPHX́YLLUM Salisb. Par. Lond. pl. 3. 1805.}

Upright herbs. Leaves opposite, simple or pinnately compound, the leaflets mostly toothed. Flowers perfect, often showy, nodding, in cymes or panicles opposite the branches. Calyx inflated, 4-toothed. Corolla nearly campanulate, or urn-shaped, the narrow limb with 4 spreading lobes. Stamens $\delta$, in 2 series, adnate to about the middle of the corolla-tube; filaments filiform; anthers mostly exserted. Carpels 4, distinct or partially united. Orules many. Follicles 4. Seeds numerous. [Greek, sprouting leaf.] Four known species of South Africa, Asia and Madagasear, the following typical.

1. Bryophyllum pinnàtum (Lam.) Kurz, Jour. Asiat. Soc. Beng. 402: 52. 1871.

Cotyledon pinnata Lam. Eneje. 2: 141. 1786.

Bryophyllum calycinum Salisb. Par. Lond. pl. 3. 1805.

Perennial, fleshy, glabrous. Stamens 4-15 dm. tall, branched; leaf-blades often pinnately compound, 1-3 dm. long; leafiets oblong, oval or elliptic, obtuse, erenate, the terminal one several times longer than the lateral ones; panicles 1-4 dm. long, conspicuous; calyx bladder-like, finally oblong-campanulate, 3-3.5 cm. long, glabrous; corolla reddish, twice as long as the calyx or shorter, its lobes lanceolate or narrowly ovate, acute.

Waste grounds near old dwellings, throughout the archipelago from Great Bahama southward to Long Island:-Bermuda; Florida; Test Indies; Mexico. Probably a native of Asia. Life Plaxt.

\section{KALANCHÒ̈̈ Adans. Fam. Pl. 2: 248. 1763.}

Frect herbs, sometimes a little woody, with opposite leaves and panicled flowers, often showy. Calyx 4-parted, shorter than the corolla. Corolla salverform, with a swollen tube and a spreading, 4-parted limb. Stamens usually 8, in 2 series on the corolla-tube, the filaments very short. Carpels 4, lanceolate, adnate to the base of the corolla-tube; ovules many. Follicles many-seeded. [Chinese name.] Twenty species or more, all but the following natives of Asia and Africa. Type species: Cotyledon laciniata L. 
1. Kalanchoë brasiliénsis Camb. in St. Hil. Fl. Bras. Mer. 2: 196. 1829.

Herbaceous, perennial, 3-10 dm. high, glandular-pubescent abore. Leares orate to obovate, short-petioled, $5-10 \mathrm{~cm}$. long, faintly pinnately reined, crenate-dentate, or the upper pairs lanceolate, much smaller and entire; inflorescence 1-3 dm. long, eymose-paniculate, its branches nearly erect, the bracts very small; flowers yellow, $12-16 \mathrm{~mm}$. long; sepals lanceolate, glandular-pubescent, acute; corolla-tube $2-3$ times as long as the calyx, the limb spreading; stamens borne on the corolla-tube a little above the middle, not exserted; follicles about $6 \mathrm{~mm}$. long, the brown seeds oblong.

Spontaneous after cultivation, pine-lands near Deep Creek, Andros :- Naturalized in Cuba and in the Virgin Islands. Native of IBazil. Brizilis KAlascrue.

\section{Family 2. AMYGDALACEAE Relib.}

\section{PLUMI FAMILY.}

Trees or shrubs, the bark exuding gum, the foliage, bark and seeds often containing prussic acid, bitter. Leaves alternate, petioled, serrate, the small stipules early deciduous, the teeth and petiole often glandular. Flowers regular, mostly perfect. Calyx inferior, deciduons, free from the ovary, 5-lobed. Disk annular. Calyx-lobes imbricated in the bud. Petals 5, inserted on the calyx. Stamens numerons, inserted with the petals. Pistil 1 in our genera; ovary 1-celled, 2-oruled; style simple: stigma mostly small and capitate. Fruit a drupe. Seed 1, suspended; endosperm none; cotyledons fleshy. About 10 genera and 120 species, widely dis. tributed. most abundant in the north temperate zone.

Style terminal.

Style basal or lateral.
1. Laurocerasus.

i. Chrysobalanus.

1. LAURocérasus Roem. Syn. Mon. 3: \$9. 1947.

Evergreen trees or shrubs, with coriaceous or subcoriaceous leares and small flowers in axillary racemes. Calyx 5-lobed, the lobes deciduous. Petals 5 , white, deciduous. Stamens $15-30$, the filaments slender. Orary sessile; ornles pendulous; style terminal. Drupe subglobose, 1-seeded, the flesh thin, not pulpy. [Laurel-cherry.] About 20 species, of temperate and tropical regions. Type species: Prunus Laurocerasus L.

1. Laurocerasus myrtifòlia (L.) Britton, N. A. Trees, 510. 1908.

Celastrus myrtifolius L. Sp. Pl. 196. 1753.

Prunus sphaerocarpa Sw. Prodr. S0. 17 S8.

Prunus myrtifolia Urban, Symb. Ant. 5: 93.1904.

A tree attaining a maximum height of about $12 \mathrm{~m}$. with a trunk up to $4 \mathrm{dm}$. thick, the nearly smooth bark reddish brown. Leares subcoriaceous, elliptic or elliptic-ovate, $5-10 \mathrm{~cm}$. long, acute, bluntish, or acuminate at the apex, narromed or obtuse at the base, glabrons, shining above, dull beneath, entire-margined, the petioles about $1 \mathrm{~cm}$. long; racemes mostly shorter than the leaves, rather densely flowered; perlicels 4-12 mm. long; ealyx-lobes toothed; petals broadly obovate, much longer than the calyx; stamens about as long as the petals; drupes globose, $9-12 \mathrm{~mm}$. in diameter, orange-brown.

In copnices, Great Iiahama and New Provldence:-Florida ; Cuba : IIspaniola : Jamaica. WEST IXDAN LAUREL-CHEnT. 


\section{CHRYSOBALÀNUS L. Sp. Pl. 513. 1753.}

Trees or shrubs, with coriaceous, entire or undulate-margined leaves, and small, white or greenish, perfect flowers in terminal or axillary cymes or panicles. Calyx with a campanulate or turbinate tube and a 5 -lobed limb, the lobes imbricated, nearly equal. Petals 5, deciduous. Stamens numerous, with slender filaments. Orary inferior, sessile, 1-celled; ovules 2, erect; style filiform, basal or lateral. Drupe pulpy, with a hard 5-6-ridged stone. [Greek, golden date.] About 3 species, 2 of them American, the other African. Type species:- Chrysobalanus Icaco L.

Fruit oval or globose: petals cuneate.

Fruit obovoid; petals spatulate.
1. C. Icaco.

2. c. pellocarpus.

1. Chrysobalanus Icàco L. Sp. Pl. 513. 1753.

An evergreen tree or shrub, attaining a maximum height of about $10 \mathrm{~m}$, with a trunk sometimes $3 \mathrm{dm}$. in diameter, the thin bark brownish, the twig glabrous or nearly so, reddish brown. Leaves elliptic to obovate or nearly orbicular, 4-8 $\mathrm{cm}$. long, glabrous, rounded, obtuse or enarginate at the apex, narrowed at the base, dark green and shining above, dull beneath, the petioles short, stout; cymes peduncled, several-many-flowered, shorter than the leaves; calyx pubescent, its lobes triangular-ovate, acute, about $2.5 \mathrm{~mm}$. long; petals white, cuneate-spatulate, twice as long as the calyx-lobes; drupes various, globose or oval, pink, white or purple, $2-4 \mathrm{~cm}$. long.

Coastal thickets and woodlands and especially on the borders of swamps. Great Bahama, Andros, New Providence, Rose Island, Great Guana, Great Exuma, Eleuthera, Cat Island. Watling's, Crooked Island, Inagua, Dellis' Cay (Caicos) and Ambergris Cay (Turk's Islands):-Florida; West Indies; Mexico to northern continental South America; tropical Africa. Ponk-Fat Apple. Coco Plux. Catesby, 1: pl. 25 .

2. Chrysobalanus pellocárpus G. F. W. Meyer, Prim. Fl. Esseq. 193. 1818.

Chrysobalanus Icaco pellocarpus DC. Prodr. 2: 525. 1825.

Sinilar to the preceding species, but not attaining as large size, usually a shrub $2 \mathrm{~m}$. high or less, sometimes a small tree. Leaves usually smaller, $6 \mathrm{~cm}$. long or less, rounded or abruptly acute at the apex; cymes shorter than the leaves; petals spatulate; drupe mostly obovoid, or oblong-obovoid, $1.5-2 \mathrm{~cm}$. long, purple.

Borders of swamps, Great Bahama, Andros, New Providence and Great Exuma:-Florida; Cuba to Porto Rico; Guadeloupe; South America. Probably a race of $C$. Icaco.

\section{Family 3. MIMOS̀ACEAE Rehb.}

\section{Minosa Famili.}

Herbs, shrubs or trees, with alternate, commonly 2-3-pinnate leares, the stipules varions, and small regular mostly perfect flowers in heads, spikes or racemes. Calvx 3-6-toothed or 3-6-lobed, the teeth or lobes mostly valvate in the bud. Corolla of as many distinct or united petals, also valvate. Stamens distinct, or monadelphous. Ovary 1-celled; style simple. Fruit a legume. Seeds withont endosperm; cotyledons fleshy. About 40 genera and 1500 species, mostly tropical.

A. Stamens numerous, at least more than 10.

Stamens united below into a tube. Pods not elastically dehiscent. 
Valres of the pod not separating from the continuous margln.

Valves of the pod thick, coiling in dehiscence in our species.

Valves o1 the pod flat and papery.

Valves of the pod separating from the contlnuous margins.

Pods elastically dehiscent from the base.

Stamens distinet.

Seeds in one row ; ovary stipitate.

Seeds in two rows; ovaly sessile.

B. Stamens only as many or twice as many as the corollasegments.

Anthers without glands.

Vilves of the pod seiarating from the continuous margin.

Valves of the pod not separating from the margins.

Shrubs or trees: seeds transverse.

Herbs; seeds longitudinal or oblique.

Anthers tipped by glands (at least in the bud).

Herbs: Howers capitate: pods flat.

Trees; Howers spicate; pods nearly terete.

1. Pithecolobium.

‥ Albizaia.

3. Lysiloma.

4. Annesliti.

5. Acacia.

6. Vachellia.

\section{PIthecolòbiUm Mart. Hort. Monac. 188. 1829.}

Shrubs or trees, often spiny, with 2-pinnate leaves, and small, mostly per fect flowers in heads or spikes. Calyx 5-6-toothed. Corolla 5-6-lobed. Stamens many, long-exserted, the filaments partly united into a tube, the anthers small. Orary sereral-many-ovuled; style slender; stigma small, capitate. Pods flattened, mostly contorted or curved, 2-valved. Seeds mostly arillate. [Greek, referring to the contorted pods of the typical species.] Perhaps 100 srecies, widely distributed in tropical and subtropical regions. Type species: Mimosa Unguis-cati L. The original spelling of the genus is Pithecellobium.

Pinnae with 1 or 2 pairs of leaflets.

Leaflets 1-6 cm.-long or longer.

Leaflets chartaceous; petioles of at least the lower leaves longer than the petiolules.

Leaflets coriaceous; petioles shorter than the petiolules or as long.

Petioles and petiolules stout, thick, the petiolules

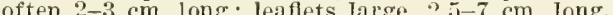

Petioles and petiolules slenter, 2-5 mm. long; leaflets $1-3 \mathrm{~cm}$. long.

Leaflets strongly spinulose-mucronate; shrub or small tree with erect branches.

Leaflets rounded, or merely mucronulate; low shrubs witl divergent branches.

Leaflets $2-8 \mathrm{~mm}$. long; petioles $6 \mathrm{~mm}$. long or less.

Pinnae with $3-6$ pairs of leaflets.

1. 1'. Enguis-cati.

2. I'. guadalupensc.

3. I. mucronatum.

4. I. bahamensc.

5. I'. Hystrix.

6. $10^{\circ}$. discolor:

\section{Pithecolobium Únguis-cáti (L.) Mart. Hort. Monac. 18s. 1829.}

Mimosa Unguis-cati L. Sp. Pl. 517. 1753.

Pithecolobium flavovirens Britton, Bull. N. Y. Bot. Gard. 3: 442. 1905.

A shrub up to $6 \mathrm{~m}$. high, rarely a small tree $8 \mathrm{~m}$. high, usually armed with stipular spines $2 \mathrm{~cm}$. long or less, the foliage glabrous. Petiole $5-20 \mathrm{~mm}$. long, bearing a round gland at the summit; pinnae ", each with one pair of obliquely obovate or oblong, obtuse, thin leaflets, 1-5 cm. long; heads slender-peduncled, in terminal racemes; flowers sessile; calyx about $2 \mathrm{~mm}$. long; corolla $5-6 \mathrm{~mm}$. long; stamens 10-15 mm. long, yellowish or pinkish; poil coiled or eurved, red, compressed, somewhat constricted between the seeds, $5-10 \mathrm{~cm}$. long, about 7 mm. wide; sceds nearly black, shining, 4-6 mm. broad.

Scrub-lands, Watling's Island, Acklin's Island, Mariguana Gleand Turk and Inagua :-Florida : West Indies; Yucatan: nortlern South Amerlea. CaT"S-CLAW.

The characters thought to dlfferentlate $P$. Alrovircns speclfically do not seem constant, since specimens from other lslands ohtalned during subsequent exploration appear to connect them with those of $P$. Cnguis-cati. 
2. Pithecolobium guadalupénse Chapm. Fl. S. U. S. 116. 1860.

Pithecolobium keyense Britton; Coker, in Shattuck, Bah. Isl. 255. Hyponym. 1905.

A usually unarmed shrub or small tree, sometimes $6 \mathrm{~m}$. high with a trunk up to $1.5 \mathrm{dm}$. in diameter, the bark gray, slightly fissured, the twigs and leares glabrous. Petioles $2-3 \mathrm{~cm}$. long, bearing a rouni gland at the summit; pinnae 2 , stalked, each bearing a single pair (rarely 2 pairs) of sessile leaflets, which are obliquely obovate or nearly orbicular, firm in texture, $3-7 \mathrm{~cm}$. long, rounded or notched at the apex, or rarely short-pointed, the margins somenhat revolute; peduncles slender, glabrous, as long as the leaves or shorter, sometimes panieled; flowering heads $2-3 \mathrm{~cm}$. in diameter; calyx about $1.5 \mathrm{~mm}$. long, 5-toothed; corolla about $3 \mathrm{~mm}$. long; stamens pink, about 3 times as long as the corolla; ovary pubescent; por coiled or much eurved, brown, 6-15 cm. long, 8-10 mm. broad; seeds black, shining.

Coppices and scrub-lands, throughout the archipelago from Abaco and Andros to Mariguana, Caicos, Inagua and the Anguilla Isles:-Florida; Cuba. BLACK-LEAD. RAM'S-HORx,

\section{Pithecolobium mucronàtum Britton; Coker, in Shattuck, Bah. Isl. 254.} 1905.

A shrub, about $2 \mathrm{~m}$. high, the young twigs and peduncles sparingly pubescent. Petiole $1 \mathrm{~cm}$. long or less, longer than or equalling the stiff sharp stipular spines, the gland stout-stalked; pinnae a single pair, stalked, each bearing a single pair of leaffets, which are coriaceous, rather narrowly obovate, 1-2 cm. long, glabrous, bright green and shining above, dull beneath, the midvein excurrent; peduncles much longer than the upper leaves; flowering heads about $1.5 \mathrm{~cm}$. in diameter; calyx puberulent, its lobes ovate, acute; corolla about $6 \mathrm{~mm}$. long, puberulent, 2-3 times as long as the calyx; stamens about $12 \mathrm{~mm}$. long.

Coastal thickets, Long Island, near Clarence Harbor. Endemic. PoINred CAT'S-CLAW. Cateshr, 2: pl. 9\%.

The records by Schoepf and by Bentham of $P$. circinale (L.) Benth., a plant of Hispaniola, as Bahamian, collected by Cateshy, refer to this species.

4. Pithecolobium bahaménse Northrop, Mem. Torr. Club 12: 3S. 1902.

A shrub, $3 \mathrm{~m}$. high or less, the branches slender, glabrous. Petioles 1-10 mm. long. bearing a stout-stalked gland at the summit; stipular spines sharp, 3-7 mm. long; pinnae a single pair; petiolules as long as the petioles or shorter; leaflets 1 pair or sometimes 2 pairs, sessile, obliquely oblong, oblanceolate or oborate, subcoriaceous, 1-2.5 cm. long, glabrous, obtuse or mucronate at the apex, shining above, dull beneath; peduncles $2-3 \mathrm{~cm}$. long; flowering hearts $2-3 \mathrm{~cm}$. in diameter; calyx about $2 \mathrm{~mm}$. long, its 5 ovate teeth acute; corolla abont $4 \mathrm{~mm}$. long, pink or crimson; stamens pink or crimson, 2-3 times as long as the corolla; ovary puberulent; pod coiled or much curved, $5-12 \mathrm{~cm}$. long, about $1 \mathrm{~cm}$. wide; seeds black.

Scrub-lands, pine-lands, savannas and coppices, Andros. New Proridence and Great Exuma:-Cuba. Rallama CAT'S-CLAW.

5. Pithecolobium Hýstrix (A. Rich.) Benth. in Hook. Icon. Pl. pl. 1168. 1876.

Inga hystrix A. Rich. Ess. Fl. Cub. 1: 471.1845.

Pithecolobium calliandriflorum C. Wright; Griseb. Cat. Pl. Cub. 83.1866.

An intricately branched shrub, $0.5-2 \mathrm{~m}$. high, the twigs very slender, but stiff, puberulent or glabrate, the internodes mostly short. Stipular spines acicular, 4-12 $\mathrm{mm}$. long; petioles $1-6 \mathrm{~mm}$. long; pinnae a single pair; petiolules 
mostly shorter than the petioles; leaflets obliquely oborate, $2-8 \mathrm{~mm}$. long, sessile, subcoriaceous, rounded at the apex, rather strongly few-reined, shining above, dull beneath; peduncles $4-20 \mathrm{~mm}$. long; heads few-several-flowered; calyx $2 \mathrm{~mm}$. long, sharply 5-toothed; corolla about $5 \mathrm{~mm}$. long; stamens rose, or pink, 2-3 times as long as the corolla: porl curvel into a nearly or quite complete circle, 6-12 cm. long, 5-8 mm. wide.

Coppices and pine-lands, Andros, New Providence and Great Exuma:-Cuba. BRISTLI CAT'S-CLAT.

6. Pithecolobium díscolor Britton, Bull. Torr. Club 41: 4. 1914.

A shrub, or a small tree up to $7 \mathrm{~m}$. high, the young twigs and leaves densely puberulent, the old leaves glabrous or somewhat puberulent, 1-2 dm. long; petioles stout, 1-2 $\mathrm{cm}$. long; pinnae 3 or 4 pairs, the glands on the rachis between them small and orbicular; leaflets $3-6$ pairs, obovate, chartaceous, 1.5-2.5 en. long, dark green above, pale beneath, reticulate-veined, obtuse or retuse; peduneles axillary, 5-11 $\mathrm{cm}$. long; flowers short-racemose; pedicels pubcrulent; calsx 4-5 mm. long, puberulent; corolla puberulent, $7-8 \mathrm{~mm}$. long; stamens 1.5-2 cm. jong; pod coiled, 6-8 em. long, S-10 $\mathrm{mm}$. wide; seeds blue and white, shining, orbicular, $4 \mathrm{~mm}$. broad.

Margin of coppice, Abaco at Old Kerr's Point, perhaps introduced :-Cuba.

2. ALBÍzzIA Durazz. Mag. Tose. 34: 11. 17 . 2 .

Unarmed trees, or some species shrubs, with bipinnate leares and solitary or panicled heads, umbels, or rarely spikes of small, mostly perfect flowers. Calyx 5 -tocthed. Corolla funnelform, the petals united to about the middle into a tube. Stamens numerous, united below, long-exserted; anthers small; pollen-grains agglomerate. Pod broadly linear, flat, thin, not pulpy within. Seeds suborbicular to oblong. [In honor of the Italian naturalist Albizzi.] About 50 species, natives of the Old Torld. Type species: Albizzia Julibrissin Durazzini.

1. Albizzia Lébbeck (L.) Benth. Lond. Jour. Bot. 3: S7. 1 S44.

Mimosa Lebbeck L. Sp. Pl. 516. 1753.

Acacia Lebbeck Willd. Sp. Pl. 4: 1066. 1806.

A tree, up to $15 \mathrm{~m}$. high, often flowering when not over $5 \mathrm{~m}$., the foliage glabrous or sparingly puberulent. Leares large, often $4 \mathrm{dm}$. long; petioles 2-10 $\mathrm{cm}$. long, bearing an oblong, sessile gland; pinnae 2-4 pairs; leaflets $4-9$ pairs on each pinna, thin, nearly sessile, obliquely oblong or the terminal pair obovate, obtuse, $2-4 \mathrm{~cm}$. long, reticulate-veined; peduneles. $3-10 \mathrm{~cm}$. long; umbels subglobose; pedicels pubescent, $2-5 \mathrm{~mm}$. long; ealyx narrowly campanulate, pubescent, abont $4 \mathrm{~mm}$. long, its teeth short; corolla ahont $6 \mathrm{~mm}$. long; stamens yellowish, about $3 \mathrm{~cm}$. long; pod straight, broadly linear, narrowed at each end, 1.5-3 dm. long, 2-t cm. wide, glabrous, shining; seeds about $1.5 \mathrm{~cm}$. broad.

Toadsides spontaneous after cultiration, New Providence near Nassau:Widely planted and established in the West Indies: natire of tropical Asia and Afrlca. Womax's-Toxgut Tree. Sixger-tree. Whistling-Beax.

3. LYSILÒMA Benth. Lonil. Jour. Bot. 3: 82. 1844.

Unarmed trees or shrubs, with slenter branches, bipinnate leaves, the small flowers in heads or spikes. Calyx campanulate, 5-lobed. Corolla 5-lobeil. 
Stamens numerous, more than twice as many as the corolla-lobes, the filaments united below into a tube. Orary sessile or short-stalked; style slender or filiform; orules several or numerous. Pods flat, linear or oblong, the ralves separating from the continuous margins. Seeds transverse, fiattened. [Greek, referring to the separating of the pod-ralres from the margins.] About 10 species of tropical and subtropical America. Type species: Lysiloma bahamensis Benth.

Leatlets few, oborate-oval; stipules oborate; pod obtuse.

Leaflets many, oblong or lanceolate; stipules ovate; pod acute.
1. L. Sabicu.

¿. L. Lahamensis.

\section{Lysiloma Sábicu Benth. Kew Jour. Bot. 6: 236. 1854.}

Acacia latisiliqua pancifoliola DC. Prortr. 2: 467. 1825.

Acacia formosa A. Rich. Ess. Fl. Cub. 463. 1845. Not Kunth. 1822.

Lysiloma formosa Hitche. Rep. Mo. Bot. Gard. 4: 83. 1893.

Lysiloma paucifoliola Hitche.; Northrop, Mem. Torr. Club. 12: 38. 1902.

A tree, attaining in Cuban forests a height of $60 \mathrm{~m}$. or more, usually much smaller, the gray bark somewhat scaly, the slender twigs glabrous. Stipules ohovate, rounded; leaves 1-2 dm. long, the petiole bearing a small circular gland; pinnae 2-4 pairs; leaflets $3-7$ pairs, oral or obovate, 1-2.5 $\mathrm{cm}$. long, rounded at the apex, rounded or narrowed at the base, glabrous, reticulatereined, short-petioled; heads about $1.5 \mathrm{~cm}$. in diameter, solitary and longpeduncled in the axils; flowers greenish white; calyx about $1 \mathrm{~mm}$. long; corolla about twice as long as the calyx, its lobes rillous abore; stamens 15-20, 2-3 times as long as the corolla; pod oblong, $7-15 \mathrm{~cm}$. long, $2-3 \mathrm{~cm}$. wide, rounded at the apex; seeds brown, flat, 6-10 mm. long.

Coppices and scrub-lands, Andros, New Providence, Eleuthera, Great Guana Cas, Great Exuma and Fortune Island:-Cuba; Hispaniola. Horseflesh. Sabict.

\section{Lysiloma bahaménsis Benth. Lond. Jour. Bot. 3: 82.1844.}

Acacia bahamensis Griseb. Fl. Br. W. I. 221. 1860.

Lysiloma latisitiqua A. Gray; Saur. Anales Acad. Habana 5: 406. 1869.

A tree, attaining a maximum height of about $16 \mathrm{~m}$. with a trunk up to 1 $m$. in diameter, the smooth, gray bark splitting into scales, the branches spreading, the twigs slender, glabrous; stipules orate, acuminate; leares 8-14 $\mathrm{cm}$. long, the petiole bearing a large gland near the lowest pair of pinnae; pinnae $2-5$ pairs, $3-8 \mathrm{~cm}$. long; leaflets $10-33$ pairs, oblong or oblong-lanceolate, sessile, 8-15 mm. long, obtuse at the apex, unequally rounded at the base, glabrous; heads $1.5-2 \mathrm{~cm}$. in diameter, racemose, globose, on peduncles $2-4 \mathrm{~cm}$. long; flowers white, mostly perfect; calyx campanulate, about $1 \mathrm{~mm}$. long; corolla twice as long as the calyx, its lobes reflexed; stamens about 20 , twice as long as the corolla; pod linear-oblong, 8-15 cm. long, 2-2.5 cm. wide, nearly straight, pointed; seeds flat, about $12 \mathrm{~mm}$. long, dark brown, shining.

Coppices and scrub-lands, Abaco and Great Bahama throughout the archipelago to Caicos and Inagua:-Florida; Cuba; Yucatan, Wild Tajarixd.

\section{ANNÉSLIA Salisb. Parad. Lond. p7. 64. 1807.}

Shrubs, or small trees, with bipinnate leaves and capitate flowers, the heads peduncled, axillary, or in terminal racemes. Calyx 5-toothed or 5-lobed. Corolla funnelform or campanluate, 5-lobed, the petals being united to the mid. dle or above the middle. Stamens numerous; filaments united below, long-ex- 
serted; anthers small, glandular-hirsute or glabrous, the pollen grains agglomerate. Ovary many-ovuled; style filiform. Pod linear, usually narrowed below the middle, flat, not pulpy within, straight or nearly so, elastically dehiscent from the base, the valves stiff with raised margins. Seeds obovate or orbieular, compressed. [In honor of George Annesley, 1769-1844, English traveler and botanist.] Over 100 species, of tropical and subtropical distribution. Type species: Annestia falcifolia Salisb.

Flowers red to purple: pod appressed-pubescent. Flcwers white; pod glabrous.
1. A. haematostoma.

2. A. formosa.

1. Anneslia haematostòma (Bert.) Britton, Mem. Brooklyn Bot. Gard. 1: 50. 1918.

Acacia haematomma Bert.; DC. Nem. Leg. 448. 1825.

Calliandra haematomma Benth. Lond. Jour. Bot. 3: 103.1844.

A much-branched shrub $3 \mathrm{~m}$. high or less, the twigs sparingly pilose or glabrous. Leaves small, 1-3 cm. long; petioles short; pinnae 1 pair; leaflets 3-8 pairs, oblong to obovate, $4-8 \mathrm{~mm}$. long, obtuse or mueronate, strongly fewnerved, coriaceous; peduncles mostly pubescent, usually shorter than the leaves, commonly clustered toward the ends of the branches; calyx striate, about $2 \mathrm{~mm}$. long; corolla silky-pubescent, $5-\tau \mathrm{mm}$. long; stamens red, 1-2 cm. long; pod pubescent, $5-8 \mathrm{~cm}$. long, $6-8 \mathrm{~mm}$. wide.

Scrub-lands and coppices, Abaco, Great Bahama, Rum Cay, Conception Island, Fortune Island, Watling's, Caicos and Inagua :-Cuba to St. Thomas. ReD Axxesuia.

\section{Anneslia formòsa (Kunth) Britton \& Millspaugh.}

Acacia formosa Kunth, Mim. 102. 1822.

Calliandra formosa Benth. in Hook. Lond. Jour. Bot. 3: 98. 1844.

Calliandra formosa cubensis Macbride, Contr. Gray Herb. II. 59: 4. 1919.

A branched shrub, $0.5-2.5 \mathrm{~m}$. high, glabrous thronghout. Leaves $7-15 \mathrm{~cm}$. long; petioles 1-3 $\mathrm{cm}$. long; pinnae 2 or 3 pairs; leaflets $6-11$ pairs, oblong to oblong-obovate, inequilateral, 10-22 mm. long; obtuse at the apex, obliquely subtruncate at the base, subchartaceous, fer-veined; peduncles slender, shorter than the leaves; calyx about $2 \mathrm{~mm}$. long; corolla glabrous, about trice as long as the calyx; stamens white, $1-1.5 \mathrm{~cm}$. long; pod glabrous, $5-9 \mathrm{~cm}$. long, about $1 \mathrm{~cm}$. wide, attenuate at the base.

Scrub-lands, coppices and thickets, throughout the archlpelago from Abaco and the Berry Islands to South Caicos, Inagua and the Angullla Isles:-Cuba: Mexlco. Recorded by IItchcock as Callimndra gracilis Griseb. and by Dolley as Calliandra portoricensis Benth. WH1TE AxxesLiA:

\section{ACACIA Willd. Sp. PI. 4: 1049. 1806.}

Shrubs or trees, with bipinnate leares, the ultimate leaflets usually small and numerous, or the leaves in many exotic species modified into flat simple phyllodes. Flowers small, in heads or spikes. Calyx campanulate, usually $4-5$-toothed, or of 4 or 5 distinct sepals. Petals mostly 4 or 5 , or wanting. Stamens distinct, exserted; filaments filiform; pollen-grains cohering in 2 's 6 's. Pod linear, oblong or oval, flat or swollen, often constricted between the seeds. [Greek, point, or thorn, many speeies being thorny.] About 450 species, chiefly in subtropical regions. Type species: Acacia nilotica Delile. 
Foliage glabrous.

Leaflets linear-oblong: base of trunk armed with clusters of long spines.

Leaflets obovate to oblong and elliptic; unarmed tree.

Foliage pubescent; leaflets many, linear.

1. A. acuifra.

2. A. choriophylla.

3. A. macrucantha.

1. Acacia acuifera Benth. in Hook. Lond. Journ. Bot. 1: 496. 1842.

A glabrons, much-branched shrub or small tree up to about $4 \mathrm{~m}$. high, the base of the trunk armed with elisters of rigid sharp spines 4-10 $\mathrm{cm}$. long, the slender twigs warty. Stipules spinescent, 2-20 $\mathrm{mm}$. long; petiole $3-10 \mathrm{~mm}$. long, bearing a sessile, nearly flat gland at the end, between the single pair of short-stalked pinnae; pinnae $5-9 \mathrm{~cm}$. long, the rachis bearing small glands between the pairs of leaflets; leaflets $8-17$ pairs, oblong, coriaceous, $5-15 \mathrm{~mm}$. long, obtuse at the apex, obliqnely truncate at the sessile base, shining above, dull beneath; peduncles solitary or fascicled, slender, 2-3.5 cm. long; flowers yellow in dense globose hearts about $8 \mathrm{~mm}$. in diameter; stamens about twice as long as the corolla; por fleshy, linear, curved, $5-\tau \mathrm{cm}$. long, $5-\tau \mathrm{mm}$. thick, slightly impressed between the seeds.

Coppices and scrub-lands, Eleuthera, Cat Island, Rum Cay, Fortune Island, Acklin's, Grand Turk, Caicos Islands, Inagua and Little Inagua. Endemic. BA-

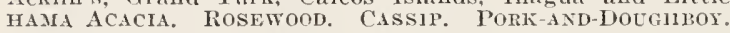

\section{Acacia choriophýlla Benth. in Hook. Lond. Journ. Bot. 1: 495. 1842.}

An unarmed tree, up to 8 or $9 \mathrm{~m}$. high, the twigs and leaves glabrous. Stipules minute, subulate; petioles rather stout, 8-15 mm. long, glandular; leares 1-2 dm. long; pinnae 1-3 pairs, short-stalked; leaffets $3-7$ pairs, sessile, oblong to obovate, subcoriaceous, $1.5-3 \mathrm{~cm}$. long, $8-15 \mathrm{~mm}$. wide, rounded or slightly emarginate at the apex, mostly obtuse at the base; peduncles mostly clustered in the axils, slender, glabrous, often numerous, 2-3.5 cm. long; flowers yellow, in dense globose heads $6-8 \mathrm{~mm}$. in diameter, the corolla puberulent; stamens about twice as long as the corolla; pod stipitate, woody, oblong, straight or somewhat curved, compressed, 4-8 $\mathrm{cm}$. long, 1.5-2.5 $\mathrm{cm}$. wide, about $S \mathrm{~mm}$. thick, short-pointed, glabrous, tardily dehiscent.

Coppices and serub-lands, throughout the archipelago from Abaco and Great Bahama to Andros, Mariguana and Inagua :- Cays of northern Cuba. Recorded by Hitcheock as Pithecolobium asplenifolium Griseb. C1xNECORD.

3. Acacia macracàntha H. \& B.; Willd. Sp. Pl. 4: 1080. 1806.

A midely branched tree, $5-15 \mathrm{~m}$. high, or sometimes a shrub, the young twigs slender, tomentose or pubescent, the tortuous branches arned with stipular spines $6 \mathrm{~cm}$. long or less, or sometimes unarmed. Leaves tomentose or pubescent, the short petiole bearing a sessile depressed gland; pinnae S-40 pairs, short-stalked, 2-4 cm. long; leaffets $15-40$ pairs, linear, 2-5 mm. long, obtuse, sessile, glabrous or nearly so; peduncles clustered or solitary in the upper axils, slender, pubescent, 1-3 cm. long; flowers yellow, capitate; heads globose, S-10 mm. in diameter; pod linear, tomentulose, turgid-compressed, 6-10 $\mathrm{cm}$. long, straight or a little curved, continuous or more or less torulose, somewhat pulpy.

Rocky plain, Salt Cay, Turk's Islands: in a yard, Matthew 'Town, Inagua:Jamaica: Cuba: Hispanioln; Vieques; St. Thomas to Tortola, Martinique and Venezuela. LONG-SPINED ACACIA.

\section{VACHÉLLIA W. \& A. Prodr. 272. 1834.}

Spiny shrubs or small trees, with bipinnate leares, numerous, small leaflets, the polygamous flowers in globular heads. Calyx 5-lobed; corolla tubularfunvelform, 5-lobed. Stamens numerous, the filaments distinct. Ovary sessile; 
style filiform. Pod woody, swollen, nearly terete, very tardily dehiscent or indehiscent, pulpy within. Seeds in two rows, immersed in the pulp. [Commemorates C. H. Vachell, an English missionary and botanieal collector in China.] A monotypie genus.

\section{Vachellia Farnesiàna (L.) W. \& A. Prodr. 272. 1834.}

Mimosa Farnesiana L. Sp. Pl. 521. 1753.

Acacia Farnesiana Willd. Sp. Pl. 4: 1083. 1806.

A shrub or small tree up to about $9 \mathrm{~m}$. high, its thin brown bark scaly, the slender branches spreading, the twigs armed with stiff paired whitish spines 1-2.5 cm. long. Leares glabrous or more or less pubescent, erenly bipinnate, 4-S cm. long, short-petioled; pinnae $3-S$ pairs, sessile or nearly so; leaflets $10-25$ pairs, linear-oblong, $2-6 \mathrm{~mm}$. long, bluntish at the apex; peduncles axillary, slender, mostly shorter than the leaves; heads $8-12 \mathrm{~mm}$. in diameter; flowers yellow, fragrant; calyx about half as long as the corolla; corolla about $1.5 \mathrm{~mm}$. long; stamens $2-3$ times as long as the corolla; pod straight or a little curved, $3-7.5 \mathrm{~cm}$. long, about $1.5 \mathrm{~cm}$. thick, pointed, dark brown; seeds shining, 6 nim. long.

Traste and schub-lands and coastal thickets, Andros, New Providence, Elenthera, Cat Island, Watling's, Great Exuma, Fortume Island. Grand 'Turk and Caicos:Florida; Cuba to Virgin Golda and Tobago: Jamaica: continental tropical America and old Torld tropics. Recorded by Dolles as Acacia tortuosa Willd., a Jamaican species. Aroua. Casmia. OPOPONAx.

\section{MIMÒsA L. Sp. Pl. 516. 1753.}

Herbs, shrubs or rarely trees, mostly with 2-pinnate, often sensitive leares, the small regular, mostly 4-5-parted, perfect or sometimes polygamous flowers in axillary, peduncled heads or spikes. Calyx small, its teeth short. Petals valvate, connate below, hypogynous. Stamens as many as the petals or twice as many, distinct; exserted; filaments mostly filiform; anthers small, eglandular. Orary 2-many-oruled; style slender or filiform; stigma terminal, small. Pod linear or oblong, usually flat, often transversely jointed, 2-valved with the continuous margins persistent. Seeds compressed. [Greek, referring to the sensitive leaves of some species.] Orer 300 species, natives of tropical and warm regions. Type species: Mimosa sensitiva L.

Low, sensitive-leared herb.

Shrub, the leaves not sensitive.

1. I. pudica.

2. M. bahamensis.

1. Mimosa pùdica L. Sp. Pl. 518. 1753.

Herbaceous, or a little woody, loosely pubescent with long hairs or glabrate, branched, $5 \mathrm{dm}$. high or less, the stems and branches armed with rather stout, somewhat curved prickles 2-4 mm. long. Stipules lanceolate, striate, acuminate, 3-6 mm. long; petioles slender, with a pulvinus at the base, $2-6$ $\mathrm{cm}$. long, deflexed when touched; pinnae 1 pair or 2 approximate pairs, also with a pulvinus at base, $2-6 \mathrm{~cm}$. long; leaflets $15-25$ pairs, thin, linear, $6-10$ $\mathrm{mm}$. long, 1.5-2 mm. wide, folding when touched, acutish at the apex, obliquely rounded at the base; heads ovoid, axillary; peduneles $1-2 \mathrm{~cm}$. long; calyx minute; petals and stamens 4; stamens pink; pods linear-oblong, 2-5-jointed, $1-1.5 \mathrm{~cm}$. long, $3 \mathrm{~mm}$. wide, constricted at the joints, the margins armed with slender straight prickles, otherwise glabrous.

Andros at Iastle Pnint, collected only by Kelth:- West Indles; continental tropical America; naturalized in the East Indies. Cultivated on New Prorldence. SENSITIVH PLANT. 
2. Mimosa bahaménsis Benth. in Hook. Journ. Bot. 4: 408.1842.

A much-branched shrub 1.5-3.5 m. high, or a small tree about $4 \mathrm{~m}$. high, the branches armed with short hooked prickles, the twigs densely brown-tomentulose. Petioles, rachis and peduncles tomentulose or rachis glabrate; leaves 4-7 cm. long; petioles 5-20 mm. long; pinnae $2-4$ pairs; leaflets $2-6$ pairs, oval or obovate, $2-6 \mathrm{~mm}$. long, subcoriaceous, glabrous or nearly so, rounded at the apex, subcordate or nearly truncate at the base, the midvein prominent, the lateral venation obseure; heads $1 \mathrm{~cm}$. broad, short-peduncled, axillary and in terminal racemes; calyx about $0.5 \mathrm{~mm}$. long; corolla about $1.5 \mathrm{~mm}$. long, 4-cleft; stamens 8, pink, 2-3 times as long as the corolla; pod linear-oblong, eompressed, 4-7 cm. long, 12-14 mm. wide, densely brown-tomentulose, 6-10-jointed, both sutures narrowly winged, the wings lacerate or nearly entire; seeds ovalquadrate, smooth, brown, 4-6 mm. long.

Scrub-lands and thickets, Watling's Island, Rum Cay, Fortune Island, Acklin's Island, Caicos Islands; Inagua. Endemic. Bahama Mruosa. HatladeK.

The plant recorded by Schoepf as Jimosa arborea has not been identified.

\section{LEUCAÈNA Benth. in Hook. Journ. Bot. 4: 416. 1842.}

Unarmed trees or shrubs, with bipinnate leaves, the white flowers in peduncled heads. Calyx narrowly campanulate, 5-toothed. Petals 5, distinct, valvate. Stamens 10, distinct, exserted, the anthers not gland-bearing, often pilose. Ovary stipitate; ovules numerous; style filiform; stigma minute. Pod broadly linear, flat, membranous, completely 2 -ralved, the orate or oborate flat seeds transverse. [Greek, referring to the white flowers.] About 10 species, mostly of tropical America, the following typical.

1. Leucaena glaùca (L.) Benth. in Hook. Journ. Bot. 4: 416. 1842.

Mimosa glauca L. Sp. Pl. 520. 1753.

Usually a shrub 2-3 m. high. but sometimes a small tree, in Porto Rico becoming a tree $20 \mathrm{~m}$. high, the young twigs puberulent. Leaves 1-2 dm. long; petiole 3-6 cm. long, with or without a gland; pinnae 3-10 pairs, the upper ones little shorter than the lower; leaflets 10-20 pairs to each pinna, oblong or lanceolate, thin, 8-15 $\mathrm{mm}$. long, inequilateral, acute at the apex, obliquely narrower at the base, light green above, pale beneath; heads globular, axillary or terminal, mostly clustered, $1.5-3 \mathrm{~cm}$. in diameter; peduncles stout, puberulent or pubescent, $2-3 \mathrm{~cm}$. long; calyx obeonic, $1 \mathrm{~mm}$. long, its short teeth blunt; petals linear-spatulate, pubescent; stamens about 3 times as long as the petals; orary pubescent; pods several or numerous, linear, $10-15 \mathrm{~cm}$. long, about $1.5 \mathrm{~cm}$. wide, abruptly acute or mueronate, tapering at the base, the thin valves with raised margins.

Pastures, coppices, waste-lands and thickets, throughout the archipelago from Abaco and Great Babama to the Calcos and Inagua:-Bermuda; Florida: West Indies: tropical America: Old World tropics. Probably native of continental tropical America. Jumbie Bean. Jimbay. Cow-Bush. Catesby $2: p l$. 42.

\section{9. ÁCUAN Medic. Theod. 62. 1786.}

Perennial herbs or shrubs, with bipinnate leaves, small stipules, and greenish or whitish small regular flowers in axillary peduncled heads or spikes. Flowers perfect, sessile, or the lowest sometimes staminate, neutral or apetalous. Calyx campanulate, its teeth short. Petals valvate, distinct, or slightly united or coherent below. Stamens 10 or 5, distinct, mainly exserted; anthers all alike. Orary nearly sessile; ovules $\infty$. Pod linear, straight or curved, acute, 
flat, sereral-seeded, 2-ralved, the ralves coriaceous or membranous. About 10 species, natives of warm and tropical America, one widely distributed in tropical regions of the Old World. Type species: Mimosa virgata $\mathrm{L}$.

Pods 6-9 cm. long; plant erect or ascending.

Pods 4-5 cm. long; plant dlffuse.
1. A. virgatum.

2. A. depressum.

\section{Acuan virgàtum (L.) Medic. Theod. 62. 1786.}

Mimosa virgata L. Sp. Pl. 519. 1753.

?.Mimosa pernambucana L. Sp. Pl. 519. 1753.

Desmanthus virgatus Willd. Sp. Pl. 4: 1047. 1806.

Desmanthus strietus Bertol. Giorn. Arcad. 21: 190. 1824.

Stem erect or ascending, glabrous or sparingly pubescent above, branched, 0.5-2 m. high. Stipules subulate, 2.5-4 mm. long; leaves $2-8 \mathrm{~cm}$. long, shortpetioled, the petiole and rachis sometimes pubescent; pinnae 1-7 pairs, the gland between the lower pair usually oblong, conspicuous; leaflets $10-20$ pairs, linear or linear-oblong, 4-9 mm. long, thin, obtuse or apiculate at the apex, subtruncate at the base; heads few-several-flowered; peduncles solitary in the axils, slender, $2-5 \mathrm{~cm}$. long; flowers white; stamens 10 , about twice as long as the petals; pod straight or slightly curved, $4-7.5 \mathrm{~cm}$. long, $3-4 \mathrm{~mm}$. wide, acute or apiculate, smooth.

Thickets and scrub-lands, Great Sturrup Cay, Andros, New Proridence, Eleuthera, Long Island, Acklin's, Fortune Island and Inagua :-Florida; Bermuda; Test Indies; continental tropical America. Virgate Mrmos.

\section{Acuan depréssum (H. \& B.) Kuntze, Rev. Gen. Pl. 1: 158. 1891.}

Desmanthus depressus H. \& B.; Will. Sp. Pl. 4: 1046.1806.

Diffusely branched, seldom over $3 \mathrm{dm}$. high, glabrous or sparingly pubescent. Stipules subulate, $3.5 \mathrm{~mm}$. long or less; leares short-petioled, $1.5-4 \mathrm{~cm}$. long; pinnae 1-5 pairs, the gland between the lowest pair small, mostly orbicular; leaflets 10-20 pairs, linear, $3-5 \mathrm{~mm}$. long, thin, obtuse at the apex, obtuse or subtruncate at the base; heads few-flowered, on,solitary axillary peduncles; stamens 10 , about $6 \mathrm{~mm}$. long, twice as long as the petals; pod straight or slightly curved, $2-5 \mathrm{~cm}$. long, about $3 \mathrm{~mm}$. wide.

Roadsides and waste places, Andros, Mangrove Cay, New Providence, Long Islanrl, Ambergris Cay and Inagua:-Florida; Cuba to Tortola and Grenada; Tamaica; Mexico to continental tropical America. Low Mraros..

\section{NEPTÙNIA Lour. Fl. Coch. 653. 1790.}

Prostrate, diffuse or floating perennial herbs, some species a little woody, with bipinnate leaves, and axillary solitary, long-peduncled heads of more or less imperfect and perfect flowers. Calyx campanulate, with 5 short teeth. F'etals 5, distinct, or united below the middle. Stamens mostly 10, distinct, exserted, the anthers bearing a stalked gland. Ovary stipitate, screral-manyoruled; style filiform with a terminal eapitate stigma. Pods broadly linear or narrowly oblong, stipitate, flat, commonly recurved, impressed between the orate transverse seeds, 2-valved, the valves thin-coriaceous. [Dedicated to Neptune.] About 10 species, of America, tropical Asia and Australia. Type species: Neptunia oleracea Lour. 
1. Neptunia plèna (L.) Benth. in Hook. Jour. Bot. 4: 355. 1842.

Mimosa plena L. Sp. Pl. 519. 1753.

Glabrous, the slender branches prostrate or ascending, 3-6 dm. long. Stipules ovate to lanceolate, thin, oblique, 4-6 $\mathrm{mm}$. long; leares $4-10 \mathrm{~cm}$. long, with slender petioles; pinnae 2-4 pairs; leaflets $12-20$ pairs, linear, thin, faintly veined, 4-10 $\mathrm{mm}$. long, obtuse; peduncles 6-12 $\mathrm{cm}$. long, usually bearing 1 or 2 cordate bracts at or below the middle; heards oroid; flowers yellow, the upper ones perfect, the lower staminate, or neutral with exserted staminodia; pods 2-5 cm. long, about $S \mathrm{~mm}$. wille, acute or apiculate, thickened on the margins.

Scrub-land opening, New Providence; Inagua, near a fresh water pond west of Great Salt Lake:- Cuban Cays: Haiti; I'orto Rico; Antigua to Grenada; Jamaica; continental tropical America. Neptuxia.

\section{PROSÒPIS L. Mant. 1: 10. 1767.}

Trees, with bipinnate leares, and small, nearly or quite sessile flowers, in axillary spikes or rarely capitate. Calyx campanulate, 5-toothed. Petals 5, valvate. Stamens 10 , distinct, the anthers usually bearing a deciduous gland. Ovary many-ovuled; style filiform; stigma small and terminal. Pod linear, subterete or somewhat flattened, coriaceous, indehiscent, the mesocarp spongy. Seeds flattened. [Greek name of some plant.] About 15 species, natives of tropical and subtropical regions. Type species: Prosopis spicigera L.

1. Prosopis julifiòra (Sw.) DC. Prodr. 2: 44i. 1925.

Mimosa juliflora $\mathrm{Sw}$. Prodr. S5. 1788.

A tree, up to $13 \mathrm{~m}$. high, but usually smaller, with widely spreading branches, armed with stipular slender straight spines, 1-4 cm. long, the slender twigs glabrous or nearly so. Leaves glabrous, or when young sparingly ciliate, 0.7-2 $\mathrm{dm}$. long; petioles slender, 1-4 $\mathrm{cm}$. long; pinnae 1 or 2 pairs, shortstalked; leaflets $12-20$ pairs, linear-oblong, sessile, $7-16 \mathrm{~mm}$. long, strongly fert-reined, obtuse or mucronulate at the apex, obliquely obtuse at the base; flomers greenish or yellomish, in dense cylindric peduncled spikes, 5-10 $\mathrm{cm}$. long, $7-8 \mathrm{~mm}$. thick; calyx about $1 \mathrm{~mm}$. long, its teeth short; petals about 2.5 $\mathrm{mm}$. long, acute, villous within; ovary villous; pod compressed, falcate, 7-20 $\mathrm{cm}$. long, $8-10 \mathrm{~mm}$. wide, $5-7 \mathrm{~mm}$. thick when mature.

Waste places, introduced but not planted, Inagua, near Nathew Town:-Cuba ; Hispaniola ; Tortola; Montserıt; Jamaica; Bonaire; Curacao; Aruba ; continental tropical America. Naturalized in the Philippine Islands. MEsecite.

\section{Family 4. CAESALPINIÀCEAE Kl. \& Gareke.}

\section{SENTA FAMILT.}

Trees, herbs or shrubs, with alternate, simple or compound, mostly stipulate leaves. Flowers mostly clustered and perfect, sometimes monoecious, dioecious or polygamous, nearly regular, or irregular. Calyx mostly of 5 sepals or 5-toothed. Petals usually 5, imbricated, and the upper (unpaired) one enclosed by the lateral ones in the bud. Stamens 10 or fewer in our genera, the filaments distinct, or more or less united. Ovary 1-celled. 1-many-ovuled. Fruit a legume, mostly deliscent into 2 valves. Seeds with or without endosperm. About 90 genera and 1000 species, mostly of tropical distribution. 
Leaves once pinnate

Anthers dorsifixed, longitudinalls dehiscent: larger petals 3 .

Anther's basifixed, mostly opening by terminal pores or slits; petals 5 .

Pod not elastically dehiscent: seeds with long funicles.

I'od elastically 2-valved; seeds with short funicles.

leares twice pinnate.

Petiole very short, terminating in a spine.

l'etioles well dereloped.

Stigma not peltate; pod not winged.

Fod splitting throngh the middle of the ralves.

rod splitting along the sutures.

Woody rines: pods broad. thick, mostly prickly. Trees or shrubs; pods narrow, unarmed.

Calyx-lobes imbricate: slirubs and low trees.

Stamens and pistils little longer than the corolla.

Stamens and pistils much longer than the corolla.

Calyx-lobes not imbricated; large introduced tree.

Stigma peltate; pod flat, thin, winged.

1. Tamarindus.

2. Crassin

3. Chamacerista.

4. Parkinsonia.

5. Haematoxylum.

6. Guilandina.

7. Cuesalpinia.

S. Poinciana.

9. Delonix.

10. Peltophorum.

\section{TAMARÍNDUS L. Sp. Pl. 34. 1753.}

An unarmed tree, with erenly pinnate leares, numerous and small leaflets, the stipules carlucous, and pink to yellow racemose flowers. Calyx-tube turbinate, its 4 segments imbricated. Petals very unequal, the 3 upper ones large, nearly alike, the 2 lower ones minute, scale-like. Perfect stamens 3, monadelphous; authers longitudinally dehiscent; staminodia minute. Orary stipitate, few-many-oruled, the stipe adnate to the calyx-tube; style long; stigma terminal, subcapitate. Pod linear or linear-oblong, curved, little compressed, indehiscent, the thin epicarp crustaceous, the mesocarp pulpy, the coriaceous endocarp septate between the oborate-orbicular seeds. Endosperm none; cotyledons thick. [Latin name of the tree.] A monotypie genus.

\section{Tamarindus índica L. Sp. Pl. 34. 1753.}

A large tree, sometimes $20 \mathrm{~m}$. high or higher, with a trunk up to $1.5 \mathrm{~m}$. thick, the branches widely sprearing, the young twigs slender, puberulent. Leaves 6-12 cm. long, short-petioled, glabrous or nearly so; leaflets 10-18 pairs, thin, reticulate-veined, oblong, $12-25 \mathrm{~mm}$. long, rounderl or retuse at the apex, obliquely obtuse or subtruncate at the base; racemes few-several-flowered, mostly terminal and shorter than the leaves; pedicels slender, $6-10 \mathrm{~mm}$. long; calyx 8-10 mm. long; larger petals a little lorger than the sepals; stamens a little longer than the petals; fod $5-15 \mathrm{~cm}$. long, about $2 \mathrm{~cm}$. thick, the epicarp brown, scaly, the flesh acid, the brown shining seeds about $1 \mathrm{~cm}$. broad.

Spontanenus after cultivation. Andros, New Providence and Inagua :--Prohably native of tropical Africa : widely naturalized in tropical America. TaMarro.

\section{CÁSSIA [Tourn.] L. Sn. Pl. 376. 1753.}

IJerbs, shrubs, or some tropical species trees, with evenly pinnate leaves, and mainly (in all our species) yellow flowers. Calyx-teeth nearly equal, generally longer than the tube. Corolla nearly regular; petals 5, spreading, nearly equal, imbricated, elawed. Stamens usually 10, sometimes 5, often unequal and some of them imperfect; anthers all alike, or those of the lower stamens larger, opening by 2 pores at the summit. Ovules $\infty$. Pods rarious. Seeds often rumerous. [Ancient name.] About 200 species, of wide distribution in warm and temperate regions. Trpe species: Cassia Fistula I. 
Pods not jointed.

Pods terete or turgid.

rods turgid, straight.

suture indistinct; seeds in a single row.

suture indistinct: seeds in a double row.

I'ods not turgid, strongly curved, narrow.

Pods flat, or the valres lightly convex; suture distinct.

Petiolar gland situated near the leaf base.

Gland wart-like.

Gland elongated. pointed.

Petiolar gland at the first pair of leaflets.

Gland wart-like.

Pods jointed. Gland elongated.

Joints continuons.

Joints moniliform.
1. C. Sophera.
2. C. bicapsularis.
3. C. Tora.
4. C. occidcntalis.
5. C. ligustrina.
6. C. bahamcnsis.
7. C. biflora.
8. C. uniflora.
9. C. villosa

1. Cassia Sóphera L. Sp. 379. 1753.

A shrub, 1-2.3 m. high, nearly glabrous throughout, with slender branches. Leaves 1-1.5 dm. long; petiole $1-3 \mathrm{~cm}$. long, bearing a sessile round gland near the base; leaflets 5-10 pairs, ciliate, at least when young, membranous, lanceolate to oblong-lanceolate, acute or acuminate at the apex, mostly rounded at the base; flowers in short racemes in the upper axils; pedicels $8-15 \mathrm{~mm}$. long; calyx about $8 \mathrm{~mm}$. long; petals about twice as long as the sepals; pod linear, straight, turgid or subterete, 5-10 $\mathrm{cm}$. long, $7-9 \mathrm{~mm}$. thick, pointed, glabrous; seeds dull, bromn, 4-5 mm. long.

Waste grounds, New Providence, near Nassau, Eleuthera, Cat Island:-West Indies; continental tropical America: Old World tropics. Kasoxd SExNa.

\section{Cassia bicapsulàris L. Sp. Pl. 376. 1753.}

A shrub, up to $3.5 \mathrm{~m}$. high, glabrous, or nearly so, throughout, the branches slender, sometimes vine-like. Stipules small, early deciduous; leaves $5-9 \mathrm{~cm}$. long, slightly fleshy, bearing an oblong gland narrowed toward the base, between the lowest pair of leaflets; leaflets $3-5$ pairs, 1-4 cm. long, short-stalked, rounded at the apex, the upper pair oborate, narrowed at the base, the others oblong to suborbicular, rounded at both ends; racemes axillary, few-flowered, as long as the leares or longer; pedicels $3-8 \mathrm{~mm}$. long; sepals oblong, obtuse, faintly veined, 8-12 mm. long; petals yellow, veiny, oblong-obovate, somewhat longer than the sepals; pod turgid, subterete, $8-15 \mathrm{~cm}$. long, about $1 \mathrm{~cm}$. thick, longitudirally dehiscent; seeds Jenticular, obliquely oral, brown, shining, about $5 \mathrm{~mm}$. long, horizontal.

Scrub-lands and loose rocky soil, North Caicos, Grand Turk Island:-Bermuda (naturalized); Cuba to Tortola and Grenada; Jamaica; continental tropical America. Cinistais-bush. WhL Ralsix.

3. Cassia Tòra L. Sp. Pl. 376. 1753.

Cassia obtusifolia L. Sp. Pl. 37т. 1753.

Annual, glabrous, 4-6 dm. high. Stipules linear-subulate, deciduous; leaves petioled, the gland borne between or above the lowest pair of leaflets; leaflets 2-4 pairs, thin, obovate, obtuse and mueronate at the apex, 2-4 cm. long; flowers 1-2.5 cm. broad, few, in short axillary racemes; calyx-lobes oblong, obtuse; stamens 10 , the anthers of the upper 3 imperfect; pod linear, very slender, subterete, strongly curved, 1-1.5 dm. long, about $3 \mathrm{~mm}$. wide.

Waste grounds, New Providence, Eleuthera:-Central and southern United States; throughout tropical and subtropical America; Old World tropics. Low SENTA.

* 4. Cassia occidentàlis L. Sp. Pl. 377. 1753.

Annual, glabrous, much branched, 1.4-2 m. high. Stipules caducous; gland borne near the base of the petiole; leaflets $8-12$, rounded at the base, $2-5 \mathrm{~cm}$. 
long, S-1S mm. wide; flowers 14-18 $\mathrm{mm}$. broad, in short axillary racemes; stamens 10 , the upper 3 imperfect; ealyx-lobes oblong, obtuse; pod linear, glabrous, 1-1.5 dm. long, about $6 \mathrm{~mm}$. wide, nearly flat, somewhat curred, its n:argins thickened.

Waste and cultirated ground, Nolth Bimini, Andros, New Frovidence, Eleu thera, Watling's, Long, Fortune, and Acklin's Islands and Inagua :-Beimuda ; sonthern United States; throughout tropical America; Old World tropics. CoffeE SEXIX.

5 Cassia ligustrìna L. Sp. Pl. 378. 1753.

Perennial, shrubby, glabrous or somewhat pubescent, branched, 5-20 $\mathrm{dm}$. high, the branches nearly terete. Stipules linear, fugacious or wanting; leaves petioled, 1-2.5 dm. long, bearing a linear-oblong gland on the petiole; leaflets 5-s pairs, short-petioluled, lanceolate or oblong-lanceolate aeuminate at the apex, rounded or narrowed at the base, $2.5-6 \mathrm{~cm}$. long; racemes few-severalflowered, peduneled, axillary and forming a terminal corymb; pedicels slender; calyx about $8 \mathrm{~mm}$. long; petals yellow, fading whitish, twice as long as the sepals; perfect stamens 10; pod linear, flat, glabrous, eurved, $7-15 \mathrm{~cm}$. long, 6-10 mm. wide; seeds compressed, parallel with the ralves.

Waste grounds, pine and scrub-lands, Abaco. Great Bahama. Andros and New Providence:-Delmuda; Florida; Jamaica; Cuba; Hispaniola: Guiana. Priret SExxA.

\section{Cassia bahaménsis Mill. Gard. Dict. ed. S, no. 9. 1768.}

Cassia bahamensis latifolia Benth. Trans. Linn. Soc. 27: 541. 1571.

A shrub, 1-3 m. high, the stems simple or branehed, glabrous or somewhat pubeseent. Leaves $7-15 \mathrm{~cm}$. long; leaflets $3-5$ pairs, rather firm in texture, oblong or elliptic to ovate-elliptic, acute or mucronate, $2.5-6 \mathrm{~cm}$. long, the petiolar gland large, sessile, wart-like, orbicular or subglobose, the linear stipules eaducous; flowers corymbose-paniculate; pedicels slender, S-20 mm. long; calyx $6-8 \mathrm{~mm}$. long; petals obovate, $10-15 \mathrm{~mm}$. long; pods linear, flat, slightly eurred, $i-10 \mathrm{~cm}$. long, $4-S \mathrm{~mm}$. wide, the seeds transverse.

Scrub-lands, coppices, thickets and pine-lands, Perry Islands, Andros. New l'rovidence, Exuma Chain, L.ong Island, Great Ragged Island, Eleuthera, Cat Island, little San Salvador. Watling's Rum Cay. Crooked Island. Fortune Island, South Caicos:-Florida: Cays of northern Cuba. Specimess from Fortune Island and South Caicos have broadly ovate-elliptic leaflets (var. latifolia Benth.). BaHas SENis. STINKING PEA.

\section{Cassia biflòra L. Sp. Pl. 378. 1753.}

Cassia angustisiliqua Lam. Enercl. 1: 649. 17 S3.

Cassia biflora angustisitiqua Lam.; Griseb. Fl. Brit. W. Ind. 208. 1860.

A shrub or rarely a small tree up to $4 \mathrm{~m}$. high, the slender twigs glabrous or pubeseent, the subulate stipules deciduons. Leares $5-10 \mathrm{~cm}$. long, bearing a eylindric sessile gland, $3-6 \mathrm{~mm}$. long, between the lowest pair of leaflets; leaflets $4-11$ pairs, oblong to oborate-oblong, 1-3 $\mathrm{cm}$. long, glabrous or sparingly pubeseent, membranous or subchartaceous, obtuse, acutish, or slightly emarginate aul commonly mucronulate at the apex, rounded or narrowed at the base: flowers in small corymbs; pedicels very slender, $8-20 \mathrm{~mm}$. long; ealyx $5-7 \mathrm{~mm}$. long; petals obovate, about three times as locg as the calyx; pod linear, flat, membranous, sparingly pubeseent or glabrous, 5-10 em. long, 4-9 $\mathrm{mm}$. ride, somewhat impressed between the seeds.

Sclub and open lands, New Providence, Eleuthera Cat Island Great Exuma, Watling's, Atwond Car, Fortune Island, Calcos and Inagua :-Jamaica : Cuba ; HIspanlola: 'Frenada ; Florida; contipental troplcal America. Busir sexxi. MosQCITO BUSH. 
8. Cassia uniflòra Mill. Gard. Dict. ed. 8, no. 5. 1768.

Cassia sericca Sw. Fl. Ind. Oce. 2: 724. 1800.

Annual, appressed-rillous with brownish long hairs, simple or branched, 3-10 dm. high. Stipules narromly linear, 5-20 $\mathrm{mm}$. long; leaves 6-15 cm. long, petioled, bearing long-stalked glands between one or more of the pairs of leaflets; leaflets $2-1$ pairs, thin, nearly sessile, oblong to obovate, $2-\overline{5} \mathrm{~cm}$. long, rounded or acutish and mucronate at the apex, rounded or narrowed at the base, glabrate above, appressed-silky beneath; peruncles axillary, 1-few-flowered, as long as the petioles or shorter; sepals rounded, about $6 \mathrm{~mm}$. long; petals about twice as long as the sepals; perfect stamens 7 ; pod uarrowly linear, $2.5-5 \mathrm{~cm}$. long, about $4 \mathrm{~mm}$. wide, compressed, deeply impressed between the oblong truncate seeds, the margins continuous.

Roadsides and waste places, New Providence, Long Island and Inagua:-Cuba; Hispaniola; Jamaica; Margarita; Mexico southward to Venezuela, Silki SExis.

9. Cassia villòsa Mill. Gard. Dict. eł. 8, no. 4. 1768.

Shrubby, densely stellate-pubescent all over, $6 \mathrm{dm}$. high or higher, branched, the branches terete. Leaves petioled, $7-15 \mathrm{~cm}$. long; stipules wanting, or very early fugacious; leaflets $3-5$ pairs, with a short-stalked gland between the lowest pair, very short-petioluled, lanceolate or oblong-lanceolate, acuminate at the apex, narrowed or rounded at the base, inequilateral; flowers few or several, in peduncled axillary racemes shorter than the leares; pedicels slender, $6-10$ $\mathrm{mm}$. long; calyx $7-8 \mathrm{~mm}$. long; petals yellow, veiny, about twice as long as the sepals; perfect stamens 7 ; pod linear, $5-8 \mathrm{~cm}$. long, compressed, moniliform, the joints 1 -seeded.

Waste places, New Providence. Native of Mexico. Mexicas Sexva.

Cassia cmarrinata L., a tree of tropical America, recorded br schoepf as seen by him on New Providence in 1784 is not otherwise known from the Bahamas.

\section{CHAMAECRÍSTA Moench, Meth. 272, 1794.}

Herbs or low shrubs, with evenly pinnate leaves, often sensitive to the touch, mostly persistent strongly nerver stipules, and yellow flomers in small axillary clusters or solitary in the axils. Calyx-lobes acuminate. Corolla somewhat irregular, three of the five petals smaller than the others. Stamens 5-10, all usually with perfect anthers opening by terminal pores. Pods linear, flat, more or less elastically dehiscent, the valves twisting. [Greek, low crest.] About 100 species, widely distributed in temperate and tropical region. Type species: Chamaecrista nictitans (L.) Moench.

Ilerbs; leares membranous.

Pubescence appressed; pod $3 \mathrm{~mm}$. wide or less.

Pubescence spreading: pod $3.5-4 \mathrm{~mm}$. wide.

1. r. Chamaccrista. Low shrubs: leaves coriaceous.

Glands short-stipitate: leaflets shining.

Franches densely pubescent.

Branches glabrous or slightly pubescent.

Leaflets lanceolate to ob]ong, acute or mucronate.

Leaflets narrowly obovate to obovate-oblong, obtuse.

Glands strictly sessile; leaflets dull.

2. C. riparia.

3. C. Iucayana.

4. C. caribaea.

5. C. inaguensis

6. C. linerata.

1. Chamaecrista Chamaecrísta (L.) Britton, Bull. Torr. Club 44: 12. 1917.

Cassia Chamaecrista L. Sp. Pl. 379. 1753.

Low, slightly woody, diffusely branched, the branches slender, ascending, spreading or prostrate, pubescent or glabrate, sometimes $2-3 \mathrm{dm}$. long. Stipules lanceolate, acuminate, strongly few-reined, $3-6 \mathrm{~mm}$. long; petioles about as long 
as the stipules, bearing a solitary small, slender-stalked gland; leaflets 5-16 pairs, linear, 5-12 $\mathrm{mm}$. long, inequilateral, thin, pubescent or glabrate, often ciliate, mucronate; peduncles 1-flowered, not longer than the petioles; sepals thin, lanceolate, 3-4 mm. long; petals obovate, slightly longer than the sepals; stamens $5-7$; pod linear, loosely pubescent or glabrate, $1.5-3 \mathrm{~cm}$. long, $3 \mathrm{~mm}$. wide or less.

Sandy and rocky soil, New Providence, South Caicos:-Cuba to St. Jan, St. kitts and Grenada; Margarita; Bonaire; Curaçao; Jamaica.

\section{Chamaecrista ripària (H.B.K.) Britton, Bull. Torr. Ciub 4t: 11. 1917.}

Cassia riparia H.B.K. Nor. Gen. 6: 369. 1824.

Erect, slightly woody, $2-5 \mathrm{dm}$. high, the stem, the ascending branches and leaf-rachis villous with long, spreading, brownish hairs. Stipules lanceolate or linear-lanceolate, striate-veined, 4-10 mm. long; petioles villous, mostly shorter than the stipules, bearing a solitary, rather stout-stalked gland; leaflets 6-2.5 pairs, linear, 6-12 $\mathrm{mm}$. long, inequilateral, aristate, glabrous or very nearly so: peduncles 1-flowered, shorter than the petioles; sepals lanceolate, loosely villous, about $5 \mathrm{~mm}$. long; larger petals $7-8 \mathrm{~mm}$. long; pod linear, loosely villous, $1.5-3$ cm. long, 3- $\$ \mathrm{~mm}$. wide.

Pine and scrub-lands, Andros, New Proridence. Eleuthera:-Grand Carman. Referred by Dolley to Cassia glandulosa L.; by Hitcheock to Cassia nictitans L.. by Mrs. Nolthrop to Cassia mimosoides I... and by Britton (Bull. X. I. Bot. Gard. $3: 443$ ) doubtfully to Cassia aspera Muhl.

\section{Chamaecrista lucayàna Britton, Bull. Torr. Club t4: S. 1917.}

Cassia lucayana Britton, Bull. N. Y. Bot. Gard. 4: 13s. 1906.

A much-branched shrub, $1.5 \mathrm{~m}$. high or less, the twigs densely pubescent, very leafy. Petiole 6-12 mm. long, somewhat pubescent, bearing a stout flattopped gland below the lowest leaflets; rachis sparingly pubescent or glabrous; leaflets 4-9 pairs, coriaceous, glabrous, minutely papillate, inequilateral, orate to orate-oblong, sessile, obliquely cordate or subcordate at the base, obtuse to acutish and distinctly cuspidate at the apex, 1-2 $\mathrm{cm}$. long, 4-12 $\mathrm{mm}$. wide, finely many-veined, the veins parallel, somewhat anastomosing; stipules lanceolate-subulate, 3-4 $\mathrm{mm}$. long; peduneles 1 or 2 in the axils, $3-4 \mathrm{~cm}$. long, pubescent; legume linear, flat, narrowed at the base, abruptly short-tippeil, nearly glabrous or with a few scattered hairs when mature, $4-5 \mathrm{~cm}$. long, 5-7 $\mathrm{mm}$. Wide, imperfectly septate between the seeds; seeds obliquely quadrate, compressed, dull, 4-5 $\mathrm{mm}$. long, about $2 \mathrm{~mm}$. broad.

Rocky scrub-lands, Exuma Chain from a cay north of wide opening to Great Exuma, Cat Island, Conception Island and Rum Cay. Fndemic.

4. Chamaecrista caribaèa (Northrop) Britton, Bull. Torr. Club 44: S. 1917.

Cassia caribaea Northrop, Mem. Torr. Club 12: 39. pl. 6. 1902.

A branched shrub, $1 \mathrm{~m}$. high or less, the young twigs sparingly appressed. pubescent or glabrate. Petiole $2-\bar{T} \mathrm{~mm}$. long, bearing a nearly cylindric gland or glandless; leaflets 2-4 pairs, coriaccous, glabrous, shining, inequilateral, oblong to narrowly elliptic or oblong-lanceolate, sessile, acute and mucronate at the apex, obliquely rounded at the base, strongly reined, $1.5-2.5 \mathrm{~cm}$. long; stipules lanceolate-subulate, about $4 \mathrm{~mm}$. long; flowers solitary in the axils, rarely 2, peduncles glabrous, very slender, $2-3 \mathrm{~cm}$. long: calyx about $1 \mathrm{~cm}$. long; the outer sepals pilose on the back; petals about twice as long as the sepals, oborate; pod linear, 3-5.5 $\mathrm{cm}$. long, $5-7 \mathrm{~mm}$. wile, sparingly shortpubescent. demic.

Rocks scrub and pine-lands, Andros, Niew I'rovidence and Cat lsland. lin- 
5. Chamaecrista inaguénsis Britton, Bull. Torr. Club 44: 8. 1917.

Cassia inaguensis Britton, Bull. N. Y. Bot. Gard. 3: 443. 1905.

A much-branched shrub, 6-12 dm. high, the twigs pubescent. Leaflets 1 or 2 pairs, glabrous, coriaceous, rigid, shining, oblong to obovate, strongly and finely many-reined, emarginate or rounded at the apex, narrowed but not cuneate at the base, more or less inequilateral, $1.5-3 \mathrm{~cm}$. long, $5-13 \mathrm{~mm}$. wide; petiole 2-6 $\mathrm{mm}$. long, sparingly pubescent, bearing a stipitate gland near the top; stipules lanceolate-subulate, $2-4 \mathrm{~mm}$. long, pubescent, persistent; flowers solitary in the axils, numerous, the filiform sparingly pubescent peduncles $2-3$ $\mathrm{cm}$. long; sepals pubescent, at least at the base, obliquely lanceolate, acuminate, $1 \mathrm{~cm}$. Iong or less; petals golden yellow, about $1.5 \mathrm{~cm}$. long; young legume densely pubescent.

Open serub-land, Grand Turk Island, Caicos and Inagua. Endemic.

\section{Chamaecrista lineàta (Sw.) Greene, Pitt. 4: 31. 1899.}

Cassia lineata Sw. Prodr. 66. 1788.

A usually much-branched shrub, 3-10 $\mathrm{dm}$. high, the twigs finely pubescent or glabrate. Leaflets $3-8$ pairs, oblong, linear-obloug, oblanceolate or obovate, coriaceous, $6-20 \mathrm{~mm}$. long, $2-7 \mathrm{~mm}$. wide, rounded and mucronulate at the apex, dull, rather strongly pinnately veined, glabrous or puberulent, the petiole $3-8$ mm. long, bearing a sessile gland; stipules lanceolate, acuminate, as long as the petioles or shorter; flowers solitary in the axils, $2-3 \mathrm{~cm}$. broad; petals oborate; sepals lanceolate, acuminate, $7-10 \mathrm{~mm}$. long; legume linear, pubescent, 2.5-6 $\mathrm{cm}$. long, 5-6 mm. wide, short-beaked.

Scrub, palmetto, and pine-lands, throughout the archipelago from Abaco and Great Bahama to Watling's, North Caicos, Ambergris Cas and Inagua :-Cuba ; Hispaniola: Anegada; Jamaica. Reported by Hitcheock and by Mrs. Northrop as Cassia polyadena DC.. and also referred to that species by Bentham; reported by Dolley as Cassia Chamaecrista L.

4. PARKTNSÒNIA L. Sp. Pl. 375. 1753.

Spiny shrubs or small trees, with nearly sessile, bipinnate leares, the common petiole rery short and spinulose-tipped, the 1 or 2 pairs of pinnae elongated, with several-many, small leaflets, the showy, yellow flowers in racemes. Calyx-tube short, the 5 narrow segments nearly equal. Petals 5, spreading, nearly equal. Stamens 10, distinct; filaments rillous at the base; anthers all alike, rersatile, the saes longitudinally dehiscent. Ovary shortstipitate, many-ovuled; style nearly filiform; stigma small and terminal. Pod linear, coriaceous, torulose, striate-veined, 2-valved. Seeds oblong, longitudinally placed, hard; endosperm horny; cotyledons flat. [Commemorates John Parkinson, an English botanist, herbalist to James I, who died in 1750.] Three known species, of tropical and subtropical America and Africa, the following typical.

\section{Parkinsonia aculeàta L. Sp. Pl. 375. 1753.}

A shrub, or a tree up to about $9 \mathrm{~m}$. high, with nearly smooth bromn bark, and slender, spreading or drooping branches, the young twigs pubescent, the stipular spines $2 \mathrm{~cm}$. long or less. Pinnae 1 or '2 pairs, appearing like sessile pinnate leaves, 2-4 $\mathrm{dm}$. long, the rachis flat, narrowly winged, bearing 10-25 pairs of short-petioluled, linear to obovate leaflets $1.5-8 \mathrm{~mm}$. long, or sometimes without leaflets; racemes few-several-flowered, as long as the leaves or 
shorter; pedicels very slender, 0.5-2 cm. long; calyx 6-5 mm. long; petals nearly orbicular, about twice as long as the calyx; stamens about one-lialf as long as the petals; porls drooping, linear-eylindrie, $5-15 \mathrm{~cm}$. long, wuch constricted between the seeds, which are oblong-eylintric, about 1 cin. long.

Scrub-lands, Grand Turk:-sonthern Cnited States: Cuba to Virgin Gorda and Trinidad; Jamaica; continental tropical America; introduced into the Old World tropics. PARKINSONia. HORSEBEAx.

\section{HAEMATOXYLUM L. Sp. Pl. 384. 1753.}

Trees or shrubs, with yellow wook, evenly pinnate leares, the leaflets obcordate, the spinescent stipules persistent or deciduous, the showy yellow minutely bracted flowers in loose axillary racemes. Calyx-tube very short, its 5 segments imbricated, somewhat unequal. Petals 5, oblong, spreading, somewhat unequal. Stamens 10, distinet; filaments pilose at the base; anthers all alike. Ovary short-stipitate, 2-3-ovuled; stỵle filiform; stigma terminal, small. I'od flat, membranous, oblong or lanceolate, not dehiscent along the sutures, but splitting through the middle of the valres. Seeds transverse, oblong; endosperm none; cotyledons 2-lobed. [Greek, bloodwood.] Two known species, the following typical.

1. Haematoxylum campechiànum L. Sp. Pl. 384. 1753.

A glabrous tree up to about $8 \mathrm{~m}$. high, or sometimes shrubby, with spreading branches, the trunk rilged, the bark smooth and light gras, the twigs slender. Stipular spines $5-15 \mathrm{~mm}$. long; leaves petioled, 5-10 $\mathrm{cm}$. long; petioles very short; leaflets $2-4$ pairs, chartaceous, cuneate-obovate, $1-3 \mathrm{~cm}$. long, finely many-reined, usually rather deeply emarginate, shining above; racemes sereral-many-flowered, short-peduneled, $2-5 \mathrm{~cm}$. long; pedicels filiform, spreading, 4-6 mm. long; ealyx 3-4 mm. long, its segments oblong-lanceolate, acute, unequal; petals obtuse, 4-6 mm. long; stamens about as long as the petals; pod oblong, delicately reined, $2-5 \mathrm{~cm}$. long, $8-12 \mathrm{~mm}$. wide, very thin, pointed at both ends.

Coastal thickets, hillsicles and borders of salines, Andros, New Providence, Exuma Chain. Cat Island, Conception Island, Long Island, Crooked Island:-West Indies and Central America. Logwoon. Catesby, $2: p l$. 66.

\section{GUILANDINA L. Sp. Pl. 381. 1753.}

Woody vines, the stems and branches mostly armed with stout recurved prickles. Leaves large, petioled, bipinnate, the leaflets often punctate. Flowers rather large, yellow, racemose or paniculate, the narrow bracts deciduous. Calyx-lobes 5, imbricated, longer than the tube. Petals 5, nearly alike, spreading. Stamens 10, the filaments pubescent below, the anthers longitudinally dehiscent. Pods oral or elliptic, not much longer than wide, subcoriaceous, compressed, usually priekly, splitting along the sutures. Seeds hard, globose or oroid, yellow, gray or black, smooth, scarcely flattened. [Commemorates Melchior Guilandinus, a German traveller and botanist who died in 1590.] Abont 12 species, mostly West Indian. Type species: Guilandina Bonduc L.

Secds gray ; stipules large.

Sceds yellow; stipules small ol wanting.

I.eriflets ovate, acute or acuminate.

Leaflets elliptic to subolbleular, obtuse or emarginate.

1. G. Crista.

2. G. Bonduc

3. G. orelifolia. 
1 Guilandina Crísta (L.) Small, Fl. SE. U. S. 591. 1903.

Caesalpinia Crista L. Sp. Pl. 380. 1753.

Guilandina bonducella L. Sp. Pl. ed. 2, 545. 1762,

Caesalpinia bonducella Fleming, Asiat. Researches 11: 159. 1810.

A vine, up to $6 \mathrm{~m}$. long, trailing or climbing, the twigs and leaves armed with hooked prickles, the twigs also more or less densely bristly. Stipules usually foliaceous, thin, usually incised, persistent, sometimes 5 cm. broad; leaves 3-8 dm. long, more or less pubesecnt; pinnae 4-8 pairs, short-stalked; leaflets 4-S pairs, oblong to ovate-oblong or elliptic, rather thin, $2.5-i \mathrm{~cm}$. long, obtuse, retuse or short-acuminate and often mucronate at the apex, nearly sessile, rounded or subcordate at the base; racemes axillary, pubescent, sometimes bristly, many-flowered, sometimes $3 \mathrm{dm}$. long; bracts linear-acuminate, reflexed or spreading, $1-1.5 \mathrm{~cm}$. long, deciduous; pedicels $1 \mathrm{~cm}$. long or less; calyx 7-9 mm. Jong; petals oblong-ovate, about $1 \mathrm{~cm}$. long; pod 5-10 cm. long, $6 \mathrm{~cm}$. wide or less, usually densely prickly; seeds gray, shining, obovoid-oval, slightly compressed, $2-2.5 \mathrm{~cm}$. lorig, about $1.5 \mathrm{~cm}$. wide.

Coastal thickets, throughout the archipelago from Abaco and Great Bahama to Mariguana, Inagua, Grand Turk and the Anguilla Isles:-Bermuda: Florida; West Indies: coasts of continental tropical America and of the Old World tropics. Gray Nickers. Brifr.

2. Guilandina Bónduc L. Sp. Pl. ed. 2, 545. 1762.

Caesalpinia Bonduc Roxb. Hort. Beng. 32. Hyponym. 1814.

Guilandina major Small, F. SE. U. S. 591, 1331. 1903.

A trailing or climbing vine, armed with hooked prickles. Stipules none; leaves often $6 \mathrm{dm}$. long, stout-petioled; pinnae $3-6$ pairs; leaflets $4-8$ pairs, crate to elliptic-orate, $4-8 \mathrm{~cm}$. long, acute or short-acuminate at the apex, rounded or obtuse at the base, subcoriaceous, somewhat shining above, glabrous or very nearly so when old; racemes $3 \mathrm{dm}$. long or less, many-flowered; bracts linear-lanceolate, erect, early deciduous; pedicels $4-8 \mathrm{~mm}$. long; calyx about $6 \mathrm{~mm}$. long; petals $1.5 \mathrm{~cm}$. long or less; pod $6-12 \mathrm{~cm}$. long, about one-half longer thau wide, rather loosely prickly; seeds bright yellow, $1.5-2.5 \mathrm{~cm}$. long.

Coastal thickets and scrub-lands, Abaco, Great Babama, Andros, and Rum Cay:- Florida; Cuba; Jamaica; East Indies. Large Yellow Nickers.

3. Guilandina ovalifòlia (Urban) Britton, Bull. N. Y. Bot. Gard. 4: 118. 1905.

Caesalpinia ovalifolia Urban, Symb. Ant. 2: 273. 1900.

Caesalpinia lucida Urban, Symb. Ant. 2: 275. 1900.

Climbing, $4 \mathrm{~m}$. long or longer, the young branches prickly, puberulent. Leaves 2-3 dm. long, the rachis puberulent; leaflets 5-8 pairs, oval or elliptic, glabrous or nearly so, shining, rounded at the apex, rounded to narrowed at the base, their terminal mucro often $2 \mathrm{~mm}$. long; racemes densely puberulent, solitary or in pairs, 1.5-2 dm. long; bracts narromly lanceolate, attenuateacuminate, $8 \mathrm{~mm}$. long, soon spreading; pedicels $1-1.5 \mathrm{~cm}$. long; sepals oblong, obtuse, densely tomentulose, 6-7 mm. long, $1.5-2 \mathrm{~mm}$. Wide, soon reflexed; petals bright yellow, about as long. as the sepals, oblong to oblong-spatulate, obtuse; pod obiiquely obovate, $6-8 \mathrm{~cm}$. long, $4 \mathrm{~cm}$. wide, $2 \mathrm{~cm}$. thick, shining, armed with numerous rather distant yellow stifi bristles $6 \mathrm{~mm}$. long or less, its sharp stout beak about $1 \mathrm{~cm}$. long; seeds globular, yellow-brown, shining, $1.6 \mathrm{~cm}$. in diameter.

Coastal thickets, Great Sturrup Cay, New Providence, and Hog Island, Rose Island, Eleuthera. Great Guana Cay, Long Island and Acklin's Island:-Florida. SMALL YeLLOW NICKERS.

We are unable to distinguish a difference between the two above species of Prof. Urban in specimens gathered, after thorough search, in the type localities be mentions which are only separated by the narrow harbor of Nassau. 
7. CAESALPINIA L. Sp. Pl. 3S0. 1753.

Unarmed or prickly slirubs or trees, with bipinnate leares and racemose yellow bracted flowers, the bracts commonly early deciduous. Calyx-tube short, its 5 segments imbricated. Petals 5, broad, imbricated, more or less unequal. Stamens 10, distinct, deelined, short-exserted; anthers all alike, longitudinally dehiscent. Orary sessile, glabrous or pubeseent; style mostly filiform; stigma terminal. Pod linear to oblong, dehiscent or inlehiscent, flat or swollen. Seeds transverse; cndosperm none. [Commemorates Amlreas Caesalpini 1519-1603, famous Italian physician aud botanist.] Thirty species or more, of tropical and subtropical regions. Type speeies: Caesalpinia brasiliensis L.

Leaflets few pairs, oborate.

Legume indehiscent.

Legume dehiscent.

Prickly thronghont: leaflets scircely reticulated.

Cnarmed or with a few prickles at the base; leaflets strongly reticulated.

Leaflets many pairs, linear-oblong.

1. C. tesicarit.

2. ('. bahamensis.

3. C. reticulata.

4. C. coriaria.

1. Caesalpinia vesicària L. Sp. Pl. 3\$1. 1753.

Caesalpinia bijuga Sw. Obs. 166. 1791.

A much-branched shrub or tree up to about $7 \mathrm{~m}$. high, the twigs and leares glabrous, armed with few prickles 4-8 mm. long, or unarmer. Leares 1-2.5 Im. long; petioles $1-3 \mathrm{~cm}$. long: pinnae 2 or 3 pairs, stalkerl; leaflets $1-3$ pairs, obliquely cuneate-oborate, subeoriaceons, 1-4 cm. long, subtruneate or emarginate at the apex, narrowed or obtuse at the base, dark green and shining above, pale and rather dull beneath; racemes simple or compound, mostly as long as the leares or longer; pedicels slender, jointed near the top, 6-9 mm. long; calyx 8-9 $\mathrm{mm}$. long; petals a little longer than the calyx; stamens about as long as the petals, the filaments densely rillous; pod oblong, straight, coriaceons, indehiscent, 4-6 cm. long, 12-20 mm. wide, about $4 \mathrm{~mm}$. thick, pribescent when young, becoming glabrous; steds few, orbicular, shining, brown.

Coastal thickets and rocky coppices, Great Guaria Cay, Long Island and Great Ragged Island:-Cuba; .Tamaica; Yueatan. lilisiletTo..

2. Caesalpinia bahaménsis Lam. Eneyel. 1: 461. 1793.

Caesalpinia Crista Griseb. Fl. Br. W. I. 205. 1560. Not L. 1753.

Caesalpinia Rugeliana Urban, Symb. Ant. 2: 275. 1900.

A prickly shrub, $1.5-2.5 \mathrm{~m}$. high, or rarely a small tree up to $4 \mathrm{~m}$. high, the young twigs and leaves brownish tomentulose or glabrate, becoming glabrous, the leares unarmed, or bearing a few prickles. Leaves $8-25$ em. long; petioles 1-3 cm. long; pinnae 2-4 pairs, stalkerl, $15 \mathrm{em}$. long or less: leaflets $3-6$ pairs, short-petioluler, oborate to elliptie, $1-4 \mathrm{~cm}$. long, subcoriacens, cmarginate or rounded at the apex, narrowed or obtuse at the base, reticnlate-reineil, shining above, dull beneath; racenes mostly as long as the leaves or longer: pedicels 1-2.5 $\mathrm{em}$. long, jointed above; calyx about $9 \mathrm{~mm}$. long: petals yellowish green, shorter than the ealyx; stamens eurved, 2-3 times as long as the calyx: pod flat, hroarlly linear, $\tilde{5}-7 \mathrm{~cm}$. long, abont $1.5 \mathrm{~cm}$. wide, glabrons, short-stipitate, acuminate.

Coppices and scrub-lands, Andros, Xew Trovidence, Eleutlera, Grent Guana

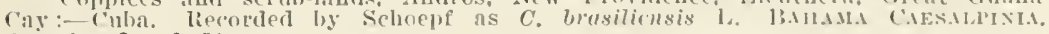
Catesby, 2: $p l .51$. 


\section{Caesalpinia reticulàta Britton, Bull. N. Y. Bot. Gard. 4: 11 ๖. 1905.}

A shrub or small tree, $4 \mathrm{~m}$. high or less, similar to C. bahamensis. Stem ant liranehes unarmesl in all specimens observel; roung shoots puberulent; leatlets 2 to 4 pairs, obliquely oral or obliquely oborate, coriaccous, glabrous when mature, strongly finely reticulate-nerved and shining above, dull and less prominently nerved beneath, rounded, truncate or slightly emarginate at the apex, narrowed or obtuse at the base, $1.5-5 \mathrm{~cm}$. long, $3 \mathrm{~cm}$. wide or less, very inequilateral; petiolules $2-3 \mathrm{~mm}$. long; racemes solitary or 2 or 3 together, $2 \mathrm{dm}$. long or less; flowers yellowish white; pediccls ascending, 1-2 cm. long: becoming very stout in fruit; calyx stipitate, the tube nearly hemispheric; stamens long-exserted; pod flat, smooth, 6-9 cm. long, $1.5 \mathrm{~cm}$. Wide, its stipe somewhat longer than or equaling the persistent calyx-tube.

Scrub-lands, Watling's, Acklin's, rrooked Jsland and Inagua, Endemic. Slightly but apparently constantly distinct from $C$. bahamensis and of diffelent distribution: perhaps a race of that species. Net-reined CaEsalrivia.

4. Caesalpinia coriària (Jacq.) Willd. Sp. Pl. 2: 532. 1799.

Poinciana coriaria Jacq. Sel. Amer. 123, 1763.

Libidibia coriaria Schl. Linnaea 5: 193. 1830.

A widely branched unarmed tree, 5-10 m. high, with slender twigs, puberulent when young, soon glabrous. Leares 1-2 dm. long; petioles and rachis finely tomentulose; pinnae 4-10 pairs, short-stalked; leaflets numerous and small, 12-26 pairs, 4-6 mm. long, very nearly sessile, oblong-linear, obtuse at the apex, subcordate or truncate at base, glabrous and dull on both surfaces, usually with one or more black dots beneath; flotrers yellow, in small panicles or racemes shorter than the leares; pedicels glabrous, 2-4 $\mathrm{mm}$. long; calyx about $5 \mathrm{~mm}$. long, its segments nearly alike; petals spatulate, about as long as the calrx; stamens about as long as the petals; pod oblong, compressed, 3-6 $\mathrm{cm}$. long, 1-2 cm. wide, laterally incurved.

Spontaneous after cultivation. New Providence, near Nassau:-Santo Domingo: Jamaica; St. Thomas to Trinidad: Curaço: continental tropical America. Divi-Diri.

\section{POINCIÀNA L. Sp. Pl. 380. 1753.}

Shrubs or small trees, sometimes prickly, with evenly bipinnate leaves, and orange red or yellow, showy flowers in panicles or racemes, the bracts early deciduous or none. Calyx-tube short, the 5 lobes imbricated, unequal, the lowest one the largest. Petals 5, unequal. Stamens 10, distinct, long-exserted; anthers longitudinally dehiscent. Orary sessile, sereral-oruled; style slender; stigma small, terminal. Pod linear or linear-oblong, flat, 2-ralved. Seeds transverse; endosperm none. [In honor of Poinci, a governor of the West Indies.] A few species, of iropical and subtropical distribution, the following typical.

\section{Poinciana pulchérrima L. Sp. PI. 380. 1753.}

Caesalpinia pulcherrima Sw. Obs. 166. 1791.

A glabrous shrub or small tree up to about $5 \mathrm{~m}$. high, the branches prickly. Leares $3 \mathrm{dm}$. Iong or less, unarmed, the petiole and lower part of the rachis stout, the upper part of the rachis rery slender; pinnae 3-9 pairs, short-stalked; leaflets 5-12 pairs, thin, very short-stalked, oblong to oblong-oborate, bright green above, pale beneath, 1-2 cm. long, $7-10 \mathrm{~mm}$. wide, rounded or subtruncate and mucronulate at the apex, obtuse at the base; racemes large, terminal, 
and axillary: pedicels slender, $5-8 \mathrm{~cm}$. long; sepals unequal, the larger about $1.5 \mathrm{~cm}$. long; petals orange or yellow, $1.5-2.5 \mathrm{~cm}$. long; stamens $5-6 \mathrm{~cm}$. long; pod flat, broadly linear, $12 \mathrm{~cm}$. long or less, 14-15 mm. wille, somewhat oblique, pointed at both ends, its ralves subcoriaceous, glabrous, twisting after dehiscence; seeds compressed.

spontaneous in waste places, and in coppices, Andros, New Proridence and Inagua :-Cuba to St. Thomas and to Trinidad; continental tropical America; Old World tropics. BarBadoes l'iridE.

\section{DELònIX Raf. Fl. Tell. 2: 92. 1836.}

Tnarmed trees, with evenly bipinnate, estipulate leaves of numerous small leaflets, and large, showy, orange to scarlet flowers in terminal or axillary corymbose racemes. Calyx deeply 5-lobed, the nearly equal lobes ralvate. Petals 5, long-clawed, the blade nearly orbicular. Stamens 10, declined; filaments distinct; anthers longitudinally dehiscent. Ovary sessile, many-oruled; style slender or short; stigma truncate, eiliolate. Pod broadly linear, flat, woody, 2-valved, nearly solid between the oblong transverse seeds. Endosperm present; cotyledons thiek. [Greek, referring to the long-elawed petals.] About 3 species, natives of Africa, the following typieal.

\section{Delonix règia (Bojer) Raf. Fl. Tell. 2: 92.1836.}

Poinciana regia Bojer; Hook. Bot. Mag. pl. 2884. 1829 .

A widely branched tree, reaching a maximum height of about $12 \mathrm{~m}$., with a trunk up to $9 \mathrm{dm}$. in diameter, the thin bark gray-brown, the twigs somewhat pubescent. Leaves 3-5 dm. long; petiole stout, reddish or yellow, i-12 em. long; pinnae 10-25 pairs, short-stalked, 8-15 cm. long, the rachis pubescent; icaflets 20-40 pairs, oblong, puberulent on both sides, 4-10 $\mathrm{mm}$. long, inequilateral, rounded at both ends; pedicels stout, $4-8 \mathrm{~cm}$. long; calrx about $2 \mathrm{~cm}$. long; petals spreading and reflexed, $5-7 \mathrm{~cm}$. long, orange to scarlet and mottleri; stamens shorter than the petals; pod $4-6 \mathrm{dm}$. long, $\bar{j}-\overline{\mathrm{r}} \mathrm{em}$. wide, dark brown.

Spontaneous after cultiration, New Proridence, near Nassau :- Videly cultirated and spontaneous after cultivation throughout the Test Indies and in southern Florida. Native of Madagascar. Roral Porxcraxi. Flasborast.

\section{PELTóPHoRUM Togel; Walp. Rep. 1: \$11. 1812.}

Unarmed trees, with bipinnate leaves of numerous small leaflets, the small stipules caducous, and yellow flowers in panicled racemes. Calyx-tube short, its 5 segments nearly equal or the lower one somewhat larger than the others. Petals 5, orbicular, spreading, imbricated, slightly unequal. Stamens 10, distinet, declined; filaments pilose below; anthers all alike. Ovary sessile, fewmany-oruler; style filiform; stigma peltate. Por oblong, flat, indehiscent, narrowed at both ends. Seeds 1-t, flat, transverse; endosperm none. [Greek, shiel/-bearing; from the peltate stigma.] About 7 speeies, of tropical distribution. Type species: Peltophorum Fogelianum Walp.

1. Peltophorum adnàtum Griseb. Fl. Br. W. I. 206. 1560.

A tree, in the Bahamas up to ahout $12 \mathrm{~m}$. high, in the Cuban forests reacling a height of $50 \mathrm{~m}$., the twigs, petioles, rachis, infloreseence, calyx, and lower leaf-surfaces densely brown-tomentose or villous. Leares petioled, 1-3 dm. 
long; pinnae 6-12 pairs, opposite, very nearly sessile, narrowly lanceolate, 5-10 em. long; leaflets 12-36 pairs, opposite, coriaceous, linear-oblong, $5-10 \mathrm{~mm}$. long, revolute-margined, glabrous and shining above, obtuse at the apex, truncate at the sessile base; panicles terminal, many-flowered, often $3 \mathrm{dm}$. long; pedicels slender, $12-20 \mathrm{~mm}$. long; calyx subglobose in bud, 5-6 $\mathrm{mm}$. long, its obovate segments imbricated, nearly equal; petals obovate, 7-10 $\mathrm{mm}$. long; stamens shorter than the petals; pod $4-5 \mathrm{~cm}$. long, $12-15 \mathrm{~mm}$. wide at the middle. BUSII.

Scrub-lands and coppices, Andros, Great Exuma, Long Island:-Cuba. HorSE-

\section{Family 5. FABÀCEAE Rehb.}

\section{Pea Family.}

Herbs, shrubs, vines or trees, with alternate mostly compound stipulate leaves, and irregular (papilionaceous) perfect or sometimes polygamodioecious flowers, mainly in spikes, heads, racemes or panicles. Calyx 4-5toothed, or 4-5-cleft, sometimes 2-lipped. Petals more or less united, or separate, perigynous or hypogynous, usually consisting of a broad upper one (standard, banner), two lateral ones (wings), and two front ones more or less united (forming the keel); the standard enclosing the wing's in the bud. Stamens monadelphous, diadelphous, or sometimes separate, 10 in most of the genera, sometimes 9, rarely 5. Pistil simple, superior; ovary mainly 1-celled, sometimes 2-celled by the intrusion of the sutures. or several-celled by cross-partitions; style simple; orules 1-many, anatropous or amphitropous. Fruit a legume, 1-many-seeded, dehiscent into 2 valves, or indehiscent, in one tribe a loment. Seeds mostly without endosperm; cotyledons thick. About 325 genera and orer 5000 species, most abundant in temperate and warm regions.

Filaments all separate.

Petal only 1; pod flat, short, wingerl.

Corolla papilionaceous: pod turgid, elongated.

Filaments monadelphous or diadelphous.

Herbs, shrubs or trees.

Fruit 2-ralved.

Leaves mostly trifoliolate.

Leaflets entile.

Leaflets serrulate.

Leaves pinnate.

Leaves unequally pinnate.

Pods 4-angled or turgid.

Pods flat.

Leares equally pinnate.

Standard broad, longer than the keel-petals; calrs-lobes acute or acuminate.

Standard narrow, shortel than the keel-petals; calyx-lobes low and broad.

Fruit a loment.

Stamens all united into a tube.

Vexillar stamen free from the others.

Joints of the loment flat.

Joints of the loment thick, fleshy.

Fruit indehiscent.

Leares 1 -foliolate; pod suborbicular; vine-like shrubs.

Leares pinnate; pod elongated, 4-winged: tree.

Vines, our species herbaceous (Phaseolus lathyroides an erect herb: Cajan erect and half-shrubby).

Keel of the corolla not curved nor coiled (somewhat bent in Canavali).

Leares equally pinnate, terminated by a bristle.

Leaves trifoliolate, rarely unifoliolate.

style bearded along the inner side.

Style glabrous or sparingly pubescent below (somewhat bearded in Dolichos).
1. Atricia.

2. Sophora.

\section{Crotaloria.}

4. Trifolium.

5. Indigofera.

6. Cracca.

7. Sesban.

8. Agati.

9. Stylosonthes.

10. Meibomia.

11. Alysicarpus.

12. Ecastophyllum. 13. Ichthyomethia.

14. Abrus.

15. Clitoria. 
Standard spurred at the base.

Standard not spmried at the base.

I'od coreled with stinging hairs.

lod without stinging hairs, pubescent or glabrous.

Iiachis of the inflorescence thlckened at the nodes.

Calyx-lobes unequal.

Calyx 2-lipped.

Rachis of the inflorescence not thickener at the nodes.

Ereet; half-shrubhy : seeds numerous,

Herbaceous, our species rines; seeds only 2 or 3.

Keel of the corolla coiled or curred.

Keel spirally coiled.

Keel not spirally coiled, incurred.

stigma terminal.

Stigma oblique or lateral.

16. Bradburya.

17. Mucunt:

18. Galactia.

19. Canocali.

20. Cajan.

21. Dolicholus.

22. I'hascolus.

23. Dolichos.

24. Tignu.

1. Ateleì Moc. \& Sesse; Benth. Ann. Wien. Mus. 2: 101. 1837.

Unarmed shrubs or small trees, with unevenly pinnate leares, and small white or greenish flowers, in narrow, simple or branched, axillary racemes. Stipules minute or none. Bracts minute. Calyx truncate or minutely 5-toothed. Wings and keel-petals wanting; standard hooded, clawed. Stamens 10, distinct; anthers orate, all alike. Ovary short-stipitate, -oruled; stigma inflexed, nearly sessile. Pod irregularly oborate-orbicular, stipitate, flat, indehiscent, the upper suture narrowly winged. Seed flat, reniform; cotyledons fleshy; radicle inflexed. [Greek, defective.] Three known species of Central America and the West Indies. Type species: Pterocarpus Ateleia DC.

1. Ateleia cubẻnsis Griseb. Mem. Am. Acad. II. 8: 180. 1860.

Swartzia multijuga 1. Rich. in Sagra, Hist. Cub, 10: 201. pl. \&?. 1845. Tot Togel. 1837.

Ateleia multijuga Hitch. Rep. Mo. Bot. Gard. 4: 80. 1893.

A shrub or small tree up to $5 \mathrm{~m}$. high, the slender twigs glabrous, gray, the inflorescence and yomg foliage densely brown-pubescent. Leaves 1-2 dm. long, 5-11-foliolate, glabrous or nearly so when old; leaflets oblong to elliptic or oblong-obovate, denscly and finely reticnlate-reined, subcoriaceous, entire, 3-6 em. long, 1-2 cm. wide, sessile, obtuse or emarginate at the apex, narrowed at the hase; racemes spike-like, shorter than the leaves, or as long; penticels very short; calyx broadly campanulate, truncate, $2-3 \mathrm{~mm}$. long: standard about 3 mm. long; pod sleniler-stipitate, glabrous, $1.5-2 \mathrm{~cm}$. long, $1-1.5 \mathrm{~cm}$. wide, reiny, cuneate-narrowed at the base.

Thickets, coppices, pine-lands and serub-lands, Great Pahama, Andros, New

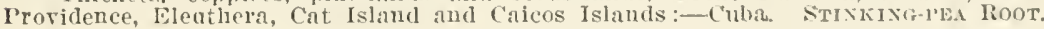

\section{SOPHÒRA L. Sp. Pl. 373. 1753.}

Leaves odd-pinnate. Flotrers white, yellow or violet, in terminal racemes or panicles. Calyx generally campanulate, its teeth short. Stanclard obovate or orbicular; wings obliquely oblong; keel oblong, nearly straight. Stamens all distinct or very nearly so; anthers versatile. Ovary short-stalked; style ineurved. Pod stalked, coriaceous or fleshy, terete, eonstricted between the seeds, mainly indehiscent. [Name Arabic, yellow.] About 25 species, natives of warm and tropical regions. Type species: Sophora alopccuroides L. 
1. Sophora tomentòsa L. Sp. Pl. 373. 1753.

A shrub 1-3 m. tall, with silky-tomentose foliage. Leares 1-2 dm. long; leaflets 11-17, the blarles leathery, oblong, oblong-obovate or oval, inequilateral, becoming glabrous and revolute-margined; racemes elongating, 1-4 dm. long; pedicels 5-10 mm. long; calyx oblong or oblong-funnelform, $5-8 \mathrm{~mm}$. long, constricted at the base, undulate or indistinctly 5-lobed; corolla yellow; standard with an ovate blade fully $1 \mathrm{~cm}$. broad, and over $1.5 \mathrm{~cm}$. long; keel-petals $20 \mathrm{~mm}$. long; pods $5-10 \mathrm{~cm}$. long, strongly constricted between the seeds, long-stalked.

Coastal thickets, coppices and wite-lands, throughout the archipelago from Great Bahama through Andros and Eleuthera to Caicos, Grand Turk, Inagua and Anguilla Isles :-Permuda: Florida; Cuba to Virgin Gorda and St. Fincent; Jamaica ; Aruba; Old World tropics. CoAst Sophora.

\section{CROTALÀRIA L. Sp. Pl. 714. 1753.}

Herbs, sometimes slightly woody, with sinıple, or in many tropical species 3-7-foliolate leares, and racemose yellow flowers. Calyx 5-toothed, slightly 2-lipped; standard orbicular or ovate, often cordate; wings oblong or obovate; keel curved. Stamens monadelphous, their sheath deeply cleft; anthers of 2 forms, alternating with each other, the one snall, versatile, the other larger; style more or less curved; pod oblong or globose, inflated, many-seeded, the seeds loose at maturity. [Greek, a rattle.] About 250 species, mainly of tropical regions. Type species: Crotalaria lotifolia L.

Leares simple.

Flowers blue, rariegated.

Flowers rellow:

Leaves 3-foliolate.

Flowers $1 \mathrm{~cm}$. wide or less: pod ahout $1 \mathrm{~cm}$. long.

Flowers large, $1.5 \mathrm{~cm}$. Wide or more; pod $2-3.5 \mathrm{~cm}$. long. Herbaceous annual; pors pilose.

Somewhat woods perennial; pods puberulent.

1. C. reruncosa.

2. C. retusa.

3. C. pumila.

4. C. incanti.

5. C. lotifolia.

\section{Crotalaria verrucòsa L. Sp. Pl. 715. 1753.}

Annual, 3-8 dm. high, branched, the branches zigzag, angled, finely ap. pressed-pubescent. Leaves simple, broadly ovate or ovate-elliptic, obtuse, rounded or acute and mucronulate at the apex, narrowed at the base, $3-7 \mathrm{~cm}$. long, glabrous or nearly so above, finely appressed-pubescent beneath, shortpetioled, the rounded stipules $3-6 \mathrm{~mm}$. long; racemes several-flomered, longer than the leares, the peduncle and rachis angled; calyx deeply cleft, its upper lobes orate, the lower lanceolate; corolla blue, variegated, $1-1.5 \mathrm{~cm}$. long, about twice as long as the corolla; pod sessile, oblong, beaked, appressed-pubescent with long hairs, 3-4 cm. long, 9-12 mm. thick.

Waste and cultirated ground, New Providence, I,ong Island and Crooked Island:- St. Thmas to Virgin Gorda and Barbadoes; Jamaica; Cuba; continental tropical America. Native of the East Indies. Purple Rattuebox.

\section{Crotalaria retùșa L. Sp. Pl. 715. 1753.}

Annual, appressed-pubescent, usually brarched, 4-10 dm. high. Stipules minute or wanting; leaves simple, oblanceolate, spatulate or oblong, shortpetioled, 4-8 cm. long, rounded or retuse at the apex, cuneate at the base, glabrous abore, appressed-pubescent beneath; racemes terminal, peduncled, loosely several-many-flowered, $2 \mathrm{dm}$. long or less; pedicels $6-10 \mathrm{~mm}$. long; calyx 2-lipped, about $10 \mathrm{~mm}$. long; petals nearly twice as long as the ealyx, Fellow, the standard variegated; pod oblong, $2.5-3.5 \mathrm{~cm}$. long, about $1 \mathrm{~cm}$. thick, short-beaked, glabrous.

Waste and cultirated land, New Proridence and Great Exuma:-Florida; Bermuda; West Indies; continental tropical America. Naturalized from the old World. laRge Yellow Ratrlebox. 


\section{Crotalaria pùmila Ortega, Hort. Matr. 23. 1797.}

Perennial, woody below, finely pubescent or glabrate, branched, the slender branches decumbent or ascending, 1-9 dm. long. Stipules 1-2 mn1. long, deciduous, subulate; petioles very slender, $0.5-2 \mathrm{~cm}$. long; leaflets 3 , oblong, oblanceolate or oborate, thin, $5-15 \mathrm{~mm}$. long, rounded or emarginate at the apex, narrowed or cuneate at the base, glabrous abore, more or less pubescent beneath; racemes fer-flowered, mostly terminal, much longer than the leares: pedicels slender, $2-5 \mathrm{~mm}$. long; calyx 5 -cleft to about the midlle, the lobes acute or acuminate; petals yellow, the standard $7-9 \mathrm{~mm}$. long, twice as long as the calrx, the keel with a short horizontal beak; pod oblong, sessile, $10-15 \mathrm{~mm}$. long, about $5 \mathrm{~mm}$. thick.

I'ine ana palmetto-lands, Abaco, Great Bahama, Andros. New Providence, Eleuthera. Cat Island, Watling's Island. Great Guana Cay. Esuma and Crooked Island:-Florida: Cuba; Hispianola; St. Kitts to Barbadoes; Jamaica; Mexico to Veneznela. Lom Rattiebox.

\section{Crotalaria incàna L. Sp. Pl. 716. 1753.}

Annual or biennial, herbaceous, usually branched, $1.3 \mathrm{~m}$. high or less, the branches, petioles and racemes densely pubescent. Stipules subulate, $5 \mathrm{~mm}$. long or less, deciduous, or wanting: petioles $2-8 \mathrm{~cm}$. long; leaflets 3 , oborate, oral or obovate-orbicular, short-stalked, $1-5 \mathrm{~cm}$. long, thin, obtuse and often mucronulate at the apex, obtuse or narromed at the base, pubescent beneath. glabrate above; racemes terminal, long-peduncled, several-flowered; calyxsegments lanceolate, acuninate, $7-9 \mathrm{~mm}$. long; corolla yellow or greenish. rellow, 10-13 mm. long; pods oblong, pendent, pubescent, $2-3.5 \mathrm{~cm}$. long, about $1 \mathrm{~cm}$. thick.

Waste and cultivated grounds, New Proridence and IIng Island:-southern Tnited States: West Indies and continental tropical America north to Mexico; old World tropics. Velvety RatTlemox.

\section{Crotalaria lotifòlia L. Sp. Pl. i15. 1753.}

Shrubby, branched, $6 \mathrm{dm} .-2 \mathrm{~m}$. high, slender and sometimes vine-like and up to $3 \mathrm{~m}$. long, the branches and petioles appressed-pubescent. Stipules minute, reciduous; petioles slender, $2-6 \mathrm{~cm}$. long; leaflets 3 , oblong to elliptic, thin, $1-4 \mathrm{~cm}$. long, obtuse at the apex, mostly narrowed at the base, shortstalked, silky-pubescent or glabrate beneath, usually glabrous above; racemes axillary, short-peduncled, few-flowered, as long as the leaves or shorter; calcxsegments lanceolate, acuminate, $5-7 \mathrm{~mm}$. long; corolla yellow, about twice as long as the calyx, the standard reddish veined; por narromly oblong, beaked, 2-3 cm. long, about $6 \mathrm{~mm}$. thick, finely appressed-pubescent.

Open scrub-lands, New I'rovidence and Eleuthera:- Cuba to Anegara and Barbadoes; Jamaica. Reported from tropical Africa. Busny Ratrifbox.

Dolles reports Crotalaria stipularis Dess, from the Bahamas: Mr. Frace has not seen the species nor have our collectors returned it from the archipelago.

\section{TRIFÒLIUM L. Sp. Pl. 764. 1753.}

Herbs, with mostly 3-foliolate (occasionally 4-11-foliolate) denticulate leaves, the flowers in dense heals or spikes. Stipules arnate to the petiole. Calyx-tecth nearly equal. Petals comnonly persistent, their claws ailnate to the stamen-tube. Stamens diadelphous, or the tenth one separate for only a portion of its length. Ovary few-oruled. Pod often inclucled in the calyx. membranous, indehiscent or tardily dehiscent by 1 suture, 1-6-seeded. [Latin. rdferring to the 3 leaflets.] About $2-5$ species, most abumlant in the north temperate zone. Type species: Trifolium pratense L.

Flowers white or plnklsh, pedicelled.

Flowers red, sesslle or very nearly" so.
1. T. Mprns.

‥ T. mattusc. 
1. Trifolium rèpens L. Sp. Pl. 767. 1753.

Perennial, glabrous or with a fer scattered hairs, the branches often rooting at the nodes, 1-3 dm. long. Leaves long-petioled; stipules oratelanceolate, membranous, acute, 4-12 mm. long; leaflets short-stalked, obovate, emarginate or obcordate, broadly cuncate at the base, denticulate, $8-20 \mathrm{~mm}$. long; heads long-peduncled; flowers $7-12 \mathrm{~mm}$. long; pedicels 2-5 mm. long, finally reflexed; corolla 2-3 times as long as the calyx; calyx-teeth acuminate, somewhat shorter than the tube; pod about 4 -seeded.

Wayside ditches and dooryards, New Providence, at Nassau :-Permuda; Cuba ; Tamaica: naturalized throughout temperate North America. Native of the Old World. White Cloter.

\section{Trifolium praténse L. Sp. Pl. 768. 1753.}

Perennial, pubescent, 1.5-6 dm. high. Leares long-netioled; stipules orate, strongly veined, subulate-tipped, 12-20 mm. long; leaflets short-stalked, oval, oblong or obovate, narrowed at base, hardly cuneate, obtuse and sometimes emarginate at the apex, ofteu dark-spotted near the middle, finely denticulate, $1-3.5 \mathrm{~cm}$. long; heads globose or ovoid, rarely slightly peduncled, about $2.5 \mathrm{~cm}$. long; flowers red (rarely white), about $12 \mathrm{~mm}$. long, remaining erect in fruit; calyx sparingly hairy, its subulate teeth shorter than the corolla.

Dooryard, New Providence at Nassau:-Bermuda: Cuba. Tidely naturalized in temperate North America. Native of the Old World. Fed Clover.

\section{INDIGÓFERA L. Sp. Pl. 751. 1753.}

Herbs, or rarely shrubs, often canescent with hairs affixed by the middle, with odd-pinnate leaves, small stipules, and pink or purple, spicate or racemose flowers. Calyx-teeth oblique, nearly equal, or the lower longer; standard orate or orbicular, sessile or clawed; wings oblong; keel erect, somewhat gibbous, or spurred; stamens mainly monadelphous; orary $1-\infty$-oruled; style slender; pod linear, 4-angled or subterete, septate between the seeds. [Name from the yield of indigo by some species.] About 275 species, natires of $\pi$ arm and temperate regions. Type species: Indigofera tinctoria L.

\section{Indigofera suffruticòsa Mill. Gard. Dict. ed. 8, no. 2. 1768.}

Indigofera Anil L. Mant. 2: 272. 1771.

A shrub, 1-2 m. high, usually much-branched, the branches slender, tough, whitish appressed-pubescent and groored when young. Leares $5-12 \mathrm{~cm}$. long; stipules filiform-setaceous, very small; petiole 1-2.5 $\mathrm{cm}$. long; leaflets 9-17, oblong or oblong-oborate, $3 \mathrm{~cm}$. long or less, obtuse or acutish and mueronate at the apex, mostly narrotred at the base, pale green, appressed-pubescent on both sides, or glabrous above, darkening in drying; racemes narrow, severalmauy-flotered, 2-5 $\mathrm{cm}$. long; pedicels about $1 \mathrm{~mm}$. long, about equalling the (ampanulate, pubescent calyx, reflexed in fruit; corolla vellowish, $3.5-4.5 \mathrm{~mm}$. long; pod falcate, appressed-pubeseent when young, glabrous when old, 8-15 mm. long, $2 \mathrm{~mm}$. thick, ridged on the sutures, 4-8-seeded.

Waste and cultivated lands, Abaco, Great Bahama, New Proridence, Eleuthera, Great Guana, Exuma, Cat Island, Watling's, Long Island, Acklin's and Inagua:Bermuda; southern United States: West Indies: Mexico to continental tropical South America, I. argentea of Schoepf. WILD IxDigo. 
6. CRÁCCA L. Sp. Pl. 752. 1753.

[Tephrosia Pers. Syn. 2: 328. 1807.]

Iferbs, sometimes slightly shrubby, with odd-pinnate not punetate leares, and purple red or white flowtrs in racemes or short elusters. Stipules small; leaflets entire. Calyx-teeth usually nearly equal. Petals all clawed; standari orbicular or broadly orate; wings obliquely obovate or oblong; keel curved; stamens monadelphous or diallelphous; orules several or many. Pod linear, flat, 2-valved, several-seederl. [Latin, retch.] About 120 species, mainly natives of warm and tropieal regions. Type speeies: Cracca villosa L.

Racemes short-peduncled; leaflets blunt, mueronate.

Iiacemes long-peduncled; leaflets emarginate, mucronulate.
1. C. cincrea.

2. C. cathartica.

1. Cracca cinèrea (L.) Morong, Ann. N. Y. Acad. Sci. 7: 79. 1892.

Galega cinerea L. Pl. Jam. Pug. 19. 1759.

Tephrosia cinerea Pers. S5n. 2: 32S. 1507.

Rootstock thick, sometimes long, woody; stems slender, usually braneher, ascending, erect or diffuse, $5 \mathrm{dm}$. long or less, more or less pubescent. Leaves 5-S cm. long; petioles $1 . \overline{\mathrm{c}} \mathrm{cm}$. loug or less; stipules subulate; leaflets 9-15, mostly oblanceolate, sometimes narrowly oblong, $1.5-2.5 \mathrm{~cm}$. iong, obtuse or acutish at the apex, often mucronate, euneate or narrorred at the base, ap. pressed-pubescent, at least beneath; racemes few; several-flowered, peiluneled, mostly opposite the leares; calyx about $5 \mathrm{~mm}$. long, its teeth acuminate; petals about trice as long as the ealyx, purple or purplish, the standard about $10 \mathrm{~mm}$. broad; pod 3-6 cm. long, 2.5-4 mm. wide, finely pubescent, containing 10 sceds or ferter.

Shaded white-lands, Care Car, Great Exuma, Rum Cay, Long Island, Acklin's, Grand Turk and Inagua :- West Indies: Mexico to South America. The plant refelred to bs Hitcheock proved to be the following species. Slexder Gonts-red.

\section{Cracca cathàrtica (Moc. \& Sesse) Britton \& Millspaugh.}

Galcga cathartica Moc. \& Sesse, Fl. Mex. ed. 2: 175. 1594.

Cracca Schottii Vail, Bull. Torr. Club 22: 25. 1895.

Tephrosia cathartica Urban, Synı. Ant. 4: 2s3. 1905.

Root deep, elongated; stem often much branched, $s \mathrm{dm}$. high or less, the branches ascending or diffuse, slender, tough, 2-4 dm. long. Leares $5-8 \mathrm{~cm}$. long; petioles slender, $2 \mathrm{em}$. long or less; stipules linear-subulate; leaflets $5-9$, oblong-oborate, $1.5-4 \mathrm{~cm}$. long, appressed-pubeseent on both sides or glabrate above, mostly retuse at the apex, cuneate-narrowed at the base; racemes terminal and opposite the leares, ferw-flowered, short or elongated; calyx about 4 $\mathrm{mm}$. long, its teeth acuminate; petals purple or rerl-purple, the standard about $8 \mathrm{~mm}$. broad; pod 3-4 em. long, 4-5 mm. wide, 5-i-scelled.

Coastal white-lınds, Elhow Car, Andros : Eleuthera :-Cuba : Ilispanlola : Porto Rico; Virgin Gorda to St. Kitts; Trinidad; Cayman Islands; Island of Ruatan, Carta. gena: Colombia. Resily Goats-ree.

\section{SÉSBAN Adans. Fam. Pl. 2: 327, 1763.}

Herbs or shrubs, with evenly pinnate leaves, the leaflets numerous, entire, not stipellate, or the stipels minute. Flowers in axillary racenies, the slender pedicels with 2 deciduous bractlets under the ealyx. Calyx campanulate, nearly equally 5-toothed. Standard broad, orate or orbieular; wings oblong, faleate; keel blunt. Stamens dialdphous (9 and 1$)$. Orary mostly stipitate, many- 
orulcul; strile glabrous; stigma small. Pou clongated-linear, wingless, ronı. pressed, partitioned between the oblong seels. [Name Arabie.] About 15 speeies, natives of warm and tropical regions. Type species: Aeschynomene Sesban L.

Leaflets apiculate, glabrous abore, silky pubescent beneath.

1. S. sericea.

Leaflets mucronate, sparingly pubeseent above, glabrous beneath. 2. S. occidentalis.

1. Sesban serícea (Willd.) DC. Proùr. 2: 266. 1825.

Coronilla scricea Willd. Enum. 773. 1809.

Agati sericea Hitehc. Rep. Mo. Bot. Gard. 4: 75. 1893.

Stem slightly woody, 1-2 m. tall, silky-pubescent, at least above. Leares 1-2.5 dm. long, the rachis pubescent; leaflets $10-20$ pairs, linear-oblong, 1.5$2.5 \mathrm{~cm}$. long, obtuse and mucronate at the apex, usually densely silky pubescent beneath, glabrous or nearly so abore, sometimes nearly glabrous on both sides; peduncles few-flowered, much shorter than the leares; pedicels very slender, $1 \mathrm{~cm}$. long or less; calyx about $4 \mathrm{~mm}$. long, its teeth triangular, very acute; standard 10-12 mm. long, Fellor, black-spotted; pod 10-16 cm. long, biconvex, $3 \mathrm{~mm}$. wide, short-beaked, not constricted between the seeds.

Taste places, usually roadsides, New Proridence and Rum Cay:-Haiti to St. Thomas and to Martinique; Jamaica. SILKY SESBAX.

\section{Sesban occidentàlis (Willd.) Pers. Syn. 2: 316. 1807.}

Coronilla occidentalis Willd. Sp. Pl. 3: 1147. 1803.

Shrubby, $3 \mathrm{~m}$. high or less, branched, glabrous, or sparingly pubescent above when young. Leares $1-2 \mathrm{dm}$. long; leaflets $10-20$ pairs, linear-oblong, obtuse at both ends; $1.5-2.5 \mathrm{~cm}$. long, mucronate at the apex; racemes shorter than the leaves, few-several-flowered; pedicels slender, 8-12 mm. long; calyx broadly eampanulate, $6-7 \mathrm{~mm}$. long, its triangular teeth very acute; corolla about $2 \mathrm{~cm}$. long, the standard vellow, purple-dotted; pod 1.5-2.5 dm. long, 2-3 mm. wide, biconvex, slightly constricted between the seeds then young.

Fields, Inagua, near Mathew Town:-Cuba to Porto Rico; Trinidad; Tamalca. The Inagua specimen is in fruit only, and is referred to this species with some hesitation. SMOOTH SESBAx.

\section{AGÁTI Adans. Fam. Pl. 2: 326. 1763.}

Rapid-growing and short-lived small trees or shrubs, with equally pinnate leares of many pairs of oblong, entire leaflets, and large, variously colored floters in axillary racemes. Calyx large, eampanulate, its lobes short and broad. Standard orate to oblong; wings narrow, longer than the standard; keel petals curved, separate at base and apex. Stamens diadelphous ( 1 and 9 ); anthers all alike. Ovary stipitate; style subulate, curved, the small terminal stigma capitate; pod linear, elongated, flat, septate betreen the seeds. [Malabar name.] A monotspic genus.

1. Agati grandifiòra (L.) Desv. Journ. Bot. 1: 120. 1813.

Robinia grandiflora L. Sp. Pl. 722. 1753.

Aescinynomene grandiflora L. Sp. Pl. ed. 2: 1060. 1763.

Sesban grandiflorus Poir. in Lam. Ener̦e. 7: 127. 1806.

A tree, up to $12 \mathrm{~m}$. high, with a trunk up to $3 \mathrm{dm}$. thick, glabrous, or very nearly so throughout, or the young foliage finely pubescent, the bark rough. 
Leaves 2-3.5 dm. long, short-petioled; leaflets 10-30 pairs, oblong, 2-4 cm. long, obtuse or retuse at the apex, inequilaterally narrowel at the base; racemes $2-5$-flowered, shorter than the leaves; calyx 2-2.5 em. long, its broadly triangular lobes mueh shorter than the tube; corolla red to white, $6-10 \mathrm{~cm}$. long; pod $2-4 \mathrm{dm}$. Iong, about $8 \mathrm{~mm}$. wide, beaked at the apex, narrowed at the base into a long stout stipe.

Waste places. spontaneous after cultiration, Fortune and Acklin's Islands:a native of the East Indies, spontaneous after cultivation in Florida, the West

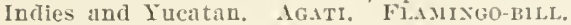

\section{STYLOSÁNTHES Si. Prodr. 108. 17SS.}

Perennial herbs, mainly with villous or viscid pubescence, 3 -foliolate leaves, and rellow terminal or axillary spicate or capitate flowers. Calyx-tube campanulate, its teeth membranous, the 4 upper ones more or less united. Petals and stamens inserted at or near the summit of the tube; standard orbicular; wings oblong: keel eurved, beaked. Stamens monadelphous; anthers alternately longer and shorter. Orary nearly sessile; orules 2 or 3 ; style filiform. Pod sessile, flattened, 1-2-jointed, reticulate, dehiscent at the sunmit. [Greek, column-flower, alluding to the column-like calyx-tube.] About 30 species, of warm and temperate regions. Type species: Stylosanthes procumbens Sw.

Foilage not riscid: leaflets oblong. nearly glabrous. Foliage riscid; leaflets elliptic, pubescent.
1. S. hamata. 2. S. viscosa.

\section{*1. Stylosanthes hamàta (L.) Taubert, Monogr. Stylos. '22. $15 s 9$.}

Hedysarum hamatum L. Syst. ed. 10: 1170. 1759.

Stylosanthes procumbens Sw. Prodr. 108. 1788.

Somewhat pubescent, branched, the branckes spreading or ascending, $0.5-5$ dm. long. Stipules adnate to the petioles, with free subulate apices. Leaflets oblong or narrowly oblong, longer than the petioles, $17 \mathrm{~mm}$. long or less, nearly glabrous, acute at both ends, strongly pinnately veined, mucronate; flowers about $6 \mathrm{~mm}$. wide, in short dense bracted spikes; loment commonly 2-jointed, the persistent hooked style-base pubescent.

Dry and moist open rocky and sandy places, Great Bahama and Little Harbor Cay, and throughout the islands from New Providence to the Calcos, Grand Turk and Jnagua :- Florida; West Indies; the Casman Islands; Mexico southward to Colombia. ComaOx PEXCIL-FLOWER.

\section{Stylosanthes viscòsa Sw. Prodr. 108. 17 Ss.}

Tiscid-pubescent, usually much-branched, 1.5-3 dm. high the branches spreading or ascending. Stipules adnate to the petioles, their tips free, subulate; leaflets elliptic or oblong-elliptic, pubescent and eiliate, pinnately veined, acute and mueronate; flowers few, in short dense bracted spikes, the bracts villous and ciliate; loment 1-2-jointed, tipped by the hooked style-base.

Scrub-lands, New Provldence:-Cuba; Jamaica. Viscid Pexcil-Fioner.

\section{MeibòmாA Heist.; Fabr. Enum. PI. Hort. Helmst. 16s. 1759.}

Perennial herbs, sometimes wooly at the base, with stipellate 3 -foliolate or in some species 1- or 5-foliolate leaves, and usually small flowers in racemes or panicles. Calyx-tube short, its teeth more or less united into 2 lips, the upper one 2-toothed, the lower teeth acute or attenuate. Standard oblong, ovate or orbicular, narrowed or rarely elawed at the base; wings obliquely oblong; 
keel nearly straight, obtuse. Stamens monadelphous or diadelphous (9 and 1 ); anthers all alike. Ovules $2-\infty$. Loment flat, $2-$ several-jointed, the joints mainly coriaceous and pubescent or muricate, indehiscent or rarely partially dehiscent, readily separable. [Named for Dr. Brandus Meibom; died at Ilelmstadt, 1740.] About 160 species, natives of warm and temperate regions. Type species: Hedysarum caradense L.

Tpper suture of the loment straight or nearly so.

Both sutures of the loment undulate. Loment several-jointed, moniliform.

Loment 2-jointed; upper joint much larger than the lower.

1. 31. supina.

2. M. tortunsa.

3. Mi. mollis.

1. Meibomia supina (Sw.) Britton, Ann. N. Y. Acad. Sci. 7: 83. 1892.

Hedysarum supinum Sw. Prodr. 106. 1iss.

Hedysarum incanum Sw. Prodr. 107. 1788.

Desmodium incanum DC. Prodr. 2: 332.1925.

Stems erect or ascending, somewhat woody, 3-9 dm. high, puberulent or short-pubescent. Stipules lanceolate, acuminate, connate below, or at length distinet, mostly shorter than the petioles; leaflets 3 or often only 1 , various in form, mostly elliptic, but also lanceolate, obovate, nearly linear, or orbicular, sometimes several forms on the same plant, glabrous or nearly so and dark green above, finely pubescent and pale beneath, 2-7.5 cm. long; stipels subulate; racemes 2-8 cm. long; bracts linear-lanceolate, pubescent, shorter than the pedicels, decidnous; pedicels 6-12 mm. long; calyx small, about $3 \mathrm{~mm}$. long, its teeth ovate-lanceolate, acute; corolla purple or purplish, 2-3 times as long as the calyx; loment 3-8-jointed, $3 \mathrm{~cm}$. long or less, its upper suture continuous, the lower margin deeply undulate, the oblong joints densely pubescent.

Drs or moist places in scrub, coppices, pine-lands, waste or cultivated lands, throughout the archipelago from Abaco and Great Bahama to Andros, Watling's, Crooked Island and East Caicos:-Florida: West Indies: continental tropical America; tropical Africa. Recorded by Schoepf as Hedysarum canescens. Commox TICK-TREFOIL.

2. Meibomia tortuòsa (Sw.) Kuntze, Rev. Gen. PI. 198. 1891.

Hedysarum tortuosum Sw. Prodr. 107. 1788.

Desmodium tortuosum DC. Prodr. 2: 332. 1825.

Erect, branched, $1.5 \mathrm{~m}$. high or less, the stem and branches finely and rather densely pubescent, striate. Stipules lanceolate, acuminate, half-cordate at base, $6-15 \mathrm{~mm}$. long; leaflets 3 , ovate to oblong or elliptic, $2-10 \mathrm{~cm}$. long, sparingly pubescent with appressed hairs, or glabrous above, mostly obtuse at the apex and narromed at the base, as long as the petioles or longer; stipels subulate; racemes simple, or sparingly branched, 1.5-3 dm. long; pedicels filiform, 1-2 cm. long; bracts narrowly lanceolate, 2-3 times as long as the calyx, deciduous; calyx about $2 \mathrm{~mm}$. long, its teeth subulate; corolla blue to purple, about $5 \mathrm{~mm}$. long; loment nearly sessile, at first much twisted, at length flat, 3-6-jointed, both margins deeply undulate, the oval-orbicular joints 4-5 $\mathrm{mm}$. long.

Waste places and roadsides, New Providence and Eleuthera:-Florida; Texas; Jamajca : Cuba to Tortola and Grenada; continental tropical America. TwiSTED TICK-TREFOIL

3. Meibonia móllis (Vahl) Kuntze, Rer. Gen. Pl. 198. 1891.

Hedysarum molle Vahl, Symb. 2: 83. 1791.

Desmodium molle DC. Prodr. 2: 332. 1825.

Stem erect, rather stout, branched, $2 \mathrm{~m}$. high or less, softly pubescent. Stipules triangular-subulate, $2-6 \mathrm{~mm}$. long; leaflets 3 , rarely only 1 , orate, $2-10$ 
$\mathrm{cm}$. long, acute or acutish at the apex, obtuse at the base, pubescent on both sides, as long as the pubeseent petioles or shorter; stipels subulate; racemes 1-2 dm. long, commonly branched; pedicels filiform, 3-5 mm. long; bracts ovate, about $1 \mathrm{~mm}$. long, deciluous; calyx $2.5-3 \mathrm{~mm}$. long, its teeth linearlanceolate; corolla blue, little louger than tha calyx; loment nearly sessile, 2. jointed, the lower joint small, twisted, the upper one elliptic or subreniform, 6-8 mm. loug, finely reticulate-reined, sparingly pubescent or glabrate.

Waste places, Andros, Fortune Island, Acklin's Island:-Cuba to Virgin Gorda and Hartinique: Cliriço: continental tropical America. lecorded from Jamaíca. VELVETY 'THCK-TIEIOLL.

\section{ALYSICÁRPUS Neck.; DC. Prodr. 2: 35̄2. 1825.}

Herbs, our species with 1-foliolate leaves and small purplish or blue flowers in short terminal racemes, the scarious bracts deciduous. Calyx narrow, deeply cleft, the lobes lanceolate, acuminate, chartaceous, striate, the two upper ones partly united. Standard suborbicular, clatred; wings obliquely oblong, adnate to the blunt incurred keel. Stamens diadelphous (9 and 1). Orary nearly sessile, sereral-ovuleil; style filiform, its apex incurved; stigma terminal, capitate. Loment nearly terete, sereral-jointed, the joints indehiscent. [Greek, chain-fruit.] About 16 species, natives of the Old World tropies. Type species: Alysicarpus bupleurifolius (L.) DC.

\section{Alysicarpus nummularifòlius (L.) DC. Prodr. 2: 353.1825.}

Hedysarum nummularifolium L. Sp. Pl. 746.1753.

Alysicarpus vaginalis DC. Prodr. 2: 353. 1825.

Perennial, branched at the base, the branches slender, diffuse, glabrous or nearly so, spreading or ascending, $5 \mathrm{~cm} .-6 \mathrm{dm}$. long. Stipules scarious, striate, lanceolate, acuminate, 4-6 mm. long; petioles very slender, $1 \mathrm{~cm}$. long or less; leares glabrous, or sparingly pubescent, the lower orbicular to oral, 5-12 mm. long, the upper oblong to ianceolate, $1-3.5 \mathrm{~cm}$. long; racemes $1-3 \mathrm{~cm}$. long; perlicels very short, pubescent; calyx $4-5 \mathrm{~mm}$. long; corolla little longer than the calyx; loment 1-2 cm. long, its puberulent or glabrous joints truneate. slightly wrinkled.

Waste places, New Frovidence, near Nassau:- West Indies. Native of southern ASIA. FALSE MONEYWORT.

12. ECASTAPHÝllum [P. Br.] Adans. Fam. Pl. 2: 320. 1763.

Woody rines, or widely branching shrubs, with alternate, 1-foliolate or unevenly pinnate leares, the leaflets estipellate, and small white bracted flowers mostly in axillary clusters. Calyx subcampanulate, its 2 upper teeth broad. Standard broadly orate or suborbicular; wings oblong; keel blunt, incurved, its petals connate on the back near the apex. Stamens all unitel into a cleft sheath, or the upper one separate or wanting: anthers ereet, their saes dehiscent by terminal slits. Orary 2-oruled, stipitate; style nearly straight; stigna terminal. Pod nearly orbicular to short-elliptic, nearly flat, 1-seeded, snb: ligneous, indehiscent. [Greek, referring to the unifoliolate leaves of the following typical species.] Fire or six species, natives of tropical and subtropical America. 
1. Ecastaphyllum Ecastaphýllum (L.) Britton, Mem. Brooklyn Bot. Gard. 1: 55. 1918 .

Hedysarum Ecastaphyllum L. Syst. ed. 10, 1169. 1759.

Ecastaphyllum Brownei Pers. Syn. 2: 277. 1507.

Hecastophyllum Brownei Griseb. Fl. Br. W. I. 202. 1860.

Dalbergia Ecastophyllum Taubert in Engl. \& Prantl. Nat. Pfl, $3^{3}$ : 335. 1594.

Dalbergia Brownei Sehinz, Bull. Herb. Boiss. 6: 731. 1898.

A widely branched, spreading or rine-like shrub 2-4 $\mathrm{m}$. high, rarely treelike and described as sometimes reaching a height of $\mathrm{S} \mathrm{m}$., the branches elongated, the young twigs finely pubescent. Stipules lanceolate, silky-pubescent. acuminate, about $1 \mathrm{~cm}$. long; leares 1 :foliolate; petioles stout, pubescent, 5-12 $\mathrm{mm}$. long; petiolule 2-3 mm. long; leaflet orate, 6-12 cm. long, rounded or subcordate at the base, short-acuminate at the apex, glabrous or nearly so abore, finely and densely pubescent beneath, at least when young; panicles axillary, pubescent, usually little longer than the petioles; pedicels $2-4 \mathrm{~mm}$. long; calyx pubescent, about $5 \mathrm{~mm}$. long; corolla about $1 \mathrm{~cm}$. long; stamens 10, diadelphous; pod suborbicular to broadly oral, $1.5-3 \mathrm{~cm}$. long, finely pubescent.

Borders of coppices and coastal thickets, Ahaco, Gieat Bahama, North Bimini, Andros, New Providence, Tatling's and Crooked Island:-Florida; Cuba to Virgin Folda and to Trinidad: Jamaica: continental tropical America; coast of tropical Africa. TI-тi. Catesbs, 2: pl. 24.

13. ICHTHYOMĖTHIA P. Br. Hist. Jam. 296. 1756.

Trees, with unevenly pinnate leares, the short-stalked leaflets large, opposite, estipellate, the pink to purplish, rather large flowers in lateral panieles, often appearing before the leaves. Calyx obliquely campanulate, 5 -toothed, the 2 upper teeth connate. Standard suborbicular; wings oblong, somewhat falcate, adherent to the keel; keel obtuse, its petals coherent on the back. Stamens monadelphous, but the upper one free at the base; anthers versatile. Ovary many-ovuled; style filiform, incurved; stigma terminal, small. Pod linear, flattened, indehiscent, with 4 broad membranous wings, several-many-seeded. [Greek, fish-killing.] A few species of tropical and subtropical America, the following typical.

1. Ichthyomethia Piscìpula (L.) Hiteheock, Gard. \& For. 4: 472. 1591.

Erythrina Piscipula L. Sp. Pl. 707. 1753.

Piscidia Erythrina L. Syst, ed. 10, 1155. 1759.

A tree, usually low, rarely $20 \mathrm{~m}$. high, the trigs finely puberulent. Leaves 2-3 dm. long; leaflets $\tilde{2}-9$ (rarely 3 ), elliptic, oblong, or the lower pair orate, 4-12 cm. long, obtuse or acutish at the apex, rounded at the base, glabrous above, at least when mature, finely pubescent beneath; panicles many-flowered, as long as the leares or shorter; ultimate pedicels short, puberulent; calyx about $6 \mathrm{~mm}$. long, its teeth triangular-orate; corolla silky, about $1.5 \mathrm{~cm}$. long; pod $5-15 \mathrm{~cm}$. long, its wings $7-12 \mathrm{~mm}$. wide, lacerate, transversely veined; seeds black.

Coastal thickets and scrub-lands, Great Bahama, Lignum Vitae rar. Andros, Manglove Cay, New Providence, Eleuthera. Cat Island, Watling's, Acklin's and Anguilla Isles:-Florida: Test Indies: continental tropical America. FisH-porson. Doftrond, Consists of several races differing mostly in pubescence and in form of the leaflets. 


\section{4. ÁBRUS L. Syst. ed. 12, 2: 172. 1767.}

Slender, somewhat woody rines, with evenly pinnate leaves, the numerous small estipellate leatlets entire, the rachis terminating in a small bristle, the small rose to white flowers clustered at the nodes of axillary or terminal racemes. Calyx subtruneate, its teeth rery short. Standard ovate, with a broal and short claw; wings oblong, falcate; keel curved, larger than the wings. Stamens 9, monadelphous. Ovary nearly sessile, several-many-oruled; style short, eurved; stigma terminal. Pod flat, 2-valved, partitioned between the subglobose, shining seeds. [Greek, graceful.] Five known species, of tropical regions, the following typical.

* 1. Abrus Abrus (L.) W. F. Wight, Contr. U. S. Nat. Herb. 9: 171. 1905.

Glycine Abrus L. Sp. Pl. 753. 1753.

dibrus precatorins L. Syst. ed. 12, 2: 472. 1767.

Stems woody below, nearly herbaceous abore, climbing or twining to a length of 2-3 m., glabrous, or the young parts sparingly pubescent. Stipules linear, acute, $3-5 \mathrm{~mm}$. Iong; petioles short, mostly less than $1 \mathrm{~cm}$. long; leares $5-10 \mathrm{~cm}$. long, the very slender rachis sparingly pubescent; leaflets $8-15$ pairs, S-20 mm. long, oblong or the upper ones oborate, glabrous abore, sparingly puberulent beneath, rounded and meronulate at the apex, rom ded at the base, very short-stalked, readily detached when dry ; racemes peduncled, $3-5 \mathrm{~cm}$. long; corolla red to purple, rarely white, $8-10 \mathrm{~mm}$. long; pod oblong, beaked, $2-3.5$ cm. long, about $1 \mathrm{~cm}$. wide; seeds scarlet with a black base.

Scrub-lands and waste places, Andros, New Providence, Eleuthera, Cat Island and fieat Exuma :- West Indies; continental tropical America; Old World tropics. CRAB'S-EYES. BLACK-EYED SESAX.

\section{CLITÒRIA L. Sp. Pl. 753.1753.}

Woory vines, or erect or climbing herbs, with pinnately 3 -foliolate or sometimes 5-9-foliolate leaves, persistent stipnles, and large axillary flowers. Calyx tubular, 5-toothed, the upper teeth more or less united; stanclaril large, erect, retuse, narrowed at the base, not spurred; wings oblong, curved; keel acute, shorter than the wings; stamens more or less monadelphous; anthers all alike; ovary stipitate; style elongated, ineurvel, hairy along the inner side; pod stalked in the ealyx, linear or linear-oblong, flattened, 2-valved, partly septate between the seeds. About 30 species, natives of warm and temperate regions. Type species: Clitoria Ternatca L.

\section{Clitoria Ternàtea L. Sp. PI. 753. 1753.}

Perennial, herbaceous or slightly wooly below, slender, twining to a height of $2 \mathrm{~m}$. or more, or, if without support, prostrate, pubescent, at least on the younger parts. Stipules linear-lanceolate, acuninate, 5-5 mm. long; petioles sleniler, pubescent, 1-3 cm. !ong; leaflets $5-9$ (usually 5 ), ovate or oral, shortstalkerl, 2-3.5 em. long, mostly ohtuse at the apex, ohtuse or narrorrerl at the hase, thin, glabrous above, somewhat pubescent beneath; pesluncles 1-floweres, 1-2 cm. long: bracts orate-orbicular, olituse, $\bar{j}-\bar{i} \mathrm{~mm}$. long: ealrx ahout $1 . i \mathrm{~cm}$. long, its lanceolate lobes acuminate; corolla lange, blue and white, the stanclaril $3-4 \mathrm{~cm}$. long; porl nearly sessile, flat, linear, beaked, pubeseent, $13 \mathrm{~cm}$. long or less, about $1 \mathrm{~cm}$. wille; seels compresserl, subreniform, mottleil, $5-6 \mathrm{~mm}$. long.

Fields and waste places, spontaneous after cultivation. New Provirlence and Inagua :- a native of tropical ifrica: spentanemus after cultivation througliout the

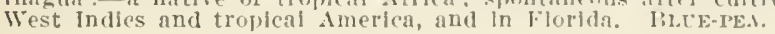


16. BRAdEÙRYA Raf. Fl. Ludov. 104. 1517.

Slender vines, with pinnately 3 -foliolate leaves (rarely $5-7$-foliolate), persistent stipules, and large axillary flowers. Calyx eampanulate, its teeth or lobes nearly equal; standard orbicular, nearly flat, spurred on the back near its base, clawed; wings obovate, curved; keel curved; stamens more or less diadelphous (9 and 1$)$; style incurverl, bearded at the apex around the stigma; porl linear, flattened, nearly sessile, partially septate between the seeds, 2. ralred, the ralves thick-edged, longitudinally finely nerved along their margins. [In honor of John Bradbury, who travelled in America early in the last century.] About 30 species, natives of America. Type species: Bradburya scandens Raf.

Pods 4.5-5.5 mm. wide, ; seeds cylindric, $7.5-8 \mathrm{~mm}$. long, black or 5ellow with black blotches. 1 . B. Horidan $t$.

Fods $3.5-4 \mathrm{~mm}$. wide; seeds cuboid-cylindric, $3.5-1 \mathrm{~mm}$. long, red-brown or with lighter blotches.

2. B. virginiana.

\section{Bradburya floridàna Britton, Torreya 4: 142. 1904.}

Stems glabrous or nearly so, $1 \mathrm{~m}$. long or more. Stipules long-acuminate; leaflets lanceolate to oval, glabrous, reticulate-veined on both sides, $8 \mathrm{~cm}$. long or less, obtuse and aristulate at the apex, rounded at the base, the glabrous petioles $2-5 \mathrm{~cm}$. long; perluncles pubescent, or glabrous, $\hat{-}-6 \mathrm{~cm}$. long; bracts acnte, pubescent, $1 \mathrm{~cm}$. long or less; corolla nearly white or violet striped with lavender or yellow, $2.5-4 \mathrm{~cm}$. long; pod $8-12 \mathrm{~cm}$. long, $4.5-5.5 \mathrm{~mm}$. wide, longtipped, glabrous; seeds black or yellow with black markings.

Scrub-lands and white-lands, Abaco, Rose Island, Berry Islauds, Eleuthera, Conception Island. Fxuma Chain, Long Island, Great Ragged Island, Acklin's and Crooked Islands :-Floida. FLORIDA BUTTERFLY-PEA.

2. Bradburya virginiàna (L.) Kuntze, Rev. Gen. Pl. 164. 1891.

Clitoria virginiana L. Sp. Pl. 753. 1753.

Centrosema virginianum Benth. Ann. Mus. Wien. 2: 120. 1838.

Centrosema virginianum angustifolium Griseb. Fl. Br. W. I. 193. 1860.

Perennial, glabrous or finely rough-pubescent, 6-12 dm. long. Stipules linear, acute; leaflets ovate, oblong-lanceolate or linear, stipellate, rounded at the base, reticulate-reined, $2.5-5 \mathrm{~cm}$. long; peduncles about equalling the petioles, 1-4-flowered; bracts ovate, acute, finely striate; flowers $2.5-4 \mathrm{~cm}$. long; corolla violet; calyx-lobes linear; por $10-13 \mathrm{~cm}$. long, $3.5-1 \mathrm{~mm}$. wide, longacuminate, its margins much thickenerl.

Scrub, rockr and grassy lands, throughout the archipelago from Abaco and Great Bahama to Grand Turk and Inagua :-New Jersey to Florida and Texas; IIexico to Boliria and Brazil: Test Indies. A species composed of a large number of insignificantly differing races with leaflets varying from linear to broadlr ovate: widely differing plants often growing close together in the same colony. SPURRED BUTTERLY-1'EA. LADY'S SLIPPER.

\section{MUCÙNA Adans. Fam. Pl. 2: 325. 1763.}

Herbaceous or woody vines, with pinnately 3 -foliolate leares, and large pedicelled flowers in axillary, long-peduncled clusters. Calyx campanulate, its two upper teeth connate. Standard folded, auricled at the base; wings incurved, longer than the standard; keel as long as the wings or longer, its apex cartilaginous or acute. Stamens diadelphous (9 and 1 ); anthers alternately longer and shorter. Orary sessile, villous; orules few; style naked, filiform; stigma terminal and small. Pod thick, coriaceous, linear or oblong, 2-valved, 
usually covered by stinging hairs, at least when young. Seeds orbicular or oblong, few, large. [Brazilian name.] About 25 species, mostly tropical, the following typical.

\section{Mucuna prùriens (L.) DC. Proilr. 2: 40.5. 1525.}

Dolichos pruriens L. Syst. ed, 10, 1162. 1759.

Slender, high-elimbing, pubeseent. Petioles as long as the leaflets or shorter: leaflets thin, appressed-pubescent, somewhat silvery beneath, the terminal one rather long-stalked, orate or rhombic-orate, the lateral ones short-stalked, obliquely orate, inequilateral; racemes several-many-flowered, elongated; calyx silvery-silky, about $1 \mathrm{~cm}$. long. 4 -eleft; corolla blue or purple; standard orate; wings and keel about twice as long as the standard, 2-3 cm. long; pod narrowly oblong, slightly curved, about $6 \mathrm{~cm}$. long and 1 em. thiek, densely covered with brittle stinging hairs.

Thickets and scrub-lands, New Providence near Nassau:-Cuba to St. Thomas and Tobago: Jamaica: continental tropical America: Old World tropics. Dolley reports Hucung urens L.e from the Bahamas but the plant has not been returned in iny of the collections we have seen; the record probably refers to 11 . pruriens. Cow-ITCY.

15. GALÁctia P. Br.; Adans. Fam. Pl. 2: 322. 1763.

Perennial vines (some species ereet and shrubby), mainly with pinnately 3-foliolate leares, small and deeiduous stipules, and small or large axillary racemose flowers. Calyx 4 -lobed, bracteolate, the lobes acute, often as long as the tube. Standard orbicular or obovate. Wings narrow, obovate, adherent to the narrow, nearly straight keel. Stamens diadelphous or nearly so (9 and 1). Ovary nearly sessile; ortules $\infty$; style filiform, not bearded. Pod linear, straight or slightly eurved, usually flattened, 2-valved, several-seeded. Fleshy few-seeded pods are sometimes produced from subterranean apetalous flowers. [Greek, milk-yielding, the typieal species deseribed as having milky branehes.] About 70 speeies natives of rarm and temperate regions, nost abundant in Ameriea. Type species: Glycine Galactia L.

Corolla about $2 \mathrm{~cm}$. long: standard parallel with the wings. Corolla $1.5 \mathrm{~cm}$. long or less; staudard erect or ascending. Leaflet only one.

Leaflets three.

Leaflets large, orate to elliptic, $4-8 \mathrm{~cm}$. lnng.

Leaflets smill, oblanceolate to obovate or oral. $1-4 \mathrm{~cm}$. Ion:.

Inflorescence longer than the leares: leares glabrous or nearly so.

Inflorescence not exceeding the leares; leaves densely appressed-pubescent.
1. G. rudolphioides.

2. G. monophylla.

3. G. spiciformis.

4. G. bahamensis.

5. G. unifloru.

1. Galactia rudolphioìdes (Griseb.) Benth. \& Hook.; Sauv, Anales Aead. IIabana 5: 337. 1569 .

Dioclca rudolphioides Griceb. Mem. Am. Acad. II. 8: 17S. 1860.

Slender, twining or trailing, woody below, 1-3 m. long, glabrous or sparingly appressed-pubescent. Petioles $2-5 \mathrm{~cm}$. long; stipules triangular or lanceolate, about $2 \mathrm{~mm}$. long; leaflets 3, oblong, oblong-lanccolate or orateoblong, 2-4 cm. long, obtuse, acutish or emarginate at the apex, rounded or narrowed at the base, glabrous on both sides, revolute-margined, the short petiolules villous; racemes slender-perluneler, longer than the leares; braets linear-subulate, 1-2 mm. long; bractlets orate or laneeolate, acute, about 1.5 
nm. long; pedicels pubescent, 2-6 mm. long; ealyx about $1.3 \mathrm{~cm}$. long, appressed-pubescent; corolla red or the standard violet, nearly $2 \mathrm{~cm}$. long; standard oborate, parallel with the wings; pod 3-5 $\mathrm{cm}$. long, 7-9 mm. wide, densely villous, several-seeded.

Scrub and pine-lands and in coppices, from Abaco and Great Bahama to Andros, New Providence. Eleuthera, Cat Island, Watling's, and Exuma ("hain to Fortune and Crooked Islands:-Cuba. liecorded by Dolley as $G$. pondula Persoon. RED MILT-PEA. Catesby, $2: p l$. 28 .

\section{Galactia monophýlla Griseb. Cat. Pl. Cub. 75. 1866.}

Slender, herbaceous, appressed-pubescent with short hairs, 8 dm. long or less, twining or trailing. Stipules narrowly lanceolate or subulate, 1-3 $\mathrm{mm}$. long; petioles slender, $5-15 \mathrm{~mm}$. long; leaflet only 1 , oblong to orate, $1-3 \mathrm{~cm}$. long, thin in texture, rounded or enlarginate at the apex, rounded or subcordate at the base, glabrous or sparingly pubescent abcve, appressed-pubescent beneath, the petiolule about $1 \mathrm{~mm}$. long; inflorescence 1 -few-flowered, not longer than the leaf; pedicels 2-3 mm. long; calyx sparingly pilose, about $6 \mathrm{~mm}$. long, its lanceolate teeth longer than the tube: corolla purplish, about $1 \mathrm{~cm}$. long, the standard obovate, erect; pod $3-5 \mathrm{~cm}$. long, about $5 \mathrm{~mm}$. wide, appressed-pilose.

Pine-1ands, Great Bahama at Barnett's Point:-Cuba. Slexder MILK-PEA.

\section{* 3. Galactia spicifòrmis T. \& G. Fl. N. A. 1: 288. 1838.}

Slender, herbaceous, twining, densely pubescent or glabrate, $2 \mathrm{~m}$. long or less. Petioles $1-7 \mathrm{~cm}$. long; stipules subulate, $2-4 \mathrm{~mm}$. long; leaflets 3 , ovate to elliptic or elliptic-oborate, chartaceous or subcoriaceous, $4-7 \mathrm{~cm}$. long, glabrous or nearly so above, appresser-pubescent or velvety beneath, obtuse or acile at the apex, obtuse or rounded at the base; inflorescence usually as long as the leaves or longer, several-many-flowered, sessile or peduncled; pedicels 1-2 $\mathrm{mm}$. long; calyx pubescent, about $6 \mathrm{~mm}$. long, its lanceolate teeth 2-3 times as long as the tube; corolla purplish, pink or nearly white, about $11 \mathrm{~mm}$. long, the broadly oborate standard erect; porl 4-7 $\mathrm{cm}$. long, 6-10 $\mathrm{mm}$. wide, often somewhat curved, more or less pubescent.

Rocky and sandy scrub-lands and coppices, throughout the islands from Abaco and Great Bahama to Andros. New Proridence, Eleuthera, Watling's and the Exuma Chain to Great Ragged Island and the Anguilla Isles:-Florida; Cuba. Referred by Mrs. Northrop to $G$. cubensis II.P.K.: recorded by Dolley as $G$. fill. formis Bth. The Teramnus uncinatus referred to by Hitchcock, proves to be this plant. SPICIFORM MIIK-PEA.

\section{Galactia bahaménsis Urban, Srmb. Ant. 2: 331. 1900.}

Very slender, twining, somewhat woody, glabrate or reddish puberulent, 5-8 $\mathrm{dm}$. long. Stipules linear-subulate, 1-2 mm. long, deciduous; petioles very slender, $0.5-2.5 \mathrm{~cm}$. long; leaflets 3 , chartaceous, nearly equally short-petioluled, oval to elliptic or obovate, $1-2.5 \mathrm{~cm}$. long, rounded or emarginate at the apex, narrowed, rounded or the terminal one cuneate at the base, glabrous and reticulate-veined on both sides, or sparingly pubescent beneath; inflorescence mostly longer than the leaves, sereral-flowered; pedicels $2-7 \mathrm{~cm}$. long; calyx pubescent, $6-8 \mathrm{~mm}$. long, its lanceolate lobes longer than the tube; corolla about $1 \mathrm{~cm}$. long, rose-purple, the nearly orbicular standard erect; pod 3-5 cm. long, 7-10 inm. wide, appressed-pubescent.

Scrub-lands and thickets, Rum Cay, Conception Island. Watling's, Crooked, Acklin's, Fortune, Grand Turk and Inagua :-Endemic. Recorded by Hitchcock as Galactio galactioides (Gliseb.) Hitche. BAHAMA MILK-PEA.

5. Galactia uniflòra Urban, Symb. Ant. 2: 325. 1900.

Slender, twining, somewhat woody below, densely whitish pubescent, sometimes $1 \mathrm{~m}$. long. Stipules narromly lanceolate, acuminate, about $2 \mathrm{~mm}$. long; 
petioles slender, pubeseent, $5-17 \mathrm{~mm}$. long; leaflets 3 , chartaceous, $1-4 \mathrm{~cm}$. long, narrowly oblong to oblong-obovate, retieulate-reined, romnled or emarginate at the apex, narrowed at the base, sparingly pubescent or glabrous abore, densely appressed-pubescent beneath, the terminal one with a petiolule $2-5 \mathrm{~mm}$. long, the lateral ones nearly sessile; inflorescence 1-2-flowered, shorter than the leares; pedicels $2-4 \mathrm{~mm}$. long; calyx about $6 \mathrm{~mm}$. long, its teeth longer than the tube; corolla pink; standari obovate, $9-10 \mathrm{~mm}$. long, short-elawed; porl linear, 3-4 cm. long, 4-5 mm. wide, lensely pubescent.

Scrub-lands. New I'rovidence. Eleuthera, Caicos, Grand Turk and lnagua:Endemic. Recorded by Hitclicock as Galactia angustifolia $\boldsymbol{I}_{\mathrm{th}}$ and as Galactia tenuiflores (Willd.) W. \& A. ONE-FLOWERE MILK-PEM.

19. CANAVÀLI Adans. Fam. Pl. 2: 325. 1763.

Perennial herbs, with prostrate or twining stems. Leaves pinnately 3 foliolate; leaflets chartaceous or thiek. Flowers large, in axillary jeduncled racemes. Calyx 2-lipped, the upper lip truncate or 2-lobed, the lower one entire or 3-lobed. Standard reflexed, suborbieular; wings eurved or tristed; keelpetals incurred, broader than the wings, obtnse or with an inflexed or spiral beak. Stamens diadelphous (9 and 1 ) or monadelphous to the middle. Style glabrous, incurved. Ovules several. Pod flat or slightly swollen, oblong or broadly linear, 2-valved. Seeds white, red or krown. [Aboriginal name in the South Sea Islands.] Abont 15 species, natives of tropieal regions. Type species: Dolichos ensiformis L.

Leaflets fleshy, obtuse.

Leaflets chartaceous, acute or acutish.

Leaflets orate. $\mathrm{s}-1 \overline{\mathrm{cm}} \mathrm{cl}$, long.

Leaflets oblong to oblong-lanceolate, $4-7 \mathrm{~cm}$. long.
1. C. lincata.

2. C. gludiatn.

3. C. bahamensis.

1. Canavali lineàta (Thunb.) DC. Prodr. 2: 404. 1825.

Dolichos lineatus Thunb. Fl. Jap. 280. Iist.

Dolichos obtusifolius Lam. Eneye. 2: 295. 1 is6.

Canaralia obtusifolia Dr. Prodr. 2: 404. 1825.

Foliage finely strigillose. Stems prostrate or climbing, 1-5 m. long, branching; leaflets leathery, suborbicular to oval or obovate, 4-10 cm. long, obtuse at the apex, rounded or broadly euneate at the base; racemes surpassing the subtending leaves; peduneles of ten longer than the racemes; pedicels spur-like; calyx helmet-like, $1+-17 \mathrm{~mm}$. long, constricted at the base; corolla pink; pods broadly linear, 10-12 em. long; seeds oblong, brown.

Coastal sands, rocks and thickets, throughout the Islands from Abaco and Freat liahama to Watling's. Inagua and the Inguilla Isles:-IBermuda; Florida to Texas. Mexico and continental tropical Soutl America; West Indies; Old World tropics. BAY-BEAX. IIORSE-REAX.

\section{Canavali gladiàta (Savi) DC. Prodr. 2: 404. 1825.}

Malocchia gladiata Sari, Nuov. Giorn. Pisa 8: 116. 1824.

Climbing or trailing, sometimes $10 \mathrm{~m}$. lcng or longer, glabrous, or wheu young finely pubescent. Leaflets thin, orate or oblong-ovate, $5-12 \mathrm{~cm}$. long, acute or short-acuminate at the apex, obtuse at the base; racemes severalmany-flowered, mostly longer than the leaves; perlicels short, thick, $5 \mathrm{~mm}$. long or less; calyx 1-1.5 cm. long; corolla white to purple, longer than the ealyx; pod broadly linear, flat, 1-2.5 dm. long, about $2 \mathrm{em}$. wille; scells oblong.

Waste places spontaneous after cultration, New Providence, and Inagua:natlye of the East Indles, spontaneous after cultivation in tropleal Amerlca. A sneclmen from Nassau referied to this by IIltchcock proves to be Dolichos Lablab L. IIORSE-BEAX. 
3. Canavali bahaménsis Britton, Bull. N. Y. Bot. Gard. 4: 119.1905.

A long rine. Leaflets thin, oblong-lanceolate to orate-oblong, $5-8 \mathrm{~cm}$. long, firm, glabrous, faintly veinel, narrowed or obtuse at the base but not cordate, the anex bluntly acute; racemes stout-peduncleri, slightly pubescent, longer than the leares, nodose, penlent, $5-8 \mathrm{~cm}$. long; pedicels curred, crect, $2-4 \mathrm{~mm}$. long; bractlets at base of calyx orbicular, $1 \mathrm{~mm}$. broad, lacerate; calyx very oblique, 6-8 mm. long, with one small acute tooth opposite the keel-jietals, the much larger upper lip with three short broad teeth; corolla about twice as long as the calyx, the standard purple, the wings and strongly curred keel pink; legune linear-oblong, compresser, about $12 \mathrm{~cm}$. long, $3 \mathrm{~cm}$. wide, $1-1.5 \mathrm{~cm}$. thick, short-pointed, narrowed at the base, not constricted, the stout stipe 1-2 $\mathrm{cm}$. long, the valves rather membranous; seeds oral, $1.5 \mathrm{~cm}$. long, $1 \mathrm{~cm}$. thick, redbrown, shining.

Climbing over coastal shrubs, and in coppices, Abaco, Andros and Eleuthera :Endemic. BAHAMA BAX-BEAx.

\section{CÁJAN Adans. Fam. Pl. 2: 326.1763.}

A perennial stiff, slightly woody herb, finely puberulent or pubescent, with pinnately 3-foliolate leaves, and showy sellow flowers in stalked axillary racemes. Calyx narrowly campanulate, its lobes acute, the 2 upper ones partly united. Standard nearly orbicular, reflexed; wings obliquely oborate; keel with a blunt incurved tip. Orary many-ovuled; style thickened above; stigma oblique. Pod linear, flattened, acute and long-tipped, its ralves impressed between the seeds. [From the Malayan name.] A monotypic genus.

1. Cajan Cájan (L.) Millsp. Field Mus. Bot. 2: 53.1900.

Cytisus Cajan L. Sp. Pl. 739. 1753.

Cajanus indicus Spr. Syst. 3: '248. 1826.

Bushy, branched, $2 \mathrm{~m}$. high or less. Leares petioled; leaflets oblong or oblong-lanceolate, $2.5-8 \mathrm{~cm}$. long, acute at both ends or obtuse at the base, relvety on both sides, dark green above, pale beneath; racemes few-flowered, as long as the leaves or longer; pedicels, rachis and calyx brown-pubescent; flowers 12-16 mm. broad; pods 5-8 $\mathrm{cm}$. long, 10-12 mm. wide, 4-7-seeded; sfeds whitish, somewhat flattened, about $4 \mathrm{~mm}$. thick.

Waste and cultirated soils, spontaneous after cultiration, throughout the islands from Andros and New Providence to Mariguana :- Native of the Old World tropics; widely spontaneous in all American tropical regions. PIGeox PeA.

21. Dolícholus Medic. Vorles. Chur. Phys. Ges. 2: 354. 1787.

\section{[RHYNCHOSIA Lour.]}

Perennial twining trailing or erect herbs, with pinnately 1-3-foliolate leares, and yellow, mostly axillary and racemose flowers. Leaflets generally punctate with resinous dots, not stipellate. Calyx 4-5-lobed, somewhat 2-lipped; standard obovate or orbicular, spreading or reflexed; wings narrow; keel incurred at the apex or falcate; stamens diadelphous (9 and 1). Ovary nearly sessile; ovules 2 , rarely 1 ; style filiform. Pod flat, oblong or obliquely orbicular, 2-ralved, 1-2-seeded. [Greek, diminutive of Dolichos.] About 200 species, natives of warm and temperate regions. Type species: Dolichos minimus L.

Leares prominently reticulate-reined heneath: long vine.

Leares not prominently reticulate-reined; small rines.

Leaflets acuminate; pods $3-4 \mathrm{~cm}$. long: seeds red.

Leaflets obtuse or acutish; pods $1-2 \mathrm{~cm}$. long; seeds olive.

1. D. reticulatus.

2. D. Surartzii.

3. D. minimus. 
1. Dolicholus reticulàtus (Sw.) Millsp. Field Mlus. Bot. 2: 53. 1900.

Glycine reticulata Sw. Proilr. 10.5. 1758.

Rhynchosia reticulata DC. Prodr. 2: 385. 1825.

A pubescent or tomentose twining or trailing vine often $5 \mathrm{~m}$. long. Leares petioled, 3 -foliolate; leaflets orate to orate-lanceolate or orate-elliptic, $\bar{j}-10 \mathrm{~cm}$. long, reticulate-reined, acuminate, acute or obtise at the apex, obtuse or rounderl at the base, the terminal one long-stalked, the lateral ones nearly sessile; racemes several-many-flowered, shorter than the leaves; pedicels vers short; calyx $7-12$ mm. long, deeply 4-cleft, the lobes lanceolate, acuninate; corolla yellow, a little longer than the calyx-lobes; pod flat, lunate, $2-2.5 \mathrm{~cm}$. long, 6-9 inm. wide; seeds nearly black.

Scrub-lands, Watling's Island between Graham's Harbor and Cockburn 'Town :Cuba to Virgin Gorda and Grenada; continental tropical America. NeT-reised DOLICIOLES.

Leaflets less densely reticulate-veined than in plants from some other West Indian islands, the apex obtuse.

2. Dolicholus Swártzii Vail, Bull. Torr. Club 26: 108.1899.

Rhynchosia Gundlachii Urban, Symb. Ant. 5: 374. 1908.

Rhynchosia caribaea Chapm. F. S. U. S. 104. 1860. Not Glycine caribaea Jacq. 17 s6.

A pubescent, resinous-dotted, somewhat woods, trailing or twining rine $0.5-1.5 \mathrm{~m}$. long, the stems slender, little branched except at the base. Stipules narrowly lanceolate, about $4 \mathrm{~mm}$. long, deciduous; petioles $1-3 \mathrm{~cm}$. long; leaflets 3 , rhombic-ovate, membranous, acuminate at the apex, obtuse or subtruncate at the base, pubescent on both sides; the terminal one slender-stalked, 4-6 cm. long, the lateral ones short-stalked, smaller, inequilateral; racemes fertflowered, mostly shorter than the petioles or little longer; pedicels $2-4 \mathrm{~mm}$. long; calyx about $3 \mathrm{~mm}$. long, its lobes shorter than the tube; corolla yellow, the standard obovate, about $8 \mathrm{~mm}$. long; pod falcate, $2-4 \mathrm{~cm}$. long, $5-7 \mathrm{~mm}$. Tide, acute, pubescent; seeds red, 5-6 $\mathrm{mm}$. long.

Coppices. Great Bahama, New Providence, Cat Island, Crooked Island:-Florida ; Cuba. SWARTZ'S Dolicholt's. BoxaxeY-BeAx.

3. Dolicholus mínimus (L.) Medic. Vorles. Chur. Phys. Ges. 2: 354. 1787.

Dolichos minimus L. Sp. Pl. 726. 1753.

Rhynchosia minima DC. Prodr, 2: 385. 1825.

A slender, puberulent or pubescent, resinous-dotted, more or less branched vine, 3-12 dm. long, trailing or twining. Stipules subulate, about $2 \mathrm{~mm}$. long, caducous; petioles rery slender, 1-t cm. long; leaflets 3, rhombic-orate or rhombic-orbicular, obtuse or acute at the apex, obtuse at the base, the terminal one slender-stalked, 1-3 cm. long, the lateral ones short-stalked, smaller or as large, inequilateral; racemes slender, several-flowered, mostly as long as the leares or longer; pedicels very short; calyx $2-3 \mathrm{~mm}$. long, its lobes lanceolatesubulate; corolla yellow; standard orbicular-obovate, retuse, 5-6 mm. long; pods falcate, $10-17 \mathrm{~mm}$. long, about $4 \mathrm{~mm}$. wide, puberulent; seeds brown, mottled.

Waste grounds and pine-lands. Abaen, Indros, Ẍew Providence, Eleuthera, Cat Island, Acklin's Island, Fortune Island, Nortl Calcos and Inagua:- South Carollna to Florida and Texas: throughout the West Indles and tropleal and warm temperate continental Amerlca: Old World troples. Sald Doliciroces.

\section{PHASĖOLUS L. Sp. Pl. 723. 1753.}

Vines, rarely erect herbs, with pinnately 3 -foliolate leaves, anil axillary racemose flowers. Calyx 5-toothed or 5-lobed, or the 2 upper teeth more or less united. Standard orbicular, recurverl, sprealing or somewhat contorted; wings 
mainly oborate; kecl spirally coiled, linear or obovoid. Stamens diadelphous (9 and 1). Style longitudinally bearded; stigma oblique or lateral; ovary sessile or nearly so; ovules $\infty$. Pod various, 2-ralved, sereral-seederl, tipped with the persistent style. Seeds mostly with rounded ends. Rachis thickened at the bases of the pedicels. [Aneient name of the Kidney bean.] About 170 species, of warm and temperate regions. Type species: Phascolus vulgaris L.

Frect: herbaceous: flowers red or purple.

Climbing rine; flowers white.

1. I. lathyroides.

‥ Iunatus.

1. Phaseolus lathyroìdes L. Sp. Pl. ed. 2, 1018. 1763.

Phaseolus semierectus L. Mant. 1: 100. 1767.

Herbaceous, erect, simple or somewhat branched, silky pubescent or glabrate, 3-6 dm. high. Stipules narrowly lanceolate, acuminate, $1.5 \mathrm{~cm}$. long or less; petioles slender; leaflets various, membranous, orate to lanceolate or linear-lanceolate, 2-6 cm. long, acute, obtuse or acuminate at the apex, acute or obtuse at the base; racemes elongated, several-many-flowered, 1-3 dm. long in fruit; pedicels very short; calyx 4-5 mm. long, its upper tecth ovate, the lower lanceolate, acuminate; corolla red or purple; standard 12-15 mm. long; pods narrowly linear, straight or a little curved, reflexed-spreading, 7-12 cm. long, about $3 \mathrm{~mm}$. thick.

Waste places and moist soils in open places, Andros, New Proridence, Acklin"s, East Caicos and Inagua :- West Indies; continental tropical America; Old Torld tropics. WILD BUSH BEAN.

2. Phaseolus lunàtus L. Sp. Pl. 724. 1753.

A usually annual, herbaceous, sparingly pubescent vine up to $3 \mathrm{~m}$. long or longer, twining or trailing. Leaves 3 -foliolate, petioled; leaflets orate, ovatelanceolate or rhombic-ovate, thin in texture, $4-7 \mathrm{~cm}$. long, acute at the apex, obtuse or subtruncate at the base, the terminal one long-stalked, equilateral, the others short-stalked, inequilateral; racemes peduncled, about as long as the leaves, sometimes longer, sereral-many-flowered; pedicels slender, mostly less than $1 \mathrm{~cm}$. long; calyx about $3 \mathrm{~mm}$. long, its teeth short, ovate; bractlets oblong, about one-half as long as the calyx; corolla greenish white, the standard about $7 \mathrm{~mm}$. broad; pod flat, subfalcate, $3-7 \mathrm{~cm}$. long, $1-1.5 \mathrm{~cm}$. wide (larger in eultivated races); seeds oblong or subquadrate, flattened.

In a coppice near Staniard Creek, Andros, spontaneous after cultivation :Test Indies; continental tropical America. Lima BEAN.

\section{DóLICHOS L. Sp. Pl. 725. 1753.}

Climbing or trailing vines, with 3 -foliolate stipellate leaves, and white to purple flowers variously clustered or sometimes solitary, their bracts small or caducous. Calyx campanulate, its two upper teeth united. Standard suborbicular; wings obovate, curved, adnate to the incurved keel. Stamens 9 and 1, their anthers all alike. Orary several-many-oruled; style bearded or penicillate below the terminal stigma. Pod flat, mostly somewhat curred, beaked. Seeds subglobose or flattened. [Greek name of some bean, referring to its long pods.] About 30 species, of tropical distribution. Type species: Dolichos Lablab L.

Pods serrulate on the margins; seeds somewhat compressed; style not penicillate. $\quad$ 1. $I$. Jablab. Pods entire on the margins; seeds globular; style penicillate. $\quad 2.0$. insularis. 


\section{Dolichos Làblab L. Sp. Pl. 72ร. 1753.}

Sparingly pubescent, climbing or trailing, $5 \mathrm{~m}$. long or less. Leaves long. petioled. Leaflets orate, acute or acmminate, $4-10 \mathrm{~cm}$. long, the terminal one equilateral and long-stalked, the others inequilateral and short-stalked; racemes axillary, several-flowered, longer than the leares; flowers short-pedicellen, 1.5$2 \mathrm{~cm}$. broad, white to purple; pods about $7.5 \mathrm{~cm}$. long, nearly $2.5 \mathrm{~cm}$. winle, the upper edge nearly straight, the lower eurved and glandular-serrulate; seeds somewhat compressed, black with a white linear strophiole, about $1 \mathrm{~cm}$. long.

Spontaneous after cultiration. Jew Providence and Eleuthera. Native of the old World tropics. Widely planted and spontaneous in tropical imerica. BLAcK BEAL:

\section{Dolichos insulàris Britton sp, nov.}

Nearly glabrons, climbing or trailing, up to $\overline{\mathrm{m}}$. long or longer. Leaflets orate, thin, 4-7 cm. long, acute, obtuse or acuminate, sparingly pubescent near the base beneath, the terminal one equilateral, rather long-stalkeil, the lateral ories inequilateral, short-stalkeil; racemes axillary, thyrsoi, many-flowereil, stont-peduncled, longer than the leares; pedicels pubescent, t-6 $\mathrm{mm}$. long: bractlets obtuse, $2 \mathrm{~mm}$. long; ealyx nnequally 5 -lobed, about $7 \mathrm{~mm}$. long, the lobes romnded; corolla purplish; standard wider than long, about $1 \mathrm{~cm}$. long, nearly sessile, emarginate; wings orate, obtuse, stalked, about $11 \mathrm{~mm}$. long, keel obliquely curred, stalled, acuminate, about $9 \mathrm{~mm}$. long; ovary pubernlent; style penicillate: pods elliptic-obovate, $2-3$-seeded, compressed, $5-7$ cm. long. about $3 \mathrm{~cm}$. wide, rather stont-beaked, the valves yellowish puberulent, entire-margined; seed globular, abont $1 \mathrm{~cm}$, in diameter, black, with a white linear strophiole.

old field, Great Cistern, Abaco:-Cuba: Mexico. Type from Cayo Ballenato Grande, Cuba (Shafer 1026). IstaxD PEAx.

\section{VÍGNA Sari, Mem. Phas. 3: 7.1826.}

Herbaceous vines, or sometimes erect herbs, with pinnately 3 -foliolate stipulate leaves, the leaflets broad. Flowers elustered at the ends of long axillary peduncles, yellowish or purplish, the rachis of the head or raceme knotty, the bracts and bractlets early decidious. Calyx 5-toothed, or the 2 upper teeth united. Standard nearly orbicular, anricled at the base; wings shorter than the standard; keel about eqnalling the standard, slightly incurred. Stamens diadelphous ( 9 and 1 ). Ovary sessile; orules numerous; style bearderl along the inner side; stigma oblique. Pod linear, nearly terete, -valved. [In honor of Domenico Vigna, a commentator on Theophrastus.] About 30 species, natives of warm and tropical regions. Type species: Dolichos luteolus Jaeq.

1. Vigna rèpens (L.) Kuntze, Rev. Gen. Pl. 212. 1591.

Dolichos repens L. Syst. ed. 10: 1163. 1759.

Dolichos luteolus Jacq. Hort. Vind. 1: 39. 1770.

Vigna luteola Benth. in Mart. Fl. Bras. 151: 194. 1859.

Foliage usually pubeseent with appressed hairs. Stems trailing or elimbing, branching, when pubeseent the hairs reflexed: leaflets 3 , ovate to lanceolate or linear, 2-8 cm. long, acute, more or less distinctly reticulaterl, short-stalker]; petioles usually longer than the leaflets; peduneles surpassing the leaves, retrorsely pubeseent at the top; pedicels 1-3 mm. long, corrmbose: ealyx campanulate, oblique, its lobes triangular to lanceolate; corolla yellowish hrown: standard nearly reniform, notehed, less than $2 \mathrm{em}$. long; poils linear, $4-5 \mathrm{~mm}$. long, nearly terete, pubescent.

Molst rondsides. Abaen and Andros:- Rermuda: Forida to Texas: Mexicn to Panama and throughout South America to Argentina; West Indies; Old World troples. YELLOW V'IGXA. 
Brya Ebenus (1.) Dr. referred to by Dolley has not been returned from the islands by any of our expeditions. It is native of Jamaica and Cuba. The record lunobibly applies to P'cra bumcliacfolia, locally called lilack Ehony.

Erythrina corallodéndron L. Recorded for the Bahamas by Catesby, by Dolley and by Mrs. Northrop is known to us only as planted on New Providence. Catesby, 2: $p l .49$.

Erythrina velutina Willd. was observed planted at West End, Great Bahama.

Foliage of a species of Lonchocarpus was collected from a tree growing near an old house at Deep Creek, Andros.

\section{Order 13. GERANIÀLES.}

Herbs, shrubs or trees, usually with petals, and these separate (wanting in most Euphorbiaceae, and in some speeies of Zanthoxylum in Rutaceae); sepals mostly distinct; stamens few, rarely more than twice as many as the sepals, opposite them when as many; oxary superior, mostly compound; orules pendulous, the raphe toward the axis of the ovary.

Petals present, usually as many as the sepals.

Flowers regular or very nearly so.

Tissues of the plant devoid of secreting cells or glands.

Filaments united below or at the base.

Stamens twice as many as the sepals.

Petals tmappendaged; leaves compound.

Petals appendaged: leaves simple. Stamens as many as the sepals.

Filaments separate.

Styles united; leaves mostly compound.

Styles separate; leaves simple.

Tissues of the plant with secreting cells or glands.

Leaves pinctate.

Leaves not punctate.

Carpela separate.

Carpels united.

Filaments separate.

Trees or shrubs with bitter. oilbearing bark.

Resiniferous trees and shrubs.

Filaments united.

Flowers very irregular; petals 3 ; stamens mostly $\mathrm{s}$.

Flower's often apetalous, monoecious; carpels mostly 3.

Fam. 1. OXALIDACEAE.

Fam. 2. ERTtURoxilaceat. Fam, 3. Lixaceae.

Fam. 4. Zxgophyllaceat.

Fam. 5. MALIGHIACEAE.

Fam. 6. Rutaceas.

Fam. 7. Surlaxaceae.

Fam. 8. Simaroubaceae.

Fam. ?. Bursericeat.

Fam. 10. MeliaceaE.

Fam. 11. Polfgalaceae.

Fam. 12. Euphorbiaceae.

\section{Family 1. OXALIDACEAE Lindl.}

\section{. TTOOD-SORREL Fajill:}

Leafy-stemmed or acaulescent herbs, or rarely shrubs, often with rootstocks, or scaly bulbs, the sap sour. Leaves mostly palmately 3 -foliolate, in some tropical species pinnate, or entire and peltate; stipules commonly present as scarious expansions of the petiole-bases; leaflets mostly obcordate. Flowers perfect, in umbel-like or forking cymes, or sometimes solitary; peduncles mostly long. Sepals 5, often unequal. Petals 5, white, pink, purple or yellow. Stamens 10-15, sometimes unequal. Ovary 5celled, 5-lobed: styles coherent or distinct; orules 2-many in each cavity; fruit a loculicidal globose or columnar capsule, rarely baccate. Embryo 
straight, in fleshy endosperm. Abont 15 genera and over 300 species, chiefly of tropical distribution.

Plants acaulescent, with coated bullos; flowers not vellow.

I'lants caulescent, with rootstoclis; flowers mostly yellow.

1. Ionoxnlis.

2. Janthoulis.

\section{IONÓXALIS Small, Fl. SE. U. S. 665. 1903.}

Low, peremial acanlescent herbs the leaves and scapes arising from coated sealy bulbs, the petioles long, the blades palmately 3-several-foliolate, the riolet, blue or white flowers in umbel-like cymes. Sepals 5, bearing apical tubereles in pairs. Petals 5. Stamens 10, the filaments united at the base. Ovary elongated; styles distinct. Capsules narrow, erect. [Greek, purple Oxalis.] Orer 100 species natives of America. Type speeies: Oxalis violacca $\mathrm{L}$.

1. Ionoxalis intermèdia (A. Rich.) Snıall, N. A. Fl. 25: 43. 1907.

Oxalis intermedia A. Rieh. Ess. Fl. Cub. 315. 1845.

Seape 1-3 dm. high, sparingly pubescent, slender, as long as the leaves or longer. Petioles sparingly pubeseent; leaflets 3 , obdeltoid, 2-6 $\mathrm{em}$. wide, bright green and glabrous above, paler and somewhat pubeseent beneath, 2-Iobed, the lobes orate; cymes 4-13-flowered; pedicels glabrous, 1-2 em. long; sepals t-5 $\mathrm{mm}$. long, bearing 1 pair of apical tubercles; petals violet, 11-1t $\mathrm{mm}$. long; shorter filaments slightly pubescent, the longer ones copiously pubescent.

Waste and cultivated lands, New Providence, at Nassau:-Cuba ; Yirgin Islands; Guadaloupe; Martinique. Cerax Purpli Wood-somel.

\section{XANTHóxALIS Small, Fl. SE. U. S. 666. 1903.}

Caulescent, annual or perennial herbs, rarely shrubs, with alternate, longpetioled, 3-foliolate leaves, the leaflets sessile, notched or obeordate, the yellow flowers in peduncled eymes. Sepals 5. Petals 5. Stàmens 10, the filaments united into a tube at the base. Orary oblong to linear; styles filiform or subulate. Capsule oblong or columuar, usually narrowed to the summit, erect. Seeds transwersely rilged or tubercled. [Greek, yellow Oxalis.] Abont 50 species, widely distributed. Type species: Oxalis corniculata L.

1. Xanthoxalis corniculàta (L.) Small, Fl. SE. U. S. 667. 1903.

Oxalis corniculata L. Sp. Pl. 435. 1753.

Pubescent or nearly glabrous, annual or perennial, deep-green, freely branching from the base; stem $2.5-15 \mathrm{~cm}$. long, the branches diffuse, maiuly procumbent and often ereeping. Leaflets $8-12$ mm. wille; petioles dilated at the base into oblong rounded or truncate stipules; peluneles 1-3-flowered; flowers 5-10 mm. wide; pedieels strigillose, more or less reflexed; capsule oblong, 1-1.8 cm. long, appressed-pubescent; seeds compressed, transversely ridged.

Waste and cultivated lands, New Providence at Nassan and Giant's Town :widely distributed ln temperite ind tropical regions of hotlo lomisplieres lieferred by II's. Northrop to Oxalis comiculate repens Zuce, JenLow Irocumext WOOD-SGIKLL. 


\title{
Family 2. ERYTHROXYLÀCEAE A. Rich.
}

\author{
COCA FaMrLF.
}

Glabrous trees or shrubs, with mostly alternate simple stipulate entire-margined, petioled leaves and small, often heterostylons, pedicelled flowers solitary or fascicled in the axils, the pedicels bracted at the base. Calyx persistent. mostly 5-eleft. Petals as many as the calyx-lobes, appendaged by a 2-lobed ligule within. Stamens 10, in 2 series, their filaments united below into a tube. Ovary 3-celled, rarely 4-celled; ovules 1 , rarely 2, in each carity, pendulons; styles 3, rarely 4; stigmas capitellate. Fruit a drupe, usually 1-celled and 1-seeded. Seed-coat thin; endosperm farinaceons; embryo straight. Only the following genus and the African Aneulophus.

\section{ERYTHRÓXYLON L. Syst. ell. 10, 1035. 1759.}

Leares alternate. Petals short-clawerl. [Greek red-wood.] About 200 species of tropical and subtropical distribution. Type species: Erythroxylon arcolatum L.

Leares $0 . \overline{5}-2.5 \mathrm{~cm}$. long. pale beneath. Leares $3 \mathrm{~cm}$. long, or longer.

1. E. rotundifolium.

Leares conspicuously areolate beneath.

Flowering pedicels as long as the petioles, or shorter; leares $5-13 \mathrm{~cm}$. long.

Flowering pedicels, or some of them, much longer than the petioles: leaves $3-4 \mathrm{~cm}$. long.

Leaves not areolate beneath, or only very faintly areolate, oborate, 3- $\mathbf{t} \mathrm{cm}$. long.

2. E. arcolatum.

3. E. reticulatum.

4. L. confusum.

1. Erythroxylon rotundifòlium Lunan, Hort. Jam. 2: 116. 1814.

Erythroxylon obovatum Macf. Fl. Jam. 1: 143. 1537.

Erythroxylon suave O. E. Schulz, in Urban, Symb. Ant. 5: 197. 1907.

Erythroxylon suave aneurum O. E. Schulz, loc. cit. 199. 1907.

A shrub or a small tree up to $7 \mathrm{~m}$. high, with slender flexible branches, the bark smooth. Leaves obovate to oblong-obovate or elliptic, firm in texture, $0.5-3 \mathrm{~cm}$. long, obtuse or emarginate, dark green above, pale beneath, inconspicuously reticulate-veined, the petioles $2.5-5 \mathrm{~mm}$. long; stipules ovate or orate-lanceolate, acute or acuminate, $1-1.5 \mathrm{~mm}$. long; flomers $1-4$ in the axils; pedicels mostly as long as the petioles or lcnger; calvx cleft to about the niildle, about $1 \mathrm{~mm}$. long, its Jobes triangular-ovate, acute; petals white, oblong, 1.5-2.5 mm. long, obtuse, the ligule about one-third as long as the blade, its lobes irregularly toothed; drupes oblong, red, obtuse, 4-6 mm. long.

Rockr plains, pine-lands and coppices, throughout the archipelago from Abaco and Great Bahama to Andros, North Caicos, Grand Turk and Inagua :-Cuba to Porto Ricn: Jamaica. Consists of several races differing in size. shave and thickness of the leaves. Referred by Hitchcock, Coker, Dollex, and by Mrs. Northrop to $E$. brevipes DC. ; formerls referred by O. E. Schulz to $E$. spinescens A. Rich. ROUND-LEAVE ERTTHROXYLON. RAT-WOOD.

\section{Erythroxylon areolàtum L. Syst. ed. 10, 1035. 1759.}

A shrub or a small tree up to $6 \mathrm{~m}$. high. Leares oblong to obovate, rather thin, $5-13 \mathrm{~cm}$. long, $3-5.5 \mathrm{~cm}$. Tide, obtuse or emarginate at the apex, narrotred at the base, dark dull-green above, pale beneath and areolate by two lines parallel with the prominent midvein, the petıoles 4-6 mm. long; stipules triangular, acute, about $2 \mathrm{~mm}$. long: pedicels fascicled, as long as the petioles or shorter; flowers appearing with the leaves of the season, or before them, fra- 
grant; calyx cleft to about the midlle, nearly $2 \mathrm{~mm}$. long, its triangular-orate lobes acute; petals white or yellowish white, oblong, obtuse, $2-3 \mathrm{~mm}$. long, the ligule about one-fourth as long as the blade; drupes red, oblong, 6-9 $\mathrm{mm}$. long.

Coppices, thickets and sclub-lands, Andros, Mangrove Cay, Eleuthera, Cat Island, Watling's and L.ong Islands:-Cuba to Porto Iilco; Jamaica; Colombla. TH1N-LEATED ERTTHOXYLON.

3. Erythroxylon reticulàtum Northrop, Mem. Torr. Club 12: 43, pl. 8. 1902.

A tall shrub, with slender, reddish brown branches. Leaves oblong-oblanceolate to oborate, rather firm in texture, 3-4 $\mathrm{cm}$. long, obtuse or retuse at the apex with the nidrein slightly excurrent, cuncate-narrowes at the base, finely and distinetly reticulate-reined, dark-green above, pale and prominently areolate beneath, the petioles $2-3$ mm. long; stipules triangular, acuminate, $2 \mathrm{~mm}$. long; flowers solitary or 2 or 3 together in the axils; perlicels slender, $5-8 \mathrm{~mm}$. Iong, thickened above; calyx about $2 \mathrm{~mm}$. long, its ovate-lanceolate lobes acute; jetals oblong, white, $3-3.5 \mathrm{~mm}$. long, the ligule-lobes contorted; young drupes oblong, purplish black, pointed, $5 \mathrm{~mm}$. long.

Thite-lands and coppices, Andros at Deep Creek and near Conch Sound:-

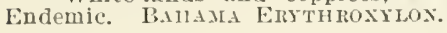

\section{Erythroxylon confùsum Britton.}

?Erythroxylon affine A. Rich. in Sagra, Hist. Cub. 10: 106. 1845. Not St. Hil. 1829.

Erythroxylon obovatum Griseb. FI. Br. W. I. 113. 1859. Nat Macf. 1837.

A tree, $4-9 \mathrm{~m}$. high, with a trunk-diameter of $1 \mathrm{dm}$. or more, the pale bark fissured. Leares oborate or oblong-obovate, rather firm in texture, $3-7 \mathrm{~cm}$. long, $3 \mathrm{~cm}$. wide or less, rounded or emarginate at the apex, narrowed or cuneate at the base, dull-green abore, pale-green beneath, not areolate, or but faintly so, not prominently reticulate-reined, the petioles $4-9 \mathrm{~mm}$. long: stipules lanceolate, $2-4 \mathrm{~mm}$. long; pedicels fascicled in the axils, or some of them solitary, shorter than the petioles; calyx about $2 \mathrm{~mm}$. long, cleft to about the middle, the orate-lanceolate lobes acute; petals oblong, obtuse, about $3 \mathrm{~mm}$. long, the ligule about one-thirr as long as the blade, its lobes acute; drupes sblong, red, somewhat longer than the pedicels.

Rocky coppices, scrub-lands and pałmetto-lands, Andros, Mangrove Car, New Providence and Great Fxuma:-Cuba; Jamaica. OBovate-Leared Enstimosilos.

\section{Family 3. LINÀCEAE Dumort.}

\section{Flax Family.}

Herbs or shrubs, with perfect regular nearly symmetrieal flowers. Stipules mostly small or none. Sepals 5, rarely 4, imbrieated, persistent. Petals of the same number and alternate with the sepals, imbrieated, generally contorted. Stamens of the same number, alternate with the petals; filaments monadelphous at the base; anthers versatile, 2-eelled. Orary 2-5-celled, or by false septa $4-10$-celled. Orules anatropons. Styles 2-5. Fruit mainly eapsular. Seeds 1 or 2 in each cavity, oily: endosperm little or none; embryo straight; cotyledons flat. Abont it genera and about 160 species of wide distribution.

\section{CATHARTOLINUM Rehb. Handb, 307. 1837 .}

Annual or perennial, branched herbs. Leaves alternate or oceasionally opposite, without stipules but sometimes with stipular glands, entire or serru- 
late, sometimes ciliate or glandular-margined. Sepals 5, all, or only the inner ones, with gland-tipperl teeth. Petals 5, yellow or white, unappendaged but sometimes pubeseent within. Stamens 5; filaments united at the base, the free portions dilated at the base, without staminodia, or with a short staminodium in each sinus. Gynoecium 5-carpellary, or rarely 2 -earpellary; styles filiform, distinct or united; stigmas distinct, eapitate. Capsule 5-celled, or rarely 2-celled and with firm septa, or completely or incompletely 10 -celled by false septa, the carpels not ribbed on the back. Seers flattened, often lunate. [Greek, referring to the medicinal qualities of some of the species.] About 70 species of wide geographic distribution. Type species: Linum catharticum L.

Staminodia wanting.

Staminodia present.

1. C. Curtissii.

Androecium pubescent or ciliate.

Stem and leares pubescent; annual.

Stem and leares glabrous.

Staminodia lanceolate: capsules oroid: perennial.

Staminodia deltoid; capsules spheroidal ; annual.

indroecium glabrous; leaves ciliate; perennial.

2. C. corallicola.

3. C. bahamense.

4. C. Bracei.

5. C. lignosum.

1. Cathartolinum Curtissii Sinall, N. A. Fl. 25: 72. 1907.

Linum Curtissii Small, Bull. N. Y. Bot. Gard. 3: 424. 1905.

Annual; glabrous; stems solitary, $5 \mathrm{dm}$. high or less, simple or corymbosely hranched above. Leaves thickish, erect or ascending, the lower opposite or alternate, oblanceolate or spatulate, $1.5 \mathrm{~cm}$. long or less, the upper all alternate, linear, acute or acuminate; bracts entire; outer sepals orate, acute or acuminate, $2.5-3 \mathrm{~mm}$. long, usually with a few glandular teeth; inner sepals ovate, rather broader than the outer, copiously glandular-toothed; petals yellow; staminodia none; capsules subglobose, about $2.5 \mathrm{~mm}$. thick.

Borders of brackish marshes and in palmetto-lands, New Providence:-Florida. CrRtiss' Flax.

\section{Cathartolinum corallícola Small, N. A. Fl. 25: 74. 1907.}

Annual; stem sparingly branched above, minutely hirsute, 2-4 dm. high. Leares oblong to linear, 6-12 $\mathrm{mm}$. long, alternate or the lower opposite, distant, rather thin, acute or acuminate, finely pubescent, glandular-eiliate; bracts lanceolate to subulate, closely glandular-ciliate; outer sepals oblong-ovate, 5 $\mathrm{mm}$. long, glandular-toothed, pubescent, the inner similar, slightly broader and shorter; filaments pubescent below the middle; staminodia deltoid, ciliate; petals yellow; styles distinct; capsules ovoid, about $2 \mathrm{~mm}$. long, much shorter than the sepals.

Rocky pine-barrens, Andros, at Mastic Point. Endemic. Rock Flax.

3. Cathartolinum bahaménse (Northrop) Small, N. A. F1. 25: 75.1907.

Linum bahamense Northrop, Mem. Torr. Club 12: 42. 1902.

Perennial, glabrous and glaucous; stems ridged, corymbosely branched above, $6 \mathrm{dm}$. high or less, the branches ascending. Leaves approximate, erect or ascending, linear to linear-lanceolate, thick, 5-12 mm. long, acute, pale green on both sides; bracts lanceolate to subulate, glandular-toothed; outer sepals ovate, $3-3.5 \mathrm{~mm}$. long, acute or acuminate, glandular-toothed, the inner similar, acuminate, slightly shorter; petals yellow; filaments pubescent below the middle; staminodia lanceolate, ciliate; styles distinct; capsules oroid, about $2 \mathrm{~mm}$. long.

White-lands, pine-lands and borders of marshes, Abaco, Andros, New Providence and Eleuthera. Endemic. Recorded by Dolley as Linum virginicum L. BAHAMA FLAX. 
4. Cathartolinum Bràcei Sulall, N. A. Fl. 25: 75. 1907.

Anuual, pale green or glaucescent, glabrous; stem eorymbosely branched abore, $1.5-3.5 \mathrm{dm}$. high, somewhat striate, the very slender branches ascending. Leaves few and distant, ascending, rather thin, spatulate to linear-oblong, 6-14 mm. long, acute, entire, ciliate, only the lower opposite; bracts lanceolate, glandular-toothed; outer sepals oval to ovate-oblong, aeute, $3.5-4 \mathrm{~mm}$. long, glandular-toothed, the inner similar, slightly shorter; petals yellow; filaments pubescent below the middle; staminodia deltoid, glabrous; styles distinct; eapsule depressed, about $2 \mathrm{~mm}$. long.

White-lands and moist situations, Abaco and Great Bahama. Endemic. BRICE'S FLAX.

5. Cathartolinum lignòsum Small, N. A. Fl. 25: 75. 1907.

Apparently perennial; stem woody, branched, with long, prominently striate branches, $3 \mathrm{dm}$. high. Leaves numerous, but not crowded, linear or nearly so, 4-11 mm. long, sessile, acuminate, glandular-ciliate; outer sepals orate, 3-3.5 mm. long, glandular-toothed, acuminate, the inner broader than the outer; petals yellow; filaments and staminodia glabrous; styles distinct.

Scrub-lands under low bushes in partial openings, Great Bahama at Eight sile liocks. Endemic. Wuour Fls.

A species of Linum, perhaps L. Lewisii Pursh, was collected by Mr. Brace in foliage only on New I'roridence in 1916 .

\section{Family 4. ZYGOPHYLLÀCEAE Lindl.}

\section{Caltrop Famils.}

Herbs, shrubs, or some tropical species trees, the branches often jointed to the nodes. Leares mostly opposite, stipulate, pinnate, or 2-3-foliolate, the leaflets entire. Stipules persistent. Flowers perfect, axillary, peduncled. Sepals usually 5, distinet, or united by their bases. Petals the same number as the sepals, or none. Stamens as many as the petals. or 2-3 times as many, inserted on the base of the receptacle. the alternate ones sometimes longer; anther's rersatile, longitudinally dehiscent: filaments usually with a small scale at the base or near the middle. Ovary $1-12$ celled; style terminal; stigma usually simple; ovules 1-numerous in each carity, pendulous or ascending. Fruits rarions, dry or quite fleshy. Abont 20 genera and 160 species, widely distributed in warm and tropical regions.

Trees or shrubs; flowel's blue or purple.

Herbs: flowers yellow.

Carpels spinose.

Carpels tubereulate.

1. Guatucum.

2. Tribulus.

3. Lillstroemia.

\section{GUAIÀCUM L. Sp. Pl. 3S1. 1753.}

Evergreen trees or shrubs, with hard resinous wool, the branehes stout, the norles often swollen. I.eares opposite, petioled, abruptly pinnate, the leaflets 2-several pairs, entire, inequilateral, reticulate-veinerl, the stipules minute. Flowers clustered, perluneled, the peduneles subtended by minute deciduous bracts. Sepals 4 or 5 , somewhat united at the base. Petals 4 or 5 , blue or purple. Stamens $S$ or 10 ; filaments filiform; anthers corilate or sagittate. Ovary stalked, 2-5-lobed, 2-5-eelled; style subulate; orules $\mathrm{S}-10$ in each cavity, anatropous. Fruit corjaceous, with $2-5$ wing-like angles. Seens oroid 
or ellipsoid; embryo nearly straight. [From the aboriginal name.] About 8 species, natives of tropical and subtropical America. Type species: Guaiacum officinale L.

Petals tomentulose; fruit broadly obcordate; leaflets mostly 4. Petals glabrous; fruit broadly obovoid; leaflets mostly 6-10.

1. G. officinale. G. Gunctum.

1. Guaiacum officinàle L. Sp. Pl. 381. 1753.

A tree up to $10 \mathrm{~m}$. high, the bark smooth and gray, the branches flexuous. Leaves $3-9 \mathrm{~cm}$. long; leaflets 4 or 6 , mostly 4 , oval to obovate, glabrous, $1-5$ $\mathrm{cm}$. long, rounded at the apex, sessile or nearly so, coriaceous at maturity; stipules $1 \mathrm{~mm}$. long, pubescent, cariucous; flowers few or many, terminal, the slender peduncles pubescent; sepals ovate to orbicular, 5-7 $\mathrm{mm}$. long, tomentulose on both sides; petals blue, narrotvly obovate, about $12 \mathrm{~mm}$. long, tomentulose at the apex, rounded or mucronate; fruit usually 2-carpellary, broadly obcordate, yellowish, 17-20 mm. long; seeds ellipsoid, the aril cream-colored.

Coppices and scrub-lands, South Caicos:-Cuba to St. Thomas and to Trinidad; Jamaica; Panama to northern South America. Ligxua Vitae.

2. Guaiacum sánctum L. Sp. Pl. 382. 1753.

A tree, sometimes $10 \mathrm{~m}$. high, the bark pale, the branches spreading or pendulous. Leaves 4-10 cm. long; leaflets 4-10, oblong to obovate or oblanceolate, $2-3.5 \mathrm{~cm}$. long, sessile, glabrous, coriaceous at maturity, usually apiculate or mucronate; stipules about $3 \mathrm{~mm}$. long, pubescent, usually cadncous; flowers solitary or several, on pubescent peduncles shorter than the leaves; sepals obovate or oblong-obovate, 5-7 $\mathrm{mm}$. long, pubescent; petals blue or purple, broadly obovate, $7-11 \mathrm{~mm}$. long, glabrous, rounded at the apex; fruit broadly obovoid, yellow to orange, $14-17 \mathrm{~mm}$. long; seeds ellipsoid, the aril scarlet.

Coppices and scrub-lands, throughout the islands from Abaco and Great Bahama to Watling's, Inagua, Anguilla Isles and North Cajcos:-Florida; Cuba to Polto Rico; Yucatan. LIGNUAI VITAE.

\section{TRÍbULUS L. Sp. Pl. 356. 1753.}

Herbs, with evenly pinnate leaves and peduncled axillary yellow flowers. Sepals 5, persistent. Petals 5, deciduous. Stamens 10, the alternate ones somewhat longer. Ovary sessile, 5-lobed, 5-celled, hairy, the hairs erect; style short; stigma 5-ridged; ovules 3-10 in each cavity, pendulous. Fruit 5-angled, spiny, splitting into 5, 3-5-seeded segments. [Greek, three-pronged, Caltrop, from the resemblance of the fruit to that implement.] About 12 species, of warm and tropical regions. Type species: Tribulus terrestris $\mathrm{L}$.

\section{Tribulus cistoìdes L. Sp. Pl. 387. 1753.}

Tribulus terrestris cistoides Oliver, Fl. Trop. Afr. 1: 284.1868.

Perennial; roots thick, woody; stems diffuse, procumbent, $3-10 \mathrm{dm}$. long, pubescent, becoming glabrate. Leaves $1-5 \mathrm{~cm}$. long; leaflets $6-8$ pairs, obliquely oblong or elliptic, acutish or obtuse and mucronulate, 4-15 $\mathrm{mm}$. long, silky-pubescent beneath; stipules subulate, $5-8 \mathrm{~mm}$. long; peduncles about as long as the leaves or longer; sepals lanceolate, half as long as the petals; petals yellow, about $2 \mathrm{~cm}$. long; carpels tubercled, each with 2 stout divergent spines and several scattered smaller ones.

Sandy waste places, Fortune Island, Grand Turk and Inagua:-Georgia and Florida; Cuba to Virgin Gorda; Guadeloupe and Martiuique; Jamaica: Panama north to the islands off the California coast. Large Yellow Caltrop. Buttercup. 
3. KALLSTROĖMIA Scop. Int. 212. 1777.

Mostly annual pubescent herbs, with opposite stipulate, evenly pinnate leaves, and solitary axillary peluncled yellow flowers. Sepals usually 5. Petals the same number, obovate or oblanceolate, deciduous. Stamens twice as many as the petals. Ovary sessile, 10-12-celled; ovule 1 in each earity, pendulous; style long, or short, 10-12-grooved, persistent; stigma mostly 10-12-ridged. Fruit 10-12-lobed, not spiny, often tubercled, splitting into 10-12 1-seeded segments. [In honor of Kallstroem.] About 20 species, widely distributed in warm and tropical regions. Type species: Tribulus maximus L.

1. Kallstroemia màxima (L.) T. \& G. Fl. N. A. I: 213. 1838.

Tribulus maximus L. Sp. Pl. 3S6. 1753.

Branches slender, prostrate, $1.5-4.5 \mathrm{dm}$. long. Leares short-petioled; stipules subulate; leaflets $3-5$ pairs, oval or oblong, inequilateral, rounded or subcordate at the base, $8-20 \mathrm{~mm}$. long; poduncles slender, $1.2-5 \mathrm{~cm}$. long in fruit; flowers $2.5 \mathrm{~cm}$. broad, or less; sepals linear-lanceolate, rery puluescent, persistent, shorter than the petals; fruit oroid-conic, about $6 \mathrm{~mm}$. in diameter, about as long as the stout persistent style, the segments tubercled.

A weed in waste and cultivated soils, New Proridence and Fortune Island:Georgia and Florida; West Indies; Mexico to Colombia. Greater Caltrop.

\section{Family 5. MALPIGHIACEAE Verit.}

\section{Malpighia Family.}

Shrubs, trees or woody vines, mostly with opposite leaves, and perfect clustered, or sometimes solitary, nearly regular flowers. Calyx of 5, usually glandular sepals. Corolla of 5 , usually clawed petals. Stamens 5 or 10 ; filaments united below, or distinet. Ovary sessile, mostly 3-carpellary; styles distinct or mited; stigmas minute. Fruit various. $\Lambda$ bout 60 genera, including over 700 species, natives of tropical and subtropical regions.

Fruit nut-like, winged, Jaterally attached to the pyramidal receptacle.

Inture carpels winged all around, the wings lobed, the

body crestless,
Mature carpels winged dorsally, the wings entire, the body crested.

Fruit fleshy, wingless, basally attached to the flat or hollow

1. Triopteris.

2. Stigmaphyllon. receptacle.

Styles distinct.

Inflorescence congested; stigmas thick. 3 , Malpighia.

Inflorescence elongated; stlgmas subulate. 4. Byrsonima.

styles united.

4. Byrsonima.

\section{TRIÓPTERIS L. Sp. Pl. 428. 1753.}

Tines, glabrous or nearly so, twining or reclining, with opposite coriaceous, mostly shining, short-petioled leaves, and small clustered flowers. Receptacle py:anidal. Calyx 8-glandular, the broad sepals persistent. Petals 5, the blacies usually undulate. Stamens 10, all antheriferous; filaments subulate; anthers very short. Ovary 3 -lobed; styles 3, distinet, nearly equal. Samaras 3 together, each 3-winged, $\mathbf{Y}$-shaped, the two upper wings longer than the lower one. [Greek, three wings.] About 4 species, natives of the West Indies. Type species: Triopteris jamaicensis L. 
1. Triopteris jamaicénsis L. Sp. Pl, 428. 1753.

Banisteria microphylla Jacq. Obs. Bot. 3: 7. pl. 56. 1768.

Triopteris rigida Sw. Prodr. 75. 1758.

Triopteris lucida H.B.K. Nov. Gen. \& Sp. 5: 167. pl. 451.1822.

Triopteris havanensis H.B.K. Nov. Gen. \& Sp. 5: 168. 1822.

Triopteris parvifolia A. Juss. Ann. Sci. Nat. Bot. II. 13: 266. 1810.

A slender vine, sometimas $10 \mathrm{~m}$. long. Leaves various, linear to cuneate or obovate, 1-2.5 $\mathrm{cm}$. long, striate-veined, emarginate or mucronate at the apex, mostly obtuse at the base; flowers racemose or paniculate; sepals ovate, 2-2.5 $\mathrm{mm}$. long; petals violet, the larger ones $4-5 \mathrm{~mm}$. long, the suborbicular or ovate-orbicular blades undulate; samaras $12-26 \mathrm{~mm}$. long, the upper wings oblong, the lower one ovate.

Scrub-lands and pine-lands, Great Bahama, Andros, New Providence, Eleuthera. Cat Island, Care Cay, Watling's Island, Iium Cay, Acklin's Island, Fortune Island, Crooked Island:-Cuba; IIlspaniola; (?) Jamaica. Apparently recorded by Schoepf as Banisteria angulosa L. Triopteris.

2. STIGMAPHYLLON A. Juss. in A. St. Hil. Fl. Bras. Merid. 3: 48.1833.

Woody vines, with opposite, coriaceous or membranous, petioled leaves, and bright sellow flowers, in axillary peduncled umbel-like corymbs. Receptacle pyramidal. Calyx 8-glandular; sepals persistent. Petals 5, their blades erose or fimbriate. Stamens 10 , only 6 of them antheriferous; filaments unequal, united at the base or up to the middle; anthers short. Ovary 3-lobed; styles 3 , distinct, unequal, sometimes foliaceous above. Samaras 2 or 3 together or solitary, with a flat dorsal wing. [Greek, leafy stigma.] About 50 species, natives of tropical America. Type species: Banisteria auriculata Car.

1. Stigmaphyllon Sagraeànum A. Juss. Ann. Sci. Nat. Bot. II. 13: 290. 1840.

Stigmaphyllon reticulatum A. Juss. Ann. Sci. Nat. Bot. II. 13: 290. 1840.

Stigmaphyllon Faustinum C. Wright; Sauv. Anales Acad. Habana 5: 244. 1868 .

A rather stout vine up to $12 \mathrm{~m}$. long, usually shorter. Leaves various, oblong to linear, ovate, or obovate, coriaceous, 2-10 $\mathrm{cm}$. long, usually mucronate, glabrous or nearly so when old, strongly reticulate-reined beneath, rounded or cordate at the base, short-petioled; peduncles and pedicels sparingly pubescent or glabrous; pedicels jointed at the base; sepals ovate, about $4 \mathrm{~mm}$. long; larger petals 10-12.5 $\mathrm{mm}$. long; samaras $1.5-2.2 \mathrm{~cm}$. long, the ventral edge of the wing auricled at the base, the body one-third to one-half as long as the wing.

Pine-lands and scrul--Iands, Andros, Long Island:-Cuba. SAgra's StigmaPHYLLON.

\section{MALPÍghIA L. Sp. Pl. 425. 1753.}

Shrubs or small trees, with opposite leaves usually bearing stinging hairs beneath, the white pink or red flowers in axillary peduncled corymbs. Calyx 6-10-glandular, persistent. Petals $5_{2}$ the blades undulate or fimbriate. Stamens 10, all antheriferous; filaments united to the middle or below; anthers short, often didymons. Ovary glabrous, 3-lobed; styles distinct; stigmas small. Fruit a fleshy drupe, usially depressed-globose. [In honor of Marcello Malpighi, 1628-1693, Italian botanist.] Over 30 species, of tropical and subtropical America. Type species: Malpighia glabra L. 
1. Malpighia polytricha A. Juss. Anu. Sci. Nat. Bot. II. 13: 336. 1540.

A shrub, up to $3 \mathrm{~m}$. high, usually much brancherl. Leaves oblong, oval or obovate, subcoriaceous, $1.5-3 \mathrm{~cm}$. long, rounded, truneate or retuse and usually mucronulate at the apex, euneate to subcoriate at base, sinuate-rentate or entire, reticulate-reined, glabrous above when mature, mostly juheseent with stinging hairs beneath and on the margins, short-petioled; cymes sessile or nearly so, several-flowered; calyx 10-glandular; sepals obleng to ovate, about $3 \mathrm{~mm}$. long; rorolla pink to searlet, the larger petals $8-10 \mathrm{~mm}$. long: styles unequal, hooked at the apex; Irupe red, suloglobose or globose-ovoil, $7-10 \mathrm{~mm}$. in diameter.

Scrub-lands, coppices and pine-Innds, tluoughout the archipelago from Abrco and Andros to Caicos and Inagua. Endemic. Consists of many liaces, the leafforms various and the stinging hairs abuldant, few or none. Recorded by Dolley and Ilitcheock as $M$. setosa spreng. : also as such by Mrs. Northrop; and by Ilitch-

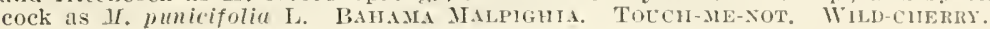

4. BYRsonima Rich.; A. Juss. Ain. Mus. Paris 18: 451. 1s11.

Shrubs or trees, with opposite petioled or sessile leares, the flowers in terminal panicles or racenes. Calyx 10-glandular, or glandless, of 5 broad persistent sepals. Petals 5 , the blarles suborbicular to reniform. Stamens 10 , all antheriferous; filaments short, slightly united at the base. Orary 3-lobed; styles 3 , slender; stigmas subulate. Drupes ovoid to globose. [Greek, tanning.] About 100 species, of tropical and subtropical America. Type species: Malpighin spicata Cav.

1. Byrsonima cuneàta (Turez.) P. Wrilson, Bull. X. Y. Bot. Garı. 8: 394. 1917.

Malpighia Tucida Sw. Prodr. 74. 178s. Not Miller. 176s.

Bursonima lucida DC. Prortr. 1: 580. 1824.

Ifalphighia cuneate Turez. Bull. Soe. Imp. Nat. Mose. 31': 390. 1858.

I'sually a shrub, $2.5 \mathrm{~m}$. high or less, sometimes a small tree up to $s \mathrm{~m}$. high, the twigs sender, mostly short. Leaves spatulate to obovate, rather thin in texture, flat, $1.5-5.5 \mathrm{~cm}$. Jong, glabrous, rounded or abruptly aeute at the apex, narrowed or euneate at the base, retieulate-reined and shining above, dull beneath, the petioles $2-5 \mathrm{~mm}$. long; pedicels sparingly pubescent or glabrous; sepals orate or oblong, about $3 \mathrm{~mm}$. long; petals white to red, the larger $\overline{5}-\bar{i}$ mm. long; drupes globose, brown, 9-12 mm. in diameter.

Coastal copplces, borders of swamps and in wet places in pine-lands; Alaco, Great Iahama, Indros, New I'rovidence, Eleuthera, Cat Island, Crooked Island, Fortune Island, Acklin's Island, Inagua :-Florida: Cuba to Inegada and Far-

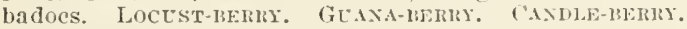

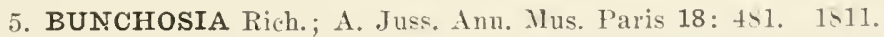

Shrubs or trees, with opposite, usually coriaceous, petioled or nearly sescile leares, and yellow or white flowers in terminal panieles. Calyx s-10-glaudular, the 5 sepals persistent. Petals 5, their brcarl blades undulate or toothed. Stamens 10, all antheriferous; filaments jartly united, glahrous; anthers short. Ovary 2-3-loherl; styles united: stigma 3-loher or eapitate. Drupe oroid, globose or reniform. [Said to be lerived from an Arabie name for coffee.] Thirty species or more, of tropical and subtropical America. Type species: Malpighia odorata Jaer. 
1. Bunchosia glandulòsa (Cav.) DC. Prodr. 1: 581. 1824.

Malpighia glandulosa Cav. Diss. 8: 411. pl. 239. f. 2. 1789.

A shrub, or sometimes a tree up to $\mathrm{S} \mathrm{m}$. high. Leaves oblong to oblanceolate or elliptic-obovate, glabrous, 3-11 cm. long, obtuse or acute at the apex, narrowel or acute at the base, bright-green, somewhat paler beneath than above, the petioles 5-12 m. long; panicles often many, as long as the leaves or shorter; pedicels finely pubescent when young, becoming glabrous; sepals oblong or ovate-oblong, about $3 \mathrm{~mm}$. long; petals yellow, the larger $6-7.5 \mathrm{~mm}$. long, with suborbicular, erose or denticulate blades; ovary and style glabrous; drupes oroid, red or orange, 2 -lobed, $9-15 \mathrm{~mm}$. in diameter.

Scrub-lands, Andros, New Providence, Elentlera, Great Exuma, Watling's Island:-Hispaniola; Porto Rico; St. 'Thomas to Martinique; Yucatan. BunchosiA.

\section{Family 6. RUTACEAE Juss.}

\section{Rue Family.}

Trees or shrubs, rarely herbs, with heavy-scented and glandular-punctate foliage, mainly compound estipulate leaves, and perfect or polygamodioecious flowers. Sepals 4 or 5, or none. Petals 4 or 5, hypogynous or perigynons. Stamens of the same number, or twice as many, distinct, inserted on the receptacle; anthers 2-celled, mostly versatile. Disk annular. Pistils 1-5, distinct, or 1 and composed of $2-5$ carpels, inserted on the receptacle. Fruit various, a capsule, berry or samara. Seeds oblong or reniform; endosperm generally fleshy, sometimes none. About 110 genera and 950 species, most abundant in South Africa and Australia.

\footnotetext{
Fruit dry, capsular or samaroid; stamens 3-5.

Fruit dehiscent, not winged; flowers whitish or greenish.

Fruit indehiscent, winged: flowers red or pinkish. Fruit pulpy, drupaceous; stamens 8 or 10.

1. Zanthoxylum. 2. Sprthelia.

3. Amyris.
}

\section{ZANTHóXYLUM [Catesby] L. Sp. Pl. 270. 1753.}

T'rees or shrubs with alternate pinnate leaves, the twigs and petioles commonly prickly. Flowers axillary or terminal, cymose, whitish or greenish, mostly small. Sepals 4 or 5, or none. Petals imbricated. Staminate flowers with 4 or 5 hypogynous stamens. Pistillate flowers with 1-5 distinct pistils, rarely with some stamens. Carpels 2-ovuled. Pods 2-valved, 1-2-seeded. Seeds oblong, black and shining. [Greek, yellow-wood.] About 150 species, of temperate and tropical regions. Type species: Zanthoxylum Clava-Herculis L.

Petiole and rachis winged; iuflorescence lateral or axillary, shortspicate.

retiole and rachis wingless; inflorescence mostly terminal, panicu-

1. Z. Fagara.

late or corymbose-paniculate.

Sepals, petals and stamens 3 ; leaflets obovate. Ovary 3-carpellary.

Ovary 1-carpellary.

Sepals, petals and stamens 5 , rarely 4 ; leaflets lanceolate to ovate.

2. Z. coriaceum.

3. Z. cubense.

4. Z. Aar'um.

1. Zanthoxylum Fagàra (L.) Sarg. Gard. \& For. 3: 186. 1890.

Schinus Fagara L. Sp. Pl. 3S9. 1753.

Fagara Pterota L. Syst. ed. 10, 897. 1759.

Fagara lentiscifolia H. \& B.; Willd. Enum. Hort. Berol., 165. 1809.

Zanthoxylum Pterota H. B. K. Nor. Gen. \& Sp. 6: 3. 1 S23.

Fagara Fagara Small, Fl. SE. U. S. 675. 1903. 
Usually a shrub, sometimes a small tree up to $10 \mathrm{~m}$. in height, intricately branched, the branches armed with hooked prickles, or occasionally unarmed, the young twigs puberulent. Leaves $2.5-10 \mathrm{~cm}$. long, odd-pinnate; leaflets $5-13$, obovate to elliptic or suborbienlar, $7-25 \mathrm{~mm}$. long, romded or emarginate at the apex, nostly euneate or narrowed at the base, crenulate, bright-green and shining above, the petiole and rachis grooved and winged; infloreseence lateral, axillary, short-spieate; sepals 4 , not more than $0.5 \mathrm{~mm}$. loug; petals 4 , rellowishgreen, $2-3 \mathrm{~mm}$. long; staminate flowers with 4 stamens, longer than the petals; pistillate flowers with a sessile ovary and slender styles; follieles globose, $3-1$ mn. in diameter; seeds black, shining.

Scrub-lands and coppices, Elbow Cas, Great Bahama, Berry Islands, North Cat Cay, Andros, New Providence, Elenthera to Watling's, Great Guana Cay, Great Exuma, Long Island, Acklin's and North Caicos:-Flolida; 'Texas ; Mexico; Central and South Imerica; West Indies. Wild Lime. SATIx-Wood.

2. Zanthoxylum coriàceum A. Rich. Ess. Fl. Cub. 326. 1845.

Fagara coriacea Krug \& Urban, Bot. Jahrb. 21: 591. 1896.

A prickly aromatic shrub or small tree up to $7 \mathrm{~m}$. high, the old wood bearing many corky conic cushions. Leaves $2 \mathrm{dm}$. long or less, glabrous, mostly evenly pinnate; leaflets 4-13, obovate or oblong-oborate, 2-6.5 cm. long, obtuse, emarginate or bluntly acuminate at the apex, narrowed or euneate at the base, lark-green and shining above, pale-green and often prickly beneath; cymes terminal, rarely axillary; flowers yellowish-white; sepals, petals and stamens 3 ; ovary 3-carpellary; petals of the pistillate flomers about 4 mm. long, a little larger than those of the staminate; follicles subglobose to ellipsoid, $5-6 \mathrm{~mm}$. long, apiculate, brown, rough; seeds 1 in each follicle, subglobose, black, shining, $3-4$ mm. long.

Coppices or sometimes in the white-lands, throughout the archipelago from Abaco and Gleat Bahama to North Bimini, Caicos and Inagua :-Florida; Cuba; Grand Cayman and Hispaniola. Referred by Dolley and Hitchcock to Zanthoxylum emarginatum Sw. Hercules' Chub. Doctor's Cle'i.

3. Zanthoxylum cubénse P. Wilson, Torreya 9: 32. 1909.

Zanthoxylum juglandifolium A. Rich. Ess. Fl. Cub. 332. 1545. Not Willd. 1806.

A prickly glabrous shrub or tree up to $13 \mathrm{~m}$. high. Leares odd-pinnate; leaflets $3-9$, obovate, $5-8 \mathrm{em}$. long, obtuse, short-aeuminate, or emarginate at the apex, narrowed at the base, shining above, rather dull beneath; inflorescence terminal, panieulate; sepals, petals and stamens 3 ; petals about $1.6 \mathrm{~mm}$. long, 4-5 times as long as the calyx; ovary 1-carpellary; follieles solitary, sessile, globose, apieulate, about $4 \mathrm{~mm}$. in diameter. woot.

Coppices and pine-lands, near Deep Creek, Andros:-Cuba, Curax Yellow-

\section{Zanthoxylum flàvum Vahl, Eelog. 3: 48. 1507.}

Funthoxylon cribrosum Spreng. Syst. 1: 946.1825.

Fagara flava Krug. \& Urban, Bot. Jahrb. 21: 571. 1596.

An unarmed tree, reaching a maximum height of about $12 \mathrm{~m}$. with a trunk about $5 \mathrm{dm}$. in diameter, usually smaller, sometimes shrubby, the light grey bark nearly smooth, the twigs finely stellate-pubeseent when young, soon glabrous. Leares 1-2.5 dm. long, odd-pinnate, finely stellate-cancscent when young; leaflets $3-11$, mostly 5 or 7 , subeoriaceous, ovate or lanecolate to elliptic, very nearly sessile, obtuse or acutish at the apex, mostly romded at the base, erenate or nearly entire, pellueid-punctate; panieles terminal, many-flowered, 5-15 cm. long; pedicels and rachis stellate-eaneseent; calyx ahout $1.5 \mathrm{~mm}$. broad; petals $2.5-4 \mathrm{~mm}$. Iong; staminate flowers with 5 , rarely 4 stamens about 
as long as the petals; pistillate flowers with a glandular-punctate ovary anl short styles; follicles obovord, 5-9 $\mathrm{mm}$. long; seeds black, shining, $4-5 \mathrm{~mm}$. long.

White-lands and low coppices, throughout the archipelago from Abaco and Great Bahama to (iland Turk and Ambergris Cay, Inagua and the Anguilla Isles :-Bermuda: Florlda: Cuban Cays: Jamaica, Santo Domingo to St. Lucia. Referred by Dolley to Zanthosylum fraxincum Willd. Yellow-Wood, SATIN-WOod.

The occurrence of Zanthoxylum Clava-Herculis L. in the Bahamas as recoriter by Dolley is extremely donbtful; both $Z$. coriaccum and Caesalpinia bahamensis are locally known through the archipelago as "Hercules' Club."

\section{SPATHÈLIA L. Sp. Pl, ed. 2, 386, 1762.}

Trees, with slender unbranched trunks, the leaf-scars long-persistent, the pinnate leaves tufted at the summit, the polygamous flowers in large terminal erect panicles. Leaflets pellucid-punctate. Sepals 5. Petals 5, imbricated. Stamens 5, alternating with the petals. Orary 3-celled, 3-angled; stigma 3 lobet ; orules 2 in each carity. Fruit dry, 3-celled, 3-winged, each cavity containing one seed. Endosperm fleshy; radicle straight. [Greek, staff-like.] About $\bar{s}$ species, natives of the West Indies. The trees die after once flowering and fruiting. Type species: Spathelia simplex L.

\section{Spathelia vernicòsa Planch. in Hook. Lond. Jour. Bot. 5: 581. 1846.}

Trunk 3-5 m. high, 5-8 cm. in diameter. Leaves several, 1.5-4.5 dm. long, the rachis narrowly wing-nargined; leaflets 25-35, oblong or oblong-elliptic, 1-5 cm. long, subsessile, obtuse at the apex, rounded or broadly euneate at the base, glabrous, dark-green above, paler beneath, shining on both sides, coarsely crenulate with gland-tipped teeth; panicle $9 \mathrm{dm}$. long or less; pedicels $3-5 \mathrm{~mm}$. long; flowers red; sepals oblong, 4-5 mm. long; petals oblong-oborate, $5-6 \mathrm{~mm}$. long; filaments with wing-like appendages at the base; fruit $10-13 \mathrm{~mm}$. long, 7-10 $\mathrm{mm}$. wide, the triangular body narrowly minged; seeds angled.

Rocky scrub-lands, Cat Island:-Cuba. Low Spathelid.

3. AMỲRIS L. Syst. ed. 10, 996, 1000. 17.59.

Shrubs or trees, with compound (sometimes unifoliolate), petioled leaves, and small white perfect flowers in terminal and axillary corymbiform panicles, the pedicels 2-bracteolate. Calyx urn-shaped, 4-5-1obed. Petals 4 or 5. Stamens trice as many as the petals, borne on the disk; filaments filiform; anthers longitudinally dehiscent. Ovary 1-celled; ovules 2, pendulous; style short or none; stigma capitate or flat. Fruit a small drupe. Seed-coat membranous; cotyledons thick, fleshy. [Greek, much balsam.] About 15 species, natives of tropical and subtropical America. Type species: Amyris balsamifera L.

* 1. Amyris elemifera L. Syst. ed. 10, 1000. 1759.

Amyris maritima Jacq. Enum. 19. 1760.

A shrub or tree, sometimes $17 \mathrm{~m}$. high, glabrous or the young trigs and inflorescence hispidulous. Leaves opposite, or mostly so; leaflets 3 or 5 , coriaceous, lanceolate to orate or rhombic-ovate, $2-\overline{c m}$. long, acute, acuminate or rounded at the apex, cuneate, rounded or subtruncate at the base, crenulate or entire, short-stalked; panicles sereral-many-flowered; calyx-lobes orate; petals 
obovate or oral, $2-3.5 \mathrm{~mm}$. long; orary glahrous; stigma sessile; lrupe globose to ellipsoil, black, 5-8 mm. long, glaucous.

Constal thickets and scrub-lands, throughout the archipelagn from Abaco and Great liahama to Caicos and Inagua :- Forida: West Indies and rentral Amerlea. Referred by Dolley to Amyris syluticn Jacq. Torchwood. WHITE Torcir. Cateshy, $2: p 7$. 33.

Ampris bijuga of schoepf is listed by him as a name only and not identified; his record of $A$. sulcalica has not been substantiated.

The Glycosmis pentaphylla recorded by Dolley, is Amyris elemifera L. according to the specimen collected by Brace.

\section{Family 7 . SURIANÀCEAE Lindl.}

\section{Bay Cedar Fatilix.}

The family consists only of the following genus.

1. SURIANA L. Sp. Pl. 284. 1753.

A branching shrub or small tree, with simple alternate entire leares, the perfect flowers in terminal clusters or solitary. Calyx of 5 persistent sepals. Corolla of 5 imbricated petals. Stamens 10; filaments nearly distinct, those opposite the petals shorter than the others. Disk adnate to the base of the calyx, or obsolete. Carpels 5, distinct; orules 2, collateral, ascending; striles 5, lateral, filifolm; stigmas capitate. Fruits achene-like. Embryo thick, horseshoe-shaped. [Named for Joseph Donat Surian, of Marseilles.] A monotypic genus.

1. Suriana marítima L. Sp. P1. 284. 1753.

Usially a shrub $2 \mathrm{~m}$. high or less, sometines a small tree up to $8 \mathrm{~m}$. high, the twigs densely leafy, and densely pubescent. Leaves linear-spatulate, 1-1 cm. long, 2-6 mm. wile, rather fleshy, sessile, densely pubescent, obtuse; flowers fer, in short clusters; sepals lanceolate to orate, $\dot{6}-10 \mathrm{~mm}$. long, acuminate; petals obovate, yellow, $7-9 \mathrm{~mm}$. long, crose near the apex; fruiting carpels $4-5 \mathrm{mnn}$. long, finely pubescent.

Maritime sands and rocks, throughout the archipelago from Abaco and Grent Pahana t" Sand Cay (Firand Turk), Inagua, the Anguilla Isles and Cay Sal:Lermuda : Florida : the West Indies: shores of the fulf of Mexico and Caribbean Sea; OId World tropiçal coasts. Bay CeDAr. Tassel Plast.

\section{Family S. SIMAROUBÀCEAE DC.}

\section{QLASSIA F.MILY.}

Trees and shrubs, the bark nsmally bitter and containing oil-sacs, with pinnate (rarely simple), mostly alternate leares and small, dioecious or polygamous, panieled racemose, or sometimes solitary, axillary flowers. Calyx of 3-T sepals. Corolla of as many petals, or wanting. Stamens as many or twice as many as the petals, ranely more numerous. Carpels $2-5$. distinet or mnited; styles distiuet, mited or none: noules mostly 1 or 2 in each eavity. Fruit varinus, usually 1 -seeder. About 30 genera, eomprising some 150 speeies, mostly tropieal, a few in the temperate zones. 
Frult drupaceous or baccate; petals usually present.

Leares 5-9-foliolate; carpels 2-ovuled.

Leares 9-21-foliolate; carpels 1-ovuled.

Fruit samaroid; leares 19-51-foliolate; petals none.

1. Picramnia.

2. Simarouba.

: divaradoa.

1. PICRÁMNIA Sw. Fl. Ind. Oce. 1: 217. 1797.

Trees or shrubs, with alternate, unequally pinnate leares, and small dioecious flowers in narrow panicles. Sepals 3-5, slightly united at the base. Petals $3-5$, or sometimes wanting. Stamens $3-5$, in the pistillate flowers represented by small staminodia; filaments slender, unappendaged; anthers broad. Orary 2-3-celled, sessile; stigmas 2 or 3 , spreading; orules 2 in each cavity, pendulous. Fruit baceate, globose to oblong or oboroid, the pulp juicy. [Greek, bitter shrub.] Some thirty species, of tropical and subtropical America. Type species: Picramnia Antidesma Sw.

\section{Picramnia pentándra Sw. Fl. Ind. Occ. 1: 220. 1797.}

A shrub, or a small tree up to $10 \mathrm{~m}$. high, the young twigs and leares finely appressed-pubescent. Leaflets $5-9$, chartaccous, oblong to ovate or lanceolate, 3-12 cm. long, acute, acuminate, or obtuse at the apex, narrowed at the base, shining abore, becoming glabrous on both sides, the petiolules short; panicles slender, loosely branched, $7-15 \mathrm{~cm}$. long; sepals 5 , ovate, acute, about $2 \mathrm{~mm}$. long; petals linear-lanceolate, about as long as the sepals; stamens 5 ; berries globose to oblong or obovoid, red or scarlet, $9-15 \mathrm{~mm}$. long.

Coppices and scrub-lands, Abaco, Great Bahama, Andros, New Providence, Eleuthera, Cat Island, Watling's, Atwood Cay, Acklin's, Long Island, Mariguana and North Caicos:-Fiorida; Cuba to Trinidad. BITTER Bush. Sxake-Roor.

2. SIMAROÙBA Aubl. Pl. Guian. 2: 859. 1775.

Shrubs or trees, usually with bitter bark, the leaves alternate, pinnate, the leaflets entire, the small, terminal or axillary panicled flowers monoecious or dioecious. Sepals 4-6, partly united. Petals 4-6, much longer than the calyx. Stamens 8-12, often represented by dilated staminodia in the pistillate flowers; filaments subulate, appendaged at the base; anthers narrow. Ovary sessile, usually 5-celled; carpels distinct. Fruit drupaceous. [Guiana name.] About 5 species of tropical and subtropical America. Type species: Simarouba amara Aubl.

1. Simarouba glaùca DC. Ann. Mus. Paris 17: 424. 1811.

Quassia Simaruba W. Wright, Trans. Roy. Soc. Edin. 2: 73. 1790. Not L. f. 1781.

Simaruba amara Hayne, Arzneipfl. 9. p7. 15. 1825. Not Aubl. 1775.

Simaruba officinalis Macf. F1. Jam. 1: 198. 1837. Not DC. 1811.

Simarouba medicinalis Endl. Nedic. Pfl. 528. 1842.

Simaruba officinalis forma glabra Krug \& Urban, in Engl. Bot. Jahrb. 15: 305.1893.

A tree, up to $16 \mathrm{~m}$. high, or shrubbr, the rather stout nearly terete twigs glabrous, the bark red-brown. Leaves $2-4 \mathrm{dm}$. long, unequally pinnate; leaflets $7-21$, oblong or oblong-obovate, $5-11 \mathrm{~cm}$. long, rounded, retuse or abruptly pointed at the apex, cuneate at the base, glabrous, or with short spreading hairs beneath, bright green abore, pale and more or less glaucous beneath, the petiolules very short; panicle 1-4 dm. long, widely branched, the staminate flowers more numerous than the pistillate; flowers short-pedicelled; sepals ovate 
to triangular-ovate, ciliolate; petals oblong to ovate, 4-6 mm. long; drupe oral, 14-20 mm. long, searlet to dark-purple.

Coppices, Abaco, Grent Tảhama, Andros, and New Irovidence:-Florida; Cuba ; Hispaniola ; Jamaica ; Mexico to l'anama. P.iridise-rTeE.

3. ALVARADÒA Liebm. Kjob. Vidensk. Merldel. 1853: 100. 1854.

Shrubs or small trees, with alternate, unequally pinnate leares clustered near the ends of the slender branches, the leaflets small and numerous, the small dioecions flowers in narrow, spreading or drooping racemes. Sepals 5, short, slightly united at the base. Petals none. Stamens 5, exserted; filaments filiform, pubescent; anthers short. Orary sessile, 2-3-celled; orules 2 in each carity; styles 2 or 3, recurved; stigmas very small. Fruit a 2-3-minged samara. [Commemorates Petro de Alvarado, a Mexican explorer.] Five or six species, of Florida, the West Indies, Central and South America, the following typical.

1. Alvaradoa amorphoides Liebm. Kjob. Vidensk. Meddel. 1853: 100. 1554.

A shrub or small tree up to $10 \mathrm{~m}$. high, the twigs puberulent. Leares 1-2 dm. long, the rachis very slender and flexible; leaflets 19-51, thin, $0.5-2.5 \mathrm{~cm}$. long, the lower orbicular to oborate, the upper orate to oblong, all rounded or retuse at the apex, dark-green and glabrous above, finely appressed-pubescent beneath, the petiolules short; sepals ovate to orate-orbieular, $1.5-2 \mathrm{~mm}$. long, obtuse or acutish; samaras lanceolate or oblong-lanceolate, $1-1.5 \mathrm{~cm}$. long, narrowed to the apex.

Scrub-lands, coppices and pine-lands, Andros, New Providence, Great Exuma and Cat Island:-Florida; Cuba; Mexico. Alvarados.

\section{Family 9. BURSERÀCEAE Kunth.}

\section{Gumbo-Limbo Fanils.}

Shrubs or trees, mostly resiniferous or aromatic, with alternate, mostly pinnate, deciduons leaves, and small regular perfeet or polyoamo-dioecious flowers, nsually panieled. Sepals 3-5, somewhat united below. Petals as many as the sepals and alteruating with them. Stamens twice as many as the petals: filaments distinct, slort; anthers 2-celled. Orary superior, mostly 3-5-celled: orules normally 2 in each carity, pendulous; style usually very short; stigma broad. Fruit drupaceous. Seed-eoat membranous; endosperm none. Abont 20 genera and over 300 species, mostly of tropical distribution.

\section{ELÄPHRIUM Jacף. Enum。3. 1760.}

[Tereblituus P. Br. IIist. Jam. 345. 1756. Not Miller 1754.]

Leaves various, compound or simple. Inflorescence axillary. Flowers polygamo-dioecious. Calyx $4-5$-loberl, the lobes sprealing. Petals 4 or 5 , orate to oblong, much larger than the calyx-lobes, imbricated in the loud, inserted at the base of the disk. Stamens $S$ or 10 , distinct, inserted with the petals. Disk an entire ring. Orary sessile, 3-cellecl. Fruit a globose or 3-angled drupe, the 
epicarp splitting into 2 or 3 coriaceous ralves, the bony stone enclosed in fleshy pulp. [Grcek, light, the wood is light in weight.] Abont 80 species, of tropical and subtropical America. Trpe species: Elaphrium tomentosum Jacq.

I.eaflets narrow, oblong to oblanceolate: angies of seed 4 , keeled. Leaflets broad, oval to obovate, acute; angels of seed $1-3$, acute.

1. Li inagurnse. $\because$ L. Simaruba.

\section{Elaphrium inaguénse (Britton) Rose, N. A Fl. 25: 245. 1911.}

Bursera inaguensis Britton, Bull. X. Y. Bot. Gard. 3: 443. 1905.

Terebinthus inaguensis Britton, Bull. Torr. Club 35: 342. 1908.

A shrub or small tree, $3.3 \mathrm{~m}$. high or less, the twigs gray, the foliage glabrons. Petiole slender, terete, $2-5 \mathrm{~cm}$. long; leaflets $3-\bar{i}$, thin but firm, light green on both sides, not strongly veined, oblong to oblanceolate or obovate, acute or obtuse at the mucronate apex, narrowerl or cuneate at the base, $6 \mathrm{~cm}$. long or less, 1-2 cm. wike, the upper surface faintly shining, the under side dull; lateral leaflets sessile or with petiolules 1-2 mm. long, the terminal one with a petiolule $3-5 \mathrm{~mm}$. long; panicles several, axillary, as long as the leaves or shorter, the slender peduncles 1-6 $\mathrm{cm}$. long; pedicels 2-3 $\mathrm{mm}$. long; calyxlobes broadly triangular, acute; petals oblong-lanceolate, acute, $2.5 \mathrm{~mm}$. long; fruit 6-s $\mathrm{mm}$. long, only one cavity seed-bearing; seed $1-6 \mathrm{~mm}$. long, acute, short-stipitate.

Scrub-lands, Eleuthera, Great Guana Cay, Great Exuma, Long Island, Ambergris Cay. Inagua and Little Inagua:- northern Cuban Cays. Referred by Hitchcock to Bursere angustata C. Wright. IBAHAנA ELAPHular.

2. Elaphrium Simarùba (L.) Rose, N. A. Fl. 25: 246. 1911.

Pistacia Simamba L. Sp. Pl. 1026. 1753.

Bursera gummifera L. Sp. Pl. ed. 2, 471. 1762.

Bursera gummifera glabrata Griseb. F1. Br. W. I. 173. 1859.

Bursera gummifera pubescens Engler, in DC. Mon. Phan. 4: 40. 1853.

Bursera Simaruba Sarg. Gard. \& For. 3: 260. 1590.

Terebinthus Simaruba iT. F. Wight; Rose, Contr. U. S. Nat. Herb. 10: 122. 1906.

A tree, reaching a maximum height of about $20 \mathrm{~m}$. with a trunk up to $1 \mathrm{~m}$. in diameter, usually much smaller, the branches spreading, the thick red-bromn, smooth and shining bark peeling off in thin lavers. Leares glabrous or sometimes pubescent, petioled, 1-2 dm. long; leaflets $3-7$, orate to oborate, firm in texture, $3-8 \mathrm{~cm}$. long, acute or acuminate: racemes glabrous or pubeseent, $5-10$ cm. long; pedicels 4-8 mm. long; calyx-lobes about $1 \mathrm{~mm}$. long; petals greenish, 2-2.5 $\mathrm{mm}$. long, ovate to oblong-lanceolate; drupes oblong, 3-angled, 5-10 mm. long, splitting into 3 ralves; seed white.

Coppices, throughout the archipelago from Abaco and Great Bahama to Turk's Islands. Anguilla Isles and Cay Sal:-Florida: West Indies: Mexico and tropical continental America. Guabo-limbo, West Ixdia Birch, Guar-elemi. Catesby, 1: pl. 30 .

Hedwigia balsamifera Sw., reported by Dolles, has not been found in the Bahamas by any of our collectors; the record is probably erroneous.

\section{Family 10. MELIÀCEAE Vent.}

\section{MAHOGANY FAIILL.}

Shrubs, trees, or sometimes shrubby herbs. Leares alternate, without stipules, pimately compound, sometimes thrice pimnate. Inflorescence 
panienlate. Flowers perfeet or polygamo-dioecious, regular. Calyx of $3-5$, distinet or partly united ralrate sepals. Coulla of 3-5 distinct or somewhat united petals which are sometimes adnate to the stamen-tube. Stamens S-10, or rarely fewer or more. inserted at the base of the disk: filanents united into a tube; anther's sessile or stalked. Carpels 3-5, united; ovary 3-j-celled, free; styles united. Orules 2-many in eacli carity, anatropous. Fruit a berry, eapsule or drupe. Seeds sonietimes winged; endosperm wanting or fleshy; embryo with leafy cotyledons. About 50 genera, including some 700 species, mostly tropical.

Leaflets membranous, serrate to incised: fruit a drupe; seeds wing-

less.
Leaflets chartaceous, entire; fruit a moody capsnle; seeds winged.

1. MÈLIA L. Sp. Pl. 35t. 1753.

Trees, with alternate, pinuate or pinnately compound leares, the leaflets stalked and serrate, the showy white to puple flowers numerous, in large axillary panicles. Calyx 5-6-parted, the lobes imbricated. Petals as many as the calyx-lobes, narrowly spatulate, spreading. Stamen-tube nearly crlindrie, dilaterl and cleft above, bearing 10 or 12 erect anthers. Disk annular. Orary $3-6$-celled; orules 2 in each carity; style slender; stigma $2-6$-lobed or eapitate. Fruit a small drupe, its stone 1-5̃-celled, with 1 seed in each eell. [A Greek name of the Ash.] About 25 Asiatic species, the following trpical.

1. Melia Azédarach L. Sp. Pl. 38t. 1753.

Melia sempervirens Sw. Prodr. 67. 17ss.

A tree, sometimes $20 \mathrm{~m}$. high, with a trunk up to $2 \mathrm{~m}$. in diameter, usually much smaller, the bark furrowed, the branches spreading. Leaves bipiunate. petioled, glabrous, or nearly so, 2-t dm. long, lecidnous; leaflets numerous, ovate to elliptic, thin, acuminate at the apex, romded or narrowel at the base, 3-7 cm. long, sharply serrate and sometimes lobed; panicles perluncled 2-3 dm. long; pedicels slender, $1-10 \mathrm{~mm}$. long; sepals acute, about 2 mm. long; petals purplish, oblong, obtuse, about $10 \mathrm{~mm}$. long; drupes yellow, globose, smooth, $1.5-2 \mathrm{~cm}$, in diameter.

Tiaste and scrub-lands, spontaneous after cultiration, Fleuthera, Cat Island and Inagud:- southeastern Inited states: Bermula : West Indies: Merico and uropical America generaily; native of southeisten Asia. I'RIDE-of-IAnis.

\section{SWIETÈNIA Jacq. Enum. 4, 20. 1760.}

Large evergreen trees, with hard reddish brown wood, and pinnate leaves with opposite acuminate leaflets, the small flowers in terminal and axillary panieles. Calyx 5-eleft, its lohes imbricated. Petals 5, sprealing. Filaments united into an urn-shaperl, 10-toothed tube: anthers 10 . Disk amular. Orary ovoid, 5-celled; stigma discoid, 5-rayed; orules many, pendulous on the axis. Capsule large, woody, 5-cellel, septicidally 5-ralvel. Seels many, imbri atel iu 2 series. [Yamed for Gerard von Swieten, 1700-177..] Three known speeies, two of tropical anil subtropical America, one African, the following typical.

\section{Swietenia Mahàgoni Jacq. Enum. 20. 1760.}

A large tree, sometimes $2.5 \mathrm{~m}$. high with a trunk $4 \mathrm{~m}$. in diameter, huttressed at the base, the redulish bark sealy, the branches sprealling, the angular twigs 
smooth. Leaves evenly pinnate, 1-2 $\mathrm{dm}$. long, the slencler petiole enlarged at the base; leaflets $4-8$, coriaceous, ovate or ovate-lanceolate, inequilateral, $3-8 \mathrm{~cm}$. long, dark-green, glabrous and shining above, paler green and glabrous or sparingly pubescent bencath; panicles axillary, $6-15 \mathrm{~cm}$. long; calyx-lobes rounded; petals white, spreading, about 4 mm. long; stamen-tube glabrous; ovary ovoid; style erect; stigma 5-rayed; capsule oroid, woody, 6-12 cm. long, splitting from the base into 5 thick valves, the 5 -winged axis persistent; seeds about $18 \mathrm{~mm}$. long, the wing obtuse.

Coppices and scrub-lands, Abaco, Great Bahama, Lignum Vitae Cay, Andros, New Providence, Great Guana Cay, Exuma. Long Island, Eleuthera to Watling's, Acklin's, Crooked Island, Mariguana, the Caicos and Inagua:-Florida; West Indies; Mexico to Peru. Mahogaxis. Madeira. Catesby, $2: p l .81$.

Cedrela odorata L., reconded by Dolley from the Bahamas, is unknown by us from any island or cay in the archipelago. It may have been planted.

\section{Family 11. POLYGALÀCEAE Rehb.}

\section{MILKWORT FAנILY.}

Herbs, rarely shrubs or small trees in tropical regions. Stipules none. Pedicels generally 2-bracted at the base. Flowers perfect, irregular. Sepals 5, the two lateral inner ones (wings) large, colored, the others smaller. Petals 3 (or 5), hypogynous, more or less united into a tube, the lower one often erested. Stamens generally 8 , united in 1 or 2 sets. Ovary 2-celled; style simple; stigma curved, dilated or lobed; ovules 1 in each cavity, anatropous. Friit mainly capsular. Seeds generally caruncled; embryo straight. About 10 genera and 1000 species, widely distributed.

Wings much larger than the other sepals and petaloid; lateral petals partially adnate to the androecium; the Bahama species herbs. 1 . Polygala. Wings somewhat larger than the other sepals, not petaloid; lateral petals coherent to the androecium at the base; shrubs or trees. 2. Badiera.

\section{POLYGALA L. Sp. Pl. 701. 1753.}

Herbs or shrubs. Flowers racemose, spicate or capitate, rarely solitary and axillary, sometimes also cleistogamous and subterranean. Sepals rery unequal. the two lateral ones (wings) large and petaloid. Petals 3 , united into a tube which is split on the back, and more or less adnate to the stamens. Stamens 8 or 6, monadelphous below, or diadelphous; capsule membranous, compressed, dehiscent along the margin. Seeds 1 in each cavity, generally hairy. [Greek, much milk.] A genus of about 450 species, of wide distribution. Type species: Polygala vulgaris L. The following descriptions were contributed by Dr. J. K. Small.

The two lower sepals wholly or partly united.

Sepals with marginal stipitate glands.

Sepals glandless.

Sepals distinct.

Racemes sessile or nearly so, permanently short; sepals with marginal glands; bracts persistent.

Racemes long-peduncled, elongate or elongating; sepals without marginal glands; bracts deciduous.

Racemes slender. interrupted in anthesis; stems slender, wiry; capsules suborbicular; seeds oblong-ovoid.

Racemes stout, not interrupted : stems stout, fleshy; capsules oblong-obovoid; seeds broadly clarate.

1. P. bahamensis.

2. P. Krugii.

3. P. spathulata.

4. P. Wightiana.

5. P. Wilsoni. 


\section{Polygala bahaménsis Blake, Contr. Gray Ilerb. IГ. 47: 64. 1916.}

Plant annual with slender roots. Stems erect, 1-1 dm. tall, branched abore, and sometimes branched from near the base, the branches glabrous or nearly so; leares glabrous at maturity, the blades various, those of the lower leaves narrowly oborate to oblong-obovate, those of the upper leaves oblong to linear, $1.5-3.5 \mathrm{~cm}$. long, longer than the lower ones, obtuse or acute, all short-petiolen, the midrib prominent beneath; racemes loosely flowered; sepals about $1 . \overline{0}-2$ mm. long, the upper one orate, eiliate, and with gland-tipped hairs; wings $3-1$ $\mathrm{mm}$. long, the blades orbicular-flabellate, several-veined, short-clawed, greenish and purple-tinged; keel about $3 \mathrm{~mm}$. long or rarely larger; petals $2.5-3 \mathrm{~mm}$. long, the blades orbicular-obovate; capsules oval or oval-orbieular, $3-3.5 \mathrm{~mm}$. long, glabrous; seed-body with spreading or reflexed-spreading hairs.

Pine-land, borders of marshes, and roadsides, Great Bahama, New Providence, Andros. Lndemic, lieferred by Mr's. Nortlrop to $P$. brizoides st. Hil., and by Small (Fl. Mlami 102) to $P$. corallicola Small, of Florida. Perhaps not distinct from the next following species.

\section{Polygala Krùgii Chodat, Mem. Soc. Phys. Hist. Nat. Geneve 31²: 63. 1893}

Plant annual with slender root. Stems erect, 3-6 dm. tall, sparingly branched, especially above, the branches glabrous; leaves glabrous, the blades various, those of the lower leaves oblong-oborate to narrowly oblong, those of the upper ones narrowly oblong, oblong-elliptic to almost linear, or rarely somewhat broadened upward, $1.5-3.5 \mathrm{~cm}$. long, longer than the lower ones, all obtuse or acutish, short-petioled, the midrib and lateral reins prominent beneath when dry; racemes very loosely flowered; sepals about $1.5 \mathrm{~mm}$. long, the upper one orate, ciliate especially near the apex and glandless; wings 3.5-4 mm. long, the blades depressed-orbieular, rounded, few-reined, purple-tinged, shortclawed; keel $4.5-5 \mathrm{~mm}$. long; petals about $3 \mathrm{~mm}$. long, the blades flabellate; capsules oval or nearly so, about $3.5 \mathrm{~mm}$. long, glabrous; seed-body about 1.5 mm. long, with spreading hairs.

Scrub-lands, pine-lands, and savannas, Great Bahama, New Providence, Andros. Endemic. KRUG's Polygala.

\section{Polygala spathulàta Griseb. Cat. Pl. Cub. 13. 1866.}

Plant perennial or sometimes annual, deep-green, glabrous. Stems slender, usually several or many from a woody base, spreading, 0.3-2.8 $\mathrm{dm}$. long; leaves numerous, whorled in 4's, the blades euneate to oborate or somewhat spatulate, sometimes nearly as ride as long, $7-9 \mathrm{~mm}$. long or rarely longer, abruptly pointed, entire or obscurely toothed, obscurely punctate, glabrous, sessile or nearly so; racemes few-flowered, rather slender, permanently short, the bracts persistent, ovate, about $0.5 \mathrm{~mm}$. long; pedieels about as long as the bracts, deciduous; flowers spreading; sepals bright-green, the upper one ovate or ovalorate, the lower ones ovate, glandular-eiliate, ali about $1 \mathrm{~mm}$. long; wings fully $2.5 \mathrm{~mm}$. long, the blade oborate or oblong-obovate, acute or acutish, whitish with green veins, short-elawed: corolla about $2 \mathrm{~mm}$. long, the petals broad, united to above the middle, often erose: eapsules oblong, fully $2 \mathrm{~mm}$. long, nearly as long as the wings or shorter; seeds narrowly oblong-oroid, less than $2 \mathrm{~mm}$. long, with spreading or reflexed hairs, the aril-lobes much more than $\frac{7}{2}$ as long as the seed-body.

Rocks, plne-lands, palm-lands, and borders of copplces, Great Rahama, New Prorl. dence, Andros, Great Exuma :-Cuba. SPATULATE-LEAVD Polrgala.

\section{Polygala Wightiàna Blake, Contr. Gray Herb. II. 47: S7. 1916.}

Plant annual, not fleshy, slender, glabrons, dark-green. Stens solitary or sereral together arising from a slender root, simple above or sparingly brancherl, the branches very slender; leaves few, whorled at the principal noles, ocea- 
sionally opposite or alternate, the blades oblanceolate to spathulate, acute, or those of the upper leares linear or nearly so, 1-1.j cm. long, longer than those of the lower leares, acute; racemes slender, spike-like, elongate in age, acute at the apex, the bracts caducous, and the pedicels deciduous at maturity; pedicels about $0.5 \mathrm{~mm}$. long; flowers spreading or ascending; sepals pale-green and scarious-margined, the upper one broadly ovate, the lower ones narrowly ovate, all $1 \mathrm{~mm}$. long or less; wings about $1.5 \mathrm{~mm}$. long, the blade oral, shortclawed, the center greenish, the margins whitish; corolla about $1.5 \mathrm{~mm}$. long, the petals very broad, united at the base, obtuse; capsules suborbicular, 1.5-2 mm. long, as long as the wings or slightly longer; seeds oblong-ovoid, about 1.5 $\mathrm{mm}$. long, covered with short spreading hairs, the caruncle less than $\frac{1}{2}$ the length of the body.

Swampy grounds, marly shores, and limestone rocks, New Providence, Andros, Acklin's Island, Crooked Island and Mariguana. Endemic. WiguT's I'olrgald.

\section{Polygala Wilsoni Small, sp. nov.}

Plant annual, fleshy, stout, glabrous, bright-green. Stems usually several or many together arising from the top of the stout root, simple or occasionally branched, usually near the base or near the inflorescence; leaves numerous, whorled on the lower part of the stem, alternate above, the blades of the lower leaves cuneate or obovate, obtuse, mucronate or apiculate, those of the upper leaves spatulate, oblong or linear, mostly 1-2 cm. long, longer than those of the lorrer leares, minutely spine-tipped; racemes stout, greatly elongate in age, acute at the apex, the brasts fugacious and the mature pedicels deciduous from the rachis; pedicels about $1 \mathrm{~mm}$. long; flowers not drooping; sepals bright green, the upper one ovate, the lower ones lanceolate, all less than $2 \mathrm{~mm}$. long; wings about $3 \mathrm{~mm}$. long, the blade oval or obovate, short-clatred, the center greenish-yellow, the margins white; corolla about $2.5 \mathrm{~mm}$. long, the petals very broad, united to near the apex, rounded; capsules oblong-ovoid, $4-5 \mathrm{~mm}$. long, much surpassing the wings; seeds broadly clavate, about $3 \mathrm{~mm}$. long, covered with spreading hairs, the caruncle less than one half the length of the body.

Type collected on the Anguilla Isles, Salt Key Bank, Bahamas, May, 1909, Wilson 8030. Related to Polygala praeterisa Chodat; differing in the very fleshy foliage, the relativelr larger parts throughout, the narrowel upper sepal, and the capsule, which is long-exserted beyond the wings. WILSON's I'OLYGALA.

\section{BADIERA DC. Prodr. 1: 334. 1824.}

Evergreen shrubs or trees, with alternate entire subcoriaceous leares, and small or minute greenish or white flowers in short axillary racemes. Sepals distinct, nealy equal, the two inner (wings) somewhat larger than the others, but not petal-like. Petals 3, the upper ones about twice as long as the wings, adnate to the stamen-tube at the base. Stamens 8, the filaments united into a tube. Orary 2-celled, often pubescent. Capsule 2-celled, but one of the cells often abortive, coriaceous, margined, compressed. Seeds pubescent or nearly glabrous. [Dedicated to Badier, an early French botanical eollector.] About 10 species, of the West Indies. Type species: Polygala diversifolia L.

1. Badiera oblongàta Britton, Bull. N. Y. Bot. Gard. 5: 314. 1907.

Polygala oblongata Blake, Contr. Gray Herb. II. 47: 13. 1916.

A shrub, $1.5 \mathrm{~m}$. high, or less, with long slender appressed-puberulent branches. Leaves coriaceous, dull, $1.7-3 \mathrm{~cm}$. long, 0.8-1.8 cm. wide, oblong or obovate-oblong, somewhat revolute-margined in drying, the midvein rather prominent, the lateral veins fer and inconspicuous, sparingly pubescent with 
short appressed hairs on both sides when young, becoming glabrous or nearly so when old, rather bright-green above, pale-green beneath, acute at the base, obtuse or emarginate at the apex, the pubescent petioles about $2 \mathrm{~mm}$. long; flowers clustered in the axils, pubcrulent, on pedicels $2 \mathrm{~mm}$. long or less: exterior sepals about $0.7 \mathrm{~mm}$. long, suborbicular, green; corolla white, about 2.5 mm. long; carina unguiculate, obtuse; capsule nearly triangular, shallowly emarginate, about $8 \mathrm{~mm}$. long and wide, subacute at the base.

Scrub-lands and coppices, Andros, New Providence: Cat Island: Acklin's Island; Crooked Island; Watling's Island; North Caicos; Providenciales:-Cuba. Recorded by Dolley as Budiera domingensis Jacq. OBLoNG-Leaved Badiera.

\section{Family 12. EUPHORBIȦCEAE J. St. Hil.}

\section{Spurge Fadilly.}

Monoecious or dioecious herbs, shrubs or trees, with acrid often milky sap. Leaves opposite, alternate or verticillate. Flowers sometimes much reduced and subtended by an involucre which resembles a calyx (Euphorbice), the number of parts in the floral whorls often differing in the staminate and pistillate flowers. Orary usually 3-celled; ovules 1 or 2 in each carity, pendulous; stỵles mostly 3 , simple, divided, or many-cleft. Fruit mostly a 3-lobed capsule. separating, often elastically, into 3, 2-ralved carpels from a persistent axis. Seeds anatropous; embryo in fleshy or oily endosperm, the broad cotyledons almost filling the seed-coats. About 250 genera and over 4000 species, of wide distribution.

A. Orules 2 in each ovary-catvity ; plants not milky.

1. Fower's petaliferous.

2. Flowers apetalous.

a. Fruit capsular or baccate: styles slender.

* Staminate flowers with a rudimentary ovary; spins shrub or tree.

** staminate flowers withont a rudimentary ovary. Trees, shrubs or woody vines.

Leaves normal; branches not flattened into phyllodia.

Flowers in leafy-bracted panicles; fruit indehiscent, baccate.

Flowers axillary: fruit dehiscent.

Leares obsolete; branches flattened into phrllodia.

Annual or perennial herbs.

b. Fruit drupaceous: styles dilated.

B. Ovile 1 in each orary-cavity.

1. lowers not in an involucre, or involucre closed. (See Pera.)

a. Filaments inflexed at the top.

b. Filaments straight.

* rlowers in forked crmes.

I'etals coherent; tree or shrub with cordate loaves.

Petals distinct: slirubs or herbs.

** Flowers nut in forked cymes.

t Lobes of the staminate caly $x$ valvate. staminate flowers with petals.

Flowers of hoth kinds apetalous.

Stamens few or many, distinct or united. Flowers not in a closed incolucre. Antlier-sacs globose to oblong.

Shrubs or trees; anther-sacs (oblong.

I'ubescrice of simple halrs, 12. Alclia.

l'ubescrice stellate. 13. Ansiorroton. IIerbs: anther-sac's globose. Antlier-sacs elongated, often flexuous.

Flower's in a globose closed involucle whe'll young.

1. Saria.

2. Securincga.

3. Cicera.

4. Hargaritaria.

5. Tylophylla.

6. Phyllaithus.

7. Drypetes.

\section{S. Croton.}

ก. Curras.

1i). d denotopium.

11. Irgythamuia.

14. Mercurinlis.

15. Acatypha.

1i. Pera. 


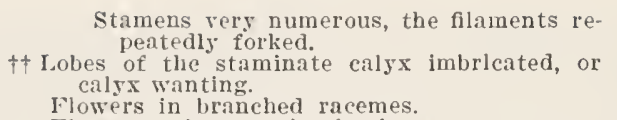

Nowers in branched racemes.

17. Ricinus.

18. Manihot.

Flowers spicate or in slmple racemes.

Bracts small; shrubs or trees.

Calyx of the staminate flowers cleft or lobed.

Filaments distinct.

Filaments connate.

Anthers 2; ovary 6-9-celled.

Anthers 3 ; ovary 3-celled.

Calys of the staminate flowers none or rudimentary.

Bracts large, membranous, at first enclosing the inflorescence; large tree.

2. Flowers in a calciform or cyathiform involucre.

Involuere calciform, the glands internal.

Inrolucre regular, the glands external.

Glands of the involucre inframarginal; shrubs or trees.

Glands of the involucre marginal.

Plants leafless or leares small and rudimentars.

Plants fleshy, cactus-like; bractlets foliaceous.

llants woody, jointed; bractlets not foliaceons.

Plants normally leafy; herbs, rarely shrubs or trees.

Inflorescence terminal.

Stem topped by an umbel; stipules none.

Stem not topped by an nubel; stipules gland-like.

Inflorescence axillary or axillary and terminal.

Leaves equilateral, ternate or verticillate; shrubs or trees.

Leares inequilateral, opposite; mostly herbs.

19. Bonania.

20. Hippomane.

21. Grimmeodendron.

22. Gymnanthes.

23. II ra.

24. Pedianthus.

25. Adenorima.

26. Euphorbia.

27. Arthrothamnus.

28. Tithymalus.

29. Poinsettia.

30. Alitema.

31. Chamacsyce.

1. SĀvIA Willd. Sp. Pl. 4: 771. 1806.

Trees or shrubs, with alternate stipulate leaves, the inflorescence racemose or short-cymose. Flowers petaliferous, dioecious or monoecious. Male flowers: sepals 5, subequal, imbricated; petals small; stamens 5, alternate with the petals; filaments separate above their insertion; anthers erect; rudimentary ovary slightly 3 -fid. Calyx of the female flowers as in the male. Capsule 3celled, the cocei 2-valved; seeds exarillate; endosperm fleshy; cotyledons plane. [Commemorates Gattano Sari, professor at Pisa, died 1844.] About 6 West Indian species. Type species: Croton sessiliflorum $\mathrm{Sw}$.

* 1. Savia bahaménsis Britton, Torreya 4: 104. 1904.

A shrub or tree up to $5 \mathrm{~m}$. high with ascending branches. Leaves oblongoborate, thick, obtuse and rounded at the apex, narrowed at the base, $7 \mathrm{~cm}$. long or less, $1.5-3 \mathrm{~cm}$. wide, dark green, shining and strongly reticulated above, pale green and inconspicuously reticulated beneath; petioles stout, about $4 \mathrm{~mm}$. long, about as long as the dense clusters of male flowers; fruit glabrous, depressed-globose, slightly and obtusely 3 -lobed, about $8 \mathrm{~mm}$. in diameter.

In thickets, from Abaco southward to Inagua :-Florida: Cuba; Jamaica. Recorded by Mr's. Northrop as S. erythroxyloidcs Griseb., of Cuba, which it resembles. IAIDEX-ITSH.

2. SECURINEGA Comm.; Gmel. Syst. 1008. 1791.

Shrubs, the leaves alternate, entire, often small, the flowers clustered or solitary in the axils, monoecious or dioecious, apetalous. Male flowers: 
sepals 5, imbricate; lobes of the disk, or glands, 5, alternate with the stamens; stamens 5 or rarely fewer, filaments free, opposite the sepals; anthers erect, their cells distinct, longitudinally dehiscent; rudimentary ovary more or less evident, slightly or markedly $2-3$-fid. Female calyx like the male, the disk subentire; ovary 3-celled; styles distinct, recurred, 2 -fid; orules 2 in each cell. [Greek, referring to the hard wood of the typical species.] About 8 species of tropical and subtropical distribution. Type species: Securinega durissima Gmel.

1. Securinega Acidòton (L.) Fawcett, Journ. Bot. 57: 68. 1919.

Adelia Acidoton L. Syst. ed. 10, 1298. 1759.

Securinega Acidothamnus Muell. Arg. in DC. Prodr. 15: 451. 1866.

Fluegria Acidothammus Griseb. Nachr. Gesell. Wiss. Goett. 1865: 164. 1865.

An intricately much-branched shrub $3 \mathrm{~m}$. high or less. Branches strongly flexuous, delicately and sharply spinous; stipules ovate-lanceolate, minute, caducous; leaves petiolate, broadly obovate, obtusely rotund, rigid, densely and prominently reticulate-reiny, pale beneath, $6-8 \mathrm{~mm}$. long, $2-6 \mathrm{~mm}$. broad; male flowers glomerate-fasciculate; female flowers solitary; styles connate below, bifid, the branches broadly 2-3-lobed; fruit at first fleshy, obtusely trigonal; seeds smooth, pallid.

Coppices and scrub-lands, Andros, New Providence, Cat Island, Great Exuma and Long Island:-Cuba to St. Jan and St. Croix; Jamaica. SEcumiNegA.

3. CICCA L. Mant. 1: 17, 124. 1767.

A tree with distichous entire leares and small monoecions flowers in leafybracted lateral panicles. Calyx 4-parted, the segments unequal, imbricated. Petals none. Male flowers with 4 distinct stamens, the anthers extrorse. Female flowers with a several-celled ovary, the styles 2 -cleft; ovules 2 in each cell. Fruit baccate, indehiscent. Seeds angular, pendulous. [Greek, wonderful tree.] A monotypic genus.

1. Cicca dísticha L. Mant. 1: 124. '1767.

Phyllanthus distichus Muell. Arg. in DC. Prodr. 15: 413.1866.

A tree, up to $12 \mathrm{~m}$. high. Leares ovate, pointed, $5-7.5 \mathrm{~cm}$. long. Flotrers panicled, the panicles many-flowered, lateral, arranged along aphyllous branches, the male and female mixed in the same fascicles; filaments alternating with exterior glands; ovary 4(3)-celled; fruit depressed-globose, angled, the angles as many as there are seels; sceds smooth.

Adventitious after cultiration at Fresh Creek, Andros:- Spontaneous after cultivation in Florida and the West Indies; native of southern Asia. OT.1lEiTE GoOSEBERRY. GOOSE Berki-TkER.

4. MARGARITÀRIA L. f. Suppl. $66,42 S$. 17SI.

Trees, shrubs or woody vines, with glabrons alternate entire leares, and small dioecious flowers, solitary or few together in the axils. Calyx usually 4-parted. Disk urceolate. Staminate flowers usually with 4 distinct stanens. Pistillate flowers with a 3-5-celled orary and 3-5 distinct styles; ovules 2 in each cavity. Fruit capsular, 3-5-lobed. [Greek, pearl-like.] Four known species, of tropical and subtropical America. Type species: Margaritaria nobilis L. f. 
1. Margaritaria bahaménsis (Urbau) Britton \& Millspaugh.

Phyllanthus bahamensis Urban, Symb. Ant. 3: 289. 1902.

A small tree about $7 \mathrm{~m}$. high. Leaves obovate-elliptic, oblong or lanceolate, 2.5-5 $\mathrm{cm}$. long, $8-25 \mathrm{~mm}$. broacl, obtuse or acute, shining above, pallid beneath; flowers produced from between the stipules on short, few-leared branchlets; outer sepals orate, inner orbicular, margin membranous; disk beyond the stamens plane, the margin free aud undulate-crenate; anthers orbicular-ovate; styles 3 , spreading, each 2 -lobed; fruit solitary, shortpedunclerl, depressed-globose, 3-lobed, about $8 \mathrm{~mm}$. Jroad.

Coppices. scrub-lands and pine-lands, Abaco, Andros, New Proridence and Eleuthera. Endemic. lieported by Coker as I'hyllunthus rivens Mnell. Arg. BAHAMA MARGARITARiA.

5. XYLOPHÝLLA L. Mant. 2: 147, 221. 1771.

Aphyllous tree-like shrubs, with flat leaf-like coriaceous branches (phyllodia). Male and female flowers mingled in glomerate or fasciculate clusters in the serratures of the phyllodia; calyx 5-6-parted; staminal colunu entire or divided, surrounded by as many glands as stamens; anthers transversely dehiscent; orules 2 in each ovary-cavity; styles 3, depressed, laciniate or 2 -cleft. Fruit capsular. Seedlings, and sometimes shoots from stumps, bear small normal leaves. [Greek, woody-leaf.] About 10 species of the West Indies and Brazil, the following typical.

1. Xylophylla Epiphyllánthus (L.) Britton; Small, Fl. Florida Keys 76. 1913.

Xylophylla latifolia L. loc. cit. 1771.

Phyllanthus falcatus Sw. Fl. Ind Oce. 1115. 1800.

A shrub, .75-2 m. high. Phyllodia subcompressed, scattered or distichous, lanceolate to rhomboid, serrate above, 5-13 cn. long, 0.8-2 cm. broad; sepals red; staminal column entire or trifid, anthers subsessile, spreading, the cells distinct, ovoid-globose; styles slender, recurved above, 2-4-fid; capsule sessile, subglobose, about $3 \mathrm{mmm}$. in diameter.

Rockr places near the coast, Andros and the Biminis southward to Grand Turk Island:- West lndies. Referred by Dolley to Phyllanthus angustifolius Sw. of Ja-

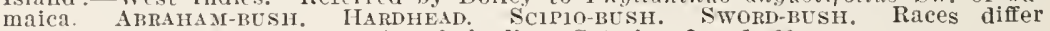
widely in size and shape of the phyllodia. Catesby, 2: $p l .26$.

\section{PHYLLÁNTHUS L. Sp. Pl. 981. 1753.}

Annual or biennial herbs. Leaves alternate, entire, often so arranged as to appear like the leaflets of a compound leaf. Flowers monoecious, apetalous, a staminate and a pistillate one often together in the axils. Calyx mostly 5-6parted, the lobes or sepals imbricated. Stamens usually 3 . Ovules 2 in each cavity; styles 3, each usually 2-cleft. [Greek, leaf-flower.] Over 50 species, of wide distribution. Type species: Phyllanthus Niruri L.

Stem and branches straight.

Seeds longer than broad, evenly ridged.

Seeds as broad as long, unevenly papillate-lined. Stem and branches zigzag.

1. P. Niruri.

2. P. pruinosus.

3. P. pentaphyllus.

\section{Phyllanthus Nirùri L. Sp. Pl. 981. 1753.}

Annual; herbaceous. Leaves distichous, 1.5-2 mm. long, subsessile, obovateoblong, rounded at the apex or mueronate, glabrous, pale beneath; stipules setaceous, persistent; pedicels axillary, from 1-6 times exceeded by the leaf; 
calyx-segments 5, ovate; anthers sessile on the top of the columin, globose, contiguous; styles short, included; capsule depressed-globose, $2 \mathrm{~mm}$. broad; seeds erenly striated on the back.

Sandy nlaces and cultivated grounds from Andros to Turks Islands:- Tiermula ; Florida: West Indies and continental tropical America; Old World tropics. GiLEOF-TISN.

2. Phyllanthus pruinòsus Poepp.; A. Rich. in Sagra, Hist. Cub. 11: 216. 1550.

Phyllanthus saxieola Small, Bull. N. Y. Bot. Gard. 3: 428. 1905.

Annual or perennial, glabrous; stem $0.5-4 \mathrm{dm}$. tall, simple or irregularly brauched. Leares relatively numerous, erect or nearly so, leathery, oblong, oblong-oborate or enneate, 4-12 nm. long, abtuse, entire, bright-green, shortpetioled; flowers very short-pedicelled; calyx of the female flowers less than $3 \mathrm{~mm}$. wide at maturity its lobes obovate; disk rather angular; eapsule spheroidal, barely $2 \mathrm{~mm}$. wide; seerls less than $1 \mathrm{~mm}$. long and nearly as wide, unevenly papillate-lined.

From Great Bahama southward to Acklin's Island:-Florida: Jamaica; Cuba.

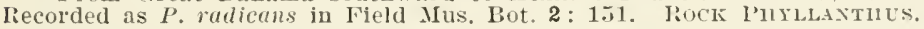

3. Phyllanthus pentaphýllus C. Wright; Griseb. Nachr. Ges. Wiss. Goett. 1865 : 167. 1865 .

Annual; stems terete, wiry, slender, nearly prostrate, divaricately branched, zig-zag. Leares oborate, $8-12 \mathrm{~mm}$. long, the base acute, the apex rounded or obtuse, the margin cntire and slightly revolute; petiole about $1 \mathrm{~mm}$. long; male flowers glomerate, the clusters about 8-12-florous, short-pedicelled; sepals orate, obtuse, white; anthers 2; female flowers solitary, pedicellate, the pedicels bisetaceous at the base; sepals not white-margined; styles very short, -lobed, recurved; capsule small, depressed, abont as long as the fruiting pedicel; seed minutely striate, the faint lines more scaly than papillate.

Low sandy meadows, Elenthera and Marjguana:-Florida; Cuba. TLFTED Phillaxtios.

\section{DRYPÈTES Vahl, Eclog. 3: 49. 1807.}

Shrubs or trees. Leaves coriaceous, glabrous; stipules deciduous; flomers axillary, faseiculate, dioecious. Calyx 4-6-partite, its lobes imbricated. Petals none. Stamens 4-6(8-2), distinct; anthers ovoid, introrse. Orary 2-1-celled its cells 2-oruled. Fruit drupaceous, usually monospermous by abortion. [Greek, a drupe.] About 10 species, of Florida, the West Indies and Brazil. Type species: Drypetes glauea Vahl.

Sepals 4, ovary 2-celled; fruit $6-11 \mathrm{~mm}$. in diameter.

Sepals s, ovar 1-celled; fruit about $2 \mathrm{~cm}$. in diameter.

Jeaves ovite, mostly blunt.

Leaves lanceolate, aristo-mucronate.

1. D. luterifora.

2. D. dirersifolia.

3. I). mucronata.

1. Drypetes lateriflòra (Sஈ.) Krug \& Urban, Bot. Jahrb. 15: 35̄. 1892.

Schaefferia lateriflora Sw. Prodr. 35. 1788.

Shrub, or sometimes a tree $9.5 \mathrm{~m}$. high. Leaves petiolate. oblong or elliptic, 5-11.5 cm. long, acute or short-acuminate at base and apex, entire, shining, delicately retieulate-veined beneath; flowers in dence axillary clusters; pericels shorter than the petioles; calyx campanulate; sepals oblong to orate, obtuse, pubescent without; stamens 4 ; drupe subglobose, $6-11 \mathrm{~mm}$. in diameter, dark brown, tomentulose.

Coppices, Great IIarbor Cay, Audros, Now Providence, Ilog Island, and Cay north of Wide Opening:- Florida; Cuba; Il ispaniola; Jamaica. Geraxa I'Lu. 
2. Drypetes diversifòlia Krug \& Urban, Bot. Jahrb. 15: 353. 1892.

Drypetes keyensis Krug \& Urban, loc. cit. 354. 1892.

Tree up to $6 \mathrm{~m}$. high; branches terete, grayish, secreting drops of resin in the axils. Leaves of two forms: the lower long-petioled, margin spinosedentate and spinons-acuminate, base rounled; the upper longer-petioled, margin entire, obtuse or subacuminate, the base rounded or ohtuse and slightly protracted down the petiole; all ovate, $7-9 \mathrm{~cm}$. long, 3.2-3.8 cm. broar. Inflorescence few-flowered, the pistillate flowers sometimes solitary; calyx yellowich; sepals oblong or cral, sometimes slightly rhomboid, ohtuse, pubescent without; stamens $S$; stigmas slightly oblique; drupe broadly oblong or oroid, $1.9-2.5 \mathrm{~cm}$. long, tomentulose.

Coppices, Great Bahama, through the larger Berry Islands to Andros and Cay Sal Bank: New Providence; Little San Salvador to Watling's Island; Great Exuma through the Crooked Island Group to Inagua :-Florida Keys. Wirtewood.

3. Drypetes mucronàta C. Wright; Griseh. Nachr. Ges. Wiss. Goett. 1865: 165. 1865.

Shrub 4-5 m. high; branches terete, lenticillate. Leaves petioled, bicolorate, $3.8-7 \mathrm{~cm}$. long, $2.5-3.2 \mathrm{~cm}$. wide, both surfaces strongly reticulatereined, the base obtuse or slightly decurrent on the petiole, rarely slightly inequilateral, the apex mucro-spinescent; female flowers subsolitary; male glomerate or fasciculate; calyx of both sexes about $2 \mathrm{~mm}$. long, pubescent within; stamens longer than the calyx; filaments and anthers pubescent; orary reddish-hairy; fruit globose, about $2 \mathrm{~cm}$. long, obscurely golden-tomentose.

Rocky coppices of Great Bahama and Andros:-Cuba. Sharp-Leaved Drypetes.

\section{CRÒTON L. Sp. Pl. 1004. 1753.}

Herbs, shrubs or trees, strang-scented, often stellate-pubescent. Leaves mostly alternate, sometimes with two glands at the base of the blade. Flowers spicate or racemose. Staminate flowers uppermost: calyx 4-6-parted (usually 5 -parted); petals usually present but small or rudimentary, alternating with glands; stamens 5 or more. Pistillate flowers: calyx 5-10-parted; petals usually wanting; ovary mostly 3 -celled; ovule 1 in each cavity; styles once, twice or many times cleft. Fruit capsular. Seeds carunculate. [Greek name of the Castor-oil plant.] Over 600 species, widely distributed. Type species: Croton Tiglium L.

A. Leaves entire or dentate; shrubs.

Leaves discolor.

Leaves narrowly linear. not nver $2 \mathrm{~cm}$. long.

Jeaves linear to oblong, 3.5-12 cm. long.

Leaves ovate-lanceolate.

Leaves stellate beneath.

Leaves silvery lepidote.

Leaves unicolor.

Leares elliptic-lanceolate, glabrous.

Leaves narrowly lanceolate, stipitate-glandular.

B. Leaves deeply lobed; herbaceous.

1. C. rosmarinoides.

2. C. linearis.

3. C. focculosus.

4. C. Eluteria.

5. C. Tucidus.

6. C. bahamensis.

7. C. lobatus.

\section{Croton rosmarinoìdes Millsp.}

Croton rosmarinifolius Griseb. Nachr. Ges. Wiss, Goett. 1865: 174. 1865. Not Salisb. 1796.

A densely branching shrub $1.25-2 \mathrm{~m}$. high. Leaves subsessile, sublinear, rigid, 8-12 $\mathrm{mm}$. long, obtuse, the margin entire and strongly incurved, densely lepidote beneath; stipules obsolete; inflorescence terminal on rery short branch- 
lets. Female flowers: sepals spathulate-lanceolate, obtuse; ovary densely lepidote; styles 4-fid to the middle. Nale flowers: petals obovate; stamens 6; filaments villous below. Capsule ellipsoid-globose, densely lepidote; seeds smooth and shining.

Scrub-lands, Cat Island, Great Exuma, Long Island and Atwood Cay :-Cuba. Rosemary Crotos.

\section{Croton lineàris Jacq. Enum. 32. 1760.}

Croton Cascarilla L. Sp. Pl. ed. 2: 1424. 1763.*

Croton Cascarilla linearis Willd. Sp. Pl. 4: 532. 1805.

Croton Cascarilla Benn. Jour. Linn. Soc. 4: 30. As to specimeu and deser. 1560.

Croton Fergusonii Small, Fl. SE. U. S. 695. 1903.

A shrub 1-2 m. high, with yellowish, densely stellate twigs. Leaves shortpetiolate, narrowly linear (on young shoots often oblong) $3.8-7 \mathrm{~cm}$. long, $2-6$ mm. wide, obtuse, dark and smooth above, silvery or golden with stellate tomentum beneath, narrowing to the biglandular base. Inflorescence racemose, the male 4-S mm. or more long, the female shorter. Male flowers: sepals 5-6, triangular; petals spatulate, obtuse, ciliate, longer than the sepals; stamens about 15. Female flowers: sepals narrow, acuminate; petals obsolete or rudimentary. Capsule subglobose, yellowish-floceose; seeds broadly oblong, dark greenish brown, minutely and very shallowly puncticulate, $3 \mathrm{~mm}$. long, $2.8 \mathrm{~mm}$. broad.

Coastal rocks and plains throughout the archipelago to Caicos and Turks Islands:-Florida; Jamaica: IIspaniola. Referred to in Field Mus. Bot. 2: 152 and by Coker as $C$. discolor Willd. LINEAR-LEAVEd Crotos. BaL WORMTOOD. GRANNY-BUSH.

\section{Croton flocculòsus Geisl. Crot. Monog. 14. 1807.}

A low shrub with yellowish-tomentose branchlets. Leaves long-petioled, ovate or orate-lanceolate, $3.8-10 \mathrm{~cm}$. long, $2-3.5 \mathrm{~cm}$. wide, stellate-scabrous above, stellate-downy beneath, entire, acuminate, the base obtuse, biglandular; glands globose-scutelliform, sessile; inflorescence terminal, racemose, $3 . \overline{\mathrm{cm}}$. long; seeds ovoid-lenticular, dark grayish green, scattered shallow-poculate, $2 \mathrm{~nm}$. long, $1 \mathrm{~mm}$. broad.

Waste places near Nassau, New Prowidence:-Hispaniola; Guadeloupe: Martinique; Barbados. Referred by Dolley to $C$. flacens L., which it resembles. Rock BALSAM.

\section{Croton Elutèria (L.) Sw. Prodr. 100. $178 S$.}

Clutia Eluteria L. Sp. Pl. 1042 (ante). 1753.

Clutia Cascarilla L. loc. cit. (post). 1753.

Croton Cascarilla Benn. loc. cit. 30, as to references." 1860.

A silvery-shining shrub or small tree, 2-4 m. high, with a rich spicy odor; branchlets rusty-lepidote. Leaves ovate-lanceolate, entire or repand, bluntpointed, long-petioled, 3.2-7.6 cm. long, 12-16 mun. broad near the rounded base, dark and glabrous above, minutely silvery-lepidoce beneath, minutely pellucid-punctate; stipules early deciduous. Infloreseence in terminal racemes 3.7-5 cm. long. Female flowers: petals white, villous on the margin; styles bipartite, the branches 2-fid. Nale flowers: stamens 10-12. Seeds oval-oblong, biconvex, opaque, blotched, $8 \mathrm{~mm}$. long, $6 \mathrm{~mm}$. broad.

Coppices, becoming scarce, Great IIarbor Cay of the Rerry Group soutliward to Marlguana. Endemic. Cascarilla liark. Sweetwood Balk. Elettuera liark. Catesby, 2: $p l$. 40 .

* For a detalled consideration of Croton Cascarilla see Fleld Mus. Bot. 2 : 306-S. 
5. Croton lùcidus L. Syst. el. 10, 1275.1759.

Croton H Jalmarsonii Griseb. Fl. Br. W. I. 40. 1859.

Croton lucidus pubigerus Griseb. loc. eit. 1859.

A broal shrub 1.5-2 m. bigh; branchlets glabrous or glabreseent. Leaves elliptic to oblong-lanceolate, 5-15 $\mathrm{cm}$. long, 2-4 cm. wide, glabrous or pubescent, minutcly pellucid-punctate, entire, narrowing to a roundish base and apex; petiole about one-fourth the length of the blacle; stipules ephemeral. Inflorescence in terminal racemes. Male flowers: sepals orate, imbricative, much smaller than those of the female, ciliate on the margin; female flowers: calyxlobes oblong, blunt, margin reduplicate, somerhat persistent at the base; styles 4-partite, the branches bifid to near the base. Seeds oroid-oblong, shining, flattish on the ventrum, the dorsum convex.

Rocks thickets and openings, throughout the archipelago from Great Sturrup Cay south to Grand Turk Island:-Cuba; I'orto lico; Jamaica and the Caymans. Croton glabellum of Schoepf. FInE-BUSII.

An examination of the type, and many specimens, indicates that $C$. H jalmarsonii is but a race of this species which develops many interspersing races, differing in the size of the leaves and in pubescence, both in Jamaica and in the Bahamas.

\section{Croton bahaménsis Millsp. Field Mus. Bot. 2: 308. 1909.}

A shrub 1-2 $\mathrm{m}$. high with a peppery odor; branchlets white stellatetomentose. Leares lanceolate, $3-7 \mathrm{~cm}$. long, $7-17 \mathrm{~mm}$. broad, acuminate, mucronate, base slightly oblique and rounded, with 2 patellate glands, green above anil equidistantly stellate-pubescent, densely stellate-pubescent beneath, the margin subentire or crenate-dentate with stipitate glands in the sinuses; stipules fimbriate and stipitate-glandular. Inflorescence in dense terminal racemes. Female flowers: calyx-segments oblong, stellate-pilose; styles 4-fid to the base and rillous with moniliform hairs. Male flowers: calyx nonglanduliferous; petals white, cymbiform, the apex minutely fimbriate; stamens 35-50. Capsule globose, deeply suleate, glabrous below but long-pilose in the sulci and at the apex; seeds brownish black, the rugae rib-like.

Open pastures and in thickets bordering openings, Eleuthera and Long Island to Mariguana. Endemic. Referred to in Field Ius. Bot. 2: 153, and by Hitchcock as $C$. humilis L.; by Grisebach and by Dolley as $C$. humilis origanifolius. Bandus CROTON. PEPPER-BT'SH.

\section{Croton lobàtus L. Sp. Pl. 1005. 1753.}

A low herb, 3-6 dm. high, the branches and branchlets pilose, the longer hairs simple. Leaves membranous, 3-5-lobed, glabrous, papillate, the segments elliptic to elliptic-lanceolate, acuminate, serrate; petioles nearly as long as the blades. Female flowers: calyx-lobes spathulate-lanceolate, glanduliferous and with a few long acicular hairs; styles free or nearly so, 3-8-fid at the apex. Male flowers: sepals glabrous; petals lanceolate. Capsule globose-ellipsoid, the cocci with a number of scattered acicular hairs; seeds ochre-color, quadrangularcylindrie, $5 \mathrm{~mm}$. long, $3 \mathrm{~mm}$. broad, the dorsum apiculate at the caruncle, all the facets marked by incomplete and more or less transverse ridges.

Adrentitious in waste places, New Proridence, near Nassau :-West Indies; continental tropical America. LORED CRoTos. neous.

Schoepf's record of Croton argenteum L., as Rahamiau, is, presumabls, erro-

\section{CÚRCAS Adans. Fam. Pl. 2: 356. 1763.}

Glabrous or nearly glabrous trees or shrubs with petioled, lobed or entire leares, and monoecious flowers in compound or simple cymes. Calyx 5-lobed or 5-parted. Corolla gamopetalous, the petals united to or above the middle. Stamens about 10, in 2 series. Orary 2-3-celled; orules 1 in each cavity. Fruit a capsule, splitting into 2 or 3 valres. [Malabar name.] Perhaps 10 species, natives of tropical regions, the following typical. 
1. Curcas Cúrcas (L.) Britton of Millspaugh.

Jatrophe Curcas L. Sp. Pl. 1006. 1753.

Curcas indica. A. Rieh. in Sagra, Hist. Cub. 11: 208. 1n50.

A small tree or sometimes shrubby, 2-5 m. high. Leares subcordate, roundish, angular or obsoletely 3-5-lobed, glabrous or glabrate, the petiole about as long as the blade; stipules deciduous; inflorescence in contracted cymes; ealyx 5-partite; corolla vellow, 5-partite, villous within, twice as long as the calyx; stamens 10-15; styles bifid, cohering below; capsule oval, slightly fleshy, 3-t em. long; seeds oblong, nearly $2 \mathrm{~cm}$. long.

Waste grounds, New Providence:-Bermuda; West Indies; continental tropical America ; old World tropics.

\section{ADENOROPIUM Pohl, Pl. Bras. 1: 12. 1527.}

Monoecious or rarely dioecions perennial herbs, or shrubs, with entire lobed or divided leaves, the flowers in eymes. Staminate flowers on the upper parts of the cymes, with a corolla-like 5-lobed calyx, 5 distinet petals, the stamens usually several or numerous. Pistillate flowers in the lower forks of the cymes; capsule oroid or subglobose, easily separating into 2-valved carpels. [Greek, glandular bush.] Eighty species or more of tropical and subtropical distribution. Type speeies: Adenoropium ellipticum Pohl.

\section{Adenoropium gossypifòlium (L.) Pohl, Pl. Bras. 1: 16. 1ธ27.}

Jatropha gossypifolia L. Sp. Pl. 1006. 1753.

Herbaceous; stem 6-10 $\mathrm{dm}$. high, branched. Leares ciliate or glanduliferous on the margin, 3-5-partite or 3-5-lobed, pubescent, glabreseent beneath or glabrous, the segments ovate, pointed, denticulate or entire; petiolar and stipular glands brancher; infloreseence in contracted cymes; calyx 5-parterl; corolla twice as long as the calyx; petals olovate, deep purple, spreading; stamens S-12; stigmas 2-branched; capsule truneate at both ends, 3-suleate, about $1 \mathrm{~cm}$. in diameter. America.

Waste grounds, New Providence:-Florida; West Indies; continental tropical

\section{ARGYTHÁMNIA Sw. Prodr. 39. 1iss.}

Low shrubs containing purple pigment. Leares simple, entire or dentate, stipulate. Infloreseence in few-flowered, axillary subsessile racemes; flowers short-pedicellate, the 1-3 inferior pistillate. Flowers monoceious. Calyx 4-5. parted, ralvate. Petals of staminate flowers 4 or 5 ; stamens 4 or 5 cohering at the very base and surrounding a central rudiment, anthers subglobose, introrse; discal glands 4 or 5. Styles cut into $3-8$ branches. Capsule 3-coccous. [Greek, silvery bush.] Some 35 species, all American. Type species: Argythamnia candicans $\mathrm{Sw}$.

Leaves lanceolate to oblanceolate or obovate.

l.eares entira, subsessilt, yullow-serlerous: styles $3-4$-firl.

Leaves denticulate, petiolate, silvery-sericrous; styles "̈-fid. Leaves orate to orato-janceolate.

1. Acricen.

2. 1. argenteu.

3. i. lneayana.

1. Argythamnia serícea Griseb. Fl. Br. Wr. I. 44. 1559.

A low leafy shrub entirely coveren with silky lown. Leaves ohnrate, mueronate, entire, subsessile, sericeous, $1.5-3$ cm. long, $10-17$ mm. broal, the 
principal reins 3 or 4 on each side, straightish, prominulous, parallel to the cuneate leaf-base; stipules lanceolate, setaceous, persistent, 1 em. long; infloreseence in contracted scorpioid racemes. Ilale flowers 3 or 4 , one above the other, 2-3-bracteolate, short-pedicellate, $2 \mathrm{~mm}$. long; calyx 5-parted, the segments lanceolate; petals reddish, lanceolate, cut at the obtuse apex; glands of the disk alternate with the petals; stamens 5, as long as and opposite the petals, the filaments slightly cohering at the base. Female flowers subsolitary, inferior, short-pedicellate; calyx as in the male; petals none; styles 3 -4-fid with linear, unequal branches. Capsule depressed, earpels subglobose; seeds punctate-scabrous, $1 \mathrm{~mm}$. in äiameter.

Open white-lands and dunes, Fortune Island and Inagua. Endemic. Silkr ARGXTHANIIA.

\section{Argythamnia argéntea Millsp. Field Mus. Bot. 2: 154. 1906.}

Argithamnia lanceolata Pax \& K. Hoffm. Pfanzenreich 147: 79. 1912.

A small shrub, branching from the base; branches canescent, densely leafy. Leares lanceolate, attenuate at both ends, short-petioled, $1.5-3.5 \times .6-1 \mathrm{~cm}$., margin sparingly and slightly dentate above, silvery-sericeous; stipules broad, cuspidate. Inflorescence in axillary racemes. Male flowers 3 ; sepals 4 , ovatelanceolate; petals 4, thick; sepals similar, shorter; bract 1 , scaphoid. Female flowers 3 ; sepals elongate-lanceolate; petals minute, ligulate, alternate with the glands of the disk; styles 3 , bifureate nearly to the base, the apex bilobed; orary canescent. Capsule and seeds unknown.

Scrub-lands, Inagua, Castle Island, Grand Turk and South Caicos:-Hispaniola. Silteri ATgithaMNiA.

\section{Argythamnia lucayàna Millsp. Field Mus. Bot. 2: 154. 1906.}

A small branching ascending or prostrate shrub, the branches minutely sericeous, sparsely leaved, $3-5 \mathrm{dm}$. long. Leaves sessile, elliptic- or obovatelanceolate, bluish green, $2.5-3.5 \times 1-1.5 \mathrm{~cm}$., the apex acute or short-acuminate, the margin entire or very minutely and remotely glandular-denticulate, sparsely and minutely strigose-pilose when young, glabrous when mature; racemes 6-10 $\mathrm{mm}$. long, 4-6-flowered. Male flowers: sepals deltoid-lanceolate equaling the spatulate, pilose petals; stamens 4 , glabrous. Female flowers: lobes lanceolate, acuminate; petals minute, narrowly-lanceolate, obtuse, paleaceous, many times shorter than the sepals; ovary villous; styles villous, 2-3-dichotomous, the terminal divisions short. Seeds globose, dark brown, apiculate, $1.5 \mathrm{~mm}$. diam., anastomose-reticulate, the surface coated with a hydnum-like porous integument.

Rocky and sandy coppices, Berry Islands and Andros to Eleuthera, Long Island, Caicos and Inagua. Baliama specimens previously referred to $A$. candicans $\mathrm{SW}$., to which the species is related, belong here. Endemic. Bamama Argithamina.

\section{ADĖLIA L. Syst. ed. 10, 1298.1759.}

[Bernardia P. Br. Hist. Jam. 361. Hyponym. 1756.]

Shrubs with serrate stipulate leares pubescent with simple hairs and dioe. cious flowers. Nale flowers in axillary amentaceous spikes, each flower sessile in the axil of a bract; calyx 3-5-parted; stamens 15-20, distinct, the interior central and mixed with some glands; anthers eruciate-globose, 4-celled, 2 cells anterior. Female flowers few or solitary, subterminal, 3-bracteate; calyx 5-6parted, biseriate; styles 3, short, lacerate-crenate. [Greek, referring to the inconspicuous flowers.] A few species of tropical America, the following trpical. 
1. Adelia Bernárdia L. Syst. ed. 10, 129S. 1759.

Bernardia carpinifolia Griseb. Fl. Br. W. I. 45. 1859.

Bervardia dichotoma M̈̈ll. Arg. Linnaea 34: 172. 1865.

Bernardia Bernardia Millsp. Fiel.1 Mus. Bot. 2: 5S. 1900.

A tomentose shrub .75-3 m. high. Leares petioled, orate-oblong, 4-S cm. long, rounded at the biglandular base, tapering from the middle to a bluntish point, obtusely serrate, tomentose beneath, primary veins distant, prominulous beneath; stipules setaceous, $2 \mathrm{~mm}$. long. Male spikes sessile, 6-12 $\mathrm{mm}$. long, tomentose; bracts oval, aeute; calyx-lobes $3-5$, orate, acute, nearly equalling the staniens: eentral disk minute; anthers yellow. Capsule densely appressedpubescent; seed ovate, acute, $5 \times 4 \mathrm{~mm}$., nearly smooth, brown with darker brown markings, the dorsum strongly keeled, rentral surface flattened, a small rounded prominence on each side of the hilum above and a minute dark raised point at the extremity of the keel.

Coppices and thickets, Elenthera, Cat Island, Watling's Island, Rum Car, Fortune and Acklin's Islands:-Cuba to Porto Rico: Jamaica. Referred by Hitchcock to Bernardia mexicana (H. \& A.) IIuell-Alg. ADELiA.

\section{LASIOCRÒTON Griseb. F1. Br. W. I. 46. 1859.}

Shrubs or trees, with broad stellate-tomentose leares. Inflorescence monoe. cions, in axillary spikes, the female flowers few and inferior. Male calyx 4-partite; stamens $7-14$, inserted upon a minute disk; anthers oblong, adnate, the cells curved, introrse. Ovary globose, markedly 3-carpellate. Seeds globose, ecarunculate. [Greek, relvety Croton.] A few West Indian species. Type species: Lasiocroton macrophyllus Griseb.

\section{Lasiocroton bahaménsis Pax \& K. Hoffm. Pflanzenreieh, 63: 61. 1914.}

Lasiocroton micranthus Pax \& K. Hoffm. loc. cit. 1914.

A high leafy tomentose shrub, or a tree up to about $S \mathrm{~m}$. high. Leaves long-petioled, roundish or ovate to ovate-lanceolate, $5 \times 2.3-10 \times 7 \mathrm{~cm}$., truneate to cordate at the base, bluntish, entire or repand on the thickish subrevolute margin, pale green above, golden-tomentose beneath; secondary veins transverse, strongly reticulate; petioles articulated at the estipulate base. Inflorescence densely many-spicate near and at the ends of the branchlets; spikes short-pedunculate; bracts including a glomerule of $3-5$ male flowers. Male flowers densely tomentose; ealyx valvate; sepals 3-angular; stamens distinct, included; filaments purple, as long as the anthers. Female flowers sparse, scattered near the base of the spike, densely pubescent; calyx-lobes 5, unequal, reflexed, ovate, blunt; disk large, flat, 5-crenate; styles $2-3$, thick, entire, spreading. Capsule tomentose; seeds smooth, ashen; raphe distinct, delicate.

Rocky plains, Andros, Eleuthera, Great Ragged Island:-Cuba. Referred by Mrs. Northrop to L. macrophyllus (Sw.) Griseb., of Jamaica. WrLd OAK. LigirtWOOD. BitTERS.

14. MERCURIÀLIS L. Sp. Pl. 1035. 1753.

Annual or perennial herbs or shrubs, the leares opposite, often dentate. Inflorescence mostly dioecious, the male in more or less elongate spikes or racemes. Flowers apetalous. Nale flowers: calyx membranous, sepals 3, ralvate; stamens $8-20$; filaments listinct; anthers subglobose, opening lengthwise. Female flowers: sepals 3; ovary 2-celled; styles 2, distinct or nearly so; stigmas entire. Capsule generally 2-earpelled; seeds solitary in each earpel; testa smooth or tubereulate. [The herb of Mercury.] About 7 species, natives of the Old World, the following typical. 
1. Mercurialis ánnua L. Sp. Pl. 1035. 1753.

A weak glabrous annual 2-6 dm. high. Leaves thin, ovate to lanceolate, $3-6 \times 1.5-2.5 \mathrm{~cm}$., narrowed at the base, acute or acuminate at the apex, crenate or serrate with rounded teeth; petioles somewhat less than half the length of the blade; male flowers in interrupted spikes longer than the leares; female flowers clustered in the axils. Capsnle 2-earpelled, 4-5 $\mathrm{mm}$. broad, hispid; seeds oroid, $2.5 \times 2 \mathrm{~mm}$., grayish green, densely shallow-pitted.

Adventitious in waste grounds near Nassau, New Providence:-Bermuda; Delaware to Texas. Nitive of Europe. IIEnis IEnctry.

\section{ACALỲPHA L. Sp. Pl. 1003. 1753.}

Herbs or shrubs. Stems mostly erect. Leares alternate, stipulate. Flowers in spikes or spike-like racemes; staminate cluster often peduncled, each flower in the axil of a minute bractlet, with a 4-parted ealyx and 8-16 stamens united at their bases. Pistillate flowers subtended by a foliaceous bract, which often equals or overtops the staminate, the ealyx $3-5$-parted; petals wanting in both kinds of flowers; eapsule usually of 3, 2-ralved carpels, each 1-seeded. [Greek, nettle.] About 250 species, mostly tropical and subtropical. Type species: Acalypha virginica $\mathrm{L}$.

Inflorescence densely cylindric.

Inflorescence loosely spicate.

Female bracts cleft to about the middle.

Plants perennial, prostrate.

Plants annual, erect.

Female bracts cleft to the base.
1. A. alopecuroidea.

2. A. rhamaedrifolia.

3. A. ostryacfolia.

4. A. setosa.

1. Acalypha alopecuroìdea Jaeq. Ie. Rar. 3: 19. 1793.

Herbaceous, annual, 1-3 dm. high. Leares broadly orate, $5-7 \times 3-4.5 \mathrm{~cm}$, appressed-pubescent, membranous, flaceid, truncate or slightly cordate at the base, 5 -nerved, cuspidate-acuminate, serrate, the petiole as long as the blade or longer; spikes terminal, closely flowered, $5 \mathrm{~cm}$. long; female bracts 1 -flowered, membranous, ovate-triangular, $7-9 \mathrm{~mm}$. long, 3-5-lacerate to the base; calyxlobes ovate, acute; orary hirsute abore; styles elongated, delicate, attenuate, entire or shortly bifid; carpels slightly keeled; seeds ovoid, apiculate, $1 \times .8$ mm., reddish-brown; testa densely and minutely pitted-cellular; earuncle waxen, longitudinal, linear.

Adventitious in waste places, Abaco and New Providence:-Cuba; Porto Rico; Jamaica; Iexico; Central America; Caribbean coast of South America. Referred by Dolles to Acalipha polystachya Jacq. SPlCate ACalYPHA.

2. Acalypha chamaedrifòlia (Lam.) Muell. Arg. in DC. Prodr. 15²: 879. 1866.

Croton chamaedrifolius Lam. Encyel. 2: 215. 1786.

Acalypha reptans Sw. Prodr. 99. 1788.

A prostrate herbaceous or suffrutescent perennial, pubescent or glabrate, with branches $1-3 \mathrm{dm}$. long. Leares orate, $.8 \times .5-3.5 \times 1.5 \mathrm{~cm}$., base blunt or rounder, apex acute, margin crenate-dentate; petioles about one-third the length of the blades; inflorescence in eylindric terminal subsessile androgynous racemes, male above and few-flowered female below, sometimes with similar superaxillary racemes or female clusters, the flowers sessile; bracts roundish, dentate or erenate, the teeth ovate, seeds ovate-globose, apiculate, brown, $3 \times 1 \mathrm{~mm}$; t testa very minutely pitted-cellular; earuncle longitudinal, waxen, wrinkled.

Red-lands and rocky coppices, Eleuthera:-Florida; Cuba; Hispaniola to Tortola and Guadeloupe; Jamaica. Prostrate ACALipha. 
3. Acalypha ostryaefòlia Riıld. Syn. Fl. W. States 33.1835.

Acalypha caroliniana Ell. Bot. S. C. \& Ga. 2: 645. 1824. Not Walt. 1788. Aealypha persimilis Mueli. Arg. Linnaea 34: 25. 1865.

An erect, rather stout innual, dark green, minutely pubescent, $2-S \mathrm{dm}$. tall. Leaves thin or membranous, ovate, $5-10 \mathrm{~cm}$. long, base obtuse or cordate, apex short-acuminate, margin closely and sharply serrate; petiole often as long as the blade; infloreseence spiciform, the male and female separate; male bracts minute, the female conspieuous, lobed; capsule strongly depressed, short, thick, 2-6-laciniate above; seeds reddish-brown, ovoirl-globose, apiculate, the testa warty-wrinkled; (arunele flat, papyraceous, fusiform.

Waste grounds near Nassau, New Providence :-New Jersey to Kansas; South-

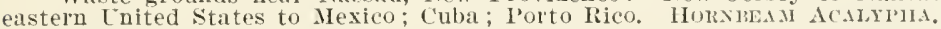

4. Acalypha setòsa A. Rich. in Sagra, Hist. Cuba 11: 204. 1850.

An erect annual 3-6 dm. tall, the younger parts hirtulo-pubescent. Leaves orate, thin, 3-5-nerved, $4-7 \times 2.5-5 \mathrm{~cm}$., base obtuse or slightly cordate, apex short-acuminate, margin finely-serrate; inflorescence monoecious, in eylindrie spikes, the male axillary, lax-flowered, the female terminal, dense-flowered, $3-5 \mathrm{~cm}$. long; female bracts 2-flowered, ovate, 5-6 mm. long, $7-13$-partite, the divisions laciniate, papillo-scabrous; calyx-lobes ovate-lanceolate, ciliate; styles short, thick, 2-6-laciniate above; seeils reddish-brown, ovoid-globose, apiculate, $1.4 \times 1 \mathrm{~mm}$; testa dencely papillo-punetate; caruncle a single straight membranous line.

Waste grounds near Nassau, New Providence:-Cuba; Hispaniola; Porto Rico; Mexico to Costa Rica. SRTuse Acalrpila.

16. PÈRA Muris, Vet. Akad. Stoekh. 5: 299.1784.

Glabrous or pubescent trees, the leaves alternate, short-petioled, entire, coriaceous, penninerved. Infloreseence dioecious or rarely monoecious, pisiform, in the axils of the leaves and at old norles, short-pericelled or subsessile, 2-3bracteate. Flowers sessile in small involueres, very small, apetalous; involucres globose, gaping or valvate in anthesis; disk none. Male flowers: calyx minute, valvate, 2-3-fid, or rudimentary or wanting; stamens 2-6; filaments connate at or near the base; anthers dorsally fixerl at or near the base, the cells longitudinally contiguous and dehiscent. Female flowers: calyx none or reduced to scales; ovary 3-celled; styles short; stigmas thick, peltate, disciform, or 3 lobed; orules solitary in each cell. Capsule globose or pyriform; pericarp firm, dehiscent into 3,2 -eleft valves; seells ovoid or obovate, compressed; testa crustaceous, black and shining; endosperm thick, fleshy; cotyleilons plane, broad. [Greek, a pouch.] About 25 species, of tropical America. Type species: Pera arborea Mutis.

1. Pera bumeliaefòlia Gricè. Nachr. Ges. Wiss. Goett. 1865: 180, 1865.

A small tree up to $12 \mathrm{~m}$. high, or shrubby, with slender branches, the petioles and involueres densely ferrugineous-lepidote. Leaves olive-green, $7-9 \times 2-3$ en., elliptic-lanceolate, obtusely acuminate, narrowerl to the petiole, shining above, rlull and sparsely lepidote-punetate beneath; petioles about 1.5 cm. long, sleniler; male calyx globose-ellipsoill, 4-5-lacerate-dentate (as many toothed as there are anthers); capsule oliviform. the pericarl transversely sharp-wrinkled when ary; seeds flattened-pyrifnon, gaping open at the apex, black and shining, minutely shallow-punctate, $5 \times 3.5 \mathrm{~mm}$.

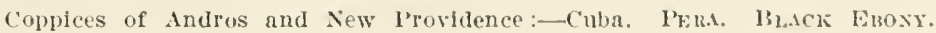




\section{RÍCINUS L. Sp. Pl. 1007. 1753.}

A tall stont monoecious herb, glabrous and glaucous, with alternate large peltate palmately lobed leaves, and numerous small apetalous greenish flowers in terminal racemes, the pistillate above the staminate. Staminate flowers with a 3-5-parted calyx, the segments valvate, and numerous crowded stamens; filaments repeatedly branched. Pistillate flowers with a caducous calyx. Capsule subglobose, or oval, separating into 3, 2-valved carpels. Endosperm fleshy and oily. [Latin name of the plant.] A monotypic genus.

\section{Ricinus commùnis L. Sp. Pl. 1007. 1753.}

Stem erect, 1-5 m. tall, more or less branched, becoming tree-like in warm regions. Leaves nearly orbicular in outline, 1-6 dm. broad, 6-11-palmately lobed and peltate, the lobes toothed, acute or acuminate; capsule $12-16 \mathrm{~mm}$. in diameter, usually spiny; seeds shining, smooth, black, variegated with white, or mottled with gray and brown markings.

Adrentitious in waste places on New Providence and Cat Islands:-Bermuda : North Carolina to Florida, Texas and Ilexico; West Indies; continental tropical America. Native of the old World tropics. Castor-oIL Plaxt.

\section{MÁNIHOT Adans. Fam. Pl. 2: 356. 1763.}

Monoecious herbs or shrubs of vigorous growth, generally with glaucous glabrous leaves. Leaves alternate, the blades entire or palmately 3-7-lobed, the segments membranous or leathery, entire or lobed. Flowers apetalous, in branched racenies, the staminate with a calyx of 5 partially united sepals; stamens 10, in 2 series; filaments slender, those of the inner series attached to the lobes of the disk; anthers opening lengthwise. Pistillate flowers with a calyx similar to that of the staminate but the tube often shorter; ovary 3celled; styles 3 , slightly united at the base; ovules solitary in each cell. Capsule 3-celled; seeds solitary in each carpel. [Name Brazilian.] About 80 species of South America, the following typical.

\section{Manihot Mánihot (L.) Cockerell, Bull. Torr. Club 19: 95. 1892.}

Jatropha Manihot L. Sp. PI. 1007. 1753.

Herbaceous; stems 0.8-1.5 m. high, more or less branched. Leaves 3-7parted, the segments linear to elliptic or slightly broadest above the middle, acute or acuminate, entire; petiole about as long as the blade or longer; bracts shorter than the pedicels; calyx campanulate, 6-8 $\mathrm{mm}$. long, its lobes ovate, obtuse, about as long as the tube; calyx of the pistillate flowers with a shorter tube than that of the staminate.

Reappearing after cultivation, Andros and Eleuthera:-Widely cultivated and more or less persistent in tropical and subtropical regions. Native of South Ameríca. Cassaya.

\section{BONÀNIA A. Rich. in Sagra, Hist. Cuba 11: 201.1850.}

Low glabrous shrubs with alternate coriaceous leaves and axillary spicate monoecious flowers. Leaves short-petioled, small, entire or glandular-dentate or serrate. Disk none. Male flowers 3 from each bract, subsessile; calyx membranous, the margin truncate or broadly and slightly 2-3-lobed. Stamens 2 (rarely 3); filaments free, short; anthers small, the cells dis- 
tinct, oroid, parallel-contiguous; rudimentary orary none. Female flowers solitary at the base of the spike, sessile or pedicelled; calyx 3-fid; orary 3 -celled; styles 3 , distinct or slightly connate at the base, slender, recurvedspreading, entire; orule 1 in each cell. Capsule globose; cocci 2-ralved; seeds globose, estrophiolate. [Commemorates Sebastian Bonani.] About 6 species of Cuba and the Bahamas. Type species: Bonania cubana A. Rich.

1. Bonania cubàna A. Rich. in Sagra, Hist. Cub. 11: 201, pl. 68. 1850.

Excoecaria cubana Muell. Arg. Linnaea 32: 122. 1863.

A much branched shrub about $2 \mathrm{~m}$. high with shining leathery glabrous leaves. Leaves $12-18 \times 6-11 \mathrm{~mm}$, ovate, obtuse, sometimes slightly emarginate, distinctly nerved, glandular-crenate; petioles short; stipules ovate; male spikes $12-16 \mathrm{~mm}$. long, slender; bracts 1-3-flowered; calyx sessile, about $1 \mathrm{~mm}$. long, urceolate. its lobes short, entire; anthers subincluded; capsule flattenedglobose, smooth, slightly 3 -sulcate; seed globular, grayish, $3 \mathrm{~mm}$. in diameter, smooth, flecked with a few minute, scarcely perceptible, yellowish markings.

Thickets, coppices and rocky plains, Andros, New Providence, Eleuthera, Cat Island, Great Exuma and Long Island:-Cuba. Boxaxis.

\section{HIPPOMÀNE L. Sp. Pl. 1191. 1753.}

Trees with glabrous leaves and acrid poisonous milky juice. Leaves alternate, coriaceous, with rather long petioles. Flowers in terminal monoecious amentaceous spikes, the rachis stout, the male above the female in clusters of S-15, subtended by 2-glandular bracts; calyx membranous, 2-3lobed; stamens 2-3, exserted; filaments more or less united; anthers erect, extrorse. Female flowers: calyx ovoid, 3-parted, closely surrounding the ovary and furnished with several glands; ovary 6-8-celled, sessile; styles 6-8, recurved, stigmatic on the inner surface; orules 1 in each cell, pendulous, anatropous. Drupe slightly 6-8-ridged, variegated, the pulp milky, the endocarp bony, 6-8-celled; seeds elongated, flattened. [Greek, horse-poison.] A monotypic genus.

\section{Hippomane Mancinélla L. Sp. Pl. 1191. 1753.}

An evergreen tree 4-20 m. high. Leaves shining, glabrous, thickish, orate or oval, 4-10 $\mathrm{cm}$. long, blunt or somewhat narrowed at the base, acute or short-acuminate, undulate or slightly shallow-serrate; principal veins at nearly right angles to the midrib; reinlets delicately reticulate; petioles slender, somewhat shorter, or at times longer, than the blades; stipules 4-8 mm. long; bracts broader than long, crenulate; male calyx with 3 unequal acute lobes; female calyx of ovate or orbicular sepals; drupe spheroidal when fresh, $2.5-3.5$ $\mathrm{cm}$. in diameter, yellowish; nut depressed, often bearing numerous grouped thorn-like projections.

Rocky coppices and white-lands, Abaco, Andros. Great Guana Cay, Atwood Cay, Fortune Island, Inagua, Providenciales and Anguilla Islands :-Florida; West Indies ; Mexico and continental tropical America. MANcriosel. Catesby, 2 : $p l .95$.

\section{GRIMMEODÉNDRON Urban, Symb. Ant. 5: 397. 1908.}

Glabrous trees or shrubs. Leaves alternate, petiolate, erenate-serrate. Inflorescence in terminal monoccious spikes; flowers apetalous; disk none. Male flowers: calyx 3 -lobed or 3 -fid, membranous, the lobes valvate; stamens 3 ; 
filaments coalescent near the apex of the column; anthers exserted beyond the calyx, their sacs oroid, longitudinally contiguous and dehiscent; rudimentary ovary absent. Female flowers: calyx 3 -fid; ovary 3 -relled; styles coalescent below, patent above, thick, mulivided at the apex. ('apsule spherical or depressed, sessile, 3-sulcate. Seeds orate-globose. [Greek, Grimm's tree.] Two known species, the following typical, the other endemic in Jamaica.

1. Grimmeodendron eglandulòsum (A. Rich.) Urban, Symb. Ant. 5: 398. 1908.

Stillingia eglandulosa A. Rich. in Sagra, Hist. Cub. 11: 202. 1850.

Excaecaria Sagraei Mnell. Arg. Linnaea 32: 121. 1863.

Excaccaria eglandulosa Muell. Arg.; DC. Prodr. 15: 1209. 1866.

A shrub or a tree up to $8 \mathrm{~m}$. high. Leaves shining, oblong to oblong-lanceolate, $3-8 \times 1-2.5$ cm., base obtuse or narrowed to the mostly 2-glandular petiole, apex bluntly pointed, margin subserrulate with hooked-spinous teeth; male flowers 2 or 3 ; capsule $5-7 \times 8-9 \mathrm{~mm}$; seeds oroid-globose, $4 \times 3.2 \mathrm{~mm}$., cinnamon-brown, marked with dark brown blotehes and points.

Low coppices, Andros, New Providence, Great kxuma and Watling's Island:Cuba. roisox Busil.

22. GYMNÁNTHES Sw. Prodr. 95. 1788.

Evergreen trees or shrubs with glabrous leaves and milky juice, the leaves alternate. Flowers monoecious or rarely dioecious, the male in slender axillary bracteolate racemes, the female solitary, long-peduncled, arising from the axils with the male; perianth rudimentary or lacking. Stamens 2 or 3 ; filaments distinet or united at the base, subtended by the rudimentary perianth of 3 , seale-like parts. Styles 3, recurred. Capsule 3-carpelled; seeds pendulous, the testa membrano-crustaceous. [Greek, naked flower.] About 12 species, of tropical America. Type species: Gymnanthes elliptica Sw.

1. Gymnanthes lùcida Sw. Prodr. 96. 1788.

Excoecaria lucida Sw. Fl. Ind. Oee. 2: 1122. 1800.

An evergreen shrub or tree often $10 \mathrm{~m}$. high. Leaves petioled, glabrous, coriaceons, oblong or lanceolate-spatulate, 5-11 $\mathrm{cm}$. long, narrowed at the base, shining above, the margin undulate and generally obscurely toothed near the apex; racemes shorter than the leaves, continuous; bracts reniform; stamens or 3 , subtended by bractlets; female flowers solitary on curved peduncles somewhat shorter than the racemes; ovary stipitate; capsule depressed, about $1 \mathrm{~cm}$. broad; carpels rounled; seeds ovoid, $5 \times 4 \mathrm{~mm}$., gray, striped longitudinally with fine goldcn-brown lines of irregular width and form.

Coppices, from Allen's Cay throughout the archipelago to Inagua and Atwood Cay :-Florida and the West Indies. Crab-Woon.

\section{HÙRA L. Sp. Pl. 1008. 1753.}

Large glabrous trees with milky juice, and large many-carpelled, flattenedglobose fruits, the broad cordate leares shining, biglandular above the base of the blade. Inflorescence monoecious, in terminal, oval or oblong, long-peduncled spikes; male flowers densely imbricated above, the female at the base or in the inferior axils. Calyx cupuliform, irregularly toothed; staminate column central, bearing below its verticillate projections an indefinite number of sessile 
extrorse anthers. Style simple, infundibuliform at the apex; stigma manylobed, with hanging subulate branches. Capsule deeply sulcate into many cocei; seeds rounded, compressed. [Aboriginal name.] Two or three species of tropical America, the following typical.

\section{Hura crépitans L. Sp. Pl. 1008. 1753.}

A high, umbrageous tree, the trunk and branches often prickly. Leaves variable in shape, roundish, about $5-7 \mathrm{~cm}$. in diameter, cordate at the base, abruptly acuminate, serrate or subentire, the blade often shorter than the petiole; stipules linear-lanceolate, pubescent; anthers usually 1-3-seriate; stigma large, violet-red; capsule coneave at both ends, splitting noisily when ripe and dry, $7-8$ em. broad, $3-4 \mathrm{~cm}$. high.

Planted in Nassau, New Irovidence, and perhaps spontaneous after cultivation :West Indies and Mexico to tropic America. SAxDBox-TREE.

\section{PEDILÁNTHUS Poit. Ann. Mus. Paris 19: 390. 1812.}

Shrubs with fleshy branches and milky juice, alternate leaves with the midrib thickened beneath (rarely leafless), glandular stipules (if present), opposite floral leaves, and cymose terminal or axillary involucres. Involucres oblique, shoe-shaped, the tube more or less fissured superiorly and notched inferiorly at the bilabiate apex or throat, with 2 lateral and 1 median accessory lobes more or less closing the fissure, the tube bearing an appendix on the superior side of its posterior extremity. Appendix gibbous aud interiorly glandular, its lip notehed or 2-3-lobed and extending anteriorly above the posterior end of the fissure of the tube. Flowers pedicellate, the male numerous, ecalyculate, sometimes with linear bracteoles at the base; female single with the long style finally protruding and generally declinate from the throat of the tube; stigmas 3 , connate, often separate at the apex and frequently 2-lobed. Seeds ecarunculate. [Greek, slipper-flower.] About 30 species. Type species: Euphorbia tithymaloides L.

Leafy : appendix 4-glandular.

Leafless; appendix 2-glandular.
1. P.tithymaloides. 2. P. bahamensis.

1: Pedilanthus tithymaloides (L.) Poit. Ann. Mus. Paris 19: 390. 1812.

Euphorbia tithymaloides L. Sp. Pl. 453. 1753.

Branched, 1.2-1.8 m. high; leaves glabrous, subsessile, cuneate at the base, ovate or oblong, $3.5-7.5 \mathrm{~cm}$. long, apex acute often recurved, margin subundulate, the mid-vein prominently undulate-carinate beneath. Cymes terminal, dense; floral leaves ovate, long-acuminate, slightly longer than the peduncles, early deciduous; involueres purple, 1.1-1.3 em. long; tube thin, smooth; appendix 4-glandular the lobe linear short; male pedicels hairy, the female glabrous; style shortly bifid; capsule $7.5 \mathrm{~mm}$. long, $9 \mathrm{~mm}$, broad, truncate at base and ajex; cocei keelerl; seeils orate, $5 \mathrm{~mm}$. long.

Waste places and in copplees, Andros and Cat Island:-Florida: West Indies; Mexico; Central and Caribhean South Anerlca. Slmprimlaxt. Fidnlf-flower.

2. Pedilanthus bahaménsis Millsp. Field Mus. Bot. 2: 359. 1913.

Glabrous, 1-1.5 in. high, leafless, irregularly branched, the branches grar, roughened with transverse rilges. Inflorescence terminal; bracts cucullate, one thirl to one quarter the length of the peduncles; involucres about $9 \mathrm{~mm}$. long, 
pubcrulent, malder-lake in color; inferior cleft of the tube shallow, the superior fissure open half the length of the tube; main lobes blunt, finely erose-lacerate, the two lateral lobes minute, free only at the apex, the fifth lobe flabelliform, free half its length; anthers glabrous; female pedicel puberulent; style very slightly trifid; appendix narrow, about one half the length of the tube, sarcous, usually sigmoid, the lobe blunt, slightly notehed, strongly gibbous at the base; glands 2, stipitate; capsule flattened-globose; seeds trigonal, olivaceous, the clorsal angle quite prominent, apiculate and with a minute raised pimple at the apex, $3 \times 2.5 \mathrm{~mm}$.

Stony floor of serub-lands, Deep Creek, Andros, Atwood Cay, Acklin's Island, Inagua, South Caicos and Grand 'Turk to Salt Cay. Endemic. BisHAMA FidDLEFLOWER. MOXIEY-FIDDLE.

\section{ADENORIMA Raf. Fl. Tellur. 4: 112. 1838.}

Trees with thick branches and profuse thick milky juice. Leaves clustered at the ends of the branches, entire. Cymes corymbose, terminal and superaxillary. Involucres large; glands 4 , on the outer wall of the involucre below its lip. Styles more or less connate below, bifid into long branches, the apices rarely thickened. Capsule 3-coccus; seeds smooth, ecarunculate. [Greek, gland-pit.] Fifteen species, or more, of the West Indies and Mexico. Type species: Euphorbia punicea $\mathrm{Sw}$.

\section{Adenorima gymnonòta (Urban) Millsp.}

Euphorbia gymnonota Urban, Symb. Ant. 5: 396. 1908.

Euphorbiodendron gymnonotum Millsp. Field. Mus. Bot. 2: 305. 1909.

A tree, 6-6.5 m. high, the branches fleshy, dichotomous. Leaves alternate, linear-oblanceolate, $4-8 \times .8-1 . .4 \mathrm{~cm}$., entire, membranous, narrowed to the sessile base, the apex rounded-mucronate or acute-mucronate; inflorescence 5-7flowered, terminal; bracts crimson, ovate; involucre urceolate, the margin entire or sparingly crenate-dentate; glands 4, ovate to ovate-oblong, vertically placed at or just above the middle of the tube, exappendiculate, fleshy, concave; style short, 3-fid; eapsule 3-angled, smooth; seed globose, gray, $4 \mathrm{~mm}$. in diameter, the outer gray coat broken through in places revealing the inner dark, irregular markings.

Margins of thickets, Watling's Island, Crooked, Fortune and Acklin's Islands; Little and Great Inagua: South Caicos: Ambergris Cay. Endemic. Referred to in various Bahama publications as Euphorbia punicea Sw. BAHAMA ADENoRiMa.

26. EUPHórbia Linn. Sp. Pl. 450. 1753.

Cactus-like shrubs with thick fleshy, generally angular stems, and few reduced true leaves or none. Leaves and stipules generally represented by spines but often by snall or minute caducous bracts. Cymes lateral or terminal, subsessile, often few-flowered or even single-flowered; involucres subtended by dilated bractlets; glands of the involucre entire, exappendiculate. Capsules thick, often ligneous; seeds ecarunculate. [Commemorates Euphorbus, King Juba's physician.] About 30 species, of the Old World. Type species: Euphorbia antiquorum L.

1. Euphorbia láctea Haw. Syn. Pl. Suce. 127. 1812.

A tall, dark-green, many-branched, spinous milky-juiced shrub, 2-5 m. high, the branches 3 -angled, the faces $3-8 \mathrm{~cm}$. broad, plano-convex, the angles 
repand-dentate, compressed on the margin; spines short, thick, divergent, 4-6 $\mathrm{mm}$. long.

Widely established in many plices, often forming dense thickets. New Irovidence, Cat Island; Watling's, Iong Island and Inagua:-Florida: West Indies: Iexico. Naturalized from lndia ind the Molucens. Referred by llitcheock and Mrs. Northrop to Euphorbia antiquorum L. MotTLED SP'Lrge.

27. ARthrothámNUs Kl. \& Gke. Monats. Akad. Berlin 1859: 251. 1859.

Leafless, shrubby plants with jointed branches. Involneres not subtended by dilated bractlets. Leaves reducer to opposite sessile scales glandular on both surfaces; stipules none. Involucres minute, terminal, campannlate, dioecious, minutely bibracteate at the base. Glands transverse, thick, orbicular or semiorbicular, spreading, plane, entire. Bracteoles plumose. Styles 3, bifid, revolute. Seeds orate-tetragonal, serobienlate. [Greek, jointed bush.] About 10 species, of tropical America and sonthern Africa. Type species: Euphorbia Tirucalli L.

1. Arthrothamnus cassythoides (Boiss.) Millsp. Field Mus, Bot. 2: 306.1909.

Euphorbia cassythoides Boiss. Cent. Euph. 20. 1860.

Plant 1-2 m. high, the branches white-barked, verticillate below, dichotomous abore; branches with internodes $8-15 \mathrm{~cm}$. long and $6-7$-angled, the nodes gummy. Cymes terminal, dichotomous; involueres prodnced between small thick triangular bractlets; tube short-campanulate, glabrous within; lobes triangular-orate, 4-5-dentate, hairy; glands fleshy; styles short, hairy, bilobate at the apex; capsule oroid; cocei subcarinate; seeds white, each facet 2-3foreolate. SPURGE.

Sandy soil near Deep and Fresh Creeks, Andros:-Cuba. Learless Cubax

28. TITHYMÀLUS [Tourn.] Adans. Fam. 2: 355. 1763.

Annual or perennial milky herbs $01^{\circ}$ shrubby plants with simple or branched stems topped by several-rayed cyme-like umbels. Leaves below the umbel scattered or alternate, estipulate, often broadened upward; bracts of the umbel quite different from the stem-leares, entire or toothed. Involncres sessile or peduncled, the lobes often toothed; glands 4 , transversely oblong and appearing reniform by the cornuate extremities or appendages. Capsule smooth or tuberenlate; cocei rounded or more or less carinate. Seeds rarionsly pitted, often carunculate. [Greek, referring to the milky juice.] Abont 250 speeies, of wide geographic distribution. Type species: Euphorbia dendroides L.

1. Tithymalus trichòtomus (II.B.K.) Kl. \& Gke. Monats. Akad. Berlin 1860: 81. 1860 .

Euphorbia trichotoma II.B.K. Nor. Gen. 2: 60. 1817.

Perennial, glabrous. Stem commonly branched and more or less woody at the base, the branches erect or ascending, 1-4 dm. tall, widely forking above. Leares numerous, rather approximate, small, thickish, cuneate to oblong, obtuse or acutish, 5-12 mm. long, minutely erose when mature: inflorescence trichotomous; involueres campannlate, sessile or nearly so, 2 mm. long; glands reniform, $1 \mathrm{~mm}$. long, yellow; capsule tricoccons, the cocei rounded; scerls white, globose, $2 \mathrm{~mm}$. in diameter. smooth; caruncle thin, circular.

Coastal sands, Allen's Cay. Frent Lahama and Andros:-Florida: Culat; the Cayman Islands. Horisig SiURe. 


\section{PoINsÉttia R. Graham, Edin. N. Phil. Jour. 20: 412. 1836.}

Jlerbs, rarely shrubs, the inflorescence elnstered at the tips of the branches, often subtended by highly colored leares, the leares alternate below; opposite above, the blades similar throughout or very various in form. Involucral lobes fimbriate; glands sarcous, concare, saucer-, cup- or goblet-shaped, solitary or rarely 3 or 4, marginal, exappendicnlate. Capsule exserted, its cocei rounded; seed narromed upward, generally tuberculate, ecarunculate or with a mere indication of a carmeular body. [In honor of Joel Roberts Poinsette of South Carolina.] About 12 species, mostly American. Type species: Euphorbia pulcherrima Willd.

1. Poinsettia heterophýlla (L.) Kl. \& Gke. Monats. Akad. Berlin 1859: 253. 1859.

Euphorbia heterophylla L. Sp. Pl. 453. 1753.

Euphorbia havanensis Willd.; Boiss. in DC. Prodr. 15: 73, as synonym. 1862.

Euphorbia graminifolia Michx. Fl. Bor. Am. 2: 210. 1803.

Annual or perennial, bright green, pubescent or nearly glabrous, mostly erect, 3-10 dm. tall, woody below; branches ascending or the lower often spreading, leafy at the ends. Leares varions even on the same stem, from linear through all shapes to orbicular, entire, dentate, sinuate or even panduriform; involucre-lobes ovate or oblong, laciniate; gland 1, sessile, exappendiculate; seeds ovoid-oblong, pointed, grayish, $2.8 \times 2 \mathrm{~mm}$. minutely and irregularly tuberculate in more or less transverse lines.

Good soil of grassy places and cultivated fields, Abaco and Great Bahama southward to Grand Turk:- Bermuda; Illinols to Nontana and southward through the American tropies; West Indies. Jacob's Ladder. Governor Graxts Livery.

\section{AKLÉMA Raf. Fl. Tellur. 4: 114. 1838.}

Shrubby or rarely herbaceous, the branches jointed. Leares equilateral, entire, penninerved, cuneate at the base, ternate or verticillate (sometimes opposite), long-petioled; stipules glanduliform. Cymes axillary and terminal, corymbose or paniculate (rarely reduced to a single involucre), the terminal involucres generally hermaphrodite, often many-flowered; glands of the involucre appendiculate; bracteoles between the male flowers numerous, plumose. Capsule depressed, deeply trisulcate; seeds irregularly scrobiculate, ecarunculate. [Greek, not explained.] A few species of tropical America. Type species: Euphorbia nudiflora Jaeq.

1. Aklema petiolàre (Sims) Millsp. Ann. Mo. Bot. Gard. 2: 43. 1915.

Euphorbia petiolaris Sims, Bot. Mag. pl. 883. 1805.

Alectoroctonum petiolare Kl. \& Gke. Monats. Akad. Berlin 1859: 248. 1859.

Shrnbby or tree-like and $7 \mathrm{~m}$. high, the branches glabrous, swollen at the nodes. Leaves ternate, ovate or orbicular, 1-1.5 cm. long, truncate or almost peltate at the base, obtuse or slightly emarginate, entire, the petiole slender, twice or more the length of the blade; inflorescence subtrifloral, shorter than the leares; involucres long-pedicelled (6-10 $\mathrm{mm}$.), hemispherie, smooth; lobes ovate, short-fimbriate; glands transverse, ovate, stipitate; styles divaricate, bifid, not thickened at the apex; capsule smooth; cocci obtusely carinate; 
seeds oroid-globose, $3 \times 2.4 \mathrm{~mm}$, pointed, white, foreolate with numerous large shallow irregular pits.

In a sisal field on South Caicos Island:-Hispaniola: Mona: I'orto lico: Culebra : Vieques; St. Thomas; St. Jan: St. Martin; Anegada; Tortola; Ilartinique and Tobago. BRosD-LEAVED SIURGE.

31. CHAMlaEsỸCe S. F. Gray, Nat. Arr. Brit. Pl, 2: 260. 1821.

Annual or perennial herbs or shrubs, the stems often diffuse at the base: the branches prostrate or ascending, forking. Leares opposite, inequilateral, more or less oblique at the base, entire or toothed; stipules minute, entire or lacerate. Inflorescence solitary or capitulate, axillary and terminal; involucre toothel, glandular on the margin; glands 4, naker or appendagerl (the 5th gland represented by a sulcus in the margin of the involucral tube). Capsule more or less globose, 3-coccous, the cocei sharply angled or rounded; seeds minute, oroid or elongated-ovoid, more or less quadrangular, the facets snooth or transversely ridged. [Greek, ground fig.] About 225 species, widely distributed. Type species: Chamaesyee maritima S. F. Gray.

Suffrutescent; leares thick, mostly entire.

Leaves orate to elliptic or oblong.

Inflorescence terminal-axillary: plants glabrous.

Inflorescence throughout the upper axils.

Leaves glabrons.

Leaves entire.

Stipules deItoid. acicular-bristled. Stipules not bristled.

Leares dentate.

Stipules broad, fimbriate-ciliate.

Stipules narrow, entire, aristate.

Leares densely tomentose.

leaves canescent, entire.

Leaves linear or narrowis oblong.

Leares $2-4 \mathrm{~cm}$. long, involucres peduncled.

Leares $8-12 \mathrm{~mm}$. long. involucres sessile.

1. G. buxifolia.

aceous; leaves thin, mostly serrate.

Leaves glabrons.

Inflorescence clustered; leaves oblong, acute, sharply

serrate.
Leaves broadly falcate; seeds red.

Leaves narrowly falcate: seeds black.

Inflorescence solitary; leares ovate, blunt, dentate or entire.

Capsule glabrous.

Capsule hairy on the angles.

Leaves hairy.

Inflorescence clustered.

Leares ovate to lanceolate, sharp-serrate, acute.

l.eares ovate, cremate-dentate, obtuse.

Inflorescence solitary: leares orbicular to elliptic, entire or apically denticulate.

2. C. Irilsomi.

3. C. lecheoides

4. C. insulac-salis.

5. C. crumcnsis.

G. C. caycnsis.

7. C. Bracci.

8. C. articulata.

9. C. vaginulata.
10. C. hypericifolia.

11. C. Urasiliensis.

\section{C. Blodgettii.}

13. C. prostrata.

14. C. hirta.

15. C. Berteriano.

16. C. Brittonii.

1. Chamaesyce buxifòlia (Lam.) Small, Fl. SE. U. S. 711. 1903.

Euphorbia buxifolia Lam. Eneyc. 2: 421.1788.

Low, generally erect, glabrous, shrubly, fleshy, 2-5 dm. high; branches usually many. Leaves glabrous, thick, wrinking in drying, ovate or hroadly oblong, S-12 mm. long, obliquely subcordate at the hase, acutish, margin entire, involute: petioles about $1 \mathrm{~mm}$.; involucres campanulate, about $1.5 \mathrm{~mm}$., as long as the peduncles or shorter; glands trausversely oblong; alpendages a mere whitish bordering line; capsule broad. glabrous; seeds white, ovoil-quallraugular, somewhat apiculate, $1.2 \times 1 \mathrm{~mm}$, the angles very blunt; facets very shallowly broad-pitted by indistinet and irregularly anastomosing transverse ridges.

Maritime sands throughout the archipelago:-Iicrmuda; Florlda: coasts of the Gulf of llexico and the Curbbean seal. Codst Sperok. 


\section{Chamaesyce Wilsònii Millsp. Field Mus. Bot. 2: 301.1909.}

Prostrate, spreading, matted, purplish-einereous; branches densely numerous, wiry, divaricate. Leaves sulall, fleshy, ovate, $2-4 \times 1.5-2.5 \mathrm{~mm}$., ol)liquely auriculate-cordate at the base, obtuse, the margin entire; petioles very short; stipules deItoid, stiff-eiliate; involueres solitary in the upper forkings, eylindric-eampanulate, short-pedicellate, the tube glabrous without, densely erisped-pilose within; lobes aristate; glands 4, orbicular, convex, the fifth represented by a large, triangular lobe; appendages rudimentary; styles short; stigmas bilobed; capsule oroid; cocei slightly carinate; seeds white, oroid-quadrangular, $1 \times .7 \mathrm{~mm}$., angles comparatively sharp, facets indistinctly marked by low irregular transverse ridges.

White-lands of Castle Island and Grand Turk. Endemic. Wrisox's Srerge.

3. Chamaesyce lecheoìdes Millsp. Field Mus. Bot. 2: 301. 1909.

Euphorbia lecheoides Millsp. Field Mus. Bot. 2: 163. 1906.

Erect, shrubby, slender, profusely branching, grayish farinose, perennial, 2-3 dm. high; branches diffuse, dichotomous, the inferior internodes about 1 cm. long, the upper branchlets virgate, wiry. Leares short-petioled, deltoidorate, triangular-orate or elliptic, $2.5-5 \times 1-2.5 \mathrm{~mm}$., ahruptly attenuate at the apex, the margin thickened and revolute; stipules broadly ovate, stiffciliate; involueres solitary, turbinate, short-pedicellate, the tube glabrous without, barbellate at the throat within; lobes triangular, acute, ciliate; glands dark, flattened, orbicular, the face pock-marked; appendages minute, fleshy, or obsolete; stigmas bifurcate to the middle; filaments barbellate; capsule glabrous; seeds reddish-brown, ovoid-quadrangular (the ventral angle indistinct), apiculate, $.8 \times .5 \mathrm{~mm}$., the facets indistinctly transrersely rugose.

Scrub-lands of the southwest extremity of Watling's Island, Mariguana, Inagua, South Caicos and Grand Turk to Salt Cay. Endemic. I'IX-WEED SPrRge.

\section{Chamaesyce insulae-sàlis Millsp. Fielı Mus. Bot. 2: 395.1914.}

Perennial, ercet, $7-10 \mathrm{~cm}$. high, from a densely nodular rootstock; branches densely tufted, wiry, glabrous, the internodes $1.5-2 \mathrm{~cm}$. long. Inflorescence solitary, terminal and terminal-axillary; leaves opposite, sarcous, glabrous, $2-4 \times 1.5-3 \mathrm{~mm}$., marked only by the thickish midrib, subcordate, acute, entire or in the lowermost indistinctly denticulate, petioles about $1 \mathrm{~mm}$. often with a tuft of ciliae between the base and the stipule; stipules of many forms from deltoid and entire through lanceolate, bifid, and lance-aristate to a mere tuft of ciliae; involucres campanulate, sessile or nearly so, the outer surface smooth, the inner densely woolly; lobes triangular-aristate, densely woolly on the inner recurred surface; glands transversely oval; appendages greenish white, entire or nearly so, about the width of the glands; styles bifid to half their length; capsule glabrous, strongly tricoccous; seed ovoid-quadrangular, 1 X. $\mathrm{mm}$., white, acute, the angles sharp (except the ventral), facets smooth or with a few irregular indistinet ridges.

Sands of Salt Cas (Cay Sal Bank). Endemic. CaY Sal Spurge.

\section{Chamaesyce exuménsis Millsp. Field Mus. Bot. 2: 301. 1909.}

Perennial, $3 \mathrm{dm} .-1.5 \mathrm{~m}$. high, purplish-or greenish-cinereous; stem erect or reclinate-prostrate; branches strict, denuder? below, the nodes somernat swollen; branchlets subtenuous, divaricate. Leaves thick, ovate, .8-1.1 $\times .6-.8$ mm., short-petioled, obliquely cordate, obtuse or acutish, entire or slightly and remotely dentate near the apex; stipules aristate; involueres terminal and in the upper forkings, turbinate, short-pedicellate, glabrous without, densely barbellate within; lobes triangular, setaceous at the apex; glands 4 (the fifth represented by a larger inrolueral lobe), огate, plane; appendages white, 
entire; stamens 5; filaments eristate-barbellate at the base; styles short, deeply bifil; capsule oroid; cocei acutely carinate; seeds oroid-quadrangular, the ventral angle obtuse, pinkish gray, $1.1 \times .8 \mathrm{~mm}$., facets slightly and indistinctly anastomose and transversely ridged.

Coastal sands, white-lands and sand-pockets in coastal rocks, Eleuthera, tlue Exumas, southward to Foltune Island. Fndemic. Referred by Viueller to Euphorbia Balbisii Boiss: by Coker to Euphorbia cayensis Millsp.; and in Field Mus. Bot. 2: 161 to Euphorbia flexuosa Kith. Exeva SPLige.

\section{Chamaesyce cayénsis Millsp. Field. Mus. Bot. 2: 301. 1909.}

Euphorbia cayensis Millsp. Torreya 4: 172. 1904.

Low, densely white-eanescent; stems stout, ligneous, multinodal, branching below, 2-3 dm. high, spreading above. Leaves thick, oral, $4-6 \times 3-1 \mathrm{~mm}$., obliquely cordate at the base, entire, eanescent alike on both surfaces; petioles 1-1.5 mm.; inrolueres campanulate, short-peduneled, $1.5 \mathrm{~mm}$. , canescent, bearded in the throat; glands green, transversely oblong, thick, tumid, . 7 $\mathrm{mm}$. broad (fifth gland represented by a large, deltoid tooth on the inrolueral margin); appendages lineal, hardly distinguishable; capsule canescent; cocei bluntly keeled; seeds pinkish ashen, ovoid-quadrangular, the ventral angle slight, $1 \times .8 \mathrm{~mm}$., facets distinctly transversely anastomose-ridged.

Coastal white-lands, Man-o'-War Cay (Abaco), the Berly Islands and Joulter's Cays, Anguilla and Water Cass (Cay Sal Bank). Endemic. BaIIaAa Sptrge.

7. Chamaesyce Bràcei Millsp. Field Mus. Bot. 2: 302. 1909.

\section{Euphorbia Bracei Millsp. Field Mus. Bot. 2: 159. 1906.}

Nearly prostrate, branching from the base; branehes ligneous, eanescent. Leares thickish, oblong to orate, $5-\delta \times 3-5$ mm., rery short-canescent and dotted with amber-like resin globules on both surfaces, the base narrowing to the petiole, the apex obtuse, the margin entire, revolute; petiole one-fifth the length of the blade: stipules triangular, 2-toothed or more, the teeth tipped with a stalked dark globular gland; involueres upper-axillary, eup-shaped, the perlicels equalling the tube, canescent without, ciliate within, the inner wall with 5 alate columns from the base to the glands; lobes triangular, acute; glands 4 (the fifth represented by a broader, longer involucral tooth), minute, transversely-ovate; appendages rery narrow, erenate, or wanting; stigmas bifureate to the base; capsule acicular-hairy; seeds oroid-quadrangular, $.9 \times . i$ num., very slightly anastomosely transverse-ridged.

White-lands of Ahaco and Man-o'-War Cay. Endemic. Bruce's Sptraf.

8. Chamaesyce articulàta (Aubl.) Britton, Mem. N. Y. Bot. Gard. 6: 574. 1916.

Euphorbia articulata Aubl. Pl. Guian. 1: 480. 1775.

Euphorbia linearis Retz. Obs. 3: 32. 1753.

Shrubby, glabrous, 3-6 m. high, the branehes divaricate. Leaves glabrous or slightly canescent, ligulate to oblong-linear or narrowly oblong, $2-6 \mathrm{~cm}$. $X$ 4-6 mim., rouniled or narrowel at the oblique base, acute or blunt, mucromulate, entire, glaucous beneath; petioles short; stipules interpetiolar, broally ileltoill, eiliate; involucres single, terminal-axillary; peduneles more or less winged; tube thiek, glabrous without, minutely appressed-silky within; involueral lobes wanting, the margin of the tube thickened: glands 4, eup-shaped, with a nipplelike projection at the inner edge (resembling the tip of an elephaut's proboseis); bracteoles very numerous, ligulate below, brush-like above; stigma 3 -furcate above the middle; capsule glabrous, strongly 3 -coceons; seed pinkashen, ovoid-quadrangular, $1.5 \times 1 \mathrm{~mm}$., facets transversely anastomose-rugose.

I.w scrub-lands near Jacksonville, East Caicos:-Forto Rlco to Anegila and St. Vincent. Bu'sir' SPurge. 
9. Chamaesyce vaginulàta (Griseb.) Millsp. Field Mus. Bot. 2: 302.1909.

Euphorbia vaginulata Griseb. FI. Br. W. I. 52. 1859.

A low, densely bramehed shrub, $2 \mathrm{dm}$. to $2 \mathrm{~m}$. high, the branchlets closely ringed with the old persistent stipular sheaths, giving the whole shrub an ashen hue. Leares small, $3-15 \times 1 \mathrm{~mm}$., fleshy, linear (in some specimens globular), glabrous, entire, obtuse, very short-petioled, springing from a broad seaphoid sheath-like stipule with a eiliate margin; involucres solitary, terminal on the branchlets, turbinate, short-pedicelled; tube thick-walled, glabrous without and within; lobes triangular, eiliate; glands 4, large, orbicular, sareous, dark purple, the fifth represented by a larger involneral lobe; bracteoles ligulate, glabrous; capsule glabrous, strongly 3 -coccous, the cocei mottled with fine dark confluent punctae; seeds ovoid-quadrangular, bluish white, $1.2 \times .8 \mathrm{~mm}$., blunt-pointed, smooth, the testa minutely punctate.

liock white-lands of Watling's Island, Castle Island, the Inaguas and throughout the Caicos and 'Turk's Islands. Endemic. SHEATned SPURG.

* 10. Chamaesyce hypericifòlia (L.) Millsp. Field Mus. Bot. 2: 302.1909.

Euphorbia hypericifolia L. Sp. Pl. 454. 1753.

Annual, erect or ascending, 2-8 dm. Leares oblong or oblong-lanceolate, often falcate, $1.5-3 \mathrm{~cm} . \times 5-10 \mathrm{~mm}$. , obliquely truncate at the base, blunt, more or less sharp-serrate on the upper third, short-petioled, glabrous or somewhat hairy; stipules ovate, acute, thin, dentate and ciliate on the margin; inflorescence densely eymose in the axils of the upper and terminal leaves, the foral bracts linear and often white-margined; iurolueres turbinate, thin, glabrous without, hirtellous at the throat within; lobes lanceolate-triangular, lacerate into 3-5 teeth; glands small, roundish, stalked, the fifth gland represented by a leep sinus flanked by a larger, inore triangular lobe; appendages white, orbicular or orate; styles short, deeply bifid; capsule glabrous, strongly 3 -coccous, the cocci carinate; seeds ovoid-quadrangular, red, $.8 \times .6 \mathrm{~mm}$., the angles prominent, the facets marked with many transverse broken ridges.

Open grassy places throughout the archipelago:-Bermuda; Gulf of Mexico region of the United States; Mexico: Central and South America; West Indies. Referred by Mrs. Northrop to Euphorbia nutans Lag. IIrPERICUsl-LEAIED SPURG.

\section{Chamaesyce brasiliénsis (Lam.) Small, Fl. SE. U. S. 712. 1903.}

Euphorbia brasiliensis Lam. Eneyc. 2: 123. 1788.

Annual, erect or ascending, similar in habit to the last, but with more filiform branchlets, smaller and more falcate leaves, ferrer-flotrered cymes, and black seeds. Stipules broadly deltoid, bifurcate into lacerate lobes; involueres glabrous without and within, very short-pedicelled; lobes triangular, mostly entire; glands minute, long-stalked, the fifth represented by a very shallow sinus flanked by two larger involueral lobes; capsule glabrous, strongly 3 -coccous; seeds oroid-quadrangular, black, $1.2 \times .9 \mathrm{~mm}$. , the strong. but rounded, angles white-edged, dorsal facets marked by 3 complete transverse ridges, ventral 2 -ridged.

Open places and grassy corerts, New Providence and Eleuthera:-Florida to Arizona; Bermuda; Cential America to Brazil; West Indies. Brazilix Spurge.

\section{Chamaesyce Blodgéttii (Engelm.) Small, Fl. SE. U. S. 712. 1903.}

Euphorbia Blodgettii Engelm.; Hitch. Rep. Mo. Bot. Gard. 4: 126. 1893.

Annual, glabrous, prostrate or ascending, branching at the base. the branches 1-4 dm. long, forking. Leaves oblong or nearly so, 3-8 mm. long, minutely serrate toward the apex, oblique at the base, obtuse, petiolate; stipules broadly triangular, acute, ciliate-margined; involucres solitary in the 
upper axils, campannlate, less than 1 mm. long, short-pechneulate, glabrous without, ciliate at the throat within; lobes triangular; glands 4, slightly stalked, orbicular to orate, the fifth represented by a sinus with a rounder fundus and flanked by two larger, nearly quadrilateral lobes: appenilages nearly as broad as the glands, entire or 2-3-crenate; capsule bluntly tricoccous, glabrous; seeds ovoid-quadrangular, pinkish or brownish, $1 \times .8 \mathrm{~mm}$., angles prominent, facets slightly transversely ridged.

On rocks, in sand and in pot-looles, from the southeru coast of Great Bahama to Ambergris Cay:-Florida; Bermuda: Cuba: Jamaica; Caymans. Referred by Irs. Northrop and by Dolley to Euphorbia serpens İth., and by Dolley again to Euphorbia maculata L. BLODGETT'S SPURGE.

\section{Chamaesyce prostràta (Aiton) Small, Fl. SE. U. S. 713.1903.}

Euphorbia prostrata Aiton, Jlort. Kew. 2: 139. 1759.

Annual, prostrate, more or less pubescent, or glabrate; stems branched at the base; branches slender, .5-15 $\mathrm{dm}$. long, forking. Leaves thin, oblong or orate, strongly oblique at the base, $4-7 \mathrm{~mm}$. long, obtuse, more or less serrulate toward the apex, minutely pubescent on both sides, petiolate; stipules thin, papyraceous, broadly deltoid, eiliate at the acute apex; involucres glabrous, axillary, minute; lobes elongate-triangular, ciliate on the margin; glands 4, transversely oral, the fifth replaced by a small extra glabrous tooth on the involucral margin: appendages about the width of the glands, finely manycrenate; capsule strongly tricoccous, glabrous except on the keels of the cocei which bear a fringe of long hairs; seeds pink, elongated-oroid-quadrangular, pointel, $1 \times .5 \mathrm{~mm}$., strongly and sharjly sculptured by numerous, strictly transverse, ridges which include the angles.

Grassy places on New Providence and Grand Turk Island:-Bermuda; North Carolina to Missouri and southward to Brasil and Peru; West Indies. Prostmate SPURGE.

\section{Chamaesyce hirta (L.) Millsp. Field Mus. Bot. 2: 303. 1909.}

Euphorbia hirta L. Sp. Pl. 45t (ante). 1753.

Euphorbia pilulifera L. loc. cit. (post). 1753.

Amual, prostrate or ascending, pubescent with amber-colored, multicellular hairs; stems branehing from the base, 1-4 dm. long, forking or simple. Leaves ovate to oblong-lanceolate, more or less falcate, $1-3 \mathrm{~cm}$. long; sometimes blotched with deep-red, strongly oblique at the luase, acute, sharply serrate above the middle, petiolate; stipules long cylindro-aristate, hairy; involueres densely eapitulate in peduncled clusters, turbinate; lobes large, triangnlar, densely long-ciliate: glanils $t$, stipitate, the fifth replaced by at shallow, rouniled suleus in the inrolucral inargin: appendages none: eapsule strongly 3-coecons, with short crisped multicellular hairs; scerls salnon-pink, elongated-ovoid-quadrangular, $.8 \times .5 \mathrm{~mm}$., the angles sharp, facets strongly marked with numerous, mostly incomplete, transverse ridges.

Rocks, path-sides and cultivated gromnds, Andros and lew l'rovidence to Inagua :- Termuda: Florida: Mexico: West Indies: Central America; American and Old World tropics. HARY SPEncik,

15. Chamaesyce Berteriàna (Balbis) Millsp. Field Mus. Bot. 2: 303.1909.

Euphorbia Berteriana Balbis; Spreng. Syst. 3: 794. 1§26.

A low, prostrate or ascending, denely puleseent annual, with a clustered terminal inflorescence. Leaves oblong-ovate, obtuse, $1-1.5 \times .4-6 \mathrm{~mm}$., strongly inequilateral and oblique at the base, obtusely or crenately denticu. late; stipules eylindro-aristate with a broatened base, glabrous: infloreseence corymbose at the apices of the smaller branclilets; involucres minnte, ohlongturbinate, glabrous below, long-ciliate-hairy at the throat withont and within; 
lobes triangular, ciliate; glands 4, minnte, orbicular, stipitate, with or without narrow white, entire or bi-crenate, appendages; styles thick, bifurcate to the middle, the branehes somewhat swollen at the tips; eapsule erisped-hairy; еосеi distiuet; seed white or pinkish, elongated-ovoid-quadrangular, angles sharp and prominent, facets with a few prominent broad, mostly incomplete, transverse ridges.

Red-lands of Great Exuma, Long lsland, Atwood Cay, Mariguana and Castle Island :-Ilispaniola to Martinique. BErTeno's SPURge.

16. Chamaesyce Brittònii Millsp. Field Mus. Bot. 2: 303. 1909.

Euphorbia Brittonii Millsp. Field Mus. Bot. 2: 159. 1906.

A low, slender, ereet herb branehing from the base, $5-7 \mathrm{~cm}$. high; branches wiry, ascending. Leaves thick, short-petioled, rotund or oblong-elliptie, $4 \times 3$ mm., slightly oblique-cordate, entire or subdentate, revolute, midrib prominent beneath, under surface glaucous, pilose; stipules triangular, more or less equally fimbriate; involueres solitary in the axils, campanulate, pedicellate, glabrous without, densely tomentose at the throat within; glands ovate, greenish; appendages large, orbicular, white; stamens pilose; stigmas bifurcate above; eapsule smooth; seeds roseate-cinereous, ovoid-quadrangular, the ventral angle flattened, facets slightly transverse-rugose.

White-lands near Nassau, New Providence. Endemic. Brutrox's Spunfe.

[Sapium laurifolium Griseb., reported by Dolley as Bahamian, has not been seen on the islands by any of our investigators; his record is presumahly erroneous.]

\section{Order 14. SAPINDÀLES.}

Mostly trees or shrubs. Petals usually present and separate. Sepals mostly distinct. Stamens rarely more than twice as many as the sepals, when as many or fewer, opposite them. Ovary superior, compound. Ovules pendulous, with the raphe away from the axis of the ovary, or erect or ascending.

Petals wanting.

Petals present.

Ovary mostly 1-celled; plants with resin-bearing tissues. Fam. 2. ANacArdiaceaE.

Ovary 2-several-celled.

Leaves simple, pinnately reined.

Ovule 1 in each ovary-cavity.

Orules 2 or more in each ovary-cavity.

Flowers with a disk and petals.

Disk obsolete: corolla wanting.

Leaves compound; fruit various.
Fam. 1, BuxaceaE.

Fam. 3. IlicAceae.

Fam. 4. Celastraceae. Fam. 5. Dodonaeaceae. Fam. 6. SAPINDACEAE.

\section{Family 1. BUXÀCEAE Dumort.}

\section{Box Fanilly.}

Monoecious or dioecious trees, shrubs or perennial herbs, with simple mostly evergreen leaves, the sap not milky. Flowers regular, bracted. Petals none. Staminate flowers with 4-7 distinct stamens, the anthers 2-celled; sometimes with a rudimentary pistil. Pistillate flowers with a 2-4-celled (mostly 3-celled) ovary, with 2 or 1 anatropous ovules in each cavity; styles as many as the ovary-cavities, simple. Fruit a capsule or drupe, its carpels 1-2-seeded. Embryo straight; endosperm fleshy, or almost wanting. About 6 genera and 40 species of both the Old World and the New. 
1. TRICERÀ Sw.; Schreb. Gen. 630. 1791.

Evergreen shrubs or snall trees, with opposite entire coriaceous shortpetioled leaves, and small monoecious flowers in small, axillary or terninal, sessile or short-stalked clusters, the bracts small, herbaceous or coriaceous. Terminal flowers of the clusters usually pistillate, the lower staminate. Pistillate flowers usually with 6 imbricatel sepals, the ovary 3 -celled, the 3 styles separate, or connate below; ovules 2 in each ovary-eavity, pendulous. Staminate flowers with 4 sepals, 4 stamens with oblong anthers and a rulimentary ovary. Capsule 2-3-horned. [Greek, three-horned.] About 23 speeies, natires of the West Indies. Type species: Crantzia laevigata Sw.

* 1. Tricera bahaménsis (Baker) Britton, Bull. N. Y. Bot. Gard. 4: 139. 1906.

Buxus bahamensis Baker, in Ilook. Ic. Pl. 19: pl. 1806. $18 \varsigma 9$.

A much-branched shrub, 1-2 $\mathrm{m}$. high, rarely a small tree about $3 \mathrm{~m}$. high, glabrous throughout, the angulate twigs rather densely leafy. Leares oblong to elliptic, rigid, 2-4 em. long, 2-3 times as long as wille, sharply acute at the apex, narrowed at the base, the midvein rather prominent, the lateral renation very obscure, the petioles $1-3 \mathrm{~mm}$. long; inflorescence axillary, nearly sessile, much shorter than the leares; bracts ovate, acute, 1-2 mm. long; pistillate flomers 1 or few; staminate flowers usually several, pedicelled, about $2 \mathrm{~mm}$. long; stamens longer than the sepals; eapsule $6-7 \mathrm{~mm}$. long; style distinct.

Scrub-lands, pine-lands and coppices, Andros, New Providence, Exuma Cbain, Cat Island to Caicos, Grand Turk and Inagua:-Cuban Cays and Jamaica. Ballays TrICERA.

\section{Family 2. ANACARDIÀCEAE Lindl.}

\section{Sumac Famiry.}

Trees or shrubs, with acrid resinons or milky sap, alternate or rarely opposite leares, and polygamo-dioecious or perfect, mainly regular flowers. Calyx 3-7-cleft. Petals of the same number. imbrieated in the bud. or rarely none. Disk generally annular. Stamens as many or twice as many as the petals, rarely fewer, or more, inserted at the base of the disk; filaments mostly separate: anthers commonly versatile. Ovary in the staminate flowers 1-celled. Ovary in the pistillate flowers 1- or sometimes 4-5celled; styles 1-3; ovules 1 in each cavity. Fruit generally a small drupe. Seed-coat bony or crustaceous; endosperm little or none; cotyledons fleshy. About 60 genera and 500 species, most abundant in warm or tropical regions, a few extending into the temperate zones.

Leaves pinnate or trifoliate; drupes small.

Stone of the subglobose dripe liard. ribbed; our specles a vine. 1. Toricodendron.

Stone of the oblong drupe parchment-like; tree.

Leares simple; drupes large.

2. Metopium.

3. Jangifera.

\section{TOXICODÉNDRON [Tomm.] Mill. Gard. Dict. Abr. Ėl. 4. 1754.}

Shrubs, small trees, or vines climbing by aerial rootlets, with 3 -foliolate or pinnate leares poisonous to the touch, and axillary panieles of small, greenish or white polygamous flowers. Calyx 5-eleft; petals and stamens 5; ovary 1-ovuled; style terminal. Drupes small, glabrous, or sparingly pubescent when young, the stone striate. [Greek, poison-tree] About 20 species, natives of North America and Asia. Trpe species: Rhus Toxicodendron L. 
1. Toxicodendron radicans (L.) Kuntze, Rer. Gen. Pl. 153. 1891.

Thus radicans L. Sp. P1. 266. 1753.

Thus Blodgettii Kearney, Bull. Torr. Club 21: 486.1894.

Toxicodendron Blodgettii Greene, Leaflets 1: 126. 1905.

A woody vine, climbing by numerous aerial rootlets, or bushy and ereet, the stem sometimes $7-10 \mathrm{~cm}$. in diameter. Leares petioled; leaflets ovate or rhombic, 2.5-15 cm. long, entire or sparingly dentate or sinuate, acute or shortacuminate, the lateral sessile or short-stalked, inequilateral, the terminal one stalked; flowers green, $3 \mathrm{~mm}$. broad, in loose axillary panicles $2-8 \mathrm{~cm}$. long; drupes subglobose, $3-5 \mathrm{~mm}$. in diameter, grayish-white.

Moist depressions in pine- and scrub-lands. and in savannas, Andros. Abaco, Great Bahama, North Cat Cay and New Providence:-continental North America, south to Mexico. Recorded by Dolley as Rhus Toxicodendron L. Poison IvY.

\section{METòpium P. Br.; Engler, in DC. Mon. Phan. 4: 367. 1883.}

Poisonous trees, with alternate petioled pinnate leaves, the several leaflets entire, subcoriaceous, the small greenish dioecious flowers in axillary panicles. Sepals 5, imbricated. Petals 5, imbricated, longer than the sepals. Disk ammlar. Stamens 5, the filaments short, subulate, the anthers longitudinally dehiscent. Ovary 1-eelled; style short; stigma 3-lobed; ovule one. Drupe oblong, glabrous, pointed, containing a parchment-like stone. [Greek, forehead, significance not explained.] Three species, natives of the West Indian region. Type species: Rhus Metopium L.

4 1. Metopium toxìferum (L.) Krug \& Urban; Urban, Bot. Jahrb. 21: 612. 1896.

Amyris toxifera L. Syst. ed. 10, 1000. 1759.

A poisonous tree, up to $14 \mathrm{~m}$. high with a trunk sometimes $2 \mathrm{dm}$. in diam. eter, the thin bark reddish-brown without, orange within, splitting into large scales, the branches widely spreading. Leaves $3 \mathrm{dm}$. long or less, glabrous; leaflets $3-\bar{i}$, ovate to suborbicular or obovate, chartaceous, $2.5-10 \mathrm{~cm}$. long, acute, obtuse or emarginate at the apex, narrowed to cordate at the base, bright green and shining above, dull beneath, the petiolules 1-3 cm. long; panicles many-flowered, as long as the leaves or longer; pedicels rather stout, 2-4 mm. long; sepals obtuse, much shorter than the ovate obtuse yellowishgreen petals; drupes oblong, orange-yellow, 1-1.5 cm. long, in spreading or drooping panicles.

Pine-lands and scrub-lands and coppices, throughont the archipelago from Abaco and Great Bahama to Caicos, Inagua and the Anguilla Isles:- Florida: Cuba: Haiti: Porto Rico. Referred by Hitcheock and by Dolley to Rhus Metopium L.: by Irs. Nolthrop to Jetopium II topium (L.) Small. Polsox-Tree. Catesby, 1: pl. 40.

3. MANGİFERA L. Sp. PI. 200. 1753.

Trees, mostly large, with alternate petioled entire coriaceous leaves, and small polygamous flowers in terminal panicles. Calyx 4-5-parted, deciduous, the lobes imbricated. Petals 4 or 5, narrow, imbricated. Stamens $1 \vdash 5$, unequal, all polleniferous or some sterile, the filaments sometimes connate below. Orary sessile, superior, 1-celled, 1-ovuled; style lateral, curved; stigma simple. Drupe ovoid, oblique, large, fleshy, the stone fibrous. Seed flattened, its testa thin, the cotyledons plano-convex, usually lobed, the radicle ascending. [Latin, mango-bearing.] About 14 species, natives of tropical Asia, the following typical. 
1. Mangifera indica L. Sp. Pl, 200. 1753.

A large tree, sometimes $20 \mathrm{~m}$. high or more, with a trunk up to $2.5 \mathrm{~m}$. in diameter, the branches spreading, the stout twigs glabrous. Leaves coriaceous, lanceolate or oblong-lanceolate, $15-25 \mathrm{~cm}$. long, aente, acuminate or sometimes blunt at the apex, narrowed at the base, glabrous, dark green abore, the petioles about $2.5 \mathrm{~cm}$. long; panicles large, terminal, pubeseent, the flowers very numerous, green, about $4 \mathrm{~mm}$. wide; fruit pendnlous, usually $8-12 \mathrm{~cm}$. long, smooth, greenish or yellowish, the flesh soft and juicy.

Wood-lands, New Providence. Naturalized. Native of tropical Asia. Widely naturalized in the West ludies and tropical continental America. MAxGo.

Conocladia ixteginfolia L., recorded by Dolley, has not been found by us on any of the cars or islands of the archipelago; it is only known to inhabit Jamaica and II ispaniola.

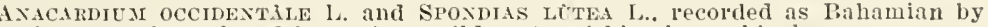
Dolley, have not been found by us in a wild state within the archipelago.

\section{Family 3. ILICÀCEAE Lowe.}

\section{Holly Family.}

Shrubs or trees, with watery sap, and alternate petioled simple leaves. Flowers axillary, small, white, mainly polygamo-dioecions, regular. Stipules minute and deciduous, or none. Calyx 3-6-parted, generally persistent. Petals 46 (rarely more), separate, or slightly mited at the base, hypogynous, deciduous, imbricated. Stamens hypogynous, as many as the petals, or sometimes more; anthers oblong, cordate. Disk none. Orary 1, superior, 3-several-celled; stigma discoid or capitate; style short or none; ovules 1 or 2 in each cavity. Fruit a small berry-like drupe, enclosing several untlets. Seed pendulous; endosperm fleshy; embryo straight. Three genera and about 300 species, of temperate and tropical regions.

\section{1. İLEX L. Sp. Pl. 125. 1753.}

Leares minutely stipulate. Flowers eymose or solitary, perfect or polyg. amous. Calyx small, 4-5-eleft or toothed. Petals 4-9, somewhat united at the base, oblong, obtuse. Stamens of the same number, adnate to the base of the corolla. Berry-like drupe globose, with $4-8$ bony or crustaceous nutlets. [Ancient name of the Holly Oak.] Ahout 280 species, mostly natives of America. Type speeics: Ilex Aquifolium L.

Leaves dark green above, pale beneatl.

l.eaves dalk green above and beneatl.

Jeaves obovate, obtuse or emarginate.

Leaves ovate-cliptic to ovate-lauceolate, acuminate.

\section{I. Cassine.}

2. I. repanda.

3. I. Hrugiana.

1. Ilex Cassìne L. Sp. Pl. 125. 1753.

A shrub, or small tree. Twigs pubescent; leaves oblaneeolate or oblong. obovate, $5-10 \mathrm{~cm}$. long, 1.25-2.5 em. widle, acute at the base, glabrous and dark green above, pale and usually pubeseent beneath; petioles 6-5 mim. long; staminate eymes several- or many-flowered; peduncles and pedicels pubescent; fertile cymes commonly 3-flowered; calyx-lobes eiliate; drupes red, globose, 4-6 mm. in diameter.

I'almetto-lands, and coppices, Great Bahama, at Barnett's l'olnt: Andros, near Staniard Creck:- Virglnia to Florida and Loulsiana; Cuba. D.110or Ilollr. 
2. Ilex repánda Griseb. Mem. Am. Acad. II. 8: 172. 1860.

A shrub or small tree up to $8 \mathrm{~m}$. tall, the leaves and twigs glabrous. Leaves obovate or elliptic-obovate, $4-i \mathrm{~cm}$. long, $2-4 \mathrm{~cm}$. wille, rounded, obtuse or emarginate at the apex, acute at the base, dark-green and shining above, duil beneath, sparingly repand-dentate or entire, the petioles $3-5 \mathrm{~mm}$. long; cymes several-flowered; pedicels $3-5 \mathrm{~mm}$. long, glabrous; calyx obtusely 4-lobed; drupes subglobose or obovoid, about $5 \mathrm{~mm}$. in diameter.

Coppices and scrub-lands, Abaco, Great Bahama, Andros, New Providence and Eleuthera :- Cuba. Recorded by Dolley as Ilcx montana Griseb. Cunan IIoLLY.

\section{Ilex Krugiàna Loes. Bot. Jahrb. 15: 317. 1892.}

A tree, attaining a height of $15 \mathrm{~m}$. and a trunk-diameter of $3 \mathrm{dm}$., usually smaller, and sometimes shrubby, the slender twigs gray, becoming nearly white, the bark thin, smooth, nearly white. Leares elliptic to ovate-lanceolate, chartaceous, 5-10 cm. long, acmminate at the apex, rounded or narrowed at the base, entire, revolute-margined, glabrous, shining above, dull beneath, the slender petioles 1-2 cm. long; flowers few or several in axillary elusters; peduncles abont $1 \mathrm{~cm}$. long; pedicels very short; calyx-lobes triangular, acute; corolla about $2.5 \mathrm{~mm}$. broad, its lobes ovate; drupes purplish, usually containing 4 nutlets, about $4 \mathrm{~mm}$. in diameter.

Coppices, pine-lands and scrub-lands, Abaco, Great Bahama. Andros and New Providence :- Florida; Hispaniola. Recorded by Dolley as Ilex Macoucoua Pers. KRUG'S HOLLY.

Schoepf records a New Providence plant as Ilex cuncata, giving the name only without description or reference, therefore not identified.

\section{Family 4. CELASTRÁCEAE L.}

\section{StAFF-TREe FAMILT.}

Trees or shrubs, some species elimbing. Leares simple. Stipnles, when present, small and caducous. Flowers regular, generally perfect, small. Pedicels commonly jointed. Calyx 4-5-lobed or -parted, persistent, the lobes imbricated. Petals 4 or 5, spreading. Stamens inserted on the disk. Disk flat or lobed. Ovary sessile, mostly 3-5-celled; style short, thick; stigma entire or 3-5-lobed; ovules 2 in each cavity, anatropous. Fruit drupaceous or capsular. Seeds with or without an aril; embryo large; cotyledons foliaceous. About 45 genera, and 375 species, widely distributed.

Fruit a dehiscent capsule; seeds arillate.

Fruit indehiscent; seeds not arillate.

Cells of the ovary 1-ovuled.

Sepals connate near the base.

Sepals distinct or nearly so.

Leares opposite; ovule pendulous.

Leares alternate: orule erect.

Cells of the ovary 2-ovuled.
1. Haytenus.

2. Rhacoma.

3. Gyminda.

4. Sehaefferia.

5. Elaeodendrum.

1. MAYTĖNUs Molina, Sagg. Chile 177. 1782.

Unarmed, evergreen shrubs or trees, with alternate petioled coriaceous serrate leaves, and small polygamous axillary flowers, solitary or in clusters. Calyx 5-lobed. Stamens 5, the filaments subulate. Disk orbicular, undulate. Ovary immersed in the disk, 2-4-celled; orules 1 or 2 in each cavity, erect; style slender or none; stigma 2-4-lobed. Fruit a small coriaceous capsule, 1-3-celled, loculicidally 2-3-valved. Seeds ereet, the testa crustaceous; the aril fleshy; cotyledons foliaceous. [From the Chilean name.] Type species: Maytemus Boaria Molina. 
1. Maytenus lucayàna Britton, Bull. N. Y. Bot. Gard. 4: 140. 1906.

A white-barked shrub, the twigs angular. Leares orbicular-orate, $1.5-3 \mathrm{~cm}$. long, 1.5-2.7 cm. wide, coriaceous, rounded at the apex, cordate at the base, shining above, dull beneath, bright-green, the midrein slender and impressed in both surfaces, the fer lateral veins more slender and similarly impressed, the stout petiole only 1-1.5 mm. long; pedicels solitary or few together at defoliated axils, about $2 \mathrm{mn}$. long; petals not seen; calyx-lobes ovate, acute, nearly $1 \mathrm{~mm}$. long; young fruit ovoid, pointed, tipped by a style $0.5 \mathrm{~mm}$. long; stigmas 2.

Rocky margins of ponds, Great Bahama at West End. Endemic. Bamas MAYTENUS.

\section{Maytenus buxifòlia (A. Rich.) Griseb. Cat. PI. Cub. 53. 1866.}

Monteverdia buxifolia A. Rieh. in Sagra, Hist. Cub. 10: 142, pl. 36.1845.

A shrub or a tree up to $10 \mathrm{~m}$. high, the trunk up to $2.5 \mathrm{dm}$. in diameter, the twigs gray, glabrous, becoming nearly terete. Leaves oblong to obovate or oblong-spatulate, 1-4 cm. Iong, 4-20 mm. wide, coriaceous, obtuse or subtruncate at the apex, obtuse, narrowed, or cuneate at the base, short-petioled, faintly shining above, dull beneath, the midrein impressed on both sides, the lateral venation obsolete; flotrers few in the clusters; pedicels $1-4 \mathrm{~mm}$. Iong; calyxlobes semiorbicular, $0.5 \mathrm{~mm}$. long; petals greenish yellow, nearly $2 \mathrm{~mm}$. long, ovate, obtuse; fruit globose-obovoid, red or orange, $5-9 \mathrm{~mm}$. long.

Thickets and scrub-lands, throughout the archipelago from Abaco and Great Bahama to Caicos and Inagua :-Cuba; Hispaniola. Box-Leaved Maytexus.

\section{RHÁCOMA L. Syst. eđ. 10, 896. 1759.}

Shrubs or low trees, with coriaceous small evergreen leaves, and small perfect greenish axillary flowers. Calyx 4-5-lobed. Disk depressed, 4-5lobed. Petals 4 or 5 , inserted under the disk. Stamens 4 or 5. Ovary 4 celled; stigmas 4 ; ovules 1 in each earity of the ovary, erect. Drupe with a somewhat fleshy, thin exocarp and a bony stone. [Name used by Pliny for some Old World plant.] About 12 species, of warm and tropical America. Type species: Rhacoma Crossopetalum L.

Leaves entire or crenulate.

Inflorescence nearly sessile; leares entire.

Inflorescence slender-peduncled; leaves crenulate at least toward the apex.

Leaves splnulose-serrulate.

Leaves long spinulose-toothed: fruit nearly sessile.

Leaves short spinulose-toothed; fruit slender-pedicelled.

1. R. coriacea.

2. R. Crossopetulum.

3. R. aquifolia.

4. R. ilicifolia.

1. Rhacoma coriàcea (Northrop) Urban, Symb. Ant. 5: 71. 1904.

Crossopetalum coriaceum. Northrop, Nem. Torr. Club 12: 48. 1902.

A low shrub, $6 \mathrm{dm}$. high or less, the quadrangular twigs densely leafy, glabrous. Leaves opposite, coriaceous, glabrous, obovate or oblong-obovate, 1-3 cm. long, 7-12 mm. wide, rouncled or obtuse at the apex, narromed at the base, entire, dull green on both sides; inflorescence 1-5-flowered, sessile or nearly so; calyx-lobes 4, half-orbicular; petals 4 , ovate to orbicular, reddish, $1 \mathrm{~mm}$. long; disk 4-lobed; stamens 4 ; drupe obovoid, red, about $4 \mathrm{~mm}$. long.

Low copplces, sand-dunes and savanuas, Andros, New l'rovldence, Eleuthera, Great Guana. Endemic. limama Riscom.. 
2. Rhacoma Crossopétalum L. Syst. ed. 10, 896. 1759.

Myginda Rhacoma Sw. Proilr. 39. 178s.

Myginda pallens J. E. Smith in Rees Cycl. 25: no. 4. 1813.

Crossopetalum pallens Kuntze, Rev. Gen. Pl. 116. 1891.

Crossopetalum Rhacoma Hitchc. Rep. Mo. Bot. Gard. 4: 70. 1893.

Rhaeoma pallens Maza, Anal. Soc. Esp. Hist. Nat. 19: 239. 1900.

A shrub or tree up to $8 \mathrm{~m}$. high, with smooth grey bark and angular twigs. Leaves opposite or whorled, linear to oblong or obovate, short-petioled, 1-4 cm. long, somewhat crenate, glabrous, acutish or blunt at the apex, narrowed at the base, paler green beneath than above; flowers elustered in the axils, the clusters slencler-peduncled; calyx ureeolate, with 4 obtuse lobes; petals 4 ; disk 4 -lobed; stamens 4 , inserted between the lobes of the disk; ovary 4-celled; drupe about $6 \mathrm{~mm}$. long, slightly oblique, red.

Coppices, thickets and scrub-lands, throughout the archipelago from Abaco and Great Bahama to Grand Turk, Inagua and the Anguilla Isles:-Florida; Bermuda ; West Indies; Colombia. Species composed of a large number of races, the leaf-form from linear-spathulate to suborbicular. Poisox Cherry. Wild Cherr.

3. Rhacoma aquifòlia (Griseb.) Urban, Symb. Ant. 5: 77. 1904.

Myginda aquifolia Griseb. Cat. Pl. Cub. 55. 1866.

Crossopetalum aquifolium Hitche. Rep. Mo. Bot. Gard. 4: 70. 1893.

A shrub, $3 \mathrm{am}$. high or less, branched at the base, the branches prostrate or nearly so, 1-3 dm. long, the young twigs densely pilose. Leaves coriaceous, sessile or very short-petioled, opposite, ovate in outline, 1-3 $\mathrm{cm}$. long, spinulosedentate with long rigid teeth, densely pubertilent on both sides or becoming glabrous above, strongly pinnately veined; inflorescence glomerate, few-flowered, nearly sessile iu the axils; sepals semiorbicular; petals greenish, about $1 \mathrm{~mm}$. long; fruit obliquely obovoid, red, 4-7 mm. long.

Mangrove swamps and pine-lands, Andros and Eleuthera:-Cuba. SPINY-LEAred Rhacona.

4. Rhacoma ilicifòlia (Poir.) Trelease in A. Gray, Syn. Fl. 1²: 399.1897.

Myginda ilicifolia Poir. in Lam. Eneycl. 4: 396. 1796.

Crossopetalum ilicifolium Kuntze, Rev. Gen. Pl. 116. 1891.

Crossopetalum floridanum Gardner; Small, F1. SE. U. S. 736. 1903.

A low, nearly glabrous shrub, $3 \mathrm{dm}$. high or less, branched from the base, the branches ascending or nearly prostrate, 2-4 dm. long, the young twigs puberulent. Leaves subcoriaceous, mostly opposite, very short-petioled, ovate to elliptic, 1-2.5 $\mathrm{cm}$. long, acute at the apex, narrowed or obtuse at the base, pinnately veined, sharply dentate with spinulose-tipped teeth; eymes axillary, short-peduncled, few-several-flowered; sepals half-orbicular; petals red, ovate to suborbicular, 1-1.5 mm. long; fruit obovoid, oblique, $3.5-5 \mathrm{~mm}$. long.

Coppices and pine-lands, Great Bahama:-Florida; Hispaniola. HoLLY-Leaved RнАCONA.

\section{GYMíNDA Sargent, Gard. \& For. 4: 4. 1891.}

Trees or shrubs, with opposite, short-petioled leaves, and small greenish dioecious flowers in axillary cymose clusters. Calyx deeply 4-lobed. Petals 4, longer than the calyx. Staminate flowers with 4 stamens about as long as the petals, and a minute abortive ovary. Pistillate flowers with a 2-celled ovary, each cavity with a single pendulous ovule; style none; stigma peltate. Fruit a small drupe. Seeds usually solitary, with copious endosperm. [Anagram of Myginda.] Two known species, the following typical one, the other Costa Rican. 
1. Gyminda latifỏlia (Sw.) Urban, Symb. Ant. 5: 80. 1904.

Myginda latifolia Sw. Prodr. 39. 1789.

Gyminda Grisebachii Sargent, Gard. \& For. 4: 4. 1891.

A shrub, or a tree with maximum height of ahout $9 \mathrm{~m}$, the thin hark reddish brown, the trunk seldom over $1.5 \mathrm{dm}$. in diameter, the young twigs t-angled, glabrous. Leaves oblong or oblong-oborate; subeoriaceous, glabrons, $2-6 \mathrm{~cm}$. long, obtuse or emarginate at the apex, narrowed at the base, the petioles rery short; peduneles slender, $6-15 \mathrm{~mm}$. long; petals about $2 \mathrm{~mm}$. long; drupe ellipsoid, obtuse, $4-8 \mathrm{~mm}$. long.

Scrub-lands and coppices, throughout the archipelago from Abaco and Great Bahama to Andros, Caicos, Grand Turk and Inagua:-Florida; Cuba to St. Thomas and to St. Vincent; Jamaica; Mexico. Graxda. False Boxwood, Walla-berry.

4. SCHAEFFìriA Jacq. Enum. 10, 33. 1760.

Shrubs or trees, with alternate or fascicled, entire, chartaceous or subcoriaceous leaves (in one species reduced to small scales), and small, mostly dioceious, white or greenish flowers, solitary or clustered in the axils, the peduncles short. Calyx 4-parted, the lobes rounded, imbricated. Petals 4, obtuse. Stamens 4. Dise inconspicnous. Orary sessile, oroid, 2-celled; orules 1 in each carity, erect; style short; stigma 2-parted, large. Fruit coriaceous, indehiscent: Seeds erect, exarillate, with little endosperm and flat cotyledons. [Commemorates J. C. Schaeffer, a German naturalist.] Five known species, of tropical and subtropical America, the following typical.

\section{Schaefferia frutéscens Jaeq. Enum. 33. 1760.}

A tree, up to $14 \mathrm{~m}$. high, with a maximum trunk diameter of about $3 \mathrm{dm}$, usually mueh smaller, commonly a shrub, the thin bark gray, the slender twigs glabrous. Leaves obovate, spatulate or oblong, chartaceous, glabrous, veiny, 2.5-6 cm. long, acute, obtuse or rarely emarginate at the apex, narrowed at the base, the petioles $3-8 \mathrm{~mm}$. long; flowers greenish, about $3 \mathrm{~mm}$. wide; peduncles slender, mostly somewhat longer than the petioles; fruit globose or oval, orange-red, groored, apiculate, 5-6 nm. long.

Scrub-lands, Great Bahama, Andros. New Providence and Eleuthera to Mariguana and Inagna:-Florida; Cuba to Virgin Gorda and Grenada; Jamaica. COMMON SCMIAEFERIA.

\section{ELAEODÉNDRUM Jaeq. f.; Murray, Syst. 241. 17S4.}

Erergreen trees or shrubs, with opposite or alternate coriaceous leares, the rery small stipules carlucous, and small, often dioecious, greenish or white flowers in small axillary clusters. Calyx 5-parted. Petals 5, spreading. Stamens 5, inserted miler the disk; filaments short; anthers globose. Orary alnate to the disk, 2-5-cellerl; style slort; stigma 2-5-lobed, orules 2 in each ovary-cavity. Fruit a rather large drupe. [Greek, olive-wood; the fruit resembles an olive in form.] About 35 species, natives of tropical regions. Type species: Elaeodcndron oricntale Jacq.

1. Elaeodendrum attenuàtum A. Rich. Ess. F7. Cub. 2: 343.1845.

Cassine attcnuata Kuntze, Rer. Gen. Pl. 114. 1891.

Elacodendron rylocarpum bahamense Urban, Symb. Ant. 5: Ss. $190 t$.

A tree, with maximum height of about $16 \mathrm{~m}$., usually much smaller and often shrubby, the bark gray, the twigs and leaves glabrous. Leares pale green, 
oborate to elliptie, 3-S $\mathrm{cm}$. long, remotely low-rlentate or entire, rounded or obtuse at the apex, narrowed at the base, revolute-margined, the stout petioles 2-10 $\mathrm{mm}$. long; flowers greenish yellow; sepals about $1 \mathrm{~mm}$. long; petals about $2 \mathrm{~mm}$. long, those of staminate flowers a little longer than those of pistillate; drupe oroil or subglobose, yellow, pointed or rounded, $1.5-2.5 \mathrm{~cm}$. long, the stone very hard.

Scrub-lands and coppices, Abaco, New Providence, Tatling's Island, Crooked Island, Fortune Island, Grand Turk and Inagua :-Cuba. Referred by Irs. Northrop to $E$. rylocarpum DC. OLITE-WOOD.

\section{Family 5. DODONAEÀCEAE H.B.K.}

\section{DodoNaEa Family.}

Shrubs or trees, commonly sticky with a resinous excretion. Leaves altemate, without stipules. Flowers clustered, polygamous or polygamodioecious. Sepals 3-5. nearly equal. Corolla and disk wanting. Androecium of 5-S regularly inserted stamens; filaments distinet; anthers 4 angled. Gynoecium of 3 or 4 united carpels, wholly superior. Ovary 3-1-celled; styles united. Orules 2 in each cavity, half-anatropous, often superposed, the upper one ascending and the lower one pendulous. Capsule membranous or leathery, reticulated, 2-6-angled, the angles obtuse, or winged. opening septicidally by $2-6$ ralves. Seed subglobose or flattened, without an aril; endosperm none; embryo spiral. Only the following genus.

\section{DODONAÈA Jacq. Enum. 19. 1760.}

Characters of the family, as given above. [In honor of Rembert Dodoens, 151S-1555, Dutch herbalist.] About 50 species, of tropical and subtropical regions. Type species: Dodonaea viscosa Jacq.

\section{Dodonaea Ehrenbérgii Schl. Linnaea 18: 36. 1844.}

Dodonaea viscosa obovata Hitche. Rep. Mo. Bot. Gard. 4: 73. 1893.

A nearly glabrous shrub or small tree sometimes $5 \mathrm{~m}$. high, the foliage slightly riseid, the trigs slender. Leaves oblanceolate to obovate, $1.5-6 \mathrm{~cm}$. long, obtuse, rounded or emarginate at the apex, cuneate-narrowed at the base, the petioles $1 \mathrm{~cm}$. long or less; panicles terminal, rather densely many-flowered, puberulent, not longer than the leaves; pedicels short; flowers yellowish green, about $5 \mathrm{~mm}$. broad; anthers oblong; capsule-wings finely reined, obtuse, 5- $\$$ mm. wide, papery, shining.

White-lands and scrub-lands, throughout the archipelago from Abaco to Grand Turk, Ambergris Cay and Inagua :-Cuba; Hispaniola; Mona; Anegada; Desirade. JOGWOOD.

\section{Family 6. SAPINDĀCEAE.}

\section{SOAPBERRY FAMILY.}

Trees or shrubs, with watery sap, rarely vines. Leaves alternate (opposite in one Chilian genus). nostly pinnate or palmate, without stipules. Flowers polygamo-dioecious. regular or slightly irregular. Sepals or calyx-lobes 4 or 5. mostly imbricated. Petals 3-5. Disk fleshy. Stamens 5-10 (rarely fewer or more), generally inserted on the disk. Ovary 1, 2-4lobed or entire, 2-4-celled; orules 1 or more in each carity. Fruit various. 
Seeds globose or compressed: embryo mainly convolute; endosperm none. About 125 genera, including over 1,000 species, widely distributed in tropical and warm regions.

Vines; mostly climbing by tendrils.

Fruit 3-winged.

Fruit bladdery.

Shrubs and trees.

Finit samaroid.

Fruit drupaceous.

Inflorescence spicate-paniculate or racemose-paniculate. Leares 1-3-foliolate; flowers irregular. Leaves evenly pinnate: flowers regular. Inflorescence corrmbose-paniculate.

Orary 2-celled; leares erenly pinnate.

Orary 3-celled; leaves trifoliolate.

1. Serjania.

2. Cardiospermum.

3. Thyana.

4. Allophylus.

5. Heticocer

6. Exothea.

†. Hypclate.

1. SERJÀNIA Plum.; Schum. Skr. Natur. Selsk. Kjoeb. 3²: 125. 1794.

Woody vines, with alternate petioled, mostly biternately compound leares, and small polygamous white or yellowish flowers, in axillary racemes or panicles, which often bear tendrils. Sepals 5, imbricated. Petals 4, with small scales between. Disk undulate or sometimes glanduliferous. Stamens S, the filaments sometimes united at the base. Orary 3-celled; styles partly united; stigmas 3, small: orules 1 in each cavity. Fruit of 3 samaras attached by their backs, each bearing a seed near the apex. [Commemorates Paul Sergeant.] About 175 species, of tropical and subtropical America. Type species: Serjania sinuata (I.) Schum.

Leaflets strongly reticulate-veined, few-toothed or entire; seed not enclosed in the ring.

1. S. subdentata.

Leaflets nnt strongly reticulate-Feined, dentate; seed encloser in the wing.

2. S. diversifolia.

\section{Serjania subdentàta Juss.; Poir. in Lam. Encycl. 5: 102. 1504.}

Climbing on trees or shrubs, sometimes $7 \mathrm{~m}$. long, usually shorter; young twigs suleate, glabrous, or sparingly pullescent. Leaflets elliptic to oblonglanceolate or orate, coriaceous, $3-8 \mathrm{~cm}$. long, mostly acute or acuminate at the apex, narromed or rounded at the base, sharply dentate with few or several teeth, shining above; panicles commonly longer than the leaves, puberulent; pedicels $2-5 \mathrm{~mm}$. long; petals oborate, about $4 \mathrm{~mm}$. long; fruit $1.2-2 \mathrm{~cm}$. long, the seeds not enclosed in the ends of the samara-wings.

Rocky coppices, sclub-Iands and thickets. Andros, Mangrove Car, New Proridence, Elenthera. Cat Island, Rum ('ar, Great Guana Cas and Great Exuma:-Cuba. Referred by Hitcheock to s. panieulata H.I.K. FowL-Foot.

2. Serjania diversifòlia (Jacq.) Radlk. Mon. Serj. 136. 1875.

Paullinia diversifolia Jacq. Enum. 36. 1760.

Slender, often high-climbing on trees, sometimes $10 \mathrm{~m}$. long, the young trigs puberulent. Leaflets orate to olovate, $3-5 \mathrm{~cm}$. long, coriaceous, acute or obtuse, fer-toothed near the apex or entire, shining above, ilull beneath; panicles puberulent, eommonly longer than the subtending leaves; pedicels $5-8 \mathrm{~mm}$. long: petals oblong-obovate, about $5 \mathrm{~mm}$. long; fruit rather broadly ovate, $1.5-2$ $\mathrm{cm}$. long, the seeds enclosed in the upper part of the samara-wings.

Thickets and scrub-lands, Green Turtle Car, Andros, New Iroridence. Eleuthera, Cat Island, Watling's and Long IsIand:-Cubal; IIspanlola, IReferred by Hitcheock to $S$. lucida Schum, and recorded by Schoepf as Iaullinia Seriana L. FOTLFOOT. 


\section{CARDIOSPÉR.MUM L. Sp. Pl. 366. 1753.}

Vines, with alternate bipinnate or decompound leares, and small axillary tendril-bearing corymbs of slightly irregular polygamo-dioecious flowers. Tendrils 2 to eacl corymb, opposite. Pedicels jointed. Sepals 4, the 2 exterior smaller. Petals 4, appendaged at the base, 2 larger and 2 smaller. Disk 1-silled, unclulate. Stamens 8; filaments unequal. Orary 3-cellerl; style short, 3-cleft; orules 1 in each cavity. Capsule inflated, 3-lobed or 3-angled. Seeds globose with a large hilum; cotyledons conduplicate. [Greek, heart-seed.] About 15 species, of warm and temperate regions. Type species: Cardiospermum Halicacabum L.

Capsules longer than broad, $3-3.5 \mathrm{~cm}$. long. Capsules broader than long, about $1 \mathrm{~cm}$. broad.
1. C. Halicacabum. 2. C. microcarpum.

\section{Cardiospermum Halicácabum L. Sp. Pl. 366. 1753.}

Aunual or biennial, slender, glabrous or slightly pubeseent, $0.6-5 \mathrm{~m}$. long. Leaves petioled, 5-10 cm. long; segments stalked, ovate or oblong, acute or acuminate, sharply serrate; perfuncles commonly longer than the leaves; flowers white, $6-8 \mathrm{~mm}$. broad; petals oborate; filaments pubescent; capsule about $3 \mathrm{~cm}$. long, globose-pyriform, pubescent. seeds globose, nearly black, about $5 \mathrm{~mm}$. thick, the large white hilum cordate.

Scrub-lands and cultivated grounds, New Providence and Eleuthera:- New Jersey to Missouri, Florida, and Texas; West Indies; Mexico to tropical South America. BALLOON-VINE.

2. Cardiospermum microcárpum H.B.K. Nov. Gen. 5: 104.1821.

Climbing to a length of 1.5-3 $\mathrm{m}$., branched, finely pubescent, slender, the stem grooved. Leares thin, Jiternately compound, slender-petioled, $7-15 \mathrm{~cm}$. long and about as broad as long, the ultimate segments orate to lanceolate in outline, coarsely lobed, eleft or incised; peduncles slender, about as long as the leaves; corymbs several-flowered; flowers white, about $4 \mathrm{~mm}$. broad, the upper petals 3 times as long as the sepals; capsule subglobose, 3-lobed, pubescent, veiny, depressed at the top, about $1 \mathrm{~cm}$. thick; seeds similar to those of the preceding species but smaller.

Waste-lands, Abaco and New Providence:-Bermuda; Florida; West Indies; continental tropical America. SArall BaLloox-riNe.

\section{THYÀNA Hamilt. Prodr. 36. 1825.}

[Thounia Poit. Ann. Mus. Paris 3: 70. 1804. Not L. f. 1781.]

Shrubs or trees, with alternate 3-foliolate or 1-foliolate leaves and small, mostly white, regular clustered polygamous or dioecious flowers. Calyx 4-5parted. Petals 4 or 5 or wanting. Dise annular, lobed. Stamens 8-10, distinct, the filaments pilose. Ovary 3-lobed, 3-celled; orules 1 in each cavity; style slender, 3-cleft or entire. Fruit samaroid, the samaras usually 3, coriaceous, at length separating from the axis. Seeds exarillate. [From the Greek name of an odoriferous tree.] About 15 species, natives of tropical America. Type species: Thyana simplicifolia (Poit.) Hamilt.

\section{Thyana díscolor (Griseb.) Hitche. Rep. Mo. Bot. Gard. 4: 72. 1893.}

Thouinia discolor Griseb. Fl. Br. W. I. 127. 1859.

A shrub, up to $2.5 \mathrm{~m}$. high, or a small tree, sometimes $5 \mathrm{~m}$. high, the rather slender twigs and the inflorescence whitish-tomentose. Petioles $2.5 \mathrm{~cm}$. long or 
less, tomentose; leaflets 3, nearly sessile, thin, narrowiy elliptic to obovate, entire, obtuse or rounded at the apex, narrowed or emeate at the base, $2-8 \mathrm{~cm}$. long, glabrous and green above, white-tomentose beneath, or becoming green when old, the midvein ratler prominent, the lateral veins few and slender; racemes many-flowered, peduneled, 2-6 $\mathrm{cm}$. long; pedicels filiform, 4-5 $\mathrm{mm}$. long, single or fascieled; calyx and petals about 1 num. long; samaras glabrous, shining, veiny, obtuse, $\mathrm{S}-10 \mathrm{~mm}$. long.

Rocky coppices and scrub-lands, on the larger islands throughout the archlpelago from Abaco and Great Bahama to Mariguana, Inagua and North Caicos. Endemic. Quicksilver-Busi. NAKED-Wood. HAHD-Birk.

\section{ALLOPHYLUS L. Sp. Pl. 348. 1753.}

Shrubs or small trees, with alternate estipulate 1-3-foliolate leaves, the leaflets broad, usually punctate or lineate, the small subglobose, somewhat irregular, polygamous or dioecious flowers in axillary, simple or compound raremes. Sepals 4 , in 2 pairs, imbrieated, hooled, the outer smaller than the inner. Petals 4, small, or sometimes wanting. Disk unilateral, lober or 4-glandular. Stamens short. Orary excentrie, compressed, 2-celled or rarely 3-celled; orules 1 in each eavity; style stont, 2-3-lobed, or styles 2 or 3 . Fruit small, dry, leathery or fleshy. Seed with a short fleshy aril; cotyledons 2-plicate. [Greek, exotic.] Eighty species or more, mostly of tropieal America. Typo species: Allophylus zeylanicus L.

\section{Allophylus Cominia (L.) Si. Prorlr. 62. 17 SS.}

Rhus Cominia L. Syst. ed. 10, 964. 1759.

A shrub or small tree or sonetimes up to about $15 \mathrm{~m}$. higls, the twigs, petioles, lower leaf-surfaces and infloreseence brownish-tomentose. Petioles rather slender, $2-i \mathrm{~cm}$. long; leaflets 3 , short-stalked, elliptic to orate-elliptic, low-serrate 4-15 cm. long, acute or acuminate at the apex, narrowed or rounded at the oblique base, the lateral ones inequilateral; racemes very slemler, longpeduncled, densely many-flowered, simple or few-branched, 5-s em. long, the flowers fascicled; pedicels $1-1.5 \mathrm{~mm}$. long; flowers greenish yellow, about $1 \mathrm{~mm}$. long; fruits subglobose, about $5 \mathrm{~mm}$. iu diameter, red or orange. PIIYLE.

Coppices, Abaco and Sew Providence:-Cuba; Hispaniola; Jamaica. Allo-

5. MELICóCCA L. Sp. Pl. erl. 2, 495. 1762.

Trees, with alternate estipulate equally pinnate leaves, and small polygamons or dioecious, regular flowers in componm or simple racemes at the ends of the branehes. Calyx $4-5$-lobed, the lohes nearly orlyeular, thin, imbrieated. Petals 4 or 5, obovate or orbieular. Disk flattener, 4-5-loberl. Stamens S; filaments filiform, distinet, glabrous; anthers small. Orary 2-3-eelled; ovules 1 or 2 in each earity; style short; stigma 2-3-lobet. Fruit a somewhat fleshy drupe. Seed ereet, the testa coriaceons, the aril large, pulpy; cotyleulons thick. [Greck, honey-berry.] Two known species, the following typical, the other South American.

1. Melicocca bijùga L. Sp. Pl. er. 2, 495. 1762.

A large tree, sometimes becoming $25 \mathrm{~m}$. high, with a trunk up to $1.7 \mathrm{~m}$. in diameter, the branches sprealing, the slender twigs, the leaves and the inflorescence glabrous. Leaves petioled; rachis winged or wingless; leaflets 2 
pairs, opposite, elliptic or orate-elliptic, thin, 4-10 $\mathrm{cm}$. long, mostly acute or acuninate at the apex, obliquely narrowed at the base, sessile, pinnately veined; racemes uarrow, many-flowered, $6-10$ em. long, often numerons in terminal panicles; pediecls spreading, 4-6 $\mathrm{mm}$. long; flowers very fragrant; calyxsegments about $2 \mathrm{~mm}$. long; petals obovate, obtuse, greenish white, ciliate, $3-4$ min. long; drupe green, edible, pleasantly acid, subglobose, 2-4 cm. in diameter.

New Proridence, apparently spontaneous after cultivation:-West Indies; Central America and northern South America. Gexil.

\section{6. ЕХотнЀA Macf. Fl. Jam. 1: 232. 1837.}

Trees or shrubs, with alternate petioled evenly pinnate leaves, and small white somewhat irregular, dioecious or polygamous, panicled flowers. Sepals 5, partly united, imbricated. Petals 5, short-clawed, unappendaged. Stamens 7 or 5 , those of staminate flowers about as long as the petals, those of pistillate flowers shorter. Orary 2-celled, sessile; orules 2 or 3 in each cavity; style very short, simple, the stigmas glabrous. Fruit a small, globose berry-like drupe, the exocarp slightly fleshy. Seed exarillate. [Greek, to expel, the genus having been taken from Melicocca.] The genus is probably monotypic. Type species: Exothea oblongifolia Maef.

1. Exothea paniculàta (Juss.) Radlk.; Durand Index Gen. Phan. \&1. 1888.

Melicocca paniculata Juss. Mem. Mus. Paris 3: 157. 1517.

IIypelate paniculata Camb. Mem. Mus. Paris 18: 32. 1829.

Exothea oblongifolia Macf. Fl. Jam. 1: 232. 1837.

A tree, attaining a nlaximum height of about $20 \mathrm{~m}$., with a trunk up to 5 $\mathrm{dm}$. thick, the thin, reddish brown bark sealy. Leaves short-petioled; leaflets 2,4 , or 6 (rarely 1 or 3 ), oblong to elliptic-obovate, 5-13 em. long, glabrous or nearly so, entire, dark green and shining abore, pale green beneath, acute, obtuse or emarginate at the apex, narrowed to the nearly sessile base; panicles terminal and axillary, pubescent; sepals orate, about $3 \mathrm{~mm}$. long; petals oblongorate, about as long as the sepals; orary pubescent; drupes 10-13 mm. in diameter, purple, the juicy pulp orange.

Coppices and scrub-lands, Abaco, Great Bahama, Goat Cay, Andros, Eleuthera, Cat Island and Watling's Island:-Florida; Cuba; Jamaica; Hispaniola; Porto Ríco. Butter Bovgh.

7. HYPELÀTE P. Br.; Sir. Prodr. 61. 1788.

A tree or shrub, with alternate 3 -foliolate petioled leaves, and small, white or greenish white, panicled, monoecious or polygamo-dioecious flowers. Sepals 5, imbricated. Petals 5, unappendaged, sessile. Stamens $8-10$ in the staminate flowers, wanting or inperfect in the pistillate; filaments glabrous. Pistillate flowers with a 3 -celled, sessile orary, the style short, the stigmas capitate; orules 2 in each carity, superimposed. Fruit a small drupe, with thin flesh. [Greek name for Ruscus, the Butcher's Broom.] A monotypic genus.

\section{Hypelate trifoliàta Sw. Prodr. 61. 1788.}

A tree, sometimes $13 \mathrm{~m}$. high with a trunk up to $5 \mathrm{dm}$. in diameter, usually smaller, sometimes shrubby, the thin gray bark smooth or nearly so. Petioles $1-5 \mathrm{~cm}$. long; leaflets obovate or spatulate, firm in texture, $2-5 \mathrm{~cm}$. long, entire, glabrous, shining above, rather dull beneath, finely veined, the apex obtuse, 
emarginate or acutish; sepals ovate, ciliate; petals suborbieular, about ㄴ mu. long, ciliate, about as long as the sepals; drupes ovoil, black, $\bar{j}-\bar{r} \mathrm{~mm}$. long.

Copplces and scrub-lands, Indros, New Providence, Eleuthera, Cat Island, Watling's Island, Great Exuma, Long Island, Acklin's Island, Crooked Island, Fortune Island and Inagua:- Florida: Cuba to PoIto Iifco; St. Martin and Anguilla; I:Imaica. WHite Inoxwood. Enowi.

\section{Order 15. RHAMNÀLES.}

Shrubs, vines, or small trees, with nearly always alternate leaves. Flowers small, regular. Sepals mostly more or less united. Petals distinct or wanting. Stamens as many as the sepals or calyx-lobes and alternate with them, opposite the petals when these are present. Orary compound, superior; ovules erect.

Shrubs, small trees, or vines: petals 4 or 5 , or none: fruit a drupe or capsule.

Vines, climbing by teudrils, larely shrubs; petals caducous ; fruit a betry.

Fam. 1. RHAMNACE.AE.

Fam. 2. Vitaceae.

\section{Family 1. RHAMNÀCEAE Dumort.}

\section{Buckthora Family.}

Erect or climbing shrubs, or small trees, often thorny. Leares simple, stipulate, mainly alternate, often 3-5-nerved. Stipules small, deciduous. Inflorescence commonly of cymes or panicles. Flowers small, regular, perfect or polygamous. Calyx-limb 4-5-toothed or 4-5-lobed. Petals 4-5, inserted on the calyx, or none. Stamens 4-5, inserted with the petals and opposite them; anthers short, versatile. Disk fleshy. Ovary sessile, free from or immersed in the disk, 2-5- (often 3-) celled; ovules 1 or 2 in each cavity, anatropous. Fruit often 3-celled. Seeds solitary in the cavities, erect; endosperm fleshy, rarely none; embryo large; cotyledons flat. About 50 genera and 600 species, of temperate and warm regions.

Fruit drupaceous.

Petals none: plants unarmed.

Endosperm ruminated: pit of the drupe thick-walled.

Endosperm none: pit of the drupe thin-malled.

Petals 5 ; young twigs spins.

Fruit dry, separating into nutlets.

3. Sarcomphalus.

Trees and shrubs: fruit seated in the calyx. 4. Colubrina.

Woody vines; nutlets winged.

\author{
1. Reymosia. \\ 2. Krugiodendron \\ 5. Gonaniu.
}

\section{REYNòsia Griseb. Cat. Pl. Cub. 33. 1566.}

Shrubs or small trees, with entire short-petioled opposite leares, and small perfect yellowish green flowers in axillary elusters. Calyx-lobes valvate, spreading. Disk fleshy. Petals none. Stamens 5; filaments subulate. Ovary 2-3-celled; styles short and thick; stigma 2-3-lohed; orules 1 in each eavity, erect. Fruit a drupe with thin flesh and a hard stone. [Dedieated to Alvaro Reynoso, a Cuban chemist and agrieulturist, who dierl in 1SsS.] About 9 species, of the West Indies and Florida. Type species: Reynosia retusa Grisel.

Leares obovate to elliptic: petioles $1 .,-3$ mm. : drupe subglo-

bose or ovill.

1. Li. septentrinnalis.

Leives obloug to lanceolate; petloles $\bar{\tau}-7 \mathrm{~mm}$. : drupe elllpsoid. 2 . R. Sorthropiuna. 
1. Reynosia septentrionàlis Urban, Symb. Ant. 1: 356. 1899.

Reynosia latifolia Chapm. Fl. S. U.S., ed.2, 612. 1883. Not Griseb. 1866.

Usually a shrub, sometimes a tree up to $9 \mathrm{~m}$. high, with a trunk diameter of $2 \mathrm{dm}$, the bark reddish-brown, splitting into thin plates, the mood dense and heavy. Leaves opposite, elliptic to oval or obovate, $2-4 \mathrm{~cm}$. long, coriaceous, glabrous, rounded or emarginate at the apex, narrowed at the base, finely reticulate-veined, revolute-margined, the petioles short; flowers yellowish green, about $5 \mathrm{~mm}$. wide in small axillary nmbels; pedicels $4-5 \mathrm{~mm}$. long; calvx-lobes ovate, acute; drupe oroid, dark purple, $1-1.5 \mathrm{~cm}$. long, tipped with the base of the style, the thin pulp edible, the stone hard.

Scrub-lands and coppices, throughout the archipelago from Great Sturrup Cay, the Biminis and Eleuthera, to Grand Turk, Inagua and Cay Sal :-Florida. Recorded by Hitcheock as Rhamnidium revolutum C. Wright. Comion Rexiosis.

\section{Reynosia Northropiàna U'rban, Symb. Ant. 3: 315. 1902.}

A shrub, 1-2 m. high, the slender young twigs puberulent, soon becoming glabrous. Stipules triangular, connate, lanceolate, 1-2 mm. long; leaves opposite, subcoriaceous, oblong, elliptic or oblong-lanceolate, $3-8 \mathrm{~cm}$. long, 1-2.5 cm. wide, rounded or emarginate at the apex, rounded or narrowed at the base, obsoletely crenate or entire, dark green above, pale green beneath, finely reticulate-veined on both sides, the petioles $3-7$ nim. long: cymes short-peduncled; few-several-flowered; calyx about $2.5 \mathrm{~mm}$. long, its 5 lobes triangular-ovate, acute; petals half-orbicular, emarginate, nearly $1 \mathrm{~mm}$. long; drupe ellipsoid, obtuse, $6-8 \mathrm{~mm}$. long.

Thickets and coppices, Andros, New Providence, Eleuthera, Cat Island and Great Exuma. Endemic. BaHada Reriosia.

\section{KRUGIODENDRON Urban, Symb. Ant. 3: 313. 1902.}

An unarmed evergreen tree or shrub, with entire short-petioled leaves, and small perfect flowers subumbellate in the axils. Calyx mostly 5-parted, the lobes much longer than the tube. Petals wanting. Stamens as many as the calyx-lotes; filaments subulate; anthers obtuse. Dise annular, crenate. Ovary short-conic; style short; stigmas 2, small; ovules 2 . Drupe small, ovoid, the pit thin-walled. Testa of the seed adherent to the endocarp; cotyledons semiglobose, fleshy; endosperm none. [Greek, Krug's tree, in honor of Leopold Krug, a student of the West Indian flora.] A monotypic genus.

1. Krugiodendron fërreum ( $\mathrm{Vahl}$ ) Urban, Symb. Ant. 3: 314. 1902.

Rhamnus ferreus Vahl in West, St. Croix 276. 1793.

Ceanothus ferreus DC. Prodr. 2: 30. 1825.

Scutia ferrea Brongn. Ann. Sci. Nat. I. 10: 363. 1827.

Condalia ferrea Griseb. Fl. Br. W. I. 100. 1859.

Rhamnidium ferreum Sargent, Gard. \& Flor. 4: 16. 1891.

A tree, attaining a maximum height of about $10 \mathrm{~m}$., with a trunk diameter up to $\bar{\partial} d \mathrm{~m}$., usually much smaller, often shrubby, the bark ridged, the branches spreading, the young twigs tomentulose. Leaves mostly opposite, orate to oval, rather thin, $2-5 \mathrm{~cm}$. long, obtuse or emarginate at the apex, rounded or narrowed at the base, bright green above, dull beneath, nearly glabrous when mature, the petioles $3-6 \mathrm{~mm}$. long; flowers yellow-green, about $4 \mathrm{~mm}$. wide, in axillary clusters much shorter than the leaves; ealyx-lobes triangular-orate; stamens a little shorter than the calyx; drupes globose or ovoid, black, $5-8 \mathrm{~mm}$. long, the stone bony.

Coastal scrub-lands and thickets, Lignum Vitae and Great Harbor Cays, South Cat Cay, Andros, New Providence, Eleuthera, Watling's, Freat Guana Cas, Great Exuma, Long Island, Fortune, Crooked, Acklin's and Inagua :-Florida ; Cuba to Porto Rico, Anegada and St. Vincent; Jamaica; Bonaire. 
3. SARCómphalus P. Br.; Raf. Sylva Tell. 29.1838.

Shrubs or trees, often spinescent, with flat glabrous coriaceous entire petioled leaves, and small perfect bractless flowers in terminal panicles. Calyx 5-eleft, the lobes spreading. Petals 5, with a slender claw and a hooded limb. Disk undulate. Stamens 5, distinet, not longer than the petals; anthers extrorse. Orary immersed in the disk, ovoid, superior; styles 2 ; stigma obtuse. Fruit a small, nearly dry, oroid or oblong drupe, the bony pit 2-celled, 2 -seeded. [Greek, fleshy navel.] About 8 species, natives of the West Indies. Type species: Sarcomphalus retusus Raf.

\section{Sarcomphalus Tàylori Britton, Bull. N. Y. Bot. Gard. 3: 445. 1905.}

A glabrous, densely branched shrub, $2 \mathrm{~m}$. high or less, or a tree up to $6 \mathrm{~m}$. high, some of the branches long and prostrate, the bark gray, the twigs green, angied, unarmed, or oceasionally with a spine $1-2 \mathrm{~cm}$. long in the upper axils. Leaves alternate, obovate, bright green on both sides, but a little paler beneath than above, $1.5-2.5 \mathrm{~cm}$. loug, $2 \mathrm{~cm}$. wide or less, emarginate or rounded at the apex, narrowed at the base, 3-nerver just above the base, the veins elevated on the upper surface, and impressed on the lower; petioles about $2 \mathrm{~mm}$. long; flowers in small elusters at the ends of the branches, green, glabrous, $3 \mathrm{~mm}$. broad, on pedicels $2 \mathrm{~mm}$. long; calyx campanulate, 5-lobed, the lobes ovate, acute, $1 \mathrm{~mm}$. long; petals clawed, hooded, about as long as the calyx-lobes and the stamens; ovary oblong, tipped with two slightly divergent styles; fruit oblong, about $8 \mathrm{~mm}$. long.

Low rocky coppices and rocky scrub-lands, Allen's Cay, Rose Island, Eleuthera, Little San Salvador, Cat Island, Conception, Watling's, Ship Channel Cay, Cay north of Wide Opening. Great Exuma, Fortune Island, East Caicos, South Caicos, Grand Turk, Little Inagua and Inagua:-Mona. TAYLoR's Sarcompiralus.

\section{COLUBRINA Rieh.; Brongn. Ann. Sei. Nat. I. 10:368. 1827.}

Trees or shrubs, with alternate, petioled leaves, and small perfect yellow or greenish flowers in axillary elusters. Calyx-tube hemispherie, the 5 lobes spreading. Disk angled or lobed. Petals 5, hooded. Stamens 5, the short filaments slender. Orary immersed in the disk, 3-celled. ovules 1 in each cavity; styles 3 , united below; stigmas blunt. Drupe small, 3-lobed or 3-grooved, splitting into 3 nutlets, its flesh thin. Seeds smooth and shining, the endosperm thin. [Latin, coluber, a serpent.] About 15 species, 1 of them Asiatic, the others of tropical America. Type speeies: Colubrina ferruginosa Brongn.

Leaves thin, elliptic to ovate-lanceolate acute, glabrous, or nearly so. 1. C. rcclinata. Leares thick.

Leaves oblong or elliptic, velutinous on both sides.

Leaves orate to elliptic, pointed, smooth above. ferruginous beneath.

2. C. cubcusis.

3. C. colubrina.

1. Colubrina reclinàta (L'Her.) Brongn. Ann. Sci. Nat. T. 10: 369. 1527.

Ceonothus reclinatus L'Her. Sert. Angl. 6. 17 SS.

A tree, sometimes $20 \mathrm{~m}$. high with a trunk diameter up to $1.5 \mathrm{~m}$., usually much smaller, with orange-brown furrowed hark which exfoliates in thin layers, the young twigs finely pubeseent. Leaves elliptic to ovate-laneeolate, rather thin, 4-S cm. long, acute or bluntish at the apex, rounded or narrowed at the 2-glandular base, the slender petioles 5-15 mm. long; flower-clusters pubeseent, 
as long as the petioles or shorter; calyx-lobes acute; petals hooded, shorter than the calyx-lobes; style slender; fruit globose, orange-red, $8-10 \mathrm{~mm}$. in diameter.

Rocky scrub-lands and coppices, Andros, Mangrove Cay, New I'rovidence, Eleuthera, Cat Island, I.ong Island and Grand Turk:-Florida ; Cuba to Anegada and to Martinique; Jamaica. Smootil Sxake-L.kк. Catesby, 1: $p l .10$.

2. Colubrina cubénsis (Jacq.) Brongn. Ann. Sci. Nat. I. 10: 369. 1827.

Rhamnus cubensis Jacq. Enum. 16. 1760.

Ceanothus cubensis Lam. Tabl. Eneye. 2: 90. 1797.

A shrub or a small tree up to $5 \mathrm{~m}$. high, the twigs, leares, and inflorescence densely relvety-pubescent. Leaves oblong or elliptic, $4-10 \mathrm{~cm}$. long, $1-\overline{\mathrm{cm}}$. wide, rather thick, rounded or acute at the apex, rounded or obtuse at the base, strongly pinnately veined, the petioles $5-15 \mathrm{~mm}$. long; flower-elusters peduncled, longer than the petioles; pedicels 4-9 $\mathrm{mm}$. long; calyx densely pubescent, its lobes triangular-ovate, acute, about $2 \mathrm{~mm}$. long; petals yellow, about as long as the ealyx-lobes; fruit globose, about $7 \mathrm{~mm}$. in diameter.

Scrub-lands, Andros, near Nicoll's Town:-FIorida; Cuba; Hispaniola. Cuban SXAKE-BARK.

3. Colubrina colubrìna (Jacq.) Millsp. Field Mus. Bot. 2: 69. 1900.

Thammus colubrinus Jacq. Enum. 16. 1760.

Colubrina ferruginosa Brongn. Ann. Sei. Nat. I. 10: 369. 1827.

?Celastrus ovata Hill, Veg. Syst. 13: 62, pl. 12. 1768.

A shrub or tree, $8 \mathrm{~m}$. high or less, or in Jamaica sometimes forming a tree up to $15 \mathrm{~m}$. high, the twigs and young leaves brownish tomentulose. Leaves ovate to elliptie, subcoriaceous, 5-10 cm. long, obtusish, acute or short-acuminate at the apex, rounded or subcordate at the base, the pubescent petioles 5-20 mm. long, the upper surface glabrous when mature, the under surface permanently tomentulose; flower-clusters pubescent, mostly shorter than the petioles; calyx-lobes ovate, obtuse; petals spatulate, yellow, shorter than the ealyx-lobes, notched; fruit obovoid-globose, $8-9 \mathrm{~mm}$. in diameter, nearly black.

Rocky coppices, scrub-lands and pine-lands, Abaco, Great Bahama, Andros, Green Cay, New I'rovidence, Cat Island, Rum Cay, Great Exuma, Long Island, Great Ragged Island, Acklin's, Mariguana, Inagua, Anguilla Isles, Car Sal and Grand Turk:-Florida; Cuba to Virgin Gorda, St. Croix and Saba; Barbadoes; Jamaica; Cayman Islands. Commox SNAlie-BARl., BitTers.

5. GOUÀNIA Jacq. Stirp. Sel. Am. 263. 1763.

Woody vines, climbing by tendrils, with alternate petioled broad leares, and small polygamous flowers in panicled spikes or narrow racemes. Calyx obconic, with 5 spreading lobes. Disk 5-angled or 5-horned. Petals 5, hooded. Stamens 5, short. Ovary immersed in the disk, 3-celled; ovules 1 in each carity; styles 3 , united at the base; stigmas very small. Fruit dry, 3-winged, separating into 3 nutlets. Seeds shining. [Commemorates Antoine Gouan, 1733-1821, professor in Montpellier.] Type species: Gouania tomentosa Jacq.

1. Gouania lupuloìdes (L.) Urban, Symb. Ant. 4: 378. 1910.

Banisteria lupuloides L. Sp. Pl. 427. 1753.

Gouania domingensis L. Sp. Pl. ed. 2, 1663. 1763.

Gouania glabra Jaeq. Stirp. Sel. Am. 264. 1763.

A woody vine, sometimes $7 \mathrm{~m}$. long, climbing by coiled tendrils, the branches glabrous below, loosely pubescent above. Leaves ovate to elliptic, thin, 3-9 em. long, glabrous or sparingly pubescent, serrate with blunt teeth, 
acute or short-acuminate at the apex, subcordate or rounded at the base, the veins slender, the petioles $5-15 \mathrm{~mm}$. long; racemes slender, pubescent, $\overline{5}-15 \mathrm{cul}$. long; pedicels elustered, pubescent, 1-3 mm. long; calyx pubescent, about 1.5 $\mathrm{mm}$. long; corolla yellowish, $2-3 \mathrm{~mm}$. wide, the petals ovate, acute; fruit reticulate-reined, 3-minged, $8-10 \mathrm{~mm}$. broad including the wings which are broader than the body, rarely wingless.

Coppices, Andros, New Irovidence:-Florida; Cuba to Tortola and Grenada; Jamaica; continental tropical America. CHew-stick.

\section{Family 2. VITÀCEAE Lindl.}

\section{Grape Family.}

Climbing vines or erect shrubs, with copious watery sap, nodose joints, alternate petioled leaves, and small regular greenish perfect or polygamodioecious flowers, in panicles, racemes or ermes. Calyx entire or 4-5toothed. Petals 4-5, separate or coherent, valvate, caducous. Filaments subulate, inserted at the base of the disk or between its lobes; disk sometimes obsolete or wanting; anthers 2-celled. Ovary 1, generally immersed in the disk, 2-6-celled; ovules 1-2 in each cavity, ascending, anatropous. Fruit a 1-6-celled berry (commonly 2-celled). Seeds erect; testa bony; raphe generally distinct; endosperm cartilaginous; embryo short. About 10 genera and over 500 species, widely distributed.

\footnotetext{
Hypogynous disk of the flower annular or cup-shaped; leaves simple or 3-foliolate.

Petals cohering into a caducous cap. $\quad 1$. Titis.

Petals distinct, spreading. 2 . Cissus.

Hypogynous disk wanting or obsolete; leares digitately 5-7-

foliolate in our species.

3. Parthcnocissus.
}

\section{VİTIS [Tourn.] L. Sp. Pl. 202. 1753.}

Woody vines, rarely shrubby, mostly with tendrils. Leaves simple, usually palmately lobed or dentaté. Stipules mainly small, caducous. Flowers mostly dioecious, or polygamo-dioecious, rarely perfect. Petals hypogynous or perigynous, coherent in a cap and deciduous without expanding. Disk annular or cup-shaped. Ovary 2-celled, rarely 3 -4-celled; style very short, conic; orules 2 in each carity. Berry globose or oroid, few-seeded, pulpy, edible in most species. [The ancient Latin name.] About 40 species, natives of marm and temperate regions. Type species: Titis vinifera L.

1. Vitis Munsoniàna Simpson; Planch. in DC. Monogr. 5: 615. $18 s 7$.

- Muscadinia Munsoniana Small, Fl. SE. U. S. 757. 1903.

A vine up to $6 \mathrm{~m}$. long or more, the young twigs glabrous, the bark smooth, the pith continuous through the nodes. Leares suborbicular or reniform, thin, but rather firm in texture, 4-8 cm. broad, coarsely dentate, cordate at the base, glabrous above, pubescent in the axils of the reins beneath, the petioles as long as the blades or shorter; tendrils simple, very slender when young; panieles 2-8 $\mathrm{cm}$. long; berries globose, $1-1.5 \mathrm{~cm}$. in diameter, nearly black, acid, the skin thin, the seeds $3-5 \mathrm{~mm}$. long.

Copplces, pine-lands and scrub-lands. Abaco, Great Bahama, Andros, New Irovldence:- Georgia; Florida. Reported by Dolley as IIItcheock, Coker and II's. Northrop as rotundifolia Mlchx. WILD GMIE. 


\section{CÍssus L. Sp. Pl. 117. 1753 .}

Mostly elimbing vines with fleshy foliage. Leaves 3 -foliolate or simple, when compound the leaficts commonly separating in drying. Flowers mostly perfect. Petals usually 4, spreading. Disk cup-shaped, adnate to the base of the orary, mostly 4-lobed. Disk cup-like, 4-lobed. Stamens 4. [Greek, iry.] A large genus, mostly tropical. Type species: Cissus vitiginea L.

Leares simple.

Leaves trifoliolate.

Fruit tubercled: leaflets $3-6 \mathrm{~cm}$. long.

Fruit smooth: leaflets $1-3 \mathrm{~cm}$. long.

Leaflets orate to oborate, deeply and sharply serrate, very fleshy.

Leaflets oblong to oblong-lanceolate, sparingly toothed, slightly fleshy.
1. C. sicyoides.

2. C. tuberculata.

3. C. trifoliata.

4. C. intermedia.

\section{Cissus sicyoìdes L. Syst. ed. 10, 897. 1759}

A rine, climbing to a height of $6 \mathrm{~m}$. or more, the foliage pubescent or nearly glabrous. Leaves simple, petioled, ovate or ovate-oblong, 2-8 cm. long, acute or acuminate at the apex, truncate or cordate at the base, serrate, the teeth acute or bristle-tipped, the petioles 1-4 cm. long; tendrils slender, often as long as the leaves; cymes peduncled; berries subglobose, black, $8-10 \mathrm{~mm}$. in diameter; seeds $4-5 \mathrm{~mm}$, long.

Rocky coppices and scrub-lands, Andros, New Providence and Eleuthera:-Bermuda; Florida; the Test Indies and continental tropical America. Commox Cissus.

\section{Cissus tuberculàta Jacq. Hort. Schoen. 1: 14. pl. 32. 1797.}

A somewhat woody, rather fleshy vine, up to $6 \mathrm{~m}$. long or longer, glabrous or nearly so, the stemis usually tuberculate. Leares long-petioled, 3-foliolate; leaflets orate to elliptic or oblong-lanceolate, 3-6 cm. long, obtuse or acute at the apex, narrowed or rounded at the base, low-serrate or nearly entire, the lateral ones oblique; cymes compound, slightly and sparingly pubescent; pedicels $10 \mathrm{~mm}$. long or less; petals red or pink, reflexed, ovate, acute; berry oboroid, tubercled or at length smooth, black, $6-8 \mathrm{~mm}$. in diameter.

Rocky open places and coppices, Great Bahama, Andros, New Providence and EJeuthera:-Cuba. Reported by Mrs. Northrop and by Coker as C. microcarpa Vahl. WARTY Cissus. Catesby, 2: $p l$. 48.

3. Cissus trifoliàta L. Syst. ed. 10, 897. 1759.

Sicyos trifoliata L. Sp. Pl. 1013. 1753.

Cissus acida L. Sp. Pl. ed. 2, 170. 1762.

A very fleshy vine up to $5 \mathrm{~m}$. long, glabrous throughout. Leares 3 -foliolate; leaflets orate to obovate or suborbicular, 1-3 $\mathrm{cm}$. long, sharply toothed abore the middle, narrowed or cuneate at the base; flowers in compound cymes; berries globose to ovoid, dark purple, apiculate, $5-7 \mathrm{~mm}$. in diameter, the fruiting pedicels recurved; seeds obovoid.

Rocky plains and scrub-lands, Long lsland. Acklin's, East Caicos and Little Inagua :-Florida ; Jamaica ; Cuba to Virgin Gorda and St. Croix; lecorded south to Martinique and from northern South America. THick-LEAved Cissus.

4. Cissus intermédia A. Rich. Ess. Fl. Cub. 1: 311. 1845.

A slender, slightly fleshy vine, sometimes $2 \mathrm{~m}$. long or longer, the branches and leaves glabrous, the stems and branches sometimes warty or tuberculate. Leares slender-petioled, trifoliolate; leaflets oblong to oblong-lanceolate, 1.5-3 cm. long, mostly acute, sparingly serrate, the terminal one equilateral, 
mostly cumeate-narromed at the base, the lateral ones oblique; cymes conipound, glabrous; pclicels 2-6 mm. long; petals red, reflexed, ovate-lanceolate, acute; berry subglobose, black, about $7 \mathrm{~mm}$. in diameter, smooth.

Rocky places, Andros, New Irovidence, Eleuthera, Grand Turk:--Cuba. Recorded by Mrs. Northrop as Cissus sp. BeLL-VINE.

3. PARTHENOCISSUS Planch. in DC. Mon. Phan. 5² 44i. 1887.

Woody vines, the tendrils often tipped with adhering expansions (disks), or sometimes merely coiling, our species with digitately compound leaves. Flowers perfect, or polygamo-monoecious, in compound cymes or panicles. Petals 5, spreading. Stamens 5. Orary 2-celled; ovules 2 in each carity; style short, thick. Berry 1-4-seeded, the flesh thin, not edible. About 10 species, natives of Eastern North America and Asia, the following typical.

1. Parthenocissus quinquefòlia (L.) Planch, iıı DC. Mon. Phan, 5²: 448, 1887.

Hedera quinquefolia L. Sp. Pl. 202. 1753.

Ampelopsis quinquefolia Michx. Fl. Bor. Am. 1: 160. 1803.

Parthenoeissus quinquefolia latifolia Rehder, Trees and Shrubs 1: 184. 1905.

Tendrils usually -numcrous, and provided with terminal adhering expansions, the vine sometimes supported also by aerial roots; leaflets oval, elliptic, or oblong-lanceolate, $5-15 \mathrm{~cm}$. long, narrowed at the base, coarsely toothed, at least above the middle, glabrous or somemhat pubescent; panicles ample, erect or spreading in fruit; berries blue, 6-10 $\mathrm{mm}$. in diameter, usually 2-3seeded; peduncles and pedicels red.

Coppices and scrub-lands, Abaco, Great Pahama, Andros, New Providence, Great Exuma :- Quebec to Manitoba: Florida and Mexico; Bermuda; Cuba. Consists of several races. Virginia Crieper.

\section{Order 16. MALVÀLES.}

Herbs, shrubs or trees, with simple, mostly alternate leaves. Flowers regular, usually perfect. Sepals separate, or more or less united, valvate. Petals separate, very rarely wanting. Stamens usually numerous. Ovary superior, compound, the placentae united in its axis. Disk inconspicuous or none.

Stamens twice as many as the sepals, or more.

Stamens in several sets; anther's -celled; embryo straiglit. Fam. 1. TilidcesE.

Stamens monadelphous: anthers 1 -celled; embryo curved.

Style branches as many or twice as many as the carpels or ovary-cavities.

Style entire, or merely lobed.

Fam. 2. MALNACE.H.

IVIM. 3. BOMBACACEAE,

Stamens as many as the sepals.

Fam. 4. S'TERCLLIACEAE.

\section{Family 1. TILIÄCEAE Juss.}

\section{LINDEN FAMILY.}

Trees, shrubs or herbs, with alternate (rarely opposite) simple leaves, mostly small and deciduous stipules, and solitary cymose or paniculate, nsually perfect fiowers. Sepals .j, rarely 3 or 4 , valvate, deciduous. Petals of the same number, or fewer, or none, mostly imbricated in the bud. Stamens $\infty$, mostly 5-10-adelphous. Ovary 1, sessile, 2-10-celled; ovules 
anatropous; styles united. Fruit 1-10-eelled, drupaceous or baceate. Cotyledons ovate or orbicular; endosperm fleshy, rarely wanting. About 35 genera and 275 species, widely distributed, the Bahama speeies herbs or low shrubs.

Fruit a loculicidal capsule without prickles.

Fruit indehiscent, prickly, separating into its carpels at maturity.

1. Corchorus.

2. Triunfetta.

\section{CóRCHORUS [Touru.] L. Sp. Pl. 529. 1753.}

Herbs or low shrubs, with alternate serrate leaves, and yellow, solitary or clustered flowers, axillary or opposite the leaves. Sepals and petals 5, rarely 4. Stamens twice as many as the petals or more numerous; filaments filiform, simple; anthers introrse. Orary superior, 2-5-celled; ovules numerous in each carity; stigma dilated, undulate. Capsule linear or oblong, many-seeded. [Greek, for some bitter plant.] About 40 species of tropical and subtropical distribution. Type species: Corchorus olitorius L.

Capsule glabrous or pubescent.

Capsule 5-celled, with 5 short points; basal serratures of leaves long-bristled.

Capsule 2-celled, with 2 bifid teeth; basal serratures of leaf not bristled.

Capsule densely woolly.

1. C. olitorius.

2. C. siliquosus. 3. C. hirsutus.

\section{Corchorus olitòrius L. Sp. Pl, 529. 1753.}

Herbaceous, glabrous, $1.5-3 \mathrm{~m}$. high. Stipules setaceous, 1-2 cm. long; leaves oblong-lanceolate or ovate-oblong, $5-12 \mathrm{~cm}$. long, acute or acuminate at the apex, mostly obtuse at the base, serrate all around, the basal teeth recurved, tipped by a filiform appendage 1-2 cm. long; flowers mostly solitary at the nodes, short-peduncled; sepals 5-6 mm. long, subulate-tipped; petals a little longer than the sepals; capsule linear, 4-5 cm. long, 3-4 mm. thick, 5-celled, tipped by 5 short teeth, its cells septate.

Waste and cultivated land. naturalized. New Providence. near Nassau:-Naturalized from tropical regions of the old World; also in Jamaica and Trinidad. ixdia Corchores. Graxigrais.

\section{Corchorus siliquòsus L. Sp. Pl. 529. 1753.}

Shrubby, branched, 3-10 dm. high, glabrous, or the young branches and leares puberulent or pubescent, the branches often with a line of hairs. Leaves ovate to oblong-lanceolate, $1-5 \mathrm{~cm}$. Jong, serrate, acute or acuminate at the apex, mostly rounded or obtuse at the base, the short petioles slender; flotiers solitary or 2 together, short-peduncled, the pedicels about as long as the peduncles; sepals linear, acute, about $6 \mathrm{~mm}$. long; petals obovate, about $5 \mathrm{~mm}$. long; capsule linear, glabrous, or when young somewhat pubescent, 5-8 em. long; about $3 \mathrm{~mm}$. thick, 2 -celled, tipped by 2 short bifid teeth.

Waste and cultivated land, coppices aud scrub-lands, Abaco, Andros, Great Bahama. New Proridence, Eleuthera, Crooked Island, Acklin's, Fortune Islands and Torth Caicos:-Florida; Cuba to Tortola and Trinidad; Texas to Colombia and Guiana; Jamaica. Ssooth Corchorus.

\section{Corchorus hirsùtus L. Sp. Pl. 530. 1753.}

A shrub, $2 \mathrm{~m}$. high or less, usually erect, but on rocks sometimes nearly prostrate, the young twigs, the leaves and the inflorescence densely pale scurfytomentulose. Leaves short-petioled, orate to oblong-lanceolate, crenate-dentate, 2-6 cm. long, mostly obtuse; flowers in small umbels opposite the leaves, the peduncle about as long as the pedicels; sepals tomentulose, 5-6 $\mathrm{mm}$. long; 
petals obovate, bright yellow, about as long as the sepals; capsule oblong, densely tomentose, obtuse, 4-celled, as long as the eurved pedicels or longer, about $6 \mathrm{~mm}$. thick.

A common shrub in pastures, coppices and scrub-lands, throughout the archi. pelago from Abaco, Great Bahama and Andros to Grand Turk and Inagua :- West Indies; Mexico to tropical south America. Recorded by Dolley as Cenchrus hirsutus. WOOLLY CORCHORUS. MALLET. JaCK SWitch.

\section{TRIUMFETTA L. Sp. Pl. 444. 1753.}

Herbs or low shrubs, with alternate broad petioled leaves, and yellow clustered flowers, axillary or opposite the leaves. Sepals 5. Petals 5, pitted at the base, or wanting in some species. Stamens numerous, borne on an elongated receptacle, the filaments filiform, the anthers introrse. Ovary borne in the cup-shaped top of the receptacle, 2-5-celled; stigma 2-5-lobed; orules 2 in each carity. Capsule subglobose, echinate. [In honor of G. B. Triumfetti, an Italian botanist.] About 70 species, of trcpical and warm regions. Type species: Triumfetta Lappula L.

\section{Triumfetta semitríloba Jacq. Enum. 22. 1760.}

Triumfetta althaeoides Lam. Encyel. 3: 420. 1791.

Annual, stellate-tomentulose. Stems 1-1.5 m. tall, branched; leaves orate, rhombic or suborbicular in outline, $3-6 \mathrm{~cm}$. long, serrate, angulate or often 3 -lobed, rounded or truncate at the base; petioles as long as the blades or shorter; panicles narrow, elongated; sepals lanceolate, 5-6 $\mathrm{mm}$. long, appendaged below the apex; petals cuneate-spatulate, slightly pubescent at the base; stamens often 15; fruit 1-5 mm. in diameter, 2-celled, copiously prickly, the prickles about as long as the diameter of the body, hooked at the apex.

A weed in waste and cultirated land, Abaco, Andros, New Providence, Eleuthera and Thatling's Island :- Bermuda: Florida; West Indies; continental tropical America. A species represented by many races, differing in leaf-form and in minor intermixed characters. Burm Busin.

\section{Family 2. MALVÀCEAE Neck.}

\section{MaLlow Familt.}

Herbs or shrubs (sometimes trees in tropical regions), with alternate leaves. Stipules small, deeidnous. Flowers regular, usually perfect, often large. Sepals 5 (rarely 3 or 4), more or less united, usually valvate; calyx often bracted at the base. Petals 5, hypogynous. convolute. Stamens $\infty$. hypogynous, forming a central column around the pistil, united with the bases of the petals; anthers 1-celled. Ovary sereralcelled: styles united below, distinct above, and generally projecting bevond the stamen-column, mostly as many as the eavities of the ovary. Fruit capsular (rarely a berry), several-celled, the earpels falling away entire or else Ineulicidally dehiscent. Seerls reniform. globose or obovoid: embryo curved; cotyledons lar@e, plicate or conduplicate. About 45 genera and 900 species, widely distributed.

Fruit of several or many radiately arranged earpels which mostly separate from each other at maturity.

Carpels as many as the stigmas. Carpels 2-several-seeded.

Involucre present.

1. Phymosia. 
Involuere none.

Carpels leathery or chartaceous.

Carpels membranous, bladdery.

2. Abutilon.

Carpels only 1 -seeded.

Flowers with an involuere.

Flower's without an involucre.

Carpels separating at maturity. Carpels permanently united.

Carpels half as many al the stigmas.

Carpels dry, achene-like.

Carpels with a dorsal spine.

Carpels not spined.

Carjels fleshr, the fruit drupe-like.

Fruit a loculicidal capsule, or rarely indehiscent.

Strles distinct.

Herbs and shrubs; capsule without false partitions.

Calyx j-toothed or j-cleft.

Calyx spathaceous.

Tree; capsule with false partitions.

Styles united.

Bractlers of the involucre entire, small : fruit indehiscent.

Bractlets of the involucre lacinate, large ; capsule loculicidally dehiscent.

3. Gayoides.

4. Halvastrum.

5. Sida.

6. Bastardia.

7. Paronia.

8. Malachc.

9. Halvariscus,

10. Itibiscus.

11. Abelmoschus.

12. Puriti.

13. Thespesia.

14. Gossypium.

1. PHYMòsIA Desv. in Hamilt. Prodr. 49. 1825.

Herbs or shrubs. Bractlets 3 , distinct, or united at the base. Stamencolumn anther-bearing at the summit. Cavities of the ovary $5-\infty, 2-3$-ovuled. Style-branches the same number as the ovary-cavities, stigmatic at the apex; carpels 2-valved, not septate between the seeds, separating from the axis at maturity. Seeds reniform. [Greek, swollen, referring to the somewhat inflated carpels of the following typical species.] About 40 species, natives of America and South Africa.

1. Phymosia abutiloìdes (L.) Desv. in Hamilt., Prodr. 50. 1825.

Malva abutiloides L. Sp. Pl. ed. 2, 971. 1763.

Sphaeralcea abutiloides G. Don, Gen. Hist. 1: 465. 1831.

Abutilon Eggersii E. Baker, Jour. Bot. 31: 75. 1893.

An erect, sparingly branched shrub up to about $3 \mathrm{~m}$. high, densely stellatetomentose. Leaves nearly orbicular in outline, the lower often $2 \mathrm{dm}$. broad, sharply 5-7-lobed, the lobes serrate, acute or acuminate, the stout petioles shorter than the blades; upper leares much smaller; flowers corymbose in the upper axils, or forming a terminal panicle; involucel-bractlets linear, deciduous, shorter than the calyx; calyx 5-toothed, its teeth triangular-ovate, acute; petals pink or rose, white-veined, red-streaked at base, 1-1.5 cm. long; carpels about 20 , stellate-tomentose on the back, at length glabrous, reniform, obtuse, $1 \mathrm{~cm}$. long; seeds black.

Scrub-lands and coppices, Abaco. Great Babama, New Providence, Eleuthera. Endemic. Bahasia Physosia. Catesby, $1: p l$. $\pi$.

\section{AвÙTILON [Tourn.] Mill. Gard. Dict. Abr. Ed. 4. 1754.}

Herbs or shrubs, sometimes trees in tropical countries, mostly soft-pubescent, with cordate angular or lobed leaves and axillary flowers. Involucels

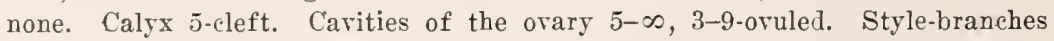
the same number as the ovary-carities, stigmatic at the apex; carpels 2-valved, often rostrate, falling away from the axis at maturity. Seeds reniform, the upper ascending, the lower pendulous or horizontal. [Name given by the celebrated Arabian physician Aricenna (Ibn Sina), died 1037.] About 100 species, natives of warm and tropical regions. Type species: Sida Abutiton L. 
Carpels $15-30$, thin, merels acute.

Carpels $\overline{5}-10$, chartaceous to coriaceous, subulate-beaked.

Carpels attenuate-beaked, tlower's $2-2.5 \mathrm{~cm}$. broad.

Leaves not strongly reticulate-veined beneath; carpels 1 $\mathrm{cm}$. long.

Leaves distinctly reticulate-reined beneath; carpels 1.5 $\mathrm{cm}$. long.

Carpels abruptly minutely beaked.

CarpeIs puberulent.

Carpels villous.

1. A. hirtum.

2. A. permolle.

3. A. abutiloides.

4. A. trisulcutum.

5. A. puuciftorum.

1. Abutilon hírtum (Lam.) Sweet, Hort. Brit. 1: 53. 152 .

Sida hirta Lam. Encycl. 1: 7.1783.

Abutilon indicum hirtum Griseb. Fl. Br. W. I. 7S. 1859.

Perennial, velvety-canescent and rillons-viscid, branched, 1-5 dm. high. Leaves ovate or nearly orbicular, $15 \mathrm{~cm}$. long or less, cordate at the base, irregularly crenate, the petioles as long as the blades or shorter; peduncles mostly shorter than the petioles, sometimes as long; calyx somewhat enlarged in fruit, its orate lobes acute or acuminate; petals yellow, commonly with a purple base, $1.5-2 \mathrm{~cm}$. long; carpels $15-30$, very thin, a little longer than the calyx, $8-10$ mm. long, mueronulate.

Waste lands, Harbor Island; New Providence (?) :-Florida; Cuba to st. Thomas and Barbadoes: Jamaica; Old World tropics. Recorded by Dolley as Abutilon indicum G. Don. HAlRY ABUTILOX.

\section{Abutilon permólle (Willd.) Sweet, Hort. Brit. 1: 53. 152\%.}

Sida permollis Willd. Enum. Hort. Berol. 723. 1809.

Perennial, velvety, $0.6-1.5 \mathrm{~m}$. high, branched, the branches slender. Leares orate, $2.5-10 \mathrm{~cm}$. long, acuminate at the apex, rather deeply cordate at the base, erenulate, white-tomentulose beneath, the petioles as long as the blades or shorter; calyx scarcely enlarged in fruit, its ovate or ovate-lanceolate, acuminate lobes longer than the tube; petals yellow, obovate, $1-1.5 \mathrm{~cm}$. long. carpels $\tau-10$, slender-beaked, longer than the calyx, nearly $1 \mathrm{~cm}$. long.

Waste places and scrub-lands, Little Harbor Cay, New Providence, Elenthera, Little San Salvador, the Exumas to Long Island, Crooked Island, Fortume Island, Inagua, East Caicos and Anguilla Isles:-Florida; Cuba; Jamaica. Velvetr ABUTILOX.

3. Abutilon abutiloìdes (Jacq.) Garcke, Bot. Jahrb. 15: 495. 1893.

Sida abutiloides Jacq. Obs. 1: 17. 1764.

Abutilon lignosum G. Don, Gen. Hist. 1: 501. 1831.

A shrub, up to $1.5 \mathrm{~m}$. high, the twigs densely stellate-tomentose. Leaves broakly ovate, $2-5 \mathrm{~cm}$. long, serrate nearly all around, stellate-tomentulose on both sides, reticulate-reinel beneath, acuminate at the apex, cordate at the base, the petioles somewhat shorter than the blares; peduncles longer than the petioles; calyx little enlarged in fruit, its broadly ovate acuminate tomentulose lobes sharply acuminate; petals bright yellow, about $1 \mathrm{~cm}$. long; carpels i-10, slender-beaked, about. $1.5 \mathrm{~cm}$. long.

Waste places, Harbor Island, Long Island:-Cuba; IIspaniola, Jamaica; Mexico. Bushy ABUTILON.

4. Abutilon trisulcàtum (Jacq.) Britton \& Millspaugh.

Sida trisulcata Jacq. Enum. 26. 1760.

Abutilon triquetrum Presl, Reliq. Haenk. 2: 115. 153.5.

A shrub, 1-1.6 m. high, with slender ascending densely tomentulose branches. Leaves ovate, slenter-petioled, $4-12 \mathrm{~cm}$. long, erenate or crenulate. fincly velvety on both sides, the upper ones much snaller than the lower; 
fowers solitary anil slenter-peduncled in the axils of leaf-like bracts, or subpaniculate; ealyx $4-\overline{\mathrm{mm}}$. long, its lobes triangular-orate, acuminate; petals yellow, reddish blotched at the base, $5-7 \mathrm{~mm}$. long; carpels about 5 , stellatepuberuleut, short-tipped, about 8 mm. long.

Scrub-lands, New Trovidence and Great Exuma :-Cuba ; ILxico.

5. Abutilon paucifì̀rum St. Hil. Fl. Bras. Mer. 1: 206.1825.

A densely stellate-tomentose shrub, $6 \mathrm{dm}$. high, or higher. Leares orbicular-ovate, $5-7 \mathrm{~cm}$. long, obtuse, acute or short-acuminate at the apex, deeply corlate at the base, crenate, the petiole as long as the blade or shorter; peduncles axillary, about as long as the petioles; calyx 10-12 mm. long; its lobes orate, acute or acuminate; petals somewhat longer than the calyx; carpels 8-10, densely villous, 2-cuspidate.

Waste grounds, Long Island, at Clarence Town:-Florida; Jamaica; Cuba; Mexico to Paraguay. WOOLLY ABrTilos.

3. GAYOİDES Small, Fl. SE. U. S. 764. 1903.

A slender perennial finely velvety and often also villous herb, with petioled ovate cordate leaves and solitary axillary filiform-peduncled, whitish flowers. Involucels none. Calyx deeply 5-cleft. Petals 5, distinet. Carpels numerous, 1-celled, membranous and inflated in fruit, the apex rounded; styles slender; stigmas terminal; ovules 2-6 in each carpel. Seeds glabrous. [Similar to the genus Gaya.] A monotypie genus.

1. Gayoides críspum (L.) Small, Fl. SE. U. S. 764.1903.

Sida crispa L. Sp. Pl. 685. 1753.

Abutilon crispum Medie. Malv. 29. 1787.

Usually much branched, the branches diffuse or ascending, 3-10 $\mathrm{dm}$. long. Leaves thin, broadly ovate, $2-7 \mathrm{~cm}$. long, acute or acuminate at the apex, deeply cordate at the base, crenate or crenulate, the petioles equalling the blades, or shorter, sometimes very short; peduncles as long as the leaves, or shorter, jointed below the flower; calyx velvety and often villous, its lobes ovate or ovate-lanceolate, acute, $4-6 \mathrm{~mm}$. long; petals pale yellow or whitish, obovate, about twice as long as the calyx; fruiting head of carpels $12-20 \mathrm{~mm}$. thick, the inflated carpels somewhat pubescent.

Waste and cultivated lands, throughout the archipelago from Abaco and Great Bahama to Caicos, Grand Turk, Ambergris Car, Inagua and the Anguilla Isles and Water Cay :- Southern Tnited States; West Índies, east to St. Thomas, south to Grenada; Mexico to tropical America; Old World tropies. Recorded by Dolley as Abutilon filiforme Jacq. Low ABUTILoN.

4. MAIVÁstrum A. Gray, Mem. Am. Acad. II. 4: 21. 1849.

Herbs, with entire cordate or divided leaves, and solitary or racenose, short-pedicelled perfect flowers. Calyx 5-cleft. Bractlets of the involucels

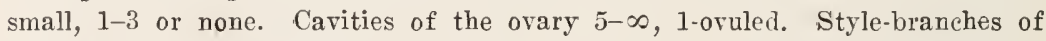
the same number, stigmatic at the summit only, forming capitate stigmas; carpels indehiscent or imperfectly 2-valved, falling array from the axis at maturity, their apices pointed or beaked. Seed ascending. [Greek, star-mallow.] About 75 species, natives of America and S. Africa. Type species: Malvastrum coccineum (Pursh) A. Gray.

Carpels with a short filiform awn; flowers mostly solitary. 1. Mr. coromandelianum. Carpels not awned; flowers mostly capitate.

2. MI. corchorifolium. 
1. Malvastrum coromandeliànum (L。) Garcke, Bonplanłia 5: 297. 1857.

Malva coromandeliana L. Sp. Pl. 687. 1753.

Malvastrum tricuspidatum A. Gray, Pl. Wright. 1: 16. 1552.

Malvastrum americanum Torrey, Bot. Mex. Bound. Surv. 38. 1859.

Perennial, strigose-pubescent, branched, 3-10 dm. high. Leares orate to oblong-ovate, slender-petioled, 2-8 cm. long, acute, sharply serrate, the hairs of the upper surfaces mostly simple; flowers mostly solitary in the axils, on peduncles shorter than the petioles; involucels of 3 small bractlets; calyx-lobes triangular, acute, longer than its tube; petals pale yellow, somewhat longer than the ealyx, obliquely truncate; carpels $\mathrm{S}-12$, hirsute on top, with an awn near the inflexed apex and 2 beaks on the back.

Waste grounds and cultivated soils, Great Pahama, North Bimini, Eleuthera, Watling's:-Bermuda; Florida to Texas: the West Indies; continental tropical Amelica; tropical and snbtropical Asia. FALsE MLLOW.

\section{Malvastrum corchorifòlium (Desr.) Britton; Small, Fl. Miami 119. 1913.}

Malva corchorifolia Desr. in Lam. Eneycl, 3: 755. 1791.

Malvastrum Rugelii S. Wats. Proc. Am. Acad. 17: 367. 1582.

Similar to the preceding species, about as pubescent and the leaves much alike in both, the hairs of the upper surfaces mostly forked. Flowers mostly in terminal heads 1-2 cm. long, or some of them solitary in the axils; calyxlobes triangular-ovate, acuminate; petals orange or yellow, longer than the ealyx; carpels about 10 or fewer, hispidulous, beakless, or sometimes with a blunt protuberance.

Waste and cultirated lands. Abaco, New Frovidence, Eleuthera, Cat Island, Fortune Island, Acklin's, Grand Turk, Inagua and Anguilla Isles:- Fiorida; Cuba : Virgin Gordá; Jamaica, ReGel's FaLse ila Low.

\section{SİDA L. Sp. Pl. 653. 1753.}

Herbs, with serrate crenate or lobed leares, and perfect flowers. Bractlets of the involucels none. Calyx 5 -toothed or 5-cleft. Cavities of the ovary $5-\infty$, 1-ovuled; style-branches of the same number, stigmatic at the summit. Carpels indehisent, or at length 2-valved at the apex. Seed pendulous. [Greek, used by Theophrastus.] About 75 species, natives of the warner parts of America, Asia, Africa and Australasia. Type species: Sida alnifolia L.

Flowers capitate, congested at the apices of the branches, their peduncles adnate to the long-ciliate bracts.

Flowers solitary or variously clustered, not adnate to the floral bracts.

Calyx angular.

Leaves narrowed or rounded at the base.

Leares short-petioled. Leaves long-petioled.

Leaves distinctly coldate at the base.

I'lants prostrate, creeping, leaves sub-orbicular.

I'lants erect or difruse, leares ovate to orate-lanceolate.

Inowers glomelate, very short-pedicelled; plants with stinging hairs.

Flowers solitary or few together, slender-pedicelled. Leaves acuminate, plants erect.

Calyx-tube terete. Leares obtuse or merely acutisl, plants diruse.

1. Sida ciliàris L. Syst. ed. 10, 1145. 1759.

1. S. ciliaris.

2. S. carpinifolia.

3. spinosu.

4. S. hederacfolia.

5. S. urens.

f. S. glutinosa.

7. s. procumbens.

S. S. acuminata.

Perennial, strigose-pubescent, diffusely branched at the base from a decp woody root, the slender branches prostrate or ascending, 1-3 dm. long. Leares 
oblong or elliptic, $0.7-3.5 \mathrm{~cm}$. long, obtuse or emarginate at the apex, mostly obtuse at the base, serrate, mostly above the middle, slencler-petioled, usually glabrous above and stellate pubescent beneath; flowers elustered at the ends of the branches, their short peduncles alnate to the petioles of the foliaceous bracts; stipules linear or linear-spatulate, long-ciliate, about as long as the petioles; calyx hirsute, its triangular acute lobes about as long as the nearly terete tube: petals red, yellow or purplish, blotehed at the base, $6-12 \mathrm{~mm}$. long; carpels 5-8, wrinkled or tubercled, 2-beaked.

liocky soils and cultivated grounds, Great Sturup Cay to New Providence, Eleuthera. Atwood's, Fortune lsland, East Caicos, and Inagua :-Florida; West Indies; tropical continental America. Frisged Sid.

\section{Sida carpinifòlia L. f. Suppl. 307. 1781.}

Sida acuta carpinifolia K. Schum. in Mart. Fl. Bras. 123: 326. 1891.

Sida antillensis Urban, Symb. Ant. 5: 418. 1908.

Puberulent or glabrous. Stems erect, 3-9 dm. tall, branching; leaves lanceolate, oblong-ovate or ovate, 2-10 cm. long, acute or acuminate, irregularly serrate, obtuse or subcordate at the base, the petioles $3-7 \mathrm{~mm}$. long; stipules conspicuous, narrowly linear to lanceolate, surpassing the petioles; peduncles mostly shorter than the pedicels, 1- $7 \mathrm{~mm}$. long; calyx 5-10-ribbed, its lobes triangular, slightly acuminate, about as long as the tube; petals yellow to white, 6-12 mm. long. carpels reticulate-wrinkled, 2-beaked.

Fields and waste places, Abaco. Great Sturlup Cas, Andros, New Providence, Eleuthera to Watling's, Great Exuma, Long Island, Grand Turk and Inagua:-
Bermuda: North Carolina to Florida and Texas: West Indies and tropical continental America. Referred by Hitchcock to Sida glomerata Car. Wine-Weed.

3. Sida spinòsa L. Sp. Pl. 683. 1753.

Sida angustifolia Lam. Encyel. 1: 4. 17\$3.

Sida spinosa angustifolia Griseb. Fl. Br. W. I. 74. 1859.

Annual, finely pubescent, 3-6 dm. high. Leaves 'orate to oblong-lanceolate, 2-5 cm. long, petioled, truncate or cordate at the base, crenate-dentate; flowers axillary, short-peduncled, yellow; peduncles shorter than the petioles; calyx. teeth triangular, acute; carpels 5 , dehiscent at the apex into 2 beaks; stipules linear; petioles of the larger leaves with a small spine-like tubercle at the base.

Taste and cultivated lands, Great Bahama, Great Sturrup Cay, New Proridence, Eleuthera, Cat Island, Watling's, Great Exuma, Long Island, Fortune Island, East Caicos, Inagua and the Anguilla Isles:-New York to Kansas, Florida and Texas; West Indies; tropical continental America. False Mallow.

\section{Sida hederaefòlia Cav. Diss. 1: S. 1785.}

Loosely stellate-pubescent or glabrate; stems branched at the base, the slender, trailing branches 3-5 $\mathrm{dm}$. long. Leaves nearly orbicular, slenderpetioler, 1-3 $\mathrm{cm}$. broad, cordate, crenate-dentate, the petioles often longer than the blades; peduncles solitary in the axils, filiform, sometimes longer than the leaves: calyx about $4 \mathrm{~mm}$. long, angled, its broadly ovate acute teeth about as long as the tube; petals yellow, somewhat longer than the calyx; carpels 2aristate.

Waste places and roadsides, Great Bahama at Eight Mile Rocks:-Cuba to Porto Rico. ITY-LEAVED SIDA.

\section{Sida ùrens L. Syst. ed. 10, 1145. 1759.}

Harshly hirsute, erect, ascending, weak, branched or sometimes simple, 3-15 $\mathrm{dm}$. high. Leaves orate or ovate-lanceolate, $2.5-8 \mathrm{~cm}$. long, acute or acuminate at the apex, cordate at the base, sleniler-petioled, serrate, loosely stellatepubescent; flowers subsessile in axillary and terminal, usually dense clusters, 
or some of them axillary, solitary and short-pedicelled; calyx hirsute, 5-cleft, angular, $6-i \mathrm{~mm}$. long, its triangular-orate, acute or acuminate teetb about as long as the tube; petals yellow, redlish at base; earpels $\tilde{j}$, glabrous, 2 . denticulate.

Waste and cultivated land, New Irovidence at Nassau:-Cubal to Forto Iifco and Trinidad; continental tropical America; Uld World tropies. Strekr sids.

6. Sida glutinòsa Comm, ; Cav. Diss, 1: 16. 17S5.

Sida nervosa DC. Prodr. 1: 465. 15थ4.

Erect, 5-10 dm. high, branched, the stem and branches densely tomentulose, somewhat glutinous, sometimes also with long sprealing hairs. Leaves ovate to lanceolate, $S$ cm. long or less, acuminate at the apes, cordate at the base, crenulate, the lower long-petioled, the upper usually much smaller thau the lower and shorter-petioled; flowers 1-several in the axils or in terminal panicles; pelicels filiform, mostly much longer than the calyx, pubescent; calyx angled, 3-t $\mathrm{mm}$. long, its 5, broadly orate, sharply acute teeth shorter than the tube; petals yellow, about twice as long as the calyx; carpels 5, pubescent above, 2-aristate.

Waste and cultivated land, New Providence at Nassau:-Cuba to Forto Rico, St. Jan and Trmidad; continental tropicai America; Old World tropics. stcky SIDA.

\section{Sida pròcumbens ST. Prour. 101. 17ss.}

Sida supina L'Her. Stirp. Nor. $109^{2}$. 1759.

Branched at the base, the branches slender, prostrate or nearly so, 1-6 dm. long, densely puberulent, glabrate or pilose. Leaves ovate or ovate-orbicular, $1-2.5 \mathrm{~cm}$. long, slender-petioled, crenate, obtuse at the apex, cordate at the base, densely puberulent on both sides; peduncles axillary, solitary, abont as long as the leaves or shorter, or longer, filiform, sometimes pilose; calyx about $t \mathrm{~mm}$. long, puberulent or pilose, its 5 orate acuminate lobes somewhat shorter than the angled tube; petals pale yellom or white, $4-6 \mathrm{~mm}$. long; carpels mostly 5 , reticulate, 2-beaked, about $2 \mathrm{~mm}$. long.

Fields, pastures and waste places, New I'rovidence, Eleuthera, I,ong lsland, Fortune Island, South Caicos, Amberglis Cay and Inagua:-Llorida; West Indies; continental tropical Imerica. C'ReEpria Sibi.

\section{Sida acuminàta DC. Prodr. 1: 462. 18ะ4.}

Sida acuminata Bracei E. Baker, Journ. Bot. 30: 295, 189 ‥

Densely stellate-pubescent, usually branched, somewhat woody, erect, j-S dm. high, branched or sometimes simple. Leaves ovate to ovate-lanceolate, rather short-petioled, $2-7 \mathrm{~cm}$. long, acute, obtuse or acuminate at the apex, rounded, or subeordate at the base, low crenate-serrate; flowers few or solitary in the axils, and often in small terminal clusters, nearly sessile or filiformpeduncled, the perluncles sometimes 2-3 cm. long; calyx j-6 mm. long, terete, its 5, broally ovate, acute teeth somewhat shorter than the tube; jetals yellow, 4-5 mm. long; earpels 5-8, stellate-jubescent, scarcely beaked.

roadsides and waste places. Abaco, New l'rovidence, Bleutluera, Cat Island, IRum Cay, Great lixuma, Long lsland, clooked Island, Fortune Island, Acklin's and Ifariguana, Eist Caicos:-C'ubal to Vhrgln Golda and Antigual; C'entral America. liaces differ in the number and size of the llowers. VLLVits sibi.

6. BASTARDIA Il.B.K. Nor. Gen. 5: 25t. 15:1.

Velvety-pubescent or tomentose shrubs or perenuial herbs, with fretioled cordate leares, and small yellow peduneled flowers, solitary or few in the axils. Involucel none. Calyx 5-toothel or 5-eleft. Petals 5. Stamerecolumn 
livided into several or many filaments at the apex. Orary 5-celled; orules 1 in each carity, pendulous; style-branches 5; stigmas eapitate. Capsule deIressed-globose, 5-groored, 3-5-ralvel. [Commemorates the French botanist T. Bastard.] Six known species, of tropical America. Type species: Bastardia parvifolia II.B.K.

\section{Bastardia viscòsa (T.) H.B.K. Nov. Gen. \& Sp. 5: 256.1822.}

Sida viscosa L. Syst. ed. 10, 1145. 1759.

Finely relvety-pubescent and riseid, sometimes also pilose, erect, branched, 3-7 dm. high. Leaves orate, 1-6 cm. long, acnte or acuminate at the apex, cordate at the base, irregularly denticnlate, the slender petioles as long as the blades or shorter; pedicels nearly filiform, longer than the petioles, often longer than the leaves, rarely not longer than the calyx; calyx about $4 \mathrm{~mm}$. long, its 5 , orate-lanceolate, acuminate teeth about as long as the tube; petals yellow, 4-5 mm. long; capsule about as long as the calyx, its carpel-valves beakless.

Waste lands, Eleuthera and Long Island:-West Indies; Mexico to Colombia and Feru. Hitchcock's plant referred to this species is Silla glutinosa Comm. VISCID BASTARDIA.

7. PAvònIA Car. Diss, 3: 132. 1787.

Shrubs or shrubby herbs. Leaves alternate, stipulate, angled or lobed. Flomers perfect, commonly solitary on axillary peduncles. Involucel of 5-15 bractlets. Calyx 5-1obed. Petals 5. Carpels 5, 1-celled; styles 10; stigmas capitate; ovules solitary. Mature carpels separating from axis, 1-3-spined on the back, more or less deeply 2-valved. Seeds solitary, ascending. [In honor of Joseph Pavon, Spanish botanist and explorer.] Sixty species or more, mostly of tropical distribution, the following typical.

\section{Pavonia spínifex (L.) Cav. Diss. 3: 133. 1787.}

Hibiscus spinifex L. Syst. ed. 10, 1149. 1759.

A branching shrub, 1-3 m. tall, hirsute and strigillose. Leaves ovate or oblong-orate, 5-10 cm. long, acute or somerhat acuminate, doubly crenate: dentate, truncate or subcorilate at the base, the petioles densely pubescent; peduncles axillary, much louger than the petioles; bractlets of the involucel. 5 , linear to lanceolate, acute, nearly $1 \mathrm{~cm}$. long; ealyx about as long as the bractlets, its lobes lanceolate to orate-lanceolate; petals yellow, $2.5 \mathrm{~cm}$. long, cuneate; carpels 5-6 mm. high, with 1 medial and 2 lateral retrorsely barbed awns.

Waste lands, New Providence and Long Island:-Bermuda; South Carolina to Florida; the West Indies and tropical continental America. PAroxis.

\section{MALÁCHE B. Togel; Trew, Pl. Sel, 50. 1772.}

Tall shrubs or small trees, with alternate broad, lobed or nearly entire leares, and large peduncled flowers solitary in the axils. Involucre of several bractlets. Calyx 5-lobed. Pctals 5, broad. Carpels mostly 5, 1-celled; styles 10. Orules solitary. Carpels 2-ralved, knobbed on the back, not spined, coriaceous, tardily dehiscent. [Greek, mallow.] Three known species, the following, and one in Jamaica. Type species: Malache scabra B. Togel.

Stamen-column not longer than the corolla. Stamen-column twice as long as the corolla.
1. M. scabra. 2. Mr. bahamensis. 
1. Malache scábra B. Vogel; Trew, Pl. Sel. 50. 1772.

Pavonia spicata Car. Diss. 3: 136. 1787.

Paronia racemosa Sw. Fl. Ind. Oce. 2: 1215. 1800.

An erect, usually little-branched shrub, 1-5 $\mathrm{m}$. high, the branches and inflorescence densely roughish-pubescent. Leaves ovate to oblong-orate, firm in texture, 5-15 $\mathrm{cm}$. long, palmately reined, repand-dentate or entire, acuminate at the apex, subcordate or rounded at the base, the petioles $3-6 \mathrm{~cm}$. long; racemes loosely several-flowered; pedicels ascending, 2-5 em. long; involucelbractlets oblong-lanceolate, about $1 \mathrm{~cm}$. long; ealyx as long as or a little longer than the bractlets, its lobes ovate, acute; petals yellowish, about twice as long as the calyx, finely pubescent, longer than the stamen-column; carpels somewhat shorter than the ealyx, with 2 short blunt beaks on the upper marging and a short terminal crest.

Borders of mangrove swamps, Andros at Conch Sound :-Florida; Cuba to Porto Rico and Trinidad; Jamaica; coasts of tropical continental America. Swarp Bush.

\section{Malache bahaménsis (Hitehe.) Britton \& Millspaugh.}

Pavonia bahamensis Hitche. Rep. Mo. Bot. Gard. 4: 63. 1893.

Malvariscus Cokeri Britton; Coker in Shattuck, Bahama Islands, 259. 1905.

A shrub, or small tree, up to $4 \mathrm{~m}$. high, with round glabrous branchlets. Leaves orate or nearly orbicnlar, acuminate, cordate, thin, 7 -nerved, entire or slightly repand, the upper surface glabrous but papillose, the under side glabrous except for tufts of hairs in the axils of the principal reins, and a few scattered ones on the reins, the blades $4-7 \mathrm{~cm}$. long, $3-6 \mathrm{~cm}$. wide, the petioles slender, 1.5-2.5 $\mathrm{cm}$. long; peduncles slender, puberulent, 2 or 3 times as long as the petioles; involucrel-bractlets narrowly linear, acuminate, glabrous, $1 \mathrm{~cm}$. long, $1 . \overline{\mathrm{mm}}$. wide, about as long as the ealyx; calyx-lobes triangular-ovate, acuminate, about one-half as long as the tube, woolly within; petals about $2 \mathrm{~cm}$. long; stamen-column $3 \mathrm{~cm}$. long or more; carpels with 2 compressed rounded terminal lobes and a central crest.

Rocky coastal thickets, Watling's Island, Crooked Island, Fortune lsland, Acklin's Island and Pine Cas (Caicos). Endemic. Ballam SWAMP-BUsm.

\section{MALVAVISCUS Dill:; Adans. Fam. Pl. 2: 399. 1763.}

Shrubs or small trees, with broad usually dentate or lobed, petioled leares, and red flowers. Involucel of several narrow bractlets. Calyx 5-eleft. Petals ereet-connivent. Stamen-column truncate or 5-toothed, bearing numerous stamens. Ovary 5-celled; ovules 1 in each eavity; style-branches 10 , stigmatic at the capitate summit. Fruit baceate, the indehiscent carpels finally separating. [Latin-Greek, similar to Malva.] About 10 species of tropical America. Type species: Mibiscus Malvaviseus L.

1. Malvaviscus Sagraeànus A. Rich. in Sagra, Hist. Cub. 10: 46. 1845.

Malvariscus arboreus Sagracams Griseb. Fl. Br. W. I. 83. 1559.

A branehing shrub, 2-4 $\mathrm{m}$. high, the twigs finely pubeseent or glabrate, slender. Leaves orate to orate-lanceolate, inregularly erenate, sonetimes 3lobed, 5-15 cm. long, acuminate at the apex, romider or subcordate at the base, glabrous, or with a few seattered hairs, the slender pubescent petioles shorter than the blades; involucel-bractlets linear-spatulate, $8-10 \mathrm{~mm}$. long, about as ?ong as the calyx, glabrous or pubescent; corolla red to scarlet, about $2 \mathrm{~cm}$. long; fruit depressed-globose, about $1 \mathrm{~cm}$. in diameter.

Scrub-lands of Abaco and Great Bahama :-Cuba. Sagra's Malraisces. 


\section{HIBÍscUS L. Sp. Pl. 693. 1753.}

IJerbs, shrubs, or in tropical regions even small trees, with dentate or lobed leares, and showy, mostly campanulate flowers. Bractlets numerous, narrow. Calyx 5-cleft or 5-toothed. Column of stamens anther-bearing below along much of its length. Ovary 5-celled, the cavities 3-several-ovuled; style-branches 5, stigmatic at the capitate summit. Capsule 5-valred. Seeds reniform. [An ancient name, used by Dioscorides for the Marsh Mallow.] About 180 species, midely distributed. Type species: Hibiscus Trionum L.

\section{Hibiscus bahaménsis Britton, Bull. N. Y. Bot. Gard. 4: 120. 1905.}

A shrub, the leaves, calyx, peduncles and twigs densely and finely stellatepubescent. Leaves orate in outline, palmately veined, $10 \mathrm{~cm}$. long or less, firm in texture, cordate to truncate at the base, 3 -lobed or 5 -lobed with the middle lobe much the longest and acuminate, the lateral lobes acute or obtuse, irregularly dentate; npper leaves varying to lanceolate, and merely dentate; petioles as long as the blades or shorter; pedumeles stout, solitary in the axils, longer than the subtending petioles, jointed near the middle; bractlets linear-lanceolate, acuminate, rery unequal, the longer about $1.5 \mathrm{~cm}$. long; calyx $2-2.5 \mathrm{~cm}$. long, densely stellate-pubescent, its oblong lcbes strongly veined, acuminate; petals bromnish, $3.5 \mathrm{~cm}$. long, densely pubescent, without, oblanceolate, obtusish; capsule oval, $2.5 \mathrm{~cm}$. long, $2 \mathrm{~cm}$. thick, densely silky.

Rocky scrub-lands and coppices, Abrce, Andros, Eleuthera, Cat Island, Conception Island, Rum Cay. Acklin's. Endemic. Recorded by IIrs. Northrop as H. cryptocarpus Rich. Erroneously called wild cotton. Barama HiBiscus.

\section{ABELMóschus Medic. Malv. 45. 1787.}

Tall herbs, with broad, lobed leaves, and large axillary and terminal flowers. Bractlets several or numerous, narrow. Calyx spathaceous, splitting along one side, deciduous. Stamen-column bearing numerous anthers. Ovary 5-celled, its cavities sereral-oruled; style-branches 5, stigmatic at the summit. Capsule elongated, 5-valved. [Name said to be Arabic.] A few species, natires of the Old World. Type species: Abelmoschus moschatus Medic.

\section{Abelmoschus esculéntus (L.) Moench, Meth. 617. 1794.}

\section{Hibiscus esculentus L. Sp. P1. 696. 1753.}

Annual, erect, little-branched, 1-2 m. tall, sparingly hirsute. Leaves longpetioled, nearly orbicular in outline, 1-3 dm. broad, deeply 5-7-lobed, the lobes lanceolate to obovate, irregularly serrate, acute or obtuse; peduncles stout, 1-3 cm. long; bractlets linear, bristly-hirsute, about $1.5 \mathrm{~cm}$. long; calyx about $2 \mathrm{~cm}$. long; petals broad, yellowish, purple-blotehed at the base, $3-4 \mathrm{~cm}$. long; capsule angled, $2 \mathrm{dm}$. long or less, long-tipped.

Taste-lands, spontaneous after cultivation; Cat Island and Fortune Island:spontaneous in most tropical and subtropical regions; native of the old World tropics. OKRA.

\section{PARÍtI Adans. Fam. Pl. 2, 401. 1763.}

Trees, with broad cordate petioled leaves, large deciduous stipules, and large, terminal or axillary flowers, solitary or few together, the petals yellow or changing to red. Involucre 8-10-toothed. Calyx 5-toothed. Style pubescent 
above, 5-cleft, the stigmas broad. Capsule loculicidally 5-celled, many-sceded, the cells vertically partitioned by a dissepiment which splits at dehiscence into two membranes. [Name said to be Malabaric.] A few species of tropical regions, the following typical.

\section{Pariti tiliàceum (L.) St. Hil. Fl. Bras. Merid. 1: 256.1827.}

Hibiscus tiliaceus L. Sp. Pl. 694. 1753.

A tree, sometimes $18 \mathrm{~m}$. high, the young foliage velvety-tomentose. Leares long-petioled, the blades $i-20 \mathrm{~cm}$. broad, nearly orbicular, cordate at base, abruptly acuminate at apex, shallowly dentate or subentire, the venation prominent beneath; involucre 10 -cleft, about $12 \mathrm{~mm}$. long; petals yellow, obovate, 5-6 $\mathrm{cm}$. long; calyx about $2 \mathrm{~cm}$. long; capsule ovoid, tomentose, $15-18 \mathrm{~mm}$. long; seeds glabrous or minutely downy.

Coastal thickets, Abaco, Andros, New I'rovidence, Cat Island, I'ine Cay (Caicos): -Bermuda; Florida; throughout the West Indies and tropical continental America; old World tropies. iLAHOE. Catesbs, $2: 0 l .90$.

13. THespèsra Soland.; Correa, Ann. Mus. Paris 9: 290. 1807.

Shrubs or trees. Leaves alternate, entire or merely angulately lobed, commonly ample, usually cordate, petioled. Flowers perfect, showy. Involucel of $3-5$ narrow decidurous bractlets. Calyx truneate or nearly so. Petals 5. Orary sessile, J-celled; styles 5 , united or rarely distinct; stigmas decurrent on the styles. Orules few in each carity. Capsule firm, woody-leathery, 5celled, indehiscent. Seeds glabrous or pubescent. [Greek, marvellous.] About $S$ tropical species, the following typical.

1. Thespesia popúlnea (L.) Soland.; Correa, Ann. Mus. Paris 9: 290. 1807.

Hibiscus populneus L. Sp. Pl. 694. 1753.

A tree, sometimes $7 \mathrm{~m}$. high, with a trunk up to $2 \mathrm{dm}$. in diameter, usually smaller, often a shrub, the stont twigs scurfy when young. Leares firm in texture, slightly fleshy, ovate-orbicular, $5-12 \mathrm{~cm}$. long, acuminate at the apex, cordate at the base, undulate-margined; petioles nearly as long as the blades; peduncles shorter than the petioles; calyx subhemispheric, nearly truncate; petals $4-\vec{i} \mathrm{~cm}$. long, yellow with a purple base, changing to purple; fruit depressed-globose, leathery, $3-4.5 \mathrm{~cm}$. in diameter, $1.5-2 \mathrm{~cm}$. high; seeds pubescent.

Borders of marshes, and in sandy scrub-lands, New frovidence and Grand Turk: -Florida: the West lndies and tropical continental America; Old World tropies. Sea-side iahoe. Cork-tree. Spanish Cork.

\section{GOSSỲPIUMI L. Sp. Pl. 693. 1753.}

Herbs, shrubs or small trees, with alternate petioled, usually lobed leares, and large, mostly solitary, peduncled, yellow or white to purple flowers subtended by 3 broal, often corlate, incised bracts. Calyx trumeate or 5-lobed. Stamen-column usually naked below. Orary 5 -celled; orules numerous in each carity; style club-shaped, 5-groored; stigmas 5. Capsule coriaceous, loculicidally 5-valved. Seeds usually densely covered with long white hairs (cotton); endosperm thin or none; cotyledons plicate. [Latin for cotton, perhaps of Arabic origin.] Abont 40 species, of tropical distribution. Type species: Gossypium arboreum L. 
Cotton readily separable from the seed.

Cotton adherent to the seed.

1. G. barbadense.

2. G. punctutum.

\section{Gossypium barbadénse L. Sp. Pl. 693. 1753.}

Perennial, shrubby, flowering as an anuual, glabrous or nearly so, 1-2.5 m. high. Leares suborbicular in outline, $7.5-20$ cm. broad, rather deeply $3-5$ cleft, the lanceolate or orate-lanceolate lobes acuminate, the basal simus narrow; petals 6-10 cm. long, yellow, or with orange or red bases, fading pink; capsules 3-5 $\mathrm{cm}$. long; cotton readily separated from the seed.

Scrub-Iands and waste lands, apparently spontaneous after cultivation only, Abaco, New Providence, Cat Island, Great Gaillot Cay, Fortune Island and Inagua :North Carolina to Florida; widely spontaneous aftel cultivation in tropical and subtropical regions. COTTOన.

\section{Gossypium punctàtum Sch. \& Thon. Besk. Guin. Pl. 309. 1827.}

A shrub, or small tree, up to $4 \mathrm{~m}$. high, the young twigs pubescent or glabrate. Leaves ovate-orbicular or suborbicular in outline, cordate or nearly truncate at the base, usually 3 -lobed, rarely 5-lobed, or some of them entire, the lobes short, ovate, acuminate, pubescent beneath, at least when young, nearly giabrous above; petals $3-6 \mathrm{~cm}$. long, white or yellowish, sometimes crimsonblotehed at the base, fading pink or purplish; capsules $2-2.5 \mathrm{~cm}$. long; cotton firmly attached to the seed.

Ium Cay, at Port Nelson :-Southern Florida; Jamaica: Cuba: Porto Rico; Grenada. Recorded from other West Indian islands. Cultivated in tropical regions of the New World and the old. WILD CoTros.

\section{Family 3. BOMBACÀCEAE Schumann.}

\section{Bombax Family.}

Trees, mostly with palmately compound leaves and large and showy perfect flowers. Calyx inferior, mostly 5-toothed. Petals 5. Stamens commonly very numerous, with long filaments and short anthers. Ovary 2-5-celled; style simple; stigmas as many as the ovary-cavities. Fruit various, dry or fleshy. Seeds usually woolly. About 20 genera and 150 species, of tropical distribution.

\section{CEIBA Adans. Fam. Pl. 2: 399. 1763.}

Large deciduous trees, with alternate petioled palmately compound leaves, and large clustered axillary flowers, the trunk buttressed at the base, the branches and young trunks spiny. Calyx 5-lobed. Petals tomentose without, glabrous within. Column 5-divided, each division bearing 2 or 3 unilocular anthers at the top. Capsule 5-celled, loculicidally dehiscent, many-seeded. Seeds long-woolly. [Aboriginal name.] About 12 species, the following typical.

1. Ceiba pentándra (L.) Gaertn. Fr. \& Sem. 2: 244.1791.

Bombax pentandrum L. Sp. PI. 511. 1753.

Eriodendron anfractuosum DC. Prodr. 1: 479. 1824.

A tree, reaching a maximum height of $60 \mathrm{~m}$. or more, the trunk above the often immense buttress sometimes $3 \mathrm{~m}$. in diameter. Petioles slender, glabrous, $5-15 \mathrm{~cm}$. long; leaflets $5-7$, stalked, or nearly sessile, glabrous, entire or serrate, 
oblong to oblaneeolate, $S-15$ cm. long, mostly acute or aemminate at the apex and narrowed at the base; flowers in many axillary clusters, often appearing before the leares; pedieels $4-6 \mathrm{~cm}$. long; ealyx obeonie, about $1.5 \mathrm{~cm}$. long; petals about $3 \mathrm{~cm}$. long, about as long as the stamens; stigma eapitate; capsule oblong, wookly, $\mathrm{S}-12 \mathrm{em}$. long.

Waste-lands, spontaneous after cultivation, New I'rovidence, near Nassau ; planted for shade and for ornament:-Cuba to St. Jan and Barbadoes; northern South America; Old World tropics. SilK-cotTus 'Tres.

\section{Family 4. STERCULIĀCEAE H.B.K.}

\section{Chocolate Fanily.}

Herbs, shrubs or trees, with alternate, often stellate-pubescent leaves, the flowers regular, mostly perfect, in a few genera polygamous or unisexual, clustered or rarely solitary, usually axillary. Calyx deeply 5 -cleft, usially persistent, the lobes or sepals valvate. Petals 5, hypogynous, or wanting. Stamens 5 or more; filaments more or less mnited below into a cup or tube; anthers mostly 2-celled, extrorse; staminodia present in some genera. Ovary superior, 2-5-celled, or sometimes monocarpellary; styles usually as many as the orary-carities. distinct or more or less united. Fruit mostly capsular or follicular, rarely indehiscent. Seeds various, the cotyledons commonly foliaceons. Abont 45 genera and over 600 species, mostly tropical.

Petals with flat blades.

Gynoecium of $\bar{j}$ united carpels.

Fruit of 5 dehiscent follicles.

Capsule pyramidal or fruit 5 -coccous.

Fruit a $\overline{5}$-angled capsule. Fruit 5-coccous.

Gynoecium of a single carpel.

Petals with hooded blades; capsule 5 -celled, muricate.

1. Helicteres.

2. Moluchia.

3. Melochia.

4. Taltheria.

5. Ayenir.

\section{HeLÍCtERES L. Sp. Pl. 963. 1753.}

Pubeseent shrubs or trees, the pubescence stellate or of branched hairs, with broad leaves and axillary or terminal, clustered or solitary flomers, the bractlets small, or distant from the ealyx. Calyx tubular, 5-eleft or 5-toothed, somewhat 2-lipped. Petals 5, elawed. Stamen-eolumn slender, elongated, bearing 5 or 10 sessile or short-stalked anthers; anther-saes divergent or confluent. Ovary borne within the ring of stamens, 5 -eelled, 5-lobed, the cells many-ovuled; style 5, or united into 1 ; stigma small, eapitate. Carpels distinet at maturity, twisted or straight, follieular, dehiseent along the rentral suture, many-seeded. Seeds warty or smooth; endosperm little; cotyledlons foliaceous. [Greek, referring to the eoiled earpels of some species.] Thirty species or more, of tropieal distribution. Type species: Helicteres Isora L.

Capsule glabrous; carpels straight.

Capsule lanate; carpels twisted into a spiral.
1. II. semitriloba.

‥ II. jamaicensis.

\section{Helicteres semitriloba Bərtero; DC. Prodir. 1: 476. 1524.}

A branehed shrub 1-3 $\mathrm{m}$. high, rarely a small tree up to $5 \mathrm{~m}$. high, the young twigs, petioles, lower leaf-surfaces, pedieels, ealyx and ovary densely stellate-tomentulose. Leares troarly ovate to orbieular, subeoriaeeous, $3-8 \mathrm{em}$. long, uminlate-ileutate or somewhat 3-lober, obtuse or acute at the apex, corlate or truncate at the base, becoming glabrous above, the petiole as long as the blade or shorter; flowers usually numerous in terminal eompound eorymbs; 
pedicels short; bractlets linear; calyx campanulate, 5-toothed, 2-lipped, 5-6 mm. long; petals white, fading reddish, $8-9 \mathrm{~mm}$. long; column slender, glabrous, $3-5 \mathrm{~cm}$. long; anther-sacs oblong; fruit linear, straight or a little curved, 1.5-4 em. long, sejlarating into 5 , glabrous, pointed follicles.

Coppices and scrub-lands, Andros, New Providence, Elenthera, Cat Island, Watling's, Great Exuma. Crooked lsland, Acklin's, Fortune Island, North Caicos and Inagua :-Cuba; Ifispaniola. Straight-Fruited llelicteiles. Wild SALve.

\section{Helicteres jamaicénsis Jacq. Enum. 30. 1760.}

Helicteres spiralis Northrop, Mem. Torr. Club 12: 50, pl. 11. 1902.

A shrub, 1.5-3 m. high, or a small tree sometimes $6-7 \mathrm{~m}$. tall, the foliage densely stellate-tomentose. Leaves ovate to ovate-lanceolate or ovate-oblong, $5-17$ cm. long, mostly acute or acuminate at the apex, cordate or sometimes rounded at the more or less oblique base, crenulate nearly all around, the stout petioles $0.5-2.5 \mathrm{~cm}$. long, the upper surface darker green than the lower; peduncles stout, 2-3 cm. long, 1-fem-flowered; pedicels short; calyx $1.5-2 \mathrm{~cm}$. long, 5-toothed, somewhat 2-lipped, densely tomentose; petals mhite, inequilateral, somewhat longer than the calyx; column 6-10 cm. long, declined; stamens 10; staminodia 5; ovary tomentose; carpels about 10, spirally twisted, densely tomentose, forming a cone-like, oblong fruit $2.5-5 \mathrm{~cm}$. long.

Coppices, thickets and white-lands, Abaco, Great Bahama, Andros, Mangrove Car, New I'rovidence, Eleuthera, Cat Island, Mariguana, Atwood Cay. Great Guana Cay, Great Exuma, Long Island, Great Ragged Island, Crooked Island, Acklin's, Fortune Island, Watling's Island and the Inaguas:-Cuba to Tortola, St. Martin and St. Croix: Jamaica. Recorded by Śchoept as $H$. Isora L. Cow-Bush. SalzBUSH. BLIND-EIE BUSH.

\section{MOLÚchIA Medic. Malv. 10. 1787.}

Herbs, shrubs or small trees, with alternate toothed leaves, and small, terminal or axillary, mostly clustered, perfect flowers, the petals flat, marcescent. Involucels none. Calyx 5-cleft, usually campanulate. Petals 5, narrow. Stamens 5, the filanients somewhat united belor, opposite the petals; staminodia none, or minute. Orary 5-celled, each cavity 2 -ovuled; styles 5, distinet, at least above; stigmas clavate. Capsule pyramidal, loculicidally 5 valved, כ̄-seeded, the seeds obovoid, ascending. Endosperm fleshy; embryo straight; cotyledons flat. [Name altered from Melochia.] About 6 species, of tropical and subtropical regions. Type species: Moluchia fruticosa Medic.

Foliage stellate-tomentose or stellate-puberulent; capsules with rounded angles.

Foliage nearly glabrous; capsules with sharply acute angles.

1. M. tomentosa.

2. M. pyramidata.

1. Moluchia tomentòsa (L.) Britton, Mem. Brooklyn Bot. Gard. 1: 69. 1918.

Melochia tomentosa L. Syst. ed. 10, 1140. 1759.

A branched shruk, $2 \mathrm{~m}$. high or less, rarely a small tree up to $4 \mathrm{~m}$. high, the slender twigs, the leares, inflorescence, calyx and capsule densely stellatepubescent or tomentose. Leares chartaceous, ovate to oblong-lanceolate, 1-6 cm. long, obtuse or acute at the apex, ronnded, truncate or cordate at the base, crenate or serrate, the petioles shorter than the blades; peduncles at the axils of upper leaves or terminal, few-sereral-flowered; calyx-lobes lanceolate; petals blue, violet or purple, obovate, $10-12 \mathrm{~mm}$. long; capsule-body 6-8 $\mathrm{mm}$. long, subulate-beaked, its angles rounded, knobbed.

White-lands, sclub-lands and coppices, Abaco, Andros, Mangrore Cay, New Providence, Eleuthera, Little San Salvador, Cat Island, Tatling's, Atwood Cay, Rum Cay, 
Great Guana Cay, Long Island, Great Rigged Island, Acklin's, East Caicos, Grand Turk Ambergris Cay, and Tuagma:-Texas; West Indies; Nolth Jexico to continental tropical America. The species is represented by many races of vartous leaf-forms and sizes, finding their smallest development in the plants of Grind Turk, Ambergris Cay and Inagua: these are the subject of Grisebach's Helochia crenata, not $M$. crenata Vahl. Velvetr Molechis,

2. Moluchia pyramidàta (L.) Britton, Mem. Brooklỵn Bot. Gard. 1: 69. $191 \mathrm{~s}$.

Melochia pyramidata L. Sp. Pl. 674. 1753.

Subherbaceous, nearly glabrous, the roung foliage somewhat pubeseent; stems slender, branched, ascending, decumbent or nearly erect, 2-6 dur. long, the young branches with a line of pubescence. Leaves membranous, lanceolate, ovate, or the lower nearly orbicular, 2-6 $\mathrm{am}$. long, sharply serrate, acute or acuminate at the apex, mostly rounded or subtruneate at the base, the slender petioles much shorter than the blades; peduncles pubescent, 1-few-flowered, about as long as the petioles, terminal or opposite the leaves; calyx-lobes lanceolate, 3-4 mm. long: petals pink, red or lavender, about $6 \mathrm{~mm}$. long, obovate; capsule inflated, membranous, 6-7 mm. long, sharply 5 -angled, short-beaked, each angle cuspidate at the base.

Waste places and roadsides, New Providence:-Texas: West Indies east to Tortola, south to Grenada: Curaço; Mexico; continental troplcal America and Old World tropics. SHootu MoLucinA.

3. MELOCHIA [Dill.] L. Sp. Pl. 674. 1753.

Herbs or shrubs, often stellate-pubescent, with petioled, serrate leaves and small, sometimes involucellate, perfect flowers in axillary or terminal glomerules or panicles. Sepals or calyx-segments little enlarged in fruit. Petals convolute, marcescent. Stamens opposite the petals; filaments more or less united below; staminodia none, or rarely present and minute. Ovary 5-celled; orules 2 in each carity; styles distinct, or united near the base. Fruit a small 5coccous capsule, loculicidally dehiscent. Seeds with fleshy endosperm. [Arabic name.] About 50 species, natives of tropical and subtropical regions. Type species: Melochia corchorifolia L.

1. Melochia nodiflòra Sw. Prodr. 97. 17ss.

Mougeotia nodiflora H.B.K. Nov. Gen. 5: 330. 1823.

A shrub, $2 \mathrm{~m}$. high or less, with slender ascending branches, the young trigs sparingly pubescent. Leaves thin, orate, $3-10 \mathrm{~cm}$. long, serrate, glabrous or nearly so, acute or acuminate at the apex, rounded, truncate, or subcordate at the base, the slender pubescent petioles 1-3 cm. long; flowers nearly sessile, in dense axillary subglobose clusters; calyx-lobes triangular-lanceolate, acuninate, $2-3 \mathrm{~mm}$. long; petals rose, a little longer than the calyx; filaments united; styles distinct; ovary 5-celled; young fruit deeply 5-lobed, at length separating into 5 pubescent carpels about $3 \mathrm{~mm}$. long.

Waste places, New Providence:--West Indies; tropical continental America. MELOCHIA.

\section{WALTHĖRIA L. Sp. Pl. 673. 1753.}

Herbs, shrubs or trees, with stellate or simple pubescence. Leares toothed; stipules narrow. Flowers small, perfect, usually in axillary clusters or small eymes. Involucel of 3 deciluous bracts. Sepals 5, united at the hase into a turbinate 10 -nervel tube. Petals 5, spatulate, convolute, witheringpersistent. Stamens 5; filaments united below, not accompanied by staminodia; 
anthers with parallel sacs. Ovary 1-celled, sessile; style simple, not central; stigma club-shaped or brush-like. Orules 2 in a cavity. Follicles 1-celled, 2 valved lengthmise. Sced solitary, ascending. Endosperm fleshy. Embryo straight, axile. [In honor of A. F. Walther, Professor in Leipzig.] About 35 American species, mostly tropical. Type species: Waltheria americana L.

Pubescence densely tomentose.

Finely stellate-pubescent.
1. ГГ. americana.

2. W. bahamensis.

\section{Waltheria americàna L. Sp. Pl. 673. 1753.}

Foliage tomentose. Stems 6-12 dm. tall, stiff; leaves ovate to oblong, 1-5 cm. long, serrate, rounded or cordate at the base, stout-petioled; flowers in dense sessile or peduncled axillary elusters; sepals subulate, about $5 \mathrm{~mm}$. long, villous-hirsute, similar to the bractlets; petals yellow, slightly longer than the sepals; follicles $2.5-3 \mathrm{~mm}$. long, pubescent at the top.

Rocky scrub-lands, fields and cultivated soil, Abaco and Great Bahama to South Bimini, Andros, the Crooked Island group and to Nolth and East Caicos:-Florida: Permuda; the Test Indies and tropical continental America; Old World tropics; Oceanica. Commox Tilthemia.

\section{Waltheria bahaménsis Britton, Torreya 3: 105. 1903.}

Branched from the base, stellate-puberulent, the branches $6 \mathrm{dm}$. long or less. Leaves oblong to ovate-oblong, 1-2 cm. long, sharply dentate, strongly veined, dark-green above, pale green beneath, stellate-pubescent on both surfaces, obtuse at both ends, or the base subcordate, the slender petioles half as long as the blades or less; flower-clusters sessile or nearly so in the axils, dense, less than $1 \mathrm{~cm}$. broad; bractlets sharply toothed; petals thin, spatulate, $3-5 \mathrm{~mm}$. long, obtuse or slightly notched; filaments united into a tube.

Sandy and rocky fields, scrub-lands and pine-lands, Abaco, Great Bahama, Great Harbor Cay, Little Harbor Cay, Andros, New Providence, Eleuthera, Cat Island, Rum Cay and Great Guana Cay. Endemic. Bahasia Watmeria.

\section{AYÈNIA Loefl. Iter. 257. 1758.}

Shrubs, some species subherbaceous, with serrate petioled leaves, and axillary, mostly clustered, pedicelled flowers. Calyx 5-parted. Petals 5, concave or hooded, long-clawed, the tip inflexed, adnate to the stamen-cup. Filaments united into a short cup, the anthers solitary in its sinuses, its truncate or rounded lobes alternate with the petals; anthers 3-celled. Ovary 5-celled, its cavities 2-oruled; style short; stigma capitate or somewhat 5-lobed. Capsule subglobose, muricate, splitting into 5 carpels, each 2 -ralved. Seeds rugose; endosperm none; cotyledones spirally convolute. [In honor of the French botanist Ayen.] About 10 species, natives of tropical America. Type species: Ayenia sidaeformis Loefl.

\section{Ayenia pusilla L. Syst. ed. 10, 1247. 1759.}

A low shrub or suffrutescent perennial herb, usually much-branched at the base, the slender branches ascending, erect or prostrate, 1-4 dm. long, puberulent. Leares lanceolate, ovate, oval or suborbicular, $0.8-3 \mathrm{~cm}$. long, puberulent or glabrate, sharply serrate, acute or obtuse at the apex, rounded or cordate at the base, the petioles $1-5 \mathrm{~mm}$. long; pedicels longer than the petioles, sometimes $10 \mathrm{~mm}$. long; calyx about $2 \mathrm{~mm}$. long, its lobes lanceolate; claw of the petal much longer than the hooded limb; lohes of the stamen-cup longer than the anthers; capsule depressed-globose, densely muricate, 4-6 $\mathrm{mm}$. in diameter. 
In red soil pockets and red-lands, New Providence, Cat Island, Great Exuma, Long Island, Great liagged Island, Fortune Island, Aeklin's, Crooked Island, Mariguana and Ambergris Cay:- the Florida Keys and Texas to California; West Indies, south to Guadelope; continental tropical America. Commos Arexis.

\section{Order 17. HYPERICÀLES.}

Herbs, shrubs, or trees, the flowers mostly complete, perfect and regular (irregular in Violaceae). Sepals distinct, or more or less united, imbricated or convolute. Petals present and distinct or wanting. Stamens usually numerous. Ovary compound, superior; placentae mostly parietal.

Styles none; trees or shrubs with small imbricated leaves.

Styles present, separate or united.

Styles separate or partly united.

Stigmas not brush-like; endosperm little or none.

Herbs or low shrubs, rarely trees; flowers perfect: stamens distiuet.

Trees or shrubs: stamens mostly united.

Flowers dioecious or polygamous; placentae axile.

Flowers perfect; placentae parietal.

Stigmas brush-like; endosperm copious.

Styles completely uuited; endosperm fleshy.
Fam. 1. TAMARICACEAE.

Fam. 2. HYPERICACEAE.

Fam. 3. Chusiachae.

Fam. 4. Canellaceaf.

Fam. 5. TURNERACEAE.

Fum. 6. Flacourticeae.

\section{Family 1. TAMARICÀCEAE Lindl.}

\section{TAMARISK FAMILT.}

Shrubs or trees. Leares alternate, without stipules, relatively small or scale-like, entire, often imbricated. Flowers mainly perfect, regular, usually in spikes or racemes. Calyx of 5 , or rarely 4 or 6 , imbricated sepals. Corolla of 5 , or rarely $4 \mathrm{or}^{*} 6$, distinet imbricated petals. Disk 10-lobed or obsolete. Stamens 5 to many; filaments distinct, free; anthers opening lengthwise. Ovary 1-celled, superior, with 3-5 basal placentae. Stigmas 3-5, distinet. Ovales 2-many on each placenta. Fruit a capsule. Seeds erect, terminating in a coma. Four genera and about 100 species, natives of the Old World.

\section{TÁMARIX L. Sp. Pl. 270. 1753.}

Shrubs or trees, with irregularly and widely branching stems, the wood firm. Leaves small, seale-like, elasping or sheathing. Flowers in dense spikes, racemes or panicles. Sepals 4 or 5, rarely 6, distinct. Petals white or pink, inserted under the lobed disk, distinct. Stamens 5-10; filaments not adnate to the corolla. Stigmas 2-5, short. Seeds numerous. Endosperm wanting. [Latin name.] About 60 species, of the Old World, the following typical.

\section{Tamarix gállica L. Sp. Pl. 270. 1753.}

A shrub or a small tree, with slender spreading branches, the branchlets very numerous, approximate or elustered, completely elothed with the imbrieater, scale-like, acute leaves which are $1 \mathrm{~mm}$. long or less; spikes nunerous, in panicles; sepals triangular, about $0.5 \mathrm{~mm}$. long; petals white or pinkish; capsule pyramidal, about $1 \mathrm{~mm}$. long.

Waste places, spontaneous after cultlvatlon, South Caicos and Grand Turk Island:- Naturalized from southern Europe in various localities from New York to New Mexlco and southward, and in Bermudr and the West Indles. Tamarisl. 


\title{
Family 2. HYPERICÀCEAE Lindl.
}

\author{
St. Johi's-wort Family.
}

Herbs or shrubs, sometimes small trees in tropical regions, with opposite, or rarely verticillate, simple entire or rarely glandular-ciliate or dentate leaves, 110 stipules, and solitary or cymose-paniculate flowers. Foliage pellucid-punctate or black-dotted. Flowers regular and perfect. Sepals 5 or 4 , imbricated. Petals of the same number, hypogynous, generally oblique or contorted. Stamens $\infty$, hypogynous, often in sets of 3 or 5 ; anthers versatile or innate, 2-celled, longitudinally dehiscent. Ovary 1-i-celled, composed of 1- $\bar{\tau}$ carpels; styles as many as the carpels; ovules $\infty$, in 2 rows in each carity, anatropous. Fruit mainly capsular with septicidal dehiscence; seeds mainly straight; endosperm none. About 10 genera and more than 300 species, mainly of temperate and warm regions.

\section{1. ÁSCYRUM L. Sp. Pl. 787. 1753.}

Leafy glabrous low shrubs, with small narrow entire black-punctate leaves, the flowers bright yellow. Sepals 4 , in 2 pairs, the exterior ones broad and round, the interior smaller and narrower. Petals 4, oblique or slightly contorted, deciduous. Stamens $\infty$, distinct, or united in elusters. Ovary 1 celled, with 2-4 parietal placentae; styles 2-4. Capsule 1-celled, 2-4-valved, dehiscent at the placentae. [Greek, not rough.] About 6 species, natives of eastern North America, Central America and the West Indies. Type species: Ascyrum hypericoides L.

1. Ascyrum linifòlium Spach, Hist. Veg. Phan. 5: 459. 1836.

An erect shrub, 3-6 dm. high, much branched, the twigs rery slender, densely leafy. Leaves linear to linear-oblong or linear-spatulate, nearly sessile, obtuse, 1-2 cm. long, 1-3 mm. wide; flowers solitary at the ends of the trigs, very short-peduncled; outer sepals oblong, acute, 6-8 $\mathrm{mm}$. long, the inner petal-like; petals widely spreading nearly in one plane, as long as or somewhat longer than the outer sepals; capsule linear-oblong, beaked, about as long as the outer sepals.

Pine-lands and palmetto-lands, Abaco, Great Bahama, Andros and New Providence :-Florida to Texas. ST. AXDrew's Cross.

\section{Family 3. CLUSIÀCEAE Lindl.}

\section{Clusia Family.}

Shrubs or trees, sometimes epiphytic, with resinons sap, opposite coriaceous estipulate entire leaves, the small or large, recular, polygamons, dioecious or rarely perfect flowers usually clustered, sometimes bracteolate. Sepals 2-6, rarely more, strongly imbricated. Petals usually as many as the sepals, sometimes more, hypogynous. Staminate flowers with numerous hypogynous stamens, the filaments united or distinet, with or without a rudimentary ovary. Pistillate flowers with a 2-several-celled ovary, and as many sessile or sub-sessile stigmas as there are ovary-cavities; staminodes or some perfect stamens usually present. Fruit baccate, drupaceous or capsular, usually fleshy. Seeds often arillate; endosperm none. About 25 genera and over 250 species, mostly tropical. 
1. CLÙSIA L. Sp. Pl. 509. 1753.

Evergreen trees or shrubs with resinous sap, often epiphytic or halfclimbing on other trees and sometimes strangling them, the leares opposite, entire, the usually polygamous, large flowers solitary or eymose. Sepals 4-16, imbricater. Petals 4-9, also imbricated. Stamens many in the staminate flowers, fewer in the pistillate ones; anthers linear. Pistillate flowers with several or many staminodes; orary 4-12-celled; stignas sessile, rarliating; ovules many in each eavity. Capsule leathery or fleshy, at length dehiscent. Seeds arillate, the embryo small, the cotyledons plano-convex. [Commemorates Charles de I'Eeluse, a French botanist of the sixteenth century.] About s0 species, of tropical and subtropical Ameriea. Type species: Clusia major L.

1. Clusia ròsea Jacq. Enum. 34. 1760.

A tree attaining a maximum height of about $16 \mathrm{~m}$., the stout twigs glabrous. Leaves obovate, glabrous, thick, coriaceous, rigid, 10-15 en. long, 7-12 cm. wide above the middle, elosely pinnately many-veined, rounded at the apex, cuneate at the base, the stout petioles about $1 \mathrm{em}$. long; flowers solitary or sometimes 2 together, short-peduncled; sepals 6 , rounded, 1-1.5 em. broad; petals white or rose, broadly obovate or nearly orbicular, $3-4 \mathrm{~cm}$. long, broadjy cuneate at the base; stigmas $7-9$; fruit glcbose, nearly white, $5-8 \mathrm{~cm}$. in diameter, fleshy.

Coastal coppices, Andros, New Providence, Inagua and East Caicos:-Florida: Cuba to Tortola, and to Trinidad; Jamaica; continental tropical America. Catesbs; 2: $p l .99$. P'ITCH APPLE.

Clusia flaza Jacq., a tree similar to $C$. rosea, with cuneate-obovate leaves and yellow flowers, is recorded by Schoepf, as seen by him on New I'rovidence in 1754 .

\section{Family 4. CANELLÀCEAE Mart.}

\section{Canella Fajilt.}

Aromatic trees or shrubs, with alternate pinnately reined, coriaceous or subeoriaceous, entire estipulate petioled leaves, and corrmbose regular perfect flowers. Sepals 3, distinct, imbricated. Petals 4-12, or wanting. Stamens many, the filaments united into a tube, the anthers extrorse. Orary superior, 1-celled, with 2-5 parietal placentae; orules 2-sereral. nearly anatropous; style stout; stigma 2-5-lobed. Fruit baceate. Seeds with a smooth erusteaceons testa; embryo suberlindric. in copious fleshy endosperm. Five genera and seven known species, of tropical America and Africa.

1. CANÉlla P. Br. Hist. Jam. 275. 1756.

An evergreen tree, glabrous throughout, with coriaceous leaves and terminal bracteolate corymbs of purple, red or violet flowers, the bark and leaves pleasantly aromatic. Petals 5. Stamens 10-20, the filament-tube not appendaged by seales, the anthers contiguous, longitudinally dehiseent. Orary with 2 or 3 parietal placentae each bearing 2 orules; style short; stigma $2-3$. lobed. Berry globose, its gelatinous pulp enelosing ferr, oboroill to orbicular sceds. [Latin, eimamon.] A monotypic genus. 
1. Canella Winteràna (L.) Gaertn. Fr. \& Sem. 1: 373. 17S8.

Laurus Winterana L. Sp. Pl. 371. 1753.

Winterana Canella L. Sist. Ed. 10, 1045. 1759.

Canella alba Murray, Syst. Yeg. 443. 1784.

A tree up to $10 \mathrm{~m}$. high, usually much smaller, sometimes shrubby, the trunk up to $2.5 \mathrm{dm}$. thick, the bark grey. Leaves oblanceolate or spatulate, 3-10 cm. long, dark green and somewhat shining above, rather dull beneath, rounded or obtuse at the apex, not prominently veined, the slender petioles about $1 \mathrm{~cm}$. long; corymbs few-several-flowered; pedicels slender; sepals reniform-orbicular, thick, about $3 \mathrm{~mm}$. long, ciliolate; petals obovate, obtuse, nearly twice as long as the sepals; stamen-tube $3-4 \mathrm{~mm}$. long; anthers yellow; berry erimson or nearly black, about $1 \mathrm{~cm}$. in diameter; seeds black.

White-lands, scrub-lands and thickets, Great Lahama, Andros, New Providence, Eleuthera, Rum Cay, Atwood Cay, Long Island, Acklin's Island, Crooked Island and Little Inagua :-Florida and the West Indies. Caxella. Wild Cixxayos. WhiteWOOD Bark. CixNajox Bark. Catesby, 2: $p l$. 50.

\section{Family 5. TURNERĀCEAE H.B.K.}

\section{Turnera Fanily.}

Herbs or shrubs, with alternate simple leaves mostly serrate and often 2-glandular at the base, the flowers regular, mostly perfect. Calyx-lobes or sepals 5, imbricated. Petals 5, thin, convolute, fugacious. Stamens 5, distinct, opposite the sepals; filaments compressed or subulate; anthers oblong. Ovary superior, 1-celled, with 3 parietal placentae; styles 3, filiform, simple or 2-cleft; stigmas usually flabellate and many-cleft; orules many, anatropous. Fruit a 1-celled capsule, partly or completely 3-ralved. Seeds foveolate, with fleshy endosperm and a membranous aril. Four genera and about 80 species, of tropical and subtropical distribution.

\section{TÚURNERA L. Sp. Pl. 271. 1753.}

Herbs or low shrubs, with toothed leares and solitary axillary yellow flowers, the peduncles often adnate to the petioles. Calyx 5-cleft. Petals obovate to spatulate, borne on the calyx-throat. Stamens borne below the petals, sometimes hypogynous. Ovary sessile; styles filiform; stigmas severalmany-cleft. Capsule 3-valved to the base, mostly many-seeded, the seeds borne near the middle of the valves, oblong or cylindric, curved, the aril narrow. [In honor of William Turner, herbalist, the "Father of English Botany," died 1568.] About 75 species, nearly all of tropical and subtropical America. Type species: Turnera ulmifolia L.

Calyx 5-fid or 5-partite; styles penicellate, multifid; capsule 3valred abore; leares large.

Calyx 5-dentate: strles 6-fid at summit; capsule 3 -ralved to the base: leaves small.

1. T. ulmifolia.

2. T. diffusa.

\section{Turnera ulmifòlia L. Sp. Pl. 271. 1753.}

Shrubby, erect, branched, 3-9 dm. high, more or less pubescent. Leares lanceolate to ovate-oblong, thin, short-petioled, $2-8 \mathrm{~cm}$. long, serrate, acute or acuminate at the apex, mostly narrowed at the 2 -glandular base; peduncles short; bractlets as long as or longer than the calyx; calyx deeply 5-lobed, its 
segments lanceolate, acute or acuminate; petals obovate, 1-3 cm. long; capsules 6-10 $\mathrm{mm}$. long, much shorter than the bractlets, 3 -valved above.

Rocky plains and white-lands, Abaco and Grent Bahama to Andros, the Caicos Islands, Grand Turk and Inigua:-Bermuda: Florida; the West Indies: Mexico to tropical South America. Consists of numerous races, differing in leaf-form, pubescence and size of flowers. Buttercups. Yellow Alder. LARGe-LeAved Turaera.

\section{Turnera diffùsa Willd.; Schultes, Syst. 6: 679. 1820.}

Triacis microphylla Griseb. Fl. Br. W. I. 297. 1860.

A pubescent, much-branched shrub, $2 \mathrm{dm}$. to $1.3 \mathrm{~m}$. high, the branches slender, spreading. Leaves small, 5-20 mm. long, spatulate or oblanceolate, firm in texture, coarsely few-tootheil, nearly sessile, deeply impressed-veined and glabrous abore, pubeseent beneath, mostly obtuse at the apex, attenuate to the base, the margin revolute; pelluneles very short; ealyx 5-toothed; petals spatulate, 3-8 mm. long, much longer than the calyx-teeth; stamens very short; capsule subglobose, about $1.5 \mathrm{~mm}$. in diameter, 3 -valved to the base.

Rocky plains and white-lands, Whale Cay, Joulter's Cay, New Providence, Eleuthera, Cat Isiand, Rum Cay. Great Guana Cay, Great Exuma, Crooked Island, Acklin's and Inagua:-Cuba to Virgin Gorda and St. Croix. SMall-Leaved TurNera.

\section{Family 6. FLACOURTIÀCEAE Lindl.}

\section{Flacourtia Fayily.}

Trees or shrnbs, with alternate simple, usually dentate leares, the stipules minute or wanting, the small regular flowers usually elusterer, perfect, dioecions or polygamous. Calyx 3-7-lobed or of $\dot{3}-\overline{7}$ distinct sepals. Petals as many as the calyx-lobes or sepals, or rarely more, or wanting. Stamens few or numerous, in some genera altemating with staminodia; filaments distinet or connate; anthers 2-celled. Ovary superior, 1-celled; ovnles few or numerous, on parietal placentae. Frnit capsular or baccate. About 70 genera, including over 500 species, of tropical regions.

Pètals present.

Petals none.

Stamens hypogrnous; leares not punctate.

Stamens perigrnous: leares mostly punctate. Style nowe: stamens numerous. Style present: stamens $6-15$.

\section{Banara. \\ 2. Myroxylon. \\ 3. Zuelania. \\ 4. Cascaria.}

1. BANARA Aubl. Pl, Guian. 1: 547. 1775.

Shrubs or trees with alternate petioled, somewhat inequilateral, usually glandular-deutate and punctate leaves, small stipules, and small perfect flowers in racemes, corymbs or panicles. Calyx persistent, 3-5-lobed, the lobes valvate. Petals as many as the calyx-lobes and similar to them, persistent, imbricated. Stamens many, with filiform filaments; staminodia none. Orary superior, 1-eelled or by intrusion of the placentae nearly several-eeller; ovules many; style slender; stigma eapitate. Fruit a fleshy or leathery, indehisent, many-sceded berry. Seeds striate, the endosperm fleshy. [Guiana name.] About 15 species, natives of tropieal America. Type speeies: Banara guianensis Aubl. 
1. Banara reticulàta Griseb. Cat. Pl. Cub. 8. 1566.

A glabrous shrub, 1-3 m. high or a small tree up to about $8 \mathrm{~m}$. high, the slenter tmigs terete. Leares oblong or orate-oblong, coriaceous, $2.5-7 \mathrm{~cm}$. long, somewhat inequilateral, low-serrate with blunt teeth, rounded, obtuse or some of them acute at the apex, mostly rounder or subcordate at the base, densely and strongly reticulate-veined, shining above, the petioles $4-8 \mathrm{~mm}$. long: corrmbs several-many-flowered, 3-6 $\mathrm{cm}$. broad; pedicels $5-10 \mathrm{~mm}$. long, thickened in fruit; calyx about $5 \mathrm{~mm}$. long, its segments broadly orate, rounded, puberulent and ciliolate; petals yellomish, about as long as the calyx; fruit oroid, red, about $8 \mathrm{~mm}$. long, tipped by the style.

Rocky pine-lands, Andros, New Providence, Eleuthera and Great Exuma :-Cuba. BAxARx. Catesby, 2: 17.42.

\section{MYROXYLON Forst. Char. Gen. 126. 17i6.}

Shrubs or trees, usually spiny, with usually toothed, sometimes spinulosedentate leaves and small, dioecious or polygamous flowers, fascicled or shortracemose in the axils. Sepals 4 or 5 , imbricated. Petals wanting. Stamens several or numerous, borne on a glandular disk, the anthers versatile. Ovary with 2-6 parietal placentae; orules few or sereral; style simple or eleft, sometimes very short; stigmas dilated, rarely lobed. Fruit a small, 2-several-seeded berry, the seeds obovoid. [Greek, balsam wood.] About 30 species, tropical and subtropical in distribution. Type species: Myroxylon suaveolens Forst.

1 Myroxylon ilicifòlium (Northrop) Britton, Bull. N. Y. Bot. Gard. 4: 141. 1906.

Xylosma ilicifolia Northrop, Mem. Torr. Club 12: 51. 1902.

A shrub, $3 \mathrm{~m}$. high or less, much branched, the twigs slender, the stem and branches usually armed with slender, often branched spines. Leares oral to oborate or oblanceolate, coriaceous, short-petioled, $2-3 \mathrm{~cm}$. long, entire or with 1-3 spinulose-tipped teeth, the apex acute and spinulose, the base narrowed, the upper surface strongly shining, the lateral renation obscure; fascicles fewflowered; pedicels of staminate flowers slender, 2-4 mm. long; sepals rellow or greenish, ciliate, about $1 \mathrm{~mm}$. long; pedicels of pistillate flowers 1-2 mm. long; berry bluish-black, globose, about $5 \mathrm{~mm}$. in diameter.

Coppices, and pine-Iands, Andros, New Proridence, Elenthera, Cat Island. Endemic. Holly-Leaved Mrroxylox. Recorder by Dolles as Tylosma nitidum A. Gray and as I. buxifolium; and by Hitcheock as if. buxifolium pauciflorum.

\section{Myroxylon bahaménse Britton, Bull. N. Y. Bot. Gard. 4: 141. 1906.}

An intricately branched shrub or small tree $4 \mathrm{~m}$. high or less, the trunk and larger limbs densely armed with branched spines $5 \mathrm{~cm}$. long or less. Wood vellowish-white, rery hard and dense; twigs armed with subulate spines $1.5 \mathrm{~cm}$. long or less; leaves orate or oblong to oblanceolate, coriaceous, $6-30 \mathrm{~mm}$. long, scarcely shining above, dull and paler green beneath than above, entire or with 1 to 4 blunt teeth, the apex acute, the base rounded, or narrorred, the petiole about $1 \mathrm{~mm}$. long; fruit oboroid-oblong, obtuse, $6 \mathrm{~mm}$. long, $3 \mathrm{~mm}$. in diameter.

Scrub-lands and coppices, Abaco, Great Bahama, New rroridence. Endemic. Batiaja MrRoxtLON. 
3. ZUELÀniA A. Rich. Ess, Fl. Cub. 88, 1845 .

Trees or shrubs with alternate petioled serrate punetate leaves, and small fascieled flowers, the pedicels jointed, bracted at the base. Calyx $1-5$ lobed, the lobes imbriested. Petals wanting. Stamens 20-40, alternating with staminodia. Orary superior; orules numerous, on parietal placentae; stigma almost sessile, peltate. Fruit a large globose fleshy, berry-like capsule, at length dehiseent Seeds numerous, arillate, with fleshy endosperm. [Commem. orates José Maria Talenzuela, a Cuban botanieal collector.] One or two West Indian species, the following typical.

\section{Zuelania Guidònia ( $\mathrm{S} \pi$.) Britton \& Millspaugh.}

Laetia Guidonia Sw. Prodr. 83. 1785.

Zuelania laetioides A. Rich. Ess. Fl. Cub. S8. 1845.

Casearia laetioides Northrop, Mem. Torr. Club 12: 55. 1902.

A tree, up to about $30 \mathrm{~m}$. high, usually mueh smaller, the stout twigs densely pubeseent when young. Leaves thin, deeiduous, oblong to oblong-lanceolate or elliptie, $7-20 \mathrm{em}$. long, low-crenate or nearly entire, strongly pinnately veined, aeute or aeuminate at the apex, obtuse or rounded and mostly somewhat oblique at the base, glabrous or nearly so above, pubeseent beneath, the petioles $1 \mathrm{em}$. long or less; faseicles many-flowered; pedieels pubeseent, 6-10 mm. long; sepals pubescent, suborbicular, about $7 \mathrm{~mm}$. long; staminodia about one-half as long as the stamens; fruit subglobose, $3-5 \mathrm{~cm}$. in diameter.

Coppices and scrub-lands, Abaco, Andros and New Providence:-Cuba; Jamaicil. ZEELAXIA.

\section{CASEÀRIA Jacq. Enum, 4, 21. 1760.}

Shrulss or trees, sometimes spinescent, with alternate, mostly toothed and punetate or lineate leaves, small stipules, and small regular green or yellowish flowers in braeted, lateral faseicles or umbels, the pedieels jointed at or above the base. Calyx-lobes $1-6$, imbricated. Petals wanting. Stamens 6-15; filaments distinct or united below, alternating with staminodia. Orary superior; ovules many, borne on parietal plaeentae; style short, undiviled or 3-cleft; stigma capitate. Capsule dry or fleshy, 3-4-valved, several-many-seeded. Seeds with a fleshy aril, the testa coriaceous; endosperm fleshy. [Commemorates John Casearius, a Duteh missionary of the seventeenth century.] Over 75 speeies, natives of tropical and subtropieal regions. Type species: Casearia nitida (L.) Jacq.

Leaves ovate, glabrous, shining; Howers in stalked glabrous cymes. 1. C. bahumcnsis. Leaves obovate to elliptic, pubescent at least wlien young; cymes sessile or very nearly so, densely puberulent.

2. C. spinesecns.

1. Casearia bahaménsis Urban, Symb. Ant. 3: 322. 1902.

A glabrous shrub or small tree sometimes $4-5 \mathrm{~m}$. high, mueh-branehed, the twigs slender and terete. Leaves ovate to elliptie, subcoriaecous, $1.5-\overline{\mathrm{cm}}$. long, obtuse, acute or aeuminate at the apex, obtuse or subcordate at the base, crenulate, shining above, and finely retieulate-reined, the petioles $6-12 \mathrm{~mm}$. long; eymes axillary, peduncled, severat-flowered; pedieels slender, 5-10 mm. long; ealyx about $5 \mathrm{~mm}$. long, densely short-pilose within; stamens shorter than the ealyx; staminolia $1-1.5 \mathrm{~mm}$. long, short-pilose; f'ruit subglobose, rellow, 5-6 $\mathrm{mm}$. in diameter, $1-\overline{0}$-seeded.

Scrub-lands aud copplees, Andros, Xew lrovidence and Great Exuma :-Cuba.

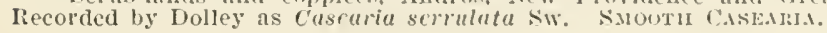




\section{Casearia spinéscens (Sw.) Griseb. Cat. Pl. Cub. 10. 1566.}

Samyda spinescens Sw. Prodr. 68. 1788.

A shrub, $3 \mathrm{~m}$. high or less, or a small tree about $4 \mathrm{~m}$. high, unarmed, or with short spinescent spurs, the branches sometimes elongated and vine-like, the young twigs appressed-pubescent. Leaves oborate to oral or elliptic, membranous, 2-7 em. long, obtuse or acute at the apex, narrowed at the base, low-erenate, pubescent on both sides when young, becoming glabrate, the petioles 2-8 $\mathrm{mm}$. long; eymes several-flowered, pubescent, sessile in the axils or on leafless twigs; pedicels stout; ealyx pubescent, 5-6 mm. long, green, about as long as the pedieel, its rounded segments ovate or elliptie, obtuse; staminodia orate, broad, a little shorter than the stamens; fruit oblong, $1.5-2 \mathrm{~cm}$. long.

Coppices, New Providence, at Waterloo: Andros, near Crow IIil :-Cuba: Hispaniola ; Tobago; Trinidad: Guiana. IRecorded in Bull. N. Y. Bot. Gard. 5: 316, as C. alba A. Rich., following Grisebach. SPlNi CASEAR]A.

\section{Order 18. PASSIFLORÀLES.}

Herbs, tendril-bearing vines, shrubby plants, or succulent trees with a milky sap. Leaves alternate, entire or lobed. Flowers perfect, or when dioecious, the staminate and pistillate very different. Calyx of 5 more or less united sepals. Corolla of 5 distinet or partially united petals, sometimes accompanied by a fringed crown. Stamens 5 or 10 in 2 unequal rows. Ovary superior, 1-celled, with 3-5 parietal placentae. Stigmas entire, notched or forked. Fruit a berry or capsule.

Corolla accompanied by a crown (corona) : flowers perfect, all alike.

Corolla not accompanied by a crown; flowers mainly dioecious, the staminate and pistillate different.

Fam. 1. Passifloraceae.

Fam. 2. CARicaceae.

\section{Family 1. PASSIFLORÀCEAE Dumort.}

\section{Passion-Flower FaMily.}

Tines, climbing by tendrils, or rarely erect herbs, with petioled usually palmately-lobed leaves, and perfect regular flowers. Calyx-tube persistent. Petals usually 5, inserted on the throat of the calyx, distinct, or in some species united. Stamens 5. Throat of the calyx crowned with a double or triple fringe. Filaments subulate or filiform, monadelphous, or separate. Ovary free from the calyx, 1-celled; placentae $3-5$, parietal; styles 1-5. Fruit a berry or capsule, usually many-seeded. About 18 genera and 350 species, of warm and tropical regions, most abundant in South America.

1. PASSIFLòra L. Sp. Pl. 95̃5. 1753.

Climbing tendril-bearing rines, with alternate or rarely opposite leaves, and large axillary flowers, on jointed, often bracted peduneles. Calyx-tube cup-shaped or campanulate, 4-5-lobed, the lobes narrow, imbricated in the hud, its throat erowned with a fringe ealled the corona. Petals 4 or 5 (rarely wone), inserted on the throat of the ealyx. Orary oblong, stalked. Filaments monadelphous in a tube around the stalk of the ovary, separate abore; an- 
thers narrow, versatile. Fruit a many-secled berry. Seeds pulpy-arilled, flat, ovate; endosperm fleshy. [Flower of the Cross, or Passion, as emblematic of the crucifixion.] Abont 300 species, mostly of tropical America, a few in Asia and Australia. Type species: Passiflora incarnata L.

Calyx subtended by an involncre of 3 pectinate or incised bracts.

Bracts pectinate into filiform segments.

Plant villous-pubescent; leaves flaccid.

Plant glablous or somewhat glandular; leaves firm in texture.

Practs linear-lanceolate, irregularly incised-pectinate.

Calyx not subtended by an iuvolucre.

Petals none.

I'etals 5

Leares softly pubescent or glabrate.

Leares oblong, entile.

Leaves broader than long, 2-lobed, cordate.

Leaves glabrous.

Leaves 2-lobed, wider than long.

Leaves ovate-oblong, narrowel than long.

1. P. foetida.

2. P. bahamensis.

3. Pectinati.

4. P. pallida.

5. P. multiflora.

6. P. rubra.

7. P. biffora.

S. P. cupiaca.

\section{Passiflora foètida L. Sp. Pl. 959. 1753.}

Herbaceous, villous and glandular-riscid, trailing or climbing, sometimes $2.5 \mathrm{~m}$. long. Leaves slender-petioled, broadly orate or ovate-orbicular in outline, 3-lobed or 3-angled, flaccid, irregularly low-dentate, $3-12 \mathrm{~cm}$. long, cordate or subcordate at the base, acute at the apex, the stipules $5-10 \mathrm{~mm}$. long, pinnatiseet; peduncles $1-3$ in the axils, mostly longer than the petioles, not jointed; involuere of 3 finely pinnatisect bracts $2-4 \mathrm{~cm}$. long, the ultimate segments nearly filiform, gland-tipped; calyx 5-parted, $1.5-2.5 \mathrm{~cm}$. long; petals white or pinkish, about as long as the calyx; crown pink, of three series of segments; berry ovoid, $2- \pm \mathrm{cm}$. long, nearly dry when mature.

Roadsides, New Providence:- West Indies and tropical continental America, north to Texas. VISCID PASSIOX-FLOWER.

2. Passiflora bahaménsis Britton, Bull. N. Y. Bot. Gard. 5: 315. 1907.

Stems slender, purple, usually trailing, sometimes elimbing on low shrubs, $0.5-1.5 \mathrm{~m}$. long. Tendrils wiry, mostly as long as the leaves or longer; petioles 1-3 cm. long, bearing scattered stalked glands, rarely glandless; stipules small, glandular-fimbriate; leaf-blades firm in texture, panduriform, $7 \mathrm{~cm}$. long, or less, 3-loberl, cordate at the base, shining above, dull beneath, the basal lobes rounded or somewhat angled, one fourth to one half as long as the acute middle one, the margin with stalked glandular hairs all around; perluneles glabrous, longer than the petioles; involuere-segments bipinnatisect, 2-3 cm. long, with very numernus stalkerl glands; calyx-segments oratelanceolate, acute; petals orate-oblong, about $2 \mathrm{~cm}$. long; crown purple, its outer segments about three fourths as long as the petals; berry globose, about $2 \mathrm{~cm}$. in diameter, bright red and shining when ripe, its stalk above the persistent involnere $6-5 \mathrm{~mm}$. long; seeds oblong, rough, $4 \mathrm{~mm}$. long.

Pine-lands, copplces, white-lands and sandy soil, Andros: New Irovidence: Cat Island. Endemic. Referred by Grisebach and by Dolley to the Jamaican P. ciliata Ait., and by Mrs. Northrop to $P$. pectinate Griseb. BaIAala Passrox-flower.

\section{Passifiora pectinàta Griseì. Fl. Br. W. I. 294. 1560.}

Glabrous, high-climbing or trailing. Leaves ovate, rather firm in texture, 3-8 cm. long, erenate, 5- $-\mathbf{- n e r r e d}$, somewhat contracted near the middle, cordate at the base, acute or blunt at the apex, with minute glands at the ends of the veins, the petioles $2.5 \mathrm{~cm}$. long or less, eglaudular; tendrils slender, as long as the leaves, or longer; flowers solitary in the upper axils, about $6 \mathrm{~cm}$. broad, on peduncles longer than the petioles; involucre of 3 linear pectinate 
or pinnatifid bracts about $2.5 \mathrm{~cm}$. long; erown about one half as long as the oblong white sepals; fruit ellipsoid, red, slightly fleshy, about $2.5 \mathrm{~cm}$. long; seeds rough.

Littoral sands and savamnas, Little San Salvador, Cat Island, Conception Island, Watling's lsland. Cave Cay, Great Guana Car, Great liagged Island, Acklin's Island, Crooked Island, Fortune Island, Green Car, South Caicos, Grand Turk, Little Ambergris Cay, and the Inaguas :-Bermuda; IIispaniola. The plant recorded by Hitcheock as $p$. ciliat" viparia. Wr. proves to be the above species. PECTINATE PASSION-FLOWER. WILD APRICOT.

\section{Passiflora pallida L. Sp. Pl. 955.1753.}

Passiflora minima L. Sp. Pl. 959. 1753.

Passiflora suberosa L. Sp. Pl. 958. 1753.

Passiflora angustifolia Sw. Prodr. 97. 1788.

A slender vine, with nearly glabrous or pubescent foliage. Leaves ovate to linear, 6-15 cm. long, ciliate, 5-nerved at the broadly cuneate or cordate hase, entire, toothed, or 3 -lobed to above the middle, the lobes ovate or triangnlar, acute or acuminate, the middle one much the larger; petioles 5-15 mm. long, each with 2 glands at or above the middle; peduncles surpassing the petioles, commonly in pairs; calyx greenish, 2-2.5 cm. broad; sepals lanceolate or linear-lanceolate; S-12 min. long; corolla wanting; crown-filaments purple at the base, shorter than the sepals; berries subglobose or oral, 10-12 mm. in diameter.

Coppices and scrub-lands, throughout the archipelago from Abaco and the Berry Islands to East Caicos, Grand Turk and Inagua:-Bermuda; Florida; West Indies; continental tropical America.

The species consists of a large number of races, glabrous or pubescent, the leares varying from linear-lanceolate to nearly orbicular, and the fruit from globose to ellipsoid. Referred to by Hitcheock as $P$. villosa Macf. Juxiper-BERrY. SMLALL PASSION-FLOWER. Catesby, 2: $p l$. 51 .

\section{* 5. Passiflora multiflòra L. Sp. Pl. 956. 1753,}

A somewhat woody, slender rine, elimbing to a length of $6 \mathrm{~m}$. or more, the stems and leaves finely pubescent or sometimes glabrous. Leares oblong or ovate-oblong, 5-12 $\mathrm{cm}$. long, entire, pinnately veined and triplinerved, reticulate-reined beneath, obtuse or acute and mucronulate at the apex, obtuse, rounded or subcordate at the base, the short petiole 2-glandular at the top; peduncles 2-6 together in the axils, slender, jointed near the middle, 5-15 mm. long; involucre none; sepals oblong-lanceolate, greenish-yellow, about 6 $\mathrm{mm}$. long; petals linear, white, shorter than the sepals; carpophore none; berry globose, 6-10 mm. in diameter.

Coppices and scrub-lands, Andros; New Providence ; Eleuthera :-Florida; Cuba to Tortolo. OBLONG-LEAVED PASSION-FLOWER.

\section{Passiflcra rùbra L. Sp. Pl. 956.1753.}

A softly pubescent, slightly woody vine, sometimes $2 \mathrm{~m}$. long or more. Leares thin, eglandular, broader than long, $7-12 \mathrm{~cm}$. broad, 5-nerred, deeply eordate at the base, broadly 2-lobed or subtruncate, the lobes orate, acute or acutish, the midvein excurrent, the petioles 1-4 $\mathrm{cm}$. long; peduncles solitary or 2 in the axils, slender or filiform, longer than the petioles, jointed below the flower; flowers $3-5 \mathrm{~cm}$. broad, greenish-white, the 5 sepals somewhat longer than the 5 petals; crown of 3 series of subulate processes, about as long as the petals; berry oral or subglobose, pubescent, 6-ribbed, $2-4 \mathrm{~cm}$. in diameter, longer than the earpophore.

Open fields and scrub-lands, Abaco: New Providence :-Cuba to Porto Rico and Trinidad; Jamaica; continental tropical America. BroAD-LEAVEd PAssion-flower. 
7. Passiflora biflòra Lam. Encyel. 3: 36. 1 ¡ S9.

Passiflora lunata Will.. Sp. Pl. 3: 612. 1801.

Glabrous, somewliat woody, I m. long or longer. Leaves chartaceous, 2-lobed, mostly broader than long, $5-\mathrm{s} \mathrm{cm}$. broad, acellate beneath, strongly 3-nerved, reticulate-reined on both surfaces, subcordate or obtuse at the base, shining above, dull beneath, the lobes obtuse or rounded, the slender glaniless petioles 1-4 cm. long; flowers white, about $2 \mathrm{~cm}$. broal, solitary or in pairs in the axils, the peduncles as long as the petioles or longer; flowertube campanulate; crown white or yellowish, its outer segnents spreading, nearly as long as the petals, dilated above; berry subglobose, about $2 \mathrm{~cm}$. in diameter, fleshy.

Pine-lands, Abaco, New Providence:-Tamaica; tropical continental America. TWO-LOBED PASSTOX-FLowER. Apparently recolded by Shoepf as $P$. Vespertilio L.

\section{Passiflora cupraèa L. Sp. Pl. 955. 1753.}

A somewliat woody, glabrous vine, 1-2 m. long. Leares orate to elliptic, rather thin, short-petioled, 3-5 cm. long, 3-nerved, dark green, rounded and mucromulate at the apex, rounded or subcordate at the base, reticulate-veined on both sides, with a few distant flat circular glands beneath; peduncles longer than the petioles, jointed at about the middle; ealyx white to red or purple, 2-3 cm. Jong; petals narrowly oblong, shorter than the calyx; crownsegments few, linear; carpophore $2-3 \mathrm{~cm}$. long; berry globose, $10-20 \mathrm{~mm}$. in diameter, dark purple.

Sclub-lands, coppices, and constal thickets, Abaco and the Berry Islands to South Bimini, Andros, Inagua, Nolth Caicos, the Anguilla Isles and Cay Sal:-Cuba. Devil's Puapkix. Wild WAterafelos. Shooti Passion-Flower. Catesby, $2: p l .93$.

\section{Family 2. CARICÀCEAE Dumort.}

\section{PAPAW FAMILY.}

Trees, with milky sap, ample broad palmately 7-9-lobed leaves and unisexual, or rarely perfect flowers. Calyx short. Staminate flowers with a salver-shaped corolla, its tube slender; the lobes 5, valvate or convolute; stamens 10, inserted in the throat of the corolla; filaments short; anthers adnate to the filaments, 2-celled. Pistillate flower's with 5 distinct petals and no staminodia; ovary compound, 1-celled, or sometimes imperfectly 5-celled, free, sessile; stigmas 5, sessile; ovules numerous, in two or many series on the 5 placentae. Fruit a large fleshy berry. Seeds numerous, flattened, with a roughened testa; endosperm fleshy; embryo axile. There are two genera, the following composed of about 25 species of tropical and subtropical distribution, and Jacaratia of tropical Africa and America, which differs from Carica by having the stamens partly united.

\section{CARÌCA L. Sp. Pl. 1036. 1753.}

Characters of the family. [Named from the fancied resemblance of the fruit to that of the Fig.] Type species: Carica Papaya L.

\section{Carica Papàya L. Sp. Pl. 1036. 1753.}

A small tree, with a simple wand-like stem, 3-6 $\mathrm{m}$. tall, leafy at the top. Lares large, thick, suborbicular in outline, 2-6 dm. broad, mostly palmately 
7-lobed, pale or glaucous beneatl, each lobe pinuately lobed, the segments obtuse or acute, or the larger ones acuminate; petioles stout; staninate flowers in slender panicles 1-several $\mathrm{dm}$. long; calyx of the staninate flowers 1-1.5 mm. long, that of the pistillate flowers 5-10 $\mathrm{mm}$. long, the lobes longer than the tube; corolla yellow, that of the staminate flowers $2.5-3 \mathrm{~cm}$. long, its tube slender, dilated near the top, its lobes lanceolate or elliptic-lanceolate, barely as long as the tube; corolla of the pistillate flowers longer, the petals distinct, lanceolate, twisted; berries oblong to subglobose, $0.6-3 \mathrm{dm}$. long, yellow or orange, with a milky juice.

Scrub-lands, spontaneous after cultivation, Eleutbera, on the margin of the salt pond about half way between the Glass Window and Gregory Town, Andros and Inagua :-naturalized in many places in the West Indian Islands, and in Florida, its native home unknown, but, doubtless, in tropical America. PAPAW.

\section{Order 19. LOASÀLES.}

Herbs, often armed with hooked stinging or viscid hairs, with estipulate leaves, and regular perfect white yellow or reddish flowers. Calyx-tube adnate to the ovary, its limb 4-5-lobed, persistent. Petals 4 or 5, inserted on the throat of the calyx. Stamens $\infty$, inserted with the petals; filaments filiform, commonly arranged in clusters opposite the petals; anthers introrse. Orary 1-celled (rarely 2-3-celled), with 2-3 parietal placentae; ovules anatropous. Capsule usually 1-celled, crowned with the calyx-limb. Seeds mostly numerous; endosperm scanty.

\section{Family 1. LOASÀCEAE Rehb.}

\section{Loasa FaMiLY.}

Characters of the order. About 20 genera and 250 species, all but 1 natives of America.

\section{MENTZÈLIA L. Sp. PI. 516. 1753.}

Erect or straggling herbs, with entire, lobed or pinnatifid leares, and terminal, cymose or solitary flowers. Calyx-tube cylindric, linear or clubshaped, the limb usually 5-lobed. Petals 5, convolute in the bud, spreading, deciduous. Stames 20-100. Orary 1-celled; styles 3, more or less united; stigmas small, obtuse. Capsule dehiscent at the summit, few-many-seeded. Seeds mostly prismatic, rough or striate. [In honor of C. Mentzel, a German botanist, died 1701.] About 35 species, natives of America. Type species: Mentzelia aspera $\mathrm{L}$.

\section{Mentzelia floridàna Nutt.; Torr. \& Gray, Fl. N. Am. 1: 533. 1840.}

Ascending or diffusely branched, 3-6 dm. high, the slender stem and branches rough-pubescent. Leares ovate or triangular-orate, scabrous-pubescent, rather firm in texture, short-petioled, 2-9 $\mathrm{cm}$. long, acute or acuminate at the apex, subtruncate or broadly cuneate at the base, dentate, sometimes 3-lobed; flowers sessile and solitary in the upper axils; sepals lanceolate or linear-lanceolate, $5-6 \mathrm{~mm}$. long; petals yellow, about 3 times as long as the sepals; ovary obconic, densely hispid; capsule hispid, 1-1.5 cm. long.

Sandy waste grounds, Eleuthera, near Governor's Harbor:-Florida. Florids MEXTZELLA. 


\section{Order 20. OPUNTIÀLES.}

Fleshy plants, with continuous or jointed stems, mostly leafless, or with small leaves, generally abundantly spiny, the spines developed from cushions of hairs or bristles (areolae). Flowers mostly solitary and sessile, perfect, regular, showy. Calyx-tube adnate to the ovary, its limb manylobed. Petals numerous, imbricated in several rows, mostly distinct. Stamens numerous, inserted on the throat of the calyx. Filaments filiform; anthers small. Ovary 1-celled; ovules numerous, anatropous, borne on several parietal placentae. Style terminal, elongated; stigmas numerous. Fruit a berry, mostly fleshy, sometimes dry. Seeds smooth, or tubercled, the testa usually crustaceous or bony; endosperm little, or copious. Only one family.

\section{Fanily 1. CACTÀCEAE Lindl.}

\section{Cactus Fajily.}

Characters of the order. Abont 100 genera and not less than 1000 species, natives of America.

Areoles with spines but withont glochides; corolla not rotate.

Plants tall or long, erect or climbing.

Ilants tall, mostly elect, with ribbed, columnar branches. Flowers short-campanulate, the style exserted; fruit smooth.

Flowers elongated-campanulate, the style included; fruit tubercled when young.

Plants climbing or trailing, with aerial roots; flowers nocturnal, large, widely campanulate.

Joints sharply trigonous; corollil-tube not woolly.

Joints terete, ribbed or $4-8$-angled; corolla-tube woolly.

rlants globose or oroid, not more than twice as high as thick.

Plants ribbed, surmounted by a woolly cephalium which bear's the Hower's.

Plants with no cephalium, tubercled, the areoles bearing spines and flower's.

1. Cephalocerus.

2. Harrisia.

3. Huloecreus.

4. Seleniefreus.

5. Cactus.

6. Coryphantha. Areoles with or withont spines, but with glochides; corolla rotate.

7. Opuntia.

\section{CEPHaLocìreus Pfeiffer, Allg. Gartenz. 6: 142. $183 \mathrm{~s}$.}

[Pilocereus Lemaire, Cact. Gen. Nov. \& Spec. 6. 1839.]

Large, simple or branched, erect, columnar cacti, the joints leafless, elongated, ribbel and grooverl, the upper areoles of ten densely lanate or lougvristly. Flowers solitary at upper areoles, nocturual, fleslyy, rather small, the tube short-funnelform or campanulate, the segments not very willely expanding; ovary subglobose, naked or bearing a few scales, spineless; style usually short-exserted. Fruit a globose or depressed-globose smooth berry: seeds small and numerous, black or brown. [Greek, head-Cereus.] Forty species or more, of tropical and subtropical America. Type species: Cactus senilis Haw.

Flowering areoles whth wool as long as the splnes or longer; plant pale-pruluose.

Flowering areoles without wool or the wool much shorter than the splnes; plant dull green, not prulnose.

1. C. Millspanghii.

2. C. bahamensis. 
1. Cephalocereus Millspaùghii Britton, Contr, U. S. Nat. Herb. 12: 417.1909.

Stem branched, 2-6 m. high, $20 \mathrm{~cm}$. thick at the base, the branches nearly erect, $5-12 \mathrm{~cm}$. thick, pale grayish green, pruinose, $8-13$-ribbed, the ribs acutish, about as wide as high or a little wider; areoles $1-2 \mathrm{em}$. apart; spines about 20, acicular, willely radiating, $1-2 \mathrm{~cm}$. long, or at the flower-bearing (upper) areoles 3-7 cm. long, the old ones gray bromn, the young ones yellow or yellow-brown, with darker bases; upper areoles on one side of the plant with large tufts of whitish wool often as long as the spines or longer; flowers $6 \mathrm{~cm}$. long.

Rocky hillsides, coppices and thickets, Care Cay, Cat Island, Conception Island, Watling's, Acklin's, Mariguana, Long Island, Caicos Islands, Cotton, Salt and Ambergris Cars, and Little Inagua :-Cuban Cays. Recorded by Dolley and by Hlitcheock as Cereus Suartzii Griseb.; by Coker as Pilocerus lanuginosus. MIILSpaUgh's Dildo. Wild F'tg. OLd Mlix Cactes.

2. Cephalocereus bahaménsis Britton, Contr. U. S. Nat. Herb. 12: 415. 1909.

Plant 3-4 m. high, often $20 \mathrm{~cm}$. thick at the base, the branches dirergentascending, 7-9 $\mathrm{cm}$. thick, dull green, not pruinose, 10- or 11-ribbed, the ribs blunt or acutish, rather higher than wide; areoles 1-1.5 em. apart; spines 1520, acienlar, radiately spreading and aseending, gray-brown to yellow-brown when old, 1-1.5 $\mathrm{cm}$. long, the young ones yellowish with darker bases, the uppermost 2.5-3 cm. long; wool very short (shorter than the spines), or none; flower 5-6 em. long, brownish outside, the petals creamy-white.

Rocks hillsides, Frozen Car, Andros, Eleuthera, and Crooked Island. Endemic. Recorded by Mrs. Northop as Cereus Swartzii Griseb. BahaMa Dildo.

2. HARRISIA Britton, Bull. Torr. Club 35: 561. 1908.

Night-flowering cacti, mostly with upright branched cylindric stems, the branches fluted, with from 8-10 rounded ribs, separated by shallow grooves and bearing leafless areoles at frequent intervals, each areole with acicular spines. Flowers borne singly, at areoles near the ends of the branches, funnelform, large, with a eylindrie sealy but spineless tube as long as the limb or longer; buds globose, ovoid, or obovoid, densely scaled, the scales subtending long or short woolly nairs; sepals pink or greenish, linear-lanceolate; petals white; stamens shorter than the petals; style somewhat longer than the stamens; fruit globose to ovoid-globose, green to yellow, tubereled or becoming smooth, spineless, with mostly deciduous seales; corolla withering-persistent; seeds very numerous, small. [In honor of William Harris, Superintendent of Public Gardens and Plantations of Jamaica, distinguished for his contributions to the knowledge of the flora of that island.] About 8 species, natives of Florida and tropical America. Type species: Cereus gracilis Mill.

\section{Harrisia Broòkii Britton, Bull. Torr. Club 35: 564. 1908.}

Plant $5 \mathrm{~m}$. high, much hranched, light green; branches $3-4 \mathrm{~cm}$. thick, 10-ribbed, the ribs sometimes prominent, with deep depressions between them. Areoles about $2 \mathrm{~cm}$. apart; spines $6-12$, the longer ones $2-2.5 \mathrm{~cm}$. long; bud oroid, prominently long-pointed, its scales with few eurled white hairs $7-10$ $\mathrm{mm}$. long; fruit yellowish, subglobose or ellipsoid, about $8 \mathrm{~cm}$. in diameter, rounded at both ends, or narrowed above, the tubercles very low, with tips only $1.5 \mathrm{~mm}$. high, the linear scales persistent.

Scrub-lands, Long Island at Clarence Town. Endemic. Recorded hy Dolley as Cercus repandus Haw, and also as Cereus pellucidus (presumably). Named in honor of Herbert M. Brook, for many years Registrar of the Bahamas, who greatly facilitated our explorations. At the place of publication Clarence Town was inad. vertently printed George Town. Brook's Dildo. 
3. HYLOCĖREUS (Berger) Britton \& Rose, Contr. U. S. Nat. Herb. 12: 42 S. 1909 .

Climbing or trailing cacti, with 3-winged or 3-angled, mostly stout stems and branehes emitting aerial roots, but bearing no leaves, the areoles horne on the wings or angles and armed with few or several short spines. Flowers nocturnal, very large, regular, the ovary and tube bearing large, orate to linear-lanceolate scales, nsually without spines or hairs, the perianth-segments numerons, linear or narrowly lanceolate, widely spreading, the outer green, the inner mostly bright white. Stamens very many. Fruit a scaly berry, not spiny nor bristly. [Greek, forest-cerens.] About 20 species, natives of tropical America. Type species: Cereus triangularis L.

1. Hylocereus undàtus (Haw.) Britton \& Rose; Britton, Fl. Berm. 256. 1918.

Cercus undatus Haw. Phil. Mag. 7: 110. 1830.

Cereus tricostatus Cosselin, Bull. Soc. Bot. France 54: 664. 1907.

Stems stout, fleshy, glabrous, sometimes $7 \mathrm{~m}$. long, often climbing on trees, the branches 3-12 $\mathrm{dm}$. long, green, 3-winged, the wings flat, 1-2.5 $\mathrm{cm}$. broad, coarsely crenate, their margins with a narrow horny border; spines $2-5$ at each areole, brownish, $3-4 \mathrm{~mm}$. long; flowers about $3 \mathrm{dm}$. long, the tube about $3 \mathrm{~cm}$. thick, rather shorter than the limb, bearing several linearlanceolate scales $3-8 \mathrm{~cm}$. long; ovary $2 . \overline{5}-\overline{\mathrm{cm}}$. long, bearing several ovate acute scales $2.5 \mathrm{~cm}$. long or less; style stout, about as long as the stamens; berry oblong, red, pulpy, about $8 \mathrm{~cm}$. long, corered with orate scales.

on trees and walls, spontaneous or persistent after cultivation. New Irovidence :-Bermuda : Florida : the Test Indies: continental tropical America : native of Mexico. Has been confused with Cercus triangularis L., of Jamaica. NigHTBLOOMING CERELS.

4. SELENICEREUS (Berger) Britton \& Rose, Contr. U. S. Nat. Herb. 12: 429. 1909.

Climbing or trailing, rine-like eacti, the joints several-ribbed, fluted or angled, giring off aerial roots, the large funnel-form flowers nocturnal; the stem-areoles bearing conic or acieular spines, but no leares. Orary and flowertube bearing small scales, usually with long hairs and bristles or spines in their axils. Perianth segments numerous, narrow, spreading or recurved, the inner white. Stamens numerous. Fruit a globose or ovoid berry, usually large, bearing clusters of deciduous spines. [Greek, moon-cereus.] About 14 species, natives of tropical America. Type speeies: Cactus grandiflorus L.

Stems fluted; spines about $2 \mathrm{~mm}$. long, shorter than the wool.

Stems 4-6-angled, or ribbed; spines 6-8 mm. Iong, much longer

than the wool.

1. S. Bocckmani.

2. S. grandillorus.

1. Selenicereus Boéckmanni (Otto) Britton \& Rose, Contr. Nat. Ilerb. 12: 429. 1909.

Cerens Bocchmanni Otto; Salm-Dyck, Cact. Hort. Dyek. 1849: 217. 1850.

Stems light green, 1-2 em. thick, several-ribbed or angled. Spines 3-6 at the areoles, subconie, about 2 mm. long, bromnish or yellowish; flowers about $3 \mathrm{dm}$. long; outer perianth-segments and seales of the flower-tube linear, brown or brownish; inner perianth-segments oblanceolate, about $10 \mathrm{~cm}$. long 
and $3 \mathrm{~cm}$. wide; wool of the areoles of ovary and flower-tube brown, silky; style greenish; ovary strongly tubercled; fruit globose, 5-6 $\mathrm{cm}$. in diameter.

On walls, persistent or spontaneous after cultivation, New Providence:-Cuba ; Hispaniola ; east coast of Mexlco. QUEEN-OF-THE-NigHT.

2. Selenicereus grandiflòrus (L.) Britton \& Rose, Contr. U. S. Nat. Iferb. 12: 430. 1909.

Cactus grandiflorus L. Sp. Pl. 467. 1753.

Cereus grandiflorus Mill. Gard. Dict. er. 8, no. 11. 1768.

Stems light green, but often becoming deep purple, up to $3 \mathrm{~cm}$. in diameter; ribs 4-S, rather prominent but less so on the older branches; areoles small, white; spines acieular, $1 \mathrm{~cm}$. long or less, yellowish; deflexed bristles or hairs from the lower part of the areoles several, white, often longer than the spines; flowers $2 \mathrm{dm}$. long; onter perianth-segments and scales of the tube linear, greenish or brownish, sometimes nearly rose-colored; inner perianth-segments acute, rather broad; style cream-colored, stout; areoles of orary and flowertube bearing short wool and long silky whitish hairs and white bristles; ovary tubercled; fruit ovoid, about $8 \mathrm{~cm}$. long.

Thickets, Care Car, persistent after cultivation :-Cuba ; Jamaica. QueEx-OFTHE-NIGHT. Often cultivated.

5. CÁCTỰS L. Sp. Pl. 466. 1753.

Subglobose ovoid or short-cylindric, ribbed leafless cacti, the spinebearing areoles borne on the ribs, the flowering areoles confluent into a terminal, densely woolly and bristly cephalium. Flowers with a cylindric tube, sometimes enlarged at the base, the limb several-many-lobed, the lobes imbricated. Stamens several or numerous, the filaments capillary, the anthers oblong. Ovary smooth; style filiform; stigma-rays few or many; ovules many. Fruit an obovoid or subclarate, fleshy and juicy berry, at length protruded from the cephalium, crowned by the withering perianth. Seeds many, small, black, without endosperm. About 20 species, natives of tropical America. Type species: Cactus Melocactus L.

\section{Cactus íntortus Mill. Gard. Diet. ed. 8, no. 2. 1768.}

Plant depressed-globose when young, when old ovoid, 3-4 dm. high and often $3 \mathrm{dm}$. in diameter, rather light dull green, 15-20-ribbed, the ribs 2-4 cm. high, crenate, the areoles bearing $7-13$, stout subulate spines $1.5-4 \mathrm{~cm}$. long; cephalium at first nearly flat, at length eylindric, about $10 \mathrm{~cm}$. in diameter, sometimes $3 \mathrm{dm}$. high, densely white-woolly and brown-bristly; flowers pink or rose, 1-1.6 cm. long; inner perianth-segmerts acute or cuspidate; fruit red or rose, narrowly obovoid, $2-2.5 \mathrm{~cm}$. long.

Rocky soil. Long Island, Acklin's Island, Mariguana, East and South Caicos, Turks Islands, Eastern Cay, Cotton Cay. Ambergris Car, Little Inagua and Inagua:Mona to Virgin Gorda and Antigua. Recorded by Dolley as Helocactus communis DC. TERK'S-C.AP.

\section{CORYPHÁNTHA Lemaire, Cact. 32. 1868.}

[Mammllaria Haw. Syn. Pl. Succ. 177. 1812. Not Stackh. 1809.]

Stems globose or ovoid, tubercled. Tubereles conic or cylindric, woolly and with clusters of spines at the apex. Leaves none. Flowers borne in areolae at the bases of the tubercles. Calyx-tube prolonged beyond the ovary, which 
is often hidden between the tubercles. Petals in several rows. Ovary smooth, oroid; style filiform. Berry emersed, crowned by the withering corolla. [Greek name of some prickly plant.] About 300 deseribed species, natives of warm and tropical America. Type species: Mammillaria sulcolanata Lemaire.

1. Coryphantha nivòsa (Link.) Britton, Annals Mo. Bot. Garł. 2: 45. 1915.

Mammillaria nivosa Link; Pfeiff. Enum. 11. 1837.

Plants globose or globose-oblong, solitary or tufted, becoming 10-12 cm. in diameter, and sometimes $1.5 \mathrm{dm}$. long. Tubereles many, dull green, oblongconic, 1-1.5 cm. high, obtuse; areoles bearing several yellow or yellowish brown, acicular spines $2 \mathrm{~cm}$. loug or less, and when young, tufts of bright white wool; flowers cream-eolor, about $1 \mathrm{~cm}$. broad; perianth-segments acute or acuminate; herry obovoid or oblong-obovoid, obtuse, 1-1.5 cm. long, red. Woolly NipPLECACTUS.

Rocky places, South Caicos and Inagua :-Mona; Culebra to Tortola and Antigua. Recorded by Dolley as Echinocactus sp.

7. OPÚNTIA [Tourn.] Mill. Gard. Dict. Abr. ed. 4. 1754.

Suceulent plants, with jointer branching stems, the joints flat, or eylindrie, and small, mostly subulate, deciduous leares, the areolae usually spine-bearing. Flowers usually lateral. Calyx-tube not prolonged beyond the ovary, its lobes spreading. Petals numerons, slightly united at the base. Stamens rery ummerous. Orary eylindrie, exserted; style eylindrie, longer than the stamens; stigma 2-i-rayed. Berry globose to oboroid, often spiny. [Named from a town in Greece where some species grew.] About 250 species, natives of America. Type species: Cactus Opuntia L.

Plants with erect continuous stems branching into flat joints at the summit.

I'lants abundantly spiny.

Branches erect or ascending; areoles not pitted.

Branches widely spreading: areoles pitted, spineless except at and near the edges of the joints.

Plants nearly or quite spincless.

Plants bushy-branching from the base.

Joints much longer than wide. the spines pale rellow.

Joints little or somewliat longel than wide; spines dark yellow or yellow-brown.

Affinity uncertain.

1. O. Nashii.

2. O. Millspaughii.

3. O. bahamana.

4. O. Iисауала.

5. O. Dillenii.

6. O.Darrahiana.

\section{Opuntia Náshii Britton, Bull. N. Y. Bot. Garł. 3: 446.1905.}

Tree-like, dull green. Main axis round, 1-4 m. high, 5-12 cm. in diameter, spiny; branches flat or beeoming round below, the prineipal ones continuous, $1 \mathrm{~m}$. long or more, $6 \mathrm{~cm}$. wide or less, erenate, blunt; lateral branches opposite or alternate, oblong to linear-oblong, often $3 \mathrm{dm}$. long, and $8 \mathrm{~cm}$. wide, only about $6 \mathrm{~mm}$. thick, blunt, crenate; areoles $1-3 \mathrm{~cm}$. apart, slightly elerated; spines mostly 5 at each areole (2-5), divergent, slenter, straight, light gray, pungent, the longer $3-5 \mathrm{~cm}$. long: gloehiles very small, lorownish; ovary $3 \mathrm{~cm}$. long, 1.5 "m. thick, somewhat clavate, tubercled, the tubereles hearing areoles and spines similar to those of the joints, but the spines somewhat shorter; flowers $1.5 \mathrm{~cm}$. broal when expanded, reil; petals broadly oval to obovate, blunt, about $8 \mathrm{~mm}$. long, much longer than the stamens.

Scrub-lands and rocky plains, Andros, silp Channel Cay, Atwood Cay, Fortume Island. Crooked Island, North and Soutl Calcos, Grand Turk, Eastern Cay. Turk's Islands and Inagua. Endemic. leerorded by Mrs. Northrop and by IItelicock as Opuntia spimosissima; and by Coker and presumably by Dolley as o. triumutha.

NASII'S PRICKLY'PRAR. 


\section{Opuntia Millspaùghii Britton, Smiths. Misc. Coll. 50: 513. 1908.}

Trunk terete, $7 \mathrm{~cm}$. thick at base, $5 \mathrm{~cm}$. thick at top, $6 \mathrm{dm}$. high or less, branching at the summit, the branches divaricate-ascending, narrowly oblong, much compressed, $40 \mathrm{~cm}$. Iong or less, 5 to $10 \mathrm{~cm}$. wide, 1 to $1.5 \mathrm{~cm}$. thick, light green. Branchlets obliquely lanceolate, obtuse, as wide as the branches, but shorter, $1 \mathrm{~cm}$. thick or less, floriferons at and near the apex; areoles of the older branches pittell, about $1 \mathrm{~cm}$. apart, those of very young shoots slightly elevated, the glochicles very short, yellow-brown; spines of the trunk $15 \mathrm{~cm}$. long or less, very numerous and densely clothing the trunk, very slender, gray, mostly strongly reflexed, pungent, those of the branches and branchlets restricted to the areoles on their edges, shorter than those of the trunk, but similar, those of the fruit yellow-gray, $2 \mathrm{~cm}$. long or less; flowers eupulate, crimson-lake, $1 \mathrm{~cm}$. wide; sepals fleshy, ovate, acute, $4 \mathrm{~mm}$. long and wide; petals erect-ascending, obovate, mucronulate, about $4 \mathrm{~mm}$. wide; stamens half as long as the corolla; style about as long as the corolla; stigma oblong, yellowish crimson; fruit compressed-obovoid, $2 \mathrm{~cm}$. long, $1.5 \mathrm{~cm}$. thick, bearing one or two spines at most of the areoles.

On nearly flat and smooth limestone rocks, Eleuthera, at Rock Sound: Long Island, on Thatch Cas; Great Ragged Island:-Cuban Cays, MILLSPAUGH's PRickirPEAR.

3. Opuntia bahamàna Britton \& Rose, Cactaceae 1: 203, f. 254, 255. 1919.

Branched from a short trunk, bushy, about $1.5 \mathrm{~m}$. high. Joints oblong to lanceolate, flat and thin, 1-5 dm. long, 4-10 cm. wide, dnll green, obtuse, scarcely undulate; areoles $1.5-3 \mathrm{~cm}$. apart, scarcely elevated, about $2 \mathrm{~mm}$. in diameter, spineless, or bearing 1-4 acicular yellow spines $2 \mathrm{~cm}$. long or less; glochides few and short; corolla about $6 \mathrm{~cm}$. broad; petals obovate, rose-tinted below, yellowish-rose above; sepals dark rose, whitish-margined.

Rocky places, Cat Island at The Right. Endemic. Tentatively referred to $O$. lanceolata Haw., in Smitl. Misc. Coll. 50: 525. BAHAid Prickly-Pear.

\section{Opuntia lucayàna Britton, Bull. N. Y. Bot. Gard. 4: 141. 1906.}

Stems ascending, often forming dense elumps. Joints various, linearoblong to obovate, often $10 \mathrm{dm}$. long, 6-15 $\mathrm{cm}$. ride, olive-green, slightly lustrous, more or less crenate, about $1.5 \mathrm{~cm}$. thick, knobbed at the areoles; areoles distant, nearly $1 \mathrm{~cm}$. broad, white-velvety; glochides numerous, yellow, $6 \mathrm{~mm}$. long or less, mostly borne at the upper margins of the areoles; spines 3-8 at each areole, light-yellow, flattened on the upper side, subulate, straight, often somewhat twisted, the longer ones $12 \mathrm{~cm}$. long or less; flowers yellow, $7-8 \mathrm{~cm}$. broad; stamens about half as long as the petals; ovary narrowly pyriform, 4-5 cm. long, its upper areoles bearing 1-3 subulate pale-yellow spines $2.5 \mathrm{~cm}$. long or less, which are sometimes persistent on the fruit; berry pyriform, 5-6 cm. long, $2-3 \mathrm{~cm}$. in diameter.

Scrub-lands, Grand Turk Island. Endemic. Ture's Islaxds Prickly-pear.

The reference to Opuntia Tuna at the place of original publication of this species is erroneous; as now understood, $O$. Tun grows naturally only in Jamaica. $O$. 7ucayana may be a hybrid between $O$. Dillenii and $O$. Nashii.

5. Opuntia Dillènii (Ker-Gawl.) Haw. Suppl. Pl. Suce. 79. 1819.

Cactus Dillenii Ker-Gawl. Bot. Reg. 3: pl. 255. 1818.

Bushy-branched, 0.5-1.8 m. high, often forming masses $2 \mathrm{~m}$. in diameter. Joints green, glabrous, mostly obovate and $1-2.5 \mathrm{dm}$. long, about $8 \mathrm{~mm}$. thick, erenate, the areoles $2-6 \mathrm{~cm}$. apart, somewhat elevated, bearing $1-4$, stout yellow spines 1-4 cm. long, or spineless, the numerous glochides yellowish to brownish, $6 \mathrm{~mm}$. long or less; flowers solitary at the areoles, often abundant, bright 
yellow, about $7.5 \mathrm{~cm}$. broad; ovary obovoid, with glochisle-bearing areoles; petals obovate; stamens much shorter than the petals; fruit pyriform, red or purple, edible, $5-8 \mathrm{~cm}$. long.

Maritime and coastal rocks, Abaco and Great Bahama to Grand Turk and Inagua :-Dermuda: Florida: West Indies: eastern coast of Jlexico. Recorded by Hitehcock, Coker, irs. Northrop and Dolles, as O. Tuna (L.) 11 ill. and by schoepit as Cactus Tuma l. CoMMox l'RickLY-PLAld.

6. Opuntia Darrahiàna Weber, Bull. Mus. Hist. Nat. Paris 10: 388. 1904.

Forming tufts 2-2.5 $\mathrm{dm}$. high and $4 \mathrm{dm}$. in diameter, much-branched. Joints green, 7-8 cm. long, 4-5 cm. wide; areoles 1-2 cm. apart; glochides none; spines about 6 , the longer $4-4.5 \mathrm{~cm}$. long, the shorter not more than $1 \mathrm{~cm}$. long, all white or grayish-white, brownish at the tip, straight, acicular, rigid.

Obtained by Darrah from Turk's Islands according to Weber; known to us only from the description; neither the flowers nor the fruit are described. D.innu's PRICKLY'PEAR.

\section{Order 21. MYRTÀLES.}

Herbs, shrubs or trees, unarmed, sometimes aquatic or amphibious. Leares alternate or opposite. Flowers regular or irregular, complete, and often showy, or reduced to a stamen and pistil aduate to the hypanthinm. Hypanthium merely enclosing the ovary or adnate to it. Stamens few or many. Anthers opening by slits, valves or pores. Stigma terminating the style, or sessile. Fruit capsular or baccate, or resembling an achene.

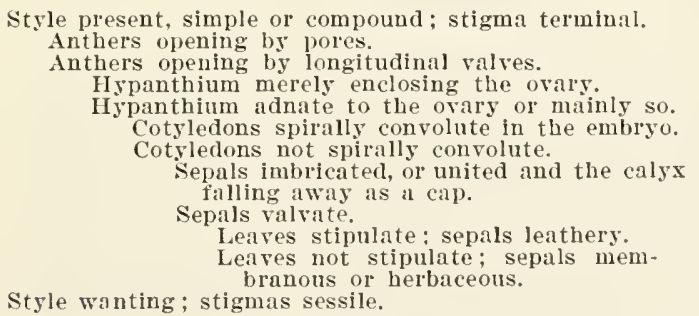

.Fam. 1. Melastonaceae.

Fam. 2. Lithraceae.

Fim. 3. Terminalichae.

Fam. 4. Mrrtaceae.

Fam. 5. Rinzophoraceae.

Fam. 6. ONAGRICEAE.

Fim. 7. HALORAGIDACEAE.

\section{Family 1. MELASTOMÁCEAE R. Br.}

\section{Meadow-beauty Fanily.}

Herbs, or many shrubs or trees in tropical regions, with opposite 3-9nerved leaves, and regular perfect often showy but rarely odorons flowers. Stipules none. Calyx-tube usually 4-5-lobed, the lobes imbricated. Petals as many as the lolies of the ealyx and inserted on its throat, imbrieaterl. Stamens twice as many, or equal in number to the petals, often inelined or declined, the alteruate ones sometimes shorter. Ovary 2-several-celled (often 4-celled); style terminal, simple; orules $\infty$, anatropous. Fruit included in the ealyx-tube, capsular or baceate. Seeds mainly small, with no endosperm. Abont 150 genera and 2500 species, widely distributed in tropical regions, most abundant in South Ameriea. 
1. TetrazỲgia L. C. Rich.; DC. Prodr. 3: 172. 1828.

Trees or shrubs, the foliage often scurfy, with petioled, entire or toothed leaves, and rather small flowers in terminal panicles or corymbs. Calyx constricted abore the orary, its limb $4-5$-lobed or subtruncate. Petals 4 or 5, oborate. Stamens S or 10, nearly equal; filaments subulate; anthers linear, opening by a pore. Orary 4-5-celled; style curved, filiform; stigma minute. Fruit a 4-5-celled fleshy berry. [Greek, referring to the 4-parted flowers of the type species.] About 16 species of the West Indian region. Type species: Tetrazygia tetrandra (Sw.) DC.

1. Tetrazygia bícolor (Mill.) Cogn. in DC. Monogr. Phan, 7: 724. 1891.

Melastoma bicolor Mill. Dict. ed. 8, No. 6. 1768.

A shrub or small tree up to $6 \mathrm{~m}$. high, with scaly bark, the young twigs scurfy. Leares lanceolate to oblong-lanceolate, 0.8-2 dm. long, strongly 3ribbed and with many widely spreading lateral veins, entire, acuminate at the apex, mostly obtuse at the base, green above, whitish-scurfy beneath, the slender scurfy petioles 2-4 cm. long; panicles peduncled, 1-2 dm. long, several-many-flowered; pedicels slender, $5-10 \mathrm{~mm}$. long; calyx-limb subtruncate; petals 4, white, $7-8 . \mathrm{mm}$. long; berry subglobose, purple or black, 8-10 mm. in diameter.

Scrub-lands, pine-lands and coppices, Abaco, Great Bahama, Andros, New Prov1dence and Eleuthera:-Florida: Cuba. Reported by Grisebach and by Dolley as $T$. angustiflora Griseb. and by Schoepf as Nelastoma discolor L. TetrizigiA.

\section{Family 2. LYTHRĀCEAE LindI.}

\section{Loosestrife Falithy.}

Herbs, shrubs, or often trees in tropical regions, mostly with opposite leaves and perfect flowers. Stipules usually none. Calyx persistent, free from the ovary, the limb toothed. Petals as many as the primary calyzteeth, inserted on the calyx, or none. Stamens inserted on the calyx. Anthers versatile. Orary 2-6-celled or sometimes 1-celled; style 1; orules $\infty$, rarely few, anatropous. Capsule 1 -several-celled. Seeds without endosperm; cotyledons flat, often aurieled at the base. About 21 genera and 400 species, of wide distribution.

Fruit globose : flowers regular.

$\begin{array}{ll}\text { Herbs with axillary inflorescence. } & \text { 1. Ammannia. } \\ \text { Shrubs or small trees with terminal inflorescence. } & \text { 2. Latesonia. }\end{array}$ Fruit elongated; flowers irregular.

2. La-iesonia.

\section{AMMÁNNIA [Houst.] L. Sp. Pl. 119. 1753.}

Annual glabrous or glabrate herbs, mostry with 4-anglea stems, opposite sessile narrow leaves, and small axillary flowers. Calyx campanulate, globose or ovoid, 4-angled, 4-toothed, often with small accessory teeth in the sinuses. Petals 4, deciduous or none. Stamens 4-8, inserted on the calyx-tube. Orary nearly globular, 2-4-celled. Capsule bursting irregularly. [Named for Johann Ammann, 1699-1741, a German botanist.] About 20 species, of wide distribution. Type species: Ammannia latifolia L. 
1. Ammannia latifòlia L. Sp. Pl. 119. 1753.

Erect, 2-11 dm. high, the branches nearly erect, or ascending. Leaves linear-lanceolate or linear-oblong, 2-7 cm. long, 2-10 $\mathrm{mm}$. wide, acute or blunt at the apex, sessile, clasping the stem by an auricled base; flowers minute, green, sessile and solitary or few together in the axils; calyx about $2 \mathrm{~mm}$. long; petals none; style short; eapsule about $4 \mathrm{~mm}$. in diameter, enclosed by the calyx.

Borders of fresh-water holes and marshes, Great lBahama, Andros, New Providence, Elcuthera, Cat Island, Watling's, Long Island, Acklin's, Crooked Island, North Caicos and Inagua:-Florida; the West Indies; IIexico and continental tropical America. Amaxinia.

2. LAWSÒNIA. L. Sp. Pl. 349. 1753.

A glabrous shrub, the terete branches sometimes spinescent, the small leares opposite and entire, the numerous small white flowers corymbose. Calyx turbinate, 4 -angled, the 4 lobes spreading. Petals 4 , sessile. Stamens 8 , borne near the base of the calyx-tube; filaments subulate; anthers oblong. Ovary subglobose, 4-celled; ovules numerous; style filiform; stigma eapitate. Capsule subglobose, 4-celled, irregularly rupturing, many-seeded. Seeds 4 angled, cuneate, truncate; cotylectons orbicular. [Commemorates Isaac Lawson, English physician and botanist, died 1747.] A monotypic genus.

\section{Lawsonia inérmis L. Sp. Pl. 349. 1753.}

Lawsonia alba Lam. Encycl. 3: 106. 1789.

A shrub $5 \mathrm{~m}$. high or less, with slender gray branches, unarmed or spiny. Leares thin, elliptic or elliptic-lanceolate, $1-4.5 \mathrm{~cm}$. long, acute, obtuse or abruptly acuminate at the apex, narrowed or euneate at the base, the short petioles slender; corymbs several-many-flowered, forming a terminal panicle; perlicels slender, scarcely longer than the flowers; calyx-lobes ovate, acnte, 2-3 mm. long; petals somewhat longer than the calyx-lobes; stamens longer than the petals or equalling them; capsules about $6 \mathrm{~mm}$. in diameter.

Scrub-lands, spontaneous after cultiration, Inagua near Iatthew Town:spontaneous in many localities throughout the West Indles, Mexico, aud tropical continental America. Native of the Orient. Hexis P'LANT.

3. PARsónsia P. Br.; Adans. Fam. Pl. 2: 234. 1763.

[Curnes P. Br.; Adans. loc. cit. Ilyponym. 1763.]

ITerbs (some shrubs in tropical regions), with opposite or verticillate leaves. Flowers axillary, irregular anı unsymmetrical. Calyx-tube elongated, 12-ribbed, gibbous or spurred at the base, oblique at the mouth, with 6 primary teeth and usually as many accessory ones. Petals 6, unequal. Stamens 6-11, inserted on the throat of the calyx, unequal; filaments short. Ovary with a curved gland at its base, unequally 2-celled; style slender; stigma 2lobed. Capsule oblong, 1-celled, laterally dehiscent. Seeds flattened. [In honor of James Parsons, M. D., a Scotch botanist.] About 180 species, natives of America. Type species: Lythrum Parsonsia L. 
1. Parsonsia Parsónsia (L.) Britton; Northrop, Mem. Torr. Club 12: 53. 1902.

Lythrum Parsonsia L. Syst. el. 10, 1045. 1759.

Cuphea Parsonsia R. Br., Steud. Nom. 1: 245. 1821.

Parsonsia radicans Hitehe. Rep. Mo. Bot. Gard. 4: 87. 1893.

Annual; herbaceous; stem little-branched, the branches prostrate or ascending, 1-3 lm. long, rongh-puhescent. Leaves ovate or oblong, 1-2 cm. long, very short-petioled, acute or obtuse at the apex, mostly narrowed at the base, scabrous or nearly smooth; flowers solitary in upper axils, shortpeduncled; calyx about 4 nm. long, gibbous at the base, its teeth rery small; petals pale purple, about $2 \mathrm{~mm}$. long; stamens 6 , included; filaments glabrous; capsule about $5 \mathrm{~mm}$. long, few-seeded.

Dry coral rocks and sink-holes, New Providence and Great Exuma :-Cuba to Porto Kico and Martinique; Jamaica ; Mexico. I'Uríle Parsonsia.

\section{Family 3. TERMINALIÀCEAE J. St. Hil.}

\section{White MaNgrove FaMiLY.}

Trees, shrubs, or vines, with petioled, usually simple and entire, estipulate leaves, and regular, perfect or rarely polygamo-dioecious flowers, mostly spicate, racemose or capitate. Tube of the calyx adnate to the ovary, the limb 4-S-cleft. Petals usually small or none. Stamens various; filaments filifolm; anthers didymous or 2-celled, the saes dehiscent longitudinally or by valves. Ovary 1-celled; ovules 1-several; style usually straight; stigma simple. Fruit various, mostly indehiscent, coriaceous or baccate. Abont 15 genera and some 275 species, mostly tropical.

Fruit terete.

Petals wanting.

Petals 5 ; calyx persistent.

Fruit an ellipsoid, flatteued drupe; petals none.

Fruit a cone-like mass of scale-like drupes: petals none.

1. Bucida.

2. Laguncularia

3. Terminalia.

4. Canocarpus.

\section{BUCIDA L. Syst. ed. 10, 1025. 1759.}

Trees or shrubs, sometimes spinescent, with coriaceous entire alternate leaves clustered at the ends of the twigs, and small spicate or capitate flowers, some perfect, some staminate. Calyx broadly campanulate, slightly 5toothed, persistent. Corolla none. Stamens 10, in 2 series; filaments slender, exserted. Fruit a small, slightly fleshy drupe, crowned by the at length deciduous calyx. [Latin; slender horn-like galls develop from the fruit after it is bitten by a mite.] Two species, natives of the West Indian region. Type species: Bucida Buceras L.

Flowers spicate; tree: drupe $8 \mathrm{~mm}$. long.

Flowers capitate; spinescent shrub or tree; drupe $3-4 \mathrm{~mm}$. long.

1. B. Buceras.

2. B. spinosa.

1. Bucida Bucèras L. Syst. ed. 10, 1025. 1759.

A tree, attaining a maximum leight of about $25 \mathrm{~m}$., the trunk up to 1 m. in diameter or more, the young twigs and leares pubescent, becoming glabrous. Leaves clustered at the ends of twigs, spatulate to elliptic, 3-9 $\mathrm{cm}$. long, obtuse or emarginate at the apex, narrowed at the base, shortpetioled; spikes peduncled, slender, pubescent, $3-10 \mathrm{~cm}$. long; ealyx-lobes tri- 
angular, acute; stamens exserted; drupe ovoid-conic, about $8 \mathrm{~mm}$. long, tomentulose, slightly eurred, the persistent ealyx at length deeiduous.

Thickets and scrublands. Andros, New Proridence, North and South Caicos and Inagua :-Florida; West Indies; Panania. leferred to by Hitcheock as Buceras angustifolia (DC.) Hitchcock. Erroneously called O.AK, BLACK OLIVE.

\section{Bucida spinòsa (Northrop) Jennings, Ann. Carn. Mus. 11: 201. 1917.}

Terminalia spinosa Northrop, Nem. Torr. Club 12: 54. 1902.

A shrub or flat-topper tree, $45 \mathrm{~m}$. high, with spreading branches, the trunk 1.5-2 $\mathrm{dm}$. in dianeter, the twigs divarieate, spiny. Leaves fascicled, subsessile, oblanceolate to spatulate, $1-2.5 \mathrm{em}$. long, 4-6 $\mathrm{mm}$. wide, firm in texture, glabrous, entire, obtuse or retuse at the apex, narrowerl at the base; spines slender, $3-7 \mathrm{~mm}$. long, mostly in 3 's at the ends of the twigs; flowers few, greenish, in axillary short peduneled spikes; calyx eampanulate, about 3 nim. long, subtrumeate, rillous witlin; stamens $\mathrm{S}$ or 9 , abont $3 \mathrm{~mm}$. long; drupe ovoid, $3-t \mathrm{~mm}$. long, the ealyx rather early deciduous.

Coastal and savanna coppices and sclub-lands, Great Balıma and Andros:Cuba. SPINY Black OLIVE. Brier-tree, I'RICKLY-Tree.

\section{LAGUNCULARIA Gaertn. f. Fr. \& Sem. 3: 209. 1805.}

A halophytic tree or shrub, with opposite entire leaves, the petioles 2glandular, and small greenish flowers in elustered spikes. Flowers polygamous or perfect. Calyx-tuhe terete, 5-loberl. Petals 5, minute. Stamens 10, short, the filaments subulate, the anthers cordate. Ovary with a scalloped epigynous disk; style short, glabrous; stigma somewhat 2-lobed; orules 2 in each carity. Drupes coriaceous, ribhed or angled. Seed solitary, germinating within the drupe. [Latin, from the fancied resemblance of the drupe to a flask.] A monotypie genus.

\section{Laguncularia racemòsa (L.) Gaertn. f. Fr. \& Sem. 3: 209. 1505.}

Conocarpus racemosa L. Syst. ed. 10, 930. 1759.

A tree, reaching a maximum height of about $20 \mathrm{~m}$. with a trunk up to $8 \mathrm{dm}$. in diameter, usually much smaller, and often shrubby, the reddish brown, glabrous trigs thiekened at the norles. Leares ollong, oval or obovate, $2-7$ em. long, emarginate or rounded at the apex, rounded, narrowed or subeordate at the base, the stout petioles $0.5-2 \mathrm{~cm}$. long; spikes $3-6 \mathrm{~cm}$. long, fewsereral-flowered; ealyx tomentulose, its lobes rounded; petals 5, orbieular, not longer than the calyx; Arupes oblong to obovoid, reddish, 1.5-2 em. long, constricted below the persistent ealyx-lohes.

Borders of mangrove mud and in sea-shallows. Great Bahama, Great Sturrup Cay, Little Inrbor Cay, Andros, New Providence, Shin Chamnel Cay, Great Guana Cay, Freat Exuma, Eleuthera, Cat Island, Fortune Isliund, Grand Turk, and the Anguilla Isles :- Florida ; Wost Indies: tropic conthental Ameriean coasts. Wirte

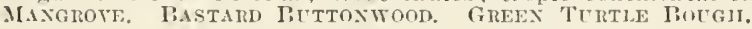

\section{TERMINALIA L. Mant. 1: 21, 12S. 1767.}

Trees or shrubs, with broad alternate entire leares, usually elusteed at the enis of the hanches, and small spieate fowers. Calyx-tube terete, ribless, the lohes deciduous. Corolla none. Stamens 10 to 20 , exserterl, the filaments slender, the anthers corlate. Fruit a drupe. [Latin, referring to the clustered leares at the ends of the branehes.] About 100 species, mostly of the Old World tropies. Type speeies: Terminalia Catappa L. 


\section{Terminalia Catáppa L. Mant. 1: 12s. 1767.}

Buceras Catappa Hitche. Rep. Mo. Bot. Gard. 4: 85. 1893.

A tree, up to $24 \mathrm{~m}$. high, with a trunk diameter of $1.5 \mathrm{~m}$., usually much smaller, the spreading branches whorled, the twigs stout, glabrous. Leaves clustererl at the ends of the twigs, obovate or broadly oblanceolate, 1-3 dm. long, short-petioled, glabrous, rounder, or short-pointer at the apex, cuneate at the base, dark green and shining abore, pale green beneath; spikes slender, many-flowered, 5-15 cm. long; calyx S-10 mm. long, pubescent, its ovate lobes about as long as the tube or longer; drupe ellipsoid, compressed, glabrous, 2-edged, pointed, 4-7 cm. long; seed 3-4 cm. long.

In coppices, spontaneous after cultivation; planted and sometimes spontaneous near towns on all the larger islands:- spontaneous after cultivation in Florida, in many of the West Indian islands and most inhabited parts of continental tropical America. Native of the old World tropies. IxdiA AlsoNd. AlmoNid-TREe.

\section{CONOCÀRPUS L. Sp. Pl. 176. 1753.}

A shrub or tree of the seacoast, with alternate entire leathery leaves, the petioles 2-glandular, the small greenish perfect flowers in racemose or panicled heads. Calyx-tube flattened, not prolonged beyond the ovary; sepals 5, deciduous. Petals none. Stanens mostly 5, with slencler elongated filaments and cordate anthers. Style pubescent. Orules 2. Drupes scale-like, densely aggregated. Seeds flat; cotyledons convolute. [Greek, referring to the cone-like heads of fruit.] A monotypic American genus.

\section{Conocarpus erécta L. Sp. Pl. 176. 1753.}

A glabrate or silky-puhescent shrub or tree, sometimes $20 \mathrm{~m}$. tall, sometimes less than $1 \mathrm{~m}$. high, with angled or winged twigs. Leares $2-5 \mathrm{~cm}$. long, elliptic to oval, acute or acuminate at both ends, entire, short-petioled; racemes $3-5 \mathrm{~cm}$. long, peduncled; heads $5-8 \mathrm{~mm}$. in diameter at flowering time; hypanthium funnel-like, greenish, a little over $1 \mathrm{~mm}$. long; sepals triangular-orate, about as long as the limb of the hypanthium, pubescent; stamens and style conspicuously exserted; heads of fruit 9-14 mm. long; drupes seale-like, $2 \cdot \pi$ inged, $4-7 \mathrm{~mm}$. long.

Coastal mud, savannas and salina-borders, throughout the archipelago to Cay Sal :-Bermuda; Florida: West Indies and continental tropical America. A species of many races, several of which have received rarietal distinction from herbarium specimens; the distinctive characters are, however, not maintained in the field. BCtтosmood. Catesby, 2: pl. 33 .

\section{Family 4. MYRTÀCEAE R. Br.}

\section{Mrrtle Fajilly.}

Trees or shrubs, with simple, usually opposite and entire, pellueidpunctate, estipulate leaves, the regular and perfect. often bracteolate flowers mostly panicled. Calyx-tube (hypanthium) adnate to the ovary, the limb usually 4-5-cleft. Petals usually 4 or 5, imbricated, rarely wanting. Dise mostly annular and fleshy. Stamens usually numerous, sometimes only as many as the petals; filaments filiform, distinct. or united at the base; anthers small, 2-celled. Orary inferior, 2-several-celled, or rarely 1-celled, style simple; stigma terminal, small: ovules usually 2-several in each carity. Fruit drupaceous or baccate, often crowned by the calyxlimb, or in some genera capsular. Seeds various; endosperm usually wanting. About 60 genera, including orer 1700 species, mostly tropical in distribution. 
Calyx of several, persistent, valvate sepals; petals present.

Calyx of regularly separating sepals.

Inflorescence centripetal, flower's in racemiform, umbelliform, or contracted clusters.

Inflorescence centrifugal; flowers in cymes.

Embryo spiral.

Embryo annular.

Calrx of irregularly separating sepals.

Calyx lid-like, deciduous; petals none.

1. Eugenia.

2. Pimenta.

3. Anamomis.

4. Psidium.

5. Calyptranthes.

1. EUGÈNIA L. Sp. Pl. 4ĩ0. 1753.

Shrubs or trees, with usually glabrous foliage. Leaves opposite, commonly leathery, pinnately-reined, the flowers axillary, solitary or in umbellike, raceme-like or congested clusters. Calyx-lobes 4 or 5 . Petals 4 or 5 , white. Stamens numerous; filaments filiform, distinct and in sereral series, or aggregated into 4 groups and slightly united. Orary sessile, 2-3-eelled. Orules several in each cavity. Berries crowned by the ealyx-lobes. Seeds often 1-4. Embryo with thick cotyledons and a short radicle. [Named in honor of Prinee Eugene of Saroy (1663-1736), a patron of botany and horticulture.] About 600 species, of tropical distribution. Type species: Eugenia uniflora $\mathrm{L}$.

Pedicels short, shorter than the flowers or as long, at least shorter than the fruits. Leaves ovate to lanceolate: fruit subglobose.

Leares obovate to oblanceolate; fruit longer than broad.

Pedicels as long as or longer than the flowel's, mostly longer than the fruits.

Leares long-acuminate, shining above.

Leaves bluntly acuminate, dull above.

Pedicels $1-1.5 \mathrm{~cm}$. long or less; fruit Jess than $1 \mathrm{~cm}$. in diameter.

Pedicels $2-5 \mathrm{~cm}$. long; fruit $2 \mathrm{~cm}$. in diameter, edible.

1. E. axillaris.

2. E. buxifolia.

Flowers unknown; leaves small, linear.

3. E. confusa.

4. E. rhombea.

5. E. uniflora.

6. E. androsiuna.

1. Eugenia axillàris (Sw.) Willd. Sp. Pl. 2: 970. 1800.

Iyrtus axillaris Sw. Prodr. 78. 17 S8.

Eugenia axillaris microcarpa Krug. \& Urban, Bot. Jahrb. 19: 641. 1895.

A shrub or tree, reaching a height of $8 \mathrm{~m}$., with a maximum trunk diameter of about $3 \mathrm{dm}$., the bark shallowly fissured, the branchlets terete. Leares elliptic-orate to orate-lanceolate or nearly elliptic, unpleasantly odorous, $3-5$ $\mathrm{cm}$. long, recolute-margined, paler beneath than above and black-dotted, the petioles 2-5 $\mathrm{mm}$. long, margined; racemes short, eluster-like, axillary; pedicels short, pubescent; calyx-lobes 4, rounderl; corolla $3-4 \mathrm{~mm}$. broad; petals 4, surpassing the calyx-lobes, glandular-punctate; fruit depressed-globose, 10-12 mm. in diameter, black, smooth, glandular-punctate, sweet.

Coppices and scrub-lands, throughout the archipelago from Great Bahama to Caicos, Inagua and the Anguilla Isles:- Rermuda; Florida ; Cuba to Forto Rico and Guadeloupe; Jamaica. Referred by Dolley, by IIrs. Nolthiop, and by Hitchcock to E. monticola Griseb. White Stopper. Wattle.

2. Eugenia buxifòlia (Sw.) Willd. Sp. Pl. 2: 960. 1800.

Myrtus buxifolia Sw. Prodr. 7S. 17ss.

A small tree, becoming about $6 \mathrm{~m}$. high, with a trunk up to $3 \mathrm{dm}$. in diameter, usually smaller, often shrubby, the bark reddish-brown, scaly, the slender twigs sparingly pubescent or glabrous. Leares ohorate, ohlanceolate or nearly oblong, glabrous, 2-4 cm. long, rounded or obtuse at the apex, narrowed at the base, short-petioled, dark green above, pale green beneath; 
racemes axillary or lateral, few-flowerer; perlicels pubescent, rery short; ealyx 4-lobed, the lobes obtuse; petals oblong, 2-3 mm. long; fruits oral to subglobose, black, $\bar{b}-\bar{i} \mathrm{~mm}$. in diameter.

Scrub-lands and coppices, throughout the archipelago from Abaco and Great Bahama to Caicos Islands, Inagua and the Anguilla Isles:- Florida; Cuba to St. Thomas and St. Croix; Jamaica, lieferred by Dolley to E. lateriflora Griseb. SPAxISH STOPPEI. BLACK WATTLE.

\section{Eugenia confùsa DC. Prodr. 3: 279. 1828.}

\section{Eugenia filiformis Macf. Fl. Jam. 2: 116. 1850.}

A tree, attaining a maximum height of about $18 \mathrm{~m}$., with a trunk up to $5 \mathrm{dm}$. in diameter, usually much smaller, the bark sealy, the slender twigs glabrous. Leares orate to lanceolate, coriaceons, glabrous, 3-6 cm. long, longacuminate at the apex, narrowed or obtuse at the base, dark green and shining above, dull green beneath, pinnately many-veined, the slender petioles 5-10 mm. long; flowers umbellate or solitary in the axils, on filiform pedicels 2-3 times as long as the petioles; ealyx-lobes broadly ovate, 1.5-2 mm. long; petals orate, about twice as long as the calyx-lobes; fruit subglobose, orange to searlet, 5-6 $\mathrm{mm}$. in diameter.

Coppices and serub-lands, Great Bahama, Lignum Vitae Cay, Andros, New Providence, Great Guana Cay, Eleuthera, Watling's and Crooked Islands :-Florida ; Cuba; Porto Rico to Dominica; Jamaica. 'The record of $E$. pseudopsidium by Schoepf may apply to this species. Irowwond.

\section{Eugenia rhómbea (Berg) Krug \& Urban, Bot. Jahrb. 19: 614.1895.}

Eugenia foetida rhombea Berg, Linnaea 27: 212. 1856.

A small tree, sometimes $8 \mathrm{~m}$. high with a trunk up to $3 \mathrm{dm}$. in diameter, the twigs slender, the smooth bark gray, the foliage glabrous. Leaves ovate to elliptic or rhombic-ovate, rather thin, inconspicuously veined, $3-6 \mathrm{~cm}$. long, bluntly acuminate or acute at the apex, obtuse or narrowed at the base, shortpetioled; flowers in sessile axillary umbel-like clusters, often appearing on twigs from which the leaves have fallen, the slender glabrous pedicels 8-15 $\mathrm{mm}$. long; calyx-tube shorter than the 4 rounderl lobes; petals orate, about $5 \mathrm{~mm}$. long, about twice as long as the ealyx-lobes; fruit depressed-globose, orange, red or nearly black, $0.8-1.5 \mathrm{~cm}$. in diameter.

Sclub-lands. Cave Cay, Long Island, Great Ragged Island, Acklin's, Inagua and the Anguilla Isles:-Florida; Cuba to Guadeloupe; Jamaica. Red Stopper.

\section{Eugenia uniflòra L. Sp. Pl. 470. 1753.}

A shrub or small tree up to $5 \mathrm{~m}$. high, with slender branches. Leaves orate to orate-lanceolate, dark green and shining above, paler beneath, bluntly acute or acuminate at the apex, rounder at the base, dotted, thin in texture, 2.5-6 cm. long; pedicels solitary or few together, very slender, glabrous, about $2.5 \mathrm{~cm}$. long, bracted at the base and 2 -bracteolate near the summit; calyx-lobes linear-oblong, obtusish; petals about twice as long as the calyxlobes; fruit subglobose, longitudinally furrowed, $8-10 \mathrm{~mm}$. in diameter, bright red, spicy, edible.

Apparently only spontaneous after cultivation, though recorded as indigenous by Doller and admitted into the Bahamas by Grisebach. New Proridence:-Bermuda: Cuba to Trinidad and South America: Jamaica; Cayman Islands; introduced into the Old World tropies. Natise of South America. Strinam Cherry.

\section{Eugenia androsiàna Urban, Repert. 13: 467. 1915.}

A glabrous shrub, about $1 \mathrm{~m}$. high, diffusely branched, the twigs rery slender. Leares linear or linear-oblong, 1-2 cm. long, 1.5-3 mm. wide, acute 
or obtuse at the apex, narrowed at the base, finely punctate, the margins slightly revolute, the petioles $0.5-0.5 \mathrm{~mm}$. long.

Near Lisbon Creek, IIangrove Cas, Audros. Endemic. When flowers of this shrub ale obtained, they may show it to belong to one of the other genera of Myrticeile.

Eugenia ligustrina Willd., West Indian, recorded as Bahamian by Grisebach and by Dolley, was not found during our exploration of the arehipelago; the speeimen eited by Grisebach as collected in the Bahamas by Swainson was not found in the Kew Herbarimu when seareh was male for it there in 1911. We regard the reeords as probably erroneous.

\section{PIMENTA Lindl. Coll. under pl. 19. 1821.}

A tree, with nearly smooth bark, oblong or elliptic, petioled aromatic pinnately veined leaves, and small white 4-parted flowers, borne in compound eymes in the upper axils. Calyx-tube eampanulate, its lobes spreading, persistent. Petals spreading. Stamens numerous, in several series. Stigma peItate; ovary 2-celled; orules mostly solitary in each cavity. Fruit berry-like, aromatic. Seerls few, subglobose; embryo spiral. [Greek, rieh in oil.] A monotypic genus of the West Indies and Central America.

\section{Pimenta Piménta (L.) Cockerell, Bull. Torr. Club 19: 95. 1892.}

Myrtus Pimenta L. Sp. Pl. 4i2. 17.53.

Pimenta officinalis Lindl. Coll. under pl. 19. 1821.

Pimenta vulgaris Lindl. in Loudon Eneycl. 418. 1829.

Beeoming $13 \mathrm{~m}$. high or more, glabrous, except the puberulent inflorescence. Leaves coriaceous, $7-15 \mathrm{~cm}$. long, mostly obtuse at the apex, narrowed at the base, with petioles about $1 \mathrm{~cm}$. long, the veins rather prominent beneath; eymes stalked, many-flowered; flowers about $6 \mathrm{~mm}$. hroad; ealyx-lobes blunt; orary puberulent; berries subglobose, about $6 \mathrm{~mm}$. in diameter, usually 2 -seerled.

Thickets and coppices: spontaneous after cultivation, New Providence, at Grant's Town and near Lake Cunningham. Native of Jamaica and Cuba; spontaneous after cultivation in Bermuda and in Central America. Erroneously called CINNAMON. ALLSPICE.

\section{ANAMOMIS Griseb. Fl. Br. W. I. 240. 1860.}

Evergreen aromatic trees or shrubs, with opposite eoriaceous leaves and axillary peduneled flowers, in eymes or solitary, when in eymes the central flower sessile or stalked. Calyx-lobes 4 or 5. Petals 4 or 5. Stamens many, with filiform filaments ant short antlers. Orary 2-eelled or 4-eellenl, about as long as the ealyx-tube; ovules sereral in each cavity; style slender or filiform. Berry oral or subglobose, 1-sereral-seeted, erowner by the calrx-lobes. [Greek, like Imomis.] About $S$ speeies, natives of the West Indies and Florilla. Type speeies: Anamomis fragrans (Sw.) Griseb.

I.eaves shining ahove, not revolute-margined : flowers mostly solltary : calyx glabrous,

Petals orbiculal" leaves mostly $2 \mathrm{~cm}$. Widle or less, acute, acutish or rounded at the base.

l'ctals obloug-orblcular: leaves mostly over $2 \mathrm{~cm}$. wlde, obtuse and rounded or subcordate at the base.

Jeaves dull above, revolute-margined (at least whell old) ; flow ers several (rarely solltary); (allyx pubescent.

\author{
1. A. longipes. \\ 2. A. bahamensis. \\ 3. A. Iucayana.
}


1. Anamomis lóngipes (Berg) Britton; Small, Fl. Miami 132. 1913.

Eugenia, longipes Berg, Linnaca 27: 150. 1856.

A glabrous shrub or small tree up to $4 \mathrm{~m}$. high, the branches slender, erect-ascendling, or diffuse. Leaves flat, orate, oval or oblong-lanceolate, 1-3.5 $\mathrm{cm}$. long, 1-2 cm. wicle, shining above, acute or obtuse at the apex, acute or rounded at the base, reticulate-veined, the petioles 1-2 $\mathrm{cm}$. long; peduncles usually 1-flowered, as long as the leaves or longer, when screral-flowered the terminal flower of the eyme long-stalked; calyx-lobes about $2 \mathrm{~mm}$. long; petals orbieular, white or pink, 5-6 nmm. long; berry 6-10 $\mathrm{mm}$. in diameter, red, several-seeded.

Coppices, pine-lands, palmetto-lands and scrub-lands, Abaco, Great Bahama, Andros, New Providence:-Florida. Long-STaLKed Stopper.

\section{Anamomis bahaménsis (Kiearsk.) Britton; Small, Fl. Florida Keys 104.} 1913.

Eugenia bahamensis Kiearsk. Bot. Tidsk. 17: 226. 1890.

A glabrous shrub, usually straggling or diffnsely branched and $1 \mathrm{~m}$. high or less, rarely a small tree. Leaves elliptic or ovate-elliptic, 3-6 cm. long. shining above, dull beneath, rounded or obtuse at the apex, subcordate or rounded at the base, the petioles $2-8 \mathrm{~mm}$. long; leaves of shoots sometimes linear-oblong, 2-3 cm. long, 4-8 mm. wide; peduncles slender, compressed, as long as the leaves or somewhat longer; eymes 3-flowered or flowers solitary; calyx-lobes rounded, about $3 \mathrm{~mm}$. long; petals oblong-orbicular, 5-7 $\mathrm{mm}$. long; berries S-10 $\mathrm{mm}$. in diameter.

Coastal rocky plains, scrub-lands, coppices and white-lands, throughout the archipelago from Abaco, the Berry Islands and Andros to South Caicos, Dellis Cay and Inagua. Recorded from Big Pine Key, Florida, apparently erroneously. Endemic. Individual specimens are separable only with difficulty from the preceding species, but typical specimens are widely different. Barama Stopper. WiLd Guava.

\section{Anamomis lucayàna Britton, sp. nov.}

A shrub or a small tree up to 6.5 meters high, the bark grayish-white, the young trigs appressed-pubescent to glabrate. Leaves oblong to elliptie, pale green, but darker above than beneath, dull, revolute-margined, obtuse or emarginate at the apex, narrowed at the base, $3-5 \mathrm{~cm}$. long, $1-2.5 \mathrm{~cm}$. wide, the midrein impressed above, prominent beneath, the lateral reins few and obscure, the stout petioles 2-4 mm. long; peduneles slender, as long as the leaves or longer, sparingly pubescent or glabrous; cymes 3-7-flowered, the lateral pedicels slender, $1 \mathrm{~cm}$. long or less, each central flower sessile; hypanthium obconic, glabrate or pubescent, 1.5-2 $\mathrm{mm}$. high; sepals suborbicular, pubescent and eiliate, or nearly glabrous, $2-2.5 \mathrm{~mm}$. wide; petals broadly obovate, 4-5 $\mathrm{mm}$. long; stamens about as long as the petals, the style a little longer; fruit red, subglobose, 7-9 $\mathrm{mm}$. in diameter.

Scrub-lands and coppices, Andros, New Providence, Eleuthera, Cat Island, Great Guana, Great Exuma, Long Island, Crooked Island, Acklin's, North Caicos and the Inaguas :-Cubau Cays. 'Type, Nash \& Taylor, 1426, Inagua. Referred by Coker as Eugenia punctata Vahl, and by Mrs. Northrop as Myrtus punctata Griseb. The Bahamian record of Eugenia fragrans by Urban (Symb. Ant. 4: 452), probably refers to this species. PALE STOPPER. NAKED-WOOD.

\section{PSÍdIUM L. Sp. Pl. 470. 1753.}

Trees or shrubs with pinnately veined leaves and large, axillary or lateral, solitary or elustered flowers. Calyx-tube somewhat prolonged beyond the ovary, its 4 or 5 lobes often united in the bud, irregularly parting at 
anthesis. Petals 4 or 5, spreading. Stamens numerous, with filiform filaments in several series. Ovary 4-5-celled; orules several or many in each cavity. Berries crowned by the calyx-lobes. Seeds several or many. Embryo curved, with small cotyledons and a long radicle. [Greek, referring to the edible fruit.] A large genus, of which about 100 species hare been deseribed, the following typical.

\section{Psidium Guajàva L. Sp. Pl. 470. 1753.}

Psidium Guava Griseb. Fl. Br. W. I. 241. 1860.

A shrub, or a small tree, sometimes $5 \mathrm{~m}$. tall, with pubescent 4-angled branchlets. Leaves firm-leathery, oblong or nearly so, $4-8 \mathrm{~cm}$. long, mostly obtuse, pubescent beneath, with prominent rib-like nerves, short-petioled; calyx-lobes $1-1.5 \mathrm{~cm}$. long, united in the bud; petals $1.5-2 \mathrm{~cm}$. long; berries globular or pyriform, 3-6 cm. in diameter.

Sclub-lands, roadsides and waste places, spontaneous after cultivation; planted and spontaneous near towns on all the larger islands:- spontaneous after cultivation in Florida and in Bermuda; West Indies; continental tropical America. Guava.

5. CALYPTRÁNTHes Sw. Prodr. 79. 1788.

[Chytraculia P. Br. Hist. Jam. 239. Hyponym. 1756.]

Evergreen shrubs or trees, with opposite coriaceous or subcoriaceous leaves, and small panicled cymose or rarely solitary flowers. Calyx closed at anthesis, circumscissile, the top falling away like a cap or calyptra. Petals none. Stamens numerous, in several series; filaments filiform; anthers longitudinally dishiscent. Ovary 2-3-celled; ovules 2 in each cavity. Fruit a 1-few-seeded berry, crowned by the basal part of the calyx. [Greek, referring to the cap-like lid of the calyx.] About 75 species, of tropical and subtropical America. Type species: Calyptranthes Chytraculia (L.) Sw.

Inflorescence glabrous; leaves short-petioled.

Inflorescence tomentulose; leaves distinctly petioled.

1. C. Zuгygium.

2. C. pallens.

1. Calyptranthes Zuzỳgium (L.) Sw. Prodr. 79. 1789.

Myrtus Zuzygium L. Syst. ed. 10, 1056. 1759.

Chytraculia Suzygium Kuntze, Rev. Gen. Pl. 1: 238. 1991.

A tree, up to about $12 \mathrm{~m}$. high, glabrous throughout, the twigs terete, slender. Leaves elliptic, or elliptic-obovate, $4-7 \mathrm{~cm}$. long, abruptly blunttipped or obtuse at the apex, narrowed at the base, delicately reined, somewhat shining above, dull beneath, the petioles $3 \mathrm{~mm}$. long or less; panieles mostly somewhat longer than the leaves; flowers several or many; pedicels 4-7 $\mathrm{mm}$. long; calyx ovoid, about $4 \mathrm{~mm}$. long, its lid mammillate; berries subglobose, 8-10 $\mathrm{mim}$. in diameter.

Copplees, New Providence at Waterloo; Andros, near Lisbon Creek:-Florida ; Cuba; IIspaniola; Jamaica. MrRTLE-OF-THE-RIVEI.

2. Calyptranthes pállens (Poir.) Griseb. Kar. 67. 1857.

Eugenia pallens Poir. in Lam. Encyel. Suppl. 3: 122. 1813.

A tree, attaining a maximum height of about $10 \mathrm{~m}$., with a trunk sometimes $1.5 \mathrm{dm}$. in dianeter, usually smaller and sometimes shrubby, the bark thin and light gray, the young twigs pubescent, soon becoming glabrous. Leaves elliptic to oblong-elliptic, $3-8 \mathrm{~cm}$. long, acuminate at the apex, nar- 
rowed at the base, shining above, the petioles 5-12 $\mathrm{mm}$. long; panicles as long as the leares or longer, pubescent, many-flowered, the flowers sessile or nearly so, about $3 \mathrm{~mm}$. broal; fruit subglobose or oral, 5-7 $\mathrm{mm}$. in diameter.

Coppices and scrub-lands, Andros, Great Exuma, lileuthera, Cat Island, Watling's, Acklius, Crooked Island and Ilariguana:-lilorida; Cuba to St. Croix and Guadeloupe; Jamaica; Cayman Islands. Srice-Wood. Wirte Stopper.

\section{Family 5. RHIZOPHORÀCEAE Lindl.}

\section{Maxgrove Family.}

Shrubs or trees, with terete branches and usually glabrous foliage. Leaves usually opposite, leathery, with stipules. Flowers perfect, solitary in the axils or in spikes, racemes, cymes or panicles. Calyx with 3 or 4 valvate sepals. Petals as many as the sepals, 2-cleft or lacerate. Stamens trice or four times as many as the petals, or rarely of the same number, inserted at the base of a disk; filaments short or elongated; anthers 2celled, opening lengthwise. Ovary inferior, or partly inferior, usually 3-5-celled or ravely 1-celled; styles united; stigmas sometimes lobed. Orules 2 or rarely 4 or more in each cavity, pendulous. Fruit leathery, crowned with the calyx, indehiscent or tardily septicidal. The family consists of about 15 genera, containing some 50 species, natives of tropical and subtropical regions.

\section{RHIZÓPHORA L. Sp. Pl. 443. 1753.}

Evergreen trees, with an astringent bark, and stout pithy twigs. Leaves opposite, entire; stipules elongated, interpetiolar, caducous. Flowers creamcolored or yellow, 2 or several on forking peduncles. Calyx-tube short, adnate to the base of the ovary, the 4 lobes leathery. Petals 4, emarginate, leathery. Stamens 4-12, alternate with the petals; filaments short. Orary 2-celled, halfinferior, produced into a fleshy cone. Stigma 2-lobed. Ovules 2 in each cavity. Fruit pendulous, 1-celled, leathery. Seed solitary, germinating in the persistent fruit, the elongating radicle sometimes reaching the ground before the fruit falls. Endosperm wanting. [Greek, root-bearing.] Three known species, the following typical, the others natives of the Old World tropics.

\section{Rhizophora Mángle L. Sp. Pl. 443. 1753.}

A shrub or tree, reaching a height of $10 \mathrm{~m}$. or more, forming impenetrable thickets by the greatly elongating radicles of the embryo and the numerous roots. Leares $5-15 \mathrm{~cm}$. long, leathery, elliptic or elliptic-obovate, obtuse, with a stout midrib; petioles $0.5-1.5 \mathrm{~cm}$. in length; peduncles $1-4 \mathrm{~cm}$. long, 2-3florrered; pedicels stout, $5-10 \mathrm{~mm}$. long; bractlets scale-like; calyx-tube fleshy, turbinate or campanulate the lobes $3-5 \mathrm{~nm}$. long; sepals lanceolate, abont $1 \mathrm{~cm}$. long, involute, keeled within, very firm, recurved at maturity; petals pale yellow, linear or nearly so, cleft at the tip, involute above the middle, robwebby along the edges; anthers clustered around the style; fruit $2-3 \mathrm{~cm}$. long, curved, the radicle protruding as a narrowly clavate pendent body.

Inritime shores and salinas, throughout the archipelago:-Bermuda: Florida; West Indies; Mexico to Brazil; west coast of Africa; Pacific islands. Maxgrote. Catesby, 2: $p l$. 63 . 


\section{Family 6. ONAGRÀCEAE Dumort.}

\section{Evening-Primose Fajily.}

Herbs, or rarely shrubs, with alternate or opposite leaves, no stipules or mere glands in their places, and generally perfect flowers. Calrx-tube adnate to the ovary, the limb 2-6-lobed (usually 4-lobed). Petals 2-9 (usually 4), convolute in the bud, rarely none. Stamens usually as many or twice as many as the petals. Ovary 1-6-celled (usually 4-celled); styles united; stigma capitate, discoid or 4-lobed; ovules generally anatropous. Fruit a capsule or small nut. Endosperm rery little or none. Forty genera and about 350 species of wide geographic distribution, most abundant in America.

Stamens 4.

Leaves opposite.

Leaves alternate.

Stamens 8-12 in 2 series.

1. Isnardia.

2. Luduigia.

3. Jussiaca.

1. ISNÁRDIA L. Sp. Pl. 120. 1753.

Succulent herbs. Stems creeping or floating; leaves opposite, relatively few, petioled. Flowers axillary, sessile, not yellow. Calyx-segments 4, shorter than the tube or slightly longer. Filaments rery short. Orary very short; styles often almost wanting. Capsule oboroid or turbinate, straight. [In honor of Antoine Dante Isnard, a French botanist, and a member of the Academy of Sciences, died 1724.] About 4 species in North America, Mexico and the West Indies. Type species: Isnardia palustris L.

1. Isnardia répens ( $\mathrm{Sw}$.) DC. Prodr. 3: 60. 1828.

Ludwigia repens Sw. Prodr. 33. 1788.

Ludwigia natans Ell. Bot. S. C. \& Ga. 1: 581. 1821.

Isnardia natans Small, Fl. SE. U. S. 825. 1903.

Stems $6 \mathrm{dm}$. long or less, branched or simple. Leares elliptic, oral, or oborate, 2-6 cm. long, acute or blunt at the apex, narrowed at the base into rather slender petioles; flowers solitary, sessile or short-peduncled; bractlets linear, acute, shorter than the fruiting calyx; calyx-lobes 4 or 5 , sharply triangular, acute, longer than the petals; eapsule 6-8 mm. long, bluntly tetragonal, narrowed at the base, 3 times as long as the calyx-lobes.

Sink-holes and fresh-water swamps. Great Bahama and New Frovidence:North Carolina to Florida, Mexico and California; Bermuda; Cuba; Hispaniola; Jamaica. Larger Marsh PURSLaxe.

\section{LUDWIGIA L. Sp. Pl. 118. 1753.}

Perennial or annual herbs, with alternate usually entire leaves, and axillary or terminal flowers. Stems erect or ascending, sometimes angled, or winged. Calyx-lobes generally persistent. Petals usually 4. Stamens nsually 4. Orary 4-5-celled. Capsule terete, ribbed or winged, septicilally ilehiscent. or opening by an apieal pore. [Named in honor of C. G. Ludwig, 1709-1773, Professor of Botany at Leipsic.] About 25 species, natives of warm and temperate regions, most abunlant in North America. Type species: Ludwigia alternifolia $\mathrm{L}$. 
1. Ludwigia microcàrpa Michx. Fl. Bor. Am. 1: 88. 1803.

Perennial; glabrous; stems erect or diffuse, simple or branehed, 1-4 dm. long. Leares oborate or spatulate, entire, pinnately few-veined, $0.5-3 \mathrm{~cm}$. long, obtuse or apiculate at the apcx, narrowed into short petioles; flowers solitary and sessile in the axils; calyx-lobes triangular-ovate, about $1 \mathrm{~mm}$. long; petals none; capsule obpyramidal, about $2 \mathrm{~mm}$. long.

l'resh-water marshes, Great Bahama:-North Carolina to Florida and Mississlppi ; Cuba ; Jamaica. SALALl-Freited LUdwigia.

\section{JUSSIAÈA L. Sp. Pl. 35s. 1753.}

Perennial herbs, some speeies woody, with alternate, mostly cntire leaves and solitary axillary flowers, the petals usually yellow. Calyx-tube cylindric or prismatie, not prolonged beyond the ovary, the limb 4-6-parted, its lobes persistent. Petals 4-6, mostly longer than the calyx-lobes. Stamens 8-12, in 2 series. Ovary 4-6-eelled. Capsule narrowly eslindric, prismatic or clavate, ribbed, the pericarp deteriorating. Seeds numerous and minute. [In honor of Bernard de Jussieu, 1699-1777, eminent French botanist and physician.] About 50 species, of tropical distribution, mostly American. Type species: 'Jussiaea repens $\mathrm{L}$.

\section{Jussiaea suffruticòsa L. Sp. Pl. 3९s. 1753.}

Jussinea angustifolia Lam. Eneycl. 3: 331. 1789.

Jussicua palustris Meyer, Prim. Fl. Esseq. 173. 1818.

Ereet, 6-10 dm. high, somewhat branched, more or less pubescent, at least abore. Leaves linear to oblong-lanceolate, entire, short-petioled, $2.5-10 \mathrm{~cm}$. long, acute at the apex, narrowed at the base; peduneles mostly not longer than the petioles; calyx-lobes 4, rarely 5, lanceolate or ovate-lanceolate, acute or acuminate, 6-12 mm. long; petals obovate, bright yellow, 2-3 times as long as the calyx-lobes; capsule 3-6 $\mathrm{cm}$. long, subcylindrie, tapering to the base.

Fresh-water marshes and sink-holes, Great Bahama, New Providence, Eleuthera, Cat Island, Great Exuma, Acklin's Island and Crooked Island:-North Carolina to Florida and Texas; West Indies and continental tropical America; Old World tropies. Bushy Jussiaea.

\section{Family 7. HALORAGIDĀCEAE Kl. \& Gareke.}

\section{Water-Milfoil Family.}

Perennial or rarely annual herbs, mainly aquatic, with alternate or verticillate leaves, the submerged ones often pectinate-pinnatifid. Flowers perfect, or monoecious, or dioecious, axillary, in interrupted spikes, solitary or clustered. Calyx-tube adnate to the orary, its limb entire or 2-4-lobed. Petals small, $2-4$, or none. Stamens 1-8. Ovary ovoid-oblong, or shortcylindric, 2-S-ribbed or winged, 1-4-celled; styles 1-4; stigmas papillose or plumose. Fruit a nutlet, or drupe, compressed, angular, ribbed or winged; indehiscent, of 2-4 one-seeded carpels. Endosperm fleshy; cotyledons minute. Eight genera and about 100 species, of wide distribution.

\section{PROSERPINÀCA L. Sp. Pl. 88. 1753.}

Aquatic herbs. Leaves alternate, laneeolate, dentate or peetinate-pinnatifid. Flowers perfect, axillary. Tube of the calyx adnate to the triquetrous orary, the limb 3-4-parted. Petals none. Stamens 3 or 4 . Styles 3 or 4, 
cylindrie or conic-subulate, stigmatic above the middle. Fruit bony, 3-4-celled, with 1 seed in each carity. [Middle Latin, forward-creeping.] Four known species of North and Central America and the West Indies. Type species: Proserpinaca palustris L.

\section{Proserpinaca platycárpa Small, Bull. N. Y. Bot. Gard. 3: 432.1905.}

Perennial, glabrous, 1-3.5 $\mathrm{dm}$. long, densely leafy. Leaves oblong or elliptic, 1.5-5.5 cm. long, sharply serrate; flowers solitary and sessile in the axils; calyx wing-angled, its deltoid teeth about $1 \mathrm{~mm}$. long; fruit $4-5 \mathrm{~mm}$. wide, constricted above the middle, its 3 angles dilated.

Fresh-water swamps and sink-holes, Great Bahama, New I'lovidence, Eleuthera and Cat Island. $\rightarrow$ Florida. Recorded by Schoepf as P. palustris L. SouTHERN MERMIAID-IVED.

\section{Order 22. AMMIÀLES.}

Herbs, shrubs or trees, almost always with petaliferons flowers. Calyxsegments and petals usually 5. Stamens 4 or 5. Ovary inferior, adnate to the calyx, compound; ovules 1 in each cavity.

\section{Family 1. AMMIÀCEAE Presl.}

\section{Carrot Fajilly.}

Herbs, with alternate compound or sometimes simple leaves, the petioles often dilated at the base. Stipules none, or rarely present and minute. Flowers small, generally in compound or simple umbels, rarely in heads or capitate clusters, often polygamons. Umbels and umbellets commonly involucrate or involucellate. Calyx-tube adnate to the ovary, its margin truncate or 5-toothed, the teeth seldom conspicnous. Petals 5, inserted on the margin of the calyx, usually with an inflexed tip, often emarginate or 2-lobed, those of the outer flowers sometimes larger than those of the inner. Stamens 5, inserted on the epigynous disk; filaments filiform; anthers versatile. Ovary inferior, 2-celled; styles 2, filiform, persistent, often borne on a conic or depressed stylopodium; ovules 1 in each cavity, pendulous, anatropous. Fruit dry, composed of 2 carpels (mericarps), which generally separate from each other at maturity along the plane of their contignous faces (the commissure). Fruit eitlier flattened laterally (at right angles to the commissure), or dorsally (parallel to the commissure), or nearly terete (not flattened). Carpels after parting from each other supported on the summit of a slender axis (the carpophore), each with 5 primary ribs in their pericarps (rarely ribless), and in some genera with 4 additional secondary ones, the ribs or some of them often winged. Pericarp membranous or corky-thickened, usually containing oil-tubes between the ribs, or under the ribs and on the commissural sides, sometimes irregularly scattered, sometimes none. Seeds 1 in each carpel, usually adnate to the pericarp; seed-coat thin; endosperm cartilaginous; embryo small, placed near the hilum; entyledons ovate, oblong or linear. About 170 genera and 1600 species, of wide distribution. The mature fruit is necessary for the certain determination of most of the genera and many of the species. 
Leaf-blades orbicular or ovate, merely toothed; flowers white. Involucle none. Involucre conspleuous.

Leaf-blades pinnatifid into filiform segments. Fruit margined, flat; flowers yellow. Fruit not milrgined.

Flowers yellow.

Flowers white.
1. Hydrocotyle.
2. Centella.
3. Anethum.
4. Foeniculum.
5. Helosciadium.

1. HYDROCOTỲLE L. Sp. Pl. 234. 1753.

Perennial herbs, prostrate and commonly rooting at the joints, with palmately lobed or veined, often peltate leaves, the bases of the petioles with 2 scale-like stipules, and small white flowers in umbels opposite the leares. Bracts of the involuere few, or none. Calyx-teeth minute. Petals entire. Disk flat. Fruit laterally compressed, orbicular or broader than high. Carpels with 5 primary ribs, the lateral ones usually curved; no large oil-tubes but an oil-bearing layer of tissue beneath the epidermis. [Greek, water-cup.] About 75 species of wide distribution. Type species: Hydrocotyle vulgaris $\mathrm{L}$.

Plant glabrous.

Leares and inflorescence villous-pubescent.
1. H. verticillata.

2. H. hirsuta.

1. Hydrocotyle verticillàta Thunb. Diss. Hydrocot. 5. 1798.

Glabrous; leaves orbicular, peltate; inflorescence proliferous, $2-5 \mathrm{~cm}$. long; verticils $2-6$-flowered; pedicels usually less than $1 \mathrm{~mm}$. long; fruit about $2 \mathrm{~mm}$. long, 3-4 nm. broad, rounded or truncate at each end; intermediate ribs not corky-thickened, the dorsal one acute.

Wet paImetto-lands, Great Bahama at Barnett's Point ; Andros at Couch Sound : - Bermuda; Jamaica; Cuba: Hispaniola; Porto Rico; Guadeloupe; southern Africa; Massachusetts to Florida and Arizona. Recorded by Mr's. Northrop as $H$. pugmaea Wright. Determination of the Bahama plant is from leaf-specimens only. WhORLED MARSi PENyYWORT.

2. Hydrocotyle hirsùta Sw. Prodr. 54. 1788.

Hydrocotyle spicata Lam. Encycl. 3: 153.1789.

Stems ereeping, rooting at the nodes, very slender, glabrous or nearly so, 0.5-3 dm. long. Petioles villous, 1-8 em. long; leaf-blades suborbicular or reniform, 1-3 cm. broad, crenate, rather deeply cordate, villous on both sides, densely so beneath; spikes peduncled, interrupted, usually longer than the leares, sometimes $8 \mathrm{~cm}$. long, the peduncles and rachis villous; fruits sessile, glabrous, emarginate at top and bottom, about $1.5 \mathrm{~mm}$. broad.

Grassy places, New Providence near Nassau:-Cuba; IIispaniola; Porto Rico; Curagao. Hairy jarsh Pexnywort.

Hydrocotyle umbellata L. recorded for the Bahamas by Dolley has not been found by us anywhere in the islands; Mr. Brace thinks that the reference really applied to Centella asiatica.

\section{CENTÉLLA L. Sp. Pl. ed. 2, 1393. 1763.}

Perennial herbs (some African species shrubby), ours with prostrate stëns rooting and sending up tufts of petioled leaves at the nodes, together with 1-3 long-rayed umbellets of small white flowers, the true umbel sessile. Petiolebases sheathing. Bracts of the involucels 2-4, mostly prominent. Calyx-teeth none. Disk flat, or slightly concave. Styles filiform. Fruit somewhat flattened laterally, rather prominently ribbed, the ribs mostly anastomosing; oiltubes none. [Latin, diminutive of centrum, a prickle.] About 20 species, of 
wide distribution, abundant in South Africa. Type species: Centella villosa L.

1. Centella asiàtica (L.) Urban in Mart. Fl. Bras. 11: 2S7. 1879.

Ilydrocotyle asiatica L. Sp. Pl. 234. 1753.

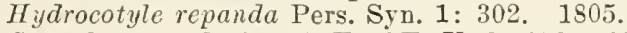

Centella repanda Small, Fl. SE. U. S. 859. 1903.

Stem 2-15 cm. long. Petioles 0.5-3 dm. long, sometimes pubescent; blades ovate, rather thick, rounded at the apex, broadly cordate at the base, not peltate, 2-4 em. long, repand-dentate; pedicels much shorter than the leaves, 1-5 cm. long; umbellets capitate, 2-4-flowered, subtended by 2 ovate bracts; flowers nearly sessile; fruit $4-5 \mathrm{~mm}$. broad, about $3 \mathrm{~mm}$. high, prominently ribbed and reticulated.

Moist ground, Abaco, Great Bahama, Andros, New Providence, Great Exuma, Eleuthera, Fortune Island and North Caicos:-Bermuda: Maryland to Florida and Texas; Jamaica ; Cuba ; Hispaniola; Guadeloupe; Martinique; continental tropical America: Old World tropics. Iiecorded by Dolley presumably as Hyurocotyle $u m$ beilata. L. Ovate-LedVed Marsh PENitwort.

\section{ANÈTHUM [Tourn.] L. Sp. Pl. 263. 1753.}

Erect, mostly annual, glabrous herbs, with decompound leaves and small yellow flowers in many-rayed compound umbels. Involucre and inrolucels none, or of very few bracts. Calyx teeth obsolete. Petals suborbicular. Stylopodium small, conic. Fruit elliptic or ovate, flat, margined; carpel-ribs slender; oil-tubes solitary in the intervals. [Greek, like anise.] A few European and Asiatic species, the following typical.

\section{Anethum gravèolens L. Sp. Pl. 263. 1753.}

Stem terete, simple or branched, slender, 3-9 dm. high. Leaves tripinnately dissected into nearly filiform segments, the petiole somewhat sheathing; umbel $12 \mathrm{~cm}$. wide or less; involuere and involucels none; rays slender, 4-7 cm. long; umbellets several-many-flowered; petals bright yellow; fruit ovateelliptic, about $6 \mathrm{~mm}$. long, distinctly margined.

Waste and cultivated grounds, escaped from cultivation, Andros, Harbor Island, Eleuthera, Long Island and Dellis' Cay:-escaped in Guadeloupe, Martinique and other Test Indian Islands and in Florida. Native of Europe. DillmeED.

\section{FoenÍculum Adans. Fam. Pl. 2: 101. 1763.}

Erect glabrous herbs, with pinnately decompound leaves, the segments linear or capillary, and compound umbels of yellow flowers. Involuere and involucels none. Calyx-teeth obsolete. Stylopodium large, conic. Fruit linearoblong, glabrous, terete, or nearly so. Carpels half-terete, dorșally flattened, prominently ribbed; oil-tubes solitary in the intervals. Seed-face flat, or slightly concave. [Latin, diminutive of foenum, hay, from its odor.] About 4 species, of the Old World. Type species: Anethum Foeniculum L.

\section{Foeniculum Foenículum (L.) Karst. Deutsch. F]. 837. 1882.}

Ancthum Foeniculum L. Sp. Pl. 263. 1753.

Foeniculum vulgare Gaertn. Fr. \& Sem. 1: 105. 1788.

Perennial, 6-12 dm. high. Leaves dissected into capillary segments; petioles broad, clasping; umbels large, 9-25-rayed, the rays rather stout; somewhat glaucous, $2-8 \mathrm{~cm}$. long in fruit; pedicels $2-5 \mathrm{~mm}$. long; fruit about $6 \mathrm{~mm}$. long. 
Waste places, New Providence at Grant's Town:-Bermuda; New Jersey and Pennsylvania to Florida, Texas and California; locally in the West Indies and in continental tropical America. Native of the old World. Fexisu.

5. HelosciaidiUm Koch, Nov. Act. Nat. Cur. 12²: 125.1824.

Low herbs, with decompound or dissected leaves, and compound umbels of small white flowers mostly opposite the leaves. Involucre and involucels wanting in the following species. Calyx-teeth very small or obsolete. Petals entire. Stylopodium depressed. Style short. Fruit ovate or oblong, laterally compressed. Carpels with 5 filiform ribs, the oil-tubes solitary in the intervals, 2 on the commissural side. [Greek, marsh-parasol, some of the species inhabiting marshes.] Six species or more, natives of the Old World. Type species: Helosciadium nodiflorum (L.) Koch.

\section{Helosciadium Ámmi (L.) Britton, Fl. Bermuda 279. 1918.}

Sison Ammi L. Sp. PI. 252. 1753.

Apium Ammi Urban in Mart. Fl. Bras. 11²: 341. 1879.

Slender, glabrous, much-branched, $0.7-6 \mathrm{dm}$. high. Leaves ternately pinnatisected, the ultimate segments narrow, often incised; umbels $1-4 \mathrm{~cm}$. broad, opposite the leaves, sessile, the umbellets filiform-stalked; fruit ovate, glabrous, about $2 \mathrm{~mm}$. long, the ribs equal and prominent.

Waste grounds, New Providence, at Grant's Town:-Bermuda: southern Tnited States; Cuba; Hispaniola: Guadeloupe: Martinique; Barbadoes; Jamaica; Mexico to Paraguay: Australla. Frne-Leaved Marsh l'arster.

\section{Series 2. Gamopétalae.}

Petals partly or wholly united, rarely separate or wanting.

The coherence of the petals is sometimes slight or they are quite separate, as in some Primulaceae, Plumbaginaceae, Asclepiadaceae, Oleaceae and Cucurbitaceae. From this condition the coherence varies through all stages to the tubular or funnelform corollas of some Convolvulaceae, Caprifoliaceae and Carduaceae.

\section{+ Ovary superior.}

Stamens borne on the corolla, as many as its lobes and opposite them, or twice as many, or more.

Herbs, shrubs or trees: ovary 1-celled.

Shrubs or trees; ovary several-celled.

Stamens borne on the corolla, as many as its lobes or fewer, and alternate with them (in Forestiera of the oleaceae there is no cololla).

Corolla not scarious, nerved.

Ovaries 2, distinct (except in some Loganiaceae, and in Gentianaceae in which the ovary is compound with 2 cavities or rarely more, or with 1 cavity and 2 placentae) ; flowers regular; stamens mostly adnate to only the lower part of the corolla; leaves mostly opposite.

Orary 1, compound (2-divided in Dichondra: in Boraginaceae and Lamiacea mostly deeply 4-Iobed around the style); flowers regular or irregular: stamens mostly adnate to the middle of the corolla-tube or beyond; leares opposite or alternate.

Corolla scarious, nerteless.

Anthers distinct.

+t? Oxary inferior.

Anthers united (except in Ambrosiaceae).
Order 1. Primilales.

Order 2. EBExales.

Order 3. Gentianales.

Order 4. Polemoniales. Order 5. Plantaginales.

Order 6. Rubiales. Order 7. CaMpaxulaLes. 


\section{Order 1. PRIMULÀLES.}

Herbs, shrubs or trees. Corolla usually present, gamopetalous. Calyx mostly free from the ovary. Stamens bome on the corolla, as many as its lobes, or twice as many, or more.

Style 1.

Shrubs or trees, the fruit drupaceous or baccate.

Staminodes none; fruit 1 -seeded.

Corolla bearing staminodes at the sinuses; fruit several-many-seeded.

IIerbs; fruit capsular.

Styles 5; herbs; fruit an achene or utricle.

Fam. 1. MrRsinaceat.

Fam. 2. Theopirastaceae.

Fam. 3. I'RIMULACEAE.

Fam. 4. Plumbagivaceae.

\section{Family 1. MYRSINÀCEAE Lindl.}

\section{Mrrane Family.}

Trees or shrubs, usually glabrous, the leaves mostly alternate, punctate in lines, estipulate, the small regular flower's variously clustered. Calyx inferior, persistent, 4-6-parted. Corolla mostly rotate or salverform, rarely tubular or of separate petals. Stamens as many as the corolla-segments and opposite them; filaments usually short, distinct or sometimes united; anthers longitudinally dehiscent; staminodes none. Ovary superior, 1celled; style short or long; stigma various; ovules few, usually immersed in the central placenta. Fruit small, baceate, 1-seeded, sometimes nearly dry. Seed subglobose, the testa thin, the endosperm fleshy or lorny. About 20 genera and over 450 species, mostly tropical in distribution.

Inflorescence paniculate.

Inflorescence short, umbellate, lateral.
1. Icacorea. 2. Rapanea.

\section{ICACORÈA Aubl. Pl. Guian. 2: Suppl. 1. 1775.}

Shrubs or trees, with alternate, mostly eatire leaves and perfect or polygamo-dioecious white or pink flowers in cymes or pauicles. Calyx campanulate, 4-5-parted. Corolla nearly rotate, usually 5-parted, the segments spreading or reflexed. Stamens usually 5; filaments short or slender, borne at the top of the short corolla-tube; anthers acute or acuminate. Ovary globose; stigma discoid or truneate; orules several or few. Berry little fleshy. [Guiana name.] Over 200 species, of tropical and subtropical regions. Type species: Icacorca guianensis Aubl.

Style filiform, much longer than the ovary.

Style subulate, not longer than the ovary.
1. I. panieulata.

2. I. guadalupensis.

× 1. Icacorea paniculàta (Nutt.) Sudw. Gard. \& For. 6: 324. 1893.

Cyrilla paniculata Nutt. Am. Jour. Sci. 5: 290. 1822.

Ardisia Pickeringia Torr. \& Gray; DC. Prodr. 8: 124.1844.

A shrub or small tree, attaining a maximum height of about $7.5 \mathrm{~m}$. with a trunk up to $1.5 \mathrm{dm}$. in diameter, the bark white, scaly, the twigs rather stout, puberulent or glabrous. Leaves coriaceous, glabrous, short-petioled, oblanceolate, obovate or elliptic, 6-16 cm. Ioug, yellowish or dark green above, pale green beneath, the midveiu prominent, the lateral veins slender, the apex obtuse or acute, the base narrowed; panicles terminal, densely many-flowered, 
$5-12 \mathrm{cn}$. long; pediccls short, slender; calyx $2 \mathrm{~mm}$. long, its 5 segments orate, acute, unsymmetrical, eiliate; corolla rotate, its 5 oblong or obovate segments reflexed, 3-4 mm. long, white, with purplish lines and dots; anthers orange; fruit globose, black, shining, $7-9 \mathrm{~mm}$. in diameter, tipped by the filiform style.

Copplees and scrub-lands, Abaco, Great liahama, New l'rovidence and Eleuthera :-Florida; Cuba ; Mexico. Marlberrx. Dog-Berm.

2. Icacorea guadalupénsis (Duchass.) Britton; Wilson, Bull. N. Y. Bot. Gard. 8: 401. 1917.

Ardisia guadalupensis Duchass; Griseb. Kar. 89. 1857.

A glabrous shrub $1-3 \mathrm{~m}$. high, or a tree up to $15 \mathrm{~m}$. high, the stout twigs light grey. Leares elliptic to elliptic-obovate, coriaceous, 10-15 cm. long, obtuse or acutish at the apex, narrowed or cuneate at the base, paler green beneath than abore, delicately veined, the stont petioles $7-12 \mathrm{~mm}$. long; panicles terminal, densely many-flowered, $10-15 \mathrm{~cm}$. long; pedicels $2-4 \mathrm{~mm}$. long, rather stont; calyx about $2 \mathrm{~mm}$. long, its 5 segments oblong, obtuse, punctate: corolla white, rotate, its 5 segments ovate or ovate-elliptic, obtuse, symmetrical, more or less punctate or lineolate; fruit subglobose or depressedglobose, black when mature, $C-8 \mathrm{~mm}$. in diameter, tipped by the short style.

Coppices, North Caicos:-Porto Rico to Virgin Gorda and Santa Lucia. GuadeLOC PE MARLEERR.

\section{RAPANÈA Aubl. Pl. Guian. 1: 121. 1775.}

Shrubs or small trees, with alternate coriaceous leaves, and small bracted polygamo-dioecious flowers in lateral or axillary fascicles. Calyx mostly 4-5cleft, persistent. Corolla 4-5-parted, or rarely of 4 or 5 separate petals, the segments spreading or recurved. Stamens borne on the bases of the corollasegments; filarnents short; anthers obtuse. Ovary globose or ovoid; style short or slender; stigma various; ovules few or many. Fruit a globose, nearly dry, small 1-seeded berry. [Guiana name.] Orer 80 species, mostly of tropical regions, the following typical.

1. Rapanea guianénsis Aubl. Pl. Guian. 1: 121. 1775.

A shrub or small tree up to $6 \mathrm{~m}$. high, the trunk sometimes $1.5 \mathrm{dm}$. in diameter, the foliage glabrous, the bark smooth and gray. Leaves mostly clustered near the ends of the rather slender twigs, short-petioled, obovate or oblong, 4-10 cm. long, obtuse at the apex, narrowed at the base, bright green and somewhat shining above, dull green beneath, the midvein prominent, the lateral reins faint; flowers green, about $4 \mathrm{~mm}$. broad, nearly sessile on the twigs below the leaves; sepals ovate, about $1.5 \mathrm{~mm}$. long; corolla-lobes oblong, glandular-eiliate, 2-3 times as long as the sepals, somewhat unequal; fruit globose, black when mature, about $4 \mathrm{~mm}$. in diameter.

Coppices, pine-lands and scrub-Ionds, Abaco, Great Bahama, Andros, New Providence. Cat Island, Crooked Island and Mariguana:-Florida: Cuba to Porto Rico and to Trinidad; Jamaica; norther'n South America. Recorded by Dolley as diyrsine lacta DC. Mrrsice.

\section{Family 2. THEOPHRASTÀCEAE D. Don.}

\section{Theophrasta Fajily.}

Trees or shrubs, with evergreen coriaceous estipnlate leaves, and regular, perfect or polygamo-dioecious flowers in axillary or terminal clusters or solitary. Calyx inferior, mostly 5 -parted, the segments obtuse, imbricated. 
Corolla gamopetalous, rotate-campanulate or cylindric-campanulate, mostly 5 -lobed, the lobes imbricated. Stamens 5, rarely 4, borne near the base of the corolla-tube; filaments subulate or flattened; anthers mostly extrorse. Staminodia 5. Orary superior, 1-celled; style short or slender; stigma capitate or discoid; orules ninmerous. Fruit coriaceous or fleshy, indehiscent, few-sereral-seeded. Five genera and about 50 species, of tropical distribution.

\section{JACQUÍNIA L.; Jacq. Enum. 2, 15. 1760.}

Evergreen shrubs or small trees, with opposite or verticillate coriaceous leaves, and small perfect white or yellow, racemed, corymbed or panicled flowers. Sepals 5, imbricated. Corolla salverform or short-campanulate, 5lobed, the lobes imbricated in the bud, spreading at anthesis. Staminodia 5, borne on the corolla-tube. Stamens 5 , borne on the base of the corolla-tube. Ovary 5-carpellary; style short; ovules usually many. Fruit oroid or globose, coriaceous. Seeds compressed, with eartilaginous endosperm. [Commemorates Nicolas Joseph ron Jacquin, 1727-1817, distinguished Austrian botanist.] About 25 species of tropical America. Type species: Jacquinia ruscifolia Jacq.

Flowers single in the upper axils and in small terminal clusters.

1. J. Berterii.

Fluwers in terminal racemes.

2. J.keyensis.

\section{Jacquinia Bertèrii Spreng. Syst. 1: 668. 1825.}

Jacquinia Berterii retusa Urban, Symb. Ant. 1: 378. 1899.

A much-branched shrub, 1-3 m. high, or tree up to about $7 \mathrm{~m}$. high, the bark whitish, the young twigs scurfy-lepidote. Leaves varions in form, oblong to obovate or oblong-lanceolate, coriaceous, $2-4 \mathrm{~cm}$. long, rounded, retuse or acute at the apex, cuneate at the base, usually inconspicuously reined, the petioles 1-2 mm. long; inflorescence terminal or in the uppermost axils, 1-6flowered, much shorter than the leaves; pedicels 5-5 mm. long, thickened upwardly in fruit; sepals nearly orbicular, $1.5-2 \mathrm{~mm}$. long, glabrous; corolla about $3 \mathrm{~mm}$. long, its lobes reflexed; staminodia much shorter than the corollalobes, somewhat longer than the stamens; fruit ovoid to subglobose, orange or yellow, 6-8 $\mathrm{mm}$. in diameter.

Coppices, Cat Island, Watling's, Long Island, Acklin's and Stubb's Car, Caicos Islands:-Cuba to Anegada and Guadeloupe. Berter's JAcouixis.

\section{Jacquinia keyénsis Mez in Urban, Symb. Ant. 2: 444.1901.}

A tree, up to $6 \mathrm{~m}$. high, with a trunk sometimes $2.5 \mathrm{dm}$. in diameter, the nearly smooth bark light gray, the young twigs finely pubescent, somewhat angled, densely leafy. Leaves oblong-oborate to spatulate, $3-7 \mathrm{~cm}$. long, obtuse or retuse and apiculate at the apex, narrowed at the base, glabrons, shining above, dull beneath, the petioles short; racemes $6 \mathrm{~cm}$. long or less; pedicels stout, about $1 \mathrm{~cm}$. long; sepals ovate-orbicular, obtuse; flowers very fragrant; corolla salverform, about $1 \mathrm{~cm}$. broad, its lobes longer than the tube; stamens shorter than the staminodia; berry subglobose, orange-red, 8-10 $\mathrm{mm}$. in diameter, hard.

Coastal rocks, copnices and scrub-lands, throughout the archipelago from Abaco and Great Bahama to Grand Turk, Inagua and the Anguilla Isles:-Florida: Cays of northern Cuba: Jamaica. Referred by IIerrick, hy Dolley and by IItcheock to Jacquinia armillaris Jacq. JOE-WOOD. JOE-BUS11. InoNwood. Catesby 1: pl. 98. 


\section{Family 3. PRIMULÀCEAE Vent.}

\section{Primrose Fajily.}

Herbs, with perfect regular flowers. Calyx free from the ovary (adnate to its lower part in Samolus), usually 5-parted, persistent or rarely deciduous. Corolla gamopetalous in our species, usually 5-eleft, deciduous. Stamens as many as the corolla-lobes and opposite them, liypogynous or rarely perigynous, inserted on the eorolla; filaments distinct or connate at the base: anthers introrse, 2-eelled, the saes longitudinally dehiscent. Disk obsolete, or none. Ovary superior (partly inferior in Samolus), 1-eelled; placenta central, free; ovules anatropous, or amphitropous; style 1 ; stigma simple, mostly capitate, entire. Capsule 1-eelled, 2-6-valved, rarely circumseissile or indeliscent. Seeds few or several, the testa adherent to the fleshy or horny eopious endosperm; embryo small, straight; cotyledons obtuse. About 28 genera and 400 species of wide distribution.

\section{SÁMOLUS L. Sp. Pl. 171. 1753.}

Perennial glabrous herbs, with alternate entire leares, or the basal ones rosulate. Flowers small, white, in terminal racemes or panicles in our species. Calyx persistent, its tube adnate to the ovary below, its limb 5-cleft. Corolla perigynous, subcampanulate, 5-lobed or 5-parted, the lobes obtuse. Stamens 5, inserted on the tube of the corolla, opposite its lobes, alternating with as many staminodia (these wanting in $S$. ebracteatus), filaments short; anthers cordate. Ovary partly inferior; ovules amphitropous. Capsule 5-valved from the summit. Seeds minute. [Name Celtic.] About 10 species, of wide distribution. Type species: Samolus Valcrandi L.

Stems leafly to the inflorescence.

Stems scapose, leafy below.
]. S. floribundus.

2. S. ebratcatus.

1. Samolus floribúndus H.B.K. Nor. Gen. 2: 224. 1818.

Samolus Valerandi americanus A. Gray, Man. ed. 2, 274. 1856.

Ereet or ascending, 1.5-6 dm. high. Leaves $2-8 \mathrm{em}$. long, obovate, obtuse; flowers less than $2 \mathrm{~mm}$. broad, in elongated panicled racemes; pedicels filiform, spreading, 8-25 min. long, bracteolate near the middle; calyx-lobes acute, shorter than the corolla; corolla-lobes longer than the tube; staminodia 5; capsule 2-3 $\mathrm{mm}$. in diameter.

Moist soil, New Providence :- thronghont temperate North America to Florida, Texas, California and Mexico; Cuba. WATER PIIPERxel.

\section{Samolus ebracteàtus H.B.K. Nor. Gen, 2: 223. 1818.}

Samodia ebracteata Baudo, Ann. Sei. Nat. II. 20: 350. 1843.

Erect, $4 \mathrm{dm}$. high or less. Leares $4-12 \mathrm{~cm}$. long, spatulate or oborate, obtuse or the upper acute; flowers white, $6-7 \mathrm{~mm}$. broad, in long-stalked simple or sometimes branched racemes; pedicels ascending, very slender, 15-25 mm. long; calyx-lobes ovate, acute, about one-half as long as the corolla; corollalobes shorter than the tube; staminodia none; eapsule $3-4 \mathrm{~mm}$. in diameter.

Moist ground, Andros, at Red Bays:-Florida to Texas and New Mexico; Cuba. LARger WATER PimperNel. 


\title{
Family 4. PLUMBAGINĀCEAE Lindl.
}

\author{
Plumibago Famili.
}

Perennial herbs or shrubs, with basal or alternate leaves, and perfect and regular clustered flowers. Calyx inferior, gamosepalous, 4-5-toothed, plaited at the sinuses, the tube 5-15-ribbed. Corolla of 4 or 5 hypogynous clawed segments connate at the base, or united into a tuhe. Stamens 4 or 5 , opposite the corolla-segments, hypogynous; anthers 2-celled, attached by their backs to the filaments, the sacs Iongitudinally dehiscent. Disk none. Orary superior, 1-celled; orule solitary, anatropous, pendulons; styles 5. Fruit a utricle or achene, enclosed by the calyx, rarely a dehiscent eapsule. Seed solitary; testa membranous; endosperm mealy, or none; embryo straight; cotyledons entire. About 10 genera and 350 species, of wide distribution, many in saline situations.

\section{PLUMBAGO L. Sp. Pl. 151. 1753.}

Perennial herbs, shrubs or vines, with alternate, often clasping leaves, the purple blue red or white flowers in bracted spikes. Calyx tubular, 5-ribbed, glandular, with 4 or 5 erect lobes. Petals 4 or 5 , their claws united into a tube, their blades entire, spreading, the corolla thin, salverforn. Stamens 5 , distinct, the filaments dilated at the base, the anthers linear. Styles filiform, stigmatic on the inner side, partly united. Fruit capsular. [Latin, leadwort.] About a dozen species, natives of southern Europe and Westcentral Asia and tropical America. Type species: Plumbago europaea L.

\section{Plumbago scánđens L. Sp. Pl, ed. 2, 215. 1762.}

A perennial woody herb, the branches often elongated and vine-like, glabrous, sometimes $1 \mathrm{~m}$. long. Leaves orate to oblong-lanceolate, membranous, glabrous, 3-10 $\mathrm{cm}$. long, acute or acuminate at the apex, narrowed at the base, the petioles $1 \mathrm{~cm}$. long or less; spikes slender, peduncled, severalmany-flowered, 5-12 cm. long; bracts lanceolate, acuminate, persistent, about $5 \mathrm{~mm}$. long; calyx about $1 \mathrm{~cm}$. long, beset with long-stalked glands; corolla white, its filiform tube about $2 \mathrm{~cm}$. long, its obovate mueronate spreading lobes $5-i \mathrm{~mm}$. long.

Waste and cultivated grounds, New Providence, Harbor Island, Cat Island and Grand Turk:- Norida to Arizona; West Indies and continental tropical Amelica. White Plumbaga Doctor-BLsil.

\section{LIMÒNIUM Adans, Fam. Pl. 2: 283, 1763.}

Ilerbs, mostly with flat basal leaves, and numerous small flowers eymosepaniculate on bracted scapes, in 1-3-flowered bracteolate clusters, forming onesided spikes. Calyx campanulate or tubular, the limb scarious, 5-toothed, the tube usually 10-ribbed. Petals 5, elawed. Stamens adnate to the bases of the petals. Styles 5, separate in our speeies, stigmatic along the inner side. Fruit a utricle. [Ancient name of the wild beet.] About 120 species widely distributed. Type species: Statice Limonium L. 
1. Limonium bahaménse (Griseb.) Britton, Bull. N. Y. Bot. Gard. 4: 142. 1906.

Statice bahamensis Griseb. F. Br. W. I. 389. 1861.

Perennial by a leep root; scapes several or many, erect, slender, much branched, 2-4 dn. high, glabrous but sealy, fleshy, terete. Leares linear or narrowly spathulate, $5 \mathrm{~cm}$. long or longer, mostly wanting at flowering time; seales of the seape triangular-acuminate, scarious-margined, $2-4 \mathrm{~mm}$. long; spikes 1.5-4 cm. long, the flower-clusters densely aggregated; lower bractlet ovate, obtuse, much shorter than the scarious-margined upper one; flowers purple, about $5 \mathrm{~mm}$. long.

Salinas, South caicos and Grand Turk Island. Endemic. Bahama Sed LavenDER. HE.ATHER.

\section{Order 2. EBENÀLES.}

Shrubs or trees, with alternate simple leaves, the flowers mostly regular. Calyx free from the orary (inferior) or more or less adnate to it. Corolla gamopetalous or sometimes polypetalous. Stamens borne on the tube or base of the corolla, as many as its lobes, and opposite them, or more numerons.

Stamens as many as the corolla-lobes.

stamens twice as many as the corolla-lobes, or more.

Fam. 1. SAPOTACEAE. Fam, 2. EBExACEAE.

\section{Family 1. SAPOTÃCEAE Reichenb.}

\section{SAPODILLA FAMILY.}

Shrubs or trees, the sap often milky, the leares mostly alternate, entire, estipulate, often finely veined, the perfect or rarely polygamous flowers clustered. Sepals 4-12, imbricated. Corolla lobed, often appendaged between the lobes. Stamens as many as the corolla-lobes, often alternating with broad staminodia; filaments distinct. Ovary sessile, 4-12-celled; styles united; ovules solitary in each cavity, anatropous. Fruit a berry, often large. Seerls slining, smooth; embryo straight. About 35 genera, comprising orer 400 species, mostly of tropical distribution.

Calyx 4-5-parted.

Flowers without staminodia or corolla-appendages.

Flowers with staminodia.

Corolla without appendages.

Seeds with abundant endosperm.

Seeds without endosperm.

Corolla with appendages.

Ovary smooth: endosperm copious.

Ovary hairy; endosperm little or none.

Calsx 6-12-parted.

Seeds only 1 or 2.

Seeds 4 or 5 .

1. Chrysophyllum.

2. Sideroxylon.

3. Luсuma.

4. Diphotis.

5. Bumelia.

6. Iimusops.

7. Sapota.

1. CHRYSOPHÝLLUM L. Sp. Pl. 192. 1753.

Unarmed evergreen trees, with alternate coriaceous leaves, and small, mostly 5-parted flowers, in axillary or lateral fascicles, the sap milky. Sepals nearly alike. Corolla-lobes unappendaged. Stamens included; staminodia none. Ovary pubescent; style short. Fruit a large or small, drupe-like berry. Seeds with a hard, often shining testa and fleshy endosperm. [Greek, refer- 
ring to the lustrous pubescence on the under side of the leaves of some species.] Sixty species or more, mostly of tropical America. Type species: Chrysophyllum Cainito L.

1. Chrysophyllum olivifórme L. Syst. ed. 10, 937. 1759.

Chrysophyllum monopigrenum. Sז. Prodr. 49. 17ss.

A tree, reaching a maximum height of about $10 \mathrm{~m}$., with a trunk up to 3 $\mathrm{dm}$. in diameter, the bark fissured, the young twigs brownish-pubescent. Leaves oblong to ovate, $3-10 \mathrm{~cm}$. long, acutish or short-acuminate at the apex, rounded or narrowed at the base, green, glabrous and shining above, densely reddish or brownish-pubescent beneath, the petioles S-12 mm. long; fascicles fewflowered; pedicels $5-10 \mathrm{~mm}$. long; sepals silky, about $1.5 \mathrm{~mm}$. long; corolla white, 4-6 mm. wide; filaments very short; berry oval, 1-2 $\mathrm{em}$. long, purple, usually 1 -seeded.

Coppices and scrub-lands, Andros, New Providence, and North Caicos:-Florida ; Cuba to Porto Rico; Jamaica. C. Cainito of Schoepf. SATixiedf. SAFrrox-tree.

\section{SIDERóXYLON L. Sp. Pl. 192. 1753.}

Unarmed, hard-wooded, evergreen trees or shrubs, with alternate coriaceous, slender-petioled leares, and small, 5-parted, greenish-yellow or white flowers in dense axillary or lateral fascicles. Sepals mostly obtuse, imbricated. Corolla nearly rotate, its lobes obtuse, not appendaged. Stamens borne near the middle or top of the corolla-tube, included, opposite the lobes; filaments slender; anthers extrorse; staminodia entire or toothed, alternating with the filaments. Ovary 5-celled or sometimes 2-3-celled; orules ascending; style short or slender. Berry ovoid or subglobose, usually 1-seeded. Seed with a crustaceous testa and cartilaginous endosperm. [Greek, referring to the hard mood.] About 75 species, natives of warm and tropical regions. Trpe species: Sideroxylon inerme $\mathrm{L}$.

\section{Sideroxylon foetidíssimum Jaeq. Enum. 15. 1760.}

Sideroxylon mastichodendron Jaeq. Coll. 2: 253. 1785.

A tree, attaining a maximum height of about $25 \mathrm{~m}$., with a trunk up to $1.5 \mathrm{~m}$. in diameter, the bark splitting into scale-like plates, the twigs rather slender, glabrous. Leaves oblong to oblong-ovate or oval, $5-15 \mathrm{~cm}$. long, sparingly pubescent when young, becoming glabrous, mostly rounded at the apex, rounded or narrowed at the base, lustrous, the slender petioles $2-7 \mathrm{~cm}$. long; faseicles several-many-flowered, shorter than the petioles; pedicels 4-10 $\mathrm{mm}$. long; sepals nearly orbicular, obtuse, glabrous, about $2 \mathrm{~mm}$. long; corolla greenish-yellow, about $7 \mathrm{~mm}$. broad, its lobes oblong, obtuse; staminodia lanceolate, acuminate, $1 \mathrm{~mm}$. long; berry drupe-like, yellow, oval, 2-2.5 cm. long, glabrous, acid.

Coppices and sclub-lands, Abaco, Berry Islands, South Cat Cay, Andros, Jew Providence, Exuma Chain, Eleuthera, Cat Island, W'atling's and Crooked:-Florida ; Cuba to St. Thomas and to Barbadoes; Jamaica. Catesby, $2: p l$. 75 . MASTIC-BLLLY.

\section{LUCÙMA Molina, Sagg. Chile 186. 1782.}

Trees, or some species shrubs, the leaves mostly coriaceous, the small flowers in axillary or lateral glomerules, or solitary. Calyx-segments usually 4 or 5 , strongly imbricated. Corolla urn-shaped, the tube short, the 4,5 or 6 
lobes imbricated. Stamens 4, 5 or 6 , borne on the corolla-tube opposite its lobes, the filaments short or slender. Staminodes linear or scale-like, borne at the simuses of the corolla. Orary 2-6-celled, mostly villous; style subulate or conie. Fruit a berry, the pericarp fleshy or thin. Seeds 1-5. [Peruvian name.] Fifty species or more, mostly of tropical America, a few Australasian. Type species: Lucuma bifera Molina.

\section{Lucuma Serpentària H.B.K. Nov. Gen. 3: 242. 1819.}

Lucuma pauciflora A. DC. in DC. Prodr. 8: 168. 1844.

A tree, up to about $10 \mathrm{~m}$. high, the bark gray, the rather stout twigs pubermlent when young. Leaves oblong-obovate, coriaceous, 5-13 cm. long, glabrous, somewhat shining above, rounded at the apex, narrowed at the base, reticulate-veined, the puberulent petioles $3-15 \mathrm{~mm}$. long; peduncles solitary or 2 together in the axils, stout, puberulent, about as long as the petioles or a little longer; calyx-segments round-orate, puberulent, 6-8 mm. long; corolla about twice as long as the calyx, 6-lobed, the lobes rounded, as long as the tube; ovary 6-eelled, tomentose; berry globose, $2-3 \mathrm{~cm}$. in diameter, 3-6-seeded; seeds $1.5-2 \mathrm{~cm}$. long.

Coppices, Andros and New Providence:-Cuba. Referred by Coker to L. multiflora A. DC. EgG-FruiT.

\section{DÍPHOLIS A. DC. in DC. Prodr. 8: 18s. 1844.}

Evergreen unarmed shrubs or trees, with alternate leaves, and small, mostly 5-parted, greenish, often fragrant flotrers in axillary or lateral fascieles. Sepals ovate to nearly orbicular, imbricated. Corolla rotate or funnelform, its lobes with 2 appendages at each sinus. Stamens borne on the corolla-tube, opposite the lobes, exserted, the filaments filiform, the anthers extrorse; staminodia 5, often petaloid, alternating with the stamens. Ovary glabrous, 5celled; ovules ascending; style slender. Fruit an ovoid, subglobose or oblong berry, usually 1-seeded. Seed with a coriaceous testa, and fleshy endosperm. [Greek, referring to the appendages of the corolla.] About 10 species, natives of the West Indian region, the following typical.

1. Dipholis salicifòlia (L.) A. DC. in DC. Prodr. 8: 18S. 1844.

Achras salicifolia L. Sp. Pl. ed. 2: 470, 1762.

A slender tree, reaching a maximum height of about $16 \mathrm{~m}$. , with a trunk up to $5 \mathrm{dm}$. in diameter, the bark scaly, the slender young trigs appressedpubescent. Leaves subcoriaceous, oblong to elliptic-oblanceolate, slenderpetioled, 6-12 cm. long, acute or acuminate at the apex, narrowed at the base, somewhat silky-pubescent when young, soon glabrous, dark green and shining above, dull green beneath; flower-clusters mostly shorter than the petioles; pedicels 2-3 mm. long; sepals silky-pubescent, $1.5 \mathrm{~mm}$. long, ovate or oblong, obtuse; corolla about $4 \mathrm{~mm}$. broad, its lobes oval, obtuse, about as long as the tube, the appendages about one-half as long; staminodia ovate, irregularly toothed; berry ovoid or subglobose, black, $6-5 \mathrm{~mm}$. in diameter.

Coppices and scrub-lands, Great Bahama, Andros, New Providence, Great Exuma, Eleuthera to Mariguana and Caicos Islands:-Florida; Cuba to St. Jan and Guadeloupe; Barbadoes; Jamaica; Mexico. Bustic. WlLd CAssada, CASsada-Tood. 


\section{BUMElLIA Sw. Prodr. 49. 1788.}

Shrubs or trees, the branches often spinescent, the wood rery hard. Leares sometimes clustered at the nodes. Flowers small, pedicelled, green or white, fascicled in the axils. Calyx deeply 5-parted, the sepals unequal. Corolla 5 -lobed, with a pair of lobe-like appendages at each sinus, its tube short. Stamens 5, inserted near the base of the corolla-tube; anthers sagittate. Staminodia 5, petaloid. Ovary 5-celled; style filiform. Berry small, the pericarp fleshy, enclosing a single erect seed. Seed shining, the hilum at the base. [Greek, ox (large) ash.] About 35 species, natives of America. Type species: Bumelia retusa $\mathrm{Sw}$.

Leaves narrow, linear to spathulate, $2-10 \mathrm{~mm}$. Wide, wider only on shoots : fruit oblong-cylindric.

Leares obovate to oblanceolate, $1-1 \mathrm{~cm}$. wide, fruit globose to oroid.

Pedicels little if at all longer than the petioles: Jeaves oborate or oblanceolate, or on shoots suborbicular.

Pedicels much longer than the petioles; leares spatbulate to oblanceolate.

1. B. angustifolia.

2. B. loranthifolia.

3. B. bahamensis.

1. Bumelia angustifòlia Nutt. Sylv. 3: 3S, t. 93. 1849.

Bumelia Eggersii Pierre in Urban, Symb. Ant. 5: 146. 1904.

A glabrous shrub or small tree, reaching a maximum height of about $8 \mathrm{~m}$. Leares linear to spatulate, or those of shoots oborate, 2-4 cm. long, mostly obtuse at the apex, narrowed at the base, short-petioled; fascicles fer-many. flowered; pedicels $3-6 \mathrm{~mm}$. long; sepals orate, about $2 \mathrm{~mm}$. long, obtuse, the inner wider than the onter; corolla-lobes orbicular, erose-denticulate, the lanceolate appendages acuminate; staminodia ovate to ovate-lanceolate, $2 \mathrm{~mm}$. long, erose; fruit oblong to oblong-cylindric, 1-2 $\mathrm{cm}$. long, purple-black.

Palmetto-lands, coastal thickets, borders of salinas. Great Bahama, Cat Cay, Andros, New Providence, and Rose Island:-Florida; Cuban Cays. Recorded by Mrs. Nortbrop and by Coker as B. microphylla Griseb. Narrow-Leared Buarelia.

\section{Bumelia loranthifòlia (Pierre) Britton, Bull. N. Y. Bot. Gard. 3: 447.} 1905 .

Bumelia retusa loranthifolia Pierre in Urban, Symb. Ant. 5: 145. 1904.

A shrub, 1-3 m. high, or sometimes straggling, or a tree up to $S \mathrm{~m}$. high, the young twigs densely brown-tomentulose. Leaves obovate or oblanceolate, coriaceous, $1-5 \mathrm{~cm}$. long, glabrous and shining abore, brown-tomentulose beneath when young, beconing glabrous, rounded or somewhat retuse at the apex, cuneate at the base, the petioles $2-5 \mathrm{~mm}$. long; pedicels as long as the petioles or a little longer; sepals suborbicular, $2-3 \mathrm{~mm}$. long, the outer ones tomentulose; corolla about twice as long as the sepals, its lobes about as long as the tube; staminodia lanceolate; fruit globose, oblong or ovoid, 6-9 mm. in diameter, black.

Coppices, pine-lands, white-lands and scrub-lands, throughout the archipelago from Abaco and Great Bahama to Inagua, Mariguana, Cotton Cay and the Anguilia Isles. Endemic. Referred by Ifitchcock and by Dolley to B. retusa Sw.; recorded by Mrs. Northrop as B. culcnsis Griseb. WiLD SAFFrox. MIL-IRRR:

3. Bumelia bahaménsis Britton, Bull. N. Y. Bot. Gard. 3: 447. 1905.

A shrub with slender puberulous tmigs, related to $B$. loranthifolia. Leares spatulate-oblanceolate, coriaceous, revolute-margined, $8 \mathrm{~cm}$. long or less, 1.5$2.5 \mathrm{~cm}$. wile, rounded at the apex, narrowly cuneate at the base, dull green and glabrous above, densely brown-tomentulose beneath, rather strongly pinnately veined, the reins ascending at a narrow angle; petioles stout, $\overline{5} \mathrm{~mm}$. long or 
less; flowers about 6 in each axillary cluster; pedicels brown-furfuraceous, stout, $8-10 \mathrm{~mm}$. long, three times as long as the calyx.

Coastal thickets and scrub-lands, New I'rovidence, Irose Island and Isong Island. Endemic. l'erhaps a long-leaved, long-pedicelled race of the preceding species. BanAMA BUMELIA.

\section{MÍMUSOPS L. Sp. Pl. 349. 1753.}

Evergreen milky trees, with coriaceous leaves, and lateral, axillary or terminal flowers. Sepals 6-12, in 2 series. Corolla 18-24-lobed, its tube short. Stamens 6-12, borne on the corolla-tube, the filaments short, the anthers lanceolate; staninodia 6-12, petal-like, toothed or lacerate. Ovary hirsute, 6-12. celled. Berry sub-globose, the epicarp usually erustaceous. Seeds 1 or 2, oblique, compressed. [Greek, aspect of an ape.] About 40 species, mostly tropical in distribution. Type species: Mimusops Elengi L.

\section{Mimusops emarginàta (L.) Britton, Torreya 11: 129. 1911.}

Sloanea emarginata L. Sp. PI. 512. 1753.

Achras Zapotilla parvifolia Nuttall, Sylv. 3: 28. 1849.

Mimusops parvifolia Radlk. Sitz. Akad. Wiss. Muench. 12: 344.1882.

Achras bahamensis Baker, in Hook. Ic. 18: pl. 1795. 1888.

Mimusops floridana Engl. Bot. Jahrb. 12: 524. 1890.

Mimusops bahamensis Pierre, Not. Sapot. 37. 1891.

Manilkara parvifolia Dubard, Ann. Mus. Col. Marseille III. 3: 16. 1916.

A tree, up to $10 \mathrm{~m}$. high, the trunk sometimes $3 \mathrm{dm}$. in diameter, the twigs stout, the young foliage finely pubescent. Leaves clustered at the ends of the twigs, oblong, 3-10 $\mathrm{cm}$. long, emarginate at the apex, narrowed or rounded at the base, glabrous or nearly so when old, the petioles 1-2 cm. long; flowers several or many in the clusters, on tomentose nodding pedicels $1-3 \mathrm{~cm}$. long; sepals tomentose, lanceolate; corolla $1.5-2 \mathrm{~cm}$. broad, light yellow, its linear lobes often toothed at the apex; appendages similar to the corolla-lobes, about one-half their length; staminodia triangular; berry depressed-globose, nearly $3 \mathrm{~cm}$. in diameter, sealy.

Scrub-lands, throughout the archipelago from Abaco and Great Bahama to East Caicos, Ambergris Cay and Inagua :-Florida ; Cuba.

Recorded by Grisebach, by Dolley and by Mr's. Northrop as Mimusops dissecta R. Br.: recorded by Hitchcock, b5 Small and by Coker as Mimusops Sicberi DC. WILD Dilly. Catesby, $2: p 7$. 8\%.

\section{SAPÒTA [Plum.] Mill. Gard. Dict. ed. 7. 1759.}

An unarmed evergreen tree, with alternate coriaceous, oblong to elliptic leaves, and rather large, peduneled, mostly 6-parted, whitish flowers solitary in the axils, the sap milky. Calyx-lobes in 2 series. Corolla urceolate, scarcely longer than the calyx; anthers sagittate; staminodia little shorter than the corolla-lobes. Ovary 10-12-celled; ovules ascending; style slender, exserted; stigma small. Fruit a large, rough-skinned berry. Seeds black, shining, the endosperm fleshy. [Aboriginal West Indian name.] A monotypic genus.

1. Sapota Áchras Mill. Gard. Dict. ed. 8. no. 1. 1768.

Achras Zapota L. Syst. ed. 10, 988. 1759. Not A. Zapota L. Sp. Pl. 1190. 1753.

A tree up to about $15 \mathrm{~m}$. high, the bark dark brown, the twigs rather stout, the petioles, peduncles and calyx brownish pubescent. Leares mainly clustered 
at the ends of the twigs, $5-12 \mathrm{~cm}$. long, the lateral veins nearly transverse, delicate, close together, the apex obtuse, the base mostly narrowed, the slender petioles 5-20 mm. long; peiluncles about as long as the petioles; sepals 8-10 mm. long; corolla-lobes about half as long as the tube; staminodia longer than the stamens; fruit globose or ovoid, $3-8 \mathrm{~cm}$. in diameter, rough, brown, the flesh sweet, brownish, milky; seeds usually sereral, flattened, about $2 \mathrm{~cm}$. long, with a white scar on the inner edge.

Scrub-lands, spontaneous after cultivation, in various localities in the Bahamas: -Florida; West Indies; Mexico and northern South America. SAPodilla.

\section{Family 2. EBENÀCEAE Vent.}

\section{EвоNт Famili.}

'Trees or shrubs with very hard wood, entire estipulate leaves, and dioecious polygamous, or rarely perfect, regular flowers, solitary of cymose in the axils. Calyx inferior, $3-7$-lobed, commonly accrescent and persistent. Corolla gamopetalous, deciduous, 3-7-lobed, the lobes usually convolute in the bud. Stamens 2-3 times as many as the lobes of the corolla in the sterile flowers, and inserted on its tube, usually some imperfect ones in the pistillate flowers; anthers introrse, erect. Disk none. Ovary superior, several-celled; in the staminate flowers rudimentary or none; ovules 1-3 in each cavity, suspended; styles 2-S, distinct, or united below; stigmas terminal, sometimes 2-parted. Fruit a berry. Seeds oblong, the testa bony; endosperm copious, cartilaginous; embryo small; cotyledous large, foliaceous. About 6 genera and 275 species, mostly tropical.

\section{MĀBA Forst. Char. Gen. Pl. 121. 1776.}

Hard-wooded trees or shrubs, with alternate petioled leares, and dioecious (rarely monoecious) axillary, mostly 3-parted flowers, usually solitary, or the staminate ones in small clusters. Calyx campanulate or tubular-campanulate, accrescent and persistent in fruit. Corolla campanulate or tubular. Staminate flowers with few or several stamens, the filaments separate or connate, the anthers oblong or linear, the orary rudimentary. Pistillate flomers with a 3 -celled or 6-cellerl ovary, and 3 styles or a 3 -cleft style, sometinies with staminodia. Fruit baceate, somewhat fleshy or dry. Seeds 1-6, the endosperm commonly ruminated. [Tonga Islands name.] Sixty species or more, natives of tropical regions. Type species: Maba clliptica Forst.

\section{Maba crassinérvis (Krug \& Urban) Urban, Symb. Ant. 7: 329. 1912.}

Maba caribaea crassinervis Krug \& Urban, Bot. Jahrb. 15: 327. 1893.

A shrub 1-3 m. high, or a small tree up to about $7 \mathrm{~m}$. high, the branches slender, gray, stiff, the young twigs pubescent. Leaves oborate to elliptie, coriaceous, $3-7 \mathrm{~cm}$. long, rounded, subtruncate or obtuse at the apex, obtuse or narrowed at the base, glabrous, lark green and shining above, pale, strongly and densely reticulate-veined and pubescent beneath, the stout pubescent petioles 2-7 mm. long; staminate flowers 3 together on short axillary peiluncles: calyx 3-4-toothed, densely pubescent, about $4 \mathrm{~mm}$. long; corolla glabrous within, densely pubescent without; stamens 9 ; pistillate flowers solitary; fruit solitary and short-peduncled in the axils, globose, yellowish, $1.5-2.3 \mathrm{~cm}$. in diameter, the persistent calyx 1-2 $\mathrm{cm}$. wile; seets about $1 \mathrm{~cm}$. long, oroid, oblique. 
Copplces and rocky scrub-lands, Andros, New lrovldence, Great Guana Cay, Great Exuma, Elenthera, Watling's, Atwood Cay, Geat liagged Island, Fortune, Acklin's and Crooked Islands:-Cuba; IIisinniola. Recorded by Coker as Macreightia caribaca A. DC, and referred by Ilitelieock to Diospyros halesioides Grlseb. lentiler-ibed. Bon-Twood.

\section{Order 3. GENTIANÀLES.}

Herbs, shrubs, vines or trees. Leaves opposite, or rarely alternate. Flowers regular. Corolla gamopetalous, rarely polypetalous, nerved, wanting in Forestiera of the Oleaceae. Stamens mostly borne on the lower part of the corolla when this is present, as many as its lobes or fewer and alternate with them. Oraries 2, distinet, or 1 with 2 cavities (rarely more), or 2 placentae.

a. Stamens (usually 2), fewer than the corolla-lobes,

$$
\text { or corolla none. Fam.1. Oleaceae. }
$$

b. Stamens as many as the corolla-jobes.

Stigmas distinet; juice not nilky; ovary 1 , compound.

Ovary 2-celled; leaves stipulate, or their bases connected by a stipular line.

Ovary 1-celled: leaves not stipulate.

Leares opposite, rarely rerticillate: corolla-lobes convolute or imbricated in the bud.

Leaves tufted or alternate; corolla-lobes induplicate-ralrate in the bud; Bahama species aquatic.

Stigmas united: juice milky ; oraries usually 2.

Styles united; stamens distinct; pollen of simple grains.

Styles distinct; stamens mostly monadelphous; pollen-grains united into waxy masses.

Fam. 2. LOgAxiACEAE.

Fam. 3. Gextiaxaceae.

Fam. 4. Mexianthaceae.

Fam. 5. Apocyxaceae.

Fam. 6. Asclepiadaceat.

\section{Family 1. OLEÀCEAE Lindl.}

\section{Olive Faniliy.}

Trees or shrubs (a few genera almost herbaceotus) with opposite or rarely alternate, simple or pinnate, estipulate leaves and regular 2-4-parted flowers in panicles, cymes or fascicles. Calyx inferior, usually small, sometimes none. Corolla various, or none. Stamens 2-4; filaments separate; anthers ovate, oblong or linear, 2-celled, the sacs longitudinally dehiscent. Ovary superior, 2-celled; ovules few in each cavity, anatropous or amphitropous; style usually short or none. Fruit a capsule, samara, berry or drupe. Endosperm fleshy, horny or wanting; embryo straight, rather large; radicle usually short. About 21 genera and 525 species, of wide distribution in temperate and tropical regions.

Corolla none: fruit a drupe.

1. Forestiera.

Corolla large, conspicuous.

Corolla salverform: fruit fleshy, didymous.

Petals distinct ; fruit drupaceous.

\section{Jasminum.} 3. Hayepea.

1. FORESTIÈRA Poir. in Lam. Encycl. Suppl. 2: 664.1812.

Shrubs or trees, with opposite deciduous simple leaves, and very small, clustered, incomplete and commonly imperfect flowers axillary or on twigs of the previous season. Calyx-tube short, the limb deeply 4-6-lobed. Corolla none (rarely of 1 or 2 small petals). Stamens 2 or 4 . Ovary 2-celled; stigmas thick, sometimes 2-lobed; ovules 2 in each cavity, pendulous. Drupe commonly 
1-seeded. Endosperm fleshy. [Commemorates Charles Le Forestier, a French physician.] About 10 American species. Type species: Forcstiera acuminata (Michx.) Poir.

1. Forestiera segregàta (Jacq.) Krug \& Urban, Bot. Jahrb. 15: 339.1893.

Myrica segregata Jacq. Coll. 2: 273. 1788.

Adelia porulosa Michx. Fl. Bor. Am. 2: 224. 1803.

Adelia segregata Kuntze, Rev. Gen. Pl. 410. 1891.

Foresteria cassinoides Poir. in Lam. Encycl. Suppl. 2: 665. 1812.

Forestiera segregata stenocarpa Krug \& Urban, Bot. Jahrb. 15: 340. 1893.

A shrub, or a small tree up to $7 \mathrm{~m}$. high and a trunk diameter of $1.5 \mathrm{dm}$., the branches slender. Leares rather firm in texture, oblong to lanceolate or obovate, $1.5-6 \mathrm{~cm}$. long, obtuse or acutish at the apex, narromed at the base, shining abore, pale and reticulate-reined beneath, punctate when dry, shortpetioled; flowers very small, yellowish green; drupes oblong to oval, 6-10 $\mathrm{mm}$. long, short-pedicelled, purplish, the stone longitudinally ribbed.

Scrub-lands, throughout the islands from Abaco and Great Bahama to Mariguana and Grand Turk:-Bermuda; Florida; Cuba to St. Croix; Tortola; Jamaica. FloRIDA I'RIVET, IXK-BUSH.

\section{JASMINNUM L. Sp. Pl. 7. 1753.}

Shrubs or woody vines, with mostly opposite, simple or compound leaves, and large, clustered or solitary flowers. Calyx lobed or parted. Corolla salverform, its tube eylindric, its limb lobed or parted, the lobes imbricated. Stamens 2, included; filaments short; anthers laterally dehiscent. Ovary 2-celled; style very slender; stigma capitate or 2 -lobed; orules mostly 2 in each cavity. Fruit didymous, fleshy. Seeds without endospern. [Ancient name, of Arabic origin.] About 100 species, natives of the Old World. Type species: Jasminum officinale $\mathrm{L}$.

\section{Jasminum Sámbac (L.) Soland.; Ait. Hort. Kew. 1: 8. 1789.}

Nyctanthes Sambac L. Sp. Pl. 6. 1753.

A shrub, 1-2 $\mathrm{m}$, high, the young shoots sparingly pubescent. Leares orate to elliptic, membranous, deciduous, $3-i \mathrm{~cm}$. long, acute, obtuse or shortacuminate at the apex, rounded or obtuse at the base, glabrous and finely reticulate-reined on both sides, the pubescent petioles 3-6 $\mathrm{mm}$. long; cymes peduncled, terminal, few-several-flowered, pubescent; pedicels 6-12 mm. long; ealyx-segments numerous, linear, about $1 \mathrm{~cm}$. long; corolla white, fragrant, its tube somerrhat longer than the calyx, its limb about 2 em. wide, the lobes obtuse.

Presumably spontaneous after cultivation. New Proridence. collecter br Cooper in 18.9:- Esciped from cultivation in various West Indian Islands and in South America. Native of the East Indies. Aribiar Jasmixe.

3. MAYEPÈA Aubl. Pl. Guian. 1: \$1. 1775.

Trees or shrubs, with opposite entire leaves, the rather large, mostly white bracteolate flowers usually panicled. Calyx small, 4-eleft or 4-toothed. Petals 4 , distinct or rery nearly so, narrow. Stamens 2 , rarely 4 , borne at the bases of the petals; filaments short; anthers orate to linear. Ovary 2-celled; orules 
2 in cach carity; style short; stigma oblong to globose. Fruit a small oblong drupe, with thin flesh and hard culocarp. [Guiana uame.] About 50 species, natives of tropical regions. Type species: Layepea guianensis Aubl.

1. Mayepea bumelioìdes (Griseb.) Krug \& Urban, Bot. Jahrb. 15: 344. 1893.

Linociera bumelioides Griseb. Cat. Pl. Cub. 169. 1866.

A tree, up to $10 \mathrm{~m}$. high, the branches erect or ascending, the bark pale, the twigs slender, pale gray, glabrous. Leaves elliptic to oblong or obovateoblong, subcoriaceous, $5-10 \mathrm{~cm}$. long, $1.5-5 \mathrm{~cm}$. wide, coarsely reticulate-veined, glabrous, bright green and shining above, pale green beneath, the petioles 1-2 $\mathrm{cm}$. long; panicles axillary and terminal, as long as the leaves or shorter, several-many-flowered, puberulent; bractlets orate, acute, 1-1.5 mm. long; pedicels about as long as the bractlets; calyx 1.5-2 $\mathrm{mm}$. long, its teeth ovate, acute; petals linear, white, 6-8 $\mathrm{mm}$. long; filaments about $2 \mathrm{~mm}$. long; anthers orate-oblong.

Coppices near Nicholl's Town and Crow Hill, Andros:-Cuba. BцAck Eвoxr.

An opposite-leaved shrub, found in foliage only near Staniard Creek, Andros (Small and Carter 8998 ), may be of this genus.

\section{Family 2. LOGANIÀCEAE Dumort.}

\section{Logania FamiLy.}

Herbs, shrubs, vines or some tropical genera trees, with opposite or verticillate simple stipulate leaves, or the leaf-bases connected by a stipular line or membrane, and regular perfect 4-5-parted flowers. Calyx inferior, the tube campanulate, sometimes short or none, the segments imbricated, at least in the bud. Corolla gamopetalous, funnelform, campanulate, or rarely rotate. Stamens inserted on the tube or throat of the corolla; anthers 2-celled, the saes longitudinally dehiscent; pollen-grains simple. Disk usually none. Ovary superior, 2-celled (rarely 3-5-celled); ovules anatropous or amphitropous. Fruit a 2-valved capsule in our species. Embryo small, usually straight; endosperm copious; radicle terete or conic. About 30 genera and 400 species, widely distributed in warm and tropical regions.

Corolla-lobes ralvate.

Corolla funnelform or salverform, styles united.

Corolla urn-shaped, styles soon distinct.

Corolla-lobes imbricated.

1. Spigelia.

2. Cynoctonum.

3. Polypremum.

\section{SPIGÈLIA L. Sp. Pl. 149. 1753.}

Herbs, with opposite membranous entire, pinnately veined leaves, small stipules, or the leaf-bases connected by a stipular line, and red yellow nearly white or purple flowers, in scorpioid cymes or unilateral spikes, or terminal and in the forks of the branches. Calyx deeply 5-parted. Corolla 5-lobed, the tube finely 15-nerved. Stamens 5, inserted on the corolla-tube; anthers 2-lobed at the base. Orules numerons, on peltate placentae; style filiform, jointed near the middle; stigma obtuse. Capsule didymous, 2-celled, somewhat flattened contrary to the dissepiment, circumscissile, the 2 carpels becoming 2 -valved. Seeds peitate, not winged. [Named for Adrian ron der Spigel, 1558-1625, physician.] About 35 species, all American. Type species: Spigelia Anthelmia $\mathrm{L}$. 
1. Spigelia Anthélmia L. Sp. Pl. 149. 1753.

Annual, simple or branched, $5 \mathrm{dm}$. high or less. Leaves lanceolate, 3-10 cm. long, acute or acuminate, pale beneath, finely ciliolate; inflorescence subtended by a whorl or pair of lanceolate or ovate bracts larger than the leares; flowers small, in slender unilateral spikes $5-12 \mathrm{~cm}$. long; ealyx-lobes narrowly lanceolate, about $2 \mathrm{~mm}$. long; corolla purplish white, 5-9 mn. long; capsules 5-6 $\mathrm{mm}$. broall, tubereled.

Ioist soils, Abaco, Andros, New Providence, Great Exuma, Eleuthera, cat Island, Watling's, Acklin's, Crooked and Fortune Islands and IIriguana:-Florida : Viest Indies; continental tropical America. SPIgelid. PINK.

2. CYNÓ́TONUM J. F. Gmel. Syst. 443. 1791.

Herbs, our species annual, with opposite entire leaves, and minute stipules, or the leaf-bases connected by a stipular line. Flowers small, whitish, in onesided spikes forming cymes. Calyx 5-parted. Corolla urn-shaped, 5-lobed. Stamens 5, included; filaments short; anthers cordate. Orules numerous, on peltate placentae; style short, 2-divided below, united above by the common stigma, the divisions becoming separate. Capsule 2-lobed at the summit; carpels divaricate, dehiscent along the inner side. Seeds numerous, small, tuberculate. [Greek, dog-killing.] About 5 species, of warm and tropical regions. Type species: Cynoctonum sessilifolium Gmel.

1. Cynoctonum Mitrèola (L.) Britton, Mem. Torr. Club 5: 25s. 1894.

Ophiorrhiza Mitreola L. Sp. Pl. 150. 1753.

Mitreola petiolata T. \& G. Fl. N. A. 2: 45. 1541.

Stem glabrous, erect, terete, 3-6 $\mathrm{dm}$. high. Leares lanceolate to orate, petioled, $2.5-5 \mathrm{~cm}$. long, $6-25 \mathrm{~mm}$. wide, acute at both ends, glabrous; eymes terminal and often also in the upper axils, slender-peduneled; flowers about $2 \mathrm{~mm}$. broad, numerous, sessile or nearly so; capsule deeply 2-lobed, compressed, the lobes at length widely diverging, acute.

Savannas, brackisl marshes, palmetto-lands and borders of mangrove swamps, Great Bahama, Andros and lew Providence:-Virginia to Florida, Texas and Mexico; Cuba to I'orto Rico and to Trinidad; Jamaica. The Andros plant recolded by Irs. Northrop as Cynoctonum sessilifolia (T. \& G.) Britton, proves to be better referable to this species. MITlEwORT.

\section{POLYPRÈMUM L. Sp. Pl. 111. 1753.}

A glabrous diffusely branehed annual herb, with opposite linear-subulate leaves, their bases comnected by a stipular membrane, and small white flowers in terminal bracted eymes. Calyx deeply 4 -parted (rarely 5-parted), the segments subulate. Corolla campanulate, bearder in the throat, shorter than the calyx, 4-lobed (rarely 5-lobed). Stamens 4 (rarely 5), inserted on the corolla, included; filaments short; anthers oroid-globose. Orules mumerous, on oblong placentae; style short; stigma capitate or obscurely 2-lobed. Capsule slightly compresserl, dilymous, loculicidally 2-valved, the carpels at length septicilal. Seels minute, smooth. [Greek, many-stemmed.] A monotypic genus.

\section{Polypremum procúmbens L. Sp. Pl. 111. 1753.}

Stems tufted, somewhat rigid, 4 -angled, $5-30 \mathrm{~cm}$. long. Leaves $1-4 \mathrm{~cm}$. long, 1-2 mm. wide, acute, sessile, minutely rough-toothed on the margins, often 
with smaller ones fascicled in their axils; flowers solitary, sessile in the forks of the cymes and along their branches, leafy-bracted; corolla $2 \mathrm{~mm}$. long or less; capsule crustaceous, didymous, about $2 \mathrm{~mm}$. in diameter, slightly 2-lobed, the lobes obtuse.

Scrub-lands, Inagua at Matthew Town:-New Jerses to Kentucky, Florida, Mexico and Colombia; Cuba; Jamaica. Polyprenum.

\section{Family 3. GENTIANÀCEAE Dumort.}

\section{Gentian Famill.}

Bitter mostly glabrous herbs, with opposite (rarely verticillate) estipulate entire leaves, reduced to seales in Leiphaimos, and regular perfect flowers in clusters, or solitary at the ends of the stem or branches. Calyx inferior, persistent, 4-12-lobed, toothed or -divided (of 2 sepals in Obolaria), the lobes imbricated or not meeting in the bud. Corolla gamopetalous, often marcescent, 4-12-lobed or -parted. Stamens as many as the lobes of the corolla, alternate with them, inserted on the tube or throat; anthers 2celled, longitudinally dehiscent. Disk none, or inconspicuous. Ovary superior in our genera, 1-celled or partly 2-celled; ovules numerous, anatropous or amphitropous; stigma entire, or 2-lobed, or 2-cleft. Capsule mostly dehiscent by 2 valves. Endosperm fleshy, copious; embryo small, terete or conic. About 70 genera and 700 species, widely distributed.

Corolla-lobes convolute in the bud; leaves broad or narrow.

Stigmas roundish, much shorter than the style.

Corolla-tube surpassing the calyx.

Corolla-tube much shorter than the calyx.

Stigmas linear or nearly so, about as long as the style.

Corolla-lobes imbricated in the bud; leares reduced to scales.

1. Centaurium.

2. Eustoma.

3. Sabbatia.

4. Leiphaimos.

\section{Centaurium Hill, Brit. Herbal 62. 1756.}

Herbs, mostly annual or biennial, with sessile or amplexicaul leaves, and pink white or yellow flowers in cymes or spikes. Calyx tubular, 5-4-lobed or -divided, the lobes or segments narrow, keeled. Corolla salverform, 5-4-lobed, the lobes spreading, contorted, convolute in the bud. Stamens 5 or 4 , inserted on the corolla tube; filaments short-filiform; anthers becoming spirally twisted. Ovary 1-celled, the placentae sometimes intruded; style filiform; stigma 2-lobed. Capsule 2-valved. Seed-coat reticulated. [Latin, 100 gold pieces, referring to supposed medicinal value.] About 25 species, both in the Old World and the Ner. Type species: Gentiana Centaurium L.

\section{Centaurium Brittònii Millsp. \& Greenm. Field Mus. Bot. 2: 308.1909.}

Annual, glabrous, much-branched, 5-18 $\mathrm{cm}$. high, the branches very slender, quadrangular. Basal and lower leaves obtuse or oblong-spatulate; upper leaves sessile, oblong-lanceolate to linear, acute, $1.8 \mathrm{~cm}$. long or less; peduncles nearly filiform, much longer than the upper leares; flowers white with a yellowish eye, 3-5-parted (mostly 4-parted); calyx 5-6 mm. long, its segments narrowly linear, acute; corolla 6-10 mm. long, its lobes oblong, about one-half as long as the tube; capsule linear-elliptic, $6-8 \mathrm{~mm}$. long.

Dry sandy roadsides and sandy edge of marshes, Eleuthera, Watling's and Great Exuma:-Anegada. BRitTox's Cextaury. 
2. EUSTÒMA Salisb. Parad. Lond. pl. 34. 1806.

Glabrous, often glaucous, annual herbs, with opposite, sessile or elasping, entire leaves. Flowers large, blue, purple or white, long-peduncled. Calyx deeply 5-6-cleft, the lobes !anceolate, acuminate, keeled. Corolla deeply 5-6lobed, the lobes oblong or obovate, convolute in the bud. Stamens 5-6, inserted on the throat of the corolla; filaments filiform; anthers oblong, versatile. Ovary 1-celled; stigma 2-lamellate. Capsule 2-ralved. Seeds small, numerous, foveolate. [Greek, open-mouth, referring to the corolla.] Four or five species, natives of the southern United States, Mexico and the West Indies. Type species: Eustoma silenifolium Salisb.

\section{Eustoma exaltàtum (L.) Griseb. Fl. Br. W. I. 422. 1861.}

Gentiana exaltata L. Sp. Pl. ed. 2, 331. 1762.

Erect, slightly fleshy, 1-9 dm. high, large plants often much-branehed and many-flowered, small plants simple and 1-flowered. Leaves oblong or oblonglanceolate, somewhat clasping, sessile, 1.5-9 em. long, the lower obtuse, the upper acute; calyx-lobes nearly filiform-acuminate, 1-2 cm. long; corolla blue or nearly white, sometimes light blue above and dark blue below within, $2-4 \mathrm{~cm}$. broad, its lobes obovate, irregularly dentate; style about twice as long as the stigma-lobes; capsule oblong, obtuse, $2-2.5 \mathrm{~cm}$. long.

Brackish borders of marshes and savannas, North Bimini, Andros, New Proridence, Great Exuma, Long Island, Cat Island and Acklin's:-Florida to Texas, Mexics and south to nerthern South America; Cuba; Hispaniola; Jamaica. MarsH Gextiax.

3. SABBÀtiA Adans. Fam. Pl. 2: 503. 1763.

Annual or biennial erect glabrous herbs, with opposite or sometimes vertieillate, sessile or rarely petioled or clasping leaves, and terminal pink rose or white flowers. Calyx 4-12-parted or -divided, the tube eampanulate, sometimes very short, the lobes or segments usually narrow. Corolla rotate, deeply 4-12. parted. Stamens 4-12, inserted on the short tube of the corolla; filaments filiform short; anthers curved, revolute or eoiled in anthesis. Ovary 1-celled, the placentae intruded; style 2-cleft or 2-parted, its lobes filiform, stigmatic along their inner sides. Capsule 2-valved, many-seeded. Seeds small, reticulated. [In honor of L. Sabbati, an Italian botanist.] About 18 species, natives of eastern North America, Mexico and the West Indies. Type species: Gentiana dodecandra $\mathrm{L}$.

Corolla 2-3 cm. wide, rose-pink; stigmas oblong-linear. Corolla less than $2 \mathrm{~cm}$. wide, pule white; stigmas spatilate.

1. S. campanulata. 2. S. simulata.

1. Sabbatia campanulàta (L.) Torrey, Fl. U. S. 1: 217.1824.

Chironia campanulata L. Sp. Pl. 190. 1753.

Sabbatia gracilis Salisb. Parad. Lond. pl. 32. 1806.

Stem 3-6 dm. high. Leaves linear or linear-lanceolate, 2-4 cm. long, sessile, acute or the lowest much shorter, obtuse, oblong or oblanceolate, the uppermost almost filiform; flowers pink with a yellow eye, about $2.5 \mathrm{~cm}$. broad, mostly 5-parted; calyx-lobes filiform-linear, equalling the oblong-oborate corolla-segments, or somewhat shorter; stigmas oblong-linear; capsule oboroid, about $5 \mathrm{~mm}$. high.

liackish marshes, Abaco and Great Bahama:-Eastern Massachusetts to Florida and Louisiana :-Cubi. Slexder MAlsil PINK. 


\section{Sabbatia simulàta Britton. 13ull. N. Y. Bot. Garl. 3: 448. 190 J.}

Similar to $S$. companulata but more slemele than that species and with smaller white flowers. I'lant 4 dm. high or less, the upper leaves narrowly linear, 1-3 em. long, ahont $1 \mathrm{~mm}$. wille, the lower spatulate, acute, $4 \mathrm{~cm}$. long or less, $2-5$ mul. Wille, the basal ones spatulate to orbienlar; ealyx-lobes narrowly linear, less than $1 \mathrm{~mm}$. wide, nearly as long as the corolla or shorter; corolla 1-2 "m. broal, its segments oval, ol,tuse; eapsule ovoid, about $6 \mathrm{~mm}$. long, tippeal by the short style; stigmas narrowly spatulate.

savannas, palmetto-lands and eriges of brackish pools, Abaco, Andros, New I'rovilence. Eleuthera and Cat Island. Endemic. lieferred by Mrs. Northrop and lis Cokel to $S$. compmulata (I.) 'Jorr., and listed by lolley as S. gracilis Sallsb. IIITE Mansu Pixk.

4. LEIPHÀIMOS Schl. \& Cham. Linnaea 6: 387. 1531.

Small saprophytic pale simple-stemmed herbs, without ehlorophyll, the stems white or yellowish, bearing opposite sessile seales or the lower seales altermate, the flowers terminal, eymose or solitary. Calyx bracteolate at the base, 4-5-toothed. Corolla salverform or funnelform, 4-5-lobed, small. Stamens 4 or 5 , incluled; filaments mostly short; anthers introrse. Ovary 1-celled, with 2 parietal placentac; style one; stigma eapitate or dilated. Capsule oblong or linear, septieidally dehiseent at the middle. [Greek, pallid.] About 20 speeies, mostly of tropical America, the following typical.

\section{Leiphaimos parasitica Schl. \& Cham. Limnaea 6: 3S7. 1831.}

Toyria mexicana Griseb. Gen. et Spee. Gent. 208. 1838.

Stem somewhat fleshy, whitish, 1-4 dm. high, ereet, slender, simple or little-branched, bearing few opposite seales $3-5 \mathrm{~mm}$. long. Calyx-lobes lanceolate, obtuse; corolla whitish or yellowish, $6-8 \mathrm{~mm}$. long, its triangular acute lobes about one-fourth as long as the tube; eapsule $5-6 \mathrm{~mm}$. long.

Floor of coppices in leaf mold. Abaco, freat liahama, Andros, New Providence, Eleuthera, Watling's, Crooked IsIand and North Caicos:-Fiorida; Cuba; Jumaica; Iexico. LEHIJIIIOS.

\section{Family 4. MENYANTHÀCEAE G. Don.}

\section{BüCKBEAN FAMILT.}

Peremial aquatic $o r^{\circ}$ marsh herbs, with basal or alternate leaves, and clustered regular perfeet flowers. Calyx inferior, deeply 5-parted, persistent. Corolla 5-lobed or 5-cleft, the lobes induplieate-valvate, at least in the bud. Stamens 5, borne on the corolla, and alternate with its lobes; anther-saes longitudinaly dehiscent: pollen-grains 3-angled. Ovary 1celled, the 2 placentae sometimes intruded. Fruit a eapsule, or indehiseent. Five genera and about 35 speeies, widely distributed.

\section{NYMPHOIDES Hill, Brit. Herbal 77. 1756.}

[Limanthemum S. G. Gmel. Nov. Aet. Aead. Petrop. 14¹: 527. 1769.]

Aquatic herbs, with slender rootstocks. Leaves petioled, ovate or orbicular, entire or repand, or the primary ones different; flowers yellow, or white, umbellate at the summit of filiform stems at the bases of the petioles, or axillary. Calyx 5-parted. Corolla nearly rotate, deeply 5-eleft, the lobes induplicate- 
valvate in the bul, sometimes fimbriate on the margins. Stamens 5, inserted on the base of the corolla; anthers sagittate, versatile. Ovary 1-celled; style short or none; stigma 2-lamellate. Capsule indehiseent or irregularly bursting. [Greek, resembling Nymphaca.] About 20 species, widely distributed. Type speeies: Nymphoides flava Hill.

\section{Nymphoides aùreum Britton.}

Limnanthemum aureum Britton, Bull. N. Y. Bot. Gard. 4: 142. 1906.

Rootstock 1 cm. thıek, 3-4 cm. long. Stolons rather slender, purple-ilotted, 2-3 dm. long, or longer, bearing a petioled floating leaf and an umbel of slender-pedieelled flowers at its summit but no tufts of tubers; leaves subpeltate, floating, ovate-orbicular, $8 \mathrm{~cm}$. long or less, entire, or irregularly repand, thiek, dull-green above, purple and densely dotterl beneath, the basal sinus narrow, acute, or the obtuse lobes somewhat overlapping; petioles stout, $2-4 \mathrm{~cm}$. long, inserted on the leaf-blade 1-3 $\mathrm{mm}$. from the sinus; umbel several-flowererl; pedieels slenter, 3-5 cm. long in fruit; sejals oblong-Ianceolate, acutish, 5-1j $\mathrm{mm}$. long; corolla-segments about $8 \mathrm{~mm}$. long, golicn-yellow, their margins fimbriate; capsule oblong-ovoir, as long as the sepals; style subulate, persistent, 2-3 nm. long; sceds compressed-globose, wingless, smooth, $1 \mathrm{~mm}$. broad and about one half as thick as wirle.

I'onds on Great Exuma, near feorgetown and on Andros near Nicholl's Town. Endemic. IBAmana Fontisi; lIEAKT.

\section{Family j. APOCYNÀCEAE Lindl.}

\section{Dogbane Fajilly.}

Perennial herbs, slurubs, vines, or some tropical genera trees, mostly with an acrid milky juiee, with simple estipnlate leaves, and perfect regular 5-parted flowers. Calyx inferior, persistent, the lobes imbricated in the bud. Corolla gamopetalous, its lobes convolute in the bud and often twisted. Stamens as many as the lobes of the corolla, alternate with them, inserted on the tube or throat; anthers 2-celled; pollen-grains simple. Ovary superior, or its base adherent to the ealyx, of 2 distinct earpels, or 1-celled, with 22 parietal placentae. or 2-eelled ; ovules anatropous or amphitropous; style simple, or 2-divided; stigma simple. Fruit usually of 2 follicles or drupes. Seeds often appendaged; endosperm fleshy; embryo straight; radicle terete, usually shorter than the coryledons. About 130 genera and 1100 species, very widely distributed, mostly in tropieal regions.

Fruit folliculat.

'T'rees, shruls, or shrublor herbs.

Woody trees or shrubs.

Serds with al wing.

Seerls with a comal.

IIrobiceous plant, shrubby at the base.

Vines; seeds with a comal.

Corollit-tube subcylindric.

Corollatube uarrowly campanulate above the short, eylindirlc lase.

Cit]yx-loles short.

Fruit flesliy.

Calyx-lobes long, linear-acuminate.

1. Mlumicra.
9. Nobracen.
B. Cotharanthus.
4. Echites.

5. Rhabdadenia.

i. Lrechites.

7. Cerbera.

S. Riancolfia.

9. Vallesia. 


\section{PLUMIÈrA L. Sp. Pl. 209. 1753.}

Trees or shrubs, with rery stout branches, copious milky sap, alternate petioled feather-veined leaves, and large bracted flowers in terminal, peduncled çmes. Calyx small, fleshy, 5-cleft, eglandular. Corolla salverform, the tube subeylindrie, the 5 lobes sinistrorse. Stamens borne near the base of the corolla-tube, included; anthers obtuse, their sacs unappendaged. Carpels 2, distinct; orules many in each earpel; style very short; stigma oblong, not annulate, obtusely 2-lobed at the apex. Follicles 2, coriaceous, usually linear and divarieate, many-seeded. Seeds flat, winged, the endosperm fleshy. [Commemorates Charles Plumier, a distinguished Freneh botanist, born 1646.] About 45 species, of tropical Ameriea. Type species: Plumicra rubra L.

Leares glabrous or very nearly so.

Leares obtuse or emarginate.

Corolla-tube as long as the lobes; leares oblong to oblongobovate.

Corolla-tube shorter than the lobes; leares oborate.

Leaves acute or mucronate.

Leaves lanceolate to linear-lanceolate; color of flowers unknown.

Leaves broadly elliptic to obovate; flowers red or purple. Leares densely pubescent beneath.

1. P. obtusa.

2. P. inaguensis.

3. P. bahamensis.

4. P. rubra.

5. P. sericifolia.

\section{Plumiera obtùsa L. Sp. Pl. 210. 1753.}

A tree, 4-6 m. high, often flowering when not more than $1.5 \mathrm{~m}$. high, the stout twigs, the leaves and the inflorescence glabrous. Leaves oblong to oblongoblanceolate or oblong-obovate, $7-20 \mathrm{~cm}$. long, rounded or emarginate at the apex, mostly narrowed or somewhat euneate at the base, the lateral veins nearly straight and rather widely spreading, the slender petioles $2-6 \mathrm{~cm}$. long; panicles few-several-flowered; peduncle as long as the leaves or shorter; pedicels short; ealyx about $3 \mathrm{~mm}$. long; corolla white with a yellow eye, the lobes obovate or oblong-obovate, rounded at the apex, $1.5-2 \mathrm{~cm}$. long, about as long as the tube; follicles $7-12 \mathrm{~cm}$. long, about $1 \mathrm{~cm}$. in diameter.

Scrub-lands and coppices, Abaco and Great Bahama to Andros, Watling's, Providenciales, Caicos and Grand Turk:-Cuba: Hispaniola; Mona; recorded from Jamaica. Hitcheock's Governor's Harbor specimen referred to $P$. emarginata is thls species. Recorded by Schoepf as P. alba L. Blunt-leaved Plumiera. FranglPANNi. Cateshy, 2: $p l .93$.

\section{Plumiera inaguénsis Britton, Bull. N. Y. Bot. Gard. 3: 448. 1905.}

A glabrous tree, $5 \mathrm{~m}$. high or less. Leaves obovate, rather thin, the blade 6-10 $\mathrm{em}$. long, 4-6 $\mathrm{cm}$. wide, emarginate or rounded at the apex, narrowed or cuneate at the base, dark green and shining above, bright green and dull beneath, the numerous veins diverging from the midrib at an angle of about $80^{\circ}$, the midrib impressed on the upper surface, elevated beneath; petioles stout, 1-2 cm. long; peduncle stout, 4-10 cm. long; cyme compound, $8 \mathrm{~cm}$. broad or less, densely many-flowered; pedicels slender, 8-12 mm. long; calyx shorteampanulate, slightly 5-lobed, the lobes broad, rounded; corolla white, its tube slender, about $1 \mathrm{~cm}$. long, its 5 lobes narrowly obovate, rounded or slightly emarginate, somewhat longer than the tube; stamens about one-third the length of the corolla-tube; follieles linear, terete, $9 \mathrm{~cm}$. long, $8 \mathrm{~mm}$. in diameter.

Scrub-lands, Fortune Island and the Inaguas. Endemic. Ixagua Plumiera.

3. Pulmiera bahaménsis Urban, Symb. Ant. 1: 387. 1900.

A small tree, about $3 \mathrm{~m}$. high, the twigs about $1 \mathrm{~cm}$. thick. Leaves lanceolate or linear-lanceolate, glabrous, $8-16 \mathrm{~cm}$. lcng, 1-3.5 cm. wide, ehartaceous, acute or acuminate at the apex, narrowed at the base, the midvein impressed 
above, prominent beneath, the lateral veins numerous, straight ascending; follicles (Brace no. 4275 from Acklin's island, the type locality) about $10 \mathrm{~cm}$. long and $12 \mathrm{~mm}$. in diameter; corolla (Brace, Fortune Island) about $2 \mathrm{~cm}$. broad, the slender tube about as long as the lobes.

Rocky scrub-lands, Acklin's and Fortune Islands. Endemic. Bamasid Plumera.

4. Plumiera rùbra L. Sp. Pl. 209. 1753.

A tree, 5-S m. high, the young twigs, peduncles and pedicels pubescent. Leares elliptic-oblong to elliptic-obovate, $1.5-4 \mathrm{dm}$. long, acute or short-acuminate at the apex, narrowed at the base, glabrous on both sides, the lateral veins rather distant and widely spreading, the petioles $3-6 \mathrm{~cm}$. long; panicles severalmany-flowered, mostly shorter than the leaves; pedicels stout, thickened above, $1.5-3 \mathrm{~cm}$. long; calyx about $3 \mathrm{~mm}$. long; corolla purple or red, $5-7 \mathrm{~cm}$. broad, the tube rather shorter than the limb, the lobes broadly elliptic, obtuse; follicles $1.5-2.5 \mathrm{~cm}$. long, about $2.5 \mathrm{~cm}$. in diameter.

Open scrub-lands, Mangrove Cay:-Porto Rico to Trinidad; Jamaica. JEsss-

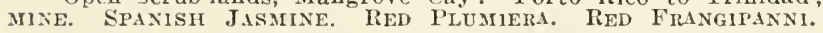

\section{Plumiera sericifòlia C. Wright; Griseb. Cat. Pl. Cub. 171. 1866.}

A small tree, sometimes $5 \mathrm{~m}$. high, the stout twigs pubescent when young. Leaves oblong or oblong-obovate, coriaceous, 7-15 cm. long, emarginate or rounded at the apex, narrowed or obtuse at the base, dark green and glabrous or nearly so above, pale and densely pubescent beneath, the stout pubescent petioles 1-4 cm. long; peduncles stout, pubescent, 1-2.5 dm. long; cymes several-many-flowered; pedicels about $1 \mathrm{~cm}$. long or less; calyx-teeth very short. broad; corolla white, the sparingly pubescent tube about $1.5 \mathrm{~cm}$. long, the narrowly obovate or oblong, obtuse lobes $1.5-2 \mathrm{~cm}$. long; follicles glabrous, $2 \mathrm{dm}$. long or less.

Scrub-lands, Inagua :-Cuba. Hairi Plumiera.

\section{NEOBRĀCEA Britton.}

[Bracea Britton, Bull. N. Y. Bot. Gard. 3: 448. 1905. Not King. 1898.]

A shrub, with thick oblanceolate or oblong petioled leaves. Flowers solitary or two together in the upper axils, white or reddish, peduncled. Calyx deeply 5-cleft, its lobes narrowly lanceolate, acute. Corolla nearly salverform, the short tube slightly and gradually dilated above, about as long as the 5 obliquely ovate lobes. Stamens 5 , borne near the base of the corolla-tube; filaments short; anthers sagittate, hairy on the back. Follicles long-linear, slightly torulose. Seeds comose. [In honor of I. J. K. Brace, a diligent collector of the Bahamian flora.] A monotypic genus.

\section{Neobracea bahaménsis Britton.}

Bracea bahamensis Britton, Bull. N. Y. Bot. Gard. 3: 448.1905.

About $1 \mathrm{~m}$. high, with grayish brown branches leafy only near the ends, the young twigs pubescent. Leaves firm in texture, revolute-nargined, oblongoblanceolate, obtuse or slightly emarginate at the apex, narrowed at the base, 4-10 $\mathrm{cm}$. long, 1-2.5 $\mathrm{cm}$. wide, bright green above, densely and finely tomentose with the veins promineutly reticulated beneath; petioles $4-7 \mathrm{~mm}$. long; flowers appearing with the leares; peduncles tomentose, about $1 \mathrm{~cm}$. long; calyx-lobes tomentose, $3 \mathrm{~mm}$. long; corolla white with a reddish throat, pubescent outside, smooth within, about $2 \mathrm{~cm}$. broad; follicles $15 \mathrm{~cm}$. long or less, $2 \mathrm{~mm}$. thick, pubescent, striate, pendent. 
Coastal thickets, pine-lands and borders of hrackish swamps, Great Bahama, Andros, New l'rovidence, cat Island, Great lixuma, lortune Island and Crooked Island. Eindemic. Ramana Neobracea.

3. CATHaranthus G. Don, Gen. Syst. 4: 95. 1838.

Ilerbs or low shrubs, with opposite leaves, and large axillary flowers, solitary or 2 together. Calyx eglandular, 5-cleft, the lobes narrow. Corolla salverform, its cylindrie tube slightly enlarged abore, its 5 broad lobes sinistrorse. Stamens included; anthers not appendaged. Disk of 2 large glands. Carpels 2, distinct; style rery slender; stigma thick, pilose; orules many in each earpel. Follicles narrowly eylindric, many-seeded. Seeds small, unappendaged. [Greek, pure flower.] Three known species, the following typical one native of tropical America, widely distributed through cultivation, one East Indian, the other of Malagascar.

\section{1. Catharanthus ròseus (L.) G. Don, Gen. Syst. 4: 95. 1838.}

Tinea rosea L. Syst. ed. 10, 944. 1759.

Ammocallis rosea Small, Fl. SE. U. S. 936. 1903.

Somewhat woody, usually branched, pubescent, $8 \mathrm{dm}$. high or less. Leares oblong to oblong-oblanceolate, $3-8 \mathrm{~cm}$. long, obtuse or retuse at the apex, mucromulate, narrowed at the base into short petioles; peduncles very short, pubescent; calyx-lobes linear-subulate, $3-4 \mathrm{~mm}$ long, pubescent; corolla white or pink, the finely pubescent tube $2.5-3 \mathrm{~cm}$. long, the oblique lobes somewhat shorter than the tube; follicles cylindric, pubescent, $2-3 \mathrm{~cm}$. long.

Traste grounds, naturalized, Great Cay, Andros, New Providence, Eleuthera, Cat Island, Acklin's, Long 1sland, Grand Turk, Salt Cay and Inagua :-Florida : West Indies: continental tropical America, old World tropics. Erroneously called TUlip and SWeEt WILLIAN. RED PERIWIXKLe. OLD MAID.

4. ECHITES Jacq. Enum. 2, 13. 1760.

Twining, somewhat woody vines, with opposite petioled leaves, and rather large flowers in cymes. Calyx 5-lobed, glandular. Corolla salverform, the eylindric tube somewhat swollen, the lobes spreading. Stamens included, the anthers appendaged at the base. Fruit of 2 spreading follicles, many-seeded. [Greek, an adder, referring to the twining stem.] About 40 species, of tropical and subtropical America. Type species: Tabernaemontana Echites L.

\section{Echites Echites (L.) Britton; Small, Fl. Miami 147. 1913.}

Tabernaemontana Echites L. Syst. ed. 10, 945. 1759.

Echites umbellata Jacq. Enum. 13. 1760.

A glabrous, somewhat moody vine, 1-2 $\mathrm{m}$. long, the stems sometimes warty below. Leaves rather thick, orate or broadly elliptic, 3-10 cm. long, shortpetioled, pinnately reined; cymes axillary, few-flowered, peduncled; pedicels stout, 1-2.5 cm. long; calyx 1.5-2.5 mm. long, its lobes orate-lanceolate, acute; corolla greenish white, its tube 4-6 cm. long, exlindric below, swollen at about the middle, narrowerl above, its lobes obliquely obovate, 1-2.5 cm. long; anthers acuminate; follicles spreading, 1-2 dm. long, subcylindric.

Scrub-lands and sandy places, throughout the archipelago from Abaco and Great Bahama to Fast Caicos, Grand Turk, Inagua, Anguilla Isles and Water Cay:Florida: Cuba to Porto Rico; Jamaica. Devil's Potato-root. Wild Potato. RubBER-Yixe. DAXish. Catesby, $1: p l .58$. 


\section{RHABDADÈNIA Muell. Arg. in Mart. Fl. Bras. 6 ${ }^{1}: 173.1560$.}

Woody vines, rarely erect shrubs, with opposite petioled leaves, and large flowers in small racemes or solitary. Calyx 5-cleft. Corolla tubular-campanulate, with a short eylindric oase and a spreading 5 -lobed limb, the lobes broad, dextrorse. Stamens short, included, borne near the top of the corolla-tube; anthers oblong, connivent around the stigma, the sacs with short obtuse appendages at the base. Carpels 2, distinct; style slender; stigma thick, its base dilated into a reflexed membrane; ovules many in each earpel. Follicles linear, parallel or little divergent, many-seeded. Seeds linear, comose. [Greek, wandgland, probably referring to the frnit.] About 10 species, of Florida, the West Indies and South Ameriea. Type species: Rhabdadenia Pohlii Muell. Arg.

Corolla white; leaves slender-petioled.

Corolli yellow; leares very short-petioled.
1. R. paludosa. 2. R. Sagraei.

1. Rhabdadenia paludòsa (Vahl) Miers. Apoc. S. Am. 119. 1878.

Echites paludosa Vahl, Eclog. 2: 19.1798.

A glabrous, somewhat woody rine, often $6 \mathrm{~m}$. long or longer. Leares oblong or elliptic, slightly fleshy, 3-9 $\mathrm{cm}$. long, obtuse or acutish and mueronate at the apex, mostly narrowed at the base, faintly pinnately veined, the slender petioles 8-15 mm. long; cymes long-peduncled, 1-few-flowered; pedicels slender; calyx-segments narrowly oblong, 6-9 $\mathrm{mm}$. long, apiculate, one-third to one-half as long as the narrowly eylindric part of the corolla-tube; corolla white, $5-6$ $\mathrm{cm}$. long, the limb about $4 \mathrm{~cm}$. wide; follicles linear, 10-16 $\mathrm{cm}$. long, about 4 $\mathrm{mm}$. thick.

Mangrore swamps, Great Ballama. Indros, New Providence and Crooked Island: -Florida: Cuba: Ilispaniola: Jamaica: western tropical continental Amelica. Referred by Schopp and Mrs. Northrop to Erhites biflor Jaca. and by Coker and by Small to Rhabdadenia biflora (Jacq.) Muell. Arg. Maxgrove SWAMp Vixe,

2. Rhabdadenia Sagraèi (A. DC.) Muell. Arg. Linnaea 30: 435. 1860.

\section{Echites Sagraei A. DC. in DC. Prodr. 8: 450. 1844.}

A slender, slightly woody vine, usually less than $1 \mathrm{~m}$. long, pubescent above. Leaves oblong, 1-3 cul. long, subcoriaceons, fairtly pinnately veined, obtuse and mucronulate at the apex, obtuse, rounded or subcordate at the base, the margins somewhat revolute, the petioles 1-2 $\mathrm{mm}$ long; eymes few-several-flowered; pedicels very slender; calyx-segments orate, acute, $1.5-3 \mathrm{~mm}$. long, one-fourth to one-third as long as the linear cylindric part of the corolla; corolla bright yellow, $2-3 \mathrm{~cm}$. long, the limb about $2 \mathrm{~cm}$. wile; follicles linear, $7-11 \mathrm{~cm}$. long, 1.5-2 mm. thick.

Scrub-lands, coppices and pine-lands, Abaco and Great Bahama to Andros and Mariguana and North Caicos:-Cuba. Lice-Root.

Echites jamaicensis Griseb., recorded from the Bahamas by Grisebach as collected by swainson, is otherwise unknown to us from the arelipelago. It may have been mistaken for the preceding species.

\section{URECHITES Muell. Arg. Linnaea 30: 440, 1860.}

Somewhat woody, twining vines, with opposite petioled leaves, and large mostly yellow, eymose flowers. Calyx-lobes 5, narrow; calyx-tube 5-glandular within. Corolla eylindric below, expanded into a narrowly campanulate throat, the limb 5-lobed, somewhat spreading. Anthers appendaged at the base, partly alherent to the stigma. Fruit of 2 long, linear follicles. Sceds narrow, 
comose. [Greek, tailed-Echites.] A few species: of tropical America. Type species: Urechites Tarwinshii Muell. Arg.

1. Urechites lùtea (L.) Britton, Bull. X. Y. Bot. Gard. 5: 316. 1907.

Tinca lutea L. Cent. Pl. 2: 12.1756.

Echites suberecta Jacq. Enum. 13. 1760.

Echites Catesbaei G. Don, Gen. Syst. 4: 74. 1838.

Echites Andrewsii Chapm. Fl. So. U. S. 359. 1860.

Crechites Andreusii Small, Fl. SE. U. S. 936. 1903.

Echites neriandra Griseb. Fl. Br. W. I. 415. 1861.

Pubescent or glabrous, slender, often $3 \mathrm{~m}$. long or more. Leares oblong to obovate or suborbicular, herbaceous, $2-8 \mathrm{~cm}$. long dark green above, pale green beneath, mostly obtuse at the apex and narrowed at the base. the slender petioles about $1 \mathrm{~cm}$. long; cymes few-several-flowered; pedicels slender; calyx. lobes narrowly lanceolate, acuminate, $8-12 \mathrm{~mm}$. long; corolla yellow, 3-4 cm. long; anthers mostly tipped by filiform appendages; follicles linear, $10-15 \mathrm{~cm}$. long, 4-5 $\mathrm{mm}$. thick.

Scrub-lands and coppices, throughout the archipelago from Abaco and Great Dahama to Andros, Grand Turk and Inagua :-Florida: Cuba to Tortola and St. Kitts: Jamaica. Species composed of several races, the foliage and inflorescence either glabrous or pubescent, the flowers differing much in size and the pods much in length. Wild Ixction. Catesby's Vixe. Catesby 2: pl. 53.

\section{7. Ć́rBerA L. Sp. Pl. 208. 1753.}

Glabrous trees or shrubs, with alternate, 1-nerred and pinnately veined leares, and large yellow flowers in terminal, peduncled cymes. Calyx 5-parted, many-glandular within at the base. Corolla funnelform, the tube cylindric. below, bearing pilose scales at the top within, abruptly expanded into a campanulate throat, the 5 broad rounded lobes sinistrorse. Stamens borne with the scales at the top of the tube; anther-sacs unappendaged. Disk wanting. Ovary 2-lobed, 2-celled; style filiform; stigma discoid, its small tip 2-lobed; ovules 2 in each carity of the ovary. Fruit a compressed drupe, broader than high, the flesh thin, the bony endocarp 2-celled. Seeds with a thick testa and no endosperm. [Named for Cerberus, the three-headed dog of mythology.] About 7 species, natives of tropical America. Type species: Cerbera Ahouai L.

1. Cerbera Thevètia L. Sp. Pl. 209. 1753.

Thevetia nereifotia Juss.; Steud. Nom. ed. 2, 2: 680. 1841.

Theretia Thevetia Millsp. Field Mus. Bot. 2: 83. 1900.

A shrub or small tree up to about $10 \mathrm{~m}$. high, glabrous throughout, the twigs rather stout, densely leafy. Leares linear, 7-15 cm. long, 5-10 mm. wide, narrowed at both ends, very nearly sessile, bright green and shining above, rather dull beneath, the midvein prominent, the lateral venation obscure; calyx-segments about $7 \mathrm{~mm}$. long, ovate-lanceolate, acuminate; corolla yellow, about $7 \mathrm{~cm}$. long, funnelform with the tube shorter than the limb; drupe triangular-compressed, $3-4 \mathrm{~cm}$. broad, about $2 \mathrm{~cm}$. high, and $1-1.5 \mathrm{~cm}$. thick, nearly truncate, the flesh thin.

Thickets, spontaneous after cultivation. New Providence near Nassau:-Florida; Cuba to Porto Rico and Grenada; Jamaica: continental tropical America. Luckrsut. Cathartic-Bark. Frexch TrUMPET-FLOWER. LUCK-SEed. 


\section{RAUWÓLFIA L. Sp. Pl. 208. 1753.}

Shrubs or trees with whorled or opposite leaves. and small flowers in peduncled cymes. Calyx eglandular, 5-cleft or 5-parted. Corolla salverform, the tube subcylindric, the 5 lobes sinistrorse. Stamens included; anthers ob. tuse, their sacs not appendaged. Disc annular or cup-shaped. Carpels 2, dis. tinct or connate; style filiform; stigma thick, annular or with a reflexer membrane at the base; orules 2 in each carpel. Fruit of 2 drupes, usually connate, the fruit thus usually emarginate and 2-grooved. Seeds ovoid with fleshy endosperm. [Commemorates Leonh. Rauwolf: a German botanist.] Forty species or more, natires of tropical regions and of South America. Type species: Rauzolfia tetraphylla $\mathbf{L}$.

\section{Rauwolfia tetraphýlla L. Sp. Pl. 208. 1753}

Rauxolfia nitida Jacq. Enum. 14. 1760.

A glabrous shrub or tree, up to $20 \mathrm{~m}$. high, the twigs slender. Leaves oblong-lanceolate or elliptic-lanceolate, verticillate in 4's or some of them opposite, acuminate or acute at the apex, tapering at the base, shining abore, rather dull beneath, the lateral veins numerous, widely spreading, the petioles 6-12 $\mathrm{mm}$. long; peduncles shorter than the leaves; cymes many-flowered; pedicels very short: calyx 5-lobed, $2 \mathrm{~mm}$. long, its lobes orate; corolla white, its tube cylindric, 2-3 times as long as the calyx, its lobes about one-half as long as the tube; fruit 1-1.5 $\mathrm{cm}$. broad, $8-10 \mathrm{~mm}$. high, red, its lobes ovoid, rounded.

Coastal thickets and scrub-lands, New Proridence, at Delaport:-Cuba to Tortola and St. Croix; Jamaica; recorded from St. Bart's. Smooth RaUtolfia.

\section{VALLESIA R. \& P. Fl. Per. 2: 26.1799.}

Branching shrubs or small trees, with alternate, short-petioled leaves, the small flowers in long-peduncled cymes opposite the leaves. Calyx 5-lobed, the lobes short. Corolla salverform, the tube swollen above, constricted at the mouth, the 5 equilateral lobes shorter than the tube, sinistrorsely convolute. Anthers unappendaged, free from the stigma, cordate; filaments borne on the corolla-throat. Stigma clarate. Fruit a 1-2-seeded drupe. Seeds naked. [Commemorates Francisco Valles, physician to Philip II. of Spain.] Two known species, the following typical.

\section{Vallesia glàbra (Car.) Link, Enum. Hort. Berol. 1: 207. 1821.}

Raurolfia glabra Cav. Ic. 3: 50. 1794.

Tallesia dichotoma R. \& P. Fl. Per. 2: 2b̉. 1799.

A glabrous shrub or small tree, $6 \mathrm{~m}$. high or less, the slender branches sometimes elongated and rine-like. Leaves oblong or oblong-lanceolate, somewhat fleshy, shining above, dull beneath, 3-6 $\mathrm{cm}$. long, short-petioled, mostly acute at both ends; eymes few-scveral-flowered, often forked; pedicels slender; calyx about $1 \mathrm{~mm}$. long, its lobes ovate, acute; corolla white, about $6 \mathrm{~mm}$. long, its narrow lobes one-third to one-half as long as the tube; fruit oblong, rounded at apex, narrowed at the base, about $10 \mathrm{~mm}$. long and $4 \mathrm{~mm}$. thick.

Scrub-lands and white-lands New Proridence. Rose Island, Eleuthera, Cat Island, Conceptlon Island, Great Exuma, Long Island and Anguilla Isles :-Florida; Cuba; Jamalea; tropical Ilexico to Bolivia. Tallesia. 


\title{
Family 6. ASCLEPIADĀCEAE Lindl.
}

\author{
MILKWEED FAMILY.
}

Peremial herbs, vines or shrubs, mostly with milky juice, with estipulate leaves, and cymose or umbellate, perfect regular flowers. Calyx inferior, its tube rery short, or none, its segments imbricated or separate in the bud. Corolla campanulate. urceolate, rotate or fumelform, 5-lobed or 5-eleft, the segments commonly reflexed. A 5-lobed or 5-parted crown (corona) between the corolla and the stamens and adnate to one or the other. Stamens 5, inserted on the corolla; filaments short, stout, mostly monadelphons, or distinct; anthers attached by their bases to the filaments, introrsely 2-celled, connivent around the stigma, or more or less united with each other: anther-sacs tipped with an inflexed or erect scarious membrane, or unappendaged at the top, sometimes appendaged at the base; pollen coherent into waxy or granular masses, one or rarely two such masses in each sac. connected with the stigma in pairs or four's, by 5 glandular corpuscles altemate with the anthers. Disk none. Orary of 2 carpels; styles 2. short. connected at the summit by the peltate discoid stigma; orules numerous in each earpel, mostly anatropous, pendulous. Fruit of 2 follicles. Seeds compressed, usually appendaged by a long coma; endosperm cartilaginous; embryo nearly as long as the seed; cotyledons flat. About 220 genera and 2,000 species of wide distribution.

Pollinia granular; vines.

Pollinia waxy.

Erect herbs, shrubs or trees.

Corona-segments with an internal horn.

Corona-segments spurred on the back.

vines.

Corona simple.

Corona double.

1. Cryptostegia.

2. Asclcpias.

3. Culotropis.

4. Metastelma.

5. Philibertella.

1. CRYPtOSTEigia R. Br. Bot. Reg. pl. 435. 15:0.

Glabrous, high-climbing vines, with broad opposite leaves and large flowers in terminal cymes. Calyx 5 -parted, the segments lanceolate. Corolla funnelform, the tube short, the throat campanulate, the limb 5-lobed, the lobes dextrorsely twisted; corona-scales 5, subulate, entire or 2-lobed. Stamens borne at the base of the corolla-tube; filaments filiform, short; anthers connivent around the convex stigma, acute; pollen granular, the grains cohering in small masses. Follicles thick, woody, divergent, ribbed and 3-winged. Seeds comose. [Greek, bidden integument.] Two known species, the following typical, the other native of Madagascar.

\section{Cryptostegia grandifiòra R. Br. Bot. Reg. pl. 435. 1520.}

A stout vine, $2 \mathrm{~m}$. long or longer, the twigs glabrous or nearly so. Leaves elliptic, subcoriaceous, 5-9 cm. long, acute or short-acuminate at the apex, obtuse or somewhat narrowed at the base, glabrous on both sides, the rather stout petioles 1-2 cm. long; inflorescence puberulent; eymes few-several-flowered; sepals broadly lanceolate, acuminate, puberulent, about $1.5 \mathrm{~cm}$. long; corolla pink-purple without, white within, $5-6 \mathrm{~cm}$. long, its lobes ovate; follicles widely dirergent, glabrous, pointed, 10-12 cm. long.

Scrub-lands, escaped from cultivation, New Providence and Inagua:-Escaped from cultiration in Cuba and in Florida. Native home unknown, probably East Indian. Rubber-rixe. 


\section{ASCLÉPIAS L. Sp. Pl. 214. 1753.}

Perennial herbs, with entire leaves, and middle-sized or small flowers in umbels. Calyx 5-parted or 5-divided, usually small, the segments or sepals acute, often glandular within. Corolla deeply 5-parted, the segments mostly valvate, reflexed in anthesis. Corona-column generally present. Corona of 5 concave hoods, each bearing within a slender or subulate incurved horn. Fila. ments connate into a tube; authers tipped with an inflexed membrane, winged, the wings broadened below the middle; pollen-masses solitary in each sac, pendulous on their caudicles. Stigma nearly flat, 5-angled or 5-lobed. Follieles acuminate. Seeds comose in all but one species. [Dedicated to Esculapins.] About 95 species, mostly natives of the New World. Type species: Asclepias syriaca $\mathrm{I}$.

\section{Asclepias curassávica L. Sp. Pl. 215. 1753.}

Asclcpias curassavica concolor Krug \& Urban; Urban, Symb. Ant. 1: 389. 1899.

Glabrous, or finely pubescent above, $8 \mathrm{dm}$. high or less. Leares opposite, oblong to oblong-lanceolate, thin, 5-12 $\mathrm{cm}$. long, acute or acuminate, the petioles $5-15 \mathrm{~mm}$. long; umbels usually several, few-several-flowered; pedicels 1-2 cm. long; corolla-lobes ret-purple, $6-8 \mathrm{~mm}$. long, orate to oblong; column distinct; hoods erect, ovate, about $4 \mathrm{~mm}$. high, obtuse, flattened, shorter than the flat, eurved horn; fruiting pedicels erect; follicles fusiform, glabrous or minutely pubescent, $3-10 \mathrm{~cm}$. long; seeds $6 \mathrm{~mm}$. long, the coma $3-4 \mathrm{~mm}$. long.

Waste grounds and coppices, Abaco, Great Bahama, Andros, New Providence and Eleuthera, throughout the archipelago to Grand Turk and Inagua:-Bermuda : Florida and Louisiana; West Indies and continental tropical America; Old World tropics. Tecorded by Ilerrick and by Dolley as A. paupercula. WiLd IPEcac. Hippo.

3. CALótropis R. Br. in Ait. f. Hort. Kew. ed. 2, 2: is. 1811.

Shrubs or trees, with broad, nearly sessile, opposite leaves, and rather large flowers in terminal or axillary umbel-like cymes. Calyx 5-parted, bearing several-many glands at the base within. Corolla subrotate, 5-cleft, with broad lobes; corona-scales 5, fleshy, adnate to the stamen-tube, lobed or toothed, short-spurred. Stamens borne at the base of the corolla; filaments connate, forming a short tube; anthers tipped by an inflexed membrane; pollinia solitary in each sac, pendulous. Follicles thick, pointed. Seeds comose. [Greek, beantiful keel.] Three species, natives of the Old World tropies, the following typical.

1. Calotropis pròcera (Ait.) K. Br. in Ait. f. IIort. Kew. ed. 2, 2: 7S. 1511. Asclcpias procera Ait. 1!ort. Kरew. 1: 305. 1759.

Arboreous, 1-5 m. high, branched, with the aspect of a gigantic herb. Leaves obovate-oblong to broally elliptic or nearly orbieular, mostly euspidate at the apex, cordate at the base, white-felted when young, glabrous when old; the stout petiole $1 \mathrm{~cm}$. long or less; cymes $5-8 \mathrm{~cm}$. broad, several-many-flowered, on stout peduncles $4-8 \mathrm{~cm}$. long; pedicels 1-3 $\mathrm{cm}$. long; ealyx-segments ovate, about $4 \mathrm{~mm}$. long; corolla white, tinged with red, $2-2.5 \mathrm{~cm}$. broad; follicles swollen, $3-8 \mathrm{~cm}$. long.

Fields and waste places, spontaneous after eultiratlon. New provirlence, Eleuthera, Llttle San Salvadol. Cat Island, l,ong Island, Foltune Island, East Caicos, Dellis Cay, Salt Cay and Grand Turk:- Mest Indies and contlnental tropical Amerjea; old World tropies. GIANT MILK-WEED. ST. T1IOMAS BUSII. WILD DOWX. WILD COTTOX. 


\section{Metastélma R. Br. Mem. Wern. Soc. 1: 52.1809.}

Slender perennial vines, with small opposite leaves, and small white or greenish flowers in axillary cymes. Calyx-lobes 5, usually with a gland in each sinus. Corolla subrotate or campanulate, rather deeply 5-lobed. Corona simple, 5-parted, its segments narrow. Pollinia waxy. Gynostegium sessile or stipitate. Stigma flat. Follicles small, slender, smooth. [Greek, referring to the parted corona.] Fifty species or more, natives of tropical and subtropical America. Type species: Cynanchum parviflorum Sw.

Gynostegium long-stipitate.

Gynostegium sessile or subsessile.

Coroma longer than the grnostegium.

Corona as long as the gynostegium or shorter.

Corolla-lobes papillose-pubescent or villous within.

Corolla-lobes papillose-pubescent within.

Leaves ovate to oblong or lanceolate.

Leaves oblanceolate to spatulate.

Corolla-lobes villous within.

Leaves linear to linear-oblong.

Leares elongated-linear, $1.5 \mathrm{~mm}$. Wide.

Leaves linear to linear-oblong, $2-3 \mathrm{~mm}$. wide.

Leaves obovate to spatulate.

Corolla-lobes glabrous; cymes long-peduncled; corollalobes acute; leaves linear.
1. 11. Northropiae.

2. IT. hamatum.

3. II. bahamense.

4. H. inaguense.

5. M. linearifolium.

6. M. barbatum.

7. M. Eggersii.

S. M. palustre.

1. Metastelma Northròpiae Schltr. in Urban, Symb. Ant. 5: 468. 1908.

A slender glabrous vine, 1-2 m. long. Leaves ovate to oblong or oblonglanceolate, $1.5-3 \mathrm{~cm}$. long, acute at the apex, rounded or narrowed at the base, the slender petiole $3-8 \mathrm{~mm}$. long; cymes few-flowered, on peduncles about as long as the petioles; calyx-lobes ovate, obtuse or acutish; corolla about $5 \mathrm{~mm}$. long, 5-lobed, glabrous without, pubescent within, its lobes oblong, obtuse; gynostegiunı long-stipitate; corona-segments linear, acute; follicles linear, glabrous, 5-6 cm. long.

White-lands, coppices and scrub-lands. Andros and Great Bahama to Cat Island and Little San Salvador; Florida; Cuba. Referred by Mrs. Northrop to Mr. bahamense Griseb., which it much resembles, except in its long-stipitate gynostegium. Northrop's Metastelala.

2. Metastelma hamàtum Griseb. Cat. Pl. Cub. 173. 1866.

A slender glabrous vine. Leaves ovate to oblong or linear, acute at the apex, rounded or narrowed at the base, 1-2 $\mathrm{cm}$. long, 2-7 $\mathrm{mm}$. wide, the petiole 2-6 mm. long; cymes few-flowered, short-peduncled; calyx-lobes ovate, obtuse or acutish; corolla deeply 5-lobed, the lobes oblong-lanceolate, obtuse or acutish, puberulent within; corona-segments linear-lanceolate, about twice as long as the sessile gynostegium.

White-lands and rocky soll, Cat Cay, Little Inagua, Castle Island, Caicos Islands, Grand Turk :-Cuba.

3. Metastelma bahaménse Griseb, Cat. Pl. Cub. 174. 1866.

Metastelma cubense Griseb. Fl. Br. W. I. 417. 1861. Not Dene. 1844.

Epicion bahamense Small, Fl. Miami 149, 200. 1912.

A slender glabrous vine, sometimes $3 \mathrm{~m}$. Iong. Leaves oblong, ovate or ablong-lanceolate, 1-3 cm. long, acute or mucronate at the apex, mostly rounded at the base, the petiole $3-7 \mathrm{~mm}$. long; cymes few-several-flowered, short-peduncled; calyx-lobes oblong to ovate, acutish or obtuse; corolla deeply 5 -cleft, $3-5 \mathrm{~mm}$. long, its lobes oblong, papillose-puberulent on the inner side; corona-segments oblong-lanceolate, acuminate, about as long as the shortstipitate gynostegium; follicles linear, 4-7 cm. long.

Scrub-lands and white-lands, throughout the archipelago from Abaco and the Berry Islands to Mariguana and the Anguilla Isles.-Florida; Cuba.

Prof. Coker's doubtful record of Mr. brachystephanum Griseb. probably refers to this species; his specimen is imperfect. Referred by Hitchcock to M. Sehlechtendahlit Dene. Bahama Metastelaia. 
4. Metastelma inaguénse Vail, Bull. N. Y. Bot. Gard. 4: 142. 1906.

A glabrous vine. Stems slender, terete; leares $2-4 \mathrm{~cm}$. long, obovate, oblong-obovate or linear-oborate to linear-oblanceolate, obtuse, rounded and apiculate at the apex, tapering to a short petiole (or when linear-lanceolate acute at each end); cymes short-peduncled; calyx-segments orate, obtuse, glabrous; corolla deeply 5-parted, the segments $3-3.5 \mathrm{~mm}$. long, oblong or linear-oblong, obtuse, glabrous outside, papillose-puberulent except in the center and towards the base within; corona-segments subulate, acute.

Scrub-lands, sand-dunes and white-lands. Conception Island, Watling's Island and Inagua. Endemic. INagua Metastelisa.

5. Metastelma linearifòlium A. Rich. in Sagra, Hist. Cub. 11: 96.1850.

A very slender glabrous vine, $3-10 \mathrm{dm}$. long. Leaves narrowly linear, $2-4$ cn. long, 1-1.5 mm. wide, acute, the petioles 1-2 mm. long; cymes umbel-like, several-flowered, short-peduncled, the flowers short-pedicelled; calyx-segments ovate, obtuse; corolla white, campanulate, about $3 \mathrm{~mm}$. long, deeply 5-lobed, the lobes oblong, obtuse, white-villous on the inner side; corona-segments about half as long as the nearly sessile gynostegium; follicles about $5 \mathrm{~cm}$. long.

Pine-lands, Great Bahama, at Eight Mile Rocks:-Cuba. Narrow-LEAved Metastelia.

\section{Metastelma barbàtum Northrop, Mem. Torr. Bot. Club 12: 58. 1902.}

A slender glabrous vine, $1 \mathrm{~m}$. long or less. Leaves linear, linear-lanceolate, or linear-oblong, $1-3.5 \mathrm{~cm}$. long, acute or obtuse and cuspidate at the apex, obtuse at the base, the petioles 2-4 mm. long; cymes few-several-flowered, short-peduncled; pedicels 1-3 mm. long; calyx-lobes orate, obtuse; corolla greenish-white, deeply 5-cleft, the lobes oblong-lanceolate, obtuse, densely villous within; corona-segments ligulate, about as long as the gynostegium; follicles slender, $3-4 \mathrm{~cm}$. long.

Borders of brackish marshes and savannas, coppices and pine-lands, Great Bahama, Andros and New Providence. Endemic.

\section{Metastelma Éggersii Schltr. in Urban, Symb. Ant. 1: 258. 1899.}

A rather stout vine, sometimes $2 \mathrm{~m}$. long, the branches glabrous or densely puberulent, often flexuous, somerhat roody. Leaves oblong-spatulate to oborate, $0.7-1.5 \mathrm{~cm}$. long, obtuse or retuse at the apex, narrowed at the base, glabrous, subcoriaceous, usually fascicled, the midrein distinct, the lateral venation obscure, the petioles very short; flowers mostly solitary in the axils, yellowish-green or whitish, the glabrous or puberulent pedicels about as long as the ealyx; calyx-lobes oblong, obtuse; corolla-lobes oblong, obtuse, villous within, 3-1 mm. long; corona-segments lanceolate; follicles 3-4 cm. long.

White-lands and scrub-lands, Whale Car, Eleuthera, Cat Island, Mariguana, Atwood Cay, Great Ragged Island, Fortune Island, Castle Islaud, Crooked Island, Caicos Islands, Grand Turk and Inagua. Endemic. Referred to by Dolley as Oxypetalum SP. EGgERS' MET.ASTEJ.MA.

8. Metastelma palùstre (Pursh) Schltr. in Urban, Symb. Ant. 1: 258. 1899.

Ceropegia palustris Pursh, Fl. Am. Sept. 1: 1S4. 1814.

Lyonia maritima Ell. Bot. S. C. \& Ga. 1: 316. 1817.

Seutera maritima Dene. in DC. Prodr. 8: 590.1844.

Vincetoxicum palustre A. Gray, Syn. Fl. 21 : 102. 1878.

Lyonia palustris Small, Fl. Miami 149, 200. 1912.

A slender glabrous vine, 5-10 dm. long. Leaves narrowly linear, acute, short-petioled, 2-8 cm. long, 1.5-3 mm. wide; peduncles slender, mostly shorter than the leaves; cymes several-flowered; calyx $2-2.5 \mathrm{~mm}$. long, its lobes lanceolate or ovate-lanceolate, acute; corolla purplish or greenish-white, about 8 
$\mathrm{mm}$. broad, its lobes ovate, acuminate; erown-lobes $1.5-2 \mathrm{~mm}$. long, retuse; anther-wings $1 \mathrm{~mm}$. long; follicles $4.5-7 \mathrm{~cm}$. long, slender, about $5 \mathrm{~mm}$. thick.

Borders of salinas and salt marshes, Frozen Cay, Andros, New Providence, Eleuthera, Cat lsland, Watling's, Long Island, Fortune Island, Mariguana, Freen Cay and Inagua :-Nortl Carolina to Florida and'Texas; Cuba. IA MsH Intastruma.

5. PHILIBERTÉlla Tail, Bull. Torr. Club 24: 30.. 1897.

Twining vines, with opposite leaves and cymose axillary flowers, their buds 5-angled. Calyx small, 5-parted. Corolla subrotate or widely campanulate, 5-lobed. Corona double, the exterior one annular, adnate to the base of the corolla, the interior one of 5 scales. Stamens borne on the base of the corolla, the filaments united into a short tube, the anthers with a terminal inflexed membrane. Pollinia solitary in each cell, oblong, waxy. Follicles elongated, smooth. [Commemorates J. C. Philibert.] About 30 species of tropical and subtropical America. Type species: Philibertella clausa (Jacq.) Tail.

1. Philibertella claùsa (Jacq.) Vail, Bull. Torr. Club 24: 306. 1897.

Asclepias clausa Jacq. Enum. 17. 1760.

Sarcostemma Brownei Meyer; Spreng. Syst. 1: 854. 1825.

Phitibertia clausa Schum, in Engl. \& Prantl, Nat. Pflanzf. $4^{2}$ : 229. 1895.

A somewhat fleshy, herbaceous vine often $3 \mathrm{~m}$. long or longer. Leares oblong to oblong-lanceolate or orate-oblong, short-petioler, 3-8 cm. long, glabrous, acute or acuminate at the apex, rounded or subcordate at the base; perduncles glabrous, longer than the leaves; umbels several-flowered; pedicels slenter, puberulent, 7-12 $\mathrm{mm}$. long; calyx puberulent, $4 \mathrm{~mm}$. long, its lobes oblonglanceolate; corolla white, 10-12 mm. broad, its lobes oblong or orate; follicles glabrous, 5-8 cm. long.

Wet places, Great Bahama and New Providence:-Florida; Cuba; IIispaniola; Jamaica; Grenada. MrLK VINE.

Iarsdenia floribunda (Brongn.) Schltr. (Stephanotis floribunda Brongn.) recorded by Dolley as cultivated in gardens is not known to us as having become spontaneous at any place in the islands.

Fruiting specimens of an undetermined asclepiadaceous vine, with lanceolate leaves and a fusiform follicle, were collected by small \& Carter, in pine-lands near Lisbon Creek, Mangrove Cas, Andros, perhaps a species of Astephanus.

\section{Order 4. POLEMONIÄLES.}

Mostly herbs; rarely shrubs or trees. Corolla almost always gamopetalous, regular or irregular. Stamens adnate to the corolla-tube nsually to the middle or beyond, as many as the corolla-lobes. or fewer and alternate with them. Orary 1. superior, compound (in Boraginaceae and Lamiaceae deeply t-lobed around the style).

\section{a. Corolla regular.}

1. Ovary not 4-lobed, the carpels not separating as distinct nutlets at maturity.

Ovary 2-celled, rarely 3-4-celled.

Leaves and flowers mostly large; plants not parasitic.

Ovary 2-4-celled.

Ovary 2-divided.

Leaves none; flowers very small ; slender parasitic vines.

Ovary 1-celled; style 1, 2-lobed, or 2-parted.

Fam. 1. Coxiolvelaceae.

Fam. 2. DichoNDRACEAE.

Fam. 3. Crscetachae.

Fam. 4. HydROPH YLACEAE.

2. Ovary deeply 4-iobed around the style, or not lobed; carpels mostls separiting as distinct nutlets.

Ovary not lobed; styles terminal.

Style arising from between the orary-lobes.

Fam. 5. Eireticeat.

Fam. 6. Boragixaceat. 
b. Corolla irregular, more or less 2-lipped (regular in Soldxacese, and nearly or quite so in Verbena and Callicarpa of the Verbexicese).

1. Carpels $1-2$-seeded.

Orary not lobed, 2-4-celled, the style apical; carpels separating into 1 -seeded nutlets or fruit drupaceous. Fam. 7. Verbexacere.

Oraly t-lobed around the style, the lobes ripening into 1 -seeder nutlets.

Fam. S. LAMIACEAE.

2. Carpels sereral-many-seeded (2-seeded in some Acanthaceae).

† Fruit a berry, or more commonly a capsule which is 1-2-celled, 2-valyed, eircumPlacentae axile. scissile, or irregularly bursting, not elastically dehiscent.

Flowers regular ; fertile stamens 5 ( 4 in Petunia) ; fruit a berry or capsule.

Flowers more or less irregular: fertile stamens 2 or $^{\circ}$ (5 in Verbascum) ; fruit a eapsule. Orary 2-celled. rarely 3-5-celled.

Oviry 1-celled: marsh or aquatic herbs with flowers on scapes.

Placentae parietal.

Trees, shrubs, or woody vines; capsule 2-celled. Fam. 12. Bigroxiacese.

Herbs, annual or perennial.

Orary 2-celled or falsely 4-celled; flowers axillary.

Fam. 9. Solaxiceae.

Fam. 10. Scropilt LatidceaE.

Fam. 11. Lextibulariaceae.

Fam. 13. Pedaliaceae.

Fam. 14. MARTYNIACEAE.

\$⿳亠口冖丸 Capsule completely 2-celled, elastically loculicidally dehiscent; opposite-leaved herbs; placentae axile. Fam. 15. Acaxthaceas.

3. Orary 2-celled with 1 orule in each carity; trees or shrubs with alternate leares. Fam. 16. MYOPORACEAE.

\section{Family 1. CONVOLVULÀCEAE Tent.}

\section{MIORYING-GLORY FAaIiLY.}

Herbs or vines, some tropical species slumbs or trees, with alternate estipulate leaves, and regular perfect axillary eymose or solitary flowers. Calyx inferior, 5-parted or 5-divided, ustrally persistent, the segments or sepals imbricated. Corolla gamopetalous, the limb 5-angled, 5-lobed or entire. Stamens 5, inserted low down on the tube of the corolla and alternate with its lobes, all anther-bearing, the filaments filiform, or dilated at the base; anthers 2-celled, the saes longitudinally dehiscent. Disk anuular or none. Orary superior, sessile, 2-3-celled, with 2 orules in each carity, or falsely 1-6-celled with a single orule in each carity, usually entire; styles 1-3, terminal, orules anatropous. Fruit mostly a 2-4-ralved capsule. Seeds erect, the testa villous, pubescent or glabrons; embryo plaited or crumpled; cotyledons foliaceous; endosperm fleshy or cartilaginous. usually scanty. About 45 genera and probably 1,000 species, of wide distribution.

Pericarp dehiscent.

Styles separate nearly or quite to the base.

Styles united up to the stigma or stigmas.

Stigmas oval to oblong, flattened.

Stigmas globose.

Stamens and style exserted.

Corolla-limb very broad. the tube crlindric.

Corolla funnelform or salverform.

Ovary f-celled; herbaceous vines.

-celled; vines woody at the base.

1. Evolinlus.

2. Jacqucmontia.

3. Calonyction.

4. Quamoclit.

i. Inrmomert.

7. Turbina.

Pericarp lndebiscent; sepals spreading ln fruit.

1. EVólvulus L. Sp. Pl. el. 2, 391. 1762.

Mostly silky-pubeseent or pilose herbs, with small leaves, and axillary small flowers. Sepals nearly equal. Corolla funnelform, eampanulate or rotate, the 
limb plaited, 5-angled or 5-lobed. Filaments filiform; anthers ovate or oblong. Ovary entire, 2-celled; styles separate to the base, or near it, each division deeply 2-cleft; stigmas linear-filiform. Capsule 2-4-valved, 1-4-seeded. Seeds glabrous. [Latin, unrolling.] About 85 species, of warm and tropical regions. Type species: Evolvulus nummularius L.

Erect low shrubs with small linear or scale-like leaves.

Leaves scale-like; calyx-lobes ovate.

Leaves linear, 6-15 mm. long; calyx-lobes lanceolate.

Prostrate, creeping or erect herbs.

Leaves ovate, $3-6 \mathrm{~mm}$. long; plant silvery-pubescent.

Leaves linear, or oblong to orbicular; plants glabrous or pubescent.

Leaves suborbicular to orbicular-obovate, rounded or notched at the apex.

Leaves linear to oblong, acute or mucronate.

Peduncles 1-flowered, very short, much shorter than the leaves.

Peduncles filiform, elongated, 1-several-flowered, mostly as long as the leaves or longer.

Leaves oblong-obovate, mucronulate; sepals about one-third as long as corolla.

Leares linear to oblong, acute or obtusish ; sepals at least one-half as long as corolla.

Plant pilose-pubescent; leares oblong to oblong-lanceolate, bluntish.

Plant spariugly pubescent or glabrate; leaves linear-lanceolate or linear-oblong, acute.

1. E. squamosus.

2. E. bahamensis.

3. E. Bracei.

4. E. nummularius.

5. E. sericeus.

6. E. glaber.

7. E. alsinoides.

8. E. linifolius.

1. Evolvulus squamòsus Britton, Bull. N. Y. Bot. Gard. 3: 449. 1905.

An intricately branched erect shrub, $3 \mathrm{dm}$. high or less, the slender terete twigs densely appressed-pubescent. Leaves scattered, reduced to mere lanceolate-acuminate scales, $2 \mathrm{~mm}$. long or less, appressed-pubescent; flowers solitary in the upper axils, on appressed-pubescent peduncles, which are about as long as the calyx; calyx-lobes ovate, acute, appressed-pubescent, one-half as long as the white corolla, or less; corolla about $6 \mathrm{~mm}$. broad, slightly 5 -lobed, the broad lobes a little emarginate; stamens a little shorter than the corolla, their filaments filiform, their anthers oval, short; ovary densely pubescent, oblong; styles 2, 2-cleft to about the middle.

Rocky coppices and scrub-lands, Andros, New I'rovidence. Eleuthera, Cat Island, Cay north of Wide Opening, Great Guana Cay and Great Exuma:-Anegada. Recorded as E. arbuscula Poir, by Mrs. Northrop and by Dolley. Broom-Busir.

\section{Evolvulus bahaménsis House, Bull. Torr. Club 35: 89. 1908.}

Shrubby, erect, intricately branched, appressed-pubescent, 4-10 dm. high, the branches wiry. Leaves linear, 6-15 mm. long, about $1 \mathrm{~mm}$. wide, ascending or appressed; flowers axillary, solitary, on peduncles about $5 \mathrm{~mm}$. long; calyxlobes lanceolate or ovate-lanceolate, long-acuminate, 2-3 $\mathrm{mm}$. long; corolla white, $1.2-2 \mathrm{~cm}$. broad, its limb nearly entire; stamens nearly as long as the corolla.

Rocky plains and scrub-lands, Eleuthera, Conception Island, Watling's, Mariguana, North Caicos, Ambergris Cay, Great Ragged Island, Fortune Island, Crooked Island. Acklin's and Inagua. Endemic. Referred to E. arbuseula Poir. in Bull. X. Y. Bot. Gard. 3: 450, 1905; also by Hitcheock, by Coker and by Grisebach. BiHAMA EVOLVULUS.

\section{Evolvulus Bràcei House, Bull. Torr. Club 35: 90. 1908.}

Perennial by woody roots; stems several, 5-20 cm. long, simple or branched, prostrate or ascending, appressed-pubescent with long white hairs when young. Leaves close together, ovate or elliptic-ovate, 3-6 mm. long, acute or shortacuminate at the apex, rounded or narrowed at the base, nearly sessile, loosely long-pubescent above, densely so beneath; flowers solitary and short-peduncled in the upper axils; calyx-lobes lanceolate, acuminate, about $2.5 \mathrm{~mm}$. long; 
corolla white or pale blue, about $7 \mathrm{~mm}$. broad; capsule globose, about $2.5 \mathrm{~mm}$. in diameter; seeds brown.

Red soil in open places, Mangrove Cay, Andros, Crooked Island, Mariguana and North Caicos:-Cuba. BlideE's Erolvelus.

\section{Evolvulus nummulàrius L. Sp. Pl. ed. 2, 391. 1762.}

Diffuse, herbaceous, the stems 5-20 $\mathrm{cm}$. long, branched, the branches rooting at the nodes, pilose or glabrate. Leaves orbicular or broadly oval, 4-20 mm. long, rounded or retuse at the apex, obtuse or subcordate at the base, short-petioled, pilose or glabrate; peduncles 1-flowered, much shorter than the leaves; sepals oblong or oblong-oborate, obtuse, about $2 \mathrm{~mm}$. long; corolla pale blue or white, 5-8 mm. in diameter; eapsule globose, $2 \mathrm{~mm}$. in diameter.

Shaded moist places and red-lands, New Providence, Eleuthera, Cat Island, Watling's, Mariguana, Great Exuma, Crooked Island and Nolth Caicos:-Cuba to St. Jan and Grenada; Mexico to Colombia. Moxerwort Evolvelus.

\section{Evolvulus serìceus ST. Prodr. 55. 17s8.}

Herbaceous, erect or ascending, usually branched from near the base, slender, silky-pubescent, 1-3 dm. high. Leaves linear, lanceolate or narrowly oblanceolate, nearly sessile, $1-2.5 \mathrm{~cm}$. long, about $3 \mathrm{~mm}$. wide or less, acute or acuminate; peduncles 1-flowered, much shorter than the leaves, often shorter than the calyx; sepals lanceolate to orate-lanceolate, acute or acuminate, $3-4$ mm. long; corolla white or pale blue, 6-10 mm. broad; capsule subglobose, about as long as the.calyx.

Pine-lands and palmetto-lands, Great Bahama and New Providence:-southeastern United States ; Jamaica; Cuba to Anegada and st. Vincent. Silkx Evolvulus.

\section{Evolvulus glàber Spreng. Syst. 1: S62. 1525.}

Evolvulus mucronatus Sw.; Wikstr. Vet. Akad. Handl. Stockh. 1827: 61. 1827.

Finely silky-pubescent when young, becoming glabrate, branched, the branches very slender, prostrate or ascending, 4 dm. long or less. Leares oblong to obovate, 1-3 $\mathrm{cm}$. long, mucronate, short-petioled; peduncles nearly filiform, as long as the leaves or longer; pedicels longer than the flowers; sepals oblong or ovate-oblong, acute, $3-4.5 \mathrm{~mm}$. long; corolla rotate, white, 7-10 $\mathrm{mm}$. broad; capsule subglobose, 2-2.5 $\mathrm{mm}$. in diameter.

Margins of salinas and salt ponds, Long Island, Fortune Island, Acklin's, Mariguana, Caicos, Grand Turk and Inagua :-Florida; Cuba; West Indies and northern South Americi, SHooth Erolyulus.

\section{Evolvulus alsinoides L. Sp. Pl. ed. 2, 392. 1762.}

Villous; stems usually several from a deep root, slender, simple or branched, prostrate or ascencling, 1-4 im. long. Leares oblong or oblong-lanceolate, 0.5$2.5 \mathrm{~cm}$. long, more or less pubescent with long hairs, blunt or acutich at the apex, rounder or narrowed at the base, the petioles 1-2 $\mathrm{mm}$. long; peduncles filiform, 1-5-floweresl, mostly longer than the leaves; pedicels filiform; sepals lanceolate or ovate-lanceolate, acuminate, about $2 \mathrm{~mm}$. long; corolla pale blue or white, 6-8 mm. broad; capsule somewhat longer than the calyx.

Waste and cultivated ground. Andros. New rovidence, Eleuthera, Cave Cas, Great Exuma, Iong Islancl, Great liagged Island. Crooked Island. Mariguana, Inagui and Anguilla Isles :- Florda to Texas; Cuba: Hispaniola; Aluba; Curacao; Mexlco and South America; Old World tropics. CHICKWED Wrotich's.

8. Evolvulus linifòlius L. Sp. Pl. ed. 2, 392. 1762.

Pubescent or glabrate; stems sereral or many from a rather slender root, simple or few-branched, diffuse or nearly ereet, 4 dm. long or less. Leaves lanceolate, linear-lanceolate or linear-oblong, 1-2 cm. long, acute or mucronate, 
nearly sessile; peduneles filiform, 1-3-flowered, mostly longer than the leares; sepals lanceolate, acute or acmminate, $2-3 \mathrm{~mm}$. long; corolla white or pale blue, 5-6 mm. broad; capsule longer than the calyx.

Babamas (according to Frisebach) :-Jamaica; continental tropical America ; Old World tropics. NARRow-LEAYed Evoltilus.

2. JACQUEmóntiA Choisy, Mem. Soc. Phys. Gen. 6: 476. 1833.

Trailing or climbing vines, mostly herbaceous, the leaves usually entire, the mostly small, violet blue or white flowers cymose or subcapitate. Sepals nearly equal or the outer ones larger than the inner. Corolla campanulate or rotate-campanulate, the limb 5-angled. Stamens shorter than the corolla; filaments filiform, or their bases dilated; anthers oblong. Ovary 2-celled; orules mostly 4 ; united styles filiform; stigmas 2. Capsule small, 2-celled. [Commemorates Victor Jacquemont, a French botanical traveller, died 1828.] Thirty species or more, mostly of tropical and subtropical America. Type species: Convolvulus coeruleis Schum.

Corolla only 3-4 mm. broad; cymes sessile or nearly so.

Corolla $1-5 \mathrm{~cm}$. broad.

Corolla white; leaves not cordate: cymes short-peduncled.

Leaves linear to oblong-lanceolate.

Leaves ovate-oval to suborbicular. thick and fleshy.

Corolla usually blue; leaves cordate or subcordate; cymes long-peduncled.

1. J. verticillata.

2. J. jamaiernsis.
3. J. caycnsis.

4. J. pentantha.

1. Jacquemontia verticillàta (L.) Urban, Symb. Ant. 3: 339. 1902.

Ipomoea verticillata L. Syst. ed. 10, 924. 1759.

Convolvulus micranthus R. \& S. Syst. 4: 276.1819.

Jacquemontia micrantha G. Don. Gen. Syst. 4: 283. 1838.

Stems very sleniler, appressed-pubescent at least above, $2 \mathrm{~m}$. long or less. Leaves oblong to lanceolate, membranous, repand or entire-margined, $1.5-4 \mathrm{~cm}$. long, mucronate at the apex, cordate or subcordate at the base, more or less pubescent, short-petiolerl; cymes sessile or very short-perlunclerl, several-flowered; pedicels about as long as the sepals; sepals orate-lanceolate, acute, $2.5-3$ mm. long: corolla 3-4 mm. broad, purple or pink, its limb 5-cleft; capsule globose, about $2 \mathrm{~mm}$. in diameter; seeds brownish, rugulose.

Waste and cultivated ground, Andros and New Providence:-Cuba; Hispaniola; Jamaica. SMALL-FLOWERED JACQEEMOATIA.

\section{Jacquemontia jamaicénsis (Jacq.) Hallier f.; Solereder, Syst. Anat. 641. 1899.}

Convolvulus jamaicensis Jacq. Obs. 3: 6. 1768.

Finely pubescent or glabrate; stems slender, 1-2 m. long. Leaves lanceolate to oblong, entire, rather firm in texture, short-petioled, $1.5-4 \mathrm{~cm}$. long, obtuse, mucronulate or acute at the apex, narrowed or rounded at the base, sparingly pubescent or glabrate; cymes 1-several-flowered, short-peduncled; sepals broad, ovate, acute, about $2 \mathrm{~mm}$. long; corolla white or purplish, 1-1.5 cm. broad, the limb 5-cleft, the narrow segments acute; capsule subglobose, about $4 \mathrm{~mm}$. long; seeds rough.

Pine-lands and scrub-lands, throughout the archipelago from Great Bahama and the Perrv Islands to Marignana, the Inaguas, and the Anguilla Isles:-Florida; Cuba to St. Thomas and St. Croix; Jamaica. Recorded from Bermuda. The species evidently consists of a large number of races differing greatly in leaf-form and in pubescence; none of the Bahamian plants collected are exactly identical with the typical race from Jamaica, Commos JACQUemontia. 


\section{Jacquemontia cayénsis Britton, sp. nor.}

Stem rather stout, somewhat wooly, branched, trailing or ascending, 0.52.5 $\mathrm{m}$. long, finely pubescent $\mathrm{or}^{\circ}$ glabrate. Leaves fleshy, oblong to broadly ovate, entire, 1-3 cm. long, obtuse, reture or acute at the apex, narrowed or rounded at the base, short-petioled, sparingly pubescent or glabrous; peduneles shorter than the leares; eymes few-flowered; sepals ovate, apiculate, about 2 $\mathrm{mm}$. long: corolla white or yellowish, 5-cleft, $\mathrm{s}-12 \mathrm{~mm}$, broad; capsule ovoidglobose, about $5 \mathrm{~mm}$. long.

Coastal rucks, white-lands and sauds, Ahaco and Great Bahama to Grand Turk, Inagua and Cay Sal:-Cuba; Anegada. Type from Cistle lslaud (Wilson ir91). lieferred in liull. $\mathbf{N}$. Y. liot. Gard. 4: 121 to J. reclinata llouse, of F'lorida, which proves to be distinct. Flesil JACQUEMONTI.

\section{Jacquemontia pentántha (Jacq.) G. Don, Gen. Syst. 4: 253. 1538.}

Convolvulus pentanthos Jacq. Coll. 4: 210. 1790.

Jacquemontia violacea Choisy, Mem. Soc. Phys. Genéve 8: 61. 1838.

Slender, glabrate or densely pubescent, 0.5-2 m. long, sometimes much branched. Leaves ovate, 2-4 cm. long, slender-petioled, entire or slightly repand, acnte or acuminate at the apex, cordate at the base; peduncles slender, mostly as long as the leaves or longer; eymes dense, several-flowered; pedicels usually shorter than the calyx; sepals ovate to lanceolate, acute or acuminate, $5-7 \mathrm{~mm}$. long, the onter broader than the inner; corolla blue, rarely white, $2-3$ cm. broad; capsule subglobose, about as long as the sepals or a little shorter.

Anguilla Isles:-Florida; West Indies and continental tropical America. IBLuE JACQCENONTIA.

3. CALONÝCtion Choisy, Mem. Soc. Phys. Genéve 6: 441.1833.

Long twining rines, with large, entire or 3-lobel leaves and large white nocturnal flowers. Sepals lerbaceous or subcoriaceous, the outer appendager or unappendaged. Corolla long-salverform with a nearly cylindric tube. Stamens and style exserted. Styles united; stigmas globose. Fruit a dehiscent oval or oblong capsule. [Greek, night-beauty.] A few species, of tropica] regions. Type species: Calonyetion speciosum Choisy.

Outer sepals with infraterminal tail-like appendages; stems more or less aculeate.

Outer sepals without appendages; stems not aculeate.

1. C.aculcatum.

2. C. Tubu.

1. Calonyction aculeàtum (L.) House, Bull. Torr. Club 31: 590. 1904.

Convolvulus aculeatus L. Sp. Pl. 155. 1753.

Ipomoea bona-nox L. Sp. Pl. ed. 2, 22S. 1762.

Glabrous, trailing or high-climbing, sometimes $20 \mathrm{~m}$. long or Ionger, the sap milky. Leaves orbicular-orate, membranous, 5-15 $\mathrm{cm}$. long, entire, repand or sometimes 3-lobed, long-petioled, acuminate at the apex, decply corlate at the base; peduncles 1-several-flowered, stont, shorter than the leaves; sepals about $1 \mathrm{~cm}$. long, appressed, the outer subulate-appendaged; corolla-tuhe slenter, 10-12 cul. long, the limb $8-10 \mathrm{~cm}$. wille, each lobe with a broal green median band terminating in a cusp; eapsule ovoid, pointed, about $2 \mathrm{~cm}$. long; seeds glabrouls or nearly so.

New Providence and Acklin's Island:-Florida: Cubn to I'orto lilen: Guade-

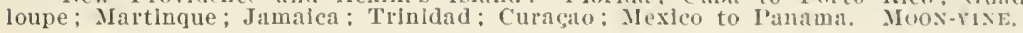


2. Calonyction Tùba (Sehlecht.) Colla, Nov. Sp. Calon. 15. 1840.

Convolvulus Tuba Schlecht. Linnaea 6: 735. 1831.

Calonyction grandiflorum Choisy, Mem. Soc. Phys. Genéve 6: 442. 1833.

Ipomoea tuba G. Don. Gen. Syst. 4: 271. 1838.

Calonyction album House, Bull. Torr. Club 31: 591. 1904. Not Ipomoea alba L. 1753.

Glabrous, fleshy, usually climbing, sometimes $10 \mathrm{~m}$. long. Leaves ovateorbicular, slender-petioled, 6-10 cm. long, acute or short-acuminate at the apex, deeply cordate at the base; peduncles stout, 1-2-flowered, shorter than the leaves; sepals ovate-oblong, obtuse, appressed, about $2 \mathrm{~cm}$. long; corolla white, its tube stout, cylindrie, 5-6 $\mathrm{cm}$. long, the limb 5-6 $\mathrm{cm}$. broad, with 5 narrow greenish bands; capsule subglobose, $2-2.5 \mathrm{~cm}$. in diameter; seeds densely puberulent, villous on the angles and at the hilum.

Sandy shores, Abaco, Frozen Cay, South Cat Cay, Andros, New Providence, Ship Channel Cay, Eleuthera, Conception, Watling's, Rum Cay, Iong Island, Mariguana, Inagua, Gibb's Car, Anguilla Isles, Water Cay and Cas Sal:-Florida: Cuba to St. Jan and Martinique; Jamaica; continental tropical Amerlca and Old World tropics. Recorded by Mrs. Northrop as Ipomoea grandiflora Lam. COAST MooN-vine.

\section{QUÁMOCLIT [Tourn.] Moench, Meth. 453. 1794.}

Twining herbaceous vines, with petioled leaves, and peduncled axillary flowers. Sepals 5, herbaceous, equal, acuminate, mucronate or appendaged. Corolla salverform (scarlet in the following species), the tube longer than the spreading limb. Stamens and united styles exserted; stigma capitate; ovary 2-celled or falsely 4-celled, 4-ovuled. Capsule usually 4-celled and 4-seeded. [Greek, dwarf kidney-bean.] About 10 species, of warm and tropical regions. Type species: Ipomoea coccinea L.

Leaves pinnately parted into very narrow segments. Leares cordate, acuminate, entire or angulate-lobed.

1. Q. Quamoclit. 2. Q. coccinea.

1. Quamoclit Quámoclit (L.) Britton, in Britton \& Brown, Ill. Fl. 3: 22. 1898.

Ipomoea Quamoclit L. Sp. Pl. 159. 1753.

Quamoclit vulgaris Choisy, in DC. Prodr. 9: 336. 1845.

Annual, glabrous. Leares orate in outline, $5-18 \mathrm{~cm}$. long, pinnately parted into segments less than $2 \mathrm{~mm}$. wide; peduncles 1-6-flowered; pedicels thickening in fruit; sepals obtuse, usually mucronulate, 4-6 mm. long; corolla 2.5-4 $\mathrm{cm}$. long, the tube expanded abore, the limb nearly flat, the lobes ovate, acutish; ovary 4-celled; capsule ovoid, 4 -valved, about $1 \mathrm{~cm}$. high, twice as long as the sepals.

Waste and cultivated ground, Abaco near Marsh Harbor:-Virginia to Florida, Kansas and Texas: West Indies; II exico to continental tropical America; Old World tropics. CTPRESS FiNE.

\section{Quamoclit coccinea (L.) Moench, Meth. 453. 1794.}

Ipomoea coccinea L. Sp. Pl. 160. 1753.

Annual. Leaves ovate to orbicular, long-acuminate, 5-15 cm. long, entire or angulate-lobed, slender-petioled; peduncles few-several-flowered; sepals obtuse, about $4 \mathrm{~mm}$. long, subulate-appendaged; corolla 2-4 cm. long, the limb obscurely 5-lobed; ovary 4-celled; capsule globose, 4-valved, 6-8 mm. in diameter.

Waste grounds, New Providence, near Nassau :-Pennsylvania to Arizona, Texas and Florida: West Indies; Mexico and continental tropical America. SMaLL RED MORNING-GLORY. 
5. EXoGònIUM Choisy, Mem. Soc. Phys. Genére 6: 443. 1833.

Vines, woody at the base, with alternate leaves and showy, cymose or solitary, axillary flowers. Sepals 5, obtuse, somewhat unequal. Corolla salverform or funnelform. Ovary 2-celled; styles united; stigmas globose. Stamens more or less exserted. Fruit a capsule. [Greek, referring to the exserted stamens and styles.] Some 25 species or more, of tropical and subtropical America. Type species: Ipomoea bracteata Cav.

1. Exogonium microdáctylum (Griseb.) House, Bull. Torr. Club 35: 102. 1908.

Ipomoea microdactyla Griseb. Cat. Pl. Cub. 204. 1866.

Exogonium microdactylum integrifolium House, Bull. Torr. Club 35: 103. 1908.

Glabrous, slightly succulent, the stem sometimes spinulose toward the base, 1-3.3 m. long, arisiug from a large tuber-like root. Leaves various, slenderpetioled, 3-10 cm. long, orate to lanceolate, entire or palmately several-lobed; cymes few-flowered, short-peduncled; pedicels as long as the peduncle or shorter; sepals orbicular-ovate, about 6 mm. long; corolla scarlet to carmine, its slender tube $2.5-1 \mathrm{~cm}$. long, its limb about $2.5 \mathrm{~cm}$. wide, the lobes ovate; capsule subglobose, pointed, 10-12 mm. thick; seeds brown-hairy.

Pine-lands and scrub-lands, throughout the arehipelago from Abaco and Great Bahama to Mariguana and Caicos:-Florida; Cuba. Recorded by Grisebach and by Dolley as Ipomoca arenaria Steud. SAlverfonar MorNixg-glory. Catesby $2: p l$. $8 \gamma$.

\section{IPOMOĖA L. Sp. Pl. 159. 1753.}

Twining trailing or rarely erect herbs, with large showy axillary flowers. Corolla funnelform or campauulate, the limb entire, 5-angled or 5-lobed, the tube plaited. Stamens included. Ovary entire, 2-4-celled, 4-6-ovuled; styles united, included; stigmas 1 or 2, capitate or globose. Capsule usually septifragally 2-t-valved, 2-4-seeded. [Greek, worm-like.] About 400 species, of wide distribution. Type species: Ipomoea Pes-tigrinus L.

Sepals herbaceous, elongated.

Sepals long-hirsute.

Sepals not long-hirsute.

Leaves silky-pubescent beneatl.

Leaves glabrous or nearly so.

Sepals short, coriaceous or membranous.

Stems prostrate or ereeping, not twining : fleshy littoraJ speeies.

Flowers purple; leares suborbicular, notelied.

Flowers creamy-white; leaves various, oblong to lanceolate and entire or pinnitely lobed.

Stems twining, at least their tips.

Seeds with a coma, or covered with long hairs.

Seeds glabrous or pubescent, without a coma. lionts not fleshy and edible.

Leaves 5-7-parted, the segments toothed or piunatifid.

Leaves entire, sagittate or 3-lobed.

Leaves sagittate.

Leares cordate, entlre or 3-lobed.

Corolla $2 \mathrm{~cm}$. long or less

Corollis $5-7$ em. long.

Roots fleshy, edible; leaves vilious.

1. I. hederacea.

2. I. rillosa.

3. I. cathartica.

4. I. Pes-caprae.

5. I. stolonifcra.

6. I. carolina.

7. I. dissecta.

S. I, sagittuta.

9. I. triloba.

10. I. tiliacea.

11. I. Butatas.

1. Ipomoea hederàcea Jacq. Icon. Rar. 1: 4, pl. 36. 1786.

Stem 6-15 dm. long, slender, retrorsely hairy. Leaves ovate-orbicular in outline, long-petioled, deeply 3 -lobed, $5-13 \mathrm{~cm}$. long, the lobes orate, acuminate; peduncles 1-3-flowered, much shorter than the petioles; flowers opening in early morning, soon closing; sepals lanceolate with long linear often recurver tips, ciensely birsute below, sparingly so abore, 1.5-2.5 cm. long; corolla funuelform, 
the tube usually nearly white, the limb light blue or purple; eapsule depressedglobose, 3-valveil, about as long as the lincelate portion of the sepals.

Roadsides, New Providence at Nassau:-continental tropical America. Naturalized in the eastern United States. Iry-Liven Joming-Glom.

\section{Ipomoea villòsa R. \& P. Fl. Per. 2: 12.1799.}

Pubescent, twining. Leaves thin, slender-petioled, the blarles $7-15 \mathrm{~cm}$. long, pubescent on both sides, entire or 3-lobed, long-acuminate at the apex, deeply cordate at the base; peduncles 1-4-flowered, axillary, as long as the petioles or shorter; bracts linear-lanceolate, 1.5-2.5 ens. long; sepals lanceolate, acuminate, pubescent, about $2.5 \mathrm{~cm}$. long; corolla purple, about $7.5 \mathrm{~cm}$. long.

Sea-beach, Andros, a]ong road to Little Creek:-Bermuda; Trinidad; northern South America; Old World tropies. Included in this flora with doubt, the specimen showing foliage only. V'ILLOUS MORNING-GLORY.

\section{Ipomoea cathártica Poir. in Lam. Eneyel. Suppl. 4: 633. 1816.}

Pharbitis cathartica Choisy, in DC. Prodr. 9: 342. 1845.

Perennial, minutely strigillose or glabrate. Stems more or less twining, branching. Leaves broadly ovate, 5-9 cm. long, entire or 3-lobed, acuminate, cordate; peduncles shorter than the subtending petioles; sepals glabrate, linear-lanceolate or orate-lanceolate, 1-2 cm. long, acuminate; corolla pinkpurple or erimson, the limb 6-8 $\mathrm{cm}$. broad, undulate; eapsules spheroidal, about $1 \mathrm{~cm}$. broad; seeds glabrous, about $3 \mathrm{~mm}$. in diameter.

Scrub-]ands, Abaco, Great Bahama, Biminis, Andros, New Providence, Eleuthera, Long Island, Crooked Island and Anguilla Isles:-Bermuda; Florida ; throughout the West Indies and continental tropical America. The record of I. purpurea Lam., by Dolley, for the Babamas, probably refers to this species, which was entered in Mrs. Northrop's List, in part, as I. jamaicensis Don. Referred by Mrs. Northrop to $I$. commutata R. \& S., and also so referred by Hitchcock. PURPLE MORIING-GLORY. GLORY-MIORNING.

* 4. Ipomoea Pes-cáprae (L.) Roth, Nov. Sp. 109. 1821.

Convolvulus Pes-caprae L. Sp. Pl. 159. 1753.

Convolvulus brasitiensis L. Sp. Pl. 159. 1753.

Perennial, glabrous, suceulent. Stems prostrate, creeping, sometimes $20 \mathrm{~m}$. long or more, branching; leaves suborbicular, 6-10 $\mathrm{cm}$. broad, usually notehed at the apex, rounded or cordate at the base; petioles as long as the blades or shorter; peduncles stout, 1-several-flowered; pedicels more slender than the peduncles; sepals glabrous, oval or suborbicular, about $1 \mathrm{~cm}$. long, obtuse; corolla purple, $4-5 \mathrm{~cm}$. long, its tube broadly funnelform, its limb undulatelylobed, 5-s cm. broad; eapsules broadly ovoid or globose-ovoid, $1.5 \mathrm{~cm}$. high; seeds pubescent.

Sea-beaches and coastal rocks, throughout the archipelago from Abaco and Great Bahama to Watling's Island, Inagua, Angnilla Isles and EIbow Cay:-Bermuda; Georgia and Florida; coasts of the West Indies; continental tropical America and OId World tropies. BAY HOPS. BAY WINDERS.

5. Ipomoea stolonifera (Cyrill.) Poir. in Lam. Encycl. 6: 20. 1804.

Convolvulus littoralis L. Syst. ed. 10, 924. 1759. Not Ipomoea littoralis Blume. 1826.

Ipomoea littoralis Boiss. Fl. Orient. 4: 112. 1879.

Stem slender, buried in sand, sending up branches which rise 0.5-2 dm. above the surface, glabrous and fleshy. Leares ovate to ovate-oblong, or broader, long-petioled, fleshy, glabrous, 3-7 cm. long, entire or variously lobed, narrowed at the base or the later ones rounded or cordate; flowers few or solitary; peduneles mostly shorter than the leaves; sepals oval or oblong, 10-15 $\mathrm{mm}$. long, mucronate; corolla white, funnelform-campanulate, $4-5 \mathrm{~cm}$. long; eapsules globose, 1-1.5 cm. long; seeds smooth. 
Creeping in littoral sands, North Bimiui, Eleuthera, Great Guana Cay, Watling's Island, Mariguana, Delectable Cay:-Soutl Carolina to Florida, Texas, IIexico and South America : Cuba to Culebra and Inartinique; Jamaica (according to Grisebach). old World tropics. Beacil MorNING-GLORY.

6. Ipomoea carolina L. Sp. Pl. 160. 1753. Not Pursh. 1814.

Ipomoea heptaphylla Griseb. Mem. Am. Acad. II. 8: 527. 1862.

Glabrons, slightly fleshy, climbing, sometimes $8 \mathrm{~m}$. long. Petioles slender, 3-6 cm. long; leares pedately 4-i-livided, the segments oblanceolate, entire, 3-6 em. long, obtuse or acute at the apex, cuneate at the base, slender-stalked; peduneles somewhat shorter than the petioles; cymes several-flowered; pedicels short and stout; sepals ovate, obtuse, about $1 \mathrm{~cm}$. long; corolla tubular-campanulate, $3.5-4.5 \mathrm{~cm}$. long; capsule oroid, $8-10 \mathrm{~mm}$. long; seeds woolly.

I'ine-lands and thickets, Andros, New I'rovidence:-Cuba. Catesby, IIist. Carol., 2: $p l$. 91. A specimen from Andros (Brace 4950), with foliage only, is referred to this species with doubt. I'EDATH-LEATED MORXING-GLORY.

\section{Ipomoea dissécta (Jacq.) Pursh, Fl. Am. Sept. 145. 1814.}

Convolvulus dissectus Jacq. Obs. 2: 4. 1767.

Ipomoea sinuata Ortega, Hort. Matr. Dec. S4. 1798.

Operculina dissecta House, Bull. Torr. Club 33: 500. 1906.

Perennial, villous-hirsute, or glabrate. Stems twining, branching; leaves suborbicular, 3-10 em. in diameter, 5-7-parted, the segments oval to oblong or lanceolate, coarsely toothed or pinnatifit; petioles as long as the blades or longer, villous-hirsute; sepals glabrate, oblong to oblong-oval, $1-2.5 \mathrm{~cm}$. long; obtuse; corolla white with purple throat, its tube funnelform, $2-3 \mathrm{~cm}$. long, its limb 3-5 cm. broad; capsules about $1.5 \mathrm{~cm}$. long; seeds smooth and glabrous.

Climbing on walls or bushes, Andros, New Providence, Eleuthera, Cat Island and I'arrot Cay, Caicos Islands:--Bermuda; Florida to Texas; West Indies and coutinental tropical America. Norad Vixe.

\section{Ipomoea sagittàta Lam. Tabl. Eneyel. 1: 466. 1791.}

Perennial, glabrous. Stems twining, up to $2 \mathrm{~m}$. long, or longer, branching, relatively' slender. Leaves $3-10 \mathrm{~cm}$. long, sagittate or hastate-sagittate, the lobes linear or lanceolate, the lateral about one half as long as the terminal one; petioles about as long as the basal lobes; peduncles usually 1-flowered; sepals glabrous, oblong to suborbicular, 6-9 mm. long, obtuse or cuspidate; corolla purple, 5-6 cm. long, the tube funnelform, the limb $6-7 \mathrm{~cm}$. broad; capsules oroid, 1-1.5 $\mathrm{cm}$. long; seeds rillous.

Palmetto lands and wet sands, Great Bahama, New Providence:-Bermuda ; North Carolina to Florida, Texas and Mexico; Cuba. Anom-LeaYed Jomixg-GLory.

\section{Ipomoea tríloba L. Sp. Pl. 161. 1753.}

Somewhat pubescent or glabrate; stem herbaceous, slender, 5-10 dm. long, usually trailing. Leaves usually very deeply $3-5$-lobed, sometimes entire, ovate, 2-10 $\mathrm{cm}$. long, acute or acuminate at the apex, corlate at the base, the petioles slender; peduncles mostiy longer than the petioles, 1-few-flowered; pedicels 1-2 em. long, thiekening in fruit; sepals oblong, acute or mueronate, pilose, 5-6 mm. long; corolla red or purple, funnelform-eampanulate, about $1.5 \mathrm{em}$. broad; capsule subglobose, pilose, 2-celled, about $7 \mathrm{~mm}$. in diameter; seeds glabrous.

Waste and cultivated grounds, throughout the archipelago from Abaco and Great liahama to Andros, Grand Turk and Inagua:-Florida: West Indies: cont1. nental tropleal America; tropical Asia. Chenpixg Momisg-glom. 
10. Ipomoea tiliàcea (Willd.) Choisy, in DC. Prodr. 9: 375. 1845.

Convolvulus titiaceus Willd. Enum. 1: 203. 1809.

Convolvulus fastigiatus Roxb. Ilort. Beng. 13. 1814.

Ipomoea cymosa G. F. W. Meyer, Prim. Fl. Esseq. 99. 1818.

Ipomoea fastigiata Sweet, Hort. Brit. 2ss. 1826.

Ipomoea gracilis House, Ann. N. I. Acad. Sci. 18: 248. 1908. Not R. Br. 1810.

Glabrous or sparingly pubescent, twining, up to $2 \mathrm{~m}$. long or longer, the root sometimes tuberiferous. Leaves ovate, $5-8 \mathrm{~cm}$. long, membranous, acute at the apex, cordate at the base, the slender petioles sometimes half as long as the blades; peduncles as long as the petioles or longer; cymes few-severalflowered; pedicels short; sepals oblong, mucronate or aristulate, about $8 \mathrm{~mm}$. long; corolla purple, pink or rarely white, usually with a dark eye, funnelformcampanulate, 5-6 em. long; capsule 2-celled, subglobose, $8-10 \mathrm{~mm}$. in diameter; seeds glabrous.

Swampy scrub-lands, Great Rahama and Andros:-Florida; the West Indies; continental tropical America. DARK-EYED MORNING-GLoRY.

> 11. Ipomoea Batàtas (L.) Lam. Encyel. 6: 14. 1804.

Convolvulus Batatas L. Sp. Pl. 154. 1753.

Rootstocks large, fleshy, a well-known vegetable. Stems glabrous or nearly so, trailing, $1 \mathrm{~m}$. long or longer. Leaves various, ovate to suborbicular, entire, dentate or lobed, acuminate at the apex, cordate at the base, $5-15 \mathrm{~cm}$. long; peduncles as long as the petioles or shorter, ferv-flowered; sepals oblong, acute, cuspidate, somewhat unequal, $7-10 \mathrm{~mm}$. long; corolla pale purple or nearly white, about $5 \mathrm{~cm}$. long; ovary and capsule 2 -celled; seeds glabrous.

Thickets and cultivated soils, spontaneous after cultivation, Abaco, Andros, New Providence and Eleuthera :-spontaneous after cultivation, Florida to Arkansas and Texas: West Indies; continental tropical America, and old World tropics. Native habitat unknown. Catesby, 2: pl. 60. Swent Potato.

\section{TURBÌNA Raf. Fl. Tell. 4: 81. 1838.}

Vines with cordate leaves, and axillary peduncled clusters of large or middle-sized flowers. Sepals ovate to lanceolate. Corolla campanulate or funnelform. Ovary 2-celled or 4-celled; stigmas 2. Fruit dry, woody, indehiscent, subglobose or ovoid, 1-celled, mostly 1-seeded, the seeds smooth. [Latin, from the supposed top-shaped fruit.] About 20 species, natives of tropical regions, the following typical.

1. Turbina corymbòsa (L.) Raf. Fl. Tell. 4: 81. 1838.

Convolvulus corymbosus L. Syst. ed. 10, 923. 1759.

Convolvulus domingensis Desv. in Lam. Encycl. 3: 554. 1791.

Convolvulus sidaefolius H.B.K. Nov. Gen. 3: 99. 1818.

Ipomoea sidaefolia Choisy, Mem. Soc. Phys. Genéve, 6: 459. 1833.

Ipomoea antillana Millsp. Field Mus. Bot. 2: 84. 1900.

High-climbing or trailing, glabrous. Leaves slender-petioled, ovate, entire, 4-10 cm. long, acute or acuminate at the apex, cordate at the base; peduncles axillary, as long as the leaves or longer, corymbosely or paniculately severalmany-flowered, the pedicels slender; sepals oblong, persistent, the 3 inner ones 8-12 mm. long, nearly twice as long as the two outer; corolla white, $2.5-3 \mathrm{~cm}$. long; capsule ovoid, acute, about half as long as the longer sepals, 1-seeded.

Coppices, walls and thickets, Andros, New Providence, Cat Island, Iratling's Island:-Florida; Bermuda; Cuba to Guadeloupe; Barbadoes: Jamaica; Mexico to northern South America. Recorded by Mrs. Nolthrop as Ipomoea fastigiata Sweet. Christias-vine. Christifas-Flower. 


\section{Family 2. DICHONDRĀCEAE Dumont.}

\section{DiCHONDRA FAMILY.}

Prostrate or creeping slender herbs, with nearly orbicular, corlate or reniform, petioled entire leaves, and small solitary axillary peduncled flowers. Sepals nearly equal. Corolla open-campanulate, deeply 5-lobed. Stamens shorter than the corolla; filaments filiform. Ovary villous, deeply 2-parted, each lobe 2-celled; styles 2, simple, arising from the bases of the orary-lobes; stigmas capitate. Fruit of two pubescent, 2-ralved or indehiscent, 1-2-seeded capsules. Only the following genus.

\section{DICHÓNDRA Forst. Char. Gen, 39. 1776.}

Characters of the family. [Greek, two-grained, referring to the capsules.] About 5 species, of warm and tropical regions. Type species: Dichondra repens Forst.

\section{Dichondra carolinénsis Michx. Fl. Bor. Am. 1: 136. 1803.}

Somerhat pubescent, or glabrous; stems almost filiform, rooting at the norles, $1.5-6 \mathrm{dm}$. long. Leaves orbicular to reniform, deeply cordate, $6-30 \mathrm{~mm}$. in diameter, palmately veined, the petiole often much longer than the blade; flowers '2-4 mm. broad; peduncles filiform; sepals obtuse, spatulate or obovate, villous; corolla yellow to white, shorter than the sepals, its lobes ovate to oblong; capsule $3 \mathrm{~mm}$. high or less.

Waste places and cultivated soils, Great Bahama. New Providence, Eleuthera, Great Exuma and Crooked Island :-Bermuda; Virginia to Florida and Texas. Referred by previous authors to Dichondra repens For'st. CAROLINA DICHONDra. SIIFEr-grass.

\section{Family 3. CUSCUTÀCEAE Dumort.}

\section{DODdER FAMILY.}

White, red or yellow slender parasites, dextrorsely twining, the leaves reduced to minute alternate scales. Calyx inferior, 5-lobed or 5-parted (rarely 4-lobed or 4-parted), or of 5 distinct sepals. Corolla 5-lobed (rarely 4-lobed), the tube bearing as many fimbriate or crenulate scales as there are lobes and alternate with them, or these sometimes obsolete. Stamens as many as the corolla-lobes, inserted in the throat or sinuses above the scales; anthers short, ovate or oval, obtuse, 2-celled, the sacs longitudinally dehiscent. Ovary, 2-celled; ovules 2 in each cavity; styles 2 , terminal, separate, or rarely united below; stigmas linear or capitate. Capsule globose or oroid, circumscissile, irregularly bursting or indehiscent, 1-4-seeded. Seeds glabrous; embryo linear, terete, curved or spiral, its apex bearing 1-4 minute altemate scales; endosperm fleslyy; cotrledons none.

\section{CÚsCUTA [Tourn.] L. Sp. Pl. 124. 1753.}

Characters of the family. The filiform twining stems are parasitic on herbs and shrubs by numerons minute suckers. The seels germinate in the soil and the plantlet attaches itself to its host, its root and lower portion soon perishing. The subsequent nutrition of the parasite is apparently wholly through its suckers. Indications of a small amount of green coloring matter, 
possibly chlorophyll, have been observed in some species. [Name from the Arabic.] About 100 species, of wide distribution. Type species: Cuscuta europaea L.

Capsule circumscissile; corolla-lobes obtuse; plant orange.

Cipsule indehiscent; corolla-lobes acute; plant yellow.

1. C. americana.

2. C. pentayona.

\section{Cuscuta americàna L. Sp. Pl. 124. 1753.}

Plant orange, the stems sleniler, the inflorescence glandular. Flowers short-pedicelled in dense or rather loose clusters; calyx-lobes 5, ovate-orbicular, obtuse; corolla about $2 \mathrm{~mm}$. long, its 5 lobes obtuse, shorter than the tube, the broad scales fringed all around; eapsules subglobose, about $3 \mathrm{~mm}$. in diameter, circumseissile near the base.

I'arasitic on various plants, Frozen Cas, Eleuthera, Cat Island, Watling's Island, Care Cay. Great Exuma, Acklin's, Fortune Island. Grand Turk and Anguilla Isles:Trest Indies and tropical continental America. Reported by Dolley as $C$. obtusiflora. LOVE-YIXE.

\section{Cuscuta pentàgona Engelm. Am. Journ. Sci. 43: 340. 1842.}

Cuscuta ariénsis Beyr.; Hook. Fl. Bor. Am. 2: 77. As synonym. 1834.

Plant pale yellow; stems filiform, the flowers nearly sessile in small clusters. Calyx broad, 5-lobed, the lobes obtuse; corolla nearly campanulate, 5 -lobed, the lobes acnte or acuminate, as long as the tube, their tips reflexed, the scales large, orate, densely fringed all around with short irregular processes; stamens not exserted; style shorter than the orary; stigmas capitate; capsule depressed-globose, indehiscent.

Parasitic on rarious weeds. Great Bahama, Andros, Eleuthera and Cat Island:New York and Canada to Florida and Texas; Jamaica; Cuba; Porto Rico. Referred by Mrs. Northrop to $C$. americana L. FIELD DODJER.

\section{Family 4. HYDROPHYLLÀCEAE Lindl.}

\section{TAter-Leaf FAJHLY.}

Herbs, mostly hirsute, pubescent or scabrous, with alternate or basal, rerely opposite leares, and perfect regular 5-parted flowers, in scorpioid cymes, spikes or racemes, or rarely solitary. Calyx inferior, deeply eleft or divided. Corolla gamopetalous. Stamens 5, inserted on the corolla, and alternate with its lobes; filaments filiform; anthers mostly versatile, 2-celled, the sacs longitudinally dehiscent. Disk amnular, or none. Ovary superior, 2-celled, or 1-celled with 2 placentæ; styles 2, separate, or partly united; stigmas small, terminal; orules anatropous or amphitropous. Capsule 1-2-celled. mostly loculieidally 2-ralved. Seeds usually pitted, rugose or reticulated; endosperm fleshy or cartilaginous; embryo small; cotyledons half-terete or plano-convex. About 17 genera and 175 species, mostly natives of western North America.

\section{MARIIAUNIDIUM Kuntze, Rev. Gen. Pl. 434. 1891.}

Branching pubescent herbs, with alternate entire leaves, the flowers solitary in the axils. Calyx 5-cleft. Corolla funnelform or salverform. 5lobed, the lobes imbricated in the bud. Stamens mostly included, borne on the corolla-tube. Ovary 1-celled, or incompletely 2-celled; ovules numerous. Fruit a 2-valved capsule. [In honor of Dr. Anton Kerner, Knight of Marilaun.] About 20 species, natives of America, the following typical. 
1. Marilaunidium jamaicénse (L.) Kuntze, Rev. Gen. Pl. 434. 1891.

Nama jamaicense L. Syst. ed. 10. 9.50. 1759.

Anmual, much branched, the branches prostrate, $0.7-4 \mathrm{dm}$. long. Leares thin, spatulate or oborate, 1-5 $\mathrm{cm}$. long, obtuse or apiculate, narrowed to a sessile, somewhat decurrent base; peduncles $6 \mathrm{~mm}$. long or less; calrx-segments hirsute, linear, 6-S mm. long; corolla white or purplish, about as long as the calyx, its lobes broad; capsule oblong, a little longer than the calyx.

Waste grounds, Great Bahama, Little lIarbor Cay, New Providence, Eleuthera, Tatling's, Great Ragged Island, Crooked Island, South Cafcos and Grand Turk:Bermuda; Florida: Texas: Cuba to St. Thomas and Martinique; Barbadoes; Jamaica ; Curaço; Vexico to Venezuela. Jasica WEen.

\section{Famiiy 5. EHRETIÀCEAE Schrad.}

\section{Ehretia Fanily.}

Shrubs, trees or rarely herbs, with alternate, estipulate. simple and mostly entire leaves, and perfect regular flowers in heads, spikes or crmes. Calyx 2-5-lobed, persistent. Corolla gamopetalous, mostly 5-lobed. the lobes spreading. Stamens mostly 5 , borne on the base of the corolla-tube, the anthers introrse. Ovary superior, 1-1-celled; styles 2, distinct or rarely united, or 4 , united in pairs; ovules 1 or 2 in each cavity of the orary. Fruit a drupe. Seeds 1-4. About 20 genera, including some 3.50 species. of tropical and wam-temperate regions.

Styles twice bifid.

Calyx wholly adnate to the large drupe; corolla large, orange to red ; trees.

Calsx rupturing at the top or regularly dentate, not wholly adnate to the drupe; shrubs or small trees. Styles bifid or connate.

Corolla salverform.

Corolla rotate.

1. Scbesten.

2. Tarronia.

3. Bourreria.

4. Rochefortia.

1. SEBÉSTEN Adans. Fam. Pl. 2: 177. 1763.

Trees or shrubs with alternate broad petioled, entire or few-toothed leares, and large showy flowers in terminal cymes or rarely solitary. Calyx tubular, $3-5$-toothed. Corolla salverform, the tube nearly cylindric, the limb speading, 5-15-lobed. Stamens borne on the corolla-tube, as many as the corolla-lobes; anthers sagittate. Ovary 2-1-celled; styles usually 2, each 2-cleft; stigmas capitate. Drupe oroid, artnate to the aecrescent calyx and enclosed by it, the stone bony. Seeds without endosperm. [Name Arabic, originally applied to a different tree.] About 12 species, of tropical and subtropical America, the following typical.

1. Sebesten Sebéstena (L.) Britton; Small, Fl. Miami 15S. 1913.

Cordia Sebestena L. Sp. Pl. 190. 1753.

A tree, reaching a maximum height of about $10 \mathrm{~m}$, with a trunk up to $1.5 \mathrm{dm}$. in diameter, the sealy bark dark brown, the young twigs brownhairy. Leaves orate to oblong-ovate, thick, $8-20 \mathrm{~cm}$. long, repani-ilentate or entire, dark green and scabrous above, paler green beneath, aemininate, acute or obtuse at the apex, rounded or subeorlate at the base, the petioles $3-\overline{\mathrm{cm}}$. long; cymes compound, several-many-flowered; pedieels 5-15 $\mathrm{mm}$. long; calyx strigose, eylindrie, 1-1.5 cm. long, its !obes short; corolla orange, its tube twice 
as long as the calyx, its limb $2.5-4 \mathrm{~cm}$. broad; drupe round, 5-lobed, white, pointed, 2-4 $\mathrm{cm}$. long, the flesh thin.

Scrub-lands, Abaco, North Blmini, Gun Cay, Andros, New Providence, Eleuthera, Long Island, Crooked Island, Fortune Island, Inagua, Grand Turk, Cay Sai and Water Car :- Florida; Cuba to Tortola and to Trinidad; Nexíco. Catesby, 2: $p l .91$. geiger Tize. Axaconda. Spanish Colidi.

2. VARRÒNIA P. Browne, Ilist. Jam. 172. 1756.

Shubs, or small trees, with scabrous or pubescent leares, the small, usually white flowers variously clustered, mostly sessile in heads, spikes or glomerules. Calyx 4-5-toothed. Corolla salverform or funnelform, the limb 4-5-lobed. Stamens as many as the corolla-lobes, mostly included. Ovary 4-celled. Styles 2-cleft; stigmas small, eapitate. Fruit a small, slightly fleshy drupe, of ten little longer than the calyx-tube and sometimes enclosed by it, containing $t$ nutlets or fewer. [In honor of Marens Tarro, a distinguished Roman, born 116 B.C., died 27 B.C.] Seventy species or more, of tropical and subtropical America. Type species: Lantana corymbosa L.

Flowers in globose heads.

Calxy-teeth filiform; leaves coarsely serrate.

Calyx-teeth triangular with linear tips; leares entire or with a few teeth.

Flowers in spikes.

Leaves linear-oblong to oblanceolate; filaments pilose at the base.

Leares spatulate-oborate; filaments glabrous.

1. V. globosa.

2. V. bahamensis.

3. T. Brittonii.

4. V. lucayana.

1. Varronia globòsa Jaeq. Enum. 14. 1760.

Cordia globosa H.B.K. Nov. Gen. 3: 76. 1818.

A usually much-branched shrub, 1-3 m. high, the slender twigs hispid. Leaves ovate to ovate-lanceolate or orate-oblong, $1.5-6 \mathrm{~cm}$. long, rather coarsely serrate, short-petioled, rough and papillose-hispid above, pubescent and strongly veined beneath, acute or bluntish at the apex, narrowed or obtuse at the base; flowers in dense globular peduncled heads, the peduncles mostly shorter than the leaves; calyx hispid, 5-cleft, $6-8 \mathrm{~mm}$. long, its teeth nearly filiform; corolla white, about $6 \mathrm{~mm}$. long; drupe red, about $4 \mathrm{~mm}$. long.

Scrul-lands. Andros, New Providence, Long Island, and Watling's:-Florida ; Cuba to Porto Rico and Trinidad; Jamaica; Cayman Islands; Curagao; Mexico to northern South America. Capitate Varroxia.

2. Varronia bahaménsis (Urban) Millsp. Field Mus. Bot. 2: 310.1909.

Cordia bahamensis Urban, Symb. Ant. 1: 392. 1900.

A usually much-branched shrub, 1-2 $\mathrm{m}$. high, rarely a small tree $3-4 \mathrm{~m}$. high, the branches slender, the young shoots appressed-setulose. Leaves various, linear-oblong to elliptic or obovate-elliptic, $2-10 \mathrm{~cm}$. long, $0.5-5 \mathrm{~cm}$. wide, acute, obtuse or rounded at the apex, narrowed or obtuse at the base, entire or fewtoothed, subcoriaceous, setulose-seabrous above, pilose beneath, at least on the reins, the petioles $4-20 \mathrm{~mm}$. long; peduncles as long as the leaves or shorter; flowers capitate; heads several-many-flowered; calyx loosely pubescent, 4-5lobed, the lobes triangular with slender tips $2-3 \mathrm{~mm}$. long; corolla white, subcrlindric, 4-5-lobed, 3-4 mm. long, its lobes orate, obtuse; drupe oroid, obtuse, red to black, about $4 \mathrm{~mm}$. long.

Scrub-lands, coppices and sarannas, throughout the archipelago from Abaco and Great Pahama to Andros, Mariguana, North Caicos and Inagua :-Cuban Cays; Anegada. Recorded by Grisebach, by Mrs. Northrop, and by Dolley as Cordia Lima R. \& S., and by Hitcheock as Cordia globosa H.B.K., and Cordia sp. The species is composed of several races with leaves varring from linear and quite entire to broadly ovate or oborate and slightly toothed. Rough VARRoxia. CocoBer. 
3. Varronia Brittònii Millsp. Field Mus. Bot. 2: 311. 1909.

Cordia Brittonii Macbride, Contr. Gray Herb. II. 49: 16. 1917.

A usually much-branched shrub, $2.5 \mathrm{~m}$. high or less, the young twigs puberulent. Leares linear-oblong or oblanceolate, viscid in drying, sparingly erenulate or entire, rounded or acutish at the apex, narrowed at the base, puberulent and resinous-dotted on both sides, $1.5-3 \mathrm{~cm}$. long, the petioles only 1-1.5 mm. long; spikes slender, peduncled, densely several-many-flowered, 2-3 cm. long; calyx 2.5-3 mm. long, campanulate, its 5 teeth ovate-deltoid; corolla white, about $4 \mathrm{~mm}$. long, its 5 lobes irregularly dentate; filaments short, pilose, borne abore the midale of the corolla-tube; drupe $2-2.5 \mathrm{~mm}$. long.

Coppices and scrub-lands, Great Bahama, Andros, Eleuthera, Cat Island and Long Island:-Cuba. Recolded by Coker as Cordia cylindrostachya R. \& S., and referred by Mis. Northrop to C. angustifolia R. \& S. Britton's Varroxia.

4. Varronia lucayàna Millsp. Field Mus. Bot. 2: 311. 1909.

A much-branched shrub, I-2 m. high, with terete branches, the young twigs densely puberulent. Leares spatulate or narrowly oborate, thin, $2 \mathrm{~cm}$. long or less, crenate, repand or subentire, rounded or truncate at the apex, cuneate or narrowed at the base, puberulent and resinous-dotted on both sides, the petioles 1-2 mm. long; flowers fer, in terminal spikes 1-1.5 cm. long, the peduncles 5-20 mm. long; calyx campanulate, its 5 teeth ovate-triangular; corolla white, about $5 \mathrm{~mm}$. long, its 5 unequal lobes irregularly crenate; filaments glabrous, borne near the top of the corolla-tube; drupe $2.5-3 \mathrm{~mm}$. long.

Rocky plains, Acklin's Island, Mariguana, South Caicos, and Inagua. Endemic. BAILAMA VARRONIA.

\section{BOURRÈria P. Browne; Jacq. Enum. 2, 14. 1760.}

Shrubs or small trees, with alternate petioled entire leaves, and white flowers in terminal corymb-like eymes. Calyx campanulate, 2-5-lobed, the lobes valvate. Corolla salverform, the limb 5-lobed. Stamens 5, borne on the corolla-tube, the filaments filiform. Ovary sessile, 2-celled or incompletely 4-celled; styles 2-cleft or connate; stigmas flattened. Fruit a drupe, with thin flesh, inclosing 4 bony nutlets ridged on the back. [Commemorates J.A. Beurer, a Nuremberg apothecary.] About 25 species of tropical America. Type species: Bourreria succulenta Jacq.

\section{Bourreria ovàta Miers, Amn. Mag. Nat. Hist. IV. 3: 203.1869.}

A shrub or small tree up to $10 \mathrm{~m}$. high or perhaps higher, with a trunk sometimes $1.5 \mathrm{dm}$. in diameter, the bark reddish-brown, the trigs and leares glabrous or very slightly pubescent, or shoots from stumps sometimes with pubescent foliage. Petioles rather stout, $4 \mathrm{~cm}$. long or less; leaves oblanceolate, oral or nearly orbicular, 4-12 cm. long, subcoriaceous, rounded or emarginate at the apex, mostly narrowed at the base; cymes commonly many-flowered, 5-10 cm. broad; pedicels short; ealyx 5-6 mm. long, irregularly 5-lobed; corolla about $10 \mathrm{~mm}$. long, its lobes nearly orbicular; styles connate; filaments glabrous; drupe orange-red, 10-15 $\mathrm{mm}$. in diameter, subglobose.

Scrub-lands and coppices, throughout the archipelago from Abaco and the Berry Islands to Grand Turk, Inagua, the Anguilla Isles and Cay Sal - llorida; Cuba.

The species is composed of a number of laces with the leares rarring from oblanceolate to suborbicular; the leaves are usually quite glabrous but those on shoots from cut stumps ale pubescent. The species is distinct from $B$. tomentosa (Iam.) Griseb. to which It has been referred by Grisebacl and by Dolley: It was referred to $B$. havancnsis Miers, by Hitcheock and by Mrs. Northrop, and recorded by Schoepf is Ehrctia tinifnlia and $\dot{E}$. Bcureria. Cotesbs, $2: p l$. $\pi 9$. Closely related to B. sueculenta. Jaç. StroNi-BAck. 


\section{ROCHEFóRTIA Sw. Prodr. 53. 1788.}

Shrubs or small trees, mostly armed with short spines, the leares entire, petioled, often fascicled, the small flowers eymose or glomerate. Calyx 4-5parted, the lobes imbricated. Corolla subrotate, the tube very short, the 4 or 5 lobes broad, imbricated. Stamens 4 or 5 , borne on the corolla-tube, exserted; filaments filiform; anthers orate. Dise thick. Ovary 2-eclled or falsely 4-celled; styles 2, terminal, filiform; stigmas dilated. Drupe fleshy, globose, containing 4 hard nutlets. [Commemorates César de Rochefort, a French naturalist of the seventeenth century.] About 8 species, natives of the West Indies and northern South America. Type species: Rochefortia cuneata $\mathrm{Sw}$.

\section{Rochefortia bahaménsis Britton, Bull. N. I. Bot. Gard. 5: 317.1907.}

A shrub or small tree up to $4 \mathrm{~m}$. high, with a trunk $6 \mathrm{dm}$. thick, the bark sealy, the branches spreading, the twigs gray-green, flexuous, sometimes with spines 4-6 $\mathrm{mm}$. long at the notles. Young foliage sparingly puberulent, soon glabrous; leares coriaceous, obovate to orbicular, $2-6 \mathrm{~cm}$. long, obtuse or emarginate at the apex, obtuse to cuneate at the base, the midvein prominent, the few lateral veins inconspicuous, the upper surface dark-green and dull or faintly shining, the under surface somewhat lighter green, the petioles 2-10 $\mathrm{mm}$. long, green or yellowish; cymes axillary, 2-4-flowered, their peduncles pubescent, $5 \mathrm{~mm}$. long or less; calyx sparingly pubescent, obconic, about $4 \mathrm{~mm}$. long, its 5 lobes nearly orbicular, ciliate; corolla greenish-white, $6 \mathrm{~mm}$. long, cleft to about the middle, its lobes oblong, obtuse; filaments abont as long as the anthers; ovary ovoid, about $3 \mathrm{~mm}$. long, the two styles erect or a little incurved.

Scrub-lands and rocky coppices, Tratling's, Crooked, Acklin's and Fortune Islands. Endemic. BaHaia Rocheforta.

Cordia gerascanthoides Kunth, referred to by Dolley as Bahamian, has not been found by us in the archipelago. The record is, presumably, erroneons.

Cordia alba (Jacq.) R. \& S. is doubtfully recorded as Bahamian by Urban (Symb. Ant. 4:516) from his examination of a barren specimen, which proves to be Sebesten Sebestena.

\section{Family 6. BORAGINÀCEAE Lindl.}

\section{Borage FaMiLY.}

Herbs or shrubs. Leares alternate, rarely opposite or verticillate, estipulate, mostly entire and hispid, pubescent, seabrous or setose. Flowers perfect, usually regular, in one-sided scorpioid spikes, racemes, cymes, or sometimes scattered. Calyx inferior, mostly 5-lobed, 5-cleft, or 5-parted, usually persistent. Corolla gamopetalous, mostly regular and 5-lobed, rarely irregular. Stamens as many as the corolla-lobes and alternate with them, inserted on the tube or throat; anthers 2-celled, the saes longitudinally dehiscent. Disk commonly inconspicuous. Ovary superior, of 2, 2-ovuled carpels, entire, or the carpels commonly deeply 2-lobed, making it appear as of 4.1-ovnled carpels; style simple, entire or 2-cleft; orules anatropous or amphitropous. Fruit mostly of 4, 1-seeded nutlets, or of 2, 2-seeded carpels. Endosperm fleshy, copious, or none; cotyledons mostly flat or plano-convex; radicle short. About $\$ 5$ genera and 1,500 species, of wide distribution.

Fruit drunaceous.

Fruit hollowed at base; coastal canescent shrub.

Fruit not hollowed at base; Bahama species vines. Fruit separating into nutlets.

1. Mallotonia.

2. Tournefortin.

3. Heliotropium. 
1. MALLotòniÁ [Griseb.] Britton, Ann. Mo. Bot. Gard. 2: 4\%. $191 \overline{.}$

Silvery-silky shrubs of the seacoast, with alternate leaves and small white flowers in dense, 1-sided cymes, the fruits almost eapitate. Calyx mostly 5parted; corolla salverform, the 5-lobed limb shorter than the nearly cylindrie tube, the lobes broad, ralvate. Stamens short, inclnded. Style simple. Drupe dry and bony, ovoid-eonie, hollowed at the base, 2-pyrenous, the dissepiments solid. [Latin, related to Mallota.] One species, or perhaps 2, of tropical and subtropical distribution, the following typical.

1. Mallotonia gnaphalòdes (L.) Britton, Ann. Mo. Bot. Gard. 2: 47. 1915.

Heliotropium gnaphalodes L. Srst. ed. 10, 913. 1759.

Tournefortia gnaphalodes R. Br.; R. \& S. Syst. 4: 535. 1819.

A somewhat fleshy shrub, 3-12 am. tall, with silky-tomentose foliage, much branched and often forming large clumps, the twigs densely leafy. Leares numerous, linear-spatulate, $4-10 \mathrm{~cm}$. long, obtuse; eymes with $2-1$ recurved branches; calyx campanulate, its lobes $2-3 \mathrm{~mm}$. long, oblong; corolla surpassing the calyx; fruit ovoid, $5 \mathrm{~mm}$. high, black, with 2 nutlets.

Coastal rocks and sands, throughout the alehipelago from Abaco and Great Bahama to Caicos and Turk's Islands, Inagua, the Auguilla Isles, Cay Sal and Water Cay :-Bermuda; Florida; West Indies; coast of tropical ILexico. Bar LAVENDER.

2. TOURNEFóRtiA L. Sp. Pl. 140. 1753.

Trees, shrubs or vines, with alternate entire leaves, and small secund flowers in terminal, often forked eymes, the eyme-branches usually elongated. Calyx persistent, 5-parted. Corolla mostly salverform, the tube cylindrie, swollen above, the lobes spreading. Stamens 5, borne on the corolla-tube, ineluded; filaments short; anthers ovate to laneeolate. Orary 4-celled; style terminal, 2-lobed at the apex. Drupe small, the exocarp fleshy or corky, containing 4 nutlets or fewer. [Commemorates Joseph Pitton de Tournefort, 1656-1708, renowned Freneh botanist.] Orer 100 speeies, of tropieal and subtropieal regions. Type species: Tournefortia hirsutissima L.

Leares glabrous or somewhat pubescent.

1. T'. rolubilis.

Leaves densely white-pubescent beneath.

2. T, poliochros.

\section{Tournefortia volùbilis L. Sp. Pl. 140. 1753.}

A slender roody vine, sometimes $3.5 \mathrm{~m}$. long, the branches aud leaves pubeseent, puberulent or glabrate. Leaves orate to oblong or oblong-lanceolate, $2-\pi \mathrm{em}$. long, thin, acute or acmininate at the apex, narrowed or obtuse at the base, the slender petioles $5-15 \mathrm{~mm}$. long; infloreseenee slender-peduneled, of several very slender, secund spikes $2-4$ em. long; ealyx abont $1 \mathrm{~mm}$. long, its lobes ovate-laneeolate, acnte; corolla greenish-white, twice as long as the ealyx, its lobes linear-subulate, shorter than the tube: anthers orate, ineluded; fruit depressed, 2-3 mm. broad, of 2-4 rounded mutlets.

Scrub-lands and coppices, IFery Islands, Andros, New Irovidence and Eleuthera to Caicos, Grand Turk, Inagua, and Angulla Isles:-1*lorda ; Texas: Culsa : St. Jan to Grenada; Jamalca. The Bahama plant is usually less pubescent than that

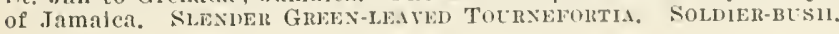




\section{Tournefortia polióchros Spreng. Syst. 1: 644. 1825.}

A canescent slender wooly vine $2 \mathrm{~m}$. long or less, or sometimes shrubby. Leaves lanceolate to ovate, $3-7.5 \mathrm{~cm}$. long, thin, aeuminate or acute at the apex, narrowed or obtuse at the base, rather dark green ani densely appressedpubeseent above, densely white-pubeseent beneath, the petioles $5-15 \mathrm{~mm}$. long; infloreseenee rather short-peduneled, of few or several slender secund spikes $3-7 \mathrm{~cm}$. long; calyx $1-1.5 \mathrm{~mm}$. long, pubeseent, its lobes lanceolate or ovateianceolate; corolla 2-3 times as long as the ealyx, pubescent, its lobes lanceolate, acute or aenminate; anthers ineluded; fruit depressed, $3-4 \mathrm{~mm}$. broad, of 4 rounded nutlets or fewer.

Scrub-lands, Eleuthera, Cat Island, Fortune Island, Great Ragged Island:Cuba; II ispaniola: Jamaica. leferred to $T$. tomentosa Jill. in Bull. $\mathrm{Y}$. $\mathrm{J}^{\text {. Bot. }}$ Gard. 5 : 317. WIITE-LEAVED TOURXEFORTIA,

\section{HELIOTRÒPIUM [Tourn.] L. Sp. Pl. 130. 1753.}

Herbs or shrubs, with alternate mostly entire leaves, and small blue or white flowers, in scorpioid spikes, or scattered. Calyx-lobes or segments lanceolate, ovate, or linear. Corolla salverform or funelform, naked in the throat, its tube cylindic, its lobes imbricated, plicate or induplicate in the bud. Stamens included; filaments short, or none. Stigma conic or annular. Fruit 2-4-lobed, separating into 4, 1-seeded nutlets, or into 2, 2-seeded earpels. [Greek, sunturning, $i$. e., turning to or with the sun.] About 125 species, widely distributed. Type speeies: Heliotropium europaeum $\mathrm{L}$. Nutlets conic, strongly ribbed. united in pairs; flowers pale blue.
Nutlets subglobose or ovoid, smooth or rugose; flowers white or nearly white.

Nutlets united in pairs.

The four nutlets separating.

Plants glabrous, fleshy.

Plants pubescent.

Annual; flowers spicate.

Leaves obtuse.

Leaves acute or short-acuminate.

Perennials.

Flowers short-spicate: low shrub.

Flower's solitary in the axils; depressed peren-

1. H. indicum.

2. H. partiflorum.

3. H. curassavicum. nials.

Plants densely covered with appressed white hairs.

Leaves imbricated.

Leaves oblong or elliptic.

Leaves lanceolate.

Leaves scattered, linear.

Plant loosely strigose.
4. H. inundatum.
ธ. H. Eggersii.
6. Ir. ternatum.
7. H. nanum.
S. H. inaguense.
9. H. diffusum.
10. H. Nashii.

1. Heliotropium indicum I. Sp. Pl. 130. 1753.

Annual, hirsute or hispid; stem 3-9 dm. high. Leaves orate or oval, obtuse, rounded or subcordate at the base, 5-15 cm. long. repand or undulatemargined, petioled; flotrers blue, $4-6 \mathrm{~mm}$. broad, sessile in terminal dense bractless, usually solitary, scorpioid spikes; calyx-segments acute, shorter than the strigose corolla-tube; style very short, deciduous; fruit deeply 2-lobed, glabrous, about $2.5 \mathrm{~mm}$. long.

Waste and cultivated grounds, New Providence, near Nassau :-Florida, the West Indies and continental tropical America. Naturalized from the old World tropics. IXDIAN HELIOTROPE.

2. Heliotropium parvifiòrum I. Nant. 2: 201. 1771.

Annual, or sometimes of longer duration, loosely pubescent, branched, 2-8 $\mathrm{dm}$. high, or vine-like and $1 \mathrm{~m}$. long. Leaves oblong-lanceolate to elliptic, 7 
cm. long or less, acute or short-acuninate at the apex, narrowed at the base, the petioles 5-15 mim. long; spikes solitary or 2 together, slender, $5-15 \mathrm{~cm}$. long; calyx-lobes acute; corolla white, bearded in the throat, about $2 \mathrm{~mm}$. broad, its tube about as long as the ealyx; fruit didymous, depressed, $3-4 \mathrm{~mm}$. broad, finely pubescent.

Waste grounds, street sides, coppices, and sclub-lands, Great Sturrup, Little Harbor Cay, North Cat Cay, Andros, New l'rovidence, Elenthera, Cat Islaud, Watling's, Great Guana, Great Exuma, Long lslaud, Great liagged Island, Fol'tune Island, East Caicos and Inagua :- Florida: "Vest Indies and continental tropical America, IIORSE-BCSil. SORE-BUSH. SCORPION-TAIL.

\section{Heliotropium curassávicum L. Sp. Pl. 130. 1753.}

Annual, fleshy, more or less glaucous, diffuse, the branches $1.5-4.5 \mathrm{dm}$. long. Leares linear, or linear-oblong, entire, inconspicuously veined, $2-5 \mathrm{~cm}$. long, 3-6 mm. wile, obtuse, narrowed into petioles, or the upper sessile; scorpioid spikes dense, bractless, mostly in pairs; flowers about $4 \mathrm{~mm}$. broad; calyx-segments acute; corolla white mith a yellow eye or changing to blue; stigma umbrella-shaped; anthers acuminate; fruit globose.

Salinas, sea-beaches, margins of salt-ponds, Gun Cas, Andros, New Proridence, Eleuthera, Little San Salrador, Cat Island, Watling's, Great Exuma, Long Island, Fortune Island, Acklin's, Grand Turk, Inagua, and Cay Sal :-Bermuda; FIorida to Texas: coasts of the West Indies and continental tropical America. SEAside HELIOTROPE. POND-TEED.

\section{Heliotropium inundàtum Sw. Prodr. 40. 17ss.}

Annual, often branched from the basc, 1-6 dm. tall, the stems and leares gray-strigose. Leares oblong to oval or oblong-spatulate, $2-5 \mathrm{~cm}$. long, obtuse at the apex, narrowed at the base, short-petioled; spikes 1 or few, slender, at length 3-6 $\mathrm{cm}$. long; calyx $2-3 \mathrm{~mm}$. long, its lobes linear-lanceolate; corolla white, about as long as the calyx, its lobes lanceolate; nutlets subglobose, about $1 \mathrm{~mm}$. in dianeter.

Drr soil, Acklin's Island, Inagua:-Lonisiana to California, Panama and Paraguay; Cuba; Hispaniola: I'orto Rico; Jamaica: Trinidad. Recorded from Guadeloupe. Slexder Heliotrope. Erroneously called WILD THYMe.

\section{Heliotropium Eggérsii Urban, Srmb. Ant. 5: 4\$1. 1908.}

Annual, branched from the base, procumbent, $2 \mathrm{dm}$. long or less, the pubescence appressed or spreading. Leaves oblong-elliptic, 5-10 mm. long, densely sericeous, acute or short-acuminate at the apex, narrowed at the base, the slender petioles $1-3 \mathrm{~mm}$. long; spikes solitary or rarely in pairs, $t \mathrm{~cm}$. long or less, many-flowered, pilose; sepals unequal, four of them linear and $1 \mathrm{~mm}$. long, the fifth oblong and $1.5 \mathrm{~mm}$. long; corolla $1.5 \mathrm{~mm}$. long, its lobes sub. orbicular. much shorter than the tube; nutlets about $1.3 \mathrm{~mm}$. in diametcr, strigose, twice as wille as long.

Fortune Isiand. Endemic. Eggers' IIfLiotrofe.

\section{Heliotropium ternàtum Vahl, Symb. 3: 21. 1794.}

Tournefortia humilis L. Sp. Pl. 141. 1753. Not H. humile Lam. 1791.

A strigose-pubescent, bushy-branched shrub $6 \mathrm{dm}$. high or less, the branches slender, ascending. Leaves lanceolate or linear, scssile, subrerticillate in 3 's, or opposite, or alternate, $1-3 \mathrm{~cm}$. long, $1.5-8 \mathrm{~mm}$. wide, acutish, rerolutemargined, rough-strigose on both sides; flowers white, in short terminal spikes; calyx ahout $3 \mathrm{~mm}$. long, its lobes orate, acute; corolla-tube somewhat longer than the calyx, the limb $3-4$ nim. wide; nutlets subglobose.

Scrub-lands, Great Ragged Island:-Cuba to Virgin Gorda and Iartinlque; continental tropical America. LesHY IIELIOTROPE. 


\section{Heliotropium nànum Ninthrop, Nem. Torr. Club 12: 61. 1902.}

Slırubby, usually much branched, densely strigose-canescent, $8-15 \mathrm{~cm}$. high, the branches nearly erect ol ascending, slender. Leares oblong or elliptic, sessile, appressed, about $2 \mathrm{~mm}$. long, aente; flowers solitary at the axils, scattered, a little shorter than the leaves; calyx-lobes lanceolate, acute; corolla white, somewhat longer than the calyx, its lobes short, orate-oblong; stamens borne at about the middle of the corolla-tube; style short; stigma annular; fruit depressed-globose, 4-lobed, separating into 4 pubescent nutlets.

Sarannas, white-lands and sand dunes, Little Harbor Cay, Andros, New Providence. Lindemic. Low Asilx Heliotrope.

\section{Heliotropium inaguénse Britton, Bull. N. Y. Bot. Gard. 4: 122. 1905.}

A low shrub, 5-20 cm. high, intricately much-branched, very densely appressed-strigose all over with nearly white hairs. Leaves opposite, ascending or appressed, lanceolate or oblong-lanceolate, $3-5 \mathrm{~mm}$. long, about $1 \mathrm{~mm}$. wide, sessile, acutish, somewhat revolute-margined, mostly longer than the intermodes; flowers few, solitary and very nearly sessile in the upper axils; sepals similar to the upper leares; corolla white, its tube $2 \mathrm{~mm}$. long, its 5 orate acute lobes about $1 \mathrm{~mm}$. long, spreading; stamens nearly sessile on the corollatube below the middle; style very short, stout; stigma 4-lobed.

Whitelands, scrub-lands and sand dunes. Exuma Chain, Eleuthera, Cat Island. Concention Island, Little San Salvador, Long Island, Fortune Island, Great Ragged Island, Caicos, Turk's Islands and Inagua. Endemic. IXAGOA HeLotrope. White PUSSLEY.

\section{Heliotropium diffùsum Britton, Bnll. X. Y. Bot. Gard. 4: 122. 1905.}

Perennial by a slender deep root. Stem slender, $4 \mathrm{~cm}$. high or less, the branches diffusely spreading, very slender, longer than the stem, $8 \mathrm{~cm}$. long or less, appressed-strigose; leaves linear, $3-4 \mathrm{~mm}$. long, about $1 \mathrm{~mm}$. wide, sessile, acute, appressed-strigose; flowers white, minute, enclosed in the tufts of upper leaves; sepals lanceolate to ovate-lanceolate, acute, about $2 \mathrm{~mm}$. long, very hairy; ovary deeply 4-lobed; fruit 4-lobed, depressed, about $1 \mathrm{~mm}$. wide, and about one half as high as wide, the very short style capped by a broad abruptlytipped stigna.

Moist scrub-lands, Rum Cay, Acklin's, Mariguana, South Caicos, Grand Turk, sand Cay, Little Inagua. Endemic. DIFFese Low Heliotrope.

10. Heliotropium Náshii Millsp. Field Mns. Bot. 2: 309. 1909.

Heliotropium brevicaule Urban, Repert. 13: 474. 1915.

Diffusely branched, perennial, the branches rery slender, prostrate or nearly so, the young trigs appressed-pubescent. Leaves sessile, ovate, about $2 \mathrm{~mm}$. long and $1 \mathrm{~mm}$. Wile, acute, appressed-pubescent on both sides, the margins flat; floters solitary and sessile in the upper axils; calyx a little more than $1 \mathrm{~mm}$. long, its lobes orate-lanceolate, acutish; corolla white, $1.5-2 \mathrm{~mm}$. broad, its lobes orate, acute; fruit about $1 \mathrm{~mm}$. in diameter.

Scrub-lands, Inagun, near Matthew Town. Endemic. Referred by Hitchcock to H. microphyllum Sw. NASH'S IELIOTROPE.

\section{Family 7. VERBENÀCEAE J. St.Hil.}

\section{Tervalix Famiti.}

Herbs, shrubs or some tropical genera trees, with opposite verticillate or rarely alternate leares, and perfect irregular, or sometimes regular flowers, in spikes, racemes, cymes or panicles. Calyx inferior, mostly 
persistent, usually 4-5-lobed or 4-5-eleft. Corolla reguar, or 2-lipped, the tube usually erlindric and the limb 4-5-cleft. Stamens 4, didynamous, rarely only 2, or as many as the corolla-lobes, inserted on the corolla and alternate with its lobes; anther's 2-celled, the saes longitudinally dehiscent. Orary superior, 2-t-celled (rarely S-10-celled), composed of 2 carpels, each carpel with 2 anatropous or amphitropous orules, thus in 4-celled oraries 1 orule in each carity; style terninal; stigmas 1 or 2 . Funit dry, separating at maturity into $2-1$ mutlets, or a drupe containing the "2 1 nutlets. Endosperm little or none, or rarely fleshy; embryo straight. About 75 genera and 1,300 species, of wide geographic distribution.

A. Inflorescence centripetal, in spikes, heads or racemes.

inflorescence spicate or capitate.

spikes terminal.

Flowers partly buried in the rachis; stamens 2.

Flowers not buried in the rachis; stamens 4. Calyx elongated, cylindric in fruit. Calyx globular or oroid in iruit.

Spikes axiliary and terminal.

Rachis slender.

Flowers seattered along the axis ; fruit dry, horned. 4. Ghinia. Flowers densely or loosely capitate or spicate.

Fruit dr'y. Fruit fleshy.

Rachis thick; flowers capitellate.

Inflorescence racemose; racemes peduncled.

Drupe 2-psrenous, 4-spermous; stigma 2-lobed.

Orupe 4-psrenoús, S-spermous; stigma 4-lobed.

B. Inflorescence centrifugal, cymose.

Pyrenae separate.

Cymes short-peduncled; drupes 4-pyrenous.

Cymes loug-pedunclerl.

Drupe 1-pyrenous, 4-locularis.

Drupe 2-pyrenous, 2-locularis.

Pyrenae cohering in pairs.

Crmes axillary, short-peduncled; spiny shrub.

Cymes terminal; unarmed herbs or shrubs.

C. Inflorescence in pedunculate thyrsoid corymbs; fruit capsular.
1. Talerianoides.
2. Bouchea.
3. Prica.

\title{
5. Lippia. \\ 6. Lantana. \\ i. Nashio.
}

8. Cithavexylum.

9. Duranta.

\author{
10. Callicarpa. \\ 11. Petitia. \\ 12. Pscudocarpidium. \\ 12. Tolkameria. \\ 14. Clerodendrum.
}

15. Aviecnnia.

1. VALERIANoİdes [Boerh.] Medic. Phil. Bot. 1: 177. 1759.

Annual or perennial herbs, or shrubs. Leaves opposite or alternate, toothed. Flowers spicate, solitary and sessile in the axils of bracts, or imbedded in excarations of the thick rachis. Calyx membranous or herbaceous, its lobes 5, usually unchanged at maturity. Corolla-tube sometimes slightly dilated abore, the limb spreading, 5-lobed. Stamens 2, included; anthers with unappendaged connectires; staminodia 2, small. Ovary 2-celled. Orules solitary in each cavity. Fruit inclusled in the calyx, separating into 2 nutlets. [Signifies similarity to I'aleriana, but this is obscure.] More than 40 species, of tropical and subtropical America. Type species: Terbena jumaicensis L.

Shrub; leaves apically serrate, punctate; spikes sliort, $6-15 \mathrm{~cm}$. IIerb; leares ser'ate throughout, not punctate; spikes long, $12-$ $45 \mathrm{~cm}$.

1. T.fruticosa.

2. V. jamaiecnsis.

1. Valerianoides fruticòsa Millsp. Field Mus. Bot. 2: 178. 1906.

Stachytarpheta fruticosa B. L. Robinson, Proc. Am. Acal. 51: 531. 1916.

A glabrous shrub, 2 $\mathrm{m}$. high or less, the branches slender, the twigs 4 sided. Leaves lanceolate to oblong, ovate-lanceolate or oblanceolate, punctate, 4-8 cm. long, serrate above the middle, acute at the apex, narrowed at the base into petioles $\bar{j}-10 \mathrm{~mm}$. long; spikes $5-15$ em. loug, $3-4$ mm. thick; bracts 
orate-lanceolate or lanceolate, acuminate, $5-\tau$ mm. long; calyx compressed, 2-cleft; corolla purple; fruit obpyriform, about $6 \mathrm{~mm}$. long.

Rocky plains and scrub-lands, Grent Bahama, liose Island, Cay north of Wide Opening, Eleutlera, lium Cay, North Caicos, Grand Turk, Cotton Cay and Inagua.

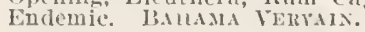

\section{Valerianoides jamaicénsis (L.) Kuntze, Rev. Gen. Pl. 509. 1591.}

Terbena jamaicensis L. Sp. PI. 19. 1753.

Stachytarpheta jamaicensis Tahl, Enum. 1: 206. 1805.

Abena jamaicensis Hitche. Rep. Mo. Bot. Gard. 4: 117. 1893.

Annual, often purplish, with sparingly pubescent or glabrate foliage. Leaves alternate or opposite, oblong, ovate or oval, $2-8 \mathrm{~cm}$. long, coarsely serrate, narrowed at the base, the petioles margined, as long as the blades or shorter; spikes stiff, $1.5-5 \mathrm{dm}$. long; bracts imbricated, lanceolate to oblonglanceolate, acuminate, serrulate, 5-8 $\mathrm{mm}$. long; flowers in depressions of the rachis; calyx-lobes triangular or triangular-ovate; corolla blue, somewhat irregular, S-11 mm. long, its tube slightly curved, the limb $\mathrm{S} \mathrm{mm}$. broad; nutlets $3 \mathrm{~mm}$. long, buried in the rachis.

Waste places, coppices and scrub-lands, throughout the archipelago from Great Bahami and the Berry Islands to Andros, East Caicos, Grand Turk and lnagua :Bermuda: Florida: West Indies, and continental tropical America; Old World tropics. JaMaica Vervali. Blue-Flower.

\section{BoUCHÈA Cham. Linnaea 7: 252. 1832.}

Herbs or low shrubs, with opposite petioled toothed leares, and small flowers in terminal bracted spikes or narrow racemes. Calyx tubular, 5. toothed, 5-ribbed, cylindric in fruit. Corolla-tube cylindric, slender, the limb obliquely spreading, 5-cleft, the lobes nearly equal. Stamens 4, didynamous, borne on the corolla-tube at or above the middle; filaments short; anthers ovate. Ovary 2-celled; ovules 1 or 2 in each cavity, erect; style filiform, subclarate above. Fruit linear or oblong, dry, enclosed in the calyx, separating into 2 linear nutlets. [Commemorates P. C. Bouché and C. D. Bouché, German gardeners.] About 15 species of tropical and warm temperate regions. Type species: Terbena Pseudogervao St. Hil.

1. Bouchea prismática (iL.) Kuntze, Rer. Gen. Pl. 502. 1891.

Verbena prismatica L. Sp. Pl. 19. 1753.

Bouchea Ehrenbergii Cham. Linnaea 7: 253. 1832.

Annual, erect, simple or fer-branched, finely pubescent, 2-5 dm. high, the branches ascending. Leaves ovate, slender-petioled, $2-6 \mathrm{~cm}$. long, serrate all around, acute at the apex, obtuse or subtruncate at the base; racemes narrow, elongated, often $2 \mathrm{dm}$. long or longer; pedicels very short, about $1 \mathrm{~mm}$. long, erect; calyx narrowly cylindric, appressed to the axis of the raceme, about 10 $\mathrm{mm}$. long, its teeth linear-subulate, about one-third as long as the tube; corolla violet or purplish, about $10 \mathrm{~mm}$. long; fruit a little longer than the calyx.

A meed in waste places, New Providence and Cat Island :-Cuba to St. Thomas and Antigua; Barbadoes; Jamaica; Curaço; Mexico to Venezuela. NArrow-Fruted VERTAIN.

3. PRİVA Adans. Fam, Pl. 2: 505.1763.

Perennial caulescent herbs. Leares opposite, membranous, toothed, the flowers in slender peduncled racemes. Calyx-tube 5-ribbed; lobes 5. Corolla 
salverform, its tube straight or incurved, slightly dilated abore, its limb spreading, oblique, slightly 2-lipped, with 5 short lobes. Stamens 4 , didynamous, included; anthers with parallel or slightly divergent sacs. Orary 2celled, each cavity with more or less well developed septa. Orules 2, or by abortion 1, at base of each cavity. Fruit enclosed in the calyx, separating into 2 nutlets. [Name unexplained.] Abont 10 species, of tropical distribution, the following typical.

1. Priva lappulàcea (L.) Pers. Syn. 2: 139. 1806.

Terbena lappulacea L. Sp. Pl. 19. 1753.

Priva cchinata Juss. Aun. Mus. Par. 7: 69. 1806.

More or less pubescent. Stems 2-6 dm. tall, branching: leaves orate, 2-10 $\mathrm{cm}$. long, acute or acuminate, serrate, truncate or cordate at the base, the petioles much shorter than the blades; racemes loosely flowered, $5-15 \mathrm{~cm}$. long; pedicels 1-2 mm. long; calyx cylindric-prismatic, 2-3 mm. long, accrescent, pubescent; corolla slightly surpassing the calyx, salverform, with short rounded lobes; fruit oroid-pyramidal, $5-7 \mathrm{~mm}$. long; nntlets included in the calyx, spiny-tuberculate on the back, 3-4 $\mathrm{mm}$. long.

Waste places, coppices and cultivated ground. Abaco, Andros. New Proridence, Eleuthera, Watling's, Parrot Cay and Inagua :-Florida: West Indies: Mexico to Brazil. Erroneously referred by Dolley to Teucrium inflatum Sw. Bur VEnrar. CAT'S-TOXGLE.

4. GHINIA Schreb. Gen. 19. 1789.

[TAMoxèA Aubl. Pl. Guian. 2: 659, pl. 268. 1775.

Not Aubl. 1: 441, pl. 175. 1775.]

Herbs or low shrubs, with slender stiff branches, opposite, nearly sessile, dentate or incised leaves, and small bracted flowers in terminal and axillary slender spikes. Calyx tubular, subtruncate, 5-ribbed, the ribs excurrent as short teeth. Corolla with a cylindric tube slightly enlarged above, and an oblique, spreading, 5-cleft limb. Stamens 4, didynamous, borne on the corolla. tube, included; anther-sacs parallel, the connective with a gland-like appendage. Ovary nearly completely 4-celled; ovule 1 in each cavity; style short; stigma oblong. Fruit small, hard, mostly 4-horned, 4-celled. Seeds usually 4, without endosperm. [Guiana name.] Four or five species, of tropical America. Type species: Tamonea spicata Aubl.

1. Ghinia curassávica (L.) Millsp. Field Mus. Bot. 2: 17t. 1906.

Terbena curassavica L. Sp. Pl. 19. 1753.

Tamonea curassavica Pers. Syn. Pl. 2: 139. 1806.

Tamonca scabra Cham. \& Schl. Linnaea 5: 99. 1830.

Erect, simple or branched, roughish, 2.5-6 dm. high, slender. Leares crate, short-petioled, membranous, sparingly puberulent, $2-4 \mathrm{~cm}$. long, serrate, acute at the apex, mostly obtuse at the base; racemes long-pelunelell. very slender, the flowers distant; pedicels shorter than the calyx; calyx oblong. about $4 \mathrm{~mm}$. long, distended by the ripening fruit and becouning obconic, its teeth linear, about $1 \mathrm{~mm}$. long; corolla 5-6 $\mathrm{mm}$. long; fruit $4-5 \mathrm{~mm}$. loug, its spines 1-2 $\mathrm{mm}$. long. TerTat:

A weed in waste places, New Irovidence:-Cuba; Mexico. SPri-Fruten

5. LIPPİA L. Sp. Pl. 633. 1753.

Perennial herbs, or shrubs, with opposite, or rarely alternate leaves, and small bracted flowers, in spikes or heads. Calyx suall, oroid, campanulate or 
compressed and 2-winged, 2-1-toothed or 2-4-cleft. Corolla-tube cylindric, the limb oblique, somewhat 2-lipped, 4-eleft. Stamens 4, didynamous; anthers orate, not appendaged, the sacs nearly parallel. Orary 2-celled; orules 1 in each carity; style short; stigma oblique or recurved. Fruit dry, with a mem. branous exocarp, at length separating into 4 nutlets. [Named in honor of Auguste Lippi, 167S-1703, a French naturalist.] About 100 species, most abundant in tropical America. Type species: Lippia americana $\mathrm{L}$.

Shrubs, erect or ascending.

Leaves lanceolate, sharply serrate.

Leaves ovate or oblong. crenate.

Prostrate or ascending herhs.

Leares inconspicuously reined.

Leaves usually prominently reined.

1. L. stocchadifolia.

2. L. geminatu.

3. $I$. nodiflara.

4. L. reptans.

1. Lippia stoechadifòlia (L.) H.B.K. Nov. Gen. 2: 265. 1818.

Terbena stoechadifolia L. Sp. Pl. 19. 1753.

Phyle stoechadifolia Small, Bull. N. Y. Bot. Gard. 36: 162. 1909.

Shrubby, loosely appressed-strigose, ascending or suberect, usually little branched, 2-4 dm. high. Leaves narromly lanceolate or oblong-lanceolate, rather firm in texture, $2.5-6 \mathrm{~cm}$. long, strongly pinnately veined, sharply and evenly serrate, acute at the apex, narrowed into short petioles; peduncles axillary or lateral, mostly longer than the leaves; heads at first subglobose, at length oblong-cylindric, 1-2 cm. long, obtuse; bracts suborbicular, mucronate; calyx 2-toothed, compressed; corolla about $4 \mathrm{~mm}$. long, longer than the bracts, its tube trice as long as the calyx.

Borders of fresh-water pockets and ponds, New Providence, Cat Island, Watling's, Great Exuma, Long Island and Fortune IsIand:-Cuba ; Porto Rico; Guadeloupe; Jamaica; Mexico. MARSH LIPPIA.

\section{Lippia geminàta H.B.K. Nor. Gen. 2: 266.1818.}

Lippia geminata microphylla Griseb. Fl. Br. W. I. 495. 1861.

An aromatic, densely puberulent shrub $1 \mathrm{~m}$. high or less, usually much branched, the branches slender. Leaves orate or oblong, $1.5-7 \mathrm{~cm}$. long, acute or obtuse at the apex, narrowed at the base, crenate or crenulate, puberulent, rugose above, the petioles $3-8 \mathrm{~mm}$. long; peduncles axiiary mostly much shorter than the leaves; heads subglobose, or short-oblong, 8-12 $\mathrm{mm}$. Iong; bracts ovate, puberulent, acute, about $3 \mathrm{~mm}$. long, nearly as long as the corolla; calyx 2-toothed; corolla purple, violet or white, its tube about 3 times as long as the calyx.

Turk's Islands (according to Grisebach), not found there by us :-Cuba; Jamaica ; Porto Rico; Antigua to Trinidad; continental tropical America. Often planted for its fragrant foliage. Bushr LipPia.

3. Lippia nodiflòra (L.) Michx. Fl. Bor. Am. 2: 15. 1803.

Terbena nodiflora L. Sp. Pl. 20. 1753.

Phyla nodiflora Greene, Pittonia 4: 46. 1899.

Minutely and rather densely puberulent, herbaceous, creeping, or the branches ascending, 3-9 dm. long. Leaves thickish, spatulate, oblanceolate, or obovate, 1-6 cm. long, $0.6-2.5 \mathrm{~cm}$. wide, inconspicuously reined, mostly cibtuse, narrowed into a cuneate entire base, sharply serrate abore the middle; heads at length eylindric and $1-2.5 \mathrm{~cm}$. long; corolla purple to white, little longer than the bracts.

Palmetto lands and moist waste places. Great Babama, North Cat Cay, New Providence, Mariguana, Acklin's, Fortune Island, Grand Turk and Inagua:-Bermuda ; North Carolina to Texas: West Indies: Mexico to northern South America; warmtemperate and tropical parts of the Old World. Referred by Mrs. Northrop and by Coker to $L$. canesecns H.B.K. CAPE-TEED. CREePiNg LiPPia. 
4. Lippia réptans H.B.K. Nor. Gen. 2: 263. 1818.

Similar to $L$. nodiflora, densely appressed-strigilose, herbaceous, the stems prostrate or aseending, 2-5 dm. long. Leaves obovate, 2-6 $\mathrm{cm}$. long, obtuse or acutish at the apex, cuneate at the base, coarsely and sharply dentate above the base, usually rather prominently veined, the petioles $5-10$ nim. long; peduneles mostly longer than the leaves; heads oroid, becoming subeylindrie and $2 \mathrm{~cm}$. long or less; corolla white.

Margins of brackish marshes, sarannas and pools, Eleuthera and Inagua:-Cuba to St. Croix and to Barbadoes: Jamaica: Mexico to Brazil. This species is, apparently, not certainly distinct from the preceding. LARGEn CrEEPING LipPIA.

\section{LANTÀNA L. Sp. Pl. 626. 1753.}

Shrubs, or rarely herbs, with pubescent foliage, the stems sometimes armed with prickles. Leares opposite, toothed. Flowers in dense peduncled heads or spikes. Calyx membranous, with a truncate or sinuate border. Corolla-tube slender, often curved, sometimes slightly dilated above, the limb more or less 2-lipped, the lobes 4 or 5 . Stamens 4, didynamous; filaments adnate to about the middle of the corolla-tube. Ovary 2-celled; stigma oblique; orules solitary in each cavity. Fruit small, drupe-like. Nutlets 2celled or separating into 2 one-seeded nutlets. [Named from fancied similarity to Tiburnum Lantana.] About 60 species, natives of tropical and warm regions. Type species: Lantana Camara L.

Flowers yellow or orange or changing to orange or red, not involucrate.

Leaves ovate, truncate or subtruncate at the base; straggling shrub.

Leares orate to lanceolate, narrowed at the base ; erect shrubs. Corolla orange, changing to red; bracts half as long as the corolla-tube.

Corolla yellow, changing to orange; bracts one-third as long as the corolla-tube.

Flowers white to lilac, often with a sellow eye or throat, involucrate.

Leaves $2-1 \mathrm{~cm}$. long.

Leares ovate to elliptic or oborate, not more than twice as long as wide.

Leaves oblong to oblanceolate, 2.5 to 3 times as long as wide.

Leares $10 \mathrm{~mm}$. long or less.

1. L. oratifolia.

2. L, Camara.

3. L. bahamensis.

4. L. involucrata.

5. L. demutata.

6. L. balsamifcra.

1. Lantana ovatifòlia Britton, Bull. N. Y. Bot. Gard. 4: 123. 1905.

Stems woody, little branched, diffusely spreading, $7 \mathrm{dm}$. long or less, bluntly 4-angled, very rough-pubescent with stiff appressed hairs. Leaves orate, thick, short-petioled, $5 \mathrm{~cm}$. long or less, rery scabrous on the upper surface, rough-pubescent with stiff hairs beneath, especially on the 4 to 6 principal veins on each side of the prominent mid-vein, acute at the apex, abruptly cuneate-narrowed at the obtuse or subtruneate base, the margin low-crenate nearly all around; petioles rather stout, rough, $3-5 \mathrm{~mm}$. long; peiluneles axillary, slender, about $4 \mathrm{~cm}$. long, smooth or nearly so when old; corolla-tube orange-retl, the limb yellow, about $6 \mathrm{~mm}$. broad; fruit subglobose, about 4 mm. in diameter, black, shining.

Pine-lands, copplces and scrub-lands, Great Babama and Andros:-l*lorida. Andros plants were referred by Mrs. Northrop to $I_{\text {. }}$ crocca Jacq. Ovite-LEavid L.NTANA.

2. Lantana Camàra L. Sp. P1. 627. 1753.

A branching shrub 1-1.5 m. tall, rigid-pubescent, nearly or quite unarmed. Leares orate to oblong-orate, 4-12 cm. long, obtuse, acute, or short-acuminate, 
finely erenate-serrate, rounded or narrowed at the base; bracts oblong to lanceolate, 4-7 mm. long; calyx very thin, $3 \mathrm{~mm}$. long; corolla orange-yellow or orange, changing to rel, the tube about $1 \mathrm{~cm}$. long, puberulent, slightly curved, barely enlarged above the middle; limb 6-8 mm. wide; drupes black, about 3 mm, in diameter.

Waste grounds, Fleuthera, Watling's, Long Island and Inagua:-Bermuda; Georgia to l'loridi and 'Fexis: West lndies and continental tropical America. IReferred to by Coker as $L$. crocea as to his Eleuthera plant. LAstax.. IRed Sige-Busir.

\section{Lantana bahaménsis Britton, Bull. N. Y. Bot. Gard. 3: 450. 1905.}

Shrub $1 \mathrm{~m}$. high or less, with slender striate branches, which are smooth or sometimes bear minute prickles less than $0.5 \mathrm{~mm}$. long, the twigs minutely pubescent; leaves thin, oblong-lanceolate, varying from acute to blunt at the apex, more or less narrowed at the base, and somewhat decurrent on the petiole, minutely short-pubescent on both sides, or becoming glabrous above, closely crenate, the primary veins rather conspicuous on the under side; blades $5 \mathrm{~cm}$. long or less, 1.5-2 $\mathrm{em}$. wide; petioles very slender, $2 \mathrm{em}$. long or less; peduncles terminal and axillary, shorter than the leaves; bracts lanceolate, acntish, very pubescent, about $4 \mathrm{~mm}$. long; flowers $8-15$ in the heads; calyx $2 \mathrm{~mm}$. long, pubescent, the 2 short lips abont equal; corolla yellow, changing to orange, its tube pubescent, enlarger above, about $8 \mathrm{~mm}$. long, its limb about $4 \mathrm{~mm}$. wide, irregularly lobed; fruit globose, black, shining, about $3 \mathrm{~mm}$. in diameter.

Scrub-lands and coppices, Andros. New Providence, Eleuthera, Cat Island, Watling's, Rum Cay, Great Exuma, Long Island, Acklin's and North and East Caicos:Cuban Cays. The New J'oridence plants were l'eferred by Mrs. Northrop to $L$. Cumara, and by Hitchcock, Grisebach and Dolley to the Jamaican $L$. crocea. Erroneously called Goldex-Rod, Bafama Lantaxa.

4. Lantana involucràta L. Cent. Pl. 2: 22. 1756.

Lantana odorata L. Syst. ed. 12, 41S. 1767.

A pubescent, much branched shrub, 6-15 dm. high, the branches stiff, nearly terete. Leares elliptic or ovate, petioled, 1-4 cm. long, crenulate, obtuse at the apex, narrowed or obtuse at the base, scabrous above, pubescent beneath; peduncles $1-5 \mathrm{~cm}$. long, slender; heads several-flomered, involuerate by several orate or orate-lanceolate bracts $3-6 \mathrm{~mm}$. long; corolla lilac or nearly white, its tube $6-8 \mathrm{~mm}$. long; drupes about $4 \mathrm{~mm}$. in diameter; drupes blue, about $3 \mathrm{~mm}$. in diameter.

Scrub-lands, thickets and pine-lands, throughout the archipelago from Allen's Cay and Great Bahama to Grand Turk, Little Ambergris Cay, Inagua, the Anguilla Isles and Cay Sal :- Florida: Bermuda; Cuba to Virgin Gorda and Guadeloupe; Jamaica. Wild Sage. Big Sage.

\section{Lantana demutàta Millsp. Field Mus. Bot. 2: 175.1906.}

A widely branched shrub, 1-2 $\mathrm{dm}$. high, the young twigs densely puberulent, the older ones glabrous. Leaves oblong or oblanceolate, short-petioled, 1-2 cm. long, erenate, puberulent on both sides, rugose and scabrous above; peduncles slender, puberulent, 2-4 cm. long; heads 5-8-flowered, involucrate by ovate or oblong obtuse bracts about $4.5 \mathrm{~mm}$. long; flowers white; corollatube about $3 \mathrm{~mm}$. long; drupes blue, pubescent, 2-3 $\mathrm{mm}$. long.

Scrub-Jands, Harbor Island, Eleuthera, Cat Island, Great Exuma and Long Island. Endemic. BaHaJA SAgE-besh.

\section{Lantana balsamifera Britton, Bull. N. Y. Bot. Gard. 4: 123. 1905.}

A shrub, $1.6 \mathrm{~m}$. high or less, forming large masses, with a balsamic odor, the slender bluntly angular branches ascending, puberulent; the internodes short. Leares elliptic to orate elliptic or nearly orbicular, 5-10 mm. long, 5 $\mathrm{mm}$. wide or less, puberulent, acute or obtuse, firm, crenulate, rugose-reticulated above, paler and rather strongly veined beneath, the petioles 1-1.5 $\mathrm{mm}$. long; 
peduncles slender, thickened abore, $8-15 \mathrm{~mm}$. long in fruit; heads about $6 \mathrm{~mm}$. broad, sereral-flowered; bracts lanceolate, pubervlent, obtusish, 2.5-3 inm. long; calyx 2-toother?, pubescent, $1 \mathrm{~mm}$. long, its teeth blunt; corolla purple. its slightly gibbous tube about $3 \mathrm{~mm}$. long, its spreading limb with 5 unequal obtuse lobes: stamens borne near the top of the corolla-tube, the anthers as long as the filaments or longer.

Scrub-lands, Little Inagua, at Ionjean IIarbor. Endemic. Ix̃guA S.af-BUsir. A small-leaved shrub, growing iu sand alongside typical $L$, in rolucrata on Whale Cay, Berry Islands, appearing very distinct from it, and a simllar specimen from Eleuthera, first referred by us to this species, may represent another race or species: these specimens are barren.

\section{NÁshIA Millsp. Field Mus. Bot. 2: 176. 1906.}

Pubescent aromatic shrubs, with rather stout branches, opposite or fascicled leares and small capitate bracteolate, white or greenish flowers. Calyx short, annular, subtruneate. Corolla tubular-campanulate, its limb nearly equally 4-lobed. Stamens 4, didynamous, nearly equal in length. Orary 2-celled. Fruit drupaceous, small, the bony nutlets coherent. [Dedicated to George Valentine Nash.] Tro or three species of the Bahamas and Cuba, the following trpical.

1. Nashia inaguénsis Millsp. Field Mus. Bot. 2: 177. 1906.

Lippia inaguensis Urban, Symb. Ant. 7: 353. 1912.

A much-branched shrub $2 \mathrm{~m}$. high or less, the bark gray, the branches ridely spreading, the young twigs densely short-pubescent, elliptic to oborate or spatulate, 5-10 $\mathrm{mm}$. long, obtuse at the apex, narrowed at the base, rugose and sparingly pubescent abore, tomentose beneath, the margin entire, revolute, the petioles about $1 \mathrm{~mm}$. long; hearls axillary, sessile, few-flowered; bracts ciliate, apiculate, longer than the flowers; corolla white, about $2 \mathrm{~mm}$. long; drupes pyriform, about $4 \mathrm{~mm}$. long; nutlets smooth.

Scrub-lands, Inagua, near Matthew Tomn. Endemic. Moujeax TEA.

8. CITHARÉXYLUM L. Sp. P1. 625. 1753.

Trees or shrubs, with alternate leares and small flowers in terminal or axillary spikes or racemes, the pedicels subtended by minute bracts. Calyx narrowly campanulate, minutely $\overline{5}$-lobed, persistent. Corolla salverform, its limb slightly oblique, 5 -lobed. Stamens 4 or 5 , adnate to the corolla-tube, the fifth one mostly sterile or rudimentary; filaments filiform. Orary sessile, incompletely 4-celled; orules solitary, anatropous; stigma 2-lobed. Drupes berry-like, the fleshy pulp enclosing a bony stone which separates into 2, 2seeded nutlets. [Greek, fidlle-wood; French, bois fidèle.] About 20 species, of tropical America. Type species: Citharexylum spinosum L.

Flowers subsessile; nutlets 2-celled.

Flowers with pedicels longer than the bracts; nutlets 1-celled.

1. C. fruticosum.

2. C. coudatum.

1. Citharexylum fruticòsum L. Syst. el. 10, 1115. 1759.

Citharexylum cinereum L. Sp. Pl. ed. 2, 872. 1763.

Citharexylum villosum Jacq. Icon. Rar. 1: 12. 1756.

Citharexylum subserratum Sw. Prodr. 91. 1788.

Citharexylum bahamense Millsp. Bull. N. Y. Bot. Gard. 3: 450. 1905

A tree, attaining a maximum height of about $10 \mathrm{~m}$., with a trunk up to $2 \mathrm{dm}$. in liameter, the nearly smooth bark light brown, the twigs slender and 
angled, the foliage glabrous or pubescent. Leares oblong to obovate, various, 5-15 cm. long, 1-4 cm. Wile, acute, obtuse or emarginate at the apex, narrowed at the base, reticulate-reined, shining above, dull beneath, the petioles $2.5 \mathrm{~cm}$. long or less; spikes slender, $5-12 \mathrm{~cm}$. long; pedicels $1 \mathrm{~mm}$. long or less; calyx narrowly campanulate, about $3 \mathrm{~mm}$. long; corolla white, its tube somewhat longer than the calyx, its spreading limb about $6 \mathrm{~mm}$. wide; drupe subglobose, $\hat{b}-10 \mathrm{~mm}$. in diameter, reddish brown to black; nutlets 2-celled.

Coppices and scrub-lands, Abaco and Andros to Mariguana, Last Caicos and Inagua :- Florida: Cuba to Virgin Gorda and Guadeloupe; Jamaica. leferred by Mrs. Northrop to $C$. Berterii spreng, by Coker to $C$. quadrangulare Jacq. The species consists of a large number of l'ices, the leaves vilying flom glabrous to pubescent and from narrowly lanceolate or oblanceolate to obovate, occasionally dentate. SPICATE FIDDLEWOUD. LOXig TOM.

2. Citharexylum caudàtum L. Sp. PI. ed. 2, si2. 1763.

Citharexylum Berterii Spreng. Syst. 2: 763. 1825.

Citharexylum lucidum Cham. Linnaea 5: 97. 1830.

A shrub, or a tree up to $20 \mathrm{~m}$. high, the nearly terete, slender twigs glabrous. Leaves oblong, rather thin, $7-15 \mathrm{~cm}$. long, mostly obtuse at the apex, narrower at the base, shining above, dull beneath, the petioles $1-2 \mathrm{~cm}$. long; racemes narrow, elongated, 4-8 dm. Iong; pedicels $1.5-3 \mathrm{~mm}$. long; calyx campanulate, about $3 \mathrm{~mm}$. long, nearly truncate; corolla white, its tube about trice as long as the calyx, its limb spreading, 4-5 $\mathrm{mm}$. wide; drupe globose-oblong, black, shining, 2-3 times as long as the calyx; nutlets 1-celled.

Coastal coppices, Andros, at Conch Sound:-Cuba; Hispaniola; Porto Rico; Mexico. RaCeMose FiddeEWOOD.

\section{DURÁNTA L. Sp. Pl. 637. 1753.}

Shrubs or small trees, the branches sometimes armed. Leaves opposite or whorled, entire or toothed. Flowers small, in elongated or short, terminal or axillary racemes. Calyx-tube campanulate or tubular, truncate or minutely 5-lobed. Corolla funnelform or salverforn, its tube cylindric, straight or incurved, its limb spreading, oblique or of 5 equal lobes. Stamens 4, didynamous, included; anthers with unappendaged connectives, the sacs distinct. Orary partially or imperfectly s-celled. Stigma oblique, sometimes unequally 4-lobed. Orules solitary or 2 in each cavity. Drupe included in the calyx, of 4 nutlets. Seeds without endosperm. [In honor of Castor Durante, a physician of Rome.] About $S$ species, of tropical America, the following typical.

\section{Duranta rèpens L. Sp. Pl. 637. 1753.}

Duranta Ellisia Jaeq. Enum. 26. 1760.

Duranta Plumieri Jacq. Select. Am. 186. 1763.

A shrub or small tree reaching a height of $6 \mathrm{~m}$., with glabrate or finely pubescent foliage and unarmed or spiny, slender, often drooping or trailing branches. Leares numerous, ovate-elliptic, oval or obovate, $1.5-5 \mathrm{~cm}$. long, obtuse or apiculate, entire or serrate above the middle, short-petioled; racemes 5-15 cm. long, recurving; pedicels $1-5 \mathrm{~mm}$. long; caly $3-4 \mathrm{~mm}$. long, angled, its lobes acnte, shorter than the tube; corolla lilac, the tube surpassing the calyx, the limb 7-9 mm. broad; fruit yellow, globular, $7-11 \mathrm{~mm}$. in diameter, enclosed by the accrescent vellowish calyx which is produced into a curted beak.

Pine-lands and scrub-lands, Abaco, Great Bahama, Andros, New Providence, Eleuthera, Cat Island, Acklin's and Mariguana :-Bermuda; Florida ; West Indies and Mexico to northern South America. Figeox-BERry. 


\section{CALlicärpa L. Sp. Pl. 111. 1753.}

Shrubs or trees, with opposite leaves, and small blue purple or white flowers in axillary eymes. Calyx short, campanulate, 4-toothed (rarely 5toothed), or truncate. Corolla-tube short, expanded above, the limb 4 -cleft (rarely 5-eleft), the lobes equal. Stamens 4 , equal, exserted; anther-sacs parallel. Ovary incompletely 2-celled; ovules 2 in each carity, laterally attached, amphitropous; style slender; stigina eapitate, or 2-lobed. Fruit a berry-like drupe, much longer than the ealyx, containing 1-4 nutlets. [Greek, handsome fruit.] About 35 species of Asia, Africa and America. Type species: Callicarpa americana $\mathrm{L}$.

\section{Callicarpa Hitchcóckii Millsp. Field Mus. Bot. 2: 312.1909.}

A shrub, 2-3 m. high, with weak elongated rine-like branches, the slender trigs densely brown-scurfy. Leaves oblanceolate or linear-oblanceolate, subcoriaceous, $2-3 \mathrm{~cm}$. long, $\overline{5}-\boldsymbol{i} \mathrm{mm}$. wide, rerolute-nargined, rugose, glabrous and dark-green above, densely brown-scurfy beneath, obtuse at the apex, narrowed at the base, entire, the petioles about $4 \mathrm{~mm}$. long; cymes ferr-sereralflorered, much shorter than the leares: calyx glabrous, obscurely toothed; corolla white; fruit subglobose, bluish, resinous-dotted, about $5 \mathrm{~mm}$. in diameter.

Scrub-lands, pine-lands and savannas, Andros. New Providence and Cat Island :Cuban Cars. Referred-by Hitchcock, and in Field Col. Mus. Bot. 2: 1s0, to C. fulva A. Rich. BOAR-HOG Busil.

\section{PETitia Jaeq. Enum. 1, 12. 1760.}

Trees or shrubs, with large opposite entire petioled tomentulose leaves, and small axillary eymose-paniculate flowers. Calyx campanulate, 4-toothed or subtruncate. Corolla short-salverform, the limb spreading, 4-eleft, the lobes imbricated. Stamens 4, borne near the top of the corolla-tube, equal; filaments very short; anthers ovate. Ovary 2 -celled; ovules 2 in each cavity; style 2-cleft at the apex. Fruit a small drupe, the endocarp 2-1-celled. [Commemorates François Petit, 1664-1741, a French physician.] Two or three species of the West Indies and Mexico, the following typical.

\section{Petitia domingénsis Jaeq. Enum. 12. 1760.}

Petitia Poeppigii Schauer, in DC. Prodr. 11: 639. 1547.

A tree, up to $22 \mathrm{~m}$. high, usually much smaller or sometimes a shrub, the slender twigs, the petioles and the inflorescence densely brownish-tomentulose. Leaves elliptic-oblong or elliptic-lanceolate, $7-15 \mathrm{~cm}$. long, rather thin, acute or acuminate at the apex, obtuse or rounded at the base, dark green, dull and glabrous or nearly so abore, rusty-tomentulose beneath, the slender petioles $7 \mathrm{~cm}$. long or less; panicles many-flotrered, as long as the leaves or shorter; calyx about $1.5 \mathrm{~mm}$. long; corolla whitish, its tube about trice as long as the calyx, its limb $4-5 \mathrm{~mm}$. broad; flowers fragrant; drupes nearly black, globose to obovoid, 4-5 $\mathrm{mm}$. in diameter.

Pine-barrens, coppices and scrub-lands, Abaco, Great Bahama, Andros, New Providence, Eleuthera, and Cat Island:-Cuba: Hispaniola: Porto iRico: Jamalca; Cayman Islands. Recorded from St. Croix. I'etitia. Bistalid Stoprer.

\section{PSEUdOCARPidtuM Millsp. Field Mus. Bot. 2: 181. 1906.}

Shrubs or trees, with opposite petioled simple subcoriaceous, spinulosedentate or entire leares, and small axillary panicled flowers. Calyx campanu- 
late, equally 5-lentate. Corolla tubular-funnelform or salverform, the limb 2-lipped, 5-lobed. Stamens 4, exserted. Ovary at length 4-celled; style simple; stigma 2-cleft. Fruit dry or slightly fleshy, 3-4-lobed. [Greek, false carpid.] Six known species, of Cuba and the Bahamas. Type species: Vitex ilicifolia A. Rich,

\section{Pseudocarpidium Wríghtii Millsp. Field Mus. Bot. 2: 182. 1906.}

A shrub or small tree $u$ p to $5 \mathrm{~m}$. high, the young twigs and the inflorescence puberulent, the bark light gray or nearly white. Leaves elliptic to oborate or ovate-lanceolate, $2-5 \mathrm{~cm}$. long, obtuse at the apex, rounded or subcordate at the base, spinulose-dentate, glabrous, shining and reticulate-reined abore, puberulent at least on the veins beneath, the petioles $3-5 \mathrm{~mm}$. long; panicles peduncled, several-many-flowered, mostly exceeding the leaves; calyx 2-3 mm. long, its tecth ovate, acute; corolla violet, about 4 times as long as the calyx; fruit depressed, about $8 \mathrm{~mm}$. broad, its lobes rounded.

Coppices and scrub-lands, Andros and Mangrove Cay:-Cuba. Recorded by Mrs. Northrop as Titex ilicifolia A. Rich., which it resembles. WRight's I'SEUDOCARPIDIUM.

13. VOLKAMÈRIA L. Sp. Pl, 637. 1753.

A vine-like, spiny shrub, with opposite petioled entire leaves, and white flowers in axillary eymes. ('alyx campanulate, 5-toothed. Corolla salverform, with a slender tube, the limb 5-lobed. Stamens 4, exserted, somewhat unequal. Style filiform. Stigma 2-lobed. Fruit a subglobose drupe, the 2 nutlets each 2-celled. [In honor of J. C. Volkamer, a Nuremberg botanist, who died in 1720.] Only the following species, native of tropical America.

1. Volkameria aculeàta L. Sp. PI. 637. 1753.

Clerodendron aculeatum Griseb. Fl. Br. W. I. 500. 1861.

Ovieda aculeata Hitche. Rep. Mo. Bot. Gard. 4: 118. 1893.

Climbing to a length of $3 \mathrm{~m}$. or more, or nearly erect, the slender branches densely puberulent, armed with stout oposite spreading spines $8 \mathrm{~mm}$. long or less. Leaves thin, slender-petioled, oblong to elliptic-obovate, obtuse or acute at the apex, narrowed to the base, $2-5 \mathrm{~cm}$. long; cymes stalked, fewseveral-flowered; pedicels slender, puberulent, 6-14 mm. long; calyx about 3 $\mathrm{mm}$. long, puberulent, its teeth triangular-ovate, acute; tube of the corolla about $18 \mathrm{~mm}$. long, its limb about $12 \mathrm{~mm}$. broad; stamens purple; drupe 4grooved, 6-8 $\mathrm{mm}$. in diameter.

Scrub-lands, New Providence and Inagua:-Bermuda; Cuba to Virgin Gorda and Martinique; Jamaica; continental tropical America. I'RICKLY MrRTu.

\section{CLERODÉNDRUM [Burm.] L. Sp. Pl. 637. 1753.}

Shrubs, vines or perennial herbs, with opposite entire leaves, and flowers in terminal or axillary cymes or panicles. Calyx 5-toothed or 5-lobed. Corolla salverform or funnelform, the tube mostly longer than the 5-lobed limb. Stamens 4 , borne on the corolla-tube, exserted, somewhat unequal. Stigma 2 lobed; ovary 4-celled. Fruit a drupe, enclosing 4, 1-seeded nutlets. [Greek, tree of fortune.] Probably 100 or more species, mostly natives of tropical regions. Type species: Clerodendrum infortunatum L. 
1. Clerodendrum fràgrans Tent. Jard. Malm. pl. 70. 1504.

Ovieda fragrans Hitche. Rep. Mo. Bot. Gard. 4: 118. 1893.

Half-shrubby, finely pubescent, $6-15 \mathrm{dm}$. high, the stout branches angled. Leaves very broadly ovate, 1-2 dm. long, acute at the apex, cordate or nearly truneate at the base, coarsely dentate, long-petioled; flowers white, fragrant, donble in all American specimens examined, in dense terminal cymes, the eorolla about $2.5 \mathrm{em}$. broad; calyx 5-cleft, its laneeolate lobes acuminate; corolla-lobes rounded.

Roadside, New Providence :- Bermuda: Florida: West Indies and continental tropical America. Naturalized from the tropics of Asia. ODorous Clerodexdrox, WILD JESSAMINE.

\section{AVICÉNNIA L. Sp. P1. 110. 1753.}

Evergreen trees, sometimes shrubby, with nodose twigs, opposite entire leathery leaves without stipules, and peduncled elusters of white bracted flowers. Calyx eup-shaped, silky, with 5 persistent lobes. Corolla eampanulate, its short tube nearly eylindric, its limb spreading, 4-lobed. Stamens 4, adnate to the corolla-tube, the anthers introrse. Ovary sessile, 1-celled; orules 4, on a central placenta; style short, 2 lobed. Fruit capsular, oblique, apieulate. Seeds mithout endosperm, usually germinating in the eapsule. [In honor of Avicenna (980-1036) of Bokhara, a distinguished oriental physician.] Three known species of tropieal and subtropieal seacoasts. Type species: Avicennia officinalis L.

\section{Avicennia nítida Jacq. Enum. 25. 1760.}

A tree, up to about $16 \mathrm{~m}$. high, with shallowly fissured dark scaly bark, orange-red within, the young twigs finely pubeseent. Leaves pubescent when young, soon becoming glabrous above, oblong or oblong-lanceolate, $3-8 \mathrm{~cm}$. long, obtuse or apiculate at the apex, finely caneseent beneath, narrowed at the base into short petioles; panieles $2-5 \mathrm{~cm}$. long; corolla $10-14 \mathrm{~mm}$. broad, its lobes rounded; eapsule oblong or elliptie, 2-5 $\mathrm{cm}$. long, light green, slightly pubescent.

In mangrove mud and shallows of the sea, throughout the alchipelago from Abaco and Great Bahama to Grand Turk, Inagua and Cay Sal:-Bermuda ; Florida to Texas: West Indies and continental tropical America. Catesbr, 1: pl. 85. BLack Maxgrove. Greex Turthe Bough.

\section{Family S. LAMIĀCEAE Lindl.}

\section{Mint FAMiLY.}

Aromatic punctate herbs, or shrubs (a few tropical species trees), mostly with 4 -sided stems and simple opposite leares; stipules none. Flowers irregular, perfect, clustered, the inflorescence typically cymose, usually bracteolate. Calyx inferior, persistent, 5-toothed or 5-lobed (rarely 4-toothed), mostly nerved. Corolla with a short or lnng tube, the limb 4-5-lobed, mostly 2-lipped, regular in a few genera; upper lip 2-lobed, or sometimes entire; lower lip mostly 3-lobed. Stamens borne on the corolla-tube, typically 4 and didynamons, sometimes 2, rarely equal; filaments separate, alternate with the corolla-lobes; anthers 2-celled, intror'se, or confluently 1-celled, or sometimes of a single sae. Disk usually present, fleshy. Ovary 4-lobed, or 4-parted, superior, each lobe or division with 1 mostly anatropous orule; style arising from the eentre of the lobed or 
parted ovary, 2-lobed at the summit. Fruit of 4, I-seeded nutlets. Seed erect (trinsverse in scutellaria); endosperm seanty, or none; embryo mostly straight; radicle short, inferior. About 160 genera and 3,200 speeies, of wide distribution.

Ovary of 4 united carpels, 4-lobed: style not basal.

Ovary of 4 distinct or nearly distinet carpels; style basal.

Calyx with a crest on the upper side.

1. Melosmon.

Calyx without a crest.

Corolla distinctly -lipped, the lips different, the upper one concave.

Anther-bearíng stamens 4 Calyx-lobes 5 . Calyx-lobes $8-10$.

Anther-bearing stamens 2

Corolla nearly regular, or if 2-lipped, the upper lip not concave.

Filaments converging under the upper lip of the corolla.

Lower pair of filaments appressed to the lower lip of the corolla.

Lobes of the calyx nearly equal.

Upper lobe of the calyx broad, decurrent.

2. Scutcllaria.

\section{MELósMoN Raf. Fl. Tell. 3: 85. 183i.}

Herbs with incised or pinnatifid leaves, the white or blue pedicelled flowers solitary in the axils of leaf-like bracts. Calyx with a short, 10-ribbed tube and 5 long nearly equal lobes. Corolla irregular, the upper lip small, the lower lip 3-lobed, its middle lobe much longer than the lateral ones. Stamens 4, exserted. Ovary 4-lobed, of 4 partly united carpels; style not basal. Nutlets laterally attached, roughened or smooth. [Greek, of uncertain application.] A few species, natives of temperate and tropical America. Type species: Melosmon bicolor Raf.

1. Melosmon cubénse (Jacq.) Small, Fl. SE. U. S. 1019, 1337. 1903.

Teucrium cubense Jacq. Enum. 25. 1760.

Annual (?) ; sparingly fubescent or glabrate; stems often branched near the base, slender, $2-5 \mathrm{dm}$. high, the branches ascending. Leaves ovate to spatulate in outline, 1-3 cm. long, incised, the lobes mostly entire; bracts similar to the leaves; pedicels $2-5 \mathrm{~mm}$. long; calyx $4-5.5 \mathrm{~mm}$. long, its linearlanceolate pubescent acuminate lobes several times longer than the tube; corolla bluish-white, 11-14 mm. long; nutlets about $2 \mathrm{~mm}$. long, irregularly roughened.

Waste places and cultivated soils, Great Bahama, New Providence. Eleuthera to Long Island, Inagua:-Alabama, Texas and Mexico; Cuba. West Ixplai Germaxder.

\section{SCUTELLÀRIA L. Sp. Pl. 598. 1753.}

Bitter herbs, some species shrubby. Flowers blue to violet, in bracted, mostly secund, spike-like racemes, or solitary or 2-3 together in the axils. Calyx campanulate, gibbous, 2-lipped, the lips entire, the upper one with a erest or protuberance upon its back and often deciduous in fruit. Corolla recurved-ascending, dilated above into the throat, glabrous within, the limb 2-lipped; upper lip arched, entire or emarginate; lower lip spreading or deflexed, its lateral lobes small and somembat connected with the upper, its middle lobe broad. Stamens 4, didynamous, all anther-bearing, ascending under the upper lip, the upper pair somewhat the shorter, their anthers 2 - 
celled, ciliate; anthers of the lower pair of stamens 1-celled, also ciliate. Nutlets papillose or tuberculate. [Latin, a dish, from the appendage to the fruiting calyx.] About 100 species of wide distribution. Type species: Scutellaria peregrina L.

\section{Scutellaria havanénsis Jacq. Enum, 25. 1760.}

Scutellaria cubensis A. Rich. in Sagra, Hist. Cnb. 11: 15S. 1550.

Scutellaria longiflora Small, Bull. N. Y. Bot. Gard. 3: 437. 1905.

Perennial; stems very slender, often branched near the base, erect or ascending, $3 \mathrm{dm}$. high or less, pubeseent or puberulent. Leaves orate or ovateorbicular, short-petioled, 3-9 mm. long, puberulent on both sides, few-tootherl or entire; flowers solitary in the axils on ascending peduncles $3-7 \mathrm{~mm}$. long; flowering calyx about $1.5 \mathrm{~mm}$. long; corolla dark blue, about $1.5 \mathrm{~cm}$. long, the middle lobe of the upper lip emarginate, the lower lip 3-lobed; fruiting ealyx about $3 \mathrm{~mm}$. long.

Rocky places, red-lands and pine-lands, Great Bahama, Eleuthera, Cat Island, and Great Exuma:-Florida ; Cuba ; IIispaniola ; Porto Ríco. SkullcaP.

Scutellaria purpurasccns Sw. mentioned by Hitchcock as occurring on Eleuthera was not found in his collections; the record is probably based on the above species.

\section{LEONÙRUS L. Sp. Pl. 584. 1753.}

Tall herbs, with palmately eleft, parted or dentate leaves, and small white or pink flowers verticillate in dense axillary clusters. Calyx tubular-campanulate, 5-nerred, nearly regular and equally 5-toothed, the teeth rigid, subulate or aristate. Corolla-limb 2-lipped; upper lip erect, entire; lower lip spreading or deflexed, 3-lobed, the middle lobe broad, obcordate or emarginate. Anthers 2-celled, the sacs mostly parallel. Nutlets 3-sided, smooth. [Greek, lion'stail.] About 10 species, of Europe and Asia. Type species: Leonurus Cardiaca L.

\section{Leonurus sibíricus L. Sp. PI. 584. 1753.}

Biennial, puberulent or glabrate; stem 6-18 dm. high. Leares longpetioled, 3-parted into ovate or lanceolate, acute or acuminate, cleft and incised segments, the lobes lanceolate or linear, acute, the uppermost linear or lanceolate; clusters dense, usually all axillary; calyx eampanulate, $6 \mathrm{~mm}$. long, glabrous or minutely puberulent; corolla purple or red, densely puberulent without, S-12 mm. long, its tube naked within; anther-sacs divergent.

Waste places, New Providence and Harbor Island:-Bermuda: Delaware and Marrland: West Indies; continental tropical America. Nituralized from the Old World tropics. LION'S TAL. PIPE-SHANK.

4. LEONÒTIS R. Br. in Ait. Hort. Kew ed. 2, 3: 409. 1 s11.

Annual or perennial caulescent herbs or shrubby plants, the leares opposite, broad, toothed, petioled, the flowers in dense whorls, short-pedicelled. Calyxtube 10-nerved, oblique at the mouth, its lobes 8-10, unequal, bristle-tipped. Corolla yellow, orange or scarlet, 2-lipped, the tube dilated above, curved; upper lip erect, rather long; lower lip with 3 lobes, the middle lobe scarcely longer than the lateral. Stamens 4; filaments all anther-bearing; anthers 2celled; saes diverging. Nutlets 3 -angled, smooth. [Greek, lion 's-car.] About 12 species, natives of Africa. Type species: Leonotis Leonitis (L.) R. Br. 
1. Leonotis nepetaefòlia (L.) R. Br. in Ait. Hort. Kew ed. 2, 3: 409. 1811.

Phlomis nepetacfolia L. Sp. Pl. 5S6. 1753.

Annual, softly pubescent. Stems 3-20 dm. tall, rather stout, simple or branched; leaves ovate to orate-deltoid, 4-12 cm. long, coarsely crenate, cuneate or subcordate at the base; flower-elusters dense, $4-6 \mathrm{~cm}$. in diameter; pedicels 1-2 $\mathrm{mm}$. long; calyx puberulent, becoming at least $2 \mathrm{~cm}$. long, its tube reticulated above the middle, its lobes 8 , awn-tipped; corolla scarlet or orange-yellow, $2-2.5 \mathrm{~cm}$. long, villous-hirsute, its tube eurved, the upper lip as long as the tube, the lower lip much shorter than the upper, with 3 narrow lobes; nutlets $3 \mathrm{~mm}$. long, sharply angled.

Taste places, New Providence, Eleuthera, Acklin's Island, Mariguana, Grand Turk and Inagua:- Belmuda; Tennessee to Florida and Louisiana; West Indies: Texas to Brazil ; Old World tropies. IJON"S-EAR.

\section{SÁLVIA L. Sp. Pl. 23. 1753.}

Herbs, or some species shrubs, with elustered flowers, the elusters mostly spiked, racemed, or panicled. Calyx mostly naked in the throat, 2-lipped; upper lip entire or 3-toothed; lower lip 2-cleft or 2-toothed. Corolla strongly 2lipped; upper lip entire, emarginate or 2-lobed; lower lip spreading, 3-eleft or 3-lobed. Anther-bearing stamens 2 (the posterior pair wanting or rudimentary); connective of the anthers transverse, linear or filiform, bearing a perfect anther-sac on its upper end, its lower end dilated, capitate or sometimes bearing a small or rudimentary one. Nutlets smooth, usually dereloping mucilage and spiral tubes when wetted. [Latin, salrus, safe, from its healing virtues.] About 500 species, of wide distribution. Type species: Salvia officinalis $\mathrm{L}$.

Corolla blue to white. 4-10 mm, long.

Leaves cuneate-nariowed at base.

Leaves rounded or cordate at base. Corolla red or scarlet, $2-2.5 \mathrm{~cm}$. long.

1. S. occidentalis.

2. S. serotina.

3. Soccinea.

\section{Salvia occidentàlis Sw. Prodr. 14. 17 S8.}

Annual; stems ascending, decumbent or prostrate, branched, densely pubescent at least above, $0.5-2 \mathrm{~m}$. long. Leares ovate, $2-5 \mathrm{~cm}$. long, serrate, shortpetioled, acute or acuminate at the apex, narrowed or subtruncate at the base; panicles narrow, 0.5-3 dm. long, the clusters few-flowered, the lower ones distant, the upper close together; ealyx about $3 \mathrm{~mm}$. long densely glandularpubescent, ribbed, the upper lip obtuse, the lobes of tri 'otrer lip acute; corolla blue, about $5 \mathrm{~mm}$. long, its tube a little shorter than the calyx; nutlets about $2 \mathrm{~mm}$. long.

Waste places and coppices, Andros, New Providence, Eleuthera and Great Exuma : -Florida: West Indies and continental tropical America; recorded from Bermuda. WEST IXDIAX SAGE.

\section{Salvia serotina L. Mant. 1: 25. 1767.}

Salvia micrantha Vahl, Enum. 1: 235. 1805.

Perennial, finely pubescent; stems $1.5-7 \mathrm{dm}$. tall, much branched. Leaves orate or orbicular-osate, $1-4 \mathrm{~cm}$. long, obtuse, crenate-serrate, rounded or subcordate at the base, slender-petioled; panicles 2-10 $\mathrm{cm}$. long; calyx longer than the pedicels, glandular-hirsute, becoming 5-8 $\mathrm{mm}$. long; lips about $\frac{1}{3}$ as long as the long-campanulate tube; corolla 6-10 $\mathrm{mm}$. long, white or blue, its tube included; style glabrous; nutlets fully $2 \mathrm{~mm}$. long. 
Wraste places and scrub-lands, throughout the archipelago from Abaco and Great Bahama to Audros, The Ciacos, Grand 'íl'k and Inagua:-Wermuda; Florida; West Indies; continental tropical America. Consists of many races differing in pubescence, the corolla blue to white. Appalently referred to s. tenclla Sw. by Hitchcock. Erroneously called Catxlip. Ifisted by Dolley as Nepeta Cataria L. SMaLl WHTE SAGE.

\section{Salvia coccínea Juss, in Murray, Comm. Gott. 1: S6. 17is.}

Anmual, softly pubescent; stens ereet, $3-\bar{i}$ dm. tall, simple or sparingly branched. Leaves ovate or deltoid-orate, 3-6 cm. long, obtuse or acutish, erenate-serrate, truncate to subcordate at the base; panieles $5-20 \mathrm{~cm}$. long; pedicels 2-6 nmm. long, slender; calyx minutely pubescent, 10-12 mm. long, its tube many-ribbed, the upper lip reniform, abruptly pointed, the lower lobes orate-apiculate; corolla deep scarlet, $2-2.5 \mathrm{~cm}$. long, puberulent, the tube contracted above the base, then gradually enlarged, the lower lip 7-8 $\mathrm{mm}$. broad, merely notched at the apex; nutlets $2.5 \mathrm{~mm}$. long, slightly variegated.

Waste places, Watling's Island, at Cockburn Town :-Bermuda: South Carolina to Floricla, 'Texas and Mexico; West Indies and continental troplcal America. ScarLET SAge, COUNTRY Belle.

\section{MICROMÈRIA Berth. Bot. Reg. 15: under pl. 1282. 1829.}

Shrubs or perennial herbs, with entire or dentate leaves and small axilary clustered or solitary flowers. Calyx tubular, its tube mostly 13-ribbed, its 5 lobes nearly equal. Corolla 2-lipped; upper lip erect, often very small; lower lip 3-lobed, the middle lobe commonly emarginate. Stamens 4 , converging under the upper corolla-lip; anthers 2-celled, the saes divergent. Ovary 4earpellary; style basal. Nutlets smooth, basally attached. [Greek, referring to the small flowers.] Sixty species or more, natives of temperate and tropical regions. Type species: Sabbatia corymbosa Moench.

1. Micromeria Brownei (Sw.) Benth. Lab. 372. 1834.

Thymus Brownei Sw. Prodr. S9. 17ss.

Satureia Brownei Briquet, in E. \& P. Nat. Pflanzf. $4^{3 a}$ : 300. 1596.

Perennial, glabrous or nearly so; stems branched near the base, rery slender, the branches prostrate and creeping, 1-1 dm. long. Leaves hroadly orate or orbicular, $5-12 \mathrm{~mm}$. broad, crenulate, obtuse or acute at the apex, truneate or subcordate at the base, the petioles 1-6 mm. long; flowers mostly solitary in the axils; pedicels filiform, 3-12 mm. long, as long as the upper leaves or longer; calyx narronly turbinate, $4-5 \mathrm{~mm}$. long, its triangular-orate, ciliolate lobes about one-half as long as the tube; corolla white, $\bar{i}-\mathrm{b}$ mul. long, its upper lip orate, sometimes emarginate.

Moist soils at fresh-water holes, Abaco and Great Iblhama southward to Crooked Island :- Hlorida; Jamalea. Iecorded by Dolley as Tepeta coerulcu L. WEst livid. THYHE.

\section{HYPTIS Jaeq. Coll. 1: 101. 1786.}

\section{[Mesosphaerum P. Br. ITist. Jam. 257. Myponym. 1756.]}

Ilerbs, mostly erect and branched, the leares usually dentate, the flowers variously elustered. Calyx tubular, oroid or campanulate, equally 5-lobed, the lobes acute or aristate. Corolla 2-lipped, the upper lip erect or spreading, the lower saceate and drooping. Stamens $f$, leelined, all antheriferous, the filaments distinet, the anthers 2-celled. Ovary t-arpellary; style basal. Nutlets 
smooth or rough. [Greek, bent backward.] About 300 species, mostly of tropical America. Type species: IIyptis verticillata Jacq.

Flowers in secund spiked cymes: calyx $3-4 \mathrm{~mm}$. long. l'lowel's in axillary clusters; calyx $\mathrm{S}-10 \mathrm{~mm}$. long.

1. H. pectinata.

2. II. suarculens.

1. Hyptis pectinàta (L.) Poit. Ann. Mus. Paris 7: 4i4. 1806.

Tepeta pectinata L. Syst. Eג. 10, 1097. 1759.

Perennial, densely puberulent; stems erect, 3-20 dm. high. Leaves ovate, 2-8 cm. long, serrate, acute at the apex, mostly obtuse or subcordate at the base, the petioles $4.5 \mathrm{~cm}$. long or less; flotrers in secund spiked crmules, the inflorescence elongated; calyx $3-4 \mathrm{~mm}$. long, puberulent, its subulate lobes nearly as loug as the tube; corolla whitish, little longer than the calyx, the upper lip 2-lobed, the lower 3-lobed; nutlets granular, about $1 \mathrm{~mm}$. long.

Waste places, Andros, Cat Island, and Inagua :-Florida; West Indies and continental tropical America. Pectixate Hrptis.

\section{Hyptis suaveòlens (L.) Poit. Ann. Mus, Paris 7: 472. 1806.}

Ballota suaveolens L. Syst. ed. 10, 1100. 1759.

Annual? Stem stout, often much branched, loosely pilose, 3-8 dm. high. Leaves ovate or ovate-orbicular, slender-petioled, $4 \mathrm{~cm}$. long or less, acute or obtuse at the apex, obtuse or subcordate at the base, low-serrate, sparingly pubescent on both sides; flowers 2-5 together, nearly sessile, in short-peduncled, axillary clusters, or the clusters crowded in a terminal panicle and subtended by small leaves; calyx campanulate, strongly ribbed, at length $8-10 \mathrm{~mm}$. long, its subulate teeth shorter than the tube; corolla 5-6 mm. long, bluish.

Waste and cultirated soils. New Proridence, Eleuthera and Great Exuma :-West Indies; continental tropical America; East Indies. PILOSE HrPTIS. Wild Basil.

\section{8. ÒCIMUIM L. Sp. Pl. 597. 1753.}

Herbs or low shrubs, with erect or ascending branched stems, usually dentate petioled leares and clustered flowers. Calyx deflexed in fruit, its tube campanulate or ovoid, 5-lobed, the lobes unequal, the lower ones somewhat united. Corolla white or nearly white, its tube usually shorter than the ealyx, its lobes nearly equal. Stamens 4 , didynamous, the lower pair appressed to the lower lip of the corolla; filaments naked or appendaged. Ovary 4-carpellary; strle basal. Nutlets smooth or rugose. [Greek, odorous.] About 40 species widely distributed in warm and tropical regions. Type species: Ocimum basilicum L.

\section{Ocimum micrànthum Willd. Enum. Hort. Berol. 630. 1509.}

Annual, pubescent; stem erect, branched, 2-5 dm. high. Leares ovate or oblong-ovate, 1-5 cm. long, serrate, acute at the apex, narrowed or subtruncate at the base, the petioles $5-20 \mathrm{~mm}$. long; panicles 2-10 $\mathrm{cm}$. long; flowers several in the clusters; pedicels $4-7 \mathrm{~mm}$. long; calyx puberulent, $6-7 \mathrm{~mm}$. long in fruit, the upper lip concave, the lower of 4 narrow subulate-tipper lobes; corolla about $4 \mathrm{~mm}$. long, its tube dilater above, its upper lip with 2 rounded lobes, the lower lip with 2 orate lateral lobes and a notched middle one; nutlets about $1 \mathrm{~mm}$. long.

Waste and cultivated grounds, New Providence and Eleuthera:-Florida; West Indies: Jamaica; Mexico to continental tropical America. Wild Basil. Potmargin.

Marrubium vulgare L.; listed by Dolley, has not been found by our collectors on the islands. 


\section{Family 9, SOLANÀCEAE Per's.}

\section{Potato Family.}

Herbs, slirubs, vines, or some tropical species trees, with alternate or rarely opposite estipulate leares, and perfect regular, or nearly regular, cymose flowers. Calyx inferior, mostly 5-lobed. Corolla gamopetalous, mostly 5-lobed, the lobes induplicate-valvate or plicate in the bul. Stamens as many as the lobes of the corolla and alternate with then, inserted on the tube, all perfect in the following genera; anthers various, 2-celled, apically or longitudinally dehiscent. Orary superior, 2-celled (rarely 3-5-celled); ovules numerous on the axile placentæ, anatropous or amphitropous; style slender, simple; stigma terminal; fruit a bery or capsule. Seeds numerous; endosperm fleshy; cotyledons semiterete. About 75 genera and 1,750 species, most abundant in tropical regions.

Fruit a berry.

Corolla plicate.

Berry enclosed in the accrescent calyx.

Berry not enclosed in the calyx.

Corolla not plicate, or scarcely plicate.

Corolla rotate.

Corolla salvelform to funnelform.

Stamens unequal; filaments adnate to the mouth of the corolla-tube.

Fruit a capsule.

Stamens equal or nearly so; filaments adnate to about the middle of the corolla-tube.

Calyx tubular, at length circumscissile.

Calyx ovoid or campanulate, 5-cleft.

1. Physalis.

3. Capsicum.

4. Lycium.

5. Cestrum.

6. Datura.

7. Nicotiuna.

1. PHÝSALIS L. Sp. Pl. 182. 1753.

Herbs, sometimes a little woody below, with entire or sinuately toothed leaves. Peduncles slender, in our speeies solitary in the axils. Calyx campanulate, 5-toothed, in fruit enlarged and bladdery-inflated, membranous, 5-angled, or prominently 10-ribbed and reticulate, wholly enelosing the pulpy berry. Corolla often with a brownish or purplish center, open-campanulate, or rarely eampanulate-rotate, plicate. Stamens inserted near the base of the corolla; anthers oblong, opening by longitudinal slits. Style slender, somewhat bent; stigma minutely 2-eleft. Seeds numerous, kidney-shaped, flattened. [Greek, bladder, referring to the inflated calyx.] The number of reeognized speeies is about 50, midely distributed. Type species: Physalis Alkekengi L.

Fruiting calyx 5-angled: leaves narrowed at the base.

Fruiting calyx 5-winged; leares cordate, rounded or obtuse at the base.

Glabrous, or nearly so.

Densely pubescent.

1. P. angulata.

2. P. turbinata.

3. P. pubescens.

\section{Physalis angulàta L. Sp. Pl. 1S3. 1753.}

Physalis Linkiana Dunal, in DC. Prodr. 13²: 448. 1852.

Ereet, 4-9 dm. high, glabrous; stem angled; leaves orate, usnally with cuneate base and long-acuminate teeth, $5-6.5 \mathrm{~cm}$. long, on slender petioles, thin, the veins not prominent; peduncles slender, $2-3 \mathrm{~cm}$. long, erect, in fruit often reflexed but sellom exceeding the fruiting calyx; calyx-teeth triangular to laneeolate, generally shorter than the tube; corolla $5-10 \mathrm{~cm}$. in diameter; anthers purplish tinged; fruiting ealyx about $3 \mathrm{~cm}$. long, oroid, not prominently angled, at last nearly filled by the yellow berry.

Wiaste places, Andros and New Providence:-Bermuda: southern Inlted States; West Indies and contlnental troplcal America. CUT-LeAled GRousd-Cilerry. I'Oppers. 
2. Physalis turbinàta Medik, in Act. Acad. Theod. Palat. 4: 1ss, t. 5, fig. 2. 1750.

Annual, glabrous, or minutely puberulent when roung. Stems rather stout, acutely angled and divaricately branched; leaves broally ovate, obtuse or corlate and slightly oblique at the base, thin and dark green, repand-dentate, short-acuminate; peduncles short, in fruit about $1.5 \mathrm{~cm}$. long, calyx-lobes lanceolate, acuminate; corolla $8-10 \mathrm{~mm}$. wide, yellow with a purplish eye; fruiting calyx $3-3.5 \mathrm{~cm}$. long, long-attenuate, almost pyramidal, deeply retuse at the base.

Waste and cultivated grounds, Acklin's Island and Caicos Islands :-Bermuda ; southeru Inited states; West Indies and continental tropical America. Ssrooth GROCND-CHERRY.

3. Physalis pubèscens I. Sp. Pl. 183. 1753.

Physalis barbadensis Jaeq. Mise. 2: 359. 1781.

Annual, pubescent and riscid. Stems tall and erect, or widely spreading, acutely 3-4-angled; leaves 3-6 cm. long, heart-shaped, acute, or usually abruptly acuminate, sharply repand-dentate, pubescent with short hairs; peduncles short, at maturity sometimes $2 \mathrm{~cm}$. long; calyx generally densely riscid-hirsute, its lobes lanceolate, acuminate; corolla $5-10 \mathrm{~mm}$. in diameter, vellow, with a purplish eye; anthers purplish; fruiting calvx $2.5-3 \mathrm{~cm}$. long, attenuate, reticulate, retuse at the base.

Waste grounds, Andros and New Providence:-West Indies: continental tropical and temperate America. ?P. curassarica of Schoepf. HAIRT GRodxd-CHERrT,

\section{SOLĀNUM L. Sp. Pl. 184. 1753.}

Herbs or shrubs, often stellate-pubescent, sometimes climbing. Florrers cymose, umbelliform, paniculate, or racemose. Calyx campanulate or rotate, mostly 5-toothed or 5-cleft. Corolla rotate, the limb plaited, 5-angled or 5lobed, the tube very short. Stamens inserted on the throat of the corolla; filaments short; anthers linear or oblong, acute or acuminate, connate or connirent into a cone, each sac dehiscent by a terminal pore, or sometimes by a short introse terminal slit, or sometimes also longitudinally. Orary usually 2-celled; stigma small. Berry mostly globose, the calyx either persistent at its base or enclosing it. [Name, according to Wittstein, from solamen, quieting.] About 900 species, of wide geographic distribution. Type species: Solanum nigrum L.

Pubescence not stellate.

Plants copiously armed with long slender prickles.

Plants unarmed.

Pubescence densels stellate.

Leaves large, lanceolate to obovate.

Inflorescence racemose.

Inflorescence corrmbose.

Inflorescence terminal : plants unarmed. Corolla-lobes ovate. Corolla-lobes lanceolate.

Inflorescence subaxillars; plants usually with some prickles.

Leaves minute, not over $\mathbf{3} \mathrm{mm}$. long.

1. S. aculeatissimum.

2. S. nigrum.

3. S. bahamense.

4. S. rerbascifolium.

5. S. Blodgettii.

6. S. torvum.

†. S. didymacanthum.

\section{Solanum aculeatíssimum Jacq. Coll. 1: 100. 1786.}

Perennial, slightly moods, usually much branched, 6-12 dm. high, somewhat pilose, or becoming glabrous, the branches, petioles, leaf-blades and peduncles armed with straight yellow prickles. Leaves thin, broadly orate in outline, $7-1 \tilde{\mathrm{cm}}$. long, pinnately lobed or repand; cymes few-flowered, lateral; 
ealyx armed with stont prickles, about one-third as long as the corolla, its lobes orate, acute; corolla white, about $12 \mathrm{~mm}$. broad; anthers orate-lanceolate; berry globose, searlet, glabrous, $1-2 \mathrm{~cm}$. in diameter.

Waste and cultirated ground, Great Bahama, Andros, New I'rovidence. Eleuthera and Cat Island; recorded from Green Turtle Cay :-Southern I'nited States; Bermuda; West Indies and continental tropical America. Cock RosciI LERRY.

\section{Solanum nìgrum L. Sp. Pl. 186. 1753.}

Solanum nodiflorum Dunal, Hist. Sol. 151. 1813. Not Jacq. 1793.

Solanum americanum Mill. Gard. Dict. ed. 8, no. 5. 1768.

Solanum purpuratum Bitter, Repert. 12: 5.5. 1913.

Annual, glabrous, or somewhat pubeseent with simple hairs, 3-8 $\mathrm{lm}$. high. Leaves orate, petioled, more or less inequilateral, $2-8 \mathrm{~cm}$. long, thin, acute, acuminate or acutish at the apex; peduneles lateral, umbellately 3-10-flowered; pedicels 6-1t mm. long; flowers $5-10 \mathrm{~mm}$. broad; calyx-lobes oblong, obtuse, much shorter than the corolla, persistent at the base of the berry; filanents somewhat pubescent; anthers obtuse; berries glabrous, globose, $\dot{8}-10 \mathrm{~mm}$. in diameter, black, on nodding peduneles.

Waste and culticated grounds, throughout the archipelago from Great Bahama to Watling's. East Caicos, Grand Turk and Inagua :-all temperate and tropical legions of both hemispheres. Consists of many races differing in length of pedicels and size of flowers, the leaves varying from entire to coarsels toothed. Recorded by Hitcheock as Solanum nigrum oleraceum; by Small as Solanum gracile Link. BLAck Nightshade. INK-BERri, Goosa-BUSH.

\section{Solanum bahaménse L. Sp. Pl. 188. 1753.}

Solanum bahamense lanceolatum Griseb. Fl. Br. W. I. 440. 1861.

Solanum subarmatum Willd. Enum. Hort. Berol. 240. 1809.

A prickly or unarmed sbrub, $2 \mathrm{~m}$. high or less, the twigs, leares and infloreseence stellate puberulent, the prickles slender. Leaves oblong to laneeolate, 4-12 em. long, slender-petioled, acute or obtuse at the apex, narrowed or obtuse and often oblique at the base, the margin entire or somewhat undulate, the veins rather distant; peduncles lateral, longer than the petioles; inflorescence racemiform, sometimes forked, few-sereral-flowered; pedicels slender, thickened upward, 6-12 mm. long, nodding in fruit; calyx $1.5 \mathrm{~mm}$. long, its lobes ovate; corolla blue, rarely white, $10-15 \mathrm{~mm}$. broad; berry red, globose, 6-8 $\mathrm{mm}$. in diameter.

White-lands and scrub-lands throughout the arehipelago from Abaco and Great Bahama through the Biminis and Andros to Grand Turk Islands, Ambergris Cay and Inagua :-Florida: Cuba; Iispaniola: Jamaica. Consists of many races, unarmed or very prickls, with the leaves entire or toothed, and the flowers and fruits varying considerably in size. IRecolded by Dolley and by IItcheock as Solanum ignaeum 1 . BaIIAIA SOLANUM. CANKER-BERKY.

\section{Solanum verbascifòlium L. Sp. Pl. 184. 1753.}

A stellate-tomentulose unarmed shrub, 1-3 $\mathrm{m}$. high, rarely forming a small tree up to $10 \mathrm{~m}$. high, with a trunk up to $1.5 \mathrm{dm}$. in diameter. Leaves ovate to elliptie, rarely obovate, 1-3 dm. long, entire or very slightly repand, acute, acuminate or obtuse at the apex, rounded or narrowed at the base, the stout petioles $7 \mathrm{~cm}$. long or less; eymes terminal, several-many-floterel, longpeduneled; pedicels stout, 6-12 mm. long; ealyx $5-7$ mm. loug, densely stellate, its lobes triangular-ovate; corolla white, $10-15 \mathrm{~mm}$. wide, its lobes ovateoblong; berry subglobose, 1-2 em. in diameter, yellow.

Waste places, scrub-lands, coppices and old fields, throughout the archlpelago from Great Bahama, Abaco and Andros to Mariguin: and Dellis Cay (Caicos):Florida: West Indies: Mexico and Central America; old World tropies. MulleisLEAYED SOLANUM. WiLD TOBACCO. SALIE-BUSII. 
5. Solanum Blodgéttii Chapm. Fl. So. U. S. 349. 1860.

An umarmed shrub, 0.5-1.5 m. high, the branches spreading, the young twigs, leares and inflorescence stellate-tomentulose. Leaves oblong, $5-15 \mathrm{~cm}$. Iong, entire or undulate, obtuse or acnte at the apex, mostly obtuse at the base, the petioles 1-3 cm. long; peduncles longer than the leares; panicles deuse, short, several-niany-flowered; pedicels $3-7 \mathrm{~mm}$. Iong; calyx about 3 mm. long, its teeth minute, deltoid; corolla white or blue, its lobes linear or linear-lanceolate, 6-7 mm. leng, pubescent without; anthers linear, apically dehiscent; ovary glabrous; berries red, 4-6 $\mathrm{mm}$. in diameter.

Scrub-lands, North Cat Cay, Biminis:-Florida. Blodgetr's Soldxum.

\section{Solanum tórvum Sw. Prodr. 47. 1788.}

A stellate-tomentulose shrub, 1-4 m. high, the rather stout branches sparingly armed with short flattened, nearly straight prickles, or unarmed. Leaves broadly ovate in outline, $\overline{5}-20 \mathrm{~cm}$. long, stout-petioled, angular-lobed or sinuate-margined, acute or obtuse at the apex, truncate or subcordate at the base, sometimes with a few prickles on the petiole and on the midvein beneath, the upper surface scabrous; cymes lateral, short-peduncled, severalflowered; flowering pedicels slender, glandular, 5-8 $\mathrm{mm}$. long, thickening in fruit; calyx glandular, about $4 \mathrm{~mm}$. long, 5-cleft, its lobes ovate, acute; corolla white, 5-cleft, 10-15 mm. broad; berry globose, 10-14 $\mathrm{mm}$. in diameter, yellow.

Waste and cultivated grounds near Nassau, New Providence:-Bermuda (according to Grisebach); West Indies and continental tropical America. Bushy WHite SOLANUM.

\section{Solanum didymacánthum Millsp. Field Mus. Bot. 2: 183. 1906.}

Branches stellate-pilose, prickly; leaves minute, entire, stellate-pilose on both surfaces. Plants shrubby, branched, 1-2 m. high; prickles needle-like, in pairs at the nodes, $2-3$ times as long as the leaves, slightly recurved, divaricately horizontal, reddish brown, thickened at the base, somewhat less than $12 \mathrm{~mm}$. long; leaves fasciculate, petiolate, oblong or obovate, entire, about $3 \mathrm{~mm}$. long, the base acute, the apex acute or obtuse; inflorescence terminal, solitary, single-flowered; peduncles, calyx and corolla stellate-pilose, unarmed; calyx 5-dentate; corolla white, 5-partite, the lobes liguliform, about $8 \mathrm{~mm}$. long, somewhat shorter than the corolla; ovary globose; style filiform, longer than the stamens; berry sessile, globose, compressed at the base and apex, yellow, translucent, not exceeding the persistent calyx.

Coppices and scrub-lands, Cat Island near Port Howe, Great Exuma on Haynes Road. Endemic. CAT'S-PAW.

\section{CÁPSICUM L. Sp. Pl. 188. 1753.}

Annual or perennial herbs or shrubs, with forking stems. Leaves flat, entire or repand. Flowers solitary in the axils, or in small cymes. Calyx scarcely accrescent, somewhat 5-lobed. Corolla usually white, nearly rotate, its lobes 5, imbricated. Stamens 5, adnate to the base of the corolla; anthers bluish, the sacs opening lengthwise. Ovary 2-3-celled; stigma club-shaped or dilated. Berries red, sellow or green, often nodding, pungent. Seeds flattened. [Latin, capsa, a box, referring to the shape of the fruit in forms of the typical species.] About 30 species, natives of America. Type species: Capsicum annuum $\mathrm{L}$. 
1. Capsicum baccàtum L. Mant. 1: 47. 1767.

Shrubby, more or less pubescent. Stems 1-3 m. tall, sometimes vine-like, widely branehing; leaves ovate, oblong-ovate or ovate-lanceolate, $2-5 \mathrm{~cm}$. long, acute or acuminate, entire, abruptly narrowed or truncate at the base; petioles one half as long as the blades or shorter; pedicels narrowly elubshaped, 1-2 cm. long; calyx $2.5-3 \mathrm{~mm}$. long, its lobes as long as the tube or somewhat shorter; berries globose to ellipsoid, 5-10 $\mathrm{mm}$. long, red, obtuse.

Scrub-lands, Little Harbor Cay, New Providence and Eleuthera to Mariguaua, Dellis' Cas (Caicos), Inagua and the Anguilla Isles:- southern United States: West Indies; continental tropical America: Old World tropics. C. frutescens of Hitchcock, from Inagua, and of Dolley, is this species. BIRD I'EPPER.

\section{LÝCIUM L. Sp. Pl. 191. 1753.}

Shrubs, or moody vines, often spiny, with small alternate entire leaves, commonly with smaller ones faseicled in their axils, and white greenish or purple, solitary or elustered flowers. Calyx eampanulate, 3-5-lobed or -toothed, not enlarged in fruit, presistent. Corolla-tube short or slender, the limb 5lobed (rarely 4-lobed), the lobes obtuse. Stamens 5 (rarely 4); filaments filiform, sometimes dilated at the base; anther-sacs longitudinally dehiscent. Ovary 2-celled; style filiform; stigma capitate or 2-lobed. Berry globose, oroid, or oblong. [Named from the country Lycia.] About 75 species, widely distributed. Type species: Lycium afrum L.

\section{Lycium spathulifòlium Britton, Bull. N. Y. Bot. Gard. 3: 451. 1905.}

A glabrous shrub, $1.3 \mathrm{~m}$. high or less, with long slender drooping branches, some of the twigs tipped by spines $2-4 \mathrm{~mm}$. long, the bark gray. Leares 2-4 together at the nodal eushions, or solitary, spatulate, fleshy, entire, 6-15 mm. long, 1.5-3 mm. wide, obtuse, long-attenuate from above the middle to the base; flowers few, solitary; peduncle filiform, $5 \mathrm{~mm}$. long, gradually thickened above; calyx eampanulate, $2-2.5 \mathrm{~mm}$. long, somewhat scurfy, its teeth broadly ovate, obtuse, whitish-lanate; corolla funnelform, white, its tube 4-5 mm. long, its 4 oblong obtusish lobes two thirds as long as the tube.

Coppices at upper savannah, Inagua; rocky plains, East Caicos and Ambergris Cay. Endemic. Ixagua Ixiclus.

\section{CÉSTRUM L. Sp. Pl. 191. 1753.}

Shrubs or trees, with alternate entire petioled leaves, the mostly yellow or white flowers in eymes or panicled. Calyx 5-lobed or 5-toothed. Corolla salverform or funnelform, the tube long, slender, the 5 lobes spreading. Stamens borne on the corolla-tube, included; filaments filiform, often pilose below, sometimes with a tooth-like appendage; anthers small, their sacs parallel. Ovary 2-eelled, usually short-stipitate; ovules few; style filiform; stigma dilated, entire or 2-lobed. Fruit a small berry. Seeds oblong, smooth. [Greek, hammer, referring to the filaments.] Perhaps 150 species, natives of tropical America. Type species: Cestrum nocturnum L.

1. Cestrum bahaménse Britton, Bull. X. Y. Bot. Gard. 4: 123. 1905.

A shrub $3 \mathrm{~m}$. high or less, glabrous throughout, the bark light gray. Leares ovate to orate-elliptie, pale green on both sides, but slightly darker green above than beneath, $5-10 \mathrm{~cm}$. long, $5 \mathrm{~cm}$. wide or less, firm in texture, acute at both ends, or the apex obtusish, faintly $7-9$-reined on each side of the 
mid-rein; petioles slender, 1-1.5 cm. long; cymes axillary, few-sereral-flowered, their peciuncles much shorter than the petioles; pedicels $1.5-3 \mathrm{~mm}$. long; calyx oblong-campanulate in flower, $4 \mathrm{~mm}$. long, its teeth triangular-lanceolate, $1.5 \mathrm{~mm}$. long; corolla-tube greenish yellow, 9-13 mm. long, narrowly abconic, its lobes lanceolate, acuminate, purplish, $4-5 \mathrm{~mm}$. long, white-lanose within; stamens inserted on the tube of the corolla just below the lobes, the free part of the filament scarcely longer than the anther; berry blue-black, shining, oboroid, about $12 \mathrm{~mm}$. long, 5-6 mm. thick; fruiting calyx broadly obconic, loosely enclosing the narrowed base of the berry.

Coppices, savannns and scrub-lands, Great Bahama and Abaco to Andros, Cat Island and Long Island :-Cuban Cays. Referred by Grisebach, Dolley, MIrs. Northrop and Hitcheock to Cestrum pallidum Lam.; recorded by Coker as Solimum havanense Jacq. and by Schoepf as Cestrum vespertinum. B.haira Cestrudr. dence,

Cestrum diernum L., recorded by Dolley, has been cultivated on New Provi-

\section{DATÙRA L. Sp. Pl. 179. 1753.}

Tall narcotic herbs, some tropical species shrubs or trees, with alternate petioled leaves, and large solitary erect, short-peduncled, white purple or violet flowers. Calyx elongated-tubular or prismatic, its apex 5-cleft or spathe-like, in the following species circumscissile near the base which is persistent and subtends the prickly capsule. Corolla funnelform, the limb plaited, 5-lobed, the lobes broad, acuminate. Stamens included or little exserted; filaments filiform, very long, inserted at or below the middle of the corolla-tube. Ovary 2-celled, or falsely 4-celled; style filiform; stigma slightly 2-lobed. Capsule 4-ralred from the top, or bursting irregularly. [The Hindoo name, dhatura.] About 12 species, of wide distribution. Type species: Datura Stramonium L.

Spines of the capsule subulate.

Capsules erect.

Capsules nodding.

Spines of the capsule short, deltoid.

1. D. Stramonium.

2. D. Hetel.

3. D. fastuosa.

1. Datura Stramònium L. Sp. Pl. 179. 1753.

Datura Tatula L. Sp. Pl. ed. 2, 256. 1762.

Annual, glabrous or the young parts sparingly pubescent; stem stout, 3-15 dm. high. Leaves thin, orate, acute or acuminate, mostly narrorred at the base, 0.7-2 dm. long, irregularly sinuate-lobed, the lobes acute; flowers white, about $1 \mathrm{dm}$. high; calyx prismatic, less than one-half the length of the corolla; capsule ovoid, erect, densely prickly, about $5 \mathrm{~cm}$. high.

Waste places, Great Bahama, Lignum Vitae Cay, Eleuthera and Acklin's Island :Bermuda; temperate and tropical America; West Indies; Old World. THoRN-APPLE. TISHTOMAN'S BESH.

\section{Datura Mètel L. Sp. Pl. 179. 1753.}

Annual, finely glandular-pubescent, 1-3 m. high. Leaves broadly ovate, acute, inequilateral, rounded or subcordate at the base, 1-2.5 dm. long; flowers white, 1.5-1.8 dm. high; calyx about one-half as long as the corolla; capsule globose or ovoid-glohose, nodding, obtuse, prickly and pubescent, 2.5-4 $\mathrm{em}$. in diameter.

Waste grounds, Andros and Inagua:- southern United States; West Indies; Mexico and tropical America; Old World tropics. Prickly-rur.

3. Datura fastuòsa L. Syst. ed. 10, 932. 1759.

Annual, nearly glabrous; stem erect, branched, 1-2 m. high. Leares orate-lanceolate to elliptic, 5-17 cm. long, acute or acuminate, undulate or 
repand-dentate, the slender petioles $3-\vec{r} \mathrm{~cm}$. long; calyx about $6 \mathrm{~cm}$. long, its ovate lobes acute or short-acnuinate; corolla violet withont, white within, 14-18 en. long; capsule oroid, erect, 4-6 $\mathrm{cm}$. long, its stout prickles corrugated at the base.

Waste places at Pol't Home. Cat Island:-sonthern United States: West Indies: continental tropieal Ameriea; Old World tropies. GARDEx DATURA. Bell-Flower.

\section{NICOTIÀNA [Tourn.] L. Sp. Pl. 180. 1753.}

Viscid-pubescent narcotic herbs or shrubs, with large alternate entire or slightly undulate leaves, and white yellow greenish or purplish flowers, in terminal racemes or panicles. Calyx tubular-campanulate or oroid, 5-cleft. Corolla-tube nsually longer than the limb, 5-lobed, the lobes spreading. Stamens 5, inserted on the tube of the corolla; filaments filiform; anthersacs longitudinally dehiscent. Ovary 2-celled (rarely 4-celled); style slender; stigma capitate. Capsule 2-ralved, or sometimes 4-valved at the summit. Seeds numerous, small. [Named for John Nicot, French ambassador to Portugal, who sent some species to Catherine de Medici, about 1560.] Abont 50 species, mostly natires of America, the following typical.

\section{Nicotiana Tabácum L. Sp. Pl. 180. 1753.}

Annual, 1-2 m. high, iittle branched or simple-stemmert. Leaves oblong to oblong-lanceolate, $1-3 \mathrm{dm}$. long, sessile, acute or acuminate at the apex, narrowed at the base, the lower ones decurrent on the stem; calyx about 12 $\mathrm{mm}$. long, its lobes ovate; corolla funnelform, about $5 \mathrm{~cm}$. long, pink, its lobes triangular-subulate; capsule longer than the calyx.

Spontaneous in waste places, Great Bahama :- widely eultivated and spontaneous after cultivation in warm and tropieal regions. Native of South America. Tobicco.

\section{Family 10. SCROPHULARIÀCEAE Lindl.}

\section{Figwort Fanily.}

Herbs, shrubs or trees, with estipnlate leaves, and perfect, mostly complete and irregular flowers (corolla wanting in one species of Synthyris). Calyx inferior, persistent, 4-5-toothed, -cleft, or -dirided, or sometimes split on the lower side, or on both sides, the lobes or segments valvate. imbricate or distinct in the bud. Corolla gamopetalous, the limb 2-lipped, or nearly regular. Stamens 2, 4 or 5, didynamous, or nearly equal, inserted on the corolla and alternate with its lobes; anthers 2-celled; the sacs equal, or unequal, or sometimes confluent into one. Disk present or obsolete. Pistil 1, entire or 2-lobed; ovary superior, 2-celled, or rarely 1-celled; ovules anatropons or amphitropous, on axile placentr; style slender, simple: stigma entire, 2-lobed or 2-lamellate. Fruit mostly capsular and septicidally or loculicidally dehiscent. Seeds mostly numerons: endosperm fleshy; embryo small, straight or slightly curred; cotyledons little broader than the radicle. Abont 165 genera and 2.700 species, widely distributed.

Upper lip or lobes of the corolla external in the bud, or wanting.

Corolla-tube witl a sac on the lower side; vines.

Corolla-tube without a sac.

Flowers cymose; our species a shrub.

Flowers solitary, racemose or splcate: herbaceous plants.

Anther-bearing stamens 4 (1:arely 5$)$; corolla 2 -lipped or nearly regulat.
1. Haurandya.

2. Russcllia. 
Sepals equal or nearly so.

Sepals rery unequal.

Corolla nearly regular.

Corolla manifestly 2-lipped.

Anther-bearing stamens 2 ; corolla of only 1 lip; minute herbs.

Lower lip or lobes of the corolla external in the bud (except in Cupraria and Scoparia).

Sepals distinct or nearly so. Corolla-lobes 5 ; leaves alternate. Corolla-lobes 4 ; leaves opposite.

Sepals more or less united below into a tube Corolla campanulate to funnelform; capsule not enclosed in the calyx.

Stamens equal or nearly so.

Stamens manifestly didynamous.

3. Stemodia.

4. Bramia.

5. Jecardonia.

6. Hemianthus.

lye calyx 10. Agatinis.

1. MAURÁNDYA Ort. Hort. Matr. Dee. 21. 1797.

Annual or perennial vines, the leaves alternate, or opposite below, flat, hastate, angulate or coarsely toothed. Flowers on axillary peduncles. Sepals partially united. Corolla showy, pink, purple or violet, irregular, its tube scarcely gibbous at the base, with 2 often pubescent lines or plaits in the throat. Stamens 4, included; filaments thickened at the apex; anther-saes often confluent. Styles with 2 dilated lobes at the apex. Ovules nunerous. Capsule short, opening by transverse or irregular chinks. Seeds sometimes minged, wrinkled or tuberevlate. [In honor of Maurandy, a botanist of Cartagena.] About 6 species, natives of warm and tropical America. Type species: Usteria scandens Cav.

1. Maurandya antirrhinaeflòra H. \& B.; Willd. Hort. Berol. pl. 83. 1807.

Antirrhinum antirrhiniflora Hitche. Rep. Mo. Bot. Gard. 4: 113. 1893.

Tery slender, climbing or trailing, sometimes to a length of $3 \mathrm{~m}$. or more, glabrous throughout. Leaves triangular-hastate, acute, 1-2.5 cm. long, slender-petioled; peduncles very slender, mostly longer than the petioles; sepals linear-lanceolate, acuninate, nearly as long as the corolla-tube; corolla purple, $1.5 \mathrm{~cm}$. long, its limb much shorter than its tube; eapsule depressed-globose, about $1 \mathrm{~cm}$. in diameter.

Roadsides, walls and thickets, New Providence:-southwestern United States and Mexico; naturalized in Florida, Bermuda and in Jamaica. Rovisg SAILoR.

\section{RUSSÉLLIA Jacq. Enum. 6, 25. 1760.}

Shrubby plants, with cpposite or whorled leaves, sometimes reduced to mere seales, and cymose or panicled, mostly showy flowers. Calyx-lobes ovate. Corolla tubular, or tubular-funnelform, the tube long, the lobes short, somewhat unequal. Stamens 4, with divergent anther-sacs; no staminodes. Capsule oroid to globose. [In honor of Alexander Russell, English physician and traveller, who died in 1768.] About 15 species, natives of tropical America. Type species: Russellia sarmentosa Jacq.

1. Russellia equisetifórmis Schl. \& Cham. Linnaea 6: 37\%. 1831.

Russellia juncea Zuce. Flora 15: Beibl. 99. 1832.

A glabrous, much-branched shrub, 4-12 dm. high, with spreading or arching striate branches, the twigs very slender. Leaves of the stem and branches, or most of them, reduced to acute scales about $2 \mathrm{~mm}$. long, those of sterile 
twigs spatulate, $1.5 \mathrm{~cm}$. long or less; calyx about $4 \mathrm{~mm}$. long; corolla bright red, about $2.5 \mathrm{~cm}$. long, its lubes ovate, 4-6 mm. long; capsule ovoir.

Roadsides, New Providence, St. George's Cay, Cat Island. Native of Mexico. Naturalized in Florida, Fermuda, Jamaica and from Porto Rico to Tortola ; Parbadoes. RUSSEllia. FOUNTAIX-PLANT.

\section{STEMÒDIA L. Syst. ed. 10, 1118. 1759.}

Herbs or low shrubs, mostly glandular-pubescent and orlorous, with opposite or verticillate leaves, the flowers solitary in the axils or in terminal, often leafy-bracted spikes or racemes. Calyx 5-parted, the segments imbricated, nearly distinct and equal. Corolla with a nearly cylindric tube and a 2lipped limb, the upper lip notcher or entire, erect, external in the bud, the lower 3-lobed. Stamens 4, didynamous, included; filaments filiform; anthersacs distinct, stipitate. Ovules many; style usually 2-lobed. Capsule 2valved, the valves 2-cleft. Seeds striate or reticulated, small. [Greek, double stamens.] About 30 species, of tropical and subtropical regions, the following typical.

\section{Stemodia maritima L. Syst. ed. 10, 111S. 1759.}

Perennial (?), pubescent or puberulent and somewhat riscirl, usually much branched, $6 \mathrm{dm}$. high or less, the branches decumbent or ascending, leafy. Leaves opposite, oblong or cblong-lanceolate, 1-2.5 cm. long, serrate, sessile, acutish at the apex, cordate at the base: flowers nearly sessile in the axils, solitary. shorter than the leaves; ealyx about $2 \mathrm{~mm}$. long; corolla purplish, longer than the ealyx, its upper lip nearly entire.

Moist ground and marshes, Andros, New Providence, Eleuthera, Cat Island, Watling's Island. Fortune Island, Acklin's Island, Mariguana, Great Exuma :-Cuba to Porto Rico: Jamaica: Curacao; South America. Recorded by IItchcock from Cat Island as $S$. durantifolia (L.) Sw. COAST STEModi.

\section{BRĀMTA Lam. Encyel. 1: 439. 1785.}

Diffuse or prostrate herbs, with opposite, mostly entire, obtuse, palmately reined leaves, and small peduncled flowers, mostly solitary in the axils. Calyx subtended by 2 bracts, 5-parted, the upper segment the broadest. Corolla nearly regular, the tube cylindric, the limb nearly equally 5-lobed. Stamens 4, didynamous, included. Style slender; stigma capitate, or 2-lobecl. Seeds numerous. [From Brami, a Nalabar name.] About 20 species of warm and tropical regions. Type species: Bramia indica Lam.

1. Bramia Monnièri (L.) Drake, Pl. Polyn. Franc. 142. 1592.

Iysimachia Monnieri L. Cent. Pl. 2: 9. 1756.

Gratiola Monnieri L. Syst. ed. 10, 851. 1759.

Herpestis Monnieria H.B.K. Nor. Gen. 2: 366. 1818.

Monniera Brownei Pers. Syn. 2: 166. 1506.

Monniera Monniera Britton, Mem. Torr. Club 5: 292. 1594.

Bacopa Monniera Wettst. in E. \& P. Nat. Pflanz. $1^{3 \mathrm{~b}}$ : 77. 1591.

Perennial, glabrous, fleshy; stem creeping, rooting at the nodes, $1.5-5 \mathrm{dm}$. long. Leares spatulate or cuneate-obcordate, sessile, rounded at the apex, entire, or sparingly denticulate, 6-20 $\mathrm{mm}$. long; peduncles mainly in alteruate axils, 2-bracteolate at the summit, in fruit longer than the leaves; flowers pale blue, abont $1 \mathrm{~cm}$. long; upper ealyx-segment orate, acute; corolla ob- 
scurely 2-lipped; stamens nearly equal; capsule ovoid, acute, shorter than the calyx.

Wet places, Great Bahama, Abaco, Andros, New Providence, Eleuthera to Watling's Island and Long Island:- Bermuda; southeastern Lnited States; West Indies; continental tropical America and Old World tropics. MONxIER's HEDGE-MYSSOP.

\section{MECARDònIA Ruiz \& Pavon, Syst. 164. 1798.}

Perennial, erect or diffuse, low herbs, with opposite serrate pinnately veined leaves, aud solitary axillary slender-peduncled flowers. Sepals 5, unequal, the upper one the largest. Corolla 2-lipped, the upper lip emarginate. Stamens 4, borne on the throat of the corolla. Dise wanting. Stigma 2 lobed. Capsule septicidally dehiscent. Seeds numerous. [Commenorates Meca y Cardona, a founder of the Botanical Garden of Barcelona.] About 4 species of tropical and subtropical America. Type species: Mecardonia ovata Ruiz\& Pavon.

1. Mecardonia procúmbens (Mill.) Small, Fl. SE. U. S. 1065, 1338. 1903.

Erinus procumbens Mill. Gard. Dict. ed. S, no. 6. 1768.

Glabrous, nsually branched from the base, the branches decumbent or suberect, $1.5-4 \mathrm{dm}$. long. Leares orate or oval, 1-2 cm. long, serrate, shortpetioled, darkening in drying; perluucles slender, as long as the leares or longer, sometimes 3 times as long; upper sepal at length $8-10 \mathrm{~mm}$. long; corolla white or pink, about $10 \mathrm{~mm}$. long; capsule oblong, 6-10 mm. long.

Sandy coppices and clearings, Great Bahama:-Florida; Cuba to St. Croix; Antigua; Grenada to Trinidad; Jamaica; continental tropical America.

\section{HEMIÀnTHUș Nutt. Journ. Acad. Phila, 1: 119.1817.}

Diminutive prostrate herbs, often rooting at the nodes, with opposite entire 3-nerved leaves, and minute solitary, nearly sessile or peduncled flowers. Calyx deeply cleft, 4-lobed. Corolla (in our species) 1-lipped, the lip 3-lobed, its middle lobe somewhat longer than the lateral ones. Stamens 2, borne on the throat of the corolla; filanents short, with a basal appendage; staminodes none. Style 2-cleft abore the middle. Capsule globose, 2-valred, membranous. Seeds several or many, few-ribbed and trausversely striate. [Greek, referring to the deficient corolla.] A few species of the West Indies and the eastern United States. Type species: Hemianthus micranthemoides Nutt.

1. Hemianthus callitrichoìdes Griseb. Mem. Am. Acad. II. 8: 522. 1862.

Hemianthus multiflorus C. Wright; Griseb. Cat. Pl. Cub. 185. 1866.

Glabrous; matted; stems filiforn, 2-4 cm. long. Leaves elliptic, membranous, sessile, about $3 \mathrm{~mm}$. long, rounded or obtuse at the apex; peduncles filiforn, 1-3 mm. long; calyx about $1 \mathrm{~mm}$. long; lobes of the corolla-lip oblong.

Creeping on ret soil and mud, Andros, Cat Islind, Acklin's Island:-Cuba. WATER-STARTORT HEMIIANTHUS.

7. CAPRÀRIA L. Sp. Pl. 628. 1753.

Perennial herbs or shrubby plants. Leares alternate, longer than broad, toothed. Flowers on axillary pedicels. Calyx of 5 narrow, almost equal 
sepals. Corolla white, eampanulate, with 5 flat lobes. Stamens usually 4; anther-saes 2, divergent, confluent. Stigmas dilated or 2-lobed. Capsule short, 2-grooved, loculicidally dehiscent. Seeds reticulated. [Latin, from capra, a nanny-goat.] About 4 species, of tropical and subtropical America, the following typical.

\section{Capraria bifiòra L. Sp. Pl. 62S. 1753.}

Capraria biflora pilosa Griseb. Fl. Br. W. I. 427. 1861.

Stems 3-9 dm. tall, branching, sometimes pubescent. Leaves oblanceolate, cuneate or oblong, 1-4 em. long, acute, sharply serrate above the midlle; pedicels solitary or 2 together, shorter than the leaves; sepals linear-lanceolate to linear-subulate, 4-6 mm. long; corolla about $1 \mathrm{~cm}$. long, the tube campanulate, the lobes lanceolate, about as long as the tube; capsules oval or ora!oroid, about as long as the sepals.

Roadsides, waste grounds and costal dunes, Abaco and Andros to Grand Turk, Ambergris Cay and Inagua :-Bermuda: Florida, Texas, south through continental tropieal America; West Indies. GodT-WEed. STOW-WEED.

\section{S. SCOPĀRIA L. Sp. Pl. 116. 1753.}

Herbs or low shrubs, mostly branched, with opposite or vertieillate, punctate leares, and small bractless pedicelled flowers solitary or in pairs in the axils. Calyx 4-5-parted, the segments nearly distinet, imbricated. Corolla nearly rotate, 4-cleft, densely bearded in the throat, its lobes nearly equal, obtuse. Stamens 4, nearly equal; filaments filiform; anther-sacs distinct, parallel or divergent. Style clavate above; stigma truncate or notched; ovules many. Capsules septicidally dehiseent, its valves entire, membranous. Seeds many, angular. [Latin, a broom.] About 6 species, of tropical and subtropical America, the following typical one also widely distributed in warm and tropical parts of the Old World.

\section{Scoparia dúlcis L. Sp. Pl, 116. 1753.}

Annual, glabrous, often much branched, 3-10 dm. high, the branches slender. Leaves ovate to oblong-lanceolate, opposite or verticillate in 3 's or 4 's, serrate or the upper ones entire, short-petioled, acute at the apex, narrowed or cuneate at the base, the lower $2-3 \mathrm{~cm}$. long, the upner smaller; pedicels filiform, as long as the upper leares or shorter, often borue in most of the axils; sepals oblong or oblong-obovate, acute, sometimes ciliolate, about $1.5 \mathrm{~mm}$. long; corolla white, 3-4 mu. wide; capsule ovoid-globose, a little longer than the sepals.

Waste places, New Providence, Great Exuma:-sonthern I'nited States: West Indies; tropical and subtropical contiuental America; Old World tropics. Scoparis.

\section{AFZÈLIA Gmel. Syst. 2: 927. 1791.}

Ereet branched herbs, mostly with opposite leaves, at least the lower 1-2pinnately parted or dissected, and yellow flowers solitary in the axils, or in terninal bracted spikes or racemes. Calyx campanulate, $\overline{5}$-eleft or 5-parted. Corolla slightly irregular, campanulate or rotate, the tube short, the limb 5lobed, the lower lobe exterio: in the but. Stamens 4, slightly unequal; filaments short, villous, at least near the base; anthers 2-celled, the saes parallel, distinet. Capsule aeute and more or less compressed at the summit. Seeds 
numerous, reticulated. [Named for Adam Afzelius, 1750-1812, botanical professor at Upsala.] Ahont 10 species, of the southern United States and Nexico, the following typical one reaching the Bahamas.

\section{Afzelia cassioides (Walt.) Gmel. Syst. 2: 927. 1791.}

Anonymos cassioides Walt. Fl. Car. 171. 1788.

Puberulent, much branched, 0.5-1.2 m. high, the very slender branches ascending. Leares approximate, sessile or nearly so, 1-2.5 cm. long, dissected into filiform segments; flowers in long narrow racemes terminating the hranches and usually also in the upper axils; pedicels filiform, $3-7 \mathrm{~mm}$. long; calyx-tube $1 \mathrm{~mm}$. long, the lobes filiform, 1-2 mm. long; corolla glabrous, about $S$ imm. broad; capsule 5-6 mm. long, its acute tip flattened.

I'ine-lands of Great Bahama:--southeastern Inited States. AFzELIA.

\section{AGALİNIs Raf. N. Fl. 2: 61. 1837.}

Ercet herbs, mainly with opposite and sessile narrow leaves. Flotrers showy, usualy large, purple, pink or white, in loose bracted racemes. Calyx campanulate, 5-toothed or 5-lobed. Corolla somewhat irregular, campanulate, or funnelform, the tube broad, the limb 5-lobed, slightly 2-lipped, the lower lobes exterior in the bud. Stamens 4, didynamous, included; filaments pubescent; anthers 2-celled, their sacs obtuse or mucronate at the base; style filiform. Capsule loeulicidally dehiscent, many-seeded. Seeds mostly angled. Type snecies: Agalinis palustris Raf.

Pedicels short. not longer than the calyx.

Pedicels as long as the ealyx or longer, at least in frnit.

1. A. Harperi.

2. A. spiciflora.

\section{Agalinis Hárperi Pennell; Small, Fl. Miami 167, 200. 1913.}

Annual, glabrous or nearly so, little-branched, $8 \mathrm{dm}$. high or less. Leaves narrowly linear, $1.5-3.5 \mathrm{~cm}$. long, spreading; bracts similar to the leaves, the lower often as long as the flowers; racemes 8-20-flowered, the flowers mostly opposite; pedicels shorter than the calyx, 2-3 mm. long; calyx-lobes triangularlanceolate, about $1 \mathrm{~mm}$. long; corolla $15-18 \mathrm{~mm}$. long, pubescent without, pinkish purple, with 2 yellow lines within, the lobes rounded or truncate, ciliate; stamens woolly; capsule subglobose, 4-5 mm. long.

Borders of marshes and in scrub-lands, Great Bahama, Abaco, Andros and Eleuthera :-Florida. Reported by Mrs. Northrop and also by Dolley as Gerardia purpurea L. ; recorded as Gerardia domingensis Spreng. in Bull. N. Y. Bot. Gard. 4: 125.

2. Agalinis spiciflòra (Engelm.) Pennell, Proc. Acad. Nat. Sci. Philad. 71: 277. 1920.

Gerardia spiciflora Engelm. Bost. Jour. Nat. Hist. 5: 227. 1845.

Annual, fleshy, glabrous, branched or simple, 2-6 dm. high, erect or usually so Leares linear, 1-4 cm. long, spreading; bracts similar to the upper leaves, but much smaller, often not longer than the pelicels; racemes distantly 4-12-flowered; pedicels 4-12 $\mathrm{mm}$. long, ascending, longer than the calyx, thickened uprard; calyx-lobes triangular, about $1 \mathrm{~mm}$. long; corolla 15-20 mm. long, pink, puberulent without, its lobes rounded or emarginate, ciliate; stamens woolly; capsule globose or aroid-globose, $4.5-6 \mathrm{~mm}$. long.

Marshy places, Abaco. Great Bahama. Andros. New Providence and Eleuthera :southern Tnited States: Cuba. Reported by Mrs. Northrop and by Coker as Gerardia maritima Raf., and as Gerardia purpurea L. br Dolley. MARsi Agalisis. 


\section{BÜCHNERA L. Sp. PI. 630. 1753.}

Erect, perennial or biennial, strict hispid or scabrous herbs, blackening in drying, the lower leares opposite, the upper sometimes alternate. Flowers rather large, white, blue, or purple, in terminal bracted spikes, the lower commonly distant. Caly $\mathrm{x}$ tubular, or oblong, 5-10-nerved, 5-toothed. Corolla salrerform, its tube cylindrie, somewhat eurved, its limb nearly equally 5-cleft, spreading, the lateral lobes exterior in the bud. Stamens 4, didynamous; anther-saes confluent into 1 . Style slender, thickened or club-shaped above; stigma small, entire or emarginate. Capsule loculicidally dehiscent. Seerls numerous, reticulated. [Namer] for J. G. Buchner.] About 30 species, of warm and temperate regions. Type species: Buchnera americana L.

\section{Buchnera elongàta Sw. Frodr. 92. 1758.}

Stems rough-hispidulous, 2-5 $\mathrm{\lambda m}$. high, simple or branched abore, slender. Leaves scabrous, sparingly toother or entire, the basal ones obovate or oblong, short-petioled, 1-3 $\mathrm{cm}$. long, those of the stem oblong to linear, $1.5-8 \mathrm{~cm}$. long; spikes slender, distantly-flowered; calyx 5-6 mm. long, hispidulous, its upper lobes triangular, acute; corolla blue or white, 9-12 mm. long, its tube somewhat pubeseent; capsules ovoid, $5-7 \mathrm{~mm}$. long.

Pine-lands and sir rannas, Great Bahama, Andros and New Provldence :-Florida; Jamaica; Cuba; IIispaniola : continental tropical America. Puchnera.

Verbascey PLlierulextum Mill. is recorded from Green Turtle Cay, Abaco, by Herrick. The specimen cannot be found among his plants nor has any species of the genus been seen by our collectors in the archipelngo.

Lixaria vulgatis Mill. is reported by Dolley to be naturalized in the Bahamas. While this may be possible neitler $\mathrm{Mr}$. Brace, nor any of our other collectors, has seen the plant on the islands. It may have been cultivated.

\section{Family 11. LENTIBULARIĀCEAE Lindl.*}

\section{Bladdertrort FAMILY.}

Aquatic plants, or terestrial on moist ground, with the leaves bacal and tufted, or borne on branching stems. Seapes ereet. Flowers perfect, irregular. Calyx inferior, 2-5-parted. Corolla 2-lipped, spnrred or saccate at the base. Stamens 2; anther-saes eonfluent into 1. Orary superior, oroid or globose, 1-celled, with a free-central placenta; ovules numerous: style short or none; stigma 2-lamellate. Fruit a eapsule, irregularly bursting, or dehiscent by valves. Seerls retieulate, or variously sculptired or appendaged; endosperm none. About 16 genera and 300 speeies. widely distributed.

Scape witl scales, or hracts, or both, 1-many-floweled: calys 2-parted; corolla witl a prominent palate, closing the throat.

Fedicels several times as long as the bracts at their bases: bractlets none.

Buacts attached by the base; lower corolla-lip faintly lobed.

Practs peltate; lower corolla-lip divergently :-lohed.

Pedicels barely if at all exceeling the bracts; a pait" of lateral bractlets as well as a bract at tlue bas? of each pedlcel.

Scape naked, 1-flowered; calyx isparted: corolla with a subulate palate within the tube, or none, the throat open.

1. Utricularin.

2. Srtiscapella.

3. Stomoisia.

4. Pinguicula.

* Contrlbuted by Dr. Jolin II. Barnhart. 


\section{UTRICULÀRIA L. Sp. Pl. 18. 1753.}

Aquatic herbs, the submersed stems with finely divided leaves bearing minute bladders. Flowers racemose or solitary at the summits of the scapes, each pedicel with a single bract at its base. Calyx 2-parted, the lobes herbaceous. Corolla strongly 2-lipped, the lower lip with a prominent 2-lobed palate. [Latin, utriculus, a little bag.] Abont 75 species, of wide distribution. Type species: Utricularia vulgaris $\mathrm{L}$.

Stems free-floating; scapes manr-flowered; pedicels recurved in fruit. Stems creeping on the bottom in shallow water; scapes 1-4-flowered; pedicels straight, ascending in fruit.

1. U. foliosa.

2. U. pumila.

\section{Utricularia foliòsa L. Sp. Pl. 18. 1753.}

Stems elongate, up to $25 \mathrm{dm}$. or more long, free-floating except for a single point of attachment. Leaves $3-10 \mathrm{~cm}$. long, forked at the base, each fork pinnately dissected into numerous capillary segments, often copiously bladder-bearing; seapes solitary, 1-3 dm. high, 10-20-flowered; pedicels recurved in fruit; corolla yellow, 15-20 mm. broad; spur slenderly conic, shorter than the lower lip; eapsules few-seeded.

Fresh water of a palmetto swamp at Barnett's Point, Great Bahama :-Florida to Louisiana; Cuba; Haiti; Jamaica. LEAFY BLADDERWORT.

\section{Utricularia pùmila Walt. Fl. Car. 64. 1788.}

Stems short, creeping on the bottom in shallow water, radiating from the base of the scape. Leaves less than $1 \mathrm{~cm}$. long, dichotomously divided into few capillary segments, bladder-bearing; scapes solitary or 2 together, 5-12 cm. high, 1-4-flowered; pedicels erect-ascending in fruit; corolla yellow, 12-15 $\mathrm{mm}$. broad; spur slenderly conic or subulate, equalling or usually exceeding the lower lip; capsules many-seeded.

In shallow water, Great Bahama, Andros, New Providence, Great Exuma :eastern United States. Specimens from Andros, without flowers, were doubtfully determined by Morong as $U$. foliosa L. and as $U$. gibba L.; the former is certainly, the latter probabls, referable to this species. TWO-FLowered BLADDERWORT.

\section{SETISCAPÉLLA Barnh. in Small, F1. Miami 170. 1913.}

Terrestrial herbs, with short root-like branches from the base of the seape, the delicate and evanescent leaves and minute bladders rarely seen. Flowers in zig-zag racemes or solitary at the summits of the wiry scapes, each pedicel with a single peltate bract at its base. Calyx 2-parted, the lobes scarious, ribbed. Corolla 2-lipped, the lower lip divergently 3 -lobed, with a prominent 2-lobed palate. [Latin, seta, bristle, and scapus, scape.] About 12 species, in Asia, Africa and America, the following typical.

1. Setiscapella subulàta (L.) Barnh. in Small, Fl. Miami 170. 1913.

Utricularia subulata L. Sp. Pl. 18. 1753.

Stems and leares usually evanescent before flowering-time. Scapes 3-20 $\mathrm{cm}$. high, filiform, bronze-colored, 1-12-flowered; pedicels ascending; corolla yellow, 4-6 mm. broad; spur appressed to the lower lip and nearly or quite equalling it in length.

In mud, near Deep Creek, Andros:-eastern Lnited States; Cuba; Porto Rico; northern and eastern South America. Zig-ZAG Bladderwort. 
3. STOMoisia Raf. Fl. Tellur. 4: 108. 1839.

Terrestrial herbs, with short root-like brauches from the base of the scape, the delicate and evanescent leaves and minute bladders rarely seen. Flowers racemose, often subscapose, or solitary at the summits of the slender scapes, each pedicel with a bract and a pair of bractlets at its base. Calyx 2-parted, the lobes thin and veiny. Corolla strongly 2 -lipped, the upper lip with a distinct claw, the lower consisting chiefly of the helmet-shaped, laterally compressed palate. [Greek, hairy mouth.] About 50 species, of wide distribution, the following typical.

1. Stomoisia cornùta (Michx.) Raf. Fl. Tellur. 4: 108. 1838.

Utricularia cornuta Michx. Fl. Bor. Am. 1: 12. 1803.

Stem and leaves inconspicuous, rarely seen. Scapes stiffly erect, 1-4 dm. high, 2-5-flowered, the flowers approximate; pedicels usually shorter than the bracts; corolla yellow, the lower lip 12-15 mm. long; spur subulate, pendent, about $12 \mathrm{~mm}$. long.

In a large sink-hole, near Deep Creek, Andros:-eastern North America; Cuba. HORNED BLADDERWORT.

\section{PINGUícULA L. Sp. Pl. 17. 1753.}

Terrestrial herbs, with fibrous roots, and the entire leaves in a basal rosette. Flowers solitary at the summits of the naked scapes. Calyx 5-lobed, more or less 2-lipped. Corolla more or less 2-lipped, the spreading limb sometimes almost equally 5-lobed. Capsule 2-ralved. [Latin, pinguis, fat, the leaves of some species being greasy to the touch.] About 30 species, of wide distribution. Type species: Pinguicula vulgaris L.

\section{Pinguicula pùmila Michx. Fl. Bor. Am. 1: 11. 1803.}

Leares elliptic-obovate, $1-3 \mathrm{~cm}$. long, rounded at the apex, narrowed at the base but scarcely petioled, faintly reined. Scapes very slender, erect, $0.5-2 \mathrm{dm}$. high; calyx-lobes $2-3 \mathrm{~mm}$. long, oblong, obtuse; corolla pale violet or white, somewhat 2-lipped but the 5 lobes subequal, 1-2 $\mathrm{cm}$. broad; spur subulate, about $3 \mathrm{~mm}$. long, longer than the sac-like base of the corolla; capsule subglobose, a little longer than the calyx-lobes.

Savannas, Andros:-sontheastern Lnited States. Low BetTermont.

\section{Family 12. BIGNONIÀCEAE Pers.}

\section{TRUMPET-CREEPER FAMILY.}

Trees, shrubs or woody vines, a few species herbaceous, with opposite (rarely altermate) leaves, and mostly large and slowy, clustered, more or less irregular flowers. Calyx inferior, gamosepalous. Corolla gamopetalous, 5-lobed, somewhat 2-lipped, at least in the bud. Antherbearing stamens 2 or 4 , inserted on the tube of the enolla and alternate with its lobes; anthers 2-eelled, the saes longitudinally dehiseent. Disk annular or emp-like. Orary mostly 2-eelled; planeenta parietal, or on the partition-wall of the ovary; oriles nmmerons, horizontal, anatropons; style slender; stigma terminal, 2-lobed. Capsule 2-valved. Seeds flat, 
transverse, winged in many genera; endosperm none; eotyledons broad and flat, emarginate or 2-lobed; radicle short, straight. About 60 genera and over 500 species of wide clistribution in tropical regions, a few in the temperate zones.

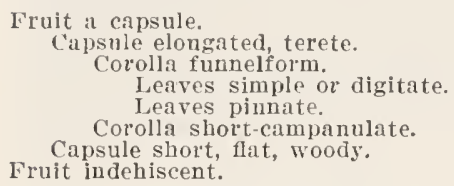

1. Tabebuia.

2. Trecoma.

3. Macrocitalpa.

4. Jacaranda.

5. Crescentia.

1. TABEBÙIA Gomez, Obs. 2: 7, pl. 2. 1803.

Trees or shrubs, with opposite petioled, digitately 1-i-foliolate or simple leaves, the large showy flowers in terminal cymes or panicles. Calyx tubular, variously toothed or cleft. Corolla funnelform or funnelform-campanulate, the limb spreading, slightly 2-lipped or nearly regitlar, the 5 lobes rounded. Stamens 4, didynamons, included; filaments slender, curved; anthers oblong or linear, glabrous. Ovary sessile; orules many, in 2 -several series. Capsule linear or linear-oblong, nearly terete, loculicidally dehiscent, its valves membranous or coriaceous, convex. Seeds numerous, minged. [Brazilian name.] Seventy-five species or more, natives of tropical America. Type species: Bignonia Tabebuya Vell.

Leaflets mostly 3 , green on both sides; lateral leaflets sessile or nearly so.

Leaflets mostly 5 , white-lepidote beneath: all the leaflets petioled.

1. T. lepidota.

2. T. bahamensis.

1. Tabebuia lepidòta (H.B.K.) Britton, Bull. Torr. Club 42: 377. 1915.

Bignonia lepidota H.B.K. Nov. Gen. 3: 139. 1818.

Tecoma lepidota DC. Prodr. 9: 220. 1845.

A shrub, 1-3 m. high, or in Cuba sometimes a tree up to about $6 \mathrm{~m}$. high, the young twigs more or less lepidote. Leaves mostly 3 -foliolate, rarely 1-2foliolate, or those of shoots 5 -foliolate; petioles $1-2.5 \mathrm{~cm}$. long; leaflets oblanceolate to oblong-obovate, about $5 \mathrm{~cm}$. long or less, coriaceous, rounded or retuse at the apex, narrowed at the base, the terminal one stalked, the lateral ones sessile, all somewhat lepidote, at least beneath; flowers usually few, pink, 5-7 cm. long; calyx lepidote, oblique; capsule 6-12 cm. long.

Scrub-lands, Andros:-Cuba. The specimens are incomplete and are referred to this species with hesitation.

2. Tabebuia bahaménsis (Northrop) Britton, Bull. Torr. Club 42: 379. 1915.

Tecoma bahamensis Northrop, Nem. Torr. Club 12: 65. 1902.

Bignonia pentaphylla L. Sp. Pl. ed. 2, 870. 1763. Not Tabebuia pentaphylla (Juss.) Hemsl. 1882.

A shrub or small tree up to $10 \mathrm{~m}$. high, the young twigs lepidote. Leares 3-5-foliolate, long-petioled; leaflets oblong to elliptic, stalked, $2-7 \mathrm{~cm}$. long, entire, rounded or retuse at the apex, mostly obtuse at the base, densely white-lepidote beneath, sparingly lepidote or elepidote above; panicles severalflowered; pedicels rather stout, brown-lepidote, $12 \mathrm{~mm}$. long or less; ealyx narrowly campanulate, brown-lepidote, irregularly 2-lipped, 1-1.5 $\mathrm{cm}$. long; corolla pink, 4-6 cm. long, its lobes rounded, slightly undulate; capsule 8-12 $\mathrm{cm}$. long, about $7 \mathrm{~mm}$. thick.

Scrub-lands, pine-lands and coppices, Freat Bahama, Abaco, South Biminl and Andros to Crooked Island, North Caicos and Inagua :-Cuba. BEEF+Bush. GUNwOOD. ABove-ALL. White Cedar. Referred by Grisebach and by Dolley to Tecoma Leucoxylon Mart. Catesby, 1: pl. 37. 


\section{TÉCOMA Juss. Gen. 139. 1789.}

Shrubs or trees, with opposite, pinnate or rarely simple leares, and large flowers racemose or panieled at the ends of the branches. Calyx tubulareampanulate, 5-toothed. Corolla funnelform-campanulate, the limb slightly 2-lipped, 5-lobed, the lobes nearly equal. Stamens 4, didynamous. Ovary sessile or nearly sessile; orules mostly in one series on the placentae. Capsule linear, loculieidally dehiseent, many-seeded, the seels winged. [From the Aztec name Teeomaxochitl.] About 10 speeies, natives of tropical and warmtemperate America, the following typical.

\section{Tecoma stáns (L.) H.B.K. Nor. Gen. 3: 144. 1818.}

Bignonia stans L. Sp. Pl. ed. 2, 871. 1763.

Stenolobium stans Seem. Journ. Bot. 1: 88. 1863.

A shrub, or small tree up to about $8 \mathrm{~m}$. high, glabrous throughout. Leares 1-3 dm. long, petioled; leaflets 5-13, laneeolate, oblong-lanceolate or elliptic, short-stalked, serrate, aeute or aeuminate at the apex, mostly narrowed at the base; raeemes several-many-flowered; pedicels sleuder, $1 \mathrm{~cm}$. long or less; ealyx $3-5 \mathrm{~mm}$. long, its teeth triangular-orate, aeute; corolla bright sellow, $3.5-5 \mathrm{~cm}$. long, the cylindric part of its tube about twice as long as the calyx, its lobes broad; eapsule 1-2 am. long, 5-6 mm. in diameter, beaked.

Waste places, scrub-lands and borders of coppices, New Prosidence, Cat Island, Watling's Island, Grand Turk and Inagua:- Flolida; continental tropical America and the West Indies. TruMPET-FLower. YELLOW ELDer.

3. MACROCATÁLPA Britton, Journ. N. Y. Bot. Gard. 19: S. 1918.

[Catalpa, seet. Macrocatalpa Griseb. Cat. Pl. Cub. 191. 1566.]

Trees, with opposite or verticillate, simple, ovate to oblong-lanceolate, slender-petioled entire leaves, and medium-sized flowers panieled at the ends of the branches. Calyx closed in bud, 2-cleft at anthesis. Corolla membranous, obliquely campanulate, the short tube mueh expanded above, the limb 2-lipped, 5-lobed, the lobes broad, obtuse, undulate. Stamens 2, included, the filaments slender, the anthers glabrous; staminodia 3, small. Ovary sessile; style filiform; stigma 2-lamellate; orules in several series. Capsule linear, very long, subterete. Seeds eompressed, linear, long-pilose. [Greek, great Catalpa.] Two or three speeies, natives of the West Indies, the following typical.

1. Macrocatalpa punctàta (Griseb.) Britton, Journ. N. Y. Bot. Gard. 19: S. 1918.

(?) Echitcs macrocarpa A. Rich. in Sagra, Hist. Cub. 11: 94. 1850. Catalpa punctata Griseb. Cat. Pl. Cub. 192. 1866.

A tree, sometimes $10 \mathrm{~m}$. high, the branches spreading, the young shoots puberulent. Leaves opposite or some of them vertieillate in 3's, oblong to elliptie, subeoriaceous, $\bar{y}-\bar{\imath} \mathrm{cm}$. long, obtuse, rounded, or acutish at the apex, mostly rounderl at the base, finely reticulate-reinerl beneath and lepidotepuncticulate when young, dull and glabrous above, the petioles 1-3 em. long, puberulent when young; panicles few-several-flowereil, slenter-perluneled; pedicels very slender, $8-20 \mathrm{~mm}$. long; calyx-lobes lepidote, obtuse, about $7 \mathrm{~mm}$. long; corolla light yellow with orange and brown bands in the throat, $1.2-2 \mathrm{~cm}$. long; capsule $3-4$ dm. long.

Copplces, Andros:-Cuba. Cевix C.tali.ı. 
[Macrocatalipa longíssima (Jacq.) Britton (Catalpa longissima Jacq.) is reported by IIitcheock from Cat Island, and a speciment of the species so labeled is in his collections. We judge, however, that there is an error in this report and in the labeling of the specimen, as Prof. Hitcheock admits the possibility of error and does not remember the exact locality where the specimen may have been collected, nor could we find the tree in passing over his exact route with the native who accompanied him. The Jamaica specimen in his collection is a counterpart of the one labeled Cat Island. Prof. Rothrock, who was with him, returns no specimen from Cat Island though his collections contain a counterpart of Prof. Hitcheock's from Jamaica.]

\section{JACARÁNDA Juss. Gen. 138. 1789.}

Trees, with opposite, mostly bipiunate leaves, and showy panicled blue or violet flowers. Calyx campanulate or tubular-campanulate, 5 -toothed. Corolla obliquely funnelform, the tube cylindric below, expanded above, the limb somewhat 2-lipped, with 5 spreading rounded lobes. Stamens 4, didynamous, included; anthers glabrous; staminodium about as long as the stamens, clarate, usually villous. Orary 2-celled, sessile; ovules borne in 1 or 2 series. Capsule oblong to suborbicular, compressed, loculicidally dehiscent, its flat valves coriaceous or ligneous. Seeds flat, winged. [Brazilian name.] About 20 species, natives of tropical America, the following typical.

\section{Jacaranda coerùlea (L.) Griseb. Fl. Br. W. I. 446.1861.}

Bignonia coerulea L. Sp. Pl. 625. 1753.

Jacaranda caroliniana Pers. Syn. 2: 174. 1806.

Jacaranda bahamensis R. Br. Bot. Mag. under pl. 232\%. 1822.

A tree, attaining a maximum height of about $12 \mathrm{~m}$., the foliage glabrous. Leaves evenly bipinnate, petioled, often $3 \mathrm{dm}$. long; pinnae 4-13 pairs, stalked; leaflets 17-35, obliquely oblong, sessile, 1-2.5 cm. long, acutish at the apex, narrowed at the base; panicle many-flowered, 1-2 dm. long, puberulent; pedicels short; calyx pubernlent, 5-6 mm. long, its teeth triangular, acute; corolla puberulent, about $4 \mathrm{~cm}$. long; capsule oval, glabrous, 4-6 $\mathrm{cm}$. long, emarginate.

Scrub-lands and coppices, Andros, New Providence, Eleuthera, Cat Island, Great Guana Cay, and Great Exuma :-Cuba; recorded from Martinique. Boxwood. CaNcerTREE. WIAT o'CLOCK. Catesby, 1: pl. 42.

\section{CRESCÉNTIA L. Sp. Pl. 626.1753.}

Trees, with glabrous simple alternate or fascicled leaves, and large, solitary or clustered, lateral or axillary flowers. Calyx leathery, elosed in bud, 2-parted or 5-cleft at anthesis. Corolla with a subcampanulate swollen tube and an oblique lacerate or 5-lobed limb. Stamens 4, didynamous, included or a little exserted; anthers glabrous. Ovary 1-celled, sessile; ovules many, on 2 parietal placentae. Fruit globose or ovoid, large, indehiscent, the shell hard. Seeds numerous, wingless, compressed, borne on spongy placentae. [Commemorates Petrus de Crescentius, a celebrated Italian, born in 1230.] Abont 5 species, natives of tropical America, the following typical.

1. Crescentia Cujète L. Sp. Pl. 626. 1753.

A tree, attaining a maximum height of abont $10 \mathrm{~m}$. , the trunk up to 2 dm. in diameter, with long spreading branches. Leaves spatulate to oblance- 
olate, fascicled, $5-15 \mathrm{~cm}$. long, obtuse, acute or short-acuminate at the apex, narrowed to the nearly sessile base; flowers stout-peduncled; calyx 2-2.5 c111. long, its lobes broad, rounded or obtuse; corolla yellowish-purple, $5-6 \mathrm{~cm}$. long, its lobes lacerate, much shorter than the tube; fruit subglobose to oral, 1.5-3 dm. in diameter, its rind hard.

Jumbie Hole, Acklin's Isiand:-Florida; West Indies; continental tropical America. Often planted for its valuable fruit.' CaLamasil.

\section{Family 13. PEDALIÀCEAE Lindl.}

\section{Pedaliuar Fajilly.}

Mostly herbs, often mucilaginous, the leares opposite or the upper alternate, and axillary, solitary or sometimes fascicled, perfect irregular flowers. Calyx 5-cleft or 5-parted. Corolla with a subcrlindric tube and a usually short, obseurely 2-lipped, 5-lobed limb. Stamens mostly 4 and didynamous, included; anthers dorsifixed, the sacs parallel, or in some genera distinct. Disk fleshy. Ovary sessile, 2-t-celled; ovules sereral or many, anatropous; style filiform. Fruit varions. Seeds without endosperm. About 14 genera, including some 45 species, natives of the Old irorld.

\section{SÉSAMUM L. Sp. Pl. 634. 1753.}

Herbs, usually erect, the lower leaves opposite, the upper alternate, or all sometimes alternate, the violet to white, short-peduncled flowers solitary in the axils. Calyx 5-parted. Tube of the corolla oblique at the base, somewhat gibbous, the limb 5-lobed, slightly 2-lipped, the lobes spreading. Stanens 4, didynamous, borne near the base of the corolla; anthers sagittate. Orary 2celled; orules many in each carity, superimposed in a single series. Fruit an oblong, 4-sided loculicidal capsule. [Arabic name.] About 12 species, watives of tropical Africa and Asia, the following typical.

\section{Sesamum orientàle L. Sp. Pl. 634. 1753.}

Sesamum indicum L. Sp. Pl. 634. 1753.

Erect, simple or brancher, more or less pubescent, $0.7-2 \mathrm{~m}$. high. Leares lanceolate or orate-lanceolate, $7-15 \mathrm{~cm}$. long, acuminate at the apex, mostly narrower at the base, papillate beneath, the petioles $1-5 \mathrm{~cm}$. long; peduncles about $4 \mathrm{~mm}$. long; sepals linear-lanceolate, about $1 \mathrm{~cm}$. long; corolla pale rose, 2-3 cm. long; capsule linear-oblong, short-beaked, 4-grooved, $2-3 \mathrm{~cm}$. long.

Spontaneous after cultivation, Eleuthera and Cat Island:-Florida; West Indies and continental tropical Amerlca. Native of the East Indies. SEsmin. BexNy-SEED.

\section{Family 14. MARTYNIÀCEAE Link.}

\section{UNICORN-PLANT FAMILT.}

Herbs, with opposite leaves, or the upper alternate, and perfect irregular flowers. Calyx inferior. 4-5-cleft or $4-\overline{5}$-parted, or sometimes split to the base on the lower side. Corolla gamopetalous, irregular, the tube oblique, the limb slightly 2-lipped, 5-lobed, the lobes nearly equal, the 2 upper ones exterior in the bud. Anther-bearing stamens 4, didynamous, or 2, or the posterior pair sterile; anthers 2-celled, the sacs longitudinally dehiscent. 
Orary 1-celled, with 2 parietal placente expanded into broad surfaces, or 2-1-celled by the intrusion of the placentre or by false partitions; ovules anatropous; style slender; stigma 2-lobed or 2-lamellate. Seeds compressed; endosperm none; embryo larce: cotyledons fleshy, flat; radicle short, straight. Three genera and about 12 species, mainly tropieal.

\section{MARTÝNIA L. Sp. Pl. 618. 1753.}

Coarse glandular-pubescent and viscid strong-scented herbs, with longpetioled leaves, and large flowers in short terminal racemes. Calyx 1-2bracteolate at the base, campanulate, inflated, deciduous. Corolla funnelformcampanulate. Anthers gland-tipped, their sacs divergent. Orary 1-celled, the 2 parietal placentae intruded and expanded in the center of the cavity into broad surfaces bearing the orules in 1 or 2 rows. Fruit an incurved beaked loculicidally 2-valved capsule, the exocarp somewhat fleshy, the endocarp fibrous, woody, crested below or also above, 4-celler by the extension of the placentae. Seeds numerous, tuberculate. [Named for John Martyn, 16931768, profesor of botany at Cambridge, England.] About 8 species, natives of America. Type species: Martynia annua L.

1. Martynia ånnua L. Sp. PI. 618. 1753.

Martynia diandra Glox. Obs. Bot. 14. 1785.

Viscid-pubeccent, brancher, 5-8 $\mathrm{dm}$. high, the stem and branches rather stout. Leaves thin, flaccid, opposite, long-petioled, avate-orbicular, $8-15 \mathrm{~cm}$. long, sinuate-dentate, palmately reined, acute at the apex, cordate at the base; racemes short-peduncled, several-flowered; pedicels 1-2 $\mathrm{cm}$. long, slender, thickening and recurved in fruit; calyx very deeply 5-cleft, about $1.5 \mathrm{~cm}$. long, its segments acute; stamens 2; corolla pink, or nearly white, $3-5 \mathrm{~cm}$. long, its rounded lobes purple-blotched; capsule obliquely ov oi $\bar{x}$, compressed, 2-2.5 cm. long, viscid, tipped with a hooked beak about $3 \mathrm{~mm}$. long.

Waste places. Nassau, New Proridence:-Cuba to Porto Rico, St. Thomas and Antigua: Martinique and Bequia: continental tropical America. SurLL-Freited MARTYAIA.

\section{Family 15. ACANTHÀCEAE J. St. Hil.}

\section{ACANTHUS Famili.}

Herbs, or some tropical genera slurubs or small trees, with opposite simple estipnlate leares, and irregular, or nearly regular, perfect flowers. Calyx inferior, persistent, 4-5-parted or 4-5-cleft, the sepals or segments imbricated. Corolla gamopetalous, nearly regularly 5-lobed, or 2-lipped. Anther-bearing stamens 4, didynamous, or 2 only; anther-sacs longitudinally dehiscent. Disk annular, or cup-like. Ovary 2-celled; ovules 2-10 in each cavity, anatropous or amphitropous; style filiform. simple; stigmas 1 or 2. Capsule dry, 2-celled, loculicidally elastically 2-ralred. Seeds not winged, borne on curved projections (retinacula) from the placentæ, the testa close, mostly roughened, often developing spiral threads and mucilage when wetted. About 175 genera and 2,000 species, natives of temperate and tropical regions.

Herbs or shrubs.

Stamens 4, didynamous.

Caulescent herbs or shrubs.

Flowers in densely bracted terminal spikes.

Flowers solitary or cymose.

Acaulescent herbs with spicate flowers.

1. Blechum.

2. Ruellia.

3. Gerardia. 
Fertile stamens only 2

Shrubs with opposite spines: staminodia 2.

Unarmed herbs or shrubs; staminodia none.

seeds 6-12.

Seeds $2-4$.

Capsule oblong.

Capsule ovate or orblcular.

Twining rines; flowers solitary, axillary, subtended by 2 large bracts ; stamens 4 .

4. Anthacanthus.

5. Androyraphis.

6. Justicia.

7. Diapedium.

S. Thunbergia.

1. BLÉCHuM P. Br.; Juss. Ann. Mus. Paris 9: 269. 1507.

Perennial herbs, with repand-dentate or entire, petioled leares, and small flowers in dense terminal spikes, the large foliaceous bracts imbricated. Calyx 5-parted, the slightly unequal segnents linear-subulate. Corolla with a slender tube little expanded above and a spreading, nearly equally 5-lobed limb, the lobes rounded. Stamens 4, didynamous, borne at or above the middle of the corolla-tube; anthers oblong, their saes parallel. Orules few or sereral in each ovary-carity; style with a subulate apex. Capsule orate or suborbicular with a short, narrowed base. Seeds orbicular. [Name Greek, originally applied to some different plant.] About 4 species, natires of tropical America. Type species: Ruellia Blechum L.

\section{Blechum Brównei Juss. Ann. Mus. Paris 9: 270. 1507.}

Annual, puberulent, erect or ascending, 2-7 dm. high, branched, the liranches slender. Leares orate, thin, petioled, $2-i \mathrm{~cm}$. long, acute at the apex, obtuse or narrowed at the base; spikes dense, 4-sided, 3-6 cm. long; bracts ovate, pinnately reined, $1-1 . \overline{\mathrm{cm}}$. long, loosely strigose and ciliate, acutish at the apex, rounded at the base; corolla whitish, a little longer than the subtending bract; capsule oblong, puberulent, about $6 \mathrm{~mm}$. long.

Waste places in good soil, Abaco, Andros, New Proridence and Eleuthera:west Indies and continental tropical America; Philippine Islands. Buecurar.

\section{RUÉllia L. Sp. PI. 634. 1753.}

Perennial herbs, or shrubs, mostly pubescent, with entire or rarely dentate leares and large flowers, solitary or clustered in the axils, or cymose in terminal panicles. Calyx 5-cleft or 5-parted, the segments narrow. Corolla funnelform or salverform, the tube usually narrow, slightly enlarged above, the limb spreading, 5-lobed, the lobes obtuse. Stamens 4, didynamous. Anthersacs not mucronate at the base. Apex of the style recurved; stigma simple, or of 2 unequal lobes. Capsule oblong or club-shaped. Seeds compressed, ovate or orbicular, attached by their edges to the retinacula. [Yamed for I. De la Ruelle, 1474-1537, an early French herbalist.] About 200 species, mainly of tropical America. Type species: Ruellia tuberosa L.

\section{Ruellia tuberòsa I. Sp. Pl. 635. 1753.}

Roots narrowly fusiform, clustered; stem erect or ascending, branched or simple, 2-6 dm. high, finely pubescent. Leares orate or ohlong, $10 \mathrm{~cm}$. long or less, undulate, finely pubescent, narrowed into margined petioles; crmes several-flowered, peduncled; bracts narrow, small; calyx hispicl-pubescent, its linear lobes 12-20 $\mathrm{mm}$. long; corolla purple, $4-6 \mathrm{~cm}$. long, its tube rather abruptly expanded above; capsules puberulent, abont $1.5 \mathrm{~cm}$. long.

Shaded grounds, New Providence, Eleuthera and Cat Island:- -sonthern Lnited States: West Indies and continental tropieal America. Tumbrocs Ruelli. 


\section{GERÁrdia [Plum.] I., Sp. Pl. 610. 1753.}

[Stexaxprium Nees, in Lindl. Introd. Nat. Syst. ed. 2, $444 . \quad 1836$.

Low and small pubescent perennial herbs, acaulescent or nearly so, the leares in a basal tuft, the pink or purple flowers spicate on bracted seapes. Calyx-lobes 5, narrow, nearly equal. Corolla with a slender tube, enlarged into a slightly curved throat, the oblique 5-lobed limb spreading, the lobes unequal and imbricated. Stamens 4, didynamous, included, the anthers 1-celled. Ovules 2 in each eavity of the ovary; stigma 2-lobed. Capsule fusiform or narrowly oblong. Seeds flattened, rough or pubescent. [Commemorates John Gerardi, 1545-1607, fanous English herbalist.] About 25 species, of tropical and subtropical America. Type species: Gerardia tuberosa L.

Bracts linear to linear-lanceolate, the lower $3-7 \mathrm{~mm}$. long; leares entile.

Bracts lanceolate, the lower $1 \mathrm{~cm}$. long; leaves repand-dentate or undulate.

1. G. droseroides.

2. G. bracteosa.

\section{Gerardia droseroides (Nees) Blake, Rhodora 20: 68. 1918.}

Stenandrium droseroides Nees, in DC. Prodr. 11: 284. 1847.

Pubescent all over with soft hairs. Basal leaves forming small tufts, membranous, oblong, entire, $3-4.5 \mathrm{~cm}$. long, rounded or obtuse at the apex, the petioles as long as the blades or shorter; scapes slender, $8-15 \mathrm{~cm}$. high; spikes slender, several-many-flowered; bracts linear to linear-lanceolate, 3-7 $\mathrm{mm}$. long, acuminate; calyx-lobes linear, $2-3 \mathrm{~mm}$. long; corolla white, its tube 3-4 mm. long, about as long as the lips; filaments rery short; capsule oblong, acute, glabrous, $4-5 \mathrm{~mm}$. long; seeds suborbicular.

Pine-lands, Abaco and New Providence:-Cuba. Suxdew Gerardia.

\section{Gerardia bracteòsa Britton \& Millspaugh, sp. nov.}

Pubescent all over with long soft hairs. Basal leares in large tufts, $7 \mathrm{~cm}$. long or less, firm in texture, the flat petioles of the larger ones as long as the blades or longer, the blades oblong to oblong-oborate, $2-3.5 \mathrm{~cm}$. long, 8-18 $\mathrm{mm}$. wide, undulate or nearly entire, obtuse or acutish at the apex, narrowed at the base; seapes rather stout, 10-20 cm. high, naked toward the base, but floriferous for nearly two-thirds their length; bracts lanceolate or linear-lanceolate, acute or acuminate, 8-12 $\mathrm{mm}$. long; calyx-lobes linear, acute about $6 \mathrm{~mm}$. long; corolla pink, about $17 \mathrm{~mm}$. long, the tube somewhat shorter than the larger lobes of the limb; anthers nearly sessile; capsule oblong, about $8 \mathrm{~mm}$. long; seeds suborbicular.

Fields and coppices, Mariguana ( $P$. Wilson $\gamma_{4} ; 2$, type; 74,0 )

Apparently the same as Egger's 3960, from Acklin's Island, referred by Lindau to stenandrium rupestre (Sw.) Nees=Gcrardia tuberosa I. Bracted GERsRDA.

\section{ANTHACÁNTHUS Nees; DC. Prodr. 11: 460. 1847.}

Slender, much-branched shrubs armed with opposite axillary, curved or straight spines, the leares small, entire, often fascicled in the axils, the solitary or fascicled flowers axillary, slender-peduncled. Calyx 5-cleft. Tube of the small corolla cylindric, somewhat enlarged above, the limb spreading, unequally 5-lobed. Stamens 2; filaments short; anthers oblong, 2-celled; staminodia 2, clavate or filiform. Style filiform; ovules 2 in each cavity of the ovary. Capsule oblong, stipitate. Seeds 4 or fewer, compressed, tubercled. [Greek, spiny flower.] About 6 species, natives of the West Indies. Type species: Justicia spinosa Jacq. 


\section{Anthacanthus spinòsus (Jacq.) Nees, in DC. Prodr. 11: 460. 18ti.}

Justicia spinosa Jacq. Enum. 11. 1760.

A shrub, erect or diffuse, $2 \mathrm{~m}$. high or less, the long slender branches pubescent or glabrous, the stiff subulate spines more or less recurved, 4-12 $\mathrm{mm}$. long. Leaves coriaceous, glabrous or nearly so, ovate to oblong, elliptic or oblanceolate, $3-20 \mathrm{~mm}$. long, obtuse, acute or enarginate at the apex, narromed or obtuse at the base, the midrein rather prominent, the lateral venation obscure, the petioles very short; flowers few or solitary at the axils; peduncles 6-10 mm. long; calyx $3-4 \mathrm{~mm}$. long, its lobes lanceolate, acute; corolla purple or riolet, puberulent or glabrous, its tube about $8 \mathrm{~mm}$. long, its oblong lobes about as long as the tube; style filiform, about $10 \mathrm{~mm}$. long; eapsule about $2 \mathrm{~cm}$. long; seeds mrinkled, $2-3 \mathrm{~mm}$. in diameter.

Scrub-lands and thickets, throughout the archipelago from Great Bahama and Andros to Elenthera, Watling's Island, Caicos Islands and Inagua:- Jamaica; Cuba to Virgin Gorda, and Martinique. Recorded by Mrs. Northrop, by Coker, and by Lindau as A. acicularis ( $\mathrm{Sw}$.) Nees, which is known to us only from Jamaica. Races differ in pubescence, in size and shape of leares, and in length of spines. PRICKLY BusH,

\section{ANDROGRÁPHIS Tall. Pl. Asiat. Rar. 3: 77, 116. 1532.}

Herbs, erect or diffuse, the small flowers in panieles or cymes, with small bracts and bractlets. Calyx 5-parted. Corolla with a short tube, somewhat expanded above and a 2-lipped limb. Stamens 2; filaments sometimes bearded above; anthers 2-celled. Capsule linear to oblong, scarcely stipitate. Seeds 6-12, flattened. [Greek, bearder-stamens.] About 15 species, natives of the East Indies. Type species: Andrographis panicu?ata (Burm.) Nees.

1. Andrographis paniculàta (Burm.) Nees; Wall. Pl. Asiat. Rar. 3: 116.1832.

Justicia paniculata Burm. Fl. Ind. 9. 1768.

Annual, erect, glabrous below, glandular above, 3-6 dm. high, simple or branched, the stem 4-sided. Leares lanceolate or oblong-lanceolate, membranous, 4-10 cm. long, acuminate at the apex, narrowed at the base into short petioles; racemes commonly numerous, slender, often branched, or paniculate; flowers secund, distant, purple; pedicels slender, 4-8 $\mathrm{mm}$. long; calyx about $3 \mathrm{~mm}$. long, its segments linear-lanceolate, acuminate; corolla $3-4$ times as long as the calyx; capsule about $1.5 \mathrm{~cm}$. long.

Waste grounds on New Providence:-Cuba; Dominica to Barbadoes; Jamalca ; Panama; naturalized from the East Indies. Axdrograpils.

\section{JUSTícIA [Houst.] L. Sp. Pl. 15. 1753.}

Herbs, or shrubs, with entire leaves, the flowers variously clusteren. Calyx deeply eleft, its segments narrow, nearly equal. Corolla-tube mostly shorter than the 2-lipper limb, the upper lip 2-cleft. the lower 3-cleft. Stamens 2 , borne in the throat of the corolla; anthers 2-celled; staminodes none; lower anther-sac minutely appendaged. Style filiform; ovules 2 in each orarycavity. Capsule oblong. [In honor of James Justice, a Scotch gardener.] Over 100 species, of tropical distribution. Type species: Justicia Adhatoda L.

1. Justicia carthaginénsis Jaeq. Enum, 11. 1760.

Herbaceous, erect, branchel, $0.5-1.5 \mathrm{~m}$. high, the branches and leares glabrous or very sparingly pubescent. Leares ovate or elliptic-ovate, membranous, 5-12 em. long, acuminate at the apex, narrowed or rounded at the base, some- 
what decurrent on the petioles; flowers violet to purple, in dense terminal bracted spikes $3-7 \mathrm{~cm}$. long; bracts oblong, pubescent or ciliate, $12 \mathrm{~mm}$. long or less, the lower pointed, the upper truncate and cuneate; bractlets narrower than the bracts; calyx-segments lanceolate, about $1 \mathrm{~cm}$. long; corolla-tube about $1.5 \mathrm{~cm}$. long, the upper lip about as long as the tube, the lower somewhat longer; capsule 1.5-2 cm. long, acute, pulvescent.

Waste places, New Providence and Long Island:-Hispaniola; St. Thomas to Barbadoes and Grenada; continental tropical America. Justicra.

7. DIAPÈDIUM Konig; Konig \& Sims, Ann. Bot. 2: 189. 1805.

[Dicliptera Juss. Ann. Mus. Paris 9: 267. 1807.]

Herbs, with entire petioled leares, and blue, red, or violet flowers subteniled by involucres of $2-4$ bracts, the inflorescence mostly cymose or spicate, the involucres subtending 1 flower or several. Calyx 4-5-cleft, the lobes linear or subulate. Corolla-tube slender, slightly enlarged above; upper lip erect, concare, interior in the bud; lower lip spreading, entire or 3-toothed. Stamens 2 ; auther-sacs parallel, sometimes unequal, separated by a narrow connective. Style filiform; ovules 2 in each eavity of the orary. Capsule flattened, ovate or suborbicular, 2-4-seeded. Placentae separating elastically from the walls of the capsule. Seeds compressed, nearly orbicular. About 60 species, of warm and tropical regions. Type species: Justicia chinensis L.

\section{Diapedium assúrgens (L.) Kuntze, Rev. Gen. Pl. 485. 1891.}

Justicia assurgens L. Syst. ed. 10, 850. 1759.

Diclipterc assurgens Juss. Ann. Mus. Paris 9: 269. 1807.

Erect, often much branched, glabrous or somethat puberulent, 3-15 dm. ligh. Leaves ovate to oblong-lanceolate, $4-10 \mathrm{~cm}$. long or the upper smaller, acute or obtuse at the apex, obtuse or narrowed at the base, the petioles slender; flowers in small bracted clusters, in slender interrupted, simple or brauched spikes 5-15 cm. long; bracts lanceolate or spatulate, $8-15 \mathrm{~mm}$. long; calyx about $4 \mathrm{~mm}$. long, its linear-lanceolate lobes as long as the tube or longer; corolla scarlet or red, 2-2.5 cm. long, its tube curved, its lips lanceolate; capsule $5-6 \mathrm{~mm}$. long.

Taste grounds, scrub-lands and thickets, throughout the archipelago from Abaco and Great Bahama to the Anguilla Isles and Crooked Island :-Florida; West Indies; continental tropical America. DIAPEDIuar. Erroneously called Hoxisucrile.

8. THUNBÉRgIA Retz. Phys. Sallsk. Handl. 1: 163.1776.

Herbs or herbaceous vines, with opposite, mostly hastate or cordate leares, and large 2-bracted flowers solitary in the axils or in terminal racemes. Bracts foliaceous, large. Calyx short, annular. Corolla with an oblique, more or less flattened tube enlarged above, and a spreading 5-lobed limb, the lobes rounded, contorted, nearly equal. Stameus 4, didynamous, borne near the base of the corolla-tube, the filaments thickened below, the anthers with an apiculate connectire. Disk fleshy. Orary fleshy; style dilated at the apex; ovules 2 in each cavity. Capsule coriaceous, globose, abruptly beaked, loculicidally dehiscent. [Commemorates Karl P. Thunberg, 1743-1528, eminent Swedish traveller and botanist.] About 40 species, natives of the Old World tropies. Type species: Thunbergia capensis Retz. 
1. Thunbergia frágrans Rox̉̉. Pl. Corom. 1: 47. 1795.

Thunbergia volubilis Pers. Syn, 2: 179. 1506.

A slender, finely pubescent rine, often $2 \mathrm{~m}$. long, usually climbing. Leares ovate or ovate-lanceolate, $5-10 \mathrm{~cm}$. long, remotely few-toothed toward the base or entire, acuminate at the apex, subtruncate, hastate or cordate at the base, the slender petioles $1-4 \mathrm{~cm}$. long; peduncles rather stout, $2-7 \mathrm{~cm}$. Iong; bracts lanceolate or ovate-lanceolate, pubescent, acuminate, $1.5-2 \mathrm{~cm}$. long; calyx deeply eleft, much shorter than the bracts; corolla white, $2.5-3 \mathrm{~cm}$. long, its lobes crenate, nearly as long as the tube; capsule depressed-globose, pubescent, about $S \mathrm{~mm}$. in diameter, tipped by a stout subulate beak 1-1.5 cm. long.

Spontaneous after cultivation, New Providence near Nassan :-Cuba to I'orto Rico, Tortola and Trinidad; Jamaica. Naturalized from Asia. WIIte Thuxbergis.

2. Thunbergia alàta Bojer; Sims, Bot. Mag. pl. 2591. 1825.

A pubescent vine, usually not more than $1 \mathrm{~m}$. long, trailing or climbing. Leaves orate or triangular-orate, $4-8 \mathrm{~cm}$. long, remotely few-toothed or entire, acute at the apex, cordate or hastate at the base, the wing-margined petioles as long as the blades or shorter; peduncles slender, mostly longer than the petioles; bracts orate-lanceolate, acute or acuminate, pubescent, about $1.5 \mathrm{~cm}$. long; calyx cleft to about the middle; corolla sellow or white, usually with a purple eye, 2.5-4 cm. long; capsule depressed-globose, pubescent, $8-10 \mathrm{~mm}$. in diameter, its stout beak about $1 \mathrm{~cm}$. long.

Waste places near Nassau, New Providence:-Cuba to Tortola and Trinidad; Jamaica: Mexico to continental tropical America. Naturalized from eastern Africa. WINGED THUNBERGIA.

\section{Family 16. MYOPORÁCEAE Lindl.}

\section{MYOPORUMI FAJILY.}

Shrubs or trees, with alternate or opposite, entire estipulate leares, and perfect, more or less irregular flowers, solitary or clustered in the axils. Calyx inferior, 5-parted. Corolla gamopetalous, its limb 2-lipped or oblique. Stamens 4, mostly didynamons, borne on the corolla-tube, the filaments filiform. Ovary usually 2-celled; style terminal; stigma terminal and small; orules 1 in each ovary-cavity. Fruit a drupe. Five genera and So species or more, most Australian, only the following American.

\section{BóNTIA L. Sp. Pl. 638. 1753.}

A tree or shrub, with alternate narrow fleshy entire pointed leares, and rather small, purplish peduncled flowers, solitary or clustered in the axils. Calyx 5-parted, the segments imbricated. Tube of the corolla straight, cylindrie, the limb deeply 2-lipped, the posterior lip concave, 2-cleft, the anterior lip recurved, 3 -cleft, its middle lobe densely bearded. Stamens 4, didyuamous; filaments thickened and villous near the base. Ovary 2-celled; ovules 4 in each earity, superimposed in pairs; style very slender. Drupe oroid, the exocarp fleshy, the endocarp bony, 2-celled. Seeds small, ovoid, with little endosperm. [Commemorates Petar Bontius, a Dutch naturalist and traveller of the seventeenth century.] A monotypic West Indian genus.

1. Bontia daphnoides L. Sp. Pl. 638. 1753.

A shrub or small tree, sometimes $9 \mathrm{~m}$. high, nearly glabrous throughout, with terete, rather slender twigs. Leares oblong or oblong-lanceolate, falling 
away from the twigs in drying, $10 \mathrm{~cm}$. long or less, aeuminate at the apex, narrowed at the base, the slender midvein prominent, the lateral venation obscure, the petioles 1-2 cm. long; peluneles slender, 1-3 cm. long; calyx-segments broadly ovate, subulate-tipped, about $3 \mathrm{~mm}$. long, eiliolate; eorolla about $2 \mathrm{~cm}$. long, yellow, purple-blotehed, or the lip purple within; Arupe pointed, yellow, 1-1.5 cm. long.

Serub-lands and palmetto-lands, Great Bahama, South Caicos, Grand Turk:Cayman Islands : Cuba to 'Tortola and Barbadoes; Curaço; Aruba; Guiana. BontiA. Eironeously called OLIVE.

\title{
Order 5. PLANTAGINÀLES.
}

Only the following family:

\section{Family 1. PLANTAGINÀCEAE Lindl.}

\author{
Plantain Familis.
}

Herbs, with basal, or, in the canlescent species, opposite or alternate leares, and small perfect polygamous or monœeious flowers, bracteolate in spikes or heads, or rarely solitary. Calyx 4-parted, inferior, persistent, the segments imbricated. Corolla hypogynous, scarions or membranous, mostly marcescent, 4-lobed. Stamens 4 or 2 (only 1 in an Andean genus), inserted on the tube or throat of the corolla; filaments filiform, exserted or included; anthers versatile, 2-celled, the sacs longitudinally dehiscent. Orary sessile, superior, 1-2-celled, or falsely 3-4-celled. Style filiform, simple, mostly longitudinally stigmatic. Ovules 1 -several in each cavity of the ovary, peltate, amphitropous. Fruit a pyxis, circumscissile at or below the middle, or an indehiscent nutlet. Seeds 1-several in each cavity of the fruit; endosperm fleshy; cotyledons narrow; radicle short, mostly straight. Three genera and over 225 species, of wide distribution.

\section{PLANTÃGO L. Sp. Pl. 112. 1753.}

Leafy-stemmed, short-stemmed or aeaulescent herbs, with opposite, alternate or basal leaves, bearing axillary or terminal spikes or heads of small greenish or purplish flowers (flowers solitary in a few exotic species). Calyxsegments equal, or two of them larger. Corolla salverform, the tube cylindric, or eonstricted at the throat, the limb spreading in anthesis, erect, spreading or reflexed in fruit, 4-lobed or 4-parted. Stamens 4 or 2. Ovary 2-celled, or falsely 3 -4-eelled; ovules 1 -several in each cavity. Fruit a membranous pyxis, mostly 2-celled. Seeds various, sometimes hollowed out on the inner side. [The Latin name.] Orer 200 speeies, of wide geographic distribution. Type species: Plantago major L. The following are aeauleseent weeds.

\section{Plantago màjor L. Sp. Pl. 112. 1753.}

Perennial, glabrous or pubeseent; rootstock short, thiek, ereet. Leaves long-petioled, mostly ovate, ertire, or coarsely dentate, $2.5-25 \mathrm{~cm}$. long, 3-11ribbed; scapes $0.5-9 \mathrm{dm}$. high; spike linear-cylindrie, usually dense, eommonly blunt, 5-25 em. long, 6-8 mm. thiek; flowers perfeet, proterogynous; sepals broadly ovate to obovate, scarious margined, one-half to two-thirds as long as the obtuse or subacute, 5-16-seeded pyxis; stamens 4 .

Roadsides and waste places, Abaco, Great Bahama, Andros and New Providence: -Bermuda; United States; West Indies; Central and South America. Naturalized from the old World. Greater Plantain. 
2. Plantago lanceolàta L. Sp. Pl. 113. 1753.

Perennial or biennial, pubescent; rootstock short, erect, with tufts of brown hairs at the bases of the leaves. Leares narrowly oblong-lanceolate, shorter than the scapes, entire, acute or acuminate, gradually narrowed into petioles, 3-5-ribbed, $5-30 \mathrm{~cm}$. loug; scapes slender, channeled, sometimes 7.5 din. tall; spikes dense, at first oroid, becoming cylindric, blunt and $1-10 \mathrm{~cm}$. long in fruit, $\mathrm{S}-12 \mathrm{~mm}$. thick; flowers perfect, proterogynous; sepals orate. with a narrow green midrib and broad searious margins, the two lower ones commonly united; corolla glabrous; filaments white; pyxis oblong, very obtuse, 2 -seeded, slightly longer than the calyx, circumscissile at about the middle.

Roadsides, New Providence:-Bermuda; North America; Cuba; Jamaica. Naturalized from the old World. RiBWont.

\section{Order 6. RUBIÀLES.}

Corolla gamopetalons. Anthers separate, the stamens as many as the corolla-lobes and alternate with them (one fewer in Linnaea of the Caprifoliaceae) or twice as many. Orary compound, inferior, adnate to the calyx-tube. Orules 1 or more in each cavity of the orary. Leares opposite or verticillate.

Leaves stipulate, usually blackening in drying.

Fam. 1. RuRiACEAE.

Leares usually estipulate, not blackening in drying.

Fam. 2. CAPRIFOLIACEAE.

\section{Family 1. RUBIÀCEAE B. Juss.}

\section{MADDER FAMIITT.}

Herbs, shrubs, or trees, with simple, opposite or sometimes rerticillate, mostly stipulate leaves, and perfect, often dimorphons or trimorphous, regular and nearly symmetrical flowers. Calyx-tube adnate to the ovary, its limb rarious. Corolla funnelform, club-shaped, campanulate, or rotate, 4-5-lobed. Stamens as many as the lobes of the corolla and alternate with them, inserted on its tube or throat. Orary 1-10-celled;

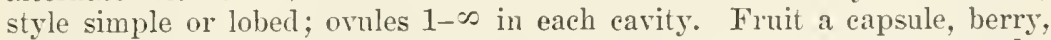
or drupe. Seeds rarious: seed-coat membranons or crustaceous; endosperm fleshy or homy (rarely wanting in a few genera); cotyledons ovate, cordate, or foliaceons. A large family of some 340 genera and about 6,000 species, of wide distribution.

1. Cavities of the ovary with several or many ovules; sceds several or many.

Fruit dry, capsular.

Herbs.

Shrubs or trees.

Seeds wingless; leaves linear, grooved.

Seeds winged; leaves broad.

1. Oldenlandia.

2. Rachicallis.

Frult pulpy, baccate.

Fruit 2-celled.

Flower's in cymes.

Flowers solitary.

Corolla-lobes $\overline{5}$, conrolute.

Corolla-lobes 4, valvate.

Fruit 5-celled.

3. Exostcma.

B. Carities of the ovary with a single ovule; seeds solitary.

4. Casasia.

5. Rundia.

6. Cutesuaca.

7. Hamclia. Ovule pendulous.

Fllaments wholly or partly adnate to the corolla-tube, Calsx-limb deciduous, though often tardily so, Calyx-limb persistent, crowning the fruit.

Fllaments not adnate to the corolla-tube.

Inflorescence terminal, or sometimes also axillary. inflorescence axlllary.

\author{
S. Gucttarda. \\ 9. Stchostomum. \\ 10. Erithalis.
}


Stamens exselted, filaments distinct.

Stamens included, filaments monideiphous at base. Calyx-tube ovoid, limb 5 -dentate; corolla-lobes valvate.

Calyx-tube oblong, limb 4-partite; corolla-lobes imbricated.

Orule not pendulous.

Corolla-lobes imbricated.

Corolla-lobes valvate.

Orule or seed with a basai attachment.

Ovile or seed with a lateral attachment.

Shrubs or trees; fluit a syncarp.

IIerbs or low shrubs ; fruit not syncarpous.

Stipules relatively small or inconspicuous, more or less cleft.

Fruit drupaceous, carpels neither dehiscent nor separating.

Fruit not drupaceous, earpels dehiscent or separating.

Fruit septicidal, both carpels rentrally dehiscent.

Fruit separating into carpels, one dehiscent the other indehiscent.

Stipules foliaceous, usually resembling the leares.

11. Phialanthus.

12. Chiocoeca.

13. Scolosanthus.

14. Strumpfia.

15. Psychotria.

16. Horinda.

17. Ernodea.

18. Borreria.

19. Spermacoce.

20. Galium.

1. OLDENLÁNDIA L. Sp. Pl. 119. 1753.

Herbs, with opposite leares, and small white or pink flowers. Calyx-tube oboroid or subglobose, the limb 4-5-toothed. Corolla rotate or salverform, 4-5-lobed. Stamens 4 or 5 , inserted on the throat of the corolla; anthers oblong. Ovary 2-celled; orules numerous in each cavity; style slender, 2-lobed. Capsule small, ovoid, top-shaped or hemispheric, wholly adnate to the calyxtube, loculicidally dehiscent at the summit. Seeds angular, not peltate; endosperm fleshy; embryo elub-shaped. [Named for H. B. Oldenland, a Danish botanist.] About 175 species, mostly of tropical distribution. Type species: Oldenlandia corymbosa $\mathrm{L}$.

\section{Oldenlandia callitrichioìdes Griseb. Mem. Am. Acad. II. 8: 506.1862.}

Stems filiform, creeping, glabrous, $2-10 \mathrm{~cm}$. long, rooting at the nodes. Leares ovate-orbicular, very thin, petioled, the blades 1-4 mm. long, glabrous or with a few long hairs, obtuse or acutish at the apex, contracted into slender petioles of about the same length; stipules minute or obsolete; peduncles solitary in the axils, filiform, 2-3 times as long as the leares; calyx 4-5-toothed, the teeth orate to lanceolate, bearing a few long hairs, much shorter than the tube; corolla white, funnelform, 1.5-2 mm. long, the 4 or 5 lobes shorter than the tube; capsule turbinate, about $2 \mathrm{~mm}$. long.

Moist ground, Rum Cay :-Cuba; Guadeloupe. Recorded from St. Croix. SMalL OLDENLAXDI.

\section{RACHICÁLIIS DC. Prôrr. 4: 433. 1830.}

A low, white-wooly, densely and intricately branched shrub, with small opposite fleshy linear imbricated leaves, persistent connate stipules, and small opposite sessile solitary flowers half-inclosed by the stipular sheaths. Calyx-tube very short, its 4 lanceolate teeth with smaller accessary ones between them. Corolla salverform, with 4 oblong imbricated lobes. Stamens 4 ; filaments short. Ovary 2-celled, half-superior; styles thick, slightly 2-lobed; orules numerous in each carity. Fruit capsular; seeds angled. [Greek, beauty of rocky shores.] A monotypic genus. 
×1. Rachicallis americàna (Jacq.) Hitche. Rep. Mo. Bot. Gard. 4: 92. 1893.

Hedyotis americana Jacq. Enum. 12. 1760.

Hedyotis rupestris Sw. Prodr. 29. 1788.

Rachicallis rupestris DC. Prodr. 4: 434. 1830.

Rigid, erect, or prostrate, the short stout twigs densely woolly, bearing the leaves in tufts at the ends. Leares bright green, 4-9 $\mathrm{mm}$. Iong, about 1 $\mathrm{mm}$. wide, thick, grooved on the back, glabrous, sharply mucronate; stipules broadly ovate, nucronate, densely pubescent and ciliate; corolla $5-6 \mathrm{~mm}$. long, villous-pubescent, its obtuse lobes about one third as long as the tube. Plaut fragrant when dry.

Maritime rocks and coastal coppices, throughout the archipelago:-Cuba; Hispaniola; Jamaica; the Caymans: Cozumel. Reported from Bermuda, perhaps erro.

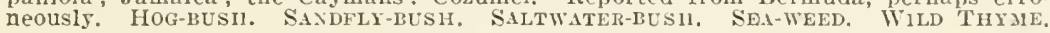

\section{ExostÈMA Rich.; H. \& B. Pl. Aeq., 1: 131. 1808.}

Shrubs or trees, with opposite petioled leaves, deciduous stipules, and solitary or panicled flowers. Calyx-tube cylindric to turbinate, with 5 linear lobes. Corolla salverform, the slender tube elongated, the limb with 5 long imbricated lobes. Stamens 5, borne near the base of the corolla; filaments filiforn, long; anthers narrowly linear, basifixed, exserted. Orary 2-celled; style filiform, exserted; orules numerous in each cavity. Fruit a '2-ralved eapsule, many-seeded; seeds broadly winged. [Greek, exserted stamens.] Thirty species or more, natives of tropieal America. Type species: Exostema parviflorum A. Rich.

\section{Exostema caribaèum (Jacq.) R. \& S. Syst. 5: 18. 1819.}

Cinchona caribaea Jacq. Enum. 16. 1760.

A glabrous shrub or small tree up to $8 \mathrm{~m}$. high, with a trunk sometimes $1 \mathrm{dm}$. in diameter, the bark bitter. Leaves oblong-lanceolate to elliptic, rather thin, 3-8 $\mathrm{cm}$. long, 1-3 $\mathrm{cm}$. wide, acuminate or acute at the apex, narrowed at the base, the midvein prominent, the few lateral veins obscure, the slender petioles about one-fourth as long as the blades; stipules broadly ovate, acuminate, about $1.5 \mathrm{~mm}$. long; flowers solitary in the axils; peduncles slender, about as long as the calyx; calyx clavate-cylindric, 4-5 mm. Iong, its teeth short; corolla white or pinkish, its tube $2-3 \mathrm{~cm}$. long, slightly longer than the lobes; anthers long-exserted; capsule oblong, smooth, woody, 10-15 mm. long.

Coppices, pine-lands and scrub-lands, throughout the archipelago from Abaco, Great Bahama and Andros to Caicos Islands :- Florida ; Cuba to Anegada, St. Ifartln and Grenada; Jamaica; Central America and northern South America. Priscliwood.

4. CASASIA A. Rich. in Sagra, Hist. Cub. 11: 9. 1850.

Shrubs or trees, with tercte branches. Leares opposite, leathery; stipules deciduous. Flowers perfect, in short-peduncled cymes. Calyx turbinate or eampanulate, truncate or with 5 or 6 obtuse senals, persistent. Corolla white or yellow, salverform or nearly rotate, pubescent in the throat, its lobes 5 or 6 , spreading, contorted. Stamens 5 or 6 , adnate to the mouth of the corollatube; anthers sessile. Disk cup-like. Ovary 1-2-celled; styles stout. Orules numerous in each cavity. Fruit a thick pulpy berry. Seeds numerous, angled, flattener, the testa somewhat filmrous. [In honor of Luis de las Casas, Captain General of Cuba.] About $S$ species, natives of Florida and the West Inclies. Type species: Casasia calophylla A. Rich. 
1. Casasia clusiaefòlia (Jacq.) Urban, Symb. Ant. 5: 505. 1908.

Gardenia clusiaefolia Jaeq. Coll. 5: 37. 1796.

Genipa clusiaefolia Griseb. Fl. Br. W. I. 31i. 1861.

A branching shrub, 1-3 $\mathrm{m}$. tall, the foliage glabrous, turning black in drving. Leaves clustered, leathery, obovate to cuneate, $5-15 \mathrm{~cm}$. long, rounded or retuse at the apex, lustrous, often mucronate, entire, short-petioled; calyxtube $8-10 \mathrm{~mm}$. long, turbinate, the lobes subulate, shorter than the tube; corolla fleshy, glabrous, its tube $1.5-2 \mathrm{~cm}$. long, its lobes lanceolate or oblonglaneeolate, shorter than the tube; berries oroid to obovoid, $5-7 \mathrm{~cm}$. long.

Coastal rocks, Berry Islands, the Biminis, Andros, New Providence, Eleuthera to Watling's, Caicos, Inagua and the islands of the Cay Sal Bank:-Florida; Bermuda; Cuba. Sevex-rear APple. Catesby, $1: p l .59$.

\section{RÁNDIA L. Sp. Pl. 1192. 1753.}

Evergreen, often spiny shrubs or trees, with oposite leaves and perfect solitary, usually axillary flowers. Calyx-lobes 4. Corolla funnelform, salverform or campanulate, its lobes 5, convolute. Stamens 5, adnate to the throat of the corolla; filaments short or nearly wanting. Disk annular or cushionlike. Ovary 2-celled or very rarely 3-4-celled; ovules sereral or many in each carity; styles usually united, stout, terninating in a club-shaped, spindleshaped or rarely cleft stigma. Berry usually 2 -celled. Seeds free or in a pulp; testa thin, the endosperm horny. [In honor of Isaac Rand, English apothecary.] About 100 species, natives of tropical regions. Type species: Randia mitis $\mathrm{L}$.

1. Randia mitis L. Sp. Pl. 1192. 1753.

Randia aculeata L. Sp. Pl. 1192. 1753.

A virgate branching shrub, 1-3 m. tall, or a small tree up to $7 \mathrm{~m}$. high, usually spiny, the foliage glabrous or nearly so. Leaves often elustered, spatulate, oborate, elliptic, oval or suborbicular, $1-\overline{\mathrm{cm}}$. long, narrowed into short petioles; flowers axillary, short-stalked; calyx-lobes triangular or orate; corolla white, 6-8 mm. long, its lobes oblong, shorter than the tube; berries subglobose or oval, white, 8-12 $\mathrm{mm}$. long.

Scrub-lands and coppices, throughout the archipelago from Abaco, Great Bahama and Andros to Turk's Islands and Inagua :- Bermuda; Florida; West Indies and Mexico. Races differ in size and shape of leaves and in size of fruit. Box Briar.

\section{CAtésbaea L. Sp. Pl. 109. 1753.}

Spinescent shrubs or small trees, with terete twigs and small glabrous, often fascicled leares, the small stipules deciduous. Flowers white, solitary and short-peduncled in the axils. Calyx subcampanulate, with 4 narrow persistent lobes. Corolla funnelform or campanulate, its 4 lobes ralvate. Stamens 4 , borne near the base of the corolla. Ovary 2-celled; stigma 2-lobed. Orules several or many. Fruit a white berry. Seeds with fleshy endosperm. [In honor of Mark Catesby, 1679-1749, traveller and naturalist.] About 8 species, natives of Florida and the West Indies. Type species: Catesbaea spinosa L.

Flowers very large, drooping.

Flowers very small, nearly concealed among the leaves.

Leaves $3-10 \mathrm{~mm}$. long, suborbicular to oblanceolate.

Leaves $8-13 \mathrm{~mm}$. long, linear to oborate-spatulate.

1. C. spinosa.

2. C. parviflora.

3. C. foliosa. 
1. Catesbaea spinòsa L. Sp. Pl. 109. 1753.

A glabrous shrub, 2-3 cm. high, or a small tree up to $5 \mathrm{~m}$. high, with very spiny slender branches, the spines opposite, axillary, $1.5-3.5 \mathrm{~cm}$. long. Leaves ovate-elliptic, thin, $0.6-3 \mathrm{~cm}$. long, acute or acutish at both ends, mostly shorter than the spines, short-petioled; peduncles mostly shorter than the leares, about as long as the calyx; calyx-teeth subulate; corolla 10-15 cm. long, yellow, nodding, the very slender tube tapering into the throat above the middle, the short lobes orate, acute; berry globose to oroid, $1.5-5 \mathrm{~cm}$. long.

Scrub-lands and coppices, Andros. New Providence, Eleuthera and Long Island: -Cuba. Catesby, $2: p l$. 100. LARGE-FLOWERED CATESBYA. I'RICKLY-APPLE. SPANISH GUAYA.

2. Catesbaea parvifiòra Sw. Prodr. 30. 1788.

Catesbaca campanulata Sagra; DC. Prodr. 4: 401. 1830.

Catesbaea parviflora septentrionalis Krug \& Urban; Urban, Symb. Ant. 1: 429.1899.

Catesbaea fasciculata Northrop, Nem. Torr. Club 12: 66. 1902.

A much-branched shrub, $2 \mathrm{~m}$. high or less, the branches long and slender, usually copiously armed with slender spines 5-20 $\mathrm{mm}$. long, rather densely leafy. Leaves coriaceous, obovate to suborbicular or oblanceolate, 3-10 $\mathrm{mm}$. long, rounded at the apex, rarrowed at the base into short petioles; flowers sessile or nearly so in the axils; ealyx-teeth subulate; corolla about $6 \mathrm{~mm}$. long, its 4 lobes obtuse; berry globose, white, about $2 \mathrm{~mm}$. in diameter.

White-lands, savannas and coppices, Abaco, Berry Islands, Andros, New Providence, Eleuthera, Little San Salvador, Exuma Chain to Great Ragged Island, Green Cay :-Florida; Cuba ; Porto Rico; Jamaica. Sarall-Flowered Catesbra.

3. Catesbaea foliòsa Millsp. Field. Mus. Bot. 2: 312. 1909.

A stout-branched, spreading shrub, 1-2 m. high, with or without spines, the bark loose and grayish-white; branchlets densely and minutely resinous, setose. Leaves thiek, $\mathrm{S}-13 \mathrm{~mm}$. long, 2-6 $\mathrm{mm}$. wide, linear-spatulate to oborate, dark green, subsessile, the apex obtuse, rarely mucronulate, the margin revolute, the upper surface appearing as if varnished; flowers pedicellate; calyx-teeth subulate, obtuse, about $1 \mathrm{~mm}$. long, minutely setulose; berry white, globose, $2-3 \mathrm{~mm}$. in diameter; seeds reddish, ovate, umbonate in the center on both sides.

White-lands and sclub-lands, Conception Island, Watling's Island, Atwood Cay, Crooked Island, Fortune Island, Acklin's Island, Mariguana, Caicos lslands, Grand Turk, Ambergris Cay and Inagua. Referred to in Field Col. Mus. Lot. 2: Iti as C. campanulat , and possibly a large-leared race of the preceding species though appearing distinct. LeAry CATESBI.

\section{HAMĖLiA Jacq. Enum. 2, 16. 1760.}

Shrubs, or small trees, with opposite or verticillate, petioled leaves, narrow deciduous stipules, and red or yellow flowers secund on the branches of terminal compound cymes. Calyx-tube ovoid to turbinate, its 5 short lobes persistent. Corolla tubular, or narrowly eampanulate, eonstricted at the base, the limb 5-lobed, the lobes short, imbricated. Stamens 5, borne near the base of the corolla; filament short; anthers basifixed, linear, scarcely exserted, or ineluded, the connective appendaged. Orary 5 -celled; style filiform; stigma rarrowly fusiform; ovules lumerous in each cavity. Berry small, ovoid, 5lobed, 5-celled. Seeds very small, angled. [In honor of II. L. du IIamel de Monceau, 1700-1782, French botanist.] About 25 specics of tropical aud subtropical America. Type species: Hamelia erecta Jacq. 
1. Hamelia erécta Jacq. Enum. 16. 1760.

Mamelia patens Jacq. Enum. 16. 1760.

A shrub, or small tree up to about $4 \mathrm{~m}$, high, with slender branches, the twigs, leares and inflorescence puberulent. Leaves opposite, or verticillate in 3 's to 5 's, thin, elliptic to orate-elliptic, $5-15 \mathrm{~cm}$. long, acute or acuminate at the apex, mostly narrowed at the base, the slender petioles one-fourth to one-half as long as the blades; stipules lance-subulate, 2-3 $\mathrm{mm}$. long; cymes 3-5-rayed; flowers numerous, very short-pedicelled; corolla crimson to scarlet, tubular, 12-20 mm. long, its lobes rery short; berries dark red or purple, 5-6 nim. long, a little produced berond the calyx.

Coppices, New Frovidence:-Florida; West Indies; continental tropical America. SCARLET IIAMELIA.

8. GUETTÁRDA L. Sp. Pl. 991. 1753.

Trees or shrubs, with opposite leares and deciduous stipules, the axillary cymose, or sometimes solitary flowers, perfect or polygamo-dioecious. Calyx with an ovoid or globose tube, the limb tubular, rarely persistent, mostly truncate or irregularly toothed. Corolla salverform, the tube elongated, sometimes curved, the limb with 4-9 obtuse imbricated lobes. Stamens as many as the corolla-lobes, borne on the corolla-tube; filaments very short or none; anthers linear. Orary 4-9-celled; ovules 1 in each eavity, pendulous; style filiform; stigma capitate or 2-lober. Fruit drupaceous. [In honor of Jean Etienne Guettard, 1715-1786, French botanist.] Sixty species or more, mostly of tropical America. Type species: Guettarda speciosa I.

\section{Leaves coriaceous.}

Leaves scabrous abore; fruit $1-6 \mathrm{~mm}$. in diameter.

Leares smooth above; fruit $9-12 \mathrm{~mm}$. in diameter.

1. G. scabra.

2. G. Krugii.

Leaves chartaceous or membranous.

Leaves strongly reticulate-reined, and densely pale-pubescent beneath: corolia $1-3 \mathrm{~cm}$. long.

Inflorescence several-many-flowered.

Leares $9-12 \mathrm{~cm}$, long. acute at apex : corolla $2 \mathrm{~cm}$. lono. Leares $5 \mathrm{~cm}$. long or less, rounded at apex; corolla $1 \mathrm{~cm}$. long.

Flowers solitary in the upper axils: corolla $3 \mathrm{~cm}$. long.

Leares not reticulate-reined, finely pubescent or glabrate beneath; corolla about $6 \mathrm{~mm}$. long.

3. G. Nashii.

4. G. Taylori.

5. G. inaguensis.

6. G. elliptica.

* 1. Guettarda scábra (L.) Lam. Tabl. Encycl. 2: 218. 1819.

Matthiola scabra L. Sp. P1. 1192. 1753.

A shrub or tree up to $10 \mathrm{~m}$. high, the young twigs villous-tomentose. Leaves elliptic to ovate or oborate, coriaceous, $3-15 \mathrm{~cm}$. long, obtuse or shortpointed and mucronate at the apex, subcordate or obtuse at the base, usually rery rough (rarely becoming smooth) above, densely reticulate-veined and finely pubescent beneath, the stout pubescent petioles $0.5-2 \mathrm{~cm}$. long; stipules triangular-lanceolate, acute, $2-3 \mathrm{~mm}$. long; peduncles few-flowered, $2-10 \mathrm{~cm}$. long; calyx finely pubescent, about $3 \mathrm{~mm}$. long; corolla $1.5-2 \mathrm{~cm}$. long, appressed-pubescent, white, its oblong lobes much shorter than the tube; fruit globosc, red, finely pubescent, 4-6 $\mathrm{mm}$. in diameter, the calyx-limb at length wholly deciduous. Flowers fragrant.

Scrub-lands and coppices. Abaco, Great Bahama, Andros. New Providence, Eleuthera, Cat Island, Crooked Island, Iariguana, Caicos and Inagua:-Florida; Cuba to Virgin Gorda and Martinique: Jamaica; continental tropical America. G. speciosa of Schoepf.? Rougil Velvet-SEed. Veltet-BerRy. 
2. Guettarda Krùgii Urban, Symb. Ant. 1: 431. 1899.

A shrub, 1-1 m. high, in Porto Rico sometimes becoming a tree up to 10 $\mathrm{m}$. high, the twigs stout, the young ones densely tomentulose, the older gray and glabrous. Stipules orate, obtuse or acutish, brownish villous, deciduous; leares orate to suborbicular or elliptic-obovate, coriaceous, or those of shoots subchartaceous, obtuse, rounded or acutish at the apex, rounded or cordate at the base, smooth and glabrous above, densely pubescent, strongly and densely reticulate-reined beneath, $3-11 \mathrm{~cm}$. long, the stout, villous and tomentose petioles $6-15 \mathrm{~mm}$. long, or those of shoots larger aud longer-petioled; cymes 1-few-flowered in the upper axils; peduncles $1 \mathrm{~cm}$. long or less; calyx brownish villous, $5-6 \mathrm{~mm}$. long, its limb irregularly subtruncate; corolla white, appressed-rillous, about $1.5 \mathrm{~cm}$. long, its lobes about one-fourth as long as the tube; fruit globose, densely tomentulose, 9-12 mm. in diameter.

Scrub-lands and rocky coppices, Abaco, Fleuthera, Exuma Chain, Cat Island and Wratling's to Grand 'Turk, Ambergris cay and Inagua:-I'orto Rico. Iiecorded by Hitchcock as $G$. calyptrata A. Rich. Some of oul specimens are bal'en and are referred to this species with hesitation. KIRU'S VELVET-SEED. F'roGwOOD.

\section{Guettarda Náshii Britton \& Millspaugh, sp. nov.}

A large shrub or small tree, with slender branches, the young twigs, petioles and peduneies densely tomentulose. Stipules oblong-lanceolate, acute, appressed-villous, deciduous, 10-12 $\mathrm{mm}$. long; leaves elliptic to elliptic-obovate, or rhombic-elliptic, chartaceous, 9-12 $\mathrm{cm}$. long, sharply acute at the apex, rounded or truneate at the base, pubescent on the veins but otherwise glabrous above, densely reticulate-reined and pilose-tomentulose beneath, the rather slender, tomentulose petioles 1.5-2 em. long; peduncles axillary, rather slender, tomentulose, $2.5-3.5 \mathrm{~cm}$. long; cymes $\mathrm{S}-12$-flowered, their branches $1-2 \mathrm{~cm}$. long; flowers sessile; calyx tomentulose, obliqnely truncate, $6-\bar{\imath} \mathrm{mm}$. long; bracts linear, longer than the calyx; corolla white, appressed-pubescent with long hairs, $2 \mathrm{~cm}$. long, the cblong obtuse lobes about one-fourth as long as the tube.

Scrub-lands, Matthew Town, Inagua (Tash \& Taylor, 1369). NASH's Veltet-SeEd.

\section{Guettarda Taylòri Britton \& Millspaugh, sp. nov.}

A small tree, up to $4 \mathrm{~m}$. high, with slender branches, the young twigs densely tomentulose. Stipules broadly orate-elliptic, obtuse, densely tomentulose and appressed-villous, 8-10 mm. long; leares elliptic, ovate-elliptic or obovate, membranous, $3-5 \mathrm{~cm}$. long, obtuse and rounded at the apex, rounded or subeordate at the base; pubescent on the reins, but otherwise glabrous above, densely tomentulose, appressed-rillous on the veins, and reticulatereined beneath, the slender villous petioles $\mathrm{S}-12 \mathrm{~mm}$. long; peduneles slender, axillary, tomentulose, about twice as long as the petioles; cymes compact, 5-8. flowered; flowers sessile; bracts linear, longer than the ealyx; calyx tomentulose, $5 \mathrm{~mm}$. long, pointed in bud; corolla white, appressed-strigose, $1 \mathrm{~cm}$. long, its lobes more than one-half as long as the tube.

Matthew Town, Inagua (Nash \& Taylor, 918). TAYLoR's VELFET-SEed.

\section{Guettarda inaguénsis Britton \& Millspaugh, sp. nov.}

A small tree, up to $4 \mathrm{~m}$. high, with slender stiff straight glabrous kranches, the joung twigs tomentose. Leares membranous, broadly elliptic, 3-5 cm. long, obtuse or rounded at the apex, cordato to truncate at the base, sparingly pubescent with long scattered hairs above, densely tomentulose, finely reticulate-reined and appressed-rillous on the midrein beneath, the rather stout, villous petioles $5-10 \mathrm{~mm}$. long; stipules orate, obtuse, tomentulose and villous, about $8 \mathrm{~mm}$. long, deciduous: flowers solitary, sessile in the axils: calyx narrowly campanulate, 2-lobed, 5-6 $\mathrm{mm}$. long, densely pubescent; 
corolla nearly $3 \mathrm{~cm}$. long, densely pubescent, its very slender tube 5-6 times as long as the oblong lobes; fruit subglobose, densely puberulent, 10-11 mm. in diameter.

Matthew Town, Inagua (Nash \& Taylor, 919). IXAGCA Veliet-SEl:D.

\section{Guettarda ellíptica Sw. Prodr. 59. 1788.}

A shrub or a tree up to $8 \mathrm{~m}$. high, with slender branches, the young twigs loosely pubescent. Leaves chartaccous, elliptic to ovate-elliptic or ellipticlanceolate, $2-7 \mathrm{~cm}$. long, obtuse, acutish or apiculate at the apex, narrowed, obtuse, or (on young shoots) rarely subcorlate at the base, sparingly pubescent or glabrate above, finely appressed-silky beneath, the petioles $3-8 \mathrm{~mm}$. long, or those of shoot-leaves longer; stipules lanceolate, 4-10 $\mathrm{mm}$. long; peduncles slender, pubescent, shorter than the lcaves, fer-several-flowered; bracts lanceolate or oblong, shorter than the calyx; calyx about $2 \mathrm{~mm}$. long, puberulent, nearly truncate; corolla white or yellowish-white, above $6 \mathrm{~mm}$. long, silky-pubescent, its 4 oblong lobes about one-fourth as long as the tube; fruit globose, red, turning black, 6-8 $\mathrm{mm}$. in diameter, the calyx-limb at length deciduous.

Coppices and scrub-lands, throughout the archipelago from Abaco, Great Bahama and Andros to the Caicos Islands and Inagua:-Florida; Cuba; Jamaica; Hispaniola; Mona; St. Thomas. Comaox Velvet-SEed.

\section{STENóstomum Gaertn. f. Fr. \& Sem. 3: 69. 1805.}

Mostly glabrous shrubs or trees, often resinous, with opposite leaves and small, sessile or short-pedicelled flowers secund on the branches of axillary peduncled cymes. Calyx-tube mostly oroid, its 4-5-toothed or nearly truncate limb persistent. Corolla salverform or funnelform, its 4 or 5 lobes imbricated. Stamens 4 or 5 , borne on the throat of the corolla; filaments short or filiform; anthers linear. Ovary 2-6-celled; ovules 1 in each cavity; style slender; stigma capitate or lobed. Fruit a small, 2-6-celled drupe. [Greek, narrow mouth.] About 15 species, ratives of the West Indies. Type species: Stenostomum lucidum. (Sw.) Gaertn. $\mathbf{f}$.

Leares thin, manifestly petioled.

Leares thick. Sessile or nearly so.

Leares elliptic to obovate-oblong, $3 \mathrm{~cm}$. Iong or less.

Leaves oblong-lanceolate, $4-9 \mathrm{~cm}$. long.
1. S. lucidum.

2. S. myrtifolium. 3. S. densiflorum.

1. Stenostomum lùcidum (Sw.) Gaertn. f. Fr. \& Sem. 3: 69. 1805.

Laugeria lucida ST. Prodr. 48. 1788.

Antirrhoea Tucida Benth. \& Hook. Gen. Pl. 2: 100. 1873.

A smooth-barked tree, 5-13 m. high, or often a shrub, with slender spreading glabrous gray branches. Leaves elliptic to oblong, chartaceous, glabrous, 4-10 cm. long, obtuse or acutish at the apex, obtuse or narrotred at the base, bright green, shining, pinnately reined, the petioles $4-10 \mathrm{~mm}$. long; stipules narrowly lanceolate, puberulent, about $8 \mathrm{~mm}$. long; inflorescence glabrous, shorter than or equalling the leaves, the branches of the cyme few, very slender; flowers sessile; calyx turbinate, 5 -toothed, about $2.5 \mathrm{~mm}$. long, the teeth rounded; corolla white, 4-5 mm. long, with 5 rounded lobes; drupe oblong, red to black, $5-7 \mathrm{~mm}$. long, crowned by the calyx-limb.

Coppices and scrub-lands, Andros, New Providence and Cat Island to Great Ragged Island, Inagua and Mariguana:-Cuba to St. Thomas and St. Croix; Jamaica ; recorded south to Trinidad. SHIxisg STExostomus. 
2. Stenostomum myrtifòlium Griseb. Fl. Br. W. I. 334. 1861.

Antirrhoea myrtifolia Urban, Symb. Ant. 1: 440. 1599.

A much-brancher, resinous rigid shrub, 6-13 dm. high, the young trigs pubescent. Leares clustered at the ends of the twigs, coriaceous, viscid, oblong to elliptic or elliptic-oborate, $3 \mathrm{~cm}$. long or less, $8-17 \mathrm{~mm}$. wile, obtuse or short-pointed at the apex, narrowed or rounded at the base, finely reticulate-reined, glabrous or nearly so, the stout puberulent petioles about $2 \mathrm{~mm}$. long; stipules deltoid-orate; peduncles 2-3-flowererl, pubescent, much shorter than the leaves; flowers sessile; calyx about $2 \mathrm{~mm}$. long, the limb 5 toother; corolla white, 6-8 mm. long, its 5 oblong obtuse lobes much shorter than the tube; drupe globose-ellipsoid, black, $4 \mathrm{~mm}$. long.

White-lands, pine-lands, coppices, and scrub-lands, Berry Islands, North Pimini, Andros, New Providence and Eleuthera to North Caicos and Inagua:-Cuban Cays. MYRTLE STEXOSTOMUM.

3. Stenostomum densifiòrum Griseb. Cat. Pl. Cub. 132. 1866.

Laugeria densiflora Hitehc. Rep. Mo. Bot. Garı. 4: 93. 1593.

Gucttarda densiflora Maza, Anu. Soc. Esp. Hist. Nat. 23: 290. 1594.

A shrub, usually 1-3 $\mathrm{mm}$. high, or sometimes a small tree up to $5 \mathrm{~m}$. high, the bark smooth, the slender, glabrous branches ascending. Leares coriaceous, viscid-resinous at least when young, oblong to elliptic-lanceolate, acute at both ends, dark green and shining above, dull and paler beneath, the petioles very short, the short-orate stipules connate, eiliate, persistent; peduncles several-flowered, as long as the leaves or shorter, the cyme usually 2-forked; flowers sessile; calyx about $1 \mathrm{~mm}$. long; corolla about $1 \mathrm{~mm}$. long, its oblong lobes shorter than the tube; drupe globose or globose-ellipsoid, pink to blue-black, $3-4 \mathrm{~mm}$. long.

scrublands and coppices, Abaco, Andros, New Providence:-Cuba. Yiscid STENosi ilis.

10. ERITHÀLIS P. Br.; L. Syst. ed. 10, 930. 1759.

Glabrous shrubs or sma!l trees, with broad, dark green, opposite petioled leares, connate stipules, and small flowers in corymbose panicles. Calyx-tube globose to ovoid, the short limb truncate or $4-5$-toothed. Corolla nearly rotate or salrerform, its 5-10 narrow lobes valvate, recurved or spreading. Stamens $5-10$, borne at the base of the corolla; filaments filiform; anthers basifixed, narrow. Orary 5-10-celled; orules solitary in each cavity, pendulous; style stout. Fruit a small drupe, containing 5-10 nutlets. [Greek, very green.] About 6 species, of the West Indies, Florida and Central America. Type species: Erithalis frutirosa L.

\section{Erithalis fruticòsa L. los. cit. 1759.}

Erithalis odorifera Jacq. Select. Am. i2. 1763.

A shrub, $6 \mathrm{dm}$. to $4 \mathrm{~m}$. high, or a tree up to $8 \mathrm{~m}$. high, with terete branches. Leaves elliptic to oblong, obovate or suborbicular, subcoriaceous, dark green, shining, $4-15 \mathrm{~cm}$. long, rounder or short-pointed at the apex, mostly narrowed at the base, the petioles $t-16 \mathrm{~mm}$. long; stipules connate, mueronate, the sheath persistent, 1-2 mm. long; panicles pedunclel, severalmany-flowered; calyx 1-2 mm. long, the limb repand-denticulate; corolla $4-10$ mm. long, deeply 5-partell, its lobes linear-oblong; anthers as long, as the filaments or longer; drupe globose or depressed-globose, 5-10-furrowed, '2-5 
mm. in liametcr, black when mature. Consists of many races, differing in size of the plant, leaves, fruit and flowers, and length of the calyx-limb.

Serub-lands, coppices and coastal thickets, throughout the archipelago:-Florida; West Indies; Central America. In IBulletin N. Y. Iiot. Gard. 3: 452, E. odorifera was referled to as distinct from $E$. fruticosa, but the differences observed do not now appear to be sufficient to maintain the two as species. Referred to E. rotundatu Griseb. by Irs. Northrop. BLACK ToncI.

\section{PHIALÄNTHUS Griseb. Fl. Br. W. T. 335. 1861.}

Resiniferous shrubs or small trees, with terete branches, coriaceous opposite short-petioled, oblong to lanceolate leaves, and small axillary clustered, sessile or short-pedicelled flomers, the stipules connate. Calyx turbinate, with 4 or 5 persistent lobes. Corolla funnelform, its 4 or 5 lobes obtuse, valvate. Stamens 4 or 5, borne on the base of the corolla-tube. Ovary'2-celled; style filiform; stigma obtuse; ovules 1 in each cavity, pendulous. Fruit drupaceous. [Greek, urn-flower.] Four known West Indian species. Type species: Phialanthus myrtilloides Griseb.

1. Phialanthus myrtilloìdes Griseb. Fl. Br. W. I. 335. 1861.

A shrub, or rarely a small tree, 1-3 m. high. Leaves oblong to oblong. spatulate, $1.5-5 \mathrm{~cm}$. long, $0.5-2 \mathrm{~cm}$. wide, obtuse or bluntly acute at the apex, narrowed at the base, the midvein rather prominent, the lateral venation almost wholly obscure; fascicles of flowers mostly opposite, very shortpeduncled; calyx-tube narrowly turbinate, $1.5-2 \mathrm{~mm}$. long, the 4 persistent thin, oblong to spatulate, obtuse lobes $2-2.5 \mathrm{~mm}$. long.

Coppices, pine-lands, and scrub-lands, Andros, New Proridence, Cat Island, Exuma, Crooked and Fortune Islands, the Inaguas and Cafeos Islands:-Cuba. MrrTLE Phialanthus. Candletwood.

\section{CHIOcócCA P. Br.; L. Syst. ed. 10, 917. 1759.}

Woody vines, or shrubs, with broad opposite subcoriaceous or chartaceous leares, broad stipules, and small, yellow or white flowers in axillary, simple or compound racemes. Calyx-tube ovoid to turbinate, the limb 5-toothed, persistent. Corolla funnelform or narrowly campanulate, with 5 valvate reflexed or spreading lobes. Stamens 5, borne toward the base of the corollatube; filaments mostly pubescent, connate at the base; anthers linear, basifixed, not exserted. Ovary 2-celled, rarely 3-celled; style filiform; ovules solitary in each eavity, pendulous. Drupe flattened, leathery, white. Seedcoat membranous; endosperm fleshy. [Greek, snowberry.] About 10 species, natives of Florida, Bermuda and tropical America. Type species: Chiococca racemosa $\mathrm{L}$.

Leares bright green, mostly $4-8 \mathrm{~cm}$. long; corolla bright yellow; fruit $6-8 \mathrm{~mm}$. broad.

Leaves dark green. mostly $2-4 \mathrm{~cm}$. long; corolla white or purple to pale Jellow; fruit about $\overline{5} \mathrm{~mm}$. broad.

1. C. alba.

2. C. pinetorum.

1. Chiococca álba (L.) Hitche. Rep. Mo. Bot. Gard. 4: 94. 1893.

Lonicera alba L. Sp. Pl. 175. 1753.

Chiorocca racemosa L. Syst. ed. 10, 917. 1759.

Chiococca parvifolia Wullschl.; Griseb. Fl. Br. W. I. 337. 1561.

A glabrous shrub, 1-3 m. high, with slender spreading branches, or a vine $5 \mathrm{~m}$. long or more. Leaves elliptic, oblong, ovate or ovate-lanceolate, 
2-8 cm. long, acute, acuminate or bluntish at the apex, narrowed at the base, the midvein prominent, the lateral veins few and obseure, the slender petioles 1-12 mm. long; racemes several-many-flowered, as long as the leares, or longer, or shorter; corolla 5-lobed nearly to the midale, yellow, 6-9 mm. long; drupes bright white, orbicular, 5-5 mm, broad.

Coppices, scrub-lauds and pine-lands, throughout the archlpelago from Abaco, Great bihama and Andros to Mariguana, North Cilicos and luigua:-Florida; West Indies; continental tropical America. Consists of many races differing ln size of corolla, shape of leaves and with calyx-teeth deltoid to deltoid-lanceolate, the anther tips either included or somewhat exserted beyond the corolla-tube. WEST IXDIAX SNOWBEMRY. SNALEROOT.

\section{Chiococca pinetòrum Britton; Millsp. Field Mus. Bot. 2: 171. 1906.}

A vine, ereeping or low-elimbing, sometimes $1.5 \mathrm{~m}$. long, usually shorter. Branches short; leaves orate, lanceolate or elliptic, small, $2-4.5 \mathrm{~cm}$. long, varying from acute to obtuse at the apex, narrowed at the base, coriaceous, dark green and shining above, paler and dull beneath, the midrein impressed on the under side, the lateral reins few and obseure, the petiole slender, 2-3 min. long; racemes few-flowered, shorter than the leaves or about equalling then; pedicels about as long as the calyx, or sometimes a little longer; ealyx campanulate $2 \mathrm{~mm}$. long; corolla funnelform-campanulate, about $5 \mathrm{~mm}$. long, white or purple changing to yellow; berry white, somewhat compressed, 4-6 mm. in diameter.

Pine-lands aud scrub-lands, Abaco, Great Bahama, Andros, New Providence. Cat Island and Watling's:-Florida. PIXELAxD Sxowbelrir.

\section{SCOLOSÁNTHUS Vahl, Eclog. 1: 11. 1796.}

Shrubs, often spiny, with opposite petioled coriaceous leaves, and small or minute, axillary, solitary or clisterel, peduncled flowers. Calyx-tube short, the limb 4-eleft, the lobes narrow. Corolla small, funnelform, its 4 short spreading lobes imbricated. Stamens 4, included, the filaments filiform, the anthers linear. Ovary 2-eelled; style slender, pilose; stigma notehed or '2cleft; ovules solitary in each ovary-earity, pendulous. Fruit a small drupe. [Greek, eurved flower, of no obrious application.] About 7 species, natives of the West Indies. Type species: Scolosanthus versicolor Tahl.

\section{Scolosanthus bahaménsis Britton, Bull. X. Y. Bot. Gard. 3: 458. 1905.}

An intricately branched, somewhat resinous shrub, $8 \mathrm{dm}$. high or less, with gray-brown bark, the young twigs greenish, densely papillose, 4-angled, armed with slender seattered pungent solitary spines $1 \mathrm{~cm}$. Iong or less. Leaves opposite or fascieled, 2-5 mm. long, thick, papillose, orate to elliptie, revolute-margined, obtuse, very short-petioled, dark green above, naler beneath; flowers not seen; fruits solitary, oblong to globose, white, soft, $2-1 \mathrm{~mm}$. long.

Coppices and pine-lands, Andros, New Irovddence and Cat Island. Endemic. BAHAMA SCOLOSAXTIIUS.

\section{STRÚMPfiA Jacq. Enum. S, 2S, 1760.}

A low, mueh-branched shruh, with linear, revolute-margined, coriaceons, very short-petioled leaves verticillate in 3 "s, and crowiled near the ends of the short-jointed branches, the small white flowers in sliort axillary racemes, tho small stipules persistent. Calyx ovoil, the limb j-eleft, the lohes persistent. Corolla deeply 5-eleft, the lobes laneelate, imbrioatel, the tulie rery short. Stamens 5, borne at the base of the corolla-tube; filaments short, slightly 
united at the base; anthers narrowly oblong, connate. Ovary 2-celled; orules 1 in each eavity, erect, anatropous; style pubesent; stigma 2-lobed. Fruit a smail fleshy drupe, containing 1 or 2 stones. Seed oblong; endosperm fleshy; embryo minute. [Named for Karl Strumpf, professor iu Halle.] A monotypic West Indian genus.

\section{Strumpfia maritima Jacף. Enum. 28. 1760.}

A shrub $2 \mathrm{~m}$. high or less, the rather stout twigs densely pubescent or puberulent, scarred by the persistent stipule-bases. Leares $1-2.5 \mathrm{~cm}$. long, apiculate, pubescent when young, the margins revolute so as to meet and cover the under surface; peduncles pubescent, $2-10 \mathrm{~mm}$. long; calyx about $1 \mathrm{~mm}$. long; calyx-lobes triangular-ovate, acute; corolla pubescent, $3-4 \mathrm{~mm}$. long, its short tube campanulate, its lobes much longer than the tube; drupes white or red, $3-6 \mathrm{~mm}$. in diameter.

Coastal rocks and rock plains, throughout the archipelago from Abaco, Great Bahama and Andros to Grand Turk and Inagua :-Florida; Tíest Indies and Cozumel. Strumpfia.

\section{PSYCHÒtRIA L. Syst. cd. 10, 929. 1759.}

Shrubs or trees, rarely perennial herbs, with opposite or rarely rerticillate leaves, the stipules persistent or deciduous, the small flowers in terminal corymbs or panicles, rarely in axillary fascicles. Calyx short, the limb $4-\bar{\xi}$ toothed. Corolla funnelform or subcampanulate, the limb $4-5$-lobed, the lobes valvate. Stamens 5 , borne on the corolla-tube, the filaments mostly short, the anthers linear or oblong. Ovary 2-celled; ovules 1 in each cavity, erect, anatropous; style short or elongated; stigma 2-cleft. Fruit a globose to oblong drupe containing 2 pyrenae, smooth, angled or ribbed. Seed convex; endosperm fleshy or eartilaginous. [Greek, to gire life, from supposed medicinal properties.] A very large genus, containing 500 speeies or more, natives of tropical and subtropical America. Type species: Psychotria asiatica L., of Jamaica.

Fruit subdidymous, broader than long; pyrenae angled. Fruit ellipsoid; pyrenae furrowed.

Panicles sessile.

Panicles stalked.

1. P. pubescens.

2. P. undata.

3. P. ligustrifolia.

\section{Psychotria pubéscens Sw. Prodr. 44. 1788.}

Myrstiphyllum pubescens Hitche. Rep. Mo. Bot. Gard. 4: 95. 1893.

A shrub, $3 \mathrm{~m}$. high or less, rarely a small tree $5 \mathrm{~m}$. high, the branches slender, sometimes constricted at the nodes, the twigs, leares and inflorescence finely pubescent or pubernlent, rarely glabrous. Leares membranous, elliptic to oblong-lanceolate, $7-15 \mathrm{~cm}$. long, acuminate at the apex, narrowed at the base, prominently pinnately veined, the slender petioles 8-1s $\mathrm{mm}$. long, the subulate geminate stipules nnited by their broad bases; panicles peduncled, usually many-flowered; pedicels very short; calyx about $1 \mathrm{~mm}$. long, its teeth ovate; corolla yellow, whitish or pinkish, 4-5 mm. long, usually puberulent outside, pubescent in the throat, its oblong lobes shorter than the tube; drupe subglobose, black, 3-4 mm. in diameter, the pyrenae angled.

Pine-lands and coppices, Abaco, Great Bahama. Andros and New Providence:Cuba to St. Thomas; St. Kitts; Jamaica. HAInx WiLd CoFfeE. 
2. Psychotria undàta Jacq. Hort. Schoen. 3: 5. 1798.

Psychotria lanceolata Nutt. Am. Journ. Sei. I. 5: 290. 1522.

Myrstiphyllum undatum llitehc. Rep. Mo. Bot. Gard. 4: 9J. 1493.

A shrub, $0.5-3 \mathrm{~m}$. high, the twigs, leaves and inflorescence usually glabrous, sometimes pubescent. Leares elliptie to oblong-elliptic, chartaceous, 6-12 $\mathrm{cm}$. long, strongly pimately veinell, acuminate at the apex, narrowel at the base, bright green abov, pale-green beneath, the slender petioles $15 \mathrm{~mm}$. long or less, the stipules connate-sheathing, deciduous: panicle sessile, severalmany-flowered; flowers sessile or very nearly so; calyx about $1 \mathrm{~mm}$. long, ite limb nearly truncate; corolla white, about $4 \mathrm{~mm}$. long, its lobes shorter than the tube; drupe red, ellipsoid, blunt, $5-7 \mathrm{~mm}$. long; pyrenae grooved.

Pine-lands, scrub-lands and coppices, throughout the archipelago from Abaco, Great Bahama, the Biminis and Andros to Watling's and Long Island :- Flortda and the West Indies; Central America. PP. asiatica of Schoepf. WILD CoffEe.

3. Psychotria ligustrifòlia (Northrop) Millsp. Field Mus. Bot. 2: 1ĩ. 1906.

Myrstiphyllum ligustrifolium Northrop, Mem. Torr. Club 12: 6s. 1902.

Psychotria Gahamensis Millsp.; Britton, Bull. N. Y. Bot. Gard. 3: 451. 1905.

A nearly glabrous shrub, rarely more than $2.5 \mathrm{~m}$. high. Leares thin, lanceolate to oblaneeolate, broalest at or abore the mildale, narrower to the apex and to the petiole, slightly pilose beneath, especially along the mid-rib; stipules large, orbicular, dimidiate-sheathing, apieulate; infloreseence paniculate, peduncled, 4-ehotomous, exceeded by the leaves; calyx with 5 short deltoid teeth; corolla-tube glabrous without, bearded in a ring at the insertions of the filaments within, its lobes 5, elliptie, acute, strongly deflexer, nearly as long as the tube; fruit ellipsoid, red, about $5 \mathrm{~mm}$. long; prrenae planoconvex, grooved.

Pine-lands and scrublands, throughout the archinelago from Abaco, Great Bahama, the Biminis and Andros to Mariguana, North Caicos and Inagua:-Florida : Bermida: Cuba; Hispaniola; Porto Iíco. Suootil Wild Coffer.

\section{MORINDA L. Sp. Pl. 176. 1753.}

Shrubs, vines or trees, with opposite or verticillate leares, and mostly perfect, white or red flowers in derise terminal or axillary capitate clusters. Calyx truneate or obseurely toothed. Corolla funnelform or salverform, its $4-i$ lobes valvate. Stamens as many as the corolla-lobes, the short filaments arluate to the throat of the corolla. Ovary mostly 2-celled; styles connate; stigmas slender; ovules 1 in each cavity, ascending. Fruit a fleshy synearp. [Latin. Indian Mulberry.] Forty species or more, of tropical distribution, the following typical.

\section{Morinda Roỳoc L. Sp. Pl. 176. 1753.}

A shrub, $3 \mathrm{~m}$. high or less, with slender straggling lranches, or a vine up to $7 \mathrm{~m}$. long, glabrous or very nearly so throughout. Leares oblong to oblongoblanceolate, thin, but somewhat fleshy, $5-10 \mathrm{~cm}$. long: acute or acmuninate at the apex, narrowed or euncate at the base, darkening in drying, the petioles 5-10 $\mathrm{mm}$. long, the broal persistent stipules subulate-tipjed: llowers white or pinkish, in axillary, short-perlundell heals; corolla 6- 5 mm. long, its ohlong lobes shorter than the tube; synearp subglobose, $5-25 \mathrm{~mm}$. in dianeter, yellow.

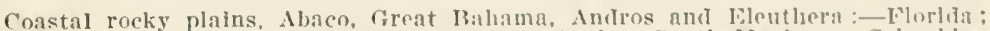
Cuba: IIspanjola: Jamalca: Jonalre: Iuraço: Aruba: Somtl Mexleo to Colombla: recorded from Bermuda. Called lintisnu. Wiso McLmiux. 


\section{ERNÒdEA* Sw. Prodr. 29. 178s.}

Glabrous, or somewhat pubescent, low shrubs, the branches erect, decumbent or trailing, with opposite, linear to lanceolate, nearly sessile leaves, the stipules connate into a sheath; florers small, solitary and sessile in the axils. Calyx-tube short, the limb 4-6-parted, the lobes triangular to linear or subulate, persistent. Corolla white to pink, the tube nearly cylindrie, the 4-6 lobes narrow, rerolute, valvate. Ovary 2-celled; style slender; stigma subcapitate; ovules 1 in each ovary-cavity. Drupe fleshy, grooved, containing 2 cartilaginous, 1-seeded pyrenes. [Greek, a shoot or off-shoot.] Only the following species are known. Type species: Ernodea littoralis $\mathrm{S} \pi$.

Calyx-lobes nearly as long as the fruit or longer.

Leares lanceolate to elliptic, oblanceolate or oblong-lanceolate, $5-10 \mathrm{~mm}$. wide.

Corolla white to pink; leaves relatively broad; plant mostly of coasts.
corolla red to scarlet; leaves relaticely nariow; plant Corolla red to scarlet
mostly of pine-lands.

Leares narrowly linear, 1-3 mm. wide.

Calmx-lobes much shorter than the fruit.

Leares oblong-lanceolate, 6-8 mm. wide.

Leares narrowly linear to linear-oblanceolate, $1-3 \mathrm{~mm}$. wide.

Leaves bristle-tipped; calyx-lobes half as long as the fruit.

Leares merely mucronate; calyx-lobes one-third as long as the fruit.

\section{E. littoralis.}

2. E, angusta.

3. E. Cokeri.

4. E. Millspaughii.

5. E. Taylori.

6. E. Jashii.

1. Ernodea littoràlis Sw. Prodr. 29. 1788.

A glabrous or glandnlar-puberulent shrub, 1-16 dm. high, erect, or nearly or quite prostrate, the branches 4-angled, usually densely leafy. Leares 3-5nerved, shining, somewhat fleshy, oblong, elliptic, linear-oblong or oblanceolate, 2-3.5 cm. long, 4-10 mm. wille; entire or glandular-serrulate; stipules 1.5-2 $\mathrm{mm}$. long; calyx-lobes linear-lanceolate, louger than the tube; corolla white or pink, its tube $1-1.5 \mathrm{~cm}$. long; fruit subglobose, yellow, $4-6 \mathrm{~mm}$. in diameter, about as long as or somewhat shorter than the calyx-lobes.

Coastal rocks and sands within the influence of ocean spray, throughout the archipelago from Great Bahama, Abaco and Andros to Mariguana and Inagua :Florida: Cuba to Porto Rico and Anegada; St. Croix; Guadeloupe; Jamaica. Races differ in habit, pubescence, size and width of leares. CoMmox ERNoDEA.

2. Ernodea angústa Small, Bull. N. Y. Bot. Gard. 3: 438. 1905.

Similar to prostrate races of E. littoralis, glabrous or nearly so. Leaves linear, coriaceous, 2-4 cm. long, 1.5-6 mm. wide; calyx-lobes linear-lanceolate, acute, about one-half as long as the corolla-tube; corolla mostly pink or red to scarlet, its tube $8-10 \mathrm{~mm}$. long; fruit oval, 5-6 mm. long.

Coastal pine-lands of Garden Cay, Great Babama, Andros, New Providence:Florida. PINELAND ERxodea.

\section{Ermodea Còkeri Britton; Coker in Shattuck, The Bahama Islands 264.} 1905.

Stems very slender, trailing, branched, finely pubescent, $3-9 \mathrm{dm}$. long. Leares narrowly linear, 2-3 cm. long, 1-3 mm. wide, acute, rough-pubescent, 1-nerved. narrowed at the base into short petioles; stipules about $2 \mathrm{~mm}$. long; fruit globose-obovoid, about $4 \mathrm{~mm}$. long; calyx-lobes subulate, $6-7 \mathrm{~mm}$. long; fruit oral, about $5 \mathrm{~mm}$. long.

Trailing on sand dunes and in scrub-lands of Abaco, Great Babama and Andros. Endemic. COKER's Erxodea.

* For a study of the species and races see Bulletin of the Torrey Botanical Club $35: 203-8$. 1908 . 
4. Ernodea Millspaùghii Britton, Bull. Torr. Club 35: 207. 1905.

A shrub, 6-12 dm. high, the twigs and leaves glabrous. Leares ollongcblanceolate, sharply pointed, $2-3 \mathrm{~cm}$. long, 5-8 mm. wide, the short broal stipules cuspidate; flotrering ealrx obovoid, about $3 \mathrm{~mm}$. long, the triangular lobes only one-fifth to one-fourth as long as the ovary; corolla white, $1 \mathrm{~cm}$. long, its lobes about one-half as long as the tube; fruit nearly oval, $5 \mathrm{~mm}$. long, the calyx-lobes triangular-lanceolate, $1.5-2 \mathrm{~mm}$. long.

Constal sands of Long Islaud, Great Iragged Island, and Grand Turk, Endemic. MiLLSPACGI'S EKMODEA.

\section{Ernodea Tàylori Britton, Bull. Torr. Club 35: 20S. 1908.}

Spreading, with long slender branches, glabrous. Ieaves narrowly linear, stiff, 1.5-2.5 cm. long, $1.5-2 \mathrm{~mm}$. Wile, revolute-margined, spinulose-tipper, the stipules triangular-subulate; flowers not seen; fruit golden-vellom, oval, 5 $\mathrm{mm}$. long, the calyx-lobes narrowly linear, $2 \mathrm{~mm}$. long.

On white-lands at Tenados, Inagua. Endemic. TaYlon's Erxodea.

\section{Emodea Náshii Britton, Bull. Torr. Club 35: 20s. 1908.}

Prostrate, glabrous throughont, the branches $6 \mathrm{dm}$. long, or more, the branchlets erect or aseending, 0.5-2 dm. high, the twigs very densely clothed with leares. Leares linear-oblanceolate, leathery in texture, $2-2.5 \mathrm{~cm}$. long, 2-3 mm. wide, mucronulate; florrering ealrx $4.5 \mathrm{~mm}$. long, its lobes acute, 1.5 $\mathrm{mm}$. long; corolla $1.5 \mathrm{em}$. long, its lobes white within, brown without, about one-third as long as the tube; fruit oroid-oral, $5 \mathrm{~mm}$. long, the persistent acnte ealyx-lobes $1.5 \mathrm{~mm}$. lorg.

White-lands at Moujean Harbor, Little Inagua and at the west end of that island. Endemic. NASIl's lirNodEs.

1S. BorrèriA G. F. W. Meyer, Prin. Fl. Esseq. 79. 1919.

Annual or perennial herbs, or shrubby plants, with opposite entire leares, the stipules sheathing, the flowers perfect, solitary in the axils, or in axillary or terminal elusters. Calyx-tube oboroid or turbinate, its lobes persistent, sometimes accompanied by small teeth. Corolla white, pink or blue, fumnelform or salverform, the lobes 4, valrate, spreading. Stamens 4, arlnate to the corolla-tube, sometimes up to its throat. Disk obsolete or cushion-like. Orary 2-celled; 'styles wholly or partially united; orules solitary in each earity, amphitropous. Fruit leathery or erustaecous, the 2 earpels opening along their inner faees. [In honor of W. Borrer, British lichenologist.] About 90 species, natives of tropical and warm regions. Type species: Borreria suaceolens Meyer.

Annual herbs.

Calyx-tecth orate, much sliorter than the tube.

Calyx-tceth subulate. nearly as long as the tube.

Shrubs or woody prennlal herbs.

Stems more or less pubescont: learcs clllate.

Stem-pubescence short, stiff.

Stem-pubescence loose, flocense.

Stems glabrous: leaves not clliate or but sllghtly clliate.

I.caves linear-oblong, $1.5-3 \mathrm{~mm}$. Nide; corolla $4.5-5 \mathrm{~mm}$. long.

Leawes llnear, 0.8-1.2 mm. wide: corolla $2.5-4 \mathrm{~mm}$. long. Calyx-lobes inng-clliate: eorollil $+\mathrm{mm}$. Iong. Calix-lobes glabions : corolla $2.5 \mathrm{~mm}$. long or less. Leaves firm lu texture, $1-1.5 \mathrm{~cm}$. long; internoles of branches short: calrx-lohes mostly 2 or 3 .

Leares thin in texture, 1-3 cm. Inng; interuodes of branches elougated: calyx-lohes 4.

1. R. laris.

2. B. orimoides.

3. B. thumifolin.

4. B. innournsis.

5. R. saricola.

6. B. Milsonii.

7. B. buhamensis.

S. B. saremuarum. 
1. Borreria laèvis (Lam.) Griseb. Fl. Br. W. I. 349. 1861.

Spcrmacocc lacvis Lam. Tabl. Eneycl. 1: 273. 1791.

Slightly pubescent, branched, the branches spreading or ascending, 1.5-3 im. long, somewhat angled. Leares oblong to elliptic-lanceolate, 2-4 cm. long, acute or acuminate at the apex, narrowed at the base into short petioles, pinnately veined; stipular sheath subtruncate, bearing several bristles 4-6 $\mathrm{mm}$. long; flowers white, about $3 \mathrm{~mm}$. wide, capitate-clustered in the axils; calyxIobes 4, orate, minute; fruit obovoid, about $2 \mathrm{~mm}$. long; seeds oblong, striate.

Sink-holes, pine-lands and meadows, Great Bahama and New Providence to Watling's and Inagua:-Bermuda; West Indies and continental tropical America. ButToגWEED.

2. Borreria ocimoides (Burm. f.) DC. Prodr. 4: 544. 1830.

Spermacoce ocimoides Burm. f. Fl. Ind. 34. 1768.

Borreria parviflora G. F. W. Meyer, Prim. Fl. Esseq. 83. 1818.

Annual, $6 \mathrm{dm}$. high or less, slender, erect or sometimes diffusely branched, glabrous, the stem and branches 4-angled. Leaves linear to oblong-elliptie, or the lower spatulate, $0.5-2.5 \mathrm{~cm}$. long, 1-8 mm. wide, acute, short-petioled; stipular sheath with setaceous teeth $2-3 \mathrm{~mm}$. Iong; glomerules several-manyflowered, 6-8 mm. in diameter; calyx-teeth 4, subulate, about $0.7 \mathrm{~mm}$. long; corolla white, a little shorter than the calyx-teeth, its lobes ovate; fruit ellipsoid to obovoid, pubescent, nearly $1 \mathrm{~mm}$. long.

South Caicos, Mariguana:-Florida; West Indies; continental tropical America; East Indies. Slender Borreria.

\section{Borreria thymifòlia Griseb. F]. Br.W. I. 350. 1861.}

Perennial, suffrutescent; stems bushy-branched, forming elumps up to 1 m. broad, $3.5 \mathrm{dm}$. high or less, the internodes short, the 4 -angled branches loosely rather stiff-pubescent. Leaves linear, channeled, stiff, eiliate, 2-6 mm. long, sessile, the apex spinulose-apiculate; smaller leaves are commonly fascicled in the axils of the larger ones; stipular sheath ciliate; flowers few together in small terminal hearls subtended by the upper leaves; ealyx-lobes 2 or 3, oblong-lanceolate, sparingly ciliate, acute; corolla white, about $3 \mathrm{~mm}$. long, its lobes deltoid-ovate.

Sandy and rocky soil, Turk's Islands. Endemic.

\section{Borreria inaguénsis Britton, sp. nor.}

Intricately branched from a stout woody root, forming clumps $4 \mathrm{dm}$. in diameter or more, about $2 \mathrm{dm}$. high, the branches very slender, 4-angled, loosely soft-pubescent, the internodes mostly longer than the leaves. Leaves linear, rather stiff, channeled, ciliolate, $1.5-3 \mathrm{~mm}$. long, spinulose-tipped, often with smaller ones fascicled in their axils; flowers few or solitary at the ends of the branches subtended by the upper leaves; calyx-lobes 4, linearlanceolate, acuminate, $1 \mathrm{~mm}$. long, with minute accessary teeth; corolla white, nearly $2 \mathrm{~mm}$. long, its lobes ovate-elliptic, obtuse.

Scrub-lands, Moujean Harbor, Little Inagua (Nash \& Taylor, 2124).

\section{Borreria saxícola Britton, sp. nov.}

Shrubby, loosely branched, 3-4 $\mathrm{dm}$. high, the twigs slender, glabrous, 4-sided, the internodes mostly longer than the leaves. Leaves linear-oblong, glabrous, rather firm in texture, $10-18 \mathrm{~mm}$. long, $1.5-3 \mathrm{~mm}$. wide, acute or acuminate at the apex, slightly narrowed toward the base, usually with smaller ones fascicled in the axils; stipular sheath sparingly puberulent, the stipules short, acute; flowers capitate at the ends of the twigs, subtended by the upper leaves; calyx-teeth 3 or 4 , triangular-lanceolate, acuminate, glabrous, 1.5-2 $\mathrm{mm}$. long; corolla 4.5-5 mm. long, its lobes ovate, obtuse.

Loose rocky soil, South Caicos (type, Millspaugh, 9242). Endemic. 


\section{Borreria Wílsonii Britton, sp. nor.}

Perennial with a tap-root 1.5-2 dm. long, bushy-brancherl, about $1.5 \mathrm{dm}$. high and as broal as high, the slenter quadrangular twigs glabrous or very nearly so, the internodes about as long as the leaves or somewhat longer. Leaves linear, glabrous, $4_{-7}^{-7} \mathrm{~mm}$. long, about $1 \mathrm{~mm}$. widle, apieulate, shining, straight or somewhat curred with smaller ones fascicled in their axils; stipular sheath with a few subulate teeth; flowers few together at the ends of the twigs; ealyx-lobes 4, laneeolate, acuminate, long-ciliate, $1.5 \mathrm{~mm}$. long; corolla $4 \mathrm{~mm}$. long, its lobes ovate, obtuse.

Castle Island (Wilson, irsy). Endemic.

\section{Borreria bahaménsis Britton, sp. nov.}

A low mueh-branched glabrous shrub, $1.5-3.5 \mathrm{dm}$. high, the internodes mostly less than $2 \mathrm{em}$. long. Leares linear, rather stiff, $8-15 \mathrm{~mm}$. long, mueronate, $0.5-1.5 \mathrm{~mm}$. wille, usually with smaller ones faseieled in the axils; stipular sheath ferr-toothed; flowers eapitate at the ends of the branehes, subtended by the upper leares, the heads abont $5 \mathrm{~mm}$. in diameter; ealyxlobes 2 or 3 , rarely 4 ; corolla white, $2-2.5 \mathrm{~mm}$. long, its lobes orate, acute.

Sandy and rocks soil, Cat Island, Crooked Island, Fortune Island, Rum Cay, Ambergris Cay and lnagua. Trpe from Crooked Island (Brace, frig). Recorded by Hitcheock as B. thymuccphala Griseb., and listed by Cokel as Bourreria thymifolia. Endemic.

\section{S. Borreria savannàrum Britton, sp. nov.}

A much branched glabrous shrub 3-10 dm. high, with very slender, elongated, 4-angled branches, the internodes mostly longer than the leaves. Leaves linear-filiform, $1-3 \mathrm{~cm}$. long, about $0.5 \mathrm{~mm}$. wille, thin in texture, apieulate, darkening in drying, often with smaller ones fascicled in their axils; stipular sheath with several subulate teeth; flowers eapitate at the ends of the branehes, the heads $3-4 \mathrm{~mm}$. in diameter, subtended by the uppermost leares; calyx with 4 linear lobes about as long as the tube; corolla white, $2.5 \mathrm{~mm}$. long, its lobes orate, obtuse.

Savannas, Inagua (type Nash \& Taylor, 1320) ; also on Acklin's Island and Fortune Island. Endemic.

\section{SPERMACÒCE L. Sp. Pl. 102. 1753.}

Herbs, with 4-silled stems, opposite stipulate leaves, and small white flowers, in dense axillary and terminal clusters. Calyx-tube oboroid, or obconic, its limb 4-toothed. Corolla funnelform, 4-lobed. Stamens 4, inserted on the tube of the corolla. Orary -eelled; orules 1 in each earity; style slender; stigma eapitate, or slightly 2-lobed. Capsule coriaceous, didymons, of 2 carpels, one dehiseent, the other usually indehiscent. Secls oblong, convex on the back; endosperm horny; embryo central; cotyledons foliaccons. [Greek, seell-point, from the sharp ealyx-teeth surmounting the carpels.] Two or three speeies, natives of America. Type speeies: Spcrmacoce tcnuior L.

Glabrous or nearly so: leares $2-6 \mathrm{~mm}$. wlde.

I'ubescent with long halrs; leav's $8-20$ mu. wide.
1. S. tenuior.

2. S. tetraquetra.

\section{Spermacoce tenùior I. SP. Pl. 102. 1753.}

Glabrous or nearly so. Stems simple anil erect or more or less diffusely branehed from the lose, the branches 1-3 dm. long; leaves linear, oblong or oblong-lanceolate, $2-5 \mathrm{~cm}$. lorg, acute or acuminate at loth enls, narrowed into short petioles; ealyx-lobes subulate or laneeolate-subulate; corolla white, 
twice or thrice as long as the calyx-lobes, its lobes broad, rounded, the fruit about 2 mm. long.

Waste grounds and sink-holes, throughout the archipelago from Abaco, Great Bahama and Andros to Watling s, Crooked, Inagua and Caicos Islands:- Bermuda ; southern Lnited States; West Indies and continental tropical Americil.

\section{Spermacoce tetraquètra A. Rich. in Sagra, Hist. Cub. 11: 29. 1850.}

Stouter and larger than $S$. tenuior, sometimes $6 \mathrm{dm}$. high, densely pubescent nearly all over with, long, whitish hairs. Leaves lanceolate to oblonglanceolate, rather strongly reined, acute at the apex, narrowed or obtuse at the base. $2-8 \mathrm{~cm}$. long, $2 \mathrm{~cm}$. wide or less; calyx-lobes lanceolate, acuminate; corolla white, about twice as long as the calyx-lobes; fruit about $2 \mathrm{~mm}$. long. Cuba.

Waste grounds, Andros, New Providence, Inagua:-Bermuda (naturalized) ;

\section{GÀLIUMI L. Sp. Pl. 105. 1753.}

Herbs, with 4-angled slender stems and branches, apparently rerticillate leaves, and small flowers, mostly in axillary or terminal crmes or panicles. Flowers perfect, or in some species dioecious. Calyx-tube oroid or globose, the limb minutely toothed, or none. Corolla rotate, 4-lobed (rarely 3-lobed). Stamens 4, rarely 3; filaments short; anthers exserted. Ovary 2-celied; ovules one in each cavity. Styles 2, short; stigmas capitate. Fruit didymous, separating into 2 indehiscent carpels, or sometimes only 1 of the carpels maturing. Endosperm horny; embryo curred; cotyledons foliaceous. [Greek, milk, from the use of G. verum for curdling.] About 250 species, of wide distribution. The leaves are really opposite, the intervening members of the rerticils being stipules. Type species: Galium Mollugo L.

\section{Galium bermudénse L. Sp. Pl. 105. 1753.}

Galium hispidulum Michx. Fl. Bor. Am. 1: 79. 1803.

Relbunium bermudense Britten, Journ. Bot. 47: 42. 1909.

Perennial, much branched, hirsute, hispid or nearly glabrous, 3-6 dm. high. Leaves in 4's, 1-nerver, oval, mucronate, rather thick, 6-20 mm. long, 3-8 $\mathrm{mm}$. wide, the margins more or less revolute in drying; flotrers few, terminating the branchlets, white; pedicels $6-8 \mathrm{~mm}$. long, rather stout, becoming deflexed in fruit; fruit fleshy, minutely pubescent, about $4 \mathrm{~mm}$. broad.

Pine-lands and coppices, Abaco, Great Bahama. Andros, New Providence and Eleuthera:-Bermuda: southeastern Tnited States. Plants glabrous or vers pubescent. Reported by Dolley as Galium hypocarpium.

\section{Order 7. CAMPANULÀLES.}

Herbs, rarely shrubs, the corolla gamopetalous, or petals sometimes separate in Cucurbitaceae. Stamens as many as the corolla-lobes (fewer in the Cueurbitaceae); anthers united (except in Ambrosiaceae). Orary inferior.

Flowers not in involucrate heads; juice mostly milky.

Endosperm none; flowers regular, monoecious or dioecious; oul species rines.

Endosperm present, fleshy; flowers perfect, irregular. Stigma not indusiate.

Stigma indusiate.

Flowers in incolucrate heads.

Fam. 1. Cucurbitaceae.

Fam. 2. LOBELIACEAE.

Fim. 3. Goodexiaceie. 
Flowers all expanded into rays (ligulate) juice milky. Flowers all tubnlar, or the outer expauded into rays ; julce very rarely mllky.

Stamens distinct, or nearly so.

Stamens united by their anthers into a tube around the style.

\section{Family 1. CUCURBITÀCEAE B. Juss.}

\section{Gotrd FayilT.}

Herbaceous rines, nsually with teudrils. Leares alternate, petioled. generally palmately lobed or dissected. Flowers monocions or diocions. Calyx-tube adnate to the ovary, its limb usually 5-lobed, the lobes imbricated. Petals usually 5, inserted on the limb of the calyx, separate, or united into a gamopetalous eorolla. Stamens mostly 3 (sometimes 1 ), 2 of them with 2-celled anthers, the other with a 1-celled anther; filaments short. often somewhat monadelphous. Ovary 1-3-celled; style terminal. simple. or lobed; orules anatropous. Fruit a pepo, indehiscent. or rarely dehiscent at the summit, or bursting irregularly; or sometimes dry and membranous. Seeds usually flat; endosperm none. About 90 genera and 700 speeies. mainly of tropical regions.

Orules horizontal.

Anther-saes fiexuous.

Anther-sacs straight or curved, not flexuous.

Stamens 3 ; an anuular disk at the base of the style.

Stamens 2 ; disk none, or obscure.

1. Homordica. Orules ascending.

1. MOMÒRDICA L. Sp. Pl. 1009. 1753.

2. Melothria.

3. Anguria.

4. Cayaponia.

Herbaceous, climbing or prostrate vines, with simple or forked tenilrils, and dioecious or monoecious mostly yellow flowers, the staminate solitary or clustered, the pistillate solitary. Staminate flowers with a 5-lobed calyx, a nearly rotate, 5-parted or 5-lobed corolla, and usually 3 stamens with short distinct filaments. Pistillate flowers with calyx and corolla like those of the staminate, a 1-celled ovary with 3 -placentae, the numerous orules horizontal, the style slender, the stigmas 3. Fruit ovoid to cylindric, 3-valved or inlehiscent. [Latin, of uncertain application.] About 25 species, natives of the Old World tropics. Type species: Momordica Balsamina L.

1. Momordica Charántia I. Sp. Pl. 1009. 1753.

Stem slender, more or less pubescent, 1-2 m. long, with simple filiform tendrils opposite the leaves. Leares thin, reniform or sulorbicular in outline, $4-12 \mathrm{~cm}$. broad, deeply perlately $\overline{5}-\bar{i}$-lober, glabrate or pubescent, the lobes dentate, acute or obtuse, the slender petioles $3-6 \mathrm{~cm}$. long; peduncles with an orate entire cordate bract at or below the midile; sepals oral or orate, $3-1.5$ $\mathrm{mm}$. long; corolla-segments obtuse or emarginate, 1.5-2 cm. long, yellow; fruit ovoil or oblong, bright rellow, tubercled, $2-12 \mathrm{~cm}$. long; seeis flat, 12-16 $\mathrm{mm}$. long.

Waste grounds, New Provldence at Nassau:-southern Uulted States: West Indies and continental tropical Amerien; old World troples. liecorded by Dolley as Momordica Balsamina L. WILD BALSAM-APPLE.

\section{MELOTHRIA I. Sp. Pl. 35.1753.}

Slender vines, with simple or rarely bifid teudrils, thin leaves, and small, white or yellow, monoecious flowers, the staminate clustered, the pistillate of ten 
solitary. Calyx campanulate, 5-toothed. Corolla campannlate, deeply 5-parted. Stamens 3 in the staminate flowers, the anthers distinet or slightly united, the pistil wanting or rudimentary. Fertile flowers with 1 pistil; orary ovoid, constricted below the corolla; placentae 3 ; orules numerous; style short; stigmas 3, linear. Fruit suall, berry-like, pulpy. [From the Greek for some rine, probably Bryonia eretica.] About 64 speeies, natives of warm and tropical regions. Type species: Mclothria pendula $\mathrm{L}$.

1. Melothria guadalupénsis (Spreng.) Cogn. in DC. Mon. Phan. 3: 580. 1881.

Bryonia guadalupensis Spreng. Syst. 3: 15. 1826.

Melothria pervaga Griseb. Fl. Br. W. I. 289. 1860.

A slender glabrous vine, sometimes $2 \mathrm{~m}$. long, elimbing by filiform tendrils. Leaves various, orate, or orate-lanceolate in outline, $3-7 \mathrm{~cm}$. long, scabrous, repand or 3-5-lobed with the middle lobe often longer than the lateral ones, acute or acuminate at the apex, deeply cordate at the base; petioles slender, 1-t cm. long; staminate racemes few-flowered, peduncled; peduncle of the pistillate flower $2-4 \mathrm{~cm}$. long; ealyx-teeth subulate, minute; corolla short-villous, aboit $4 \mathrm{~mm}$. broad, its lobes obtuse; pepo ovoid, 1-1.5 cm. long, red or purple.

Pine-lands and cultirated grounds, Abaco, New Providence, Eleuthera:-West Indies and continental tropical America. GUADAloupe CreEping-Cucumber.

\section{ANGÙRIA Jacq. Enum. 9, 31. 1760.}

Climbing vines, with slender simple tendrils, the leaves various, the polygamons flowers mostly small, clustered at the end of a long peduncle, the calyx and corolla of staminate and pistillate flowers similar. Calyx with an elongated, more or less swollen tube and a 5-cleft or 5-toothed limb. Corolla 5 -parted, rotate. Staminate flowers with 2 included stamens, the filaments short, the anther-saes narrow. Pistillate flowers with 2 rudimentary stamens, an ovoid ovary, a slender 2-cleft style, the stigmas 2-eleft. Frnit manyseeded, ovoid or oblong. [Greek, similar to water melons.] Species 40 or 50, all American. Type speeies: Anguria pedata Jacq.

\section{Anguria pedàta Jacq. Enum. 31. 1760.}

Anguria Keithii Northrop, Mem. Torr. Club 12: 69. 1902.

A glabrous monoecious vine, trailing or elimbing, $3 \mathrm{~m}$. long or longer, the root elongated, the stem groored, somewhat woody below. Leaves deeply $5-7$ divided, reniform-orbicular in outline, usually divided into 3 short-stalked segments, the 2 lateral omes again 2-3-divided, the segments lanceolate or oblong, acute or obtuse, few-toothed or entire; peduneles slender, about as long as the leares; staminate racemes several-flowered; pedicels $5-16 \mathrm{~mm}$. long; calyx ovoid, $5-7 \mathrm{~mm}$. long, its tube orate or laneeolate, acute, one-third to one-half as long as the tube; petals orange, $1-1.5 \mathrm{~cm}$. long; pistillate flowers solitary or in pairs: frnit ovoid, short-beaked, about $3 \mathrm{~cm}$. long. Coppices, Conch Sound, Lisbon Creek and Mangrore Cay, Andros, Eleuthera:-
Cuba to Porto Rico; recorded from Panama. Lefered to by Dolley as Cucumis Anguria L.

4. CAYAPòní Manso, Enum. Subst. Bras. 31. 1836.

Climbing herbaceous vines, with entire toothed lobed or palmately divided leaves, simple or divided tendrils, and rather large, monoecious or 
dioecious, mostly panicled or racemose flowers. Calyx campanulate, its limb 5-cleft. Corolla 5-partel, rotate or subcampamulate. Staminate flowers with 3 distinct stamens, the anther-saes flexuous, the rudimentary ovary 3-loberl. Pistillate flowers often with 3 rudimentary stamens; ovary 3-eelled; orules 1 or 2 in each cavity; style 3 -cleft, the 3 stigmas dilatel. Fruit rather small, slightly fleshy, mostly 3-seeded. [Brazilian name.] About 60 species of trop. ical and subtropical America, one in tropical Africa. Type species: Cayaponia diffusa Manso?

Calyx $3-1 \mathrm{~mm}$. long, its teeth triangular ; corolla-lobes $3-5 \mathrm{~mm}$. long. 1. C. racemosa. Calyx 6-9 mm. long, its teeth lanceolate; corolla-lobes $12-15 \mathrm{~mm}$. long. 2. C. americana.

1. Cayaponia racemòsa (Sw.) Cogn. in DC. Mon. Phan. 3: 765. 1851.

Bryonia racemosa Sw. Prodr. 116. 17ss.

Trianospermum racemosum Griseb. Cat. Pl. Cub. 112. 1866.

A somewhat woody, often high-climbing vine, up to $7 \mathrm{~m}$. long, the stem and branches glabrous. Leaves ovate-orbicular in outline, 6-13 cm. long, variously lobed, or the upper entire or nearly so, acute or acuminate at the apex, cordate or subreniform at the base, scabrous above, pubcrulent or hispidulous beneath, the rather slender petioles $2-7 \mathrm{~cm}$. long; flowers racemose or racemose-paniculate, distant; pedicels 3-6 mm. long; calyx campanulate, 3-4 mm. long, its teeth triangular-ovate, very small; corolla about $1 \mathrm{~cm}$. broad; pepo oblong, ret, 1-2 cm. long.

Coppices and ciearings, Abaco, New Providence:-Cuba to Tortola; Tobago ; Trinidad and continental tropical America. Racrasose Caraposia.

\section{Cayaponia americàna (Lam.) Cogn. in DC. Mon. Phan. 3: iS5. 1851.}

Bryonia americana Lam. Encycl. 1: 498. 1785.

A long vine, glabrous, similar to C. raccmosa, the leares various, 3-5. lobed or nearly entire, the petioles $2-7 \mathrm{~cm}$. long. Flowers few, clustered in short racemes or panicles, or sometimes solitary; pedicels $2-6 \mathrm{~mm}$. long; calpx campanulate-cylindric, $6-9 \mathrm{~mm}$. long, its teeth lanceolate, 2-4 $\mathrm{mm}$. long; corolla 2-3 cm. broad; pepo oblong to ellipsoid, 1t-15 mm. long.

Coppice, Conch Sound. Andros :-Cuba to Tortola and St. Vincent. Fecorded by Irs. Forthrop as Trianosperma raccmosum. PANicled CaYaroxis.

\section{Family 2. LOBELIÀCEAE Dmort.}

\section{LoBELia F.hIILY.}

Herbs, or in tropieal regions rarely shumb or trees, often with milky sap which eontains a nareotic-acid poison, with altermate estipulate simple entire, toothed or pinnately parted leaves, and solitary spicate racemose or panienlate flowers. Calyx-tube adnate to the ovary, its limb 5 -lobed or 5-parted, the lohes equal or nnerual. Corolla gamopetalons. ilregular, often bilabiate, its tube open on one side nearly or yuite to the base, its limb 5 -lobed; stamens 5 , inserted with the eorolla; filaments sometimes eohering into a tube; anthers united. Ovary 2--j-eelled; style single; stigma fringed; orules numerous, sessile, horizontal, anatropois. Frnit a 1-5-eelled eapsule, or a berry. Seeds mumerons, with a smooth or firrowed testa. Endosperm fleshy. About 20 genera and 600 speeies, of wirle geographie distribution 


\section{LOBÈLIA L. Sp. Pl, 929, 1753.}

Herbs (some tropieal speeies shrubs), with alternate or basal leaves, and racemose spicate or paniculate, often leafy-bracted, red yellow blue or white flowers. Calyx-tube turbinate, hemispherie or oroid, adnate to the ovary. Corolla-tube straight, oblique, or incurved, divided to the base on one side, -lipper in our species, the lobe on each side of the eleft ereet or recurved, turned away from the other 3 which are somewhat united. Stamens free from the eorolla-tube, monadelphous, at least above, 2 or all the 5 anthers with a tuft of hairs at the tips, 3 of them usually larger than the other 2, all united into a tube or ring around the style. Orary 2 -celled, the 2 plaeentae manyoruled; stigma 2-lobed or 2-cleft. Capsule loeulieidally 2-valved. [Named after Matthias de L'Obel, 1539-1616, a Flemish botanist.] About 250 species of wide geographic distribution. Trpe speeies: Lobelia Dortmanna L.

\section{Lobelia lucayàna Britton \& Millspaugh, sp. nor.}

Annual, slender, pilose with strap-shaped hairs. Stems simple, scapiform, ereet, 3-12 cm. high; basal leaves rosulate, small, 1-2 cm. long, ovate or orbieular, obtuse, attenuate to the petiole, crenate-dentate, the teeth mueronulate; eauline leares infrequent, spatulate or oblanceolate, sessile or shortpetioled; racemes few-flotrered, 2-T $\mathrm{em}$. long; flowers long-pedicelled, the pedicels slender, mueh longer than the braets; corolla blue, about $4 \mathrm{~mm}$. long, bilabiate, the tube elongate-erlindric, deeply fissured; inferior lip 3-lobed, the lobes equal; superior lip 2-Iobed, the lobes lanceolate, divergent; mature capsule $3 \mathrm{~mm}$. long; seeds orbicular, biconvex, about $2.5 \mathrm{~mm}$. in diameter, dark and shining.

Type from North Caicos, in the vicinity of Kew, Wilson rr13 in herb. N. Y. Intanical Garden: shady places in rich soil. "Tatling's Island at the southeast end. Habitally like L. Feayana A. Gras, of southern Florida, but in our specles the seeds are lenticular. dark brown and polished, while in $L$. Feayana they are oblong and tuberculate. BAHAMa LOBELIa.

\section{Family 3. GOODENIÀCEAE Dumort.}

Goodenia Fadili.

Herbaceous or shrubby plants, with watery sap. Leaves alternate or sometimes opposite, without stipules, entire, toothed or rarely pinnatifid. Flowers perfect. Calyx 5-toothed, an entire border, or sometimes obsolete. Corolla 5-lobed, split on one side. Stamens 5, distinct, the anthers opening lengthwise. Ovary mostly inferior, 1-2-celled; styles usually united. Stigma surrounded with an indusium. Ovules 1 or 2, or more in each caritr, mostly erect or ascending. Fruit dupaceous, berry-like or eapsular. Seeds usually one in each cavity; embryo straight in the axis of the fleshy endosperm. About 12 genera and orer 200 species, mostly Australian.

\section{SCAEVÒLA L. Mant. 2: 145. 17i1.}

Fleshy stout herbs or shrubs, with alternate or rarely opposite, mostly entire leares, the flowers irregular, axillary, in dichotomous cjmes or rarely solitary. Calyx 5-lobed, or a mere border. Corolla white or blue, its lobes winged, its tube split to the base on one side, rillous within. Stamens epigynous. Orary inferior or nearly so, 2-celled or rarely 1-celled; stigma sur- 
rounded by a ciliate indusium. Orules 1 in each eavity, or 2 in 1-celled ovaries, erect. Berry with a fleshy exocarp and a bony or woody endocarp. [Latin, referring to the irregular ilowers.] About 60 speeies, mostly Australian, the following typical.

1. Scaevola Plumièrii (L.) Vahi, Sỵmb. 2: 36.1791.

Lobelia Plumierii L. Sp. Pl. 929. 1753.

Seccevola Lobelia Murr. Sist. ed. 13, 175. 1774.

Perennial, nearly glabrous, more or less sbrubby, 6-15 $\mathrm{dm}$. high, much branched and straggling. Leares alternate, ohovate, 4-6 $\mathrm{cm}$. long, entire, shining, narrowed into very short winged petioles, or nearly sessile, with a tuft of silky hairs in each axil; peduneles shorter than the leaves; ealyx-lobes much broader than high, rounded; corolla glabrous without, about $2.5 \mathrm{~cm}$. long, the tube shorter than the lobes, the lobes nearly linear, with broal crisped wings; stamens nearly as long as the corolla-tube, hanging through the eleft; berry oval, black, juiey, 2-seeded, 10-14 mm. long.

Coastal rocks and sands, throughout the archipelago:-Bermuda; Florida: West Indies and Caribbean IIexico; tropical Africa. I.KuERr. BLAK Sodp. Catesby, 1: $p l$. $: 9$.

\section{Family 4. CICHORIACEAE Reichenb.}

\section{CHICORY FAdily.}

Herbs (two Paeifie Island genera trees), almost always with milky, aerid or bitter juice, alternate or basal leaves, and yellow, ravely pink, blue, purple, or white flowers in involuerate heads (anthodia). Braets of the involnere in 1 to sereral series. Receptacle of the head that or flattish, naked, sealy (paleaceous), smooth, pitted, or honeycombed. Flowers all alike (heads homogamous), perfect. Calyx-tube eompletely adnate to the ovary, its limb (pappus) of seales. or simple or plumose bristles, or both, or wanting. Corolla gamopetalous, with a short or long tube, and a strapshaped (ligulate) usually 5-toothed $\operatorname{limb}$ (ray). Anthers commate into a tube around the style, the saes sagittate or anricled at the base, not tailed, usually appendaged at the summit, the simple pollen-grains ustrally 12sided. Ovary 1-celled; ovule 1, anatropous; style very slender, 2-elett, or 2-lobed, the lobes minutely papillose. Fruit an achene. Seed erect; endosperm none; radiele narrower than the cotyledons. About 70 genera and 1,500 speeies, of wide geographic distribution.

Achenes truncate.

Achenes narrowed or beaked at the summit.

1. Sonchus. 2. Lactucu.

\section{SóNCHUS L. Sp. Pl. 793. 1753.}

Annual or perennial suceulent herbs, with alternate, mostly auriculateelasping, entire dentate lobed or pinuatifid, jrickly-margined leaves, and large or middle-sized, peduneled, corymbose or paniculate heads of ycllow flowers. Inroluere oroid or camlanulate, usually becoming thickened and more or less conic at the base when old, its bracts herbaceous or menbrauous, imbrieated in sereral series, the outer suceessively smaller. Reeeptacle flat, naked. Rays truncate and $\tilde{j}$-toothel at the apex. Anthers sagittate at the base. Stylebranches sleniler. Achenes oral, oblong, or linear, more or less flattenel, 10- 
20-ribhed, somewhat narrowed at the base, truncate. Pappus of very copious soft white simple capillary bristles, usually falling away connected, sometimes with 1 or 2 stouter ones which fall separately. [The Greek name of the Sowthistle.] About 45 species, of the Old World. Type species: Sonchus oleraceus $\mathrm{L}$.

\section{Sonchus oleràceus L. Sp. Pl. 794. 1753.}

Annual, with fibrons roots; stem leafy below, nearly simple, $3-30 \mathrm{dm}$. high. Basal and lower leaves petioled, lyrate-pinnatifid, 10-25 cm. long, the terminal segment commonly large and triangular, the margins denticulate with mueronate or searcely spiny teeth; upper leaves pinnatifid, elasping by an auricled or sagittate base; uppermost leaves often lanceolate and entire; heads several or numerons, pale yellow, 1s-30 mm. broad.

Waste places and cultivated fields, Abaco, Great Bahama, the Biminis, New Providence and Eleuthera to Acklin's Island and Grand Turk:-Bermuda; the Inited States to continental tropical America; West Indies. Naturalized from Europe. Som-THistif.

\section{IACTÙCA L. Sp. Pl. 795. 1753.}

Tall leafy herbs, with small panicled heads of yellow, white or blue flowers, and alternate leaves. Involuere cylindric, its bracts imbricated in several series, the outer shorter, or of 1 or 2 series of principal nearly equal inner bracts, and several rows of short onter ones. Receptacle flat, naked. Rays tuncate and 5-toothed at the summit. Anthers sagittate at the base. Style-branches mostly slender. Achenes oval, oblong or linear, flat, 3-5-ribbed on each face, narrowed above or contracted into a narrow beak, which is somewhat expanded at the summit into a small disk bearing the copious soft capillary, white or brown pappus-bristles. [The ancient Latin name, from lae, milk, referring to the milky juice.] About 95 species, natives of the northern hemisphere. Type species: Lactuea sativa L.

\section{Lactuca intybàcea Jacq. Ic. Rar. 1: 16. pl. 162. 1786.}

Annual, glabrous; stem terete, simple and leafy below, paniculately branched and nearly leafless above, $3-10 \mathrm{dm}$. high. Leaves thin, $0.5-2 \mathrm{dm}$. long, runcinate or irregularly lobed and toothed, the lower oblanceolate or obovate, petioled, the upper lanceolate, acuminate, sessile and clasping; heads solitary or in small clusters on the branches, distant, short-peduncled; involucre narrowly eylindric, 10-12 $\mathrm{mm}$. long, its outer bracts ovate or lanceolate, broadiy searious-margined, much shorter than the linear acute inner ones; rays yellow or white; achenes linear, muricate, $3 \mathrm{~mm}$. long; pappus white, plumose.

Waste places and cultivated ground, Eleuthera. Cat Island, Conception Island, Great Exuma, Long Island, Acklin's Island, Grand Turk. Inagua and Anguilla Isles: -Florida; Cuba to Tortola and to Trinidad; Jamaica ; Margarita ; Curaça ; Bonaire ; Mexico to Tenezuela. WiLd IETTuce.

\section{Family 5. AMBROSIÀCEAE Reichenb.}

\section{RAGWEED FAMILY.}

Herbs, monœcions, or sometimes diœcious, many of them weeds, rarely shrubby, with alternate leaves, or the lower opposite, and small heads of greenish or white flower's subtended by an involucre of few, separate or 
united bracts, the pistillate heads sometimes larger and nut-like or bur-like. Staminate and pistillate flower's in the same, or in separate heads. Receptacle chaffy. Pistillate flowers with no corolla, or this redueed to a short tube or ring; ealyx adnate to the 1-celled orary, its limb none, or a nere border; style 2-cieft. Staminate flowers with a funnelform tubular or obconie + 5-lobed corolla; stamens mostly 5, separate, or their anthers merely connivent, not truly syngenesious, with short inflexed appendages: orary rudimentary; summit of the style often liairy or penicillate. Eight genera and about 60 species, mostly natives of America.

Staminate and pistillate flowers in different heads.

Bracts of staminate involucres distinct.

Bracts of staminate involucres united.

Staminate and pistillate flowers in the same heads.

1. Tunthium. 2. Ambrosia.

3. Iva.

\section{XANTHIUM L. Sp. Pl. 957. 1753.}

Monoccious annual branching coarse rough or spiny herbs, with alternate lobed or dentate leaves, and rather small heads of greenish discoid flowers, the staminate ones eapitate-clustered at the ends of the branches, the pistillate axillary. Staminate heads with a short involucre of 1 to 3 series of distinct bracts; receptacle cylindric, chaffy; corollas tubular, 5-toothed; anthers not coherent, mucronate at the apex; filaments monadelphous; style slender, undivided. Pistillate heads of an ovoid or oblong, closed involucre, eovered with hooked bristles, 1-2-beaked, 2-celled, each carity containing one oboroid or oblong achene; corolla none; pappus none; style 2-cleft, its branches exsertel. [Greek, yellow, from its yielding a yellow hair-dye.] About 25 species, of wide geographic distribution. Type species: Tanthium strumarium Linn.

1. Xanthium chinénse Mill. Garł. Dict. ed. 8, no. 4. 1768.

Tanthium longirostre Wallr. Beitr. Bot. 1²: 237. 1544.

Hispidulous, $1 \mathrm{~m}$. high or less. Leares broadly ovate-reniform in outline, slender-petioled, 8-15 cm. long and about as wide as long, acute or acuminate at the apex, rather thin, coarsely irregularly toothed and usually 3-5-lobed, scabrous on both sides, the base triangular-cuneate; staminate heals numerous, about $5 \mathrm{~mm}$. in diameter; fruit oblong, its body $2 \mathrm{~cm}$. long or less, $5.5-\mathrm{s}$ mm. thick, hispidulous and glandular or sometimes glabrous; bristles rather slender, 3-1.5 $\mathrm{mm}$. long, hispidulous toward the base; beaks stout, $4-6 \mathrm{~mm}$. long, somewhat incurved.

Waste piaces in New Providence:- Bermuda: Cuba to Tortola and Martinique: Jamalca: United States and Central America. Reported by Dolley and by IItcheock as $\mathrm{T}$. strumarium L. WEST INDIA CocKLEBTr.

\section{AMBRÒsIA L. Sp. Pl. 987. 1753.}

Monoecious (rarely dioecious) branching herbs, with alternate or opposite, mostly lobed or divided leares, and small heals of green flowers, the staninate spicate or racemose, the pistillate solitary or elusterel in the upper axils. Involucre of the pistillate heals globose, oroid or top-shapel, closel, 1-flowered, usually armed with 4-5 tuhereles or spines; corolla none; stamens none: style-branches filiform; achenes oroil or obovoil: pappus none. Involuere of the staminate hearls mostly hemispheric or sauer-shaped, 5-12-lohed, open, many-flowerel; receptacle nearly flat, nakel, or with filiform chaff; corolla 
funnelform, 5-toothed; authers seareely coherent, mueronate-tipped; style undiviled, penicillate at the summit. [The ancient classical name.] About 15 species, mostly natives of America. Type species: Ambrosia maritima L.

Annual ; elect; pubescent or puberulent.

Ferennial; repent; hirsute or hispid.
1. A. paniculata.

2. A. hispida.

1. Ambrosia paniculàta Michx. Fl. Bor. Am. 2: 183. 1503.

Annual, pubeseent or puberulent, paniculately branched, 3-12 dm. high. Leares thin, 1-2-pinnatifid, petioled, 5-8 cm. long, the upper alternate, the lower mostly opposite, pale or eaneseeut beneath, the lobes oblong or lanceolate, obtuse or acute; racemes of sterile heards numerous, $2-12 \mathrm{~cm}$. long, the involueres hemispherie, about $3 \mathrm{~mm}$. broad, crenate; fertile heads few, obovoid or subglobose, 2-3 mm. long, short-beaked, pubescent.

Waste places at Nassau, New Providence:-Florida; Cuba; Hispaniola; Jamalca ; continental tropical America. Referred by Dolles and by Hitchcock to A. artemisiaefolia. L. SOUTHERs RAGWEed.

2. Ambrosia híspida Pursh, Fl. Am. Sept. 743. 1814.

Ambrosia crithmifolia DC. Prodr. 5: 525. 1836.

Perennial, hirsute or hispid; stems branched at the base, the branches diffusely spreading or ascending, 2-S dm. long, leafy. Leaves opposite, 2-3pinnately divided, rather firm in texture, 4-12 cm. long, short-petioled; racemes of sterile hearls elongated, mostly solitary, the involueres spiny-pubescent; fertile heads clustered, 2.5-3 mm. long, short-beaked, usually tubercled.

Sea-beaches, thronghout the archipelago:-Florida: Cuba; Hispaniola; Porto Rico; Virgin Gorda to Barbadoes; Mexico. SWEet-Bay. Bay Geranidr. Bay Taxsy.

\section{3. İVA L. Sp. Pl. 9s8. 1753.}

Puberulent or scabrous herbs or shrubs, with thick opposite leares, or the upper alternate, and small nodding, axillary and solitary, spicate racemose or panieulate heads of greenish flowers. Involucre hemispheric or eup-shaped, its bracts few, rounded. Receptacle chaffy, the linear or spatulate chaff enveloping the flowers. Marginal flowers 1-6, pistillate, fertile, their corollas short, tubular or none. Disk-flowers perfect, sterile, their corollas funnelform, 5lobed, their styles undivided, dilated at the apex. Anthers entire at the base, rellow, scarcely coherent with each other, tipped with mucronate appendages. Achenes compresserl, oboroid, glabrous. Pappus none. [Named after Ajuga Iva, from its similar odor.] About 12 species, natives of America. Type species: Iva annua $\mathrm{L}$.

Involucres about $5 \mathrm{~mm}$. broad; plant glabrous; leares mostly alternate.

Involucres $3-4 \mathrm{~mm}$. broad; plant pubescent; leaves opposite.

\section{I. imbricata.}

2. I. cheiranthifolia.

\section{Iva imbricàta Walt. F1. Car. 232. 1788.}

Perennial by woody roots, glabrous or nearly so throughout, fleshy; stem 3-6 dm. high, simple, or sparingly branched. Leaves all but the lowest alternate, sessile, oblong-spatulate, or laneeolate, obtusish, mucronulate, entire, or rarely serrate, obscurely 3 -nerred, the larger $3-5 \mathrm{~cm}$. long, 6-10 $\mathrm{mm}$. wide; heads short peduneled or nearly sessile, the upper ones longer than their subtending leares; involucre broadly eampannlate, about $5 \mathrm{~mm}$. broad, its bracts 6-9, somewhat imbricated in 2 series; fertile flowers $2-4$, their corollas tubular, the staminate ones much more numerous.

Sea-strands, Great Bahama, Great Harbor Cay, Andros, New Providence and Inagua :-Virginia to Florida and Louisiana; Cass of northern Cuba. BeAcH Ivs. 
×2. Iva cheiranthifòlia H.B.K. Nov. Gen. 4: 276. 1520.

A much-branched shrub, 1-2 $\mathrm{m}$. high, the slender twigs, the leaves and the involucres densely and finely pubescent. Leares opposite, narrowly oblong to oblong-lanceolate or the lower obovate, 3-9 cm. long, obtuse or acute at the apex, narrowed at the base, 3 -nerved, the petioles $3-15 \mathrm{~mm}$. long, the upper ones much smaller; peduncles shorter than the involucres; heads nodding, numerous; involucre $3-4 \mathrm{~mm}$. broad, its bracts $3-5$, nearly orbieular; fertile flowers $3-5$; staminate flowers 5-S.

Waste places and scrub-lands, Great Bahama, the Berry Islands, the Biminis, Andros, New Frovidence and Elentbera to Long Island:-Cuba. IBUSH Irs.

\section{Family 6. CARDUÀCEAE Neck.}

\section{Thistle FaMiLY.}

Herbs, rarely shrubs (some tropical forms trees), with watery or resinous (rarely milky) sap, and opposite alternate or basal estipulate leaves. Flowers perfect, pistillate, or neutral, or sometimes monoecious or dioecious, borne on a common receptacle, forming heads, subtended by an involucre of few to many bracts arranged in one or more series. Receptacle naked, or with chaffy scales subtending the flowers, smooth, or variously pitted or loneyeombed. Calyx-tube completely adnate to the ovary, the limb (pappus) of bristles, awns, teeth, scales, or crownlike, or cup-like, or wanting. Corolla tubular, usually 5-lobed or 5-cleft. the lobes valvate, or that of the marginal flowers of the head expanded into a ligule (ray); when the ray-flowers are absent the head is said to be discoid; when present. radiate; the tubular flowers form the disk. Stamens usually 5 , borne on the corolla and alternate with its lobes, their anthers united into a tube (syngenesious), often appendaged at the apex, sometimes sagittate or tailed at the base; pollen-grains globose, often rough or prickly. Orary 1-celled; orule 1, anatropous; style of fertile flowers 2cleft; stigmas marginal; style of sterile flowers commonly undivided. Fruit an achene. Seed erect; endosperm none: embryo straight; lypocotyl inferior. About $\$ 00$ genera and not less than 10,000 species, of wide geographic distribution.

Perfect flowers with regular colollas.

Stigmatic lines at the base of the stigma or below

the middle.

Stlgmas filiform or subulate, hispldulous.

Stigmas more or less clavate, papillose-puberulent.

Stigmatic lines extending to the tip of the stigma or to the appendages.

Anthers without elongated appendages at the tlp. Anther-sacs talled at the base.

Anther-sacs not talled at the base. Receptacle naked.

Bracts of the involucre well imbricated. StIgmas of the perfect flowers with terminal appendages.

Stigmas of the perfect fluwers with truncate, halpy or papllose tlps.

Bracts of the involucre IIttle if at all imbricated except when the broad outer overlap the Inner.

Receptacle chaffy i hracts of the Involucre herbaceous, sometlmes foliaceous.

Anthers with elongated, cartlinglnous, mostly connate appendages.

Perfect flowers, or all, with bilablate corollas.

\section{Tribe I. VersoxieaE.}

Tribe II. EUPATORIFAE.

Tribe IV. INULEAE.

Tribe III. Asterkat.

Tribe VI. IIELENIEAE.

Trlhe VII. SENecioneaf.

Tribe V. IIELIANTIEAE.

Trlbe VIII, CYNARE.IE. l'rlbe IA: MUTISIF.A. 
Tribe I. Vernoxieat.

Pappus of 2 series; bracts of involucre usually not appendaged.

1. Vernonia.

Tribe II. EupatoriedE.

Pappus of scales.

Pappus of capillary bristles.

Involucre of more than 4 bracts. 5-many-flowered.

Involucre of 4 (rarely more) bracts, 4 -flowered.

2. Agcratum.

3. Eupatorium.

4. Mikania.

Tribe III. Astereas.

Ray-florets present: plants not dioeclous.

Ray-florets ligular.

Ligules yellow: pappus copious, rar-achenes fiattened.

Ligules white or colored (not yellow).

Involucral bracts in $3-5$ series.

Ligules long and narrow; bracts mainly herbaceous.

Ligules short and broad: bracts not herbaceous. Involucral bracts in 1-2 series.

Iigules longer than the diameter of the dlsk.

Ligules shorter than the diameter of the disk.

Ray-florets tubular: pappus 2-serial.

Ray-florets wanting; plants dioecious.

5. Chrysopsts.

6. Aster.

7. Gundiachia.

8. Erigcron.

9. Leptllon.

10. Eschenbichia.

11. Baccharis.

Tribe IV. IxUleat.

Bracts broad; plants leafy throughout.

Bracts narrow; plants leafy only at the base.

12. Pluchea.

13. Sachsia.

Tribe $\mathrm{V}$. Heliaxtheae.

Disk-florets perfect but not fruit-producing.

Achenes not flattened.

Fruit unarmed achenes quadrangular.

Fruit armed with hooked prickles.

Achenes marked]y flattened.

Disk-florets fruit-producing.

Ray-florets persistent on the achenes.

Ray-florets not persistent on the achenes or wanting.

Pappus a mere crown or cap, or of few teeth, awns or bristles,

Achenes not compressed.

Chaff of the receptacle mere awns or bristles.

Chaff of the receptacle concave or clasping.

Pappus of slender caducous awns.

Pappus wanting.

Achenes sharp-edged, 4-6-angled.

Achenes of the disk neither sharp-edged, margined nor winged.

Achenes acutely 4-angled.

Achenes indistinctly 4 -angled.

Achenes of the disk broadly ulite-vinged.

Achenes markedly flattened parallel with the involucral bracts.

Involucre single,

Involucre donble.

Pappus of 2 short cornuate awns.

Pappus of 2-4 long barbed awns.

Pappus of numerous plumose ciliate scales.

14. Tetranthus.

15. Acanthospermum.

16. Parthenium.

17. Crassina.

18. Verbesina.

19. Melanthera.

20. Isocarpha.

21. Borrichia.

23. Timcresia.

24. Synedrella.

25. Salmea.

26. Bidens.

27. Tridax.

Tribe VI. Helexieat.

Plant-tissues without oil glands; bracts of the involucre united below.

Plant-tissues with oil glands: bracts separate.

Involucral bracts 2-seriate; pappus a crown.

Involucral bracts 1 -seriate.

Pappus of copious capillary bristles.

Pappus of a few sharp awns.

28. Flaveria.

29. Ncothymopsis.

30. Porophyllum.

31. Pectis.

Tribe VII. Senecioneat.

Bracts of the involucre markedly overlapping.

Bracts of the involucre slightly if at all overlapping.

Achenes elongated, sharply 5 -ribbed.

Achenes short, pilose-striate.

32. Neurolaena.

33. Emilio.

34. Erechthites. 
Tribe VIII. Crisinear.

Bracts of the involucre spined at the apex; leares plickly. 35. Cirsium.

Tribe IX. Mutisieae.

Heads homogamous: achenes conic, pubescent; leafy shrubs. 36. Anastraphia. IIeads heterogamous; achenes 5 -ribbed, rostrate; herbs. 37. Chaptalia.

1. VERNÒNIA Schreb. Gen. Pl, 2: 541. 1791.

Erect branching perennial herbs, or some tropical species shrubby, with alternate (rarely opposite), cutire or toothed, sessile or petioled leaves, and discoid cymose-paniculate heads of purple, pink, or white tubular flowers. Inrolucre hemispheric, campanulate or oblong-cylindric, its bracts imbricated in several or many series. Receptacle flat, naked. Corolla regular, 5-cleft. Anthers sagittate at the base, not caudate. Style-branches subulate, his. pidulous their whole length. Achenes 8-10-ribbed, truncate. Pappus in 2 series, the inner of numerous roughened capillary bristles, the outer of much shorter small seales or stout bristles. [Named after William Ternon, Einglish botanist.] Over 500 species, of $\pi$ ide distribution in warm-temperate regions, most abundant in South America. Type species: Ternonia noveboracensis (L.) will.

Shrubs or perennial herbs.

IIeads scorpioid, solitary in the axils of the upper leaves: canescent or tomentulose shrubs.

Leares broadest at or near the middle, not conspicuously attenuate at the base.

Leaves broadest above the middle, attenuate at the bast. Leaves broadly obcordate. Leares spatulate to elliptic.

Heads cymose, long-peduncled; plant nearly glabrous; leaves elongated-linear: herbaceous perennial.

Annual herb; heads in terminal cymes.

1. V. arbuscula.

2. V.obcordata.

3. V. bahamensis.

4.. . insularis.

5. V. cincrea.

\section{Vernonia arbúscula Less. Linnaea 6: 664. 1831.}

Ternonia arctata Gleason, Bull. Torr. Club 33: 1S5. 1906.

A shrub, up to $8 \mathrm{dm}$. high, usually lower, more or less brancher], the main branches nearly erect, the twigs tomentose, rather densely leafy. Leares elliptic to oblong-obovate, 1-2 cm. long, acute or mucronate at the apex, narrowed or obtuse at the base, tomentose beneath, glabrate above, the petioles $3-i \mathrm{~mm}$. long; heads crowded at the ends of the twigs, several or numerous, sessile or short-peduncled; involucre campanulate, $4-5 \mathrm{~mm}$. long, its bracts lanceolate, tomentose; achenes $2.5 \mathrm{~mm}$. long, pubescent; pappus nearly white.

I'lne-lands of New Provldence and Andros. lindemic. Recorded as $Y$. mhamensis by Coker and by Mrs. Nolthrop. The plant was erronenusly attributed to Maurltius by Lessing. (See Elkman, West Inclian Vernonine 5s). Low Bustur Versosis.

\section{Vernonia obcordàta Gleason, Bull. Torr. Club 33: 1S7. 1906.}

A much-brancherl shrub 6-9 $\mathrm{lm}$. high, the branches crooked, the young twigs angled, tomentose. Leaves crowded near the enils of the twigs, broadly obeordate, $1.5 \mathrm{~cm}$. long or less, about as wide as long, grew-tomentose, especially beneath, narrowed into petioles about $5 \mathrm{~mm}$. long; heals fow, sessile among the leaves, 8-13-flowered; involuere campaulate, $4-5 \mathrm{~mm}$. long, its bracts orate-lanceolate, tomentose, acute; achenes hirsute, about $\simeq$ mm. long; pappus yellow.

Rocky serub-lands at Monjean II:lrbor, Little Inggua. Endemle. Ixaca VERNONIA, 
3. Vernonia bahaménsis Griscb. Fl. Br. W. I. 352. 1861.

A shrub, 0.5-2 m. high, dichotomously branched, the twigs and leaves pale-tomentulose. Young twigs angled; leaves spatulate to elliptic, $1.5-5{ }^{\circ} \mathrm{cm}$. long, entire, obtuse, mucronate or retuse at the apex, narrowed into slender petioles $5-10 \mathrm{~mm}$. long; heads few, sessile on the twigs among the upper leares, $7-13$-flowered; involucre campanulate, $3-4 \mathrm{~mm}$. long, its bracts oratelanceolate, acute, tomentose, imbricated in few series; achenes hirsute, 2-2.5 mm. long; pappus nearly white, 4-5 mm. long.

Scrub-lands, rocky plains and white-lands, Crooked Island,* Fortune Island, Acklin's Island, Castle Island, Mariguana, Caicos Islands, Cotton Cay and Salt Cay, Turk's Islands and Inagua. Endemic. Ballasi Yerxosia.

4. Vernonia insulàris Gleason, Bull. Torr. Club 33: 184. 1906.

Perennial by a horizontal rootstock; stem erect, glabrous, or puberulent above, $1 \mathrm{~m}$. high or less, simple or little-branched. Leaves narrowly linearoblong, 6-10 cm. long, 8-12 $\mathrm{mm}$. wide, entire, glabrous or very nearly so, acutish or obtuse and mucronate at the apex, narrowed to the sessile base; heads 4-25, cymose, the peduncles $4 \mathrm{~cm}$. long or less; involucre about $5 \mathrm{~mm}$. high, its bracts glabrous, acuminate, the outer lanceolate, the inner oblong; achenes $2 \mathrm{~mm}$. long, striate; pappus tawny, $6 \mathrm{~mm}$. long, the outer bristles minute.

Pine-lands of Great Bahama and Abaco. Endemic. Loxg-Leated Verioxid.

5. Vernonia cinèrea (L.) Less. Linnaea 4: 291. 1829.

Conyza cinerea L. Sp. Pl. 862. 1753.

Annual, simple or little-branched, erect, 3-10 dm. high, appressed-pubescent, leafy nearly to the base. Leaves flaccid, ovate to lanceolate, repand or entire, acute or obtuse, the lower petioled, $4-\bar{i} \mathrm{~cm}$. long, the upper much smaller and sessile; heads numerous, slender-peduncled, in terminal compound leafless cymes; inrolucre about $3.5 \mathrm{~mm}$. high, its bracts narrowly lanceolate, sharply acuminate, pubescent, the outermost minute; flowers purple; achenes pubescent; pappus white.

Waste and cuItivated grounds, New Providence and North Caicos:-Florida, Test Indies and continental tropical America; Old World tropies. Herbaceovs VERTONIA.

\section{AGERÀTUM L. Sp. Pl. S39. 1753.}

Annual or perennial herbs, or shrubs, with mostly toothed leaves, the small heads in terminal corymbs or cymes, the flowers all tubular. Involucre campanulate or subhemispheric, its narrow bracts nearly equal, imbricated in 2 or 3 series, sometimes with 1-3 smaller outer ones. Receptacle flat to conic. Corolla 5-toothed, white, blue, violet or purple. Anthers linear to oblong. Achenes 5-angled. Pappus of awned or awnless scales, distinct or connate. [Greek name of some similar plant.] About 25 species, mostly of tropical distribution. Type species: Ageratum conyzoides L.

1. Ageratum latifólium Car. Icon. 4: 33. pl 35\%. 1797.

Ageratum muticum Griseb. Fl. Br. W. I. 356. 1861.

Loosely villous or pubescent, erect or ascending, annual, simple or branched, 1-6 dm. high. Leaves ovate, membranous, 2-5 cm. long, crenate-dentate,

* Hitchcock's reference to the species on Cat Island is, apparently, an error, his label reads "Crooked Island." 
acute or obtuse at the apex, mostly rounded or obtuse at the base, the slender petioles $5-15 \mathrm{~mm}$. long; heads several in the corsmb; peduncles $5-10 \mathrm{~mm}$. long; involucre about $4 \mathrm{~mm}$. high, its iracts oblong-lanceolate, acute; Howers violet or white; pappus seales lanceolate, eiliolate, amnless or some of them loristletipped, about one-third as lorg as the achene.

Waste places and cultirated fields, Abaco, Great Bahama and Andros to Acklin's Island. Caicos and Turk's Islands and Inagua :-Cuba : Jamaica : IIispanlonla ; continental tropical America. Specimens from New Providence and IIarbour Island, referred by Dr. B. L. Robinson (Proc. Am. Acad. 49: 463) to Ageratum conizzides inacquipalcacem IIieron., do not appear to be specifically distinct from 1 , latifoliun.

Recorded by Schoepf, Doller, Hitcheock and Mrs. Northrop as A. eonyzoides I.. which it closely resembles. WiLd Ageratum. GOAT-BUsir.

\section{EUPATÒRIUIM [Tourn.] L. Sp.. Pl. S36. 1753.}

Erect herbs or shrubs, with opposite or verticillate, or sometimes alternate, often punctate leares, and, in most species, cymose-corymbose discoid heads of white, blue or purple flowers. Involucre oblong, ovoid, campanulate, or hemispheric, the bracts imbricated in 2-several series. Receptacle naked. Corolla regular, its tube slender, its limb 5-lobel or 5-toothed. Anthers obtuse and entire at the base, appendiculate at the apex. Style-branches elongated, flattened, or thickened above, stigmatic at the base. Achenes 5-angler, truneate. Pappus of numerous capillary, usually scabrous bristles arranged in 1 row. [Named for Mithridates Eupator. i. e., of a noble father.] Orer 500 species, mostly of Tarm or tropical regions. Type species:Eupatorium cannabinum L.

Leares dissected into filiform segments.

IIeads not secund; plants copiously pubescent. 1 . E. rapillifolium.

Heads secund: plants essentially glabrous. 2. E. leptophyllum.

Leaves entire or dentate.

Scales of the campanulate involucre in 1-3-series. I'ants glabrous.

I'lants finely pubescent.

Scales of the crlindric involucre imbricated in several series. Scales without densely pubescent tips; leaves entire, serrate, or crenulate.

I,eares acute or acuminate, seriate.

Leares rounded or ohtuse, entire or crenulate.

Involucre 2-2.5 mm, thick; scales narrow, 3 . striate.

Involucre $3-4 \mathrm{~mm}$. thick; scales broad, 5 -striate.

Scales with densely pubescent tips; leaves coarsely crenate.

3. E. haranense.

4. E. villosum.

5. E. odoratum.

6. E. Tahamense.

T. E. lucayanum.

S. E. corymbosum.

1. Eupatorium capillifòlium (Lam.) Small, Mem. Torr. Club 5: 311.1594.

Artemisia capillifolia Lam. Encye. 1: 267. 1783.

Eupatorium foeniculaceum Willd. Sp. Pl. 3: 1750. 1804.

Erect, paniculately much branched, with the aspect of an Artemisia, the stem finely pubescent, 1-3 $\mathrm{m}$. high. Leaves crowded, dissected into filiform segments, alternate, the lower petioled, the upper sessile; heals verF numerous, about $3 \mathrm{~mm}$. high, short-peduncled, racemose-paniculate, 3-6-flowerel ; bracts of the involnere in about 2 series, linear, cuspidate, narrowly scarious-margined, glabrous; flowers greenish white.

Moist places, In copplees and scrub-lands, Great Fahama, Abaco, Nortli Cat Cay, Andros, New Providence. Gleat Guana Cay, Elenthera, Cat Islund, Watllng Island and Fortune Island:-Bermuda; southern lulted States: Cuba. Dog-Frxirt.

2. Eupatorium leptophýllum DC. Prodr. 5: 176. 1836.

Erect, usually much branched above, $4-15 \mathrm{dm}$. high, similar to the precesting species, but glabrous. Leares numerous, mostly alternate, disserted into 
filiform segments; heads numerous, 3.5-4.5 mm. high, short-peduneled, in terminal secund racemes $2-10 \mathrm{~cm}$. long; bracts of the involucre in about 2 series, linear, euspidate or aristate; flowers nearly white.

Border of marsh at Adelaide, New Irovidence:-South Carollna; Florida : Cuba. SMOOTII DOG-FENMEL.

3. Eupatorium havanénse H.B.K. Nov. Gen. 4: 128. 1820.

Eupatorium ageratifolium DC. Prodr. 5: 173. 1836.

Shrubby, branched, glabrous or nearly so, the branches spreading. Leaves opposite, ovate to orate-lanceolate or deltaid-orate, $2-8 \mathrm{~cm}$. long, acute or obtuse, coarsely dentate or crenate-dentate, obtuse to subcordate at the base, petioled; heads commonly numerous; involucre 10-30-flowered, 4-5 $\mathrm{mm}$. high; its bracts linear to linear-spatulate; flowers white; achenes $2-3 \mathrm{~mm}$. long.

Coppices, pine-lands and scrub-lands, Abaco, Great Bahama, Andros, New Providence, Eleuthera :-Cuba ; Texas and Mexico. Cat-Toxgue. Havaxa ThoroughWORT.

\section{Eupatorium villòsum Sw. Prodr. 111. 17SS.}

A branching shrub, $2 \mathrm{~m}$. high or less, the leaves and branches tomentulose. Leaves opposite, petioled, ovate, $1.5-7 \mathrm{~cm}$. long, obtuse, repand-dentate or entire; heads small, usually numerous; involucre about $3 \mathrm{~mm}$. high, $8-15$ flowered, its bracts oblong or linear-oblong, obtuse; flowers white or purplish; achenes $1.5-2 \mathrm{~nm}$. long.

Scrub-lands, coppices and pine-lands, Abaco, Great Bahama and Andros to Crooked Island and Atwood Cay :-Florida; Cuba; Jamaica and the Cayman Islands. VELVET THOROEGHWORT. JACKMADA.

* 5. Eupatorium odoràtum L. Syst. ed. 10, 1205. 1759.

Eupatorium conyzoides Vahl, Symb. 3: 961794.

Shrubby, much branched, more or less pubescent, erect, or in thickets halfclimbing, 1-3 m. high. Leaves thin, orate to orate-lanceolate, $5-15 \mathrm{~cm}$. long, 3-nerved, dentate, often with large acute teeth, acuminate at the apex, usually cuneate at the base, the slender petioles 1-t $\mathrm{cm}$. long; heads in terminal corymbs $5-10 \mathrm{~cm}$. broad, cylindric, 8-12 mm. long; involuere-bracts imbricated in about 4 series, striate-nerved, glabrous or nearly $\mathrm{so}_{2}$ shining, all obtuse, or the inner acute or acutish; flowers 10-20, white to blue; achenes rough-angled.

Rocky plains and scrub-lands from Andros, New Providence and Eleuthera southward to Cay Sal islets and the Cajcos group:--southern United States: West Indies and continental tropical America. Recorded from Bermuda. Busur Troplcal Thonoughwort. TONRA-BEAN, BitTer-BCsh, Erroneously called VANilla.

\section{Eupatorium bahaménse Northrop, Mem. Torr. Club 12: 70. 1902.}

Shrubbs, branched, 1-1.6 m. high, the twigs puberulent. Leaves orate to lanceolate, rather firm in texture, punctate, glabrous or sparingly puberulent, 2-7 cm. long, obtuse at the apex, cuneate to subtruncate at the base, entire or sparingly crenate, 3-nerved, the petioles $2 \mathrm{~cm}$. long or less; corymbs dense, 2-5 cm. broad, the heads sessile or short-peduncled; involucre cylindric, 8-10 $\mathrm{mm}$. high, $2-2.5 \mathrm{~mm}$. thick, its seales imbricated in 4 or 5 series, oblong to lanceolate, obtuse, 3-nerved; flowers pale blue or lavender; achenes $3-4 \mathrm{~mm}$. long, 3-5-angled, tapering to the base.

Sand-dunes, coppices and scrub-lands, Little Harbor Cay of the Berry Islands, Andros, New Providence, Eleuthera and Great Guana Cay of the Exuma Chain. Endemic. Recorded by Dolley and by Eaton and Setchell as E. integrifolium Bert. BAHAMA THOROUGHWORT. 


\section{Eupatorium lucayànum Britton, sp. nov:}

A much-branehed shrub, t-6 $\mathrm{lm}$. high, the young loranches finely puberulent. Leaves ovate, short-petioled, $4 \mathrm{~cm}$. long or less, obtuse or rounlerl at the apex, obtuse or subtruncate at the base, entire-margined, puberulent, at least on the reins beneath, copiously punctate, somewhat fleshy, 3-nerved, the puberulent petioles $3-7 \mathrm{~mm}$. long; corymbs dense, $3-6 \mathrm{~cm}$. broal, the heads sessile on their branches; involuere obiong-cylindric, $i-9 \mathrm{~mm}$. high, $3-4 \mathrm{~mm}$. thick, its scales in 5 or 6 series, suborbicular to oblong, obtuse, puberulent, strougly 5 -striate; flowers lilac or pale purple; achenes narrowly obpyramidal, about $4 \mathrm{~mm}$. long.

Rocky soil and coastal rocks, Abaco, Frozen Cay, Berry Islands, Acklin's Island, Crooked Island, Mariguani and East Caicos. Type from Jariguana (Wilson, 7.j25). Recorded by Dolley and by Hitcheock as Eupatorium repandum Willd.

\section{S. Eupatorium corymbòsum Aubl. Pl. Guian, 2: 799. 1775.}

Eupatorium atriplicifolium Lam. Encyel, 2: 407. 17 SS.

Eupatorium repandum Willd. Sp. Pl. 3: 1767. 1804.

A shrub about $6 \mathrm{dm}$. bigh, the young shoots, petioles and branches of the inflorescence densely puberulent. Leares firm in texture, slightly fleshy, 4.5 $\mathrm{cm}$. long or less, the blades reniform-cordate to suborbicular, rounded at the apex, mostly about as wide as long, coarsely crenate, glabrous or nearly so above, puberulent and pitted beneath with the midvein rather prominent, the lateral veins few; corymbs several, dense, $3-4 \mathrm{~cm}$. broad, the heads sessile on the short branches; involucre eylindric with a somewhat narrowed base, $6-i$ $\mathrm{mm}$. high, $1.5-2 \mathrm{~mm}$. thick; seales in four series, oblong to linear-oblong, strongly striate-nerved, obtuse, their tips pubescent; flowers light purple: achenes obpyramidal, $3-3.5 \mathrm{~mm}$. long; pappus brownish.

Sand-dunes, Clarence Town and Water Car. Long Island:-Porto Rico to Tortola; Virgin Gorda; St. Croix; Martinlque; northern South America.

\section{MாKÀNIA Willd. Sp. Pl. 3: 1742. 1804 .}

Herbaceous twining vines, or some tropical species shrubs, with opposite, petioled leares, and discoid, mostly eymose-paniculate heads of white or pink flowers. Heads 4-flowered. Involuere oblong, of 4 slightly unequal narrow bracts. Receptacle small, naked. Corolla regular, its tube slender, the limb campanulate, 5-cleft. Anthers entire and obtuse at the base. Style-branches elongated, acutish. Achenes truncate, 5-angled. Pappus of numerous eapillary roughish bristles in 1 or 2 series. [In hollor of J. G. Mikan, 1743-1814, professor at Prague.] Abont 150 species, natires of America. Type species: Mikania hastata (L.) Willd.

\section{Mikania scándens (L.) Willd. Sp. Pl. 3: 1743. 1504.}

Eupatorium scandens L. Sp. Pl. \$36. 1753.

Mikania batatifolia DC. Prodr. 5: 197. 1836.

Mikania orinoccnsis H.B.K. Nov. Gen. 4: 134. 1820.

Willoughbya scandens Kuntze, Rer. Gen. PI. 37․ 1491.

Willugbacya heterophylla Small, Fl. SF. U. S. 1170, 133.. 1903.

A vine, glabrous or nearly so, $1.5-4.5 \mathrm{~m}$. long. Leaves ovate or liastate, deeply cordate, acuminate, repand or obtusely dentate, $5-10 \mathrm{~cm}$. long, $2-5 \mathrm{~cm}$. wide; petioles slender, shorter than the blades; heads in compound clusters 
borne at the ends of the branches; involucre about $6 \mathrm{~mm}$. long, its bracts lanceolate, acuminate or apiculate; flowers white or pink; achenes resinous.

Marshes, Great Bahama, Andros, and New Providence:-eastern continental North America; West Indies; continental America south to Argentina. Chimblig HENPWEED.

\section{CHRYsópsis Nutt.; Ell. Bot. S. C. \& Ga. 2: 333. 1824.}

Perennial herbs, with alternate sessile entire leaves, or the basal ones dentate, and large many-flowered hearls of both tubular and radiate yellow flowers (rays wanting in some western species), loosely corymbose, or solitary at the ends of the branches. Involucre campanulate to hemispheric, its bracts narrow, imbricated in several series, the outer shorter. Receptacle usually flat, foveolate. Ray-flowers pistillate. Disk-flowers mostiy all perfect. Pappus double in both the disk- and ray-flowers, the inner of numerous rough capillary bristles, the outer of smaller or minute scales or bristles. Achenes flattened, oblong-linear or obovate. Style-branches narrow, somewhat flattened, their appendages linear or subulate. [Greek, golden aspect.] About 20 species, of North America and Mexico. Type species: Inula gossypina Michx.

1. Chrysopsis graminifòlia (Michx.) Ell. loc. cit. 334. 1824.

Inula graminifolia Michx. Fl. Bor. Am. 2: 122. 1803.

Slender, corymbosely branched above. Leaves 3-5-nerved, shining, the basal ones $7-30 \mathrm{~cm}$. long, 4-10 $\mathrm{mm}$. Wide, the upper much smaller, and the uppermost subulate and erect; heads several or numerons, about $1 \mathrm{~cm}$. broad, solitary at the ends of the branches; involucre campanulate, its bracts glabrate; achenes linear-fusiform.

Pine-lands of Great Bahama:-southeastern United States. Grass-LEAtmD GOLDEN ASTER.

\section{6. ÀSTER L. Sp. Pl. 872. 1753.}

Perennial or rarely annual, mostly branching herbs, with alternate leaves, and corymbose or paniculate (rarely racemose or solitary) heads of both tubular and radiate flowers. Involucre hemispheric, campanulate or turbinate, its bracts various, imbricated in several series, the exterior usually smaller and shorter. Receptacle flat or convex, generally foveolate. Ray-flowers white, pink, purple, blue, or violet, pistillate. Disk-flowers tubular, perfect, their corollas 5-lobed, usually yellow and changing to red, brown, or purple. Anthers obtuse and entire at the base. Style-branches flattened, their appendages subulate, lanceolate or orate, acute. Pappus-bristles slender, numerous, scabrous or denticulate, usually in 1 series, sometimes in 2 series. Achenes mostly flattened and nerred. [Greek, star.] A genus of not less than 250 species, most abundant in North America. Type species: Aster Amellus L.

Rootstocks tuberous.

Inflorescence sub-racemose or narrowly thyrsoid; leares oblong. 1. A. lucayanus.

Inflorescence corymbose; leares, except lower, reduced to appressed scales.

Rootstocks not tuberous; roots of thick fibres.

Leares all linear, fleshy.

Involucral bracts abruptly acute.

Involueral bracts gradually acuminate.

2. A. adnatus.

3. A. Bracet.

4. A. exilis.

Leaves not fleshy; the basal ones oblong to oblong-lanceolate. 5. A. bahamensis. 


\section{Aster lucayànus Britton, Bull. N. Y. Bot. Garıl. 4: 1.13. 1906.}

Rootstoek short, tuber-like; stems ereet, $\overline{-}-\bar{i}$ dn. high. Leaves reticulateveined, entire, sessile (basal ones not seen), the lower oblanceolate, obtuse, those above the middle of the stem lanceolate to oblong-lanceolate, acuminate, $2-3.5$ $\mathrm{cm}$. long, 5-8 $\mathrm{mm}$. wide, those of the inforescence similar, smaller; heals racemose or racemose-eampanulate, about $2 \mathrm{~cm}$. broarl; peduncles slender, sericeous; involuere turbinate-campanulate, its bracts loose, narrowly oblonglanceolate, acmminate, scriceous, the inner $5-7 \mathrm{~mm}$. long; rays purple, $2 \mathrm{~mm}$. wide; achenes sericeous, $3 \mathrm{~mm}$. long, half as long as the whitish pappus.

l'ine-tands of Great Bahama. Endemic. I'INE-LAND ASTER.

\section{Aster adnàtus Nutt. Jour. Acad. Sei. Phila. 7: 82. 1834.}

Rootstock tuberous; stem $2-8 \mathrm{dm}$. high, hispidulous, branched. Leares various, the basal ones obovate, $1.5-2.5 \mathrm{~cm}$. long, those of the stem numerous, oblong to lanceolate, 3-12 mm. long, scabrous, sessile, those of the branches reduced to very small scales; heals few, terminating the branches; involuere 4-6 $\mathrm{mm}$. high, its linear braets with slightly spreading green tips; rays numerous, violet, $7-10 \mathrm{~mm}$. long; achenes glabrous.

Pine-lands of Great lahama :-southeastern Cnited States. Scale-LEaved ASTER.

3. Aster Bràcei Britton; Sinall, Fl. Miami 190. 1913.

Annual? Fleshy, glabrous, roots sereral coarse fibres; stem rather slender, often zigzag, brancherl above, the branches divaricatels ascending; leaves all narrowly linear, thick, entire, acute, somewhat narroweil toward the clasping base, the lower ones and those of shoots $10 \mathrm{~cm}$. long or less, $3-1 \mathrm{~mm}$. wide, the upper much shorter, those of the branches few, linear-subulate, very small; heads mostly solitary at the ends of the slender branches; inrolucre campanulate-eylindric, $3-4.5 \mathrm{~mm}$. high; bracts in 3 or 4 series, light green, linear to linear-lanceolate, abruptly acute or short-acuminate; rays pinkish, 4-5 mm. long; achenes 1-1.5 $\mathrm{mm}$. long, rough on the angles.

Brackish marshes and savannas, Ahaco, Great Bahama, Andros, New Prorldence:-Florida ; Cuba. Recorded as A. tenuifolius by Coker. BRACE'S ASTER.

4. Aster exilis Ell. Bot. S. C. \& Ga. 2: $344.18 \Omega 4$.

Annual, glabrous, somewhat fleshy, erect, 3-12 dm. high, usually much branched, the branches slender. Stem-leaves linear or linear-lanceolate, 2-10 $\mathrm{em}$. long, entire, acute, sessile or nearly $: 0,2-5 \mathrm{~mm}$. Wide, those of the branches subulate, $2-10 \mathrm{~mm}$. long, the basal ones oblong-lanceolate, petioled; hearls usually many, loosely panicled; involucre 5-6 mm. high, its linear-subulate, appressed bracts imbricated in 3 or 4 series; rays several, $2-4$ mm. long, purplish or white, longer than the pappus; achenes pubescent.

Wet grounds, Andros:-southeastern Inited States; Cuba. Sill Aster.

\section{Aster bahaménsis Britton, Bull: Torr. Club 41: 1t. 191 .}

Stout, fibrous-rooter, slightly fleshy, glabrous, 3-20 dm. high. Lower leaves anil those of sterile shoots with sheathing petioles $4-7 \mathrm{~cm}$. long, the blarles oblong to linear-oblong or ollong-lanceolate, obtuse or acute, t-s cm. long, 5-20 mm. Wille, sparingly erenate-dentat, or entire, narrowed into the petiole, the mirlvein prominent, the lateral veins obseure; upper stem-leaves linear, entire, $6 \mathrm{~cm}$. long or less, those of the branehes nearly subulate, 3-1: mm. long; heads numerous, paniculate; involuere nearly eylinilrie, li-s mm. high, its braets linear, acuminate, about 0.7 mus. while, green with surious margins, or the inner merelr green-tippeel; rays purple, $4-5$ mul. long; achenes columnar, $2.5 \mathrm{~mm}$. long, the angles roughenel; pappus hrownith, twice as Iong as the achene.

Molst grounds and marshes, Greatt liahana, Andros, Fleuthern nud ('at Island:Cuba. Ballama Aster. 
7. GUNDláchiA A. Gray, Proc. Am. Acad. 16: 100. 1550.

Somewhat viscid, leafy shrubs, with alternate entire, linear to oblanceolate leares, and numerous small hears of both discoid and radiate white flowers in terminal thyrses or compound corymbs. Ray-flowers few, pistillate; disk-flowers somewhat more numerous, perfect. Involucre obconic, its bracts coriaceous, imbricated in 4 or 5 series, the outer much shorter than the inner. Achenes nearly terete, 5-nerved. Pappus a single series of capillary bristles. [In honor of John Gundlach, 1810-1896, traveller and naturalist.] A few species, natives of the West Indies. Type species: Gundlachia domingensis (Spreng.) A. Gray.

1. Gundlachia corymbòsa (Urban) Britton; Boldingh, Fl. Ned. West-Ind. 391. 1913.

Gundlachia domingensis corymbosa Urban, Symb. Ant. 3: 406. 1903.

Nearly glabrous, viscir above, bushy-branched, 6-12 dm. high. Leaves oblanceolate to oblong-lanceolate, $3-8 \mathrm{~cm}$. long, 5-20 mm. wide, fleshy, obtuse and rounded at the apex, or emarginate or mucronulate, narrowed at the base, short-petioled, the midvein rather prominent, the lateral reins few and obscure; corymbs dense, convex, 3-10 $\mathrm{cm}$. broad; heads short-peduncled; involucre about $5 \mathrm{~mm}$. high, its bracts acute or acutish, the outer ovate, the inner linearlanceolate; rays spreading, 4-5 $\mathrm{mm}$. long.

Sand-dunes, serub-lands, pine-lands and borders of saline marshes, Andros, Eleuthera to Acklin's, Grand Turk and Inagua :- Porto Rico: Anegada; Saba; Barbuda ;

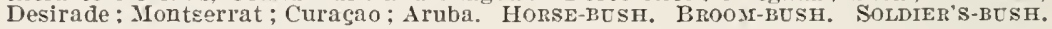

\section{ERÍGERON L. Sp. PI. 863. 1753.}

Branching or scapose herbs, with alternate or basal leares, and corymbose, paniculate or solitary, peduncled heads, of both tubular and radiate (rarely all tubular) flowers. Involucre hemispheric or campanulate, its bracts narrow, nearly equal, imbricated in but 1 or 2 series in most species. Receptacle nearly flat, usually naked. Ray-flowers usually numerous, white, violet or purple, pistillate. Disk-flowers yellow, tubular, perfect, their corollas mostly 5-Iobed. Anthers obtuse and entire at the base. Style-branches more or less flattened, their appendages short, mostly rounded or obtuse. Achenes flattened, usually 2-nerred. Pappus-bristles fragile, slender, scabrous or denticulate, in 1 series, or often an additional outer shorter series. [Greek, early-old, alluding to the early hoary pappus.] A genus of some 130 species, of wide distribution. Trpe species: Erigeron acre $\mathrm{L}$.

I * 1. Erigeron quercifòlium Lam. Tabl. Encyc. 3: 258. 1823.

Perennial, pubescent; stems 1-7 dm. high, commonly branched above, erect, slender. Basal and lower leares spatulate, oblanceolate or oblong, 4-12 $\mathrm{cm}$. long, sinuate-pinnatifid, narrowed into margined petioles, the upper oblanceolate to lanceolate, distant, smaller, mostly sessile; heads rather few; involucre about $3 \mathrm{~mm}$. high, its bracts linear, acute or acuminate; rays many, white or purplish, 3-4 mm. long.

Moist grounds, Abaco, Great Bahama, Andros, New Providence, Eleuthera :Florida. Referred to E. tenuis T. \& G. by Dolley. Southers Fleabane. 
9. LÉPtILON Raf. Am. Month. Mag. 2: 268. 1818.

Annual or biennial herbs, with small racemose, thyrsoid or panicled heads of white flowers, the rays small, usually shorter than the diameter of the disk or none. Involucre mostly campanulate, its narrow bracts in 2 or 3 series. Receptacle naked. Ray-flowers pistillate; disk-flowers perfect, their corollas usually 4-lobed or 4-toothed, the anthers obtuse at the base; style-branches somewhat flattened, their appendages short. Achenes flattened. Pappus of numerous simple fragile bristles in 1 series. [Greek, referring to the small heads.] About 20 speeics, natives of America and Asia. Type species: Erigeron divaricatum Miehx.

Bracts of the involucre very pubescent; plant hirsute. I'lant glabrous or nearly so throughout.

1. L. linifolium. 2. L. pusillum.

1. Leptilon linifòlium (Willd.) Small, Fl. SE. U. S. 1231, 1340. 1903.

Erigeron linifolius Willd. Sp. Pl. 3: 1955. 1804.

Hirsute; stem slender, branehed or simple, $7 \mathrm{dm}$. high or less. Leares linear or linear-spatulate, $1.5-10 \mathrm{~cm}$. long, the upper entire, sessile, the lower mostly ineised-serrate, and petioled; heads panieulate or subracemose, several or numerous; involucre about $5 \mathrm{~mm}$. high, its bracts linear, acuminate, pilose; achenes glabrous; pappus tamn, about 3 times as long as the achene.

Waste grounds. New Proridence at Nassau:-Bermuda: southeastern Inited States; Cuba; Old World tropies and subtropies. IIAJR IIORSEWEeD.

\section{Leptilon pusílium (Nutt.) Britton, Torreya 14: 198. 1914.}

Erigeron pusillus Nutt. Gen. 2: 148. 1818.

Stem glabrate, 7-30 dm. high, the larger plants panieulately much branched. Leares usually ciliate, the basal and lower spatulate, petioled, mostly entire, 2-10 em. long, obtuse or acutish, those of the stem linear and mainly entire; heads few or numerous, about $4 \mathrm{~mm}$. broal ; involucre, $2-3 \mathrm{~mm}$. high, its bracts linear, acute, glabrate, often purplish-tipped; rays numerous, white, shorter than the pappus and mostly shorter than their tubes.

Pine-lands, eultivated grounds, sandr soil aud serub-lands, Great Bahama, Abaco and Andros to Watling's Island. North Caicos and Inagua:-Dermuda: contlnental eastern North America: West Indies. Formerly included in Erigcron canadcnsis L., and thus recorded by prevlous authors. SMOOTI IIORSEWEL.

\section{ESCHENBÁCHIA Moench, Meth. 573. 1794.}

Iferbs, with alternate leares, and mostly corymbose or panicled heads of tubular flowers. Involuere eampanulate, several-many-floweres, its narrow bracts imbricated in 2-several series, the outermost usually much smaller than the others. Receptacle convex or flat, mostly nakel. Marginal flowers pistillate with narrow or filiform, 2-3-toothel corollas; disk-flowers tubular, perfeet, 5 -toothed. Anthers obtuse at the base. Aelienes flattenal, their silles nerveless or 1-nerved. Pappus of 1 or 2 series of bristles. [Commemorates J.F. Eschenbach, German botanist.] Perhaps 50 speeies, of tropieal and warmtemperate regions. Type species: Erigcron aegyptiacum L. 


\section{Eschenbachia lyràta (H.B.K.) Britton \& Millspaugh.}

Conyza lyrata H.B.K. Nor. Gen, 4: 70. 1820.

Perennial, erect, branched, viscir-pubescent, 4-9 dm. high, the branches ascending. Basal and lower leares oborate, coarsely dentate, 4-8 cm. long, obtuse, narrowed into margined petioles; upper leaves much smaller than the lower, oblong to obovate, dentate or lyrate, sessile or nearly so; hearls few or solitary at the ends of the brauches, slender-peduncled; involucre eampanulate, about $8 \mathrm{~mm}$. high, its bracts linear, acuminate.

Waste grounds, Long Island, at Clarence Town; Great Exuma, near Georgetown:-Cuba; Mexico to Colombia. STICKY-WEeD.

\section{BÁCCHARIS L. Sp. Pl. 860. 1753.}

Dioecious shrubs, with alternate leaves, and small, paniculate or corymbose hears of tubular flowers. Involucre campanulate or oblong, its many bracts imbricated in several series, the outer shorter. Receptacle flat, naked, commonly foreolate. Corolla of the pistillate flowers slender, that of the staminate tubular, 5-lobed. Anthers obtuse and entire at the base. Style-branches narrow or subulate, those of the fertile flowers smooth, exserterl, those of the sterile flowers rudimentary, tipped with an orate pubescent appendage. Achenes more or less compressed, ribberl. Pappus of the fertile flowers copious, capillary, that of the sterile flowers short. [Naned for Bacchus; originally applied to some different shrubs.] About 300 species, all American, most abundant in South America. Type species: Baccharis ivifolia L.

Leares linear to narrowly oblanceolate, the lower often dentate. Leares obovate to elliptic or oblanceolate.

At least the lower leares dentate.

Leaves all entire.

1. B. angustifolia.

2. B. halimifolia.

3. B. dioica.

1. Baccharis angustifòlia Michx. Fl. Bor. Am. 2: 125. 1803.

A branching shrub, $2.5 \mathrm{~m}$. high or less, the foliage resinous. Leaves mostly linear, sessile, $1-8 \mathrm{~cm}$. long, entire, or the lower denticulate; heads numerous, glomerate in peduncled clusters, or solitary; involucre of the staminate heads campanulate, about $2.5 \mathrm{~mm}$. high, that of the pistillate ones oblong, $4-5 \mathrm{~mm}$. high, its bracts ovate to lanceolate, obtuse or acutish; achenes about $1 \mathrm{~mm}$. long; pappus white, twice as long as the involucre.

Borders of marshes, Abaco, Great Baliama, Andros, New Providence:- Southeastern United States. NiRrow-LEAVE Grotidsel-bush.

\section{Baccharis halimifòlia L. Sp. Pl. 860.1753.}

A branching glabrous shrub, 1-3 $\mathrm{Im}$. high, the branchlets angled, sometimes minutely scurfy. Leaves thick, those of the stem and larger branches 2- $7 \mathrm{~cm}$. long, 1-j $\mathrm{cm}$. wide, those of the branchlets oblanceolate, short-petioled or sessile, entire, or few-toothed toward the apex; heads in terminal peduncled clusters of $1-5$, those of the sterile plant nearly globose when young, the bracts of the involucre oblong-ovate, obtuse, glutinous, appressed, the inner ones of the pistillate heads lanceolate, acute or acutish; pappus bright white, $6-8 \mathrm{~mm}$. long, much exceeding the involucre.

Borders of marshes, Treat Bahama. Andros, New Proridence:-Coast of the eastern and southeastern Tnited States. The Andros specimen (Brace 5203) may represent the rariety angustior DC., abundant in Cuba. Grovxdsel-BUsH. 
3. Baccharis dioica Vahl, Symb. 3: 98. 1794.

Baccharis Tahlii, DC. Prodr. 5: 411. 1836.

Glabrous, branchesl, $2 \mathrm{~m}$. high or less, shrubby, soinewhat glutinous, the twigs striate, densely leafy, sometimes granular. Leaves obovate or cuneateobovate, 2-4 cm. long, 1-2 cm. wide, obtuse or subtruncate and mueronulate at the apex, narrowed at the base into short petioles, the milvein rather prominent, the lateral venation obscure; heads clustered at the ends of the trigs: involuere 4-i mm. high, its bracts oblong, imbricated in 4 or 5 series; pappus of the pistillate heads about as long as the corollas; achenes 10-ribbed, glabrous.

Scrub-lands and coppices, Great Bahama, Abaco, Andros, New Providence, Eleuthera, Cat Island, lnagua:-Florida ; Cuba : Hispaniola ; St. Croix; Montserrat; Jamaica. Fahl's Grotydel-blish. Broom-besh.

\section{PlứheA Cass. Bull. Soc. Philom. 1817: 31 . 1817.}

Pubescent or glabrous herbs, or some tropical species shrubby, with alternate dentate leares, and small heals of tubular flowers in terminal corymbose cymes. Involucre oroid, campanulate, or nearly hemispheric, its bracts appressel, herbaceous, imbricated in several series. Receptacle flat, naked. Outer flowers of the head pistillate, their corollas filiform, 3-cleft or dentate at the apex. Central flowers perfect, but mainly sterile, their corollas 5-cleft. Anthers sagittate at the base, the auricles caudate. Style of the perfect flowers 2-cleft or undivided. Achenes 4-5-angled. Pappus a single series of capillary scabrous bristles. [Named for the Abbé N. A. Pluehe, of Paris.] About 35 species, widely distributed in warm and temperate regions. Type species: Conyza marilandica Michx.

Plants shrubby.

Plants herbaceous.

Perennial: leaves sessile.

Annual; leaves petioled.
1. P. odorata.

2. P. foetila.

3. P. purpurascens.

1. Pluchea odoràta (L.) Cass. Diet. Sci. Nat. 4: 3. 1826.

Conyza odorata L. Syst. ed. 10, 1213. 1759.

A densely and finely pubescent shrub, up to $3 \mathrm{~m}$. high. Leaves oblong, entire, or undulate-serrate with small blunt teeth, $8-20 \mathrm{~cm}$. long, $1.5-5 \mathrm{~cm}$. wide, rather dark green, loosely pubescent, becoming nearly glabrous abore, finely and densely pubescent and pale beneath, acute or acuminate at the apex, narrower at the base, the petioles $1-4 \mathrm{~cm}$. long; corymbs mostly large; peduncles and involucre densely pubescent; inrolucre about $5 \mathrm{~mm}$. high, its bracts ovate to lanceolate, acute to acuminate; flowers creamy pink or whitish.

Rocky scrub-lands, copplces and clearings throughout the archipelago from Great Bahama and Andros to Grand Turk and Inagua:-Bernuda: Florida: West

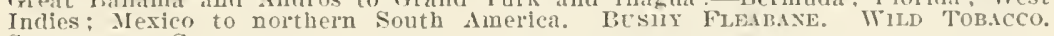
SOUR-BUS11. COUG11-BUsir.

2. Pluchea foètida (L.) B.S.P. Prelim. Cat. N. Y. 2S. 1sss.

Baccharis foetida L. Sp. Pl. S61. 1753.

Pluchca bifrons DC. Prod. 5: 451. 1 s36.

Perennial; stem simple or sparingly hranched at the summit, puberulent and slightly viseid, $4-9 \mathrm{im}$. high. Leaves oblong, orate or ovate-lauceolate, sharply denticulate, sessile, pubescent or puberulent, 5-10 cm. Iong, 1-t cm. 
wide, reticulate-veiny; clusters of heads compact, leafy-bracted; involucre 5-6 $\mathrm{mm}$. high, its bracts lanceolate, acute, viscid-puberulent.

Marshy places, Great Bahama, Andros, New Providence, Eleuthera:-southeast. ern United States to Texas and North Mexico; Cubi. Perexial II Ansil Fleabane.

3. Pluchea purpuráscens (Sw.) DC. Prodr. 5: 452. 1836.

Conyza purpurascens Sw. Prodr. 112. 1785.

Iferbaceous, annual; stems rather stout, finely pubescent at least above, simple or branched, $3-12 \mathrm{dm}$. high. Leaves orate to ovate-lanceolate, sparingly finely pubescent or glabrate, dentate or crenate-dentate, acute or acuminate at the apex, narrowed or obtuse at the base, $5-12 \mathrm{~cm}$. long, the petioles $3 \mathrm{~cm}$. long or less, the upper ones smaller, nearly sessile; heads usually numerous; involucre $4-5 \mathrm{~mm}$. high, its bracts ovate to lanceolate, acute, pubescent; flowers pink.

Trackish swamps and bolders of coppices, Great Bahama and Andros to Fortune Island and Inagua :- snutheastern United States; Bermuda; West Indies, south to Guadelompe: Mexico and Central America. Reported by Mrs. Northrop as $P$. camphorata DC. to which it is closely related. ANNUAL MARSH FLEABANE.

13. SÁCHSIA Griseb. Cat. Pl. Cub. 150. 1566.

Perennial scapose herbs, with tufted basal serrate leaves and loosely corymbose or panicled small heads of tubular and radiate flowers, the rays white. Involucre campanulate, its bracts imbricated in several series, acute, rigid, the outer successively smaller. Receptacle naked, flat or convex. Rayflowers fertile, with filiform 2-3-toothed corollas; disk-flowers tubular, regular, fertile, or the inner sterile. Achenes compressed, 4-5-angled; pappus a single series of capillary barbed bristles. [In honor of F. G. J. von Sachs, German plant physiologist.] Four known species of Cuba, Florida and the Bahamas. Type species: Sachsia polycephala Griseb.

1. Sachsia bahaménsis Urban, Symb. Ant. 3: 40S. 1903.

Scape slender, erect, villous at the base, rough-glandular above, bearing 2-5 very small and distant leaves. Basal leaves several, spatulate to oblongobovate, firm in texture, $7 \mathrm{~cm}$. long or less, obtuse at the apex, narrowed at the base into short petioles, repand-dentate, minutely glandular and sparingly pubescent beneath; inflorescence loosely corymbose-paniculate; peduncles slender, mostly longer than the heads; involnere about $7 \mathrm{~mm}$. high, its bracts in about 6 series, the outer ovate to lanceolate, densely glandular, the inner narrowly linear; outer flowers in several series, their filiform corollas 3 -toothed; achenes linear, striate, about $2 \mathrm{~mm}$. long; short-pilose; pappus yellowish-white, about $4 \mathrm{~mm}$. long.

Pine-Iands and savannas of Great Bahama, Andros and New Providence:Florida. BaHAMA SACHSIA.

\section{TETRANTHUS Sw. Prodr. 116. 1788.}

Small prostrate herbs, with opposite petioled leaves, and very small discoid heads solitary and peduncled in the axils, usually 4-flowered, with 2 flowers fertile and 2 sterile. Bracts of the involucre 4, sometimes with 4 minute exterior ones. Receptacle naked. Corolla tubular with a somewhat campanulate 5-lobed limb. Anthers obtuse. Achenes oblong, angled or striate; pappus short, crown-like. [Greek, four-flowered.] Four known species, natives of the West Indies. Type species: Tetranthus littoralis Sw. 
1. Tetranthus bahaménsis Britton, Bull. N. Y. Bot. Gard. 5: 31S. 1907.

Stems smooth, slender, creeping, 3-6 $\mathrm{cm}$. long. Leaves ovate, about $4 \mathrm{~mm}$. long and $3 \mathrm{~mm}$. wide, obtuse at the apex, rounded or subcordate at the base, glabrous on both sides, the veins very obseure, the petioles about $3 \mathrm{~mm}$. long, sparingly pilose; heads solitary, 4-flowered, on sparingly pilose peduncles, about $1 \mathrm{~cm}$. long; involucre bracts 4, oborate, about $1.5 \mathrm{~mm}$. long, and $1 \mathrm{~mm}$. wide, 3-nerved, sparingly pilose without and slightly ciliate; corolla about 1 $\mathrm{mm}$. long, glabrous, the lobes slightly shorter than the tube; anthers large, apiculate; style glabrous, $0.5 \mathrm{~mm}$. long, its branches glandular-pilose; achenes bluntly quadrangular, glabrous, $0.5 \mathrm{~mm}$. long.

In crevices of rocks under shrubs, Great Ragged Island, Acklin's Island, Marjguana. Endemic. BaHAMA TeTrasthes.

15. ACANTHOSPERMUM Schrank, Pl. Rar. Hort. Monac. pl. 53. 1819.

Annual rather coarse herbs, with pubescent foliage and erect or creeping stems, opposite broad, often leathery, toothed leaves, and radiate but inconspicuous heads, axillary to leaf-like bracts. Involuere double, an outer one of flat herbaceous bracts, and an inner one of several smaller bracts which become bur-like and fall away enclosing an achene at maturity. Receptacle concare or convex. Ray-flowers few, in 1 series, the rays very small, yellowish, concave or hooded. Disk-flowers perfect, sterile. Anthers entire at the base. Achenes broadest above the midale, slightly curred. Pappus wanting. [Greek, thorn-seed, from the prickly, bur-like fruits.] About 3 species, natives of tropical America. Type species: Acanthospermum brasilium Schrank.

\section{Acanthospérmum hùmile (Sw.) DC. Prodr. 5: 522. 1836.}

Melampodium humile Sw. Prodr. 11t. 17ss.

Tillous-pubescent, branched, erect, $3-9 \mathrm{dm}$. high. Leaves ovate, $2-4 \mathrm{~cm}$. long, very coarsely dentate, obtuse or acute at the apex, obtuse or subtruncate at the base, the broadly margined petioles 1-2 cm. long, often coarsely toothed; heads sessile or nearly so; pistillate flowers $3-\overline{7}$; inner bracts of the involucre bearing short hooked prickles and 2 rigid subulate beaks $2-3 \mathrm{~mm}$. long.

A weed in cultirated and waste grounds near Nassau, New Providence :-southeastern Lnited States; Cuba; Hispaniola; Culebrita; St. Martin; Tobago; Jamalca. SPINY-BUR.

\section{PARTHÈNTUM L. Sp. Pl. 988. 1753.}

Erect, mostly pubescent or canescent herbs, or shrubs, with alternate leares, and small coryubose or paniculate heads of both tubular and radiate white or yellow flowers. Involucre broadly campanulate or hemispherie, its bracts imbricated in 2 or 3 series, obtuse, appressed, nearly egual. Receptacle conrex or conic, chaffy, the chaff membranous, surrounding the disk-flowers. Ray-flowers about 5, pistillate, fertile, their ligules słort, broad, 2-toothel or obcordate. Disk-flowers perfect, sterile, their corollas 5-toothed, the style undivided. Anthers entire at the base. Acheres compressed, keeled on the inner face, margined, bearing the persistent rays on the summit. Pappus of 2-3 seales or awns. [Greek, virgin.] About 10 American species. Type species: Parthenium IIysterophorus L. 
1. Parthenium Hysteróphorus L. Sp. Pl. 98S. 1753.

Annual, strigose-pubeseent or somewhat villous, usually much branched, $3-7 \mathrm{dm}$. high. Leaves ovate to oblong in outline, 1-2-pinnately parted into linear or lanceolate, toother or pinnatifid segments, thin, and flaceirl hearls nunierous, 5-6 min. broad; involuere saucer-shaped, its bracts concave, the outer ones rhombic, the inner broader; ray-flowers few; rays reniform, white, about $1 \mathrm{~mm}$. wide; achenes oborate, about $1 \mathrm{~mm}$. long.

Waste places and pine-lands, Andros. New Providence, Eleuthera to Watling's Island, Long Island and Inagua:-Rermuda; Lnited States to continental tropleal America; West Indies. SAxta Maria.

17. CRASsinA Scepin, Acido Teg. 42. 1755.

[Zinvia L. Syst. ed. 10, 1221. 1759.]

Annual or perennial herbs, some species shrubby, with opposite entire, or sparingly serrate, mostly narrom and sessile leaves, and large or middle-sized heads of both tubular and radiate flowers. Ray-flowers pistillate, yellow or rariegated, persistent on the achene. Disk-flowers perfect, fertile; corolla eylindraceous, its lobes villous. Involuce campanulate to nearly cylindric, its bracts obtuse, dry, firm, appressed, imbricated in 3 series or more, the outer gradually. shorter. Receptacle conic or cylindris, chaffy, the chaff subtending and enwrapping the disk-flowers. Style-branches elongated, not appendaged. Achenes of the ray-flowers somewhat 3 -angled, those of the disk flattened. Pappus of few awns or teeth. [In honor of Paul Crassus, an Italian botanist of the 16th century.] About 12 species, natives of western America. Type species: Chrysogonum peruvianum L.

1. Crassina multifiòra (L.) Kuntze, Rev. Gen. 331. 1891.

Zinnia multiflora L. Sp. Pl. ed. 2, 1269. 1763.

Annual, erect, simple or branched, 1-6 dm. kigh, the branches nearly erect, sparingly hispid. Leares lanceolate, rough-hispid, thin, entire, $2-7 \mathrm{~cm}$. long, acute or acuminate at the apex, rounded at the nearly sessile base; peduncles thickened upזard, 1-6 cm. long; involucre campanulate, about $1.5 \mathrm{~cm}$. high, its bracts oblong, dark-margined above; rays obovate, $1-2 \mathrm{~cm}$. long; receptaclescales obtuse, entire; disk-achenes 1-awned.

Bahamas, collected by Swainson :-Cuba to Porto Rico and Guadeloupe; Mexico to Brazil and Peru. Zixis.

18. VERBESINA L. Sp. Pl. 901. 1753.

Erect or diffuse, branching, pubescent or hirsute herbs, with opposite leaves, and small peduncled terminal and axillary heads of tubular and radiate whitish flowers. Involucre hemispheric or broadly campannlate, its bracts imbricated in about 2 series, nearly equal, or the outer longer. Receptacle flat or convex, chaffy, the chaff awn-like, subtending the achenes. Ray-flowers pistillate, fertile. Disk-flowers perfect, mostly fertile, their corollas tubular, t-toothed or rarely 5-toothed. Anthers entire or minutely 2-toothed at the base. Achenes thick, those of the rays 3 -sided, those of the disk compressed. Pappus none, or of a fer short teeth. [Name changed from Verbena.] About 4 species, the following typical. 
1. Verbesina álba L. Sp. Pl. 902. 1753.

Eclipta erecta L. Mant. 2: 286. 17i1.

Eclipta alba Hassk. Pl. Jar. Rar. 522. 15+5.

Annual, appressed-pubescent, ereet or diffuse, 1.5-9 dm. high. Leaves lanceolate, oblong-lanceolate or linear-lanceolate, acute or acuminate, denticulate or entire, narrowed to a sessile base, or the lower petioled, 2-12 cm. long, 4-20 $\mathrm{mm}$. wide; heads commonly numerous, $6-12 \mathrm{~mm}$. broal, nearly sessile, or slender-peduneled; rays short, nearly white; anthers brown.

Wet or moist soil, New Irovidence, Great Exuma and Iong IsIand :- IBermuda ; the United States from New York, Illinois and Nebraska, soutluward to temperate South America; West Indies; all warm temperate and tropical reglons. Ecisim.

\section{MELANTHERA Rohr, Skrift. Nat. Selsk. 2: 213. 1792.}

Perennial herbs, often quite woody, with opposite petioled dentate, sometimes hastate leaves, and peduncled heads of small white yellowish or riolet tubular flowers. Involucre low-hemispheric, its few orate to lanceolate, nearly equal bracts imbricated in 2 or 3 series. Receptacle convex or low-conic, scaly. Corollas subeylindrie, with an expanded throat, 5-toothed. Anthers sometimes black, truncate or subsagittate at the base. Style-branches long. Achenes 4-angled; pappus of distinet eaducous amns. [Greek, black anther.] About 10 species, of tropical and subtropical America. Type species: Bidens nivea L.

1. Melanthera deltoìdea Michx. Fl. Bor. Am. 2: 107. 1803.

Melanthera brevifolia O. E. Schulz, in Urban, Symb. Ant. 7: 123. 1911. Melanthera crenata O. E. Schulz, loc. cit. 1911.

Sparingly appressed-pubescent, scabrate, branched, 5-s dn. high, the branches aseending. Leaves orate or hastate-orate, seabrate, $2-7 \mathrm{~cm}$. long, serrate, incised or erenate, acute, obtuse or acuminate at the apex, narromed or subtruncate at the base, the petioles $0.5-3 \mathrm{~cm}$. long; heads slender-peduncled, solitary or few together, $6-8 \mathrm{~mm}$. in diameter; bracts of the involucre ovate or oblong-orate, $3-4.5 \mathrm{~mm}$. long, ohtuse or acutish; eorolla white, 5-6 $\mathrm{mm}$. Jong.

Waste and cultivated grounds, throughout the archipelago from Abaco, Great Pahama and Andros to Watling's. Fortune Island and the Cay Sal bauk:-lilorida; Cuba: Jamnica. Referred by Schcepe to Bidens nivea L., by Mrs. Northrop to Amellus asperk (Jacq.) Kuntze. Recorded by Hitchcock as Elcutheranthera ruderulis. Consists of several races differing in leaf-form and serration. MELAxTHER.

2. Melanthera hastàta (Walt.) Miehx. Fl. Bor. Am. 2: 107. 1503.

Athanasia hastata Walt. Fl. Car. 201. 17ss.

Similar to M. deltoidea, but with acute or acuminate involvere-hracts, the fruiting heads about $10 \mathrm{~mm}$. in diameter, the leaves often more leeply incised or lobed.

Water Cay, Cay Sal Bank:- southenstern Ínited States; Cuba; Mexico to Panama. Hastate MeLAXTHEH.

20. ISOCÁRPHA R. Br. Trans. Linn. Soe. 12: 110. 1817.

Branched slender herbs, with alternate or opposite, entire or toothed leares, and many-flowered, small heads of tubular white, perfect and fertile flowers, solitary or elustered at the end of the branches. Involuere-bracts imbricated in 2-1 series, slightly unequal. Receptacle oblong or conic, chaffy, 
the chaff enveloping the flowers. Corollas regular, the limb 5-lobed. Anthers truncate, entire. Achenes glabrous, truncate, angled; pappus none. [Greek, equal chaff.] About 5 species, of tropical America, the following typical.

1. Isocarpha oppositifòlia (L.) R. Br.; DC. Prodr. 5: 107. 1836.

Calea oppositifolia L. Sp. Pl. ed. 2, 1179. 1763.

Isocarpha angustata Griseb. Fl. Br. W. I. 376. 1861.

Pereunial, usually pubescent, stem rather stiff, divaricately branched, 3-6 $\mathrm{dm}$. high. Leaves opposite, sessile or nearly so, linear to lanceolate, 3-nerved, entire, acutish or obtuse at the apex, narrowed at the base; heads solitary or few together at the ends of slender naked peduncle-like branches; involuere 4-5 mm. high, its bracts oblong, strongly striate, acute and mucronate.

White-lands and rocky places, Andros, Great Guana Cay, Great Exuma, Long Island, Great Ragged Island and Atwood Cay :-Cuba; Jamaica; Tobago; Trinidad; Curaçao; Margarita; Texas through Mexico to Venezuela. Bostox Catnep.

21. BORRICHIA Adans. Fam. Pl. 2: 130. 1763.

Fleshy, more or less canescent, branching shrubs of the seacoast, with opposite, entire or denticulate, cuneate oblong spatulate or obovate, 1-3-nerved leares, and terminal large long-peduncled heads of both tubular and radiate sellow flowers. Involucre hemispheric, its bracts slightly unequal, imbricated in 2 or 3 series, the inner ones coriaceous. Receptacle convex, chaffy, the chaff rigid, concave, subtending or enwrapping the disk-flowers. Ray-flowers pistillate, fertile. Disk-flowers perfect, the corolla tubular, 5-toothed, the stylebranches elongated, hispid. Achenes of the ray-flowers 3 -sided, those of the diskflowers 4-sided. Pappus a short dentate crown. [Named for Olaf Borrick, a Danish botanist.] About 5 species, natives of America. Type species: Buphthalmum frutescens $\mathrm{L}$.

\section{Borrichia arboréscens (L.) DC. Prodr. 5: 489. 1836.}

Buphthalmum arborescens L. Syst. ed. 10, 1227. 1759.

Borrichia argentea DC. Prodr. 5: 489. 1836.

Borrichia glabrata Small, Fl. SE. U. S. 1263, 1340. 1903.

A branching shrub, $1.3 \mathrm{~m}$. high or less, densely white silky-canescent, or green and glabrous. Leaves fleshy, oblanceolate to spatulate, entire, $6 \mathrm{~cm}$. long or less, 6-15 mm. Wide, acute or obtuse and cuspidate at the apex, narrowed to the base, sessile, obscurely veined; heads mostly solitary, rarely 2 together; peduncle $2-5 \mathrm{~cm}$. leng; involucre $1-1.5 \mathrm{~cm}$. high, its bracts obtuse, or acute, appressed; rays fer, 6-9 $\mathrm{mm}$. long.

Coastal rocks and sands and margins of brackish ponds throughout the archipelago:-Florida: Bermuda; Jamaica; Cuba to Anegada and Guadeloupe; Yucatan. Foliage either white-canescent or green and glabrous, sometimes on the same plant. bay Marigold. Sea Ox-eif. Sea-busir. Catesby, 1: pl. 93.

\section{WEDÈLIA Jacq. Enum. 8, 28. 1760.}

Herbs or shrubs, with opposite, toothed or entire leaves, and peduncled heads of both radiate and discoid yellow flowers. Involuere oroid to hemispheric, its bracts in about 2 series, the outer somerhat foliaceous. Receptacle flat or convex, its scales enreloping the disk-flowers. Ray-flowers pistillate. Disk-flowers perfect, their corollas tubular with a cylindric to campanulate limb. Achenes oblong to obovate, smooth, pilose or tubercled, truncate or conic 
at the top; pappus cup-like, toothed or dirided, or obsolete. [Commemorates George Wolfgang Wedel, 1645-1721, Professor at Jena.] About 50 species, of warm-temperate and tropical regions. Type species: IIedelia fruticosa Jacq.

Ierbaceous, prostrate with erect branches, nearly glabrous, somewhat fleshy.

Erect, shrubby, strigose-hairy.

1. IT trilobata.

2. W. bahamensis.

1. Wedelia trilobàta (L.) Hitche. Rep. Mo. Bot. Gard. 4: 99. 1893.

Silphium trilobatum L. Syst. ed. 10, 1233. 1759.

Wedelia carnosa L. C. Rich. in Pers. Syn. 2: 490. 1507.

Stemmodontia trilobata Small, Fl. SE. U. S. 1262, 1340. 1903.

Herbaceous, prostrate or with ascending branches, sparingly strigosepubescent, often rooting at the nodes, $3-10 \mathrm{dm}$. long. Leares somerwat fleshy, elliptic to obovate, 2-12 cm. long, obtuse or acute at the apex, dentate, often sereral-lobed, narrotred or cuneate at the base, triplinerved and pinnately veined, sessile or nearly so; peduncles solitary in the upper axils, 2-14 cm. long; involucre $7-12 \mathrm{~mm}$. long, its bracts oblong-oborate, foliaceous; rays about 10, bright yellow, 10-15 mm. long; achenes $5 \mathrm{~mm}$. long, tuberculate.

Moist places along the coast, New Providence:-Florida; West Indies; Honduras to Colombia. Trillixg WEDELIA.

2. Wedelia bahaménsis (Britton) O. E. Schulz, in Urban, Symb. Ant. 7: 106. 1911.

Stemmodontia bahamensis Britton, Bull. X. Y. Bot. Gard 4: 126. 1905.

Perennial, erect, densely strigose-pubescent all orer, pale green, 6-10 $\mathrm{dm}$. tall, the branches striate. Leaves lanceolate to orate, $5-12 \mathrm{~cm}$. long, $1.5-3 \mathrm{~cm}$. wide, acute to long-acuminate at the apex, narrowed at the base, rather firm in texture, sparingly low-serrate or entire, 3-nerved ahore the base, the short stoutish petioles mostly not orer $1 \mathrm{~cm}$. long; heads solitars or 2 or 3 together. on erect peduncles 2 or $3 \mathrm{~cm}$. long; outer bracts of the inrolucre oblong to ovate-oblong, apiculate or acutish, about $9 \mathrm{~mm}$. long, faintly many-nerved, a little longer than the inner; rays bright yellow, ol)long, $1 \mathrm{~cm}$. long or less, emarginate, about 3 times as long as wide; achenes linear, appressed-pubescent, at least $3.5 \mathrm{~mm}$. long.

Constal thlckets, coppices and scrub-lands, Andros, New Proridence and Eleuthera to Caicos and Frand Turk. Endemle. Recorded by Grisebach. Dolley and Hitchcock as W. buphthalmoides Griseb. BAHAMA WEDELlA. Rosig-13Usil, Erro. neously called Mirigold. Catesby, $1: p l$. 92 .

\section{XIMENESIA Car. Icon. 2: 60. 1793.}

Pubeseent caulesent herbs, with alternate or sometimes opposite, simple, toothed or somerhat laciniate leares, and solitary or few, raliate slowy peduncled heads. Involuere rather flat, of narrow spreading bracts. Receptacle convex, chaffy. Ray-flowers pistillate, fertile, numerous, tlic rays yellow. Disk-flowers numerous, perfect, fertile. Anthers somewlat sagittate at the base. Style-branches with slender pubeseent appendages. Aehenes flat, winged. Pappus of short and straight awns. [In honor of Josepli Ximenes, a Spanish botanist.] About 4 sjecies, natises of America, the following typical. 
1. Ximenesia encelioìdes Cav. Icon. 2: 60. 1793.

Terbesina encelioides Benth. \& Hook.; A. Gray, Bot. Cal. 1: 350. 1876.

Annual; stem densely puberulent, much branched, 3-6 dm. high. Leaves deltoid-ovate or deltoid-lanceolate, thin, $5-10 \mathrm{~cm}$. loug, actminate, acute or blunt at the apex, coarsely dentate, or even laciniate, green anil ininutely pubescent above, pale and densely canescent beneatl, all alternate, or the lowest opposite, narrowed at the base into naked or wing-margined petioles, which are often provided with lilated appenilages at the base; heals screral or numerous, 2.5-5 cm. broad; involucre hemispherie, about $12 \mathrm{~mm}$. high, its bracts lanceolate, canescent; rays 12-15, bright golden yellow, 3-toothed; achenes of the disk-flowers obovate, winged, pubescent, their pappus of 2 subulate awns, those of the ray-flowers rugose, thickened, often wingless.

Waste grounds, Eleuthera, Fortune Island, Great Ragged Island:- Southwestern United States and Mexico; introduced into Key W'est (Florida), Cuba and l'ol'to Rico. GOLdeN Crownieard.

\section{SYNEDRÉLLA Gaertn. Fr. et Sem. 2: 456. 1791.}

Annual pubescent herbs, with opposite dentate petioled leaves, and small, solitary or glomerate, axillary or terminal heads of radiate and discoid flowers. Inrolucre oblong, of few bracts, the outer 1 or 2 foliaceous, the inner paleaceous. Receptacle small, the scarious narrow chaff subtending the diskflower's. Ray-flowers pistillate, with a filiform tube and a short 2-3-toothed limb; disk-flowers perfect, the corolla tubular, t-cleft. Ray-achenes compressed, 2-winged, the wings produced into awns, those of the disk-fiowers narrower, 2-3-aristate. [Greek, referring to the elustered flower-heads.] Two known species, natives of tropical America, the following typical.

1. Synedrella nodiflòra (L.) Gaertn. Fr. \& Sem. 2: 456. 1791.

Terbesina nodiflora L. Cent. Pl. 1: 28. 1755.

Ucacou nodiflorum Hitche. Rep. Mo. Bot. Gard. 4: 100. 1893.

Stem appressed-pubescent above, glabrate below, rather widely branched, 3-8 $\mathrm{dm}$. high. Leaves thin, ovate to elliptic, 3-10 cm. long, triplinerved, lowserrate, acute at the apex, narrowed at the base into short margined petioles, loosely appressad-pubescent above, rather densely appressed-pubescent beneath; heads few or several together in nearly sessile, axillary or terminal clusters; involncre about $8 \mathrm{~mm}$. high, its 1 or 2 outer bracts pubescent, oblong-lanceolate, the inner narrower, glabrous; achenes $4-5 \mathrm{~mm}$. long, those of the rayflowers with ascending marginal bristles and 2 short awns, those of the diskflowers with 2 subulate awns.

Waste places, Abaco, New Providence and Crooked Island:-Florida; West Indies and continental tropical America. NoDEWEED.

\section{SÀLMEA DC. Cat. Hort. Monsp. 140. 1813.}

Shrubs or woody vines, the branches terete or nearly so, the leaves opposite and petioled. Heads small, corymbose, discoid. Involucre campanulate or turbinate, its bracts appressed, imbricated in few series. Receptacle conic, its scales enveloping the flowers. Flowers white, all perfect and fertile; corollas with a narrowly campanulate or funnelform limb. Achenes laterally compressed, mostly margined or narrowly winged. Pappus of 2 awns. [In honor of Count Salm-Salm, patron of Palermo.] About 7 species, of Mexico and the West Indies. Type species: Salmea Eupatoria DC. 
1. Salmea petrobioìdes Griseb. Fl. Br. W. I. 375. 1861.

A much-branched shrub, $2 \mathrm{~m}$. high or less, the twigs slender, ereet-ascending, glabrous. Leaves oborate or elliptie-oborate, $2-5$ en. long. $8-2.5 \mathrm{~mm}$. wide, rounded or apiculate at the apex, narrowed or euneate at the hase, fleshy, the midrein prominent, the lateral veins obseure, the petioles $1.5-3 \mathrm{~mm}$. long; heads numerous, in terminal compound, nearly flat-topped corymbs; involuere glutinous, narrowly campanulate, about $4 \mathrm{~mm}$. high, its bracts in 2 series, oblong to oval, obtuse, the outer much smaller than the inner; receptacle acute; achenes oblong, glabrous exeept at the apex.

Coastal rocks, white-lands, sand-dunes and coppices, thronghout the archipelago from Dbaco, Great Bahama and the Biminis to Cat Island, Long Island and Grand Caicos:-Cuban Cays; Cayman Islands. Busuy Salues. Sirdxis. Catesby, 1:pl. 72.

\section{BİDENS L. Sp. Pl. 831. 1753.}

Annual or perennial herbs, with opposite serrate lobed divider or dissected leares, or the mppermost alternate, and mostly large heads of both tubular and rarliate flomers, or the rays none, or rudimentary. Involuere campanulate or hemispherie, its braets in 2 series, distinet or slightly united at the base: the outer often foliaceous and much larger than the inner. Receptacle flat or nearly so, chaffy, the chaff subtending the disk-flowers. Rays, when present, nentral, mostly entire, yellow in our species. Disk-flowers perfeet, fertile, their corollas tubular, j-toothed. Anthers entire, or minutely sagittate at the base. Style-branches with short or subulate tips. Achenes flat, quadrangular or nearly terete, euneate, oblong, or linear. Pappus of 2-6 teeth or subulate awns, upwardly or downwardly barbed or hispid. [Latin, twotoothed, referring to the achenes.] About 75 species of wide geographic distribution. Type species: Bidens tripartitus L.

Achenes 4-awned; rays yellow, small: leaves pinnatisect. Achenes 2-awned; rays white or none; leaves $3-5$ pinnately dirided.

1. B. cynapiifolia.

2. B. pilosa.

\section{Bidens cynapiifòlia H.B.K. Nov. Gen. 4: 235. 1820.}

Annual; stem quadrangular, erect, branehed, 0.2-2 m. high. Leares thin, petioled, 1-3-pinnately dissected into ovate or oblong, toothed or lobed segments; heads usually numerons, long-peduneled, 4-8 $\mathrm{mm}$. broad; involuere narrow, its outer bracts linear, ascending, nearly as long as the broader ereet inner ones; rays 3-4, yellow, short, sometimes none; achenes eurver, linear, 4-angled, narrowed upward, $7-17 \mathrm{~mm}$. long, the outer ones commonly shorter than the inner; pappus of $4-6$ downmardly barbed, slightly spreading amns, mueh shorter than the achene.

Wiste and cultivated grounds, New Provdence and Elenthera:- West Indies: contlnental tropical Americi. Recorded by Dolley and by Iriteheock as B. bipinnati L., which it resembles. BEGGdi-Ticks.

\section{Bidens pilòsa I. Sp. Pl. 832. 1753.}

Coreopsis leucantha I. Sp. Pl. eil. 2, 1282. 1763.

Bidens leucantha Willd. Sp. Pl. 3: 1719. 1804.

Annual, glabrous or somewhat pubescent, 3-10 im. high, more or less brancherl. Leaves petioled, 3-rlividerl, their segments orate to laneeolate, 2-s cm. long, serrate, acute or acuminate, the uppermost sometimes uniliviled; involucre eampanulate, about $5 \mathrm{~mm}$. high, its outer bracts linear-oblong, usually 
shorter than the inner; rays, when present, white, 1-2 cm. long, 2-3-lobed; achenes fusiform, unequal, the inner louger than the involucre; pappus of 2-4 yellow, downwardly barbed awns.

Waste and cultivated ground. New Ploridence, Great Bahama, Andros, South Cat Cay, Eleuthera, Cat Island, Fortune Island and East Caicos:- southern United States; West Indies and Bermuda; continental tropical Amerlca. White BegGarTICKS. SIIEPHERD'S-NEEDLE.

\section{TRIDAX L. Sp. Pl. 900. 1753.}

Perennial herbs, with opposite, dentate or incised leaves and long-peduncled heads of tubular and radiate flowers, the disk-flowers perfect and fertile, the ray-flowers pistillate, the rays often 3 -lobed. Involucre ovoid to hemispheric, its nearly equal bracts in fer series, or the outer smaller than the inner. Receptacle flat or convex, the chaff subtending the disk-flowers. Anthers auricled at the base or sagittate. Style-branches of the disk-flowers subulate-appendaged. Achenes silky-villous. Pappus of many aristate plumose scales. [Greek, referring to the ö-lobed rays.] About a dozen species, natives of tropical America, the following typical.

\section{Tridax procúmbens L. Sp. Pl. 900. 1753.}

Hirsute, branched from the base, the branches spreading or ascending, slender, $2-5 \mathrm{dm}$. long. Leaves ovate to ovate-lanceolate, short-petioled, 2-6 cm. long, incised-dentate, acute or acuminate at the apex, mostly cuneate at the base; peduncles solitary, terminal, 1-3 dm. long; involucre subcampanulate, about $6 \mathrm{~mm}$. high, its bracts hispid, the inner elliptic, the outer lanceolate; rays nearly white; achenes about $2 \mathrm{~mm}$. long.

Waste places, Lignum Vitae Cay, New Providence, Eleuthera, Cat Island and Fortune Island :-Florida; Cuba; Grenada; continental tropical America. Recorded by Hitcheock as Amellus aspera (Jacq.) Kuntze. 'TuIDAx.

28. FLAVÈRIA Juss.; J. F. Gmel. Syst. 2: 1269. 1791.

Glabrous or minutely puberulent, light green, annual or perennial herbs, with opposite sessile leaves, and small, 1-several-flowered, usually sessile, oblong, densely eymose-capitate heads of tubular, or both tubular and radiate, yellow or yellowish flowers. Involucre of $2-5$ narrow, nearly equal, appressed bracts, sometimes with 1 or 2 additional small exterior ones. Receptacle small, naked. Ray-flower commonly one, pistillate, fertile, sometimes wanting. Disk-flowers 1-15, perfect, fertile, their corollas 5-toothed. Anthers entire at the base. Style-branches of the disk-flowers truncate. Achenes oblong or linear-oblong, 8-10-ribbed. Pappus none. [Latin, flavus, yellow, from its dyeing properties.] Type species: Flaveria chilensis J. F. Gmel.

\section{Flaveria lineàris Lag. Gen. et Sp. Nov. 33. 1816.}

Perennial, glabrous or nearly so, somewhat woody, usually branched, erect or decumbent, 3-9 dm. long. Leaves linear, entire, 3-7 cm. long, 1-6 mm. wide; heads commonly numerous, in terminal corymbose eymes, short-peduncled; involucre narrow, about $4 \mathrm{~mm}$. high, its principal bracts about 5, lanceolate or oblong, acute; ray-flower usually only one, its ligule $3-4 \mathrm{~mm}$. long.

Coastal coppices and scrub-lands, Joulter's Cays, Andros, New Providence, Water Cay on Cay Sal bank:-Florida; Cuba; Alacran Shoals; Yucatan. The Cay Sal bank plant is of a broad-leaved race. NARrow-Leaved Flaveria. 
29. NEOTHYMÓPSIS Britton \& Millspaugh.

[Thrmopsis Benth. in Benth. \& Hook, Gen. Pl, 2: 407. 1873.

Not Jaub. \& Spach, 1813.]

Low diffuse, annual or perennial, hirsute or puberulent herbs, with opposite small broad leaves, and few-flowered, small heads of tubular flowers, the outer pistillate the inner perfect. Bracts of the involucre few, nearly equal, hirsute or ciliolate. Reeeptacle naked, flat. Corolla of pistillate flowers slender, 2-3-toothed, shorter than the style, minutely 2-4-toothed; corolla of perfect flowers with a campanulate, 4-toothed limb. Anthers obtuse at the base, entire. Achenes oblong, nearly terete, striate. Pappus a fringed erown of several scales. [Greek, new-Thymopsis.] Only the two following species are known. Type species: Tetranthus thymoides Griseb.

Plants hirsute-hispid throughout; flowers 10 in a head: awned. Plants slightly pubescent; flowers 5 in a head; perennial.

1. N. Wrightii.

2. N. Brittonii.

\section{Neothymopsis thymoìdes (Griseb.) Britton \& Millspaugh.}

Tetranthus thymoides iriceb. Cat. Pl. Cub. 286. 1866.

Thymopsis Wrightii Benth. loc. eit. 1873.

Thymopsis thymoides Urban, Symb. Ant. 5: 254. 1907.

Annual; stems very slender, little branched, 1-3 dm. long, short-hirsute. Leaves ovate, $10 \mathrm{~mm}$. long or less, acute or obtuse at the apex, narrowed into petioles, hirsute-hispid; heads nearly sessile in the axils, about 10-flowered; involucre of 5 or 6 oblong, obtuse, hirsute bracts about $3 \mathrm{~mm}$. long.

Molst places, Acklin's Island and Mariguana:-Cuba.

\section{Neothymopsis Brittónii (Greenm.) Britton \& Millspangh.}

Thymopsis Brittonii Greenm. Bull. N. Y. Bot. Gard. 3: 453. 1905.

Perennial; stems sereral, erect or ascending, slender, 4-10 cm. long, puberulent. Leares rhombic-orate to somewhat spatulate, 4-S mm. long, onehalf as broad, obtuse, entire, revolute-margined, narrowed below to a short petiole, sparingly puberulent to glabrous, dark green abose, paler and glandular-punctate beneath; heads terminating the stem and branches, sessile, about $3 \mathrm{~mm}$. high, 5 -flowered; involuere of 5 (4) oblong obtuse, narieular, or somewhat obtusely earinate-coneave, eiliolate green bracts.

Moist places, New Provldence and Great Exuma, Endemic.

30. POROPHÝLlum Vaill; Adans. Fam. Pl, 2: 122.1763.

Herbs, or some species shrubby, glanduliferous, glabrous and often glaucous. Leares alternate, or the lower opposite, toothed or entire. Ileads corymbose or solitary, long-stalked. Involucre narrowly campanulate or cylindrie, its bracts 5-9. Receptacle small, not ehaffy. Ray-flowers none. Diskflowers perfect and fertile; corollas with a slender tube and narrowly eampanulate limb. Achenes linear, many-striate, glabrous or pubescent. Pappus of copious eapillary roughish bristles in 1 or 2 series. [Greek, porose-leaved.] About 25 species, of warm-temperate and tropical America, the following typical. 
1. Porophyllum Porophýllum (L.) Kuntze, Rev. Gen. Pl. 3²: 168. 1898.

Cacalia Porophyllum L. Sp. Pl. S34. 1753.

Porophyllum ruderale Griseb. Fl. Br. W. I. 379. 1861. Not Cass., 1826.

Annual; stem erect, often much branched, pale, slightly glaucous, $1 \mathrm{~m}$. high or less. Leaves thin, slender-petioled, oblong to ovate, obtuse or acute, low-crenate or entire, $2-7 \mathrm{~cm}$. long, bearing marginal glands or sometimes glandless; heads solitary at the ends of the branches, many-flowered; involucre about $2 \mathrm{~cm}$. high, its 5 bracts linear, acute, bearing narrowly linear glands; corolla about $10 \mathrm{~mm}$. long; achenes linear, about $8 \mathrm{~mm}$. long, dark brown, hispidulous.

Waste places and pot-holes in good soil, Abaco, Andros, New Frovidence, IIarbor Island, Eleutheri, Cat Island and Great Exuma :-W'est Indies and continental tropical America. Porophylü.

31. PÉCTIS L. Syst. ed. 10, 1221. 1759.

Annual or perennial, diffuse prostrate or erect, mostly glabrous herbs, gland-dotted and strong-scented, with opposite narrow, sometimes brstly-ciliate leaves, and small, usually cymose heads of both tubular and radiate yellow flotrers. Involuere cylindric, oblong or campanulate, its bracts in 1 series, narrow, keeled, distinct. Receptacle small, naked. Ray-flowers pistillate, the rays small, entire or 3-lobed. Disk-flowers perfect, their corollas with expanded, somewhat irregularly 5-cleft limbs. Anthers entire at the base. Style-branches of the disk-flowers very short, obtuse. Achenes linear, slightly angled, striate. Pappus of scales, slender bristles or awns, sometimes with a few outer smaller additional ones. [Latin, pecten, comb, referring to the pappns.] About 75 species, natives of the warmer parts of America. Type species: Pectis linifolia L.

Pappus of scales.

Pappus of $2-4$ subulate awns.

1. P. leptoccphala.

2. P. linifolia.

1. Pectis leptocéphala (Cass.) Urban, Symb. Ant. 5: 280. 1907.

Chthonia leptocephala Cass. Dict. Sci. Nat. 27: 206. 1823.

Pectis Lessingii Fernald, Proe. Am. Acad. 33: 67. 1897.

Glabrous or nearly so; stems slender, diffusely branched, 1-4 dm. high. Leaves narrowly linear, $1-3 \mathrm{~cm}$. long, less than $1 \mathrm{~mm}$. wide, acute, bearing a few bristles below the middle; heads filiform-peduncled, mostly solitary; involucre narrow, 4-5 mm. high, its bracts linear; achenes narrow, about 3 mm. long; pappus of subulate-lanceolate scales.

Limestone soll, Andros, New Providence:-Florida; Cays of northern Cuba ; Hispaniola. Recorded by Mrs. Northrop. by Dolley and by Hitcheock as P. linifolia L. Narrow-leated Peictis. Wrongly called PexNiroyal.

2. Pectis linifòlia L. Syst. ed. 10, 1221. 1759.

Pectis punctata Jaeq. Enum. 28. 1760.

Annual; stems glabrous, very slender, usually nuch-branched, 2-9 dm. high. Leaves linear, $2-8 \mathrm{~cm}$. long, usually not more than $3 \mathrm{~mm}$. wide, narrowed at both ends, sparingly glanduliferous, commonly bearing $1-3$ bristles at the base; heads on filiform peduncles $7-35 \mathrm{~mm}$. long, 5-9-flowered; involucre about $6 \mathrm{~mm}$. long, its 4 or 5 linear glabrous bracts obtuse with revolute margins; flowers purplish to orange: achenes linear, $4-6 \mathrm{~mm}$. long, gla- 
brous or sparingly pubescent; pappus of $2-4$ subulate, spreading or reflexed awns about $2 \mathrm{~mm}$. long.

Sandy and rocky soils, Acklin's, Mariguana, South Calcos, Ambergris Cay, Grand Turk, Sand Cay, Inagua and Little Inagua :-West Indies, east to Anegada, sonth to Grenada; Aruba; Curatgao ; continental tropical America. AWN-FrUITED I'ECTIS.

32. NEURolakna R. Br. Trans. Linu. Soc. 12: 120. 1817.

Tall shrubby perennials, with large alternate leaves, and numcrous small corymbose-paniculate heads of tubular yellow flowers, all perfect and fertile. Involucre campanulate, its obtuse nerved bracts imbricated in 3 or 4 series. Receptacle nearly flat, with membranous 1-nerved scales which are early deciduous. Corolla-tube slender, the limb somerhat expanded. Anthers sagittate. Achenes narrowed at the base. Pappus of many capillary persistent, somewhat unequal bristles. [Greek, referring to the nerved bracts.] Two known species of tropical America, the following typical.

1. Neurolaena lobàta (L.) R. Br.; DC. Prodr. 6: 292. 1837.

Conyza lobata L. Sp. Pl. 862. 1753.

Stems somewhat woody, erect, usually much branched, $1.5-3 \mathrm{~m}$. high, appressed-pubescent and seabrous. Leaves lanceolate to ovate-lanceolate, pubescent and scabrous, dentate, denticulate or variously lobed, acuminate at the apex, narowed at the base, the lower up to $3 \mathrm{dm}$. long and petioled, the upper nuch smaller, sessile or nearly so; corymbs terminal, often $8 \mathrm{~cm}$. broad or more; peduncles rather slender, bracted, pubescent; involucre 6-8 $\mathrm{mm}$. high, its bracts oblong, pubescent, 3-nerved, the outer shorter than the inner; achenes pubescent; pappus brownish-white.

Thickets at Red Bass, Andros :-Cuba to St. Thomas and to Trinidad; Jamaica; continental tropical America.

33. EMİlIA Cass. Bull. Soc. Philom. 1817: 68. 1817.

Herbs, with alternate and basal, often clasping leaves, and long-peduncled, solitary or loosely corymbose heads of pink, purple or orange, tubular, perfect and fertile flowers. Involucre nearly eylindric, its bracts in a single equal serics. Receptacle flat, naked. Corolla-limb eylindric. Achenes nearly terete or 5-angled. Pappus of numerous soft white eapillary bristles. [Name unexplained.] About 5 species, natives of the Old World tropies. Type species: Emitia flammea Cass.

1. Emilia sonchifòlia (L.) DC. Prodr. 6: 302. 1837.

Cacalia sonchifolia L. Sp. P1. 835. 1753.

Annual, glabrous, or somewhat pubescent below, usually branched, 2-T dm. high. Basal and lower leaves petioled, sometimes $12 \mathrm{~cm}$. long, oborate to oblanceolate, repand-dentate to lyrate-pinnatifid, obtuse or acute at the apex; upper leaves lanceolate, sessile, sagittate-clasping, dentate, lobed or entire; heards loosely corymbose, many-flowered; peduncles very slendel or filiform; involucre 10-12 nm. high, its bracts linear-lanceolate, acute, at length reflexed; flowers rose, red or purple.

Waste places in good soli. Andros, New Irovldence, Eleuthera, Cat Island, Long Isiand and Forth Caicos:-Florida: Bermuda: West Indies and continental tropieal America. Naturalized from the East Indies. Fulrie Euras. 
34. ERECHTITES Raf. F1. Lußov. 65. 1817.

Erect, usually branching herbs, with alternate lcaves, and (in our species) rather large, discoil, many-flowered heads of whitish flowers, corymbose-panieulate at the ends of the stem and branches. Involucre eylindric, swollen at the base, its principal bracts in 1 series, linear, with or without much smaller outer ones. Receptacle concave, nakel. Marginal flowers in 2-several series, pistillate, fertilc, their corollas filiform, the limb 2-t-toothed. Central flowers perfect, fertile; corolla narrowly tubular, the limb 4-5-toothed, the stylebranches elongated, truncate or obtuse at the summit. Anthers obtuse and entire at the base. Achenes linear-oblong, angled or striate. Pappus of copious capillary soft smooth white bristles. [Ancient name of some groundsel.] Abont 12 species, natives of America and Australasia. Type species: Erechtitcs praealta Raf.

1, Erechtites hieracifòlia (L.) Raf.; DC. Proßr. 6: 294. 1837.

Senecio hieraeifolius L. Sp. Pl. 866. 1753.

Annual, glabrous, or somemhat hirsute; stem striate, succulent, usually branched, 3-25 $\mathrm{dm}$. high. Leaves thin, lanceolate or ovate-lanceolate, dentate and often deeply incised, 5-20 cm. long, the upper sessile or auriculate-clasping, mostly acuminate, the lower usually narrowed into petioles; heads 12-20 $\mathrm{mm}$. long, about $6 \mathrm{~mm}$. in diameter, the involucre conspicuously swollen at the base before flowering, its bracts numerous, striate, green, with narrow scarious margins; pappus bright white.

Cultivated fields and coppices, Andros:- West Indies and temperate and tropical continental America. FIRE-WEED.

\section{CÍRSIUM [Tourn.] Mill. Gard. Dict. abr. ed. 4. 1754.}

Erect, branched or simple, prickly herbs, some species acaulescent, with alternate or basal, sinuate-dentate lobed or pinnatifid, usually very spiny leares, sometimes decurrent, and large many-flowered, solitary or clustered, discoid heads of purple, yellow or white, tubular, perfect and fertile, or rarely dioecions flowers. Involucre ovoid or globose, its bracts prickle-tipped or unarmed, imbricated in many series. Receptacle flat or convex, bristly. Corollatube slender, the limb deeply 5-cleft. Filaments pilose, or rarely glabrous. Anthers sagittate at the base. Style-branches short or elongated, obtuse. Achenes oborate or oblong, compressed or obtusely 4-angled, glabrous, smooth or ribbed. Pappus of several series of slender, plumose, bristles, connate at the base. [Greek, the thistle was used as a remedy for swollen reins.] Over 200 species, widely distributed in the northern hemisphere. Type species: Carduus heterophyllus L.

\section{Cirsium Smállii Britton.}

Carduus pinetorum Small, FI. SE. U. S. 1308, 1341. 1903.

Cirsium pinetorum Small, Fl. Miami 199, 200. 1913. Not Greenm., 1905.

Stem simple or little-branched, sparingly floccose, rather slender, $9 \mathrm{dm}$. high or less. Leares more or less floccose, runcinate-pinnatifid or entire, the teeth and margins armed with yellowish acicular spine-like bristles $1.5 \mathrm{~cm}$. long or less; basal and lower leares oblanceolate or spatulate-oblong, 1-2.5 dm. 
long, the upper smaller, lanceolate, acuminate, sessile, or half-elasping the stem; heads few; inroluere about $3.5 \mathrm{~cm}$. high, the outermost bracts spinulosetipped, the inner acuminate; flowers pink; pappus white, long-plumose; achenes about $5 \mathrm{~mm}$. long.

l'ine-lands, Abaco and Great liahama :-Florida. PINE-Land TuIStle.

36. ANAStráphiA D. Don, in Trans. Linn. Soc. 16: 295. 1530.

Shrubs or trees, with alternate leares, and terminal discoid heads of tubular, perfect and fertile flowers. Involucre campanulate or turbinate, its bracts imbricated in sereral or many series, appressed or recurved, the outer gradually shorter than the inner. Receptacle flat or nearly so, naked. Corollalimb scarcely expanded, 5-parted, the lobes narrow. Anthers sagittate at the base, the auricles elongated. Style-branches short. Achenes linear, villous or pubescent. Pappus of 1 or 2 series of filiform bristles. [Greek, turned backward.] About 20 species, natives of the West Indies. Type species: Anastraphia ilicifolia D. Don.

Bracts of the involucre recurved.

Bracts of the involucre strictly erect.
1. A. Northropiana.

2. A. bahamensis.

1. Anastraphia Northropiàna Greenm. Trans. Acad. St. Louis 7: 435. 1897.

An irregularly branched shrub, 1-2 m. high, or, on the coast of southern Cuba becoming a tree up to $10 \mathrm{~m}$. high, with a trunk $2 \mathrm{dm}$. in diameter, the bark rough, the slender twigs densely white-tomentose. Leaves oblong to elliptic or obovate, $1-t \mathrm{~cm}$. long, coriaceous, obtuse at the apex, narrowed or obtuse at the base, serrate with few spinulose-tipped teeth, or entire, glabrous above, densely white-tomentose beneath, short-petioled; involucre campanulate, 12-15 $\mathrm{mm}$. high, its bracts pubescent, the inner linear, acute, reflexed, the outer gradually smaller; flowers $8-10$, orange, about $3 \mathrm{~cm}$. long; achenes villous, $3 \mathrm{~mm}$. long; pappus tarny, $12-16 \mathrm{~mm}$. long.

Low coppices and pine-lands, Andros, New Proridence and Cat Island:-Cuba. Northrop's Axastraplita. Caxdlewood.

\section{Anastraphia bahaménsis Urban, Symb. Ant. 3: 415. 1903.}

Anastraphia cuneifolia Greenm. Bull. N. Y. Bot. Gard. 4: 126. 1905.

Shrub 1-2 m. high, much-branched; stem and branches covered with a light gray bark. Leaves obovate-cuneate, 1-2 cm. long, $0.5-1.2 \mathrm{~cm}$. broal, revolute-margined, sparingly spinulose-dentate in the terminal portion, entire and narrowed below the middle into the petiole, slightly puberulent above in the carly stages but soon glabrate and rather conspicuously reticulate-reined, densely and permanently white-tomentose beneath; petioles $3-5 \mathrm{~mm}$. long, tomentose; heads few, about $2 \mathrm{~cm}$. long, sessile, mostly terminating the nltimate branchlets, 5-flowered; involucre narrowly campanulate, $8.5-10 \mathrm{~mm}$. long; bracts of the involucre 5 -6-seriate, triangular-ovate to lance-linear, acute, externaly arachnoid-tomentulose, brownish, slightly sprealing at maturity; mature achenes $3.5-t \mathrm{~mm}$. long, pubescent; pappus about $13 \mathrm{~mm}$. in length, persistent, tawny.

Low coppices and scrub-lands, Indros, Eleuthera, Cat Island, Great lixuma. Crooked. Fortune and Acklin's Islands, IIariguana. Dellis Cay, Caicos Islands and Inagua:-Cuba. leported by Hitcheock and by Mirs. Northrop as 1 . peucifloscula C. Wright, an unpublished name, Bandas Axistrapnid. Carrajo-Busi. 
37. CHAPtàlia Tent. Jarł. Cels. $p l .61 .1800$.

Perennial scapose herbs, with floccose-tomentose foliage. Leares basal, persistently pubescent beneath. Heads heterogamous, radiate, solitary and terminal. Involuere many-flowered, its bracts narrow, in few series, the inner successively larger. Ray-flowers pistillate, fertile, rose-purple. Disk-flowers perfect, wholly or partially neutral, their corollas white or purplish, more or less 2 -lipped, the outer with 3 lobes to the lower lip, the inner with 2 lobes. Achenes 5-nerved, columnar or fusiform. Pappus of numerous soft hair-like bristles. [In honor of J. A. C. Chaptal, 1756-1831, French chemist and statesman.] About 25 spceies, natives of warm-temperate and tropical America. Type species: Chaptalia tomentosa Vent.

1. Chaptalia dentàta (L.) Cass. Dict. Sci. Nat. 26: 104.1823.

Tussilago dentata L. Sp. Pl. ed. 2, 1213. 1763.

Tussilago albicans Sw. Fl. Ind. Oce. 3: 1348. 1806.

Chaptalia albicans Northrop, Mem. Torr. Club 12: 73. 1902.

Leares oblanceolate or oblong-oblanceolate, $2-20 \mathrm{~cm}$. long, repand-dentate or entire, obtuse or acute at the apex, long-attenuate at the base, loosely floccose or becoming glabrous and bright green above, densely white-felted or grayish-felted beneath, the petioles very short or sometimes as long as the blades; scape slender, more or less floccose, 1-3 dm. tall; head not nodding; involucre $13-22 \mathrm{~mm}$. high, its linear bracts floceose, acuminate, the outer much shorter than the inner; flowers white (?); achenes glabrous or pubescent, the body 5-6 mm. long, the filiform beak longer; pappus straw-color, $8-10 \mathrm{~mm}$. long.

Grassy places, pine-lands and coppices. Great Bahama, Abaco, Andros, New Providence :-Florida: Cuba; Hispaniola: Porto Rico; Jamaica. Recorded as $C$. nutans Hemsl. by Hitchcock. Low Chaptalia.

[Artemisia rulgaris L. is reported by IIerrick as growing on Green Turtle Cay, Abaco: we hare not succeeded in finding the species within the archipelago; this European species would probably not long endure the Bahama climate.]

\section{Class 2. GYMNOSPÈRIMAE.}

Ovules (macrosporanges) naked, not enclosed in an ovary, this represented by a scale or apparently wanting. Pollen-grains (microspores) dividing at maturity into two or more cells, one of which gives rise to the pollen-tube (male prothallinm), which directly fertilizes an archegone of the nutritive endosperm (female prothallium) in the ovule.

The Gymnosperms are an ancient group, first known in Silurian time. They became most numerous in the Triassic age. They are now represented by not more than 450 species of trees and shrubs.

There are three orders, Pinales, Cyeadales and Gnetales, the two first represented in the Bahama Flora.

Leaves scale-like, linear or needle-like.

Leares large, pinnate, in a terminal crown.

\section{Order 1. PINÀLES.}

Trees, or rarely shrubs, growing from both terminal and lateral buds, thus freely branehing, the trunks mostly excurrent. Leaves scale-like, linear or needle-like, sometimes fascicled. Flowers mostly monoecious. Fruit a cone, with woody or fleshy scales, or drupaceous. 


\section{Family 1. PINÁCEAE Lindl.}

\section{Pine Family. Conifers.}

Resinous trees or shrubs, mostly with evergreen uarrow entire or scalelike leaves, the wood uniform in texture, without tracheae, the tracheids marked by large depressed disks, the pollen-sacs and ovules borne in separate spikes (aments). Perianth none. Stamens several together, subtended by a scale; filaments more or less united; pollen-sacs (anthers) 2-several-celled, variously dehiscent; pollen-grains often provided with two lateral inflated sacs. Ovules with two integuments, orthotropous or amphitropous, borne solitary or several together on the surface of a scale, which is subtended by a bract in nost genera. Fruit a cone with numerous, several or few, woody, papery or fleshy scales; sometimes berry-like. Seeds wingless or winged. Endosperm fleshy or starchy, copious. Embryo straight, slender. Cotyledons 2 or several. About 25 genera and 250 species of wide distribution, most abundant in temperate regions.

Fruit a large cone with many woody scales; leaves linear, in sheaths. $1 . P i n u s$. Fruit a berry-like cone of few fleshy scales; leaves acicular or scale-like. 2. Juniperus.

\section{PİNUS [Tourn.] L. Sp. Pl. 1000. 1753.}

Evergreen trees with two kinds of leaves, the primary ones linear or scalelike, deciduous, the secondary ones forming the ordinary foliage, narrowly linear, arising from the axils of the former in fascicles of 2-5 (rarely solitary in some western species), subtended by the bud-scales, some of which are united to form a sheath. Staminate aments (flowers) borne at the bases of shoots of the season, the clusters of stamens spirally arranged, each in the axil of a minute scale; filaments very short; anthers 2-eelled, the saes longitudinally dehiseent. Orule-bearing aments (flowers) solitary or clustered, borne on the twigs of the preceding season, composed of numerous imbricated minute bracts, each with an orule-bearing scale in its axil, ripening into a large cone, which matures the following autumn, its seales elongating and becoming woody. Seeds 2 on the base of each seale, winged abore, the testa crustaceous. [Name Celtic.] About 100 species, of the northern hemisphere. Type species: Pinus sylvestris L.

1. Pinus caribaèa Morelet, Rev. Hort. Cote d'Or. 1851.

Pinus bahamensis Griseb. Fl. Br. W. I. 503. 1861.

A tree, with a maximum height of about $30 \mathrm{~m}$, the trunk up to $1.5 \mathrm{~m}$. in diameter, the thick bark splitting into irregular plates, the stout twigs glabrous. Leares in fascicles of 2 or 3, dark green, shining, 17-30 $\mathrm{cm}$. long, the sheaths 1-1.5 cm. long; staminate aments 2-4 cm. long; orule-bearing aments mainly terminal; cones narrowly conic when elosed, 9-14 $\mathrm{cm}$. long, their seales thin, nearly flat, rounded at the apex and thickened into a low knob which bears a small spine; seeds $5-8 \mathrm{~mm}$. long, the thin wing 2-2.5 cur. long.

Great IBahama, Abaco, Andros. New Irovldence, North Caicos and Pine Cay, Caicos Islands:- southeastern Lnited States; Cuba. CalibBeax I'INe-tree. 


\section{JUNÍPERUS L. Sp. PI. 1038. 1753.}

Evergreen trees or shrubs with opposite or verticillate, subulate or scalclike, sessile leaves, commonly of 2 kinds, and dioecious or sometimes monoecious, small glohose axillary or terminal aments. Leaf-buds naked. Staminate aments oblong or ovoid; anthers 2-6-celled, each sac 2-valved. Ovule-bearing aments of a few opposite somewhat fleshy scales, or these rarely verticillate in 3 's, cach bearing a single erect orule or rarely 2. Cones globose, berry-like by the coalescence of the fleshy scales, containing 1-6 wingless bony seeds. [Name Celtic.] About 40 species, natives of the northern hemisphere. Type species: Juniperus communis L.

\section{Juniperus lucayàna Britton, N. A. Trees, 121. 1908.}

Juniperus australis Pilger, in Urban, Symb. Ant. 7: 479. 1913.

A tree, seldom over $12 \mathrm{~m}$. high, with a trunk up to $6 \mathrm{dm}$. in diameter, the thin bark separating in low strips, the branches ascending or the lower drooping, the twigs slender. Leaves of young plants, and often those of the lower parts of twigs, acicular, pungent, $5-10 \mathrm{~mm}$. long; leaves of mature plants scale-like, appresser, t-ranker, 1-1.5 mm. long; fruit blue, oblong-globose and somewhat laterally flattened, $5-6.5 \mathrm{~mm}$. long.

Great Bahama. Abaco. Cat Cay, Andros. New Providence, Eleuthera:-Cuba ; Jamaica. Recorded by Grisebach, by Mrs. Northrop. by Coker and by Dolley as $J$. barbadensis L., by Schoepf as $J$. bermudiana L., and by Dolley as J. virginiana L. IIEST Indiax Red Cedar.

\section{Order 2. CYCADÄLES.}

Palm-like or fern-like, dioecious, woody plants with ereet trunks, sometimes short and wholly buried in the gromir, growing only from the summit and thus unbranched, althongh sometimes forming lateral adventitious buds, the large piunate leaves in a terminal crown. Flowers in terminal cones, or on modified leaves. Scales of the staminate cones bearing several anther-sacs. Ovule-bearing scales or leaves with two or more naked ovules. Seeds drupe-like or nut-like. Only the following family.

\section{Family 1. CYCADÀCEAE Lindl.}

\section{Cycad Family.}

Nine genera and about 90 species, of tropical and subtropical distribution.

\section{ZÀMIA L. Sp. Pl. ed. 2, 1659. 1753.}

Woody, dioecious plants, the trunk or caudex wholly or partly buried in the ground, the palm-like leaves tufted at its summit, pinnately compound, coriaceous, the segments entire or toothed, parallel-veined, the petioles unarmed in the following species, prickly in some others, the inflorescence strobilar, peduncled, densely many-flowered, the cones from oblong-cylindric to subglobose, the female thicker than the male. Scales of the cones peltate, nearly flat, more or less hexagonal, closely set together, vertically superimposed. Scales of the male cone at length deciduous, bearing several sessile pollen-sacs, those of the 
female cone persistent, bearing 2 sessile, ovoid orules. Seeds more or less angled, the testa fleshy. [Said to be Latin for a fir-cone.] About 25 species, natives of tropical and subtropical America. Type species, Zamia pumila L.

Leaflets $3-15 \mathrm{~mm}$. wide.

Leaflets $7-15 \mathrm{~mm}$. Wide, close together.

Leallets $3-7 \mathrm{~mm}$. wide.

Leaflets distant, $3-6 \mathrm{~mm}$. wide; scales of male cone wider than high.

Leaflets closer together, $6-\boldsymbol{i} \mathrm{mm}$. wide; scales of male cone scarcely widel than high.

Leaflets about $2.5 \mathrm{~cm}$. wide.

1. Z. pumila.

2. Z. angustifolia.

3. Z. tenuis.

4. Z. lucayana.

1. Zamia pùmila L. Sp. Pl. ed. 2, 1659. 1763.

Caudex stout, $2 \mathrm{dm}$. long or longer, the upper part usually exposed, but sometimes completely buried. Basal scales ovate, acute or acuminate, villous, $2-3 \mathrm{~cm}$. long; petiole silky-villous below, glabrous above; leares 3-10 dm. long; leaflets $20-50$, coriaceous, shining, $5-15$ em. long, $7-15$ mm. wide, entire, or fewtoothed at the obtuse apex, the pairs separated $0.5-2 \mathrm{~cm}$; peduncles stout, villous-pubescent, 5-10 cm. long; male cone oblong, 5-8 cm. long, 2-2.5 cm. thick, its seales tomentose, broader than high or the lower nearly equally broad and long; ripe female cone ellipsoid, 7-11 cm. long, 5-8 cm. thick, short-tipped, its hexagonal scales tomentose, broader than high; seeds angled, $2-2.5 \mathrm{~cm}$. long.

Thickets and woodlands among rocks, Great Bahama, Andros, New Providence:Florida; Cuba. BAY-RUSH.

\section{Zamia angustifòlia Jacq. Coll. 3: 263. 1789.}

Caudex slender, $2 \mathrm{dm}$. long or longer, completely buried in sand. Basal scales broadly ovate to orate-lanceolate, acuminate, densely villous $3-5 \mathrm{~cm}$. long; leaves 2-10 dm. long; leaflets 5-20 pairs, narrowly linear, entire or with a few callous teeth at the obtuse apex, 5-20 $\mathrm{cm}$. long, 3-6 mm. wide, nearly parallel-margined or slightly tapering to both ends, shining, the pairs distant, those of larger leaves about $2 \mathrm{~cm}$. apart; peduncles villous, those of male cones $5-8 \mathrm{~cm}$. long, those of female cones stouter; male cone oblong-cylindric, 5-7 $\mathrm{cm}$. long, about $2 \mathrm{~cm}$. thick, pointed, its scales oblong, or rotund, hexagonal, tomentose, $6-7 \mathrm{~mm}$. wide, $3-5 \mathrm{~mm}$. high; ripe pistillate cone $8-9 \mathrm{~cm}$. long, about $5 \mathrm{~cm}$. thick, stout-tipped, its seales $2-2.5 \mathrm{~cm}$. wide, about $1.5 \mathrm{~cm}$. high; seeds $2 \mathrm{~cm}$. long, red.

In white calcareous sand, Eleuthera:-Cuba, NARrow-LEATEd BAY-RUSH.

3. Zamia ténuis Willd. Sp. Pl. 4: S46. 1806.

Caudex unknown definitely. Leares $6 \mathrm{dm}$. long or longer; leaflets 40 or fewer, narrowly linear, $7-17 \mathrm{~cm}$. long, 6-7 mm. wide at or below the middle, tapering to the obtuse, callously 1-several-toothed apex, the pairs separated by $1.5 \mathrm{~cm}$. or less; peduncles pubeseent; male cone cylindric, its scales deseribed as subquadrate-hexagonal, tomentose, little broader than high.

Bahamas, according to Willdenow and subsequent authors. A leaf from a New Providence plant, communicated by Hon. H. A. Brook, is tentatively referred to this species. A specimen from near Nuevitas, Cuba (Shafcr 793), is also referred to it with hesitation. A leaf of the type specimen is figured by Miquel (Linneae 19:p7,6). The species may not be distinct from $Z$. angustifolia.

4. Zamia lucayàna Britton, Bull. N. Y. Bot. Gard. 5: 311.1907.

Caudex stout, subfusiform, about $3 \mathrm{dm}$. long, $1 \mathrm{dm}$. thick, two thirds buried in the ground. Leares glabrous, about $1 \mathrm{~m}$. long; petiole obtusely angled, $3-4$ $\mathrm{dm}$. long; rachis somewhat angled; leaflets about 14 on each side of the rachis, spreading nearly at right angles, $17-21 \mathrm{~cm}$. long, $2-2.7 \mathrm{~cm}$. wirle, $4-5 \mathrm{~cm}$. apart, linear-oblong, obtuse, or irregularly rounded or subtruncate, and finely sparingly 
toothed at the apex, falcately narrowed at the base, the margins thickened and slightly revolute, the 40-50 nerves elosely parallel; fruiting peduncle about 4 $\mathrm{cm}$. long, $1.2 \mathrm{~cm}$. thick below, $2 \mathrm{~cm}$. thick at the top, densely pubescent; fruiting cone ohlong, mberulent, $T \mathrm{~cm}$. long, $4 \mathrm{~cm}$. in diameter, its acute conic tip $8 \mathrm{~mm}$. high, its scales oblong, hexagonal, about $1.5 \mathrm{~cm}$. wide and $8 \mathrm{~mm}$. high.

Sandy coastal thicket, Clarence Town, Long Island. Endemic. Bahama Bar-Rush.

\section{Phylum 2. PTERIDÓPHYTA.}

Ferns and Fern-Allies.

Plants containing woody and vascular tissues, producing spores asexually, which, on germination, develop small flat mostly green prothallia (gametophyte). On these are borne the reproductive organs, the female known as archegones, the male as antherids. From the fertilization of the egg in the archegone by spermatozoids produced in the antherid, the asexual phase (sporophyte) of the plant is developed; this phase is represented by an ordinary fern, lycopod, or horsetail. Comprising about 6000 living species, of which more than three fourths are confined to tropical regions.

Spores produced in sporanges borne on the leares, or panicled or in special conceptacles.

Spores all alike: Bahama species all terrestrial or epiphytic plants.

Spores of two sizes: small floating plants.

Spores produced in sporanges borne in the axils of sealelike leares.

Order 1. Filicales.

Order 2. SALTixiales.

Order 3. Lrcopodiales.

\section{Order 1. FILICÀLES.}

Spores all of one kind and size, produced in sporanges, which are borne usually in clusters (sori) on the back of a leaf or on greatly modified pinnae.

Sporanges borne in sori on the back or the margin of a leaf, opening transversely.

Sam. 1. POLYPODIACEAE. Sporanges in spikes or panicles, opening vertically. Fam. 2. SchizaEaceae.

\section{Family 1. POLYPODIÀCEAE R. Br.}

\section{FerN FAMILY.}

Ferns of various habit, the rootstocks horizontal and often elongated, or short and erect, the leaves entire, pinnate, pinnatifid or decompound, coiled in vernation, mostly with petioles (stipes). Sporanges borne in clusters (sori) on the lower side or margins of the leares or their segments, stalked, provided with a vertical ring, opening transversely. Sori with or without a membranous covering (indusium). Prothallium green. About 150 genera and 4,500 species of wide distribution. 
A. Sori confluent, without indusia, covering the under side of leaf-segments: large pinnate marsh ferns.

B. Sori separated, or forming marginal rows on the under side of leares or of leaf-segments.

1. Sori marginal or submarginal.

a. Sori without indusia.

Leares grass-like : venation regularly areolate, without included veinlets

Leaves narrow; renation irregularly areolate, with numerous included veinlets.

b. Sori with indusia.

Indusia formed of the inrolled margins of leafsegments.

Sori forming a continuous mal'ginal band. Indusia double. Indusia simple.

Sori borne on leaf-lobes at the ends of veins.

Indusia cup-like at the truncate ends of leaf-segments.

2. Sori dorsal.

1. Sori linear or oblong, more than twice as long as wide.

Sori parallel to the midrein of leaf-segments.

Sori oblique to the midrein.

2. Sori orbicular or nearly so.

a. Sori without indusia.

Sori nearly confluent; leares much dirided, powderr beneath.

Sori distinctly separated; leares not powdery. Veins free.

Teins anastomosing.

Leares pinnatifid.

Leares entire.

Small-leaved, climbing ferns.

Large-leared, tufted ferns.

b. Sori with indusia (indusia restigial or wanting in species of Dryopteris).

Sori borne on the backs of veins.

Veins copiously anastomosing, the areoles irregular.

Veins free or, if anastomosing, the areoles regular.

Sori borne at the ends of veins; indusia large, reniform or orbicular.

1. Acrostichum.

\section{Tittoria.}

3. Paltonium.

4. Pteris.

5. Pychorloria.

6. Adiuntum.

7. Sphenomeris.

S. Blechnum.

9. Asplenium.

10. Pityrogramma.

11. Polypodium.

12. Phlebodium.

13. Phymatodes.

14. Campyloneuron.

15. Tectaria.

16. Dryopteris.

17. Nephrolepis.

1. ACRÓSTICHUM L. Sp. PI. 1067. 1753.

Swamp-inhabiting, large ferns, with pinnate leaves growing in crowns. Sporanges spread over the whole surface of the leaf-blades, or of the upper segments. Veins forming copious areolae without free veinlets. [Greek, signifying a summit row.] A few species, natives of warm temperate and tropical America. Type species: Acrostichum aureum L.

Petiole usually armed with spurs; venation of the pinnae rery oblique to the midrib.

Petiole unarmed; renation not rery oblique.

1. A. aurenm.

2. A. excelsum.

1. Acrostichum aùreum I. Sp. Pl. 1067. 1753.

Rootstocks stout, erect, often forming large colonies. Leares 1-3 m. high; petioles tufted, erect, channelled, of ten armed with horny spurs; blades leathery in texture, longer than the petioles; pinnae 10 pairs or more, the renation very oblique; sporanges usially borne only on the upper pinnae; segregate of corpuseles covering sporanges not sausage-shaped.

Wet saline soil, North Cat Cay. Grent Pabama, Andros, New Proridence. Acklin's Island, Caicos, Inagua :-Florida; West Indies. Glast Fens. Leather Fers.

2. Acrostichum excélsum Maxon, Proc. Biol. Soc. Wash, 18: 224. 1905.

Acrostichum lomarioides Jenman, Bull. Bot. Dept. Jamaica, 5: 154. 1598. Not Bory, 1 S53. 
Rootstocks erect, solitary, or in masses. Petioles tufted, unarmed, erect, woody, 1-6.5 dm. long, flattish, channeled; blades leathery, 1-3 m. long, 3-4.5 dm. wide: pinnae 10 pairs or more, close or distant, the venation somewhat oblique to the midvein; sporanges confined to the upper half or third of the leaf-blade, or all segments spore-bearing, or all without spores; segregate of corpuscles covering sporanges sausage-shaped.

About fresh-water ponls and in sink-holes, Andros, New Providence:-Florida ; lermuda: West Indies and continental tropical America. GIaxt Fers.

Young plants collected by l'erey Wilson on Cat Island (7186), show that one or the other of these tcrostichums grows on that island.

2. Vittaria J. E. Smith, Mem. Acad. Turin, 5: 413. 1793.

Usually epiphytic ferns with narrowly linear, grass-like, entire leaves, the linear sori continuous in a groove along each margin, without indusia. Lateral reins obscure, forming a row of areoles on each side of the midvein. [Latin, ribbon-like.] About 40 species, widely distributed in tropical and subtropical regions. Type species: Pteris lineata L.

1. Vittaria lineàta (L.) Si. in Journ. Bot. Schrad. 1800²: i2. 1801.

Pteris lineata L. Sp. Pl. 1073. 1853.

Leares usually numerous, drooping, smooth, shining, tufted on trees, 1-9 dm. long, 2-3 mm. wide, the rootstock short, branched, scaly.

On palmettos, Andros. New Proridence:-Florida; West Indies and continental tropical America. Grass-FERx. SHOESTING-FERN.

\section{PALTónIUM Presl, Epin. 156. 1849.}

Epiphytic ferns, with short-creeping rootstocks and narrow entire leaves, the renation reticulated. Sori linear, submarginal, continuous or interrupted, without indusia. [Greek, like a javelin.] Two known species, the following typical one, the other of southern China.

1. Paltonium lanceolàtum (L.) Pres], Epim. 156. 1849.

Pteris lanceolata L. Sp. Pl. 1073. 1753.

Taenitis lanceolata Kaulf. Enum. 130. 1824.

Cheilogramma lanceolata Maxon, Proc. U. S. Nat. Mus. 23: 630. 1901.

Rootstock short. Leares tufted, narrowly linear-oblong, glabrous, subcoriaceous, $1.5-4 \mathrm{dm}$. long, $0.8-3 \mathrm{~cm}$. wide, tapering to both ends, entire, the midrein prominent, the lateral renation obseure. Sporanges in a continuous or interrupted marginal row above the middle of the leaf, often only near the apex.

On trees in connices. Great Bahama, Andros. New Providence:-Florida; Jamaica: Cuba to St. Thomas; St. Eustatius; Guadaloupe to Barbadoes; Central America. NARROW-LEATED BRAKE.

\section{PTERIS L. Sp. Pl. 1073.1753.}

Large, mostly coarse ferns, growing in open sunny places, with variously divided leares, and marginal linear continuous sori which occupy a slender or filiform receptacle, connecting the tips of free veins. Indusium double, the outer one conspicuous, membranous, formed of the reflexed margin of the leaf, the inner one delieate and obscure. Stipes continuous with the rootstock. [Greek name for ferns, from the fancied resemblance of their leares to the wings of birds.] A few species of wide distribution. Type species: Pteris aquilina L. 
1. Pteris caudàta L. Sp. Pl. 1075. 1753.

Pteridium caudatum Maxon, Proc. U. S. Nat. Mus. 23: 631. 1901.

Pteris aquilina caudata Hook. Sp. Fil. 2: 196.1858.

Leares erect, 1-2 m. tall; blades triangular in outline, 2-1-pinnate; dirisions pinnatific, the ultimate segments narrow, with recurved margins, remote from one another, scarcely decurrent on the rachis except near the apex, the larger with 1-12 similar but shorter segments.

Pine-lands, scrub-lands and coppices, Abaco, Great Pahama, Andros, New Providence, Cat Island, Crooked Island, North Caicos:-Florida: Bermuda: Jamaica: Cuba: II ispaniola; Forto Rico; Montserrat; continental tropical America. SocthERN BRACKEN.

5. PYCNODóRIA Presl. Epim. 101. 1849.

Mostly large ferns, the petioles not jointed with the rootstocks, the leaves variously dirided. Sori marginal, continuous or nearly so, on a filiform or narrow receptacle connecting the tips of the free veins; indusium simple, membranous, formed by the reflexed margin of the leaf. Sporanges pedicelled, prorided with a rertical ring which bursts transversely. [Greek, thick-skinned.] Many species, of warm and tropical regions. Type species: Pteris opaca J. Smith.

1. Pycnodoria longifòlia (L.) Britton, Fl. Berm. 418. 1918.

Pteris longifolia L. Sp. Pl. 1074. 1753.

Leares somewhat spreading; petioles $1.5-3 \mathrm{dm}$. long, clothed below with pale brown scales; blades simply pinnate, oblong-lanceolate, 3-6 $\mathrm{dm}$. long; pinnae linear, $4-8 \mathrm{~mm}$. wide, entire, sessile; reins elose. usually ance branched; indusium yellowish brown.

In sink-holes, Great Pahama, Andros. New Providence:-Florida: Bermuda : Tamaica: Cuba: Hispaniola : Porto Rico; St. Thomas; St. Croix; St. Kitts; Guadeloupe: Dominica : Martinique.

In a monstrous form from Nicholl's Town, Andros, the pinnae are deeply cut into linear lobes $4 \mathrm{~cm}$. long or less. Loxg-Leitied Brake.

\section{AdIÁNTUM [Tourn.] L. Sp. Pl. 1094. 1753.}

Graceful ferns of rocky hillsides, woods, and ravines, with much dirided leares and short marginal sori borne on the under side of the reflexed and altered portion of the pinnule, which serves as an indusium. Stipes and branches of the leaves slender or filiform, often polished and shining. TName ancient.] A genus of orer 175 species, mostly of tropical America. Type species: Adiantum Capillus-Teneris $\mathrm{L}$.

Leaf-segments stalked. cuneato at base.

Leaf-segments sessile, truncate at base.

1. A. tenerum.

2. 1. melanoleucum.

\section{Adiantum ténerum Sw. Prorlr. 135. 1788.}

Rootstock short, thick. Stipes smooth, nearly black, shining, 1-3 dm. long. Blattes 2-t-pinnate, 2-4 rlm. long, glahrous; pinnules many, filiform-stalketl, subrhombic, membranous, euneate at the base, dentate or incised ahore, delicately many-veined, jointed with the stalk, $8-25 \mathrm{~mm}$. long; sori few or sereral, roundish or oblong.

In cares, sink-holes and on steps, Abaco, Andros, New Providence, Elouthera:Florida : Iamaica : Cuba to St. Thomas and St. Croix; St. Kitts to Tobago: continental tropical Ameriea. The fern recorded by Coker as idiantum Capillus-Tencris

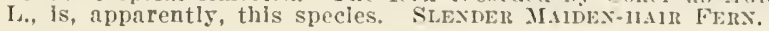


2. Adiantum melanoleùcum Willd. Sp. Pl. 5: 443. 1910.

Rootstock short. Stipes slender, smooth, nearly black, shining, 1-3 dm. long. Blades mostly 2-pinnate, sometimes only once pinnate, 1-4 dm. long, glabrous; pinnules usually many, sessile, obliquely oblong, thin, $\mathrm{S}-2 \overline{\mathrm{mm}} \mathrm{m}$. long, irregularly toothed or lacerate on the upper and outer margins, the lower margin entire or nearly so; uppermost segments commonly confluent; sori few, oblong or semilinear.

In sink-holes, New Providence, Eleuthera :-Florida ; Jamaica ; Cuba ; IIispaniola ; Porto Rico. DakK MaIDEx-hail Fers.

\section{SPHENómERIS Maxon, Journ. Wash. Acad. Sci. 3: 144. 1913.}

Slender mostly small ferns, with creeping rootstocks covered by hair-like scales, the leaves 3-4-pinnately divided into narrow cuneate segments, the veins free. Sori borne solitary on the terminal margins of the segments, the indusium cup-like, attached at the base and sides. [Greek, referring to the wedgeshaped leaf-segments.] A few species of tropical and subtropical regions, the following typical.

1. Sphenomeris clavàta (L.) Maxon, Journ. Wash. Acad. Sei. 3: 144. 1913.

Adiantum clavatum L. Sp. Pl. 1096. 1753.

Davallia clavata J. E. Smith, Mem. Acad. Turin 5: 415. 1790.

Odontosoria clavata J. Smith, Hist. Fil. 264. 1875.

Rootstock short, $2-7 \mathrm{~cm}$. long. Leaves of ten many, glabrous, nearly erect, close together, 1.5-6 dm. long, the smooth straw-colored stipe usually shorter than the much divided blade; leaf-divisions alternate; ultimate-segments 8-15 $\mathrm{mm}$. long, 1-2.5 $\mathrm{mm}$. wide at the truncate apex.

In sink-holes, most abundant in pine-lands, rarely on cliffs, Abaco, Great Bahama, Andros, Liew Providence, Rose Island, Great Guana Cay, Cat Island, Eleuthera :Florida; Jamaica; Cuba. PINE-LAND FerN.

\section{BLÉCHNUM L. Sp. Pl. 1077. 1753.}

Terrestrial ferns with stout rootstocks and clustered pinnate leaves, the veinlets of the fertile pinnae joined transversely near the base. Sori linear, contiguous, parallel with the midvein of leaf-segments and close to it, the indusium membranous. [Greek, tasteless.] Forty species or more, mostly tropical in distribution. Type species: Blechnum orientale $\mathrm{L}$.

1. Blechnum serrulàtum L. C. Rich. Act. Soc. Nat. Paris 1: 114. 1792.

Leares erect, tufted, $3-9 \mathrm{dm}$. high, rather stiff, the plants often forming large colonies. Blades subcoriaceous, oblong-lanceolate, once pinnate, glabrous; petiole stout, shorter than the blade; pinnae numerous, oblong, linear or oblonglanceolate, sessile, mostly close together, obtuse or acute, $3-8 \mathrm{~cm}$. long, the upper ones fertile, all incised-serrulate; veins numerous, delicate, free beyond the sori; sori approximate to the strong midvein, conspicuous; fertile segments narrower than the sterile.

Borders of swamps and lagoons, Andros, New Providence :-Florida ; West Indies ; continental tropical America. Marsh FerN. 


\section{ASPLÈNIUM L. Sp. Pl. 1078. 1753.}

Large or small ferns with entire lobed pinnate, 2-3-pinnate, or pinnatifil leaves, and linear or oblong sori oblique to the midribs or rachises. Leaves mostly uniform. Veins free. Indusia straight or curved, opening toward the nidribs. [Aneient Greek name; some species were supposed to be remedies fer diseases of the spleen.] A genus of some 400 species, of very wide geographical distribution. Type speeies: Asplenium Trichomanes L.

\section{Asplenium dentàtum L. Sp. Pl. 10S0. 1753.}

Petioles tufted, $5-15 \mathrm{~cm}$. long, naked, weak, blackish below. Fertile leafblades 5-12 $\mathrm{cm}$. long, with 6-8 pairs of stalked oblong or rhombie pinnae, the lower side truneate with a curve, the outer edge irregularly erenate; sterile leares similar but with shorter petioles; rachis naked; sori copious.

In a care, New Providence: in a deep sink-hole, Cat Island:-Florida; Bermuda ; Jamaica; Cuba: Mispaniola; Guadelope: Barbados; Mexico and Central America. TOOTHED SPLEEN WORT

Schoepf records observing Asplenium rhizophyllum L., and A. marinum L., on New Providence in 1784; we do not know what ferns he had in mind.

\section{PITYROGRÁMMA Link, Handb. 3: 19. 1833.}

Terrestrial ferns, - with tufted, mostly bipinnate leares, usually whitepowdery or yellow-powdery on the under side, the sori dorsal, linear along the veins, nearly confluent. Indusia wanting. [Greek, bran-fern, with reference to the powdery under leaf-surfaces.] Ten species, or more, natives of tropical and subtropical regions. Type species: Acrostichum chrysophyllum $\mathrm{Sw}$.

1. Pityrogramma calomelànos (L.) Link, Handb. 3: 19. 1833.

Acrostichum calomelanos L. Sp. Pl. 1072. 1753.

Gymnogramme calomelanos Kaulf. Enum. Fil. 76. 1824.

Neurogramme calomelanos Diels in E. \& P. Nat. Pfl. $1^{4}$ : 264. 1599.

Rootstoek short, rather stout, erect or nearly so. Leaves tufted, erect or arching, ovate to ovate-laneeolate in outline, 2-pinnate, $2-8 \mathrm{dm}$. long, the dark brown shining petiole usually shorter than the blade; rachis dark brown, shining; pinnae lanceolate, aeuminate, usually white-pulverulent beneatl ; pinnules lanceolate, aente or acuminate, dentate or entire, chartaceons, deeurrent, the upper commonly eonfluent.

Sink-hole, Smith Hill Coppice, Andros:-West Indies; continental tropical America, SILVER-FERx.

\section{POLYPÒDIUM [Tourn.] L. Sp. Pl. 10S2. 1753.}

Pinnate or simple ferns with stipes artieulated to the ereeping rootstocks. Sori hemispheric, dorsal, in one or more rows on either side of the midribs. Indusium none. Teins free or variously anastomosing. [Greek, in allusion to the knob-like prominenees on the rootstocks of some species.] Abont 350 species, of wide distribution, mostly tropieal. Type species: Polypodium vulgare L.

liootstocks slender. wide-creaping, the leaves distant; sorl deeply impressed.

Rootstocks thicker, short-creeplng, the leares approximate; sori superficial.

1. P. polypodioides.

2. P. squamatum. 
1. Polypodium polypodioides (L.) Watt, Can. Nat. 11: 15s. 1866.

Acrostichum polypodioides L. Sp. Pl. 1068. 1753.

Polypodium incanum Sw. Fl. Ind. Oce. 3: 1645. 1806.

Rootstoek widely creeping, woody, covered with small brown seales. Stipes densely appressed-scaly, 2.5-10 cm. long: blarles oblong-lanceolate in outline, acute, coriaccous, evergreen, 3-15 $\mathrm{cm}$. long, $2.5-4 \mathrm{~cm}$. wide, eut very nearly or quite to the rachis into entire, oblong or linear-oblong, obtuse segments, glabrous or nearly so on the upper surface, the lower densely covered with gray unappendaged peltate scales with darker centres, as are also the rachises; veins inclistinct, usually once forked, connected or free.

On trees, especially in coppices, Abaco, Great Bahama, Andros, New Providence, Crooked Island:- southeastern Lnited States; Jamaica; Cuba to St. Jan and Trinidad; continental tropical America. Grir I'OLripodr.

\section{Polypodium squamàtum L. Sp. Pl. 1506. 1753.}

Rootstock stout, creeping, covered with linear, ciliate scales. Stipes scaly, 5-25 cm. long; blades oblong-lanceolate in outline, 2-4 dm. long, 4-10 $\mathrm{cm}$. wide, coriaceous, evergreen, eut nearly or quite to the rachis into entire linear, acute or obtusish segments; rachis and nnder surface of the leafsegments densely covered with appressed scales with linear, ciliate appendages; reins hidden.

On trees, Conch Sound, Andros :-Jamaica; Cuba ; Hispaniola ; Porto Rico. SCALY POLYPODY.

12. PHLebòdiUM [R. Br.] J. Smith in Hook. Journ. Bot. 4: 58. 1841.

Large, mostly epiphytic ferns, with stout creeping chaffy rootstocks, and deeply pinnatifid, rather thick, drooping or spreading leaves, the reins anastomosing. Sori dorsal, orbicular, without indusia, mostly in 1 row or more, parallel with the midvein of the leaf-segments, usually borne at the end of a pair of free veinlets. [Greek, referring to the veins.] Perhaps 10 species, tropical and subtropical, the following typical.

1. Phlebodium aùreum (L.) J. Smith in Hook. Journ. Bot. 4: 59. 1841.

Polypodium aureum L. Sp. Pl. 1087. 1753.

Rootstock short and stout, creeping, densely elothed with linear-lanceolate membranous acuminate scales. Stipe stout, glabrous, $1-2.5 \mathrm{~cm}$. long. Blade once-pinnate, glabrous, pale and glaucescent, $1.5 \mathrm{~m}$. long or less, submembranous, the lanceolate segments more or less united near the rachis, acuminate, acute or obtusish, $0.7-2 \mathrm{dm}$. long, reticulate-veined; sori large, mostly in 1 or 2 rows on each side of the midrein.

on trees, especially palmettos, Great Bahama. Whale Cay, Andros, New Providence, Eleuthera, Cat Island, Crooked Island:-Florida; West Indies; continental tropical America. Recorded by Dolley as Pteris aurea. SERPExt-FERx.

\section{PHYMATÒdES Presl, Tent. Pter. 195. 1836.}

Slender creeping or climbing ferns with elongated rootstocks or stems and simple, short-petioled leaves. Sori dorsal, cireular, in 1 or 2 rows on each side of the midrein; indusium wanting. Veins delicate, usually inconspicuous, copiously anastomosing, their $\epsilon$ nds sometimes enlarged. [Greek, a swelling.] Perhaps 50 species of tropical and subtropical regions. Type species: Polypodium phymatodes $\mathrm{L}$. 
1. Phymatodes exíguum (Hew.) Unclerw. Torreya 3: 1S. 1903.

Polypodium exiguum Hew. Mag. Nat. Hist. II. 2: 458. 1838.

Polypodium Suartzii Baker, in Hook. \& Baker, Syn. Fil. en 2, 357. 1874.

Rootstocks ereeping on trees or shrubs, slender, elothed with brown linearlanceolate scales, simple or branched, sometimes $8 \mathrm{dm}$. long. Leaves thin, various, linear, oblong, lanceolate or oblanceolate, 5-10 cm. long, 5-15 $\mathrm{mm}$. wide, acnte or obtuse at the apex, narrowed at the base into petioles 4-12 $\mathrm{mm}$. long, entire or slightly undulate; sori mostly in 2 rows, one row on each side of the midrein.

On tree-trunks in coppices, Andros, New Providence:-Florida; Jamaica; Cuba to St. Jan; St. Croix; Montserrat. Chimbixg Poly podr.

\section{CAmpylonéurum Presl, Tent. Pter. 189. 1836.}

Tufted ferns, with large narrow entire leaves. Sori dorsal, mostly in 1 or 2 rows on each side of the primary veins; indusium none. Primary renation regularly pinnate, the veins connected by nearly parallel veinlets forming regular areoles. [Greek, crooked-nerved.] Twenty speeies or more, natires of tropical and subtropical regions, the following typical.

1. Campyloneurum Phyllitidis (L.) Presl, Tent. Pter. 190. 1836.

Polypodium Phyllitidis L. Sp. Pl. 1083. 1753.

Rootstock short, stout. Leares sereral or many, short-petioler, broadly linear, narrowed to both ends or rarely obtuse at the apex, 3-10 dm. long, 2-10 $\mathrm{cm}$. wide, rather firm in texture, smooth and shining; sori small, often very numerous.

On trees and in sink-holes in coppices, Abaco, Great Bahama, Andros, New Proridence, Crooked Island:-Florida; West Indies; continental tropical America. STRAP-FERN.

\section{TECTÀRIA Cav. Anales Hist. Nat. 1: 115. 1799.}

Usually terrestrial ferns, with ereeping or horizontal rootstocks, and thin broar lobed, coarsely toothed or pinnate leaves. Sori orbicular, dorsal, borne on the backs of veins. Indusia orbicular to reniform. Veins copiously anastomosing, forming many areolae. [Latin, referring to the indusia.] Over 40 species, natives of tropical and subtropical regions. Type species: Polypodium trifoliatum L.

Fully developed leaves not much longer than broad.

Basal lobes and usually all lobes of the fully developed leaf long-acuminate; leaves rather firm in texture.

At least the basal lobes obtuse, merely acute or rarely acuminate: leaves thin in texture.

Fully developed leat $2-3$ times as long as broad, the lobes all rounded.

1. T. heracleifolia.

2. T. minima.

3. T. Amesiuna.

1. Tectaria heracleifòlia (Willd.) Underw. Bull. Torr. Club 33: 200. 1906.

Aspidium heracleifolium Willd. Sp. Pl. 5: 217. 1810.

Rootstock stout, brown-sealy. Leaves 2-10 dm. high; petioles brown, shining, as long as the blacles or shorter; blades various in form, rather firm in texture, the finely developed ones broadly triangular, little longer than wide, at least the lower lobes or segments long-acuminate; less developed leaves orate, the apex long-acuminate; sori usually many, in 2 more or less complete rows parallel with the lateral veins, $2-2.5 \mathrm{~mm}$. in diameter.

Coppices, New Irovldence:-Florida; Texas; West Indies; continental tropleal America, IIALBEID-FLIS. 


\section{Tectaria mínima Underw. Bull. Torr. Club 33: 199.1906.}

Rootstock slender, short, brown-scaly. Leaves $0.8-4 \mathrm{dm}$. long; petioles green, or brownish, slender, commonly much longer than the blades, often very slender; blades various, thin, ovate or ovate-lanceolate, but the fully developed ones not much longer than broad, lobed, pinnatifid or sometimes trifoliolate, the basal lobes obtuse, acute or rarely acuminate; sori usually few, seattered, or in 1 or 2 more or less complete rows parallel with the lateral veins, $1-1.5$ $\mathrm{mm}$. in diameter.

In sink-holes, wells and caves, Abaco, Andros, New Proridence, Eleuthera, Cat Island:-Florida; Cuba. SMALI, HALIERD-FERN.

Recorded by Mrs. Northrop as Tectaria trifoliata (L.) Cav. and by Dolley as Aspidium trifoliatum Sw.

\section{Tectaria Amesiàna A. A. Eaton, Bull. Torr. Club 33: 479. 1906.}

Rootstock short, stout. Leaves $4 \mathrm{dm}$. long or less; petioles rather slender, about as long as the blades or shorter; blades narrowly orate or ovate-lanceolate in outline, rather thin, pinnate-pinnatifid, the segments and lobes obtuse or rounded, the lower 1 to 3 pairs of pinnae short-stalked; sori scattered or in 1 or 2 more or less rows paralle! with the venation, $1-1.5 \mathrm{~mm}$. in diameter.

Eleuthera, at Gregory Town (Cokcr 372 ) : referred to this species with hesitation. Known otherwise only from one station in Florida. AMES' HaLberd-Fern.

\section{DRYóPtTERIS Adans. Fam. Pl. 2: 20, 550. 1763.}

Ferns with simple to $2-3$ pinnate or pinnatifid leaves and round sori usually borne on the backs of the reins, the fertile and sterile leaves usually similar. Indusium flattish, roundish-reniform, superior, fixed by its sinus, or the indusium minute and vestigial or altogether wanting. Stipe continuous, not jointed with the rootstock. Veins free or anastomosing. [Greek, signifying oak-fern, in allusion to the forest habitat of most species.] Species several hundred, of wide distribution. Type species: Polypodium Filix-mas L.

Leaves mostly erect; veins free.

Pinnae elongated, linear-lanceolate.

Pinnae lanceolate.

Leaves reclining, often rooting at the tip.

Stipe and rachis laxly puberulent, many of the hairs simple; veins with several branches, the basal ones joined.

Stipe and rachis closely stellate-puberulous, nearly or quite deroid of long simple hairs; veins mostly forked, usually free.

1. D. augescens. 2. D. normalis.

3. D. reptans.

4. D. cordata.

1. Dryopteris augéscens (Link) C. Chr. Danske Vidensk, Selsk. Skr. VII. 10²: 152. 1913.

Aspidium augescens Link, Fil. Sp. 103. 1841.

Rootstock horizontal, rather stout, scaly. Leaves once pinnate, mostly erect, sometimes $1 \mathrm{~m}$. long or longer, lanceolate in outline, the petiole usually shorter than the blade, puberulent and sealy at the base, otherwise smooth; pinnae many, close together, linear-lanceolate, sessile, often $1.5 \mathrm{dm}$. long, 1-2 cm. wide, deeply pinnatifid, slender-tipped, more or less pubescent at least beneath, the segments ovate-lanceolate, acute, entire, the lower ones somewhat larger than the others; veins free.

Pine-lands, coppices, caves and sink-holes, Great Bahama, Andros, New Providence, Eleuthera :-Florida; Cuba; Central America. Reported by Mrs. Northrop as Dryopteris patens (Sw.) Kuntze.

2. Dryopteris normàlis C. Chr. Arkiv. Bot. 9: 31. 1910.

Rootstock horizontal, slender, scaly. Leares erect or ascending, once pinnate, $3-15 \mathrm{dm}$. long, lanceolate to ovate-lanceolate in outline, the petiole usually 
shorter than the blade, puberulent and usually bearing some seales toward the base, otherwise smooth; pinnae usually many, rather elose together, sessile, mostly less than $1 \mathrm{dm}$. long, 1-2 cm. wide, lanceolate, long-tipped, deeply pinnatifid, pubeseent beneath, the segments ovate, obtuse or acute, entire, the lower pair somewhat larger than the others; veins free.

Pine-lands, coppices, sink-holes and marshes, Abaco, Andros, New Providence, Lignum Vitae Cay, Rose Island. Eleuthera, Cat Island, Acklin's Island, Watling's Island, Great Guina Cay, Great Exuma, North Caicos:-Florida; West Indies. Referred to D. patens by Dolley, by Mrs. Northrop and by Coker.

Dolley recolds a fern under the name Aspidlum incisum friseb.; this name applies to a West Indian Dryopteris not known to inhabit the Bahamas. The record may apply to one of the preceding species.

3. Dryopteris réptans (Gmel.) C. Chr. Ind. Fil. 288. 1905.

Polypodium reptans Gmel. Syst. 2: 1309. 1791.

Goniopteris reptans Presl, Tent. Pter. 182. 1836.

Phegopteris reptans D. C. Eaton, Bull. Torr. Club 10: 101. 1883.

Rootstoek short, ascending or erect. Leaves usually several, reclining or arehing, 2.5-9 dm. long, once pinnate, often rooting at the apex and sometimes along the rachis, the slender petioles mostly shorter than the blades; pinnae several or many, oblong to lanceolate, about $4 \mathrm{~cm}$. long or less, pubescent, obtuse or acute at the apex, subtruneate at the base, crenate, sessile or very nearly so; veins slender; sori commonly few, borne about midway between the midvein and the margin; indusia restigial or none.

In cares, and sink-holes in coppices, Abaco, Andros. New Providence, Eleuthera, Cat Island:-Florida: West Indies. Recorded by IIrs. Northrop as Dryopteris asplenioides Baker. WaLKIXg Wood-FerN.

4. Dryopteris cordàta (Fée) Urban, Symb. Ant. 4: 18. 1903.

Phegopteris cordata Fée, Gen. Fil. 241. 1850-52.

Aspidium reptans cordata Mett. Asp. 99. 1858.

Similar to $D$. reptans, but usually smaller, and with entire or merely undulate pinnae, and having the veins usually free.

In sink-holes in pine-lands, Andros:-Cuba : Porto Rico; recorded from Jamaica. Recorded by Mrs. Northrop as Goniopteris reptans cordata.

Dolley lecords a fern as Aspidium adiantifolium Sw., but there is no such published species. Schoepf's record of Polypodium pubcseens L. Was probably based on some species of Dryopteris.

\section{NEPHRÓLEPIS Schott, Gen. Fil. pl. 3. 1834.}

Leaves spreading or pendent, pinnate, elongated; pinnae numerous, approximate, jointed at the base, with whitish dots on the upper surface. Sori round, arising from the apex of the upper branch of a vein, usually near the margin. Veins free. [Greek, referring to the shape of the indusium.] About 12 species, natives of tropical and warm-temperate regions. Type speeies: Polypodium cxaltatum L.

Indusla renlform ; leaves $7-20 \mathrm{~cm}$. broad.

Indusia olbicular; leaves $20-10 \mathrm{~cm}$. broad.

1. N. craltata.

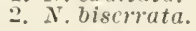

1. Nephrolepis exaltàta (L.) Schott, Gen. Fil. under pl. 3. 1834.

Polypodium cxaltatum L. Syst. ed. 10, 1326. 1759.

Petioles $7-15 \mathrm{~cm}$. long; leaf-blades $1 \mathrm{~m}$. long or less. Pinnae sessile, lanceolate, sometimes erenulate, $2.5-8 \mathrm{~cm}$. long, the upper side auricled at the base, the lower rounded, the rachis nearly naked; sori almost marginal, covered with firm distinetly reniform indusia.

In a cave, Fast Caicos:- Termuda: Florida: West Indies ; continental tropleal Amerlea; Old world tloples. Sword-rexi. Bostox Feis. 
2. Nephrolepis biserràta (Sw.) Schott, Gen. Fil. under pl. 3. 1834.

Polypodium biserratum Sw. in Schrad. Journ. Bot. 1800²: 32. 1801.

Similar to the preceding species, the petioles $10-20 \mathrm{~cm}$. long, the leafblarles up to $1.2 \mathrm{~m}$. long. Pinnae lanceolate, sessile, acute or acuminate, serrulate, crenulate or entire, $10-20 \mathrm{~cm}$. long, $10-18 \mathrm{~mm}$. wide, the base subtruncate or auricled on the upper side, rounded on the lower; sori close to the margin, the indusia nearly orbicular.

In a care, East Caicos, with the preceding species:-Florida; West Indies; Central America. SWORD FERx.

\section{Family 2. SCHIZAEÀCEAE Reichenb.}

Ferns of various habit, with simple or pinnate leaves. Sporanges borne in spikes or panicles, on modified leaves or leaf-segments, oroid, sessile. provided with an apical ring, opening vertically by a longitudinal slit. Several genera and about 100 species, mainly tropical.

\section{ANÈMTA Sw. Syn. Fil. 6, 155. 1806.}

Small to medium-sized ferns, mostly with horizontal or creeping rootstocks, the leaves distichous or tufted, pinnatifid or decompound, often dimorphous (the sterile ones quite different from those bearing sporanges). Venation mostly free. Sporanges borne in a single row on the margins of the ultimate segments of fertile pinnae, with or without an indusium. [Greek, wind.] Thirty species or more, of tropical and subtropical America. Type species: Anemia Phyllitidis L.

Leares wholly fertile or wholly sterile.

Segments of sterile leaf oborate, cuneate.

Segments of sterile leaf rhombic-orate or rhombic-oblong. only the basal segments of the leaf fertile.

1. A. Wrightii.

2. A. cicutaria.

3. A. adiantifolia.

1. Anemia Wríghtii Baker in Hook. \& Baker, Syn. Fil. 435. 1868.

Ornithopteris Trightii Millsp. Field Col. Mus. Bot. 3: 14. 1903.

Rootstock creeping, finely hairy. Leaves membraneous, dimorphous. Sterile leaves $5-12 \mathrm{~cm}$. long, with slender straw-colored stipes $3-7 \mathrm{~cm}$. long, the blade ovate or rhombic-orate in outline, $2-4 \mathrm{~cm}$. wide, sparingly pilose; pinnae 3 or 4 pairs, ascending, rather distant; ultimate leaf-segments obovate, cuneate, dentate or incised at the apex, or entire. Fertile leaves about twice as long as the sterile ones, their stipes much longer than the panicles of sporanges.

In a sink-hole, coppice near Fresh Creek, Andros:-Cuba, A little-collected plant, perhaps not specifically distinet from the following species. TrIGHT's AxEMlA.

2. Anemia cicutària Kunze; Spreng. Syst. 4 : 31.1834.

Anemia bipinnata Moore, Index Fil. cxvi. 1857.

Ornithopteris cicutaria Underm. Mem. Torr. Club 12: 15. 1902.

Rootstock short, densely brown-hairy. Leaves membranous, dimorphous. Sterile leaves $1.5 \mathrm{dm}$. long or less, the slender, straw-colored stipes about as long as the blades or shorter; blades deltoid-ovate in outline, 2-3-pinnate, with 3-7 pairs of pinnae, the ultimate segments rhombic-ovate or rhombic-oblong, dentate or incised above. Fertile leaves much longer than the sterile ones, their stipes longer than the panicles of sporanges.

In sink-holes, Abaco, Andros, New Providence :-Cuba ; Yucatan. Parsley Axemia. 
3. Anemia adiantifòlia (L.) Sr. Syn. Fil. 157. 1806.

Osmunda adiantifolia L. Sp. Pl. 1065. 1753.

Ornithopteris adiantifolia Bernh. Nenes Journ. Bot. Schrad. 1²: 50. 1506.

Rootstock ereeping, densely hairy. Leaves distichous, elose together, subcoriaceous, $1.5-8.5 \mathrm{dm}$. long, 2-1-pinnate, ovate to subpentagonal in outline, the straw-colored stipe usually as long as the blade or longer; pinnae several or numerous, the lower the longer, the ultimate segments commonly elose together, deltoid to oblong or ovate, obtuse or acutish, entire or few-toothed, 4-15 mm. long. Fertile leaf like the sterile, but the 2 lower pinnae transformed into panieles of sporanges, which are slender-stalked and ereet.

In sink-holes and in pine-lands. Abaco, Great Bahama, Andros, New Providence, Fleuthera, Cat Island:-Florida; West Indies; Central America; northern South America, MAIDEX-MIAIR AXEMIA.

\section{Order 2. SALVINIȦLES.}

Aquatic or uliginous herbs with entire or 2-lobed, filiform, or 4-foliolate leaves. Spores of two kinds and sizes (microspores and macrospores) contained in sporocarps.

\section{Family 1. MARSILEÀCEAE R. Br.}

Perennial herbaceous plants rooting in mud, with slender ereeping rootstocks and 2- or 4-foliolate or filiform leaves. Asexual propagation consisting of sporocarps borne on peduncles which rise from the rootstock near the leaf-stalk or are consolidated with it, containing both macrospores and microspores. The macrospores germinate into prothallia which bear archegonia, while the microspores grow into prothallia bearing antheridia. Three genera and some 45 species of wide distribution.

\section{MARś́lleA Sp. Pl. 1099. 1753.}

Narsh or aquatic plants, the leares commonly floating on the surface of shallow water, slender-petioled, 4-foliolate. Peduneles shorter than the petioles, arising from their bases or more or less adnate to them. Sporocarps oroid or bean-shaped, composed of two rertical valves with several transverse compartments (sori) in each valve. [Name in honor of Giovanni Marsigli, an Italian botanist, who died about 1804.] About 40 speeies, widely distributed. Type species: Marsilea quadrifolia L.

Leaflets obliquely linear-oblanceolate. Leaflets broady obovite-cuneate.
1. I. Nashii.

2. II. vestiti.

1. Marsilea Náshii Underwood, Bull. N. Y. Bot. Garı. 4: 137. 1906.

Plants forming compact dense mats in sandy soil. Stems short, slender, smooth or with a few appressed slender hairs, forming nodes at intervals of 3-10 mm.; leaves rising in elusters from short lateral branches; petioles filiform, $5-8 \mathrm{~cm}$. long; leaf-rivisions narrow, cutlass-shaped, 10-12 mm. long, 2 $\mathrm{mm}$. wide, sparsely covered with white appressed hairs; sporoearps abundant, solitary on short peduncles, compressed-oval, averaging $7 \times 4 \times 2 \mathrm{~mm}$., the raphe ending in a short, straight tooth with a second similar basal tooth $1 \mathrm{~mm}$. beyond, the surfaces coverel with appresserl hairs, becoming smoother with age; sporangia about 12 pairs, elongate-oval, $4 \mathrm{~mm}$. long by $1 \mathrm{~mm}$. thiek, the gelatinous stalk $2.4 \mathrm{~cm}$. long; maerospores about $\mathrm{S}-10$ in each sporangium, oval; microspores numerous, globose.

Smlth's Thatch Pond, Inagua. Endemic. Nasil's l'El'PEnWolrt. 
2. Marsilea vestita IIook. \& Grev. Tc. Fil. pl. 159. 1831.

Rootstock slender. Petioles slender, $5-13 \mathrm{~cm}$. high; leaflets entire or tootherl; sporocarps $4-8 \mathrm{~mm}$. long, $4-6 \mathrm{~mm}$. wide, with a short raphe, a short and blunt lower tooth and an acute and sometimes eurved upper one, densely covered with soft spreading narrow hair-like scales; sori 6-11 in cach valve.

Wet sandy soil. Acklin's lsland and South Caicos:-southern and western Inited States. The Bahama specimens are sterile and are referred to this species with doubt. HAIIY I'EPPERWOIT.

\section{Order 3. LYCOPODIÀLES.}

Spores produced in sporanges, which are borne in the axils of scalelike or elongated leaves.

Spores all alike.

spores of two kinds.
Fam. 1. Psilotaceae.

Fam. 2. Selaginellaceae.

\section{Family 1. PSILOTÀCEAE Pritzel.}

\section{Psilotum Family.}

Perennial slender terrestrial or epiphytic plants. Sporanges sessile in the axils of the leaves, 2-3-celled, opening by valves at the apex. Spores mniform. Only the following genus, and the monotypic Tmesipteris of Australasia.

1. PSILOTUM Sw. in Schrad. Journ. Bot. 1800²: 109. 1801.

Terrestrial or sometimes epiphytic, the stem dichotomously forked. Leaves alternate, reduced to scales. Sporanges 3 -celled, opening by 3 valves at the apex. Spores mealy, oval or elongated-reniform. [Greek, referring to the nearly naked stems and branches.] A few species of tropical and subtropical distribution, the following typical.

1. Psilotum nùdum (L.) Griseb. Veg. Kar. 130. 1857.

Lycopodium nudum L. Sp. Pl. 1100. 1753.

Psilotum triquetrum Sw. in Schrad Journ. Bot. 1800²: 109. 1801.

Stems erect, 2-3 dm. tall, or, when in caves or on trees, often pendent, 3 -angled at the base, copiously forked above, the nltimate divisions with 3 wing-like angles; leaves remote, awl-like, less than $2 \mathrm{~mm}$. long; sporanges in interrupted spikes.

On tree-trunks and in sink-holes. Abaco, New Providence, Andros, Cat Island, Great Exuma :-Florida; Bermuda; West Indies; continental tropical America and old World tropies. Psilotuar.

\section{Family 2. SELAGINELLÀCEAE Underw.}

Terrestrial, annual or perennial, moss-like plants with branching stems and scale-like leares, which are many-ranked and uniform, or 4-ranked and of two types spreading in two planes. Sporanges 1-celled, solitary in the axils of leaves which are so arranged as to form more or less quadrangular spikes, some containing 4 macrospores (macrosporanges), other's containing numerous microspores (microsporanges), which develop into small prothallia, those from the macrospores bearing archegones, those from the microspores antherids. The family consists of the following genus: 
1. SElaginÉlla Beauv. Prod. Aetheog. 101. 1805.

Characters of family. [Name diminutive of Selago, ancient name of a Lycopodium.] About 600 speeies, widely distributed, most abundant in tropieal regions.

1. Selaginella Eàtoni Hieron.; Small, Ferns Trop. Florida 67. 1918.

Pale green, matted, the slender branches prostrate, $1-4 \mathrm{~cm}$. long, creeping. Leaves in two planes, those of the lower plane ovate to elliptic, spreading, 1.5 $\mathrm{mm}$. long or less, abruptly acute or obtuse, sparingly setaceous-serrulate or entire; those of the upper plane somewhat smaller, lanceolate, acuminate, those subtending sporanges near the ends of the branches lanceolate or oratelanceolate, acuminate-aristate; macrospores tubereled, about $0.2 \mathrm{~mm}$. in diameter.

Moist shaded rocky situations, Abaco, Andros:-Florida. Eatox's SElagrelda.

\section{Phylum 3. BRYÓPHYTA.}

\section{MOSSES AND LIVERWORTS.}

Small plants, producing minute usually spherical bodies, called spores, in capsules, from which arise a protonema on which are borne the plants bearing archegonia and antheridia, from which the fruit is formed, which in turn bears spores.

There are two classes which differ from each other as follows:

Stems erect or prostrate, having leaves more or less equally developed on all sides; calyptra at the apex of the capsule.

Stems usually prostrite. with the leares, when present, unequally developed on the upper and lower surfaces; calyptra at the base of the capsulc. Class 1. MUSCI.

Class 2. IIEPATICAE.

\section{Class 1. MÚsCI.}

\section{Mosses.}

Contributed by Elizabeth G. Britton.

Terrestrial, epiphytic, or rarely aquatic plants, showing two distinctly marked but closely connected and continuous phases of growth, or alternate generations, usually having stem, leaves and rhizoids but not true roots; stems arising from a more or less ephemeral protonema, which originates from the spore, forming either a filamentous or thallose growth. Sexual organs borne either apically or laterally on the stem, usually in special buds; antheridia and archegonia on the same plant or on separate plants; antheridium containing ciliate sperms; archegonium a single egg, aftcr the fertilization of which the embryo develops into the fruit, rupturing the walls of the archegonium in its growth; the upper part of the archegonium is carried up by the elongation of the pedicel, forming the calyptra, which in many mosses envers and protects the capsule while it is developing. Capsule usually with a central axis forming 
the columelia, around which the spore-sac is developed, Msually separated from the walls by air-spaces and chlorophyl-bearing tissue. Capsule splitting regularly by a lid or slits, or breaking irregularly ; when regular, frequently developing teeth around the mouth, forming the peristome, which serves in the protecting and seattering of the spores.

\section{Order 1. BRYÀLES.}

Protonema usually filamentous; calyptra apical; pedicel more or less elongated, apical or lateral; capsule generally with a well-developed lid; peristome present or absent, neck usually with stomata.

A. Acrocarpous Mosses:-Main stems erect, simple or branching; capsules terminal on the stems.

1. Plants pale green, almost white, leaves often iridescent; vein wider than the blade of leaf, blade often lacking.

2. Plants bright or dark green; vein narrower than the bIade of leaf.

a. Leaves two-ranked, with the blades duplicated

Fam. 2. Fissidentacear.
b. Leares not two-ranked, blades not duplicated at base, more or less equilateral.

Fam. 1. Leucobryacese.

* Species onlr known from sterile specimens in the Bahamas. Propagating by gemmae or brood-bodies.

Brood-bodies borne in clusters at the summit of longer apical leares. Calymperes Richordi in Fam. 3. CALY MIPERACEAE. Brood-bodies borne on filaments in the axils of the upper leaves.

Hyophilu and Burbula in Fam. 4. Tortulaceas. Not propagating by gemmae or brood-bodies.

Costa thickened and spinose above, ending below the coarsely toothed. apex. Syrrhopodon Gaudiehaudii in Fam. 3. CaLrmpraceat. Costa thick but not spinose, ending below the minutely toothed apex. Desmatodon Garberi in Fam. 4. Tortulaceae. Costa not thickened nor spinose, ending in the mucronate apex. Trichostomum in Fam, 4. TORTULACEAE.

** Species usually fruiting.

$\dagger$ Peristome and annulus none.

Leaves papillose above with minute papillae.

Leares not papillose.

Hymcnostomum flacescens in Fam, 4. TORTULAcEAE.

Waeromitrium mucronifolium in Fa
t+ Peristome and usually the annulus present.

\$ Peristome single, annulus double.

Teeth erect, not twisted.

Gyroweisia Barbula in Fam. 4. Tontulaceae.

Teeth inclined, twisted 1-2 times.

țt Peristome double.

Tortula ayraria in Fam. 4. TORTulaceae.

Capsule erect, the lid beaked; teeth erect, not twisted, deeply inserted; annulus none.

Schlotheimia in Fam. 5. OrThotrichaceae. Capsule nodding, lid not beaked; annulus double.

1. Teeth oblique, with apical appendages and united to a disc.

Fam. 6. FUNARTACEAE.

2. Teeth erect, without appendages and not united at apex. Fam. 7. BRYACEAE.

B. Pleurocarpous Mosses:-Main stems procumbent; capsules terminal or lateral on the branches.

1. Fruit unknown in the Bahamas:

Plopagating by brood-bodies, borne in clusters in the axils of the leares.

Leaves minutely papillose, with small papillae terminal on each cell.

Margins revolute, entire, the vein ending below the apex.

Leucodontopsis in Fam. S. LEUCODONTACEAE,

Margins flat, serrulate, the vein ending at apex.

Pircella in Fam. 9. Neckeraceae.

Propagating by brittle terminal buds and slender branchlets; leaves papillose, with several central papillae on each cell.

Papillaria in Fam. 10. MeteoriaceaE.

2. Fruit on elongated, erect pedicels; peristome double.

a. Capsules erect and symmetric.

Stercophyllum in Fam. 11, Ex rodostaceat. 
b Cipsules horizontal or curred.

* Leares minutely papillose, on the back.

Papillae single and central on each cell.

Papillae single and terminal at the end of each cell. 12. LESKLACEAE. Hittchothamnium in Fam. 13. IIYPXACE.AE. Papillae sereral in a row in the middle of each cell.

Taxithclium in Fam. 13. IIrPsicede.

** Leaves not papillose, the cells smooth.

† Leares uniform and regular; alar cells enlarged.

Vein lacking or short and double.

Peristome teeth without deep Iamellae on the inner surface. Isopterygium in Fam. 13. IYPXACEAE.

Peristome teeth with deep lamellae, especially at base.

Sematophyllum in Fam. 14. Sematopirluaceat.

Vein single, ending in the middle of the leaf.

Amblystegium in Fam. 13. HYPNACEAE.

†† Leares of two kinds, the lateral shorter and broader alar cells not enlarged. Tesicularia in Fam. 13. Hrpxicese.

\section{Family 1. LEUCOBRYÀCEAE C. Muell.}

\section{White Moss Family.}

Plants perennial, growing in dense pale green cushions; stems medium to large, branching; sometimes fragile and breaking off (thus propagating asexually); leaves crowded, rein broad, filling most of the leaf, the green cells of the leaf smalt, in a single central band between several layer's of larger hyaline cells; blade very narrow, sometimes lacking. Pedicels erect, terminal; capsule erect or horizontal, regular or irregular; peristome single, teeth $\mathrm{S}$ or 16 ; lid beaked; calyptra cucullate. Nine genera and 229 species are known. (Named in reference to their pale green color.)

Leaves four times longer than wide, incurred, apex concare and lanceolate.

Leares ten times longer than wide, recurred, apex flat, oblongapiculate.

1. Leucobryum.

2. Octoblepharum.

1. LEUCOBRỸUM Hampe, Flora 20: 292. 1837.

Characters of the family. A genus of 121 species, widely distributed in temperate and tropical regions. [Greek, in reference to the pale color of the plants.] Type species: Leucobryum glaucum (L.) Schimp.

1. Leucobryum álbidum (Brid.) Lindb. Oefv. Sr. Vet. Akad. Forh. 20: 403. 1863.

Dicranum albidum Brid. Musc. Ree. $2^{1}$ : 167. 1798.

Leucobryum glaucum albidum Cardot, Rev. Bryol. 38: 80. 1911.

Plants in dense, pale green eushions, seldom more than $3 \mathrm{~cm}$. high; stens erowded with branches; leares numerous at the ends of the branches, ineurved and eoneave when dry, spreading when moist from the base to a narrower concare point, 2-4 mm. long, ending in a sharp apex, the basal blades short, forming a narrow, colorless border of $3-\pi$ rows of cells; the vein eomposed of $2-4$ layers of large hexagonal clear cells with a central band of small green quadrandular cells. [Capsule terminal, on a slender pedicel, eurved and furrowed when dry; lid beakerl; teeth split to the middle; calyptra eucullate.]

only found once, sterlle, growlug on rotten wood and logs in conpices, Conch Sound, Andros, New Jersey to Floridia and Lonlsiana:-Cuba; IIlspaniola; Mexico and Guntemala. WHITE IIOSS. 


\section{OCTOBLÉphaRUM Hedw. Deser, 3: 15. 1791.}

Plants growing in loose or compact pale-green tufts, with dense branching stems. Leaves crowled at the ends of the branches, usually concave with a broader base and a narrow tapering apex, composed mostly of the broad thick costa which contains a central row of small green triangular cells, and several layers of hyaline cells above and below; the blade of the leaf is reduced to a few narrow hyaline cells on the basal margins or lacking. Pedicel short; capsule erect, symmetric, smooth; peristome single, of 8 or 16 lanceolate teeth; lid beaked; calyptra cucullate. [Greek, in reference to the 8 teeth.] Eighteen species have been described, mostly from tropical regions, the following typical.

1. Octoblepharum álbidum (L.) Hedw. Descr. 3: 15. 1791.

Bryum albidum L. Sp. Pl. 1118. 1753.

Plants in loose, pale yellowish-green cushions; stems brittle; leaves iridescent, often broken and recurved when dry, up to $6 \mathrm{~mm}$. long by $0.5 \mathrm{~mm}$. wide; tip flat, longer than the base, ending abruptly in a cuspidate apex. Autoicous. Seta erect, $\check{-}-7 \mathrm{~mm}$. long; capsule straight, smooth, 1-1.5 mm. long, narrowing to the mouth; teeth 8 , entire or perforate; lid beaked; spores rough.

On rotten wood and stumps or on palmetto, common in coppices of New Proridence [type locality], Andros, Cat Island, Eleuthera and Crooked Island :-Florida and the Trest Indies. Widely distributed in tropical regions of both hemispheres. RAINBOW-MIOSS.

\section{Family 2. FISSIDENTÁCEAE Bruch \& Schimp.}

\section{Fissidens Family.}

Small plants, usually growing in moist shady places, on earth or stones. Stems erect or decumbent, simple or sparingly branched; leares few, always two-ranked and conduplicate, clasping at base, with a single rein and with an apical and dorsal prolongation of the blade especially in the upper leaves, except in Sorapilla. Pedicel terminal at apex of stems or on lateral buds; capsule ovoid or cylindric, straight or curved; calyptra cucullate; lid conic, often beaked, peristome red, single, of 16 entire or bifid teeth, often thickened at joints and either papillose or spiral at apex. A large family of 4 genera, containing some 570 species, abundant in temperate and tropical regions.

\section{FÍSSIDENS Hedw. Fund. 2: 91.1782.}

Plants scattered or crowded into dense cushions. Stems becoming decumbent when old, with apical or rarely lateral branches; leaves with duplicate basal blades present, the apical and dorsal blades sometimes lacking or reduced in size in the lower leaves or in the bracts of the inflorescence; pedicels always exserted, often bent or curved; capsules erect, inclined or rarely curved; walls often thickened with collenchyma cells around the mouth, also the base of the lid; annulus small, often fugacious or lacking; peristome deeply inserted; teeth bifid, usually bright red and forking, with long slender apical divisions, generally quite different from the basal segments of the teeth and often suddenly bent at a sharp angle. [Latin, in reference to the split teeth.] A large genus 
of about 125 species, widely listributed in temperate and tropical regions. Type species: Hypnum bryoides $\mathrm{L}$.

Leaves entire, bordered all aromd, cells smooth.

Leares serrate, bordered only at base of duplicate blade of uppermost Ieaves; cells papillose.

Leares not bordered, margins serrate, cells mamillose.

1. F. monandrus.

2. F. Garberi.

3. F. radicans.

1. Fissidens monándrus Mitt. Journ. Linn. Soc. 12: 598. 1869.

Plants small, pale-green, erect or decumbent; seldom more than 2-5 $\mathrm{mm}$. high; leaves $4-\tau$ pairs, palmately spreading, and increasing in size upward to $2 \mathrm{~mm}$. long by $0.33 \mathrm{~mm}$. wide, overlapping and narrow at base; margins bordered all around; costa pereurrent; cells smooth, somewhat oblique and hexagonal, those of the lower blades larger at base. Autoicous. Pedicel erect, bent at base, 3 to $4 \mathrm{~mm}$. high; capsule straight, seldom more than $1 \mathrm{~mm}$. long; peristome red, paler and spiral at apex; lid beaked; calyptra small; spores smiooth.

Only known from one collection from a sink-hole, Farringdon Road, New Providence:--Florida; Cuba and the West Indies to South America. Dinisutive Fissidexs.

2. Fissidens Gàrberi Lesq. \& James, Proc. Am. Acad. Arts \& Sci. 14: 137. 1879.

Plants minute. Stems simple, seldom more than 2-3 mm. high, erect or decumbent; leaves 4-S pairs, most numerous on the sterile plants, usually all unbordered, except the two uppermost leaves of the fruiting plants which are longer and narrower than the others; vein ending in the acute apex; margins minutely serrate, with acute or truncate teeth; cells dense, with 2-4 small papillae, basal cells larger, papillose only on the outer surface; perichactial leares bordered only at the base by an obscure border of $1-3$ rows of cells. Dioicious. Pedicel terminal, erect, short, 1-2 mm.; capsule small, 0.6 to 1 mm. straight; lid beaked; teeth spirally thickened at apex; spores smooth.

On rotten wood and rocks in sink-holes, coppices on Farringdon Road, New Proridence :-Florida; Louisiana; West Indies and South America. GarBer's FissIDEXS.

\section{Fissidens radicans Mont. Ann. Sei. Nat. (II.) 14: 345. 1840 .}

Plants in dense, bright-green cushions. Stems decumbent and recurved when dry, rarely erect or simple, branching repeatedly, rarely more than $1 \mathrm{~cm}$. high; leaves circinate, often brittle and broken off, 5-10 or rarely 20 pairs, up to $1.5 \mathrm{~mm}$. long by $0.33 \mathrm{~mm}$. wide; vein ending below the acute apex; cells swollen, mamillose on both surfaces above, and only on the outer below. Autoicous; antheridial buds sometimes numerous on the fruiting plants. Pedicel slender, erect, 3-4 mm. long; capsule up to $1 \mathrm{~mm}$.; lid beaked; ealyptra small, apical; teeth papillose and spiral at apex; spores smooth.

On rotten wood in conpices, New I'rovidence and Abaco:-Florida and the West Indies to continental tropical America. Ravicaxt Fissidexs.

\section{Family 3. CALYMPERÀCEAE C. Muell.}

\section{Calymperes Family.}

Plants usually growing in dense dark green eushions on trees in shade, seldom fruiting but often propagating by brood-bodies, growing in elusters from the tips of specially modified leaves. Stems mostly ereet and sparingly branched. Leaves often crowded at the ends of the branches, erect or spreading, broad and clasping at base, lancenlate or contracted into a spathulate apex; margins entire or serrate, often with a band of elongated 
submarginal cells, basal cells large, clear, smooth, rectangular; upper cells small, round, often papillose. Pedicel terminal, erect usually exserted; calyptra campanulate or cucullate; lid long-beaked; peristome single of 16 short teeth or lacking. A family of mostly tropical mosses, containing 2 genera and about 313 species.

Leares with a sub-marginal border of long narrow cells on the hyaline batse.

Leares with a thickened or hraline margin at base, which is often coarsely serrate or donble above.

1. Calymiperes.

2. Syrrhopodon.

\section{CALYMPÉRES Sw.; Schwaegr. Suppl. 1²: 333. 1816.}

Plants in dense mats; stems crowded, simple or branching; leares curled and twisted when dry, base hyaline, often white and broader than the point, the upper leaves often contracted into a narrow apex, bearing brood-bodies, which serve to propagate the plants when sterile. Dioicous. Calyptra large, corering the capsule, spirally ribbed and often rough at apex; lid beaked; peristome and annulus lacking. [Named in reference to the large calyptra.] About 200 species of tropical distribution. Type species: Calymperes lonchophyllum Schraegr.

\section{Calymperes Richárdi C. Muell. Syn. I, 524. 1849.}

Plants crowded in dark green mats, showing the white hyaline base of the leares when dry; leares up to $3.5 \mathrm{~mm}$. long, orate-lanceolate, tapering to a blunt point; vein stout, ending below the apex, papillose on both surfaces abore; submarginal border of 2-3 rows of cells, extending to apex, not distinct in the hyaline base; margins serrulate above. Dioicous. [Seta short, slightly exserted; calyptra spirally ribbed $2 \mathrm{~mm}$. long, persistent and clasping at base, split abore; capsule ovoid, cylindric; peristome and annulus none; lid conicbeaked.]

Only known sterile. On stumps in coppice, New Proridence, Andros, Abaco and Rerr, Islands, Great Harbor Cay:-Florida; West Indies to tropical South America. Richard's CaLYMIPERES.

\section{SYRRHÓPODON Schwaegr. Suppl. 2²: 110. 1824.}

Plants growing in dense mats, frequently sterile and propagating by brood-bodies. Stems erowded, simple or branching; leaves curled and twisted when dry, crowded at the tips of the branches, with the upper part of the blade dense and often papillose, the lower part lax and translucent with large reetanguar cells, the margins of thickened or of a double layer of cells, often coarsely toothed; capsule erect, on a short terminal pedicel; peristome usually present, single; teeth usually entire and papillose; lid beaked; calyptra cucullate, rough or smooth at apex. [Greek, in reference to the united teeth of the peristome.] About 215 described species, tropical and subtropical. Type species: Syrrhopodon Gardneri Hook.

\section{Syrrhopodon Gaudichaùdii Mont. Ann. Sci. Nat. II, 2: 376. pl. 16. 1 S34.}

Plants pale yellowish-green, with the white bases of the leaves very conspicuous. Stems simple or with short crowded branches; leaves curled and twisted at apex, about $2 \mathrm{~mm}$. long; base with 5-6 rows of large rectangular hyaline cells on each side of the vein and the margins bordered by narrower 
eells; upper part of leaf with small green, obscure and papillose cells, extending a short distanee down each side of the hyaline base; margins above with a narrow pale border of $2-3$ rows of elongated smooth elear cells, mostly entire except at the spinosely toothed apex; costa also spinose on back toward the apex. Dioicous. [Seta slender, about $5 \mathrm{~mm}$. long; eapsule narrow, about 2 mm. long with a slender beaked lid; ealyptra cucullate, its tip rough; teeth narrom.]

Only a few small sterile plants found at Nicholl's Town, Andros:-Cuba; Jamaica: I'orto Rico and Guadeloupe to Brazil. Gatdichacd's srrmilopodox.

\section{Family 4. TORTULÀCEAE Lindb.}

\section{Tortula Family.}

Plants scattered or crowded into tufts. sometimes minute and ephemeral, with indehiscent capsules. Stems simple or branched; leares usually crowded, sometimes forming rosettes at the apex of the stems, generally twisted when dry. lanceolate or oblong and hyaline at base often with a broader and denser apex; rein single, stout usually pereurrent or sometimes excurrent into an awn; margins frequently recurved, entire, crenulate, or rarely sermulate; cells longer and smooth at base, smaller and denser or papillose at apex. Heteroicous. Pedicel terminal, more or less exserted and erect; capsule erect or inclined; peristome rarely double or lacking. usually single, of 16 narrow, often bifid teeth, sometimes long and twisted with a more or less exserted basal membrane; lid conic or beaked; calyptra cucullate; spores small. A large family of 46 genera and about 400 species widely distributed in all parts of the world. Sometimes called PotTiaceae.

A. Fruit on elongated erect pedicels : capsules erect.

Pelistome single; annulus double.

Teeth oblique, twisted once or twice. 1. Tortula.

Teeth erect, not twisted.

Peristome and annulus none.

B. Fruit unknown in the Bahamas. Propagating by brood-

bodies. borne in the axils of the npper leaves. or the brood-bodies unknown.

Cpper cells of leaves mamillose on upper surface only. Costa stout, ending below the denticulate apex. Costa tapering to the acuminate apex.

Cpper cells of leaves Dapillose on both surfaces. Margins flat or revolute at base, denticulate at apex. Ilargins inrolled, entire.

2. Guroweisia.

3. Hymenostomum.

4. Hyophila.

5. Desmatudon.

6. Barbula.

т. Trichestomum.

\section{Tórtula Hedw. Fund. Musc. 2: 92. 17 S2.}

Plants of various sizes, sometimes large and stout; usually growing on the grounil or on roeks, seattered or in cushions. Stems usually simple, rarely branched; with the leaves often erowded in a rosette at the top of the stem, usually spreading when dry, or tiristed, mostly broader above the midde; margins usually entire; rein single, sometimes exeurent into an awn; basal cells long, elear and smooth, the upper small ami ilense, generally papillose. Pedicel erect, elongate; capsule erect, eylindrie; lid usually long-beaked; calyptra cucullate; peristome single, usually twisted, arising from a basal membrane; teeth 16 or 32 , slenter, papillose; spores small. [Latin, with referenee to the twistel peristome.] A large genus of 156 species widely distributed in all parts of the worlil. Type speeies: Bryum murale L. 
1. Tortula agrària Sw. Fl. Inıl. Oec. 3: 1763. 1506.

Barbula agraria Hedw. Muse. Frond. 3: 17. pl. 6. 1792.

Plants almost stemless, forming a rosette of basal leaves, not much curled or twisted when dry. Leaves widest above the middle; base oblong, with long, elear, smooth cells; upper cells square, mamillose on the inner surface, smooth on the outer; apex acute; vein stout, ending in a mucronate tip; margins flat, entire or denticulate. Dioicons. Pediccl erect; capsule cylindric, ribbed when dry; annulus double; lid long-beaked, red at base; peristome red, papillose, twisted; teeth 16, long and slender, bifid or trifid with a short basal membrane; calyptra cucullate; spores smooth, small, maturing in spring.

One of the most common and widely distributed species, on limestone rocks, New Providence, Abaco, Great Exuma, Great Bahama, Cat Cav, Andros and Berry Islands, Watling's and Acklin's Islands, Crooked Island and Fortune Island:-Florida and the West Indies; Mexico and South America. Commox Tontula.

\section{GYROWEİSIA Schimp. Syn. (2d ed.) 38. 1876.}

Plants small, usually growing in depressions of limestone rocks or on old walls in dark green patches, discolored and matted together by fresh-water algae, stems short or acaulescent; leares dark green, inrolled and twisted when dry, spreading in a rosette when moist, oblong-lingulate, tip acute or obtuse, the vein ending below the apex; margins flat, crenulate or obscurely toothed at apex; lower cells very thin and longer than the rounded and swollen cells of the apical blade. Dioicous. Pedicel short, erect, terminal; capsule narrow, cylindric; peristome simple, of 16 bifid, jointed and papillose teeth; lid beaked; calyptra cueullate. [Greek, in reference to the large annulus.] A small genus of 14 species, mostly in hilly regions. Type speeies: Gymnostomum tenue Schrad.

1. Gyroweisia Bárbula (Schwaegr.) Paris, Index Bryol. ed. 2: 2: 299.1904.

Gymnostomum Barbula Schwaegr. Supp. 2²: 77. pl. 175. 1826.

-Plants small, in dark green obscure mats, often sterile and acaulescent; leaves few, recurved, forming a rosette, linear-oblong, about $2 \mathrm{~mm}$. long by $0.25 \mathrm{~mm}$. wide, usually obtuse and cucullate, sometimes acute; margins erenulate-toothed, often more coarsely and irregularly so at apex; vein ending below the apex; upper cells rounded and swollen, basal cells longer, very thin and clear on the margins; pedicel short, $4-8 \mathrm{~mm}$., rarely $1 \mathrm{~cm}$; eapsule dark when old, erect, up to $2 \mathrm{~mm}$. long, narrowly cylindric, month small; annulus double; calyptra, lid, annulus and peristome often falling off all together; peristome slightly twisted; teeth 16 , brittle, bifid, with $5-6$ basal joints, densely papillose when mature; spores brown, small; ripe in spring; calyptra cucullate.

On rocks and old walls, New Providence and Abaco:-Florida; Bermuda ; Cuba; Jamaica; Porto Rico; Brazil. BLACK-Frulted GromeIsis.

3. HYMenostomum R. Br. Trans, Linn. Soc. 12: 572. 1818.

Plants terrestrial, gregarious. Stems short and simple. Leares crowded, much curled and twisted when dry, linear-lanceolate; margins entire, inrolled; vein stout, ending in the mucronate apex; cells small and papillose in the upper part of blade, lower ones oblong and smooth. Pedicel erect, mostly exserted; capsule eylindric, straight or bent; lid large, beak short; calyptra cueullate; peristome and annulus absent; mouth closed by a membrane until the spores 
are ripe. [The name refers to this character.] A small genus of 45 species widely distributed in temperate and tropical regions. Type species: Gymncstomum.microstomum Hedw.

\section{Hymenostomum flavéscens E. G. Britton, sp. nov.}

Plants usually light yellowish-green. Stens short, $3-5 \mathrm{~mm}$. high; leaves 1.5-2 mm. long; apex lanceolate, incurred and eucullate, base broader and hyaline; margins inrolled, entire; vein stout, rough above, ending in the mucronate point; lower cells clear and smooth, up to $67 \mu$ long; upper cells only $8 \mu$ long, densely papillose on both surfaces, with 3-4 small papillae. Dioicons. Pedicel slender, 10-15 nm. long, erect; capsule ovoid-cylindric, 1-1.25 mm. long with the beaked lid; calyptra cucullate, twisted; peristome and annulus none, the mouth bordered by $5-6$ rows of smaller, denser, quadrate cells; walls thin; spores brown, papillose, ripe in winter.

New Providence, Eleuthera, Andros, Great Bahama, Abaco and Acklin's Island. Trpe from Pinder's Point, Great Bahama, Britton and Hillspaugh 2.515. Feb., 1905. BAHAMA IIYMEXOSTOMUM.

\section{HYOPHILA Brid. Bryol. Univ. 1: 760. 1826.}

Plants dark green, frequently sterile and propagating by brood-bodies borne at the apex of the stems. Leaves linear-lanceolate or oblanceolate, not very crowded; apex obtuse or acute, entire or with a few obscure teeth; vein ending in or below the apex, rarely excurrent; basal cells clear, rectangular, upper cells smaller and papillose, rarely smooth. Dioicous. Pedicel exserted, slender; capsule erect, narrow, cylindric; mouth small; annulus usually present; peristome none; lid beaked; calyptra cucullate. [Greek, referring to their moisture-loving habit.] A genus of about 80 species, occurring in tropical regions, widely distributed. Type species: IIyophila gymnostomoides Brid.

1. Hyophila Tórtula (Schraegr.) Hampe, Bot. Zeit. 4: 267. 1846.

Gymnostomum Tortula Schwaegr. Supp. 2²: 78. pl. 175. 1826.

Tortula Donnellii Austin, Bot. Gaz. 3: 31. 1878.

Barbula Donnellii Lesq. \& James, Man. 128. 1854.

Plants often growing on rocks in seattered, low eushions, usnally sterile; stems short and simple; leaves inrolled and twisted when dry, up to $2 \mathrm{~mm}$. long by $0.5 \mathrm{~mm}$. broad, lanceolate; vein stout, brown, ending in the cuspidate apex, smooth or slightly rough on the back; basal cells smooth, oblong, upper cells in transverse rows, hexagonal, mamillose on the inner surface, smooth on the back; margins sometimes denticulate at apex. Dioicous. Only known sterile, in the Bahamas, propagating by brood-bodies borne on filaments from the axils of the upper leaves. [Pedicel $8-10 \mathrm{~mm}$. long, erect; capsule $2 \mathrm{~mm}$. long, cylindric; mouth bordered by smaller, darker cells; annulus compound, falling with the beaker lid; peristome none; calyptra cucullate and slightly twisted; spores smooth, small.]

New Providence and Abaco:-Florida; West Indies; Mexico; Guntemala and South America. IIYorills.

\section{DESMÁtodon Brid. Mant. Musc. S6. 1819.}

Plants usually in cushions on limestone rocks or in exerices of walls. Stems erect, usually short and simple or forking. Leaves crowded, incurved and twisted when dry, spreading when moist, oblong-lanceolate; apex acute or 
obtuse; margins entire or serrulate, flat or recurved, sometimes bordered; costa ending below the apex, pereurrent or excurrent into a slender awn, papillose on both surfaces; upper cells smooth or papillose; lower eclls longer and smooth. MIonoicous or dioicous. Pedicel ereet; eapsules ereet or nodding, ovoid or cylindric; annulus present; peristome single, of 16 short, erect or slightly twisted, papillose, teeth united at base, with a short exserted basal membrane; lid short, conic-beaked; cells oblong; calyptra cucullate; spores rough or smooth. [Latin, in reference to the basal union of the teeth.] A small genus of ahout 12 species, varying in habit and distribution. Type species: Discranum latifolium $\mathrm{Hedw}$.

\section{Desmatodon Gárberi Lesq. \& James, Man. 112. 1884.}

Plants in dense round eushious, usually fruiting abundantly. Stews simple, up to $1 \mathrm{~cm}$. high with the leaves much twisted when dry and spreading wheu moist, more crowded at apex of stems, only about $1 \mathrm{~mm}$. long; margins incurved, entire. crenulate or slightly toothed at apex; rein stout, smooth, ending below the point or pereurrent into the euspidate apex; upper cells irregular, rounded, and projecting on the inner surface, smooth on the back, lower cells larger, clear, oblong and smooth. Dioicous. [Thus far only found sterile associated with Tortula agraria; but the type specimens from Key West, show an erect pedicel, about $5 \mathrm{~mm}$. long; the calyptra cucullate; the capsule, with the beaked lid, about $2 \mathrm{~mm}$. long, brick-red, eylindric, the narrow annulus falling in fragments with the lid; peristome short, deeply inserted; the teeth papillose, fragile and broken, irregularly split and jointed, with no risible basal menbrane; spores smooth, pale, ripe in winter.]

On limestone rocks in coppice, New Providence:-Key West, Florida; Yucatan. Garber's DeSMATODOX.

\section{BÁRBUla Hedw. Fund. Muse. 2: 92.1782.}

Plants usually a dirty greeu or brown color, often growing in muddy places. Stems slender and sparingly branched. Leaves erowded, usually small and narrowly lanceolate, keeled; margins recurved, seldom flat; vein stout, percurrent, rarely excurrent; cells of the upper part of the leaf dense, papillose on both surfaces; basal cells larger, rectangular and nearly or quite smooth. Dioicous: if sterile often propagating by brood-bodies. Pedicel erect, terminal; lid conic or beaked; calyptra cucullate; capsule usually erect, cylindric; annulus sometimes present; peristome rarely lacking, usually inserted below the rim of the capsule, of 32 slender, twisted, papillose teeth, united by a short basal membrane; spores small. [Latin, diminutive of barba, beard, referring to the peristome.] A large genus of 234 species, widely distributed in temperate and subtropical regions. Type species: Bryum unguiculatum Hudson.

\section{Barbula Crùgeri Sonder; C. Muell. Syn. Muse. 1: 618. 1849.}

Plants small, in dark brown patches on damp rocks. Stems slender, seldom more than $2 \mathrm{~cm}$. high; leaves curled and twisted when dry, spreadiug when moist, abont $1 \mathrm{~mm}$. long; base oblong, with thin rectangular cells; apex keeled; upper cells minute, dense and papillose; vein stout at base, rough on the back and ending abruptly in the cuspidate apex; margins flat or revolute, entire or rarely denticulate at apex. It has only been found sterile in the Bahamas, but propagates by elub-shaped brood-bodies borne in clusters, in the axils of the 
leaves. [Dioicous. Pedicels erect, about $1 \mathrm{~cm}$. long, twisted when dry; capsules up to $1 \mathrm{~mm}$., erect, cylindric; lid beaked; calyptra cucullate, rough at apex; peristome red, twisted; teeth slender, bifid and papillose, with a short basal membrane; annulus none; spores smooth, small, ripening in summer.]

On wet rocks in quarry at Nassau :-Florida; Louisiana; Cuba; Jamaica; Porto lico to Trinidad and south America. CRegen:'s MAmBLLA.

7. TRICHÓsTOMUM Hedw. Fund. 2: 90.1782.

Plants medium-sized, usually crowded. Stems erect, simple or branched. Leares curled and twisted when dry, larger at base than above, with a narrow sharp apex; margins flat or inrolled, entire; vein single, usually percurrent; basal cells oblong and clear; upper cells denser, small and papillose on both surfaces. Pedicel erect, elongate; capsule erect, cylindric; peristome single; teeth 16, either entire or divided to base, usually papillose; lid conic-beaked; calyptra cucullate. [Greek, in reference to the narrow teeth.] Widely distributed in various temperate and tropical regions. Type species: Weisia cylindrica Bruch.

\section{Trichostomum rivàle (Mitt.) Jacg. Adumb. 1: 245. 18i1-ĩ.}

Tortula rivalis Mitt. Journ. Linn. Soc. 12: 147. 1869.

Plants in dense bright green or yellowish cushions. Stems up to 5-10 mm. high, usually simple; leaves crowded, curled and twisted when dry, $2-3 \mathrm{~mm}$. long, base erect, clasping, the tips narrower and spreading when moist; vein smooth, excurrent into the mucronate apex; nargins entire, incurved above the middle; basal cells lax with longer cells on the margins, extending up the blade to the papillose cells of the tip; upper cells densely papillose on both surfaces. Only found sterile in the Bahamas. Dioicous. [Pedicel yellow, erect, 15-20 mm. long; capsule 2-3 mm. long, erect, eylindric; calyptra cucullate; lid conic-beaked; peristome single, of 16 slender, erect or slightly twisterl, papillose, bifid teeth, often disappearing and leaving only a ragged membrane; spores rough, brown, maturing in spring.] Very closely related to Trichostomum jamaicense Mitt.

On rocks and in pine-barrens, Iarsh Harbol, Abaco:-Cubat; Jamaica and Forto Ríco. Rock TrichostouUM.

Some poor sterile specimens of a Trirhostomum were collected in New Iroridence, by L. J. K. Brace, in June, 1918, Number 95ug. The leaves are less papillose than in $T$. ricule and the plants may represent another species, $T$. inrolutum Sull.

\section{Family 5. ORTHOTRICHĀCEAE Bruch \& Sehimper.}

\section{Orthotrichuar Family.}

Plants growing in dense dark green mats. Stems ereet or ereeping, often branching and interlacing; branehes short, ereet, densely leafy. Leaves enrled and twisted when dry, erowded, laneenlate or oblong; costa single, pereurent or expurrent into a mueronate tip; eells dense, small, obscure, smooth or papillose, basal often longer and smooth. Pedieel short, terminal; calyptra large, eampanulate, plieate and lacerate at base, smooth, hairy, or rough at apex; lid nsually beaked; eapsule smooth or ribbed; peristome single or double, seldom lacking. Twelve genera and S2t speeies, widely distributed. 


\section{MACROMITRIUM Brid. Mant. Muse. 132. 1819.}

Plants in dense dark mats, usually on trees. Stems ereeping with erect branches; leaves crowded and usually twisted when dry; vein single, pereurrent or excurrent, rarely ending below the apex; margins entire or rarely toothed at apex, not bordered, except occasionally at base; cells small and dense in the upper part of the leaf smooth or papillose, larger and clearer below. Pedicel exserted or rarely immersed, terminal; eapsule erect, ovoid, urn-shaped or cylindric; lid beaked; calyptra campanulate and lacerate at base, smooth or hairy. [Greek, in reference to the large calyptra.] A large genus of 385 species, common in tropical regions of both hemispheres. Type species: Schlotheimia acicularis Brid.

1. Macromitrium mucronifòlium (Hook. et Grev.) Schwaegr. Supp. 2²: 61 . pl. 170.1826.

Orthotrichum mucronifolium Hook, et Grev.; Brewst. Edinb. Jour. 1: 116. pl. 4. 1824.

Plants in dense dark green mats. Stems ereeping and matted together by a brown felt of rhizoids, the branches erect, short, seldon more than $2-3 \mathrm{~mm}$. high; leaves spirally twisted when dry, spreading when moist, crowded and numerous, earinate, oblong; apex blunt or sometimes notched; vein ending in a short cuspidate tip; upper cells dense, small, opaque, with thickened swollen walls; base bordered by 3-4 rows of longer and clearer cells. Pedicels erect, about $5 \mathrm{~mm}$. long; capsule about $1 \mathrm{~mm}$., ovoid and tapering at base, with a long neck, slightly ribbed when old; calyptra covering the capsule, ribbed but not hairy; lid beaked; peristome and annulus none; spores nearly smooth.

On trees in coppices, Andros and Abaco:-Florida and the West Indies to tropical South America. MUCrosate Macrojitriuj.

2. SCHLOTHEIMIA Brid. Sp. Muse. 2: 16. 1812.

Plants in dense dark mats, usually on trees. Stems ereeping, with numerous crowded and usually short simple branches. Leaves crowded, erect or spreading, often spirally twisted when dry; rein single, stout, percurrent or excurrent; margins usually entire and not bordered; upper cells much thickened, usually oblique, smooth or rarely papillose, the lower rectangular, less thickened and rertical, smooth. Pedicel exserted or immersed, terminal on the branches; capsule ovoid or cylindric; peristome double, the inner shorter than the outer, often rudimentary; lid beaked; ealyptra not ribbed, usually lobed at base, sometimes hairy. [Named for Ernest Schlotheim.] A genus of about 120 species, mostly tropical or subtropical. Type species: Hypnum torquatum Hedw.

1. Schlotheimia Sullivántii C. Muell. Syn. Musc. 1: 756.1849.

Plants in dense wide dark green or brown mats. Stems creeping and densely hairy with brown radicles; branches short, erect, crowded; leaves also densely crowded, 1-1.5 $\mathrm{mm}$. long, oblong-lanceolate; apex blunt; vein ending in a short abrupt tip; upper part of the leaf undulate, the cells thickened and hexagonal, those of the lower part elearer, oblong, not bordered. Pedicel erect, about $5 \mathrm{~mm}$. high; capsule 2-3 mm. long, cylindric, smooth or ribbed when dry; peristome double, deeply inserted, rim of 7-8 rows of cells, annulus none; the outer teeth recurved and papillose, longer than the inner ones; lid 
beaked; calyptra glossy, yellow or brown, deeply lobed at base, rough at apex; spores large and rough.

On trees and decaying wood In coppice, New Providence:-Florida and Louisiana. SulliviNt's Schlothieinia.

\section{Family 6. FUNARIÀCEAE C. Muell.}

Funaria Family.

Plants usually ammal, seldom biemial, sometimes ephemeral and minnte or rudimentary. Stems short, erect and seldom branched. Leares small and narrow, or large and broad; margins entire or toothed; vein present or rarely absent. Pedicel short and immersed, or long and exserted; capsule erect or inclined, symmetric or asymmetric, ovoid or pyriform; annulus large and conspicuous. or undeveloped; calyptra cucullate, often inflated and oblique, rarely lobed or papillose; peristome absent, rudimentary or double, its teeth straight or oblique. A family of wide distribution, including about 12 genera with some 244 species.

\section{FUNÀRIA Schreb.; L. Gen. Plant. ed. 8, 2: 760. 1791.}

Plants usually scattered, rarely crowded. Stems short, simple. Leares crowded at the summit, usually broadest above the base, entire or serrate; rein ending below the apex, percurrent or excurrent. Pedicel exserted, elongated; capsule erect or nodding, often pear-shaped; lid flat or apiculate; calyptra much inflated at base, beaked; peristome single, double or rarely lacking. [Latin, in reference to the twisted pedicels.] A large genus of about 100 widely distributed species. Type species: Mnium hygrometricum L.

Mouth of the capsule oblique: leares serrate.

Iouth of the capsule small; leaves nearly entire.
1. F. hygrometrica.

2. F. fluticans.

\section{Funaria hygrométrica (L.) Sibth. Fl. Oxon. 28s. 1794.}

\section{Mnium hygrometricum L. Sp. Pl. 1110. 1753.}

Plants bright yellowish-green turning brown. Stems short, simple; leares fer, elect, appressed around the base of the pedicel, broad and concave, acute or acuminate; the vein ending in the apex, the margins with swollen teeth; cells clear, smooth, oblong below, shorter and hexagonal above. Pedicel pale, twisted, variable in length; capsule horizontal or nodding, ribbed when dry, its mouth oblique; lid bordered with a red rim; annulus large, double, falling with the lid; peristome double, oblique, the teeth with apieal appendages attaehed to a central dise; calyptra large, inflated at base; spores rough, ripening early in spring.

On charred earth, Eight Jile Rock, Great Bahama. A cosmopolitan species. Cond-3ioss.

2. Funaria flávicans Michx. F\%. Bor. Am, 2: 303. 1503.

A smaller plant than the preceding, differing in the fewer leaves, which are entire, the rein ending in a short subulate tip; [the pedicel shorter, the eapsule more symmetric, its mouth not oblique; spores a little larger].

only known from sterile specimens collected in a copplee, Soldier's Road, New

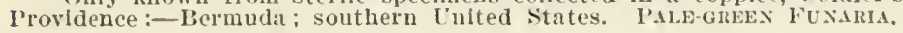




\section{Family 7. BRYÀCEAE C. Muell.}

\section{Pryuar Fanily.}

Plants usually growing in cushions, rarely scattered. Stems ereet, simple or branching near the apex, often slender. Leaves seattered, or erowded at the summit, variable in shape, from oral to lanceolate, ofter acuminate and subulate; vein single; margins entire or toothed; cells smooth, generally hexagonal, sometimes longer and narrower on the border and rectangular at the base. Pedicel terminal, erect; capsule erect or nodding, generally symmetric with a well-developed neck; calyptra cucullate; lid flat, not beaked; peristome usually double, rarely single or lacking. A widely distributed family composed of 16 genera with over 950 species most abundant in temperate, alpine and aretic regions. [Greek, meaning a moss.]

\section{BRỲUMI L. Sp. Pl. 1115. 1753.}

Plants usually growing in dense compact cushions, more or less matted with radicles. Stems erect, simple or kranching by apical innovations. Leaves more or less crowded at apex, erect, elliptic. orate or lanceolate, concave; apex acute, obtuse or with the costa percurrent into an awn; margins often bordered, more or less recurved, entire or serrate at apex; cells mostly hexagonal or rectangular at base. Inflorescence variable, heteroicous, pedicel exserted, erect or bent at apex; capsule nodding or rarely horizontal, usually oroid or pyriform, with a distinct neck; annulus often large and compound, falling with the blunt lid; peristome double, its teeth usually with a zigzag median line; endostome equalling the teeth, sometimes imperfect or with keeled segments and 2-3 cilia, arising from a basal membrane. A large genus of about 625 species widely distributed from the arctic regions to the tropics in both hemispheres. [Name Greek, a moss.] Type species: Bryum argenteum L.

Capsule cylindric, neck tapering.

Capsule pyriform, neck swollen.
1. B. capillare.

$\therefore$ B. coronatum.

\section{Bryum capillàre L. Sp. Pl. 1586. 1753.}

Plants growing in rather dense, dark green cushions. Stems short, sparingly branched; leaves crowded in a rosette at the apex, curled and twisted when dry, ovate to lanceolate, acuminate, the margins bordered by 1 or 2 rows of narrow cells, entire or slightly toothed near apex; rein ending in the top or excurrent; upper cells hexagonal, basal oblong, smooth. Pedicel long, red, bent at base, paler and twisted above; capsule elongated, nodding; neck distinct; lid small, apiculate; annulus large; peristome brown; teeth paler and papillose above; endostome with a basal membrane and appendiculate cilia; spores ripe in spring.

On base of palms in sand, a widely distributed and variable species, Great Rahama and Lignum Vitae Car:-Florida; West Indies; South America; also in Europe and Africa. HAIR-LikE BRrum.

\section{Bryum coronàtum Schwaegr. Suppl. $1^{2}$ : 103. pl. 71. 1816.}

Plants gregarious in bright green patches. Stems erect, simple or branching, usually about $1 \mathrm{~cm}$. high; leaves not crowded, spreading when moist, about $2 \mathrm{~mm}$. long, lanceolate or elliptic, with the vein excurrent into a smooth, subulate tip; margins bordered by 1 or 2 rows of narrow elongated cells, some- 
times obscurely toothel near the apex; base forming a long-decurrent wing to the next lower leaf; basal cells oblong; upjer cells hexagonal. Dioicons. Pedicel erect or bent, about $15 \mathrm{~mm}$. long; capsule nodding, about $2 \mathrm{~mm}$. long, dark red when mature, with a conspicuous swollen neck (like an acorn-cup or a crown, hence the specific name); lid falling with the large annulus more or less attached; peristome double; teeth blown; eudostome pale, its segments split along the keel, with 2-3 slender appendiculate cilia; spores small, green, ripe in winter.

In coppice, on dead wood and stones, New Providence, Abaco and Andros:Fiorida; West Indies; Sonth America; also in Asia and Africa. Cokonate Bryum.

A doubtful species of Bryum was collected by L. J. I. Brace at the quarry, Nassau, New Providence, in February, 1915 (no. 998t); the specimens are sterile and do not seem to agree with anything heretofore found.

\section{Family S. LEUCODONTÀCEAE Broth.}

\section{LeUCodon Fanily.}

Plants in dense mats or cushions, usually on trees. Stems creeping and rooting, leafless or with rudinentary leaves at the apex of new stems; branches pendent, simple or branching, usually with unequal and irregular branchlets, seldom regularly pinnate or dendroid and cireinate. Leaves crowded, often imbricate when dry, spreading when moist, usually ovate, acuminate, entire, or serrate at apex; rein single or double, sometimes lacking; cells smooth or rarely obscurely papillose or projecting at the ends; base with several rows of alar cells, generally transversely elongated or rounded and thickened. Dioicous or autoicous. Pedicels from lateral buds with clasping bracts, short or elongate; capsule ovoid, sometimes ribbed; calyptra cucullate, smootl or hairy; lid conic or beaked; amnulus usually present; peristome double, the outer of 16 short pale papillose, bifid or perforate teeth; the endostome of a more or less developed membrane with or without keeled segments and cilia. A small family of 9 genera and 69 species, widely distributed in temperate and subtropical regions.

1. LEUCodontópsis Ren. \& Card. Bull. Soc. Bot. Belg. 32: 17ð. 1893.

Plants slender and ereeping on twigs or branches. Primary stems nsually elosely attached to the bark, with short irregular spreading branches. Leaves crowded, small, erect-appressed on the branches, spreading, longer and more sharply pointed on the tips of the stems; lanceolate, acuminate, earinate and plicate; margins revolute, entire or obscurely toothed at apex; vein single, ending above the middle; upper cells long and narrow, with papillose projecting cells; alar cells round or qualrate and thickened, in several rows. Dioicous. [Named in reference to its resemblance to Leucodon.] A small genus of only three species, in all of which the fruit is unkuown. Type species: Lencodontopsis plicata Ren. \& Card.

1. Leucodontopsis floridàna (Aust.) E. G. Britton, Bryologist 15: 26.1916.

Neckera (Pilotrichella?) floridana Aust. Bot. Gaz. 4: 152. 1579.

Lcucodontopsis plicata Ren. \& Card. Bull. Soc. Bot. Belg. 32: 177. 1593. Pilotrichella floridana Ren. \& Card. Rev. Bryol. 19: 11. 1893.

Stems leafless except at the apical portions, there bearing small, ovatelanccolate, acuminate, ecostate, flat-bordered leaves; branehes seldom more 
than $3 \mathrm{~cm}$. long, simple or branched, when young more slender and flagellate, with smaller, less crowded leaves, when older with erect-appressed, crowded plicate leares, up to $1.5 \mathrm{~mm}$. long by $0.33 \mathrm{~mm}$. broad at base; vein usually single, seldom double with a short accessory basal branch; alar cells fewer on one side, up to S-10 rows, seldom reaching the vein; nargins entire, revolute almost to the serrulate apex; cells spindle-shaped, with minute, terminal papillae on both surfaces. Flowers and fruit unknown; propagating by small septate brood-bodies borne in axillary clusters.

On trees in coppices, New Iroridence and Andros:-Florida; Cuba; Porto Rico; Costa Rica and Panama. Flomida LEcCodortopsis.

\section{Family 9. NECKERÀCEAE Schimper.}

\section{NeCKera Fanily.}

Plants usually growing on trees with ereeping stems and pendent branches, either simple or pinnately decompound, sometimes quite dendroid; branches usually densely leafy, with crowded or imbricate leaves, sometimes in 2-4 ranks. Leaves symmetric or inequilateral, various, costate or ecostate, entire or serrate, smooth or papillose; the perichaetial usually quite different from the others, often surrounding and covering the capsule. Usually dioicons. Pedicel often short and straight, immersed, rarely curved or exserted; capsule ovoid or cylindric; smooth or ribbed; lid conic, beaked; calyptra smooth or hairy; peristome usually double, the inner more or less rudimentary; ammulus present or absent. A large family, of 50 genera and several hundred species, of wide temperate and subtropical distribution.

\section{PIREélla Cardot, Rev. Bryol. 40: 17. 1913.}

[Pirea Cardot, Bull. Soc. Bot. Belg. 32: 175. 1893. Not Durand, 1888.]

Stems creeping, slender and radiculose; branches erect, $2-4 \mathrm{~cm}$. long, simple or pinnately branched, blunt, or rarely slender and flagellate; leaves crowded, appressed, erect or spreading; stem-leaves ovate, abruptly acuminate, entire, ecostate; branch-leaves lanceolate, acuminate, entire or serrate at apex; vein thin, wider at base, ending below the apex; cells more or less thickened and porose, linear at base; alar cells quadrate, shorter and broader with thick walls. Perichaetial leaves, erect, ovate or lanceolate-acuminate, or subulate. Dioicous, often sterile and propagating by brood-bodies. Pedicel exserted, erect, somewhat rough above, seldom short or immersed; capsule mostly exserted, calyptra cucullate, hairy; lid small, beaked; mouth small; peristome double, its teeth lanceolate, more or less bifid, smooth, pale or red; endostome hyaline, membranous, adherent to the teeth; spores smooth. [Diminutive of Pirea.] A small genus of 10 species, confined to tropical and subtropical regions of North and South America. Type species: Pireella cavifolia Cardot \& Herzog.

1. Pireella cymbifòlia (Sull.) Cardot, Rev. Bryol. 40: 17. 1913.

Pilotrichum cymbifolium Sull. in A. Gray, Man. ed. 2, 681. 1856.

Plants usually growing on trees. Stems slender, creeping and rooting, the terminal growths slender with small acuminate leaves only about $0.5 \mathrm{~mm}$. long, with a short vein and faintly serrate margins, the alar cells few and rectangu- 
lar; branches stouter, usually simple, about $2 \mathrm{em}$. long, or pinnately branched, up to $4 \mathrm{~cm}$. long, with short branchlets; leaves crowded, imbricated in 5 ranks, concave and keeled, up to $1.5 \mathrm{~mm}$. long by $0.5 \mathrm{~mm}$. wide; vein narrow, ending in the flat acuminate tip; margins minutely toothed almost to the base; alir cells smaller, dense, rectangular; upper cells linear with projecting or obscurely papillose end walls; perichaetial leaves minute, erect, appressed, ecostate and narrowly acuminate. Dioicous, the antheridial plants unknown, as well as the fruit; usually propagating by septate brood-bodies, borne in clusters at the bases of the leaves.

Small depauperate unbranched plants have been found in coppices of New Providence and Abaco:- Florida; Louisiana; Cuba; Jamaica; Hispaniola; Virgin Islands to South America. I'revlla.

\section{Family 10. METEORIÀCEAE Fleischer.}

\section{Meteoriuni Fayily.}

Plants mostly of moist mountain regions, and of tropical and subtropical distribution, usually epiphytic and characterized by their creeping stems and long pendent, simple or rarely branched habit, sometimes rery glossy, with distichous leaves; base usually regular and broad, often auriculate; costa single, ending below the apex; cells smooth or papillose. Usually dioicous. Pedicel immersed or exserted; calyptra small, often hairy; lid generally beaked; peristome double, the inner sometimes perfect with cilia but more often imperfect with a short basal membrane; annulus lacking. A family of mostly tropical mosses with about 10 genera and 327 species.

1. PAPILLÀria C. Muell. Angstr. Oefr. K. Sv. Vet.-Ak.

Foerh. $33^{4}: 34.1976$.

[Neckera Section Papiliaria C. Muell. Syn. Muse. 2: 134. 1851.]

Plants growing on rocks or trees, usually in dense pale green or dark mats. Stems slender, often pendent or creeping, branching irregularly. Leaves broad and often auricled at base, tapering to an acuninate or subulate tip; vein single, rarely percurrent or lacking; margins entire or serrulate; basal and median cells sometimes smooth, others usually papillose with several small papillae in the median line of the narrow cells; perichaetial leaves usually longer and narrower, erect. Dioicous. Pedicel exserted or immersed, straight and smooth; capsule immersed or exserted, small and ovoid; calyptra small, campanulate, hairy; lid conic-beaked; annulus absent; peristome double; teeth lanceolate and papillose; eudostome hyaline and papillose from a short basal membrane, with or without cilia; spores papillose. About 70 species are known, mostly from tropical regions of both hemispheres. [Named in reference to the papillose leaves.] Type species: Neckera capillaris C. Muell.

1. Papillaria nigréscens (Sw.) Jaeger, Adumb. 1: 169. 1875-76.

Iypnum nigrescens Sw. Prodr. 141. 17 Ss.

Plants in dark brown mats. Young branches green; stems often 15-20 em. long, branching pinnately; branches short and irregular, nsually simple, and only 1-2 cm. long, but sometimes $4-5 \mathrm{~cm}$. cnding in clusters of slender brittle branchlets, which propagate this species. Leaves crowded, erect- 
appressed when dry, spreading when moist, small, up to $1.5 \mathrm{~mm}$. long by $1 \mathrm{~mm}$., broad at the auricled base; rein ending in the middle of the leaf; apex acuminate; margins entire, with projecting papillae; cells spinclle-shaped with thick walls anl 3-4 small papillae; basal cells longer and narrower, smooth anil radiating toward the nuargins. Dioicons. [Perichactial leaves pale, erect, lanceolate-subulate, plicate but not papillose; seta exserted up to $1 \mathrm{~cm}$. long; capsule oroid, about $2 \mathrm{~mm}$. long; calyptra pale aud hairy; lid beaked; mouth small with a dark rim; peristome pale, papillose; teeth lanceolate with a merlian line, inner membrane short with pale slenter segments, more or less adherent to the teeth; spores brown, mature in summer.] Only known from sterile specimens in the Bahamas.

On trigs and trunks of trees in coppice, New Providence:-Florida; Louisiana ; West Indies and southern California to Panama and South America. BuAckisiI PAPILLARIA.

\section{Family 11. ENTODONTȦCEAE Brotherus.}

\section{Entodon Family.}

Plants growing in glossy flat mats, either on rocks or trees. Stems creeping, usually with simple branches. Leaves spreading or flattened, usually erowded; vein single or double, rarely lacking; cells mostly longer than broad; often with the ends thickened and projecting on the back of the leaf. with the alar transversely elongated. Autoicous or dioicous. Pedicel erect, exserted; capsule cylindric, mostly erect and symmetric; lid usually short-beaked; calyptra cucullate, smooth; peristome double, often deeply inserted; teeth longer or shorter than the inner keeled segments, variously thickened; cilia usually lacking; annulus present or absent. A large family, of about 20 genera, widely distributed in tenuperate and tropical regions.

1. STEREOPHÝLLUM Mitt. Journ. Linn. Soc. Suppl. 1: 117. 1859.

Plants growing in thin flat mats, on rocks or trees. Stems ereeping and rooting, with simple irregular branches. Leares crowded, somewhat flattened and glossy; apex acute or obtuse; vein stout or lacking; margins flat, entire or rarely toothed at apex; base unequal, one side composed entirely of quadrate alar cells; upper cells short or long, often with the thickened end-walls forming minute papillae. Autoicous or rarely dioicous; pedicel elongated; capsule erect to inclined, and unequally oroid; lid conic-beaked; annulus lacking; peristome double, the onter papillose with thickened joints above, the inner narrower from a short basal membrane, withont eilia. A genus of 61 species, widely distributed in tropical and subtropical regions of both hemispheres. [Greek, in reference to the thick leares.] Type speeies: Pterygophyllum indicum Belang.

1. Stereophyllum radiculòsum (Hook.) Mitt. Journ, Linn. Soc. 12: 542. 1869.

Hookeria radiculosa Hook. Musci. Exot. pl. 51. 1818-1820.

Homalia Wrightii Sull. in A. Gray, Man. ed. 2, 665. 1856.

Plants in flat bright green mats. Stems matted together by numerous radicles; branches and branchlets with flattened glossy leaves, imbricate and secund when dry, spreading when moist, up to $1.75 \mathrm{~mm}$. long by $0.75 \mathrm{~mm}$. broad, concave with flat serrate margins; vein stout, tapering and ending above 
the midule of the leaf; apex acute; upper cells rhomboidal; alar cells rectangular and oblique, only reaching the rein and more numerous on one side of the hase; basal radiating and longer, all minutely and distinctly papillose on the back; perichaetial leares smaller, erect, clasping, more suddenly acuminate. Autoicons; pedicel up to $1 \mathrm{~cm}$. long; calyptra small, entire; capsule horizontal, slightly unequal, $1 . \overline{-}-2 \mathrm{~mm}$. long, its walls with swollen cells; lid large and pale, conic, short-beaked; annulus none, mouth with a dark rim; peristome double, the teeth yellow, paler and papillose at apex, inner with white. perforate keeled segments and shorter slender cilia; spores small and smooth, ripe in winter.

On logs and rotten rood, in coppices. New Proridence, Abaco, Great Rahama and Lignum Vitae Cay:-Florida; New Hexico; Texas; Cuba; South America.

\section{Family 12. LESKEÃCEAE Reichb.}

\section{LeSKEA FAMILY.}

Plants small or large. Stems creeping and branching, either irregularly or pinnately; branches short, nsually slender and crowded with small leaves; vein single; cells papillose on one or both surfaces; branch-leares smaller than the stem-leaves; rudimentary leaves present. Pedicel erect or inclined; calyptra cucullate; annulns often present; capsule erect or horizontal, usually symmetric. its lid conic or beaked; peristome double, the inner sometimes shorter and imperfect. Abont 23 genera, containing some 333 species, widely distributed.

\section{HAPLoclàdiUm C. Muell. Nuov. Giorn. Bot. Ital. 3: 11. 1896.}

Branehes slender, simple, not pinnately dirided; leares papillose only on the back, those at base of pedicel erect, longer and paler. [Greek, referring to the simple branches.] A genus of 43 species, natives of America and eastern Asia. Type species: Haplocladium macropilum C. Muell.

1. Haplocladium microphýllum (Sw.) Broth. in E. \& P. Nat. Pflf. 229: 1007. $190 \%$.

IIypnum microphyllum Sw. Prodr. 142. 1788.

Plants dark green or ycllow. Stems creeping and rooting, sometimes quite slender and branching irregularly; branches short and simple, erect; leares crowder, spreading or secund, ovate, acuminate, small, up to $0.5 \mathrm{~mm}$. long, those of the branches smaller and less acuminate than those of the stem; rein excurrent into a long tip; margins minutely toothed; cells small, square or oblong, papillose only on the back; leaves at base of pedicel longer and paler, erect. Pellicel 2-2.5 cm. long, slender, erect; eapsule $1 \mathrm{~mm}$. long, horizontal and curver; annulus falling with the conic lid; peristome double, the incer with keeled segments ant 3 eilia; spores smooth, maturing in summer.

On rocks in copplces. New Providence and Great Exuma:-Florlda: Fermuda :

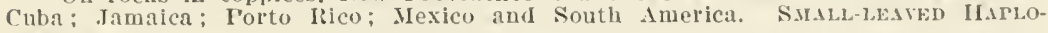
CLADIUM. 


\title{
Family 13, HYPNACEAE Hampe.
}

\author{
HypNuM FaMiLY.
}

Plants growing in loose or dense tufts, scldom floating. Stems usually decumbent and rooting, sometimes erect; branches regularly pinnate or irregular. Leaves straight or curved, erect, spreading or secund, usually symmetric; vein either lacking, single or double; cells mostly much longer than wide, smooth or papillose, those of the basal angles often different in shape and size. Pedicel more or less elongated and exserted; capsule mostly horizontal, often curved and unsymmetric; peristome double; its segments keeled; cilia usually present; spores small. A large family, widely distributed in all parts of the globe, composed of about 37 genera with over 960 species.

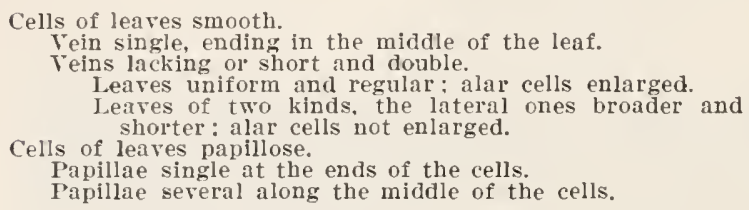

1. Amblystegium.

2. Isopterygium.

3. Vesicularia.

4. Mittenothamnium. 5. Tuxithelium.

\section{AMBLYstégiUm Bruch \& Schimp. Bryol. Eu. 55-56: 1. 1853.}

Plants usually growing in moist situations. Stems irregularly branched; branches slender; leaves symmetric, spreading; vein single; cells smooth, not much longer than wide. Pedicel erect, smooth; capsule usually curved; calyptra cucullate; lid conic; annulus present; peristome double. [Greek, referring to the blunt lid.] A genus of 47 species, widely distributed in America and Europe. Type species: Hypnum riparium $\mathrm{L}$.

\section{Amblystegium Sípho (Beauv.) E. G. Britton.}

Hурпит Sipho Beauv., Prodr. Aetheog. 70. 1805.

Amblystegium riparium floridanum Ren. \& Card. Bot. Gaz. 14: 98.1889.

Plants in thin mats on damp ground in shade. Stems ereeping, very slender, more or less branched; leaves distant, shrivelled and twisted when dry, narrowly lanceolate, acuminate, up to $1 \mathrm{~mm}$. long by $0.4 \mathrm{~mm}$. broad, the margins entire, the vein ending in the middle of the leaf; base narrow; alar cells oblong or square; upper cells 4 times longer than wide; perichaetial leaves erect, pale and faintly reined, with more slender points. Autoicous; pedicel about $1 \mathrm{~cm}$. high, red at base, paler above; eapsule short, only about $1 \mathrm{~mm}$. long, horizontal and curred; lid conic; peristome double, yellow; teeth paler at apex, inner segments split along the keel; spores small, smooth, ripe in spring.

In sink-hole, Elenthera:-southern United States. Amblystegium.

2. ISOPTERYGIUM Mitt. Journ. Linn. Soc. 12: 21.1869.

Plants usually rather small. Stems decumbent and irregularly branched; leares somethat flattened, small and crowded, usually symmetric; vein short and double or none; pedicel erect; capsule erect or horizontal; lid conic or 
apiculate; calyptra cucullate; peristome double. [Greek, referring to the symmetric leaves.] A genus of 168 species, mostly American, in temperate and tropical regions. Type species: Isopterygium planissimum Mitt.

1. Isopterygium micans (Sw.) Cardot, Bull. Herb. Boiss. 4: 10. 1896.

Hypnum micans Sw. Adnot. Bot. 175. 1829.

Plants growing in dense, glossy, fellowish-green mats. Stems slender, decumbent; branches simple or divided; leaves crowded, spreading, small, 0.85 $\mathrm{mm}$. long by $0.25 \mathrm{~mm}$. wide, ovate, acuminate, faintly serrate; veins short, double, obscure; cells 10 to 15 times longer than wide, a few at basal angles listinctly shorter and broader. Pedicel erect, slender, up to $1 \mathrm{~cm}$. long; capsule horizontal, curved, contracted below the mouth when dry, about $1 \mathrm{~mm}$. long; lid conic, slightly apiculate; cilia more or less developed; spores small.

On roots of palms and rotten wood in coppices, New Providence, Great Bahama and Abaco:-Cnited States; Bermuda; Cuba; Jamaica. GLossi Isopterrgius.

\section{VESICULÀrIA C. Muell. Flora 82: 467. 1896.}

[Homalia Section Vesicularia C. Muell. Syn. 2: 233. 1851.]

Plants growing in moist shady places, forming thin mats on the ground. Stems ereeping; branches irregularly pinnate, usually short; leaves not crowded, shrunken and twisted when dry, usually flattened and of two kinds, the lateral ones larger and unequal, or falcate, the upper and lower ones more regular and much narrower, often longer and more acuminate; veins two, short or none; margins often bordered, entire or serrate; cells large and hexagonal, smooth, the alar not enlarged. Autoicous. Pedicels exserted and slender; capsules horizontal or nodding, ovoid and contracted below the mouth when dry; annulus present; peristome double; lid flat and beaked; calyptra cucullate; spores small. About ninety species have been described, many with rery obscure and minute differences. [Named in reference to the large leaf-cells.] Type species: Hookeria Meyeniana Hampe.

\section{Vesicularia vesiculàris (Schwaegr.) Broth. Pflf. 232-233: 1094. 190 S.}

Hypnum vesiculare Schwaegr. Supp. $2^{2}: 167, p l$. 199. 1827.

Plants pale or yellowish green. Stems slender and rooting with short irregular branches; stem-leaves with long recurved tips up to $1 \mathrm{~mm}$. long, about three times longer than broad; branch-leaves of two kinds, the lateral unsymmetric, shorter and less acuminate, up to $0.55 \mathrm{~mm}$. and only about twice longer than broad with the cells about twice as long as wide; the upper and lower ones longer and narrower, with cells about five times longer than broad; leaves all ecostate or faintly bicostate, the margins bordered by one row of narrow cells, either entire or minutely toothed at apex; perichaetial leaves suddenly contracted to a slender recurved, entire or serrulate tip. Autoicous. Pedicel slender, 1.5-2 cm. long; eapsule nodling, 1-1.5 mm., ovoid, with a distinct neck; walls of swollen inflated cells; lid conic-beaked; annulus large; peristome with a red base, teeth yellow, pale and papillose at apex, lamellate on the inside; endostome brown, the keeled segments split and papillose; spores small, ripe in winter.

On branches and roots of trees in copplces and in sink-holes, New I'rovidence, Eleuthera and Andros:-Florlda; West Indies and Sollth America. Vesicularia, 
4. MITteñthÁMNIUM IIennings, Hedwigia 41: 225.1902.

[Miскотнаматм Mitt. Journ. Linn. Soc, 12: 21. 1869.

Not Naegeli, 1849.]

Stems sleucler, creeping and rooting, usually branched more or less regularly, the branches erect often regularly pinnate; leaves of two kinds, the stemleaves differing from the branch-leares in being smaller, more broadly lanceolate and sharply pointed; rein single or double; margins flat, serrate or serrulate; cells rhombic or linear, smooth or papillose at the ends; alar cells not enlarged. Monoicous, seldom dioicous. Pedicel erect, exserted; capsule erect or inclined, oroid or cylindric; mouth wide, annulus usually present; lid beaked; calyptra cucullate, smooth or hairy; peristome double, its segments split along the keel, with 1-3 cilia; spores small. A genus of about 106 species, growing on rocks and trees, mostly in tropical regions. [Named in honor of William Mitten, 1819-1906, eminent British bryologist.] Type species: Нурпит thelistegum C. Muell.

1. Mittenothamnium diminutivum (Hре.) E. G. Britton, Bryol. 17: 9. 1914.

Hypmum diminutivum Hampe, Linnaea 20: 86. 1847.

Plants growing in flat mats. Stems slender, branching irregularly, the branches short, seldom more than $5 \mathrm{~mm}$. long; leaves spreading when dry, minute, up to $0.75 \mathrm{~mm}$. long by $0.33 \mathrm{~mm}$. broad, ovate, acuminate, minutely serrulate; veins 2, short; alar cells not enlarged; upper cells linear, 8 times longer than wide, sharply papillose on the back; perichaetial leaves pale, longpointed with lax smooth cells. Autoicous. Pedicel up to $15 \mathrm{~mm}$. long, slender and red; capsule nodding, usually $1 \mathrm{~mm}$. long; lid blunt; annulus narrow; peristome double; teeth red at base, finely striate; keeled segments perforate and papillose, paler at apex; cilia 2 ; spores minute, ripe in summer.

On stems and rotten or charred wood in coppices, New Providence, Great Bahama and Abaco:-Florida: West Indies; Mexico to South America. Dininutire MitTEX'S-Mioss.

\section{TAXITHìLIUM Spruce, Cat. 14. 1867.}

Plants in thin pale mats. Stems flattened, with appressed leaves; simple or branching, more or less regularly and distantly pinnate, with short branches; leaves crowded, concare, with a narrow, somewhat auriculate base; veins short and double or absent; margins entire or serrulate; cells long and narrow, either with several small papillae or with couspicuons branching projecting ones; alar cells smooth, shorter and broader, the basal often elliptic. Autoicous or dioicous. Pedicel smooth, elongate; capsule horizontal, or nodding, slightly curved; lid blunt; calyptra cucullate; peristome double, the teeth paler at apex and lamellate on the inner surface; endostome narrow; cilia single. [Named in reference to the numerous papillae on the leaves.] A genus of 99 species, midely distributed in tropical regions of both hemispheres. Type species: Hypnum planum Brid.

\section{Taxithelium plànum (Brid.) Spruce, Cat. 14. 1867.}

Hypnum planum Brid. Spec. Musc. 2: 97. 1812.

Plants in yellowish-green thiu mats in shade. Stems creeping and rooting, with short branches, seldom more than $1 \mathrm{~cm}$. long; leaves glossy and flattened, concave and acuminate, about $0.6 \mathrm{~mm}$. long by $0.4 \mathrm{~mm}$. wide; base narrower 
and clasping with swooth enlarged, yellow cells at angles; eclls long and narrow with mumerous small papillae; margins minutely and sharply toothed nearly to the base; veins short or none. Antoicous; perichactial leaves a arrower and more acuminate, with smooth lax eells; pedicel up to $15 \mathrm{~mm}$. long, slender; eapsule about $1.5 \mathrm{~mm}$. long, horizontal, strongly contracted below the mouth when drr; lid blunt; neek distinct; peristome pale yellow, its teeth striate at base, pale and papillose at apex, deeply lamellate at base within; keeled segments slender, pointed; eilia 1 or 2 , seldom perfect; spores small, smooth, yellow, ripe in winter.

On the ground in coppice, New Providence:-Florida; West Indies; Mexico to South America. Frat TAxitheliur.

\section{Family 14. SEMATOPHYLLÀCEAE Brotherus.}

\section{Sematophyllum Family.}

Plants usually forming dense tufts. Stems creeping; branches erect, irregular and unequal, sometimes pinnate; leaves small, crowded, often secund; veins short, double or lacking; cells usually much longer than wide, smooth or papillose, those of the basal angles often larger, inflated or square. Pedicel erect; capsule usually horizontal, without an annulus; calyptra eucullate; lid usually with a long slender beak; peristome double. Twelve genera and $44 S$ species widely distributed in tropical regions.

\section{SEMATOPHYLLUM Mitt. Journ. Limn. Soc. 8: 5. 1864.}

Stems rarely pinnate with the branches usually short and erowded. Leaves secund or spreading, faintly bicostate or ecostate, with the eells all smooth, the alar cells enlarged, often vesieular; margins entire or minutely serrulate; pedicels long or short; eapsule with the lid long-beaked, often equaling the urn; teeth deeply lamellate inside, sometimes with minute projections on the outside, either with a zigzag median line or a deep central groove; endostome with the keeled segments more or less perforate and the cilia one or two, usually shorter, often papillose. A large genus of 314 speeies, mostly from tropical Ameriea. [Greek, in reference to the pointed leares.] Type speeies: Iypnum substrumulosum Hampe.

Leaves recurved when drx: perichaetial leaves longer, entire or subserrulate; peristome-teeth not deeply grooved, with a zigzag median line. Leaf-cells rhomboid, 3-5 times longer than wide.

Leaf-cells linear, s-10 times longer than wirle.

Leaves spreading when dry; perichaetial leaves shorter and serrate; peristome-teeth deeply grooved on the median line.

1. S. subpinnatum.

2. S. admistum.

3. S. sericifolium.

1. Sematophyllum subpinnàtum (Brid.) E. G. Britton, Bryol. 21: '2S. 1918.

\section{Leskea subpinnata Brid. Sp. Muse. 2: 54. 1512.}

Plants growing in bright or yellowish green cushions, usually on wood. Stems creeping and rooting, irregularly pinnate, with aseending, more or less eircinate, simple branches; leaves crowiled, recurved or seeund when dry, spreading when moist, with recurved tips and revolute margins, seldom reaching $1 \mathrm{~mm}$. in length by $0.4 \mathrm{~mm}$. wile, eoneave, with flat or revolute, entire margins: apex aente or short-aemunate; veins short and double, obseure or none; basal angles with $3-4$ rows of square eells and a few larger inflated alar cells; upper cells rhomboid, ahout $3-5$ times longer than wide; perichactial leaves 
longer, up to $1.32 \mathrm{~mm}$., erect and clasping, more acuminate, entire or finely subserrulate, ecostate with larger basal cells. Autoicous. Pedicel short, only $5 \mathrm{~mm}$.; capsule 1-1.5 $\mathrm{mm}$., ereet or slightly inclined; neek distinct; lid with a long beak equalling the urn; peristome short and teeth yellow, with deep basal lamellae on the inside, dark basal segments, paler and papillose points; median line not deeply grooved; endostome with narrow pale papillose keeled segments, which are not perforate, and the cilia often absent; spores smooth, ripe in winter.

On rotten wood and twigs in coppice, New Providence:-FIorida; Mlississippi; Cuba: Jamaica; Hispillola; Porto Rico to Trinidad; Mexico to Brazil. SubPlxxate SEALTOPHXLLAY.

2. Sematophyllum admístum (Sull.) Mitt. Journ. Linn. Soe. 12: 485.1869.

Hypnum admistum Sull. Proc. Am. Acad. 5: 289. 1861.

Plants small, yellowish-green, glossy. Stems short, creeping; branches erect; leaves crowded, recurved at apex of stems and all more or less secund when dry, spreading when moist, up to $1 \mathrm{~mm}$. long by $0.3 \mathrm{~mm}$. wide, concave and acuminate with flat or slightly revolute, entire or sub-serrulate margins; veins 2, short or none; cells eight times longer than wide, those of the basal angles, square with 2-3 alar cells enlarged aud hyaline; perichaetial leares longer, up to $1.33 \mathrm{~mm}$, more acuminate, entire, or subserrulate at apex. Autoicous; pedicel bent at base, up to $7 \mathrm{~mm}$. long; capsule $1-1.5 \mathrm{~mm}$. long, horizontal or curved, ovoid and contracted below the mouth when dry; calyptra eucullate; lid pale, long-beaked; peristome double, its teeth with short projections on the outer surface and deep ones on the inner, paler and papillose at apex; median line zigzag, not deeply groored; endostome pale, with 1-2 eilia; spores smooth, ripe in summer.

Common, in dense cushions on rotten wood in coppices, also on palmetto, New Providence, Abaco, Andros, Great Bahama and Watling's Isiand:-Florida; Cuba; Jamaica ; Porto Rico; Virgin Islands to Brazil. SH1Ning SEMATOPHYLuM.

3. Sematophyllum sericifòlium Mitt. Journ. Linn. Soc. 12: 483.1869.

Plants in thin glossy patches on rotten wood. Stems short and slender; branches erect; leaves crowded, not secund, spreading when moist, up to $1 \mathrm{~mm}$. long and only $0.2 \mathrm{~mm}$. wide at base, sharply pointed and mucronate, with inrolled entire margins, and large curved inflated alar cells; ecostate; the cells linear, about 10 times longer than wide; perichaetial leaves shorter, up to 0.85 $\mathrm{mm}$. long, clearly serrate and sometimes suddenly subulate and coarsely toothed at the shoulder. Autoicous; pedicel short, only 5-8 mm. long, slender, curved; capsule erect or slightly inclined, ovoid; lid with a long slender beak; calyptra covering only the beak; walls of collenchyma cells; mouth bordered by red cells; peristome double, the teeth with a deep outer median groove, yellow and striate, paler and papillose at apex, within with deep lamellae extending almost to the apex; endostome papillose with 2 slender cilia; spores rough, small, ripe in spring.

A few plants were collected at Nicholl's 'Town, Andros, by J. I. and A. R. Northrop in 1890:-Cuba; Jamaica; Hispaniola; Yorto Rico; Virgin Islands to Grenada. Glossy SematopHilluar.

Class 2. HEPÀTICAE.

LivERWORTS.

Contributed by Professor Alexander W. Evans.

Terrestrial, epiphytic, or rarely aquatic plants, showing a distinct alternation of generations, the gametophyte existing as an in- 
dependent individual, the very different sporophyte partially or wholly parasitic on the gametophyte. Gametophyte dorsiventral, consisting of a thallus or more or less differentiated into stem and leaves, attached to the substratum by means of rhizoids (true roots none), growing by means of an apical cell. Sexual organs borne on the upper surface of the gametophyte or terminal on more or less differentiated branches. Fertilized egg developing directly into the sporophyte, the wall of the venter of the archegonium usually developing into a protective eover, or calyptra, which is not ruptured until the sporophyte is nearly mature. Sporophyte consisting of a capsule only or differentiated into a capsule (spore-bearing organ), a stalk or a growing region, and a foot (absorbing organ). Capsule consisting of a wall of sterile cells and a spore-sac, the latter sometimes with a median sterile portion (columella), dehiseing irregnlarly or by means of a lid or of longitudinal splits; spore-sac containing spores only or spores and elaters, the latter consisting of sterile cells, often elongated and usually developing spiral bands of thickening on their walls.

Gametophyte a thallus or leafy shoot. Chloroplasts minute, many in each cell. Capsule short, spherical to oral. Without a columella, borne on a translucent stalk.

Gametophyte a thick and fleshy thallus, usually pale and differentiated into distinct tissues, rarely deep green and succulent; green tissue usually with airspaces, Capsule splitting irregularly or by means of a lid.

Gametophyte a delicate thallus or a leafy shoot; tissue differentiation slight: air-spaces not present. Capsule splitting into four longitudinal valies.

Gametophyte a thick and fleshy thallus. dalk green and succulent, tissue differentiation slight. Chloroplasts large, usually borne singly. Capsule long. cylindrical. With a basal growing region. splitting into two longitudinal valves.

Order 1. Marciantiales.

Order 2. Jugermaxiales.

Order 3. Axtrocerotales.

\section{Order 1. MARCHANTIÀLES.}

Gametophyte a prostrate. strap-shaped, dorsiventral thallus, growing apically. branching dichotomously or from the ventral surface of the median portion, and showing a distinet differentiation into tissues, the green tissue usually with air-spaces. Ventral scales more or less distinct. Rhizoids of two kinds, the one with smootl walls, the other with interior peglike papillae. Antheridia in deep depressions on the upper surface of the thallus, sonetimes seattered, sometimes grouped together in more or less definite, sessile or stalked receptacles. Archegonia similar in position but. when borne on stalked receptacles (carpocephala), becoming displaced to the lower surface through interealary growth. Sporophyte a eapsule only or differentiated into eapsule. stalk, and foot; elaters (or other sterile cells) usually present in the capsule. 


\title{
Family 1. RICCIÄCEAE Dumort."
}

\author{
Riccia Family.
}

Gametophyte terricolous or aquatic, annual or perennial, once to sereral times dichotomous, often forming rosettes, half-rosettes, or flabelliform expansions. Stomata ranting or rudimentary in Riccia, well developed in Oxymitra, moderately well dereloped in Ricciocarpus. Tentral seales usually obvious. Antheridia and archegonia arising singly from the dorsal surface just back of the growing apex, soon becoming deeply immersed in the thallus.

Sporophyte a capsule, without foot or seta, enclosed by the calyptra, in which the spores come to lie at maturity through the disappearance of the eapsnle wall. Inner cells all producing spores or (Oxymitra) an inconspicuous few of them remaining sterile; spores separating at or before maturity, the separate spores large, subspheric or more commonly more or less tetrahedral, with a rounded outer face and plane inner faces, the surfaces marked with free or most frequently mesh-forming ridges, or simply with spines, the angles of the areolae often with papilliform elevations, the inner (plane) faces usually less strongly marked than the outer.

\section{RÍCCIA [Micheli] L. Sp. Pl. 1138. 1753.}

[RICCIELla A. Br. Flora 4: 756. 1821.]

Gametophyte terricolous or rarely aquatic, usually several times dichotomously branched. Assimilatory layer consisting of vertical or subrertical columns of cells bounding very narrow air-canals, or consisting of larger polyhedral or subclarate chambers bounded by unistratose lamellae. Stomata represented by rery inconspicuous pores bounded by unmodified or only rery slightly modified epidermal cells. Latero-ventral scales hyaline-albescent, brownish, violet, or dark purple, rarely surpassing the margins of the thallus, sometines apparently wanting. Antheridia and archegonia scattered, the antheridia irregularly intermingled with the archegonia in the monoecious species, with occasional tendencies to segregation, both destitute of a special involucre. Sporophyte-wall unistratose throughout, soon disintegrated. Spores separating at or before maturity. Accessory sterile cells wanting. [Commemorates P. F. Ricei, a Florentine senator and patron of science.] A genus of 130 or more species, of temperate and tropical distribution. Type species: Riccia crystallina L.

Thallus margins and sides green or occasionally tinged with red-purple; dorsal surface resicular-areolate, becoming spongiose or lacunose-alveolate; spores distinctly angled and wing-margined.

Thallus margins and sides dark violet or blackish; dorsal surface rather obscurely and finely reticulate, remaining firm and intact; spores obscurely angled, destitute of wing margins.

1. R. crystallina.

2. R. violacea.

1. Riccia crystallìna L. Sp. Pl. 1138. 1753.

Thalli small to moderately large, 2-6 times dichotomous, forming rosettes $5-20 \mathrm{~mm}$. (rarely $30 \mathrm{~mm}$.) in diameter, or soon irregularly gregarious, usually a light erystalline green, occasionally dark green or now and then tinged with

* Contributed by Dr. Marshall A. Howe. 
red-purple or bromnish red, concolorons below, the dorsal surface vesicularareolate, soon becoming spongiose or lacunose-alveolate; main segments 1-2.5 mm. wide; margins obtuse or subacute, naked; scales wanting or rudimentary; transverse sections mostly $2-4$ times as broad as high; dorsal epidermis soon indeterminate, the cells of the primary stratum subspheric, ellipsoidal or papilliform, irregularly collapsing or subpersistent, they or their successors finally $40-110 \mu$ in maximum diameter; air-chambers elongate-polyhedral, separated by unistratose lamellae; monoecions (rarely dioecious?); antheridial ostioles elerated $75-250 \mu$; spores at first yellowish brown, soon darkening and often nearly opaque, $60-110 \mu$ in maximum diameter, distinctly angular, with a margin mostly $3-10 \mu$ wide, the outer face marked with somewhat imperfectly formed areolae usually $10-30 \mu$ wide or those in the middle sometimes larger $(30-15 \mu)$ and enclosing a free-ending spur or an isolated tuberele, the inner faces with tubercles, short, free irregular ridges, or sometimes with imperfect areolae, the older spores commonly tuberculate-papillate in profile.

On wet gromuds and in sink-holes, Great Bahama and Exuma Chain :-Yermont to Alberta, Lower California and Trinidad; Europe. Cristallixe riccia.

¿. Riccia violàcea M. A. Howe, Ann. Mo. Bot. Gard. 2: 51. 1915.

Thallus small, 1.5-4 mm. long, simple or 1-3 times dichotomous, irregularly gregarions, rather obscurely aud finely reticulate and dark green above, dark violet or blackish at margins and on sides; main segments $0.6-1.15 \mathrm{~mm}$. wide; unargins obtuse or rounded, commonly erect-connirent or inflexed on drying, bearing especially toward the apex and often low on the sides numerous or accasional violet or sometimes hyaline conic or subcylindric acute or obtuse papillae $20-110 \mu$ long and $25-45 \mu$ broad at base; scales rery short or rudimentary, dark violet, rarely orerlapping, commonly divided into a series of small irregular often tooth-like laciniae, each consisting of only a few cells; transrerse sections 1.j-2 times as broad as high; dioecious (?); antheridial ostioles elevated $20-150 \mu$, often violet; spores soon fuscous and very opaque, S0-105 $\mu$ in maximum diameter, obseurely angled or flattened-sphaeroid, destitute of wing margins, finely, irregularly, indistinctly, and almost uniformly areolate over whole surface, the areolae $7-11 \mu$ wide, soon very obscure and the spores appearing minutely and densely verruculose.

On moist ground, Eleuthera:-Mona Island; Porto Rico; Cuba; and northern Mexico. VIOLET Riccia.

\section{Family 2. MARCHANTIACEAE Corda.}

\section{Marchantia Famils.}

Thallus (except in Dumortiera) with a distinct dorsal layer of airchambers, communieating with the outside air by means of epidermal pores. Tentral seales in two (or more) longitudinal rows. Antheridia and archegonia borne on more or less definite receptacles; antheridial receptacles diseoid, sessile or stalked; earpocephala diseoid, invariably stalked, the stalk sometimes with one or two rhizoid-furrows. Sporophyte differentiated into a capsule. stalk and foot. the capsule forced through the calyptra at maturity by the elongating stalk and deliscing irregularly or by means of a more or less distinct lid; elaters present in the capsule. Gemmae discoid, present in two genera. About 25 genera and 200 species. widely distributed, especially in warm regions.

\section{MARCHÁNTiA [Marchant f.] L. Sp. Pl. 1137. 1753.}

Thallus branching dichotomously. Air-chambers with distinct boundaries, forming a single layer; green cells in short, simple or branched filaments rising 
from the floors of the chambers, the filaments mostly three or four eells long; epidermal pores bounded by sereral superinposed layers, each usually composed of four cells. Ventral scales rariable, some divided into a basal portion and an appendage. Inflorescence dioecious. Antheridial receptacle terminal on a thallus-branch, flat or slightly convex, more or less lobed, borne on a somewhat elongated stalk with two rhizoid-furrows. Carpocephalum arising from the extremity of a thallus-branch, composed of a flat or convex central portion from which four to ten rays spread out, often unsymmetrically, the rays terete or flat; stalk with two or four rhizoill-furrows; archegonia (and sporophytes) in radiating groups between the lobes, each group enclosed by a membranous involuere consisting of two folds with fringed margins; psendoperianth (around each sporophyte) tubular, membranous, with an open, irregularly eleft mouth. Capsule without a lid, splitting into from four to eight irregular teeth; cells of wall with ring-like thickenings. Gemmae discoid, several cells thick in the middle and with the growing points, borne in circular, eup-like conceptaeles. [In honor of Nicholas Marchant, director of the ducal garden at Blois, died 1678.] About fifty species, mostly tropieal. Type species: Marchantia polymorpha L.

1. Marchantia domingénsis Lehm. \& Lindenb. Pug. 6: 29. 1S34.

Thallus pale to dark green, mostly $2-3 \mathrm{~cm}$. long and $4-6 \mathrm{~mm}$. wide, flat or slightly furrowed, sinuate along the margin. Ventral scales more or less pigmented, in two longitudinal rows on each side of the middle, those of the inner row with broadly lanceolate to ovate, toothed appendages; antheridial receptacle deeply lobed, the lobes mostly four to six, palmately spreading; carpocephalum deeply rayed, the rays mostly seven, not eylindrical; spores spherical about $28 \mu$ in diameter, with low irregular ridges; elaters bispiral; gemmaeconceptacles elosely short-ciliate.

Along a drain, Fort Charlotte, New Providence:-southern Inited States: West Indies: Mexico; Central America and Venezuela. Previonsly listed from the Bahamas as 11 . chenopoda L. Sasto Donixgo Marchanti.

\section{Order 2. JUNGERMANNIÀLES.}

Gametophyte a prostrate, strap-shaped, dorsiventral thallus or more or less clearly differentiated into stem and leaves, showing slight tissue differentiation, destitute of air-spaces. Rhizoids all with smooth walls. Antheridia in deep depressions or superficial and usually protected by seales or leaves, sometimes scattered, sometimes gromped together in more or less definite receptacles or androecia. Archegonia superficial but usually more or less protected by scales or leaves. Sporophyte differentiated into capsule, stalk, and foot, the capsule splitting irregnlarly at maturity or more commonly into four equal valves; elaters always present.

\section{Family 1. JUNGERMANNIÀCEAE Dumort.}

\section{Jungermannia Family.}

Plant body usually prostrate or ascending, dorsiventral, differentiated into stem and leaves; branches lateral or ventral; leaves normally in three 
longitudinal ranks. two dorsal or lateral and one rentral, those of the rentral rank (the underleares) smaller than the others and sometimes absent altogether. Antheridia borne singly or in some gromps in the axils of more or less specialized leares, the perigonial bracts. Arehegonia borne singly or in groups at the tips of branelies, surrounded by specialized leaves, the perichaetial brats and bracteoles. Perianth present in many genera, eonsisting of a eylindrieal or prismatic tube open at the apex. Capsule spherical to cylindrical. About 150 genera and some 4,000 species, widely distributed, most abundant in tropical regions.

A. Leares undivided but often toother.

B. Leares bilobed and complicate, the ventral lobe, or lobule. smaller than the dorsal and usually specialized as an inflated watej-sic.

1. Inderleaves none.

I'lants large, perianth with a broad truncate moutb. I'lants minute, perianth abruptly contracted to a small tubular month.

2. Inderleares present, one for every lateral leaf.

3 . Inderleaves present, one for every two lateral leares. a. Lobule inflated but not helmet-shaped, attached to the dorsal lobe by a long keel.

* Underleaves bifid.

t Plants pale green to yellowish green

Divisions of underleaves not subulate.

l'eriantl inflated, more or less distinctly five-keeled.

Eobule with a hyaline papilla at the proximal base of the apical tooth.

Plants large; well-developed leaves $0.6 \mathrm{~mm}$. ol more in length.

I'lants medium-sized; well-developed leaves mostly $0.3-0.5 \mathrm{~mm}$. in length.

l'lants small ; well-dereloped leaves 0.3 or less in length.

Lobule with a hyaline papilla at the distal base of the apical tooth.

Perianth compressed, a t least when young.

Lobule with a hyaline papilla at the proximal base of the apical tooth.

Lobule with a hyaline papilla at the distal base of the apical tooth.

Divisions of underleaves subulite and spread. ing.

t+ Plants more or less pigmented with brown.

** Tnderleaves undivided.

Plants pale green to yellowish green.

Subfloral innovations none.

Subfloral innovations present.

Plants more or less pigmented with brown.

Subfloral innovations none.

Subfloral innorations present

I.eaves densely squarrose.

leriantl with five to ten keels.

lerianth with three keels.

reaves not squarrose; perianth with five keels.

b. Lobnle usually inflated and helmet-shaped, usually attached to the lobe by a very short keel.
1. Plagiochilu.

2. Radula.

4. Leptocolea.

3. Diplasiolejeunca.

10. Taxilcjeunca.

5. Lejeunea.

6. Mierolejeunca.

9. Euosmolejeunea.

7. Rectolejeunca.

8. Cheilolejeunea.

12. Leptolejeunea.

11. Ceratolejeunea.

15. Caudalejeunea.

15. Leucolejeunea.

14. Lophole jeunca.

13. Brachiolejeunea. 16. Jlastigolejeunea.

17. Arehilejeunca.

19. Frullania.

1. Plagiochìla Dumort. Recueil d'Obs. 14. 1535.

Stems ascending from a prostrate rhizome, simple or with lateral branches. Leaves suecubous, uncliviled, deeurrent dorsally and rentrally, the margin varying from entire to ciliate or spinose. Underleaves usually minute and shortlived. Infloresenee dioecious. Antheridia from one to ten in the axils of 
bracts saceate at the base, the bracts imbricated and usually arranged in elongated androecia, often proliferating at the apex. Perichaetial bracts similar to the leaves but often broader and more toothed. Perianth laterally compressed, the mouth broad, truncate, and variously dentate to eiliate. [Greek, oblique lip.] Some 800 species or more, mostly tropical. Type species: $P$. asplenioides (L.) Dumort.

\section{Flagiochila ludoviciàna Sulliv. Muse. Alleg. 223. 1845.}

Loosely tufted, yellowich to brownish green. Stems sparingly and irregularly branched. Leares obliquely spreading, imbricated, about $2.5 \mathrm{~mm}$. long and $1.2 \mathrm{~mm}$. wide, orate, long-decurrent dorsally and reflexed at the rentral base, irregularly toothed in the apical region and along the ventral margin; underleares minute or larger and narrowly laneeolate.

On bark. Maidenhead Coppice, New Proridence:-Louisiana to Florida; Cuba; Virgin Islands. LOL'1S1ANA I'LAGIOCHILA.

\section{RÀDULA Dumort. Comm. Bot. 112. 1822.}

Stems prostrate or growing from a prostrate rhizome, with numerous lateral branches arising just behind normal leares; rhizoids always borne on the ventral lobes of the leaves. Leaves complicate-bilobed, the dorsal lobes larger than the rentral, incubous, usually entire and often rounded at the apex; ventral lobes attached to the dorsal by a more or less elongated keel, the free margin usually appressed to the dorsal lobe. Underleares none. Antheridia borne singly or in groups of two or three in the axils of saccate bracts, the latter forming more or less elongated androecia. Archegonia borne on more or less elongated branches, sometimes with subfloral innorations; bracts similar to the leares. Perianth usually dorsirentrally compressed, rarely subterete or plicate, truncate and bilabiate but otherwise entire at the broad mouth. Gemmae, when present, discoid, multicellular. [Latin, a seraper or spatula.] About 400 species, largely tropical. Type species: $R$. complanata (L.) Dumort.

\section{Radula australis Aust. Bot. Bull. (Bot. Gaz.) 1: 32.1875.}

Plants dark green, loosely tufted to scattered. Stems irregularly pinnate. Leaves imbricated, the dorsal lobe spreading at about a right angle, obovateoblong. about $1 \mathrm{~mm}$. long and $0.6 \mathrm{~mm}$. wide; lobule rhomboid, rounded at the apex, the upper margin parallel with the keel; inflorescence dioecious; androecium mostly median, the bracts in about six pairs; perianth elongated.

On bark, Andros and New Providence :-Georgia and Florida. Southerx Radela.

\section{DIPLASIOLEJEÙNEA [Spruce] Schiffn. in E. \& P. Nat.} Pfff. $1^{3}$ : 121. 1894.

Stems prostrate, copiously branched, the branching as in Radula. Leaves loosely imbricated, complicate-bilobed, the dorsal lobe orate to orbicular, attached by a very short base, convex and widely spreading, entire; lobule inflated, attached to the dorsal lobe by a long arched keel, usually with two distinct teeth in the apical region; leaf-cells with more or less thickened walls, scattered ocelli usually present. Underleaves doubled, one for every lateral leaf, deeply bifid with divaricate lobes. Antheridia borne in pairs in the axils 
of saceate bracts, the latter usually in short androecia. Female inflorescence borne on a branch rariable in length, with a single subfloral innoration. Perianth sharply five-keeled, abruptly narrowed into a short beak. Gemmae discoid, borne on the surface of the leaves. [Greek, doubled Lejeunea.] About 20 speeies, tropical. Type species: D. pellucida (Meissn.) Schiffn.

\section{Diplasiolejeunea Rudolphiàna Steph. Hedwigia 35: 79. 1896.}

Plants yellowish green, in compact depressed tufts. Leaves imbricated, the dorsal lobe widely spreading, somewhat convex, broadly ovate, about 1.3 $\mathrm{mm}$. long, entire or nearly so; lobule about $0.7 \mathrm{~mm}$. long, more or less inflated, the apical tooth long and slender, ustially subparallel with the axis; leaf-cells with small trigones; unclerleaves distaut to subimbricated, broadly enneate, bifid about one half with obliquely sprealing, blunt dirisions and a rounded sinus; inforescence autoecious; female inflorescence borne on a branch variable in length, the innovation usually simple and sterile; bracts bifid to the middle or beyond, the dorsal lobe rounded at the apex, the ventral obtuse to acute; bracteole ovate, shortly bifid, with acute to obtuse divisions; perianth obovate in outline, rounded at the apex; gemmiparous leaves usually two, borne terminally on branches with limited growth.

On bark, New Proridence:-Florida; West Indies; Dutch Guiana; Brazil. RuDOLPH'S DIPLASIOLEJEL'XE.

\section{LEPTOCòLEA [Spruce] Evans, Bull. Torr. Club 38: 261. 1911.}

Stems prostrate, minute and delicate, irregularly branched, the branches as in Radula. Leaves more or less imbricated, complicate-bilobed, the dorsal lobes larger than the ventral, broadly to narrowly ovate, attached by a very short base, widely spreading, usually rounded at the apex; lobule inflated, attached to the dorsal lobe by a long arched keel, usually with two teeth in the apical region; leaf-cells often with trigones and surface-tubercles, ocelli and hyaline marginal cells sometimes present. Underleaves none. Antheridia borne singly or in pairs in the axils of the male bracts, the latter usually saccate and forming more or less elongated androecia. Archegonia borne singly on more or less elongated branches, with one or two subfloral innovations, the bracts usually with plane lobules. Perianth compressed, with sharp lateral keels and sometimes with a more or less distinct two-angled rentral keel, beak short. Gemmae discoid, borne on the surface of the leaves. [Greek, delicate sheath.] About 30 species, mostly tropical. Type species: L. micrandroecia (Spruce) Erans.

1. Leptocolea Jooriàna (Aust.) Evans, Bull. Torr. Club 38: 270. 1911.

Lejeunea Jooriana Aust. Bull. Torr. Club 6: 20. 1875.

Cololejeunea Jooriana Evans, Mem. Torr. Club 8: 173. 1902.

Yellowish green or whitish, loosely tufted or scattered. Leaves imbrieated, the dorsal lobe willely spreading, plane, ovate, about $0.5 \mathrm{~mm}$. long, gradually narrowed to the ajex, usually from one to ten hyaline cells with free extremities; lobule about half as long as the lobe, with two teeth in the apical region; leaf-cells with slightly thickened walls and indistinct trigones; inflorescence paroecious or synoccious; perianth orate to obovate in outline, truncate to very slightly retuse at the apex with a very short beak.

On bark, New Irovidence and Crooked Island:-North Carolina to Florlda and Louisiana; Horto lico. Jook's LePtocoleA. 
5. LeJeÙneA Libert, Ann. Gen. Sci. Phys. (Brux.) 6: 372. 1820.

Stems prostrate, small, irregularly branched, the branches as in Radula; rhizoids springing from the bases of the underleaves. Leares complicatebilober, the dorsal lobes larger than the ventral, incubous, attached by a long line, orate to obovate, rounded to obtuse at the apex, entire or slightly crenulate; lobule when well developed inflated, acute, bearing a hyaline papilla at the base of the apical tooth on the side next to the stem; leaf-cells thin-malled but sometimes with small trigones. Underleares orate to orbicular, bifid, the division mostly entire or crenulate. Antheridia borne or in pairs in the axils of saccate bracts, the latter in more or less elongated androecia. Archegonia borne singly on branches variable in length with one or two subfloral innorations, the bracts with plane lobules, bractole bific. Perianth inflated, fivekeeled, abruptly narrowed to a distinct tubular beak. [Commemorates A. L. S. Lejeune, Belgian botanist.] Nearly 200 species, mostly tropical. Type species: L. cavifolia (Ehrh.) Lindb.

Lobule about $0.2 \mathrm{~mm}$. long; keels of perianth smooth or nearly so. 1. L. flava. Lobule about $0.1 \mathrm{~mm}$. long; keels of perianth distinctly crenulate. 2. L. glaucesecns.

1. Lejeunea flàva (Sז.) Nees, Naturges. Eur. Leberm. 3: 277. 1838.

Jugermannia flava Sw. Prodr. 144. 1788.

Plants pale to yellowish green, scattered or growing in depressed mats. Leares imbricated, the dorsal lobe widely spreading, ovate, about $0.5 \mathrm{~mm}$. long, rounded to obtuse at the apex; lobule inflated, orate, more or less involute, apex tipped with a single blunt cell; leaf-cells thin-malled but usually with distinct trigones, areraging about $23 \mu$ in the middle of the lobe; underleares usually subimbricated, orbicular, plane, bifid about one half with the segments usually sharp-pointed and the sinus narrow; inflorescence autoecious; female inflorescence borne on a more or less elongated branch with one or two subfloral innovations; bracts a little larger than the leaves; bracteole free, ovate; perianth obovoid, the keels rounded in the upper part, smooth.

On bark, Waterloo and Maidenhead Coppice, New Providence:- North Carolina to Florida and Texas; Ireland: Australia; widely distributed in tropical regions throughout the world. YELLOW LEJECXEA.

\section{Lejeunea glaucéscens Gottsche, in G. L. \& N. Syn. Hep. 37S. 1845.}

Plants pale to bright green, scattered or growing in thin, depressed mats. Leaves subimbricated, the doreal lobe widely spreading, ovate, about $0.7 \mathrm{~mm}$. long, usually broad and rounded at the apex; lobule inflated, triangular-oroid, involute, apex tipped with a single blunt cell; leaf-cells thin-walled and usually without trigones, averaging about $33 \times 25 \mu$ in the middle of the lobe; underleaves distant, orbicular, plane, bifid about one third with rounded or obtuse lobes and a narrow sinus; inflorescence autoecious; female inflorescence borne on a more or less elongated branch with a single subfloral innoration; bracts shorter than the leaves, the lobule pointed; bracteole slightly connate, ovate to obovate; perianth obovoid, the keels rounded above, minutely erenulate.

On bark, Great Bahama and Cat Island:-Florida: tropical America; range not definitely known. The Bahamian specimens are not very well developed but seem to be referable to this species. GRAYISH LEJECNEA. 
6. MICROLEJEÙnEA [Spruce] Jack \& Steph. Bot. Centrb. 60: 107.1594.

A somewhat artificial genus differing from Lejeunea in its snaller size and relatively larger lobules, the latter often equaling the dorsal lobes in length. Structure of the lobes, lobules, underleaves and floral organs rery similar in the two genera. [Greek, ninute Lejeunea.] About 70 species, mostly tropical.

Lobule about half as long as the dorsal lobe; leaf-cells areraging about $20 \mu$.

Lobule nearly as long as the dorsal lobe; leaf-cells averaging about $12 \mu$.

1. H. laetevirens.

2. II. bullata.

1. Microlejeunea laetevirens (Nees \& Mont.) Evans, Bryol. 11: 68. 1908.

Lejeunea laeterirens Nees \& Mont. in Sagra, Hist. Cub. 9: 2S1. 184..

Plants pale green, scattered or growing in depressed mats. Leaves distant to subimbricated, the dorsal lobe obliquely spreading, ovate, about $0.25 \mathrm{~mm}$. long, rounded to obtuse at the apex; lobule inflated, about half as long as the lobe, orate, involute, apex tipped with a single, almost straight, blunt cell; leaf cells areraging about $20 \mu$ in the middle of the lobe, thin-walled throughout or with minute trigones; underleaves distant, orate, bifid about one half with acute or acuminate divisions and a narrow sinus, often unidentate on one or both sides; inflorescence dioecious; female inflorescence borne on a short branch, with one or two subfloral innorations; bracts a little larger than the leaves, the lobule rounded to acuminate; bracteole free, orate; perianth pyriform, the keels smooth.

On bark, Abaco, Berry Islands, Andros, New Providence, and Cat Island:-Virginia; Florida to Louisiana; Nidely distributed in tropical America. Jellowish GREEN MICROLEJ EUNEA.

2. Microlejeunea bullàta (Tayl.) Evans, Mem. Torr. Club 8: 164. 1902.

Le jeunea bullata Tayl. Lond. Journ. Bot. 5: 39S. 1846.

Plants pale or bright green, scattered or forming loose depressed mats. Leares distant, the dorsal lobe erect or slightly spreading, ovate, about 0.15 long, rounded at the apex, entire or nearly so; lobule strongly iuflaterl, almost as long as the lobe, orate, usually involute, the apex tipped with a single, almost straight, blunt cell; leaf cells averaging about $12 \mu$, usually thin-walled throughout; underleaves distant, ovate to orbicular, bifid more than one half with suberect, subulate lobes and a broad sinus, margin entire; inflorescence dioecious; female inflorescence borne on an elongated branch with a single subfloral innovation; bracts about twice as long as the leares, the lobe rounded to acute, the lobule narrower, usually acute; bractole slightly connate, oblong, bifid less than one half with sharp divisions; perianth pyriform, the keels smooth.

On bark, New Providence and Crooked Island:- -southern Uuited States; tropical America. INFLATED MICROLEJEUNEA.

7. RECTOLEJEÙNEA Evans, Bull. Torr. Club 33: S. 1906.

Differs primarily from Lejeunea in its flattened perianth with sharp lateral keels. Dorsal lobes, lobules and underleares similar, but the lobes commonly broader; ocelli sometines present among the leaf-cells; regetative reproduction by means of specialized caltucous leaves. [Greek, fragile Lejeunca.] About 40 species, largely of tropical America. Type species: R. flagelliformis Erans. 
Leaves with basal ocelli : carducous leaves borne on short spreading brinches with crowled persistent underleares and limited giowth.

Leaves without basal ocelli; caducous leaves bolne on ordinary branches.

Dioecious: bracteoles present along the whole length of the androecia.

Autoecious; bracteoles restricted to the base of the androecia.

1. R. Berteroana.

\section{R. Brittoniae.}

3. R. phyllobola.

1. Rectolejeunea Berteroàna (Gottsche) Erans, Bull. Torr. Club 33: 12. 1906. Lejeunea Berteroana Gottsche; Steph. Hedwigia 27: 282. 1888.

Pale green, seattered or in depressed tufts. Leaves imbricated, the dorsal lobe widely spreading, plane or nearly so, obliquely ovate, about $0.5 \mathrm{~mm}$. Iong, rounder at the apex; lobule inflated, ovoir-cylindrical, involute, apex tipped with uniformly thickened walls, areraging about $10 \mu$; basal ocelli much larger, usually occurring in groups of two to six; underleaves normally contiguous, orbicular, plane, bifid about balf way with acute lobes and sinus; inflorescence dioecious; female inflorescence borne on a short branch with a single subfloral innovation; bracts with plane lobules, otherwise much like the leaves; perianth unknown; caducous leares borne on short spreading branches with crowded persistent underleaves and limited growth.

On bark, Soldier's Road and Grantstown, New Providence:-Florida; West Indies. Bertero's Rectolejexiea.

2. Rectolejeunea Brittòniae Evans, Bull. Torr. Club 38: 209. 1911.

Yellowish green, growing in depressed mats. Leaves imbricated, the dorsal lobe widely spreading, plane or nearly so, broadly ovate to orbicular, about 0.5 $\mathrm{mm}$. long, rounded at the apex, margin raguely crenulate; lobule inflated, triangular-ovoid, inrolute, apex tipped with a straight, slightly projecting cell; leaf cells with indistinct trigones, averaging about $25 \mu$ in the middle of the lobe; underleaves scarcely overlapping, orbicular, bifid about one half with sharp or blunt lobes; inflorescence dioecious; male inflorescence variable in length, the bracteoles present throughout and similar to the underleaves; female infloreseence usually on an elongated branch, with one or two subfloral innovations; bracts and bracteoles a little larger than the leaves; perianth oblong to obovate; caducous leaves borne ou prastrate branches.

On bark, Great Bahama and New Proridence:-Florida; Cuba; Hispaniola. Mrs. BRITTON'S RECTOLEJEUNeA.

3. Rectolejeunea phyllòbola (Nees \& Mont.) Evans, Bull. Torr. Club 33: 15.

Lejeunea phyllobola Nees \& Mont. in Sagra, Hist. Cub. 9: 281. 1845.

Pale green, growing in depressed mats. Leaves loosely imbricated, the dorsal lobe widely spreading, ovate-orbicular, about $0.5 \mathrm{~mm}$. long, rounded at the apex, entire or nearly so; lobule inflated, ovate, involute, apex ustially tipper with a single rounded cell; leaf cells thin-walled but with distinct trigones, areraging about $20 \mu$; underleaves distant, broadly ovate to orbicular, bifid to about the middle with narrow and usually sharp divisions; inflorescence autoecious; male inflorescence with the bracteoles restricted to the basal portion; female inforescence usually borne on a short branch with a single subfloral innovation; bracts, bracteoles and perianths much as in the preceding species; caducous leaves borne on prostrate branches.

On bark, Great Bahama, New Providence, Cat and Watling's Islands :-Florida ; Bermuda; West Indies. LEAF-SHEDDixg RectoleJeUnea.

8. CHEILOLEJEÙNEA [Spruce] Schiffn. in E. \& P. Nat.

Pflf. $1^{3}$ : 124. 1594.

Stems prostrate, small or medium-sized, irregularly branched, the branches as in Radula; rhizoids springing from the bases of the underleaves. Leaves 
complicate-bilobed, the dorsal lobes plane or slightly convex, wilely spreading, ovate to orbicular, rouncled at the apex, entire; lobule strongly inflated and more or less contracted in the onter part, with a single apical tooth bearing a hyaline papilla at its distal base; leaf-cells usually with distinct trigones. Underleaves suborbicnlar, bifid, the divisions mostly acute and the margins entire. Antheridia usually borne in pairs in the axils of saccate bracts, the latter usually in short androecia. Arehegonia borne singly on branches variable in length, with or without subfloral innovations, the bracts with plane and usually acute lobules; bracteoles bifid. Perianth compressed with sharp lateral keels, often becoming two-lipped with age. Vegetative reproduction by means of caducous leaves. [Greek, lipped-Lejeunea.] About 60 species, mostly tropical. Type species: C. aneogyna (Spruce) Evans.

\section{Cheilolejeunea decìdua (Spruce) Evans, Bull. Torr. Club 33: 6. 1906.}

Lejeunea decidua Spruce, Trans. Bot. Soc. Edinb. 15: 257. 1884.

Pale or brownish green, growing in depressed mats. Leaves imbricated, the dorsal lobe ovate, abont $0.7 \mathrm{~mm}$. long; lobule triangular orate in ontline, apex tipped with a long, pointed, slightly curved cell; leaf-cells usually with trigones but sometimes thin-walled throughout, averaging about $20 \mu$; underleaves distant, plane, orbieular, bifid to the middle or less with triangular, erect, sharp divisions and a broad sinus. Inflorescence dioecious. Female inflorescence borne on a short branch, with or without a subfloral innovation; perianth broadly obovate; callucous leaves borne on prostrate branches.

On logs, near Nicholl's Town, Andros:-Florida ; Cuba ; Iorto Rico: Brazil. DECIDUOUS-LEATED CHEILOLEJEUNEA.

\section{EUOSMOLEJEÙNEA [Spruce] Schiffn, in E. \& P. Nat.}

Pflf. $1^{3}: 124.1594$.

Tellowish green and firm. Stems prostrate, often elongated, irregularly branched, the branches as in Radula; rhizoids springing from the base of the underleares. Leares complicate-bilobed, the dorsal lobes much larger than the ventral, incubous, attached by a long line, broadly ovate, convex, rounded at the apex, entire or nearly so; lobule strongly inflated, acute, bearing a byaline papilla in the sinus, at the base of the apical tooth; leaf-cells with conspicuous trigones; ocelli none. Underleaves varying from medium-sized to large, sometimes imbricated, orbicular and often cordate at the base, usually bifid with an acute to lumulate sinus, rarely undivided. Antheridia usually in pairs in the axils of saccate bracts, the latter in more or less elongated androecia, often proliferating. Female inflorescence borne on a more or less elongated branch, with one or two subfloral inmorations; bracts similar to the leares but with plane lobules and sometimes with pointed lobes; bracteole bifid, free. Perianth often roughened by projecting cells, sharply 5 -keeled, the keels rounded above, heak distinct. Gemmae none. [Greek, fragrant Lejeunea.] About 35s species, largely tropical. Type species: E. trifaria (Reinw. Bl. \& Nees) Sehiffu.

Dioecious, perianths ralely present.

Inderleaves small and distant, narrowed toward base.

Underleaves large and usually overlapping, rounded to cordate at base.

Autoerious, perlanths uswally present: underleaves large and usually overlapping, rounded to cordate at base.

1. E. duriuscula.

2. E. clausa.

3. L. trifaria. 
1. Euosmolejeunea duriúscula (Nees) Evans, Mem. Torr. Club 8: 135. 1902. Lejeunea duriuscula Nees, in G. L. \& N. Syn. Hep. 364. 1545.

Tellowish green, growing in loose depressed mats. Leaves loosely imbricated, the dorsal lobe ovate, about $0.4 \mathrm{~mm}$. long; leaf-cells with distinct trigones, averaging about $20 \mu$; underleares distinct, orate to orbicular, narromed toward base, bifid about one half with acute lobes and sinus; inflorescence dioecious; androecium usually intercalary on a more or less elongated branch; female inflorescence borne on a similar branch with one or two subfloral innorations.

On bark, rarely on rocks, Abaco, Andros and New Providence:- South Carolina; Florida; widely distributed in tropical America. IIARSH Evos rolejevNea.

2. Euosmolejeunea claùsa (Nees \& Mont.) Evans, Bryol. 11: 69. 1908.

Lejeunea clausa Nees \& Mont.; Mont. Ann. Sci. Nat. II. 14: 337. 1840.

In loose depressed mats. Leaves loosely imbricated, the lobe broadly ovate, about $0.5 \mathrm{~mm}$. long; leaf-cells with large trigones; underleaves contiguous or imbricated, bifid about one third with obtuse or acute divisions and an obtuse or acute sinus; inflorescence dioecious; androecium borne on a short branch, sometimes proliferating; female inflorescence borne on a short branch, with one subfloral innovation.

On logs, Soldier's Road, New Providence:--South Carolina; Florida and Alabama; Bermuda; widely distributed in tropical Ameríca. CLOSED Edos.MoleJEUNEA.

3. Euosmolejeunea trifària (Reinw. Bl. \& Nees) Schiffn. in E. \& P. Nat. Pflf. $1^{3}$ : 124 . 1594 .

Jungermannia trifaria Reinw. Bl. \& Nees, Nova Acta 12: 226. 1824.

Closely related to the preceding species but characterized by its slightly larger size, more robust trigones and autoecious inflorescence.

On logs. Soldier's Road and Waterloo, New Providence. Wridely distributed in tropical regions throughout the world; originally described from Javan material. THREEFOLD EUOSMOLEJEUNEA.

\section{TAXILEJEÙNEA [Spruce] Schiffn, in E. \& P. Nat.}

Pflf. $1^{3}$ : 125. 1894.

Plants prostrate or sometimes pendulous, bright green to whitish green, medium-sized to greatly elongated, irregularly branched, the branches as in Radula. Leaves complicate-bilobed, the dorsal Iobe often involute about the axis, usually acute or apiculate, with the margin more or less crenulate; leafcells large, thin-walled but with distinct and often large trigones. Underleaves medium-sized to large, often closely imbricated, bifid, usually crenulate. Antheridia usually borne in pairs in the axils of small saccate bracts, the androecia occupying short branches. Archegonia borne singly on branches of variable length, with subfloral innorations, the latter often repeatedly floriferous; bracts smaller than the leares. Perianth sometimes terete but usually five-kelled in the upper part, the keels smooth or winged. [Greek, swift Lejeunea.] About 100 species, mostly tropical. Type species: T. chimborazensis (Spruce) Steph.

1. Taxilejeunea obtusángula (Spruce) Erans, Bull. Torr. Club 38: 21 . 1911. Lejeunea obtusangula Spruce, Trans. Bot. Soc. Edin. 15: 221. 1884.

Pale green, scattered or forming loose depressed mats. Leaves imbricated, the dorsal lobe obliquely spreading, convex, orbicular-ovate to ovate, about 0.6 
nim. long, apex obtuse or apiculate, margin crenulate; lobule inflated, orate, involute, the apex tipped with a single, straight, slightly projecting cell; leafcells with distinct trigones, averaging about $32 \times 18 \mu$ in the middle of the lobe; underleares not overlapping, orbieular, plane, bifid one half or less, with erect, usually sharp divisions; inflorescence autoecious; female inflorescence borne on a short or more or less elongated branch, with one or two subfloral innorations, the latter not floriferous; perianth oboroid, bluntly fire-keeled in the apical region, beak lacking.

On rocks, New Plovidence:--Florida; Porto Rico; Virgin Islands; Brazil. OBTUSELY AXGLED TAXILEJEUNEA.

\section{CERATOLEJEÙNEA [Spruce] Schifin, in E. \& P. Nat.}

Pflf. $1^{3}: 125.1894$.

Plants prostrate, medium-sized, more or less pigmented with olive-brown and glossy, irregularly branched, the branches as in Radula. Leaves complicate-bilobed, the dorsal lobe convex, often toothed, the apex blunt or acute; lobule normally as in Lejeunea with a hyaline papilla at the proximal base of the apical tooth, sometimes enlarged and bladder-like; leaf-cells with more or less thickened walls and often with apparent trigones; ocelli sometimes present. Underleares medium-sized to large, orbicular to reniform, usually bifid. Antheridia borne singly or in pairs in the axils of saccate bracts, the latter in short androecia, often proliferating. Female inflorescence borme on a branch very variable in length, with one or two subfloral innorations; bracts often smaller and more dentate than the leares; bracteole more or less connate. Perianth with a distinct beak and usually with four conspicuous horns. [Greek, horned Lejeunea.] About 100 species, mostly tropical. Type species: C. plumula (Spruce) Steph.

Leares more or less dentate; autoecious.

Leares entire or nearly so; dioecious.
1. C. cubensis.

2. C. integrifolia.

1. Ceratolejeunea cubénsis (Mont.) Schiffn. in E. \& P. Nat. Pflf. $1^{3}: 125.1594$.

Lejeunea cubensis Mont. in Sagra, Hist. Cub. 9: 481. 1545.

Olive green or brown, growing in depressed mats. Leaves imbricater, the dorsal lobe orate, about $0.4 \mathrm{~mm}$. long, acute and usually irregularly toothed in the apical portion; lobule always small and of the normal Lejeunea type, sometinies poorly developed; leaf-cells apparently uniformly thickened, averaging about $15 \mu$; ocelli usually forming a basal pair; underleaves small, orbicular, plane, bifid about one half with acute dirisions; inflorescence autoecious; perianth with short, spreading to suberect horns.

On logs, Near Nicholl's Town, Andros:-Florida; widely distributed ln tropical America. CUBAN CERATOLEJEUNEA.

2. Ceratolejeunea integrifòlia Evans, Bull. Torr. Club 38: 213. 1911.

Related to the preceding species but readily distinguished by its entire leares and dioecious inflorescence. Bracts and bracteoles of the female inflorescence sometimes very sparingly toothed.

On bark, New Provldence:-Florida; Cuba; Porto Rico. Extrin-Leaved CeraTOLEJEUNEA. 
12. LEPTOLEJEÙNEA [Spruce] Schiffn. in E. \& P. Nat. Pflf. $1^{3}: 126.1894$.

Plants prostrate, small, irregularly but often copiously branched, the branches as in Radula. Leaves complieate-bilobed, the dorsal lobe usually plane, obtuse to acute; lobule as in Lejeunea, with a hyaline papilla at the proximal base of the apical tooth; leaf-cells thin-ralled but sometimes with distinct trigones; ocelli usually present. Underleares distant and minute, with widely spreading, subulate divisions. Antheridia usnally in pairs, in the axils of saceate bracts, the androecia rariable in length. Female inflorescence borne on a very short branch, simple or with a single subfloral innovation. Perianth sharply five-keeled in the upper part, the keels projecting upward as entire horns. Tegetative reproduction by means of caducous branches with specialized basal leares. [Greek, delicate Lejeunca.] A genus of about 50 tropical species. Type species: L. elliptica (Lehm. \& Lindenb.) Schiffn.

1. Leptolejeunea ellíptica (Lehm. \& Lindenb.) Schiffn. in E. \& P. Nat. Pflf. $1^{3}: 126.1894$.

Jungermannia elliptica Lehm. \& Lindenb. Pug. 5: 13. 1832.

Pale green, becoming blackish or brownish with age, growing in thin patches. Leares distant, the dorsal lobe willely spreading, oblong-ovate to oblong-lanceolate, about $0.35 \mathrm{~mm}$. long, rounded to subacute, entire; lobule inflated, ovate, the apex tipped with a single, almost straight cell; leaf-cells with small but distinct trigones, averaging about $23 \mu$; ocelli two to five, in an interrupted median row; divisions of underleaves formed of two or three cells in a single row; inflorescence antoecious or dioecious; female branch without an innovation; bracts scarcely complicate, usually bilobed; bracteole connate on both sides, linear, shortly bifid; perianth obconical, terete below, the horns acute or truncate.

On bark, Soldier's Road, New Providence:-Florida; widely distributed in the tropical regions of America, Asia, and the Pacific Islands; usualiy growing on living leares. Elliptic LeptoleJ EuNEA.

\section{BRACHIOLEJEÙNEA [Spruce] Schiffn. in E. \& P. Nat.}

Pflf. $\mathbf{1}^{3}$ : 128.1894

Plants prostrate or pendulous, medium sized to large, irregularly branched, some of the branches usually as in Frullania, the others as in Radula, color often dark brown or nearly black. Leaves imbricated, complicate-bilobed, the dorsal lobe squarrose (at least when moist), ovate, rounded to apiculate or acute, entire; lobule inflated along the keel, appressed to the dorsal lobe along the crenulate or dentate margin, hyaline papilla at the proximal base of the apical tooth, displaced from the margin; leaf-cells with distinct trigones. Underleaves undivided, orbicular to reniform, entire. Antheridia in paroecious species borne singly in the axils of scarcely modified bracts, in autoecious species borne in pairs in the axils of saccate bracts, the androecia in the latter case long and often proliferating; bracteoles everywhere present. Female inflorescence borne on a more or less elongated branch, with one or commonly two subfloral innovations; bracts scarcely complicate but often winged along the keel, unequally bilobed; bracteole rounded to shortly bilobed. Periauth 
obovoid, sometimes compressed, with from four to ten rounded keels without wings or teeth. [Greek, armed Lejeunea.] About 65 speeies, mostly tropical. Type species: B. laxifolia (Tayl.) Schiffn.

Autoecious: perianth ten-keeled.

Dioecious; perianth five- to seven-keeled.
1. B. bahamensis.

2. B. corticulis.

\section{Brachiolejeunea bahaménsis Evans, Bull. Torr. Club 35: 383. 1908.}

Dull green, varying to brown or almost black, seattered or growing in depressed mats. Dorsal lobe of leaves convolute about the stem when dry, squarrose when moist, about $0.9 \mathrm{~mm}$. long; lobule usually with five or six teeth, each usually three or four cells long; leaf-cells averaging about $25 \times 15 \mu$; underleaves broadly orbienlar, rounded at base; inflorescence autoecious; male bracts in from three to ten pairs, the androecium often proliferating; female inflorescence usually with two innorations; bracts winged, the lobule obtuse, acute, or apiculate. Perianth with ten rounded keels, scarcely compressed.

On bark. Abaco, New Proridence, Watling's and Crooked Islands:-Florida; Cuba ; Porto Rico. Ballamian Brachiolejeuses.

2. Brachiolejeunea corticàlis (Lehm. \& Lindenb.) Schiffn.; Evans, IIem. Torr. Club 8: 131. 1902 .

Jungermannia corticalis Lehm. \& Lindenb. Pug. 4: 50. 1532.

Very similar in appearance to $B$. bahamensis. Lobule usually with only four teeth, each only one or two cells long; underleaves euneate at base; inflorescence dioecious; lobule of female bracts rounded; perianth with five to eight keels.

On bark, Great Bahama and Cat Island:-Florida; tropical America. BARK BRACHIOLEJEUNEA.

\section{LOPHOLEJEÜNEA [Spruce] Sehiffu, in E. \& P. Nat.}

Pflf. $1^{3}: 129$. 1594.

Plants prostrate, usually dark brown or almost black, rarely olive green, often glossy, medium-sized, irregularly branched, the branches as in Radula. Leaves complicate-bilobed, the dorsal lobe not squarrose when moist, often revolute at the rounded or bluntly pointed apex, entire exeept in the rieinity of the female inflorescence; lobule inflated along the keel, the margin not involute, the apical tooth usually represented by a blunt, slightly projerting cell, with the hyaline papilla near its proximal base; leaf-eells with distinet trigones or apparently uniformly thickened. Tnderleaves plane, orbieular to reniform, undivided. Antheridia borne in pairs in the axils of saceate bracts, the androecia more or less elongated, with the bracteoles everywhere present. Female infloreseence borne on a more or less elongaterl braneh, without subfloral innovations; bracts more or less strongly toothed, the lobule mueh smaller than the lobe and sometimes redueed to a minnte basal tooth; bracteole usually undivided but sometimes toothed. Perianth strongly compressed with two sharp rentral keels, the keels with tootherl or laciniate wings. [Greek, erestar] Lejeunea. $]$ About 70 speeies, mostly tropical. Type species: L. Sagraeana (Mont.) Sehiffn. 
1. Lopholejeunea Sagraeàna (Mont.) Schiffn. in E. \& P. Nat. Pflf. $1^{3}$ : 129. 1894.

Phragmicoma Sagraeana Mont. in Sagra Hist. ('ub. 9: 464.1845.

Brownish or blackish green, more or less glossy, growing in depressed mats. Leaves imbricated, the dorsal lobe widely spreading, oblong-ovate, about $0.75 \mathrm{~m}$. long, rounded; apical tooth of lobule of ten indistinct; leaf-eclls apparently uniformly thickened except for minute pits, averaging about $20 \mu$; underleares subimbricated, reniform; inflorescence normally autoecious; perichaetial bracts larger than the leaves, the dorsal one suborbicular, coarsely toothed, the lobule in the form of a minute basal tooth; bracteole entire or nearly so; perianth oval to obovate in outline, the beak short and the wings deeply and closely laciniate.

On bark, Andros and New Providence:-Florida; widely distributed in tropical America; also reported from Africa and the East Indies. SAGRA's LopholeJEUNEA.

\title{
15. CAUdALEJeÙNEA [Steph.] Schiffn. in E. \& P. Nat.
}

\author{
Pflf. $1^{3}: 129.1594$.
}

Plants prostrate or ascending, medium-sized to large, green, not glossy. Leares more or less imbricated, complicate-bilobed, the dorsal lobe not squarrose, oblong-ovate, rounded to acute, usually entire; lobule inflated, the margin involute, mostly bidentate, the apical or outer tooth with the hyaline papilla near its proximal base; leaf-cells thin-walled but with distinct trigones. Underleaves orbicular, more or less retuse, entire. Antheridia in pairs in the axils of saccate bracts, the androecia more or less elongated, terminal; bracteoles everywhere present. Female inflorescence borne on a more or less elongated branch without subfloral innovations; bracts mequally bilobed, the lobe entire or toothed, the lobule narrow and scarcely projecting, entire; bracteole shortly bifid, entire or toothed. Perianth obovate, compressed and with a single sharp ventral keel, the lateral keels sometimes with entire or dentate wings. [Latin, tailed Lejeunea.] About 15 species, mostly tropical. Type species: C. Lehmanniana (Gottsche) Evans.

1. Caudalejeunea Lehmanniàna (Gottsche) Evans, Bull. Torr. Club 34: 544. 1907 .

Lejeunea Lehmanniana Gottsch, in G. L. \& N. Syn. Hep. 325. 1545.

Very variable, bright or pale green, scattered or growing in loose tufts. Dorsal lobe of leaves about $1 \mathrm{~mm}$. long, the apex usually rounded and entire but sometimes acute and irregularly angular-dentate; apical tooth of lobule acute and outwardly curved, often three or four cells long; leaf-cells averaging about $28 \times 21 \mu$; perichaetial bracts about as large as the leaves, the lobe ovate-lanceolate, more or less sharp-pointed even when entire.

On twigs, Maidenhead Coppice, New Providence:-Florida; widely distributed in the American tropics. LemMaNe's CaUdalejeunea.

\section{MASTIGOLEJEÙNEA [Spruce] Schiffn. in E. \& P. Nat.} Pflf. $1^{3}: 129.1894$.

Plants medium-sized, with prostrate or ascending secondary stems arising from a prostrate caudex; branches as in Radula, sometimes mierophyllous or flagelliform, often abundantly produced by the secondary stems; color green 
to almost black, not glossy. Leaves complicate-bilobed, the dorsal lobe squarrose when moist, ligulate to orate, entire or nearly so, the apex rounded to subacute, not reflexed; lobule normally inflated along the keel, the margin plane or involute, the apex represented by a more or less distinct tooth with a hyaline papilla at its proximal base; lobule often poorly developed. leaf-cells with distinct trigones. Underleaves more or less convex and often revolute along the sides, orbicnlar to obovate, undivided but sometimes retuse, entire. Antheridia borne singly in the axils of saccate bracts, the androecia long, sometimes proliferating; bracteoles everywhere present. Female inflorescence borne on an elongated branch, usually with but one subfloral innoration; bracts unequally complicate-bilobed, without wings; bracteole similar to the underleaves. Perianth with sharp lateral keels and a single sharp rentral keel, usually wingless. [Greek, whip-bearing Lejennea.] About 50 species, mostly tropical. Type species: M. auriculata (Wils. \& Hook.) Schiffn.

1. Mastigolejeunea auriculàta (Wils. \& Hook.) Schiffn. in E. \& P. Nat. Pflf. $1^{3}$ : 129.1894.

Jungermannia auriculata Wils. \& Hook.; Drummond, Musc. Amer. St. Merid. 170. $18+1$.

Glaucous green, varying to purplish black, growing in depressed tufts. Dorsal lobes of leares appressed when dry, squarrose when moist, about $1 \mathrm{~mm}$. long, rounded to subacute; leaf cells averaging about $21 \times 12 \mu$; underleaves broadly orbicular, truncate to retuse, usually cuneate at the base; inflorescence autoecious or dioecious; perianth oval, the keels not winged.

On bark and rocks, Andros and New Providence:-Florida to Louisiana; widely distributed in tropical America. EARED Mastigoledeunea.

17. ARCHILEJEÙNEA [Spruce] Schiffn. in E. \& P. Nat. Pflf. $1^{3}: 130.1894$.

Plants medium-sized to large, usually reddish or brownish, consisting of a prostrate eaudex and secondary, often branehed, stems, free from the substratum, the branches as in Radula. Leaves imbricated, complicate-bilobed, the dorsal lobes not squarrose when moist, suborbieular to ligulate, rounded and entire; lobule inflated along the keel, the margin more or less appressed to the lobe, entire except for the sharp apical tooth, with a hyaline papilla near the proximal base; lobules often imperfectly developed on the secondary stems; leaf-cells with distinct trigones. Underleaves orbicular to reniform, undivided, entire. Antheridia borne in pairs in the axils of saceate bracts, the androccia long but often proliferating; bracteoles everywhere present. Female inflorescence borne on a secondary stem or one of its branches, with one or (more rarely) two subftoral innovations, the innovations often floriferous, thus giving rise to cymose clusters; bracts unequally complicate-bilobed but not wingei, the lobes entire, narrower and often more sharply pointed than the leares; bracteole sometimes bidentate or retuse. Perianth oblong to obovate, more or less compressed, dorsal surface with one and ventral surface with two keels, the keels with narrow and interrupted wings. [Greek, chief Lejennea.] About 70 species, mostly tropical. Type species: A. porelloides (Spruce) Schiffn. 
1. Archilejeunea viridíssima (Lindenb.) Evans, Bull. Torr. Club 35: 169.1908.

Lejeunea viridissima Lindenb. in G L. \& Syn. Hep. 320. 1845.

Yellowish or bromnish green, becoming darker with age, neither glossy nor glaucous, growing in depressed mats; secondary stems simple or sparingly branched, often with poorly developed lobules. Leaves with broadly ovate dorsal lobes, about $0.75 \mathrm{~mm}$. long; lobule (when well-dereloped) bearing two teeth, the outer or apical often rariously curved and longer than the inner tooth; leaf-cells averaging about $24 \times 18 \mu$; underleares distant to loosely imbricated, broadly orbicular-ovate, cuneate, rounded to subretuse; inflorescence autoecious. Female inflorescence usually with a single subfloral innoration, the bracts very deeply bilobed; perianth oblong-obovate, the wings usually distinct but narror, sinuate or subcrenulate.

On bark, Eight Mile Rocks, Great Bahama:-Jamaica; Porto Rico; Venezuela. GREENEST ARCHILEJEUNEA.

\section{LEUCOLEJEÙNEA Evans, Torreya 7: 225. 1908.}

Plants medium-sized to large, pale green or glaucous, neither glossy nor pigmented, prostrate, copionsly branched, the branches as in Radula. Leaves imbricated, complicate-bilobed, the dorsal lobes not squarrose when moist, orate-oblong to suborbicular, convex and often revolute along the lower margin and in the region of the rounded apex, entire or nearly so; lobule inflated throughout, the margin more or less involute, entire except for the single blunt to acuminate apical tooth with the hyaline papilla at the distal base; leafcells with small trigones. Underleares orbicular to reniform, undivided. Antheridia borne in pairs in the axils of saceate bracts, the androecia short, not proliferating; bracteoles restricted to the base. Female inflorescence borne on a branch variable in length, innorating on one or both sides; bracts with plane lobules, otherwise similar to the leaves. Perianth five-keeled, scarcely compressed, the keels smooth or obscurely crenulate or denticulate, rarely with indistinct wings. [Greek, white Lejeunea.] A small genus, consisting of about 6 species, of tropical and temperate regions. Type species: L. clypeata (Schrein.) Evans.

Dorsal lobes slightly convex or plane, not revolute; apex of Iobule easils seen.

Dorsal lobes strongly convex and revolute; apex of lobule not easily seen except by dissection.

\section{L. unciloba.}

2. L. xanthocarpa.

1. Leucolejeunea unciloba (Lindenb.) Evans, Torreya 7: 228. 1908.

Lejeunea unciloba Lindenb. in G. L. \& N. Syn. Hep. 331. 1845.

Pale green and glaucous, growing in depressed mats. Leaves closely imbricated, the dorsal lobe plane or slightly convex, ovate-oblong, about $1.2 \mathrm{~mm}$. long; lobule inflated toward base, the margin plane except at the base, the apical tooth acuminate and sometimes hamately curved, usually three to six cells long, easily visible without dissection; leaf-cells averaging about $18 \mu$ in diameter; underleaves broadly orbicular to reniform; inflorescence autoecious.

on bark, Soldier's Road, New Providence:-Rhode Island south to Florida and west to Texas; widely distributed in tropical America. HOOK-LOBED LeucoleJeuNEA.

2. Leucolejeunea xanthocárpa (Lehm. \& Lindenb.) Erans, Torreya $7: 229.1908$.

Jungermannia xanthocarpa Lehm. \& Lindenb. Pug. 5: 8. 1832.

Strongly resembling $L$. unciloba in size and general appearance and agreeing with it in inflorescence. Distinguished by its strongly convex leaf lobes 
with revolute apex and lower margin; lobule sometimes blunt at the apex and sometines with a more or less elongated acuminate tooth, reaching a maximum length of four cells, not visible without dissection; leaf-cells averaging about $20 \mu$.

On bark, New I'rovidence:-Florida; widely distributed in the American tropies; Africa; Java. Yellow-Frt'ited Leucolejeuned.

\section{FRULLÀnIA Raddi, Atti Soc. Ital. Sei. Modena 18: 20. 1818.}

Dark green or more or less pigmented with yellow, brown or red. Stems prostrate, ascending or pendent, more or less copiously branched, the branches all arising at the bases of leaves without lobules, rhizoids springing from the bases of the underleares. Leares deeply complieate-bilobed, the dorsal lobes much larger than the ventral, incubous, widely spreading, ovate to orbieular, usually entire, lobule normally inflated, helmet-shaped; leaf-cells with distinct trigones; ocelli present in eertain speeies. Underleaves smaller than the leaves, usually bifid. Antheridia mostly in pairs, in the axils of inflated bracts with explanate lobules, the bracts imbricated and forming short or more or less elongated audroecia. Female inflorescence borne on a nore or less elongated. branch, without innorations; bracts larger than the leaves, with explanate lobules and often more or less connate with the bifid bracteole. Perianth normally 3-keeled, with one keel rentral, but often with supplementary folds, abruptly contracted into a short tubular beak. [Commemorates L. Frullani, a Florentine minister of state.] A very large genus, 800 or more deseribed species, mostly tropical. Type speeies: F. dilatata (L.) Dumort.

Leares not squarrose.

Perianth with two lateral keels and a two-angled ventral keel; lobule inflated in upper part only.

Paroecious.

Autoecious.

Perianth distinctly three-keeled; lobule inflated throughout. Leaves more or less squarrose when moist.

Perianth with two lateral keels and a two-angled ventral keel, surface smooth.

Perianth distinctly three-keeled, the surface roughened by scattered tubercles or scales.
1. F. arietiua.

2. $F$, riojancirensis.

5. F. obcordata.

4. F. squarrosa.

\section{Frullania ariétina Tayl. in G. L. \& N. Syn. Hep. 413. 1845.}

Bright green, yellowish green or brownish green, seattered or in loose tufts. Leaves imbricated, the dorsal lobe plane or nearly so, orbicular-ovate, about 1.2 $\mathrm{mm}$. long; lobule inflated in the upper part only, the lower forming a subrhomboidal expansion; leaf-eells with conspicuous trigones, averaging about $30 \mu$; underleaves orbieular, shortly bifid, entire or nearly so; infloreseence paroecious, the saecate male bracts in two or three pairs below the female infloreseence; the latter borne on a short branch; bracts in one to three pairs, the innermost with ovate, acute, sparingly toothed lobes and similar but narrower lobules; bracteoles highly connate, bifid with narrow, sharp divisions; perianth oblong with two distinet lateral keels and a broad two-angled ventral keel.

On twigs, Grantstown, New Providence:- Fiorida; widely distributed in tropical America. Ray's Head Firluaxia. 
2. Frullania riojaneirénsis (Raddi) Spruce, Trans. Bot. Soc. Edinb. 15: 23. $18 \$ 4$.

Frullanoides riojaneirensis Raddi, Mem. Soc. Ital. Modena 19: 37. 1523.

Closely related to $F$. arietina but distinguished by its autoecious inflorescence. Androceia oceupying short branches in the vicinity of the female inflorescence, not proliferating, the bracts mostly in two or three pairs; female branch short, the leares and bracts forming a gradual series.

On twigs, New Providence:-Florida; widely distributed in tropical America. Rio JaNeiro Frellaxia.

\section{Frullania gibbòsa Nees in G. L. \& N. Syn, Hep. 411. 1845.}

Greenish yellow to dark brown, growing in elosely appressed tufts or mats. Leares densely imbricated, the dorsal lobe convex when dry, concave and squarrose when moist, broadly orbicular, about $0.9 \mathrm{~mm}$. long; lobule sometimes inflated throughout but normally in the upper part only; leaf-cells with conspicuous trigones, averaging about $33 \mu$; underleaves densely crowded, orbicular to reniform, shortly and sharply bidentate at the apex with a lunulate sinus, auriculate at the base; inflorescence monoecious (autoecious or paroecious); female branch very short, the bracts in two or three pairs, the innermost with orate, rounded or obtuse, entire lobes and subequal, strongly convolute, obtuse to acute lobules; bracteole highly connate, bifid with sharp divisions; perianth oblong, with two distinet lateral keels and a broad two-angled ventral keel.

On bark, Abaco and New Providence:-Alabama; widely distributed in the American tropics. The Bahamian specimens are not typical and may represent an undescribed species. GibBous Frullaxia.

4. Frullania squarròsa (Reinw. Bl. \& Nees) Dumort. Recueil d'Obs. 13. 1835.

Jungermannia squarrosa Reinw. Bl. \& Nees, Nora Acta 12: 215. 1824.

Dark green or pigmented with brown, scattered or growing in depressed mats. Leaves imbricated, the lobe roller around the stem when dry, strongly squarrose when moist, orate, rounded at the apex, and entire; lobule about as broad as long; underleaves bifid, usually with entire margins; inflorescence dioecious; female inflorescence borne on a short and simple branch, bracts in about three pairs; perianth oblong, without supplementary keels, surface more or less roughened by scattered tubercles or scales, especially along the keels.

On bark, Great Bahama, Berry Islands, New Providence, Eleuthera and Anguilla Isles:- Connecticut to Ohio and south to Florida and Louisiana; Bermuda ; widely distributed in tropical regions throughout the world. Spreading Fruluaxia.

5. Frullania obcordàta Lehm. \& Lindenb. in G. L. \& N. Syn. Hep. 447. 1845.

Yellowish green to reddish brown, growing scattered or in closely appressed mats. Leaves elosely imbricated, the dorsal lobe convex, ovate, about $0.7 \mathrm{~mm}$. long; lobule short-clavate, inflated throughout, spreading at a wide angle; leaf-cells with more or less distinct trigones, averaging about $18 \mu$; underleares subimbricated, orbicular, bifid about one half with obtuse or subacute divisions and sinus; inflorescence autoecious; androecia occupying short branches in the vicinity of the female inflorescence, the bracts in one or two pairs; female branch long, the bracts in three or four pairs, the innermost with orate, obtuse or apiculate, entire lobes and smaller subacute lobules; bracteole free or slightly connate, bifid about one third; perianth obcuneate, the beak in a slight depression, lateral keels and the single ventral keel distinct. 


\section{Order 3. ANTHOCEROTÀLES.}

Gametophyte a prostrate dorsiventral thallus, varying from strapslaped to circular, with rery little cell-differentiation, destitute of airspaces but sometimes dereloping intercellular spaces with mucilage; green cells witl one or a few large flat chloroplasts, often with a single pyrenois. Antheridia borne singly or in groups just below the upper surface of the thallus. Archegonia in irregular dorsal groups, imbedded, the tip of the neck alone projecting. Sporophyte differentiated into a broad foot and an elongated cylindrical capsule, the latter growing indefinitely by means of a basal embryonic region, splitting at maturity into two valres. Spores surrounding a central sterile structure, the columella, and interspersed with irregular, often multicellular elaters, with or without bands of thickening. Four or five genera and about 150 species, widely distributed.

\section{Family 1. ANTHOCEROTÀCEAE Lindb.}

\section{Axthoceros Family.}

Characters of the order.

\section{ANTHóceros [Micheli] L. Sp. Pl. 1139. 1753.}

Thallus suborbicular, variously lobed and often with plate-like outgrowths, sometimes irregularly dissected, sereral cells thick and destitute of a distinct midrib; green cells with a single chloroplast. Inflorescence usually (if not always) monoecious. Capsule erect, much longer than the basal sheath, with green cells in the wall and stomata in the epidermis. Spores variously roughened; elaters without spiral bands of thickening, composed of one to several cells and sometimes branched. [Greek, flowering horn.] About 50 species, largely tropical. Type species: A. punctatus L.

\section{Anthoceros laèvis L. Sp. Pl. 1139. 1753.}

Thallus nearly plane on the upper surface, dark green and somewhat lustrous, destitute of intercellular spaces. Capsule mostly 1-3 cm. long, the base surrounded by a cylindrical sheath often flaring at the mouth; spores vellow, the surface granular-papillose; elaters yellowish, very variable in size and form, often branched.

Along the Adelaide Road, New Providence, Bracc. Widely distributed in North Amerlca, Europe and Asla. The Bahamian specimens are sterile and their determination is therefore doubtful. YELLOW-SPORED AxTHoceros.

\section{Phylum 4. THALLOPHYTA.}

This phyllum includes many thousand speeies of simple organization, grouped in many genera and families. The plants eomposing it have seareely any woody tissue, and are propagated either by spores or by vegetative division. Most of them are small, but there are some large and conspicuous types in all the slasses. 
Terrestrial, saxicolous, or corticicolous plants, compased of filaments without chlorophyll and of cells containing chlorophyll.

Aquatic plints, or microscopic terrestrial or corticicolous organisms with chlorophyll.

Terrestrial ol corticicolous plints, or microscopic aquatics, wholly without chlorophyll.

Vegetative stage mycelial.

Vegetative stage plasmoidal.

Class 1. LiCHENEs.

Class 2. Algat.

Class 3. Fuxgi.

Class 4. MYXOMYCETES.

\section{CLASS 1. LICHĒNES.}

\section{CONTRibuted By Lincols W. Riddle.}

Fruit a perithecium, more or less flask-shaped, opening by a pore at maturity.

Fruit an apothecium, open at maturity.

Apothecia disk-shaped, circular; asci deliquescing before the spores mature.

Asci persisting until after the discharge of the spores. Apothecia typically linear, elliptical, or angular; rarely circular, and then without an exciple. Apothecia circular, disk-shaped or cup-shaped.

Order 1. Prinexulales.

Order 2. Caliciales.

Order 3. Graphidales. Order 4. LECidEales.

\section{Order 1. PYRENULÀLES.}

Perithecia with an apical ostiole.

Thallus crustose.

I'erithecia solitary.

Gonidia: Pleuroeoccus.

Gonidia: Trentepohlia.

Perithecia imbedded in a stroma.

Thallus squamulose or foliose.

Perithecia with a lateral ostiole.

Perithecia solitary.

Perithecia imbedded in a stroma.

Fam. 1. Terrucariaceat.

Fam. 2. Pr Ranulaceae.

Fam. 3. TRYPETHELIACEAE.

Fam. 4. Dermatocarpaceae.

Fam. 5. Paratheliaceaf.

Fam. 6. Astrotheli.iceae.

Family 1. VERRUCARIĀCEAE.

\section{VERRUCÀRIA Pers.}

Perithecia failing out and leaving pits in the rock.

Perithecia pruinose; ostiole papillate.

Perithecia nudate above; ostiole plane.

Perithecia not leaving pits in the rock.

Thallus nale, tinged with green or brown, perithecia superficial.

Thallus dark olive-brown, perithecia immersed.

1. V. mamillaris.

2. V. rupestris.

3. V. muralis.

4. V. nigrescens.

\section{Verrucaria mamillàris Riddle, sp. nov.}

Thallus epilithicns crustaceus uniformis effusus aut subdeterminatus haud linea nigra limitatus, cretaceo-albus vel sordide albidus, crassiusculus, continuus laevigatus inaequalis. Gonidia pleurococeoidea. Perithecia nigra hemisphaerica aut deplanata aut partim subconica, apica mamilliformia aut rarius obtusa, basi deficientia, ad $0.8 \mathrm{~mm}$. lata, dispersa solitaria, primum tota immersa dein 1/2-2/3 emergentia tenuiter thallino-pruinata, demum elabentia foveolamque relinquentia. Gonidia hymenialia nulla. Paraphyses simplices deliquescentes. Asei clavati 8-spori. Sporae in ascis biseriales incolores ellipsoideae simplices membrana laevigata, $16-21 \times 9-10 \mu$.

On limestone, vicinity of Cockburn Town, Watling's Island (Britton and Millspaugh, March 13, 1917, 6130, type); without station, New Providence (Brace, 9502, 9508).

This species, belonging to the section Euverrucaria, differs from Verrucaria rupestris in the thicker thallus and the larger, mamillate, pruinose perithecia.

2. Verrucaria rupéstris Schrad. Spicil. Fl. Germ. 109. 1794.

On limestone, New Providence, Eleuthera, Cat Island, Watling's Island:-cosmopolitan. 
3. Verrucaria muràlis Ach. Meth. Lich. 115. 1503.

On limestone, New Providence:-cosmopolitan.

4. Verrucaria nigréscens Pers. in Usteri, Ann. Bot. 14: 36. 1795.

On limestone, New Providence:- North America and Europe.

\section{Family 2. PYRENULÁCEAE.}

Spores plurilocular (two to many-celled).

Spores colorless.

Spores with cylindrical cells.

Paraphyses simple and persistent.

Paraphises branched or deliquescent.

Spores with lens-shaped or rounded cells.

Spores brown.

I'araphyses simple and persistent.

Paraphyses branched or deliquescent.

Spores muriform-multilocular.

Spores colorless.

I'araphrses simple and persistent.

Paraphyses branched or deliquescent. snores brown.

\section{PORINA Ach.}

1. Porina.

2. Arthopyrenia

3. I'scudopyrenula.

4. P'yrenula.

5. Nicrothelia.

6. Clathroporina.

7. Polyulastiopsis.

8. Anthracothecium.

Perithecial wall entirely black.

'Thallus chalky-white; perithecia $0.6-0.5 \mathrm{~mm}$. in diameter.

Thallus greenish or purplish; perithecia $1.0-1.5 \mathrm{~mm}$. in diameter.

Perithecial wall black at the tip only, or not at all.

Thallus subfoliose, on rocks.

Thallus with loosely adherent. convex lobes.

Thallus closely adnate, flat and merely crenate.

Thallus crustose, on bark.

Ostiole brown or reddish.

Ostiole blackening.

Spores $7-15 \mu$ wide.

Spores $4-6 u$ wide.

Thallus marked with frequent black lines.

Thallus without such lines.

1. P. Wilsonii.

2. P. macrocarpa.

3. P. firmula.

4. P. subfirmula.

5. P. nucula.

6. P. mastoidea.

7. P. variegata.

S. P. Tetraccrae.

\section{Porina Wilsònii Riddle, sp. nov.}

Thallus epilithicus crustaceus uniformis efinsus hand limitatus, cretaceoalbus opacus tartareus, crassiusculus continuus laevigatus, spermagoniis copiose nigropunctatus. Gonidia chroolepoidea. Perithecia globosa integra nigra, $0.6-0.8 \mathrm{~mm}$. lata, primum tota immersa maculis nigrescentibus indicata dein semiemergentia, alte convexa, strato tenue thallode fere ad instar pruinae relata, demum apicibus denudatis, ostiolis minutis umbonatis, nunquam elabentia. Paraphyses persistentes tenues simplices. Asci cylindrices 8-spori. Sporae in ascis uniseriales, incolores fusiformes 4-loculares locnlis cylindricis, $13-15 \times 4-5 \mu$. Spermagonia minuta nigra apicibus emergentibus denudatis. Spermatia recta bacillaria, $3-5 \times 1 \mu$.

On limestone, Caleta Cocodrälos, Isle of Pines, Cuba (Britton, Wilson, aud Lcón, March S, 1916, 15288, type).

IBabamas: on Jimestone, New Troridence (Brace, 9634) ; Governor's IIarbor, Eleuthera (Britton and Millspaugh, 5535). A lichen occurring neal" the Columbus Monument, Watling's Island, and showing spermagonia only, agrees with this species, but the determinatlon can not be consirlered celtain.

This species, which I take pleasure in naming in honor of Mr. Perey Wilson, may be distinguished from other species of the section sagcdia, to which it helongs, by the chalky-white, tartarcous thallus, and the delicately pruinose perithecia. it bears a strong external resemblance to Terrucaria mamillaris, but can, of course, be at once distinguished by the spores.

\section{Porina macrocárpa Riddle, sp. nov.}

Thallus epilithicus crustaceus uniformis effusus linea nigra limitatus, glaucus virescens aut purpurascens opacus, crassitudine mediocris aut tenuis, 
continuus laevigatus, olim spermagoniis nigropunctatus. Gonidia ehroolepoidea. Perithecia 1.0-1.5 mm. lata, solitaria aut confluentia dimidiata, primum immersa leviter convexa dein emergentia elevata conico-hemisphaerica, basi innata, nigra sat tenue thallino suffusa aut deundata, apice obtuso aut crasso papillato, demum elabentia foveolanique relinquentia, amphithecio carbonaceo basi deficienti. Paraphyses persistentes tenues simplices. Asci cylindrices 8-spori. Snorae in ascis uniseriales, incolores ellipsoideac, 4-loculares loculis subcylindricis angulis sat rotundatis, $13-16 \times 5-7 \mu$. Spermagonia mediocria nigra apice emergente denudato. Spermatia filiformia arcuata, $18-22 \times 1 \mu$.

On limestone, lies View Hill, Vivijagua, Isle of I'ines, Cuba (Britton, Britton and Wilson, February 28-29, 1916, 15090, type).

Bahamas: on limestone, Cockburn Town, Watling's Island (Britton and Millspaugh, 6131).

Known also from two other stations in the Isle of Pines and from one station in Porto Rico.

The aftinities of this snecies seem on the whole to be with the genus Porina, section Sagedia, although it has peculiarities which make its systematic position somewhat uncertain. While the perithecia are for the most part solitary, they occur occasionally completely confluent, except for the papillate tips. Even in these cases, however, there is never any indication of a stroma. The cells of the quadrilocular spores are somewhat more rounded than is typical for Porina. There is no other species with which this is liable to be confused.

3. Porina fírmula Muell. Arg. Bot. Jahrb. 6: 401. '1885.

On limestone. Andros, at Mastic Point, and Watling*s Island, near Cockburn Town :-Cuba; Isle of I'ines.

\section{Porina subfírmula Riddle, sp. nov.}

Thallus epilithicus determinatus subfoliosus effiguratus, irregulariter rotundatus, margine integro aut crenato haud lobato, planus, arcte adnatus, crassus (crassitudine 0.15-0.2 $\mathrm{mm}$.), atro-olivacens, continuus laevigatus vel sat inaequalis nitidulus; superne corticatus cortice tenue (crassitudine 12-14 $\mu$ ) pseudo-parenchymatica, inferne ecorticatus. Gonidia chroolepoidea. Perithecia subglobosa circ. $0.3 \mathrm{~mm}$. lata, tota immersa aut apicibus leviter emergentibus et sat deuudatis, amphithecio superne nigro inferne decolore. Paraphyses persistentes simplices. Asci 8-spori. Sporae incolores fusiformes, haud bene evolutae, 6-8-loculares, loculis cylindricis, cire. $25 \times 4 \mu$.

On limestone. Sierra de las Casas, Isle of r'ines, Cuba (Britton and Wilson, March 22, 1916, 15\%41, type).

Bahamas: on limestone, New I'rovidence (Bruce, 9!87).

This species belongs to the section segestrin, and is evidently related to but quite distinct from the preceding species. Both species are decidedly Endocurponlike in appearance.

5. Porina nùcula Ach. Syn. Lich. 112. 1814.

On bark of Exotheu, New Providence, at Clifton:-widely distributed in tropical regions of both hemispheres.

6. Porina mastoìdea (Ach.) Mass. Ric. Lich. Crost. 191. 1852.

Pyrenula mastoidea Ach. Syn. Lich. 122. 1814.

Porina africana Muell. Arg. Linnaea 43: 41. 1880.

On bark, Great Bahama:-Widely distributed in tropical regions of both hemispheres.

The material represents a form with verrucose thallus and verrucae, and the Iatter are somewhat constricted: but the species is so variable that it is scarcely worth while to give this form a name.

7. Porina Tetracérae (Ach.) Muell. Arg. Bot. Jahrb. 6: 401. 1855.

Terrucaria Tetracerae Ach. Meth. Lich. 121. 1803.

on bark, New Providence, at Maidenhead Coppice:-widely distributed in tropical regions of both hemispheres.

8. Porina variegàta Fée, Suppl. Essai Crypt. 75. 1837.

On bark, Abaco, at Old Kerr's Point:-Cuba; Jamaica; Porto Rico. 


\section{ARTHOPYRÈNIA Mass.}

Spoles two-celled.

Asei eylindrical, spores uniseriate.
Spores $15-30 \times \tau-13 \mu$.
Spores $12-15 \times 5-7 \mu$.
1. A. gemmata.
2. A. biformis.

Asci clavate, spores 2- to 3 -seriate.

Perithecia spleading at the base.

Perithecia peltate, flattened, and thalline-suffused.

At least the center of the perithecium elevated and nudate.

Spore-cells cqual in size.

Spore-cells unequal.

Perithecia not spreading at the base.

3. A. planorbis.

4. A. Cinchnnae.

5. 1. fallax.

Spores four-celled.

Perithecia more or less covered by the thallus.

Thallus thin, the peritheeia mercly suffused.

Thallus thick, the perithecia imbedded with the tips emergent.

Perithecia superficial and nudate.

6. 1. consanguinea.

3. A. planorbis.

7. A. tumida.

s. A. contendens.

1. Arthopyrenia gemmàta (Ach.) Muell. Arg. Mem. Soc. Phys. Hist. Nat. Genère 16: 428. 1862.

Lichen gemmatus Ach. Lich. Suec. Prodr. 17. 1798.

On bark, New Providence:- widely distributed in temperate regions of both hemispheres.

2. Arthopyrenia bifórmis (Borr.) Muell. Arg. Flora 66: 306. 1883.

Terruearia biformis Borr. in Engl. Bot. Suppl. pl. 261\%. 1529.

On bark, New Providence. on the Farringdon Road:- - widely distribnted in the temperate regions of both hemispheres.

3. Arthopyrenia planórbis (Ach.) Mruell. Arg. Flora 66: 2ss. 1853.

Terrucaria planorbis Ach. Srn. Lich. 92. 1814.

Arthopyrenia indusiata Muell. Arg. Flora 66: 258. 1553.

Arthopyrenia fallacior Muell. Arg. Bot. Jahrb. 6: 404. 15s5.

On bark, Great Bahama, and New Providence:-Cuba ; Anegada; Costa Rica.

4. Arthopyrenia Cinchònae (Ach.) Mruell. Arg. Flora 66: 2si. 1883.

Terrncaria Cinchonae Ach. Syn. Lich. 90. 1814.

Didymella Cinchonae Wainio, Lich. Brés. 2: 233. 1890.

Arthopyrenia planior Muell. Arg. Bot. Jahrb. 6: 404. 1885.

On bark, Great Bahama. New Providence. Little San Salrador, Great Exuma, Watling's Island :-widely distributed in tropical America.

5. Arthopyrenia fállax (Nyl.) Arnold, Flora 68: 159. 1885.

Terrucaria epidermidis var. fallax Nyl. Bot. Notis. (1852) 178.

On bark. Great Bahama, at Parnett's Point, and New Providence, near Seren Irills:- Widely dlstrlbuted in the temperate regions of both hemispheres.

6. Arthopyrenia consanguinea Muell. Arg. Bot. Jahrb. 6: 404. 1885.

On hark, Fienthera Polnt:-Florida: Cuba.

very closely related to forms of Arthopyrenia cpidermidis (Fr.) Mudd.

7. Arthopyrenia tùmida Muell. Arg. Flora 67: 669. 1854.

On hark, New Providence, at Waterion Copplee:-Isle of Pines, Cuha: and Brazil.

8. Arthopyrenia conténdens (Nyl.) Muell. Arg. Flora 66: 317. 1853.

Terrucaria contendens Nyl. Act. Soc. Sei. Fenn. 7: 492. 1863.

On bark of Jacquinia keyensis. The Blght, Cat Island:-Colombla: Brazll. 


\section{PSEUdOPYRÈNUla Muell. Arg.}

1. Pseudopyrenula dirémta ( $N_{y}$ l.) Muell. Arg. Flora 66: 249. 1883.

Terrucaria dircmta Nyl. Act. Soc. Sei. Fenn. 7: 492. 1863.

On bark, New Providence:-Cuba; Venezuela; Colombia; lirazil.

\section{PYRÈNULA Ach.}

I'erithecia dimidiate.

Ierithecia spreading at the base and entirely nudate.

Perithecia not spreading, immersed when young, then emergent.

Perithecia subglobose.

Thallus orange-brown.

Thallus more or less oliraceous.

Perithecia immersed in the thallus.

Perithecia emergent to superficial.

1. I. mamillana.

2. P. leucoplaea.

3. P. ccrina.

4. P. punetella.

5. P. Glaziovii.

1. Pyrenula mamillàna (Ach.) Trev. Conspect. Verr. 13. 1860.

Terrucaria mamillana Ach. Meth. Lich. 120. 1803.

Terrucaria Santcnsis Tuck. apud Nyl. Expos. Pyren. 45. 1858.

Terrucaria Kunthii Fée, Essai Crypt. 88, pl. 34, f. 4. 1824.

Pyrenula Kunthii Fée, Suppl. Essai Crypt. 80. 1837.

Pyrenula deplanata Muell. Arg. Bot. Jahrb. 6: 411. 1885.

On bark, Great Bahama and New Providence:-widely distributed in tropical and subtropical regions of both hemispheres.

Pyjenula mamillana is an exceedingly rariable species. $P$. Kunthii is the form with the larger perithecia and spores, that is the more juxuriant form; while $P$. deplanata is the less luxuriant form with the smaller perithecia and spores. But intergradations of all sizes are to be found commonly.

2. Pyrenula leucoplàca (Wallr.) Koerb. Syst. Lich. Germ. 361. 1855.

Verrucaria leucoplaca Wallr. in Bluff and Fing. Fl. Germ. 3: 299. 1831.

On bark of Casasia clusiaefolia, Little San Salvador:-widely distributed in the temperate regions of both hemispheres.

3. Pyrenula cerìna (Eschw.) Muell. Arg. Flora 67: 667. 1884.

Terrucaria cerina Eschm. in Nart. Fl. Bras. 1: 133. 1833.

Pyrenula aurantiaca Fée, Suppl. Essai Crypt. 82, pl. 37, f. 1. $183 \pi$. America.

On bark, New Providence and Crooked Island:-widely distributed in tropical

4. Pyrenula punctélla (Nyl.) Muell. Arg. Flora 65: 400. 1882.

Terrucaria punctella Nyl. Expos. Pyren. 46. 1858.

On bark of Drypetes, Cay north of wide opening, Exuma Chain :- South Carolina; Colombia; Java. Probabls generally distributed but confused with the wellknown Pyrenula nitida (Weig.) Ach., from which it differs in the more completely immersed perithecia and the larger spores.

5. Pyrenula Glazióvii Muell. Arg. Mem. Soc. Phys. Hist. Nat. Genève $30^{3}: 32$. 1888.

On bark, New Providence, along Soldier's Road:-Brazil.

\section{MICROTHËLIA Koerb.}

\section{Microthelia quadriloculàta Riddle, sp. nov.}

Thallus epiphloeodes crustaceus uniformis effusus, albidus opacus, tenuis rimulosus. Gonidia chroolepoidea. Perithecia integra globosa, minuta ad 0.4 $\mathrm{mm}$. lata, superficialia basi thallino-tecta, superne nuda nitida, apice convexo aut minute umbilicato. Paraphyses persistentes distinctes ramoso-connexae. Asci oblongi 8 -spori. Sporae in ascis $2-3$-seriales fuscae oblongae aut fusiformes, 4-loculares loculis cylindricis, $18-20 \times 6-7 \mu$. 
On bark of Jacquinia keycnsis, vicinity of the Bight, Cat Island (Britton and Millspugh, March $1-6,1907,58.4$, type).

The white epiphloeodal thallus and the shining globose perithecla will serve to distinguish this from the few species of Iricrothelia having four-celled spores, such as 1 . thelcna var. subtriseptata Wainio.

\section{CLATHROPORINA Muell. Arg.}

1. Clathroporina nuculástrum Muell. Arg. Flora 67: 61S. 1884.

On twigs, New Proridence, at Maidenhead Coppice:-Florida; Madagasear.

\section{POLYBLASTIÓPSIS Zahlbr.}

1. Polyblastiopsis láctea (Mass.) Zahlbr. in Engler and Prantl, Nat. Pflanzenfam. $1^{1 *}: 65$. 1903 .

Blastodesmia lactea Mass. apud Koerb. Parerg. Lich. 336. 1565.

On bark, New Providence and The Bight, Cat Island:-North America; Europe.

\section{ANTHRACOTHÈCIUM MaSS.}

Thallus from orange to yellow.

Thallus from white to olivaceous.

Spores with two to four series of cells.

Spores with two series of cells.

Spores with four series of cells.

Spores with six to eight series of cells.

Perithecia immèrsed except when old.

Perithecium soon emergent and superficial.

1. A. ochraceo-flavum.

2. A. subglobosum.

3. A. corticatum.

4. A. libricolum.

5. A. americanum.

1. Anthracothecium ochràceo-flàvum (Nyl.) Muell. Arg. Linnaea 43: 44. 1850.

Terrucaria ochraceo-flavum Nyl. Expos. Pyren. 50. 1858.

Terrucaria ochraceo-flavens Nyl. Act. Soc. Sci. Fenn. 7: 491. 1863.

On bark of various species, Great Bahama, New Providence, Cave Cay, Exuma Chain, Cat Island:- widely distributed in tropical regions of both hemispheres.

\section{Anthracothecium subglobòsum Riddle, sp. nov.}

Thallus epiphloeodes crustaceus uniformis effusus haud limitatus, sordide aut virescenti-albidus, in crassitudine mediocris vel tenuis, rimosus rugulosus. Gonidia chroolepoidea. Perithecia dispersa solitaria, primum immersa, verrucis thallinis convexis, apice plus minusve nulato minute umbilicato, dein circa $1 / 4$ all $1 / 3$ emergentia, globosa, $0 . \bar{i}-1.0 \mathrm{~mm}$. diam., nigra integra. Paraphyses simplices crassinsculae. Asci cylindrices 8-spori. Sporae in ascis uniseriales, fumosae aut fusco-atrae, globosae circa $12 \mu$ diam., aut subglobosae circa $12 \times 10 \mu$, primum biloculares mox loculis altero ambobusve divisis rotundatis.

On bark, New Providence (Brace, February 11, 1919, 1006\%, type).

The sprecific name refers not to the perithecia but to the peculiar spores. The species is related to A. sinapispermum (Fée) Muell. Arg., but the latter species bas minute peritliecia, $0.15-0.2 \mathrm{~mm}$. in diameter, and oblong spores, $7-8 \times 4-5 \mu$.

3. Anthracothecium corticàtum Nuell. Arg. Bull. Soc. Roy. Bot. Belg. $30^{1}$ : 96. 1891.

On bark, New I'rovidence, at Waterloo Coppice:-Costa Rica, Venezuela.

4. Anthracothecium librícolum (Fée) Muell. Arg. Linnaca 43: 43. 1980 .

Pyrenula libricola Fée, Suppl. Essai Crypt. 82, pl. 41, f. 31. 1837.

On bark of rarious spectes, Great Pahama, New Jrovidence, freat Exuma, Long Island :- widely distributed in tropical and subtropical regions of both liemispheres.

This specles is a common and variable one. All stages mas be found from that in whlch the perithecia are completeiy buried in the thajlus and searcely discernible externalls, to that in which the perithecia become half emergent, when they are consplcuous and appear relatirely large. Superficially the two extremes look vers different. 
5. Anthracothecium americànum (Ach.) Muell. Arg. Flora 68: 339. 1885.

Terrucaria analepta var. americana Ach. Lich. Univ. 275. 1810.

On dead wood, Abaco, at Old Ker's Point, and on bark of Drypetcs diversifolia, Thatch Cay, Long Island:-Jamaica.

\section{Family 3. TRYPETHELIÀCEAE.}

Spores plurilocular (two to manj-celled).

Spores colorless.

Spores witl cylindrical cells.

Spores with lens-shaped cells.

Spores brown.

Spores muriform-multilocular, brown.

1. Tomasellia.

2. Trypethelium.

3. Melanotheca.

4. Bottaria.

\section{TOMAsÉllia Mass.}

Thallus epiphloeodal, relatively well-dereloped.

Thallus hypophloeodal.

Spores over $30 \times 12 \mu$.

Spores under $25 \times 10 \mu$.

Stroma with many ostioles indicated externally by whitened spots.

Stroma with few ostioles, concolorous with the black stroma.

1. T. exumana.

2. T. macrospora.

3. T. leucostoma.

4. T. cubana.

\section{Tomasellia exumàna Riddle, sp. nov.}

Thallus epiphloeodes crustaceus uniformis effusus glaucus, crassiusculus, undulatus laevigatus subnitidus rimulosus, linea nigra limitatus. Gonidia chroolepoidea. Stromata $0.6-1.0 \mathrm{~mm}$. lata, nigra nuda convexa rel hemispherica haud gibbosa, ambitu obtuse angulosa aut irregularia pauciostiolata, ostiolis superficie aequalibus aut gibbosula inconspicuis. Perithecia crassa integra globosa. Paraphyses persistentes ramoso-connexae. Sporae in ascis biseriales, incolores ovoideae biloculares, loculo superiore multo majore, $14-16 \times 6-i \mu$.

On bark near Georgetown, Great Exuma (Britton and Millspaugh, February 2228, 1905, 3135, type).

The well-developed thallus and the strongly convex stromata are the best characters for distinguishing this species.

\section{Tomasellia macrospòra Riddle, sp. nor.}

Thallus hypophloeodes quasi halonem albidum formans aut evanescens et cum cortice maculam testaceam constituens. Stromata $1.0-1.3 \mathrm{~mm}$. lata, solitaria aut partim confluentia, deplanata vel leviter convexa peltata ambitu rotundata, nigra thallino-pruinata aut denudata, ostiolis connatis papillata. Perithecia integra globosa. Paraphyses persistentes ramoso-connexae. Sporae incolores oblongae, 4-loculares, loculis cylindricis aequalibus, $30-38 \times 12-14 \mu$.

On bark of Zanthoxylum flavum, Great Exuma (Britton and Millspaugh, February 22-28, 1905,3002 , type).

Externally similar to Tomasellia cubana, but differing in the decidedly larger spores, these measuring in the latter species only $15-25 \times 5-9 \mu$.

\section{Tomasellia leucostòma Muell. Arg. Flora 68: 257. 1885.}

On bark, Great Bahama, New Providence, Eleuthera, Exuma, Long Island:tropical America.

The material listed under this and the following species shows considerable variation and some of the specimens mas be specifically distinct, but it has seemed best to adopt a conservative treatment.

4. Tomasellia cubàna Muell. Arg. Bot. Jahrb. 6: 397. 1885.

On bark, New Providence, Little San Salvador, Exuma, Cat Island, Conception Island :-Cuba. 


\section{TRYPETHÈLIUM Spreng.}

Spores four-celled.

spores over $35 \mu$ in length.

Spores under $30 \mu$ in length.

1. T. ochrothclium.

Stroma dark brown to black.

Stroma little developed, the individual perithecia evident.

Stroma well-developed, merely the tips of the perithecia showing.

Stroma some other color.

Thallus rustr-olange.

Stroma flat and corered by the thallus. Stroma elevated, conical.

Thallus some other color.

Stroma irregularly linear-elongated, perithecia often showing a serial arrangement.

Stroma rounded, oral, or oblong.

Stroma elerated, the black tips of the perithecia conspicuous.

Stroma depressed, the tips of the peritheeia inconspienous.

Spores six to manr-celled.

Stroma vellow within.

Thallus smooth, stroma neither yellow nor powdery externally.

Stroma varying in eolor from ashy to fulrous or chestnut-brown, strongly eonrex.

Stroma dark-brown or blackening, flattened.

Thallus smooth or nowdery, stroma yellow or powders or both.

Thallus smootl, stroma lemon-cellow and powdery.

Both thallus and stroma corered with a sulphury or aeruginous powder.

Stroma becoming brown or black within.

2. T. tropieum.

3. T. mastoideum.

4. T. aen cum.

5. T. ferrugincum.

6. 'T. catcriarium

7. T. ochrolcucum.

S. T. pallescens.

9. $T$, cluteriae and varieties.

9a. forma typica.

9b. var. truncatum. 9c. var, citrinum.

9d. var. subsulphureum. $9 c$. var. nigricans.

1. Trypethelium ochrothèlium Nyl. Act. Soc. Sci. Fenn. 7: 494. 1863.

On bark, The Bight, Cat Island:-Isle of Pines, Cuba ; Colombia.

2. Trypethelium tròpicum (Ach.) Muell. Arg. Bot. Jahrb. 6: 393.1855.

Terrucaria tropica Ach. Lich. Univ, 278. 1810.

Pyrenula tropica Tuck. Genera Lich. 273. 1872.

On bark of rarious species, Andros, Ner Providence, Cat Island, Long Island:widely distributed in tropical and subtropical regions of both bemispheres.

3. Trypethelium mastoìdeum Ach. Lich. Unir. 307. 1810.

Bathelium mastoideum Ach. Meth. Lich. 111. 1803.

Trypethelium scoria Nyl. Expos. Pyren. 74. 1858. Not Fée Essai Crypt. 69. 1524

On bark, New I'rovidence and Eleuthera:-widely distributed in troplcal and subtropical regions of both hemispheres.

4. Trypethelium à̀eum (Fschw.) Zahlbr. in Engler and Prantl, Nat. Pflanzenfam. $1^{1 *}: 70.1903$.

Terrucaria acnea Eschw. in Mart. Fl. Bras. 1: 133. 1833.

Trypethelium Kunzei Fée, Ann. Sci. Nat. I: 23: 446, pl. 15, f. 3. 1 s31.

Trypethelium heterochroum Tuck. Genera Lich. 260. 18i2.

On bark, Andros, near Nieholl's 'Town; Crooked Island, at Landrall Point; Acklin`s Island, at Boathouse Cove:-Florida; Cuba ; Costa lilca; Brazll.

5. Trypethelium ferruginèum Muell. Arg. Bot. Jahrb. 6: 392. 1985.

On bark, Andros, at Deep Creek :-Cuba. 
6. Trypethelium catervàrium (Fée) Tuck. Genera Lich. 260. 1872.

Terrucaria catcrvaria Fée, Essai Crypt. 90, pl. 22, f. 1. 1824.

On bark, New Providence, at Waterloo Coppice:-Alabama; Cuba; Porto Rico; Costa Rica; Colombia; Australia.

7. Trypethelium ochroleùcum (Eschw.) Nyl. Flora 52: 126. 1869.

Terrucaria ochroleuca Eschw, in Mart. Fl. Bras. 1: 135. 1833.

On bark, Andros, near Deep Creek:-widely distributed in tropical America, and recorded also from tropical Asia.

8. Trypethelium palléscens Fée, Ann. Sei. Nat. I: 23: 440. 1831.

Trypethelium ochroleucum var. pallescens Muell. Arg. Bot. Jahrb. 6: 392. 1885.

On bark, Eleuthera and Great Exuma:-widely distributed in tropical America.

9. Trypethelium elutèriae Spreng. Anleit. zur Kennt. Gewachse 1: 351. 1804. Trypethelium Sprengelii Ach. Lich. Univ. 306. 1810.

9a. forma typica.

On bark of various species, Great Bahama, New Providence, Eleuthera (typelocality !). Great Exuma, Cat Island, Long Island :-widely distributed in tropical regions of both hemispheres.

9b. Trypethelium elutèriae var. truncàtum Muell. Arg. Bot. Jahrb. 6: 393. 1885.

Watling's Island :-Cuba.

9. Trypethelium elutèriae var. citrìnum (Esehw.) Muell. Arg. 1. c. 1885. Astrothelium varium var, citrinum Esehw. in Mart. Fl. Bras. 1: 162. 1833. New Providence, at Waterloo Coppice:-Cuba; Brazil; Australia.

9 d. Trypethelium elutèriae var. subsulphùreum (Wainio) Riddle.

Pseudopyrenula eluteriae subsp. subsulphurea Wainio, Lich. Brés. 2: 205. 1890.

New Providence, at Lake Cunningham :-Cuba; Brazil.

9e. Trypethelium elutèriae var. nígricans (Fée) Muell. Arg. Mem. Soc. Phys. Hist. Nat. Genève $30^{3}: 21.1888$.

Trypethelium Sprengelii Fée, Ann. Sei. Nat. I: 23: 430. 1831.

New Providence and Cat Island:-tropical America.

\section{MELANOTHÈCA Fée.}

1. Melanotheca cruénta (Mont.) Muell. Arg. Bot. Jahrb. 6: 397. 1885.

Trypethelium cruentum Mont. Ann. Sci. Nat. II: 8: 357. 1837.

On bark, Great Bahama and New Providence:-widely distributed in tropical regions of both hemispheres.

\section{BотTÀrIA Mass.}

1. Bottaria cruentàta Muell. Arg. Bot. Jahrb. 6: 395. 1885.

Trypethelium cruentatum Nyl. Flora 59: 365. Hyponym. 1876.

On bark, Great Babama, Abaco, Andros, New Providence, Cat Island, Crooked Island :-Florida : Cuba.

Externally identical with the preceding species, but differing in the muriform spores, the cells of which in the specimens examined are subspherical, not cubical as given in the key in Engler and Prantl: Die Naturlichen Pflanzenfamilien $I^{1 *}: 69$. 


\section{Family 4. DERMATOCARPÀCEAE.}

Spores one-celled.

Spores muriform-multilocular.

1. Dermatocarpon.

2. Endocarpon.

\section{DERMATOCÁRPON EschT.}

Thallus mostly orer $10 \mathrm{~mm}$. in diameter, attached by a single central point.

Thallus mostly under $5 \mathrm{~mm}$. in diameter, attached by greater part of under surface.

Thallus reddish, margins free.

Thallus brown, margins adnate.

1. D. Moulinsii.

2. D. lachneum.

3. D. hepaticum.

1. Dermatocarpon Moulínsii (Mont.) Zahlbr. in Engler \& Prantl, Nat. Pflanzenfam. 1 ${ }^{1 *}: 60.1903$.

Endocarpon Moulinsii Mont. Ann. Sei. Nat. II: 20: 35s. 1843. India.

On rocks, New Providence and Cat Island, at Orange Creek:-France; Texas;

2. Dermatocarpon lachnèum (Ach.) A. L. Sm. British Lich. 2: 270. 1911.

Lichen lachneus Ach. Lich. Suec. Prodr. 140. 1798.

Endocarpon rufescens Ach. Lich. Univ. 304. 1810.

On sand, Great Sturrup Cas, Berry Islands:- -widely distributed in North America and Europe.

3. Dermatocarpon hepàticum (Ach.) Th. Fr. Lich. Aret. 255. 1860.

Endocarpon hepaticum Ach. Lich. Univ. 298. 1810.

On the ground, Abaco, at Old Kerr's Point, and Acklin's Island, at Spring Point:- cosmopolitan.

\section{ENDOCÁRPON Hedw.}

1. Endocarpon pallidulum (Nyl.) Hne, Nour. Areh. Nus. Hist. Nat. Paris III: 4: 106.1892.

Terrucaria pallidula Nyl. Flora 57: 73. 1874.

On limestone (mixed with Seytonema), New Providence:-Cuba; Peru; Japan.

\section{Family 5. PARATHELIÀCEAE.}

Spores brown, plurilocular.

Spores colorless, muriform-multilocular.
1. Parathelium

2. Campylothclium.

\section{PARATHËLIUM Nyl.}

Spores $34-40 \times 11-16 \mu$.

Spores $18-22 \times 8-9 \mu$.
1. P. indutum.

2. P. microcarpum.

1. Parathelium indùtum Nyl. Bot. Zeit. 20: 279. 1862.

On bark, Conception Island, Berry Islands. 'Stocking Island, Great Exuma, Cat Island, Long Island:-Cuba; St. Thomas ; I'orto Rico; Colombia.

2. Parathelium microcàrpum Riddle, sp. nov:

Thallus crustaceus uniformis effusus haud limitatus, cum cortice maculam nitidam ochraceo-fulvam constituens, continuus laevigatus. Gonidia chroolepoidea. Perithecia pyriformia, minuta ad $0.5 \mathrm{~mm}$. longa, $0.3 \mathrm{~mm}$. lata, integra nigra semi-innata parte emersa nudata. ostiolis lateralibus collis breviusculis. Paraphyses sparse ramosae. Asci S-spori. Sporae fuscae ellipsoideae, ad apices 
acutae, 3-septatae, ad septa modice constrictae, loculis lentiformibus, 18-22 $\times S-9 \mu$.

On bark in coppice, West End, Great Bahama (Brace, April 16-May 8, 1905, 3615, type).

Parathelium microcarpum has smaller spores than any other species of the genus. with the exception of $P$. decumbens JIuell. Arg. (Hedwigia 32: 134. 1893) which differs from the present species in the whitish thallus and the larger perithecia.

\section{CAMPYLOTHĖLIUM Muell, Arg.}

\section{Campylothelium decòlorans Riddle, sp. nov.}

Thallus epiphloeorles crustaceus uniformis effusus stramineo-albus subnitidus, tenuis vel tenuissimus, continuus laevigatus inaequalis. Gonidia chroolepoidea. Perithecia circa $1.0 \mathrm{~mm}$. lata, tota thallino-corticata parum prominentia, quasi maculam fuscescentem formantia, superne nigra, inferne decolorata, ostiolis lateralibus collis nullis. Paraphyses persistentes satis ramosae. Asci 2-6-spori. Sporae incolores oblongae merlio leviter constricto irregulariter murali-divisae, 6-8-loculares, loculi 3-1-locellati, loculis eubicis aut irregularibus, $37-43 \times \mathbf{1 6 - 1 8 \mu}$.

On bark of Drypetes, Cay North of . Wide Opening, Exuma Chain (Britton and Millspaugh, February 18, 1905 , 2295, type).

This species differs from other species of the genus in the pale color of the lower part of the perithecial wall.

\section{Family 6. ASTROTHELIÀCEAE.}

Spores colorless, plurilocular.

Spores brown, muriform-multilocular.

1. Lithothelium. 2. Parmentaria.

\section{LIтHотнїLIUM Muell. Arg.}

\section{Lithothelium bahaménse Riddle, sp. nov.}

Thallus epilithicus crustaceus uniformis effusus linea nigra limitatus, glaucus aut cinereus opacus, crassiusculus crebre contextus, continuus laevigatus. Gonirlia chroolepoidea. Stromata minuta, 0.4-0.6 mm. lata, in foreolis saxi innata, dein semi-emergentia, demum elabentia foveolamque relinquentia, tota nigra parte emersa nudata, paucicarpica, ambitu oblonga aut satis difformia, ostiolis minutis irregulariter umbonatis. Perithecia minutissima, integra nigra. Paraphyses persistentes simplices filiformes. Asci eylindrices, 8-spori. Sporae in ascis 1-2-seriales, incolores, fusiformes, 8-loculares, loculis cylindricis, $18-22 \times 5-6 \mu$.

On limestone, ricinits of Cockburn Town, Watling's Island (Britton and Mills. paugh, March 13, 1907, 6i27, type: 6129$)$.

Lithothelium bahamense differs from the only other kuown species of the genus, L. cubanum Mruell. Arg. (Bot. Jahrb, 6:386. 1885), in the color of the thallus and the eight-celled spores.

\section{PARMENTÀRIA Fée.}

1. Parmentaria astroìdea Fée, Essai Crypt. 70, pl. 20, f. 1. 1824.

on bark, New Providence, at Clifton Coppice, and Crooked Island, at Vauxhall :widely distributed in tropical and subtropical regions.

\section{Order 2. CALICIÀLES.}

\section{Family 1. CALICIÁCEAE.}

\section{CALİCIUM Pers.}

1. Calicium hyperéllum Ach. Meth. Lich. 93. 1803.

Lichen hyperellus Ach. Lich. Suec. Prodr. 85. 1798.

On palmetto, The Bight, Cat Island:-widely distributed in North America and Europe. 


\section{Order 3. GRAPHIDÀLES.}

Apothecia without an exciple.

Apothecia with an exciple.

Thallus without a cortex.

Apothecia solitary.

Apothecia typically imbedded in a stroma.

Thallus with an upper cortex.

\section{Family 1. ARTHONIÁCEAE.}

Spores two to many-celled.

Spores muriform-multilocular.

\section{ARTHÒNIA Ach}

Spores four- to six-celled.

Apothecia some shade of red.

A pothecia brown or black.

Apothecia orbicular or difform.

Apothecia about $0.3 \mathrm{~mm}$. in diameter.

Spores with cells of equal size.

Spores with end-cell enlarged.

Apothecia over $0.6 \mathrm{~mm}$. in dianeter.

Spores with cells of equal size.

Spores with one or both end-cells enlarged.

Apothecia linear, more or less branched.

Spores eight- to sixteen-celled.

Spores $22-32 \times 7-11 \mu$.

Apothecia fulrous, $0.1 \mathrm{~mm}$. wide.

Apothecia chestnut, $0.3-0.5 \mathrm{~mm}$. wide.

Spores $50-\overline{5} \times 14-23 \mu$.

Apothecia orbicular.

Apothecia linear and branched.
Fam. 1. ArTHOXIACEAE.

Fam. 2. GRAPIIIDACEAE.

Fam. 3. Cirlodectoxaceae.

Fam. 4. DIRINACEAE.

1. Arthonia gregària (Weig.) Koerb. Syst. Lich. Germ. 291. 185..

Sphaeria gregaria Weig. Obs. Bot. 43, pl. 2, f. 10. 1772.

Arthonia cinnabarina Wallr. Crypt. Germ. 1: 320. 1831.

On bark, stocking Island, Exuma Chain :-cosmopolitan.

2. Arthonia chiodectélla Nri. Flora 52: 125. 1869.

On bark, New Providence :-Florida; Lonisiana ; Texas.

3. Arthonia cinereopruinòsa Schaer. Enum. Lich. 243. 1550.

On bark, New Proridence:-North America; Europe.

4. Arthonia polymórpha Ach. Syn. Lich. 7.1814.

On bark, Great Bahama, New Proridence, Great Exuma :-widely distributed in tropical regions of both hemispheres.

5. Arthonia complanàta Fée, Essai Crypt. 54. 1824.

on bark, Great Bahama. at Pinder's I'oint:-widely distributed in tropical and subtropical America and in New Zealand.

6. Arthonia interdúcta Nyl. Act. Soc. Sci. Fenn. 7: 496. 1863.

On bark, Stocking Island, and Cay north of Wide Opening, Exuma Cbain :Florida ; Anegada Island; Nicaragua; Brazil; IIawailan Islands.

7. Arthonia fissurinea Nyl. Flora 68: 447. 1885 .

On bark, Great Bahama, near Rolletown:-Florida.

S. Arthonia septisépta Nyl. Flora 69: 104. Hyponym. 1856. Nyl. apud Willey, Synops. Arth. 11.1890.

On bark, New Proridence:-Florida: Cuba.

This species is rery closely related to the common Arthonia conferta (Fee) Nyl., differing only in having the apothecla spuriously marglned and the spores eightcelled linstead of six-celled. 
9. Arthonia platygraphìdea Nyl. Act. Soc. Sci, Fenn. 7: 483. 1863.

On bark, New Providence, on Soldier's laoad, and Cat Island, vicinity of The Bight:-l'lorida; Cuba ; Iorto Rico; Mexico; Brazil.

10. Arthonia atràta (Fée) Muell. Arg. Mem. Soc. Phys. Hist. Nat. Genère $29^{8}: 59.1857$.

Graphis atrata Fée, Essai Crypt. 35. 1824.

Not Arthonia atrata Tuck. Genera Lich. 222. 1872.

On bark, New Providence:-tropical America.

\section{ARTHOTHELLIUM Mass.}

1. Arthothelium macrothècum (Fée) Mass. Ric. Lich. Crost. 55. 1852.

Arthonia macrotheca Fée, Suppl. Essai Crypt. 42, pl. 40, f. 18. 1837.

On bark, Abaco, at Marsh Harbor, and New I'rovidence, at Soldier's' Home:widely distributed in tropical regions of both hemispheres.

\section{Family 2. GRAPHIDÀCEAE.}

Spores four- to many-celled.

Spores colorless.

Spores with cylindrical cells.

Spores with lens-shaped cells.

Spores brown.

Spores muriform-multilocular.

Spores colorless.

1. Opegrapha.

2. Graphis.

3. Phaeographis.

spores brown.

4. Graphina.

5. Phaeographina.

\section{OPEGRÁPHA Humb.}

Growing on bark.

Spores four-celled.

Spores six-celled.

Spores $2-4 \mu$ wide.

Spores $7-9 \mu$ wide.

Growing on rocks.

Spores four-celled.

Thallus white.

Thallus gray, greenish or brownish.

Spores six - to eight-celled.

Thallus some shade of brown.

Thallus thin and continuous.

Thallus of medium thickness, rimulose-areolate.

Thallus slate-gray.

1. O. atra.

2. O. vulgata.

3. o. varia.

4. O. calcarea.

5. O. saxicola.

6. O. isabellina.

7. O. bahamensis.

S. O. columbina.

1. Opegrapha átra Pers. in Usteri, Ann. Bot. 7: 30. 1794.

On bark, New Providence, at Soldiers' Home:-widely distributed.

2. Opegrapha vulgàta Ach. Meth. Lich. 20. 1803.

On bark, New Providence:- widely distributed in temperate regions.

3. Opegrapha vària Pers. in Usteri, Ann. Bot. 7: 30. 1794.

On bark, New Providence :-cosmopolitan.

4. Opegrapha calcàrea Turn. in Smith, Eng. Bot. pl. 1690. 1807.

Opegrapha Chevallieri Leight. Ann. Mag. Nat. Hist. II: 13: 90. 1854.

On limestone, Conception Island:-Europe; California; Cuba.

5. Opegrapha saxìcola Ach. Syn. Lich. 71. 1814.

On limestone, New Providence:-Europe; California; Cuba. 


\section{Opegrapha isabellina Riddle, sp. nor.}

Thallus crustaceus uniformis effusus haul limitatus, isabellinus minute albo-maculatus, tenuis continuus laevigatus. Gonidia chroolepoidea. Apothecia dispersa aut rarius aggregata superficialia elevata, simplicia recta aut rarius flexuosa, oblonga aut linearia, $0.8-2.0 \mathrm{~mm}$. longa, $0.1-0.2 \mathrm{~mm}$. lata, tota nigra, labiis haud sulcatis connicentibus disco rimaeformi; amphithecio nigricante integro basi completo. Paraphyses ramosae. Asci clavati, S-spori. Sporae incolores, fusiformes, 6-8-loculares loculis cylindricis aequalibus, $20-24 \times 4-5 \mu$.

On limestone, New Proridence (Brace, May 20, 1918, 9\%3\%,type). In the Tuckerman Herbarium there is an unnamed specimen of this species from Cuba, sent to Tuckerman by Ravenel.

Scarcely ansthing is known of the rock-inhabiting Opegraphas of the tropics. I hare been unable to find any described in the writings of Nylander, Mueller-Argau, or Wainio. The three new species here described appear to be distinct from the European species.

\section{Opegrapha bahaménsis Riddle, sp. nor.}

Thallus crustaceus uniformis effusus haud limitatus, testaceus, sat crassiusculus laevigatus aut rugulosus, rimulosus partim areolatus, sorediis nullis; hypothallo nullo. Gonidia chroolepoidea. Apothecia dispersa aut rarius aggregata, primum subinnata mox superficialia elerataque, simplicia recta, pro maxima parte brevia oblonga, $0.4-0.7 \mathrm{~mm}$. longa, rarius subelongata, ad 1.5 $\mathrm{mm}$. longa, $0.1-0.2 \mathrm{~mm}$. lata, tota nigra, labiis haud sulcatis conniventibus aut rarius hiantibus, disco rimaeformi ant rarius paullum aperto; amphithecio fusco-nigricante integro basi completo. Paraphyses sparse ramosae. Asci clavati, 8-spori. Sporae incolores fusiformes, 6-loculares loculi eylindricis aequalibus, $18-20 \times 3-4 \mu$.

On limestone, New Providence (Brace, June 5. 1918, 9454a, type).

Opcgrapha bahamensis resembles $O$. Chevalticri var. incarnata Ridale (Bull. Torrey Bot. Club $43: 150.1916$ ), but differs in the six-celled spores. From 0 . zonata Koerb., it differs in the absence of soredia and hypothallus. The key-characters will serve to distinguish it from $O$. isabellina.

\section{Opegrapha columbìna Riddle, sp. nov.}

Thallus crustaceus uniformis effusus haud limitatus, columbina aut plumbeus aut partim nigrescens, tenuissimus farinulentus. Gonidia chroolepoidea. Apothecia dispersa aut conglomerato-approximata, superficialia elerata, simplicia recta oblonga, $0.5-1.5 \mathrm{~mm}$. longa, circa $0.2 \mathrm{~mm}$. lata, tota nigra, labiis haud sulcatis connicentibus disco rimaeformi; amphithecio nigricante integro basi completo crasso. Paraphyses ramosae. Asci clarati, 8-spori. Sporae incolores fusiformes, S-loculares loculis cylindricis aequalibus, 2t-2s $\times 5-7 \mu$.

On limestone, vicinity of Gorernor's Harbor, Eleuthera Island (Britton and Millspaugh, Feliruary 19-20, 1907,5583 , type).

This species is most closely related to Opegrapha ophites Tuck. (apud Riddle in Bull. Torrer Bot. Club 43: 150. 1916), but differs in the short, straight, oblong apothecia. From $O$. lithyrga $\mathrm{Ach}$. it may be distinguished by the color of the thallus and the wider spores.

\section{GRÁPHIS Adans.}

Apothecia externally black.

Apothecia $0.4-1.0 \mathrm{~mm}$. in length.

Apothecia mostly $2-5 \mathrm{~mm}$. in length.

A pothecia not externally black.

Apothecia white, contrasting with the dark thallus or bark.

Apothecia concolorous with the glaucous thallus.

Ifps entire or nearly so.

Iips deeply suleate.

1. G. Paroniana.

2. G. scripta.

3. G. Afzclii.

4. G. restita.

5. G. cinerea.

1. Graphis Pavoniàna Fée, Essai Crypt. 40. 1824.

On bark, New Prorldence:-Texas; Bermuda. 
2. Graphis scripta (L.) Ach. Lich. Univ. 265. 1810.

Lichen scriptus L. Sp. Plant. 1140. 1753.

On bark, New lrovidence and Stocking Island, Great Exuma:-cosmopolitan.

3. Graphis Afzèlii Ach. Syn. Lich. 85. 1814. regions.

On bark, Great Bahama and New Providence:-a common species in tropical

4. Graphis vestita Fr. Syst. Orb. Veg. 2ss. 1825.

On twigs. New Providence, along road between Clifton and Fort MIt. Pleasant:tropical America.

5. Graphis cinèrea Fée, Essai Crypt. 37, pl. 10, f. 3. 1824.

On bark, New Proridence:-Jamaica; Colombia; Brazil.

3. PHAEOGRÁPHIS Muell. Arg.

Disk of apothecia dark red.

Disk of apothecia brownish-black, sometimes pruinose.

Amphithecium black at both sides and base.

Amphithecium black at the sides only.

1. P. cimnabarina.

2. P. dendritica.

3. P. inusta.

1. Phaeographis cinnabarìna (Fée) Muell. Arg. Mem. Soc. Phys. Hist. Nat. Genève $29^{8}: 2 \overline{7} .1887$.

Graphis cinnabarina Fée, Essai Crypt. 44, pl. 13, f. 4. 1824.

On bark, New Providence:-Cuba; Colombia; Brazil; Peru.

2. Phaeographis dendritica (Ach.) Muell. Arg. Flora 65: 3S2. 1 ss2.

Opegrapha dendritica Ach. Meth. Lich. 31. 1803.

On bark, New Providence:-widely distributed in temperate regions.

3. Phaeographis inústa (Ach.) Muell. Arg. Flora 65: 383.1882.

Graphis inusta Ach. Syn. Lich. 85. 1814.

On bark, New Proridence:- widely distributed in Europe, North and South America, and New Zealand.

4. GRAPHiNA Muell. Arg.

Thallus olivaceous. apothecia simple.

Thallus malachite-green, apothecia branched.

1. G. nitidescens.

2. G. virginea.

1. Graphina nitidéscens (Nyl.) Riddle, Mem. Brooklyn Bot. Gard. 1: 115. 1918.

Fissurina nitidescens Nyl. Lich. Japon. 108. 1890.

On bark, New Providence:-Florida; Cuba; Porto Rico.

2. Graphina virgìnea (Eschw.) Muell. Arg. Flora 63: 41. 1850.

Leiogramma virginea Eschw. in Nart. Fl. Bras. 1: 98. 1833.

On bark, New Providence:-a common lichen in tronical America.

\section{PHAEOgRAPHiNa Muell. Arg.}

1. Phaeographina caesiopruinòsa (Fée) Muell. Arg. Mem. Soc. Phys. Hist. Nat. Genève 29: 49.1887.

Arthonia caesiopruinosa Fée, Suppl. Essai Crypt. 36, pl. 40, f. 4. 1837.

Graphis scalpturata var. plurifera Nyl. Ann. Sci. Nat. V: 7: 332. 1867.

On bark, New Providence and Acklin's Island, at Spring Point:-Widely distributed in the tropical and subtropical regions of both hemispheres. 
$P$. caesiopruinosa differs from $P$. scalpturata (Ach.) Muell. Arg. in the character of the spores which in the former species are four to eight in each ascus and are $40-85 \times 14-22 \mu$ in size; while in the latter species, they are constantis solitary in the ascus, and $90-140 \times 22-35 \mu$ in size. For a discussion of the confusion of this species with P. quassiaccola (Fée) Muell. Arg. and the distinctions between the two species, reference may be made to the Bulletin of the Torley Botanical Club (44:324. 1917 ).

\section{Family 3. CHIODECTONȦCEAE.}

Spores with crlindrical cells.

Spores colorless.

Spores brown.

Spores with lens-shaped cells.

Spores colorless.

spores brown.

1. Chiodecton.

2. Selcrophyton.

3. Glyphis.

4. Surcographa.

\section{CHIODÉCTON A.ch.}

Either thallus or apothecia more or less brilliant red. Thallus red at least in part.

Thallus not at all red, but apothecia blood-red.

Neither thallus nor apothecia at all red.

Apothecia linear, more or less branched.

Apothecia punctiform, difform, or oblong.

Stroma distinctly conrex, apothecia seriate.

Stroma flat or absent, apothecia scattered.

Growing on bark; spores 6- to s-celled. Growing on rocks; spores 4-celled.

1. C. sanguin eum.

2. C. crucutatum.

3. C. elongatum.

1. C. quassiaccolum.

5. C. crassum.

6. C. Bracei.

1. Chiodecton sanguìneum (Sw.) Wainio, Lich. Brés. 2: 143. 1890.

Byssus sanguinea Sw. Prodr. 148. 1788.

Hypochnus rubrocinctus Ehrenb. in Nees, Hor. Phys. Berol. 84. 1820.

Chiodecton rubrocinctum Nyl. Act. Soc. Sei. Fenn. 7: 4S6. 1863.

On Juniperus stumps, Andros, at Nicholl's Town:-Widely distributed in tropical regions of both hemispheres.

\section{Chiodecton cruentàtum Riddle, sp. nov.}

Thallus epiphloeodes crustaceus uniformis effusus hand limitatus, albus rel albidus opacus, crassiuseulus verrucosus verrucis convexis hemisphericis aut subglobosis, 0.3-0.5 mm. diam., conglomeratis. Gonidia chroolepoidea. Stroma nulla. Apothecia dispersa, orbicularia oblonga aut pro maxima parte difformia, $0.4-0 . \bar{\imath} \mathrm{mm}$. lata, innata, disco plano claro cruento, margine spurie thallino cineta; hymenio incolore, $60 \mu$ altit.; hrpothecio incolore. Asci clarati, 8-spori. Sporae incolores, fusiformes, 6 -loculares, loculis cylindricis aequalibus, $13-16 \times 4 \mu$.

On bark of Eugcnia confusa, Barnett's Point, Great Bahama (Britton and Ililspaugh, February 5-13, 1905, 263\%, type).

The compact thallus and the absence of a stroma indicate that this species belongs to the section Enterographa. The absence of a stroma as well as the lack of any trace of red coloration in the thallus serve to distinguish it from the preceding species. There does not seem to be any other species with which it could possibly be confused.

3. Chiodecton elongàtum Wainio, Lich. Brés, 2: 13S. 1890.

On bark, New Providence :-Brazil.

The apothecia vary from immersed in and eren with the thallus to conditions in which there is a definite convex stroma; the spores may be ten-celled.

4. Chiodecton quassiaècolum (Fée) Mruell. Arg. Mem. Soc. Phys. Hist. Nat. Genève $29^{8}: 69.1587$.

Enterographa quassiaecola Fée, Essai Crypt. 5i, pl. 33, f. 2. 1824.

On bark of Erithalis fruticosa, Stocking 1sland, Great Exuma:-Martinique;

New Caledonia; Oceanica.

35 
5. Chiodecton crássum (DC.) Zahlbr. in Engler and Prantl, Nat. Pflanzenfam. $1^{1 *}: 104.1905$.

Opegrapha crassa DC. Fl. Frane. 2: 312. 1805.

On bark, New Providence, at Mlaidenhead Coppice:--Europe; northern Africa; Japan. Not previously recorded from North America.

6. Chiodecton Bràcei Riddle, sp. nov.

Thallus epilithicus crustaceus uniformis subdeterminatus maculas 3-15 mm. diam. formans haud linea nigra limitatus, argillaceus aut albus, in crassitudine mediocris, erebre contextus continuus laevigatus undulatus. Gonidia chroolepoidea. Stroma nulla. Apothecia dispersa aut rarius aggregata thallo immersa punctiformes aut difformia aut partim elongata, $0.1-0.5 \mathrm{~mm}$. longa, simplicia, disco siceo nigro madefacto badio, nudo plano superficiem thallo subaequante, margine tenuissime spurie thallino aut margine eranescente; epithecio fuscescente; hymenio et hypothecio incolore. Paraphyses crassiusculae ramoso-connexae. Asci clavati 8-spori. Sporae incolores fusiformes 4-loculares loculis cylindricis aequalibus, $14-20 \times 4 \mu$.

On limestone, New Providence (Braee, June 16, 1918, 9513, type). Also, Watling's Island, vicinity of Cockburn Town (Britton and Mrillspaugh.6128a).

Chiodecton Bracei belongs to the section Enterographa. It differs from C. rufescens Wainio (Journ. Bot. 34:262. 1896) in haring simple apothecia which are more often punctate or difform than elongated. I take pleasure in naming this species in honor of Mr. Brace, whose collections hare greatly extended our knowledge of the lichens of the Bahamas.

\section{SCLEROPHYTTON Esehw.}

1. Sclerophyton élegans Eschr. in Mart. Fl. Bras. 1: 103. 1833.

Stigmatidium elegans Nyl. Bull. Soc. Linn. Norm. II: 3: 274.1869.

On bark, New Providence, along Soldier's Road:-Florida; Bermuda; Cuba; Guadeloupe; Brazil.

Easily confused with species of Arthonia, as the stroma is by no means obvious.

\section{GLÝPHIS Ach.}

1. Glyphis cicatricòsa Ach. Syn. Lich. 107. 1814.

Glyphis Achariana Tuck. Amer. Journ. Sci. 25: 429. 1858.

On bark of various species, and at various localities, Great Bahama, New Providence, Watling's Island:- one of the commonest of tropical lichens.

\section{SARCOGRÁ́PHA Fée.}

1. Sarcographa tricòsa (Ach.) Muell. Arg. Mem. Soc. Phys. Hist. Nat. Genère $29^{8}: 63.1887$.

Graphis tricosa Ach. Lich. Univ. 674. 1810.

On bark, New Providence, and Long Island:-widelv distributed in tropical regions of both hemispheres.

\section{Family 4. DIRINĀCEAE.}

\section{DIRÌNA Fr.}

Growing on rocks.

Growing on bark (of Jacquinia keyensis).

1. D. repanda.

2. D. ceratoniae.

1. Dirina repánda (Fr.) Nyl. Act. Soc. Linn. Bordeaux 21: 343. 1856.

Parmelia repanda Fries, Lich. Europ. 177. 1831.

On limestone, New Providence, near Queen's Staircase, Nassau; Great Exuma, along Haynes Road; Long Cay, on Cunningham Hill :- southern Europe and northern Africa, Hawail. India. The occurrence in the Bahamas of this species, not previously known from North America, was recorded in the Bryologist (21:50. 1918). 
2. Dirina ceratòniae (Ach.) DeNot. Giorn. Bot. Ital. 2: 18s. 1846.

Lecanora ceratoniae Ach. Lich. Univ. 361. 1810.

On bark of Jacquinia keycnsis (apparentls confined to this, so far as it occurs in the Bahamas). New Providence, road south of Fox Hill, Eleuthera Island, at Miller's Point; Little San Salvador: Stocking Island, Great Exuma; Watling's Island, on island in lake:- southern Europe and northern Africa.

\section{Order 4. LECIDEȦLES.}

A. Spores with uniformly thickened wall, colorless in all Bahama genera except Leptotrema and there brown and muriform.

1. Thallus gelatinous when moist.

Gonidla : Glococapsa.

Gonidia : Nostoc

2. Thallus not gelatinous when moist.

a. Thallus appearing as a mat of Trentepohlia filaments, the hrphae to be seen only nnder the microscope.

b. Thallus not as above.

* Thallus crustose or squamulose.

$\dagger$ Thallus crustose.

Thalline exciple absent or soon disappearing.

Mrargin of apothecia pilose.

Margin of apothecia naked. Gonidia : Trentepohtia.

Apothecia with a black exciple.

Exciple not black. Gonidia : Cystococcus.

Thallne exciple present.

Apothecia immersed in the thal. lus or in thalline verrucae. Apothecia superficial and discoid.

†† Thallus squamulose, or developing erect frutlcose podetia and the original squamules disappearing.

Apothecia sessile on the souamules.

Apothecia on the tips of erect podetia.

* Thallus folinse or fruticose.

Thallus foliose.

Gonidia : Pine-green.

Gonidia: Green.

Thallus fruticose, growing on trees.

(Species of Cladonia might be sought here, but never grow on trees.)

B. Spores with irregularly thickened wa!l (i.e., polar-

Frim. 1. Pyrenopsidaceae.

Fam. 2. Collemaceae.

Fam. 3. Coenogoniacea.

Fam. 4. Pilocarpaceat.

Fam. 5. LecaNaCtinacead.

Fam. 6. Gralectaceae.

Fam. 7. Lecideaceae.

Fam. 8. Thelotrestaceae,

Fam. 9. Lecaxoraceae.

Fam. 10. Pir llopsoraceae.

Fam. 11. Cladoxidceat.

Fam. 12. Pañariaceae.

Fam. 13. Parieliaceae.

Fam. 14. Usneaceae.

bilocular) or uniformly thickened, but then

always brown: never muriform.

Spores colorless.

spores hrown.

Thallus crustose.

Thallus foliose.

Fam. 15. Caloplacaceae.

Fam. 16. Ruelliaceae.

Fam. 17. Phisciaceae.

\section{Family 1. PYRENOPSIDÀCEAE.}

\section{PSOROTÍCHIA Mass.}

1. Psorotichia Boergesènii Wainio, Ann. Acad. Sei. Fenn. A: 67 : 118. 1915.

On limestone, New Providence:-St. Thomas.

\section{Family 2. COLLEMÀCEAE.}

Spores simple.

Spores plurllocular or muriform-multilocular.

Thallus wlthout a cortex.

Thallus corticate, at least abore.

1. Physmi .

2. Collema.
3. Leptogium. 


\section{PHÝSMA Mass,}

1. Physma umbélla ('Tuck.) Riddle.

Omphalaria umbclla Tuck. apud Nyl. Syn. Lich. 1: 105. 1858.

On a rock, New Providence, at sink-hole, ou Farringdon load:-Alabama.

\section{COLLÈMA Hill.}

Surface of thallus granulose.

Thallus not granulose.

'Thallus radiately plicate, with rounded lobes.

Thallus merely uneven, with narrow lobes.

1. C. vupestre.

2. C. nlgrescens.

3. C. laciniatum.

1. Collema rupéstre (Sw.) Rabenh. Deutsch. Krypt. Flora 2: 50. 1845.

Lichen rupestris Sw. Meth. Muscor. 37. 1781.

Lichen flaccidus Ach. Nov. Act. Acad. Sci. Stockholm 5: 14, pl. 1, f. 4. 1795.

Collema flaccidum Ach. Lich. Univ, 647. 1810.

On Annona glabra, Cat Island, at Port Howe:-widely distributed in temperate regions of both hemispheres.

2. Collema nigréscens (Huds.) Ach. Syn. Lich. 321. 1814.

Lichen nigrescens Hnds. Fl. Angl. 450. 1762.

On trees, Great Bahama, at Barnett's Point, and New Providence, at Waterloc Coppice :-cosmopolitan.

The material is without isidia, and would represent what Wainio (Lich. Brés. 1: 235. 1590) calls Collema vespertilio (Lightf.) Wainio, but the original plants upon which these names were based are doubtful.

3. Collema laciniàtum Nyl. Syn. Lich. 1: 115. 1858.

At base of tree, Watling's Island, near Cockbuln Town:-Alabama; Kansas. The type came from calcareous rocks, and as the present material is sterile, the determination must be considered uncertain, although the thalline characters agree with the material in the Tuckerman Herbarium.

\section{LEPTÒGIUM S. F. Gray.}

Thallus dark green to black.

Thallus bluish lead-color.

Thalline margin of apothecia a plaited corona.

Thalline margin of apothecia thickly lobulate.

1. L. chloromelum.

2. L. bullatum.

3. L. phyllocarpum.

1. Leptogium chloromèlum (Sw.) Nyl. Syn. Lich. 1: 128. 1858.

Lichen chloromelos Sw. Fl. Ind. Oce. 3: 1892. 1806.

On trees, New Providence, Watling's Island, and Salt Key Bank, Anguilla Islands :- thronghout North America, and recorded as cosmopolitan.

This is the most "Collema-like" of all the species of Leptogium, and is very variable. Some of the specimens cited are near tlie variety stellans Tuck. Syn. N. A. Lich. 1: 163.1882 .

2. Leptogium bullàtum (Ach.) Nyl. Syn. Lich. 1: 129. 1858.

Lichen bullatus Ach. Lich. Snec. Prodr. 137. 1798.

On trees, Great Bahama, at Golden Grove, and New Providence, along Soldier's Road:-widely distributed in tropical America, and recorded from tropical Asia and New Zealand.

3. Leptogium phyllocárpum (Pers.) Nyl. Syn. Lich. 1: 130. 1858.

Collema phyllocarpum Pers. in Gaudich. Voy. Uran. 204. 1826.

Leptogium bullatum var. phyllocarpum Tnek. Syn. N. A. Lich. 1: 165. 1882.

On trees, New Providence, at Grantstown and along Soldier's Road :-widely distributed in tropical regions of both hemispheres. 


\section{Family 3. COENOGONIÀCEAE.}

\section{COENOGÒNIUM Ehrenb.}

1. Coenogonium interplèxum Nyl. Ann. Sci. Nat. IV: 16: $92,1862$.

On trees, Abaco, vicinity of Cherokce Sound, and Andros, at Louisa Coppice, near Nicholl's Town:-Costa Rica : Colombia; Venezuela.

\section{Family 4. PILOCARPȦCEAE.}

\section{PILOCÁRPON Wainio.}

1. Pilocarpon tricholòma (Mont.) Wainio, Lich. Brés. 2: 89. 1890.

Biatora tricholoma Mont. Ann. Sci. Nat. III: 16: 53. 1851.

Lecidea leucoblephara Nyl. Ann. Sci. Nat. IV: 19: 337. 1863.

On leares of Eugeniu, Crooked Island, at Stopper Hill:-widely distributed in tropical America.

\section{Family 5. LECANACTIDÀCEAE.}

\section{LECANÁCTIS Eschw.}

1. Lecanactis denticulata Wainio, Ann. Acad. Sei, Fenn. A: 67: 141.1915.

Opegrapha acicularis Riddle, Mem. Brooklyn Bot. Gard. 1: 110. 1918.

On bark of Coccolobis laurifolit, Great Harbor Cay, Berry Islands, and on Eugenia buxifolia, Watling's Island:-Florida ; Cuba ; St. Thomas ; St. Croix; Porto Rico.

It has only recently been possible for me to see a copy of Wainjo's paper. His description of $L$. dentieuluta differ's from that of $O$. acicularis only in stating that the base of the amphithecium is black, while I found it to be colorless in the matelial that I examined; but the denticulate margin of the apothecia is so peculiar and so characteristic that 1 am convinced that the plants are the same. Furthermore, the acicular spores are identical, and Wainjo has proposed a new section Bacidiactis to receive this spccies.

\section{Family 6. GYALECTÀCEAE.}

Spores one-celled.

Spores two-celled.

1. Ionaspis.

2. Hicrophiale.

\section{IONÁ́sPIS Th. Fr.}

1. Ionaspis tròpica Ridale, sp. nov.

Thallus crustaceus effusus tenuissimus cum saxo conferruminatus, fuscescens, minutissime farinosus, circa apothecia rimuloso-areolatus. Gonidia pauca chroolepoidea. Apothecia caespitosa ninuta, in areolis thallinis immersa, disco primum punctiforme dein aperto ad $0.3 \mathrm{~mm}$. lato, concavo ant plano, castaneo aut fuscescente, margine pallidiore integro tenue parum prominente persistente; epithecio fulro, excipulo et hypothecio pallido. Asci clavati S-spori. Sporae incolores simplices ellipsoideae membrano tenue, $10-12 \times 6-7 \mu$.

on limestone, New l'rovidence (Brace, November 20, 1918, 969\%, type).

ThIs species has the general appearoince of Ionaspis suaveolens (Ach.) Arnold, but differs in the brown thallus and disk of the apothecium.

\section{MICROPHIÀLE Stizenb.}

1. Microphiale lùtea (Dicks.) Steiner, Sitzungsber. kais. Akad. Wiss. Wien 106: 227. 1897.

Lichen luteus Dicks. Pl. Crypt. Brit. 1: 11. 1785.

Gyalecta lutea Tuck. Gen. Lich. 136. 1872.

On bark, New I'rorldence:-widely distributed. 


\section{Family 7. LECIDEÀCEAE.}

Spores simple.

Spores four- to many-celled.

Spores thick-walled, with more or less lens-shaped cells.

Spores thin-walled, with cylindrical cells.

spores four-celled, fusiform.

spores many-celled, acicular.

1. Lecidca.

2. Bombyliospora.

3. Bilimbia.

4. Bacidia.

\section{LECIDEA Ach.}

Growing on rocks.

Growing on bark.

Hypothecium pale.

Hypothecium blackish-brown.

1. L. immersa.

2. L. vernalis $\mathrm{v}$, minor.

3. L. furfurosa.

1. Lecidea immérsa (Web.) Ach. Meth. Lich. 34. 1803.

Lichen immersus Web. Spicil. Fl. Goett. 188. $177 \mathrm{~S}$.

Lecidea calcivora Mass. Ric. Lich. Crost. 78. 1852.

Biatora calcivora Tuck. Syn. N. A. Lich. 2: 29. 1888.

On calcareous rocks, New Providence, along Soldier's Road:-southern United States; Europe.

2. Lecidea vernàlis (L.) Ach. var. minor Nyl. apud Norrl, in Not. Saellsk. Faun. Fl. Fenn. 13: 335. 1873.

On bark, New Providence:-North America; Europe.

3. Lecidea furfuròsa Tuck, apud Nyl. Ann. Sci. Nat. IV : 19: 341. 1863.

Biatora furfurosa Tuck. Syn. N. A. Lich. 2: 19. 1888.

On bark, New Providence, at Grantstown:-Florida; Cuba.

\section{BOMBYLIOSPÒRA DeNot.}

1. Bombyliospora domingénsis (Pers.) Zahlbr. apud Wawra and Beck; Jtinera Prineip. Coburg. 2: 154. 1888.

Patellaria domingensis Pers. Annal. Wetter. 2: 12. 1810.

Heterothecium domingense Flot., Tuck. Syn. N. A. Lich. 2: 57. 1888.

On bark, New Providence, coppice near Clifton:-widely distributed in tropical regions of both hemispheres.

\section{BILÍMBIA DeNot.}

Growing on rocks; apothecia blackening.

Growing on bark or old wood.

Thallus and apothecia golden-yellow.

Thallus gray or greenish; a pothecia pallid.

1. B. trachona.

2. B. aurata.

3. B. molybditis.

1. Bilimbia trachòna (Ach.) Th. Fr. Lich. Scand. 386. 1871.

Terrucaria trachona Ach. Meth. Lich. Suppl. 16. 1803.

Lecidea phaeomela Nyl. Ann. Sci. Nat. IV: 19: 34. 1863. Europe.

On limestone, New Providence:-locally distributed in North America and

The original description of this species says, "crusta pulverulenta." Mr. L. J. K. Brace has sent in a series of collections from New Providence showing that the thallus varies from areolate-rimose, in well-developed specimens, to a dispersed and granulate condition, and in some eases disappearing. The name Lecidea phaeomela was applied by Nylander to the last named condition. The color of the thallus varies from the typical sordid-green to fuscescent. The very youngest apothecia are baybrown, but they blacken quickly. 


\section{Bilimbia auràta Riddle, sp. nov.}

Thallus crustaceus uniformis effusus haud limitatus, e flavo intense aurescens, tenuis leprosus laxe contextus. Gonidia cystococcoidea. Apothecia minutissima, $0.1-0.15 \mathrm{~mm}$. lata, sat elerata rotundata regularia ceracea, disco aurantiaco, primum plano margine tenuissime pallicliore subleproso, mox convexo margine excluso; epithecio lutescente, hymenio et hypothecio incolore. Asci clavati, S-spori. Sporae incolores fusiformes apicibus rotundatis aut altero apice subacuto, 4-loculares, loculis cylindricis aequalibus, $10-12 \times 3 \mu$.

On bark, Falringdon Road, New Providence (Elizabeth G. Britton, August, 1904, 221, type). The following sterile specimens appear to belong here also:-on dead Suriana, Andros, at Barton Creek (Brace, 5297): on dead wood. Crooked Island, at Gun Bluff (Brace, 4693). Also, Palm Beach, Florida (R. Thaxter).

The sterile specimens are similar to the Leprarie the of the older authors, although brighter and more golden. But the fertile specimen has abundant apothecia, which certainly belong to the thallus in question. The species is a very distinct one.

3. Bilimbia molybditis (Tuck.) Riddle.

Bintora molybditis Tuck. Syn. N. A. Lich. 2: 34. 1885.

On bark, New Providence:-Florida.

\section{BACIDIA DeNot.}

Apothecia pallid to flesh-color.

Apothecia reddish-brown to black.

Apothecia persistently brown.

Apothecia soon becoming black.

1. B. medialis.

2. B. fuscorubella.

3. B. atrogrisea.

1. Bacidia mediàlis (Tuck.) Riddle.

Lecidea medialis Tuek. apud Nyl. Ann. Sci. Nat. IV: 19: 346. 1863.

Biatora medialis Tuck. Syn. N. A. Lich. 2: 132. 1888.

On bark, New Providence :-Florida; Texas; Cuba; Nicaragua; Brazil.

2. Bacidia fuscorubélla (Hoffm.) Arnold, Flora 54: 55. 1871.

Terrucaria fuscorubella Hoffm. Deutsch. Fl. 2: 175. 1795.

Biatora fuscorubella Tuck. Syn. N. A. Lich. 2: 43. 1888.

on bark, New Proridence:-widely distributed in the northern hemisphere.

3. Bacidia atrogrìsea (Delise) Arnold, Flora 41: 505. 1858.

Biatora atrogrisea Delise apud Hepp, Fl. Eur. 26. 1853.

Lecidea lutcola f. endoleuca Nyl. Bot. Notis. (1853) 98.

Bacidia endolcuca Kickx, Fl. Crypt. Fland. 1: 261. 1867.

On bark, New Providence, at Iaidenhead Coppice:-widely distributed in North America and Europe.

\section{Family 8. THELOTREMÀCEAE.}

Paraphyses branched and anastomosing.

Paraphyses simple and free.

Spoles plurilocular, colorless.

Spores muriform-multilocular.

Spores colorless.

Spores brown.

1. GYRósTOMUM Fr.

1. Gyrostomum.

2. Ocellularia.

3. Thelotrema.

4. Leptotrema.

1. Gyrostomum scyphulìferum (Ach.) Fr. Syst. Orb. Veg. 26s. 1825.

Lecidca scyphulifera Ach. Synops. Lich. 27. 1814. spheres.

On bark, New Provldence:- $-\pi i d e l y$ distrlbuted in tropical regions of both heml- 
2. OCELLULȦRIA Spreng.

Spores four- to six-celled.

Spores eight- to sixteen-celled.

1. o. micropora.

2. O. subtilis.

1. Ocellularia micropòra (Mont.) Muell. Arg. Nuov. Giorn. Bot. Ital. 23: 129. 1891.

Thelotrema microporum Mont. Ann. Sei. Nat. III : 10: 130. 1848.

On bark, Andros, at Lonisa Coppice near Nicholl's Town:-Florida; Cuba; Brazil ; Tahiti ; Japan.

2. Ocellularia súbtilis (Tuck.) Riddle.

Thelotrcma subtile Tuck. Am. Journ. Sci. 25: 426. 1858.

Thelotrema bicinctulum Nyl. Ann. Sci. Nat. IV: 15: 46.1861.

On bark, New Providence:-widely distributed.

\section{THELOTRÈMA Ach.}

Apothecia in raised, convex verrucae.

Apothecia sunken in the thallus.

1. T. lepadinum.

2. T. paralbidum.

1. Thelotrema lepadinum Ach. Meth. Lich. 132. 1503.

Lichen lepadinus Ach. Lich. Suec. Prodr. 30. 1798.

On dead wood, New Providence, near Soldiers' Home :-cosmopolitan.

2. Thelotrema parálbidum Ridale, sp. nov.

Thallus epiphloeodes crustaceus uniformis effusus haud limitatus, sordide albidus, in erassitudine mediocris, rimoso-areolatus areolis subquadrangularibus $0.6-1.0 \mathrm{~mm}$. latis inaequalibus vel leviter convexis. Gonidia chroolepoidea. Apothecia approximata aut partim dispersa, areolis thallinis immersa haud verrucas formantia, suborbicularia $0.5-0.8 \mathrm{~mm}$. lata, diseo aperto plano albissimo farinoso, superficiem thalli subaequante ant paullum submerso, margine duplice crenato aut sublacerato parum prominente; intus hyalino. Paraphyses simplices. Asci clarati, 8-spori. Sporae incolores ovideae murali-divisae, 8-10loculares, loculis cubicis 2-3-locellatis, $22-25 \times 9-11 \mu$.

On bark, Maidenhead Coppice, New Providence (Elizabeth G. Britton, February, 1905, 3234, type).

Thelotrema paralbidum is extelnalls similar to Ocellularia albida (Nyl.) Riddle, (Thelotrema albidum N.yl. Act. Soc. Sci. Fenn. 7: 451 . 1863), but differs in sporecharacters. It is, perhaps, most closely related to $T$. velatum iluell. Arg. (Bull. Soc. Roy. bot. Belg. $32^{1}: 26$. 1894), but differs in the thicker, areolate thallus, the white disk, and the shorter spores.

4. LEPTOTRÈmA Mont. \& v. d. Bosch.

Apothecia in convex verrucae.

Spores 1-2 in each ascils.

Spores 8 in each ascus.

Verrucae $0.8-1.0 \mathrm{~mm}$. diameter ; spores $2 n-30 \mu$ in length.

Verrucae $0.3-0.5 \mathrm{~mm}$. diameter; spores $55-50 \mu$ in length. Apothecia sunken in the thallus.

Spores $1-4$ in each ascus.

Spores 8 in each ascus.

Spores with $4-6$ series of cells.

Spores 10-14 $106-8 \mu$ Spores 17-27 $\times 10-18 \mu$.

Spores with $6-10$ series of cells.

1. L. monosporum.

2. L. bahianum.

3. L. simplex.

4. L. bisporum.

5. L. glaucescens.

6. L. Wightii.

7. L. compunctum.

1. Leptotrema monospòrum (Nyl.) Muell. Arg. Bull. Soc. Roy. Bot. Belg. 31²: 35. 1892.

Thelotrema monosporum Nyl. Ann. Sci. Nat. IV: 15: 46. 1861.

On bark, New Providence:-widely distributed in the warmer regions. 
2. Leptotrema bahiànum (Ach.) Mucll. Arg. Mem. Soc. Physs. Hist. Nat. Genère 29: 12. 1587.

Thelotrema lepadinum rar. bahianum Ach. Meth. Lich. 132. 1503. Brazil.

On bark, New Providence, along Soldier's Road:-Cuba : Costa Rica; Colombla;

3. Leptotrema símplex (Tuck, Riddle.

Thelotrema simplex Tuck. Proc. Am. Acad. 6: 2i1. 1864.

On bark, Andros, along road to Conch Sound, and along road to Morgan's Bluff, and New I'rovidence:-Cuba.

4. Leptotrema bispòrum ( $\mathrm{Nyl}$.) Riılle.

Thelotrema bisporum Nyl. apud Hue, Nowv. Arch. Mus. Nat. Hist. Paris III : 3: 96. 1591 .

On bark, Gleat Bahama. near Eight Mile liocks:-Guadeloupe

The specimens agree exactly with the external characters of the type preserved in the Jluseum d'Histoire Niturelle in Paris liut Vylander says that the spores are 1 to 2 in the ascus and $80-115 \times 34-36 \mu$ in size; while the present material shows spores 2 to 4 in the ascus and only $38-50 \times 14-18 \mu$ in size. It is to be ex. pected, howerer, that with a larger number of spores in the ascus the size should be smaller. A similar condition is found in species of Pertusaria, for example, P'crtusaria leioplaca (Ach.) Schaer.

5. Leptotrema glaucéscens (Nyl.) Muell. Arg. Flora 65: 499. 1s\$2.

Thelotrema glaucescens Nrl. Ann. Sei. Nat. IV: 19: 499. 1582.

On bark, Andros, along road to Conch Sound:-southern United States; Cuba; Porto Rico.

6. Leptotrema Wíghtii (Taylor) Muell. Arg. Flora 65: 499. 1552.

Endocarpon Wightii Taylor in Hook. Journ. Bot. 6: 155. 1847.

Thelotrema Ravenelii Tuek, in part. (fide Muell. Arg. in herb.)

On bark. Abaco, at Old Kerr's Point:-widely distributed in the warmer regions of both hemispheres.

7. Leptotrema compúnctum (Sm.) Muell. Arg. Flora 70: 400. 18s7.

Lichen compunctus J. E. Smith apud Ach. Meth. Lich. 143. 1803.

On bark, New Providence:-Cuba: Costa Rica: Colombia: Brazil. Mueller (1. c.) misspelt the name as "compacto," but corlected the error in a list of errata published in Hedwigia $34: 36.1595$.

\section{Family 9. LECANORACEAE.}

Spores simple.

Paraphyses simple and free.

I'araphyses branched and anastomosing. spores plurilocular.

1. Lecanora.

2. Ochrolechia.

3. II acmatomma.

\section{LECANÒRA Ach.}

Growing on rocks.

Growing on bark or old wood.

Disk of apothecla distinetly brown.

Disk of apothecia not brown.

Disk typically vellow Ish-green.

Disk typlcally flesh-color.
1. L. badia.

2. L. subfusca.

3. I. raria.

4. L. cinereocarnca.

1. Lecanora bàdia (Pers.) Ach. Lich. Univ. 407. 1510.

Lichen badius Pers. in Usteri, Ann. Bot. 7: 27. 1794.

On IImestone. Eleuthera Island, at Elenthera lolnt:- Widely alstributed in Europe; local in Forth America: mountalns of I3rizil. I'eru, and Chill. 
2. Lecanora subfùsca (L.) Ach. Lich. Univ. 393. 1810.

Lichcn subfuscus L. Fl. Suec. erl. 2. 409. 1755.

On bark, New l'rovidence:-cosmopolitan.

3. Lecanora vària (Ehrh.) Ach. Lich. Univ. 377. 1810.

Lichen varius Ehrb. apul Hoffm. Pl. Lich. 1: 102, pl. 23, f. 4. 1790.

On bark and old wood, Great Bahama and New Providence:-cosmopolltan.

4. Lecanora cinereocárnea (Eschw.) Wainio, Lich. Brés. 1: 80. 1890.

Parmelia varia var. cinereocarnea Eschw. in Mart. Fl. Bras. 1: 187. 1833.

Lecanora chlaroterodes Nyl. Flora 59: 508. 1876.

Lecanora chlaronella Nyl, apud Crombie, Journ. Linn. Soc. 16: 215. 1577.

Lecanora subfusca var. cinereocarnea Tuck, in Wright Lich. Cub. no. 118.

On bark of trees and shrubs, from Berry Islands to Acklin's:-widely distributed in tropical regions of both hemispheres.

\section{OCHROLÉCHIA Mass.}

1. Ochrolechia palléscens (L.) Koerb. Syst. Lich. Germ. 149. 1855.

Lichen pallescens L. Sp. Plant. 1142. 1753.

Lecanora pallescens Schaer., Tuck. Syn. N. A. Lich. 1: 196.1888. politan.

On bark of Maba crassinervis, Watling's Island, near Cockburn Town:-cosmo-

\section{HAEMATÓMMA Mass.}

1. Haematomma puniceum (Ach.) Wainio, Lich. Brés. 1: i2. 1890.

Lecanora punicea Ach. Syn. Lich. 174. 1814. spheres.

On bark, New Providence:- widely distributed in tropical regions of both hemi-

\section{Family 10. PHYLLOPSORÀCEAE.}

1. PHYLLOPSÒRA Muell. Arg.

1. Phyllopsora parvifòlia (Pers.) Muell. Arg. Bull. Herb. Boiss. 2: appendix 1: 45.1894.

Lecidea parvifolia Pers. in Gaudich. Voy. Uran. 192. 1826.

Biatora parvifolia Tuck. Genera Lich. 157. 1872.

On tree-trunks, Andros, and New Providence, in Waterloo Coppice:-widely distributed in the warmer regions of both hemispheres.

\section{Family 11. CLADONIÀCEAE.}

\section{CLADÒNIA Hill.}

Apothecia some shade of red.

Apothecia some shade of brown.

Podetia with dilated axils or cup-shaped.

Axils or cups perforate.

Axils or cups closed.

Podetia entirely corticate and without soredia.

Cups proliferating from the center.

Cups proliferating from the margins, or not at all.

Podetia at least partially decorticate and more or less sorediate.

Podetia powdery-sorediate.

Podetia warty or scurfy or granular-sorediate. Cups rell-dereloped.

Cups reduced.

Podetia with closed axils, not at all cup-shaped, much branched.

Podetia fine and somewhat uniform in size throughout.

Podetia with main part stout and branching progressively finer.

1. C. areolata.

2. C. Dilleniana.

3. C. verticillata.

4. C. graeilis.

5. C. fimbriata.

6. C. pyxidata.

7. C. pityrea.

S. C. pycnoclada.

9. C. rangiferina. 
1. Cladonia areolàta Nyl. Syn. Lich. 1: 226. 1855.

On decaying $\log$, Eleuthera Island, between Harbor Island and Lower Bogue:Guadeloupe.

This is a peculiar and distinct species, with a subcrustose thallus.

2. Cladonia Dilleniàna Floerke, Clad. Comm. 138. 1828 .

On ground and over rocks, Andros, vicinity of Lisbon Creek, Deep Creek, Scrub Creek:-Cuba; Jamaica; Australasia; Madagascar.

3. Cladonia verticillàta Hofim. Deutsch. Fl. 2: 122. 1795.

Cladonia gracilis var. verticillata Fr.; Tuck. Syn. N. A. Lich. 1: 242. 1882.

On the ground, Abaco, along California Road:-cosmopolitan.

4. Cladonia gràcilis (L.) Willd. var. dilaceràta Floerke, Clad. Comm. 37. 1829. Cladonia gracilis var. hybrida Tuck. Syn. X. A. Lich. 1: 243, in part. $18 s 2$.

Over rocks, Great Bahama, vicinity of Eight Mile Rocks:-widely distributed in Europe and North America.

5. Cladonia fimbriàta (L.) Fr. rar. símplex (Weis.) Flot. Linnaea 18: 18. 1843.

Lichen fimbriatus var. simplex Weis, Pl. Crypt. Gott. 84. 1770.

Cladonia fimbriata var. tubaeformis Fr.; Tuck. Syn. N. A. Lich. 1: 241. 1882.

On the ground, Crooked Island, along road to Stopper Hill :-cosmopolitan.

6. Cladonia pyxidàta (L.) Fr. var. chlorophaèa Floerke, Clad. Comm. 70. $182 S$.

Cladonia pyxidata (L.) Fr.; Tuck. Srn. N. A. Lich. 1: 240, in part. 1882.

On the ground, Great Bahama and New Providence:-cosmopolitan.

7. Cladonia pityrèa (Floerke) Fr. Nor. Sched. Crit. 21. 1526.

Capitularia pityrea Floerke, Berl. Magaz. 2: 135. 1808.

Cladonia fimbriata rar. adspersa Tuck. Syn. N. A. Lich. 1: 242. 1852.

On dead wood, and on the ground, Andros, near Nicholl's Town, and Crooked Island, at Vauxhall :-cosmopolitan.

8. Cladonia pycnoclàda (Pers.) Nyl. Journ. Linn. Soc. 9: 24t. 1866.

Cenomyce pycnoclada Pers, in Gaudich. Voy. Uran. 212. 1826.

On the ground and over rocks, Abaco, at Marsh Harbor, and Mangrove Cay, Andros, at I'ineland, Lisbon Creek:- widely distributed in the southern hemisphere.

9. Cladonia rangiferina (L.) Web. in Wiggers, Prim. Fl. Hols. 90. 1iso.

Lichen rangiferinus L. Sp. Plant. 1153. 1753.

Orer rocks, Great Bahama :-cosmopolitan.

\section{Family 12. PANNARIÀCEAE.}

Lpper cortex composed of vertical hyphae; gonidia Nostoc.

Lpper cortex composed of Iongitudinal byphae; gonidia Scytonema.

1. Pannaria.

2. Coccocarpia.

\section{PANNARIA Delise.}

1. Pannaria rubiginòsa (Thunb.) Delise, Diction. Class. 13: 20. 142s.

Lichen rubiginosus Thunb. Prodr. Flor. Capens. 176. 1794.

On trees, New I'rovldence, along Soldier's lioad:-common in tropical regions and locally distributed In temperate regions of both hemispheres. 


\section{COCCOCÁRPIA Pers.}

1. Coccocarpia péllita (Ach.) Muell. Arg. Flora 65: 320. 1892. Parmelia pellita Ach. Lich. Univ. 468. 1810.

Thallus without isidia.

Hrpothallus copious and extending beyond the lobes.

Hypothallus medium or scanty.

Lobes about $0.4-1.0 \mathrm{~mm}$. Wide, repeatedls pinnatifidincised.

Lobes $2-10 \mathrm{~mm}$. wide, cuneate, subentire.

Rhizoids blue-black; apothecia blackening.

Rhizoids partly white: apothecia persistently pale brown.

Thallus more or less isidiose.

a. rar. pannosa.

b. var. genuina.

c. var. parmclioides.

d. var. smaragdina.

e. var. tenuior.

1a. Coccocarpia pellita var. pannòsa Muell. Arg. Flora 65: 320. 1882.

On trees, New Providence, at Lake Cunningham, and Crooked Island, at Vauxhall :-Cuba ; Australia.

1b. Coccocarpia pellita var. genuina Muell. Arg. Flora 65: 321. 1882.

On trees, Watling's Island, near Cockburn Town :-Cuba: Porto Rico; Brazil. This represents the Acharian type and is well illustrated in Swartz Lich. Amer. pl. 6 .

1c. Coccocarpia pellita var. parmelioides (Hook.) Muell. Arg. Flora 65: 320. 1882.

Lecidea parmelioides Hook, in Kunth Syn. Plant. Orb. 162. 1822.

Coccocarpia molybdea Pers. in Gaudich. Toy. Uran. 206. 1826.

Pannaria molybdea Tuck. Syn. N. A. Lich. 1: 124. 1882.

On trees. Great Bahama, Abaco, New Providence:-widely distributed in the warmer regions of both hemispheres.

1d. Coccocarpia pellita var. smarágdina (Pers.) Muell. Arg. Flora 65: 320. 1882.

Coccocarpia smaragdina Pers, in Gaudich. Voy. Uran. 206. 1826.

On trees, New Providence, at Lake Cunningham:-widel 5 distributed in the warmer regions of both hemispheres.

1e. Coccocarpia pellita var. tenùior (Nyl.) Muell. Arg. Flora 65: 322.1882.

Coccocarpia molybdea var. tenuior Nyl. apud Krplh. Flora 59: 76. 1876. On trees, New Irovidence, at Maidenhead Coppice:-Porto Rico; Mauritius.

\section{Family 13. PARMELIÀCEAE.}

\section{PARMĖLIA Ach.}

Mrargins ciliate.

Margins naked.

Medulla sellow.

Ifedulla white.

Thallus greenish-straw-color.

Thallus gray or whitish.

Nedulla turning red when tested with caustic potash.

Margins entirely without soredia.

Margins more or less sorediate.

Medulla not red with caustic potash.

1. P. urceolata.

2. P. sulphurata.

3. P. flava.

4. P. Tatissima.

4a. P. latissima var. cristifera.

5. P. perlata.

1. Parmelia urceolàta Eschw. in Mart. Fl. Bras. 1: 207.1833. Africa.

On trees, New Providence, along Soldier's Road:-tropical South America and 
2. Parmelia sulphuràta Nees \& Flot. Linnaea 9: 501. 1834.

on trees, New I'roridence, at Maidenhead Coppice:-widely distributed in trow ical regions of both hemispheres.

3. Parmelia flàva Krempelh. in Warming, Symbol. Flor. Bras. in Viılensk. \[eddel. 9. 1873.

On tree, Andros, along road to Concb Sound:-Brazil.

4. Parmelia latíssima Fée, Suppl. Essai Crypt. 119, pl. 38, f. 1. $183 \pi$.

On trees, Abaco, New Providence, Watling's Island, Crooked lsland:-widely distributed in the warmer regions of both hemispheres.

4a. Parmelia latissima var. cristìfera (Taylor) Hue, Nouv. Arch. Mus. Hist. Nat. Paris IV : 1: 204. 1899.

Parmelia cristifera Taylor in Hook. Journ. Bot. 6: 165. 1547.

On trees, New Plovidence, at Iaidenhead Coppice:-distributed as in the typical form.

5. Parmelia perlàta (L.) Ach. Meth. Lich. 216. 1503.

Lichen perlatus L. Syst. Nat. ed. 12, p. 712. 1767.

On trees, Great Bahama, New Providence:-cosmopolitan.

\section{Family 14. USNEÀCEAE.}

Medulla of loosely interwoven hyphae: spores two-celled.

Iedulla with a tough central strand of compacted hyphae; spores simple.

1. Ramalina.

2. Usner.

\section{RAMALINA Ach.}

Thallus more or less sorediate.

Thallus without soredia.

Thallus elongated and pendulous.

Thallus short and erect.

Branches flattened; spores ellipsoid.

Branches more or less cylindrical; spores fusiform.

1. R. peruviana.

2. R. usneoides.

3. R. complanata.

4. R. Hontagnei.

1. Ramalina peruviàna Ach. Lich. Univ. 599. 1810.

on trees, Crooked Island, road to Stopper Hill :-Jamaica; Porto Rico; Curaçao Island; Peru.

2. Ramalina usneoìdes (Ach.) Fr. Lich. Europ. 468. 1831.

Parmelia usneoides Ach. Meth. Lich. 270. 1803.

On branches of trees, Abaco and Watlings Island:-widely distributed in tropical regions of both hemispheres.

3. Ramalina complanàta (Sw.) Ach. Lich. Univ. 599. 1810.

Lichen complanatus Sw. Fl. Ind. Oce. 3: 1911. 1506.

Ramalina denticulata (Eschw.) Nyl. Bull. Soc. Linn. Norm. II: 4: 129. 1870.

On trees, Abaco, New I'rovidence, Eleuthera and Long Island:-wldely distributed in the warmer regions of both hemispheres.

4. Ramalina Montágnei DeNot. Giorn. Bot. Ital. 2: 21S. 1846.

Ramalina rigida var. Montagnei Tuck. Syn. N. A. Lich. 1: 23. 1852.

On twigs and branches, Great Bahama, New Providence, Cat, Watliug's, and Acklin Islands:- - suuthern Inited States; Cuba; Jamalca; Porto líco. 


\section{2. ÚSNEA Adans.}

1. Usnea flòrida (L.) Web. var. strigòsa Ach. Neth. Lich. 310. 1803. On trees, Crooked Island, at Stopper Island:-cosmopolitan.

\section{Family 15. CALOPLACÀCEAE.}

Thalline exciple never present.

1. Blastenia.

Thalline exciple present, or sometimes disappearing in old apothecia.

2. Caloplaca.

\section{BLASTÈNIA Mass.}

Disk of apothecia orange or rustr.

Disk of apothecia dark brown to black.

1. B. ferruginea.

2. B. floridana.

1. Blastenia ferruginea (Huds.) Koerb. Syst. Lich. Germ. 184. 1855.

Lichen ferrugineus Huds. Fl. Ang. 444. 1762.

On bark, New Providence:-cosmopolitan.

2. Blastenia floridàna (Tuck.) Zahlbr. in Engler \& Prantl, Nat. Pflanzenfam. $1^{1 *}: 227.1907$.

Lecanora floridana Tuck. Proc. Am. Acad. 5: 402. 1862.

Placodium floridanum Tuck. Syn. N. A. Lich. 1: 179. 1882.

On bark, New Providence:-widely distributed in tropical America.

2. CALOPLÀCA Th. Fr.

Thallus conspicuously white-powdery.

Thallus not at all white-powdery.

Thallus on bark, copiously isidiose.

Thallus on rocks, without isidia.

Apothecia superficial on conrex, thick, thalline areoles.

Apothecia immersed in flat, thin, thalline areoles.

1. C. galactophylla.

2a. C. aurantiaca var. isidiosella.

2b. C. aurantiaca var, erythrella.

2e. C. aurantiaca var. diffracta.

1. Caloplaca galactophýlla (Tuck.) Riddle.

Placodium galactophyllum Tuck. Proc. Amer. Acad. 12: 171. 1877.

On limestone, New Providence:-Kansas.

2. Caloplaca aurantiaca (Lightf.) Th. Fr. Lich. Arct. 116. 1860.

Lichen aurantiacus Lightf. Fl. Scot. 2: 810. 1777.

2a. Caloplaca aurantiaca var, isidiosélla (Crombie) Riddle.

Lecanora aurantiaca var. isidiosella Crombie, Journ. Linn. Soc. 15: $43 \pi$. 1877.

Lepraria Bassiae Ach. Meth. Lich. 5. 1803.

Placodium aurantiacum subsp. Bassiae Wainio, Journ. Bot. 34: 67. 1896. India.

On bark, New Providence:-Jamaica; St. Thomas; St. Vincent; Guadeloupe;

2b. Caloplaca aurantiaca var, erythrélla (Ach.) Th. Fr. Lich. Scand. 178. 1871.

Lichen erythrellus Ach. Lich. Prodr. Suec. 43. 1798.

On limestone, Eleuthera Island:-probably cosmopolitan. 
2c. Caloplaca aurantiaca var. diffrácta (Mass.) Ridale.

Callopisma aurantiacum var. diffractum Mass. Monog. Lich. Blast. 73. 1853. Italy.

On limestone, New Proridence, and Watling's Island, near Cockburn Town:-

The Bahama material agrees exactly with the specimen in Massalongo Lich. Exsic. Ital. no. 2/3.

\section{Family 16. BUELLIÀCEAE.}

\section{BUÉLLIA DeNot.}

Thallus areolate, even, medulla white.

Thallus rellow with caustic potash.

Apothecia black and nudate.

Apothecia with an aeruginous bloom.

Thallus red with caustic potash.

Thallus verrucose, the rerucae with a dark red medulla.

1. B.parascma.

1a. B. parasema var. aeruginascens.

2. B. conspirans.

3. B. sanguinariella.

1. Buellia parasèma (Ach.) Koerb. Syst. Lich. Germ. 228. 1855.

Lecidea parasema Ach. Neth. Lich. 35. 1503.

Buellia disciformis Auct.

On bark, New Providence :-cosmopolitan.

1a. Buellia parasema var. aerugináscens (Nyl.) Muell. Arg. Flora 68: 530. 1885 .

Lecidea disciformis var. aeruginascens Nyl. Bull. Soc. Linn. Norm. II: 2: 52. 1868 .

On bark, Ship Channel Cay and Stocking Island, Exuma Chain:-widely distributed in tropical America.

2. Buellia conspirans (Nyl.) Wainio, Ann. Acad. Sci. Fenn. A: 67 : 88. 1915.

Lecidea conspirans Nyl. Flora 51: 345. 1868.

Lecidea subdisciformis Leight. Lich. Fl. Brit. 308. 1871.

Buellia subdisciformis Wainio, Lich. Brés. 1: 167. 1890.

On bark, common in many of the islands from New Providence to Long Island :widely distributed in the warmer regions.

3. Buellia sanguinariélla (Nyl.) Wainio, Lich. Brés. 1: 168. 1890.

Lecidea sanguinariella Nyl. Ann. Sci. Nat. V: 7: 32S. 1867.

On bark, Crooked Island, at Vauxball and Jingo Hill :-Cuba; Colombia.

\section{Family 17. PHYSCIÀCEAE.}

Hypothecium brownish-black.

Hypothecium colorless.
1. Puxine.

2. Physeia.

1. PYXINE Fr.

Apothecla lecanorine at least when young.

Apothecia persistently lecanorine.

Apothecia soon becoming lecldeine.

Apothecia lecideine from the first.

Iledulla white.

Medulla sulphury.

1. P. pieta.

2. Il $I^{2}$ eissneri.

3. P. Cocoes.

3a. P. Cocoes rar. cudoxantha.

1. Pyxine pícta (Sw.) Tuck. Proc. Amer. Acal. 4: 39S. 1560.

Lichen pictus Sw. Prodr. 146. 1788.

Physcia picta Nyl. Syn. Lich. 1: 430. 1S58.

On trees and shrubs, Great Bahama. New Providence, Cat Island, Watling's Island :-wldely distributed in warmer reglons of both hemispheres. 
2. Pyxine Meíssneri Tuck. Proe. Amer. Acad. 4: 400. 1860.

On bark, New Irovidence:-tropical America and Africa, and East Indies.

3. Pyxine Còcoes (Sw.) Nyl. Mem. Soc. Sei. Cherb. 5: 108. 1857.

Lichen Cocoes Sw. Prodr. 146. 1788.

Circinaria dissecta Fée, Essai Crypt. 127, pl. 30, f. 2. 1824.

Pyxine dissecta Wainio, Ann. Acad. Sci. Fenn. A: 67: 70. 1915.

On bark, New Providence and Watling's Island:-widely distributed in the warmer legions of both hemispheres.

Wainio ( $l$. c.) gives reasons for dropping the name "Cocoes" and adopts Fée's "Cocoes" has been in use so long and is so well recognized, it has seemed best to retain it.

3a. Pyxine Cocoes var. endoxántha Muell. Arg. Flora 65: 318. 1882.

On bark, New Providence, Eleuthera, Cat Island:-distribution similar to that of the species.

\section{PHÝSCIA Ach.}

Thallus gray-brown.

Thallus closely adnate; center areolate.

Thallus merely appressed; center subcontinuous.

Thallus whitish or glaucous.

Rhizoids black and hispid-branched.

Rhizoids white or brown, and simple.

Lobes flat.

Lobes $0.4-0.8 \mathrm{~mm}$. broad.

Lobes $1.2-3.0 \mathrm{~mm}$. broad.

Thallus without soredia.

Thallus sorediate.

Lobes convex.

Thallus without soredia.

Lobes discrete and radiate.

Lobes more or less imbricate and irregular.

Thallus sorediate.

1. P. adglutinata.

2. P. obscura.

3. P. hypoleuca.

4. P. alba.

5. P. dilatata.

6. P. crispa.

7. P. stellaris.

S. P. integrata.

Sa. P. integrata var. sorediosa.

1. Physcia adglutinàta (Flke.) Nyl. Syn. Lich. 1: 428.1858.

Lecanora adglutinata Floerke, Deutsch. Lich. 4: 7. 1815.

On bark, New Providence:-widely distributed in temperate regions.

2. Physcia obscùra (Ehrh.) Nyl. Act. Soc. Linn. Bordeaux 21: 309.1856.

Lichen obscurus Ehrh. Crypt. no. 177.

On bark, New Proridence:-cosmopolitan.

3. Physcia hypolèuca (Ach.) Tuck. Syn. N. A. Lich. 1: 68. 1882.

Parmelia speciosa var. hypoleuca Ach. Syn. Lich. 211. 1814.

On twigs, New Providence, on Soldier's Road:-widely distributed.

4. Physcia álba (Fée) Muell. Arg. Rev. Mycol. 9: 136.1887.

Parmelia alba Fée, Essai Crypt. 125, pl. 30, f. 4. 1824.

On bark, Lignum Vitae Cay, Berry Islands and New Providence:-widely distributed in tropical America.

5. Physcia dilatàta Nyl. Syn. Lich. 1: 423. 1858.

On dead wood, and on living shrubs, New Providence, at the Race Course and Cat Island, vicinity of Port Howe :-Mexico; Colombia; Abyssinia.

This species is probably more widely distributed than the stations cited would indicate, but does not seem to have been recognized. According to original specimens in the Museum dinistoire Naturelle at Paris, $P$. dilatata has exactly the lobing and texture of the common Physcia crispa, but without the soredia of that species. From $P$. integrata, it differs in flatter lobes and in being membranaceous rather than cartilaginous. 
6. Physcia críspa (Pers.) Nyl. Syn. Lich. 1: 423. 1858.

Parmelia crispa Pers. in Gaudich. Voy. Uran. 196. 1826.

Common on trees, from Great Bahama to Cat Island:-widely distributed in the warmer regions of both hemispheres.

7. Physcia stellàris (L.) Nyl. Syn. Lich. 1: 424. 1858.

Lichen stellaris L. Sp. Plant. 1144. 1753. politan.

On trees, Berry Islands, New Irovidence, Cat, and Watling's Islands :-cosmo-

8. Physcia integràta Nyl. Syn. Lich. 1: 424. 1858.

On trees, Harbor Island, Eleuthera, Cat Island, at Port IIowe, and Watling's Island, near Cockburn Town :- tropical America.

Sa. Physcia integrata var. sorediòsa Wainio, Lieh. Brés. 1: 142. 1890.

On Cocolobis, Lignum Vitae Cay, Berry Islands:- with the species.

\section{Class 2. ALGAE.}

CoNtributed by Mirshall A. Howe.

\section{SUB-CLASS RHODOPHYCEAE.}

\section{Family 1. BANGIÀCEAE.}

1. BÁNGIA Lyngb.; Hornem. Fl. Dan. 9²: 8. 1815; Lyngb. Hydroph. Dan. 82. 1819.

? Diadenus Pal, de Beaur.; Desv. Jour. de Bot. 1: 124. 1808.

1. Bangia lùtea J. Ag. Alg. Mełl. et Adriat. 14. 1842.

Bangia pallida Kütz. Phye. Gen, 250. 1813.

Bangia bidentata Kütz. Phye. Germ. 195. 1845.

Bangia pallescens Kütz. Sp. Alg. 260. 1849.

In its short broad cells, the Bahamian plant resembles Kützing's fig. $c$ (Tab. Phye. 3: $p l .28 I V$ ) of his Bangia bidentata. It appears to be more rosaceous and less luteous than old specimens from the Mediterranean, but otherwise not essentially different.

On rocks between the tide-lines, Silver Cay (New Proridence) :-reported from Guadeloupe; Mediterranean and Adriatic seas. Type from Italy.

2. ERYTHROTRÍchIA Aresch.; Summ. Veg. Seand. 132. 1846.

1. Erythrotrichia cárnea (Dillw.) J. Ag. Till Alg. Syst. 3: 15. 1883.

Conferva carnea Dillw. Brit. Conferv. pl. 84. 1807.

Conferva ceramicola Lyngb. Hydroph. Dan. 144. pl. 48D. 1819.

Erythrotrichia ccramicola Areseh.; Phyc. Seand. Mar. 210. 1850.

On Sargassum, etc., probably common, Berry Islands:-widely distributed in temperate and tropical seas. 'Ispe from Wales.

\section{GONIÓTRICHUM Kütz. Linnaea 17: 89. 1843; Plyye.}

Gen. 244. 18t3.

1. Goniotrichum Alsídii (Zanard.) M. A. Howe, Mem. Torrey Club 15: 75.1914. Bangia Alsidii Zanard. Bibl. Ital. 96: 136. 1839; Syn. Alg. Mar. Adriat. 115. pl. 6. f. \%. 1841.

Bangia elcgans Chauv. Mém. Soe. Linn. Norm. 6: 13 (nomen nudum). 1838. Goniotrichum clegans Zanard. Not. Cell. Mar. 69. 1847.

On Spermothamnion speluncarum and Hrangelia penicillata, Mariguana :- Widely distributed in temperate and tropical seas. Type from 'Trleste. 
4. ASTEROCỲTIS Gobi, Trud. St. Peterb. Obsht. Yest. 10: 85. 1879. [Not seen.]

\section{Asterocytis ramòsa (Thwaites) Gobi, loc. cit.}

Filaments $0.5-1 \mathrm{~mm}$. long, mostly $13-28 \mu$ in diameter, sparingly dichotomous; vegetative cells (protoplasts) 5-10 $\mu$ long, 1-2 times as long as broad, chromatophore vaguely stellate or indeterminate; cysts (akinetes \&) subglobose, oroid, or ellipsoid, uniseriate or rarely in a double series, $13-19 \mu$ in longest diameter (including walls), their walls $2-5 \mu$ thick. The monospores or akinetes of the Bahamian specimens resemble in form those shown by Wille in his $f .10$ (Nyt. Mag. Naturridensk. 38: pl. 1. 1900).

On the older parts of Polysiphonia hapalacantha, Great Exuma:-apparently of wide distribution; American Virgin Islands. Type from England.

\section{Family 2. NEMALIONÀCEAE.}

1. IIAGÒRA Lamour. Nouv. Bull. Sei. Soe. Phil. 3: 185. 1812.

Branching dominantly dichotomous (dichotomy sometimes obscured by proliferations, especially in Nos. 1 and 3 ): dioicous.

Assimilatory filaments cylindric, $13-21 \mu$ in diameter in distal parts, projecting beyond the calcification and forming a more ol less conspicuous lufous ol fulvous superficial nap; antheridia in isolated compact. conicovoid, subglobose, or hemispheric tufts $40-65 \mu$ broad.

Assimilatory filaments more or less moniliate, 3-13 $\mu$ in diameter in distal parts, a superficial nap wanting or inconspicuous; antheridia in rather loose flabellate or funnelshaped clusters $10-20 \mu$ wide, commonly forming an apparently confluent and continuous peripheral stratum.

Surface of thallus in dried state smooth and compact or minutely pitted; cystocarp with a rather inconspicuous and poorly defined involucre.

Surface of thallus in dried state alveolate, farinaceous, or pulverulent; cystocarp with a sharply defined basal involucre of long ascending or partly encircling filaments.

Branching dominantly monopodial.*

Monoicous.

Calcification axial, the distal ends of the assimilatory filaments free; antheridia in compact tufts $25-40 \mu$ broad, on penultimate or antepenultimate segments ; cystocarp with an involucre of ascending filaments.

Calcification chiefly and primarily extra-peripheral; antheridia in small tufts, mostly $13-20 \mu$ broad, on ultimate and penultimate segments; involucre of cystocarp represented by a few pendent or appressed-decurrent rhizoidal filaments or wanting.

Dioicous : calcification usually light, chiefly axial; plant very flaccid and mucous; assimilatory filaments usually beautifully moniliform; cystocarp with an inconspicuous involucre of ascending filaments.

1. L. farinosa.

2. L. valida.

3. L. ceranoides.

5. L. pedicellata.

6. L. mucosa.

1. Liagora farinòsa Lamour. Hist. Polyp. 240. 1816.

Liagora elongata Zanard. Flora 34: 35. 1851.

Liagora Cheyneana Harv. Trans. Roy. Irish Acad. 22: 552. 1855.

Liagora lurida Dickie, Jour. Linn. Soe. Bot. 14: 195. 1874.

Liagora crassa Dickie, loc. cit.

Liagora cayohuesonica Melvill, Jour. Bot. 13: 262. 1875.

Liagora farionicolor Melvill, loc. eit. 263.

Liagora corymbosa J. Ag. p. p. max., Anal. Alg. Cont. 3: 104. 1896.

Extremely variable in size and in habit of branching, but constant in the large compact capitate tufts of antheridia, dioicously disposed, in the protrusion

* Occasional conditions of $L$. farinosa may be sought here. $L$. decussata Mont., not jet reported from the Bahamas, has its branches commonly denudate at base and thus apparentlr stipitate or articulate, which is not true of the other West Indian member's of the monopodial group. It differs also in being more compactly calcified, less mucous, and less adherent to paper when dried. 
of the stout eylindric assimilatory filaments beyond the axial calcification and in the eharacters of the eystocarp. Monosporangium-bearing dises, looking like epi-endophytes, but probably arising from gemmae of the Liagora, occur, especially on antheridial plants.

On rocks and stones from low-water mark down to a depth of at least two meters, New I'rovidence, Great Bahama, Gun Cay, South Cat Cay, Perry lslands, Exuma Chain, Jariguana, and Little Inagua:-Bermuda: Florida; Cula : Jamaica: St. Croix; Barbados: of wide distribution in tropical and subtropical seas. Type from the Red Sea, neal Suez.

\section{Liagora válida Harv. Ner. Bor.-Am. 2: 13s. pl. 31A. 1853.}

Liagora annulata J. Ag. (in part, at least) Sp. Alg. 3: 518. 1576.

Liagora tenuis J. Ag. p. p. max., Anal. Alg. Cont. 3: 101. 1896.

Liagora rosacea Zeh, Notizbl. Königl. Bot. Gart. Berlin 5: 271. 1912.

Extremely variable in size and habit, in the amount of ealcification, in presence or absence of annulations, in the compactness of the cortex, in the subparallel or subumbellate disposition of the distal branches of the assimilatory filaments, and in the form and size of the peripheral cells, yet specifie segregations seem to the writer to be impracticable. Plants growing on surf-beaten rocks between the tide-lines form rigid brittle closely adherent cushions suggesting fruticulose Lithothamnieae or species of the lichen genus Cladonia; those growing below the low-water line or in less agitated water are longer, laxer, less hearily calcified, and more flexible. In intermediate positions, forms of intermediate habit occur. Certain conditions of the species appear to be close to Liagora fragilis (Forsk. ?) Zanard. and L. rugosa Zanard., from the Red Sea, with which they may need further comparisons.

On rocks from near the high-water mark, in exposed positions, down to a depth of at least one metel (low-tide). New Providence. Gleat Bahama, Berry Islands, North Cat Cay, South Cat Cay, Gun Cay, Andros, Orange Cay, Exuma Chain, Eleuthera, Watling's Island, Mariguana, and Caicos Islands :-Bermuda: Florida : Cuba ; Jamaica; Porto Rico; St. Croix; and Barbados. Type from Sand Kes, near Key West, Florida.

3. Liagora ceranoìdes Lamour. Hist. Polyp. 239. 1816.

Liagora pulverulenta Ag. Sp. Alg. 1: 396. 1822.

Liagora leprosa J. Ag. Öfv. Kongl. Vet.-Akad. Förh. 4: S. 1847.

Liagora opposita J. Ag. Anal. Alg. Cont. 3: 101. 1896.

Liagora Pilgeriana Zeh, Notizbl. Königl. Bot. Gart. Berlin 5: 272. 1912.

This species, also, as here conceived, shows great variation in size and habit, in the amount of calcification, and in the presence or absence of lateral proliferations, yet is fairly constant in the alveolate or farinaceous-pulverulent character of the surface of the dried plant, in the small subglobose or oroid ultimate or penultimate cells of the assimilatory filaments, in the compact, many-filamented, small-spored cystocarp, and in the highly developed cystoearpie involuere of numerous long ascending or partly encireling filaments. Monosporangium-bearing dises, apparently arising from gemmae, are of frequent occurrence on both antheridial and eystocarpic plants.

On rocks, stones, and shells and on other algale from low-water mark down to a depth of two meters or more (taken at a depth of twenty meters loy Börgesen in the Amerlcan Virgin Islands), Great Bahama, North Cat Cay, Gun Cay, Berry Islands, Marlguana, Caicos Islands, little Inagua and Castle lslands :- licrmuda; Florida ; Jamalca : I'orto Iilco: American Virgin Islands; Ibarbados; Mexlco; Brazil: of wide distribution in tropical and subtropical seas. Trpe from St. Thomas, American Virgin Islands.

\section{Liagora pinnàta Harv. Ner. Bor.-Am. 2: 13S. pl. 31B. 1853.}

Liagora paniculata J. Ag. Anal. Cont. 3: 106. 1596.

on rocks, etc., from low-water mark down to a depth of at least two meters, Great Lahama, Berry Islands, and Exuma Chain :-Florida; Jamaica; and st. Crolx. 'Type from Sand Kiey, neal Key West. F'lolda. 


\section{Liagora pedicellàta M. A. Howe, sp. nov.}

Thallus usually very soft and flaceid, 4-16 $\mathrm{cm}$. long or high, irregularly monopodial, the main divisions paniculate or pyramido-paniculate, each braneh surrounded in the living state by a soft mucous sheath about as thick as the whole diameter of the enclosed braneh, this sheath showing a flocculent precipitate of microseopic calcareous granules arranged mostly in the walls of irregular alveolae, making surface in dried state minutely alveolate or farinaceousalveolate; branches for the most part progressively shorter, varying from rather sparse to crowded, tapering slightly to obtuse or subacute apex, 1.2-2 nmm. broad towards apex, including more or less ealcifier mucous sheath, $0.45-0.8 \mathrm{~mm}$. without sheath; central axis in basal parts $1.5-2.5 \mathrm{~mm}$. in diameter, more or less calcifier and often denulate, in ultimate branches mostly $150-175 \mu$ in diameter, usually readily visible after decalcification, commonly reduced to about four filaments towards apex, the cells subcylindric-ellipsoid or dolioform, 104$340 \mu \times 36-104 \mu$, descending rhizoids $8-13 \mu$ in diameter few in younger parts; fascicles of assimilatory filaments mostly $300-600 \mu$ long, 4- 7 times divided, usually subtrichotomous at one or two of the proximal articulations, otherwise dichotomous, intermingled in older parts with simple or subsimple filaments 8-11 cells long, all filaments submoniliate in distal parts, the distal or subdistal cells mostly obovoid, 15-26 $\mu$ long, 12-16 (20) $\mu$ broad; apical hairs numerous, slender, loug and flexuous, often cylindrie-capitate, soon gelatinizing, leaving inconspicuous vestigia; monoicous; antherillia in small inconspicuous tufts mostly $13-20 \mu$ broad, on ultimate and penultimate segments; earpogonial branch straight, $20-25 \mu$ broad, of $4-6$ cells (including the usually long pedicel cell) situated terminally or subterminally on the third or fourth segment of the fascicle; eystocarp compact, subhemispheric, 90-215 $\mu$ broad, peripheral, terminating a rather stout and rigid submonopodial axis or pedicel 300-450 $\mu$ (4-8 cells) long, involucre wanting or represented by a few short appresseddecurrent or pendent rhizoidal filaments; carpospores obovoid, ellipsoid, or pyriform, $23-39 \mu \times 15-21 \mu$.

on more or less exposed rocks, near the low-water mark (also found washed ashore), Cockburn 1Iarbor, South Caicos (Howe 555-type), Nalcolm Foad, South Caicos, Atwood Cay, Mariguana, Rose Island, Whale Cay, Great Bahama :-FIorida (Boot Key).

Liagora pedicellata is allied to $L$. pinnata Harv., in general babit, bnt differs constantls in being more flaccid and mucous, in the more external or sheathing (usually lighter) calcificatiou, in the smaller simpler more terminal tufts of antheridia, in the struighter, more terminal carpogonial branches, in the more peripheral, more obriously pedicelled, more compact and homogeneous, large-spored cystocarps, which are destitute of a proper ascending involucre. In $L$. pedicellata, the calcification is mostly in the external mucous sheath, extending irregularly down among the peripheral filaments in the older parts: the distal ends of the filaments are covered by it with the possible exception of the tips of the hairs in the apical region. In L. pinnata the calcification is in among the filaments, the distal ends of most of the filaments, with or without hairs, remaining free or protruding beyond the calcification. The essentially terminal rather than lateral carpogonial branches might be I'egarded by some as sufficient ground for placing the plant in the genus Trichogloea rather than in Liagora, but in habit and other characters the plant is essentially a Liagora, bearing, in fact, so close a resemblance to $L$. mucosa that a microscopic examination is commonly necessary for their separation.

\section{Liagora mucòsa M. A. Howe, sp. nov.}

Thallus rery soft and mucous, lightly and irregularly ealcified, $5-20 \mathrm{~cm}$. long or high, irregularly monopodial, the main divisions paniculate or pyramidopaniculate, the calcification beginning near the central axis and often extending into the extra-peripheral mucus as mostly isolated floceulent granules, the surface iu dry state pulverulent, farinaceous, or sometimes minutely alveolate; branches for the most part progressirely shorter, rarying from rather sparse to moderately erowded, tapering slightly to obtuse or subacute apex, $0.32-0.6 \mathrm{~mm}$. broad towards apex (not including hairs); central axis in basal parts $0.7-1.25$ $\mathrm{mm}$. in diameter, lightly ealeified, often denudate, in ultimate branches mostly 
$45-125 \mu$ in diameter, readily visible, commonly reducerl to three or four rather easily separable filaments towards apex, the cells subeylindric or fusiform, mostly 52-300 $\mu \times 11-75 \mu$, descending rhizoids $3-8 \mu$ in diameter few in younger parts; fascicles of assimilatory filaments mostly $150-300 \mu$ long, 3 or 4 times dichotomous, interningled in older parts with simple or subsimple filaments 8-15 cells long, all beautifully moniliate or submoniliate in distal parts at least, the distal or subdistal cells subglobose or bitruncate-subglobose to ellipsoid or obovoid, $13-24 \mu$ long, $13-19 \mu$ broad; a pical hairs very numerous, becoming 300-800 $\mu$ long, cylindric-capitate, gelatinizing and leaving inconspicuous restigia; dioicous; antheridia forming rather compact subglobose or subhemispheric tufts $25-50 \mu$ broad, crowning ultimate and penultimate segments; carpogonial branch slightly curved, $15-28 \mu$ broad, of four cells (often with conspicuous intercellular spaces), situated latero-terminally on the second or third (rarely first or fourth) segment of the fascicle; cystocarp compact, subhemispheric or subglobose, $100-200 \mu$ broad, with a few rather inconspicuous ascending involucral filaments; carpospores obovoid to pyriform-clavate, 25$32 \mu \times 14-15 \mu$.

On more or less exposed rocks, at or neal the low-water mark (also found washed ashore), Little Inagua (Howe 5rif-type), Rose Island, Whale Cas, Creat Stivup Cay, Great Bahama:-Florida (Key West, Mrs, G. A. Mall, Mrs. F. A. Curtiss) ; Barbados (Vickers, Alg. Barb. 106-a coarse form). Liagora mucosa resembles L. pediecllata so much in genelal habit that a microscopic examination is commonly necessary for their distinction, yet it differs constantly in being dioicous, in the larger tufts of antheridia, in the less distal and more lateral insertion of the more curved carpogonial branch, and in the presence of a proper, even though rather inconspicuous, ascending involucre for the cystocal'p. It differs less constantly in the shorter, mole moniliform assimilatory filaments and in the more axial, less extra-peripheral calcification.

From Liagora pinnata Harv., the species differs in being dioicous, in being less calcified, in its greater mucosity, in its shorter, more moniliform assimilative filaments, etc.

From Liagora megaguna Börg., recently described from St. Croix, L. mucosa. differs in being much more flaccid and mucous, in being less calcified, in the long and numerous apical hairs. in the fascicles of the more moniliate assimilatory filaments being about one half as long, in the absence of rhizoidal trichomes on the assimilatory filaments (except for the decurrent rhizoid springing from the basal segment), in the more curved, usually less stout, and more proximally situated carpogonial branches, etc.

\section{Family 3. CHAETANGIÀCEAE.}

1. GALAXAÙra Lamour. Nour. Bull. Sci. Soc. Phil. 3: 185. 1812.

Dichotomaria Lamarck, Hist. Nat. Anim. sans Vert. 2: 143. 1816.

BRACHYCLAdIA Sonder, Linnaea 26: 514. 1853.

Zanardinia J. Ag. Sp. Alg. 3: 533. 1576.

Thallus terete, villous, hirtous, or pubescent throughout with numerous, crowded mostly free assimilatory filaments. Only tetrasporangia known for reproductive organs; so-called species of this group probably only non-sexual phases of other species of very different habit.

Long and short assimllatory filaments in obvious alternating transverse zones.

Long and short assimilatory filaments intermingled, not obviously zonate.

Thallus coarse, reddish, central axes mostly $1-2 \mathrm{~mm}$. in diameter; intervals between dichotomies mostly i-3 em. : assimilatory filaments often brancled, their basal celis commonly amyliferous.

Thallus more slender, fuscous or reddish, axes mostly $0, f-1 \mathrm{~mm}$. in diameter.

Thallus ratlee divalleately dichotomous, usually fuscous ; intervals between dichotomies mostly less than $1 \mathrm{~cm}$.; long asslmilatory filaments mostly 0.6-1.5 mm. long.

Thallus rather fastiglately dichotomous, usually reddish: interrals between dichotomles commonly mole than 1 cin.: long assimllatory filaments mostly $0.15-0.7 \mathrm{~mm}$. long.

1. G. subrertieillata.

2. G. comans,

3. G. lapidesecns.

4. G. Ragclliformis. 
Thallus with a compact cortex, free assimilatory filaments wholly or mostly wanting.

Thallus terete or nearly so, at least when living.

Thallus continuous or only oceasionally and irregularly articulate; only sexual reproduction known.

'Thallus slightly or not all annulate, the surface com. monly more or less roughened in lower parts by free assimilatory filaments.

Thallus distinctly annulate or transversely rugose, glibrous or nearly so.

Thallus regularly articulate, the surface glabrous and often polished.

Main segments terete, 1-2 mm. broad: superficial cells $7-27 \mu$ broad, mostly with intercellular spaces, rather easily separating on decalcification: only sexual reproduction known.

Main segments often somewhat flattened, $1.5-4 \mathrm{~mm}$. broad: superficial cells $2410 \mu$ broad, mostly with ont intercellular spaces, closely coherent after decalcification; sexual and tetrasporic plants differing in structure of cortex.

Thallus distinctly flattened when living, commonly canaliculate on drying: sexual and tetrasporic plants differing in structure of cortex.

5. G. squalida.

6. G. rugosa.

7. G. oblongata.

S. G. obtusata.

9. G. marginata.

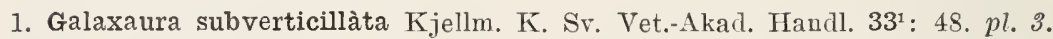
f. 12-14; pl. 20.f. 17. 1900.

On rocks at low-water mark or in shallow water, probably the tetrasporic phase of G. rugosa, New Providence, Berry Islands, Gun Cay. North Cat Cay, Salt Cay Bank, Mariguana, and Caicos Islands :- Bermuda ; Florida ; Cuba ; Jamaica ; Porto Rico; and American Virgin Islands, Type from St. Croix.

2. Galaxaura còmans Kjellm. K. Sv. Vet.-Akad. Handl. $33^{1}$ : 44. pl. 2. f. 10-18; pl. 20. f. 13. 1900.

From low-water mark down to 8 meters (fide Börgesen), perhaps the tetrasporic phase of $G$. oblonguta, Great Bahama, Berry Islands, and Exuma Chain :-Cuba ; Jamaica; Porto Rico; American Virgin Islands; and Guadeloupe. Type from Guadeloupe.

3. Galaxaura lapidéscens (Ell. \& Sol.) Lamour. Hist. Polyp. 264. 1816.

Corallina lapidescens Ell. \& Sol. Nat. Hist. Zooph. 112. pl. 21. f. g. 1786.

Perhaps the tetrasporic phase of G. cylindrica (not yet reported from the Bahamas-similar to G. oblongata, but more slender).

On rocks from low-water mark dorn to 12 meters (fide Börgesen), Eleuthera :Cuba; Jamaica; Porto Rico; and American Virgin Islands. Tspe locality unknown.

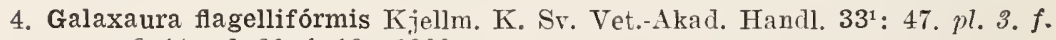
2-11; pl. 20.f. 16.1900.

Probably the tetrasporic phase of G. squalida.

On exposed rocks at low-water mark or in shallow water, New Providence, Berry Islands, Great Bahama, North Cat Cay, Caicos Islauds, and Great Ragged Islands :Bermuda; Florida; Cuba; Porto Rico; and American Virgin Islands. Type from Key West, Florida.

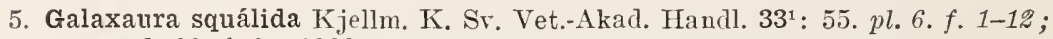
pl. 20. f. 9. 1900.

From low-water mark on exposed rocks down to at least $20 \mathrm{~m}$., New Providence, Rose Island. Great Bahama, Watling's Island, Mar'iguana, Caicos Islands, Castle Island, and Great Ragged Island:-Bermuda: Cuba: Jamaica: Porto Rico; American Virgin Islands; and Panama (Colon). Type from St. Croix.

6. Galaxaura rugòsa (Ell. \& Sol.) Lamour. Hist. Polyp. 263. 1816.

Corallina rugosa Ell. \& Sol. Nat. Hist. Zooph. 115. pl. 22. f. 3. 1786.

On rocks near low-water mark, Great Bahama:-Cuba; Jamaica; Porto Rico; American Virgin Islands; and Barbados. Type from Jamaica. 
7. Galaxaura oblongàta (Ell. \& Sol.) Lamour. Hist. Polyp. 262. 1816.

Corallina oblongata Ell. \& Sol. Nat. Hist. Zooph. 114. pl. 2. f. 1. 1786.

Dichotomaria fragilis Lamarek, Hist. Nat. Anim. sans Vert. 2: 1.4. 1816.

Galaxaura fragilis Decaisne, Ann. Sei. Nat. Bot. II. 18: 116. 1542.

From low-water mark down to 50 meters, South Bimini and Caicos Islands:Cuba; Jamaica; Porto Rico: American Virgin Islands; Barbados; and I’anama (Colon). Type from "West Indian Islands."

S. Galaxaura obtusàta (Ell. \& Sol.) Lamour. Hist. Polyp. 262. 1816.

Corallina obtusata E1l. \& Sol. Nat. Hist. Zooph. 113. pl. 22. f. 2. 1786.

Galaxaura Decaisnei J. Ag. Sp. Alg. $3^{1}$ : 526. 1876.

Galaxaura moniliformis Kjellm. K. Sv. Vet.-Akad. Handl. $3^{1}$ : S3. pl. .1\%. f. $15-30 ; \mathrm{pl} .20$. f. 54.1900.

MostIs in $7-1 \mathrm{~S}$ meters of water, type attributed to the Bahamas:-Bermuda ; Florida; Cuba; Jamaica; Porto Rico; Barbados; and Brazil.

9. Galaxaura marginàta (Ell. \& Sol.) Lamour. Hist. Polyp. 264. 1816.

Corallina marginata Ell. \& 'Sol. Nat. Hist. Zooph. 115. pl. 22. f. 6. 1786.

$Z$ anardinia marginata J. Ag. Sp. Alg. $3^{1}$ : 534. 1876.

Brachycladia marginata Schmitz, Flora 47: 438. 1889.

Galaxaura occidentalis Börg. Dansk Bot. Ark. 3': 109. f. 118-123. 1916.

Low-rittoral under shelving rocks or in shallow water, Berry Islands and Great Bahama :-Bermuda; Florida; Cuba : Jamaica; Porto Rico; American Virgin Islands ; Barbados; and Panama (Colon). Type from the Bahamas.

\section{Family 4. GELIDIÀCEAE.}

1. WRANGÈLIA Ag. Sp. Alg. 2: 136. 1828.

Principal filaments corticater.

Filaments uncorticated or with loose irregular rhizoidal cortications at nodes only.

Plants $1-3 \mathrm{~cm}$. high, purple-red; the conic-acute terminal cells of the ultimate ramuli mostly solitary.

Plants 4-10 $\mathrm{cm}$. long or high. usualiy rose-pink; the conieacuminate or acicular terminal cells of the ultimate ramuli mostly geminate.

1.

2. W. Argus.

ร. W. bicuspidata.

1. Wrangelia penicillàta (Ag.) Ag. Sp. Alg. 2: 138. 1828.

Griffitsia penicillata Ag. Syst. Alg. 143. 1824.

Variable in size, color', and habit of branching; often blackening with age or on drying. On rocks and on other algae from between the tide-lines in sprayed or surfbeaten locations down to a depth of 30 meters (fide Börgesen), New Providence, Great Bahama, North Cat Cay, Rerry Islands, Exuma Chain, Watling's Island, Mariguana, and Caicos Islands:-op wide distribution in the West lndies and in the warmer seas. Type from Italy.

2. Wrangelia Árgus (Mont.) Mont. Syll. 444. 1856.

Griffithsia Argus Mont. in Webb. \& Berth. Phyt. Canar. Pl. Cell. 176. pl. 8. f. 4. 1840.

Wrangelia plebcja J. Ag. Sp. Alg. 2: 707. 1852.

Forming low compact cushions on rocks and algae near tlie low-water mark, freat Bahama. South Biminl, and the Calcos Islands:-Mexico; Florlda: I'orto IRlco; American Virgin Islands; Barbados; and Canary Islands. Type from the Canary Islands.

3. Wrangelia bicuspidàta Börg. Dansk Bot. Ark. 3': 118. f. 127-130. 1916.

on roots of Rhizophora and on various algae and Golgoniaceae, from low-mater mark down to $30-40$ meters (file Börgesen), often abundant, Rose Island, Berry Islands, Great Pahama. Exuma Chaln, Watling's Island, Atwood Cay, Calcos Islands, and Great Ragged Island:-Amerlean Virgin Islands. Type from American Virgin Islands. 


\section{GRALLATòria M. A. Howe, gen. nov.}

Thallus filiform, monosiphonous, the primary filaments dorso-ventrally organized, repent, uncorticated, the ramuli ("short branches"') lateral and dorsal in origin, in threes or falsely fives and semi-verticillate, or in opposite pairs; opposite lateral ramuli commonly each forking in its basal cell, the two members simple or subsimple, few-celled, one of each pair ascending, the other deflexed and terminating in stelliform or avipedate haptera, giving the primary filaments the appearance of walking on stilts; dorsal ramuli comparatively stout, erect, repeatedly ramified, the branching somewhat secundly subdichotomous or occasionally subtrichotomous. Chromatophore in the younger cells an irregular subspiral band, in the older apparently consisting of numerous minute, more or less confluent granules. Sporangia on ramelli of the dorsal ramuli, usually tetrahedrally divided (tripartite). Other parts unknown.

\section{Grallatoria réptans M. A. Howe, sp. nov.}

Repent primary filaments simple or sparingly dichotomous, sinuous, 38-66 $\mu$ in diameter, their cells 1.5-2 times as long as broad, often bulging slightly above the septum, their Talls $5-13 \mu$ thick; opposite lateral ramuli from nearly every segment of the primary filament, the ascending prong simple, $200-400 \mu$ (4-8 cells) long, tapering, about $20 \mu$ in diameter near base, about $S \mu$ at apex, the deflexed stilt-like prong simple or once furcate, mostly $150-450 \mu$ (4-6 cells) long, slightly tapering, $20-26 \mu$ in diameter; dorsal erect ramuli $1-4 \mathrm{~mm}$. high, springing usually from every second segment of the primary filament, their main axes $34-16 \mu$ in diameter near base, the basal cell 1.5-2 times as long as broad, the succeeding cells mostly 3-6 times as long as broad, the penicillate, or dimidiosubfastigiate terminal divisions subsecund along the inner (anterior) faces of the divisions; tetrasporangia obovoid or pyriform, solitary, or in twos or rarely threes, 52-64 $\times 40-50 \mu$ (including wall, which is $6-8 \mu$ thick), tripartite or sometimes irregularly divided, mostly on one-celled pedicels; ovoid, globose or pyriform densely granular eysts $60-150 \mu$ in diameter occasional, especially near the distal ends of the deflexed gralliform filaments; color of plants rinaceous-purple to dark vinaceous-brown (near the color of Wrangelia Argus).

Forming a soft purple or reddish-brown lubricous velutinous coating in crevices of surf-beaten rocks near the low-water mark, covering small shells, crustaceous or prostrate algae, ete. In size and habit, the plant bears some superficial resemblance to species of Aerochaetium or to Rhodochorton Rothii, but its affinities are apparently with Wrangelia, from which, however, it amply differs in the characters indicated.

Great Ragged Island (Howe 578\%-type-and 5766).

\section{GELIDIUM Lamour. Essai, 40. 1813.}

1. Gelidium rígidum (Vahl) Grev. Alg. Brit. lvii. 1830.

Fucus rigidus Vahl, Nat. Selsk. Skr. 5²: 46. 1802.

Ahnfeltia (?) pinnatula Harv. Ner. Bor.-Am. 2: 169. 1853.

Echinocaulon rigidum Kütz. Tab. Phye. 18: 14. pl. 40. f. a-d. 1868.

Gelidiopsis rigida Web.-v. Bosse, Ree. Trav. Bot. Néer. 1: 104. 1904.

Not uncommon in tide-pools and in shallow water, North Cat Cay, South Cat Cay, Watling's Island, Mariguana, Caicos Islands, Great Ragged Island, and Salt Cay Bank:-Dermuda; Florida; and the West Indies in general. Type from St. Croix. 


\section{Family 5. GIGARTINÀCEAE.}

1. KALLYMĖNIA J. Ag. Alg. Ned. et Adriat. 98. 1842.

1. Kallymenia Limmínghii Mont. Ann. Sci. Nat. Bot. IV. 14: 173. 1860. [As Callymenia Limminghii.]

Plants suborbicular or reniform, 5-8 mm. broad, dark red, short-stipitate, sterile. Possibly a young or dwarf condition of $K$. reniformis (Turn.) J. Ag., but probably distinct.

Low-littoral, on a rock shelf in a carern, Malcolm Road, Caicos Islands :-Guadeloupe. Trpe from Guadeloupe.

\section{Family 6. RHODOPHYLLIDĀCEAE.}

1. CATENÉLLA Grev. Alg. Brit. Ixiii. 1830.

1. Catenella Opuintia (Good. \& Woodw.) Grev. loc. cit.

Fucus Opuntia Good. \& Woodw. Trans. Linn. Soc. 3: 219. 1797.

Catenella pinnata Harv. Ner. Bor.-Am. 2: 201. pl. 29B. 1853.

Catenella Opuntia pinnata J. Ag. Sp. Alg. $3^{1}$ : 58s. 1876.

On roots and truuls of Rhizophoru, etc., littoral, Berry Islands, Great Bahama, Bimini, Conception Island, Watling's Island, and Great Ragged Island:-Bermuda ; Florida; Jamaica; and the West Indies in genelal. Type from Wales.

\section{AGARDHIÉLLA Schmitz, Flora 72: 441. 1889.}

1. Agardhiella ténera (J. Ag.) Schmitz, loc. cit.

Gigartina tenera J. Ag. Linnaea 15: 18. 1841.

Sphaerococcus tener Kütz. Sp. Alg. 777. 1849.

Rhabdonia tenera J. Ag. Sp. Alg. 2: 354. 1852.

Solieria chordalis Harv. Ner. Bor.-Am. 2: 121. pl. 23.A. 1853. Not J. Ag. 1812.

Rhabdonia Baileyi Harr.; Kütz. Tab. Phyc. 16: 26. pl. 74. f. c, d. 1866. Sphaerococcus tenuis Kütz. Tab. Phyc. 18: 27. $\ell^{2}$ 75. f. d, e. 1865. [According to type in herb. Kütz.]

In shallow water. The type of Sphacrococcus tenuis Kiitz. is said to have come from "archipelago Bahamensi." The species is otherwise unknown from the Bahamas and is apparently uncommon there, at least in winter and spring when most of the collections of algae have been made, though it doubtless occur's:-Massachusetts to Florida and the Test Indies: California; Peru. Type locality indefinite (southern shores of North America and the West Indian islands).

3. MERISTOTHÈCA J. Ag. Bidr. Act. Univ. Lund. $8^{6}: 36.1872$.

1. Meristotheca Duchassaingii J. Ag. loc. cit. 37 .

On rocks, near low-water mark, Gun Cay:-Bermuda and North Carolina to Barbados. Type from Guadeloupe.

\section{EUCheùMa J. Ag. Of̈̈. K. Vet.-Akad. Förh. 4: 16. 1847.}

1. Eucheuma isifórme (Ag.) J. Ag. loc. cit.

Sphaerococcus isiformis Ag. Sp. Alg. 1: 271. 1822.

Gigartina isiformis Kütz. Tab. Phye. 18: 3. pl. \%. f. c, d. 1868.

Near low-water mark, especlally under shelving rocks and among Rhizophora roots, Exuma Chain :- Bermuda; Florlda; and the West Indies in general. Type from the West Indies. 
5. WURDEMÁNNIA Harv. Ner. Bor.-Am. 2: 245. 1853.

1. Wurdemannia setàcea Harr. loc. cit. 246.

On rocks among other algae and on sea-rods, sea-fans, etc., from low-water mark down to at least 20 meters, common. Joulter's Cay, Berry Islands, Great Bahama. South Cat Cas, Exuma Chain, Atwood Cay, and Caicos Islands:-Bermuda; Florlda; and Cuba. Type from Key Trest, Florida.

\section{Family 7. SPHAEROCOCCÀCEAE.}

1. GRACILÀriA Grev. p. p. Alg. Brit. liv, 121. 1830.

Ceramiantemum Donati, Auszug Natur-Geschichte Aririat. Neers 26. 1753.

Ceramion Adans. Fam. Pl. 2: 13. 1763.

? Plocaria Nees, Hor. Phys. Berol. 42. 1820.

Thallus plane or distinctly compressed, di-polychotomous or more or less pinnate.

Membranaceous when dry: maiu axes or segments mostly $0.3-1 \mathrm{~mm}$. thick.

Thallus dichotomo-palmatifid, marginal branches or proliferations usually wanting or few.

Thallus with main dirisions subdichotomous, these pinnately decompound or repeatedly dichotomo-pinnatisect.

Hard and corneous when drs, cartilaginous when living. mostly 2-7 mm. thick. prostrate or repent, often concrescent or anastomosing, branches irlegular, mostly distichous and deflexed. often short and rerrucaeform, sometimes subterete, digitiform or hapteroid.

Thallus terete or nearly so, corneous when dry.

Thallus rather closely and somewhat divaricately subdichotomous, the ultimate divisions short, often incurved, cervicorn.

Thallus rather distantly and somewhat fastigiately subdichotomous, the nitimate divisions not cervicoln.

1. G. lacinulata.

2. G. cerricornis.

3. G. crassissima.

4. G. damaecornis.

5. G. cornea.

1. Gracilaria lacinulàta (Vahl) MI. A. Howe, comb. nor.

Fucus lacinulatus Vahl, Nat. Selsk. Skr. $5^{2}$ : 39. 1802.

Fucus multipartitus Clem. Ensayo 311. 1807.

Chondrus agathoicus Lamour. Essai 39. pl. 9. f. 3, 4, 5. 1813.

Fucus aeruginosus Turn. Hist. Fue. 3: 29. pl. 147. 1811.

Chondrus aeruginosus Lamour. Essai 40. 1813.

Sphaerococcus polycarpus Grev. Scot. Crypt. Fl. 6: pl. 352. 1828.

Gracilaria multipartita Harv. Phyc. Brit. pl. 15. 1846.

Sphaerococcus lacinulatus Kütz. Tab. Phyc. 18: 30. pl. 8\%. f. a-d. 1868.

In shallow water. Berry IsIands:-Massachusetts to Rermuda; Florida; Mexico; and throughout the Test Indies; Europe. Type from St. Croix.

2 Gracilaria cervicórnis (Turn.) J. Ag. Sp. Alg. 2: 604. 1852.

Fucus cervicornis Turn. Hist. Fuc. 2: 132. pl. 121. 1809.

Sphaerococcus domingensis (Sond.) Kütz. Tab. Phyc, 19: 8. pl. 22. f. $a, b$. 1869.

In shallow water, New Providence and Caicos Islands :-Florida to Brazil. Type from Jamaica.

3. Gracilaria crassíssima Crouan; J. Ag. Sp. Alg. 34: 78. 1901.

? Gracilaria horizontalis Collins \& Hervey, Proc. Am. Acad. 53: 111. 1918.

Forming prostrate, crust-like, intertangled masses in shallow water, Berry Islands, North Cat Cay, South Cat Car, and Mariguana:-Dermuda (?); Porto Rico; and Guadeloupe. Type from Guadeloupe. 
4. Gracilaria damaecómis J. Ag. Sp. Alg. 2: 597. 1852.

In tide-pools and in shallow water, North Cat Cas and Calcos Islands :-Bermuda; Florida; and the West Indies generally. Type probably from St. Croix.

5. Gracilaria córnea J. Ag. Sp. Alg. 2: 59S. 1852. buco (?)

In shallow water, Caicos Islands:-Florida: Porto Rico. Type from I'ernam-

\section{HYPNÈA Lamour. Essai, 43. 1813.}

Hгрмophycus Kütz. Linnaea 17: 102.1843.

1. Hypnea muscifórmis (Wulf.) Lamour. loc. cit.

Fucus musciformis Wulf. in Jacq. Collect. 3: 154. pl. 14. f. 3. 1759.

Hypnophycus musciformis Kütz. loc. cit.

Common in shallow water, extremely variable, Berry Islands, Great Bahama, Bimini, Gun Cay, Exuma Chain, Watling's Island, Atwond Cay, Nariguana. Caicos Islands, and Great Ragged Island:-Massachusetts to Bermuda and Florida and throughout the Test Indies; widely distributed in temperate and tropical seas. Type from Trieste.

\section{Family S. RHODYMENIȦCEAE.}

1. CORDYLECLAdAIA J. Ag. Sp. Alg. 2: 702. 1852.

1. Cordylecladia irregulàris Harr. Ner. Bor.-Am. 2: 156. 1853.

Chylocladia rigens J. Ag. p. p. Sp. Alg. 2: 362. 1852. Not Sphaerococcus rigens Ag. Sp. Alg. 1: 332. 1822.

Cordylecladia rigens Collins \& Hervey p. p.; C., H., \& S., Phyc. Bor.-Am. 2186. 1917 .

In tide-pools and on rocks in shallow water, more or less steel-blue and iridescent when living, Berry Islands. Bimini, Elenthera, Exuma Chain. Watling's Island, Atwood Cay, Mariguana, and Great Ragged Island:-Bermuda; Florida; Cuba ; Jamaica : and Porto Rico. Type from Key West, Flurida.

\section{CHRYSYMÈNIA J. Ag. Alg. Mert. et Adriat. 105. 1842.}

1. Chrysymenia uvària (L.) T. Ag. loc. cit. 106.

Fucus uvarius ["ovarius"'] L. p. p., Syst. Nat. 2: 714. 1767 [er. 12].

Fucus botryoides Wulf. in Jaeq. Collect. 3: 146. pl. 13. $f .1 .1759$.

In deep water or under shelving rocks in shallow water, South Caicos:-Bermuda: North Cajolina: Florida: Porto Rico; American Virgin Islands; Barbados; Brazil; Canary Islands; Mediterianean and Adriatic seas.

3. CHÁmpIA Desr. Jour. de Bot. Desr. 1: 245. 1508.

Mertensia Thunb.; Roth, Nenes Jour. Bot. Schrar. 2: 11. 1806. Not Mertensia Roth, Cat. Bot. 1: 34. 1797.

Mature segments mostly $0.3-0.9 \mathrm{~mm}$. broad.

Mature segments mostiy $1-2 \mathrm{~mm}$. broad.

C. pariula.

C. salicornioides.

1. Champia párvula (Ag.) Harr. Ner. Bor.-Am. 2: 76.1853.

Chondria parvula Ag. Syst. 207. 1824.

On other algae, Thalussin, etc., from low-water mark down to 20 fatboms (fide Börgesen). Great Bahama, Exuma Chaln, Great Ragged Island, and Caicos Islands: -Massaclinsetts to Bermuda; Jorida; and the West Indles generally; Europe. Type from Cadiz, spaln. 
2. Champia salicornioìdes Harr. Ner. Bor.-Am. 2: 76, pl. 19B. 1553.

On other algae, stones, etc., from low-water mark down to 15 fathoms (fide Börgesen), freat liahama and Caicos lslands:-Florida; American Virgin Islands, etc. Type fiom Key West, Florida.

\section{Family 9. DELESSERIÀCEAE.}

1. HYPOGLóssum Kütz. Linnaea 17: 106. 1843.

1. Hypoglossum tenuifòlium (Harv.) J. Ag. Sp. Alg. $3^{3}:$ 186. 1898.

Delesseria tenuifolia Harr. Ner. Bor.-Am. 2: 97. pl. 22B. 1853.

Tnder shelving rocks near low-water mark and in deep water. North Cat Cay, Exuma Chain, Caicos Islands, and Great Ragged Island:-Florida and American Virgin Islands. Type from Key West, Florida.

2. CALoglóssa (Harv.) J. Ag. Sp. Alg. $3^{1}$ : 498. 1876.

Delesseria, sect. Caloglossa Harv. Ner. Bor.-Am. 2: 99.1853.

1. Caloglossa Leprieùrii (Mont.) J. Ag. loc. cit. 499.

Delesseria Leprieurii Mont. Ann. Sei. Nat. Bot. II. 13: 196. pl. 5. f. 1. 1810. Hypoglossum Leprieurii Kütz. Sp. Alg. S75. 1849.

On roots of Rhizophora, littoral, probably common, Bimini and Berry Islands :Test Point, N. Y., and Connecticut to northern South America. Type from French Guiana.

3. TAENIÒMA J. Ag. Sp. Alg. 2: 1256. 1863.

1. Taenioma perpusillum (J. Ag.) J. Ag. loc. cit. 1257.

Polysiphonia perpusilla J. Ag. Öfr. K. Vet.Akad. Förh. 4: 16. 1S47.

On or with other algre, in shallow water. West Caicos :-Bermuda; Porto Rico; and Mexico. Type from St. Augustin on the Pacific Coast of Mexico.

\section{Family 10. BONNEMAISONIÀCEAE.}

1. ASPARAGóPSIS Mont. in Trebb \& Berth. Phytog. Canar. 4: xir, xr. 1841.

Lictoria J. Ag. Linnaea 15: 23. 1841.

1. Asparagopsis taxifórmis (Del.) Collins \& Hervey, Proc. Am. Acad. 53: 117. 1917.

Fueus taxiformis Del. Deser. Egypte. Hist. Nat. 2: 295. pl. 5\% f. 2. 1812. Chondria taxiformis Ag. Sp. Alg. 1: 368. 1822.

Dasya Delilei Mont. in Webb \& Berth. Phytog. Canar. 4: 166. pl. 8. f. 6. 1841.

Asparagopsis Delilei Mont. loc. eit. xir.

Lietoria taxiformis J. Ag. Linnaea 15: 23. 1841.

In shallow water on reefs down to at least 12 fathoms (fide Börgesen), Green TurtIe Cas :-Bermuda; Jamaica; American Virgin Islands; Barbados; Canary Islands; and Mediterranean Sea. Type from near Alexandria, Egypt. 


\section{Family 11. RHODOMELÀCEAE.}

1. LAURÉNCIA Lamour. Essai 42. 1813.

Osmunded Stackh. Mém. Soe. Imp. Nat. Moscou 2: 56, 79. 1809.

Not Osmunda L. Sp. Pl, 1063, 1753.

Branching chiefly monoporial.

Walls of medullary cells of main axes with numerous refringent often lenticular or l'eniform thickenillgs, ${ }^{*}$ visible through the cortex; tronds or peripheral branches mostly nillowly virgate, with numerous small ultimate ramuli $0.2-0.45 \mathrm{~mm}$, in maximum $w i d t h$.

Walls of medullary cells of main axes without thickenings; uitimate ramuli mostly more than $1.45 \mathrm{~mm}$. broad.

Surfice celis of main axes mostly $40-130 \mu$ long in surface riew.

Surface smooth or nearly so.

Plants rather soft and flaccid, usually pink, sellowish pink, or green with pink tips; ultimate ramuli obovoid to subclavate-crlindric.

Plants elect, paniculate-decompound, with welldefined leading axes.

Plants decumbent or intertangled. without welldefined leading axes, firmer than No. 2 and with more crlindric ultimate ramuli.

Plants rather rigid, purple or greenish purple; ultimate ramuli mostly peg-shaped or rerrucaeform.

Surface cells, in apical parts at least, with mammilliform, conic-mammillate or acnleate papiliae.

Surface cells of main axes mostiy $20-40 \mu$ long in surface view; plants rigid, green or dark greenish purple, corneous when diry.

Branching chiefly dichotomous, subdichotomons, or corymbose.

Main segments of thallus $0.75-1.2 \mathrm{~mm}$. in diameter; plants mostly $1-12 \mathrm{~cm}$. high; branches free.

Main segments of thallus $0.22-0.45 \mathrm{~mm}$. in diameter : plants mostly 1-2 cm. high; branches more or less concrescent or coherent.

1. L. mierocladia.

2. L, obtusa.

3. L. intricata,

4. L. Poitei.

5. L. gemmifera.

6. L. papillosa.

7. L. Corallopsis.

S. L. nana.

1. Laurencia microclàdia Kütz. Tab. Phyc. 15: 22. pl. 60. f. b, c. 186.5.

Laurencia glomerata Subr; J. Ag. Sp. Alg. 2: 753. 1852. Not L. glomerata Kütz. Sp. Alg. S57. 1549.

Laurencia obtusa gelatinosa Collins \& Hervey, Proc. Am. Aead. 53: 119. 1917. Not L. obtusa gelatinosa J. Ag.

Distinguished from all conditions of $L$. obtusa by its virgate habit, its small ultimate ramuli, and its numerous refringent thickenings of the walls of the medullary cells.

On rocks and on other algae, low littoral down to $1 \mathrm{~m}$. or more, New Providence, Berry Islands, Great Bilhama, Watling's lsland, Mariguana, and Great lagged Island: - Bermuda; and northern South America. 'Type from the West Indies.

2. Laurencia obtùsa (Huds.) Lamour. Essai 42. 1 s13.

Fucus obtusus Huds, Fl. Angl. 586. 1778.

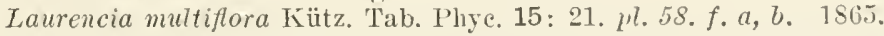

Vers common on rocks and on other algae, at low-water mark and in shallow water, New Plovidence, Rose Island, Berry Islands, Great Bahama, Nolth Cat Caly, Exuma Chain, Cat Island. Watling's Island, Atwoud ('ay, Mariguana, Cilleos Islands, Great Iagged Island, and Orange Cay:- Bermuda; riolida; and the West lndles generally: widely distributed in the warmer seas. Type from soutbern England. Specimens from Nassau have been reporter under name of Laurencia paniculata by F. S. Collins, $\mathrm{Icm}$. Torrey Club $12: 14$. In02.

* The thickenings often lose their refringent character in fluid-preserved material. 
3. Laurencia intricàta Lamour. Essai 43. pl. 3. f. 8, 9. 1813. Not L. intricata Kütz. Tab. Phyc. 15: 22. pl. 61. f. $a, b, c .1865$.

Laurencia Chauvini Bory, p. p. max. Dict. Class. Hist. Nat. 9: 239. 1826.

Laurencia implicata J. Ag. Sp. Alg. 2: 745. 1552.

Perbaps only a rariety of $L$. obtusa.

In shallow water, Rose Island, Great lahama, Bimini, Abaco, Exuma Chain, Cat Island, Mariguann, and Great Ragged Island :- Bermuda ; Florida ; Cuba ; and American Virgin Islands. Type from intilles.

4. Laurencia Poitei (Lamour.) M. A. Horre; Collins \& Hervey, Proc. Am. Acad. 53: 118. 1917.

Fucus Poitei Lamour. Diss. 63. pl. 31. f. 2, 3. 1805.

Laurencia tuberculosa J. Ag. Sp. Alg. 2: 760. 1852.

Laurencia mexicana Kütz. Tab. Phye. 15: 25. pl. 70. f. c, d. 1565.

On rocks, etc., in shallow water, New Providence, Berry Islands, Great Bahama, Abaco, Cat Island, Watling's Island, Caicos Islands, and Great Ragged Island:- Jermuda; North Carolina; Florida; the West Indies generally ; Yera Cruz; and northern south America. 'Type from Santo Domingo.

\section{Laurencia gemmífera Harv. Ner. Bor.-Am. 2: 73. pl. 18 B. 1853.}

Laurencia Chauvini Bors, p. p. min. Dict. Class. Hist. Nat. 9: 239.1826.

Sometimes simulating $L$. Poitei and $L$. papillosa, but apparently quite distinct, differing from both in the papillate epidermal cells (at least in apical parts) and differing from L. papillosa, and, in a less degree, from $L$. Poitei in the larger epidermal cells.

In shallow water, Berry Islands, Great Bahama, Bimini, Exuma Chain, Cat Island, Watling's Island, Nariguana, and Great Ragged Island:- Bermuda; Florida; Cuba; American Virgin Islands. Type from Key West, FIorida.

6. Laurencia papillòsa (Forsk.) Grev. Alg. Brit. lii. 1830.

Fucus papillosus F'orsk. FI. Aegypt.-Arab. 190. 1775.

Chondria papillosa Ag. Sp. Alg. 1: 344. 1822.

on rocks between the tide-lines and in shallow water, New Providence, Berry Islands, Great Bahama, Gun Cay, Exuma Chain, Watling's Island, Mariguana, Caicos Islands, Great Ragged Island, and Orange Cay :-Bermuda ; Florida; Cuba ; Santo Domingo; Porto Rico; American Virgin Islands; Barbados; and northern South America; widely distributed in the walmer seas. Type from the Red Sea.

7. Laurencia Corallópsis (Mont.) M. A. Howe, in Britton, Fl. Bermuda 519. 1918.

Sphaerococcus Corallopsis Mont. in Sagra, Hist. Cuba, Bot. Pl. Cell. 49. 1842 ; in Sagra, Ic. Pl. Fl. Cuba, pl. 3. f. 1. 1863.

Laurencia cervicornis Harv. Ner. Bor.-Am. 2: 73. pl. 18C. 1853.

On rocks in shallow water; reduced abortive forms of what is apparently this species occur also between the tide-lines, New Providence, Berry Islands, Great Bahama, and Iariguana:-Bermuda; Florida; Cuba; American Virgin Islands; and Barbados. 'Tspe form near Havana, Cuba.

8. Laurencia nàna M. A. Howe, sp. nov.

Densely cespitose and intricate, rose-red to garnet-brown, mostly 1 to 2 $\mathrm{cm}$. high, fragile, often innovating from broken ends, dichotomous or subdichotomous, the branches more or less conerescent or coherent; nuain segments $0.15-$ $0.45 \mathrm{~mm}$. in diameter; ultimate branches cylindric or subeylindric, mostly 0.1$0.35 \mathrm{~mm}$. broad at truncate apex; surface of cortex smooth or lightly crenulatemammillate, showing numerous or occasional rhizoidal haptera, epidermal cells orbicular-hexagonal and mostly $25-45 \mu$ broad in surface view, firm-walled; tetrasporic branches similar to the sterile or slightly enlarged.

On corals, corallines, and sea-fans, near Iow-water mark, Mariguana (Howe 5393 -type), Shroud's Cay (Exuma Chain), and Great liagged Island. 
2. CHÓNDRIA Ag. p. p. Syn. Scand. xriii. 1817.

Carpocaulon Kütz. Phye. Gen, 436. 1543.

Choxdriopsis J. Ag. Sp. Alg. 2: 794. 1563.

Apices of ultimate ramuli acute, with growing points readily visible.

I'lants erect, mostly $5-40 \mathrm{~cm}$. high, without rhizoids except at base.

I'rimary branches more slender than the stout well-defined

main axes; plants large, mostly $15-40 \mathrm{~cm}$. high, yellow-

ish brown when dried.

I'rimary branches rather similar to the often poorly defined main axes.

Plants blackish purple on drying, rather coarse, branching irregular.

Plants rellowish red or dusky red on drying, more delicate, branching sparsely virgate.

Plants low-cespitose, $2-3 \mathrm{~cm}$. high or subrepent, with numerous multicellular rhizoidal haptera.

Apices of ultimate ramuli obtuse or truncate, with growing point immersed and hidden in an apical pit.

The five pericentral siphons with conspicuous saucer-shaped, dome-shaped, or cup-shaped thickenings of their anterior end-walls, forming regular transwerse crenate lines bounding the eren-ended bundles of siphons and visible through the cortex.

Plants cespitose, the cushions $1-3 \mathrm{~cm}$. high: matn axes mostly $0.22-0.35 \mathrm{~mm}$. in diameter; apical tufts of filaments inconspicuous.

Plants solitary or merely gregarious, mostly $3-8 \mathrm{~cm}$. high ; main axes $0.4-0.75 \mathrm{~mm}$. in diameter; apical tufts of trichoblasts conspicuous, often $0.75 \mathrm{~mm}$. nr more in length. becoming yellowish brown or fuscous on drying.

1. C. littoralis.

2. C.atropurpurea.

3. C. tenuissima.

4. C. polyrhiza.

5. C. curvilincata.

6. C. Collinsiana.

Pericentral siphons without conspicuous thickenings of the anterior end-walis (or such thickenings of only irregular and occasional occurrence).

Plants pink, purple, or 5ellowish red: main axes mostly $0.5-1.5 \mathrm{~mm}$. in diameter: ultimate ramuli mostly $0.35-$ $0.75 \mathrm{~mm}$. in greatest diameter.

Plants usually yellowish brown; main axes mostly 0.22$0.32 \mathrm{~mm}$. in diameter; ultimate ramuli mostly $0.1-0.2$ $\mathrm{mm}$, in greatest diameter.

7. C. dasyphylla.

S. C. leptacremon.

1. Chondria littoràlis Harv. Ner. Bor.-Am. 2: 23. 1553.

Chondriopsis littoralis J. Ag. Sp. Alg. 2: 795. 1563.

Carpocaulon littorale Kuntze, Rev. Gen. Pl. 3²: 399. 1598.

Rather common on moderately exposed shores, near the low-water mark, New Providence, Berry Islands, Great Bahama, Exuma Chain, Watling's Island, Mariguana, and Caicos Islands:- Florida and the West Indies generally. Type from Key ivest, Florida.

2. Chondria atropurpùrea Harv. Ner. Bor.-Am. 2: 22. pl. 18E. 1553.

Chondriopsis atropurpurea J. Ag. Sp. Alg. 2: 801. 1863.

Carpocaulon atropurpureum Kuntze, loc. eit.

In shallow water, especially in creeks and lagoons, commonly straw-colored when living, Great Bahama, Great Fxuma, Watling's Island, and Great liagged Island :Bermuda; South Carolina; Florida; and the West Indies generally. Type from Charleston, South Carolina.

3. ? Chondria tenuíssmia (Good. \& Woodw.) Ag. Syn. Alg. Scand. xviii. 1817.

Fucus tenuissimus Goou. \& Woodw. Trans. Linn. Soc. 3: 215. pl. 19. 1797.

Carpocaulon tcnuissimum Kuntze, loc. cit.

Laurencia Bailcyana Nont. Ann. Sci. Nat. Bot. III. 11: 63. 1849.

Two specimens that we refer provisionally to $C$. tonuissima differ considerably from each other and from the Fuglish type of the species, in habit, texture, form and size of the cortical cells, etc.

In shallow water, Bimini and Great Bahama:-Massachusetts to Florida and Cuba; Europe. Type from southern England. 
4. Chondria polyrhìza Collins \& Herrey, Proc. Am. Acad. 53: 121. pl. 2. f. 12. 1917.

In shallow water down to 18 meters (fide Collins), Atwood Cay (with $C$. curvilincata) :-Bermuda and American V'irgin Islands. Type from Lermuda.

5. Chondria curvilineàta Collins \& Hervey, Proc. Am. Acad. 53: 120. pl. 2. $f$. 10, 11.1917.

On corals and among other algae, near low-water mark, more or less iridescent when liring, Atwood Cay, Mariguana, and Great Ragged Island:-Bermuda. Type from Bermuda.

\section{Chondria Collinsiàna M. A. Howe, sp. nov.}

Fronds erect, solitary or gregarious, mostly 3-8 em. high, texture rather soft, color (dried) stramineous to yellowish rose; branching rather sparsely virgate or paniculate-virgate, with well-defined main axes mostly $0.4-0.75 \mathrm{~mm}$. in diameter; pericentral siphons in all parts with conspicuous saucer-shaped, dome-shaped, or cup-shaped thickenings of their anterior end-walls, forming erescentric or erenate lines in regular transverse series, visible through cortex, the longitudinal walls also occasionally showing somewhat similar or more lenticular thickenings; surface cells mostly $65-160 \mu \times 26-40 \mu$ in surface view, $2-5$ times as long as wide; ultinate ramuli fusiform-obovoid to cylindric-clavate or eylindric, mostly $0.75-4.5 \mathrm{~mm}$. long, and $0.28-0.45 \mathrm{~mm}$. in greatest diameter, patent or subdivaricate, straight or slightly recurved, solitary and rather widely spaced (0.5-2.5 $\mathrm{mm}$. apart), moderately attenuate or constricted at base, the apex obtuse or subtruncate, erowned with conspicuous tufts of trichoblasts ("leaves") often $0.75 \mathrm{~mm}$. or more in length and becoming yellowish brown or fuscous on drying; the growing point immersed and concealed in an apical pit (sect. Coelochondria); tetrasporangia confined to apical part of ramulus or sometimes oceupying the whole of it.

Chondria Collinsiana differs from $C$. curvilineata as indicated in abore key and also in its yellowish or rose rather than purple-red or brownish red color.

On Penicillus, Rhipocephalus, Halimeda, Thalassia, etc., in shallow water, MIariguana (Howe 5386-type), New Providence, Berry Islands, Watling's Island, and Great Bahama.

7. Chondria dasyphýlla (Woodw.) Ag. Syn, Alg. Scand. xviii. 1517.

Fucus dasyphyllus Woodw. Trans. Linn. Soc. 2: 239. pl. 23. f. 1. 1794.

Chondria sedifolia Harv. Ner. Bor.-Am. 2: 19. pl. 18G. 1853.

Chondriopsis dasyphylla J. Ag. Sp. Alg. 2: 809. 1863.

Carpocaulon dasyphyllum Kuntze, loc. eit.

In shallow water, New Providence, Berry Islands, and Great Bahama:-Massachusetts to Bermuda; Florida; and Barbados; southern Europe and the Mediterranean. 'Type from eastern England.

8. Chondria leptacrèmon (Melv.) De-Toni, Syll. Alg. 4: 848. 1903.

Chondriopsis leptacremon Melv. Jour. Bot. 26: 333. pl. 284. f. 2a, 2b. 1888.

In shallow water in Rhizophora associations, Exuma Chain and Watling's Island :-Florida. Type from Key West, Florida.

3. ACANTHÓPHORA Lamour. Essai 44. 1813.

Spines not occurring on the main axes; main branches narrowly rirgate.

Spines of occasional occurrence on the main axes; branching rery irregular.

1. A. spicifera.

2. A. muscoidcs. 
1. Acanthophora spicífera (Vahl) Börg. Bot. Tillsskr. 30: 201. f. 18, 19. 1910.

Fucus spiciferus Vahl, Nat. Selsk. Skr. $5^{2}: 44.1802$.

Fucus acanthophorus Lamour. Diss. 61. pl. 30; pl. 31. $f .1 .1805$.

Acanthophora Thierii Lamour. Essai 44. 1813.

Chondria acanthophora Ag. Spec. Alg. 1: 363. 1822.

Acanthophora Antillarum Mont. Kütz. Tab. Phye. 15: 27. pl. 75. f. d-g. 1865 .

In shallow water, especially in sheltered bays, New Frovidence, Rose Island, Bimini, Exuma Chain, Watling's Island, Mariguaua, and Great Ragged Island:Bermuda; Florida; to Barbados and Brazil. Type from St. Croix.

2. Acanthophora muscoides (L.) Bory, Voy. Coquille, Bot. Crypt. 156. 182S.

Fucus muscoides L. Sp. Pl. 1161. 1753.

Acanthophora militaris Lamour. Essai, 44. pl. 4. f. 4, 5. 1813.

Chondria muscoides Ag. Sp. Alg. 1: 361. 1522.

Acanthophora Delilei Harv. Ner. Bor.-Am. 2: 18. 1853. Not A. Delilei Lamour. Essai, 44. 1813.

In shallow water, Great Bahama:-Florida to Prazil and Ascension Island. Type from Ascension Island.

\section{DIGÈNEA Ag. Sp. Alg. 1: 3SS. 1822.}

1. Digenea simplex (Trulf.) Ag. loc. cit. 389.

Conferva simplex Wulf. Crypt. Aquat. 17. 1803.

Fucus Lycopodium Turn. Hist. Fuc. 4: 6. pl. 199. 1819.

Digenea Wulfeni Kütz. Phye. Gen. 433. 1843.

In tide-pools and in shallow water. New Providence, Great Bahama, Bimini, Exuma Chain, Mariguana, and Great Ragged Island:-Bermuda and Fiorida to South America; widely distributed in the warmer seas. Type from Trieste.

\section{POLYSIPHÒNIA Grer. Fl. Edinb. 30s. 1824.}

q Polyostei Donati, Auszug Natur-Ges. Adriat. Meers 22. 1753.

Hutchissia Ag. Syn. Alg. Seand. xxvi. 1817. Not Hutchissia R. Br. 1812. Vertebrata S. F. Gray, Nat. Arr. Brit. Pl. 1: 338. 1821.

Grammita Bonnem. Jour. Pliys. 94: 186. 1522. [Not seen.]

Grateloupelua Bory, Diet. Class. Hist. Nat. 3: 340. 1823; 7: 480. 152J.

Dicarpella Bory, loc. cit. 3: 340. 1823; 5: 464. 1824.

CARradoria Mart. Fl. Bras. Acot. 15. 1833.

Grammitella Crouan, Ann. Sci. Nat. Bot. III. 10: 372. 1848.

Pericentral cells four.

Uncorticated or with few and inconsplcuous cortical cells in older parts.

Trichoblasts " hairs," "leaves") apparently wanting ; plants blackish purple, usually not adhering well to paper on drying.

Trichoblasts manifest, few or numerous.

Branching obviously monopodial.

Lateral branchlets arising in the axils of trichoblasts.

Maln axes mostly 50-90 $u$ in diameter : plants soft and mucous, reddish purple, branches fastigiate.

Main axes mostly $100-300 \mu$ in diameter plants firmer, brownish purple; branches not fastigiate, ver. irregular, or the ultimate ramuli sometimes short and alternatedisticlıous or pseudo-disticlıous.

Lateral branchlets arising wlthout apparent references to the trichoblasts: segments often shorter than broad, onter cell walls in adult parts commonly $12-40 \mu$ thlek.

1. P. subtilissima.

2. P. havanensis.

3. P. Binneyi.

4. P. ferulacca. 
Main branching subdiclotomous, commonly fastigiate.

I'lants $0.5-2.5 \mathrm{~cm}$. high, growing chiefty on leaves of Cymodocer, Thalassia, etc.

Plants $4-12 \mathrm{~cm}$. high, Jellowish or straw-colored when living. vinaceous-tawny to chocolate-colored when dry, commonly bearing frequent short subspinescent patent ramuli, clothed with numerous trichoblasts.

Main axes or branches strongly corticated, the main branches virgately clothed with numerous much more slender taper-pointed or subspinescent ramuli.

Pericentral celis $8-10$, trichoblast few and inconspicuous.

Pericentral cells $12-24$, trichoblasts usually numerous and very conspicuous.

5. P. Gorgoniae.

6. P. hapalacantha.

7. P. ramentacea. 8. P. exilis.

9. P. opaca.

1. Polysiphonia subtilíssima Mont. Ann. Sci. Nat. Bot. Il. 13: 199. 1840.

Tnder shelving rocks, low-littoral, Exuma Chain, and Great Ragged Island:Massachusetts to northern South America. Type from Cayenne, French Guiana.

2. Polysiphonia havanénsis Mont. Ann. Sei. Nat. Bot. II. 8: 352. 1837.

From between the tide-lines to a depth of 5 meters, found especially on the roots of Rhizophora and in mangrove associations, New Providence, Rose Island, Great Bahama, Cat Island, Watling's Island. Mariguana. Caicos Islands, and Great Ragged Island:-Bermuda; Florida; and the West Indies generally. Type from Havana.

3. Polysiphonia Bínneyi Harr. Ner. Bor.-Am. 2: 37. 1853.

Polysiphonia havanensis Binneyi J. Ag. Sp. Alg. 2: 960. 1863.

In shallow water, possibly intergrading with $P$. havanensis, but usually very distinct, New Providence, Bel'ry Islands, Joulter's Cas, Great Bahama, Exuma Chain, Watling's Island. IIariguana, Caicos Islands, and Great Ragged Island:-Florida. Type from Key West, Florida.

4. Polysiphonia ferulàcea Suhr; J. Ag. Sp. Alg. 2: 980. 1863.

Polysiphonia breviarticulata Harr. Ner. Bor.-Am. 2: 36. pl.16B. 1853. Not Hutchinsia breviarticulata Ag. Syst. Alg. 153. 1824.

Tsually low-littoral on surf-beaten rocks, New Providence, Berry Islands, Joulter's Cay, Great Bahama, Gun Cay, Watling's Island, Atwood Cay, Mariguana, Caicos Islands, and Little Inagua:-Bermuda: Florida; Mexico; and the West Indies generally. Type locality unknown, probably west Indian.

5. Polysiphonia Gorgòniae Harr. Ner. Bor.-Am. 2: 39. 1853.

On Cymodocca, Thalassia, corals, sea-fans, and occasionally on the larger algae, in shallow water, New Providence. Berry Islands, Great Bahama, North Cat Cay, Tiatling's Island, Mariguana, and Great Ragged Island:-Florida. Type from Key Tiest, Florida.

\section{Polysiphonia hapalacántha Harr. Ner. Bor.-Am. 2: 39.1853.}

In shallow water, Great Bahama and Exuma Chain :-Florida. Type from Key Test, Florida.

7. Polysiphonia ramentàcea Harr. Ner. Bor.-Am. 2: 42. pl. 16A. 1853.

Related to $P$. foeniculacea (Drap.) J. Ag. and P. hirta J. Ag. of the Mediterranean Sea, but differing considerably in its rirgate habit due to the closely set ramuli of nearly uniform length, becoming gradually shorter at apex. On rocks and other algae from low-water mark down to a depth of at least two meters, New Providence, Berry Islands, Great Bahama, Exuma Chain, and Little Inagua:-Florida. Type from Key West, Florida.

8. Polysiphonia éxilis Harr. Ner. Bor.-Am. 2: 47. 1853.

Lophosiphonia? exilis De-Toni, Syll. Alg. 4: 1070. 1903.

Near low-water mark and on sea-fans in shallow water, New Providence, Rose Island, and Great Ragged Island:-Florida. Type from Key West, Florida. 
9. Polysiphonia opàca (Ag.) Moris \& De Not. Fl. Capr. 208. pl. 5 II. 1839.

Hutchinsia opaca Ag. Syst. Alg. 14S. 1824.

Low-Iittoral on surf-beaten rocks and in tide-pools, New Proridence. Berry Islands, Great Bahama, and Watling's Island:-Bermuda; Florida; and the Hediterranean and Adriatic seas. Type from the Adriatic Sea.

6. BRYOTHÁMNION Kütz. Linnaea 17: 105. 1943;

Phye. Gen. 433 . $18 \pm 3$.

Phiscophora Kütz. loc. cit.; Phyc. Gen. 434.

1. Bryothamnion triquètrum (S. G. Gmel.) M. A. Howe, Jour. N. Y. Bot. Garl. 16 : 222. 1915.

Fucus triqueter S. G. Gmel. Hist. Fuc. 122. pl. 8. f. 4. 1768.

Fucus trifarius Swartz, Prod. 148. 1788.

Fucus triangularis .J. F. Gmel. Syst. Nat. 13£3. 1791.

Plocamium triangulare Lamour. Essai, 50. 1813.

Thamnophora triangularis Ag. Sp. Alg. 1: 226.1822.

Alsidium triangulare J. Ag. Linnaea 15: 2S. $18+1$.

Physcophora triangularis Kütz. Linnaea 17: 105. 1843.

Bryothamnion triangulare Kütz, Sp. Alg. 842. 1849.

From low-water mark down to a depth of 30 meters or more, Bimini and Caicos Islands:- Florida to Brazil. Type locality unknown.

7. LOPHOCLÀdiA Sehmitz, Ber. Deuts. Bot. Ges. 11: 222. 1893.

1. Lophocladia trichóclados (Mert.) Schmitz, loc. cit.

Conferva trichocladia Mert. fide Ag. Syst. Alg. 137. 1824.

Ceramium Trichocladis Ag. loc. cit.

Griffitsia? trichoclados Ag. Sp. Alg. 2: 132. 1828.

Dasya trichoclados J. Ag. Linnaea 15: 32. $18+1$.

Dasya lophoclados Mont. Ann. Sci. Nat. Bot. II. 18: 254.1842.

Eupogonium? trichoclados Kütz. Sp. Alg. 799. 1849.

Polysiphonia trichoclada Kütz. loc. cit. 819.

Polysiphonia lophoclados Kütz. Ioc. cit. 834.

Lophothatia trichoclados J. Ag. Till Alg. Syst. 6: 64. 1890.

Apparently in deep water, usually found washed ashore, Great Bahama:-Permuda; Florida; Santo Domingo; American Virgin Islands; and Barbados. Tspe from the IVest Indies.

8. WRIGHTIÉlla Schnitz, Ber. Deuts. Bot. Ges. 11: 221. 1893.

Main branches persistent, beset with numerous 4-ranked subulate ramuli $1-4 \mathrm{~mm}$. long.

Main branches commonly deliquescent, bearing filiform ramuli or a few subulate ramuli.

1. W. Blodgettii.

2. Tr. Tumanowiczi.

1. Wrightiella Blodgéttii (Harv.) Schmitz, loc. cit.

Alsidium Blodgettii Harv. Ner. Bor.-Am. 2: 16. p7. 15 B. 1553.

Isually found washed ashore, presumably from deep water, Great Bahama:Bermuda and Florida. Type from Key West, Florida.

2. Wrightiella Tumanowíczi (Gatty) Schmitz, loc. cit. 222.

Dasya Tumanowiczi Gatty; Harr. Ner. Bor.-Am. 2: 64. 1553.

The Bahama plants show fire pericentral cells except in ramull, but appear to be otherwise identical with the Key llest type.

Found washed ashore, Berry lslands and Abaco:-Florlda. Type from liey West, Florida. 
9. MURRAYÉLLA Schmitz, Ber. Deuts. Bot. Ges. 11: 227. 1893.

1. Murrayella períclados (Ag.) Schmitz, loc. cit.

Hutchinsiu periclados Ag. Sp. Alg. 2: 101. 1828.

Polysiphonia periclados Kütz. Sp. Alg. 822. 1849.

Bostrychia T'uomeyi Harv. Ner. Bor.-Am. 2: 58. pl. 14E. 1853.

Bostrychia periclados J. Ag. Sp. Alg. 2: 860. 1863.

Polysiphonia Binderi Sond.; Kütz. T'ab. Phye. 14: 16. pl. 45. f. a, b. 1864.

In rock caverns, on the roots of Rhizophora, etc., between the tide-lines and in shallow water, New l'rovidence and Bimini:- Bermuda and Florida to northern South America. Type from St. Croix.

10. AMPHíbiA Stackh. Mém. Soc. Imp. Nat. Moscou 2: 58, 89. 1809.

Scorpiurd Stackh. Ner. Brit. ix, xi. 1816 [ed. 2-not seen].

Bostrychia Mont. in Sagra, Hist. Cuba, Pl. Cell. 39. 1838. Not Bostrychia

Fr. Sr. Vet. Akad. Handl. 1818: 119. 1818.

Helicothanion Kütz. Linnaea 17: 105. 1843; Phye. Gen. 433. 1843.

Stictosiphonia Harv. in Hook. f. F'. Antaret. 483. 1847.

Fronds stout and rigid, having commonly a spread of $2.5-5 \mathrm{~cm}$.; sections of main ares showing $3-7$ series of pericentral cells; monosiphonous apices usually short or mole commonly wanting.

Fronds smaller; sections of main axes showing 1-3 series of pericentral cells.

Branchlets bearing numerous long deflexed and incurved often branched monosiphonous ramelli 20-50 cells long, these cells 26-55 $\mu$ long, longer than broad; plants repent or prostrate, forming thin mats; sections of main axes showing 2 or 3 series of pericentral cells.

Pranchlets without inonosiphonous ramelli or occasionally terminating in monosiphonous prolongations 2-10 (rarely -20) cells long, these cells $15-26 \mu$ long, shorter than broad at least in proximal parts; main axes showing 1 or 2 series of pericentral cells; plants forming dense mats.

Regularly bi-tri-pinnate; ultimate branchlets, $75-200 \mu$ (6-12 cells) long; main branches prostrate or ascending. Bi-tri-pinnate or often more or less quadrifarious through the development of two rows of ventral branches near the bases of the lateral branches; ultimate branchlets $200-750 \mu(12-10$ segments or cells $)$ long ; main branches deflexed or drooping.

1. A. Montagnei.

2. A. tenella.

3. A. Sertularia.

4. A. pectinata.

1. Amphibia Montàgnei (Harv.) Kuntze, Rev. Gen. Pl. 2: 881. 1891.

Bostrychia Montagnei Harv. Ner. Bor.-Am. 2: 55. pl. 14B. 1853.

On roots of Rhizophora and rarely on other objects, usually just above the lowwater mark, Bimini, Great Bahama, Exuma Chain, and Watling's Island :-Bermuda: Florida; Cuba; and Jamaica. Type from Key West, Florida.

2. Amphibia tenélla (Vahl) Kuntze, Rev, Gen. Pl. 2: 882. 1891.

Fucus tenellus Vahl, Nat. Selsk. Skr. 5²: 45. 1802.

Tihodomela calamistrata Mont. Ann. Sei. Nat. Bot. II. 8: 354. 1837.

Bostrychia calamistrata Mont.; Harv. Ner. Bor.-Am. 2: 56. pl. 14C. 1853.

Bostrychia tenella J. Ag. Sp. Alg. 2: 869. 1863.

Bostrychia Vieillardi Kütz. Tab. Phyc. 15: 10, pl. 26. f. a-e. 1865.

Creeping on rocks, roots of Rhizophora, pneumatophores of Avicennia, etc., near the high-water mark, New Providence, Rose Island, Great Bahama, Gun Cay, Watling's Island, and Caicos Islands:-Bermuda; Florida; and the West Indies generally ; widely distributed in the warmer seas. Type from St. Croix. 
3. Amphibia Sertulària (Mont.) M. A. Howe, comb. nor.

Bostrychia Sertularia Mont. Ann. Sei. Nat. Bot. IV. 12: 176. 1859.

Bostrychia sertularina Kütz. Tab. Phyc. 15: 9. pl. 25. f. a-c. 1865.

Bostrychia Mazei Crouan; J. Ag. Anal. Alg. Cont. 4: S3. 1897.

Forming dense mats on rocks near the high-water mark, Rose Island, Great Bahama, Gun Cay, Exuma Chain, and Watling's lsland:- Bermuda to northern South America. 'Tspe from Guiana.

\section{Amphibia pectinàta (Küitz.) M. A. Howe, sp. nov.}

Bostrychia Tieillardi pectinata Kütz. Tab. Phye. 15: 10. pl.26.f.f-h. 1865.

Somewhat intermediate between $A$. tenclla and A. Sertularia, being found necasionally in herbaria sometimes nnder the one specific name and sometimes under the other, but usually, in the IVest Inclies, quite distinct from either species, differing from both in its greater rigidity, in its habit of growth, and in the frequent presence of two rows of "alventitious"' ventral branches, showing in extreme cases, four ranks of branches of almost equal size and similar development.

Between the tide-lines ou roots of Rhizophora and pneumatophores of A rieennia, racely pendent from the roofs of caverns, Rose Island, Berry Islands, Great bahama, Bimini, Exuma chain, Watling's Island, and Mariguana:- rlorida and the West Indies generally; New Caledoria. Type from New Caledonia.

11. HERPOSIPHÒNIA Näg. in Schleid. \& Näg. Zeits. Wiss. Bot. 3-4: 238 (without mention of species). 1846. Ambromn, Bot. Zeit. 38: 197. 1550.

Main axes or long branches with a branch (or branch rudiment) from each node.

Iain axes or long branches strongly curved, with convexity dorsil, giving short branches a somewhat squarrose appearance; short branches mostly $8-10$ segments long; plants mostly $4-10 \mathrm{~cm} .10 \mathrm{~g}$.

Main axes or long branches nearly straight or slightly curved with concavity dorsal; short branches mostly 12-30 segments long: plants mostly $1-3 \mathrm{~cm}$. long.

Main axes or long branches with some of their nodes regularly and wholly destitute of brinches.

Plants of straggling, intricate, or repent habit, elongate and subsimple, $0.5-3 \mathrm{~cm}$. long with apex conspicuously rolled towards dorsal surface; main axes $75-150 \mu$ in diameter, even.

Plants somewhat bi-tri-pinnate, filiculoid, $2.5-5 \mathrm{~cm}$. long, with apex inconspicuously curved towards dorsal surface; main axes $150-250 \mu$ in diameter, swollen at nodes in older parts.

1. II. Peeten-Teneris.

2. II. tenella.

3. II. sccunda.

4. H. bipinnata.

1. Herposiphonia Pécten-Véneris (Harv.) Falkenb. Rhodomel. 31j. 1901.

Polysiphonia Pecten-Tencris var. a, Harr. Ner. Bor.-Am. 2: 46. pl. 16C. 1853.

On P'nicillus, IIalimeda, Thalassia, and various other objects in shallow water, New Iroridence, Rose Island, Gerry Islands, Great Bahama, Bimini, Andros, Exuma Chain, Mariguana, Caicos Islands, and Great liagged Island:-Florida. Type from Key West, Forida.

2. Herposiphonia tenélla (Ag.) Ambronn, Bot. Zeit. 38: 197. pl.4. f. 9, 11, 1316. 1850.

IIutchinsia tenella Ag. Sp. Alg. 2: 105. 1S2S.

Polysiphonia tenella J. Ag. Mlg. Ned. et Adriat. 123. 1842.

Polysiphonia Pecten-Tencris var. $\beta$, Harv. Ner. Bor.-Am. 2: 46. pl. 16D. 1853.

On snonges, various algae, roots of hhizophoru, etc., from low-watel mark dow to a depth of at leist 20 meters, lierry Islands, Greit bahama, Bimlni, Exuma Claaln, Watleg's island, Mariguani, ind Caicos Islaws :-liermuda ind North Carolina to Florida and Barbados: Irediterranean and Arliatic seas. Type from slcily. 
3. Herposiphonia secúnda (Ag.) Ambronn, Bot. Zeit. 38: 197. pl. 4. f. 8, 12. 1580.

Mutchinsia secunda Ag. Syst. Alg. 149. 1824.

Polysiphonia secunda Zanard. Syn. Alg. Adriat. 64. 1841.

On Sargassum, Chondria, Lanmencin, etc., in shallow water, Berry Islands, Great Bahama, Gun Cay, Exuma Chain, Watling's Island, Mariguana, Caicos Islands, and Castle Island:- Bermuda and Florida to Barbados; Mediterranean and Adriatic seas. Type from the Mediterranean.

\section{Herposiphonia bipinnàta M. A. Howe, sp. nov.}

Frond rose-purple, filiculoid or floceulose, free, or subrepent at base only, somethat bi-tri-pinnate, or paniculate, $2-5 \mathrm{~cm}$. long, the branchlets here and there obviously pectinate-secund; main axes stramineous or decolorate except in youngest parts, $150-250 \mu$ in diameter, somewhat swollen at the nodes, the segments $11 / 2-2$ times as long as broad, becoming subequal towards apices; pericentral cells usually 10, the central cell large, $50-90 \mu$ in diameter; branches obseurely quarlrifarious, or subsecund through the abortion of the usually frequent lateral long branches, commonly arising from two immediately consecutive nodes, one from each, followed by one or two naked nodes, and then by two branclies from immediately consecutive nodes, and so on, the branches being sometimes represented by rudiments; long branches abruptly diminishing in size at apex and rather inconspicuously dorsiflexed; short branches 8-12 segments long, slightly flexed or subfalcate, erowned with rather coarse trichoblasts, often as long as the branch, the segments 1/2-11/4 as long as broad; sporangia somewhat protuberant, mostly in a single linear series, the sporangiiferous branch $105-135 \mu$ in greatest width; cystocarps oroid, short-stalked, subtruncate, $380-5+0 \mu \times 300-450 \mu$.

In technical microseopic characters, the present species seems to be related to $H$. secunda, from which, howerer, it is amply distinct, as indicated in the above key.

On Cymodocea, washed ashore, Whale Cas, Berry Islands (Hoxe 3497-type).

\section{LOPHOSIPHONIA Falkenb. in Eng. \& Prantl, Nat.}

Pflanzenfam. $\mathbf{1}^{2}: 459$. 1897.

Trichoblasts spirally arranged.

Pericentral cells usually $11-18$.

l'ericentral cells usually 6-10.

Trichoblasts in a siugle secund series on the convex (dorsal) surface of the strongly hamate tips of the erect branches.

1. L. obseura.

2. L. subadunca.

3. L. cristata.

1. Lophosiphonia obscùra Anet. Not Hutchinsia obscura Ag. Sp. Alg. 2: 108. 1828.

? Conferva intertexta Roth, Cat. Bot. 1: 18S. pl. 3. f. 6. 1797.

Polysiphonia reptabunda Suhr; Kütz. Sp. Alg. 806. 1849.

Polysiphonia adunca Kütz. Sp. Alg. 808. 1849.

Forming mats or a turf on rocks and on roots of Rhizophora between the tidelines, common, New Providence, Rose Island, Berry Islands, Bimini, Gun Cay, Exuma Chain, Watling's Island, Caicos lslands, and Great Ragged Island :-Bermuda and Florida to the American Virgin Islands; Adriatic and Mediterranean seas and England.

2. Lophosiphonia subadúnca Kütz. Phye. Gen, 418. $18+3$.

Hutchinsia obscura Ag. Sp. Alg. 2: 108 (according to apparent original in herb. Ag.). 182s.

Polysiphonia barbatula Kütz. loc. eit. 417.

Polysiphonia pygmaea Kütz. Phyc. Germ. 313. 1845.

Iaking a close nap or turf on surf-beaten rocks, between the tide-lines, Exuma Chain:- southern Europe. Type from Corsica. 
3. Lophosiphonia cristàta Falkenb. Rhodomel. 499. pl. 9. f. 7-10. 1901.

Making a velrety coating on surf-beaten rocks, Iow-littoral, IBerry Islands, Mariguana, and Great Iiagged lsland:-St. Thomas and Iediterranean šea. Type from Naples.

13. DIPTEROSIPHÒNIA Schmitz \& Falkenb. in Eng. \& Prantl, Nat. Pflanzenfam. $1^{2}: 463.1597$.

1. Dipterosiphonia dendrítica (Ag.) Sehmitz, loc. cit. 464.

Hutchinsia dendritica Ag. Syst. Alg. 146. 1824.

Creeping on Chamacdoris and on Laurcncia papillosa, Eleuthera :-American Vir. gin Islands; Brazil. Type from Brazil.

14. AMÁNsIA Lamour. Nouv. Bull. Sei. Soe. Philom. 1: 332. 1809.

1. Amansia multífida Lamour. loc. cit. $p l$. 6. f. $2 C, D, E$.

Esually found washed ashore, Eleuthera:-Florida to Brazil. Trpe from Santo Domingo.

15. Heterosiphònia Mont. Prod. Phye. Pol. Antaret. 4. 1842.

Trichothamsion Kütz. Phye. Gen, 415. 1843.

Iain axes uncorticated, mostly $65-130 \mu$ in diameter ; fronds 1-6 $\mathrm{cm}$. Jong or high.

Irain axes strongly corticated, mostly $0.45-1.1 \mathrm{~mm}$. in diameter; the brownish diaphragms of the central siphon risible through cortex; fronds $4-1 \mathrm{~s} \mathrm{~cm}$. high.

1. H. Wurdemanni.

2. H. Gibbesii.

1. Heterosiphonia Wurdemánni (Bail.) Falkenb. Rhodomel. 63s. pl. 16. f. 11. 1901.

? Callithamnion crispellum Ag. Sp. Alg. 2: 1S3. 182S.

Dasya Wurdemanni Bail.; Harr. Ner. Bor.-Am. 2: 64. pl. 15C. 1553.

Resembling a species of Dasya, as pointed out on a later page.

On corallines and various other algae, under shelring rocks, on roots of Rhizophor , etc., low-littoral or in shallow watel, Berry Islands, Great Bahama, Bimini, Gun Cay, Exuma Chain, Watling's Island, Mariguana, Caicos Islands, and Little Inagua :-Bermuda and Florida to Barbados; Adriatic and Mediterranean seas. Type from Key West, Florida.

2. Heterosiphonia Gibbèsii (Harr.) Falkenb. Rhodomel. 653. 1901.

Dasya Gibbesii Harv. Ner. Bor.-Am. 2: 59. pl. 15 A. 1553.

In tide-pools and in shallow water down to 2 meters or more, New Proridence. Berry Islands, Great Bahama, Andros, Eleuthera, Cat Island, Exuma Chain, and Watling's Island:-FIolida. Type from Ker West, Florida.

16. DASYA Ag. Syst. Alg. xxxir, 211 (as Dasia). 1524.

RHodonema Martens, Reise nach Venedig 2: 641. 1824.

Dlchotomous monosiphonous ramelli (2-4 mm. long) springing witlout order from the firm cortex, dersely clothing the main axes or deficlent in older parts.

Stichidia on 1- or 2 -celled monsiphonous pedicels, translucent after dehiscence of sporangia, showing central axis clearly.

Plants nostly S-SO Cm. high, main axes raguely quasiplnnate or virgate: cystocarps pedicellate.

I'lants mostly 3-6.5 $\mathrm{cm}$. high, subdlclotomous : ramelli very soft and mucous, more or less coherent or confluent on drying; cystocarps sessile or subsessile.

Stlchidia sessile or on 1 -celled pedicels, rather opaque after deliscence of sporangia and conspleuously zonite-annulate.

1. D. pedicellata.

2. D. Crouaniana.

3. D. ramosissima. 
Dichotomous monoslphonous ramelli subverticillate and often subsquarrose, sometimes lightly corticated at bise; main axes well corticated.

Monosiphonous ramelli spirally disposed, patent, divaricate, or subsquarrose, diviricately dichotomons.

Matin axes $0.25-0.75 \mathrm{~mm}$. in diameter, corticated except in youngest parts; cystocarp subspheric-rostrate, $0.67-0.92$ $\mathrm{mm}$. broad.

Main axes $0.1-0.3 \mathrm{~mm}$. in diameter, uncortlcated or slightly corticated near base; cystocarp conic-ovoid, about 0.2 mm. broad (immature).

4. D. mollis.

5. D. Collinsiana.

6. D. rigidula.

1. Dasya pedicellàta (Ag.) Ag. Syst. Alg. 211. 1824.

Sphaerococcus pedicellatus Ag. Sp. Alg. 1: 321. 1822.

Rhodonema elegans Martens, Reise nach Venedig 2: 641. pl. 8. 1824.

Dasya elegans Ag. Sp. Alg. 2: 117. 1828.

Mostly in shallow water, New Providence, Berry Islands, and Great Bahama :Massachusetts to Bermuda; Florida; and the northern West Indies; Adriatic and Mediterranean seas; Canary Islands. Type from New Tork.

The southern specimens are sometimes rellowish when living instead of the customary lake-red.

2. Dasya Crouaniàna J. Ag. Till Alg. Syst. 6: 95. 1890.

On surf-beaten rocks at low-water mark, Exuma Chain:-Florida and Guadeloupe. Type from Guadeloupe.

3. Dasya ramosíssima Harv. Ner. Bor.-Am. 2: 61. 1853.

The rerticils of sterile cells of the stichidia are inclined to be protuberant and they occasionally develop into few-celled simple or one-branched trichophylls. In two observed cases the stichidium was forked near the apex.

On roots of Rhizophora near low-water mark, Great Bahama:-Florida. Type from Key Vest, Florida.

4. Dasya móllis Harv. Ner. Bor.-Am. 2: 62. 1853.

On roots of Rhizophora, under shelving rocks, etc., near low-water mark, Exuma Chain and Little Inagua:- Florida and Cuba. Type from Key West, Florida.

5. Dasya Collinsiàna M. A. Howe, in Britton, Fl. Bermuda 524. 1918.

The only specimen seen differs from the Bermudian type in being more laxly branched, in being less manifestly dichotomo-corymbose, in the more "ocellate" congestion of the ramuli at the apices, and in the lighter cortication. It also bears eystocarps, hitherto undescribed for this species. These are sessile, subspheric-rostrate, 670-920 $\mu$ broad, 600-750 $\mu$ high (without beak) the beak being $350-5.00 \mu$ long. In its cystocarps it seems to resemble $D$. ramosissima, but the ramuli of $D$. Collinsiana are coarser and more divaricately dichotomous and have a regularly spiral arrangement while those of $D$. ramosissima are irregular or inclined to be subverticillate.

In 2 meters of water, Great Bahama:-Bermuda. Type from Bermuda.

6. Dasya rigídula (Kütz.) Ardiss. Florid. Ital. 2: 140. 1878.

Eupogonium rigidulum Kütz. Phye. Gen. 415. 1843; Tab. Phye. 14: pl. 85. f. $c, d .1864$.

Eupogonium squarrosum Kütz. Phye. Gen. 415. 1843; Tab. Phye. 14: pl. 85. f. $a, b .1864$.

Dasya squarrosa Zanard. Mem. Ist. Veneto 13: 163. pl. 53B. 1866. Not Dasya squarrosa Harv. in Hooker, J. D., Fl. New Zealand 2: 232. 1855.

Much resembling Heterosiphonia Wurdemanni in size, habit, and microscopic characters and easily confused with that species, but differing in its radial instead of dorsiventral organization, in having its ramuli spirally dis- 
posed and one springing from each segment, while $H$. Turdemanni has tworanked ramuli, one from every second segment; the main axes of $D$. rigidula are also sometimes corticated towards base.

On rocks and rarlous algae in shallow water, Berrs Islands, fireat Baliama and Exuma Chain:-Bermuda: Idriatic and Mediterranean seas, Type from Spalato, Adriatic Sea.

\section{DASYópsis Zanard. Saggio Class. Fic. 52. 1843.}

Eupogodox Kütz, Phye, Germ. 312. 18tว̄.

\section{Dasyopsis Antillàrum M. A. Howe, sp. nov.}

Plants dark vinaceous-purple, elaret-bromn, or orange-rufous, $1-10 \mathrm{~cm}$. high, rather copiously, irregularly and radially branched, or quasi-pinnate, occasionally subdichotomous below; main axes subterete or slightly flattened, 1-2.5 mm. in diameter; principal branches showing more or less numerous subspinescent branchlets 1-3 $\mathrm{mm}$. long, the surface clothed at and near the apices, or sometimes to bases of the branches and branchlets, with more or less tufted dichotomous, monosiphonous, often early deciduous ramelli, these springing chiefly from slightly elerated cushious or sorus-like spots, the segments mostly $15-26 \mu$ in diameter, usually $3-6$ times as long as broad; cortical cells mostly rather short, 12-70 $\mu$ long, $1-5$ times as long as broad; stichidia fusiform, 300$450 \mu$ long, $75-150 \mu$ in maximum width, borne close to the rhachides, on onecelled pedicels or sometimes apparently sessile on the rhachides, occasionally proliferous at apex and bearing short trichophylls.

On corals in shallow water and washed ashore, Fort George Cay, Caicos Islands (Howe 5625-type), and Atwood Cay.

Dasyopsis Antillarum in color and in the character and arrangement of the monosiphonous ramelli hears some resemblance to small conditions of Dasye pedicellata, but differs in the more copions and more irregular brinching, in haring short subspinescent branchlets, in the shorter cortical cells, in the absence of visible pericentral siphons at the apices, in the more proximal location of the stichidia, ete.

From the Bermudian Dasyopsis spinuligera (Collins \& Herves) M. A. Howe (Dasya spinuligera Collins \& Herv. Proc. Am. Acad. 53: $130, p l .4 . f .2 \%, 25.1917), D$. Antillarum differs in being much larger and coarser, in the more vinaceous-purple color, in the softer longer-celled monosiphonous ramelii, and in the shorter, more fusiform stichidia (the stichidia of $D$. spinuligcra are eventually cylindric, with conic apex, and $600-800 \mu$ Iong br $75-80 \mu$ in diameter, and they are often geminate).

From the Adriatic and Irediterranean Dasyopsis penicillata and D. spinella, the species differs much in habit and in not haring the monosiphonous ramelli confined to the apices but springing irregularly from the cortes or from sllghtly elerated cushions or sorus-like areas.

18. FALKENbÉrgia Schinitz, in Eng. \& Prantl, Nat. Pflanzenfanı. $1^{2}: 479.1597$.

1. Falkenbergia Hillebrándii (Born.) Falkenb. Rhodomel. 689. 1901.

Polysiphonia Hillebrandii Born.; Ardiss. Phyc. Med. 1: 376. 1 \$\$3.

On roots of Rhizophoru, etc., in shallow water, Gun Car and Exuma Chain :Rermuda to Barbados; Canary Islands; Alediterranean Sea. Type from the Cauary lslands.

19. HALOdÍctYoN Zanard. Saggio Class. Fic. 52

(as Malydictyon). 1843 .

IIANowid Sond. Bot. Zeit. 3: 52. 1545.

Coelodicryox Kütz. Phye. Germ. 257. 1S45.

1. Halodictyon mirábile Zan. loc. cit.

On and with other algae (Heterosiphonia Wurlomanni, Jamin. Polpsiphonia, etc.) Exuma Chain and Little Inagua :-Florlda and Barbados: Mediterrnnesn and Adrintle seas. Type from the Adrlatlc Sea. 


\section{Family 12. CERAMIÁCEAE.}

1. SPERMOTHÁMNION Aresch.; Fries, Summa Veg. Scand. 127. 1845.

Cells of erect filaments mostly $10-20 \mu$ in diameter, $3-6$ times as long as broad; tetrasporangia on $1-4$-celled pedicels; plants usually growing on Galaxaura.

Cells of erect filaments mostly $20-40 \mu$ in diameter, 2-5 times as long as broad.

Tinaceous-purple or Indian lake, on Codium, manifestly repent.

Csually dark rinaceous-brown, under shelring rocks and on Jaria Galarnura, etc intricate, less manifestly repent.

Cells of erect filaments $40-65 \mu$ in diameter, $5-15$ times as long as broad: terminal cells clarate, $26-40 \mu$ in diameter, walls of all cells $6-14 u$ thick ; tetrasporangia terminal, of ten more or less corymbose; plants growing on rocks.

Cells of erect filaments $50-115 \mu$ in diameter, $3-7$ times as long as broad, their walls $5-40 u$ thick : terminal cells commonly crlindric, often onls $12-15 \mu$ in diameter. their walls $1-2 \mu$ thick; tetrasporangia at nodes, solitary or more commonly sereral and unilaterally glomerate or subverticillate; plants on or with other algae.

1. S. investicns.

2. S.gorgoncum.

3. S. spcluncarum.

4. S. macromeres,

1. Spermothamnion invéstiens (Crouan) Tickers, Ann. Sci. Nat. Bot. IX. 1: 64. 1905 .

Callithamnion investiens Crouan; Schramm \& Mazé, Alg. Guad. ¡. 1865 [not seen].

On Galaxaura flagclliformis, G. subverticillata, and $G$, comans, and on and with Jania (growing on sargassum). Great Bahama, Watling's Island, IIariguana, and Caicos Islands:-Bermuda to Barbados. Trpe from Guadeloupe.

2. Spermothamnion gorgòneum (Mont.) Bornet; Vickers, Ann. Sci. Nat. Bot. VIII. 4: 305. 189

Callithamnion gorgoneum Mont. Ann. Sci. Nat. Bot. IV. 8: 289. 185 .

On Corium isthmocladum. Berry Islands :-Bermuda to Barbados ; Canary Islands and Cape Verde Islands. Type from island of St. Nicholas, Cape Verde Islands.

3. Spermothamnion speluncàrum (Collins \& Hervey) MI. A. Horre, comb. nov.

Rhodochorton speluncarum Collins \& Herrey, Proc. Am. Acad. 53: 148. 1917 .

Tariable in length of cells and thickness of the cell-rills; cells mostly $2-4$ times as long as broad, but occasionally as much as 8 times; cell-walls usually 3-6 $\mu$ thick, but ranging up to $12 \mu$ thick; tetrasporangia occurring mostly on the lower part of the main ereet filaments, solitary or rarely two (opposite) on a segment, ellipsoid or subglobose, $52-65 \mu$ in maximum diameter, subsecund, sessile or on 1- or 2-celled pedicels; antheridial stands terminal, short-cylindric or ovoid-ellipsoid, about $40 \mu \times 20-28 \mu$. Ereet filaments sometimes tortuous and intricate, forming intertangled eushions. Related to the North-European S. roseolum (Ag.) Pringsh., especially to the form occasional in herbaria under the name Callithamnion repens Lyngb., but filaments more intricate and flexuous, more slender (commonly $22-39 \mu$ is. $35-55 \mu$ ), cells shorter (usually 2-4 times is. 3-8 times as long as broad), more often dolioform, and more often collabent.

Under shelving rocks and on rarious algae (Chamacdoris, Galaxaura, Jania, etc.) and on sponges, in shaded situations, near low-water mark, Rose Island, Great Bahama, North Cat Cay, Mariguana, and Great Ragged Island:-Bermuda. Type (sterile) from Bermuda.

4. Spermothamnion macromères Collins \& Hervey, Proc. Am. Acad. 53: 132. 1907 .

On surf-beaten, sand-corered rocks at low-water mark, Berry Islands :-Bermuda. Type from Bermuda. 


\section{Spermothamnion gymnocárpum M. A. Howe, sp. nor.}

Indian lake or purplish-vinaceous, fading to brownish-vinaceous, grayishvinaceous, or vinaceous-fawn, forming rather dense cushions $1-3 \mathrm{~cm}$. deep or somewhat straggling in habit; primary ereeping filaments $50-130 \mu$ in diameter, their cells $130-100 \mu$ long, mostly $3-5$ times as long as broat, their walls $13-50 \mu$ thick, the erect branches arising mostly from near the end of the cell; erect filaments $50-115 \mu$ in diameter, rather freely subuichotomonsly, alternately, or subsecundly branched, rarely with 3 or 4 branches at a node, the branches patent or erecto-patent, arising subterminally or laterally just below the septum, the cells $300-750 \mu$ long, mostly $3-7$ times as long as broar, eylindric or slightly enlarged at upper end, the walls $5-40 \mu$ thick, the terminal cells $40-65 \mu$ in diameter, obtuse, or in the more branched conditions often only $12-15 \mu$ in diameter with walls only 1-2 $\mu$ thick; chromatophores suborbicular, elliptic, fusiform, substellate, or difform, more or less confluent dises $2-13 \mu$ in maximun diameter; monoicous (polyoicous?); procarps and cystocarps solitary or several closely approximate; procarps subglobose or hemispheric, $40-50 \mu$ broad, the trichogrne $10-13 \mu$ in diameter; cystocarps moriform or irregularly hemispherie, $80-150 \mu$ broad, wholly destitute of an involuere; antheridial stands ovoid to subeylindrie, $40-80 \mu \times 26-10 \mu$; tetrasporangia borne on one-celled pedicels at nodes in distal parts of the main ereet filanents and their branches, solitary or more often 2-5 at a node and aggregated on the inner side, or subverticillate, subglobose, $60-80 \mu$ in diameter, their walls $5-12 \mu$ thick.

On and with various other algae (Jania, Laurencia, Chamactoris, etc.). in shal Iow water and washed ashore, Great Babama (Howe 3899 -trpe) and Exuma Chain.

The species is perhaps related to the European S. incgulare (J. Ag.) Ardiss., but manifestly differs in its longer, less ventricose cells, naked crstocarps, etc. Most of the few antheridial stands seen have been rery close to the procarps, but the procarps preponderate so much in number that it mas be suspected that dioicous conditions also occur.

2. MESOTHÁMNION Börg. Dansk Bot. Ark. 3': 208. 1917.

\section{Mesothamnion caribaèum Börg. loc. cit.}

The single Bahamian specimen seen is sterile and the determination is open to possible doubt. It is $0.5-1 \mathrm{~cm}$. high and is remarkable for its penicillately tufted apices, the lower parts of the main axes being more or less denudate.

On Gelidium rigidum, near low-water mark, Gun Cay :-American Virgin Islands. Tspe from St. Jan (dredged in 30 meters of water').

3. GRIFFÍtHSIA Ag. Syn. Alg. Scand, xxriii. (as Griffitsia). 1§17.

Branching mostly subdichotomous, the branches issuing from the upper end of the parent cell.

Iranching distinctly lateral, the branches issuing from near the middle or below the middle of the parent cell.

1. G. globulifera.

2. G. tenuis.

1. Griffithsia globulifera Harv.; Küitz. Tab. Phyc. 12: 10. pl. 30. f. a-l. 1562.

Griffithsia corallina globifera Harv. Ner. Bor.-Am. 2: 229. pl. 35.A. 1853.

Griffithsia coraltina tenuis Harv. loc. eit.

Griffithsia globifera Harv.; J. Ag. Sp. Alg. $3^{1}: 67.1876$.

Griffithsia Bornetiana Farl. Proe. Am. Acarl. 12: 243.1877.

The Bahamian plants referrerl here seem to agree essentially with the northern type in the character of the antheridia, eystocarps, and tetrasporangia, but they are smaller plants and the filaments are often more moniliform, these differences being especially manifest in sterile and more doubtful specimens that have been identified tentatively with this species. The plants oceur on surf- 
beaten rocks between the tille-lines and as epiphrtes on other algae, habitats that are not characteristic of the northern G. globulifera.

Joulter's Cay, Exuma Chain, Atwood Cay, Caicos IsIands, and Great Ragged Island :- Iassichusetts to the American Virgin Islands and Barbados (?). Type from New York.

2. Griffithsia ténuis Ag. Sp. Alg. 2: 131. 1828.

Callithamnion tenue Harv. Ner. Bor.-Am. 3: 130. 1858.

Griffithsia thyrsigera (Thmait.) Grun. Alg. Filschi 8. 187т.

An antheridial fragment, washed ashore, Berry lslands:-Massachusetts and Bermuda to Barbados; Adriatic Sea; Ceylon; Australia; etc. Type from Venice.

4. CALLITHÁMINION Lyngb. Hydroph. Dan. 123. 1819.

1. Callithamnion Hálliae Collins, in C., H., \& S., Phye. Bor.-Am. 698. 1900.

Related to C. corymbosum and $C$. byssoides, but differs from both in having the main axes uncorticated throughout.

On other algae at low-water mark, under shelving rocks (and washed ashore), Great Bahama and Exuma Chain :-Florida. Type from Key West, Florida.

\section{SEIRóspoRA Harv. Phye. Brit. pl. 21. 1846.}

1. ? Seirospora occidentàlis Börg. Bot. Tidsskr. 30: 14. f. 8, 9. 1909.

The scanty fertile material has the triangularly divided tetrasporangia sessile or on one-celled pedicels; paraspores $30-40 \mu$ broad, in branching, subterminal tufts ; main axes uncorticated throughout. Exuma Chain :-American Virgin Islands. Type from sound between St. Thomas and St. Jan.

6. HALOPLÉgMa Mont. Ann. Sei. Nat. Bot. II. 18: 258.1842.

RHodoplexia Harv, in Hook. Ic. Pl. $7:$ pl. 613. 1844.

1. Haloplegma Dupérreyi spinulòsum M. A. Howe, subsp. nor.

Differs from typical $H$. Duperreyi Nont. in having a thallus that is beset with numerous rigid subspinescent ramelli usually in twos or threes and 25-140 $\mu$ (2-11 cells) long, the cells of these ramelli mostly 1.5-3 times as long as broad.

Between the tide-lines on a rock shelf, under an overhang, Cave Cays, Exuma Chain (Hove 3998).

\section{GYMNOTHÁAMNION J. Ag. Anal, Alg. 27. 1892.}

1. Gymnothamnion élegans (Schousb.) J. Ag. loc. cit. 17 S.

Callithamnion elegans Schousb.; Ag. Sp. Alg. 2: 162. 1828; Born. \& Thur. Not. Alg. 32. pl. 10. 1876.

Ptilota Schousboei Born. in Born. \& Thur. Joe. cit. 34.

Plumaria Schousboei Schmitz; Born. Mém. Soc. Sci. Cherbourg 28: 330. 1892.

? Gymnothamnion bipinnatum Collins \& Herrey, Proe. Am. Acad. 53: 139. pl. 4.f. 26. 1917.

? Ptilothamnion bipinnatum M. A. Howe, in Britton, Fl. Bermuda 525. 1918.

The main branches are simply pinnate and the opposite ramuli are usually longer than in Bermudian specimens described as G. bipinnatum but not altogether dissimilar conditions occur in the Bermudian type and the species is probably the same. The Bahamian specimens, like the Bermudian, appear to bear only tetrasporangia (tripartite), and pending the discovery of antheridia 
and eystocarps, the generic position of the plants must remain in some doubt. There are discrepaneies between Bornet's and J. Agardh's figures of the eystocarp of Gymnothamnion elegans and the relation of Gymnothamnion to Ptilothamnion would seem to be in need of further study.

Forming a thin coating on rocks a little above the low-water mark, Gun Car:northern Africa and Mediterranean shores of Europe; Bermuda (:). Type from Tangier, Morocco.

\section{S. ANTITHÁMnION Näg. Neu. Algensyst. 200. $18+7$.}

Main axes $24-30 \mu$ in diameter, for the most part regularly bipinnate.

Main axes $75-150 \mu$ in diameter, their branches tetrastichous, the ultimate branchlets often alternate or subdistichous.

1. A. Butlcriac.

2. A. cruciatum.

1. Antithamnion Butlèriae Collins, Proc. Am. Acad. 37: 258. 1901.

The fronds in Bahamian specimens are broader and the cells are usually longer, both actually and relatively, than in the type form.

On a rock shelf under an overhang. between the tide-lines, and washed ashore, Iose Island, Exuma Chain, and Caicos Islands:-Jamaica and Barbados. Type from Kingston, Jamaica.

2. Antithamnion cruciàtum (Ag.) Näg. Neu. Algensyst. 200. 1847.

With Jania, washed ashore, Great Bahama:-Massachusetts and Bermuda to Barbados ; Europe. Type from Trieste.

9. CROUÀnIA J. Ag. Alg. Med. et Adriat. 83. 1812.

1. Crouania attenuàta (Bonnem.) J. Ag. loc. cit.

Batrachospermum attenuatum Bonnem. fide Ag.

Mcsogloia attenuata Ag. Syst. Alg. 51. 1824.

On various algae, Thalassia, etc., from near low-water mark down to 20 meters (fide Börgesen). Jow Providence, Berry Islands, Joulter's Cay, Great Bahama, Watling's Island, and Mariguana :-Bermula and Florida to Barbados; soutbern Europe. Type (in helb. Ag.) from nolthwestern France ("Armorica").

\section{SPYRÍdIA Harv. in Sm, Eng. Fl. $5^{1}$ : 336. 1833.}

Ramuli withont Iateral uncinate spines.

Ramuli normally with one or more uncinate spines on the distal nodes.

1. S. filamcutosa.

2. S. aculcata.

1. Spyridia filamentòsa (Wulf.) Harv. loc. eit. $33 \pi$.

Fucus filamentosus Wulf. Crypt. Aquat. 64. 1503.

Spyridia occidentalis Kütz. Sp. Alg. 666. 1849.

Spyridia apiculata Kütz. Tab. Phyc. 12: 15. pl. 49. f. $c, d .1862$.

Common in shallow warm water, Rose Island, Lerry Islands, Great Bahama, Bimini, North Cat Cas, Exuma Chain. Cat Island, and Calcos Islands:-Massichusetts and lermuda to South America: widely distributed in the warmer scas. 'Type from the Adriatic Sea.

\section{Spyridia aculeàta (Sehimp.) Kütz. Phye. Gen. 37\%. $18+3$.}

Ceramium aculeatum Schimp. in Unio Itin. no. 966 (not seen).

On rocks and on other algae in shallow water or down to 30 meters (fide Börgesen), Berry Islands, Great Hah:ıma. Gun Cay, and Mariguana - Bermuda and Florida to American Virgin Islands; sonthern Europe and northern Afrlcar lied Sea. Type from the Red Ser. 
11. CERÀMIUM Ag. Syn. Alg. Seand xxvi. 1817 .

?APoxi Adans. Fam. Pl. 2: 2, 519.1763.

? Episperma Raf. Prec. Somiol, 4S. 1814.

BorraA Grateloup. Bory, Diet. Class. Hist. Nat. 2: 412. 182.2.

Filaments continuously corticated.

Filaments manifestly zonate, corticated at nodes only.

Filaments regularly and equally dichotomous, more or less fastigiate, apices forcipate.

Segments mostly longer than broad, becoming $3-7$ times longer than broad below; tetrasporangia triangularly divided.

Segments mostly shorter than broad or subequal, becoming 2-3 times longer than broad below ; tetrasporangia often cruciate or decussately paired.

Filaments unequally dichotomous or showing various intermediate conditions between dichotomy and lateral branching.

'pper margins of cortex-zones commonly showing in younger parts rerticils of delicate caducous mostly 1- or 2-celled hairs; branching dichotomo-alternate and slightly zig-zag.

Hairs wanting or very rare.

Iain filaments mostly $45-75 \mu$ in diameter; nodal bands protuberant, bitruncate, most of the corticating cells, or at least the lower with their longer axes running transversely to the filament; tetrasporangia on main filaments.

Main filaments mostly $90-200 \mu$ in diameter : nodal bands not protuberant. the corticating cells with their longer axes lengthwise of the filament; tetrasporangia on clavate or fusiform lateral branches.

1. C. nitcrs.

2. C. tenuissimum.

3. C. cruciatum.

4. C. subtile.

5. C. byssoideum.

6. C. corniculatum.

1. Ceramium nitens (Ag.) J. Ag. Sp. Alg. 2: 130. 1851.

Ceramium rubrum nitens Ag. Syst. Alg. 136. 1824.

? Ceramium leptophloeum Kütz. Linnaea 15: 740. 1841.

Ceramium divaricatum Kütz. Tab. Phye. 13: 5. pl. 12. f. c-e. 1863.

Rather common in shallow water, New Providence, Berry Islands, Joulter's Cay, Great Bahama, Bimini, Exuma Chain, and Watling's Island:- Bermuda and Florida to the American Virgin Islands. Type from the "Antilles."

2. Ceramium tenuíssimum J. Ag. Sp. Alg. 2: 120. 1851.

? Ceramium diaphanum tenuissimum Roth, Cat. Bot. 3: 156. 1806.

The usually sterile Bahamian plants referred tentatirely to C. tenuissimum seem to agree essentially with other West Indian specimens currently thus referred, but their identity with the European type is doubtful. They are more regularly dichotomous, more fastigiate, firmer and more rose-colored than the plants here referred to $C$. subtile.

On various other algae, roots of Rhizophora, etc., in shallow water, Great Bahama, Exuma Chain, Mariguana, and Great Ragged Island:-Europe; Massachusetts; Lermuda; and the West Indies generalls. Type locality unknown.

3. Ceramium cruciàtum Collins \& Hervey, Proc. Am. Acad. 53: 144. pl. 4. f. 27, 28. 1917.

Similar in structure to the Bermudian plant, but less obviously repent and taller, reaching a height of 1-3 $\mathrm{cm}$.

On Digenca, Thalassia, etc., and on rocks, near the low-water mark, Mariguana, Caicos Islands, and Great Ragged Island :-Bermuda. Type from Bermuda.

4. Ceramium subtile J. Ag. Sp. Alg. 2: 120. 1851.

On Chondria and various other algae, roots of Rhizophora, etc., in shallow water, New Providence, Ber ${ }^{\circ} y$ Islands, Great Bahama, Bimini, Joulter's Cay, Exuma Chain, and Tatling's Island :-Mexico. Type from Vera Cruz. 
5. Ceramium byssoìdeum Harr. Ner. Bor.-Am. 2: 21S. 1853.

Ceramium transvcrsale Collins \& Herrey, Proc. Am. Acad. 53: 145. pl. 5. f. 29-31. 1917.

On various algae, leares of Cymodoeca, roots of Rhizophora, etc., near the lowwater mark, Berry Islands, North Cat Cas, Exuma Chain, and Mariguana :-Bermuda and Florida to the American Virgin Islands. Type from Key West, Florida.

6. Ceramium corniculàtum Mont. Ann. Sci. Nat. Bot. IV. 14: 172. 1560.

Gongroceras corniculatum Kütz. Tab. Phyc. 12: 25. pl. 81. f.e-g. 1862.

Inder shelving rocks, on roots of Rhizophura, etc., near low-water mark, Rose Island, Limini, Mariguana, and Caicos Islands :-Florida to Guadeloupe and Martinique. Type from Guadeloupe.

12. CERAMOTHÁIMNION Richards, Bull. Torrey Club 28: 257, 264. 1901.

1. Ceramothamnion Còdii Richards, loc. cit. pl. 21, 22. muda.

On Codium intertcxtum, Atwood Cay:-Bermuda to Barbados. Type from Ber-

13. CENTRócerAS Kütz. Linnaea 15: 731, 741. 1842.

1. Centroceras clavulàtum (Ag.) Mont. in Durieu, F'l. Algérie 1: 140. $18 \pm 6$.

Ceramium clavulatum Ag. in Kunth, Syn. Pl. Aeq. 1: 2. 1822.

Centroceras cryptaçanthum Kütz. loc. cit. $7 \pm 1$; Tab. Phyc. 13: pl. 1\%. $f$. $a-d .1863$.

Centroceras micranthemum Kütz. loc. cit. $7 \pm 1$; Tab. Phyc. 13: pl. 18. f. $a-d$.

Centroceras hyalacanthum Kütz. loc. cit. 742 ; Tab. Phyc. 13: $p l .19 . f . d-f$.

Centroceras oxyacanthum Kütz. loc. cit. 742; Tab. Phyc. 13: pl. 20. f. a-c.

Centroceras brachyacanthum Kütz. Tab. Phyc. 13: 8, pl. 20. f. d-f.

On rocks and on various algae, low-littoral and in shallow water; very common and variable. Most of the Bahamian specimens accord with Kützing's $C$. hyalacanthum and $C$. oxyacanthum; a few agiee $\pi$ ith his $C$. cryptacanthum (type form of $C$. clavulatum). C. micracanthum, aud C. brachyacanthum. New Providence, Rose Island, Berry islands, Great Bahama, Bimini. North Cat Cay, Abaco, Eleuthera, Cat Island, Exuma Chain, Watling's Island, Mariguana, Caicos Islands, Great Ragged Island, and Orange Cay :- Bermuda and Fiorida to South America; widely distributed in the warmer seas. 'Type from Callao, I'eru.

\section{Family 13. DUMONTIÀCEAE.}

1. DUDRESNAYA Bonnem. Jour. Phys. 94: 180. 1822 (not seen).

1. Dudresnaya bermudénsis Setchell, Unir. California Publ. Bot. 4: 244. pl. 27. 1912.

Washed ashore, Great Bahama:-Bermuda. Type from Bermuda.

\section{Family 14. RHIZOPHYLLIDÀCEAE.}

1. OCHTòdes J. Ag. Act. Univ. Lund. $8^{8}: 5.1872$.

1. Ochtodes secundiràmea (Mont.) MI. A. Howe, comb. nor.

Hypnea? secundiramca Mont. Ann. Sci. Nat. Bot. II. 18: 255.1842.

Chondrococcus filiformis Kütz. Sp. Alg. 752. 1849; Tab. Phyc. 17: 28. pl. 95. f. $c, d, e .1867$.

Sphaerococcus filiformis J. Ag. Sp. Alg. 2: 644. 1852.

Ochtodes filiformis J. Ag. Act. Univ. Lund. $8^{\prime \prime}: 5.1872$.

Acanthococcus adclphinus Mont.; Crouan in Mazé \& Scbranım, Alg. Guad. 189. $1870-1877$.

Near low-water mark, commonly Irldescent, Cave Cays, Exuma Chain:-Cuba ; Jamalca : Porto Iilco; Martinique; and Barbados. Type from Martinique (in berb. Mus, I'aris.). 


\section{Family 15. SQUAMARIÀCEAE.}

1. PEYSSONNÈLIA Decaisne, Arch. Mus. 2: 168 (as

Peyssonellia). 1841.

Squamaria Zanard. Syn. Alg. Adriat. 133. 1St1. Not Squamaria (Rivin.) Hall. 1768.

1. Peyssonnelia rùbra (Grev.) J. Ag. Sp. Alg. 2: 502. 1852.

Zonaria rubra Grev. Trans. Linn. Soc. 15: 340. pl. 3. f. 3. 1827.

On Falonia ventricosa under shelving rocks at low-water mark, Cave Cays, Exuma Chain:-Bermuda; Cuba; and American Virgin Islands; Mediterranean Sea. Trye from Greece.

The genus Peyssonnctia is represented by other species in the Pahamas and the family Squamariaceae doubtless has other generic representatives besides Peyssonnelia, but the available material has not yet been studied with sufficient care to warrant the publication of further determinations.

\section{Family 16. CORALLINÀCEAE.}

1. ARCHAEOLITHotháminium Rothpl. Zeits. Deuts. Geol.

Ges. 43: 295. 1891.

Sporolithor Heyd. Ber. Deuts. Bot. Ges. 15: 66. 1897.

1. Archaeolithothamnium dimòtum Fosl. \& Howe, Bull. N. Y. Bot. Gard. 4: 128. pl. 80. f. $1 ; p l .8 \% .1906$.

Forming rather smooth crusts on the older parts of living corals, near low-water mark, Mariguana:- Jamaica and Porto Rico. Type from Porto Rico.

2. ІттнотнÁMNIUM Philippi, Wiegm. Archiv Naturgesch. $3^{1}$ : 38т. 1837.

Thallus forming smooth, thin, fragile, often ascending, rerlapping, scarcely adherent crusts $0.15-0.2 \mathrm{~mm}$. thick.

Thallus forming an irregularly nodulose crust 10-15 mm. thick.

1. L. mesomorphum ornatum.

2. L. aemulans.

1. Lithothamnium mesomórphum ornàtum Fosl. \& Howe, Bull. N. Y. Bot. Gard. 4: 129. pl. 80. f. 2; pl. 90. f. 2. 1906.

Low-littoral on a deeply shaded rock shelf, rellowish-rose or salmon-colored when living, Cave Cays, Exuma Chain. Type of variety from Cave Cays; type of species from Bermuda.

2. Lithothamnium aémulans (Fosl. \& Howe) Fosl. \& Howe, K. Norske Vidensk. Selsk. Skr. 1908 ${ }^{7}$ : 9. 190 S.

Lithothamnium fruticulosum aemulans Fosl. \& Howe, Bull. N. Y. Bot. Gard. 4: 130.pl. 81. f. 1, 2. 1906.

Encrusting an old conch shell, Andros:-Porto Rico. Type from San Juan, Porto Rico.

3. GONIOLİTHON Fosl. K. Norske Vidensk. Selsk. Skr. 19005 : 15. 1900.

[Apparently not Goniolithon Fosl. loe. eit. 1898²: 5. 1898.]

Thallus wholly and permanently crustaceous.

Thallus commonly rather loosely attached, the margins often free and ascending; conceptacles large, mostly $0.6-1.2 \mathrm{~mm}$. broad, usually with long-rostrate ostioles.

Thallus very firmly and persistently adherent.

Thallus essentially smooth and plane or roughened only by inequalities of substratum or by conceptacles, which are $200-400 \mu$ in diameter.

1. G. solubile.

2. G. accretum. 
Thallus plane or becoming verucose or mammillate, the surface minutely and irregularly tessellated: conceptacles $300-4(1) \mu$ in diameter.

Thallus with rounded-obtuse or subtruncate warts or bosses $4-10 \mathrm{~mm}$. broad and high; superficial lasers exfoliating along concentric or zonate liues ; couceptacles $1-1.2 \mathrm{~mm}$. in diameter.

Thallus fruticulose, the vrimary crust usually disappearing or concealed by the erect branches.

Branches much anastomosed, compressed or subterete and 1.25-3.1 $\mathrm{mm}$. in dianeter, or becoming flabellate or somewhat foliar and 10-2.5 mm. broad by 1-2 mm. thick.

Branches terete or subterete.

Flants attached, the intertangled frequently anastomosing branches forming lather conpact cushions.

Plants commonly free, the branches mostly erect and strict $0{ }^{*}$, in free-lying conditions, few, elongate, and rery ir. regular or somewhat cerricorn.

3. G. Boerfsescnii.

4. G. dispulatum.

5. G. acropetum.

6. G. decutesecns.

7. G. strictum.

1. Goniolithon solùbile Fosl. \& Howe, K. Norke Vidensk. Selsk. Skr. 1907: 21. 1907 .

Goniolithon Notarisii propinquum FosI. loc. cit. 1899²: 21. 1900.

Goniolithon propinquum F'osl. loc. cit. $1908^{12}$ : 4. 1908.

Lithophyllum (?) propinquum Lemoine, in Börg. Dansk Bot. Ark. $3^{1}$ : 166. f. 161, 162, 191\%.

The name solubile appears to be the first name given to this plant in the specific eategory, propinqum antedating it as a form name only.

On old corals, coral'pebbles, and old shells in shallow water, sometimes covering and smothering living corals of fruticose hahit, Rose Island, Great Bahama, Cat Island, Atwood Car, Mariguana, and Castle Island:-Florida to Barbados. Type from Culebra Island, Porto liico.

2. Goniolithon accrètum Fosl. \& Howe, Bull. X. Y. Bot. Gard. 4: 131. pl. 85. $f$. 2; pl. 91. 1906.

Lithophyllum accretum Lemoine, in Börg. Dansk Bot. Ark. 3: 159. 1917.

On surf-beaten limestone rocks near low-water mark or in tide-pools or on old corals or pebbles. Berry Islinds. South Cat Car. Witling's Island, Mariguana, and Castle Island:-Florida to American Virgin Islands. Type from Sand's Key, Florida.

3. Goniolithon Boergesénii Fosl. K. Norske Vidensk. Selsk. Skr. 1900 : 19.1901.

Porolithon Boergesenii Lemoine, in Börg. Dansk Bot. Ark. $3^{1}$ : 17S. f. 168, 169. 1917.

On old shells, corals, and calcareous pebbles in shallow water. Berry Islands, Mariguana, and Caicos Islands :-Florida to Barbados. Type from St. Croix.

4. Goniolithon dispalàtum Fosl. \& Howe, K. Norske Vidensk. Selsk. Skr. $1908^{12}: 6.1908$.

on calcareous rocks at low-water mark, Atwood Cay. Type from Atwood Cay.

5. Goniolithon acrópetum Fosl. \& Howe, Bull. Torrey Club 33: 577. 1906.

Lithophyllum acropetum Lemoine, in Börg. Dansk Bot. Ark. 3²: 151. 1917.

Sometimes approaching $G$. deentescens and $G$. strictum, which appear to intergrade and forms of which are close to the earlier-published G. frutesecus of the South P'acific.

On old corals and calcareous rock in shallow water, Cat Island and salt Cas:Porto Ialco. Type from Culebral Island, Porto lico.

6. Goniolithon decutéscens (Heyd.) Fosl.; M. A. Howe, in Britton, Fl. Bermuda 538. 1918.

Lithothamnium (?) decutescens IIeyt. 13ot. Jahrb. 28: 541. pl. 11. f. \%. 11 Ja 1901.

Goniolithon (?) spectabile Fosl. K. Norske Viilensk. Selsk. Skr. 1900" : 16. F 1901. 
? Goniolithon Rhizophorae Fosl. \& Howe, Bull. N. Y. Bot. Gard. 4: 130. pl. S. f. 2. 1906.

? Goniolithon strictum nanum F'osl. \& Howe, loc. cit. 131. pl. 82. f. 1.

? Lithophyllum strictum nanum Lemoine, in Börg. Dansk Bot. Ark. $3^{1}$ : 164. f. $159,160.1917$.

On rocks, old corals, shells of (sometimes living) molluses, ete., in shallow water, common, Rose Island, Berry lslands, Great Bahama, North Cat Cas, South Cat Cay, Eleuthera, Exuma Chain, Watling's Island, Caicos Islands, and Great Ragged Island : - Bermuda and Florida to American Virgin Işlands. Type from Bermuda.

7. Goniolithon stríctum Fosl. K. Norske Vidensk. Selsk. Skr. 1900: 14. 1901.

Goniolithon intermedium Fosl. loc. cit. 15.

Lithophyllum strictum Lemoine, in Börg. Dansk Bot. Ark. 3': 164. 1917.

Mostly unattached or forming mats, in shallow water, common, New Providence, Rose Island, Andros, Berry Islands, Bimini, North Cat Cay, Cat Island, Watling's Island, and Mariguana:-Bermuda; Florida; and Jamaica. Tspe from Florida.

\section{LITHOPHÝLLUM Philippi, Wiegm. Arehir Naturgeseh.} $3^{1}: 38 \pi .183 \pi$.

Conceptacles $80-160 \mu$ broad, usually abundant: thallus thin $(100-300 \mu$ thick $)$, its surface nearly smooth or roughened by substratum.

Conceptacles 200-600 $\mu$ in diameter.

Thallus thin (mostly $50-600 \mu$ thick), smooth, forming suborbicular crusts $2-10 \mathrm{~mm}$. broad, epiphytic; vertical section showing small cells in superficial layer only.

Thallus usually thin $(200-500 \mu$; very rarely $5-10 \mathrm{~mm}$. thick): the surface showing imbricate, reniform-auriculate or semiorbicular lamellae; Fertical section showing a regular alternation of vertically elongate cells and very short flattened or discoid cells; usually on shells, old corals, etc.

Thallus $0.5 \mathrm{~mm} .-6 \mathrm{~cm}$. thick; the surface with densely crowded knobs, verucae, or short branches; vertical sections showing irregular, often subcrescentic or sublunate zonations; conceptacles $200-300 \mu$ in diameter, becoming overgrown and included.

1. L. caribaeum.

2. L. pustulatum.

3. L. prototypum.

4. L. munitum.

1. Lithophyllum caribaèum (Fosl.) Fosl, K. Norske Vidensk. Selsk. Skr. 1906²: 22. 1907 .

Lithophyllum decipiens caribaeum Fosl. loc. cit. 1906²: 1S. 1906.

Forming thin white or light pink crusts on locks, pebbles, and shells from just above low-water mark down to 15 fathoms (fide Börgesen), Watling's Island and Great Ragged Island:-Jamaica and American Virgin Islands. Type from the West Indies.

2. Lithophyllum pustulàtum (Lamour.) Fosl. K. Norske Vidensk. Selsk. Skr. $1904^{2}$ : 3. 1904.

Melobesia pustulata Lamour. Hist. Polyp. 315. pl. 12. f. 2. 1816.

Dermatolithon pustulatum Fosl. K. Nor'ske Vidensk. Selsk. Skr. 19005: 21. 1900.

On Dilophus, Dictyota, Sargassum, IIalimeda and Thalassia, in shallow water, Berry Islands, North Cat Cay, Watling's Island, Atwood Cay, and Little Inagua :New England to Jamaica; Europe. Type from France.

3. Lithophyllum prototỳpum Fosl. K. Norske Vidensk. Selsk. Skr. 1897¹ 18. 1897.

Dermatolithon (?) prototypus F'osl. loc. cit. 19005: 22. 1900.

On old corals, shells, etc., near low-water mark or in shallow water, Exuma Chain and Atwood Cay:-Florida; Jamaica; Porto Rico; and American Virgin Islands. Type from St. Croix. 
4. Lithophyllum munitum Fosl. \& Howe, Bull. N. Y. Bot. Gard. 4: 13․ pl, 86, 88, 89. 1906.

Corering an old coral near low-water mark under shelring rocks, Care Cays, Exuma Chain :- Jamaica and I'orto Rico. Type from Care Cays.

5. POROLithoN Fosl. K. Norske Vidensk. Selsk. Skr. 1909²: 57. 1909.

Vertical sections (of decalcified material) showing vertical rows of small oral, sub. globose, or ellipsoidal perithallic cells, mostly 4-1 $-\mu$ high, with the firmly coherent horizontal lamellations usually obscure or unrecognizable; grouped heterocysts mostly $13-15 \mu$ broad.

Vertical sections (of decalcified material) showing distinct horizontal lamellations, easily separable in pairs, each pair consisting of one moderately long-celled layer (cells 12-25 $\mu$ high) and one inconspicuous short-celled layer (cells $3-6 \mu$ high) ; grouped heterocysts mostly $20-26 \mu$ broad.

1. P. pachydermum.

1. Porolithon pachydérmum (Fosl.) Fosl. loc. cit.

Lithophyllum oncodes pachydermum Fosl. loc. cit. 1904²: 5. 1904.

Lithophyllum pachydermum Fosl. K. Norske Vidensk. Selsk. Aarsber. 1905: $22(6) .1906$.

On rocks, corals, corallines, etc., near low-water mark, New Proridence, Berry Islands, Great Bahama. South Cat Cay, Atwood Cas, Mariguana, and Great Ragged Island:-Jamaica; Porto Rico; American Virgin Islands; and Barbados. Type from West Indies.

2. Porolithon improcèrum (Fosl. \& Howe) Lemoine; in Börg. Dansk Bot. Ark. $3^{1}: 151.1917$.

Goniolithon improcerum Fosl. \& Howe, K. Norske Vidensk. Selsk. Skr. $1907^{\circ}: 24.1907$.

Hydrolithon improcerum Fosl. loc. eit. 1909²: 55. 1909.

on old corals or calcareous rocks, near low-watel mark.

The basis for recording this species from the Bahamas is a note from II. Foslie (in litt.) to the effect that a specimen of Goniolithon propinquum (=G. solubile) from Jariguana (Hoxe 5336) was "partly covering Goniolithon (IIydrotithon) improcerum." In the type (from Jamaica), the species accompanied Porolithon pachydermum, which it resembles in habit. In structure the plant is suggestive of Lithophyllum prototypum, from which, however, it differs in the presence of heterocysts (in groups) as well as in general habit and in the mostly smaller conceptacles.

\section{FOSLIÉlLA M. A. Howe, nom. nov.}

Type: Melobesia farinosa Lamour. Hist. Polyp. 315. pl. 12. f. 3. 1516. Melobesia, subgen. Eu Melobesia Fosl.K. Norske Vidensk. Selsk. Skr. $1905^{3}: 1905$. Melobesia Lamour. p. p. min. Hist. Polyp. 313. 1516. Not Melobesia Lamour. Nouv. Bull. Sci. Soc. Philom. 3: 186. 1812 (type, Corallina mombranacea Esper).

Thallus $1-3$ cells thick.

Heterocysts plesent: growing on other algae. 1. F. farinosa.

IIcterocysts wanting; growing on Thalassia.

Thallus mostly $\mathrm{S}-10$ cells thick except at or near the unistratose margin; growing on Chamacdoris.

2. F. Lejolisii.

3. F. Chamaedoris.

1. Fosliella farinòsa (Lamour.) M. A. Howe, comb. nor.

Melobesia farinosa Lamour. Hist. Polyp. 315. pl. 12. f. 3. 1816.

On rarious algae (Dietyota, Dilophus, Fadina, Surgassum, and I'olysipluonia), in shallow water, very common, Lose lsland, Berry lslands, Watling's Island, Marlguana, and Little Inagua:-Massachusetts to Larbados; widely distributed. Type European. 
2. Fosliella Lejolìsii (Rosan.) M. A. Howe, comb. nov.

Melobesia Lejolisii Rosan. Mém. Soc. Imp. Sci. Nat. Cherbourg 12: 62. pl. 1. f. 1-13. 1866.

On Thalassin in shallow water. Berry Islands and Watling's Island:-Nova Scotla to Floridis: Europe. Type from Clerbourg. France.

3. Fosliella Chamaedòris (F'osl. \& Howe) MI. A. Howe, comb. nov.

Lithophyllum Chamacdoris Fosl. \& Horre, Bull. X. Y. Bot. Gard. 4: 134. pl. 90. f. 1. 1906.

Melobesia (Pliostroma) Chamaedoris Fosl. \& Howe, K. Norske Vidensk. Selsk. Skr. 1908 ${ }^{11}$ : 6. 1908.

Encrusting and often completely encircling the stalks of Chamaedoris Peniculum, from low-water mark (under shelving locks) down to a depth of 10 meters (fide Börgesen), Cave Cays, Exuma Chain:- American Virgin Islands. Type from Cave Cass.

\section{AMPHIRòA Lamour. Nour. Bull. Sci. Soc. Plilom. 3: 186. 1812.}

Thallus usually distinctly flattened, $1-3 \mathrm{~mm}$. broad, the branches $2-5$ at a node, often patent or arcuate-deflexed. Thallus terete or subterete, $0.15-1.4 \mathrm{~mm}$. in diameter.

Thallus $0.15-0.6 \mathrm{~mm}$. in diameter, usually yellowish or pale rose when living, commonly dichotomous (rarely 3-5 branches at a node) ; nodes at the dichotomies, the nodal cushions conspicuous, often protuberant or their diameter equaling that of the segment, which is often enlarged at the nodes.

Thallus $0.45-1.4 \mathrm{~mm}$, in diameter, bluish-riolet when living; nodes mostly above the dichotomies, often obscure or more or less deficient, the nodal cushious short and their diameter $1 / 2-4 / 5$ that of the segments.

1. A. Tribulus,

1. A. Tribulus.

2. A. fragilissima.
3. A. rigida antillana.

1. Amphiroa Tríbulus (Ell. \& Soland.) Lamour. loc. cit.

Corallina Tribulus Ell. \& Soland. Nat. Hist. Zooph. 124. pl. 21. f. e. 17s6.

In shallow water, South Cat Cay and Watling's Island:-Cuba and Porto Rico. Type from the West Indies.

\section{Amphiroa fragilíssima (L.) Lamour. Hist. Polyp. 298. 1816.}

Corallina fragilissima I. Syst. Nat. 1: 806.1755 [ed. 10].

Amphiroa debilis Kütz. Sp. Alg. 700. 1949.

Variable as to diameter of the segments and in the presence or absence of nodal enlargements of the segments, and possibly including two spcies. Whether Linnaeus originally described the species from an actual specimen or relied wholly upon Sloane's description and figure of a Jamaican plant is not altogether clear.

Forming mats, especially in association with Thalassia and Cymodocea in shallow bass, common, New Providence, Berry Islands, Bimini, South Cat Cay, North Cat Cas, Watling's Island. Atwood Cay, and IIartguana :-Bermuda and Florida to Barbados ; East Indies. Type "in Indiis" (Jamaica?).

3. Amphiroa rígida antillàna Börg. Dansk Bot. Ark. 31: 182. f. 171-173. 1917.

In shallow water. often with A. fragilissima, but always distinct, South Cat Cay, North Cat Cay, and IIariguana:-Florida to Barbados. Tjpe (of var.) from St. Croix.

\section{CoRALlina L. Syst. Nat. 1: 805.1758 [ed. 10].}

Rather raguely and irregularly pinnate or subverticillate, the branches often few ; segments of main axes terete or subterete, 1.5-6 times as Jong as broad.

Pinnate or bipinnate, the rapidly tapering branchlets somewhat penicillate or fasciculate; segments of maiu axes distinctly flattened, cuneate-obovate, or inversely deltoid, about as broad as long.

1. C. cubensis.

2. C. subulata. 
1. Corallina cubénsis (Mont.) Kütz. Tab. Phyc. 8: 37. pl. 7\%.f. c, e, f. 1858.

Jania cubensis Mont.; Kütz. Sp. Alg. 709. 1549.

Forming dense cushions on ratrous algae (Sargassum, Galaxaura, Digcnca, etc.) and on rocks with other algae, in shallow water, often associated with species of Jania, New Providence, Berry Islands, Great Bahama, Gun Cay, Caicos Islands, and Great Iagged Island:-Florida to the American Yirgin Islands. Type from Cuba.

2. Corallina subulàta Ell. \& Soland. Nat. Hist. Zooph. 119. pl. 21. f. B, b. 1 IS6.

On or with Amansia multifila, Elenthera:-Brazil. Type from the West Indies.

9. JÀNIA Lamour. Nous. Bull. Sci. Soc. Philom. 3: 186. 1812.

The characters relied upon to distinguish the currently recognized European and West Indian species of Jania appear to be unstable and unsatisfactory and the determinations often arbitrary.

Branches mostly strict and fastigiate, mostly $100-160 \mu$ in diameter, the terminal segments usually acute or taper-pointed.

Dichotomies mostly wide-angled, the branehes often subdiraricate, recurred, and interworen, the terminal segments usually obtuse.

Segments mostly $90-150 \mu$ in diameter and $2-4$ times as long is broad.

Segments mostly $50-100 \mu$ in diameter and $t-10$ times as long as broad.

1. J. rutens.

2. J.adiacrens.

3. J. capillacea. .

1. Jania rùbens (L.) Lamour. loc. cit.

Corallina mbens L. Syst. Nat. 1: S06. 175S [ed. 10].

On Surgassum, Chondrit, and other algtle, from 10 -water mark down to a depth of $10-20$ meters, Rose Island, Great Bahama, Exuma Chain, Watling's Island, Caicos Islands, and Great liagged Island:-Bermuda; Florida; Cuba; and probably throughout the West Indies. Type European.

2. Jania adhaèrens Lamour. Hist. Polyp. 270. 1816.

Corallina adhaerens Kütz. Tab. Phyc. 8: 40. pl. 83. f. d, f, g, h. 1555.

On Sargassum, Bryothamnion, Gelidium, ete., in shallow water :-American Virgin Islands; lied Sea; Japan. Trpe from the Jediterranean Sea (?).

3. Jania capillacea Harr. Ner. Bor.-Am. 2: St. 1853.

On Sargassum, pneamatophores of Ariccunia, etc., in shallow water, and more or less free in lagoons. New I'rovidence, Rose Island. Berry Islands, and Great liagged Island:-North Carolina and Ilorida. Type from Bahia llonda, Florida.

\section{SLB-CLASS PHAEOPHYCEAE. \\ Family 1. ECTOCARPÀCEAE.}

1. PYlaiÉlla Bory, Dict. Class. Hist. Nat. 4: 393 (as Pilayella). 1S23.

1. Pylaiella Antillàrum (Grun.) De-Toni, Syll. Alg. 3: 535. 1595.

Ectocarpus (I'ilayella) Antillarum Grun. Reise Norara Bot. 1: 46. $\mu l .4 . f$. 2. 1567 .

Pylaiella sp. Bornet, Rev. Gen. Bot. 1: 9. $18 s 9$.

Pylaiella Hooperi De-Toni, Syll. Alg. 3: 537. 1695. Probably not Ectocarmus IIooperi Harv. Ner. Bor.-Am. 1: 143. pl. 12E. 1552.

Formlng yellowlsh brown, subcylindric, wick-like tufts, 1.5-3.5 cm. ligh in tidepools and low-llttoral on surf-beaten rocks. Great Stlrrup Cay, Berry Islands:Bermuda to northern South Amerlca. Type from Guadeloupe. 
The filaments are mostly $25-40 \mu$ in diam., while Grunow's description of the type makes the diameter only $11-25 \mu$, but as the base of one of the filaments figured by Grunow is nearly $35 \mu$ broad it seems difficult to distinguish the Bahamian plant. The later-described $P$. fulvesecns (Schousb.) Bornet may be a srnonym, but perhaps differs in the more protuberant, sometimes laterally geminate sporangia.

\section{ECTOCÁRPUS Lyngh. Hydroph. Dan. 130. 1819.}

1. Ectocarpus Mitchéllae Harv. Ner. Bor.-Am. 1: 142. pl. 12G. 1852.

On Thalassia, etc., in shallow water. Berry Islands, Great Bahama, and Exuma Chain:-Massachusetts to American Virgin lslands; apparently widely distributed in temperate and tropical seas. Type from Nantucket, Nass.

\section{Family 2. SPHACELARIÀCEAE.}

1. SPHACELÀrIA Lyngb. Hydroph. Dan. 103 p.p. 1819.

1. Sphacelaria tribuloìdes Menegh. Lett, al Corinaldi 2. 1840. [Not seen.]

Low-littoral. Berry Islands:-Bermuda to Mexico and Barbados; widely distributed in the warmer seas. Type from Italy.

\section{Family 3. ENCOELIĀCEAE.}

1. PHAEOSTRÒMA Kuckuck, in Reinbold, Schrift. Naturwiss. Ver. Schleswig-Holst. 10: 43. 1593.

1. Phaeostroma pusillum Howe \& Hoyt, Mem. N. Y. Bot. Gard. 6: 109. pl. 11. f. 1-9. 1916.

Making minute discs, $0.15-0.35 \mathrm{~mm}$. in diameter, on Polysiphonia ferulacea; the unilocular sporangia mostly in sori. Berry Islands:-North Carolina (tspe).

2. ColpomènIA (Endl.) Derb. \& Sol. Mém. Phys. Alg. 11. 1856.

]. Colpomenia sinuòsa (Roth) Derb. \& Sol. loc. cit. [C. sinuata by misprint.]

Ulva sinuosa Roth, Cat. Bot. 3: 327. pl. 12. 1806.

Encoelium sinuosum. Ag. Sp. Alg. 1: 146. 1820.

Asperococcus sinuosus Bory, Expéd. Sci. Morée 3²: 326. 1832.

Hydroclathrus sinuosus Zanard.; Mitehell, in Murray, Phye. Mem. 53-56. pl. 14. pl. 15. f. 1. 1893.

On rocks near low-water mark or in shallow water. Gun Cay:-Bermuda and Florida to Brazil : Peru; widely distributed in warm-temperate and tropical seas. Type from near Cadiz, Spain.

3. HYdRocLÁthrus Bory, Dict. Class. Hist. Nat. 8: 419.1825.

1. Hydroclathrus clathràtus (Bory) Mr. A. Howe, comb. nor.

Encoelium clathratum (Bory) Ag. Sp. Alg. 1: 412. 1822.

Hydroclathrus cancellatus Bory, Dict. Class. Hist. Nat. 8: 419. 1825.

Stilophora clathrata Ag. F'lora 10: 642. 1827.

Asperococcus clathratus J. Ag. Sp. Alg. 1: 75. 1818.

On rocks near low-water mark or in shallow. water. Gun Cay and North Cat Cay :-Bermuda and Florida to Brazil ; widely distributed in warm-temperate and tropical seas. Type from Belle Isle, France. 


\section{Family 4. MESOGLOIÀCEAE.}

1. CAStäGNeA Derb. \& Sol. Mém. Phys. Alg. 56. 1856.

1. ? Castagnea Zósterae (Mohr) Thuret; Le Jol. Liste Mar. Alg. Cherbourg 85. 1864 .

Rivularia Zostcrae Mohr, in Weber, Beitr. Naturkunde 2: 36 7.1810.

Mesogloia Zosterae Aresch. Linnaea 16: 225. pl. 8. f. 1a, b. 1842.

On Thalassia, etc., Berry Islands and North Cat Cay:-Bermuda to American Virgin Islands; Europe. 'Type from near Kiel, Germany.

\section{Family 5. CUTLERIÀCEAE.}

1. AGLAOzònIA Zanard. Saggio Class. Fie. 15, 39. [Mrr] 1813.

Padinella Aresch. Linnaea 17: 259. [My-Je] 1843.

1. Aglaozonia canariénsis Sauv. Soe. Sei, d'Areachon Trav. Lab. 8: 79. 1905. Börg. Dansk Bot. Ark, 2²: 37. 1914.

Forming dark brown closely adherent crusts on ealcareous rocks or old corals at low-water malk or a little above. New Providence, Rose Island, Atwood Cay, Mariguana, and Caicos Islands:-American Virgin Islands; Canary Islands. Type from the Canary Islands.

This plant (sterile) bears much resemblance to yonng prostrate conditions of Zonaria variegate in habit and color, in the apieal margin of large cells, and in general structure, but seems to differ in the usually thinner and more closely adherent thallus, the absence of frequent or occasional mats or tufts of brown rhizoids, and, under the compound microseope, in the more translucent thallus with a more obviously tessellated dorsal surface, 4-16 cells of the dorsal epidermis corresponding to one of the large medullary cells, while in $Z$. variegata $1-4$ (more elougate) epidermal cells correspond to and overlie a single large medullary cell; and, in section, the dorso-rentrality is seen to be more pronounced, the dorsal epidermis always consisting of more numerous and smaller cells than the ventral epidermis, while in $Z$. variegata the two epidermal layers are essentially the same.

\section{Family 6. FUCÀCEAE.}

1. CYSTOSEIrA Ag. Sp. Alg. 1: 50. 1820.

1. Cystoseira Myrìca (S. G. Gmel.) Ag. loc. cit. 53.

Fucus Myrica S. G. Gmel. Hist. Fue. 88. pl. 3. f. 1. 1768.

On rocks and in tide-pools, near low-water mark. New Providence, Rose Island, Berry Islands, Great Bahama, and Gun Cay:-Florida and the lied Sea. Type locality unknown.

2. TURBINÀrIA Lamour.; Bory, Voy. Coquille 116. 182 S.

Petiole wings entire, the lamina usually with vesicle. Petiole wings dentate, the lamina without resicle.

1. T. turbinata.

2. T. tricostata.

1. Turbinaria turbinàta (L.) Kuntze, Rev. Gen. Pl. 3: 434. 1898.

Fucus turbinatus L. Sp. PI. 1160. 1753. (Excluding presumably spurious "type" from Sumatra in herb. Limn.).

Sargassum turbinatum Ag. Sp. Alg. 1: 41. 1820.

Turbinaria vulgaris trialata J. Ag. Sp. Alg. 1: 26s. ists.

Turbinaria trialata Kïtz. Tab. Phye, 10: 24. pl. 6\%. 1860.

On surge-swept rocks, near low-water mark. New Provldence, Joulter's Cay, Berry Islands, Great Bahama, Abaco, George Island, Watling's Island, Atwood Cay, Caicos Islands. Great Ragged lsland, and Luguilla Isles :- Florida to northeru South Amerlca; Indian Ocean. Type from Jamalca. 
2. Turbinaria tricostàta Barton, Trans. Linn. Soc. Bot. II. 3: 218. pl. 54. f. s. 1891.

On surge-swept rocks, low-littoral. New Providence, South Cat Car, and Gun Cas :-Bermuda to Guadeloupe. Type from Guadeloupe (?).

Alp)axenty intergrading with $T$. turbinata.

\section{SARGÁSSUM Ag. Sp. Alg. 1: 1. 1820.}

Floating and sterile.

Leaves rery narrowls linear or linear-filiform, mostly 1-2 mm. broad, the teeth aculeate-acumiuate; resicles commonly aristate-apiculate.

Leares linear or linear-lanceolate, mostly 2-4 mm. broad, the teeth triangular-acuminate; resicles muticous.

Normally attached (uos. 3 and 10 sometimes more or less pelagic).

Leares mostly narrowly linear, usually 7-50 times as long as maximum width.

Leares rather rigid, cryptostomata usually somewhat obscure, pedicels of the muticous resicles commonly shorter than the resicles themselves; receptacles in rathel short axillary clusters.

Leaves serrate-dentile, the costa prominent and often dentate; resicles commonly large and clowded: stems often $1-2 \mathrm{~m}$. long and subsimple.

Leares subentire, the costa not dentate; resicles usually scattered; stems mostly 2-10 dm. long.

Leaves thinly membranous. crsptostomata obrious, pedicels of the often appendaged usually scattered vesicles commonly of about the same length as the resicles themselres; receptacles finally elongate and often forming a kind of loose terminal panicle through reduction of the leares.

Leaves ovate, orate-elliptic, oblong, lanceolate, or rather loroadly linear.

Cryptostomata elerated, rery large and conspicuous $(0.6-0.9 \mathrm{~mm}$. in maximum diam.) often elliptic, in a single series on either side of the costa: leaves linear or lanceolate.

Cryptostomata smaller, sometimes obscure or wanting. Cryptostomata obvious.

Receptacles mostly in a rather dense terminal panicle; leaves lanceolate or linear-oblong. rather obscurely and obtusely dentate or margins merely sinuate, cryptostomata in almost a single series on either side of the costa ; resicles sometimes fer.

Receptacles obriously lateral and axillars, elongate or contracted; crrptostomata in more than a single series.

Leares linear or linear-oblong, mostly 4-8 times as long as broad, sharply serratedentate; resicles mostly ellipsoid or oboroid, often subapiculate; receptacles contracted, often ( $(?$ ?) spinose-dentate.

Leares ovate, elliptic. obloug, or lanceolate, mostly 2-4 times as long as broad, commonly crisped, variously aculeate-dentate or Ilex-toothed; vesicles globose or subglobose, muticous; receptacles sometimes elongate, occasionally with a few subspinescent processes.

Cryptostomata obscure or wanting: leares coriaceous, oblong-elliptic, spinescent-dentate or entire or sub-entire; receptacles more ol less spinescent-dentate.

1. S. natans.

2. S. fluitans.

3. S. pteropleuron.

4. S. eymosum.

5. S. Filipendula.

6. S. platycarpum.

7. S. lendigrrum.

8. S. vulgare?

9. $S$ polyceratium.

10. S. Hystrix.

1. Sargassum nàtans (L.) Meyen, Wiegm. Arch. Naturgesch. $4^{2}: 185.1838$.

Fucus natans L. Sp. P1. 1160. 1753.

Fucus Sargasso S. G. Gmel. Hist. Fuc. 92. 1768.

Fucus bacciferus Turn. Hist. Fne. 1: 105. pl. 47. 1808.

Sargassum bacciferum Ag. Sp. Alg. 1: 6. 1820.

The chief ingredient of the "Sargasso Sea"-found floating or washed ashore throughout the archipelago. 
2. Sargassum flùitans (Börg.) Börg. Dansk Bot. Ark. 2²: 66. 1914.

Sargassum Hystrix fluitans Börg. Mindeskr. for Japetus Stecnstrup 32: 11. 1914.

Often associated with S. natans. New Providence, Rose Island, Great Bahama, Cat Island, and Watling's Island.

3. Sargassum pteropleùron Grun. Reise Novara Bot. 1: 55. pl. 5. f. 1. 1867.

In 1-3 meters of water, often detached and floating. New Plovidence, Rose Island, Berry Islands, Andros, Joulter"s Cay, Great Bahama, Green Cay, Exuma Chain, Watling's Island, Caicos Islands, and Orange Cay:-Bermuda and Florida. Type from New I'rovidence.

4. Sargassum cymòsum Ag. Sp. Alg. 1: 20. 1520.

Sargassum stenophyllum (Mert.) Mart. Ic. Pl. Crypt. S. pl. 5. 1828.

Sargassum ramifolium Kütz. Phye. Gen. 362. 1843.

Sargassum rigidulum Kütz. Sp. Alg. 615. 1849.

In shallow water and floating. Great Bahama, Exuma Chain, and Cat Island :Bermuda to Brazil. Type from Lrazil.

5. Sargassum Filipéndula Ag. Syst. Alg. 300. 182t.

Sargassum ILontagnei Bail.; Harv. Ner. Bor.-Am. 1: 5S. pl. 1A. 1852.

Sargassum Filipendula Montagnei Collins \& Hervey, Proc. Am. Acad. 53: S3. 1917.

Apparently rare in the Bahamas, its p!ace being taken by S. pteropleuron. New Providence and Orange Cay:-Massachusetts and Bermuda to South America. Type from the Gulf of Mexico (?).

6. Sargassum platycárpum Mont. Sci. Nat. Bot. II. 18: 24 S. $1 \mathrm{~S} 42$.

Carpacanthus platycarpus Kütz. Sp. Alg. 623. 1849.

In shallow water. New Providence, Berry Islands, Great Bahama, South Cat Car, and Exuma Chain:-Cuba, Jamaica, I'orto lico, and Martinique. Type from Martinique.

The most sharply defined species of Sargassum of the West Indian region, rather constint in the form of its leaves and easily identified by its very large elerated cryptostomata in a single series on each side of the costa.

7. Sargassum lendígerum (L.) Ag. Sp. Alg. 1: 9. 1820.

Fucus lendigerus L. Sp. Pl. 1160. 1753.

Nenr low-water mark. Berry Islands :-Bermuda to St. Thomas. Type from Ascension Island.

\section{8. ? Sargassum vulgàre Ag. Sp. Alg. 1: 3, 1820.}

Fucus natans Turn. Hist. Fue. 1: 99. pl. 46. 180S. Not F. natans L.

Near low-water mark. Andros, Great Bahama, Abaco, Watling's Island, Atwood Cay, Mariguana, Caicos Islands, Little Inalgua, and Castle Island:-Supposed to be widely distributed in warm-temperate and tropical seas. Type locallity unknown.

The plants that are now placed provisionally and doubtfully under $S$. 2 ulgare form a rather homogeneous group and are npparently different in species from the more diversified assemblage here grouned under ś, pulyerntium. They differ from Turner's figure $a$, which seems to have furnished the type idea for $S$. rulgure, in their more virgate habit, their somewhat smallel (both shorter and narrowel'), more sharply serrate and less sinuate-dentate leares, and their shorter, probably more spinose-dentate receptacles.

9. Sargassum polyceràtium Mont. Ann. Sei. Nat. Bot. II. 8: 356. 1837; Pl. Cell. Cuba 72. $p l$. 1. 1842.

Fucus foliosissimus Lamour. Essai 16. pl. 1. f. 1. 1S13. (Nomen nudum aut seminudum.)

Sargassum leptocarpum Kütz. Phyc. Gen, 362. 1843. 
Sargassum pteropus Küiz. Sp. Alg. 60S. 1 1S49.

Sargassum bahiense Kütz. loc. cit.

Sargassum trachyphyllum Kütz. loc. cit. 609.

Sargassum polyphyllum Küitz. loc. eit. Not S. polyphyllum J. Ag. Sp. Alg. 1: 308. 1848.

Carpacanthus polyceratius Kütz. loc. cit. 624.

Carpacanthus spinulosus Kiitz. Tab. Phyc. 11: 15. pl. 46 f. II. 1861.

At low-water mark and in shallow water. New Providence. Rose Island, Great Bahama, North Cat Cay, Watling's Island, Caicos Islands, and Castle Island:-West Indies in general. Type from Cuba.

The species, as here conceived, shows great variability in form, size, and texture of the leaves, in the size and number of the cryptostomata, in smoothness or roughness of the stem, and in the presence or absence of spines on the receptacles, but specific segregations seem impossible.

10. Sargassum Hýstrix J. Äg. Öfv. K. Vet.-Akad. Förh. 4: 7. 1847.

Sargassum Hystrix buxifolium (Chauv.) J. Ag. Sp. Alg. 1: 322. 1848.

Usually found floating or washed ashore, but also attached, in about $8 \mathrm{~m}$. of water Ver Providence. Joulter's Cas Abaco, Berry Islands, and Exuma Chain :off North Carolina, Isle of Pines, and Mexico. Type from the Campeche Banks.

A form with large oblong entire or subentire leares is var. buxifolium.

\section{Family 7. DICTYOTÀCEAE.}

1. ZONĀrRA Drap.; Ag. Syn. Alg. Scand. xx. 1817.

Stypopodium Kütz. Linnaea 17: 97. 1843.

PhyCOPteris Kütz. loc. cit.

Grmnosorus J. Ag. Anal. Alg. Cont. 1: 9. 1894. Not Gymnosorus Trevis. Alg. Coce. 108. 1848.

Thallus obscurely zonate, brownish both when living and on drying, $2-7 \mathrm{~cm}$, long, at first more or less prostrate or subrenent and semiorbicular or flabelliform, later free except at the broad or occasionally substipitate base and showing few entire or sparingly laciniate flabelliform lobes.

Thallus distinctly zonate, more or less brownish blue-green and iridescent when living, commonly blackening on drying. mostly $7-30 \mathrm{~cm}$. long, erect, stipitate or substipitate, repeatedir cleft or lobed, the lobes cuneate, cuneate-oblong, cuneate-flabelliform, or linear, occasionally lacerate or fimbriate-laciniate.

1. Z. variegata.

1. Zonaria variegàta (Lamour.) Ag. loc. cit.

Dictyota variegata Lamour. Nouv. Bull. Sei. Soc. Philom. 1: 331. 1809.

Zonaria collaris Ag. Sp. Alg. 127. 1820.

Padina variegata Gaill. in Dict. Sci. Nat. 53: 371. 1828.

Spatoglossum variegatum Kütz. Sp. Alg. 560. 1849.

Gymnosorus variegatus .J. Ag. Anal. Alg. Cont. 1: 11. 1894.

Gymnosorus collaris J. Ag. loc. cit.

On calcareous algae, rocks, old corals, Gorgoniidae, roots of Rhizophora, shells of conchs, etc. common from low-water mark down to a depth of several meters : often found rashed ashore. New Providence, Rose Island, Andros, Berry Islands, Great Bahama, Gun Cay, Abaco, Green Cay, Exuma Chain, Watling's Island, Atwood Cay. Mariguana, Caicos Islands, and Great Ragged Island:-Bermuda and Florida to Brazil: Canary Islands: Philippines: widely distributed in the warmer seas. Type from the "Antilles." Prostrate or subrepent forms are to be distinguished carefully from Aglaozonia canariensis.

2. Zonaria zonàlis (Lamour.) M. A. Howe, in Britton, Fl. Bermuda 507. 1918.

Fucus zonalis Lamour. Diss. 38. pl. 25. f. 1. 180 5.

Dictyota zonata Lamour. Nour. Bull. Sei. Soc. Philom. 1: 331. 1809.

Zonaria lobata Ag. Syst. Alg. 265. 1524.

Stypopodium lobatum Kütz. Tab. Phyc. 9: 25. pl. 63. f. I. 1859.

On rocks, etc., in shallow water, in moderately exposed positions. New Providence, Berry Islands, South Bimini, Gun Cay, Exuma Chain, and Atwood Cay ; Bermuda to Brazil; Canary Islands. Type from Santo Domingo. 
2. PADINA Adans. Fam. Pl, 2: 13. 1763.

Thallus consisting of only two larers of cells except near base; tetrasporic sori just abore evers second piliferous line and prorided with eranescent indusium.

Thallus consisting of $3-6$ lasers of cells except at sometimes bistratose apical margin; tetrasporic sori scattered irregularly or forming an irregular confluent line near middle of each interpilar zone, indusium subpersistent.

1. P. Sonctue-Crucis.

2. P. Tickersiae.

1. Padina Sánctae-Crùcis Börg. Dansk Bot. Ark. 2²: 45. f. 27, 28. 1914.

Common on rocks near the low-water mark. New Providence, Perry Islands, Gun Cay, Exuma Chain, Crooked Island, Watling's Island, Mnriguana, Caicos Islands, Great Ragged Island, Orange Cay, and Anguilla Isles:- Bermuda and Florida to northern South America. Type fiom St. Croix.

\section{o. Padina Vickérsiae Hoyt, sp. nor.*}

Spatoglossum variegatum Kütz. Sp. Alg. 560 p.p. 1849.

Zonaria variegata Kütz. Tab. Phre. 9: 30 p.p. pl. 73. f. TI. 15.5. Not Zonaria variegata Lamoux. Nour. Bull. Sci. Soc. Philom. 1: 331. 1509.

Padina variegata Hauck, Hedmigia 26: 42. 1857; Vickers, Phyc. Barb. 2: 37. pl. 8. 190S. Not Padina variegata Gaill. in Dict. Sei. Nat. 53: 371. 1929.

Thallus stipitate, 4-22 cm. tall, $5-37 \mathrm{~cm}$. broad, entire when young, becoming repeatedly more or less deeply laciniate, the segments varying from cuneatespatulate to fan-shaped, sometimes encrusted with lime, the interpilar zones $1.5-8 \mathrm{~mm}$. ride, often inconspicuous in older parts, the subterete, rhizoidcorered stipe commonly 3-12 mm. long; lamina of 2 or 3 layers of cells at revolute apical margin, of $\frac{1}{4}$ layers throughout most of thallus, becoming $6-8$ layers toward base; epidermal cells about one half as long as the central cells; dioicous; antheridia and oogonia in often broken lines near the middle of each interpilar zone, occurring on both surfaces but chiefly on the rentral, the oogonia with a thin evanescent indusium, the antheridia naked; tetrasporangia horne in a similar manner, often in scattered irregular sori near middle of interpilar zone, the thin indusium commonly subpersistent.

Type a tetrasporic plant collected from Fort Macon jetts, Peaufort. North Carolina, by W. D. Hort, August 23, 1907, and deposited in the $T$. S. National Merbarium. Representatices of this species have often been erroneously identifed with Jadinn paronin (L.) Gaill, and I'. Durvillaei Bory. Padima dubia II auck, from East Africa, is a much closer relatire and may nrove to be identical.

In shallow water. New Providence. Perrs Islands, and Eleuthera:-Bermuda and Forth Carolina to Brazil. Type from North Carolina.

3. NEUROCÁRPUS Web. \& Mohr, Beitr. Naturk. 1: 300 (242-246). 1505.

Dictropteris Lamour. Nour. Bull. Sci. Soc. Philom. 1: 332. Ny 1809.

Polmpodoidea Stackh. Mém. Soc. Imp. Nat. Moscou 2: 96, 97. 1809.

Haliseris (Mich.) Ag. Sp. Alg. 1: 141. 1820.

1. Neurocarpus Jústii (Lamour.) Kuntze, Rer. Gen. Pl. 2: 90т. 1891.

Dictyopteris Justii Lamour. Nour. Bull. Sci. Soc. Philom. 1: 332. pl. 6. f. 2A. 1809.

Mlaliseris Justii Ag. Sp. Alg. 1: 142. 1820.

On rocks in 1-20 meters of water. Gun Car, Abaco, and Green Turtle Cay :Bermuda and Florida to Barbados. Type from Santo Domingo.

Neurocarpus delifatulus (Lamour.) Kuntze is of general occurrener in the West Indlan reglon and is to be expected in the Paliamas. It is a much smaller and more delicate plant than N. Justii, the thallus segments being mostly nnly $1-4 \mathrm{~mm}$. broad, whlle in $\mathcal{T}$. Justii they are $1-3 \mathrm{~cm}$. broad: when living it commonls shows beautlfully lridescent blue-green hues. It grows in sheltered and well-shaded places.

* This preliminary diagnosis is published wlth the permission of the $\mathbf{C}$. S. Commissloner of Fisherles. 
4. DICtYòtA Lamour. Nouv. Bull. Sei. Soe. Philom. 1: 331. My 1809. Jour. de Bot. 2: 38. 1809.

Branching more or less regularly dichotomous.

Segments mostly $1-5 \mathrm{~mm}$. broad, the apical obtuse, patent or suberect. Segments linear, the dichotomies usually $1-2 \mathrm{~cm}$. apart. Segments oblong, the dichotomies usually $0 . \overline{5}-1 \mathrm{~cm}$. apart.

Segmeuts mostly $0.3-1 \mathrm{~mm}$. broad, the apical acute, acuminate or subolituse, divaricite or subdiriricate.

Branching dichotomo-pinnatifid $01^{\circ}$ cervicorn.

Branching cerricorn, or dichotomo-subpinnate below and dichotomous above: segments narrowly ribbon-shaped, mostly $0.5-1 \mathrm{~mm}$. broad, often proliferous along the middle, the apical segments acute or subobtuse, sometimes subterete or subconic, mostly patent.

Branching dichotomo-pinnatifid, main segments or axes mostly 2-5 nm. broad, the apices usually acuminate, sometimes obtuse.

1. D. dichotoma.

2. D. Bartayresii.

3. D. divaricata.

4. D. cervicornis.

5. D. dentata.

1. Dictyota dichótoma (Huds.) Lamour. Nouv. Bull. Sei. Soc. Philom. 1: 331. My 1809 .

Vlva dichotoma Huds. Fl. Angl. 476. 1762.

From near low-water mark down to a depth of several meters. Rose Island, Berry Islands, Bimini, Exuma Chain, Watling's Island, Atwood Cay, Mariguana, Caicos Islands, and Great Ragged Island:-Bermuda, North Carolina, Florida and West Indies; widely distributed in temperate and tropical seas. Type from Isle of Talnes, England.

2. Dictyota Bartayrèsii Lamour. loc. eit.

Dictyota Bartayresiana Lamour. Jour. de Bot. 2: 43. 1809.

Dictyota patens J. Ag. Till Alg. Syst. 2: 93. 1882.

Common, mostly in shallow water, often slightly iridescent when living. New Providence, Rose Island, Berry Islands, South Cat Cay, North Cat Cay, Eleuthera, Watling's Island, Atwood Cay, Mariguana, Caicos Islands, and Great Ragged Island:West Indies. Type from Santo Domingo (?).

The type specimen (in "Zonaria dichotoma" cover in herb. Lamour. at Caen) has segments $2-5 \mathrm{~mm}$. broad and obtuse apices. Specimens with acute and acuminate apices referred to this species by later writers are to be looked upon as probably representing the more dichotomous or less pinnate conditions of $D$. dentata.

3. Dictyota divaricàta Lamour. loe. eit.

In shallow water. New Providence, Berry Islands, Great Bahama, North Cat Cas, Exuma Chain, and Caicos Islands:- West Indies and warmer seas generally. Type from the Jediterranean.

Apparently intergrades with $D$. cervicornis, $D$. indiea, and D. Bartayresii.

4. Dictyota cervicórnis Küutz. Tab. Phye. 9: 11. pl. 24. f. II. 1859.

Dictyota Fasciola Harv. Ner. Bor.-Am. 1: 108. pl. 8B. 1852. Not Fucus Fasciola Roth (= Dilophus repens J. Ag.).

On rocks near low-water mark in rather exposed situations. New Providence, Rose Island, Berry Islands, Great Bahama, Gun Cay, Exuma Chain, Mariguana, Caicos Islands, and Little Inagua:-Bermuda, Florida, and probably West Indies in general. Type from Key Test, Florida.

often proliferous near the middle line of thallus and easily confused with Dilophus guinecnsis which is rather similar both in general habit and in tendency to proliferate.

5. Dictyota dentàta Lamour. Nouv. Bull. Sci. Soc. Philom. 1: 331 . My 1809.

Fucus atomarius S. G. Gmel. Hist. Fue. 125. pl. 10. f. 1. 1768. Not D. Atomaria Grev. Not Dictyota Atomaria Hauck.

Ulva Mertensii Mart. Fl. Bras. Acot. 21. 1833.

Dictyota Brongiartii J. Ag. Limnaea 15: 5. 1841.

Dictyota Mertensii Kütz. Tab. Phye. 9: 15. pl. 36. f. 1. 1859.

Dictyota subdentata Kütz. loc. cit. 14. pl. 33. f. II.

On rocks in shallow water. New Providence, Berry Islands, Great Bahama, North Cat Cay, Gun Cay, Atwood Cay, Mariguana, Caicos Islands, and Great Ragged Island:-Bermuda and Florida to Brazil. Type from the Antilles. 


\section{DILòpHus J. Ag. Till Alg. Syst. 2: 106. 18s2.}

Segments mostly $0.3-1 \mathrm{~mm}$. broad, the apices acute, acuminate or subobtuse; medulla $2-4$ cells thick or here and there only 1 cell thick.

Segments mostly $1-2 \mathrm{~mm}$. broad, the apices obtuse: medulla $2-\bar{y}$

cells thick at or near the margins, 1 or 2 cells thick in the middle. 2. D. alternans.

1. Dilophus guineẻnsis (Kütz.) J. Ag. loc. eit. 108.

Spatoglossum guineense Kütz. Phye. Gen. 339. 1843.

?Dictyota Antiguae Kiitz. Tab. Phyc. 9: 16. pl. 3\%. f. II. 1859.

Dictyota guincensis Crouan; Mazé \& Sehramm, Alg. Guad. 126. 1870-1877.

On rocks in shallow water in rather exposed situations. Rose Island, Rerry Islands, Great Bahama, Gun Cay, Watling's Island, Mariguana. Caieos Islands, Little Inagua, and Great Ragged Island:- Iermuda and Florida to Jamaica and Barbados. Type fiom St. Thomas.

Often proliferous along the middle line and often closely resembling Dictyota cericornis but usually darker on drying.

2. Dilophus álternans J. Ag. loc. cit. 108.

On rocks near low-water mark. Gun Cay, North Cat Cay, South Cat Cay, and Caicos Islands:-Florida to Barbados. Type from Key Test, Florida.

6. DICTYÉrPA Collins, Proc. Am. Acał. Arts and Sei. 37: 251. 1901.

1. Dictyerpa jamaicénsis Collins, loc. cit.

On rocks in shallow water. South Cat Cay and Watling's Island:-Jamaica. Type from .Tamaica.

Resembles narrow conditions of Dilophus guincensis, but is more irregular in its branching and is terete or subterete, with a medulla more than four cells wlde. Phyc. Bor.-Am, TSO in herb. N. Y. Bot. Gard. shows tetrasporangia (?) similar to those of Dilophus guinecnsis.

\section{SuB-CLASS CHLOROPHYCEAE. Family 1. PLEUROCOCCÀCEAE.}

1. PSEUdotetráspora Wille, K. Norske Tidensk. Selsk. Skr. $1906^{3}: 20.1906$.

\section{Pseudotetraspora Antillàrum M. A. Howe, sp. nov.}

Thallus subglobose, obovoid, pyriform, saccate, or allantoid, rariously wrinkled, constricted, or bullate, mostly 2-20 mm. in length or height, often more or less explanate and lacunose with age, yellowish brown when living, brownish or dark hrown on drying; cells subglobose or ellipsoid, mostly $3-\bar{\imath} \mu$ in maximum diameter.

Fnveloping leares of IIalodule and Thalassia and older parts of the thallus of Chondrin littoratis and other marine algae, In shallow water. Sometimes waslied ashore in great quantitles. New Froridence, Rose Island, Exuma Chain and Cat Island. Type IIoue S',3, Rose Island, Jan. 2S, 1905.

The species apparently differs from the Norwegian $P$. marina. Wille in Its rel. lowlsh brown color, its larger more saccate or allantoid thallus, and the somewhat smaller cells.

\section{Family 2. PROTOCOCCÀCEAE.}

1. PROTocóccus Ag. Syst. Alg. 13. 1824.

1. Protococcus víridis Ag. loc. cit.

Plcurococcus vulgaris Naeg. Gatt. einzel. Alg. 65. pl. 4E. f. . . 1549.

On trunks of trees, etc. (det. N. S. Collins), probably common. New Provldence :-cosmopolltun. Type from Sweden. 


\section{Family 3. ULVÀCEAE.}

1. Úlva L. Sp. Pl. 1163. 1753.

1. Ulva Lactùca L. loc. eit.

Near low-water mark, apparently not common. Berry Islands, Great Bahama, and Atwood Cay :- widely distributed. Type locality presumably European.

2. *ENTERomórpha Link, Hor. Phys. Berol. 5. 1820.

Thallus simple.

Thallus branched, the branches often monosiphonous at apices.

Chromatophores much smaller than the cells.

Chromatophores nearly filling the cell.

1. E. flexuosa.

2. E. plumosa.

3. E. salina polyclados.

1. Enteromorpha flexuòsa (Wulf.) J. Ag. Till Alg. Syst. 3: 126. 1883.

Conferva flexuosa Wulf.; Roth, Cat. Bot. 2: 188. 1797.

On stones, low-littoral. Great Bahama, Mariguana, and Caicos Islands:-Bermuda to American Virgin Islands; widely distributed in the warmer seas. Type from shores of the Adriatic Sea.

2. Enteromorpha plumòsa Kütz. Phye. Gen, 300. pl. 20. f. I. 1843.

Enteromorpha Hopkirkii MeCalla; Harv. Phye. Brit. pl. 263. 1849-'51.

On stones, etc., near low-water mark. Berry Islands, Joulter's Cay, Exuma Chain, and Mariguana:- Naine to American V'irgin Islands; Europe. Type from Trieste.

3. Enteromorpha salìna polyclàdos Kütz. Phye. Germ, 248. 1845.

Enteromorpha polyclados Kütz. Tab. Phye. 6: 13. pl. 36. f. d-f. 1856.

On stones at low-water mark. South Caicos:-Florida; Europe. Type from Spiekeroog, East Friesian Islands, North Sea.

\section{Family 4. CHAETOPHORÀCEAE.}

1. Gomóntia Born. \& Flah. Jour. de Bot. 2: 163, 164. 1888.

1. Gomontia polyrhiza (Lagerh.) Born. \& Flah. loc. cit.

Codiolum polyrhizum Lagerh. Öfvers. K. Vet.-Akad. Förh. 428: 21. pl. 28. 1886.

Boring into old crusts of various Lithothamnieae (Goniolithon Börgesenii, $G$. accretum, and Porolithon pachydermum) and probably common in shells. Berry Islands and Mariguana:-Widely distributed in temperate and tropical seas. Type from near Kristineberg, Sweden.

2. ENDODÉRMA Lagerh. Öfvers. K. Vet.-Akad. Förh. 40²: 75.1883.

Entocladia Reinke, Bot. Zeit. 37: 476. 1879. Not Endocladia J. Ag. Linnaea 15: 449.1841.

1. Endoderma víride (Reinke) Lagerh. loc. eit.

Entocladia viridis Reinke, Bot. Zeit. 37: 476. pl. 6. f. 6-9. 1879.

In the cell walls of Hypnca musciformis. Cave Cars:-Bermuda to American Virgin Islands; Europe; Peru. Type from the Bay of Naples.

* The treatment of the known Bahamian species is based upon determinations by Mr. F. S. Collins. 


\section{Family 5. CHROOLEPIDÀCEAE.}

1. TRENTEPòhliA Mart. Fl. Crypt. Erlang. 351. 1817.

Amphiconium Nees, Syst. Pilz. 69. 1817.

Chroolepus Ag. Syst. Alg. xxi, 34. 1824.

Filaments cylindric or subeylindric.

Filaments torulose, diameter of cells at middle about twice the diameter at septa; occurring on or with crustaceous lichens.

1. T. aurea.

2. T. rigidula.

1. Trentepohlia aùrea (L.) Mart. loc. cit.

Byssus aurca L. Sp. Pl. 1168. 1753.

Chroolepus aureus Kütz. Phye. Gen. 2\&4. 1843.

On rocks, fences, trunks of trees, etc., probably common. New Providence, Andros, Abaco, and Great Bahama :-cosmopolitan, Type European.

2. Trentepohlia rigídula (Müll. Arg.) Hariot, Jour. de Bot. 3: 403. f. 1\%. 1859.

Coenogonium rigidulum Müll. Arg. Flora 65: 490. 1882.

Trentepohtia torulosa De Wrild. Bull. Soc. Roy. Bot. Belg. 27²: 181. 1888.

On and with small crustaceous lichens, especially on bark of Annona sp. New Providence:- widely distributed in the warmer parts of the earth. Type from Australia.

The cell walls of the Bahamian specimens are smooth or slightly roughened, differing in that respect considerably from those of the Australian type, which are strongly rougbened.

\section{Family 6. CLADOPHORÀCEAE.}

1. CHAetomóRphA Kütz. Phyc. Germ. 203. My 1845.

Aplonema Hass. Brit. Freshw. Alg. 213. J1 1845.

Filaments attached, $400-800 \mu$ in diameter except at extreme base, commonly moniliform in upper part, with cells about as broad as long or broader, 1. C. clavata.

Flaments free, less than $400 \mu$ in diameter.

Filaments mostly $200-250 \mu$ in diameter. 2 . C. Linum.

Filaments mostly $80-180 \mu$ in diameter. 3. C. brachygona.

1. Chaetomorpha clavàta (Ag.) Kütz. Bot. Zeit. 5: 166. 1847.

Conferva clavata Ag. Syst. Alg. 99. 1824.

? Conferva intestinalis Ag. loc. cit.

In a tlde-pool, Hog Island (near Nassau) :-Jamaica, American Virgin Islands, and Barbados. Type from West Indies.

2. Chaetomorpha Lìnum (O. F. Müll.) Kütz. Phye. Germ. 204. 1845.

Conferva Linum O. F. Müll. Fl. Dan. 5 ${ }^{13}$ : 7. pl. 771. f. 2. 1778.

In a Rhizophora swamp, Rose Island:-widely distributed, especlally in the North Temperate Zone. Type from Denmark.

3. Chaetomorpha brachýgona Harv. Ner. Bor.-Am. 3: s7, pl. 46 A. 1858.

In shallow water, especlally in tldal ponds. New Provldence, Exuma Chain. Atwood Cay, and Calcos Islands:-Bermuda, Florlda, Porto Rico, Amerlcan Virgin Islands, and northern South America. Type from Key West, Florida.

\section{RHIZOCLÒNIUM Kütz. Linnaea 17: 90. 1843.}

Filaments $39-110 \mu$ in diameter: cell-walls mostly $10-26 \mu$ thick, usually laminated.

Cells $2-4$ tlmes as long as broad.

Cells 1-2 times as long as broad.

1. R. Hookeri

2. R. rrassipellitum robustum. 
Filaments $10-28 \mu$ in diameter; cell walls mostly 1-4 $\mu$ thick.

In or near salt water; cells mostly 1-2 times as long as broad; chromatophore usually ratber solid and uniform.

In fresh water; cells mostly 1-5 times as long as broad: chromatophore usually lacunose or resolved into dises, plates, or bands of protean forms.

3. R. riparium implcxum.

4. R. hicroglyphicum.

\section{Rhizoclonium Hoókeri Kütz. Sp. Alg. 383. 1819.}

High-littoral to low-water mark, often in Rhizophora association:-Bermuda and Florida to South America. Type from Kerguelen Island.

The West Indian plants currently referred to this species appear to be coarser, longer-celled, and thicker-walled than the Kerguelen Island type.

2. Rhizoclonium crassipéllitum robústum G. S. West, Jour. Bot. 42: 2 S3. 1904.

In fresh or brackish water, often in association with Rhizophora. New Providence, South Bimini, Exuma Chain, Cat Island, and Mariguana:-Barbados. Type of variety from Barbados.

The filaments of the Bahamian specimens have a diameter of $39-90 \mu$. Apparently distinct from the plants bere referred to $R$. Hooḱcri.

3. Rhizoclonium ripàrium impléxum (Dillw.) Rosenv. Nedd. om Grönland 3: 915. f. 34. 1893.

Conferva implexa Dillw. Brit. Conf. 46. pl. B. 1809.

In association with Rhizophora, often clothing its roots. Berry Islands and Bimini (det. F. S. Collins) :-widely distributed. Type from Ireland.

4. Rhizoclonium hieroglýphicum (Ag.) Kütz. Phye. Germ. 206. 1845.

Conferva hieroglyphica Ag. Flora 10: 636. 1827.

In fresh-water pools. New Providence (Brace) :-widely distributed. Type from Carlsbad, Austria.

\section{3. *CLADóPHoRA Kütz. Linnaea 17: 91. 1843.}

Plants of fresh or brackish water, unattached, usually floating: filaments much bent and curved: main filaments $60-120 \mu$ in diameter, the ramuli 20-40 $\mu$; cells $3-6$ times as long as broad.

Iarine.

Ultimate ramuli nearly as stout as the main filaments.

Filaments $35-95 \mu$ in diameter; plants spongiose-cespitose or spongiose-funicular; cells mostly 8-10 times as long as broad.

Filaments $150-320 \mu$ in diameter, plants cespitose, rather rigid, dark green or blackish green, blackening after collection, known only in association with a filamentous fungus endophytic in its cell walls.

Ultimate ramuli much more slender than the main filaments. Plants bright green or light green.

Ultimate ramuli more or less fascicled, $50-120 \mu$ in diameter, constricted at septa.

Ultimate ramuli not fascicled, $16-40 \mu$ in diameter.

Virgate in habit.

Dichotomous or trichotomous, not virgate.

Plants yellowish; cells $4-10$ times as long as broad, often somewhat enlarged at distal end; diameter of main filaments $60-80 \mu$, the often secund ultimate ramuli $18-50 \mu$.

1. C. fracta.

frecta.

2. C. crispula.

3. C. fuliginosa.

4. C. fascicularis.

5. C. nitida.

6. C. crystallina.

7. C. Iuteola.

1. Cladophora frácta (VahI) Kütz. Linnaea 17: 91. 1813.

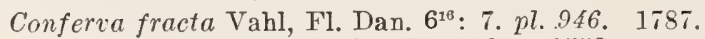

? Conferva vagabunda L. Sp. Pl. 1167. 1753.

Floating on brackish ponds, New Providence and Berry Islands:- widely distributed. Type from Denmark.

* The treatment of the recognized Bahamian species is based chiefly upon determinations by Mr. F. S. Collins. 
2. Cladophora críspula Tickers, Ann. Sci. Nat. Bot. IX. 1: 56. 1905.

On Digenea, near low-water mark. Mariguana:-Bermuda, American Virgin Islands, and Earbados. Type from Barbados.

3. Cladophora fuliginòsa Küitz. Sp. Alg. 415. 1849.

Blodgcttia confervoides Harv. Ner. Bor.-Am. 3: 4s. pl. 45 C. 1与5ร.

Common in shallow water, mostly in rather exposed places. New Providence, Rose Island, Great Bahama, North Cat Cay, Eleuthera, Cat Island. Mariguana, Caicos Islands, and Great Ragged Island:-Bermuda to the American Virgin Islands. Type from IIarana, Cubil.

4. Cladophora fasciculàris (Mert.) Kütz. Linnaea 17: 91. 1543.

Conferva fascieularis Mert.; Ag. Syst. Alg. 114. 1824.

In shallow water. Berry Islands and Great Bahama :-Florida to Brazil; Peru. Type from the West Indies.

5. Cladophora nítida Kütz. Phye. Gen. 269. 1843.

In shallow water. Great Bahama and Exuma Chain :-Jamaica: Europe. Type from Trieste.

6. Cladophora crystallina (Roth) Kütz. Linnaea 17: 91. 1843.

Conferta crystallina Roth, Cat. Bot. 1: 196. 1797.

In shallow water. Berry Islands, Great Bahama, Exuma Chain. Atwood Cay. and Caicos Islands:-Massachusetts to West Indies; Europe. Type from the Baltic Sea. forms.

The Bahamian specimens provisinnally referred to this species are not typical

7. ? Cladophora Iutèola Harv. Ner. Bor.-Am. 3: 81. 1858 .

In tide-pools. Atwood Cay and Caicos Islands:--Florida and Cuba. Type from liey West, Florida.

The Bahamian specimens somewhat doubtfully referred to this species have a more cespitose, less diffuse habit than the type, with rather stouter filaments, and less secund ultimate ramuli.

4. PITHÓPHORA Wittr. Syst. Arr. Pithoph. 49. $157 \%$.

1. Pithophora oedogònia (Mont.) Wittr. loc. cit. 5.5. $p l .6$.

Conferva (Cladophora) oedogonia Mont. Ann. Sei. Nat. Bot. III. 14: 301. 1850 .

In fresh-water holes, New Provldence (Brace) :- Tennsylrania and Nebraska to South America. Type from Cayenne.

\section{Family $\tau$. VALONIÀCEAE.}

1. CLADOPHORópsis Börg. Overs. K. Danske Viılensk. Selsk. Forh. 1905³ : 288. 1905 .

1. Cladophoropsis membranàcea (Ag.) Börg. loc. cit. 276. f. 8-13.

Conferva membranacca Ag. Syst. 120. 1824.

Claclophora acgagropila membranacca Kïtz. Sp. Alg. 415. 1549.

Siphonocladus membranacens Born.; De-Toni, Syll. Alg. 1: 35s. 1ss?.

Common in shallow water and washed ashore. New Providence, Rose Island, North Cat Cay, Gun Cay, Andros, Exuma Chain. Watling's Island, Atwond Cay, Mariguana, and Calcos Islands :-Bermuda and Florlda to Parbados. Type from St. Croix.

The plant is normally rather compactly or somewhat diffusely cespltose, but when attacked by a dark flamentous endophytic fungus it becomes depressed or prostrate and the filaments become thicker-walled. 
2. SIPHONÓCLAdUS Schmitz, Ber. Sitz. Naturf. Ges. Halle 1878: 18. $1878(8)$

1. Siphonocladus rigidus M. A. Howe, Bull. Torrey Club 32: 244. pl. 13. f. 1.; pl. 14. 1905 .

In shallow water in rather protected places, sometimes forming pulvinate crusts on colals, occasionally in tide-pools. New I'rovidence, Great Bahama, Exuma Chaln, Cat Island. Atwood Car, Mariguana, Caicos Islands, and Great Ragged Island:Bermuda, Florida, and Jamaica. Trpe from key West, Florida.

3. PETROSİpHON M. A. Howe, Bull. Torrey Club 32: 247. 1905.

1. Petrosiphon adhaèrens M. A. Howe, loc. cit. 248. $p l$. 15.

Forming crusts and patches on calcareous rocks and corals near Iow-water mark and in tide-pools, not uncommon. New Plovidence, Rose Island, Great Bahama, Exuma Chain, Watling's Island, Mariguana, and Castle Island:-Bermuda, Cuba, and Jamaica. 'Type from Silver Cay, in Nassau Harbor, N. I'.

4. CHAMAedòris Mont. Compt. Rend. Acad. Sci. 15: 171. 1842.

1. Chamaedoris Penículum (Ell. \& Soland.) Kuntze, Rev. Gen. Pl. 3: 400. 1898.

Corallina Peniculum Ell. \& Soland. Nat. Hist. Zooph. 127. pl. \%. f. 5-8; pl. 25. f. 1.1786.

Penicillus annulatus Lamarek, Ann. Mus. Hist. Nat. 20: 299. 1813.

Nesea annulata Lamour. Hist. Polyp. 256. 1816.

Chamaedoris annulata Mont. loc. cit.

Under shelving rocks near low-water mark, but more commonly found washed ashole flom deeper water. New Providence, Great Bahama, Abaco, Eleuthera, and Exuma Chain :-Florida to Barbados and South America; Mauritius; Ceylon. Type from the Bahama Islands.

5. MICRODÍctYoN Decaisne, Arch. Mus. Hist. Nat. 2: 115. 1841.

1. Microdictyon crássum J. Ag. Anal. Alg. Cont. 1: 107. 1894.

Common from low-water mark down to a depth of at least 8 meters ; especially abundant on the "Long Bank" in 3-8 meters of water, growing particularly about sponges. New Providence, Rose Island, Great Bahama, North Cat Cay, Long Bank, Green Turtle Cay, Green Car, Exuma Chain, Cat Island, Watling's Island, Atwood Cay, Mariguana, and Caicos Islands:-Cuba. Type from the Babama Islands.

6. ANADYOMìne Lamour. Nouv. Bull. Sci. Soc. Philom. 3: 187. 1812. [As Anadyomena.]

1. Anadyomene stellàta (Wulf.) Ag. Sp. Alg. 1: 400. 1822. [As Anadynomene stellata.]

Ulva stellata TVulf. in Jacq. Collect. 1:351. 1786.

Anadyomena flabellata Lamour. loc. cit.

Anadyomene flabellata Lamour. Hist. Polyp. 366. pl. 14. f. 3. 1816.

Not uncommon in shallow water and ranging down to a depth of at least 50 meters (ficle Börgesen). New Providence, Andros, Great Bahama, Exuma Chain, Watling's Island, Mariguana, Caicos Islands, and Great Ragged Island:-Bermuda and Florida to Brazil: Mediterranean and Adriatic seas. Type from the Adriatic Sea. Just above the low-water line undel shelving rocks and on roots of Rhizophora, there occurs a form of Anadyomene consisting chiefly of free or solute filaments, with the pseudoparench sma reduced to a small few-celled palmate-flabellate apical expansion or wholly deficient. Possibly this represents a species bearing to A. stellata about the same relation that Strucea anastomosans bears to the more elabolate species of Struvea, but as conditions intermediate appear to occur, the writer prefers to consider it a form, which may be designated as forma prototypa itrne Hoice 58:2, on roots of Rhizophora in a lagoon, Great Ragged Island, Dec. 26, 1907). 
7. DICTYOSPHAÈrIA Decaisne, Ann. Sci. Nat. Bot. II. 17: 32s. 1842.

1. Dictyosphaeria favulòsa (Ag.) Decaisne, loc. cit.

Valonia favulosa Ag. Sp. Alg. 1: 432. 1822.

Common, especially on old corals in shallow warm water. New Providence, Andros, Great Bahama, South Cat Cay, North Cat Cay, Bimini, Green Cay, Watling's Island, and Mariguana :- Yermuda and Florida to Barbados; widely distributed in the warmer seas. Type from the island of Iiawak, Dutch East Indies.

\section{VALÒNIA Ginn.; Ag. Sp. Alg. 1: 428. 1822.}

Thallus simple or subsimple, oroid, obovoid, pyriform, or subglobose, mostly $1.5-5 \mathrm{~cm}$. in maximum diameter.

Thallus branched.

Cells mostly $\bar{j}-10 \mathrm{~mm}$. broad, obovoid or pyriform, cceasionally subglobose; thallus sparingly or rather copiously branched.

Cells mostly $0.45-2 \mathrm{~mm}$, broad.

Cells all subcylindric or subclarate; thallus, under favorable conditions, forming subglobose, solid or finally hollow, free or attached masses $4-20 \mathrm{~cm}$. in diameter. Cells in superior or dorsal parts irregularly polyhedral or angulate-subglobose: those of descending inferior or ventral parts subcylindric; thallus cespitose or crustaceous.

1. T. ecntricosa.

2. V. macrophysa.

3. T. Aegagropila.

4. I. occllata.

1. Valonia ventricòsa J. Ag. Till Alg. Syst. 5: 96. 1887.

Under sheling rockś at low-water mark and among corallines and "mossy" algae in shallow water. Rose Island, Berry Islands, Great Bahama, North Cat Cay, South Cat Cay, Abaco, Eleuthera, Exuma Chain, Cat Island, Mariguana, and Caicos Islands:-Bermuda to Barbados. Type from St. Croix.

2. Valonia macrophỳsa Küitz. Phyc. Gen, 307. 1843.

Tnder shelving rochs at low-water mark and on and among other algae and corals in shallow water. Berry Islands, Great Bahama, Eleuthera, Atwood Cay, Irariguana, and Caicos Islands:-Bermuda. Cuba, Jamajea, and American Virgin Islands; Meditermean and Adriatic seas. Type from the island of Lessina, in the Adriatic Sea.

3. Valonia Aegagrópila Ag. Sp. Alg. 1: 429. 1822.

Valonia utricularis Aegagropila Hanck, in Rabenh. Krypt.-Fl. 2: 469. 1855.

In shallow water and at its best in lagoons. New Providence. liose Island, Great Bahama, North Cat Cay, Watlings Island, Atwood Cay, Mariguana, and Caicos Islands:-Cuba, Jamaica, Porto liico, and American Virgin Islands; widely distributed in the warmer seas. Type from the lagoons of Venice.

\section{Valonia ocellàta M. A. Howre, sp. nor.}

Plants for the most part filamentous, lensely cespitose or crustaceous, the cushions, under favorable conditions beeouning 10-20 cm. broad and $4-6 \mathrm{~cm}$. thick; the superior or dorsal parts consisting of small few-eelled dises, or more often, oblong or linear, irregular, multicellular filaments mostly 1-4 cells broad, the cells polyhedral or angulate-subglobose, $0.45-0.9 \mathrm{~mm}$. in maximum riameter, with numerous small flattened ellipsoidal or lentiform cells $50-90 \mu$ in long diameter along their separating walls; few or many of the ventral and lateral cells of the superior or dorsal facetted parts growing out into rather rigid deseending stilt-like or root-like non-septate processes, mostly $5-30 \mathrm{~mm}$. long and $0.5-0.8 \mathrm{~mm}$. in diameter; occasional cells in dorsal parts enelosing few or numerous aplanospores $200-320 \mu$ in diameter.

In shallow water ln lagoons, on pueumatophores of Aricmnir between the tldelines, and low-littoril on rocks, both In exposed and slieltererl locations, common. Niew P'rovidence, Bimini, Watling's Island, Atwood Cay, Iarjguana, and Calcos

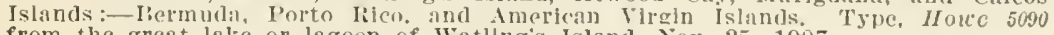
from the great lake or lagoon of Watllug's Island, Nov. $25,1907$. 
Talonia ocellata is perhaps related to Dictyospharria valonioides Zanard. which Hauck believed to be a condition of Talonia macrophysa, but manifestly differs in its smaller cells, in never being hollow, and rarely, if erer, globose, and in the absence of large vesicular marginal cells. Specimens from Iermuda and the West Indies have sometimes bren refered to latonia utricularis forma crustuccn Kuck., from which it differs in having its superior parts diviled by cross-walls into more or less polyhedral or angulate-subglobose cells instead of consisting of interworen and compacted clavate or obovoid cells. The plant bears some resemblance to young stages of species of Dictyosphaeria but the small-celled or facetted parts are usually elongate, vittate, or irregularly discoid, very rarely subglobose. It occurs in great abundance in lagoons, of ten associated with Valomia degagropila and remaining perfectly distinct. It is found in a great variety of habitats and it evidently deserves a distinctire specific name, at least until such time as cultures may prove it to be capable of assuming the characters of some previously described species.

\section{Family S. DASYCLADȦCEAE.}

\section{DASÝCLADUS Ag. Flora 10: 640. $182 \pi$.}

1. Dasycladus vermiculàris (Scop.) Krasser, Ann. K. K. Naturhist. Hofmus. 13: 459. 1899.

Spongia vermicularis Seop. Fl. Carn. 2: 412. pl. 64. 1772.

Conferva clavaeformis Roth, Cat. Bot. 3: 315. 1806.

Fucus vermicularis Bertol. Amoen. Ital. 308. 1819.

Dasycladus clavaeformis Ag. Sp. Alg. 2: $16.182 \mathrm{~S}$.

On stones, shells, etc., in shallow water, mostly in protected bays. New Providence, Rose Island, Berry Islands, North Cat Cay, Fxuma Chain, Caicos Islands, Castle Island, and Great Ragged Island:-Bermuda, Florida, Cuba, and Jamaica ; Canary and Madeira Islands: Mediterranean and Adriatic seas. Type from Adrlatic Sea.

2. BAт́́phora J. Ag. Öfv. K. Vet.-Akal. Förh. 11: 107. 1854.

Botryophora J. Ag. Till Alg. Syst. 5: 139. 1857. Not Botrxophora Bompard, Hedwigia 6: 129. 1867.

Coccocladus Cramer, Neue Denkschr. Schweiz. Naturf. Ges, 30:-(37). 1887.

1. Batophora Oérstedi J. Ag. Öfr. K. Vet.-Akarl. Förh. 11: 108. 1854.

Botryophora Conquerantii Crouan; Cramer, Neue Denkschr. Schweiz. Naturf. Ges. 32:-(6). pl.4.f.1. 1890.

Coccocladus occidentalis Conquerantii if. A. Howe, Bull. Torrey Club 31: 96. 1904.

Coccocladus occidentalis laxus M. A. Howe, loc. eit. 95. pl. 6. f. 1, 2.

Common in lagoons, creeks, ponds, and sink-holes of salt or brackish water, the laxer conditions in water that is almost iresh. New Providence, Rose Island, Berry Islands, Great Bahama, Andros, Exuma Chain, Watling's Island, Caicos Islands, Acklin's Island, and Great Ragged Island:-Florida to Guadeloupe. Type from Krause's Lagoon, St. Croix.

1a. Batophora Oerstedi occidentàlis (Harr.) M. A. Howe, Bull. Torrey Club 32: 579.1905.

Dasycladus occidentalis Harv. Ner. Bor.-Am. 3: 39. $18 j 8$.

Botryophora occidentalis J. Ag. Till Alg. Syst. 5: 141. 1887.

Coccocladus occidentalis Cramer, Nene Denkschr. Schweiz. Naturf. Ges. $30:-(37) .1857$.

On stones, shells, etc., in shallow salt water, mostly in protected bass, common. New Providence, Andros, Berry Islands, Great Bahama, Exuma Chain, Cat Island, Watling's Island, Mariguana, and Great Ragged Island:-Bermuda, Florida, and Cuba. Type of variety from Key West, Florida. 
3. NEÓMERIS Lamour. Hist. Polyp. 241. 1816.

Hairs monomorphous; ends of branches of second order forming a cortex with distinct facets.

Sporangia coherent laterally by their calcareous capsules, the plant thereby appearing transversely aunulate in the lower fertile parts. 1. $N$. anmulata. Sporangia strongly calcified but mutually free.

Hairs dimorphous, the two forms in alternating zones; branches of the second order subfusiform, scarcely forming a cortex, surface of the plant after the fall of the hairs somewhat shaggy or minutely and irregularly punctate; sporangia free or coherent in short rows of $2-8$.

2. N. $m u \cos a$.

1. Neomeris annulàta Dickie, Jour. Linn. Soc. Bot. 14: 19S. 18it.

Neomeris Kelleri Cramer, Neue Denkschr. Sehweiz. Naturf. Ges. 30:-(3$10,39) . p l .1 ; p l .2 . f .1-12 ; p l .3 . f .1,2.1587$.

on stones, shells, etc., from near low-water mark down to a depth of 50 meters (fide Börgesen). New I'rovidence, Rose Island, Rerry Islands, Great Bahama, North Cat Cay, Mariguana, Caicos Islands, Castle Island, and Great Iagged Island:Bermuda and Florida to Barbados; Mauritius, Iladagascar, and the Dutch East Indies. Type from Mauritius.

2. Neomeris mucòsa M. A. Howe, Bull. Torrey Club 36: 84. pl. 1. f. 5; pl. 5. f. 1-14. 1909.

On moderately exposed rocks, at and near low-water mark, often with other species of the genus. Atwood Cay, Caicos Islands, and Great Ragged Island. Apparently endemic. Type from Atwood Cay.

3. Neomeris Còkeri M. A. Howe, Bull. Torrey Club 31: 97. pl. 6. f. 3-12. 1904.

Common, usually under shelving rocks, near low-water line, occasionally on shells and pebbles in deeper water. New Providence, Berry Islands, Great Bahama, Gun Cay, Eleuthera, Exuma Chain, Atwood Cay, Castle Island, and Great Ragged Island. Apparently endemic. 'Type from opposite Current Town, Eleuthera.

4. CYMOPÒLIA Lamour. Hist. Polyp. 292. 1816.

1. Cymopolia barbàta (L.) Lamour. loc. eit. 293.

Corallina barbata L. Syst. Nat. 1: S06. 175 s.

Corallina Rosarium Ell. \& Soland. Nat. Hist. Zooph. 111. pl. 21. f. h, H. $H_{1-3 .} .1786$.

Cymopolia Rosarium Lamour. loc. cit. 294.

Cymopolia bibarbata Kütz. Phyc. Gen. 312. 1843.

Cymopolia unibarbata Kütz. loc. cit. 313.

Cymopolia mexicana J. Ag. Till Alg. Syst. 5: 14i. 1857.

On rocks and stones in shallow, moderately agitated water. New Providence, Andrus, Ijerry Islands, and IIariguana:-Florida, Cuba, Jamaica. IIaiti, l'orto lico, and Nexico; reported also from Canary Islands and Spain. Type from Jamaica.

\section{ACETÁBULUM ('Tourn.) Ludwig. Def. Gen. Pl. 504. 1760.}

Olivia Bertol. Rar. Pl. Ital. Dee. 3: 117. 1810.

Acetabularia Lamour. Nouv. Bull. Sci. Soc. Philom. 3: 185. 1812.

PoLrPIYsA Lamarek; Lamour. Hist. Polyp. 250. 1816.

I'lants large or medium-sized (discs 5-18 mm. broad) ; hypopeltal processes present.

rlants small or minute (discs $1-5 \mathrm{~mm}$. broad) : hypopeltal processes wanting.

Discs $2-5 \mathrm{~mm}$. hroad: coronal processes $75-150 \mu$ in radial diameter, with $5-13$ hairs or bair-rudiments; aplanospores $88-190 \mu$ in dilmeter.

Discs 1-2.5 mm. broad: coronal processes $22-35 \mu$ in radial diameter, with 2 (rarely 3 ) hairs or halrrudiments; aplanospores $6 \mathrm{~S}-82 \mu$ in diameter.

1. A. crenulatum.

2. A. polyphysoides.

3. A. pusillum. 
1. Acetabulum crenulàtum (Lamour.) Kuntze, Rev, Gen. Pl. 2: 851. 1891.

Acctabularia crenulata Lamour. Hist. Polyp. 249. 1516.

Acetabulum caribaeum Lamarck, Hist. Nat. Anim. sans Vertèb. 2: 150. 1516.

Acetabularia caraibica Kütz. Tab. Phyc. 6: 33. 1856.

On sandy bottom and on stones, shells, sticks, etc., in shallow rather quiet water (down to 10 meters or more), common, New Providence, Rose Island, Andros, Great Bahama, Green Cay, Exuma Chain. Cat Island, Watling's Island, Mariguana, Caicos Islands. and Great Ragged Island:-- Bermuda and southern Florida to Barbados. Trype from "mer des Antilles" [Santo Domingo].

2. Acetabulum polyphysoìdes (Crouan) Kuntze, Rev. Gen. Pl. 2: 8\$1. 1891.

Acetabularia polyphysoides Crouan; Solms, Trans. Linn. Soc. Bot. II. 5: 29. $p l .4 . f .2,6.1895$.

Low-littoral down to a depth of at least 4 or 5 meters. Atwood Cay. Caicos Islands, and Castle Island:-Jamaica and Guadeloupe. Type from Guadeloupe.

2a. Acetabulum polyphysoides deltoìdeum M. A. Howe, Bull. Torrey Club 36: 92. pl. 6. f. 21; pl. \%. f. 10. 1909.

Just above low-water mark, with the typical form and with Neomeris Cokeri. Atwood Cay (type station of form deltoideum).

3. Acetabulum pusíllum M. A. Howe, Bull. Torrey Club 36: 89. pl. 6. f. 13$15 ; p l .7$. f. 1-4. 1909.

Acetabularia pusilla Collins, Tufts College Stud. 2: 379. 1909.

On stones, shells, and film-covered rocks in shallow water, sometimes with $A$. polyphysoides and $A$. crenulatum. Mariguana and Castle Island:-Jamaica. Type from Iontego Bay, Jamaica.

A minute plant, only $1-3 \mathrm{~mm}$. high, and the disc areraging about $1.6 \mathrm{~mm}$. in diameter.

6. ACICULÀria d'Archiac, Mém. Soc. Géol. France 5²: 356. 1843.

Solms, Trans, Linn. Soc. Eot. II. 5: 32.1895.

1. Acicularia Schénckii (Möb.) Solms, loc. eit. 33, pl. 3. f. 9, 11, 12, 14, 15. 1895. M. A. Howe, Bull. Torrey Club 28: 323-331. pl. 24. f. 1-16, 18-22; pl. 25. 1901.

Acetabularia Schenckii Möb. Hedwigia 28: 318-320. pl. 10. f. 8-12. 1859.

On stones, etc., from near low-water mark down to a depth of at least 30 meters (fide Börgesen), usually in association with Rhizophora. Rose Island:Bermuda, Jamaica, Porto Rico, American Virgin Islands, Barbados, and Brazil. Type from Cabo Frio, Brazil.

\section{Family 9. BRYOPSIDÀCEAE.}

1. BRYópsis Lamour. Nouv. Bull. Sci. Soc. Philom. 1: 333. My 1809.

Ultimate ramull 2-ranked, the main axes for the most part simply pinnate, commonly naked in lower half.

Ultimate ramuli irregularly disposed.

Main axes usually deliquescent, the ultimate ramuli rarely less than $20 \mu$ in diameter at apex.

Main axes persistent, strongly contrasting in size with the various orders of branches and branchlets, the ultimate ramuli often only $5-15 \mu$ in diameter at apex: plant very gelatinous.

1. B. pennata.

2. B. hypnoides.

3. B. Duchassaingii.

1. Bryopsis pennàta Lamour. loc. cit.; Jour. de Bot. 2: 134. pl. \%. f. $1 a, b$. 1809.

On stones at low-water mark. Atwood Cay and Caicos Islands:-Bermuda to Barbados. Type from "Antilles." 
2. Bryopsis hypnoides Lamour. loc. cit.; Jour. de Bot. 2: 135. pl. 5. f. \& a, b. 1809.

Found washed ashore-probably from a little deeper water than the last. Great Iahama:- southern Massachusetts to Bermuda; whdely distributed in the warm temperate seas. Type from near Cette, southern France.

3. Bryopsis Duchassaingii J. Ag. Öfr. Tet.-Akad. Förh. 11: 107. 18Jt.

Trichosolen Antillarum Mont. Ann. Sci. Nat. Bot. IV. 14: 171. 1560.

Found washed ashore. Great Bahama:-Bermuda to Guadeloupe (Barbados?). Type from Guadeloupe.

\section{Family 10. CAULERPÁCEAE.}

1. Caulérpa Lamour. Nouv. Bull. Sei. Soe. Philom. 1: 332. My 1509. Chauvinia Bory, Voy. Coquille, Bot. Crypt. 204. 1829.

Tricladia Decaisne, Ann. Sci. Nat. Bot. II. 17: 337. 1842.

Herpochaeta Mont. Ann. Sei. Nat. Bot. II. 20: 305. 1843.

Stephanocoelium Kütz. Bot. Zeit. 5: 54.1847.

Chemritzia (Decaisne) Mont. Orb. Diet. 10: 53. 1849.

Phyllerpa Kütz. Sp. Alg. 494. 1849.

Stolons and upright fronds similar, filiform, in habit somewhat suggestive of Vaucheria, Derbesia, or the irregularly branched species of Bryopsis.

Stolons and upright fronds more or less different in form.

Fronds filiform, the ramuli verticillate (at least the upper), fastigiate or subfastigiate, di- or trichotomous.

Fronds stouter, ramuli not in distinct whorls.

Fronds foliaceous, entire, linear or elliptic-oblong, often proliferous.

Fronds terete, subterete, or angled, or, if flattened, pinnately dentate, lobed, or plumose-pinnate. Fronds distinctly flattened.

Fronds plumose-pinnate, the pinnules terete, mucronate.

Pinnules or teeth flattened.

Fronds linear-lanceolate in outline, 6-15 $\mathrm{mm}$. broad, the pinnules often contracted at hase.

Fronds narrowly linear, $2-3 \mathrm{~mm}$. broad, often twisted and constricted here and there, the margins occasionally entire.

Fronds terete, subterete, or angled, in general outline.

Stolons densely clothed with short simple or sparingly branched root-halirs: fronds with erowded, imbricate, hristle-like, mucronate ramuli.

Stolons naket.

Frond with a naked stipe bearing usually a dichotomo-palmate or dichotomo-nmbellate cluster of secondary ramuliferous branches; ramuli (2)3-10(16)-ranked, with acicular 2-ranked ramelli pectinately secund or pinnately disposed, the longer often sparingly dichotomous or again pinnate.

Stipe usually not well differentiated.

Frond usually angled, the ramuli mostly in 2-6 ranks, somewhat boat-shaped or prow-shaped (at least the basal), ovoid, mamilliform, or less commonly terete, always mucronate.

Frond not angled, tlie ramuli subglobose, prriform, pestle-slitped, or ocea sionally subclavate.

Ramuli in more or less elongate racemollke clusters, several-ranked,

1. C. fastigiata.

2. C. verticillata.

3. C. prolifera.

4. C. sertularioides.

5. C. crassifolia.

6. C. Freycinetii.

7. C. lanuginosa.

S. C.paspaloides.

ค. C. cupressoides. 
mostly pestle-shaped, the pedicel nsually as long as the subglobose or flattened-subglobose summit or often longer.

Ramuli mostly irregularly 2- or 3ranked, subglobose or obliquely pyriform, the pedicel usually shorter than the enlarged summit or obsolete; clusters short and somewhat botryoid or more elongate with rather distant ramull.

10. C. racemosa.

11. C. clavifera.

1. Caulerpa fastigiàta Mont. Ann. Sci. Nat. Bot. II. 8: 353. 1837.

Herpochaeta fastigiata Mont. Ann. Sei. Nat. Bot. II. 20: 305. 1843.

On stones, etc., near low-water mark. New I'rovidence, Mariguana, and Great Bahama (profusely abundant in a "boiling hole" in Golden Grove Creek) :-Bermuda and Florida to Brazil: Friendly Islands. Type from Cuba.

The plant has quite a different habit from the other West Indian species of the genus, bearing a superficial resemblance to filamentous siphonaceous algae of other genera and families, from which, however, it is usually distinguishable at sight (in the dried condition) by its greater rigidity and dull dark green color; under a moderatels high magnification, the delicate cellulose threads running from the inner surface of the wall into the lumen serve at once to determine its affinities.

2. Caulerpa verticillàta J. Ag. Öfv. K. Tet.-Akad. Förh. 4: 6. 184i.

Herpochaeta verticillata Kütz. Tab. Phye. 7: 1. pl. 1. f. II. 1857.

Stephanocoetium verticillatum Kütz. loc. cit. 7: 1.

In shallow water in sheltered places, usually in association with Rhizophora. New Proridence, Great Bahama, and Bimini:-Bermuda to Brazil: Indian and Pacific Oceans. Type locality indefinite (American Virgin Islands or Guadeloupe?). This species in habit and size is suggestive of some of the more delicate species of Nitella.

3. Caulerpa prolífera (Forsk.) Lamour. Nour. Bull, Sci. Soc. Philom. 1: 332. IIy 1809.

Fucus prolifer Forsk. F7. Aegypt.-Arab. 193. 1775.

From near low-water mark to rather deep water. Joulter's Cays, Watling's Island, Castle Island, and Great Ragged Island :-Bermuda and Florida to Guadeloupe: Canary Islands and Mediterranean Sea. Tspe from Alexandria, Egspt.

Iost of the Bahamian specimens bave short, elliptic-oblong, or obovate fronds and represent $\mathrm{f}$. obovata J. Ag.

4. Caulerpa sertularioìdes (S. G. Gmel.) M. A. Howe, Bull. Torrey Club 32: 576.1905.

Fucus sertularioides S. G. Gmel. Hist. Fuc. 151 pl. 15. f. 4. 1768.

Fucus plumaris Forsk. F1. Aegypt.Arab. 190. 1775.

Caulerpa plumaris Ag. Sp. Alg. 1: 436. 1822.

From near low-water mark to a depth of several meters. New Providence, Great Bahama, Bimini, North Cat Cay, Exuma Chain, Cat Island, Watling's Island, Mariguana, Caicos Islands, and Great Ragged Island:-Bermuda and Florida to Barbados; widely distributed in tropical and subtropical seas. Type "American."

5. Caulerpa crassifòlia (Ag.) J. Ag. Till Alg. Syst. 1: 13. 1873.

Caulerpa taxifolia crassifolia Ag. Sp. Alg. 1: 436. 1822. (Excl. syn.)

Caulerpa pinnata Web.-v. Bosse, Ann. Jard. Bot. Buitenzorg 15: 289.

1898. (Excl. syn. Fucus pinnatus L. fil. Suppl. 452. 1781.)

Caulerpa mexicana Sond.; Kütz. Sp. Alg. 496. 1849.

In sheltered localities from near low-water mark down to a depth of 30 meters (fide Börgesen). Exuma Chain, Mariguana, and Great Ragged Island:-Bermuda and Florida to Mexico and Brazil; widely distributed in tropical and subtropical seas. Type from the West Indies. 
6. Caulerpa Freycinètii Ag. Sp. Alg. 1: 446 . 1822.

On corals in shallow water. Atwood Cay :-Guadeloupe ; lied Sea ; Pacific Ocean. Type from the Mariana Islands.

The Atwood Cay specimens apparently belong witls war pretiunta Web-x. Bosse, differing from the type in being only slightly twisted and in the more regular and better developed marginal teeth; it seems to approach closely certain conditions of $C$. cupressoides.

7. Caulerpa lanuginòsa J. Ag. Till Alg. Syst. 1: 28. 18 i3.

Caulerpa Lycopodium Harr. Ner. Bor.-Am. 3: 19. pl. 37B. 1858. Not C. Lycopodium J. Ag. Ofv. K. Vet.-Akarl. Förh. 4: 6. 1847.

On a sandy bottom in shallow water. New Providence (south shore):-Florida. Type from Iíy West, FIorida.

S. Caulerpa paspaloides (Bory) Grev. Alg. Brit. lxiv. 1830.

Chauvinia paspaloides Bory, Voy. Coquille, Bot. Crypt. 205. pl. 23. f. 1. 1829.

On a sandy bottom, mostly in $1-40 \mathrm{dm}$. of water. New Providence (south shore), Long Bank, Abaco, Green Cas, and Great Bahama:-Florida and Cuba. Type from the Bahama Islands.

The type is characterized by having its ramuli in (2)3 or 4 ranks, the spikes distinctly alate or strongly angled when living and shaggy when dry, the ramelli pectinately secund, and alwars much shorter than the axis from which they spring. In addition to the type form, there are in the Bahamas two other strongly marked forms, rarieties, or subspecies, which appear to be locally distinct, that is, they seem to occur with little if any local intergrading or intermingling, though growing in similar habitats: however, when plants from various iocalities are compared, it seems difficult to maintain these three groups as distinct species.

Sa. Caulerpa paspaloides phleoìdes (Bory) J. Ag. Till Alg. Syst. 1: 32. Isi3.

Chauvinia phleoides Bory, Voy. Coquille, Bot. Crypt. 206. pl. 23. f. 2. 1529.

On a sandy bottom in shallow water. Exuma Chain. Type from the Bahama Islands. Apparently endemic.

Differs from the typical $C$. paspaloides in having its ramuli in 6-10 ranks, the spikes slightly angular or strongly ribbed when living. more or less shaggy when dry, the ramelli mostly pinnately distichous or occasionally subsecund.

Sb. Caulerpa paspaloides compréssa (Web.-v. Bosse) Mr. A. Howe, comb. nov.

Caulerpa paspaloides var. typica f. compressa Web.-v. Bosse, Ann. Jard. Bot. Buitenzorg 15: 353. pl. 30. f. 3, 4. $189 \mathrm{~s}$.

Caulerpa compressa M. A. Howe, Bull. Torrey Club 31: 93.1904.

On a sandy bottom in shallow water. Rose Island, Long Island, Exuma Chaln, and Ragged Island. Type from the liahama Islands. Apparently endemlc.

Differs from the typical $C$. paspaloides and $C$. paspaloides phleoides in haring its ramuli in $8-16$ ranks, the spikes dense and wholly terete or rery lightly ribbed, the ramell] pinnately distichous and corymbose, the lower ramelli as long or nearly as long as the axis from which they spring.

9. Caulerpa cupressoides (West) Ag. Sp. Alg. 1: 441.1822.

Fucus cupressoides West; Vahl, Nat. Selsk. Skr. 5²: 3S. 1802.

Caulcrpa hypnoides Lamour. Jour. de Bot. 2: 145. pl. \%. f. 3. 1509.

Fucus ericifolius Turn. Hist. Fue. 1: 124. pl. 56. $150 \mathrm{s.}$

Caulerpa ericifolia Ag. Sp. Alg. 1: 442. 1822.

Caulerpa mamillosa Mont. Prod. Phye. Antaret. 13. 1842.

Caulerpa Lycopodium .J. Ag. Öfv. K. Tet.-Akaıl. Förh. 4: 6. 1S47.

Caulerpa juniperoides J. Ag. Till Alg. Syst. 1: 26. 1573.

On sand-covered rocks and sandy bottoms in shallow water and in tlde-pools. common. Andros, Great Bahama, Bimini, Exuma Chain, Watling's Island. Atwood 
Cay, Mariguana, Calcos Islands, and Great Ragged 1sland:-Bermuda and Florida to South America; Indian and I'aclfic Oceans. Type from St. Croix, Amerlcan Virgin Islands.

Variable in the number of ranks of the remuli and in the length of thc ramuli. The forms or varieties chlefly represented are the typical form, the var. cricifolia (T'urn.) Web.-v. Bosse, and the var. Lycopodium (J. Ag.) Web.-v. Bosse.

10. Caulerpa racemòsa (Forsk.) J. Ag. Till Alg. Syst. 1: $35.1 S 73$.

Fucus raccmosus Forsk. Fl. Aegypt.-Arab. 191. 1775.

Fucus uvifer Turn. Hist. Fue. 4: 81, pl. 230. 1819. Not Fueus uvifer Forsk. Fl. Aegypt.-Arab. 192. 1775.

Caulerpa clavifera uvifera Ag. Sp. Alg. 1: 438. 1822.

On reefs in shallow water and in more sheltered places, as on roots of Rhizophora. New Proridence, Rose Island, Bimini, Exuma Chain, Watling's Island, Atwood Cay, and Castle Island :- Bermuda and Florida to Barbados: widely distributed in tropical and subtropical seas. Type probably from the Red Sea.

11. Caulerpa clavifera (Turn.) Ag. Sp. Alg. 1: 438. 1822.

Fucus clavifer Turn. Hist. Fuc. 1: 126. pl. 5\%. 1808.

Caulerpa racemosa clavifera Web.-v. Bosse, Ann. Jard. Bot. Buitenzorg 15: 360. pl. 33. f. 1-5. 1898.

Caulerpa racemosa uvifera Web.-v. Bosse, loc. cit. 362 p.p.

Habitat same as $C$. racemosa. Exuma Chain, South Cat Cay, Mariguana, Caicos Islands, and Great Ragged Island:-Florida to Barbados; widely distributed in tropical and subtropical seas. Type from the Red Sea.

Caulerpa raccmosa and $C$. clarifera sometimes approach each other in form and habit and rarely occurring specimens are difficult to determine, but the writer has often seen the two growing close together, in apparently identical surroundings (especially in Porto Rico and Jamaica) and maintaining their distinctions so perfectly and strikingly that it seems more satisfactory to treat them as independent species than to follow the prevailing modern fashion of regarding them as forms of a single polymorphous species.

\section{Family 11. DERBESIÀCEAE.}

1. DERBĖsIA Solier, Ann. Sci. Nat. Bot. III. 7: 158. 1847.

1. Derbesia vaucheriaefórmis (Harv.) J. Ag. Till Alg. Syst. 5: 34. 1887.

Chlorodesmis (?) vaucheriaeformis Harv. Ner. Bor.-Am. 3: 30. pl. 40 D. 1858.

Derbesia tenuissima Farl. Mar. Alg. N. E. 60 p.p. pl. 4. f. 4. 1881. Not D. tenuissima (De Not.) Crouan.

On rocks in a salt spring, high littoral, Cave Cays, Exuma Chain:-southern Massachusetts, Rermuda, and Florida. Type from Key West, Florida.

The oniy Bahamian collection seems to be sterile, like Harres's original; its filaments are somewhat coarser, being $35-93 \mu$ in diameter, while those of the type are $30-52 \mu$; the plants are also much darker green than Harvey's specimens at the present day, but the latter have doubtless suffered some loss of color in nearly serenty sears of preservation.

2. BRYobesiA Web.-v. Bosse, Ann. Jard. Bot. Buitenzorg 24: 26. 1910.

\section{Bryobesia cylindrocárpa sp. nov.}

Filaments sparingly subdichotomous, $5-15 \mathrm{~mm}$. long, $75-156 \mu$ in diameter, very rarely septate, their walls mostly $3-10 \mu$ thick, the branches occasionally with a septum at the base; sporangia short-cylindric, obovoid, or cylindric-clavate, $150-450 \mu \times 90-180 \mu$, sessile, erect or erecto-patent, constituting one arm of a 
dichotomy or pseudo-dichotomy, or sometimes apparently terminal, the filament continued by a lateral imnoration; zoospores numerous (about 200-500 to a sporangium), ellipsoid or ovoid, $20-40 \mu \times 20-25 \mu$.

Green Cas, W. C. Cokcr, June 30, 1903, dredged in 4 fathoms,-a small amount of material preserved in formalin. There is a possibility that the plant belongs in Cladophoropsis, but the terminal rather than intercalary sporangia and the large zoospores, on some of which indications of a circle of eilia have been noted, have suggested its reference to Bryobesiu, the Javan type-species of which it resembles closely, though the Babamian plant is evidentiy longer and coarser, with filaments twice as broad.

\section{Family 12. CODIÀCEAE.}

1. AVrainvíltea Decaisne, Ann. Sci. Nat. Bot. II. 18: 10s. 1842.

Fradelia Chaur. Recherches 124. 1842.

Chloroplegma Zanard. Mem. R. Ist. Ven. 7: 290. 1558.

Thallus eventually developing a flabellum (usually stipitate).

Fusco-nigrescent, yellowish brown, or tawny green; surface subrelutinous, spongiose, or strigose; filaments of flabellum $28-70 \mu$ in diameter.

Filaments of flabellum moniliform.

Filaments of flabellum cylindric, with a strong constriction at base of each branch, rarely subtorulose.

Oliraceous or cinereous: surface smooth and compact; filaments of surface of flabellum $6-24 \mu$ in diameter.

Thallus not developing a flabellum, forming more or less digitate, sometimes capitate lobes, these commonly very irregular in form, and often branching, difluent, or anastomosing.

1. A. nigricans.

2. A. longicaulis.

3. A. levis.

4. A. Rausoni.

1. Avrainvillea nìgricans Decaisne, loc. eit.

Fradelia futiginosa Chauv. Recherches 124. 1842.

Avrainvillea longicau?is Murr. \& Boofle, Jour. Bot. 27: 70 p.p. pl. 208. f. 1-5. 1889. [Excluding syn. Tihipilia longicaulis Kütz.]

Common in shallow water, mostly on reefs or in places protected by reefs. New Providence, Andros, Berry Islands, Great Bahama, fun Cas, Eleuthera, Exuma Chain, Mariguana, Caicos Islands, Castle Island, and Great Ragged Island:-Bermuda and Florida to South America. Trpe flom Iles des saintes, negr Guadeloupe.

Forma fuilva M. A. Howe (in C. II. \& S. Phsc. Bor.-Am, 14S0) differs from the tyolcal form in its thicker. more spongiose, and usually more cureate flabellum, in its flatter, broader, less differentiated stipe, and in the firmer-walled, usually coarser, though oftel more tapering filaments, which are less regularly moniliform, often mole tortuous or zig-zag, mole frequently and mole divaricately dichotomous, and nearly always yellow or yellowish brown rather than fuscous at maturity.

2. Avrainvillea longicaùlis (Kütz.) Murr. \& Boodle, Jour. Bot. 27: 70 p.p. 18s9. [Exeluding all but syn. Rhipilia longicaul is Kütz.]

Rhipilia longicaulis Kiitz. Tab. Phyc. 8: 13. pl. 2S. f. II. 155 S. Avrainvillea Mazei Murr. \& Boodle, loc. cit.

('ommon in shallow or moderately deep water, often with A. nioricans. New Proridence, Exuma Chain, Watling's Island, Mariguana. Calcos Islands. Castle Island, Great Ragged Island, and Salt Cay:-Bermuda to Barbados. 'Type from Antlgua.

3. Avrainvillea lèvis M. A. Howe, Bull. Torrey Club 32: 565. pl. \&3. f. 1; pl. 26. f. 8-10. 1905 .

Avrainvillea sordida MLurr. \& Boodle, Jour. Bot. 27: 70. 18s9. Not A. sordida (Mont.) Crouan; Mazé \&. Schramm, Alg. Guad. 89. 1870-'77. [Based upon Udotca sordida Mont. in technicalities of publication.]

Near low-water mark, Exuma Chaln, Marlguana, and Caleos Islands :- Florida, Cuba, and Jamalca. Type from Cave Cays, Fxuma Chaln. 
4. Avrainvillea Ráwsoni (Dickie) M. A. Howe, Bull. Torrey Club 34: 510. 1907.

Rhipitia Rawsoni Dickic, Jour. Linn. Soc. Bot. 14: 151. pl. 11. f. 1, 2. 1874 .

In shallow water, often at low-water line on exposed rocks. Abaco, Gun Cay, North Cat Cay, Lerry lslinds, Exuma Chain, Watling's Island, Mar'iguana, Caicos Islands, and Great lagged Island:-Jamaica, Porto Rico, Guadeloupe, and Barbados. Type from Barbados.

\section{RHIPÍlla Kütz. Tab. Phyc. 8: 12. 1858.}

1. Rhipilia tomentòsa Kütz. loc. cit. pl. 28. $f$. 1 .

Cdotea tomentosa Murr. Jour. Bot. 27: 239. 1859.

In shallow water (down to 30 meters, fide Börgesen). North Cat Cay :-Cuba, Porto Rico, American Virgin Islands, Antigua, and Guadeloupe. Type from Antigua.

3. CLAdocéphalus M. A. Howe, Bull. Torrey Club 32: 569. 1905.

1. Cladocephalus scopàrius M. A. Howe, loc. cit. pl. 25; pl. 26. f. 11-20.

In shallow water. New Providence, Exuma Chain, and Watling's Island. Apparently endemic. Type from a tidal pond, Georgetown, Great Exuma.

4. PENIĆ́luus Lamarck, Ann. Mius. Hist. Nat. 20: 297. 1813.

Nesaea Lamour. Nouv. Bull. Sci. Soc. Philom. 3: 185. 1812. Not Nesaea Commers.; Juss. Gen. Pl. 332. 1789.

Corali.iodendron Kütz. Polyp. Caleif. 11. 1841.

Corallocephalus Kütz. Linnaea 17: 95. 1843.

Surface of stipe compact, indurated, smooth or minutely granulose under a handlens; ultimate branchlets of corticating filaments short-oblong, obtuse, truncate, or capitate.

Filaments of capitulum $135-250 \mu$ in diameter.

Filaments of capitulum $300-550 \mu$ in diameter.

Surface of stipe spongiose or velutinous-tomentulose under a

hand-lens; ultimate branchlets of corticating filaments elongate, taper-pointed.

Filaments of capitulum $500-900 \mu$ in diameter.

Filaments of capitulum $150-320 \mu$ in diameter.

1. P. capitatus.

2. P. Lamourouxii.

1. Penicillus capitàtus Lamarck, loc. cit. 299.

? Corallina Penicillus L. Syst. Nat. 1: 807. 1758.

Corallina Penicillus Ell. \& Soland. Nat. Hist. Zooph. 126 p.p. pl. 25. f. 4. 1786.

Nesea Penicillus Lamour. Hist. Polyp. 258. 1816.

Penicillus elongatus Decaisne, Ann. Sei. Nat. Bot. II. 18: 109.1842.

Corallocephalus Penicillus Kütz. Linnaea 17: 95. p.p. 1843.

Corallocephalus barbatus Kütz. Tab. Phyc. 7: 8. pl. 20. f. 11. 1855.

"The Merman's Shaving-brush" ; very common, usually on a sandy or muddy bottom in shallow water (mostly in $0.5-10$ meters). New Providence, Rose Island, Berry Islands, Andros, Great Bahama, Garden Cay, Exuma Chain, Cat Island, Watling's Island, Atwood Cay, Mariguana, Caicos Islands, and Great Ragged Island: -Bermuda and Florida to Guadeloupe. Type from American seas.

2. Penicillus Lamouroùxii Decaisne, Ann. Sci. Nat. Bot. II. 18: 109. 1842.

? Corallina Penicillus Ell. \& Soland. Nat. Hist. Zooph. 126 p.p. pl. 25. f. 5. 1786.

? Nesea pyramidalis Lamour. Hist. Polyp. 25s. 1816.

Penicillus Lamouronxii gracilis A. \& E. S. Gepp, Jour. Bot. 43: 2. 1905.

On a sandy bottom in shallow water. New Providence, Rose Island, Great Bahama, Garden Cay, Bimini, Green Turtle Cay, Exuma Chain, Watling's Island, 
Mariguana, Caicos Islands, Castle Island, and Great Ragged Island :-Florida, Cuba, Jamaica, Porto Rico, and American Virgin Islands. Type frou liahama Islands.

3. Penicillus dumetòsus (Lamour.) Blainville, Man. Actin. 553. 1634. [As P. dumetosa.]

Tesea dumetosa Lamour. Hist. Polyp. 259. 1416.

Coralloceplualus dumetosus Kiitz. Sp. Alg. 506. 1s+9.

Corallocephalus affinis Kü̈tz. Tab. Plyye. 8: 13. pl. 30. 185 S.

On sandy or muddy bottom, mostly in shallow watel. Long Bank, Great Bahama, and Bimini :- Florida to Guadeloupe. Type from "Antilles."

4. Penicillus pyrifórmis A. \& E. S. Gepp, Jour. Bot. $43: 1 . p l$. 468. $f .1 a, 1 b$. 1905.

On a sand bottom in shallow water, common. New Providence, Rose Island, Berry Islands, Andros, Great Bahama, limini, Exuma Chain, Cat lsland, Watling's Island, Mariguana. Caicos Islands, and Anguilla Isles:-liermuda and Florida to Jamaica and Guadeloupe. Trpe from Bimini Ilarbor, Bahamas.

5. RHIPOCÉPHALUS Kütz. Linnaea 17: 95. 18 43 ; Phye. Gen. 311. 1843.

Filaments of capitulum $5-90 \mu$ in diameter toward apices, rather firmls and persistently coherent, in always easily recognizable flabella.

Filaments of eapitulum $100-230 \mu$ in diameter toward apices. lightly and transiently coherent, the flabella scarcely recognizable at maturity.

1. P. Phocuix.

2. P. oulongus.

1. Rhipocephalus Phoènix (Ell. \& Soland.) Kiitz. loc. eit.

Corallina Phoenix Ell. \& Soland. Nat. Hist. Zooph. 126. pl. 25. f. 2, שّ 1756.

On sandy or gravelly bottom or on rocks, mostly in shallow water. New l'rorldence, Rose Island. Rerry Islands, Andros, Bimini, Exuma Chain, Cat Island, Atwood Cay, and Mariguana:-Florida, Cuba, Janaica, Porto Rico, and Guadeloupe. Type from the Bahama Islands.

2. Rhipocephalus oblóngus (Decaisne) Kütz. Sp. Alg. 506. $15+9$.

Penicillus oblongus Decaisne, Amn. Sei. Nat. Bot. II. 18: 109. 1512.

On sandy bottom in shallow water. not common. New Providence, Berry Islands, Bimini, and North Cat Cay:-lorida and Cuba. Type from the Bahama Islands.

Often resembling certain conditions of Pcuicillus capitatus, but usually recognizable, at least in living or flud-preserved states, by the more flabelliform nrrangement of the filaments of the capitulum and by the presence of a cup-shaped apical depression.

6. UdòteA Lamour. Nour. Bull. Sci. Soe. Philom. 3: 1S6. 1 S12.

Flabellum with a compact, firm, highly speclalized cortex, distinctly \%onate.

Flabellum with an imperfect rudimentars cortex or none at all.

Filaments of flabellum without lateral appendages, each filament enclosed in a polose calleareous shenth.

Flabellum plane: trausltion from stipe to flabellum gradual: filaments of flibellum 28-(i) $\mu$ In diameter, Interwoven and tortuous. usually forming a superficial tomentulose nap; branches of the cortleating filaments of the stipe somewlint lonsely and irregularly fastiglate, the ultimate divislons mostly finger-shaped. sulneute, or taper-pointel.

Flabellum more or less cyithlform, or open on nue side and almost plane (then usually a llttle concavoconvex, at least at base): transltion from stlpe to flabellum abrupt; flaments of flabellum nearly

1. L. Flabcllum.

2. L. conglutinata. 
straight and parallel, mostly 60-100 $\mu$ in diameter: branches of corticating flaments of stipe compactly cymose-fastigiate, the ultimate divisions scarcely longer than broad, truncate, truncate-obtuse, or commonly with expanded truncate-capitate apices.

Filaments of flabellum appendaged; calcareous sheaths, if differentiated, non-porose.

Filaments strongly constricted above dichotomies; appendages crowned with 2-8 acuminate prongs or spines.

Filaments not constricted above dichotomies; appendages simple or sparingly furcate, obtuse, truncate, or capitate.

3. U. cyathiformis.

4. U. spinutosa.

5. U. Wilsoni.

1 Udotea Flabéllum (Ell. \& Solanł.) M. A. Howe, Bull. Torrey Club 31: 94. 1904.

Corallina Flabellum Ell. \& Soland. Nat. Hist. Zooplh. 124. pl. 24. f. A, B, C. 1786.

Flabellaria pavonia Lamarck, Ann. Mus. Hist. Nat. 20: 301. 1813.

Udotea flabellata Lamour. Hist. Polyp. 311. 1816.

Flabellaria incrustata Chanvin, Recherches 123. 1842.

Udotea Halimeda Kütz. Sp. Alg. 503. 1849.

Common on a sandy or muddy bottom, from near low-water mark down to 30-40 meters. New Providence, Berry Islands, Great Bahama, Garden Cay, Biminj. Exuma Chain, Watling's Island, Mariguana, Caicos Islands, Great Ragged Island, and Salt Cay:-Bermuda and Florida to fruadeloupe and Panama (Colon). Type from " West Indies."

2. Udotea conglutinàta (Ell. \& Soland.) Lamour. Hist. Polyp. 312.1816.

Corallina conglutinata Ell. \& Soland. Nat. Hist. Zooph. 125. pl, 25. f. \%. 1786.

Flabellaria eonglutinata Lamarek, Ann. Mus. Hist. Nat. 20: 301. 1813.

On a sandy bottom from near low-water mark down to 14 meters or more. New Providence, Andros, Joulter's Cays, North Cat Cay, Biminf, Green Cay, Watling's Island, Mariguana, Caicos, and Castle Island:-Bermuda and Florida to the American Virgin Islands. Type from the Bahama Islands.

3. Udotea cyathifórmis Decaisne, Ann. Sci. Nat. Bot. II. 18: 106. 1842.

Udotea conglutinata Vickers, Phyc. Barbad. 1: pl. 32. 1908.

On a sandy bottom from near low-water mark down to 30 meters or more. Berry Islands, Bimini, North Cat Cay, Exuma Chain, Caicos Islands, and Castle Island:- North Carolina to Barbados and Panama (Colon). Type from Isles des Saintes, Guadeloupe.

4. Udotea spinulòsa M. A. Howe, Bull. Torrey Club 36: 97. pl. 4. f. 2; pl. 8. f. $1-7.1909$.

On a sandy bottom near low-water mark. Bimini (type):-American Virgin Islands (in 30-40 meters, fide Börgesen).

5. Udotea Wílsoni Gepp \& Howe, Siboga Exped. Monog. 62: 130. pl. \%. f. 66; pl. 8. f. 67, 68. 1911.

On a sandy bottom in shallow water. Anguilla Isles (type) :-Florida and Cuba.

7. HALIMEd Lamour. Nouv. Bull. Sci. Soc. Philom. 3: 186 (as Halimedea* $) .1812$.

Opuntia Nace. Fl. Ven. 6: 104. 1828. Not Opuntia L.

Sertolara (Imp.) Nardo, Isis 1834: 673. 1834.

BotRYOPHORA Bompard, Hedwigia 6: 129. 1867.

Segments reniform, semiorbicular, or deltoid-obovate, margins entire or (in $H$. opuntia) crenate or sometimes lobed. Nodal filaments of central strand fusing more or less completely in pairs or in threes.

* Afterwards (1816) changed by Lamouroux himself to Halimeda. 
Peripheral utricles galeate-cuspidatc.

Peripheral utricles truncate or rounded-obtuse.

1. H. scabra.

Fusion of nodal filaments complete (or sometimes incomplete in $I I$. discoidca); segments not ribbed or nerved.

Peripheral utricles in contact for one-eiglith of their length or less; utricles of subcortical layer subturbinate, obconic, cornucopiaeform, or clavate, $35-110 \mu$ in max. width; segments moderately calcified, $5-15 \mathrm{~mm}$. broad.

Peripheral utricles in contact for one-fifth to twothirels of their length; utricles of the subcortical layer bullate, mostly ventricose-oboroid, $110-215 \mu$ in max. width; segments very lightly calcified, 6-35 mm. broad.

Fusion of nodal filaments incomplete (i.e., filaments retaining their identitr) in pairs; segments more or less ribbed or nerved.

Segments discoid or subterete, often 3-lobed or 3-dentate. Nodal filaments of the central strand coherent, communicating by pits, pores, or vely short tubular processes, rery rarely (especially in $I I$. 1 onile) mercly thick-walled and separable.

Peripheral utricles less than $80 \mu$ in arerage maximum diameter, surface view.

Peipheral utricles $49-7 T \mu$ in average maximum diameter, surface view : segments usually flattened.

Peripheral utrleles $30-44 \mu$ in average maximum diameter.

Segments mostly subterete.

Segments discoid (suggesting $H$. Tuna).

Peripheral utricles $175-190 \mu$ in average maximum diameter, surface view.

Segments obovoid, priform, or subglobose. Nodal filaments of the central strind fusing in twos or threes or rarely fours, the resulting filaments sometimes again incompletely fused.

2. H. Tuna.

3. H. discoidca.

4. H. Opuntia.
6. II. Monile.

7. II. simulans.

8. H. favilosa.

9. II. lacrimosa.

1. Halimeda scàbra IT. A. Howe, Bull. Torrey Club 32: 241. pl. 11, 12. 1905.

Common on rocks, old corals, the bases of sponges, etc., from low-water mark down to a depth of 3 meters or more. New Providence, Fose Island, Berry Islands, Great Bahama, Bimini, North Cat Cay, South Cat Car. Gun Cay, Eleathera, Exuma Chain, WatIing"s Island. Atwood Cay, Mariguana, Caicos Islands, Castle Island, Great Ragged Island. Anguilla Isles, and Salt Cay:-Florida. Type from Sands Key, Florida.

2. Halimeda Tùna (Ell. \& Soland.) Lamour. Hist. Polyp. 309. pl. 11. f. \&a. 1816.

Corallina Tuna Ell. \& Soland. Nat. Hist. Zooph. 111. pl. 20. f. e. 17 S6.

Flabellaria Tuna Lamarek, Ann. Mus. Hist. Nat. 20: 302. 1813.

Halimeda platydisca Decaisne, Ann. Sei. Nat. Bot. II. 18: 102. 1842.

On rocks, etc., from low-water mark down to 60 meters, Atwood Car, Mariguana, Caicos Islands, Great Ragged Island, and Anguilla Isles:-Bermuda and Florida to Jamaica and Rarbados: apparently of wide distribution in the warmer seas. Type from the Mediterranean Sea,

3. Halimeda discoìdea Decaisne, Ann. Sci. Nat. Bot. II, 18: 102. 1842.

Mostly in shallow, somewhat agitated water (down to $20-40$ meters, fidc Börgesen) Great Bahama :-Florida, Cubn, I'orto Rico, Lower California, Jawaii, and the Philippines. Type locality unknowu ("Kamtschatka").

4. Halimeda Opùntia (L.) Lamour. Hist. Polyp. 30s. 1816.

Corallina Opuntia I. Syst. Nat. 1: 805 p.p. 175s. Ell. \& Sol. Nat. Hist. Zooph.1110. pl. 20.f. b. 1796.

Common from near low-water mark down to a depth of 20 meters ol more, often forming extensive beds. New Provldence, liose Island, Berry Islands, South Cat Cay, Gun Cay, Exuma Chain, Watling's Island, Variguana, and Anguilla Isles: - Florida to Barbados and Janama (Colom): widely distributed in the wamel seas and important as a reef-bulder and land-former. Type from Jamaica. 
5. Halimeda trìdens (Ell. \& Soland.) Lamour. Hist. Polyp. 30s. 1816.

Corallina tridens Ell, \& Soland. Nat. Hist. Zooph. 109. 1786.

Corallina incrassata Ell. \& Soland. loc. cit. 111.

Halimeda incrassata Lamour. Hist. Polyp. 307. 1816.

Halimeda brevicaulis Kütz. Tab. Phye. 8: 11. pl. 25. f. II. 1858.

Tery common on a sandy or muddy bottom from near the low-water mark down to 40 meters or more. New Providence, Riose Island, Andros, Great Bahama, North Cat Cay. Green Cay, Exuma chain. Cat IsIand, Watling's Island, Atwood Cay. Mariguana, Caicos Islands, Castle Island, Great Ragged Island, Salt Cay, and Anguilla Isles:-Bermuda and Florida to Guadeloupe: also in the tropical seas of the Eastern IIemisphere. Type from the Iiahama Islands.

6. Halimeda Monile (Ell. \& Soland.) Lamour. Hist. Polyp. 306. 1816.

Corallina Monile Ell. \& Solant. Nat. Hist. Zooph. 110. 1786.

Halimeda incrassata monilis Harr. Ner. Bor.-Am. 3: 24.1858.

Halimeda tridens IIonile M. A. Howe, Bull. Torrey Club 32: こ64. 1905.

Common on a sands hottom. often with $H$. trilens and $H$. simulans, but distinct. Rose Island, Cat Island, Watling's Island, Jariguana, Caicos Islands. Great Ragged Island, Salt Cay, and Anguilla Isles:-Bermuda and Florida to Guadeloupe and Panama (Colon). Type from Jamaica.

7. Halimeda símulans M. A. Howe, Bull. Torrey Club 34: 503. pl. 29. 1907.

on a sandy bottom, rocks, old corals, etc., from near low-water mark down to a depth of several meters. Perry Islands, Atwood Cay, Mariguana, Caicos Islands, and Great Ragged Island:-Bermuda. Florida, Cuba, Jamaica, Porto Rico, American Virgin. Islands, and Panama (Colon). Type from Culebra Island, Porto Rico.

8. Halimeda favulòsa M. A. Howe, Bull. Torrey Club 32: 563. pl. 23; pl. 24; pl. 26. $f .1-6.1905$.

On a sandy hottom in shallow water. Rose Island and Fxuma Chain. Type from Care Cays, Exuma Chain. Apparently endemic.

9. Halimeda lacrimòsa M. A. Howe, Bull. Torrey Club 36: 93. pl. 4. f. 1; pl. 6. f. 3-11. 1909 .

On a sandy bottom from near low-water mark down to a depth of $10-20$ meters or more. Exuma Chain, Iariguana, and Great Ragged Island:- Cuba. Type from Mariguana.

8. CòdIUM Stackh. Ner. Brit. xri, xxii, xxiv. 1797.

Lamarckia Olivi, Zool. Adriat. 258. 1792. Not Lamarckia Medie. 1789. SPoxgodium Lamour. Essai 71, 72. 1813.

Agardhia Cabrera; Ag. Syn. Alg. Scand. xxir. 1817.

Thallus mostly erect and fruticose.

Periphera] utricles cylindric-clavate, mostly $75-200 \mu$ in max. diam.; thallus dull and rather rigid when dry, the branches not constricted at base.

Perinheral utricles novoid. ohronic, nr goblet-shaned, mostly $150-300 \mu$ in max. diam.: thallus commonly nitent and rather flaccid when dry, the branches constricted at base.

Thallus adherent, prostrate, or repent.

1. C. tomentosum.

2. C. isthmocladum. 3. C. intertextum.

1. Codium tomentòsum (Huds.) Stackh. Ner. Brit. xxiv. 1797.

Fucus tomentosus Huds. Fl. Angl. 584. 1778.

on rocks, ete. in shallow water. North Cat Cay. Eleuthera. Atwood Car. and Caicos Islands :- Bermuda and North Carolina to Panama (Colon) and South America: widely distributed in the warmer seas. Type from Great Britain.

Codium decorticatum (Woodw.) M. A. Howe (C. elongatum Ag.) has not yet been reported from the Bahamas, but is likely to occur. It differs from $C$. tomentosum in being more elongate, more sparingly branched, by flattened expansions under the dichotomies, and by the much larger utricles. 
2. Codium isthmócladum Viekers, Ann. Sei. Nat. Bot. IX. 1: 57. 1905.

In shallow water. Berry Islands:-Bermuda and Forida to Barbados. Type from Barbados.

The only Bahamian speclmen seen that seems referable to this species is coarser, more rigid, and less nitent than the typical form, but couforms in the characters of the peripheral utricles and sporangia.

3. Codium intertéxtum Collins \& Hervey, Proc. Am. Acad, 53: 54. 1917.

Cnder shelring rocks and in erevices, closely adherent. Gun Cay and Atwood Cay :-Bermuda and Florida to Barbados. Type from Bermuda.

3a. Codium intertextum cribròsum MI. A. Howe, var. nov.

Codium adhaerens M. A. Howe; Gardner, Univ. California Publ. Bot. 6: 492, 496. pl. 42. f. 9. 1919. Not C. adhaerens (Cabr.) Ag.

Wall of the peripheral utricles (of the more exposed at least) slightly thickened at the apex, the incrassate area mostly $5-13 \mu$ thick and internally cribrose-pitted, the walls elsewhere mostly $1-2 \mu$ thick.

On rocks and other algae, from above $1 \times-\pi$-water mark down to a depth of at least 12 meters. Little IIarbor Cay, Berry Islands (Howe 3583-type) :-Jamaica and Porto Rico.

It was at first thought that the peculiar pitting of the apical walls of the utrlcles might be sufficient to warrant ranging this plant in the specific category, but the occasional occurrence of similarly marked utricles in plants otherwise predominantly agreeing wjth $C$. intertextum (e.g., no. 3139 from Gun Cay) would seem to make this impractical.

\section{Family 13. VAUCHERIÀCEAE.}

1. DichotomosìmoN Ernst, Beih. Bot. Centralbl. 13: 115. 1902.

1. Dichotomosiphon pusíllus Collins, Tufts College Stud, 2: 431. 1909.

On and with Amphibia on roots of Rhirophora, in tide-pools and lagoons, and often forming a compact dark-green velvety turf on rocks between the tide-lines and on the mud in Rhizophora associations. New Providence, Exuma Chain, Watling's Island, and Great Ragged Island:-Bermuda to Jamaica. Type from West Indies (Jamaica).

The filaments show a wide range in size, even in a single tuft, varying from $15 \mu$ to $60 \mu$ in diameter.

\section{Family 14. CHARÀCEAE.}

\section{1. *CHÀRA L. Sp. Pl. 1156. 1753.}

Stems triply corticated, but, by imperfect development of some of the secondary cells usually appearing doubly corticated: stipulodes forming a single whorl; at least the basal leaf-internode uncortlcated; dioicous; spine-

cells conspicuous on all stem-internodes.

Stems usually very regularly triply corricated; stipules formlng a double whorl; monoicous.

Some or all leaflets well developed.

All leaflets at sterile nodes greatly reduced.

1. C. IIornemannii.

2. r. foliolos $a$.

3. C. haitensis.

1. Chara Hornemánnii Wallm. K. Vet.-Akad. Tandl. 1852: 2Sৎ. 15.54.

Chara ceratophylla Halsted, Proc. Boston Soc. Nat. Hist. 20: 182. 1879. Not C. ceratophylla Wallr.

In salt or bracklsh ponds. New Provldence, Fxuma Chain, and Watling's Island:- Southern Florida and New Mexico through the West Indies and Mexico to southern Brazil. Type from Crab Island (Vieques), I'orto Iilco.

- Determinations chlefly by the late Dr. Charles Budd Roblnson and the key and synonym adapted from the paper published by hlm in Bull. N. X. Bot. Gerres. 4: 244-30s. 1906. 
2. Chara foliolòsa Muhl.; Willd. Mem. Acad. Roy. Berlin 1803: 86. pl. 1. f. 2. 1805 .

Chara polyphylla Muhlenbergii A. Br. Boston Jour. Nat. Hist. 5: 264. $18+5$.

Chara Wiliströmii Wallm. K. Vet.-Akad. Handl. 1852: 297. 1854.

Chara gymnopus Humboldtii A. Br.; Allen, Char. Am. 2. 1880.

Chara depauperata Allen, Bull. Torrey Club 21: 167. pl. 192. 1894.

Chara zeylanica H. \& J. Groves, in Urban, Symb. Antill. 7: 40. 1911.

In fresh-water and brackish ponds. New Providence, Great Bahama, Abaco, Cat Island, and Great Exuma :-Pennsylvania to South America. Type from South America. The type of $C$. depauperata, here considered a synonym, was from New Providence.

3. Chara haiténsis Turpin, Dict. Sei. Nat. Veg. Acot. pl. 101. (Livr. $40: p l .1$ ). 1826.

Chara polyphylla A. Br. Flora 18: 70. 1835.

Chare Michauxii A. Br. Am. Jour. Sci. 46: 93. 1844.

Chara gymnopus Michauxii A. Br.; Allen, Char. 2. $18 s 0$.

Chara zeylanica Michauxii H. \& J. Groves, in Urban, Symb. Antill. 7: 42. 1911.

In fresh-water and brackish ponds. Inagua:-Illinois and Virginia to Haiti, Jamaica, and South America. Type from Haiti.

\section{Sub-class IMYXOPHỲCEAE.}

Contributed by Frank S. Coluins.

\section{Family 1. CHROOCOCCÀCEAE}

1. CHROocóccus Näg. Gatt. 45. 1849.

Cells $3-8 \mu$ in diameter.

Cells $13-25 \mu$ in diameter.

1. C. membraninus.

2. C. turgidus.

1. Chroococcus membranìnus (Menegh.) Näg. Gatt. 46. 1849.

Pleurococcus membraninus Menegh. Monogr. 34. pl. 4. f. 1. 1843.

Among other small algae, in company with Chroococcus turgidus, Caicos Islands: -Europe ; Bermuda. Type from Italy.

2. Chroococcus túrgidus (Kütz.) Näg. Gatt. 46. 1849.

Protococcus turgidus Kütz. Tab. Phyc. 1: 5. pl. 6. f. 1. 1846.

Among other blue-green algae, Caicos Islands:- of world-wide distribution, marine and fresh water. Type from Europe.

\section{APHANOCÁPSA Näg. Gatt. 52. 1849.}

I. Aphanocapsa Hówei Collins, sp. nov.

Marina. Cellulis 9-15 $\mu$ diam., sphaericis, raro subfusiformibus, membrana pertenui, plasmate homogeneo; cellulis in gelatina communi hyalina mollissima inordinatis; strato obscuro- rel atro-aerugineo.

Cells $9-15 \mu$ in diameter, spherical or rarely slightly fusiform, wall very thin, substance homogeneons, color pale aeruginous; forming a dull or dark aeruginous stratum, united by thin, homogeneous common gelatine, elosely set in no definite order. 
In $3 \mathrm{dm}$. water in a salt lake, Watling's Island, November $2 \overline{5}, 1907$, U. A. Howe 5091 (type), 5092, 5100.

The geueral gelatine is very thin, hardly perceptible except by use of stains; at first glance the plant would be taken for a species of Syncchocystis. Some of the cells, usually those near the surface of the colony, show a thicker tegument outside the very thin cell wall. Its nealest relative appears to be A. Zunardinii (IIauck) llausg.* of southern Europe and Borneo, which has cells of much the same dimen-

* The record in Forti, Syll. Myx. 68. of the occurrence of A. Zanardinii in North America "Massacliusetts (Collius)" is wrong. The writer has nerer found it, ind has nerer seen American material.

sions, but of deeper color "riridi-smaragdino," and arranged by 2 or 4 in a firmer, more sharply defined common gelatine.

\section{GLOEOCÁPSA Kütz. Phyc. Gen. 173. 1843.}

Marine; teguments brownish.

Terrestrial.

Teguments red: cells $4.5-7 \mu$ in diameter.

Teguments violet or steel-blue; cells $2.5-3.5 \mu$ in diameter.

1. G. bahamcnsis.

2. G. Magma.

3. G. liynicola.

1. Gloeocapsa bahaménsis Collins, sp. nov.

Marina. Cellulis indivisis $4-8 \mu$ dianı., sine membrana $3-5 \mu$, pallide aerugineis, in familias 4-24 cellularum unitis; tegumentis amplis, distinetis, lamellosis, sub- vel perfuseis; familiis sparsis vel inter myxophyceas varias in crustam fuscam compactis.

Undivided cells $4-8 \mu$ in diameter, without wall $3-5 \mu$ in diameter, pale aeruginous; teguments wide, lamellose, distinet, lighter or darker brown; families seattered or loosely compacted with other Myxophyceae into a brownish erust.

On the border of a salt pond, east end of Mariguana, December 12, 190T, И. A. Howe 5538 (type).

The cells in this material are dividing so rapidly that single free cells are seldom seen; the wide teguments may persist through many generations of cell dirision. G. crcpidin $u$ m 'Tluret, the best known and most generally distributed species, has thin and rather inconspicuous teguments, the cells, not including the walls, larger, the color brownish. G. deusta (Menegh.) Kiitz. also has larger cells and thinner teguments, with cells and teguments dark green to blackish.

2. Gloeocapsa Mágma (Bréb.) Kütz. Tab. Phye. 1: 17. pl. 22. f. 1. 1847.

Protococcus Magma, Bréb. Alg. de Falaise, 40.pl. 4. 1836.

Among other blue-green algae, New I'rovidence :-of wide distribution inland in warm aud temperate regions. Type from France.

3. Gloeocapsa lignícola Rab. Fl. Eur. Alg. 2: 41.1865.

On bark, New Providence, first American record:-Europe. Type from France.

4. ENTOPHÝSALIS Kütz. Phye. Gen, 177. 1843.

\section{Entophysalis violàcea Collins, sp. nov.}

Marina. Cellulis sphaerieis, $4-5 \mu$ diam., sine membrana $2-3 \mu$ diam., elongatis ante divisionem, atroviolaceis, membrana hyalina, incolori vel plusminus coeruleseente; cellulis 2, interduı 4, in membrana matrieali persistente, series longitudinales indefinitas formantibus; seriebus dense compactis in stratum tenue firmum nigrum.

Cells with wall spherical, $4-5 \mu$ in diameter, becoming elongate when dividing, without wall $2-3 \mu$ in diameter, color dark violet, wall translucent, colorless or more or less bluish; cells usually 2, oceasionally 4 in the wothercell wall, in indefinite longitudinal series, elosely paeked to form a thin smooth black crust. (type).

On rocks at low water mark, Atwood Cay, December 3, 1907, M. A. Howe 5282

E. granulosu Kïitz, the type of the genus, forms a thicker, warty and granular 
crust of a brown color; the cells are somewhat larger than in the present species, and brownish or yellowish. $E$. violacea apploaches the genus l'lacoma in the tendeney of the cells to arrange in radiate filameuts, but the tendener is less marked than in Placoma, and the frond is closely adherent to the substratum, not bullate and hollow as in Plucouma.

\section{GLOEOTHÈCE Näg. Gatt. 57. 1849.}

1. Gloeothece rupéstris (Lyngb.) Bornet; Wittr. \& Norilst. Alg. Exsicc. 399. 1850.

Palmella rupestris Lyngb. Tent. 207. pl. 69. f. D. 1819.

On rocks, nearly pure, Caicos Islands:-common everywhere in small quantity among other algae, especially in shallow pools, both alongshore and inlaud; of general distribution. Type from Denmark.

Tery raliable; teguments often diffluent, giring the appearance of Aphanothece.

6. ONCOBÝRSA Ag. Flora 10: 629. $182 \pi$.

1. Oncobyrsa marìna (Grun.) Rab. Flor. Eur. Alg. 2: 68. $156 \tilde{.}$

Hydrococcus marinus Grun. Terh. Zool.-Bot. Ges. Wien. 11: 420. 1861.

On Chondria, Mariguana :-Europe; Africa; Bermuda. Type from the Mediterranean.

\section{Family 2. CHAMAESIPHONÀCEAE.}

1. HYÉLLA Born. \& Fłah. Jour. de Bot. 2: 162. 1888.

1. Hyella caespitòsa Born. \& Flah. loe. cit.

In dead shells, common:-generally distributed. Type from France.

2. DERMOCÁRPA Crouan, Ann. Sci. Nat. Bot. IV. 9: 70. 1858.

1. Dermocarpa prasina (Reinsch) Bornet \& Thuret, Notes Alg. 75. pl. 26. f. 6-9. 1880.

Sphaenosiphon prasinus Reinsch, Contrib. 17. pl. 26. f. 1. 1875.

On Catenclla opuntia pinnata, Berry Islands; probably to be found wherever the host occurs:-Europe. Type from Europe.

The common species of the New England coast, which has passed under this name, has much Iarger cells, and was segregated by Börgesen as D. Furlouri.

3. XENocóccus Thuret, Ann. Sci. Bot. YI. 1: 373. 1875.

1. Xenococcus Schoùsboei Thuret in Born. \& Thur. Notes Alg. 76. pl.26. f. 1-2. 1880 .

Attached to wall of Lyngbya sp., Atwood Cay :-of general distribution. Type from northern Africa.

\section{Family 3. OSCILLATORIÃCEAE.}

1. OSCILlatòria Vaucher, ex Gomont, Monogr. 21s. 1893.

Trichomes not torulose, $4-10 \mu$ in diameter.

Trichomes distinctly torulose.

Stratum and trichomes red or red-brown.

Stratum and trichomes aeruginous or chalybeous.

Trichomes $10-20 \mu$ in diameter, apex straight.

Trichomes $6-10 \mu$ in diameter, apex usually curred.

4. O. tenuis.

2. O. miniata.

1. O. sancta.

3. 0 . Corallinae.

1. Oscillatoria såncta Kütz. ex Gomont, Monogr. 229. pl. 6. f. 12. 1893

Atwood Cay :-generally distributed, normally in fresh water. Type from Italy.

2. Oscillatoria miniàta Hauck ex Gomont, Monogr. 236. 1893.

Floating. with Trichodesmium Thiebautii, in Gulf Stream between Gun Cay and Florida:-Belmuda; Guadeloupe; and Adriatic Sea. Trpe from Adriatic Sea. 
3. Oscillatoria Corallinae Gomont, Monogr. 238. pl. 6. f. 21. 1893.

On Halimeda, etc., Mariguana :-Europe; North America. Type from France.

4. Oscillatoria ténuis Ag. ex Gomont, Monogr. 241. 1893.

Watling's Island:- of world-wide distribution, fresh water, occasionally submarine. Type from Sweden.

2. TRICHODÉsMIUM Ehrenb. Ann. Phys. u. Chem. 18: 506. 1830.

1. Trichodesmium Thiebaùtii Gomont, Jour. de Bot. 4: 356. 1890.

Pelagic in Gulf Stream, between Gun Cay and Florida :-Bermuda; Guadeloupe; and Canary Islands. Type from Guadeloupe.

\section{PHORMÍdIUM Kiitz. ex Gomont, Monogr. 176. 1893.}

Trichomes distinctly torulose, 1.2-2.3 $\mu$ in diameter.

Trichomes not torulose.

Trichomes less than $2 u$ in diameter : forming definite cartilaginous dises or cushions.

Trichomes $2 \mu$ in diameter or more.

Trichomes 2-2.5 $\mu$ in diameter, cells 1.5-3 diameters long.

Trichomes over $3 \mu$ in diameter.

Apical cell obtusely conical. trichomes $3-4.5 \mu$ in dia meter.

Apical cell truncate, cells $\approx \mu$ in diameter or more.

Cells usualls shorter than their diameter, dissepiments often constricted, sheaths loose and diffluent.

Cells usually longer than their diameter. trichomes always cjlindrical, sheath close, persistent.
1. P. fragitt.

2. P. Hendersonii.

3. P. valderianum.

4. P. Corium.

5. P. Ret $\approx$ ii.

6. P. pulvinatum.

1. Phormidium frágile Gomont, Monogr. 183. pl. 4. f. 13-15. 1893.

On walls of fresh-water tanks, New Providence:-Europe; Aflica ; North America. Type from Italy.

2. Phormidium Hendersònii M. A. Horre, Smiths. Mise. Coll. 68 ${ }^{11}$ : 3. 1918.

Forming definite discs or cushions on rocks, Watling's Island:-Cuba, Porto Rico. Type from Cuba.

3. Phormidium valderiànum Gomont, Monogr. 197. pl. 4. f. 20. 1893.

Among other algae. New Proridence, North Cat Cay, Watling's Island :-Europe ; North America; fresh water and marine. Type from Italy.

4. Phormidium Còrium Gomont, Monogr. 192. pl. 5. f. 1-2. 1893.

Great Ragged Island:-generally distributed. Trpe from Sweden.

5. Phormidium Rétzii Gomont, Monogr. 195. pl. 5. f. 6-9. 1893.

Caicos Islands:- generally distributed. Type from Sweden.

\section{Phormidium pulvinàtum Collins, sp. nov.}

Marinum. Strato pallide aerugineo, crasso, compacto, pulvinato; filamentis rectis $\mathrm{rcl}$ leviter curvatis, vaginis tenuibus, membranaccis, persistentibus, adhaerentibus nec diffuentibus; trichomatibus pallide aerugineis, cylindricis, apice rectis, non capitatis nee attenuatis; cellulis $7-9 \mu$ diam., $\frac{3}{4}-1 \frac{1}{2}$ diam. longis; dissepimentis non granulatis; cellula apicali rotundata.

Stratum pale aeruginous, thick, compact, pulvinate; filaments straight or slightly curved; sheaths thin, membranaceous, persistent, adherent but not diffluent; trichomes pale aeruginous, eylindrical, apex not attenuate nor capitate, $i-9 \mu$ in diameter, cells $\frac{3}{4}-1 \frac{1}{2}$ diameters long, dissepiments not granulate; apical enl! rounded. 
Abundant in 4-5 m. water, forming pulvinate masses among Thalassia, Penicillus, etc., Cockburn IIarbor, South Caicos Island, December 16, 1907, .1. A. IIoxe 5593 (type).

Cearest allied to $P$. Retzii, but differing by the firmer and more persistent sheaths, the uniformly crlindrical trichomes and the generilly longer cells, as well as br the distinctly marine habitat. There is more or less lime scattred through the mass, but incidentally : it does not form a stony mass as in the encrusting species.

\section{LÝNGBYA Ag. ex Gomont, Monogr. 138. 1893.}

Filaments attaclied at the middle, both ends free.

Filaments attached at one end or without definite point of attachment.

Filaments spirally wound about some other filamentous alga.

Filameuts not epiphrtic and spiral.

Trichomes $4 \mu$ in diameter or less, seldom over $3 \mu$.

Trichomes over $\bar{s} \mu$ in diameter.

Trichomes usually $20-40 \mu$ in diameter : length of cells $1 / 6-1 / 15$ of the diameter; dissepiments not granulate.

Trjchomes usually $16 \mu$ in diameter or less: length of cells $1 / 3-1 / 8$ of the diameter ; dissepiments usually granulate.

Trichomes usually $9-16 \mu$ in diameter: apex not attenuate nor capitate; stratum usually yellow.

Trichomes usually more or less attenuate and capitate.

Sheath becoming rellowish or brownish with age; stratum mostly aeruginous or l'usty ; trichomes usuall $10-16 \mu$.

Sheath alwars hraline; stratum dull or yellow green; trichomes $\mathbf{i}-10 \mu$ in diameter.

1. L. gracilts.

7. L. epiphytica.

6. L. Lagerheimii.

3. L. majuscula.

4. L. conferioides.

2. L. acstuarii.

5. L. semiplena.

1. Lyngbya grácilis Rab. ex Gomont, Monogr. 145. pl. 2. f. 20. 1893.

Among other algae, Exuma Chain :-Europe; North America. Type from Italy.

2. Lyngbya aestuàrii (Mert.) Liebmann ex Gomont, Monogr. 147. pl. 3. f. $\dot{1}-2$. 1893.

Exuma Chain:-common on all shores. Type from Denmark.

2a. Lyngbya aestuarii forma limícola Gomont, Monogr. 149. 1893. known.

Exuma Chain, with the trpical form; of same distribution. Type station un-

3. Lyngbya majúscula Harv. ex Gomont, Monogr. 151. pl. 3. f. 3-4. 1893.

New Providence, Berry Islands, Exuma Chain. Watling's Island, Atwood Cay, Mariguana, Caicos Islands, Great Ragged Island:-everywhere in tropical and warm temperate waters. Type from England.

4. Lyngbya confervoìdes Ag. ex Gomont, Monogr. 156. pl. 3. f. 5-6. 1893.

New Providence, Joulter's Cay, Bimini, Berry Islands, Exuma Chain, Watling's Island. Cat Island, Mariguana, Caicos Islands, Great liagged Island :- generally distributed in tropical and warm temperate waters. Type from Spain.

5. Lyngbya semiplèna J. Ag. ex Gomont, Monogr. 158. pl. 3. f. 7-11. 1893.

New Proridence, Berry Islands, Great Bahama, Exuma Chain, Watling's Island, Atwood Car, Iariguana, Great Ragged Island:-generally distributed. Type from the Mediterranean.

6. Lyngbya Lagerheìmii Gomont, Monogr. 167. pl. 4. f. 6-7. 1893.

Caicos Islands:-Europe; North and South America. Type from Brazil.

7. Lyngbya epiphýtica Hieronymus; Kirchner in Engl. \& Prantl, Nat. Pflanzenfam. $1^{19}: 67.1898$.

Winding about the filaments of Lyngbya sp.; Watling's Island, Atwood Cay :Europe; North America. Type from Germany. 
5. PLeCtonèma Thuret ex Gomont, Monogr. 116. 1893.

Trichomes torulose; flaments inhabiting colonies of gelatinous algae.

Trichomes not torulose; filaments matted into a rose-colored membrane.

1. P. nostocorum.

2. P. roseo!um.

1. Plectonema nostocòrum Born. ex Gomont, Monogr. 122. pl. 1. f. 11. 1893.

New Providence, in colonies of Gloeothcce, ete. - common everywhere in similar habitats. Type from France.

2. Plectonema rosèolum Gomont, Monogr. 122. pl. 1. f. 9-10. 1893. Germany.

On sand and mud, New Proridence:-Europe; North America. Type from

\section{SÝMPLOCA Kütz. ex Gomont, Monogr. 124. 1893.}

1. Symploca hydnoìdes forma fruticulòsa Gomont, Monogr. 127. 1893.

North Cat Cay and Great Bahama :- the typical form is widely distributed, the type from Great Britain; no type locality for the forma fruticulosu which occurs generally with the typical form.

7. HYDROcòléUM Kütz. ex Gomont, Monogr. 71. 1 s93.

Sheath crlindrical, distinet.

Sheath irregular, often becoming shapeless and diffluent.

Trichomes usually $9-11 \mu$ in diameter.

Trichomes seldom under $17 \mu$ in diameter.

Filaments forming tufts attached to algae or to sand and rocks; sheaths broad, with irregular and erose margins, but fairls persistent.

Filaments not attached, forming an indefinite gelatinous stratum; sheaths rery irregular or shapeless, soon diflluent.
1. II. comoides.

2. II. lyngbyaceum.

3. H. cantharidosmum.

4. H. glutinosum.

1. Hydrocoleum comoìdes Gomont, Monogr. 73. pl. 12. f. 3-5. 1893.

Great Bahama and Exuma Chain:-Bermuda; Guadeloupe; Australia. Type from Australia.

2. Hydrocoleum lyngbyàceum Kütz. ex Gomont, 75. pl. 12. f. 8-10. 1893. France.

Caicos Islands and Great Ragged Islands:-of general distribution. Trpe from

3. Hydrocoleum cantharidósmum Gomont, Monogr. 74. pl. 12. f. 6-\%. 1893. Islands.

Mariguana:-widely distributed in warmer waters. Type from the Canary

4. Hydrocoleum glutinòsum Gomont, Monogr. 77. 1893.

Caicos Islands:- Europe and Ameriea. Type from Sweden.

The genus IIydrocoleum is fairly distinet from neighboring genera, but the species have much similarity. Absolute certainty of determination can be obtained only by observing the development of the living plant.

\section{SCHIZòthrix Kütz, ex Gomont, Monogr. 30. 1893.}

Slieaths hyaline, trichomes $2-3 \mu$ in diameter.

Sheaths with inner layer violet or slate color; outer layer hyaline,

1. S. raginata. trichomes $7-9 \mu$ ln diameter.

2. S. chalybca.

1. Schizothrix vaginàta Gomont, Monogr. 40. pl. \%. f. 1-4. 1893. land.

New Provldence and Calcos Islands:-generally distributed. Tspe from Swltzer- 


\section{Schizothrix chalybèa Gomont, Monogr. 57. pl. 9. f. 3-5. 1893.}

On mud, in company with scytoncma rclutinum, New Providence. Trpe locality Mexico: no other records. The determination is from the description, as type material is at present inaccessible.

\section{Family 4. NOSTOCÀCEAE.}

1. Nóstoc Vancher, ex Born. \& Flah. Ann. Sei. Nat. Bot. VIT. 7: 181. 1888.

1. Nostoc commùne Taucher, ex Born. \& Flah. Ann. Sei. Nat. Bot. VII. 7: 203. 1888.

New Proridence, Castle Island, and Crooked Island:- unirersally distributed in warm and temperate regions, on ground and rocks. Type from Switzerland.

2. HoRmothámNION Grunow, ex Born. \& Flah. Ann. Sei. Nat. Bot. VII. 7: 259.1888 .

1. Hormothamnion enteromorphoides Grunow, ex Born. \& Flah. loc. cit. 260. 1888 .

North Cat Car, Caicos Islands, and Tatling's Island:-generally distributed in tropical and subtropical waters. Trpe from Guadeloupe.

\section{Family 5. SCYTONEMATÀCEAE.}

1. SCYToNìma Ag. ex Born. \& Flah. Ann. Sei. Nat. Bot. VII. 5: 85. 1887 .

1. Sheaths homogeneous or with uniform parallel strata.

1. Sheaths with plainly divergent strata.

2. Aquatic: sheaths firmly membranaceous.

2. Terrestrial.

3. Heterocysts compressed, shorter than the diameter of the trichome.

3. Heterocysts quadrate or longer.

4. Filaments mostly prostrate, $10-18 \mu$ in diameter.

4. Filaments in erect fascicles, usually $7-12 \mu$ in diameter.

5 . Strata of sheath moderately divergent, rather firm.

5. Strata of sheath strongly divergent, gelatinous and difluent.

6. Cells and heterocssts shorter than the diameter of filament.

6. Cells quadrate or longer; heterocysts quadrate or globose.

1. S. cincinnatum.

2. S. Millei.

3. S. occllatum.

4. S. Hofmanni.

5. S. myochrous.

6. S. velutinum.

7. S. erassum.

1. Scytonema cincinnàtum Thuret, ex Born. \& Flah. Ann. Sci. Bot. VII. 5: 89. 1887.

New Providence and Bimini:- widely distributed. Type from Germany.

2. Scytonema Míllei Born. \& Flah. Ann. Sci. Nat. Bot. VII. 5: 93.1887.

New Providence, Berry Islands. South Cat Cay, and Watling's Island:--North and South America. Type from Guiana.

3. Scytonema ocellàtum Lyngb. ex Born. \& Flah. Ann. Sci. Nat. Bot. VII. 5: 95. 1887.

New Providence:-widely distributed. Type from Denmark.

4. Scytonema Hófmanni Ag. ex Born. \& Flah. Ann. Sei. Nat. Bot. VII. 5: 97. 1887. Sweden.

New Providence, Abaco, and Acklin Island:- widely distributed. Type from 
5. Scytonema myochròus Ag. ex Born. \& Flah. Ann. Sci. Nat. Bot. TII. 5: 104. 1887.

Cat Island, Watling's Island, and Great Ragged Island:- widely distributed. Type from Sweden.

6. Scytonema velùtinum Rab. ex Born, \& Flah. Ann. Sci. Nat. Bot. VII. 5: 108. 1857.

New Providence, Exuma Chain, and Abaco:-Europe. Type from Germany.

7. Scytonema crássum Näg. ex Born. \& Flah. Ann. Sei. Nat. Bot. VII. 5: 109. 1887.

New Providence:-Europe; Ceylon. Type from Italy.

\section{Family 6. STIGONEMATÀCEAE.}

1. MAstigocòleus Lagerheim, ex Born \& Flah. Ann. Sci. Nat. Bot. VII. 5: 54.1857 .

1. Mastigocoleus testàrum Lagerheim, ex Born. \& Flah. loc. cit.

2. StigonèmA Ag. ex Born. \& Flah, Ann. Sci. Nat. Bot. VII. 5: 62. 1887 .

Fragments of a stigonemf have been found mixed with other algae, but not in condition for specific determination.

\section{Family 7. RIVULARIÀCEAE.}

1. CALòthrix Ag. ex Born \& Flah. Ann. Sei. Nat. Bot. VII. 3: 345. 1856.

Trichome violet.

Trichome olivaceous or aeruginous.

More or less endophytic.

Not endophrtic.

Filaments attached at the middle.

Filaments attached at one end.

Usually epiphytic, forming a bright aeruginous con tinuous coating; filaments usually $9-10 \mu$ in diameter : intercalary heterocysts often present.

Isually saxicolous, rarely epiphytic, forming a blackish green or olivaceous stratum; filaments $10-18 \mu$ in diameter; heterocysts basal.

1. C. fusco-violacea.

3. C. parasitica.

5. C. pilosa.

4. C. aeruginea.

2. C. scopulorum.

1. Calothrix fúsco-violàcea Crouan, ex Born. \& Flah. Ann. Sei. Nat. Bot. VII. 3: 352.1886.

New Providence:-Europe; North America. Type from France.

2. Calothrix scopulòrum Ag. ex Born. \& Flah. Ann. Sci. Nat. Bot. VII. 3: 353. 1856. Britain.

In small quantities, with other algae:-widely distributed. Type from Great

3. Calothrix parasítica Thuret, ex Born. \& Flah. Ann. Sei. Nat. Bot. V́II. 3 : 357. 1886.

In small quantlties, with other algae:-widely distributed. Trpe from France.

4. Calothrix aeruginea Thuret, ex Born. \& Flah. Ann. Sci. Nat. Bot. VII. 3: 358. 1886.

Rerry Islands and Great Bahama:-widely distributed. Type from Germany. 
5. Calothrix pilòsa Harv. ex Born. \& Flah. Ann. Sci. Nat. Bot. VII. 3: 363. 1886.

New Provldence:- warm waters generally. Type from Florida.

2. DICHòthrix Zan. ex Born. \& Flah. Ann. Sei. Nat. Bot. VII. 3 : 373. 1886.

Filaments $17-22 \mu$ in diameter ; branches long. erect.

Filaments about $15 \mu$ in diameter ; branches short, flexuous.

1. D. furicola.

2. D. penicillata.

1. Dichothrix fucícola Born. \& Flah. Ann. Sci. Nat. Bot. VII. 3: 379. 1886.

Watling's Island, Castle Island, and Mariguana:-Bermuda; West Indies; Central Amcrica. Type from Central America.

2. Dichothrix penicillàta Zan. ex Born. \& Flah. Ann. Sei. Nat. Bot. VII. 3: 379. 1886.

Bimini. Great Bahama, Berry Islands, Castle Island, and Watling's Island:Red Sea; Florida; West Indies. Type from Red Sea.

3. POLÝtHRIX Zan. ex Born. \& Flah. Ann. Sei. Nat. Bot. VII. 3: 380.1886.

1. Polythrix corymbòsa Grunow, ex Born. \& Flah. loc. cit. 380. 1886.

New Providence and Exuma Chain :-widely distributed in warm waters. Type from lilorida.

4. RIvUlÀriA Ag. ex Born. \& Flah. Ann. Sci. Nat. Bot. VII. 3: 345. 1886.

Trichomes tapering from middle to each end.

Trichomes tapering towards apex only.

Trichomes $5-9 \mu$ in diameter, sheaths wide, loose.

Trichomes $2-5 \mu$ in diameter, sheaths close, compacted.

3. R. polyotis.

1. R. Biasolettiana.

2. R. nitida.

1. Rivularia Biasolettiàna Menegh. ex Born. \& Flah. Ann. Sei. Nat. Bot. VII. 3: 352.1886 .

Mariguana and Atwood Cay :-Europe: North America. Type from the Adriatic.

2. Rivularia nítida Ag. ex Born. \& Flah. Ann. Sei. Nat. Bot. VII. 3: 357.1886.

New Providence and Exuma Chain :-generally distributed. Type from Sweden.

3. Rivularia polyòtis Born. \& Flah. Ann. Sei. Nat. Bot. VII. 3: 360. 1886.

Watling's Island:-Europe; North America. Type from the Mediterranean.

\section{Sub-class DIATOMEAE}

\section{Contributed by Charles S. Boyer.}

The diatomaceous flora of the Bahamas includes twenty-five or more genera most of which are common to the North American coast. Of this number, however, two genera, Plagiogramma and Mastogloia, are especially prominent. The former is represented by species first described by Greville as occurring on conch shells at Nassau and New Providence. The latter is quite prolifie in species on algae collected by Dr. Marshall A. Howe. The forms which, perhaps, are characteristic of the Bahamas are Mastogloia bahamensis Cleve, not very 
rare, and Mastogloia rimosa Cleve, which is common in one locality. Mastogloia erythraea Grun. is common but quite variable in size, ontline and the inequality of the loeuli. Mastogloia splendida (Greg.) Cleve oceurs in all localities. Podocystis adriatica Kütz. is abundant on Antithamnion. Climacosphenia moniligera Ehrenb. is also noticeable, while Grammatophora flexuosa Grun is found in all gatherings, oceurring pure on Centroceras. The minute form, Striatella delicatula (Kïtz.) Grun., not heretofore reeorded from this loeality, is abundant on Polysiphonia. One speeimen of Plagiogramma labuense Cleve, a form peeuliar to Borneo, although somewhat similar to Plagiogramma caribaeum Cleve, has been found.

The following list ineludes the greater number of the forms noticed but there are probably many more as various algae appear to differ much in the variety of diatoms found upon them.

BIDDULPHIA S. F. Gray, em. Tan Heurek.

Biddulphia Pentácrinus (Ehrenb.) Boyer. Rare.

ANAÙLUS Ehrenb., em. Van Heurek.

Anaulus minùtus Grun. Rare.

\section{GRAMMATÓPHORA Ehrenb.}

Grammatophora flexuòsa Grun. Common.

STRIATÉLLA Ag., em. Heiberg.

Striatella delicátula (Kütz.) Grun. Local.

LICMÓPHORA Ag. em. Roper.

Licmophora dalmática (Kütz.) Grun. Local.

CLIMACOSPHÈNIA Ehrenb.

Climacosphenia monilígera Ehrenb. Common.

\section{PLAGIOGRÁMMAa Grev.}

Plagiogramma inaequàle Grev. Rare.

Plagiogramma labuénse Cleve. Rare.

Plagiogramma lyràtum Grev. Not common.

Plagiogramma obèsum Grev. Not common.

Plagiogramma pulchéllum Grev. Not common.

Plagiogramma pygmàeum Grèv. Nat common.

TRACHYSPHÈNIA P. Petit.

Trachysphenia austràlis I. Petit. Rare.

\section{CYMATOSİRA Grun.}

Cymatosira Lorenziàna Grun. Oceasional.

\section{GLYPHODÉSMIS Grev.}

Glyphodesmis exímia Grev. Rare. 


\section{SYNĖDRA Ehrenb.}

Synedra Gaillònii mìnor Kiitz. Local.

Synedra supérba mìnor Kütz. Rare.

Synedra undulàta Bailey. Rare.

\section{COCCONÈIS Ehrenb.}

Cocconeis Scutéllum Ehrenb. Common.

\section{ÁMPHORA Ehrenb.}

Amphora obtùsa Greg. Occasional.

Amphora bigíbba Grun. Rare.

\section{MASTOGLÒIA Thw.}

Mastogloia angulàta Lewis. Common.

Mastogloia apiculàta $W$. Smith. Common.

Mastogloia aspérula Grun. Not common.

Mastogloia bahaménsis Clere. Not common.

Mastogloia binotàta (Grun.) Clere. Rare.

Mastogloia Cítrus Cleve. Common.

Mastogloia cocconeifórmis (Grun.) Cleve. Common.

Mastogloia cuspidàta Cleve. Common.

Mastogloia delicátula Cleve. Not common.

Mastogloia erythraèa Grun. Common and variable.

Mastogloia lanceolàta Thw. Common.

Mastogloia lemniscàta Leud. Rare.

Mastogloia minùta Grer. Common.

Mastogloia rimòsa Cleve. Rare or local.

Mastogloia Smíthii Thw. Common.

Mastogloia spléndida (Greg.) Cleve. Common and variable.

\section{DICTYONĖIS Cleve.}

Dictyoneis jamaicénsis Clere. Rare.

DIPLONĖIS Ehrenb., em. Cleve.

Diploneis vacíllans (A. Schmidt) Cleve. Rare.

Diploneis Weissflògii (A. Schmidt) Cleve. Rare.

\section{NAVÍCULA Bory.}

Navicula brasiliénsis Grun. Rare.

Navicula Lỳra dilatàta $\mathrm{A}$. Schmidt. Rare.

Navicula ramosíssima (Ag.) Cleve. Local.

Navicula suborbiculàris (Greg.) Donkin. Rare.

Navicula Zosterèti Grun. Rare.

\section{TRACHYNĖIS Cleve.}

Trachyneis áspera (Ehrenb.) Cleve. Rare.

PINNULÀRIA Ehrenb.

Pinnularia rectangulàta Greg. Rare.

PLEUROSÍGMA W. Smith.

Pleurosigma formòsum W. Smith. Rare. 


\section{TROPIDONÈIS Clere.}

Tropidoneis lepidóptera (Greg.) Cleve. Tot common.

\section{EPITHÈMIA Bréb.}

Epithemia Músculus Kütz. Rare.

\section{NÍTZSCHIA Hassall.}

Nitzschia apiculàta (Greg.) Grun. Common.

Nitzschia Sígma (Kütz.) W. Smith. Rare:

Nitzschia válida Cleve \& Grun. Rare.

\section{SURIRELLA Turpin.}

Surirella fastuòsa Ehrenb. Rare.

Surirella recèdens A. Schmilt. Rare.

PODOCÝSTIS Kütz.

Podocystis adriática Kütz. Local.

\section{CAMPYLODÍsCUS Ehrenb.}

Campylodiscus símulans Greg. Rare.

Campylodiscus imperiàlis Grer.

The following list contains additional names of species oceurring in the harbor mud of Nassau, as reported by Tempère (Diatomées du Monde entier, 144, 375. 1915). To aroid ineonsistency, the nomenclature, in some instances, is revised to agree with the classification of Cleve, Van Heurck, Deby, Grunow and others. Nearly all of the forms are more or less common along the Atlantic coast.

Meloseìra arenària Moore.

Meloseira sulcàta Kütz.

Coscinodíscus concínnus Jonesianus (Grer.) Rattray.

Coscinodíscus excéntricus Ehrenb.

Coscinodíscus léptopus Grun.

Coscinodíscus marginàtus Ehrenb.

Coscinodíscus nitídulus Grun.

Coscinodíscus nítidus Greg.

Coscinodíscus nodùlifer Janisch.

Coscinodíscus obscùrus A. Sehmidt.

Coscinodíscus radiàtus Ehrenb.

Coscinodíscus Róthii Grun.

Actinoptỳchus spléndens (Shadb.) Ralfs.

Actinoptychus undulàtus (Bailey) Ralfs.

Actinoptỳchus vulgàris Schumann.

Actinocỳclus fasciculàtus C'astr.

Actinocỹclus monilifórmis Ralfs.

Actinocỳclus Ròtula Brun, var.

Euòdia Gíbba Bailey.

Ropèria tessellàta (Roper) Grun.

Aulíscus caelàtus Bailey.

Aulíscus reticulàtus Grev.

Biddúlphia Antillàrum (Cleve) Boyer.

Biddúlphia árctica (Brightw.) Boyer. 
Biddúlphia Fàvus (Ehrenb.) Van Heurck.

Biddúlphia mobiliénsis (Bailey) Grun.

Biddúlphia peruviàna Grun.

Biddúlphia reticulàta Roper.

Biddúlphia Retículum (Ehrenb.) Boyer.

Biddúlphia Robertsiàna (Grev.) Boyer.

Biddúlphia Smithii (Ralfs) Tan Heurek.

Biddúlphia spinòsa (Bailey) Boyer.

Biddúlphia Tabellàrium (Brightw.) Boyer.

Rhabdonèma adriáticum Kütz.

Grammatôphora marìna (Lyngb.) Kütz.

Entopỳla austràlis (Arnott) Grun.

Petítia* Tempèrei Perag.

Plagiográmma decussàtum Grev.

Plagiográmma tessellàtum Grev.

Dimerográmma lanceolàtum Perag.

Dimerográmma mìnus (Greg.) Ralfs.

Synèdra formòsa Hantzsch.

Synèdra fúlgens (Grev.) W. Smith.

Synèdra supérba Kütz.

Synedrosphaènia baculifórmis Perag.

Cocconèis heteroìdea Hantzsch.

Cocconèis pseudomarginàta Greg.

Á mphora acùta arcuàta (A. Schmidt) Cleve.

Âmphora coffaeifórmis (Ag.) Cleve.

Ámphora crássa Greg.

Ámphora cymbelloides Grun.

Ámphora gigantèa fúsca (A. Schnidt) Cleve.

Ámphora Graèffei Grun.

Ámphora Gruèndleri Greg.

Ámphora Janíschii A. Schmidt.

Ámphora ostreària Bréb.

Ámphora ostreària vitraèa Cleve.

Ámphora rhómbica Kitton.

Calonèis formòsa (Greg.) Cleve.

Calonèis Liber (W. Smith) Cleve.

Calonèis Lìber Bleìschii (Janisch) Cleve.

Calonèis Powéllii (Lewis) Cleve.

Mastoglòia affînis Cleve.

Mastoglòia affirmàta Leud.

Mastoglòia amoèna túrgida Brun.

Mastoglòia bisulcàta Grun.

Mastoglòia bisulcàta corsicàna (Grun.) Cleve.

Mastoglòia Cràveni Leud.

Mastoglòia euxìna Cleve var.

Mastoglòia lineàta Cleve \& Grove.

Mastoglòia Macdonáldii Grev. var.

Mastoglòia ovàta Grun.

Mastoglòia Peragálli Brun.

Mastoglòia Pisículus Cleve.

Mastoglòia Rhómbus P. Petit.

Mastoglòia rostellàta Grun.

Dictyonèis marginàta (Lewis) Cleve.

Diploneis advèna sansegàna (Grun.) Cleve.

Diploneis Bómbus (Ehrenb.) Cleve.

* Petitia for a modern diatom genus is invalid. See Petitia Jacq. 1760, a genus of Verbenaceae, p. 373 of this book. N. L. B. 
Diploneis Campylodíscus (Grun.) Clere.

Diploneis coffaeifórmis (A. Schmidt) Cleve.

Diploneis Cràbro Ehrenb.

Diploneis démta (A. Schmirt) Cleve.

Diploneis gemmátula (Grun.) Cleve.

Trachynèis Antillàrum Cleve.

Trachynèis Débyi (Leud.) Cleve.

Navícula approximàta Grev.

Navicula complanàta Grun.

Navícula cuspidàta ambigua (Ehrenb.) ( Jeve

Navícula dirécta $W$. Smith.

Navicula irroràta Gres.

Navícula scopulòrum Bréb.

Navícula transfùga Grun.

Gyrosigma réctum (Donkin) Cleve.

Pleurosígma compáctum Grev.

Pleurosígma Weissflògii (Grun.) Cleve.

Aurícula intermèdia Cleve.

Aurícula minùta Cleve.

Epithèmia gibbérula (Ehrenb.) Kütz.

Nítzschia angulàris W. Smith.

Nítzschia compréssa (Bailey) Boyer.

Nitzschia granulàta Grun .

Nítzschia Jelinéckii Grun.

Nítzschia pandurifórmis Greg.

Nítzschia vermiculàris (Kütz.) Hantzsch.

Surirélla fusiförmis Leud.

Surirélla incurvàta A. Schmidt.

Surirélla mánca Janisch.

Surirélla mexicàna $A$. Schmidt.

Campylodíscus angulàris Greg.

Campylodíscus biangulàtus Grev.

Campylodíscus crebrecostàtus Grev.

Campylodíscus Daemeliànus Grun.

Campylodíscus Ecclesiànus Grev.

Campylodíscus làtus Shadb.

Campylodíscus limbàtus Bréb.

Campylodíscus samoénsis Grun.

Campylodíscus undulàtus Grev.

Campylodíscus Wallichiànus Grev.

\section{CLASS 3. FUNGI.}

Contributed by Fred J. SEAver.

\section{Sub-class 1. PHYCOMYCÈTES.}

\section{Order 1. PERONOSPORÀLES.}

1. Albùgo cándida (Pers.) Kuntze, Rev. Gen. Pl. 2: 65s. 1891. Accidium candidum Pers. in Gmelin, Syst. Nat. 2: 1473. 1791.

On Lepidium virginicum I., New Providence, Watling's Island:-widely dis. tributed, probably occurring wherever the host plants are found.

2. Albugo Ipomoèae-pandurànae (Schw.) Swing. Jour. Myc. 7: 112. 1892. Aeeidium Ipomocae-panduranae Schw. Schr. Nat. Ges. Leipzig 1: 69. 1822. ceding.

On Jacqucmontia cayensis Britton. Inagua:-distribution similar to the pre- 


\section{Sub-class 2. ASCOMYCÉTES.}

Spores borne in perithecia whlch are closed or open to the exterior by an ostiolum. Ostiolum wanting or obscure; vegetative mycelium superficial.

Ostlolum present aud often conspicuous; regetative mycelium not as above.

Perithecia consistiug of cavities in the stroma without well developed wall.

Perithecia provided with well developed wall, with or without stroma.

Perithecia and stroma bright colored, fleshy.

I'erithecia and stromata black, usually carbonaceous.

Spores borne in apothecia with the hymenium freely exposed at maturity.

Hymenium circular or subcircular in form.

Hymenium elongated, often opening with a slit-like aperture.

Order 1. Perisporiales.

Order 2. Dothideales.

Order 3. HYPOCRE.ILES.

Order 4. Spliatriales.

Order 5. PEZIZALES.

Order 7 . Phacidiales.

\section{Order 1. PERISPORIÀLES.}

1. Dimerospòrium guarapiénse Speg. Anal. Soc. Cient, Arg. 17: 130. 1884.

On Cestrum bahamense Britton, Great Bahama:--South America.

\section{Dimerosporium zonàtum Searer sp. nor.}

Superficial mycelium rather scant but giving the surface of the leaf a blackish appearance; perithecia black and arranged so as to give rise to a series of rings, the outer one usually reaching a diameter of $5 \mathrm{~mm}$., the individual perithecia small, pyriform, reaching a diameter of $100 \mu$, surrounded with brownish appendages; asei broad-clavate, with a short stem-like base, reaching a diameter of $16-20 \mu$ and a length of $40 \mu$; spores eliipsoid-fusoid, 1 -septate and slightly constricted at the septum, about $5-6 \times 16-20 \mu$.

On Corchorus hirsutus L. Type collected by $\mathbf{x}$. L. Britton and C. F. Millspaugh at Barrett's Point, Great Bahama, February 5-13, 1905.

3. Meliòla ambigua Pat. \& Gaill. Bull. Soc. Myc. Fr. 4: 104. 1888.

On Lantana involucrata L., New Providence:-Porto Rico; South America.

4. Meliola longipoda Gaill. Bull. Soc. Myc. Fr. 8: 178. 1892.

On Tourncfortia volubilis L., New Providence:-Porto Rico; South America.

Meliola simillima Ellis \& Ev. Rep. Missouri Bot. Garden 9: 118. 1898.

This species, recorded by Ellis as from Nassau, was really from Bog Walk, Jamajca, as shown by the specimen.

5. Perispòrium Wríghtii Berk, \& Curt. Grevillea 4: 157. 1875.

On Opuntia Dillenii (Ker.) Haw., Inagua :-Cuba ; Texas.

\section{Order 2. DOTHIDEÀLES.}

1. Phyllachòra Atelèiae Seaver, sp. nov.

Stromata rather numerous, appearing on either side of the leaf but more conspicuous on the upper side, black, shining, scarcely exceeding a diameter of $1 \mathrm{~mm}$. perithecia few to each stroma, conspicuous; asci clarate, reaching a diameter of 14-16 ; spores fusoid, hyaline, $4-5 \times 18-20 \mu$.

On Ateleia cubensis Griseb., Andros, New Providence, Great Exhuma. Type collected by J. K. Small and J. J. Carter, on Andros, January 25-27, 1910, 8715. 


\section{Phyllachora fusicárpa Searer, sp. nor.}

Stromata rather numerous, often thickly scattered over the leaf, visible on both sides but more conspicuous on the under side, small, ranging from 1-2 $\mathrm{mm}$. in diameter, several often confluent; perithecial cavities few to each stroma, opening on the under side of the leaf; asci clavate, 8 -spored; spores fusiform, slightly unsymmetrical, about $6 \times 25-30 \mu$.

On Duranta repens L. Type collected by F. S. Earle at Nassau. No date giren. Specimens collected also at Rio Piedras, Porto Rico, by H. H. Whetzel and Edgar. II. Olive.

In external appearance the species resembies Phyllachora Durantcie Rehm, but differs from that species in its much longer and narrower spores.

\section{Phyllachora Galáctiae Earle, sp. nor.}

Epiphyllous on slightly discolored areas; stromata $1 \mathrm{~mm}$. broad, confluent in long anastomosing lines which often follow the principal reins, black, shining, prominently elevated; loculi crowded, not prominent, about $150 \mu$, ostiole none; asci stipitate, cylindrical, about $65 \times 7 \mu$; paraphyses abundant, threadlike; ascospores obliquely monostichous, colorless, narrorly ellipsoid, about $20 \times 5 \mu$.

On leaves of Galactia rudolphioides, Soldiers' Road, New Proridence, June 25. 1905 , Millspaugh 2502.

A conspicuous species well characterized by the long branched and anastomosing black lines formed by the confluent stromata.

4. Phyllachora oxalìna Ellis \& Ev. Jour. Myc. 3: 41. 19sт.

On Tanthoxalis cornieulata L., New Providence:-North America.

\section{Ophiodóthis bahaménsis Seaver, sp. nor.}

Stromata occurring only on the under side of the leaf, as many as twelre to twenty on a single leaf, reaching a diameter of 1-2 mm., occasionally confluent, lenticular in form, smooth, shining-black, the surface slightly roughened by the protruding necks of the perithecia; perithecia consisting of globose or oroid cavities; asci reaching a length of $200-400 \mu$ and a diameter of $20-25 \mu$; spores filiform, nearly as long as the ascus, reaching a diameter of $2 \mu$.

On Tricera bahamensis (Baker) Britton. Trpe collected by Nash \& Taylor. October 22, 1904, on Inagua near Camfield Bay. The species has also been collected by L. J. K.' Brace on Andros.

\section{Order 3. HYPOCREÀLES.}

1. Córdyceps sobolífera (Hill.) Sacc. Michelia 1: 321. 15is.

Clavaria sobolifera Hill.; W. Wats. Phil. Trans. Royal Soe. London 53: 271. 1763 . Ceylon.

On some insect. Reported by C. G. Lloyd the exact locality not being given :-

2. Hypócrea sulphùrea (Schw.) Sace. Syll. Fung. 2: 535.1583.

Sphaeria sulphurea Schw. Trans. Am. Phil. Soc. II, 4: 193. 1532.

On the remains of some fungus, New Providence:-Cuba; eastern part of North America.

3. Sphaerostílbe gracílipes Tul., Fung. Carp. 1: 130. 1861.

On dead wood, New Providence:-southeastern North America. 


\section{Order 4. SPHAERIÀLES.}

1. Daldinia concéntrica (Bolt.) Ces, \& DeNot. Comm. Soc. Critt. Ital. 1: 198. 1863.

Sphaeria concentrica Bolt. Fungi Halifax 3: 180. 1789.

On old wood, New Providence:-Europe: Siberia; North and South America: India ; Ceylon ; Borneo; Tasmania ; New Zealand ; and Java.

2. ? Diatrype Stígma (Hoffm.) Fries, Summa Teg. Scand. 385. 1849.

Sphaeria Stigma Hoffm. Veg. Crypt. 7. 1787.

On old wood, New Providence:-Europe; Siberia; and North America.

3. Hypóxylon annulàtum (Schw.) Mont. Hist. Chil. 445. 1850.

Sphaeria annulata Schw. Jour. Acad. Sci. Phila. 5: 11. 1825. Zealand.

On old wood and bark, New Providence:-North and South America; and New

4. Hypoxylon Bómba Mont. Pl. Cell. Cuba 338. 1842.

On old wood, New Providence, Cat Island:-Cuba and South America.

5. Hypoxylon fuscopurpùreum (Schw.) Berk. \& Curt. Jour. Linn. Soc. 10: 385. 1869.

Sphaeria fuscopurpurea Schw. Jour. Acad. Nat. Sci. Phila. 5: 16. 1825. On old wood, New Providence:-Cuba and temperate North America.

6. Hypoxylon jecorìnum Berk. \& Rav. Grevillea 4: 50. 1875.

On old wood, New Providence:-southeastern North America.

7. Nummulària Bulliárdii Tul. Fung. Carp. 2: 43. 1863.

On old wood, New Providence:-North America and Europe.

8. Porònia Oèdipus Mont. Pl. Cell. Cuba 346. 1842.

On dung, New Providence:-Cuba; northern Italy; North America; Australia; Java and Borneo.

9. Sphaerélla Rajàniae Ellis \& Ev. Rep. Missouri Bot. Garden 9: 118. 1898.

On Rajania microphylla Kunth., New Proridence. Endemic.

10. Ustulìna vulgàris Tul. Fung. Carp. 2: 23. 1863.

On old wood, New Proridence; widely distributed.

11. Válsa sp.

On old wood, New Providence.

12. Xylària Arbúscula Sacc. Michelia 1: 249. 1878.

On dead wood, New Providence:-West Indies; Europe.

13. ?Xylaria aristàta Mont. Ann. Sci. Nat. Bot. IV. 3: 106. 1855.

On dead wood, New Providence:-Cuba.

14. Xylaria polymórpha (Pers.) Grev. Fl. Edin. 355. 1824.

Sphaeria polymorpha Pers. Syn. Fung. 7. 1801.

On dead wood, New Providence:-Europe; Asia; Australia - Tasmania; North and South America. 


\section{Order 5. PEZIZÀLES.}

1. Pyronèma omphalòdes (Bull.) Fuckel, Symb. Mye. 319. 1869. Peziza omphalodes Bull. Hist. Champ. 264. 1791.

On burned places, New Providence:-probably world-wide in distribution.

2. Láchnea cubénsis (Berk. \& Curt.) Sace. Syll. Fung. 8: 176. 1889. Peziza cubensis Berk. \& Curt. Journ. Linn. Soc. 10: 366. 1869. On rotten wood or on soil, New Providence:-West Indies and Texas.

\section{Order 6. PHACIDIALES.}

1. Triblìdium rúfulum (Spreng.) Ellis \& Ev. N. Am. Pyrenonı. 690. 1892. Hysterium rufulum Spreng. Vet. Akad. Handl. 1820: 50. 1820. On dead wood, New Proridence:-Cuba; North and South Amerlca.

\section{Sub-class 3. IMPERFECTI.}

Spores borne in perithecia-like bodies known as pycnidia. Order 1. SPHAERopsidalds. Sporeș not borne in pyenidia. Ordel 2. HYPhomy CETaLes.

\section{Order 1. SPHAEROPSIDÀLES.}

1. Phyllostícta Coccolòbae Ellis \& Ev. Rep. Missouri Bot. Garden 9: 11S. 1598. On Coccolobis Urifcra (L.) Jacq., New Providence:-Apparently endemic.

2. Phyllosticta Robérti Boy. \& Jacz. Bull. Soe. Bot. Fr. 40: CCXC. 1893. On Ficus aurca Nutt., Great Bahama :-Florida; Europe.

3. Phyllosticta Sapòtae Sace. Ann. Mye. 10: 312. 1912. On Sapota Achras Mill., New Providence:-Endemic.

\section{Septòria sp.}

On Plumeria obtusa L., New Providence.

\section{Order 2. HYPHOMYCETÀLES.}

1. Cercóspora Calotròpidis Ellis \& Ev., Rep. Missouri Bot. Garden 9: 120. 1898.

On Calotropis proccra (Ait.) R. Br., Fortune Island:-Apparently endemic.

2. Cercospora Melóchiae P. Henn. Hedwigia 43: 395. 1904.

On Joluchia tomentosa (L.) Britton, Eleuthera :-South America.

3. Cercospora Stachytárphetae Ellis \& Ev., Rep. Missouri Bot. Garden 9: 120. 1898 .

On Vulcrianodcs jamuicensis (L.) Medic., New Proridence:-Apparently endemlc.

4. Cercospora Túrnerae Ellis \& Er., Rep. Missouri Bot. Garden 9: 119. 1 S9S. On Turncra ulmifolia L., New Provldence :- $A$ pparently endemic.

5. Helminthospòrium Ravenèlii Curt.; Berk. \& Curt. Grevillea 3: 102.1874. On Sporobolus sp., New Providence, Great Baluama:-Bermuda; Cuba; South Carolina ; and I\%orida. 
6. Rhinotríchum Curtìsii Berk. Grevillea 3: 10s. 1874.

On old bark, New I'rovidence:-North America, south to Texas and Florida. STERLLE MYCELIUM.

1. Ozonium aurìcomum Link, Mag. Ges. Nat. Freunile Berlin 3: 21. 1809. On Wood, New lrovidence:--Europe and North America.

\section{Sub-class 4. HEMIBASIDIOMIYCETES.}

Plants usually baving different spore cycles. Plants having ouly one spore eycle.
Order 1. UREDINAIES

Order 2. USTILAGINALES.

\section{Order 1. UREDINÀLES.}

1. Nigrèdo proèminens (DC.) Arth. N. Am. Fl. 7: 259. 1912.

Uredo proeminens DC. Fl. Fr. 2: 235. 1505.

On Chamaesyce hypcrieifolia (L.) Small, Inagua:-Bermuda; West Indies; North aud South America ; Europe; Asia; and Africal.

2. Prospòdium bahaménse Arth. Bull. Torrey Club 34: 587. 1907.

On Tabebuia bahamensis (Northrop), Britton, New Providence:-Endemic.

3. Fuccìnia heteróspora Berk. \& Curt. Jour. Linn. Soc. 10: 356. 1869.

On Gayoidcs crispum (L.) Small, Fortune Island:-I'orto Rico; St. Thomas; st. Croix; and probably in other West Indian islands.

4. Puccinia Lantànae Farlow, Proc. Am. Acad. 18: 83. 1883. Thomas.

On Lantana involucrata L., Nassau:-Bermuda; Jamaica; Porto Rico; St.

5. Puccinia Leonòtidis (P. Henn.) Arth. Mycologia 7: 245. 1915.

Tredo Leonotidis P. Henn. in Eng. Pflanz. Ost-Afr. C: 52. 1895. Rico.

On Leonotis nepctaefolia (L.) R. Br., New Providence:-Jamaica; and Porto

6. Puccinia mirífica Diet. \& Holw. Erythea 3: 79. 1895.

On Borrichia arborcseens (L.) DC., Great Bahama:-Texas.

7. Puccinia oblìqua Berk. \& Curt. Jour. Linn. Soc. 10: 356. 1869.

Puccinia Cynanchi Lagerh. Bol. Soc. Brot. 7: 129. 1889.

On Metastelma palustre (Pursh) Schlecht., New Providence, on Hetastelma sp., Whale Cay, and on Philibertella clausa (Jacq.) Vail, New Providence :-Cuba ; Porto Rico ; Virgin Islands; Martinique.

8. Urómyces Bidéntis Lagerh. Bull. Soc. Mye. Fr. 11: 213. 1895.

Uredo bidenticola P. Henn. Hedwigia 37: 279. 1598.

On Bidcus pilosa L., reported from the Bahamas by Dr. Arthur:-Jamaica; Cuba; Porto Itico; and Martinique.

9. Urèdo Sapòtae Arth. \& Johnston, Mem. Torrey Club 17: 169. 1918.

On Sapota Achras Mill., Nassau :-Cuba.

10. Uredo Wílsòni Arth. Bull. Torrey Club 37: 577. 1910.

On Anastraphia bahamensis Urban, Fortune Island:--Endemic. 


\section{Order 2. USTILAGINÄLES.}

1. Cintráctia Montágnei (Tul.) Magn. Abh. Mot. Ver. Prov. Brand. 37: 9. 1896.

Ustilago Montagnei Tul. Ann. Sei. Nat. I] I. 7: 89. 1847. Afrlea.

On Rynchospora sp., New Providence:-North and South America; Europe; and

2. Mykosỳrinx Císsi (D.C.) G. Beck. Ann. Xat. Hlofmus. Wien. 9: 123. 1 494. Credo Cissi DC. in Poir. Eneyel. Meth. Bot. 8: 22s. 1508.

On Cissus sicyoides L., Long Island:-West Indies; North and Sonth America : and Africa.

3. Sphacelothèca pampàrum (Speg.) Clint. Jour. Mye. 8: 141. 1902.

Ustilago pamparum Speg. Anal. Soc. Cient. Arg. 17: 89. 158.

On Chactochloa geniculata (Lam.) Millsp. \& Chase, Anguilla Isles: Salt Key Bank :-Cuba ; Mexico; Soutb America; and Europe.

\section{Sub-class 5. AUTOBASIDIOMYCETES.}

Contributed by Wildia A. Murrill.

Sporophore gelatinous:

Basidia septate.

Basidia not septate: clarate and bifurcate.

Order 1. ACERCLLARIALES.

Sporophore not gelatinous; fleshy, membranous, or woods.

Hymenium naked at maturity, covering the surface of gllls, pores, spines, etc.

Order 2. DACMYOMYETALES.

Hrmenium enclosed in a definite peridium.

Spores borne in a gleba, which is elevated and exposed at maturitr.

Order 3. Agaricales.

Spores remaining enclosed in the peridium at maturits.

ruffbalis.

Bird's-nest fungi.

Order 4. PHallales.

Order 5. Lrcoperval.es.

Order 6. Nidulirial.Es.

\section{Order 1. AURICULARIÀLES.}

1. Auriculària Aurícula (L.) Underw. in Northrop, Mem. Torrey Club 12: 15. 1902.

Tremella Auricula L. Sp. Pl. 1157. 1753.

Dead wood, New Proridence, Andros:-tropienl reglons.

ż. Auriculària nigréscens (Sw.) Farlow, Bib. Index N. Am. Fungi 1: 30 s. 1905.

Peziza nigreseens Sw. Prod. 150. 1785.

Dead wood, Nen Irovidence:-tropical regions.

\section{Order 2. DACRYOMYCETȦLES.}

1. Guepínia pálmiceps Berk. (?)

Doubtfully recorded by Coker.

2. Guepinia Spathulària (Schw.) Fries, Elench. Fung. 2: 32. 14ㅗ.

Merulius Spathularia Sehw. Sehr. Nat. Ges. Leipzig 1: 66. 1s22.

Dead logs, New Providence:-cosmopolitan. 


\section{Order 3. AGARICÀLES.}

a. THELEPHORÀCEAE.

A number of species in this family have not been determined, especially those that belong to the genera Corticium and Stereum.

\section{Cortícium.} dence.

One or more undetermined species aare been found on dead wood in New Provi-

2. Hypóchnus spongiòsus (Sehw.) Burt, Ann. Mo. Bot. Gard. 3: 216. 1916.

Thelephora spongiosa Schw. Schr. Nat. Ges. Leipzig 1: 109. 1822.

Dead wood. Recorded by Burt from the Bahamas, collected for Dr. Farlow by A. E. Wight:-temperate North America and Europe.

3. Sebacìna spongiòsa C. G. Lloyd, Myc. Notes 5: 779. 1918.

Encircling the base of small shrubs, New Providence. Endemic.

4. Septobasídium cirràtum Burt, Ann. Mo. Bot. Gard. 3: 334. 1916.

Branches of living trees, New Providence:-Cuba.

5. Stèreum albobàdium (Schw.) Fries, Epicr. Myc. 551. 1838.

Thelephora albobadia Schw. Schr. Nat. Ges. Leipzig 1: 82. 1822.

Dead wood, New Providence:- -eastern United States.

6. Stèreum cándidum (Schw.) Fries, Epier. Mye. 552. 1838.

Thelephora candida Schw. Schr. Nat. Ges. Leipzig 1: 84. 1822.

Dead wood, New Providence:-eastern United States.

7. Stèreum Leveilleànum (Berk. \& Curt.) Sace. Syll. Fung. 6: 581. 1888.

Corticium Leveilleanum Berk. \& Curt. Jour. Bot. \& Kew Mise. 1: 238. 1849.

Dead wood, New Providence:- southern United States and tropical America.

8. Theléphora spiculòsa Fries, Epier. Myc. 539. 1838.

Ground in moist woods, New Providence:-enstern United States.

\section{b. Clavariàceae.}

9. Clavària.

One or more undetermined species were collected in New Providence, Andros, and Crooked Island.

\section{c. HYDNÀCEAE.}

Several resupinate species of this family have been found in the islands, but they have not been determined.

\section{d. Xylophagàceae.}

10. Merùlius Còrium Fries, Elench. Fung. 1: 58. 1828.

Dead wood, New Providence:-cosmopolitan. 
e. Poly porìceae.

11. Coltrícia cinnamòmea (Jacq.) Murrill, Bull. Torrey Club 31: 343. 1904.

Boletus cinnamomeus Jacq. Coll. 1: 116. 1786.

Polystictus cinnamomeus Sace. Michelia 1: 362. 1575.

Ground on humus, Andros:-cosmopolitan.

12. Coltrícia spathulàta (Hook.) Murrill, N. Am. Flora 9: 93. 1905.

Boletus spathulatus Hook. in Kunth, Syn. Pl. 1: (9). 1822.

Dead or burled wood, Crooked Island:-tropical America.

13. Coriolópsis occidentàlis (Klotsch) Murrill, Bull. Torrey Club 32: 358. 1905.

Polyporus occidentalis Klotsch, Linnaea 8: 456.1533.

Dead wood, New Providence, Andros, Eleuthera :-tropical regions.

14. Corìolus abiétinus (Dicks.) Quél. Ench. Fung. 175. 1556.

Boletus abietinus Dicks. Pl. Crypt. Brit. 3: 21. 1793.

Dead pine trunks, New Providence:-temperate regions.

15. Corìolus máximus (Mont.) Murrill, Bull. Torrey Club 34: 467. $190 \overline{7}$.

Irpex maximus Mont. Ann. Sei. Nat. II. 8: 364. 1837.-Syll. Crypt. 1it. 1556.

Dead logs, New Proridence:-tropical regions.

16. Corìolus membranàceus (Sw.) Pat. Tax. Hymén. 94. 1900.

Boletus membranaceus Sw. Prodr. 148. 17S5.-Sw. Fl. Ind. Oce. 1922. 1506.

Dead wood, New P'rovldence:-tropical America.

17. Coriolus nigromarginàtus (Schw.) Murrill, Bull. Torrey Club 32: 649 . 1906.

Boletus nigromarginatus Schw. Schr. Nat. Ges. Leipzig 1: 98. 15ュ2.

Dead wood, New Proridence, Andros:-cosmopolltan.

18. Corìolus pinsìtus (Fries) Pat. Tax. Hymén. 94. 1900.

Polyporus pinsitus Fries, Elench. Fung. 95. 1528.

Dead wood, New Providence, Great Bahama, Abaco, Eleuthera, Cat Island, Watling's Island:- tropical Anserica.

19. Coríolus sericeohịrsùtus (Klotsch) Murrill, Bull. Torrey ('lub 32: 651. 1906.

Polyporus sericeohirsutus Klotsch, Linnaea 8: 493. 1933.

Dead trunks of red cedar, New I'rovldence:-southern Cunlted States.

20. Daedàlea amanitoldes Beaur. Fl. Oware 1: 44. 1505.

Lenzites applanata Fries, Epier. MYye. 404. 1838.

Dead woor, New I'rovidence:-tropleal reglous. 
21. Elfvíngia tormàta (Pers.) Murrill, Bull. Torrey Club 30: 301. 1903.

Polyporus tornatus Pers.; Gaud. Voy. Freye. Bot. 173. 1826.

Dead wood, Abaco:-tropical regions.

22. Fávolus alutàceus Berk. \& Mont.; Mout. Ann. Sci. Nat. III. 11: 240.1849.

Recorded by Coker from Andros, but the species is probably confined to South America.

23. Fávolus ténuis (Hook.) Murrill, Bull. Torrey Club 32: 100. 1905.

Boletus temuis Hook, in Kunth, Syn. Pl. 1: (10). 1822.

Dead hardwood trunks and branches, New Providence:-tropical regions.

24. Fòmes Auberiànus (Mont.) Murrill, Bull. Torrey Club 32: 491.1905.

Polyporus Auberianus Mont. Pl. Cell. Cuba 397. 1842.

Dead or wounded hardwood trunks, New Providence:-tropical America.

25. Fulvifòmes depéndens Murrill, Tropical Polypores 87. 1915.

Pyropolyporus dependens Murrill, N. Am. Flora 9: 106.1908.

Trunks of living hardwood trees, New Providence, Little San Salrador, Atwood Cay, Caicos Islands, Great Harbor Cay, Long Cay, Andros :-West Indies.

26. Fulvifòmes Swieténiae Murrill, Tropical Polypores 87. 1915.

Iahogany stumps, Acklin's Island:-Cuba.

27. Funàlia versátilis (Berk) Mfurrill, Bull. Torrey Club 34: 469. 1907.

Trametes versatitis Berk. Lond. Journ. Bot. 1: 150. $18 \pm 2$.

Dead wood, New Providence:--tropical regions and Gulf States.

28. Fuscoporélla corúscans Murrill, N. Am. Flora 9: 7. 1907.

Dead wood, New Providence :-Cuba.

29. Ganodérma pulveruléntum Murrill, N. Am. Flora 9: 121. 1908.

Dead wood, New Providence:-Cuba, St. Thomas, Grenada.

30. Ganodérma subincrustàtum Murrill, N. Am. Flora 9: 122. 1908.

Dead wood, New Providence:-tropical America.

31. Gloeophýllum Bérkeleyi (Sace.) Murrill, Bull. Torrey Club 32: 370. 1905. Daedalea Berkeleyi Sace. Syll. Fung. 6: 381. 1888.

Pine railway ties and other forms of dead coniferous wood, New Providence, Great Bahama, Andros:-tropical America and Gulf States.

32. Gloeophýllum hirsùtum (Schaeff.) Murrill, Journ. Myc. 9: 94.1903.

Agaricus hirsutus Schaeff. Fung. Barar. pl. 76.1762.

Dead coniferous wood, New Providence:-temperate regions.

33. Gloeophýllum striàtum (Sw.) Murrill, Bull. Torrey Club 32: 370.1905. Agaricus striatus Sw. Prodr. 148. 1788.-Sw. Fl. Ind. Occid. 3: 1920. 1806.

Dead wood, New Providence, Rose Island, Fortune Island, Crooked Island, Cat Island:- tropical America? 
34. Hapalópilus licnoìdes (Mont.) Murrill, Bull. Torrey Club 31: 417. 1904. Polyporus licnoides Nont. Pl. Cell. Cuba 401. 1842.

Dead wood, New Providence:-tropical and subtropical America and Asia.

35. Inonòtus corròsus Murrill, Bull. Torrey Club 31: 598. 1904.

Decased vines and trunks, New Providence, Great Bahama, Abaco, Andros, Mariguana, Crooked Island, Anguilla Isles :-Florida; West Indies.

36. Inonòtus frùticum (Berk. \& Curt.) Murrill, Bull. Torrey Club 31: 601. 1904.

Polyporus fruticum Berk. \& Curt. Journ. Linn. Soc. 10: 310. 1868.

Liring twigs of orange, etc., New Providence:-Cuba.

37. Inonòtus porréctus Murrill, Tropical Polypores 68. 1915.

Dead rood, Caicos Islands:-Louisiana.

38. Pogonómyces hydnoìdes (Sw.) Murrill, Bull. Torrey Club 31: 609. 1904.

Boletus hydnoides Sw. Prodr. 149. 17Ss.-Fl. Ind. Occid. 3: 1924.1806.

Trametes hydnoides Fries, Epicr. Myc. 490. $153 \mathrm{~S}$.

Dead wood, New Providence, Abaco, Andros, Crooked Island:-tropical America and Gulf States.

39. Polýporus Bràcei Murrill, Mycologia 11: 222. 1919.

Buried wood, New Providence. Endemic.

40. Polýporus guyanénsis Mont. Ann. Sci. Nat. II. 13: 201. 1840.

Recolded by Coker for Andros, but the species is probably confined to South America.

41. Polýporus Tricholòma Mont. Ann. Sci. Nat. II. 8: 365.1837.

Dead sticks and logs, New Providence:-tropical America.

\section{Pòria.}

One or more undetermined species have been collected. They occur in resupinate forms on dead wood.

43. Pycnóporus sanguíneus (L.) Murrill, Bull. Torrey Club 31: 421.1904.

Boletus sanguineus L. Sp. Pl. ed. 2. 1646. 1762.

Polystictus sanguineus Fries, Nova Acta Soc. Sci. Upsal. III. 1: 75. 1851.

Dead wood, New Providence, Great Bahama, Abaco, Andros, Hog Island, North Bimini, Fortune Island, Crooked Island, Cat Island, Anguilla Isles, Cay Sal:tropical regions.

44. Rigidóporus surinaménsis (Miq̨.) Murrill, Bull. Torrey Club 34: 473. 1907. Polyporus surinamensis Miq. Bull. Sci. Phys. Nat. Neérl. 1839: 454.1839. States.

Water-soaked hardwood trunks, New Providence:-tropical America and Gulf

45. Tramètes submurina Murrill, N. Am. Flora 8: 43. 1907.

Old Iogs, New Providence:-West Indies and western Mexico.

46. Tyrómyces palústris (Berk. \& Curt.) Murrill, N. Am. Flora 9: 31. 1907.

Polyporus palustris Berk. \& Curt. Grevillea 1: 51. 157․

Pine trunks, New Providence:-Florlda: Cuba. 


\section{f. BoLetàceae.}

47. Ceriómyces commùnis (Bull.) Murrill, Mycologia 1: 155. 1909. Boletus communis Bull. Herb. Fr. pl. 393. A, C. 1788.

Sbaded soil, New Provldence:-temperate regions.

\section{g. AgaricìceaE.}

48. Chánterel cinnabarìnus Schw. Trans. Am. Phil. Soc. II. 4: 153. 1832. Agaricus cinnabarinus Schw. Schr. Nat. Ges. Leipzig 1: 73. 1822. Ground, New Provldence, Andros:- -eastern United States, Jamaica, Mexico.

49. Chánterel infundibulifórmis (Scop.) Fries, Spier. Myc. 366. 1838. Merulius infundibuliformis Scop. Fl. Carn. ed. 2. 2: 462. 1772. Shaded soil, New Providence :-temperate North America and Europe.

50. Chlorophýllum molybdites (G. Meyer) Massee, Kew Bull. 1898: 136. 1898. Agaricus molybdites G. Meyer, Fl. Esseq. 300. 1818.

Rich soil, New Providence, Cat Island:-New Jersey to Iowa and Brazil.

51. Collỳbia sp. (q)

Recorded doubtfully by Coker as occurring on decaying wood in New Providence.

52. Coprìnus micáceus (Bull.) Fries, Epicr. Myc. 246. 1838.

Agaricus micaceus Bull. Herb. Fr. pl. 246. 1785.

Rich soll or humus, New Providence:-temperate regions.

53. Crinipéllis sp.

Dead wood, New Providence.

54. Gymnópilus ténuis Murrill, Mycologia 5: 22. 1913.

Dead wood, New Proridence:-Cuba; Jamaica.

55. Gýmnopus sp.

Ground, New Providence.

56. Hydrócybe cónica (Scop.) P. Karst. Bidr. Finl. Nat. Folk 32: 236.1879. Agaricus conicus Scop. Fl. Carn. ed. 2. 2: 443. 1772.

Moist soil, New Providence:-temperate North America and Europe.

57. Lentìnus crinitus (L.) Fries, Syst. Orbis Teg. 77. 1825.

Agaricus crinitus L. Sp. Pl. ed. 2. 1644. 1763.

Exposed logs or stumps, New Providence, Great Bahama:-tropical and subtropical regions.

58. Lentìnus hírtus (Fries) Murrill, Mycologia 3: 29. 1911. Agaricus hirtus Fries, Linnaea 5: 508. 1830. Dead wood, New Providence :-tropical regions.

59. Lentìnus strigéllus Berk. \& Curt. Journ. Linn. Soc. 10: 302. 1868. Dead wood, New Providence:-tropical America. 
60. Lentìnus strigòsus (Schw.) Fries, Syst. Orbís Veg. 77. 1825.

Agaricus strigosus Schw. Schr. Nat. Ges. Leipzig 1: 89. 1822.

Old logs and stumps, New Providence, Great Bahama, Watling's Island:-cosmopolitan.

61. Lentìnus velùtinus Fries, Linnaea 5: 510. 1830.

Dead wood, New Proridence, Great Bahama :-tropical regions.

62. Lentòdium squamòsum (Schaeff.) Murrill, Mycologia 3: 27. 1911.

Agaricus squamosus Schaeff. Fung. Bavar. 4: Ind. 15. 17it.

Lentinus lepideus Fries, Syst. Orbis Veg. 78. 1825.

Structural timbers and logs, especially of coniferous trees, New Providence :cosmopolitan.

63. Lepiòta cretàcea (Bull.) Morgan, Journ. Mye. 13: 3. 1907.

Agaricus cretaceus Bull. Herb. Fr. pl. 374. 1787.

Rich soil in cultivated grounds or woods, New Providence:-cosmopolitnn.

64. Marásmius atropurpùreus Murrill, N. Am. Flora 9: 262. 1915.

Dead leaves and sticks, New Providence. Endemic.

65. Marásmius bahaménsis Murrill, N. Am. Flora 9: 265. 1915.

Dead leaves and twigs, New Providence. Endemic.

66. Marásmius bermudénsis Berk. Journ. Linn. Soc. 15: 49. 1876.

Doubtfully recorded by Coker for New Providence :-Bermuda.

67. Marásmius hemileùcus (Berk. \& Curt.) Murrill, N. Am. Flora 9: 266. 1915.

Agaricus hemileucus Berk. \& Curt. Journ. Linn. Soc. 10: 285. 1868.

Dead leaves and sticks, New Providence :-Cuba.

68. Marásmius opàcus Berk. \& Curt. Journ. Bot. \& Kew Mise. 1: 99.1849.

Doubtfully recorded by Coker as occurring on leaves in New Providence:-South Carolina and ohio.

69. Marásmius rameàlis (Bull.) Fries, Epicr. Myc. 381. 1838.

Agaricus ramealis Bull. Herb. Fr. pl. 366. 1786.

Dead branches, New Providence:-eastern United States and Europe.

70. Marásmius Rótula (Scop.) Fries, Epicr. Myc. 385. 1838.

Agaricus Rotula Scop. Fl. Carn. ed. 2. 2: 456. 1772.

Dead wood or leares, New Providence:-temperate North America and Europe.

71. Maràsmius setulósipes Murrill, N. Anl. Flora 9: 257. 1915.

Dead leaves and sticks, New Provldence. Endemic.

72. Marásmius Vaillántii Fries, Epier. Mye. 380. 1838.

Doubtfully recorded by Coker as occurring on hanana leaves in Andros:-a European species reported hy Curtis from the Carolinas.

73. Naucòria semiorbiculàris (Bull.) Quél. Champ. Jura Vosg. 100. 18 72.

Agaricus semiorbicularis Bull. Herb. Fr. pl. 422, f. 1. 1785.

Open manured ground, New Providence:-cosmopolitan. 
74. Panéllus eugrámmus (Mont.) Murrill, N. Am. Flora 9: 245. 1915. Agaricus eugrammus Mont. Ann. Sci. Nat. II. 8: 266.1837. Dead wood, New Providence:-tropical Amerlca.

75. Pleurotópsis liliputiàna (Mont.) Murrill, N. Am. Flora 9: 239. 1915. Agaricus litiputianus Mont. Ann. Sci. Nat. IV. 1: 99. 1854. Marasmius nidulus Berk. \& Curt. Journ. Linn. Soc. 10: 299. 1568. Doubtfully recorded by Coker for New Providence:-tropical America.

76. Plicatùra oblìqua (Berk. \& Curt.) Murrill, Mycologia 3: 25. 1911. Marasmius obliquus Berk. \& Curt. Journ. Linn. Soc. 10: 299. 1868. Dead wood, New Providence:-tropical America.

77. Resupinàtus subbarbátulus Murrill, N. Am. Flora 9: 241. 1915. Dead logs, New Providence :-Cuba; Jamaica; Mexico.

7S. Schizophýllus álneus (L.) Schroet. Krypt.-Fl. Schles. 3 : 553. 1889. Agaricus alneus L. Sp. Pl. 1176. 1753.

Dead wood, New Proridence, Abaco, Great Bahama, Eleuthera, Crooked Island, Rose Island :-cosmopolitan.

79. Strophària floccòsa Earle, Inf. An. Estac. Centr. Agron. Cuba 1: 241. 1906. Ground in the open, New Providence:-Cuba.

S0. Vaginàta farinòsa (Schw.) Murrill, Mycologia 4: 3. 1912.

Amanitopsis farinosa Atk. Stud. Am. Fungi 76.1900.

Soil, New Providence, Watling's Island:-New York to Alabama.

81. Vaginàta plúmbea (Schaeff.) Murrill, Mycologia 5: 82. 1913. Amanitopsis vaginata P. Karst. Bidr. Finl. Nat. Folk 32: 6. 1879. Shaded soil, New Providence:-temperate regions.

\section{Order 4. PHALLÀLES.}

1. Cláthrus cancellàtus L. Sp. Pl. 1179. 1753.

Ground, Fortune Island, Acklin's Island :-tropical and warm-temperate regions.

2. Cláthrus críspus Turp.; Fries, Syst. Myc. 2: 28s. 1823.

Dead wood, New Providence, Andros :-tropical regions.

3. Latérnea triscàpa Turp. Dict. Sci. Nat. 25: '248. 1822.

Sandy soil, New Providence :-tropical America; Texas; Chili.

4. Símblum sphaerocéphalum Schlecht. Linnaea 31: 154. 1861.

Ground, New Providence:-tropical America.

\section{Order 5. LYCOPERDÄLES.}

1. Diplocýstis Wríghtii Berk. \& Curt.; Berk. Journ. Linn. Soc. 10: 344.1868.

Ground, in soll or humus, New Providence, Great Bahama, Great Sturrup Cay, Fortune Island, Acklin's Island, Crooked Island, Conception Island, Watling's Island, Eleuthera, Inagua, Andros:- Cuba. 
2. Geáster saccàtus Fries, Syst. Mỵc. 3: 16. 1829.

Ground, New Providence:-cosmopolitan.

3. Lycopérdon sp.

Ground and humus, New Providence, Abaco.

Order 6. NIDULARIÀLES.

1. Cỳathus intermédius (Mont.) Tul. Ann. Sci. Nat. III. 1: 72. 1844.

Nidularia intermedia Mont. Pl. Cell. Cuba 321. 1842.

Dead sticks, New Providence:-tropical regions.

2. Cỳathus pállidus Berk. \& Curt.; Berk. Journ. Linn. Soc. 10: 346. 1868.

Dead wood, New Providence:-tropical regions.

\section{Class 4. MYXOMYCETES.}

The following slime-moulds have been reported on determinations made by W. G. Farlow. All were collected at Mangrove Cay, Andros. All are widely distributed.

1. ?Arcỳria Oerstédtii Rost. Mycet. Monog: 27s. 1575.

2. Arcyria cinérea (Bull.) Pers. Syn. Fung. 1St. 1801. Trichia cinerea Bull. Champ. Fr. 120. 1791.

3. Arcyria punícea Pers. N. Bot. Mag. 1: 90.1794.

4. Dictỳdium cancellàtum (Batseh) Nacbr. N. Am. Slime-moulds 172. 1899. Mucor cancellatus Batsch, Elench. Fung. 2: 135. 1759.

5. Dictydium squamulòsum (Alb. \& Schw.) Fries, Syst. Mye. 3: 118. 1829.

Diderma squamulosum Alb. \& Sehr. Consp. Fung. Ss. 1505.

6. Hemitríchia clavàta (Pers.) Rost. Versuch. Mycet. 14. 1873. Trichia clavata Pers. N. Bot. Mag. 1: 90. 1794.

7. Lycógala epidéndrum (L.) Fries. Syst. Mye. 3: 80. 15:9. Lycoperdon epidendrum L. Sp. Pl. 1184. 1753.

8. Physàrum compréssum Alb. \& Schw. Consp. Fung. 97. 1505.

9. Physarum globulíferum (Bull.) Pers. S5n. Fung. 175. 1801. Sphaerocarpus globuliferus Bull. Herb. Fr. pl. 484, f. 3. 1790.

10. Physarum víride Pers.; Usteri, Ann. Bot. 15: 6. 1795.

11. Stemonìtis herbàtica Peck, Ann. Rep. N. Y. State Mus. 26: 75.1875. 


\section{EXPLORATION AND COLLECTIONS.}

1703. Thomas Walker, Chief Justice for the Bahama Plantation, sent plants from New Providence to James Petiver in London, as recorded on the last page of Petiver's "Musei Petiveriani"' in the following paragraph:

30. Mr. Thomas WaLKer. This Generous Gentleman, at the desire of my kind Friend Mr. Robert Ellis, hath lately sent me Specimens of the Brasiletto $W o o d$, and some other Trees and Plants from New Providence, one of the Bahama Islands: for which I am extreamly obliged to him, and for his kind Promises of greater Performances, by the next and all Opportunities.

From information given us by Mr. L. J. K. Brace, it would appear that Walker lived at Nassau until 1722.

1725-6. Mark Catesby sailed from Florida to New Providence in 1725 and there began his studies of the plant life of the island in connection with his pursuit of general Natural History. He later embodied the results of his work, with that along the Atlantic Coast, in his excellently illustrated folios on the "Natural History of the Carolinas," the fine plates of which formed one of the bases of Linnaeus' Species. In the course of his work he is known to have also visited Abaco, Andros and Eleuthera. His plates illustrating Bahama species are cited in our text with the exception of plate 86 of the first volume, which we are unable to understand. The balance of his plates are either not botanical or are plants of the Atlantic Coast from Virginia southward to North Florida.

He preserved but few specimens of dried plants: one set of these he gave to his patron, Sir Hans Sloane, this set is now in herb. British Museum; another to Sherard, now in herb. Oxford; and a third series is said to have come into the possession of the Physick Garden of Chelsea.

1730-32. Francis Dale, Jr., probably of Hoxton, England, appears to have collected in both the East and West Indies. In 1730 he sent to Samuel Dale (a relative) a large number of specimens from New Providence, and in 1732 another lot from "Bahama, with seeds, some of which were raised in the Braintree Garden"' (Journ. Bot. 21: 227, 1883). His library and "Hort. Sicc." were bequeathed to the Society of Apothecaries of London with the proviso that they be deposited in the Physick Garden of Chelsea.

1784. F. Boos, in company with F. J. Märter and Dr. J. D. Schöpf, visited New Providence and other islands from March to September 1784. Their collections consisted principally of living plants which were transferred to the Botanic Gardens of Schönbrunn, near Vienna, where many of them were depicted and described by Jacquin. Märter's plants are in herb. Munich.

1789. André Michaux collected in the Bahamas from Feb. 25 to Mareh 29, 1789. His collection, which consisted largely of living material, was prineipally confined to New Providence though he also explored the nearby 
cays. His collections were sent to the Botanical Garden, Paris. (See C. S. Sargent, "Journal of André Michaux"' in Proc. Am. Phil. Soc. 26. 1888.)

1790? Dr. J. W. Crudy collected in the Bahamas "before 1810," and his collections are in the herbarium of the Botanical Museum at Münich, according to Urban (Symb. Ant. 3: 33). A more recent and extended account of Crudy and his West Indian collections, by Solereder (Symb. Ant. 7: 145-150), makes no mention of the Bahamas; from this account it seems clear that Crudy had not collected in the Bahamas prior to 1789 , and that he died in or before 1793 .

1802. J. Fraser, of Chelsea, London, after collecting in the southern United States and Cuba, spent some time in the field at Nassau, New Providence. The extent of his collections there is not known to us. The plants are deposited, with his personal herbarium, in the Linnean Society, London.

1810? Jean Baptiste Ricord-Madiana, a noted author and naturalist, went to the West Indies, from New York, in $1810(?)$ and there traveled and practised medicine extensively among the Windward Islands. How large a series of plants he collected, the exact years (1810-25?), and where his material was deposited are, at this writing, unknown to us. A very few sheets have been seen in the herbaria of Harvard University and of the New York Botanical Garden; these are labeled simply "Turks IslandMadiana."

1830-42. Swainson (whose identity is not certain: not William Swainson the Zoologist) collected in the Bahamas between 1830 and 1842 . The exact locality of his field work and the extent of his collections, are not known, though Mr. Brace judges, from frequent local inquiries, that his plants were collected, in a large part at least, on Long Island. Grisebach, who chronicles the material in his Flora of the British West Indies, mentions specifically less than 200 species. His plants were turned over to Hooker and are now in herb. Kew, London.

1857-8. Dr. Wm. F. Daniell eollected in the Bahamas in 1857-8. The extent of his collections is not definitely known. The specimens are in the herbarium of the British Museum.

1858. J. A. Hjalmarson, of Stockholm, on his return royage from conchological collecting in Hayti, stopped off at Grand Turk Island in 1858. Here he spent a fortnight in field work. The extent of his botanical collection is not definitely known. His specimens are to be found in the herbaria at Kew, Göttingen and Berlin.

1859. William Cooper risited New Providence in 1859 for the purpose of making Irerlgings for zoological material. While there he collected, in the neighborhood of Nassau, about 100 plants for his friend, Dr. John Torrey. The prime set of these plants is now in the herbarium of the Ner York Botanical Garden. (Sce Bull. Torrey Club 17: 187.)

1865. Dr. Anna H. Searing, of Rochester, N. Y., collected to some extent on New Proridence in 1865. The number of specimens, and present location of her collection we have not been able to positively determine, though the 
specimens trere probably deposited in the herbarium of the University of Pennsylvania, Philadelphia.

1S66. Henrik J. Krebs, who spent most of his life on St. Thomas, made a short trip to New Provitence in 1866. The plant collections made by him on the island are deposited in the herbarium of the Botanical Museum at Copenhagen.

1867-8. Sir Rawson Wm. Rawson collected to some extent on New Providence, and probably other islands, during his two years incumbency as Governor of the Bahamas. His collections were sent to the British Museum. Duplieates are to be found in herb. Kew and in Berlin.

1874. Dr. Edward Palmer. well known as a collector upon the North American mainland, risited Nassau in May, 1874. The algae collected by him were studied and enumerated by Prof. D. C. Eaton [see Bibliography].

1875-1919. Lewis J. K. Brace began his collections in the Bahamas in 1875. He worked principally on New Providence until 1880, but also secured material on Fortune Island or Long Cay, and Andros. His work resulted in about 525 numbers, of which his personal series is now in the herbarium of the New York Botanical Garden and duplicate sets in the herbarium at Kew and that of the Field Museum. He began field work for the survey resulting in this Flora in September, 1904 (see Britton \& Brace), and later in the same year was commissioned by the New York Botanical Garden to make an exploration of the Abaco Islands, where he collected as follows: Green Turtle Cay (1475-1515), Allen's Cay (1526-54), Spanish Cay (1555-62), Man-o'-War Cay (1563-89), Pigeon Cay (166273), Elbow Cay (1688-1712), and on the island of Abaco at Butler Cay (1516-25), Marsh Harbor (1590-1661, 1713-53, 1787-1846), Great Cister (1674-87, 1754-86), Cherokee Sound (1847-9, 1898-1980, 1999, 2080-84, 2086), Eight Mile Bay (1850-97), opposite Cherokee Settlement (1981-98, 2064-79), Old Kerr's Point (2000-2036), and California road (203i-63), a total of 611 numbers. Following this expedition he continued work on New Providence in localities from which, from time to time, it became necessary to have more material of previously secured species.

In June, 1905, a commission was given him by both the New York Botanical Garden and the Field Nuseum to continue on Great Bahama, the work already undertaken there. (See Britton \& Millspangh.) On this exploration he collected at Eight Mile Rocks (3633-5, 3671-3738), Deadman's Reef (3631-2), and the restern extremity of the island (3484-3630, $3636-37$ ). He also collected on Garden Cay (3658-70), and visited (during his sailings to and from Great Bahama) North Bimini (3461-75, 3479-83), South Bimini (3476-8), North Cat Cay (3739-54), and Andros Island (3755-6), and after returning to New Providence collected Nos. 3893-3918. He was later commissioned by the New York Botanical Garden and the Field Museum to make three further explorations. From these he has returned orer 1,800 numbers as follows: Rum Cay (3919-3993); Fortune Island (3994-4179) ; Acklin's Island (4260-1471) ; Crooked Island (4533$4776)$; and Andros (4876-5377 and 6657-7139). In the Andros work he 
not only traversed the East side but also made his way around to the diffcult swash region of the West coast, and penetrated the diriding channel across the southern third of the Island. Mrr. Brace also continued his search for interesting plants on New Providence (7141-7161 and 79057910) and during $191 \mathrm{~s}$ and 1919 obtained large collections of Cryptogams (9395-10138).

157\%. H. E. Wm. Robinson, while Gorernor of the Bahamas, took considerable interest in the plant life of the islands even to the establishment of an Experimental Botanic Station for the Study of Economic Plants suitable for the Islands. His collections of Bahamian plants (192 specimens) are in the herbarium at Kew.

1585-6. John Gardiner spent two years in the Bahamas going there in 185.5 as scientific advisor to the Board of Agriculture. Under the direction of Gorernor H. A. Blake he spent a considerable time in botanically exploring New Providence and the Out Islands, notably Andros, Berry Islands, Atwood Cay, Inagua and the Biminis; at the latter place he lost his notes and books of reference through the wreck of his ressel. Unfortunately he made no collections during his Bahama explorations, contenting himself with analyzing the plants in the field and recording his results in the lost note books.

1SS6. F. H. Herrick worked on Abaco, Pawpaw Cay, Joe's Cay and Little Abaco in June 1556, deroting most of his time to zoölogy. He made a small collection of plants which is now in the herbarium of Yale University. A large number of the species in the list of 66 plants published by Eaton $\&$ Setchell, were, however, reported from his field observations only.

1SS7. Charles S. Dolley risited New Providence in $15 S 7$ and has recently resided at Nassau. His private herbarium, principally of plants collected in the United States, is deposited in the herbarium of the University of Pennsylvania, Philadelphia. [See Bibliography.]

1887-88. H. F. A. von Eggers, plant collector for many years in various parts of the West Indies and South America, was on Grand Turk in July, 1857. From January to March, 1sss, he collected on Acklin's, Fortune, Long, and Hog Islands, and on Nerr Proridence under the auspices of the committee of the British Association for the Advancement of Science.

1559-91. Alexander Keith, of Enlinburgh, owner of a sisal plantation on Andros, collected a few plants on that island especially for Mrs. Northrop (whom see). Those preserved are in the Herbarium of the New York Botanical Garden.

1590. Mrs. Alice (Rich) Northrop, accompanied by her husband, Prof. John I. Northrop, made, in 1590, a large collection of the plants of New Proridence (nos. 1-239, 290-331), Rose Island (251), Salt Cay (240-244, 271279), Hog Island (245-S, 252-70), and Andros (332-75s). These plants formed the basis of Mrs. Northrop's "Flora of New Providence and Andros." They are now deposited in equal sets in the herbaria of the Field Museum and the New York Botanieal Garden. Tery full sets are also to be found in the herbarium at Kew and at Berlin. 
1590. Prof. J .T. Rothrock male, in the interests of the University of Pennsylvania, an expedition to the British West Indies in his 41-ton yawl "White Cap" during the winter of 1890-91. On this expedition he collected 4 days on New Providence; 2 on Cat Island; a part of one day on Watling's; 2 days on Crooked Island; 2 on Fortune Island, and a day on Great Inagua. IIis collecting was done independently from that of Prof. Hitcheock, who accompanied him. The first set was deposited in the herbarium of the University of Pennsylvania; the second, comprising 162 sheets, he has kindly placed in the herbarium of the Field Museum and the third in the herbarium of the New York Botanical Garden.

1590. Prof. Albert S. Hitchcock collected in the Bahamas in November and December, 1890. The collections were largely made on New Providence, Eleuthera, Cat, Watling's, Crooked, Fortmne, and Inagua and form the basis of his "Plants collected in the Bahamas," ete. The material collected was deposited in the herbarium of the Missouri Botanical Garden, from which, through the kindness of the director, Dr. William Trelease, the authors have been allowed to reassemble the sheets. The collection, embracing about 600 sheets, is at this writing a loan to the Field Museum. Through a later purchase of his "Florida Herbarium", the Field Museum secured 133 duplicate sheets of the Bahama plants.

1893. Miss Bertha Wilson accompanied the Bahamian Expedition from the State University of Iowa in May and June, 1893, collecting-principally algae-on Egg Island, Harbor Island, Eleuthera, New Providence, Cat Cay and Water Cay. (Narrative of the Bahamian Expedition, Nutting.) On leaving the university she took her collections with her in the anticipation of determining the species. All trace of them has since been lost to the botanists of the institution. Her land plants are said to have been but seraps and to have been thrown away.

1893-4. G. F. Curtiss, of Schenectady, New York, an amateul collector of ferns, spent the winter of $1893-4$ on the islands. The extent of his collecting (which was doubtless of ferns only) is unknown. Although his private herbarium has lately come into the possession of the Field Museum of Natural History it contains but one sheet from the Bahamas and that from Andros.

1900-2. Mrs. Emilia Royce (Crane) Anthony, of Gouverneur, N. Y., collected the ferns of the neighborhood of Nassau, New Providence, in 1900 to 1902. Her personal collections were destroyed in the great fire at Jacksonville, Florida. Duplicates of her series were deposited in the private herbaria of B. D. Gilbert, Clayville, N. Y.; and W. N. Clute, Joliet, Ill.

1901. Dr. John W. Harshberger, while on his passage to Hayti, spent a portion of July 1, 1901, in the vicinity of Natthewtown, Inagua, during the call of his steamer at that port. He made a small collection which was sent to Prof. Urban, for determination, and is now in the herbarium of the Botanical Garden of Berlin.

1903. Prof. F. S. Earle collected during one day only, on New Providence (Nos. 1-79), while on his way to Cuba, in March, 1903. His plants, 
largely from the vicinity of Nassau, are in the herbarium of the New York Botanical Garden.

1903. Prof. Lucien M. Underwood and E. W. D. Holway accompanied Prof. Earle on the trip (mentioned above). Prof. Ilolway informs us that his collections consisted solely of Rusts. These are at present in his private herbarium.

1903. A. H. Curtiss collected his first series of "West Indian Plants" in April, 1903, in the neighborhood of Nassau, New Providence. This series comprises numbers 1-211, of which the prime set, with the nnnumbered unicates, is deposited in the herbarium of the New York Botanical Garden, the first distributed set in the Herbarium of the Field Museum and several others in various American and European herbaria.

1903. Dr. William C. Coker, botanist of the Bahamian expedition of the Geographical Society of Baltimore, assisted by Messrs. C. A. Shore and F. Mr. Hanes, collected in the summer of 1903 on the following islands: New Providence (1-193, 247-305, 551), Andros Island and Little and Great Mangrove Cays (194-234), Green Cay (235-246), George's Island (306317 ), Eleuthera (318-421), Cat Island (422-437), Rum Cay (435-457), Watling's Island (45s-491, 521, 528), Long Island (492-520, 524), Water Cay (523, 525), Abaco (558-568, 575-6), and Elbow Cay (569-574). This collection was deposited in the herbarium of the New York Botanical Garden, and forms the basis of his "Vegetation of the Bahama Islands" in Shattuck's "The Bahama Islands." Owing to the insufficiency of the material secured many phanerogams therein published are based upon provisional determinations only. The cryptogams exist under a separate series of numbers.

1904. Dr. N. L. Britton collected on New Providence in April, 1904, in the neighborhood of Nassau, South Side Beach, Blue Hills, Farrindon Road, West Bay Street Road, Cunningham Road, Lake Cunningham, and Old Fort. In this preliminary investigation, in company with Millspaugh, he collected 158 numbers (1-158). An account of the field work is published in the Journal of the New York Botanical Garden 5: 129-136. See also Britton \& Brace, and Britton \& Millspaugh.

1904. Dr. C. F. Millspaugh began his collections among the islands on New Providence, in April, 1904, in company with Dr. N. L. Britton (see Britton), visiting substantially the same stations, where, as his collecting was to extend to other islanis, he kept his individual series of numerals. He collected at the following localities: Blue Hills (2048-2100), South Shore (2101-2151 and 2262-2277), West Bay Street road (2152-2178), pine barrens and hammock lands along Lake Cumningham road (2179-2217), region of Lake Cunuingham ( $2218-2.24)$, Farringdon Road ( $2245-\overline{7})$, Swingate (2248-51), Old Fort (2252-4), and Waterloo (2255-61). Then hiring and commissioning a sloop, he sailed in company with Dr. M. $A$. Howe for an investigation of the Bimini Islands, collecting at the following stations: West Enıl Bight, New Providence (2278-2393), Joulter's Cays (2294-2304), Gun Cay (2305-2328), North Cat Cay (2329-2347, 
2415), South Bimiui (2345-2365, 2379-85, 235i-98, 2406-2114), North Bimini (2369-78, 2356, 2399-2405), South Cay (2416-2441). Again in January, 1905, he collected in the following localities while awaiting the arrival of Dr. Britton (see Britton \& Millspangh) ; Blue Hills road (244244, 2461-81), Silver Cay (2445-2460), ant South Side, Soldiers Road, Fort Montague and Fort Fineastle (2452-2502). (See also Britton and Millspaugh, and Millspaugh and Millspaugh.)

1904. Britton and Brace-Dr. N. L. Britton, Mrs. E. G. Britton, and Mr. Lewis J. K. Brace collected together on New Providence (nos. 159-328, 361-S72), aud Hog Island (329-360), in September and October, 1904. They ranged New Providence with great thoroughness, penetrating to the coast region north, east, south and west, and to the coppices, pine barrens, and openings in the neighborhood of Nassau, Fort Montague, Farringdon Road, Swingate, Maidenhead, Tea House, Race Course, Delaport, Fox Hills, Village Road, Mt. Vemon, Rifle Range, Harold Road, Carmichael, Adelaide, Southwest Landing, Miller's, Blue Hills, Soldiers Road, Lake Cunningham, Wintou, Old Fort, Waterloo, Clifton, Mt. Pleasant, Fort Charlotte, Gambier, Killarney, Bonefish Pond, and Seren IIills. The commoner things were not taken, the attempt being made to secure only such species as were previously unfamiliar or those which had only been gathered when out of character. This survey resulted in 714 particularly interesting plants, embracing the series of numbers indicated above. The prime set of these collections is deposited in the herbarium of the New York Botanical Garden, the duplicates in the herbarium of the Field Museum.

An account of this expedition is published in the Journal of the New York Botanical Garden 5: 201-209.

1904, 1905, 1907. Dr. Marshall A. Howe, phycologist of the New York Botanical Garden, has collected extensively the sea vegetation" of the Bahamas, accompanying C. F. Millspaugh on his first trip, and later the first expeditiou of Britton and Millspaugh. (See Jour. N. Y. Bot. Gar. 5: 129-136 and 6: 77-85.) In 1907 he accompanied Mr. Percy Wilson on the expedition to the southern islands (see Wilson) whence he returned a large amount of interesting and eritical additional material. His large collection of algae is deposited in the herbarium of the New York Botanical Garden.

1904. Alex. E. Wight, under the patronage of the Gray Herbarium, Cambridge, Mass., made a Bahamian collection of 281 numbers from December, 1904, to May, 1905. He collected on New Providence and Hog Island (1-226 and 271-274), and on Andros at Mangrove Cay, Fresh Creek, Calabash Bay, and Small Hope $(22 \pi-270)$. The resulting plants were determined at the Field Museum and the initial set retained (with the exception of about six numbers in the Orchidaceae which are in the herbarium of Prof. Oakes Ames). Duplicate sets have been deposited in the Gray Herbarium and the herbarium of the New York Botanical Garden.

1904. Geo. V. Nash and Norman Taylor, of the New York Botanical Garden, were commissioned by the Garden, in October, 1904, to investigate the Inaguas. They made an exhanstive survey of the islands, 
collecting on Inagua $4 \$ 2$ numbers (S74-113S and 125S-1474), on Sheep Cay 23 numbers (1139-1161), and on Little Inagua 96 numbers (11621257). In September, 1905, on their return from an exploration in Haiti, they spent a week on Grand Turk Island, collecting all such plants as were noted by them at that season, 136 numbers (3757-3592). Accounts of these expeditions may be found in the Journal of the New York Botanical Garlen 6: 1-19 and 189-191.

1904. Glover M. Allen and Thomas Barbour, while collecting zoölogical material on the Bahamas in July, 1904, gave considerable attention to the plant life of Abaco, Elbow Cay, Great Guana Cay, Little Abaco, Pensacola Cays, Stranger Cay and Great Bahama. Their collections amounting to about 100 sheets are deposited in the Gray Herbarium, Cambridge, Mass.

1904. Owen Bryant collected a number of plants on Mangrove Cay and Andros in 1904 while engaged in zoölogical investigations there. IIis plants are in Herb. Gray, Cambridge, Mass.

1905 and 1907. Britton and Millspaugh-the anthors of this Flora, accompanied by Dr. M. A. Howe, began an exploration of the Berry Islands, Great Bahama, and the Exuma Chain, in January, 1905. A schooner was chartered and equipped at Nassau, where, after a day's delay on account of heary weather (during which collecting was done in the scrublands and coppices south of Nassau (20s5-2110), the expedition began at Rose Island (2111-2166) and Hog Island (2167-2176). The first island of the Berry Group visited was Whale Car (2177-2201), followed by Frozen Cay (2202-2224), Little Harbor Cay (2225-2254), Great Sturrup Cay (22552S5), Goat Cay (2286-2301), Lignum Vitae Cay (2302-2332), and Great Harbor Cay (2333-2354). The exploration began on Great Bahama Island at Fight Mile Rocks (2355-2596), and was continued at Barnett's Point (2597-2j16), and Golden Grove (2717-2741). Returning to Nassau, a fresh start was made to the Exuma Chain, of whieh the following islands were diligently searched: Ship Channel Cay (2742-2767), Cay north of Wile Opening (2765-2804), Cave Cay (2805-2836), Little Galiot (283-2550), Great Galiot (2551-2860), Great Guana (2S61-2922), Great Exuma (2923-3051, 3073-3141), and Stocking Island (3052-3072).

On Great Exuma the regions studied were the serub lands and coppices lying west of Georgetown: Hayne's Road from the east to the west shores across the island; and the Rolletown scrul, lands and coppices. The total series of this exploration is 1,057 shects. An account of this expedition may be found in Journal of the New York Botanical Garden 6: is-55.

They further undertook, in 1907 , a very exhaustive exploration of the Out Islands, embracing the following localities: Elenthera, from the Glass Window to Harbor Island (5376-5404) ; Glass Window to Gregorytown (5405$5440)$; Gorernor's IIarbor and rieinity ( $5441-5542)$; Rock Sound and vicinity (5543-5590); Miller's and Baunermantown and ricinities (55915613 ) and in the vicinity of the extreme southern point of the island (56145656). Little San Salvador (565-5701). Cat Island, from Orange Creek around the extreme north end of the island, down the northeast shore of 
Cotton Point and across (502-57.91) ; the ricinity of The Bight and across the island and back $(5792-5945)$; and Port Howe and ricinity (5946-5986). Conception Islanı (598;-6043). Watling's Island, Cockburntown ricinity (6044-6144); from Cockburntown across Little and Great Lakes to the Light on the east coast (6145-6169): Graham's Harbor south along the east coast to Columbus' Nonument (6170-6188); Graham 's Harbor around the north end of the island to Cockburntomn (61896224). Long Island, vicinity of Clarencetown and across the island to the Trest shore, and on Thatch and Strachan's Cays (6225-6359); and the extreme north end of the island at Cape St. Maria (6360-6370). New Providence in the ricinity of Nassau.

1905, 1907. Mrs. N. L. Britton, often accompanied by her cousin, Mir. Brace, risited, in April and May, 1905, all those stations on New Providence previously collected by Britton \& Brace, at which it had become desirable to secure additional material of interesting plants or characters missing on previous notable species. In addition to achieving marked success in this unilertaking, she secured many other plants of particular interest. Her surrer resulter in 310 sheets (nos. 3141-3460), and is mentioned in the Journal of the New York Botanical Garden 5: 129-136. In 1907 she accompanied her husband and the co-author as far as Harbor Island and remained there, as a base, while working that island and the extreme north end of Eleuthera (6370-6527). Returning to New Providence she did further diseriminating field work on that island (6529-6656) while awaiting the return of the anthors' second expedition.

1907 and 1909. Percy Wilson, of the New York Botanical Garden, on a commission from that institution and the Field Museum, accompanied by Dr. Howe, made an exploration of the southeastern islands from Norember 22 to December 29, 1907. His field was as follows: Cat Island, at The Bight $(7163-7197)$ and the southwest end of the island (7195-7202). Tatling's Island, at Cockburntomn (7203-7225); Graham's Harbor (7226-7258); and the extreme southeast and southwest ends ( $7259-7336$ and $733 \bar{i}-7359)$. Atrood's Cay (Samana) ( $7360-7424$ and $7903-7904)$. Mariguana, at a point ten miles west of Abraham Bay (7425-7451): Abraham Bay and ricinity (7452-7540); fire miles west of Southeast Point (7541-7557) and at Southeast Point (7558-i589). The Caicos Islauds: on South Caicos (7590-7693); Pine Cay (7694-7697); North Caicos at Ker and vicinity (769S-7748); Providenciales (7749-7752) and West Caicos (7753-7763); Little Inagua, at the restern end (7764-7 $\mathbf{7} 82)$. Castle Island (7783-7802). The Ragged Cays, at Great Ragged Island (7803-7869) and Hog Cay (7870-7882). The Exuma Chain, at Harrest Cay (7S83-7898); and Rose Island (7899-7902). From May 13 to June 7 , 1909, he explored the Cay Sal Bank, spending four days on Anguilla Islands (7932-8078, 8438) and one day each on Salt Cay (8079-8124), Water Cay (8132-8159), and Elbow Cay (8125-8131). On the trip out he spent one day at Riding Rocks (7912-7924), and one on Orange Cay (7925-7931), of the Bimini Gronp; and on his return to Nassau: six days collecting on New Provi- 
dence ( $\$ 16 \varsigma-\$ 24 \bar{\tau}, \$ 323-\$ 343, \$ 3 \bar{i} 0-\$ 413, \$ 434-843 \bar{i}$ ) and four on Hog Island (\$248-8322, $8344-8469,5414-8433)$. The collections are deposited in duplicate in the herbaria of the New York Botanical Garden and the Field MInseum.

1910. Small and Carter. Feeling that the central portion of Andros, fifteen miles from the sea, might yield species not to be found on any other of the islands, Dr. John K. Small and Mr. Joel J. Carter were commissioned by the New York Botanical Garden and the Fieli Inseum of Natural IIstory to make a thorough survey of the interior, especially in the Fresh Creek region, the broadest part of the islaml. This they thoroughly did and added two other central areas to their field of exploration (see Jour. N. Y. Bot. Gard. 11: 58-101). Beginning January 1.5, 1910, they collected on Mangrove Cay at Lisbon Creek (8439-S540), passed southward to Deep Creek (5541-863i), and worked northwaril to Smith Flill (8635-8689),

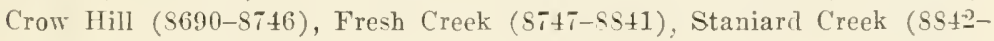
8919) and concluded their work at the north end of the island: Nichol's Town ( $8920-8976)$.

From the fact that these two indefatigable and acute Florida Ererglade workers failed to bring to light more than 8 species not before accredited to the Bahamas in our lists it would appear: first, that the great brealth of Anilros does not mitigate the salinity; seconil, that previous collecting had pretty thoroughly coveres the flora of the group.

1911. Millspaugh and Millspaugh. C. F. Millspangh and his wife (Clara Nitchell Jillspangh) undertook, in February and Narch, 1911, a surrey of the Turk's and Caicos Islands in order to ascertain the most southerly extension of the species of this Flora. They collected on Grand Turk Island (8981-9059;9324-9347;9378-9390); then, chartering a sloop, investigated the following islands: East Caicos (9060-9114); Grand Caicos (91159122) ; North Caicos (9123-9191) ; Bay Cay (9192) ; Parrot Cay (91939204); Stubb's Cay (9205-9210); Pine Cay (9211-9215); Dellis' Cay (9216-9225); South Caicos (9226-9233; 9240-9247) ; Long Cạ (92349239; 9274); Salt Cay (9245-9262; 9392); Sand Cay (9263-9270;9391); Ambergris Cay (9275-9316); Little Ambergris Cay (9317-9323); Long Cay (Turk's) (9345-9350); Gibbs' Cay (9351-9356); Cotton Cay (935i9363); Penniston Cay (936t); and East ("Eastern") Cay (936j-9377). 


\title{
BIBLIOGRAPHY
}

\author{
Prepared With the CO-OPERATION OF JohN H. BarNhart
}

Only documents dealing wholly or chiefly with Bahamian plants, and the more important treatises on West Indian botany ineluding references to Bahama species are here cited.

Allen, Glover M., and Barbour, Thomas. Narrative of a Trip to the Bahamas. Cambridge, Mass. Privately printed. 1904.

Ames, Oakes. A new Ponthieva from the Bahamas. Torreya 10: 90, 91. 1910. Description of Ponthieva Brittonae.

Anonymous, Agave seen by Columbus found. Discovery 1: 30-32. 1907. Popular account of the Agave indagatorum of Watling's Island.

Anthony, Emilia C. Fern Hunting in Nassau. Fern Bull. 10: 65-68. 1902. Popular account of ferns found on New Providence.

Bennett, John J. Note on the Species of Croton described by Linnaeus under the Names of Clutia Eluteria and Croton Cascarilla. Journ. and Proc. Linn. Soc. Bot. 4: 26-30. 1859. Copied in Pharm. Journ. and Trans. II. 1: 132-134. 1860. German translation under the title "Ueber die Croton-Art, welch die Cortex Cascarillae liefert."' Bonplandia 9: 213215. 1861 .

Discussion of three species inhabiting the Bahamas.

Britton, N. L. Review of the Prorisional List of the Plants of the Bahama Islands. Bull. Torr. Club 17: 18T, 188. 1890.

Britton, N. L. A new Waltheria from the Bahamas. Torreya 3: 105, 106. 1903.

Description of Waltheria bahamensis.

Britton, N. L. Explorations in Florida and the Bahamas. Journ. N. Y. Bot. Gard. 5: 129-136. 1904.

Record of the first visit of Dr. Britton, Dr. Millspaugh and Dr. Howe to New Providence.

Britton, N. L. Report on Exploration of the Bahamas. Journ. N. Y. Bot. Gard. 5: 201-209. 1904.

Record of collecting on New Providence with Mrs. Britton and Mr. L. J. K. Brace.

Britton, N. L. Savia bahamensis. Torreya 4: 104, 105. 1904.

Deseription of a species new to science.

Britton, N. L. Notes on the Flora of the Bahamas. Torreya 4: 190. 1904.

Remarks before the Torrey Botanical Club upon the flora of New Providence.

Britton, N. L. Contributions to the Flora of the Bahama Islands. Bull. N. Y. Bot. Gard. 3: 441-453; 4: 11ว-127; 137-143; 5: 311-318. 1905-1907. 
Deseriptions of new species and records of distribution of species. Each of the four Contributions was distributed separately in adrance.

Britton, N. L. Explorations in the Bahamas. Journ. N. Y. Bot. Gard. 6: 78S5. 1905.

Narrative of exploration of Rose Island, the Berry Islands, Great Bahama and the Exuma Cays with Dr. Millspaugh and Dr. Howe.

Britton, N. L. Report on the Continuation of the Botanical Exploration of the Bahama Islands. Journ. N. Y. Bot. Gard. 8: 71-81. 1907.

Narrative of exploration, with Dr. Millspaugh, of Eleuthera, Little San Salvador. Cat Island, Conception Island, Watling's Island, and Long Island. Mrs. Britton and Mrs. Millspaugh collected on Harbor Island.

Britton, N. L. The Genus Ermodea Strartz: A Study of Species and Races. Bull. Torr. Club 35: 203-208. 1908.

Diseussion of the six species of the Bahamas, three described as new.

Britton, N. L. The Botanical Name of the Wild Sapodilla. Torreya 11: 128, 129. 1911.

Synonymy of Mimusops emarginata (L.) Britton.

Britton, N. L. Four Undeseribed West Indian Sedges. Torreva 13: 215-217. 1913.

Stenophyllus Wilsoni, Fimbristylis inaguensis, Rynchospora bahamensis from the Bahamas.

Catesby, Mark. The natural history of Carolina, Florida, and the Bahama Islands. 2 vols., folio, London, "1731" and "1734."

Issued in ten parts, of twenty plates each, 1730-43; and an appendix of twenty plates, 1748. The plates are numbered 1-100 in each volume, and 1-20 in the appendix. Each plate, as a rule, illustrated one animal and one plant, and descriptive text accompanied each object figured; these include about sixty-five Bahama plants.

A second issue in 1754, "revised" by George Edwards, librarian to the Royal College of Physicians, is a mere reprint, with the addition of a sheet at the end of each volume giving the Linnaean names of the animals and plants in the work.

A third issue, in 1771, differs from the preceiling only in the resetting of the title-page and preface, and the numbering of the pages and plates of the appendix consecutively with those of the second volume.

The London issues all had the text in both English and French, in parallel columns. There was another edition (Nürnberg, 1750), with text in Latin and German, in parallel columns; this contained a few additional plates, not in Catesby's work.

The Bradley Bibliography mentions also a German translation by IIth (Nïrnberg, 1755), and a Dutch translation by Houttuyn in nine rolumes (Amsterdam, 1772-81), but both are indicated as not seen by the compiler.

Coker, William C. Vegetation of the Bahama Islanis. In Sliattuek "The

Bahama Islands,"' 185-270. Baltimore, 1905. Also issued as a separate.

Contains an aecount of previous botanieal exploration, a diseussion of the composition and relationships of the flora and of its distribution, notes on useful plants indigenous and introrluced, a rescription of the botanieal for- 
mations, and a list of the plants collected by the author in 1903 ; several species are described as new.

Committee. Report of the Committee, consisting of Messrs. W. Carruthers, W. F. R. Weldon, I. G. Baker, G. M. Murray, and W. T. Thiselton-Dyer (Secretary), appointed for the Purpose of Exploring the Flora of the Bahamas. Rep. Brit. Assoc. Adr. Sci. 58: 361-363. 1889. Also reprinted. Baron Eggers made collections for this Committee in 1587 and 1559.

Daniell, William F. On the Cascarilla and other species of Croton of the Bahamas and other West Indian Islands. Pharm. Journ. and Trans. II. 4: 144-150; 226-231. 1863.

Botanical and pharmaceutical descriptions of the Bahama Crotons, with illustrations.

Dolley, C. S. The Botany of the Bahamas. Proc. Acad. Nat. Sci. Phila. 1889: 130-134. 1889.

Remarks upon the flora, with reference to the list of plants presented by him for publication. (See Garliner, John, and Brace, L. J. K.)

Dyer, W. T. Thiselton. Flora of the Bahamas. Nature 37: 565, 566. 1888. Account of exploration, with a letter from Baron Eggers.

Eaton, D. C. A List of the Marine Algae collecterl by Dr. Edward Palmer on the Coast of Florida and at Nassau, Bahama Islands, Narch-August, 1874. Sro, pp. 6. New Haren, 1875.

Record of about 30 species found at Nassau, New Providence.

Eaton, D. C., ani Setchell, W. A. List of Plants from Abaco Island, Bahamas. Johns Hopkins Univ. Circ. 6: 46, 47. 1886.

A list of 65 species collected by F. H. Herrick or observed by him.

Eggers, H. F. A. Die Bahama Inseln. Globus 62: 209-214. Braunschweig, 1892.

A brief general account of the islands and of their regetation.

Ekman, E. L. West Indian Vernoniae. Arkiv. Bot. 13 ${ }^{15}$ : 1-106, pl. 6. 1914. Includes the Bahama species.

Evans, Alexander W. The Hepaticae of the Bahama Islands. Bull. Torr. Club 38: 205-222. 1911 .

Enumeration with distribution of 34 species, three of them illustrated, with descriptions, as new to science.

Gardiner, John, and Brace, L. J. K. Provisional List of the Plants of the Bahama Islands, arranged with notes and additions by Charles S. Dolley. Proc. Acad. Nat. Sci. Phila. 1889: 349-426. 1889. Also issued as a separate.

An annotated catalogue of orer 600 Bahama plants based upon a manuscript list prepared by Mr. Brace, with a glossary and index of popular names. This document is eited in the present volume as of Dolley.

Gleason, Henry A. The Genus Ternonia in the Bahamas. Bull. Torr. Club 33 : 183-158. 1906. [Separately as Contr. Bot. Dept. Col. Univ. no. 224.]

Records and descriptions of the five species, three of them described as ner.

Grisebach, A. H. R. Flora of the British West Indian Islands. 8vo, pp. 789. London, 1859-1864. 
Published in seven parts. Ineludes records and deseriptions of aljout 200 Bahamian speeies mostly from speeimens collected by Swainson and by Hjalmarson.

Grisebach, A. H. R. Die geographische Terbreitung der Pflanzen We-timliens. Abhand. Koenigl: Gesell. Wiss. Goettingen 12: 3-80. 1565. Also is suet as a separate.

A treatise on geographie distribution of West Indian species, with references to those of the Bahamas.

Guppy, H. B. The Flora of the Turks' Islands. In his "Plants. Seels and Currents in the West Indies and Azores" 27-293. Sro. London, 1917.

Harshberger, John W. Notes on the Strand Flora of Great Inagua, IIaiti and Jamaica. Torreya 3: 6i-70, 1903.

Herrick, F. H. Notes on the Flora of Abaco and alljoining Islamls. Johns Hopkins L'niv. Cïre. 6: 46. 1556.

General account of the regetation.

Hitchcock, A. S. A visit to the West Indies. Bot. Gaz. 16: 130-1 1. 1891. Narrative of a trip with J. T. Rothrock, incluling exploration on New Providenee, Eleuthera, Cat Island, Watling's Island, Crooked Island, Fortune Islands and Inagua.

Hitchcock, A. S. List of Plants collected in the Bahamas, Janaica and Grand Carman. Rep. Mo. Bot. Garil. 4: 4i-179. 1593. Also distributed separately in advance.

Record of the trip above mentioned, with a eatalogue of the plants colleeterl, a riseussion of the relations of the Bahama Flora, lescriptions and illustrations of ner species and tables of distribution.

Hitchcock, A. S. List of Cryptogams eolleeter in the Bahamas, Jamaiea and Grand Carman. Rep. Mo. Bot. Gard. 9: 111-120. 1895. Also distributed separately in ailranee.

Bahama species are listed of Lichens determinel by T. A. Williams, of Basidiomycetes by W. G. Farlow, of Uredineae by M. A. Carleton, of Ustilagimeae by P. Magnus and of Pyrenomycetes and Peronosporaeeae by J. B. Ellis. Nine new speeies of Pyrenomycetes are deseribed.

Hitchcock, A. S., and Chase, Agnes. Grasses of the West Inclies. Contr. L. S. Nat. IIcrb. 18: 261-171. 1917.

Contains many records of Bahama species.

Hooker, J. D. Bahama Flora. Rep. Progr. and Cond. Royal Garitens Kew for $1880,30.1881$.

Note on the receijt at Kew of a collection marle by L. .J. K. liraces.

House, Homer D. Two Bahamian Species of Evolvulus. Bull. Torr. Club 35 : S9, 90.190 s.

Evolvulus bahamensis and $E$. Bracci, new species.

Howe, Marshall A. Notes on Bahaman Algae. Bull. Torr. Clul, 31: 93-100, pl. 6. 1904. [Separately as Contr. X. Y. Bot. Gart. no. 51.]

Reeorls of the algae eolleeterl by Dr. W. C. Coker in 1903.

Howe, Marshall A. Collections of Marine Algae from Florilar anu the I3ahanıas. Journ. N. Y. Bot. Gard. 5: 16t-166. 1904. 
Narrative of collections made ou the shores of New Providence, at Joulter's Cays, Gun Cay, the Biminis, North and South Cat Cays, in eompany of Dr. Millspangh on the sloop "Cynosure."

Howe, Marshall A. Phycological Studies-I. New Chlorophyceae from Florida and the Bahamas. Bull. Torr. Club 32: 241-252, pl. 11-15. 1905. [Separately as Contr. N. Y. Bot. Gard. no. 67.]

Descriptions and illustrations of one genus and three species new to science.

Howe, Marshall A. Phycological Studies-II. New Chlorophyceae, new Rhodophyceae, and miscellaneous Notes. Bull. Torr. Club 32: 563-571, pl. 2329. 1905. [Separately as Contr. N. Y. Bot. Gard. no. 72.]

Includes descriptions and illustrations of one genus and three species, new to seience, from the Bahamas.

Howe, Marshall A. Phycological Studies-IV. The Genus Neomeris and Notes on other Siphonales. Bull. Torr. Club 36: 75-104, pl. 1-8. 1909. [Separately as Contr. N. Y. Bot. Gard. no. 120.]

Includes descriptions and illustrations of four Bahamian species new to science.

Howe, Marshall A., and Wilson, Percy. Report on the Botanical Exploration of the Bahama and Caicos Islands. Journ. X. Y. Bot. Gard. 9: 41-50. 1908 .

Narrative of collecting on Watling's Island, Atrood Cay, Mariguana, the Caicos Islands, Little Inagua, Providenciales, Castle Island, Great Ragged Island and Harvey's Cay.

Jackson, J. R. Princewood Bark, a Febrifuge from the Bahamas. Pharm. Journ. and Trans. III. 6: 681. 1876.

Note on the bark of Exostema caribaeum.

Millspaugh, C. F. A new Bahaman Euphorbia. Torreya 4: 172. 1904.

Euphorbia cayensis, from Joulter's Cays.

Millspaugh, C. F. Praenunciae bahamenses. Field Mus. Bot. 2: 137-1S1; 289321. $1906,1909$.

Contains accounts of collectors and collections, largely republished in the present volume (pp. 646-655), bibliography, a list of the islands on which collections have been made, lists of species of several families with descriptions of numerous novelties and a list of native plant names.

Murray, G. Catalogue of the Marine Algae of the West Indian Region. Journ. Bot. 26: 193-196, 237-243, 303-307, 331-338, 358-363. 188s; 27: 237$212,257-262,298-305.1889$.

Includes numerous records of the occurrence of marine algae in the Bahamas.

Nash, George V. Botanical Exploration of the Inagua Islands, Bahamas. Journ. N. Y. Bot. Gard. 6: 1-19. 1905.

Narrative of exploration of Inagua and Little Inagua in 1904, with Norman Taylor.

Nash, George V. A Trip to the Inaguas. Plant World 8: 63-71; 91-98. 1905. Also issued as a separate.

Popular account of the exploration of Inagua and Little Inagua. 
Northrop, Alice R. Flora of New Providence and Andros. Mem. Torr. Club 12: 1-98, pl. 1-19. 1902.

A general account of the location and conformation of these two islands, their botanical regions, an annotated list of plants collected by Mrs. Northrop and her husband, John I. Northrop, in 1590, with descriptions and illustrations of new speeies and diseussions of the distribution of species.

Nutting, C. C. Narrative and Preliminary Report of Bahama Expecition. Bull. Lab. Nat. Hist. Univ. Iowa 3: 1-252. 1595.

Contains occasional references to the regetation observed during a royage in 1893.

Rothrock, J. T. Some Observations on the Bahamas and Jamaica. Proc. Am. Phil. Soc. 29: 145-148. 1592. Also issued as a separate.

Rydberg, P. A. The Flowers and Fruit of the Turtle Grass. Journ. X. Y. Bot. Gard. 10: 261-264. 1909.

Study of Thalassia testudinum, from Bahama specimens collected by Perey Wilson.

Schoepf, J. D. Materia Medica Americana potissimum regni regetabilis. Sro, pp. xviii, 170. Erlangen, 17S7. Reprinted as Bull. Lloyd Library no. 6 (Reprod. Ser. 3). 1903.

Includes references to some 30 will and cultivated species found in the Bahamas.

Schoepf, J. D. Reise dureh einige der mittlern und siidlichen Tereinigten Staaten nach Ost-Florida und den Bahama Inseln unternommen in den Jahren 1783 und 17\$4. 2 volumes. Erlangen, 17s5. [Translated and edited by Alfred J. Morrison, under the title "Travels in the Confederation." 2 volumes, small Sro, Philadelphia, 1911.]

A chapter in the second volume (pp. 396-502), "Reise ron St. Augustin nach den Bahama-Inseln", [Translation, pp. 252-319, "Voyage from St. Augustine to the Bahama Islands'"] describes the Gulf Stream, Abaco, Egg Island and New Providence, with records of plants both cultivated and indigenous.

Small, J. K. Report on Botanical Exploration in Andros, Bahamas. Journ. N. Y. Bot. Gard. 11: \$8-101. 1910.

Narrative of exploration, with J. J. Carter, in 1910.

Small, J. K. Exploration in Andros. Torresa 10: 131-133. 1910. Account of the rork above-mentioned before the Torrey Potanical Club.

Urban, Ignatz. Additamenta ad Cognitionem Florae Indiae Oceidentalis. Bot. Jahrb. 15: 286-361; 19 : 562-681; 21 : 514-638; 24: 10-152. 1S921597.

These articles eontain numerous records and descriptions of Bahama plants.

Urban, Ignatz. Symbolae Antillanae seu Fundamenta Florae Indiae Oecidentalis. 8vo, vols. 1-7. Berlin, 1898-1913.

Each rolume was published in four parts; the work contains many records and descriptions of Balama species and lists and monographs of many families and genera of West Indian plants written by Professor Urban and by other students. 
Wilson, Henry W. A Winter Visit to the Bahama Islands. Trans. Mass. Hort. Soe. 1891: 210-229. 1891.

General description of several of the islands with accounts of the vegetation, especially of cultivated or conspicuous plants, illustrated.

Wilson, Percy. Report on the Botanical Exploration of the Islands of the Salt Key Bank, Bahamas. Journ. N. Y. Bot. Gard. 10: 173-176. 1909.

Record of eollections made in 1909 on Riding Rocks, Orange Key, Anguilla Isles, Salt Key (Cay Sal), Elbow Key, and Water Key; also on New Providence. 


\section{INDEX}

Abelmoschus, 272 esculentus, 272

Abena jamaicensis, 366

Abildgaardia, 52 monostachya, 52

Above-ail, 396

Abraham-bush, 220

Abrus, 187

Abrus, 187

preeutorius, 187

Abutilon, 264.

abutiloides, 265

Bushy, 265

orispum, 260

Eugersii, 2ttit

filiforme. 266

Hairy, 265

hirtum, 265

indieum, 265

indieum hirtum, 265

lionosum, 265

Low, 266

paueiflorum, 266

permolle, $2(i-5$

triquetrum, 265

trisulcatum, 265

Telvety, 265

Woolly, 266

Acacla, 159

acuitera, 160

Bahama, 160

bahamensis, $15 \mathrm{~s}$

ehoriophylla, 160

Farnesiana, 161

formosa. 158, 159

haematomma, 159

latisiliqua paneifoliola, 158

Lebbeck, 157

Long-spined, 160

maeraeantha, 160

tortuosa, 161

Acalypha, 228

alopecuroidea, 228

caroliniana, 220

ehama edrifolia, 228

Holnbeam, 22!r

ostryaefolia, 229

persimilis, 229

polystaehya, 228

Prostrate, 228

reptuns, 228

setosa, 22 ?

Setose, 220

Spleate, 228

ACANTIIACFAE, 100

Aeanthococcus adelphinus,

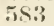

Acanthophora, 568

Antillurum, 569

Delilei, 569

militaris, 569

museoldes, 56?

spicifera, 569

Thicrii, 569

Acanthospermum, 447

humlle. 447

ACANTIUS FAMILY, 400 deetabularia, 605

earaibiea, 606

erenulata, 606

polyphysoides, 606

pusilla, (i)6

Schenekii, 606

Acetabulum, 605

caribaeum, 606

erenulatum, 606

polyuhysoides, 606

polyphysoides deltoid. eum, 606

pusillum, 606

dehras bahamensis, 324 salieifolia, 322

Zapota, 324

Zapotilla parrifolia, 324

Achyranthes, 126

aspera indiea, 126

uspera obtusifolia, 126

Beach, 126

Creeping, 127

indica, 126

Iinotweed, 127

linearifolia, 127

maritima, 126

obtusifolia, 120

polygonoides, 126 repens, 127

Acicularia, 606 Sehenckii, 606

Acoelorraphe, 60

deroehaetium, 560

Acrostichum, 465 a ureum, 465 ealomellanos, 469 excelsum, 465

lomarioides, 465

polypodioides, 470

Actinocyclus fascieulatus. 629

moniliform is, 629

Rotula, 629

Actinoptychus splendens, 629

undulatus, 629

vulgaris, 620

Acuan, 162

depressum, 163

virgatum, 163

Adelia, 227

Adelia, 226

A ciloton, 219

Bernardia, 227

porulese, 325

sequeguta. 327

Adenorima, 234

Bahama, 234

grmnonota, 234

Adenoropium, 225 gossyifolium, 225

Adiantum, 467 Capillus-Teneris, 467 rlarutum, 468

melanoleucum, 468

tenerum, 467

Aceidium candidum. 631

663

\author{
Aecilium- \\ Ipomocae-panduranae, \\ 631 \\ A esch ynomene grandiflora. \\ 152 \\ Afzelia, $3: 2$ \\ Afzelia, 39 \\ cassioides, 392 \\ Agalinis, 392 \\ Harperl, 392 \\ Marsh, 392 \\ spieiflota, 392 \\ A gardhia, 616 \\ Agardhiella, 561 \\ tenera, 561 \\ Agaricaceue, 642 \\ AGARICALES, 635 \\ Agarieus alneus, 644 \\ cinnabarinus, 642 \\ eonieus, 642 \\ eretaceus, 643 \\ erinitus, 612 \\ eugrammus, 644 \\ hemileneus, 1543 \\ hirsutus, 640 \\ hirtus, 642 \\ liliputianus, 644 \\ mieaeeus, 642 \\ molyblites, 642 \\ ramealis, 643 \\ Rotula, 643 \\ semiorbicularis, 643 \\ squam as us, 643 \\ striatus, 640 \\ strigosus, 643
}

Agati, 182

grandiflora, 182 serieca, 1 s 2

Agave, 73

aeklinieola, 75

americana, 75

bahamanis, 74

bahamana, 75

Braceana, 74

cacozela, 7 .

inaguensis, 76

indagatorum, 76

Millspaughii, -5

Nashii, 76

rigida, 75

rigida sisalana, 76

sisalnma, 76

sisalune armata, 76

sobolifera, 75

Ageratum, 436

cony $y$ oilles, 437 conyzoides inacquipale. aceum, 437

latifolium, 436

latifolium, 437

mutieum, 436

Wild. 437

Aglaozonia, 501

canariensis, 5.1

eanarimsis, 504

A grostis indiea. 32

radiata, 35

truacissima. 32

rirginiea, 33 
Alufeltia pinnatula, 560

AIZOACEAE, 136

Aklema, 230 petiolare, 236

Albizzia, 157

lebbeck, 157

Albugo candida, 631

Ipomoeae-panduranae. 631

Alectoroctonum petiolare, 236

Aletris, 70

bracteata. 70

guincensis, ga

hyacinthoidcs guianen sis, 6?

AlgAe, 553

Alisma cordifolia, 7

Alismaceae,

ALISMALES, 6

Allophrlus, 25:3

Allophylus, 258 Cominia, 253

Allspice, 305

Almond-tree, 302

Aloe, 69

barbadensis. 69

perfoliata, 69

vera, 69

vulgaris, 69

Aloes. 69

Alsidium Blodgettii, 571 triangulare, 571

ALSINACEAE, 137

Alternanthera Achyrantha 127

farcscens, 128

maritima, 126

paronychioides, 126

repens, 127

Alvaradoa, 211

Alvaradoa, 211

amorphoides, 211

Alysicarpus, 155 nummula rifolius, 185 vaginolis, 185

A manitopsis farinosa, 644 vaginata. 644

Amansia, 575

multifida, 575 multifida, $5 \mathrm{Sg}$

Amaranth, Knotweed. 124

Notch-leaved, 124

Slender, 124

Spiny, 125

Thick-stalked, 124

Amaranth FamiLr, 122

AMARANTHACEAE, 122

Amaranthus, 123

crassipes, 124

dubius, 125

emarginatus, 124

gracilis, 124

hybridus, 125

paniculatus, 125

polygonoldes, 124

spinosus. 125

tristis, 125

viridis, 12

AMARYLLIDACEAE, 73

AMARTLLIS FAMILY, 73

A mblogyna polygonoides, 124

Amblystegium, 496

Amblystegium, 496

riparium flordan um, 496
Amblystegium Sipho, 4!66

Ambrosia, 431

artcmisiacfolia, 432

crithmifolin, 432

hispida, 432

paniculata, 432

A MBROSIACEAE, 430

Amcllus aspera, 449, 454

Ames' Halberd-fern, 472

Ammannia, 299

Ammannia, 298

latifolia, $29 n$

AMMIACEAE, 311

A YruI ILES 311

A mmocallis roser, 336

1 mpelopsis quinqucfolia, 261

Amphibia, 572

Amphibia, 617

Montagnei, 572

pectinata, 573

Sertularia, 573

Sertularia 573

tenella, 572

tenclla, 573

mphiconium, 599

Amphiroa, 588

debilis, $5 \mathrm{~s}$

fragilissima, 588

fragilissima, 588

rigida antillana, $58 \mathrm{~s}$

Tribulus, 58S

Amphora, 628

acuta arcuata, 630

bigibba, 628

coffaeiformis, 630

crassa, 630

cymbelloides, 630

gigantea fusca, 630

Graeffei. 630

Gruendleri, 630

Janischii, 630

obtusa, 628

ostrearia, 630

ostrearia vitraea, 630

rhombica, 630

AIYGDALACEAE, 153

Amyris, 208

bijuga, 209

elemifera, $20 \mathrm{~s}$

maritima, 208

sylvatica, 20 ?

toxifera, 244

ANACARDIACEAE, 243

A nacardium occidentale, 245

Anacheilium, 93 cochleatum, 93

Anaconda, 358

Anadyomena, 602 flabellata, 602

Anadyomene, 602 flabellata. 602 stellata, 602 stellata, 602

Anamomis, 305 bahamensis, 306 longipes, 306 lucavana, 306

Anastraphia, 45 ?

Bahama, 45 ?

bahamensis, 450

bahamensis, 636

cuneifolia, 459

Northropiana, 459

Northrop's, 459
Anastraphia-

pulcifloscula 459

inastrophus compressus, 17

Anatherum macrurum, 14

Anaulus, 627 minutus, 627

Andrograplis, 403

Andrographis, 403 paniculata, 403

Andropogon, 13 barbatum, 36 glomeratus, 14 gracilis, 13 insulare, 16 polydactylon, 36

rcpens, 37 semiberlis, 13

tencr, 13

tenuispatheus, 14 virginicus, 14

Anemia, 474

adiantifolia, 475

bipinnata, 474

cicutaria, 474

Maiden-hair, 475

Parsler, 474

Wrightii, 471

Tright's, 474

Anethum, 313

Foeniculum, 313

graveolens, 313

AXGIOSPERMIAE, 2

Anguria, 426

Keithii, 426

pedata, 426

Anneslia, 158

formosa, 159

haematostoma, 159

Red, 159

IVhite, 159

Annona, 141

Annona. 599

glabra, 141

glabra, 540

laurifolia, 141

palustris, 141

reticulata, 142

squamosa, 141

AN NONACEAE, 141

Anonymos cassioides, 392

Anthacanthus, 402

acicularis, 403 spinosus, 403

Anthephora, 15

Anthephora, 15 hermaphrodita, 15

Anthoceros, 521

laevis, 521

Yellow-spored, 521

ANTHOCEROS FAMILY, 521

A NTHOCEROTACEAE, 521

ANTHOCEROTALES, 521

Anthracothecium, 527

americanum, 528

corticatum, 527

ibricolum, 527

ochro-flavum, 527

sinapispermum. 527

subglobosum, 527

Antigonon, 116

leptopus, 116

Antirrhinum antirhiniflora, 3 SS

Antirrhoea lucida, 414

murtifolia, 415

Antithamnion, 581 
Antithamnion, 627 Butleriae, 581 cruciatum, 581

Aphanocapsa, 618 Iowei, 618 Zanardinii, 619

Aphanothece, 620

Apium $A m m i, 314$

Aplonema, 599

APOCYNACEAE, 333

A pona. 582

A rabian Jasmine, 327

ARALES, 62

Archaeolithothamnium, 5S4 dimotum, 584

Archilejeunea, 517 Greenest, $51 \mathrm{~s}$ riridissima, $51 \mathrm{~s}$

Arcyria cinerea, 645 Oerstedtii. 645 punicea, 645

Ardisia guadalupensis, 316 Pickeringia, 315

ARECACEAE, $5 \mathrm{~S}$

ARECALES, 58

Argemone, 145 mexicana, 145

Argithamnia lan ecolata, 226

Argythamnia, 225

argentea, 226

Bahama, 22f

equdicans, 22f

lucatana. 226

sericea, 225

Silky, 226

SilverT, 226

Aristida, 30

adscensionis, 31

american $\alpha .37$

cognata. 31

grrans, 31

purpurascens, 31

scabra, 31

stricte 31

Aristolochia, 113

Coastal, 113

passifloraefolin, 113

pentandra, 113

Slender. 113

AristolochiACE.AF, 112

AfistoloChIALES, 112

Aroma, 161

Artemisin capillifolia, $43 \pi$ vilgaris. 460

Arthonia, 5.33

Arthonin, 5.3.

ntrata, 5.34

atrata. 5.34

eacsinprwinnsa. 536

chlodectella, 5.3 .3

cineronruinosa , 533

cinnabarina, 5.33

eomnlanata. 533

conferta 533

flssurinen, 533

crecaria, 5.33

interducta, 5.33

maernthrea. 5.34

platreraphiden, 534

nolrmornla. 533

septisepta. 5.33

Artuoxiactas 533

Arthopyrenia, 525

biformis, 52.

Cinchonae 525
Arthopyrenia-

consanguinea, 525

contendens, 525

cpidcrmidis, 525

fallacior 525

falla $x, 525$

geminata, 525

indusiata, 525

planior. 525

planorbis, 525

tumida, 525

Ar thothelium, 534

macrothecum, 534

Arthrostylidium, 43 capillifolium, 43

Arthrothamnus, 235 cassy thoides, 235

1rum sogittifolium, 62

frundo Plragmites, 39

Asclepiadaceae, 340

Asclepias, 341

clausa, 344

curassavica, 341

curassarica concolor, 341

paupercula, 341

procera, 341

A.SCOMYCETES, 632

Ascyrum, 280

linifolium, 280

Asparagopsis, 564

Delilei, 564

taxiformis, 564

Asperococeus clathratus, 590

sinuosus. 500

Aspidium ariantifolium, 473

ougeseens, 472

heractcifolium, 471

incisum, 473

reptans cordato, 473

trifoliot um, 472

Asplenium, 469

dentatum, 469

marinum, 469

rhiะoply llum, 469

Astephomus, 344

Aster, 440

adnatus, 441

Bahama. 441

bahamensis, 441

Bracei, 441

Brace's, 441

exilis, 441

lucayanus. 447

Pine-land, $4+1$

Scale-leaved, 441

Slim 441

tennifolius, 441

Asterocytis, .5.5

ramosa, 5.54

ASTROTHELIACEAF, 5.32

Astrathelium varium citri. $n u m, 530$

Atamaseo-lily, 78

Atamoseo, 77

cardinalls, $7 \mathrm{~S}$

rosea, $7 \mathrm{~s}$

Ateleia, 17t

cubensis, 177

cubensis, 6.32

mulijuga, 177

Athanasin linstata, 449

Atriplex, $11 ?$

arenaria, 120
Atriplex-

Crested, 120

cristata, 120

cristata arenaria, 120

Domingan, 120

domingensis, 120

pentandra, 120

Sea-beach, 120

Auliscus caelatus, 629 reticulatus, 629

Auliza, 90

nocturna, 90

Slender, , 0

Auricula intermedia, 631 minuta, 631

Auricularia A uricula, 637 nigrescens, 637

ATRICLLARIALES, 637

ArTOBASIDIOMYYETES, 637

Avicennia, $27 \pi$

A ricennia, 572. 573, 603 nitida, 375

Avrainvillea, 611 levis, 611

longicaulis, 611 longicaulis, 611

$M a \approx r i, 611$

nigricans, 611

nigricans, 611

nifricans fulva, 611

Rawsoni. 612

sordida, 611

Axonopus, 17 compressus, 17

Aruris pentundra, 120

Ayenia, $27 \mathrm{~s}$ Common, 270

pusilla, $27 \mathrm{~s}$

Baccharis, 444 angustifolia, 444

dioica, 445

factida 445

halimifolia, 444

Tahlii, 445

Bacidia, 543

atrogrisea, 54 .

cndoleuen, 543

fuscolubella. 543

medialis. 543

Baenpa Uamnicra, 35 ?

Badiera, 216

domingcnsis, 217

Oblong-lenved. 217

oblongata, 216

Balıma Iay-rush, 4 fit

Irrmenostomum, 485

Phrmosia. 264

Solanum, 3.8

Bahamian Brachlolejeunea, 515

Balloon-rlne, 252

Ballatre suarcolens, $3 \mathrm{SO}$

Bamboo, 74

Banara, 28? lotieulata, $2 \mathrm{~S} 4$

Bangia, 5i.?

.17*idlii. 5.73

birlentato. 5.5.?

eleqans. .53

lutea, 553

betlescens. $\mathrm{nos}$

pallirla . .....?

PANellCRAF, 5.T

Banistcrin angulosn, $\mathbf{2 0 4}$ 
Banisterin -

Tuputoides, 258 mierophylla, 2014

Panyin, 111 .

Iiarlindloes l'ricle, 175

Barbula, 456

(1)1 (I)

Crugeri, 4 titi

Cruger's, $4 \leq 7$

Urmmellii, 455

Bark Brachiolejeunea, $\overline{515}$

Barnyard-grass, :26

Bastard liuttonwood, 301 Stopper, 373 Torch, 143

Bastardia, 269

Viscid, 270

viscosa, 270

Bathclium mestoideum, 529

BATIDACEAE, 133

Batis, 133 maritima, 133

Bataphora, 604 Oerstedi, 604

Oerstedi occidentalis 604

Batrachaspermum attenuatum, 581

Bay-bean, 191 Cedar, 209

BAY CEDAR FAMILY, 209

Bay Geranium, 432 Hops, 352

Lavender, 361

Marigold, 450

Bay-rush, 463

Bahama, 464

Narrow-leared, 463

Bay Tansy, 432

-top, 5.9

Tinders, 352

Tormwood, 223

Basbers, 102

Bayberry Fajilly, 101

Beaked-rush, 54

Beard-grass, 13,14

Bed-grass, 14

Reef-bush, 320 $-\operatorname{Toad}, 100,132$

BEEF-TOND FAMILY, 100

Beggar-ticles, 453

Bellflower. 3st

Benny-seed, $30 \%$

Bermuda-grass, 35

Bernardiu, 226

Bermurdia $22 \pi$

carninifolia. 227

dichotama, 227

mexicana, 297

Bertero's Rectolejeunea, 510

Biatara ntrogrisen, 543

calrivara. 542

furfurosa, 542

fuscombella. 543

medialis. $5+3$

malybditis, 543

parififolia, 546

tricholoma, 541

Biddulphia, 627

Antillarum, 620

a retica, 629

Favus, 630

mobiliensis, 630

Pentacrinus, 627

peruviana, 630
Biddulphia-

reticulati, 6.30

lieticu'ym, 630

licbertsiana, 630

Smithii. (isi)

spinos:1, 6330

T:abllarium, 630

Bidens, 4.i:

bipinnata, 453

crnapiifolia, 453

lencunthe, 453

niver, 44 ?

pilosa 45.4

pilosa, 636

Big Man, 110

Sage, 370

Bignania coerulea, 398

lepidata, 396

vcntaphylla, 396

stans, 397

PIGXONIACEAE, 395

Bilimbia, 542

aurata, 543

molybditis, 543

trachona, 542

Bird Pepper, 385

BIRTHWOIT FAMILY, 112

Bitter Bush, 210, 438

Bitters, 227, $25 \mathrm{~S}$

Black-bead, 150

Bean, 195

Ebony, 196, 229, 328

-ered Susan, 187

-fruited Gyroweisia, 484

Iangrove, 375

Nightshade, 383

Olive, 301

SоAр, 429

Torch, 143, 416

Wattle, 304

Willow, 150

Wood, 10.

Blackish Papillaria, 494

Bladdel'wort. 394

BLADDERTORT FAMIILT, 393

Blastenia, 550

ferruginea, 550

floridana, 550

Blastadesmia lactea, 527

Blechnum, 468 serrulatum, $46 \mathrm{~s}$

RIechum, 401

Blechum, 401

- Brownei, 401

Bletia, 96

alta,, 86

Purple, 96

purpuren, 96

rerecundr, 96

Blind-eye Bush, 276

Blodgettia confervoides, 601

Blolly, 131, 132

Blue-eyed Grass, 81

-fower, 366 -pea, 187

Poa-wood. 326

Boar-hog Bush, 373

Roat Lily, 68

Boerhaavea, 130

coccinen, 130

erecta, 130

hirsuta. 130

paniculata, 130

scandens, 131
Boerhaavea-

splentens, 131

BOLETACWAE, 142

Bolctus abictinus, 639

cinnamomeus. 639

cammunis, 6.42

hysluoirles, fit1

membrumurecus, 639

nigramarginutus, 639

santjuine us, 641

spathulutus, 639

tenuis, 64i)

BOMIACACLAE, $2 T$

Bombax pentandrum, 274

Boxibax Fanily, 274

Bambyliospora, 542

domingensis, $\mathbf{5 4 2}$

Bonaney-bean, 193

Bonania, 231

Banania, 230

cubana, 231

BONNEMAISONIACEAE, 564

Bontia, 400

Bontia, 405 daphnoides, 405

BORAGE FAMILY, 360

PORAGINACEAE, 360

Borreria, 421

bahamensis, 423

inaguensis, 422

laevis, 422

ocimoides, 422

parviflara, 422

savannarum, 423

saxicola, 422

Slender, 422

thrmifolia, 422

thymacephala, $\mathbf{4 2 3}$

Wilsonii. 423

Borrichia, 450

arborescens, 450

arborescens, 636

argentea, 450 glabrata, 450

Boruna, 582

Boston Catnep, 450 Fern, 473

Bostruchin 5\%2

calam istrata, 572

MIazci, 573

Montagn fi. 572

pericludas, 572

Sertularia, 573

sertularina, 573

tenelln, 572

Tuomryi, 572

Vicillardi. 572

Vicillardi peotinata, 573

Botryophora, 604, 614 Canquerantii, 604 oceidentalis, 604

Bottaria, 530 eruentata, 530

Bouchea, 36 if

Ehronbergi, 366 prismatica, 366

Bourreria, 350

havanrnsis, 359

ovata, 35?

suceulenta, 359

thym ifolin, 423

tomentosa, 359

Bouteloua, 37

amerlcana, 37 
Bouteloua -

litigiosa, 37

Bow I'igeon, 11s

Bowstring Hemp, 70

Box Brlar, 410

Bux FAMILY, 242

Boxmood. $39 \mathrm{~s}$

Bracea. 33 J walumensis, 335

Brachiolejeunea, 514 bahamensis, 515 Bahamian, 515

Bark, $51 \overline{5}$ corticalis, 515

Brachycladia, 557 murvinat $a, 559$

Bracken, Southern, 467

Bradburya, 18s floridana, 1Ss virginiana, $18 \mathrm{~s}$

Brake. Long-leaved, 467 Narrow-leaved, 466

Bramia, $3 S 9$ Monnieri, 3s?

Brasiletto, 173

Brassica, 146 integrifolia, 147 orientalis, 145 Simeistrum, 147

BRASSICACEAE, 14J

IBrazilian Kalanchoe, 15

Brier, 172 tree, 301

Britton's Rectolejeunea, IIrs., 510

Bromelia Pinguin, 66

PROMELIACEAE, 1;3

Broom-bush, $346,442,445$

Broughtonia. domingensis, 95

lilacina, 95

Brya Ebenus, 196

DRYACEAE, 490

IRYALES, tis

Bryobesia, 610

Bryobesia, 611 cylindrocarpa, 610

Bryonia amcricana, 427 guadolupensis, 426 racemose +27

Bryophyllum, 152 calycinum, 152 pinnatum, 152

BRYOIIYTA, $4 T T$

BRYOPSIDACEAE, 606

Bryopsis, 606

Bryopsis.607 Duchassaingli. 607

hypnoides, 60: pennata, 606

Bryothamnion, 51

Bryothamnion, is? triungulare, 571 triquetrum, 571

Bryum, 490

albislum, 480 capillare, 490 Coronate, 491 coron.1tum, 490 latr-llie, tan

BRYLM IFIMLY, 490

Buecrus an!ustifolia, 301 Cotuppa. 302

Buchnera, 293 elongat $a, 393$
Bucida, 300

Buceras, 300

spinosa, 301

BUCKBEAN FAIILT, 332

BUCKTHORN FAMILY, 255

Buckwheat, 115

BUCKWHEAT FAMILY, 11

Buellia, 551

conspirans, 551

disciformis, 551

parasema, 551

parasema iteruginascens, 551

sanguinariella, 5๊1

subdisciformis, 551

BuElLIACEAE, 551

Buffalo-top, 59

Bull-grass, $3:$ -vine, 261

Bulrush, 42 American Great, 53 Salt Marsh, 52

Bumelia, 32 ? angustifolia, 323

Bahama, 324

bahamensis, 323

culcnsis, 323

Eggcrsii, 323

loranthifolia, 323

microplubla, 323

Narrow-leaved, 323

retust $, 32: 3$

retusa loranthifolia. 328

Bunchosia, 206

Bunchosia, 205

glandulosa, 206

Buphthalmum arborescens, 450

Bur-bush, 26:? -grass, 29, 30

-head. 7

Vervain, 367

Bursera aniustata, 212 gummiferel, 212

gummifera ylabrata, 212

gummifcra pubcsecus, 212

inclucrisis, 212

simurubn, 212

Perseraceae, 211

Bush Ira, 433

Bustic. 322

liutter-bough, 254

Buttercup. 202, 2S3

Butterflr-pen, 1SS

liuterwort, 39.5

Button-weed, 422

lint tonwood, 3112

IYXACEAE, 242

Burus bullamensis, 243

Byrsonima, 205 cuneata, 205 lucirla, 20 :

B yses us "turen, 50? sanguinea, 537

Cacalia. Porrophyll um, 456 sonchifolio, 455

ACTACEAE, 291

Cactus, 201 Dill'nii. 296 grundiflorus, 294

intortus, 294

Tuna, 297
Cactes Fasil. 291

Caesalpinia, 17:

Bahama, 173

bahamensis, 173

bahamensis, $20 \mathrm{~s}$

vijuga, 173

Bondue, 172

bonducella, 172

brasilicusis, 173

corlitia, 77

Crista, 172, 173

lucidu, 172

Net-veined, 17t

ocalifolia, 172

pulcherrima, $17 \pm$

reticulita, 174

Rugcliuna, 173

resicaria, 173

CAESALPINIACEAE, 164

Cajan, 192

Cajan, 192

Cajunus indicus, 192

Cakile, 149

acrualis, 149

lanceolata, 149

Calabash, 359

Calalue, 125

Calca oppositifolia, 450

CALICIACEAE, 53:-

CALICIALES, 532

Calicium, 53

hyperellum, 532

Calliandra formosa, 159

formosa culucnsis, 159 (1)ucilis, 159

hacmatomma, 159

portoricensis, 159

Callicarpa, 373

fulva, 373

Hitehcockii, 373

Callithamnion, 5\$U

byssoides, 580

corymbosum, 5 so

crispellum, 575

eleyuns, jol

yoryoneum, 5is

IIalliae, 5SO

incestiens, 578

repens, 57s

tenue, 5sll

Callopisme aurentiacum

diffructum, 551

Callymcnia Limminghii, 561

Caloglossa, $\overline{2}(\mathrm{it}$

Caluglossa, 561

Leprieurii, 564

Caloneis formosa, 630 Liber, fi30

Liber Iileischil, 630

l'owellii. 630

Calonyction, $34 ?$

aculeatum. 349

allum, 3511

trund iflorum, 350

Tuba, 350

Caloplaca,,$\pi 0$

aurautlaca, 5.

aurnntlaca diffricta, 5.51

a urautlaca erythrella, 5.511

a urantlaca Isidiosella, 550

galisetophyiln. 550

Calot'lacacese, 550 
Culopogon pulchellus Simpsoni, 95

Calothrix, 625

aeruginea, 625

fusco-violacea, 625

parasitica, 625

pilosa, 626 scopulorum, 625

Calotropis, 341

procer'in, 341 procera, $(63.35$

Caltrop, $2(12,208$

Caltrop FaMuly, 201

CILYMPERACEAE, 481

Calymperes, $48 \%$

lichardi, 482

Richard's, 4 S2

CALY MPEIES FAMILY, 481

Calyptranthes, 307 pallens. 307 Zuzrgium, 307

CAMPATULALES, 42

Campylodiscus, 629 angularis, 631 biangulatus, 631 crebrecostatus, 631 Daemelianus, 631 Ecclesianus, 631 imperialis, 629 latus, 631 limbatus, 631 samoensis, 631 simulans, 62 ? undulatus, 631 TVallichianus, 631

Campyloneurum, 471 Phyllitidis, 471

Campylothelium, 532 decolorans, 532

Canavali, 191

bahamensis, 192

gladiata, 191

lineata, 191

Canavalia obtusifolia, 191

Cancer-tree, 308

Candle-berrs, 205

Candlewood, 416,459

Cane-grass, 25

Canella, 28?

Canella, 281

alba. 282

Tinterana, 282

CANELla Family, 281

CaNfllaceae, 281

Canker-berry, 383

Cape-weed, 368

Caper Fajhly, 149

Caper-tree 151

Capitularia pityrea .547

CAPPARIDACEAE, 149

Capparis, 150

crnophallophora, 150 cymophallophora, 150 flexuosa, 150 janaicensis, 150

Capraria, 390 blflora, 391 biflora pilosa. 391

Capriola, 34 Dactylon. 34

Capsicum, 384 baccatium, 385 fruteseens, 385

Carara, 148 didyma, 148
Cardiospermum, 252

llalicacabum, 252

microcarpum, 25:

CARDEACLAE, 433

Carduus pinctorum, 458

Caribbean l'ine-trce, 461

Carica, 289

I'apaya, 289

CARICACFAE, 2S?

Carpueanthus platyearpus, 593

polyeeratius, 594 spinulosus, 594

Carpet-WEed Fayily, 136

Carpoeauton.567

atropuriureum, 567

dasyph yllum, 568

littorale, 567

tenuissimum, 567

Carradaria. 569

Carrajo-busl., 450

CARROT FAMILY, 311

Carteria, 52 corallicola, 83

Casasia, 40 ? clusiafolia, 410 clusiaefolia, 526

Ciscarilla Bark, 223

Casearia, 285 alba, $286^{\circ}$

bahamensis, 285

laetioides, 285

serrulata, 285

Smooth, 285

spinescens, 286

Spiny, 286

Cashia, 161

Cassada-wood, 322

Cassava, 230

Cassia, 165 angustisiliqua, 167

aspera, 16?

bahamensis, 167 bahamensis latifolia, 167

bicapsularis, 166

biflora, 167

biflora angustisiliqua, 167

earibaea, 169

Chamaecrista, 168, 170

emarginata, 168

glandulosa, 169

inaguensis, 170

ligustrina, 167

lineata, 170

Iueayana, 16 ?

mimosoides, 169

mictitans, 169

obtusifalia, 166

occidentalis, 166

polyadena, 170

riparia, 16 ?

sericea, 168

Sophera, 166

Tora, 166

uniflora, 168

villosa. 168

Cassine attenuata, 249

Cassip, 160

Cassytha, 144

americana, 144

filiformis, 144

CASSYTHACEAE, 144

Castagnea, 591
Castagnea-

ansterne, 591

Castalia, 139 (am) j) 1 a, 140

pulchella, 139

Cast or-oil l'lant, 230

Casuarina, 100 equisetifolia, 100

Casuarixaceae, 100

CASUARINALFS, 100

Cutulpa, 397 Cuban, 397 longissima 398 punctata, 397

Catenella, 561

Opuntia, 561

Opuntia pinnata, 561 , 620 pimmata, 561

Catesbaea, 410 cumpanulata, 411

faseiculata, 411

foliosa. 411

Large-flowered, 411

Leafy, 411

parviflora, 411

parviftora septentriona. lis, 411

Small-flowered, 411 spinosa, 411

Catesby's Tine, 338

Catharanthus, 336 rosells, 336

Cathartic-bark, 338

Cathartolinum, 199

bahamense, 200

Bracei, 201

corallicola, 200

Curtissii, 200

lignosum, 201

Catopsis, 66

Rerteroniana, 66

mutans, 66

vitellina, 66

Cat-tail, 4

CAT-TAIL FAMILY, 3

Cat's-claw, 155, 156, 157 -paw, 384

-tongue, 367,438

Cattleya domingensis, 95

Cattleyopsis Narthropiana, 95

Caudalejeunea, 516

Lehmanniana, 516

Lehmann's, 516

Caulerpa, 607

clavifera, 610

elavifera, 610

elavifera uvifera, 610

compressa, 609

crassifolia, 608

cupressoides, 609

eupressoides, 609

cupressoides ericifolia, 610

cupressoides Lycopodirsm, 610

ericifolia, 609

fastigiata, 608

Frexcinetii, 609

Freyeinetii peetinata, 60 ?

hupnoites, 60 ?

juniperaides, 609

lanuginosa, 609 
Caulerpa-

Lycopodium, 609 mumillos $a, 609$ mexicana, 608 paspaloides, 609 paspaloides, 609 paspaloides compressa, 609

paspaloides pluleoides, 609

petspuloides phlcoiles, 6in?

paspaloides typica compressa, 609

pinnuta, 608

plumaris, 608

prolifera, 608

prolifcra obovata, 608

racemosa, 610

racemosa, 610

racemosa. clatifera, 610

racemosa wifera, 610

sertularioides, 608

sertularioides, 608

taxifolia crassifolia, 608

rerticiliata, 608

Catlerpaceae, 607

Cayaponia, 426

americana, 427

Panicled, 427

racemosa, 427

Racemose, 427

Ceanothus cubensis, 258

ferreus, 256

reclinatus. 257

Cedrela ndorata, 214

Ceiba, 274

pentandra, 274

Celastriceae, 246

Celastrus murtifolius, 153 ovatn, 258

Celosia, 123

nitida, 123

paniculata, 128

Slender, 123

Celtis Lamarckinna, 104

Crnchorus hirsutus, 30

Cenchropsis, 28

myosuroides, 28

Cenchrus, 28

carolinianus, 29

echinatus, 30

chinat us virides, 20

hirsutus, 30, 263

microcephnlus, 29

mynsuroilles, 28

rarrmosus, 14

trlbuloides, 2 ?

tribuloides, 20

riridls, 29

Cenomuer p!rnoclada, 547

Centaurium, 230

Prittonli, 330

Centaury, 330

Centella, 312

asintirn, 31.3

asintirn, 312

reponda 313

Centroceras, 5.53

Centroesrns, 627

brachuacanthum, 583

clarulatum. 5s?

clqvulntum. 5.53

cruptacanthum, 583
Controceras-

hyalacanthum, 583

micranthemum. $5 \$ 3$

axyacanthum, 583

Centrosema virginianum, 188

virginianum angustifolium, 188

Centrostachys, 125

indice, 126

Century-plant, Acklin's "Island, 76

Bahama, 75

Brace's, 74

Inagua, 76

Millspaugh's, 75

Nash's, 76

New Proridence, 75

Watling"s Island, 76

Cephalocereus, 201

bahamensis, 292

Mrillspauchll, 292

Ceramiaceae, $5 T S$

Ceramiantemum, 562

Ceramion. 562

Ceramium, 58

aculcatum, 581

brssoideum, 583

clarulatum, 58 ?

cornieulatum 583

cruciatum, $5 \$ 2$

diaphonum tenuissi-

$m u m, 582$

divarientum. $5 \$ 2$

leptophlocum, 5s2

nitens, 5s2

rubrum nitrns, 582

subtile, 5 \&2

subtile 582

tenuissimum. 5.s2

transiersale, $5 \mathrm{~S} 3$

Trichoeladis, 571

Ceramothamnion, $5 \$ 3$ Codii, 583

Ceratolejeunea, 513

Cuban, 513

cuhensis, 513

Entire-leared. 513

integrifolia. 513

Ceratoschornus capitatus, 54

Cerbera, 338

Theretia, $33 \mathrm{~S}$

Cercespora Calotropidis, 635 Melochiar, fis:

Stachrtarphetae, 635

Turnerae, 635

Cereus Bocrkmanni, 293 grnudifforus. 294 prlluritus, 292 repandus. 292

Swartzii. 2n?

trinn?ularis, 293

tricostatus. 2าว

undatus, 293

Cerlomrees communis, 642

Ceropenin nalustris, 3.43

Cernthemnus ccriferus, 102

Cestrum, 3\&5

Bahama, 3s6

hahamense. 3.5.

baham rnse. fis?

diurnum, $3 \mathrm{sfi}$

pellislum, 3se

respertin $1 \mathrm{~m}, 3 \mathrm{~S} 6$
Ciraetaigiachae, 557

Chaetochloa, 27

genieulata, 27

geniculuta, 637

glaue $a, 27$

imberbis, 27

macrosperma, 25

setosa, 28

Chaetomorpha, 5??

brachygona, 599

clavata, 590

Liuum, 599

CiIAETOPHORACEAD, $59 \mathrm{~S}$

Chamaecrista, 168

caribaea, 169

Chamaecrista, 168

inaguensis, 170

lineata, 170

lucarana, 169

riparia, 1 fin

Chamaedoris, 602

Chamacdoris, 575, 578, 579

annulatu, 602

Peniculum, 602

Penieulum, 5SS

CHAMAESIPHOXACEAE, 620

Chama esyce, 237

articulata, 23 ?

Berteriana, 241

Plodgettil. 240

Bracei, 239

hrasiliensis. 240

Prittonil, 242

buxifolia, 237

carensis, 23 ?

exumensis, $23 \mathrm{~S}$

hirta, 241

hrpericifolia, 240

hyprririfolia, 636

insulae-salis, 238

lecheoides. 238

prostrata, 241

raginulata, 240

Tilsonii. 238

Champia, 563

parvula. 563

solleornioides, 564

Chaner-vine. 71

Manterel cinnabarinus, $6+2$ infundibullformis, 642

Chaptalia, 460

albicul1s, 460

dentata. 460

Low, 460

nutans, 460

Chara, 617

erratophylla.617

denauperata fils

follnlosa, 61s

gymnopus Irumbaldtii, Gis

gymnapus. Michauxii, 618

haitensls, 61s

ITorneminn1i. 1:17

Michmurii, fis

polumhulln. fis

poluphulln Wuhlen. brroit, fise

Tikströmii fils

zrulanira, fise

zrmanirn Michaurii.

61s

Cilarachat. fiti

Charlock. 147 
Chaurinia, 607 paspatoides, 600 phlowides, 6019

Cheilogramma lanceolata, 466

Cheilolejeunea, 510 decidua, 511 Deciduous-leared, 511

Chemnitsin, 607

CHEXOPOD1ACLAE, $11 \mathrm{~S}$

CHEXOPODIALES, 118

Chenopodium, 119

ambrosioides, 119

fruticosum, 121

murale, 119

spathulatum, 119

Chew-stick, 259

CIICKNEED FAMILY, 137

CHICORT FANIIL, 429

China-brier, 71

Chiococca, 416

alba, 416

partifolia, 416

pinetorum. 417 racemosa, 416

Chiodecton, 537

Bracei, $53 \mathrm{~s}$

Bracei, 538

crassum, 538

cruentatum. 537

elongatum, 537

quassiafecolum, 5.37

rubrocinctum, 537

rufescous, $53 \mathrm{~s}$

sanguineum, 537

CHIODECTONACEAE, 537

Chironia campanulata, 331

Chloris, 35

barbata, 36

ciliata, 36

crucinta, 35

eleusinoides, 35

Fringed, 36

Many-spiked, 36

paraguaiensis, 36

Paraguav, 36

petraea, 36

polrdactria, 36

radiata, 35

Radiate. 35

Sagraeana, 35

Sagra's. 35

Suertzimma, 36

Chlorodesmis vaucheriac-

formis, 610

CHLOROPHYCEAE, $59 \tau$

Chlorophyllum molybdites, 6.12

Chloroplegma, $\mathbf{6 1 1}$

CHOCOLATE FAMILY, 275

Chondria, 567

Chondria. 574, 582, 589, 620 acanthophora, 56 ?

atropurpurea, 567

Collinsiana, 568

curvilineata, $56 \mathrm{~s}$

dasyphylla, 568

leptacremon, $56 \mathrm{~s}$

littoralis. 567

littoralis, 5n

musroirles, 569

papillosa 566

parruln, 5es

polvrhiza, 568

sedifolia, 568
Chondria -

taxiformis, 564

tenuissima, 567

Chondriopsis, 567 atropurpurea, 567

das yphylla, 568

leptacremon, 568

littoralis, 567

Chondrococcus filiformis, $58: 3$

chondrus acruginosus, 562 aguthoirus, $56 ; 2$

CHORIPETALAE, 99

Christmas-bush, 166 -flower, 35. Vine, 354

CHROOCOCCACEAE, 618

Chroococcus, $61 \mathrm{~s}$ membraninus, 618 turgidus, 618 turgidus, 618

Chroolepid ACAE, 599

C'truolepus, 599 aureus, 599

Chrysobalanus, 154

Icaco, 154

Icaco pellocarpus, 154 pellocarpus. 154

Chrrsolite-lily, 79

Chrysophyllum, 320 Cainito, 321

monopyrenum, 321 oliviforme, 321

Chrysopsis, 440 graminifolia, 440

Chrysymenia, 563 uraria. 563

Chthonia leptocephata, 456

Chylocladia rigens, 563

Chytraculia, 307 Suะvgium, 307

Cicca, 219 disticha, 219

Cichoriaceae, 429

Cinchona caribaea, 400

Cinna glomerata, 14

Cinnamon, 305 bark, 282

Cinnecord, 160

Cintractia Montagnei, 637

Circinaria dissecta, 552

Cirsium, 458 pinetorum. 458 Smallii, 458

Cissampelos, 142 tomentosi. 142 Velvety, 142

Cissus, 260

Cissus, 261

acirla, 260

Common. 260

intermedia, 260

microcarpa, 260

sicroides, 260

sieyoides, 637

Thick-leared. 260

trifoliata, 260

tuherculata, 260

Warty, 260

Citharexylum, 371

bahamense. 371

Berterii, 372

caudatum, 372

cincreum, 371

fruticosum, $3 \pi 1$
Citharexylum-

lucidum, 372

quadrongulare, 372

subserratum, 371

villos $\mathrm{um}, 371$

Cladium jamaicense, 56 mariscus, 56 orcidentale, 56

Cladocephalus, 612 scoparius, 612

Cladonia, 546

Cladonia, 55

a reolata, 5.47

Dilleniana, 547

fimbriata adspersa, 547

fimiriata simplex, 547

fimbriata tubaeformis, 547

gracilis dilacerata, 547

gracilis hybrida, 547

gracilis verticillata, 547

pityrea, 547

pyenoclada, $5+7$

p yriclata, 547

pyxidata chlorophaea, $5+7$

rangiferina, $5+7$

verticillata, 547

CIADONIACEAE, 546

Cladophora, 600

aegagropila membranaceo, 601

crispula, 601

crystallina, 601

fascicularis, 601

fracta, 600

fuliginosa, 601

Inteola, 601

nitida, 601

CLADOPHORACEAF, 599

Cladophoropsis, 601

Cladophoropsis, 611 membranacea, 601

Clathroporina, 527

nuculastrum, 527

Clathrus cancellatus, 644 crispus, 644

Clavaria, 638 sobolifera, 633

CIAVARIACEAE, 638

Clematis, 140

bahamica. 140

gioier, 140

dioica bahamica, 140

flammulastrum, 140

Titalba, 140

Cleome, 149

gynandra, 140

pentaphylla, 149

clcrodendron aculeatum, 374

Odorous, 375

Clerodendrum, 374 fragrans, 375

Climacosphenia, 62 moniligera, 627 monilinera, 627

Climbing Ifempweed, 440 Polypody, 471

Clitoria, 187

Ternaten, 187

virminiana, 188

Closed Euosmolejeunea, 512

Clusia, 281 
Clusia-

flar $a, 251$

rosea, 281

Clesia Family, 280

Clusiaceat, 280

Clutia Cascarilla, 223

Eluteria, 223

CoCA FAIILY, 15S

Coccocarpia, 548

molybde $a, 548$

molybdea tenuior, 548

pellita, $54 \mathrm{~s}$

pellita genuina, 548

pellita pannosa, 548

pellita parmelioides, 548

pellita smaragdina, 548

pellita tenuioi, 548

smaragdina, 548

Coccocladus, 604

occidentalis, 604

occidentalis Conqueran.

tii, 604

occirlentalis laxus, 604

Coccolobis, 116

Coccolobis, 553

bahamensis, 117

diverslfolia, 117

lirugii, 118

la urifolia, 117

la urifolisu, $5+1$

lcoyanensis, 116

Northropiae. 117

obtusifolia, 117

punctata, 117

retusa, 117

tenuifolia, 117

Trifera, 116

Lifera, 635

ITrightii, 117

Cocconeis, 628

heteroidea, 630

pseudomarginata, 630

Scutellum, 628

Coccothrinax, jo

argenter, 5 ?

jucund, 59

Cock-spur, 132

Cocklebur, 431

Cockroach Berrs, 383

Coco-nut, 61

Plum, 15

Cocober. 358

Cocos, fil nucifera, 61

CODIACEAe, 611

Corlolum polyrhizum, 5ns

Codium, filf

(dhaerens, 617

derortiratum, 616

clanghlum. Gifi

intertextum, 617

intertertum, 583, 6,17

intertextum cribrosum, 617

istlimocladum, fit

isthmocladum, 579

tomentosum, 616

Coclodictyon 577

COENOROXIAREAE, 54

Coenogonium, 541 interplexum, 5.41 riglolutum . :999

Coffece Senna, ifi

Colic-root, 70
Collema, 540

flaccidum, 540

laciniatum, 540

nigrescens, 540

phyllocarpum, 540

rupestre, 540

vespertilio, 540

COLIEMACEAE, 539

Collybia, 642

Cololcjeunca Jooriana, 507

Colpomenia, 590 sinuosa, 590

Coltricia cinnamomea, 639 spathulati, 639

Colubrina, 257

colubrina, $25 \mathrm{~S}$

cubensis, $25 \mathrm{~s}$

ferruginosa, 258

reclinata, 257

Commelina, 67

communis, 67

elegans, 67

longicaulis, 67

nuditloru, 67

COMMELIXACEAE, 66

Commicarpus, 131

Commicarpus, 130 scandens, 131

Common Tortula 4 S4

Comoctadia integrifolia, 245

Condelia ferrea, 256

Conferva carnea, 553

ceramicola, 553

clavteformis, 604

clavita, 590

crystallina, 601

fascicularis, 601

flexuosa, 5es

fracta, 6 ino

hicroglyphica, 600

implexa, 600

intertexta, 574

intestinalis, 599

Lin um, 599

membranacra, 601

octoronia, 601

simplex, 509

trichocladi, .571

vagabunda, 600

Coxifers, 461

Conocarpus, 302

erecta, 302

rrecta, 10 ?

racrmost, 301

Conringia, $14 \mathrm{~s}$ orientalis, $14 \mathrm{~S}$

CONVOLTILACEAE, 345

Convolvulus aruleatus, 349

Batatrs, 354

brasilirnsis, 352

corymbosus, $35 \bar{t}$

disscetus, 253

domingensis, 3it

flstigiatus, 35.

jomrlernsis, 348

littoralis 3 -

mtcronthus, 345

pentanthos, 34 ?

Pes-caprar. 352

sidluf follus. 35t

tillaceus. 354

Tubu, ...

Con!za elnerea. 430

lobuta, 457

lyrata, 44
Conyza-

odorata, 445

purpurascens, $4+46$

Copcrivia lliohtit, (b)

Coprinus micaceus, 642

Corallina, 11ti

Corallina, Jisi

adharens, 5\$9

barbuta, 1505

con!lutinata, 614

eubensis, 5๖?

Flabellum, 614

frorjitissima, 588

incrassata, 61i;

lapidescens, 55s

marginata, $\overline{5} 59$

Jonile, 616

oblomgata, 5.5?

obtusata, 55 ?

Opuntia, 615

Penicillus, 612

Peniculum, 602

Phocnix, 613

Rosarium, 605

rubens, 589

rugose, 55s

subulata, 589

Tribulus, jss

trideny, 616

Tune, 615

Corallixaceae, 5st

Coralliodendron, 612

Corullocephalus, 612 affints, 613

barbatus, 612

dumetosus, 613

Penicillus, 612

Corchorus, 262

hilsutus, 262

hirsutus, 632

Indian, 262

olitorius, 262

siliquosus, 262

Smooth, 2fi2

Woolly, 263

Cord-moss, 489

Cordia alba 360

angustifoli $a, 35 n$

buhamensis, $35 \mathrm{~s}$

Britontt 359

cylindrustach y,, $35 n$

gerascuntluides, 360

globosa, 3.

Lima, $3 \bar{s}$

Scbcstena, 3\%

spanish, $8 \mathrm{si}$

Cordrceps sobolifera, 633

Cordylecladia, 56.3

irregularis, 563

virlens, itis

Cordyline, 6 ?

guineensis, 69

Coreousis liucantha, 453

cordolopsis oceldentalis, 6.39

Corlolus :bletimus, 6.39 maxlmus, fis?

memblinaceus, 630

nlgromarginatus, fi3?

pinsitus, 63 ?

sericeohlisutus, f 39

Colk-trec. 27 ?

Coronate Bryun, 4 n1

Coronilla ofmilentalis, 182 serien. 1s?

Coronnpus, 14s 
Coronopus-

didym us, 148

Corticium, 638

Corticium, 638 Levcillcanum, 638

Corypha Palmetto, 60

Coryphan tha, 294 nivosa, 295

Coscinodiscus concinnus Jonesianus, 629 excentricus, 629 leptopus, 629 marginatus, 629 nitidulus, 629 nitidus, 629 nodulifer, 629 obscurus, 629 radiatus, 629 Rothii, 629

Cotton, 274

Cotyledon pinnata, 152

Cough-bush, 447

Country Belle, 379

Cow-bush, 162, 276

Cowiteh, 106, 189

Crab-grass, 16,30 -Wood, 118, 232

Crab's Eyes, 18T

Cracca, 181 cathartica, 181 cinerea, 181 Schottii, 181

Cranichis, 84 luteola, 89 oligantha, 86

Crassina, 448 multiflora, 448

Crassulaceae, 152

Crataeva Tapia, 151

Creeping-Cucumber, 426

Crescentia, 398 Cujete, 398

Crinipellis, 642

Crocus, 78

Crossopetalum aquifolium, 248

coriaceum, 247

floridanum, 248

ilicifolium, 248 pallens, $24 \mathrm{~s}$

Rhecoma, 248

Crotalaria, 178

incana, $17 \%$

lotifolia, 179

pumila, 179

retusa, 178

stipularis, 179

verrucosa, 178

Croton, 222

argentcum, 224

Bahama, 224

bahamensis 224

Cascarilla, 223

Cascarilla linearis, 223

chamaedrifolius, 228

discolor, 223

Eluteria, 223

Fergusonii, 223

flavens, 223

floceulosus, 223

glabellum, 2024

Hjalmarsonii, 224

humilis, 224

humilis origanifolius, 224
Croton, Linear-leaved, 223

linearis, 223

lobatus, 224

Lobed, 224

lucidus, 224

lucidus pubigerus, 224

Rosemary, 223

rosmarinifolius, 222

rosmarinoides, 222

Crouania, 581

attenuata, 581

Crowfoot FAMILY, 140

Cruger's Barbula, 487

Cryptostegia, 340 grandiflora, 340

Crystalline Riccia, 503

Cuban Ceratolejeunea, 513 Yellow-wood, 207

Cucumis Anouria, 426

Cucurbitaceae, 425

Cuphea, 29! Parsonsia, 300

Curcas, 224

Curcas, 225

indica, 225

Cuscuta, 355

americana, 356

americant, 356

arecnsis, 356

obtusiflora, 356

pentagona, 356

Cuscutaceae, 355

Custard-apple, 142

Custard-apple FaMILY, 141

Cutrleriaceat, 591

Cuttle-fish, 64

Cyathus intermedius, 645 pallidus, 645

CXCAD FAMILY, 462

CYCADACEAE, 462

CrCADALES, 462

Cyclospathe Northropi, 61

Cymatosira, 627

Lorenziana, 627

Cymbidium utriculatum, 96 Cymodocea, 6

Cymodoceas, 570, 574, 583 , 588

manatorum, 6

CTMODOCEACEAE, 6

Cymopolia, 605

barbata, 605

bibarbata, 605

mexicana, 605

Rosarium, 605

unibarbata, 605

Cynoctonum, 32 ?

Iitreola, 329

sessilifolia, 329

Cynodon, 34

Dactulon, 34

Cynosurus aegyptius, 38

domingcnsis, 39

indicus, 37

virgatus, 38

CYPERACEAE, 43

Cyperus, 44

aristatus, 45

brunneus, 46

brunneus, 46

Capitate, 47

Coarse, 47

Coast, 47

compressus, 45
Cyperus-

confertus, $4-$

Cuspidate, 45

cuspidatus, 45

elegans, 45

fer: $x, 47$

filiform is, 47

Flat, 45

Florida, 46

floridanus, 46

fuligineus, 46

Gatesii, 44

hirtus, 51

Large, 46

ligularis, 46

Luzulae, 4 -

Marsh, 45

monostachyos, 52

ochraceus, 45

I'anicled, 44

paniculatus, 44

polystachyus, 44

pseudovegetus, 45

rotundus, 46

Sand 47

Slender, 47

Vahlii, 46, 47

Viscid 45

riscosus, 45

Yellow. 45

Cypress Vine, 350

Cyrilla pariculeta, 315

Cystoseira, 5.91

Myrica, 591

Cytisus Cajan, 102

DACRYOMY CETALES, 637

Dactylis patens, 34

Dactyloc tenium, 38

aegsptium, 38

Daedalea amanitoides, 639

Berkelevi, 640

Dahoon Holly, 245

Dalbergia Brounei, 186

Ecastophyllum, 186

Daldinia concentrica, 634

Danish. 336

Dark Maiden-hair Fern, 468

Dasia, 575

Dasya, 575

Dasya, 575

Collinsiana, $5 \pi 6$

Crouaniana, 576

Dclilci, 564

elegans, 576

Gibbesii, $5 \pi 5$

lophoclatos, $5 \pi 1$

mollis, 576

pedicellata. 576

pedicellata, 57

ramosissima, 576

rlgidula, 576

rigidula. 575

spinuligera, $5 \pi 7$

squarrosa, 576

trichoclados, 571

Tumanoucic $i, 571$

Wurdemanni, 50

DASYCLADACEAE, 604

Dasycladus, 604

claraeformis, 604

occidentalis, 604

vermicularis, 604

Dasyopsis, 577

Antillarum, 577 
Dasyopsis-

Antillarum, $57 \pi$

penicillata, 577

spinclla, $5 \div 7$ spinuligera, $5 \pi 7$

Datura, 3S6

fastuosa, 386

Garden, 387

Metel, 386

Stramonium, 386

Tatula, 356

Davallia clatata, 468

Day-flower, 67 -1ily, is

Delesscria, 56 Leprieurii, 564 tenuifolin, 564

DELESSERIACEAE, 564

Delonix, 175 regia, 175

Dendrobium polystachyum, 89

Dendropemon, $10 \mathrm{~s}$ bahamensis, 109 brevipes, $10 \mathrm{~S}$ emarginatus, 109 emarginatus lepidotus, 109

purpureus, 108

Dendropogon, 63 usneoides, 63

Derbesia, 610

Derbesia, 607 tenuissima, 610 raucherlaeformis, 610

DERRESIACEAE, 610

DERMATOCARPACEAE, 531

Dermatocarpon, 531 hepaticum, 531

lachneum, 531

Inoulinsii, 531

Dermatnlithon prototypus, $58 \mathrm{~s}$

pustulatum 586

Dermocarpa, $620^{\circ}$

Farlnuii, 620

prasina, 620

Desmanthus denressus, 163 strictus, 163 virgatus, 18,3

Desmatodon, 455

Garberl, 4sf

Garber's, 4.8n

Desmodium inranum, 184 molle. 1.84 tortunsum, 184

Devil-grass, 20

Derll's Potato-ront, 336 Pumpkin, 2S?

Diaden 1 s. 55.3

Dlaperium, 404

Diapedium, 404 assurgens, 404

DIATOMEAF, f20

Dlatrype StImon, 634

Dienrpella, 5f?

Dichondra, 35: Carollng, 355 earolinensls, 355 repens, 355

DICTONDRA FAMIIX 355

DICIINNRRACFAE, 355

Dichothrix, fi2f fucicola, $f, 26$ penjcllata, 626
Dichofomaria, 557 frayil is, 559

Dichotomosiphon, 617 pusillus, 617

Dichromena, 53 colorata, ј3

Inagua, 53

inaguensis, 53

leucoecphala, 53

Narrow-leaved,53

Dicliptera, 404

assurgens, 404

DICOTYLEDONES, 95

Dicranum albidum, 479

Dictydium cancellatum, 645 squamulosum, 645

Dictyerpa, 597

jamaicensis, 597

Dictyoneis, 628 jamaicensis, 628 marginata, 630

Dietyopteris, 595 Justii, 595

Dictyosphaeria, 603

Dietyosphaeria, 604 farulosa, 603 valonisides, 604

Dictyota, 596

Dictyota, 586, 5. 7 Antiguac, 597 Atomaria, 506 Bartayresiana, 596 Bartayresii, 596 Bartayresii, 596 Brongiurtii, 596 cervicornis, 500 eervicornis, 596,597

dentata, 596 dentatn, 596 dichotoma, 5.6

divarieata, 590

Fasciolı. 596 guinrensis, 597 indiea, 596 Mertensii. 596 patens, 5.96 subdentat $a, 596$ variegata, 594 zonata, 5.94

DICTYOTACEAE, 5.94

Diderma squamulosum, 645

Didymella Cineluonac, 525

Digenea, 560

Digenca $582,58 \Omega, 601$ simplex, 5699 1"ulfeni, 569

Digitaria fimbriat, 16 horizontalis. 16 marginat? if sanquinalis, 16

Dildo, 292

Dillweed, 313

Dilophus, 59-

Dilophus, 5.,56, 5.97 alternans, 597 gulneensis, 507 repme. 5อf

Dimerogramma laneeolatum, 6330 minus, 6.3n

Dimerosporlum guarapiense, 6.32 zonntum. 63?

Diminutlye Fissliens, 4.81 Mitten's-moss, tos
Dioclea rudolphivides, 189

Dioscorea, 79 alata, 79

Droscorieaceae, 79

Liospyros halesioides, 326

Dipholis, 32' sallcifolia, 322

Diplachne, 39 fascicularis, 39

Diplanthera Wrightii, 6

Diplasiolejeunea, 506 IRudolphiana, 507 Rudolph's 50 i

Diplocalyx chrysophylloides, 111

Diplocystis Wrightii, 644 Diploneis, 628

adrena sansegana, 630

Bombus, $6: 30$

Campylodiscus. 631

coffaeiformis, 631

Crabro, 631

demtr, 631

gemmatula, 631

racillans, 625

Weissflogii, 62S

Dipterosiphonia, 575 dendritica, 575

Dirina, $53 \mathrm{~s}$ ceratoniae, 539 repanda, 538

DIRIXIACEAE, 538

Distichlis, 42 spicata, 42

Ditcli-grass, 5

Divi-divi, 174

Doctor-bush, 319

Doctor's Club, 207

Dodder, 356

DODNER Fa iIILT, 355

Dodona ea, 250

Ehrenbergii, 250

viscosa oborata. 250

DODONAEA FAMILY, 250

DODONAEACEAE, 250

Dog-berry, 316 -drink-water, 65 -fennel $43 \pi$, 438

DOGBANE FAYILX, 333

Dogwood, 186, 250

Dolicholus, 192

minimus, 193

Net-reined. 193

reticulatus, 193

Small. 193

Swartzij, 193

Swartz's, 1,3

Dolichos, 194

insularis, 195

I.ablah, 19.

T.aUlab, 191

linertus. 191

lutenlus, 195

minimus. 193

obtusifnlius. 191

pruriens, 1 s?

repens. 195

Dondia, 120

carinatn, 121

frutiensa, 121

frutionse, 121

insularís, 121

intermedia. 121

limearls, 121

Tilsonii, 121 
Donkey Thistle, $\mathbf{1 4 5}$

DOTHIDEALES, 632

DRACAEXA FAMILY, T2

DRACAENACEAE, T"

Dropseed-gl'ass, 33

Drvmaria, 137

Drymaria, 137 cordata. 137

Dryopteris, 472 usplcnioides, 473 a ugescens, 472 cordata, 473 normalis, 472 patens, 472,473 reptans, 473 reptans, 473

Drypetes, 221

Drypetes, 526, 532 diversifolia, 222 diversifolia, 528 keyensis, 2,2 lateriflora, 221 mucronata, 222 Sharp-leaved, 222 Duck-rweed, 6:

DUCK-TEED FAMILY, 62 Dudresnaya, 583 bermudensis, 583

DUMONTIACEAE, 583

Duranta, 372 Ellisia, 372 Plumieri, 372 repens, 372 repens, 633

Eared Mastigolejeunea, 517 Eaton's Selaginella, 477

Ebexaceat, 325

EBexales, 320

Ebony, 255

EBoNy FaAILY, 325

Ecastaphyllum, 185 Brownei, 186 Ecastaphyllum, 186

Echinocactus, 295

Echinocaulon rigidum, 560

Echinochloa, 26 colonum, 26 Crus-galli, 26

Echlnodorus, 7 cordifolius, 7 rostrutus, 7

Echites, 336

Andrewsii, 338

biflora, 337

Catesbaci, 338

Echites, 336

jamaicensis, 337 macioearpa, 397 neviandra, 338 paludosa, 337 Sagraei, 337 suberecta, 338 umbellata, 336

Eelipta alba, 449 ererta, 449

Ectocarpaceat, 589

Ectocarpus, 590 Antillarum, 589 Hooperi, 589 Mitchellae, 590

Egg-frult, 322

Egrptian Grass, 38

Ehretia Beureria. 359 tinifolia, 359
EIIRETIA FAMILY, 35

EH RET IA CEAE, 357

Elaeodendron, 249

attenuatum, 249

sylocurpum, 111, 250

xylocarpum buhumense,

$$
249
$$

Elaphrium, 211

Bahama, 212

inagueuse, 212

Simaruba, 212

Simaruba, 109

Eleocharis, 47

atropurpurea, 49

atropuryurca, 49

camptotrichu Schueinit $\approx$ ii, 49

capitata, 49

celiulosa, 48

flaccida, 48

interstincta, $4 \mathrm{~S}$

ochreata, 48 prolifera, 49

Eleusine, 37

indica, 37

Eleuthera Bark, 223

Eleutheranthera raderalis, 449

Elfvingia tornata, 640

Elliptic Leptolejeunea, $\mathbf{5 1 4}$

Ela Family, 103

Elodeaceae, 8

Emilia, 457

Purple, 457 sonchifolia, 457

EXCOELIACEAE, 590

Eneoelinm clathratum, 590 sinuosum, 590

Encyclia, 90

acicularis, 92

Bahama, 91

bahamensis, 91

diurna, 92

fucata, 91

Inagua, 92

inaguensis, 92

Narrow-leaved, 93

plicata, 92

Plicate, 92

rufa, 91

Rufous, 91

Small-flowered, 91

Tampa, 91

tampensis, 91

Endocarpon, 531

hepaticum, 531

Moutinsii, 531

pallidulum, 531

rufescens, 531

Wightii. 545

Endoderma, 5?S

viride, 598

Enterographa quassiaecola, 537

Enteromorpha, 5ns

flexuosa, 508

Hopkirki, 598

plumosa, 598

polyclados. 598

salina polvclados, 598

Entire-leaved Ceratolejeunea. 513

Entocladia, 508

viridis, 508

FNTODON FAMILY, 494

ENTODONTACDAE, 494
Entophysalis, 619 granulosu, 619 violacea, 619 violacea, 620

Entopyla austrilis, 630

Epicion bahamense, 342

Epicladium, 9:3 Boothianum, 93

Epidendrum aciculare, 92

altissimum, 92

bahamense, 91

Boothionum, 93

cochleatum, 93

diurnum, 92

erythronioidcs, 93

fucatum, 91

grucile, 92

minutumi, 8 ?

noeturnum, 90

odoratissimum, 91

Ottonis, 94

papilionaecum, 93

phocniceum, 92

plicatum, 92

primulinum, 91

rigid $u m, \$ 9$

rufum, 91

tampense, 91

virens, 92

Episperma, 582

Epithemia, 629

gibberula, 651

IIusculus, 629

Eragrostis, 40

amabilis, 41

bahamensis, 41

ciliaris, 41

Elliottii, 40

gigantea, 41

macropoda, 40

major, 41

minor, 41

pectinaeea, 40

plumoso, 41

prolifera, 41

tephrosanthos, 40

Erechtites, $45 \mathrm{~s}$

hieracifolia, 458

Erigeron, 442

cantudensis, 443

linifolius , 443

pusillus, $4+2$

quercifolium, 442

tenuis, 442

Erinus procumbens, 390

Eriodendron anfractuosum, 274

Erithalis, 415

fruticosa, 415,416

fruticosa, $5: 27$

odorifera, 415,416

rotundata, $\mathbf{4 1 6}$

Ernodea, 420

angusta, 420

Cokeri. 420

Coker's, 420

Common, 420

littoralis, 420

Millspaughil, 421

Millspaugh's 421

Nashii, 421

Nash's. 421

Taylori, 421

'T:y ylor' s, 4:1

Erythrina corallodendron. 196 
Erythrina-

Piscipula, 186 vclutina, 196

Erythrodes, si

Erythrotrichia, 553 carnea, 553 ceramieola, 553

Erythroxilaceat, $19 \mathrm{~S}$

Erythroxylon, 198 affine, 199

areolatum, $19 \mathrm{~S}$

Bahama, 199

Grevipes, 108

confusum, 199

obocatum, 198, 199

Orate-leared, 199

reticulatum, 199

rotundifolium, $19 \mathrm{~S}$

kound-leaved, $19 \mathrm{~S}$

spinescens, 195

suave, 198

suare ancurum, 195

Eschenbachia, 443

lyrata, $4+1$

Eucheuma, 561

isiforme, 561

Eugenia, 303

Eugenia, 5+1

androsiana. 304

axillaris, 303

axillaris microcarpa. 303

Jahamensis, 306

buxifolia, 303

confusa, $30 t$

confusa, $5: 35$

filiform is, 304

foetirla rhombea, 304

frograns, 306

lateriflora, 304

livustrink, 305

longipes, 306

monticola, 303

pallens, 307

pseudopsidlum, 304

punctata, 306

rhombea, 304

uniflora, 304

Eumelobesiu ist

Euodia Gibba, 629

Euosmolejeunea, 511

clausa, 512

Closed, 512

duriuscula, 512

Harsh, 512

Threefold, 512

trifaria, 512

Eupatorium, 437

ageratifolium, 438

itriplicifolium, 439

bahamense, 438

caplllifolium, 437

conyzoides 435

corrmbosum, 430

foentulaceum, 437

havanense, 438

intryrifolium, 4.38

leptophyllum, $4: 3$

lucayanum, 4.39

odoratum, 43s

repandum, 439

serimdens, +33

villosum, $43 \mathrm{~S}$

Euphorbia, 23.

antiquorum, 235
Euphorbia-

articulata, 239

Balbisii, 239

Berteriana, 241

Blorlgettii, 240

Bracei, 239

brasilionsis, 240

Brittonii, 242

buxifolis, $28 \pi$

eassythoides, 235

eayensis, 239

flexuosa, 239

graminifolia, 236

glymonota, 234

havanensis, 236

heterophwlla, 236

hivta, 241

hyperieifolia, 240

lactea. $23 t$

lecheoilles, 238

lincaris, 239

maculat $a, 241$

nutans, 240

petiolaris, 236

pilulifer $\alpha, 241$

prostrata, $2+1$

punieen. 234

serpens, 241

tithymaloides, 233

trichotoma, 235

valinulata, $2+1$.

EUPHORBIACEAE, 217

Euphorbiortendron gymnonotum, 234

Eupogotion, 577

Eupogonium rigidulum, 576 squarrosum, 5To trichoeludos, 571

Eustachys, 36 petraea. 36

Eustoma, 331 exaltatum. 331

Euterpe olcraera, 61 vinifera, 61

Erening-Prindose FamiLr,

Evolvulus, 345

alsinoides, 247

(1) r) useula 340

Bahama, 340

bahamensis, 346

Bracei, $3+6$

Braces, 347

Chickweed. $3 \pm 7$

glaber $3+7$

linifolius, 347

Moneywolt, 348

muеronatus, $3+7$

Narrow-leaved. 347

nummularius, 347

sericeus, 347

Silky, $3+7$

Smooth, 347

squamosus, 346

Expafertia cglaildulosa, 232 Sugrupi. 232

Exporcaria cubana, 2.31

lusidl, 232

Exogonium, 3:1

microdactylum, 3.i1

mierorlactilum integri. folium, 351

Exostema, ton carlbacum, 400

Exothea, 254
Exothea, 524

oblongifolia, 254

paniculata, 254

FABACEAE, 176

Fagara eoriacea, 207

Fagara, 206

fla $2 a, 207$

lent iscifolia, 206

I'terota, 206

Fagopyrum, 115

esculentum, 115

Fagopyrum, 115

Falkenbergia, 577

Hillebrandii, 577

False Boxwood, 249

Mallow, 267, 26s

Moneywort, 185

Favolus alutaceus, $6 \pm 0$ tenuis, $6+0$

Feather-bed, 326

Fennel, 314

Fern, Boston, 473

Giant, 465

Leather, 465

Marsh, 468

Pine-land, 468

Serpent, 470

slender Maiden-hair. 467

FERN ALLIES, $46 t$

FERN FAMILY, 464

Fenxs, 164

Festuea faseieularis, 39

Ficus, 104

aurea, 105

aurea 635

brevifolia, 105

rimidiuta, 105

jacquinifolia, 105

laerigata, 105

pedunculatr, 105

pertusa, 105

populnca bahamensis, 105

sapotacfolia, 105

Fiddle-flower. 233 - wond 372

Figmort FAMILY, 3S7

Filicales 464

Fimbristylis, 50

enstanea, 50

diphylla, 50

exilis, 51

ferruginea, 50

glomerata, 51

Hairy, 51

hirta, :1

inaguens]s, 51

Marsh, 51

monostarh ya. 2

Silt Marsli, 50

Slender, 50

eparliee $a, 51$

spathatcea, is

West Imdlnu, 51

Finger-grass, 15, $: \frac{\tau}{7}$

Flre-bush. 224

weed 458

Fish-polsoli, 1se

Flssidens, 480

Dimlnutlve, 481

Garberl. $4 \$ 1$

Garier"s, 4S1

monandrus, 451 
Fissidens-

radicans, 481 Radicant, $4 \mathrm{~s}$

FISSIDEX'S FAMIILY, 480

FISSIDENTACEAE, 480

Fissurina nitidescens, 536

Flabellaria conglutinata, 614

incrustata, 614

pavonia, 614

Tuna, 615

Flacolrtia FaMili, 283

FlacourtiaceAe, 283

Flamborant, 175

Flamingo-bill, 183

Flat Taxithelium, 499

Flaveria, 454

Iinearls, 454

Narrow-leaved, 454

Flax, Bahama, 200

Brace's, 201

Curtiss', 200

Rock, 200

Trood, 201

FLAX FAIILY, 199

Fleabane, 442

Fleurya, 106

aestuans, 106

Floating Heart, 333

Florida Leucodontopsis, 492 Privet, 327

Flueggia Acidothamnus, 219

Foeniculum, 313

Foeniculum, 313

vulgare, 313

Fomes Auberianus, 640

Forestiera, 326

cassinoides, 327

segregata, 327

segregata stenocarpa 327

Fosliella, 587

Chamaedoris, 588

farlnosa, 587

Lejolisii, 588

Fountain-plant, 389

Four-o'clock, 130

ForR-O'CLOCK FAMILI, 129

Fowl-foot. 251

Fox-tail Grass, 27, 28

Fradclia, 611 fuliginosa, 611

Frangipanni. 334, 335

French Trumpet-ftower, 338

Frog-wood. 413

Frog's-bit 9

Frog's-BIT FAMILT, 9

Frullanla, 519

a rietina, 519

gibbosa, 520

Gibbous, 520

obcordata, 520

Obcordate, 520

Ram's Head, 51 ?

riojaneirensis, 520

Rio Janeiro, 520

Spreading, 520

squarrosa. 520

Frullanoides riojaneirensis, 520

FrCACEAE, 591

Fucus acanthophorus, 569 aeruginosus. 562

atomarius 509

bacciferus, 592
Fucus -

botryoides, 563

ccrvicomis, 562

elavifer, 610

cupressoides, 609

dasyphyllus, 568

cricifolius , 609

Fesciola 596

flamentosus, 581

foliosissimus, 593

lacinulatus, 562

lendigcrus, 593

Lycopodium, 569

multipartitus, 562

musciformis, 563

muscoides, 569

Murica, 591

nutans, 592, 593

obtusus, 565

Opuntia, 561

papillosus, 566

plumars. 608

Poitei, 566

protifer, 608

vacemosus, 610

rigidus, 560

Sargasso, 592

scrtularioides, 608

spiciferus, 569

taxiformis, 564

tenellus, 572

tenuissimus, 567

tomcntosus, 616

triangularis, 57

trifarius, 571

triqueter, 571

turbinatus, 591

uvarius, 563

uvifer, 610

vermicularis, 604

zonalis, 594

Fulvifomes dependens, 640

Swieteniae, 640

Funalia versatilis, 640

Funaria, 489

fiavicans, 489

hygrometrica, 489

Pale-green, 489

Funaria Famili, 489

FUNARIACEAE, 48?

FU IGI, 631

Furcraea, 77

cubensis, 7 .

macrophylla, 77

undulata, 77

Fuscoporella coruscans, 640

Galactia, 18 ?

angustifolia, 191

bahamensis, 100

cubensis, 190

filiformis. 190

galactioides, 190

monophrila, 190

pendula, 190

rudolphioides, 189

rudolphioides, 633

spiciformis, 190

tenuiflora, 191

uniflora, 190

Galaxaura, 557

Galaxaura, 578.589

comans, 558

comans, 578

cylindrica, $55 \mathrm{~s}$

\section{Galaxaura-}

Decuisnei, 559

tlagelliformis, 558

flagelliformis, 578

fragilis, 559

lapidescens, 558

marginata, 559

moniliformis, 559

oblongata, 559

oblongata, $55 \mathrm{~s}$

obtusata, 559

occidentalis, 559

rugosa, 558

rugo8a. 5.58

squalida, 558

squalida, $55 \mathrm{~s}$

subverticillata, 558

subverticillata, 578

Gale-of-wind, 221

Galcoa cathartica, 181

cincrea, 181

Galium, 424

bermudense, 424

hispidulum, 424

hupocarpum, 424

Gama-grass, 12

Gamopetalae, 314

Ganoderma pulserulentum. 640

sublncrustatum, 640

Garber's Fissidens, 481

Gardena, 149

Gardenia clusiaefolia, 410

Garlic-weed, 135

Gaudichaud's Syrrhopodon, 483

Gayoides, 266

crispum, 266

crispum, 636

Geaster saccatus, 645

Geiger Tree, 358

GELINTACEAE, 559

Gelidiopsis rigida, 560

Gelidium, 560

Gelidium 589

rigidum, 560

rigidum, 579

Genip, 254

Genipa clusiaefolia, 410

Gextrax Farrly, 330

Gevtiana eraltata, 331

Gextianaceae, 330

GeNTIA NALES, 326

Gerantales, 196

Gerardia, 402

Bracted, 402

bracteosa, 402

domingensis. 392

droseroides 402

maritima, 392

purpurca, 392

spicifora 392

Sundew, 402

tuberosa, 402

Ghinia, 367

curassarica, 367

Giant Fern, 465

Iilk-weed, 341

Gibbous Frullania. 520

Gigartina isiformis, 561 tenera. 561

GigARTJNACEAE, 561

Glasswort, 122

Gloeocapsa, 619

bahamensis, 619 
Gloeocapsa -

crepidinum, 619

deustu, 619

lignicola, 619

Magma, 619

Gloeophyllum Berkeleyi, $6+0$

hirsutum, $6 \pm 0$

striatum, 610

Gloeothece, 620

Gloeothece, 623

rupestris, 620

Glorr-morning, 352

Glossy Isopterygium, $\mathbf{4 9 7}$ Sematophyllum, 500

Glycine Abrus, 15T reticulota, 193

Glyeosmis pentaphylla, 209

Glyphis, $\overline{3} 38$

A chariana, 538

cicatricosa. 538

Glyphodesmis, 627 eximia, 627

Goat-bush, 437 -weed, 391

Goat's-rue, 181

Golden Aster, 440 Crownbeard, 452

Goldenrod, 370

Gomontia, $59 \mathrm{~S}$ polvrhiza, 595

Gomphrena, 126 polygonoides, 126 vermicularis, 128

Gongrocerus cornieulatum. 583

Goniolithon, 584

accretum, 5S5

accretum, 595

acropetum, 5.55

Boergeseni1, 55:

Börgescnii, 508

decutescens, 58

deeutescens, 555

dispalatum, joj

frutesecns, 585

improcerum, 5sT

intermedium. 586

Notarisii propinquum, 585

propitquum, 5\$5, 5S7

Rhizophorae, 586

solublle, 585

solubile, 5s 7

spectabile, 585

strictum, $58 \mathrm{st}$

strictum, 5S

strietum nan um, 586

Goniopteris reptons, 173

reptans corlata, 473

Goniotrichum, 553

Alsldii, 553

elcgans, 553

FOODENIA FAMILY, 428

GOODENIACEAE, 42S

Gooma-lush, 383

Gooseberry-tree, 210

GOOSEFOUT F.MILY, 118

Gossypium, 273 harbadense, 274 punctatum, 27t

Gouanla, 2.5.

domingrnsis, 258

glabru, 258

lupuloides, 258
GoLRD FAMILY, 425

Govenia, 96

swollen, 96

utriculata, 96

Governor Grant's Livery, 236

Gracilaria, 562 cerviculnis, 562 cornea, 563 crassissima, 562 dimaecornis, 563 horizontulis, 562 lacinulata, $\overline{5} 62$ multipartita, 562

Grallatoria, $\overline{6} 60$ reptans, 560

Grammatophora, 627

flexuosa, 627

pexuosu, $6: \pi$ marina, 630

Grammita, 569

Grammitclla, 569

Granigrain, 262

Granny-bush, 2:23

GraPE FAMILY, 259

GRAPHIDACEAE, 534

GRAPHIDALES, 533

Graphina, 536

nitidescens, 536

virginea, 536

Graphis, 533

Afzelii, 536

utrata, 534

cinerea, 536

einnabarina, 536

inusta, 536

Paroniana, 535

sealpturata plurifera, 536

scripta, 536

tricos $u, 538$ vestita, 536

Grass Family, 10

Grass-fern, 466 -pink, 95

Gratcloupella, 569

Gratiola IIonnieri, 389

Gray Nickers, 172 Polypody, t70

Grayish Lejeunea, 508

Green Turtle Bough, 375

Greenbrier, 71,72

Greenest Archilejeunea, jis

Greens, 11 ?

Griffithia, 57!

A rou $8,55 \%$

Bornctiang, 5-9

corollina globifcra. $5 \pi 9$

corallina ten uis, 579

globifera 57 ?

globulifera, 5i?

globulifera, $5 \$ 0$

tenuis, 580

thursigcra, 550

Griftitsin. penicillata, 550 trichoclados, $5 \pi$

Grimmeodendron, 231 eglandulosum, 232

Ground Cherry, 381, 3.2

Groundsel-bush, 444, 445

Guaiacum, 201

officinale, 202 sanctum, 202

Guana-betry, 205

Guara, 307
Guepinia palmiceps, 637 Spathularia, 637

Guettarda, $41:$ ' ealyptrata, 413 densiftoru, +15

elliptica, +14

inaguensis, 113

Krugii, 413

Nashii, 413

scabra, 412

speciosa, 412

Tis ýlori, 413

Guiana P'lum, 221

Guilandina, 171

Bonduc, 172

bonducella, 172

Crista, 172

major, 172

Joringa, 151

oralifolia, 172

Guinea-bead, 122

Grass, 22

Gum-elemi, 212

Gumborlimbo, 212

GUMBBO-LIMBO FAMILY, 211

Gundlachia, $4+2$

corymbosa, 442

domingensis corymb$\operatorname{as} a, 4+2$

Gunwood, 396

Guzmania lingulata, 66

Gyolecta lutea, 541

GYALECTACEAE, $5+1$

Gyminda, 248

Grisebachii, 243

latifolia, 24?

Gymnanthes, 232 lucida, 232

Gymnogramme calomelanos. 469

Gymnopilus tenuis, 642

Gymnopus, 642

Gymnosorus, 594 eollaris, $\bar{j} 9+$ variegatus, 594

Grurosospinat 460

Gymnostomum Barbula, 484 Tortulu, 485

Gymnothamnion, $5 \mathrm{SO}$

bipinnatum, 580 elegans, 580

Gymnothemnium, 5\$1

Gynandropsis pentaphylla, 149

Gyrosigma rectum, 631

Gurostachus perurianu, SJ

Gyrostomum, 543 scyphuliferum, 543

Gyroweisia, +54

Ii: rbul:i, 4 st

Black-fruited, 454

Haema tomma, 546 unuiceum, $5+6$

Haematoxylum, 171 campechinum, 171

IInir-like Isrum, 4m

Hail'y l'epperwort, 476

II: llberd-fern, 471 Ames, 472 Sma11

Halimeda, 614

IInlimrda, 5 tis, 573, 556, (i14, (i21

brevicoulis, 616

dIscoidea, 615

favilos: , 610

incrassata, $\mathbf{6 1 6}$ 
Halimeda-

incrussuta monilis. 616 acrimosil, 616

Monile, tilt

Opuntia, ti:

Opuntiu, 61

platydisca, 615

seabra, 615

simulans, 616

tridens, 616

tridens Wonile, 616

'Tuna, 615

Haliseris, 595

Justii, 595

Halodictyon, 577

mirubile, 577

Halodule, 6

Halodule, 597 Wrightii, 6

Halophila, s

Engelmanni, !)

Haloplegma, 580

Dupcrveyi, 5s0

Duperreyi spinulosa, 580

IALORAGIDACEAE, 310

II ulydictyon, 577

Hamelia, 411 erecta, 412

patcus 412 scarlet. 412

Hanouia, 577

Hapalopilus licnoides, 641

Haplocladium, 495 microphyllum, 495 Small-ieared, 495

IIard-bark, 25:

Irardhead, 220

Hare's-ear, 148

Harrisia, 292

Brookii, 292

Iarsh Euosmolejeunea, 512

Hat Palmetto, 60

Haulback, 16:

Heather, 320

II ccastophyllum Brownei, $1 \mathrm{~s} 6$

Hedera quinqucfolia, 261

Hedge-hyssop, 390

Hedrigia balsamifera, 212

Hedyotis anericana, 409 rupestris, 409

Hedysarum canescons, 184 Ecastaphyllum, 186 hamatum, 183 incanum, 184

mollc, 184

nummularifolium, 185 supinum, 184

tortuosum 184

Heleochavis bahamensis, 48 , 9

Sintenisii, 49

Hclicothamnion, 572

Helicteres, 275 Isora, 276

jamaicensis, 276

semitriloba, 275 spiralis. 276

Heliotropé, Pushy, 363

Diffuse Low, 364

Eggers', 363

Inagua, 364

Indian, 362

Low Ashy. 364

Nash's, 364

Seaside, 363

Slender, 363
Heliotropium, 362

brevicaule, 364

culassavicum, 363

diffusum, 364

Eggersii, 363

maphalodes, 361

inaguense, 364

indicum, 362

inundatum, 363

microply yllum, 364

nanum. 364

Nashil, 364

parviflorum, 362

ternatum, 363

Helminthosporium Ravene-

lii, 635

Helosciadium, 314

Ammi, 314

Hemianthus, 390

callitrichoides, 390

multiflorus, 390

HEYIBASIDIOMYCETES, 636

Hemitrichia clavata, 645

IIenna Plant, 299

HepaticaE, 500

Herb Mercury, 228

Hercules' Club, 207

Herpestis Monnieria, 389

Heryochact $\mathbf{6 0 7}$ fastigiata, 608 verticillata, 608

Herposiphonia, 573

bipinnata, 574

l'ecten-T'eneris, 573

secunda, 574

tenella, 573

Heterosiphonia, 575

Wurdemanni, 575

Wurdcmanni, $576,57 \pi$

Hctcrothecium domingcuse, ing

Hibiscus, 272

Babama 272

bahamensis, 272

cryptocurpus, 272

esculentus, 272

populne us, 273

suinifex, 270

tiliacens, 273

Hippo, 341

Hippomane, 231 Mancinella, 231

Hog-bush, 409

Cabbage-palm, 61

Palmetto, 61

-weed, 130

Hold-back, 132

Holly, 245

HOLLY FAHILY, 245

Holosteum cordatum, 137

Homalia, 497 Wrightii, $49-$

Honessuckle, 404

Hook-lobed Leucolejeunea, 518

Hookeria radicnlos $a, 494$

Hormothamnion, 621 euteromorphoides, 624

Horse-hean, 171, 191

-bu1sh, $176,363,442$

Horseflesh. 15s

IIorseradish-tree, 151

HORSERADISII-TREE FAMIL, 151

Horseweed, 443

Hura, 232

crepitans, 233 thurricane-grass, 51

II utchinsia, 569

breriarticulata, 570

dendritica, 575

obscura, 574

opuca, 571

pericludos, 572

sreunda, 574

tenclla, 573

UYDXACEAE, 638

HYDROCHARITACEAE, 9

IYTROCHARITALES, 8

Hydroclathrus, 590

cancellatus, 590

clathratus, 590 sinuosus, 590

Hydrococcus marinus, 620

Hydrocoleum, 623

Hydrocoleum, 623 cantharidosmum, 623

comoides, 623

glutinosum, 623

Iyngbyaceum, 623

Hydrocotyle, 312 asiatica, 313

hirsuta, 312

pygmaea, 312

repanda, 313

spicuta, 312

umbellata, 319, 313

verticillata, 312

Hydrocybe conica, 642

Hydrolithon improcerum, 587

IITDROPHYLLACEAE, 356

Hyella, 620 caespitosa, 620

Hylocereus, 293 undatus, 203

Hymenocallis, 78 arcuicola, 78 caribaed, 79 carmanensis, 79 crassifolia. 79 declinata. is declinata, 79

Hymenostomum, 484 Bahama, 485 flavescens, 485

Hyophila, 485

Hyophila, 485 Tortula, 485

Hypelate, 254 paniculata. 254 trifoliata, 254

HYPERICACEAE, 280

HYPERTCALES, 20

HYР PHOMYCETALES, 635

IYYXACEAE, 496

Hypnea, 563

musciformis, 563 musciform is, 508 sepundiramea 583

Hypnophyeus. 503 musciformis, 563

Hupn um admistum, 500

diminutivum, 498 micans, 497 microphyllum, 495 niarcseens, 493

plan um, 498

Sipho, 496

vesiculare, 497

HYPXTA FAMILY, 496

Hupochnus rubrocinctus, 537

spongiosus, 638

Hypocrea sulphurea, 633 
IIY POCREALES, 633

Hypoglossum, 56 t

Lepricurii, 564

Hypoxis, 73

juncen, 73

Hypoxylon annulatum, 634 Bomba, 6:3t

fuscopurpurenm, 634 jecorinum, 63t

Hyptis, $37 !$

pectinata, 380

lectinate, 350

Pilose, 3so

suaveolens, 380

Hysterium rufulum, 635

Ibidium, 85

lucayannm, 85

tortile, sj

Icacorea, 315

guadalupensis, 316

paniculata, 315

Ichthyomethia, 1 s 6 I'iscipula, 186

Ilex, 245

Cassine, 245

cuneata, 246

Irrugiana, 246

Macoucoua, 246

montana, 246

repanda, 246

ILICACEAE, 245

Imperata, 12

brasiliensis, 12

I IPERFECTI, 635

Indian Almond, 302

Indigofera, 150

Anil, 180

urucitca, 180

suffruticosa, 180

Inflated Microlejeunea, 509

Inya hystrix, 156

Ink-berry, 383,429 -bush, 327

Inodes Palmetto, 60

nonotus corrosns, 641

fruticum, 641 porrectus, 641

Inula araminifolia, 140

Ionaspis, 541 suateolens. 541 tronica. $5+1$

Ionoxalis, 197 intermedia, 197

Ipomoea, 351

antillang, 354

(I)enaria 351

liatatas, 354

bona-nor, 34 ?

carolina, 353

eathartica, 352

coccinca, .550

commutatr. 352

cumosu, 3.t

dlssecta, $35 . ?$

fastlinuta. 354

yracilis, 3ist

grundiflora. 350

hederacen. 351

hentuphylla, 35.

jumuirensis, 352

littoralis, 352

mlerodact $y$ ?, 351

Pes-eaprap 352

purpurea, 352

Qunmoclit 350

saglttata, 353

\section{Ipomoea -}

siducfolia, 35

sinuutu, 353

stoloniter:i, 352

tiliacea, 35

trilobil, $355^{\circ}$

tuba, :isu

verticilluta, $34 \mathrm{~s}$

villosa, 35

Iresine, 1:3

Bahama, 129

C'elosia, 128

cclosioides, 12s, 129

Coastal, 129

fla vescens, $12 \mathrm{~S}$

inaguensis, 129

keycusis, 12s

paniculatu, 128, 129

RIDACEAE, 80

IRIS FAMILY, SO

Ironwood, 304, 317

Irpex maximus, 639

Ischaemum sccundatum, 30

Island Bean, 195

Isnardia, 309

natans, 309

lepens, 309

Isocarpha, 449

ungustuta, 450

oppositifolia, 450

Isopterygium, 496

Giossy, 497

micans, 497

Iva, $43:$

Bench, 432

Bushy, 433

cheiranthifolia, 433

imbricata, 432

Jacaranda, 325

Zahumensis, 398

carblinianu. 398

coelulea, 39s

Jack-switch, 263

Jackmada, 438

Ja cob's Ladder, 236

Jacquemontia, $3+5$

Blne, 34 ?

cayensis, 340

cayensis, 631

Common, 348

Fleshy, $34 !$

jamaicensis, $34 \mathrm{~S}$

micruntha, 345

pentantha, 349

reclinat $a, 340$

Small-flowerer, $34 \mathrm{~S}$

verticillata, 348 violaceu. 349

Jacquinia, 317

armillaris, 317

Berterii, 317

Berterii retusa, 317

keyensis, 317

leyensis, $525,527,53 \mathrm{~S}$,

.Tamaica Weed, 357

Jania, 5is?

Juniu, 577, 57s, 579, 581 adhaerens, 5s! eapillacea is?

cubcusis 5s?

rubens, $5 \leq ?$

Jasminum, 327

Satnhac. 327

Jat ropha Curets, 225 gossumifolin. 225 Iruiliot, 230
Jerusalem Parsley, 113

Jessamine, 333

Jimbay, 16:

loe-bush, 317

wood, 317

Ioint-grass, 1\%, 20

Joor"s Leptocolea, 507

J UGI,A Y DALES, 102

Jumbie Rean, 16:2

fungermamia auriculata, 517

corticulis, 515

elliptica, 514

flaco, sus

squariosa, 520

trifuriu, 512

xunthocerpa, 518

JUNGEUMANXIA FAMILY, 504

JUNGERMANXIACEAE, 504

JU NGERMANXIALES, 504

Jungle Rice, 26

Juniper-berry, $28 S$

Juniperus, $46^{\circ}$

australis, 462

uarbulensis, 462

bermudiana, 462

lueayana, 462

virginiana, 462

Jussiaea, 310

angustifolia, 310

Bushy, 310

polustris, 310

suffruticosa, 310

Justicia, 403

assurgens, 104

carthaginensis, 403

puniculalu. 403

spinos $a,+0$ s

Kalanchoe, 152

brasiliensis, 153

Prazilian, 153

Kallstroemia, 203 maxima, 203

Kallymenia, 561 Limminghii, 561 reniform is, 561

Kasondi Senna, 160

Krugiodendron, 256 ferreum, 256

Iyllineu monocephala, 47

Lace-plant, 106

Lachnea cubensis, 635

Lactuca, 430

intybacen, 430

Ladics-tresses, 85,86

Iad $\Gamma$ 's slipper, is

Laeliopsis,

domingensis, 95

Lactin Guidoniu ss

Lugcnorarpus !fuiunensis, 56

Laguncularia, 301 racemosil, 301

Lamarckia, 6it6

L.AMIACEAE, 375

Lantana, 36 ?

Rahama, $3 T_{0}$

bahamensis, 370

balsamlfera, 370

Camara, 36n

Cumaru. 370

rroera. 369.370

remutriti, 370

Involucratis, 370

in roluereta, 3i1, 632 , 631)

odorata, 370 
Lantana-

Ovate-leared, 369

ovatifolia, 369

L appago alicna, 14

Lasiacis, 25 divaricata, 25

Lasiocroton, 227

bahamensis, 227

macrophyllus, 227

micranthus, 227

Laternea triscapa, 644

Laugeria densiflora, 415 lucida, 414

LAURACEAE, 143

Laurel-cherry, 153

LAUREL FAMILY, 143

Laurencia, 565

Laurencia, 574,579

Baileyana, 567

cervicornis, 566

Chauvini 566

Corallopsis, 566

gemmifera, 566

glomerata, 565

implicata, 560

intricata, 506

mexicana, 566

microcladia, 565

multiflora, 565

nana, 566

obtusa, 565

obtusa, 565, 566

obtusa gclatinosa, 565

paniculata, 565

papillosa, 566

papillasa. 575

Poitei, 566

tuberculosa, 566

Laurocerasus, 153 myrtifolia, 153

Laurus carolinensis pubcs cens, 144

Catesbyana, 143

coriacea, 143

Winterana, 282

Lawsonia, 299

alba 209

inermis, 200

Leaf-shedding Rectolejeunea, 510

Leafless Beaked-orchid, $\$ 6$

Leather Fern, 465

Lcbidibia coriaria, 174

LECA YACTIDACEAE, 541

Lecanactis, $5+1$

denticulata, 541

denticulata, 541

Lecanora, 545

adglutinata, 552

aurantiaca isidiosella. 550

badia, $5+5$

cratoniae, 533

chlaronella, $5+6$

chlaroterodes, 546

cinereocarnea, 546

floridan $a, 550$

pallescens, 546

punieea, 546

subfusca, 546

subfusca cinereocarnea, 546

varia, 546

IECAXORACEAE, 545

Lecidea, 542

calcixora, 542

conspirans, 551
Lecidea-

discifarmis aeruginascen 8,551

furfurosa, 542

immersa, 542

lcucollephara, 541

lutcola cndoleuca, 543

medialis, 543

parascma, 551

parmclioiles, $5+8$

parvifolia, 546

phaeomcla, $54^{2}$

sanguinariclla, 551

scyphulifera, 543

suludisciformis, 551

rel'nalis, 542

LECIDEACEAE, 542

LECIDELLES, 539

Lehmann's Caudalejeunea, 516

I. eiogramma virginea, 536

Leiphaimos, 332

parasitica, 332

Lejeunea, 508

Berteroana, 510

Uullata, 509

clausa, 512

cubensis, 513

decidua, 511

duriuscula, 512

flava, 508

glaucescens, 508

Grayish, $50 \mathrm{~S}$

Joariana, 507

laetevirens, 509

Lellmanniana, 516

obtusangula, 512

phyllobola, 510

uneiloba, 518

virilissima, 518

Yellow, 508

Lemna, 62

minor, 62

IEAINACEAE, 62

LENTIBULARIACEAB, 393

Lentinus crinitus, 642

hirtus, 642

lcpideus, 643

strigellus, $6 \pm 2$

strigosns, 643

Telutinus, 643

I.entodium squamosum, 643

Lenzites applanata 639

Leonotis, 377

nepetaefolia, 378

nepetaefolia, 636

Leonurus, $37 \%$

sibiricus, 377

Lepidium, 146

didymum, 148

virginicum, 146

virginicum, 631

Lepiota cretacea, 643

Lepraria Bassiae, 550 far $a, 543$

Leptilon, 443

linifolium, $4+3$

pusillum, 443

Leptochloa, $3 \dot{S}$

domingensis, 39

fascicularis, 39

Slender, $39^{\circ}$

rirgata, 38

rirgata gracilis, 39

Virgate, 38

Leptocolea, 507

Jooriana, 507

Joor's, 507
Leptogium, $5+0$

bullatum, 540

bullatum phyllacarpum, $5 \pm 0$

chloromelum, 540

phyllocirpum $5+0$

Leptolejeunea, 514

Elliptic, 514

elliptica, 514

Leptotrema, 54

bahianum, 545

bisporum, 545

compunctum. 545

glancescens, 545

monosporum, 544

simplex, 545

Wightif, $5+5$

Leskca subpinnata, 499

LESKEA FAMILY, 495

I TSSKEACEAE, 495

Leuca ena, 162 glauca, 162

LEUCOBRY ACEAE, 479

Leucobryum, 47 ?

albidum, 479

glausum albidum, 479

LUCODOY FAYILY, 491

LEUCODONTACEAE, 191

Leucodontopsis, 491

Florida. 492

floridana, 491

plicata, 491

Leucolejeunea, 518

Hook-Iobed, 518

unciloba, 518

unciloba, 518

xanthocirpa, 518

Yellow-fruited, 519

Liagora, 554

Liagora, 556

amnulata, 555

cayoluesonica, 554

cerinoides, 555

Cheyneana, 554

corymbosa, 554

crassa, 554

decussata 55

elongata, 554

farinosa, 5.54

farinosa, 554

farionicolor, 554

fragilis, 555

lcprosa, 555

luvida., 554

megagyna. 55 -

mucosa, 556

mucosa, 556, 557

opposita, 555

paniculata, 555

pedicellata, 5.56

pcdicellata, 556, 557

Pilgeriana, 555

pinnata, 555

pinnata, 556,557

pulverulenta, 555

rosacca, 55.5

rugosa, 555

tcruis, $55 \overline{5}$

valida, 555

Libidihia roriaria, $17 \pm$

Lice-root, 337

Lichen aurantiacus, 550

badius, 545

bullatus, 540

chloromelos, 540

Cocoes, 552

complanatus, 54 !

compunctus, 545 


\section{Lichen-}

erythrellus, 550

ferrugincus, 550

fimlriatus simplex, 547

flaccillus, 540

gcmmatus, 525

hyperellus, $53:$

immersus, 542

lachneus, 531

lepudinus, 544

luteus, $5+1$

nivrescens, 540

obscurus, 55

pallescens. 546

perlatus, 549

pictus, 551

rangiferinus, 547

rubiuinosus, 547

rupestris, 540

seriptus, 536

stelluris, $5 \overline{5}$

subfuscus, 546

tarius, $5+6$

LICHENES, 522

Licmophora, $6:-1$ dalmatica, 627

Lictoria, 56t

tuxiformis, 564

Life-plint, 152

Lightwood, 2207

Lignum Vitae, 202

LILIACEAE, tis

LiLIALES, is

LILT FAMILY, $6 S$

Lima Bean, 194

Limnanthenum, 332 aureum, 333

Limodorum, 95 allum, 96 diumum, 92

lancelatum, 86 purpureum.96 simpsoni, 95 tubcrosum, 95

Limonium, 319 bahamense, 320

LIXACEAE, 199

Linaria rulgaris, 393

LINDEN FAMILY, 26I

Link-vine, $\mathrm{St}$

Linociera bumelioides, 328

Linum buhamense, 200 Curtissii, 200

Lewisi, 201 virginicum, 2110

Lion's Ear, 378 Tail. 377

Lippia, 367

Bushy, 368

cunesccns, 368

Creeping, 368

gemlnata, $36 \mathrm{~s}$

geminata microphylla. 368

inaguensis, 371

Large Creeping, 369

IIar'sh, 36.5

nodiflora, $36 \mathrm{~s}$

notiftora, 369

reptans, 369 stoechadifolin, $36 \mathrm{~S}$

Lithophila, 127

Iloss-like, 12 T

muscoides, 127 rermieulatr, 128

Lithophyllum, ssfi accretum, 585
Lithophyllumacropetum, 585

caribaeum, 586

Chamacdoris, 5s

decipiens caribaeum, 556

munitum, 587

oncodes pachydermum.

$$
\overline{5} 5 \mathrm{~T}
$$

pachydermum, 5S7

propinyuum, 585

prototypun, 586

prototypum, 5s

pustulatum, 586

strictum, 556

strictum nenum, 586

Lithothamnium, 584

aemulans, 584

decutesecns, 585

fruticulosum aemulans. 5 S4

mesomorphum ornatum, 584

Lithothelium, 532

bahamense, 5.32

bahamense, 532

cubanum, 532

LIVERWORTS, 477,500

LOASA Fayily, 290

LOASACEAE, $290^{\circ}$

LOASALES, 290

Lobelia, $42 \mathrm{~s}$

Bahama, 428

Feayana, 428

lucayana, 428

Plumicrii, 429

[OBELIA FAMILY, 427

LOBELIACEAE, 427

Locust-berry, 205

LOgAXIA FAMILY, 328

LOGANIACEAE, $32 S$

Logwood, 171

I.ong-leaved Brake, 467 Tom. 372

Lonicera alba, 416

Loosestrife Family, 298

Lophocladia, 571 trichoclados, 571

Lopholejeunea, 515 Saglaeana, 516 Sagra's, 516

Lophosiphonia, 574 eristata, 575 c.xilis, 570

obscura, 57

subadunea, 5it

Lophothalia trichoclados, 571

IORANTIACEAE, 108

Loranthus emarginatus, 109 parriflorus, $10 !$ unitorus, $10 \mathrm{~s}$

Ionisiana l'lagiochila, 506

Jove-grass, $40,+1$ -vine, 3itis

LOVE-VINE FAMILY, 144

Luck-seed, 338

tucky-nut, 338

Lucuma, 321

multiflora, 322

pucifloru, 322

Serpentaria, 322

Ludwigia, 309

mierocarpa, 310

natans, 3in?

repens. 309

Small-frulted, 310

Lycium, 385
Lycium-

Inagua, sis.

spathulifolium, 385

I. ycogalia epidendrum, 645

LYCOIERDALES, $6+4$

Lycoperdon, 6its cpidendrum. 645

LYCOPONIALES, 4

Lycopodium nudum, +76

Lyngbya, 622

Lyngbya, 620, 622

aestuarii, 6?2

aestuarii limicola, 622 confervoides, 1322

epiphytics, ti2?

gracilis, $6 \mathrm{i}^{2}$.

Lagerheimit, $6: 22$

majuscula, 622

semiplena, 620

Lyoniu maritima. 343 palustris, 343

Lysiloma, $15 \pi$

bahamensis, $15 \mathrm{~s}$

formosa, $15 \mathrm{~s}$

latisiliqua, $15 \mathrm{~s}$

prucifoliola. $15 \mathrm{~s}$

Sabicu, 158

Sabicu, 109

Lysimnchia Monnieri, 38 ?

LTTHRACEAE, 298

Lythrum Parsonsia, 300

Maba, 325

caribaca crassineris, $32 \%$

crassinervis, 32-

crassincreis 540

Macreightia caribaca, 326

Macrocatalpa, 397 longissima, 398 punetata, 397

Macromitrium, 48. Mucronate, 455 mucronifolium, 4 SS

MADDER FaMrLT, 407

Madeira, 214

Wahoe, 273

IIahoging, 214

MAHOGANY FAMILY, 212

Maiden-bush. 218

Maiden-hair Anemia, 475 Fern. Dark, this Slender, 467

Malache, 270 bahamensis, $2 T$ seabra, 271

Malaxis, $8 \mathrm{~S}$

Siender Ss spicata, sS

Mallet,26:3

Mallotonia, 361 gnaplialodes, 361

Maniow FamLY, 263

Walocchire olndiuta, 191

Malpighia, 2(1)

Bahama, 20,

cullcata, 20,

olandulosa, 2tif

Jueith 2us

polytricha, 20.5

punirifolia, $211-$ sctosa, 205

Malpigha Famils, 203

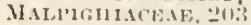

llater abutilnirles, -2tit corchorifolia, 267 coromandeliana, 267

MALVACEAE, 263 
MALraLES, 261

Malvastrum, 266

americanum, 267

corchorlfolium, 267

coromaudelianum, 267

Rugclii, atis

tricuspidatum, 267

Malvaviscus, 271

arborcus Sagracanus. 271

Cokeri, 271

Sagraeanus, 271

Sagra's, 271

M antmillaria, 294 uivesa

Manatee-grass, 6

Manatee-gras's Family, 6

Ianchioneel, 231

Mangifera, 244 indica, 245

Mango, 245

Iangrore, 308 Siwamp Vine, 337

MANGROTE FAMILY, 308

Manihot, 230

Ianihot, 230

Manilkata parvifolia, 324

Marasmius atropurpureus 643

bahamensis, 643

bermudensis, 643

hemileucus, 643

nidulus, 644

obliquzs, 644

opacus, 643

ramealis, 643

Rotula, 643

setulosipes, 643

Vaillantil, 643

Marchantia, 503

chenopoda, 504

domingensis, 504

Santo Domingo, 504

IARCHANTIA FAMILT, 503

Marcha NTIACEAE, 503

MarchaNtiales, 501

Margaritaria, 219

Bahama, 220

bahamensis, 220

Marigold, 451

Marilaunidium, 356 jamaicense, 357

Mariscus, 56

brizaeus, 46

filiformis. 47

fuligine 48,46

jamaicensis, 56

Marlberry, 316

Marrubium vulgare, 380

IIarsdenia floribunda, 344

Marsh Fern, $46 \mathrm{~S}$

Fleabane. 446

Gentian, 331

Parsley, 314

Pennywort, 312

Pennywort, Orate. leared. 313

Pink, 331, 332

Purslane, 309

Marsilea, 475

Nashii, 475

vestita, 476

MIARSILEACEAE, 475

Martynia, 400

annua, 400

diandra, 400

Small-fruited, 400
MAUTY NIACEAE, 399

Mastic-bully, $3: 1$

Mastigocoleus, 625 testarum, 6:5

Mastigolejeunea, 516 auriculata, 517 Eared, 517

Mastogloia, 628

Hastogloia, 626

affinis, 630

affirmata, 630

amoena turgida, 630

angulata, 628

apiculata, 628

asperula, 628

bahamensis, 628

buhamensis, 626

binotata, 628

bisulcata, 630

bisulcata corsicana, 630

Citrus, 628

cocconeiformis, 628

Craveni, 630)

cuspidata, 628

delicatula, 628

ersthraea, 628

erythraca, 627

euxina, 630

lanceolata, 628

lemniscata, 628

lineata, 630

Macdonaldii, 630

minuta, 628

ovata, 630

Peragalli, 630

Pisiculus, 630

Rhombus, 630

rimosa, 628

rimosa, 627

rostellata, 630

Smithii, 62s

splendida, 628

splendida, 627

Mat thiola scabra, 412

Maurandya, 388 antirrhinaeflora, 388

Mayepea, 327

bumelioides, 328

Maytenus, 246

Bahama, 247

Box-leaved, 247

buxifolia, 247

lucasana, 247

MEADOW-BEAUTY FAMILI, 297

Mecardonia, 390

procumbens, 390

Meibomia, 183

mollis, 184

supina, 184

tortuosa, 184

Melampodium humibe, 447

Melanotheca, 530

cruenta, 530

Melanthera, 449

brevifolia, 449

crenata, 449

deltoidea, 449

hastata, 449

Hastate, 449

M clastom $a$ bicolor, 298 discolor, $29 \mathrm{~s}$

MELASTOMICEAE, 29 -

Melia, 213

Azedarach, 213

semperirens, 213

MEILACEA E, 212

Melicocca, 253

bijuga, 253
Melicocca

paniculata, 254

Ieliola ambigua, 632 longlpoda, 632 similima, 632

Melobesia, 585

Chamuedoris, 588

farin os $\alpha, 587$

Lcjolisii, $5 \mathrm{~s}$

pustulnt $a, 586$

Helocactus communis, 294

Melochia, 277

crenata, 277

nodiflora, 27

pyramidata, 27

tomentose, 276

Meloseira arenaria, 629 sulcata, 629

Melosmon, 376

cubense, 376

Melothria, 425 guadalupensis, 426 pervaga, 426

MENISPERMACEAE, 142

Mentzelia, 290 Florida, 290 floridana, 290

MENYANTHACEAE, 332

Mercurialis, 227

annua, 228

Meristotheca, 561 Duchassaingil, $\mathbf{5 6 1}$

Mermaid-weed, 311

yertensia 56 ?

Merulius Corium, 638 infundibuliformis, 642 Spathularia, 637

Mcsogloia attenuata, 581 Zosterae, 591

MESOGLOIACEAE, 591

Iesosphaerum, 379

Mesothamnion, 579 caribaeum, 579

Mesquite, 164 -grass, 37

Metastelma, 342

Metastelma, 636

Bahama, 342

bahamense, 342

bahamcuse. 342

barbatum, 343

brachystephanum, 342 eubense, 342

Eggers, 343

Eggersil, 343

hamatum, 342

Inagua, 343

inaguense, 343

linearifolium, 343

Marsh, 344

Narrowed-leaved, 343

Nortliropiae. 342

Northrop's, 342

palustre. 343

palustre, 636

Schlcchtendahlii, 342

IFTEORIACEAE, $49 ?$

METEORIU M FAMILY, 493

Metopium, 244

If ctopium, 244

toxiferum, 244

Mexican Popp 145 Senna, 168

Iickle-berry, 102

Microdictyon, 60 I crassum, $60^{\circ}$

Microlejeunea, 509 bullata, 509 
Microlejeunea, inflated, 509 laetevirens, 509 Yellowish-green, こ09

Micromeria, 379 Brownei, 379

Microphiale, $5+1$ lutea, $5+1$

Microstylis spienta, SS

Micrathammium, 498

Microthelia, 526

Micrathclia, 527 quadriloculata, 526 thelena subtriscptata, 527

Mikania, 439

batatifolia, 439 orinocensis, 439 scandens, 439

Milium campressum, 17 digitatum, 16 paniccum. 15

Milk-berry. 323 - pea, 100 -rine, 344

UILKWEED FAMILY, 340

MILKWORT FAMILI, 214

Mimosa, 161

arborca, 162

Bahama, 162

bahamensis, 162

Farnesiana, 161

glauca, 162

juliftore, 161

Lehbeck. $15 \%$

Low, 163

pernambucana, 163

plena, 164

pudica, 161

Unguis-cati, 155

virgat $u, 163$

Virgate, 173

MIMOSA FAMILY, 154

IIIMOSACEAE, 151

Mimusops, 324

Mimusops, 110 bahamensis, 324

disect $a_{1}, 324$

emarginata, 321

floridana 324

parrifolia, 324

Sirberi, 324

MIXT F.MILY, 375

Mirabilis, 120

Jalapa, 129

Mistletoe, $10 \mathrm{~S}-110$

IISTLETOE FAMil, 108

Vitreola petinlata, 329

Mitrewort. 32 ?

Mittenothamnium, 4 ns diminutirum, tos

Iitten's-moss, Diminutive, 498

Inium hyarometricum, 489

Moluchia, 276

pyramidata, 277

Simooth. $27 \%$

tomentosa, 276

tomentosa. 635

Velpety, 27

Momordica, $+2-5$

Balsamina, 425

Charantla, 425

Ionkey-fiddle. 224

Jonnicra Brownel, 3S? Jonntera, 3S:

MInxncotruedoNes, 3

Iontererdia buxifolia, 247

Iloon-vine, 34 ?
MoONSEED FAMILY, 142 Coast, 350

MORACEAE, 104

Morinda, 419

lioyoc, 419

Moringa, 151

Molinga, 151

ptcrygosperma, 151

MORINGACEAE, 151

Morning-glory, ArrowIeared, 353

Beach, 353

Creeping, 353

Dark-eyed, 354

Iry-leared, 352

Pedate-leaved, 353

Purple, 352

Salverform, 351

Small Red, 350

rillous, 352

MORNIẌG-GLORY FAMILY, 345

Mosquito-bush, 167

Moss, White, 479

Mosses, 477

Mottled spurge, 235

Mougcotia noditlora, 277

Ioujean Tea, 371

Hucor canccllatus, 645

Iucronate Macromitrium, 458

Mucuna, 1Ss pruriens, 189 pruriens, 189 urens, $1 \mathrm{se}$

Muhlenbergia, 31 capillaris, 32

ITULBERIY FAILY, 104

Murrayella, 572 periclados, $57:$

Muscadinia Munsoniana, 259

MUSCI, 477

VCSTARD FaliLY, 145

Myginda aquifolia, 245 ilicifolia, 245 latifolia, -49

pallens, 24s

Rhacoma, 248

Mrkosyrinx Cissi, 63 -

IIYOPORACEAE, 405

Mroporuar Family, 405

Myrica, 102

cerifera, 102 segregut $1,32 t$

MYRICACEAE, 101

MIYTICALES, 1111

Myroxylon, 2st bahamense, 284 buxifolium puuciflorum, sst ilicifolium, 284

MrRSINACEAE, 315

Jursine lasta, 316

MrRSINE FAMILY, 315

Myrstiphyllum ligustrifolium, 419 pulsesens, $41 \mathrm{~s}$ undat um, 419

MY ITACEAE, 302

II Y'RTAIES, 297

Irrtle-nf-the-River. 307

IYRTLF FAMILX, 302

Iurtus arillaris .?ก? buxifolir, 30 ? Jimenta. 30.5 purctata, 3ofi zuz ygium, 307
MYXOMYCETES, fit5

IIYOPIY CEAE, $61 \mathrm{~s}$

Faradales, 4

Naked-wood, 253, 306

Vama jamaicense 35

Narrow-leaved Bay-1ush, 463

Brake 466

Nashia, 371

inaguensis, 371

Nash's l'epperwort, 475

Vasturtium brcvipes, $14 \mathrm{~S}$ palustre brevipes, 148

Naucoria semiorbicularis, $6 .+3$

Navicula, 62S

approximata, 631

brasiliensis, 628

complanata, 631

cuspidata ambigua, 631

directa, 631

irrorata, 631

Iyra dilatata, 628

ramosissima, 628

Scopulorum, 631

suborbicularis, $62 \mathrm{~S}$

transfuga, 631

Zostereti, 62S

Nazia, aliena, 14

Teckeru, $\mathbf{4 9 3}$

Horidana, 491

Neckera FdaItr, 492

Veckeraceat 492

Tectandra, 143 eoriacca, 143 sunguinea, 143

Nemalionaceae, 55

Neobracea, 335 bahamensis, $33 \mathrm{~J}$

Neomeris, 605 annulata, 605 Cokeri, 605

Cokeri, 606

helleri, 605 mucosa. $(j:)$

Neothymopsis, $45 \mathrm{~J}$

Britturii 45. throurides, 45-

Neottia adnata, 8 tortilis, s:

Nepeta Cutaria. 370 coerulea, 37 ? pectinata. 350

Nephrolepis, 473 biserrata, 47 croltata 473

Neptunia, 164

Neptunia, 16 . plena, 164

Tesaca, fi12

Nesca ammulata. 600 dumctosu, 61: T'enicillus, 61'? puramillalis, fi12

NeTtis FAMIIY, 165

Neurocarpus, กด delicatulus, 595 Justil. ถดร

Neurogrumme calomelanos,

Neurolaena, 4.i Iobata. 4.7

New-lurn Vied, $12 \mathrm{~s}$

Vickers. 179

Nicotiana, $3 \mathrm{~s}$ Tiln:1011, 397

Nidema, 94 
Nidema-

Ottonis, 94

Nidularia intermedia, 645

Nid Llartales, 645

Night-blooming ('ereus, 293

Nigredo proemineus, 636

Vitella. 608

Nitzschia, 629

angularis, 63

apiculata, 629

compressa, 631

granulata, 631

Jelineckii, 631

panduriform is, 631

Sigma, 629

valida, 629

vermicularis, 631

Nodeweed, 452

Nostoc, 621

commune, 624

Nostocace.te, 624

Noyau Vine, 353

Nummularia Bulliardii, 634

Nut-grass, 46 -rush, 57

YrTAGIYACEAE, 129

Nyctunthes Sambac, 327

Nymphaca ampla mulchclla, 139 pulchella, 13 ?

NYMPHAEACEAE. 139

Nymphoides, 332

anreum, 339

Oak, 301

Obcordate Frullania, 520

Obeah-bush, 135

Obtusely angled Taxilejeunеa. 513

Ocellularia, 544

albida, 544

micropora, 544

subtilis, 54.4

Ochrolechia, 546 pallescens, $5+6$

Ochtodes, 593

filiformis, $5 \mathrm{~s}$ ? secundiramea, 583

Ocimum, 380 micranthum, 380

Ocotea, 113

Ocotea, 110 Catesbyana 143 coliacea, 143

Octoblepharum, 480 albidum, 480

odontosoria clarata, 468

Okra. 272

OLACACEAE, 111

OLAX FANILT, 111

Old Maid, 336 , IInn Circtus, 2.92 Ian's Beard, 43, 63

Oldenlandia, 408 callitrichioides, 408

OLEACEAT, 32:

olire, 103,406 - wood, 250

OLIVE FAMILY, 326

Olivia, 605

Omplataria umbella, $\mathbf{5 4 0}$

ONAFRACEAE. 309

Oncidium, 97

bahamense, 97

bahrmense. 98

Leiboldi. 98

lucayanum, 98
Oncidium -

sphacelatum, 97

subrestre, as

ruricgatum, 98

Oncobyrsa, 620

marina, 620

Opegrapha, 534

acicularis, 541

atra, 534

bahamensis, 5.3.

bohamensis, 535

calcarea, 534

Cherallicri, 534

Chrevallicri incarnata. 535

columbina, 535

crassa. 538

dendritica, 536

isabellina, 53.5

isabrllina. 5.35

lithurga, 535

ophites, 535

saxicola 534

varia, 534

vulgata, 534

zonate 535

Opcreulina dissceta, 353

Ophiodothis bahamensis, 633

Ophiorrliza Mitreola, 329

Oplismenus, 26

hirtellus, 27

sctarins 27

Opoponax. 161

Opuntia, 2.95

Opuntia. 61

bahamana, 296

Darrahiana, 297

Dillenii, 296

Dillenii, 632

lanccoluta. 296

luea yana, 296

Iucayana, 296

Millspaughit, 296

Nashii, 295

spinosissima 295

triacantha, 295

Tuna, 296, 297

OPuntrales, 291

Orchid, Carter's, $\$ 3$

ORCHID FAMILY, 81

ORCHIDACEAE. 81

ORCHIDALES, $S 1$

Ornithoptris adiantifolia, 475

cicutaria, 47

Wrightii, 474

Orontium aquaticum, 62

ORPINE FAMILY, 152

Ortacline floridana, 31

OR'THOTRICHACEAE, 487

Orthotrichum mucronifo

lium, 488

ORTH OTRICHUM FAMILY, 487

Oscillatoria, 620

Corallinae, 621

miniata, 620

sancta, 620

tenuis, 621

OSCILLATORIACEAE, 620

Osmumda, 565 adinutifnlia, 475

Osmumalca, 565

Otaheite frooseherry, 219

Ovate-leaved Marsh Pennywort, 313

Ovicda aculcata, 374
Oricala-

Oxalis rornicilata, 197 rorniculata repcns, 197 intermedia, 197

Oxupetolum, 343

Oyster l'lant, 68

Ozonium auricomum, 636

Padina, 505

P'adina. 587

dubia, 595

Uurvillaci, 595

pavonia, 595

Sanctae-Crucis, 595

rariegatu 594,595

Vickersiae, 595

I'adinella, 591

Pain-in-back, 104

Pale-green Funaria, 48 ?

PALM FAMILT, 58

Palmella rupestris, 620

Paltonium, 466

Ianceolatum, 466

Pancratium declinatum, 78

Paxdaxales, 3

Panellus eugrammus, 644

Panic-grass, Bluish, 24

Brown, 22

Chapman's, 23

Dense, 23

Diffuse, 23

Hair-like, 24

Loose, 22

Narrow, 22

Nerved, 25

Red-top, 2 ?

Shining, 25

Slender, 23

Panicum, 20

adspersum, 21

agrostidiforme 23

amarulum, 24

barbinode, 22

bartoircnse, 24

brevifolium, 24

capillaceum, 24

Chapmani, 22

coerulescens, 24

colon um, 26

condensum, 23

Crus-galli, 26

Dactylon. 34

dichotomiflorum, 24

dichotomum, 24

diffusum, 23

distantifiorum, 22

divaricatum. 25

elephantipes, 22, 24

exiguiflorum, 2.5

fasciculatum, 22

filiforme, 15

fimbriatum, 16

farescens. 22

fuseum, 22

geminatum, 21

Genieulatum. 2T

Ghiesbleghtii, 23

hirtell um, 27

hirtilaginwm. 23

horizontale, 16

imberbe, 27

insulare 16

laxum. 23

leucophaeum. 16

Linkianum, 16 
Panicum-

lucidum, 25)

maximum, 22

molle, 22

neurinthum, 24

nitidum, 25

puniculutum, 22

paractacnoides, 28

paspuloiles, 21

proliferum, 24

sumguinale, 16

sctosum, 2s

tenerum, 23

tchuiculmum, 23

trichoides, 24

tricolor, 25

Pannaria, 54

molyblea, $54 \mathrm{~s}$

ruliginosi, 547

PAXXARIACEA T4

Papareraceate, $1+5$

PAPAYERALES, 145

p:ipaw, 290

PAPAII FaMILY, 289

Papillaria, 493

Plackish. 494 nigrescens, 493

Para Grass, 22

Inradise-tree, 211

PAR.TTHELIACEAE, 531

Parathelium, 5.31

lefumbens. 532

indutum, $5: 31$

microcarpum, 531

microc(ar)um, 532

Paricturia mierophylla, 106

Pariti 27.

tiliaceum, 273

Paritium tilicefum, 273

Parkinsonia, 170

aculeata, 170

Parmelia, 5 4.9

all, $a, 552$

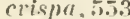

cristifera, 548

flav่, 549

latissima 5to

latissima cristifera, 549

molybdea.51s

pellita, 5.8

perlata, 5.?

repandu, 5.3.

speciose hypoleuca, 552

sulphurata. 549

urceolata, $\overline{4} 48$

usnerides 512

varia cincreocarnca, $5+6$

Parmeliarif, its

Parmentaria, astroidea, 532

Parsley Anemia, 474

Parsonsia, 209

I'irsonsis, 200

l'urple, 3000

ralienus, 300

Parthenium, 47 IIysteropliorus, 448

Parthenocissus, 2f 1

quinquefolia, 261

quinquefolia latifolia, 261

Paspalum, 17

Blorluctiti, 18

cospltosum, 18

corspitosum, 18

conjugitum, 10
Paspalum-

distichum, 20

fimbriatum, 19

Fringed, 19

glabrum, 19

inacillimum, 18

Helleri, 19

millegrana, 19

nanum, 19

Foiretii, $1 \mathrm{~s}$

roiret's, is

portoricense, $1 \mathrm{~s}$

Schrobcrianum, 19

secans, 19

Sheathed, 20

Simpsoni, 18

Simpson's, 18

slender, is

Tall, 19

tristachyon, 17

Two-spiked, 10

Indericoodii, 1?

Cnderwood's 19

viginatum, 20

reiginutum, 20

Passiflora, 256

angustifolia, 288

bahamensis, 287

biflor:a, 249

ciliatı, $2 \leq \mathrm{T}$

ciliata riparin, 2S8

cupraen, 2s!

foetida, 257

lumata as?

minima, 2ss

multiflora, $2 S S$

pallida, 25.5

pectinatia, $2 s-$

pertinata, 287

rubra, 2s s

suberosa 288

Tespertilio, 289

rillosa, 2ss

PASSifloraceae as6

PASSIFLORALES, 2S6

I'ission-flower, 287, 28s

I'ASSIOX-FLOWER FAMILY, 256

Patellaria domingensis, 542 'uublinia diversifolia, 251 Scriana, 251

Paurotis, 60

androsana. 60

Wrightij, 60

Paronia, 270

Pavonia, 270

bahamensis, 271

rucemosu. 27

spiceta, 271

spinifex, 270

PEA INAILY, 176

Pectis, 456

$\Lambda$ wn-fruited, 457

leptocevlıala $4 \overline{5} 6$

Lessinuii titi

linifollit, t.j6

Nirrow-leaverl, 456

munctutu, 450

P'FDALIACEAR, 30?

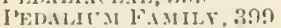

ferliecllarie jentaphylla. 14 ?

Pedilanthus, 233

bathensls, 233 ththrmaloldes, 233

Pelexia, Sf arinata, S4

I.ong-spurred, 55

\author{
Pelexia - \\ setacea, $\mathrm{S}$ \\ Short-spurred, S.t \\ spiranthoides, 54 \\ Peltophorum, 17 \\ adnatum, 17 . \\ Pencil-flower, 15: \\ Penicillus, $1 ; 12$ \\ l'unieillus, jtis, 5т3, 622 \\ aunulatus, 60: \\ calpitatus, 612 \\ dumctosa, 613 \\ Iumetosus, 613 \\ cloneutus, 612 \\ Lamourouxii, 612 \\ Lamourourit gracilis,
} 612

oblomules, 613

pyriform is, 613

Pennyroyal, 45t

Peperomia, 101 spathulifolia, 101

Pepper bush, 224, 353

[EPPER FAMIIT, 101

I'epperwort, Hairy, 4 Nash's, $47 \bar{\jmath}$

I'era, 2:09

Pera, $220 ?$

bumeliaefolia, 229 bumcliacfolia, 1:t6

PERISPORIALES, (i:3,

'erisporium W'ightii, 63 :

PERUNós PuRALES, 631

Persea, 144 pubescens, 141

Persicaria, $11 t$ Dense-flowered, 115 hydropiperoides, 11 t poltoricensis, 115 punctata, 114

Pertusaria lciopluca, 545

Petitia, 373, 630

l'etilia, 6331$)$ domingensis, 373

l'oulligii, 373 T'enperei, 630

Petiveria, 1:3 alliacea, 13.5

Petrosiphon, $60^{\circ}$ adbacrens, 602

Peyssumelliu, ist

Peyssonnelia, 551

l'cyssonneliu, ît rulura, 5st

Peai a cubcusis, $63 . \bar{J}$ nigrescens, 637 (1m) hllalorles, $6: 35$

I'vzizuLs, 633

l'11ACIUI.1Ll'S, 63é

Phaeographina, $530^{\circ}$ caesiontuinosa, 236 ('acsiom uinosa, $\overline{3}$ i quassiaceole. EST scalpturutu 537

Phaeographis, 5iti cintab:1 lna . 536 dendrltie:s, 536 inusta, $5: 36$

l'IIAEUIIICE.IE, 589

Phaeostroma, buslllum, 500

l'11.1LL,ILES, (i.44

l'harbitis cuthartica, 3.12

l'huruaceum maritimum, 136

Phaseolus, 1?? latliyroides, 124

lunitus, 194 
Phaseolus-

scmicrectus, 194

I'heyopteris cordata, 473 ieptans, 47 :

Phialanthus, 416 myrtilloides, 416 Iiritle, 416

Philibertella, 344 clausa, $3 \pm 4$ clausu, 630

Philibertia clausa, 344

Philoxerus, 127 vermicularis, 128

Phlebodium, 470 aureum, 470

Phlomis nepictaefolia, 378

Phoradendron, 109

Northropiae, 110

racemosum, 110

r'ubrum, 110

spathulifolium, 110

tctrustich um, 110 trinervium, 110

Phormidium, 621

Corium, 621

fragile, 621

Hendersonil, 621

pulvinatum, 621

Retzii, 621

Retzii, 622

ralderianum 621

Phragmicoma Sagraeana, 516

Phragmites, 39

communis, 39

Phragmites, 39

PHY COMIYCETES, 631

Phycopteris, 594

Phyla nodifiora, 368 stacchadifolia. 368

Phyllachora Ateleiae, 632 Durantae, 633 fusicarpa, 633 Galactiae, 633 oxalina, 633

Phyllanthus, 220 angustifolius, 220

bahamensis, 220

distichus, 219

falcatus, 220

Niruri, 220

pentaphyllus, 221

pruinosus, 221

radicans 221

Rock, 221

saxicola, 221

Tufted, 221

virens, 220

Phyllerpa, 607

Phyllopsora, 546 parrifolia, 546

PHYLLOPSORACEAE, 546

Phyllosticta Coccolobae, 635 Roberti, 635

Sapotae, 635

Phymatodes, 470 exiguum, 471

Phymosia, 264 abutiloides, 261

Physalis, 381

angulata, 381

barbadensis, 382

curassarica. 382

Linkinne, 381

pubescens, 382

turbinata, 382

Physarum compressum, 645 globuliferum, 645 l'hysarum-

riride, 645

Physcia, 5\%:

adglutinata, 552

alba, 55:2

crispa, 553

crispu, 55.

dilatata, 552

dilutata, $55:$

hypoleuca, 552

integrata, 553

integruta, 552

integrata sorediosa, 553

obscura, 552

picta, 551

stellaris, 553

P'Hrsciaceae, 551

I'h yscophora, 571 triangularis, 571

Physma, 540 umbella, 540

Physurus, 87

querceticola, 87

Sagraeanus, 87

Phytolacca, 135

icosandra, 135

octandra, 135

Phytolaccaceae, 133

Picramnia, 210

pentandra, 210

PicRODENDRACEAE, 102

Picrodendron, 103

baccatum bahamense, 103

juglans, 103

macrocarpum, 103

Pigeon-berry, 372

-pea, 192

-plum, 117

Pigweed, 125

Pilea, 106 herniarioides, 107 microphylla, 106

$m u s \cos a, 106$

tenerrima, 107

Pilocarpaceae, 541

Pilocarpon, 541 tricholoma, 541

Pilacereus, 291

lanusinosus, 292

Pilotrichella floridana, 491

Pilatrichum cymbifolium, 493

Pimenta, 305

officinalis, 305

Pimenta, 305

vulgaris, 305

Pixaceae, 461

PIsales, 460

PINE-APPLE FAMILY, 63

PiNe Fanili, 461

Pine-land Fern, 468 Thistle, 459

-tree, Caribbean, 461

Pinguicula, 395 pumila, 395

Pink, 329

Pinnularia, 628 rectangulata, 628

Pinus, 461

bahamcnsis, 461

caribaea, 461

Pipe-shank, 37t

PIPERACEA E, 101

Piperales, 101

Pirca, 492

Pireella, 493
Pireella, 492

cymbifolia, 492

Piscidia Erythrina, 186

Pisonia, 13:

aculeata, 132

calophylla, 131

discolor lonsifolia, 132

obtusata, 131

rotundata, 133

Round-leaved, 133

subcardata rotundata. 133

Pistacia Simuruba, 212

Pitch-apple. 251

litcher-plant, 113

Pithecolobium, 155 asplenifolium, 160

bahamense, 156

calliandriflorum, 156

circinale, 156

discolor, 157

flatorirchs, 155

guadalupense, 156

Hystrix, 156

kevense, 156

mucronatum, 156

Unguis-cati, 155

Lnouis-cati, 155

Pithophora, 601 oedogonia, 601

Pityrogramma, 469

calomellanos, 469

Placodium aurantiacum Bassiac, 550

floridanum, 550 galact op hyllum, 550

Placoma, 620

Plagiochila, 505

Louisiana, 506

Iudoviciana, 506

Plagiogramma, 627

Plagiogramma, 626 caribaeum, 627 decussatum, 630

Inaequale, 627

Iabuense, 627

labuense, 627

lrratum, 627

obesum, 627

pulchellum, 627

pygmaeum, 627

tessellatum, 630

Plantaginaceae, 406

Plantaginales, 406

Plantago, 406

lanceolata, 407 major, 406

Plantain, 406

PLANTAIN FAaILY, 406

Plectonema, 623

nostocorum, 623

roseolum, 623

PLEU ROCOCCACEAE, 597

Pleurococcus mcmbraninus, 618

vulgaris, 597

Pleurosigma, 628

compactum, 631

formosum, 628

TTeissflogii, 631

Pleurotopsis liliputiana, 644

Plica tura obliqua, 644

Ploramium triangulare, 571

Plocaria, 562

Pluchea, 445

bifrons, 145

camphorata, 446 
Pluchea -

foetida, 445

odorita, $4+5$

purpurascens, 446

PLUal Fanty, 153

Plumaria schousboei, 580

I'LU IIBAGLACEAE, 319

Plumbago, 319 scandens, 319

Plembago Family, 319

Plumiera, 334

alba, 334

Bil hama, 334

bahamensis, 334

lilunt-leaved, 334

emarginata, 334

Iniry, 335

Inagua, 334

inaguensis, 334

obtusa, $33 \pm$

obtusa, 635

lied, 335

rubra, 335

sericifolia, 335

Poa amabilis, +1

ciliaris, 41

domingertsis, 41

nitidu, 40

plumosa, 41

prolifera, 41

rirguta, 42

Podceae, 10

PoAles, 10

Podocystis, 629

adriatica, 629

adriatica, 627

Pogonomyces hydnoides, 641

Poinciana, 174

coriaria, 174

pulcherrima, 174

vervin 175

Poinsettia, 236 heterophylla, 236

Poison Bush, 232

Cherry, 248

IFF, 244

-tree, 244

Poke-bush, 136 -weed, 136

POKX-WFED FAMILY 133

Polearoxiales, $34 t$

Polyblastiopsis, 527 lacter 527

Polygala, 214

baliamensis, 215

brizoirles, 215

corallicala 215

Krngî, 215

Iring's, 215

oblongata, 216

spathulata, 215

Spatulate-leaved, 215

Wightiaua, 215

Wight's, 216

Wilsoni, 216

Wilson's, 216

POI,YGAIACEAE, 214

Polygoraceae, 114

POLYGoNales, 113

Polygonum arre, 114

Fagapyrum, 115

glabrum. 115

hydropiperoides, 114

portaricense 115

punctatum, 114

I'rifera.116

Palynster 5io

I'olyphysa, 605
Polypodaceae, 464

Polypodium, 4 (b)

aurcum, 470

biscrratum, 474

exaltat $u m, 473$

схіуиит, 471

incallum, 470

Plhyllitidis, 471

polypodioides, 470

pubescens, 473

reptans, 47 ;

squamatum, 470

Sucartii, 471

Polypodoidea, 595

Polypody, Climbing, 471 Gray, 470

Scaly 470

POLYPORACEAE, 639

'volyporus Auberiunus, 640 Bracei, 641

fruticum, 641

guyanensis, 641

licnoides, 641

occidentalis, 639

- pulustris, $6+1$

pinsitus, 639

sericeohirsutus, 639

surinumcnsis, 641

tormatus, 640

Tricholoma, 641

Polypremum, 329

procumbens, 329

Polysiphonia, 560

Polysiphonia, 577, 587, 627

adunca, 574

barbatula, 574

Binderi, 572

Binneyi, 570

ureviarticulata, 570

exilis, 570

fernlacea, 570

ferulacea, 590

freniculace $a, 570$

Gorgoniae, 570

hapalacantha, 570

hapalacantha, 554

havanensis, 570

hatanchsis, 570

havancnsis Binneyi, 570

Hillebrandii, 57

hirta, 571)

lophoclados, 571

opaca, 571

Pecten-Teneris, 573

periclados, 572

perpusilla, 564

pugmeca, 5it

ramentacea, 570

reptalunila. 574

sceunda 574

subtlipsima, 570

tenella.573

trichoclada, 571

Polystachya, SS

follosa, 89

I arge, so

lutrola, 8?

mlnuta, 89

Simall, 8?

Polystictus cinnamomcus, 639

somguincus, $6+1$

Polythrix, 626

colymbosa, 626

Pond-apple, 141

-thatch, 60

-top, 60
Pondweed, 5, 363

I'OXDWEED l MIILY, 4

Ponthieva, st

Brittonae, $8 T$

Alrs. Britton's, st

I'oppel's, 381

FoPr' FaMILY, 145

'oria, 641

Porina, $5 \geq 3$

Porinu, 5*)

africena, 524

firmula, 5:4

macrocarpa, 529

mastoidea, 524

nucula, 524

subfirmula, 524

Tetracerae, 5:4

variegata, 5․

Wilsonii, 523

Pork-and-Loughbor, 160

-bush, 136,149

-fat Apple, 154

Porolithon, $\overline{\text { ș }}$

Bocrgesenii, 585

improcerum, 557

pachydermum, 5s pachylermum, 5s , 598

Poronia Oedipus, 634

Porophyllum, 455 l'orophyllum, 456 ruderule 456

Portulaca, 138 lahama, 138

Brown-seeded, 138

gagatosperma, $13 \mathrm{~s}$

halimoides, 138

oleracea, $13 \mathrm{~s}$

placosperma, $13 \mathrm{~S}$

pilosa, $13 \mathrm{~s}$

Portulacactale, 137

Potamogeton, 4

heterophyllus, 5

Potato FaniLY, 381

Potmargin, 380

Prescottia, 86 oligantha, $\$ 6$ Sinall, 87

Prickle-grass, 14

Frickly-apple, 411 -luu, $3 \times 6$

-bush, 403

Mrrtle, 374

- pea 1, 295-297

-tree, 301

Prlde-of-india, 213

Primliose Family, 318

PRIMILACE.IE, 318

Pirirctidies, 315

l'rincew ood, 409

Priva, 366 crhinata, 367 lappulacea. 36 -

I'rivet Senna, $16 \pi$

Proserpinaca, 3111 pulustris, 311 platyearpa, 311

Prosopis, 164

fuliflora, 164

I'rospodium bahamense, 636

l'ROTOCOCCACEAE, 597

Protococcus, 597 Magma. 61? turniting, fils viridis, 597

Prunus mirtifolia, 153 spliacrocarpa, 153

Pseudocarpldinm, 373 Wrightli, 37t 
Pseudocarpidium Wright's, 374

Pseudophoenix, 60 Sargentii. 61 viuifera, 61

Pseudopyrenula, 526 diremta, 526 cluteriae subsulphurea, 530

Pseudotetraspora, 597 Antillarum.50T marina, 597

Psidium, 306 Guajava, 307 Guala 307

Psilotaceae, 476

Psilotum, 476 nudum, 476 triquetrum, 476

Psiloteal Family, 476

Psorotichia, 53!) Poercesenit, 539

Psychotria, 418 asintica, 41 ? bahomcnsis, 41 ? lemecolata, 41 ? ligustrifolia, 419 pubescens, 418 indata, 419

Pteridium caudatum, 467

PTERIDOPHTTA, 464

Pteris, 46 fi aquilina caudata, 467 aurea, 470 caudata, 46 lanefolata, 466 lincreta, 466 longifolia, 467

Ptilota schousuoci, 580

Ptilothamnion, 5s1 bipinnatum, 580

Puccinia Cynanchi, 636 heterospor: 636 Lantanae. 636 Leonotidis, 636 mirifica, 636 obliqua, 636

Pull-back, 132

Purple-grass. 32 Purslane, 13s

Prislane FaJili, 137

Pycnodoria, 467 longifolia, 467

Pycnoporus sanguineus, 641 Pyerarus ferrugineus, 4

Pylaiella, 589 Antillarum. 589 IIooperi, 589

PIREXOPSIDACEAE, 539

Pyrenula, 526 aurantiaca, 526 cerina, 526

deplanata. 526 Glaziovii, 526

Kunthii, 526

leucoplaca. 526

librirola, 527

mamillana, 526

mamillana, $52 \mathrm{f}$

mastoidea. 524 nitilla. 526

punctella, 526 tropica 529

PYRENTLACEAE, 523

PyRextllaLes, 522

Pyronema omphalodes, 635 Pyropolyporus depcndens, 640
Pyxine, 551

Cocoes, 552

Cocoes endoxantha, $\mathbf{5 5 2}$ dissect $a, 552$

leissneri, 552

victa, 551

Quamoclit, 350

coccinea, 350

Quamoclit. 350

rulgaris, 350

QUassia FaMiLy, 209

Ouassia. Simarouba, 210

Queen-of-the-Night, 294

Quicksilver-bush, 253

Rabbit-grass, 42

Rachicallis, 408 americana, 409 rupestris, 409

Radicant Fissidens, 481

Radicula, 147 brevipes, 148

Radula, 506

australis, 506

Southern, 506

Ragweed, Southern, 432

RAGWEED FAMILY, 430

Ra inbow-moss, 480

Rajania, 80

hastato, 80

microphylla, so

microphilla, 634

Small. 80

Ramalina, 549

complanata, 549

denticulate 5.49

Ifontígnei, 549

peruviana, 549

rigida Montamei, 549 usneoides, 549

Ram's Head Frullania, 519 -holn, 156

RANALES, 139

Randia, 410

aculeata, 410

mitis, 410

RANUNCULACEAE, 140

Rapanea, 316 guianensis, 316

Raphanus lanceolatus, 149

Rat-root, 417 -wood, 1 ?

Rattlehox, 178

Rauwolfia, 339

glabra, 330

nitida, 339

Smooth, 339

tetraphylla, 339

Rectolejeunea, 50 ?

Berteroana. 510

Bertero's, 510

Brittoniae, 510

Leaf-shedding, 510

Mr's. Britton's, 510

phyllobola, 510

Red Bay, 144

Cedar, 462

Clover, 180

Morning-glory, 350

Periwinkle, 336

Sage-bush, 370

Stopper, 304

top. 23

Reed-grass, 30

Relbunium bermudense. 424

Rencalmia tsueoides, 63
Resuplaatus subbarbatulus, 644

Reynosia, 255

Bahama, 256

Common, 256

litifolia, 256

Northropiana, 256

septentrionalis. 256

Rhabdadenia, 337

biflora, 337

paludosa, 337

Sagraei, 337

Rhabdonema adriaticum, 630

Rhabdonia Bailcyi, 561 tener $a, 5,31$

Rhacoma, 247

aquifolia, 24.8

Bahama, 247

corlacea, 247

Crossopetalum 248

Holly-leaved, 248

ilicifolia, 248

pallens, 248

Spiny-leaved, 248

RHAMNACEAE. 255

RHAMNALES, 255

Rhamnitium ferretm, 256 revolutum, 256

Rhammus colmbrinus, 258 cubensis, 258 ferreus, 256

Rhinotrichum Curtisii, 636

Rhipilia, 612

Iongicaulis, 611

Rawsoni, 61?

tomentosa, $61 \mathrm{~s}$

Rhipocephalus, 613

Rhipocephalus. 568 oblongus, 613

Phoenix, 613

Rhizoclonium 50? crassipellitum robustum, 600

hierogixphicum, 600

Hookeri, 600

riparium implexum,

Rhizophora, $30 \mathrm{~s}$

Rhizophora, 559, 561, 564, $570.572,573,574,575$ $576,577,582,583,594$, $599,600,602,606,608$, 61ก. 617

Nangle, 308

RHIZOPHORACEAE, 308

RHIZOPHYLLIDACEAE, 583

Rhodochorton Rothit, 560 speluncmirum. 578

Rhorlomela calamistrata, 572

RHODOMELACEAE, 565

Rhodonema, 5T5 clegans, 576

RHODOPHYCEAE, 553

RHODOPHYLLIDACEAE, 561

Rhodoplexia, 580

RHODYMENIACEAE, 563

Rhoeo, 68 discolor, 68

Rhubarb, 41?

Rhus Blodecttii. 244

Cominir. 253

Metopium. 244

ralicans, 244

Toxicorlentron, 244

Rhynchosia. 192

caribaca, 193

Gundlachii, 193 
lihynelhosiaminimu, 193 reticulata, 193

Ribwolt, $40 \mathrm{~T}$

Riccia, 502

crystallina, 502

cristalline, 503

volacen, 503

tolet, 503

Ricel. FAM 502

RICCJACEAE, 502

Ricciclla, 5u:

Richard's Calymperes, 482

Ricinus, 231) communis, 230

rigidoporus surinamensis, (i)1

Rio Janeiro Frullania, 520

Rivina, 13.1 humilis, 134

lactis, $12 t$

octandra 131

Rivularia, 626 Biasolettians, 626

nitidi, 626

polyot is, 626

Zosterne, 591

RIVTIARIACE.AE, 625

Robinia grandiflora, 182

Rochefortia, 360 tahamensis, 360

liock Palsam, 223 Trichostomum, 487

Rong-bush, 451

lioperia tesseliata, 62 ?

ROSALES, 151

Rosewond, 160

Rousselia, 107 humllis, 107 laip) ylacea, $10 \pi$

Roving sailor, 3ss

Royal I'alm, 61 l'oincians, 175

lioustonce regia , 61

Rubber-vine, 336,340

REIIACEAE, 407

Ri"BIALES, $40 T$

Ruclolph's Diplasiolejeunen, 507

RIF FuMLT, 206

Ruellia, 401 tuberosa, 401 Tuberous, 401

Ruppia, 5 maritima, 5

Rush, rlat-spiker, 52 -grass, 32-34 White-hended, 53

Russella, 3s efuisetiformis, $38 S$ juner, 358

IRUTACE.AE 2UR:

Rynchospora, 53

Rynehospora, 63T bahamensls, $5 \bar{j}$ repitutu, 54

crperoiles, 54

divergens, 55

jubuta, is ;

marisculus, if

microcarpa, 50

perplexn, $5 \overline{5}$

tenuis, is

'Tracyi, 54

Sabal, 59

l'ilmetto, 60
Sabal-

Palmetlo bahamensis,

umbraculifera, 60

Sabbatia, 331

campanulata, 331

cumpermulatu, $3: 3$ gracil is, 331,332 simulata, 332

Sabicu, 158

Sachsia, 446 bahamensis, 446

Saffron-tree, $3: 1$

Sage, Iig. 370

scarlet, 379

small White, 379

West Indian, 378

Vild, 370

Sage-bush, Lahama, 370 lnagua, 371 IRed 370

Sagittaria, $\tau$ Lance-leaved, s lancifolia, $s$

Sagra's Lopholejeunea, 516 st. Andrew's Closs, 2so

ST, JUHX̃S-WORT FAMILY, "siti

St. Thomas Bush, 341

Salicornia, 121

ambiyua, 122

Bigelovii, 122

fruticosa, 122

mucronata, 122 perennis, 122

Salmea, 452

Bushy, 453

petrobioides, 453

Sulsolu linearis, 121

Salt Grass, $3-1$

-weed, 125

- wol't, 133

Saltwort Fadily, 133

Saltwater-bush, 409

Salve-bush, 383

Salvia, 378

coccinen, 379

uierantha, 378

occidentalis, 378

serotina, $3 \pi \mathrm{s}$

tenclle 379

SALVINIALES, 475

Salz-bush, 276

Samodia curactcata, $31 \mathrm{~s}$

Samolus, $31 \mathrm{~s}$

ebracteatus, 315

floribundus, $31 \mathrm{~s}$

Tulframeli americanus, $31 \mathrm{~s}$

Samplre, 12s

Sumbla spincsecns, 286

sandbox-tree, "23:

Sandfly-bush, fug

sunsericra 69 guinechsis, 69

Santa Marla, 1 is

SANTALALES, $10 T$

Santo Domingo Marchantla. 504

S.IIINDACE.IE, 2:I0

Silixuldes of.

cupium laurifolium, 242

Sapodllla, 325

S.IIOUILIA F.IMILY, 320

Sapota, $3: 4$

Achris, 324

fehres, $0.35,630$

SAIOTICEAL, 320
Sarcographa, $53 \mathrm{~s}$

trleosa, $5: 3$.

Sarcomphalus, $25 \pi$

'Taylori, 25

'Taylor's, 257

Sarcostemma Brounei, 344

Sargassum,

survussul, 5i, 5it, 57s. $\overline{5} 86,587,589$

baceiferum, 592

britherse, sidt

crmosum, 598

Folipendula, 593

Filipenelula Iontagnei, 593

fluitans, 593

Hystrix, 591

II ystrix burifolium, 594

Hystrix fluitans, 593

lendigerum, 593

Irptocarpum, 593

yontugnei, 593

natans, 592

nutuls, 593

platycapum, 593

polyceratium, $5: 93$

polyphyllum, 594

pteropleuron. 593

pteropus, 594

ramifolium, 523

rifialulum, 593

stcmophyllum, 599

trurhyphyllum, 594

tubinatum, 591

rulgire, 593

Satin-Wood, 207, 208

Sitinleaf, 321

Soturein Brownei. 379

Saturium orchioides, 86

Savia, 218

bihamensis, 218

(rythroxyloides, 218

Saw-brier, T1 -rriss, 46,56 Pil Imetto, 60

Scaevola, 428 Lobeliu, 429

Plumierii, 429

Scaly I'olypody, $4 \pi 0$

Searlet Sage, 379

Schaefferia, 24 ?

Common, 24?

frutescers, 24 ?

luterilura, 221

Sehinus Hurgara, 206

Schizachyrium, 13 Ericile, 13

semilbertie, jï

SCIIZALACEAE, 474

Schizophyllus alnens, 644

Schizothrix, 1223

chalybea, fi2.

vaginata, 623

Schlothelmia, $4 S S$

SuIJIvantli, 4SS

Sullibunt's, 4 s?

Srlimidelin metrocarpa, 103

Schoenus, $5 t^{\circ}$

colorutus, 58

eyproviles, 54

nlgilctins, 5 i

niaricons. 47

Schooptta, 111 chrysophyl]oldes, 111 olovata, 111

Selplo-bush, 220

Scirpus, is

utropurpurcus, 4 ? 
Scirpus-

capitatus, $4 !$

custuncus, 50

diphyllus, 50

cxilis, 51

ferrugineus, 50

flaccidus, 4S

glomeratus, 51

interstinctus, 48

lithospermus, $5 T$

ochreatus, 48 robustus, 52 ralidus, 53

Scleria, 5-

filiformis, 28, 5 T

lithosperma, 57

rerticillata, 57

Sclerophyton, 53s elegans, $53 \mathrm{~s}$

Scleropus amaranthoides, 124

Scolosanthus, 417 bahamensis, 417

Scoparia, 391

Scoparia, 391

dulcis, 391

Scorpion-tail, 363

Scorpiura, 572

SCroph Ulariaceae, 387

Scutellaria, 376

cubcnsis, $37 t$

havanensis, 377

longiflora, 377

purpurascens, 377

scutia ferrea, 256

Scy tonema, 624

Scytoncma, 531

cincinnatum, 621

crassum, 625

Hofmanni, 624

Millei, 624

myochrous, 625

ocellatum, 624

velutinum, 625

velutinum, 624

SCrTonematTACEAE, 624

Sea-beach grass, 24

Blite, 121

-bush, 450

Grape, 117

Larender, 320

Oats, 42

Ox-eуe, 450

Purslane, 136, 137

-rocket, 149

-weed, 409

Sebacina spongiosa, 638

Sebesten, 357

Sebestena, 357

Securinega, 219

Securinega, 218

A cirlnthamnus, 219

Acidoton 219

Sedge, Plack-headed, 57

SEDGE FANIILY, 43

Seirospora, 580 occidentalis, $\mathbf{5 8 0}$

Selaginella, 477

Fatoni, 477

Eaton's 477

Selaginellaceate, 476

Selenicereus, 293

Boeckmanni, 293

grandiflorus, 294

SEMATOPHYLLACEAE, 499

Sematophyllum, 499

admistum, 500

Gloss 5,500
Sematophyllum-

sericifolium, 500

Shining, $5(1)$

Subpinnate, 500

subplnnis tum, 499

SEMatopIILLUM FaMLY, 499

Senceio hieracifolius, 458

Senna, 166, 167

SENCA FAMIT, 164

Sensitive Plant, 161

Septobasidium cirratum, 638

Septoria, 635

screnoa arborescens, 60

Serjania, 251

diversifolia, 251

lucid $a, 251$

paniculata, 251

subdentata, 251

Serpent-fern, 470

Scrtolara, 614

Sesame, 399

Sesamum, 399

indicum, 399

orientale, 399

Sesban, 181

grandiflorus, 1 S2

occideutalis, 182

sericea, 152

Silky, 182

Smooth, 182

Sesuvium, 136

maritimum, 136

pentandrum, 136 portulacastrum, 136

Setaria caudata, 28

filiformis 28

glauca, 27

macrostachya, 28

setosa, 28

Setiscapella, 394

subulata, 394

Seutera maritima, 343

Seven-year Apple, 410

Shanks, 453

Sheep-grass, 355

Shell Orchid, 94

Shepherd's-needle, 454

Shining Sematophyllum, 500

Shoestring-fern, 466

Sicyos trifoliata, 260

Sida, 267

abutiloides, 265

acuminata, 269

acuminata, Bracei, 269

acuta carpinifolia, 268

angustifolia , 268

antillensis, $26 \mathrm{~s}$

carpinifolia, 268

ciliaris, 267

Creeping. 269

crispa, 266

Fringed, 268

glomerata, 268

glutinosa, 269

glutimosa, 270

hederaefolia, $26 \mathrm{~S}$

hirta, 265

Ivy-leaved, 268

nervosa 269

permollis, 265

procumbens, 269

spinosa, 268

spinosa angustifolia, 268

Stlcky, 269
Sida-

supina, 269

trisulcutu, 265

urens, 268

Velvety, 269

riscos, 270

Sideroxylon, 321

foetidissimum, 321

mastichodendron, 321

Silk-cotton Tree, 275

Silky-grass, 17 Senna, 168

Silphium trilobatum, 451

Silver-fern, 469

-plume-grass, 13

-thatch, 59

-top, 59

Simarouba, 210

glauca, 210

medicinalis, 210

Simaroubaceae, 209

Simaruba amara, 210 officinalis, 210

officinalis glabra, 210

Simblum sphaerocephalum, 644

Sinapis, 147

arrensis, 147

brelssicata, 147

integrifolia, 147

Singer-tree 157

Siphonocladus, 602 mcmbranaceus, 601 rigidus, 602

Sisal, 77

Sison Ammi, 314

Sisyrinchium, 80

miamiense, 81

Skullcap, 377

Slag, 4

Slender Maiden-hair Fern. $+67$

Sea Purslane, 136

Slipper-plant, 233

sloanea cmarginata, 321

Small Halberd-fern, 472 -leared Haplocladium, 495

SMilacaceae, 70

Smilax, 70

auriculata. 71

Beyrichii, 71

domingensis. 71

havanensis, 7

havanensis dentata. 71

havanensis ovata

lacvis, 71

laurifolia, 72

oblongata, 71

oblongata viscifolia. 71

populnea, 71

Walteri, 72

SMILAX FAIILY, 70

Snake-bark, 258 -root, 210,417

Snowberry, 417

Snowdrop, 78

SOAPBERTY FAMIIX, 250

SOLANACEAE, 381

Solanum, 382

aculeatissimum, 382 american $u m, 383$

bahamense, 383

bahamense lanccolatum, 383

Blodgettii, 384 
Solanum -

Iilodgett's, 3st

Ijushy White. $38 t$

didrmacantluum, 394

gracile, 383

hatancnse, 386

itmacum, 35?

Mullein-leaved, 383

nigrum, 383

nigrum oleraccum, 3 S?

nodiflorum, 3\$3

purpuratum, $3 \varsigma 3$

suburmatum, 383

torrum, 384

verbasscifolium, 383

Soldier-bush, $361,4+2$

Solicria chorlalis, 561

Sonchus, 429 oleraceus, 430

Sophora, 177

Coast, $17 \mathrm{~S}$

tomentosa, $17 \mathrm{~S}$

Sore-busl, 363

Sour-busli, 445

Southern Bracken, 467 Radula, 506

Sow-thistle, 430

Sowbane 11?

Spanish Bayonet, 72 Cedar, 100

Cordia $35 \mathrm{~s}$

Cotk, 273

Guava, 411

Tasmine, 335

Moss, 63

I'lum, 112

Stopper, 304

- top, 60 )

Spartina, 3 t

juneca, 34

piltens, 34

Spathelia, 205

Low, 208

remicosa, 208

Spathiger, 89

rigidus, 8 ?

Spatoglossum guincense, 597

vuricyatum, 594595

Spermacoce, 423

lucris, 422

orimoides, 422

tenuior, 423

tetraquetra, 424

SPERMATOPIITA, 2

Spermothamnion, i7s

gorgoneum, its

grmnocarpum, 579

investiens, $5-\mathrm{i}$

irrequlare, 57 ?

mitcromeres, its

rosfolum, $5 \mathrm{Ts}$

spelunearum, its speluncrarum, 53

Sphacelaria, 590

tribuloides, $5: n$

SPILACEIARIACFAE, 590

Sphacelotheca pamparum, 6.37

sphurnosiphon prasinus, 6i:0

Sphacraleea abutiloiles, 26+

Sphaerella Rajaniae. fist

Sphurrig annulate. 634 conemtricill 633

fusenpurpurera, fo.34 gregeria, 533 polymorpha, 634
Sphacria-

Stiyma, $63+$

sulphurea, 633

SiHAERLALES, 634

sphocrocarpus globuliferus, 645

SpHaterococcace.in, 562

Sphacrococcus Corallopsis, 566

domingensis, 562

filiformis, 583

isiformis, 561

lacinulatus, 562

pediccllatus, 576

polycarpus, 562

rigens, 563

tene', 561

tenuis, 561

SPHAEROPSIDALES, 635

Sphaerostilbe gracilipes, 633

Sphenomeris, $46 \mathrm{~S}$

clavata, 468

Spice-wood, $30 \mathrm{~s}$

Spider-flower, 150

$$
-1 i l y, 79
$$

SPIDERTORT FAMILY, 66

Spigelia, 328

Anthelmia, 329

Spike-grass, 40,42 -rush, 48,49

Spinr-bur, $4+7$

Spiranthes clata, 86 lueayuna, 85 tortilis, 5.5

Spleenwort. Toothed, 469

Spondias lutea, 245

sponyia rermieularis, 604

spougorlium, 616

Sponia Lamarckiana, 10 -

Sporobolus, 32

sporobolus, 635

angustus. 33

argutus, 33

atrovireus, 33

bahumensis, 33

Perteroinus. 33

domingensis, 33

indlcus, 32

Jucquemontii, 32

tenacissimus, 32

rirginicus, 33

Sporolithon 5.94

Spreading Frullania, 520

Spurge, Eahama, 239

Fertero's, 242

I3lodgett's, 241

lirace's, 239

Brazilian, 240

Britton's, 242

Brond-leaved, 237

Bushy, 23.

Cay Sal, $23 s$

Const, 237

Fxuma, 23n

lorking, 23is

IIniry. 241

Ifypericum-leaverl. 240

Leafless Cuban, 235

Iottled, 23.

J'in-ween, 238

l'rostrite, 241

Sheathed, 240

Wils on's, 23s

SPIRGE F.MILY, 217

Spyridia, is

aculeata, 5.91

aplculuta, 581

filamentosa, 581
Spyridia occiscutalis, 581

sifuamariu, ist

Siguamamicear, 584

Stachyturpheta fruticosa. $36 \%$

jamaicrusis, 360

STAFI-TREA FAMILY, 246

Star-of-the-Earth, $14 \mathrm{~s}$

Staties bahamensis, 320

Stclis foliosa, s?

stcmmodontia bahamensis, 451

trilobata, 451

Stemodia, $3 \times 9$

Coast, 389

durantifolia, $3 \mathrm{~S} 9$

maritima, 3s?

Stemonitis herbatica, 645

Stenandrium, 402 droseroides, 402 rupestre, 402

stennlobium stums, 397

Stenophyllus, 49

IVilsoni, te

I'ilson's, 50

Stenorrhynchus, $8 f$ lanceolatus, 86 orchiolires, $\mathrm{S} 6$

Stenostomum, 414 densiflor $u$ m. 415

lucidum, 414

myrtifolium, 415

Mrtle, 115

Shining. 411

Viscid, $41 \mathrm{~T}$

Stenotaphrum, 30 amrictmum, 30 secunditum, 30

stephanocoelium, 607 verticillat um, 60s

Stephomotis floribunda, 344

STERCUlticeat 275

Stereophyllum, to 4 ridiculosum, 494

stercum, 639

Stereum albobadium, $63 \mathrm{~s}$ enndidum, 63s Invilleantum, 635

Sticky-weed, 44

Stictosinhonin, 572

Stigmaphyllon, 204

Fanstinum, 204

reticulatum, 204

Sagraeanum, 204

Sagra's, 204

Stigmatidum clegans,, 5.38

Stigonema, 62\%

stigoneme fon

STIGONEMAT.ACE.AE, $62-$

stillingia collanduTore, 232

stilophora fluthrata, ion

Stinking Pea, $16 \pi$ -peat, Root, 177

Stipa, 31 repillaris, 32

Stomolsia, 395 cornuta, 3nj

Stopper,liahama, 306

long-stalked, 306

I'ale, 30it;

lied, $: 304$

Spanish, 304

White, 303,308

Stow-weed, 3n1

Sirap-fern, 47

streptarlune cubcusis, 31 scibra, 31

Striatella, 627 
Striatella

delicatula, 6:7 delicotulu, $6:-7$

Strong-bitck 3 is

Stropharia floccusa, 744

Strumpfia, 418

Strumpfia, 417 maritima, $41 \mathrm{~s}$

strueca, bon anastomosans, 602

Stylosanthes, $18 ?$ hamata, 183 procumbens, 183 riscusa 183

Stypopodium, 594 lobatum, 594

Suacela interinedia 121

Subpinnate Sematophyllum. 500

Sugar-apple, $1 \pm 1$

Sullivant's Schlotheimia, 48 !)

SuMAC FAMILT, 243

Suriana, 20?

Suritut, 543 maritima, 209

SERIANACEAE, 209

Surinam Cherry, 304

Surirella, 629

fastuosa, 629

fusiformis, 631

incurvata. 631

manca, $6: 31$

mexicann, 631

recedens, fi29

Swamp-bush. 271

Suartaia multijuga, 177

Sweet-bay, 432

I'otato, $3 . \overline{5}$

Torch, 143

William. 336

Sweetwood Bark, 223

Swietenia, 213

Mabagoni, 213

Mahagoni, 109

Swold-bush, 220

-fern, 478

Symploca, 62:

hydnoides fruticulosa, 6?:3

Symechocustis, 619

Synedra, 628

formosa, 630

fulgens. 630

Gaillonii minor, 628

superba. 630

superba minor, 628 undulata. $62 \mathrm{~S}$

Synedrella, 452 nodiflora, 4 i2

Synedrosphaenia baculiformis, 630

Syntherisma, 15

digitata, $1 \mathrm{f}$

filiformis, 15

marginatum, 16

paniceum, 15

sanguinalis, 16 sctosa, 16

Syrrhopodon, 482

Gaudichaudii, 482

Gaudichand's', 483

Tabebuia, 396

bahamensis, 396

bahamensis, 636

lepidota, 396
Tauernaemontana Echitcs, 336

Taenioma, jtit perpusillum, 564

Tucnitis lanceolutu, 466

Tallow Wood, $11:$

It mala pubeseens, 144

TAMARICACEAE, 279

famalind, 16i5

Tamarindus, $16 \%$ indica, 165

Tamarisk, 2i?

CAMARISK 1 AMLX, 279

Tamarix, 27 ? gallica, 279

Tamonra, 367 curassarica, 367 scabra, 367

Tape-grass, 8

TAPE-GRASS FAMILI, 8

Tassel Plant, 209

Taxilejeunea, 512 obtusangula, 512 Obtusely-angled, 513

Taxithelium, $49 \mathrm{~S}$ Flat, 499 planum, 498

Tecoma, 397 bahamensis. 396 lepidota. 396 Leucorylon, 396 stans, 397

Tectaria, $\$ 71$

Amesiana 472

heracleifolia, 471 minima, 472 trifoliata. 472

Tephrosia, 181 cathartica, 181 cincrea, 181

Teramus unciuatus, 190

Terebinthus, 211 inaguensis. 212 simarulua 212

Terminalia, 301 Catappa, 302 spinos $a, 301$

TERMINAIACEAE, 300

Tetramicra, 94 Bahamia, 94 Trbaniann, 94

Tetranthus, 446 Bahama, 447 bahamensis, 447 thymoides, 455

Tetrazygia. 298

Tetrazygia, $29 \mathrm{~S}$ an gustiflora, 298 bicolor, 298

Teucrium, cubcuse, 3 - 6 influtum, 367

Thalassia, 0

Thalassia, 563. 568, 570. $573,581,582,586$. 5.8. $590,591,597$. 622

testudinum,?

ТнALLOPUTA, 521

Thamnophora triangutaris, 571

Thatch-paim, 59

Thelephora albobadia, 63s candida. $63 \mathrm{~s}$ spiculosa, 6.38 spontiosa. 638

THELEPHORACEAE, 638

Thelotrema, 544 albilum, 544
Thelotrema-

licinctulum, 544

bisporum, 545

vlaucescens, $5+5$

lepadiuum, 544

lcpadinum bahianum. 545

microporum, $5 \pm 4$ monosporum, 544 parlabidum, 544 iuralbidum, 54

liarcuelii, 545

simplex, 545

subtile, \pm \pm

velatum, 544

THELOTILAACEAE, 543

T'JEUPHRASTA F'AML), 316

THEUPHRAST.ACEAE, 316

Thespesia, 273 populnea, 273

Therctia nercifolia, 338 Theretia, 338

THISTLE FAMILY, 433

Thorn-apple, 386

Thoroughwort, 438

Thouinia, :252 discolor, 25"?

Threefold Euosmolejeunea, 512

Thrinax, $5 \mathrm{~s}$

argentea, 59

bahamersis, 58

floridan $a, 5 !$

keyensis, 58

microcarya, $5 \mathrm{~s}$

parviflora, 59

yarviftora, 59

Thunbergia, 404

alata, 405

filsraus, 405

volubilis, 405

White, 405

Winged, 405

Thyana, 2

disculor, 252

Thymopsis $4 \overline{5} 5$ Brittonii, $45 \overline{5}$

thymoides, 455

Пrightii, $\$ 55$

Thymus Brownei, 370

Tick-trefoil, 184

Tie-tongue, 118

TILIACEAE, 261

Tillandsia, 64

aloifolia, 65

Balbisiana, 64

Berteroniana, 66

bulbosa, 6j

cancscens, 66

circinata, 65

fasciculata, 65

thexuos $u, 65$

lingulata, 66

polystachyu, 6 -

recurvata, 64

usncoides, 63

utriculata, 65

Talenzuelana, 64

Tithymalus, 235 trichotomus, $23 \%$

Ti-Ti, 186

Tobacco. 387

Tomasellia, 528 cubana. 528

cubana, 528

exumana, 528

leucostoma, 528

macrospora, 528 
Tonka IBean, 438

Toothed spleenwort, 469

Torch-wool, 209

Torrubia, 121

Pricel, 132

Cokeri, 131

longifolia, 132

ohtusata, 131

Tortula, 4 s3

agraria, 4.5

Common, tst

Domncllii, 4s

rivalis, 4ST

TorTULA FANILY, 483

TORTULA CEAE, 4 S3

Touch-me-not, 205

Tournefortia, 361

(gmaphalodes, 361

humilis, 363

noliochios, 362

slender Green-leatred, 361

tomentosa, 362

volubilis, 361

valubilis 632

White-leared, 362

Toxicodendron, 243

Blodgettii. 244 radicans, 244

Trachyneis, 62.5

Antillarum, 631

aspera, 628

Delori, 0331

Trachysphenia, 627 anstralis, 627

Tradrscantia discalor, 65 viroinice, 68

Trametes hulnoides, $6+1$ submurina, $6+1$ rersatilis, 640

Trema, 104

L:Imarckíana, $10-$ Lima, 104

Tremella I urieula, 637

Trentepohlia, 5!) aurea, is?n rigidula, 5on torulosu, ion

Triacis microphylla, 2\$3

Trianospermum racemosum. $4=1$

Tribliclium rufulum, 635

Tribulus, 212 cistoirles, 202 murimus, an? terrestris cistoidcs, 202

Tricera, 243

Bahama, 243

bathamensis, 243

bahomensis, 633

Trichurlane insularis, 16

Trichin cincrea 645 rlarata, i.4.

Trichodesmium, 621

Thlebautli, fi:l Thichautii 690

Triehorlace, isti

Tricholaena leurophaca, 17

Triphosolen lntillarum, Got

Trlchostlgma, $1 \ldots$

Trichostigma, 13 octandrum, 134 riloinoirles, 134

Trichostomum, AST

Trichostomum, fsi invalutum, 4si jamaiecnse, 457 rivale, 457
Trichostomumrivale, 457 liock, 457

Trichothammion, 575

Trirladia, 607

Tridax, 454 procumbens, 454

Trifolium, 179 pratense, 180 reluens, 180

Triopteris, 204

Triopteris, $20:$

huranensis, 204

jamaicensis,

lucida, 204

parvifolia, 204 rigida. $20+4$

Tiple-awned Grass, 31

Tripsacum, 12 dactyloides, 12 hermaphroditum, 15

Triumfetta, 263

althacoides, 263 semitriloba, 263

Tropidoneis, 629 lepidoptera, 62?

'IRUMPET-CREEPER FAMILY, $30 \%$

Trumpet-flower, 397

TRYPETUIELACEAE, $52 S$

Trypethelium, 52\%

teneum, 52!

eatervarium, 530

cruentatum, $\div 30$

crucntum, 530

eluteriae, 530

eluteriae citrinum, 530

eluteriae nigricans, 530

eluteriae subsulphureum, 530

eluteriate truncatum. 530

ferrugineum, 529

hetcrochroum, 529

fiun $\approx$ ci, 529

mastojdeum, ה29

ochroleucum, 530

ochrolcuenm jullesechs. 5.30

ochrothelium, 529

pallescens, 530

scriviu, ז2!

sprenyelii, 530

tropicum, 520

Tulip, 336

Turbina, 3\%. corymbesa, 35t

Turbinaria,

triulute 591

trieostata, $5: 2$

turbinata, $5 n 1$

turbinata 592

vulgaris trialata, 5:1

Turk's-cal, 294

Turnera, $25^{\circ}$

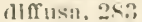

Simall-ipared. 283

ulmifolia, 2s? ulmlfolin, 6.3.

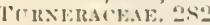

Tulth-grass, ?

- weed, 13.2

T'ussiluyo ullirans, ifon dentata, 460

Typha, 4

angustifolla, 4

anguslifolia domingrn sis, $t$
Typha-

domingrusis, $t$ latifolin. $t$

TIPUACEAE, 3

'lyromyees pulustris, 641

Icacou nadiflorum, 452

Udotea, $61:$

conglutinata, 614

cyathiformls, 614

Habellata, 614

Flabellum, 614

Halimedn. 61 t

sortirla, 61

spinulosa, 614

tomentosa. 612

Wilsoni, fitt

THIACWE, $10 ?$

Ulva, 5es

dichotoma. 596

Lactuca, 595

Lertensii, 596

sin $10 \times \pi, 590$

stcllata, 602

Tixaceat, ios

UNICORN-PLANT FAMILY, 399

Uniola, 41

paniculata, 42

reemiflora, 12

spicat $u, 42$

virgitia, 42

Urechites, $3: 37$ Andrewsii, 335 luten, 3.:s

TREDINALES, 636

Tredo bidenticola, 636 Cisst, 6.37

Lconotillis, 630; proeminens, 636

Sapotae 63.3

Wilsoni, 636

I'romrces Bidentis, 636

Urtica aestums. 100 humilis, 107 lav) ulecer, 10 T

IRTICACEAE, 105

I RTICALES, 103

Usnea, 5 in

florida strigosa, 550

ISNEACEIE, 54?

I'STILAGINAI.ES, 637

Istilngo Mentagnei. 637 mamp arum. 6:37

Tstulina vulgaris, 634

Utricularia, 394 cornuta, 205

foliosa, 394

foliose, 3nt

glbba, 394

pumílis, $39-4$

subulata, 391

Vachellia, 1bo Wa mesiana, 161

Vaglnatia forinnsin, tift plumhen. 6it

Valerianodes, 365 frutlcosi, 3ti. jamileensls, Bor jumairensis, 635

vallesla, $3: 30$

Vallesta, 320 divhotoma . 339? glubra. 330

Valonia, 610 ; Aegigenplla, 60, Iryen!lopiln. 604 faculose fios 
Valonia-

macrophysa, 603 macrophysa, 604 ocellata, 603 ocellata, 604 utricularis A cgagropila, 603

utricularis crustacca, 604

rentricosa, 603

ventricosa, 584

FAlONIACEAE, 601

Valota, 16

insularis, 16

Valsa, 634

Vanilla, 83, 84, 438

Vanilla, 83 articulata, 84 clarieulata, 83 Eggersi in 83 pliaeantha, 83

Varronia, 358

Bahama, 359

bahamensis, 358

Brittonii, 359

Britton's, 359

globosa, 358

Capitate, 358

lucayana, 359

Rough, 358

Tauchcria, 607

VAUCHERIACEAE, 617

Velvet-berry, 412 -seed, 412-414

Verbascum pulverentum, 393

Verbena curassavica, 367

jomaicensis, 366

lappulacea. 367

nodiflora, 368

prismatica, 366

stocchadifolia, 368

Verbenaceae, 364

Verbesina, 448

alba, 449

encelioirles, 452

nodiflora, 452

Vernonia, 435

a rbuscula, 435

arctata, 435

Bahama, 436

bahamensis, 436

bahamensis, 435

cinerea, 436

Herbaceous, 436

Inagua, 435

insularis, 436

Long-leaved, 438

Low Bushy, 435

obcordata, 435

Verrucaria, 522

acnea, 52 ?

analepta amcricana, $5 \mathrm{~s}$

viformis, 525

catervaria, 530

cerina. 526

Cinchonae, 525

contendcns. 525

diremta. 526

epidermidis fallax, 525

fuscorubella, 543

Kunthii, 526

leucoplaca, 526

mamillana, 526

mamillaris, 522

mamillaris, 523

muralis, 523
Verrucaria

nIgrescens, 523

ochraceo-flavens, 527

ochraceo-flavum, 527

ochrolcuca, 530

pullidula, 531

planorbis, 525

punctclla. 526

rupestris, 522

rupestris, 522

Santensis, 526

Titruccrae, 524

trachona, 542

tropiea, 529

Verrucariaceae, 522

Vertebrata, 569

Vesicularia, 497

Vesicularia, 497 vesicularis, 497

Vigna, 195

luteola, 195

repens, 195

Yellow, 195

Vilfa arguta, 33

atrovircus, 33

Berteroana, 33

dom ingensis, 33

Villamilla, 134 octundru, 134

Vinca lutea, 338 rosea, 336

Vincetoxicum palustre, 343

Virginia-Creeper, 261

Virgin's-bower, 140

Viseum purpureum, 108 racemosum, 110 rubrume, 110

tinervium, 110

YITACEAE 259

Titex ilicifolia, 374

vitis, 259

caribaca, 259

Munsoniana, 259

rotundifolia, 259

Vittaria, 466

lineata, 466

Volkameria, 374

aculeata, 374

Voyria mexicana, 332

Walking Wood-fern, 473

TValla-berry, 249

waltheria, $27 \pi$

americana, 278

Bahama, 278

bahamensis, 278

Common, 278

Trasherwoman, 127

Washerwoman's Bush, 386

Water-grass, 21

WATER-LEAF FAMILY, 357

Water-lily, 140

WATER LiLY FAMILY, 139 NILLFOIL FAIIIT, 310

Water Pepper, 114 Pimpernel, 318

ITater Plantain Family, 7

Tiater Smartweed, 115

Wattle, 303

Wax-herry, 102

Wedelia, 450

Bahama, 451

bahamensis, 451

buphthalmoides, 451

earnosa, 451

Trailing, 451

trilobata 451

Test Indian Birch, 212
IVest Indian Germauder, 376 Grass, 37

Sage, 378

Thyme, 379

What o"clock, 398

Whistling-hean, 157

White Beefwood, 11 I lieggar-ticks, 454 Cedar, 396

Clover, 180

-headed Rush, 53

lronwood, 255

Mangrove, 301

White Maxgrove FaMily, 300

White Moss, 479

IVHITE Moss FAMILY 479

White I'ussley, 364 Stopper, 303, 308 Torch, 209

Whitewood, 112, 222 bark, 28 ?

Wild Apricot, 288

Balsam-apple, 425

Basil, 380

Bush-bean, 194

Cane, 2-5

Cassada, 322

Cherry, 205, 248

Cinnamol, 262

Coffee, 418, 419

Coral, 122

Cotton, 274, 341

Dilly, 324

Down, 341

Fig, 105,292

Flax, 200

Grape, 259

Guava, 306

Indian, 90

Indigo, 180

Ipecac, 341

Jessamine, 375

Lettuce, 430

Lime, 207

IIulberry, 410

Mustard, 147

Oak, 227

Onion, 65

Pepper, 101

Peppergrass, 146

Pine, 64, 65

Potato, 336

Raisin, 166

Saffron, 323

Sage, 370

Saive, 276

Sisal. 77

Tamarind, 158

Tea, 102

Thrme, 363,409

Tobacco, $383, \mathbf{4 4 5}$

Tomato. 134

Torch, 209

Inction, 338

Watermelon, 289

Yam, 80

Willoughbya seandens, 459

Willugbaeya heterophyila, 439

Tinterana Canclla, 282

IVire-grass, 37 -weed, 268

Witch-grass, 24

IVoevine, 144

Woman's-tongue Tree, 157

Wood-fern, Walking, 473 -grass, 27 
Wood-

Sorrel, 197

WOOD-SORREL FAMILY, 196

Worm-rine, st

Wormseed, 119

Wrangelia, 55?

Argus, 5.59

Argus, 560

bicuspidata, 55?

peniclllata, 559 penicillata. 553 plebcja. 559

Wrightiella, 571 Blodgettii, 571 Tumanowiczl, 571

Wright's Anem!a, 47t

Wurdemannia, 562 setacea, 562

Xanthium, 431

clinense, 431

longirostre, 431

strumarium, 431

Xanthoxalis, 197

corniculata, 197 eorniculata, 633

Tanthoxylon cribrosum, 207

Xenococcus, 620 Schousboci, 620

Ximenesia, 451 encelioides, 452

Ximenia, 112

americana, 112

inermis, 112

Tylaria Arbuscula, 634
Xylaria-

aristata, 634 polymorpha, 634

XilophaGaCEAE, 638

Xylophylla, 220 Epiphyllanthus, 220 latifolia, 220

rylosma burifolium, 284 ilieifolia, 28 nitillum, 281

Tyridales, 63

Iam, $\mathrm{so}$

IVild, so

YAM FAMILY, 79

Yellow Cress, 148 EIder, 397

-ered Grass, 73

-fruited Leucolejeunea, 519

I.ejeunea, 508

Procumbent Wood-Sorrel, 197

-spored Anthoceros, 521

Vigna, 195

-wood, 208

-wood, Cuban, 207

Vellowish Grcen Microle

jeunea, 509

Yucca, $\mathrm{T}$

aloifolla, 72

Zamia, 462

angustifolia, 463

angustifolia 463

lueayana, 463

pumila, 463
Zamla -

tenuis, 463

Zanardinia. 557

marginata, 559

ZANXICHELLIACEAE, 4

Zanthoxylum, 206

Clava-II cronlis, 208

coriaceum, 207

coriaceum, nus

cribrosum, 207

cubense, 207

cmarginatum, 207

Fagala, 200

flavum, 207

flavum, 5.8

fraxineum, $20 \mathrm{~s}$

juglandifolium, 207

Pterota. 200

Zephyranthes cardinalis, is rosea. is

Zinnia, 448

Zinnia, 448 multiflora, $\$ 48$

\section{Zonaria, 594}

collaris, 594

diehotoma, 590

lobata, 594

rubra, 584

rariegata, 504

varicfota, 591,595

zonalis, 594

Zuelania, 285

Zuelania, 285

Guidonia, 2S5

lactioides, 255

ZYGOPHYLLACEAE, 201 









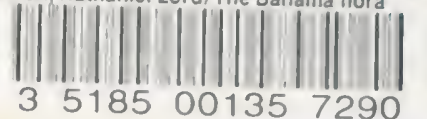


